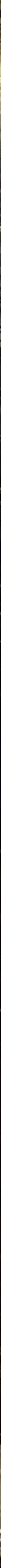


$h_{0} 1287$

7 Partan.

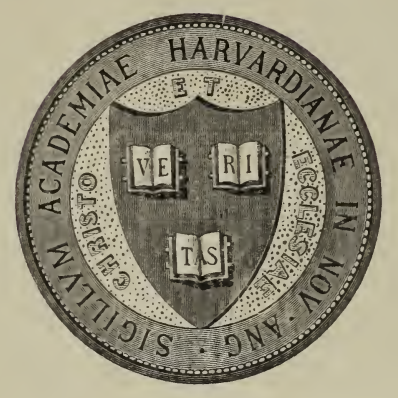

HARVARD UNIVERSITY

LIBRA FY

OF THE

GRAY HERBARIUM

Received 26 March 1912 


Digitized by the Internet Archive in 2017 with funding from BHL-SIL-FEDLINK 



\section{A POCKET}

\section{BOTANICAL DICTIONARY,}

COMPRISING THE

NAMES, HISTORY, AND CULTURE OF ALL PLANTS KNOWN IN BRITAIN;

With a fUll explanition of techNical teris.

BY

JOSEPH PAXTON, F.L.S., H.S., \&c.

ASSISTED BY

dotn

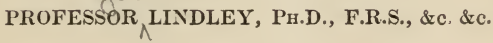

L O NDON :

J. ANDREWS, 167, NEW BOND STREET; AND W. S. ORR AND CO., FATERNOSTER ROW. 
"7)

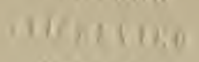

Whasint

MAR 261912

Gray Herbarlum

Harvard University

Bot. Dict.

P28
180

LONDON:

BHADHURY AND BVANS, PKINTKHS, WHITHFRIARS. 


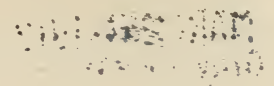

\section{PR E F A C E.}

W HEN an author offers to the public a work, the greater part of the information contained in which is already available in detached fragments or other forms, his first duty is to exhibit the propriety of its publication ; and prove, beyond question, that he has been instigated to his task by no unworthy desire of fame, but by a distinct and certified persuasion of its demand and utility.

Happily, in the present case, we are enabled to court scrutiny into our motives, being fully prepared to explain and justify them. During the numerous interviews enjoyed by us with the leading patrons of floriculture, the want of a pocket companion, such as that now furnished, has ever been especially and forcibly urged. There are, it is true, Catalogues, Encyclopædias, Lexicons, and Cultural Directories, all highly valuable in their respective spheres, and essential adjuncts to a gardener's or amateur's library: but they are too elaborate, verbose, technical, or uninteresting, to be readily and thoroughly appropriated; the expense, also, of several is necessarily enormous, and beyond the means of the great majority of those who thirst after botanical and floricultural literature; and no single one, much less a set, embracing all the subjects of this Dictionary, is conveniently portable, or can ever be carried, without discomfort, beyond the porch of the proprietor's domicile.

Comprehensive compendiums, in which scientific and popular details are abridged, combined, and thus brought within the pecuniary reach as well as easy examination of those whose income and time are subjected to many other more pressing exactions, are highly commendable if attentively and clearly arranged; but their usefulness is in proportion to the precision and accuracy of the manner in which they are compiled.

The Pocket Botanical Dictionary, then, has been prepared solely as an instant resource and standard of consultation; and for this purpose will be found invaluable 
to the professors and lovers of horticulture, in all its branches and of every grade. Within its columns is compressed all the most important information relative to admired plants which its small size and avowed design would admit. With this in his pocket, the possessor or cultivator of plants may perambulate his own garden, visit those of his friends or public establishments, and attend floricultural exhibitions, in the full assurance that if any particular object engage his attention, he may at once derive every fact of interest respecting both it and its congeners which is yet known in this country, and form an idea of the facility or difficulty, and consequent expense, attending its conservation. Such is, cursorily, the prime purport of this publication, and the aim of its author. To supersede the necessity for attaching the meaning of every specific appellation, and at the same time to afford the most ample means for acquiring a knowledge of all the phrases peculiar to the science, a voluminous glossary has been incorporated; wherein, in addition to the more abstruse Latin terms, a number of ordinary words that are used botanically in a peculiar sense are fully explained.

One inestimable quality of a popular synopsis of any sort, is the discreet abridgment of uninteresting matter, and detailed record of merely the most attractive particulars. On the judicious selection and proper apportionment of desirable intelligence, the value of a summary entirely rests. In this respect we have much to claim for the volume to which the present address is prefixed. On account of the extreme scarcity, or non-existence in Britain, of many plants, considerable perplexity has been experienced in assigning to each species its due share of honour. For this reason, if a few plants are unjustly elevated, and others improperly debased, some little allowance may fairly be expected. Those indigenous species which are ranked with the ornamental sorts, are not to be regarded as worthless because of their commonness, but may be cultivated with advantage in the more secluded and sylvan flower borders.

To take a general glance at the arrangement and composition of this Dictronary, it will be better to show more lucidly the intent and application of each separate point, and afterwards advert to the abbreviations. Compactness and facile portability being the primary and principal elements of the design, condensation of the letter-press was an inevitable result. On this score, however, we have just grounds for eulogising our printers, as nothing can be more beautiful or perfect than the mechanical execution of the work; while the objection that might attach to the I minuteness of the type, is completely removed by its exceeding clearness. 
Under the head of each genus, besides the authority for its name, its origin, and position, both in the Linnæan and Natural System, a concise outline is given of its most striking members, with adequate instructions for their cultivation, and observations on their particular medicinal or useful properties. In conformity to the principle of giving prominence to only the most interesting subjects, the worthless genera are passed over with a slight statement of their insignificance ; and to prevent repetition, reference is occasionally made to other genera for directions on treatment, when the habits of both closely correspond. For all the suggestions on culture, we hold ourselves, for the most part, responsible; the notes in those instances where we have no personal cognizance being extracted from the best authors, with the usual acknowledgments. Immediately succeeding the above-named sketches, a list of specific synonymes is furnished, with figures of allusion affixed to each, and similar ones to the species they represent, by which the observer may instantly perceive what names are applied to the same plant, that in the last or descriptive text being always the most authentic.

In the enumeration of genera and species, we are indebted chiefly to Mr. Geo. Don's General System of Gardening and Botany, Dr. Lindley's Introduction to the Natural System, and Mr. Loudon's Arboretum et Fruticetum Britannicum, comparing these with all other catalogues extant,-of which Loudon's Hortus Britannicus is the principal and best,- -and adopting such readings as are most obviously correct. We rely greatly on our own rigid research into these matters, having been engaged in it for several years, but still more so on a careful revision of both MSS. and printed proofs, undertaken by Dr. Lindley in the most disinterested and kind manner. Nevertheless, such is the typographical diminutiveness, that we cannot imagine but some errors have eluded us. Should it reach another edition, we shall have great pleasure in effecting any emendations which our correspondents or friends may discover and communicate. It will be manifest that two distinct courses have been followed with regard to the ornamental and trivial species. Possessing nothing to recommend them to notice, or to render the enrolment of their habits, native country, \&c., at all desirable, we have arranged the latter in aggregated groups; after their more interesting allies where these exist, and directly following the general remarks on those genera which comprise no ornamental species. On the description of each meritorious plant included in the columns opposite its appellation, we shall descant more largely, when considering the abbreviations. 
Respecting the number of scientific terms herein explained, we may be allowed to say that no other popular glossary contains such a copious collection. Their explication is in exact accordance with the views of the most learned botanists, merely being reduced to dimensions which best comport with simplicity and conciseness.

Considering the immense field which this volume occupies, the accentuation of generic, specific, and all purely botanical names that are not Anglicised, must be regarded as a highly valuable characteristic. By the extreme perspicuity of the Imarks employed, their full and universal adaptation, and the fact that they were all supplied by the first botanist in England, (Dr. Lindley,) the botanic student or other assiduous examiner will here meet with a fund of accurate instruction in this particular, to which only the most laboured and extremely expensive publication can at all pretend.

It might be assumed that the signs used are sufficiently common to require no comment; but, for the benefit of the less informed, we shall just show the manner in which they apply. In the first place, the vowel in each word over which the primary accent occurs, sustains all the emphasis of the syllabic pronunciation, independently of the real nature of the sign. Further, the employment of the long | quantity $\left(^{-}\right)$or the short quantity ( $\left.{ }^{\sim}\right)$ simply denotes that the vowel above which they are placed is to be sounded long and broadly, or short and abruptly. To vary our expression, the short vowel is perpetually pronounced in conjunction with the next consonant, and the long one has its own distinct and final sound, as if the letter were doubled, but the voice rested on each. In all cases when the last | syllable but one is marked long $\left({ }^{-}\right)$, the accent falls on that syllable; and when the last syllable but one is marked short $\left({ }^{~}{ }^{\prime}\right)$, the accent falls on the last syllable but two. Thus Romānŭs would be accented Románus, and trǐcŏlŏr would be accented trícolor, although the $\mathrm{i}$ on which the accent is placed is short. It is extremely important to bear this in mind.

To reduce the work to the smallest practicable size, it has been found requisite to abridge the language conveying many of the details, and that this may be rightly comprehended, we shall now enter on its elucidation. First, the numerical figures which follow the recognised specific names in the general list, and such as precede the synonymes, have, as before hinted, a direct connexion with each other, establishing the identity. Thus, in page 1, under the genus Acacia, the synonyme "1. A. acicularis" is but another appellation for "A. Brownei 1 ," in the 
ensuing text; "2. Mimosa tortuosa," is synonymous with " A. Burmanniana 2 ;" and so on, in like manner, throughout the whole. Next, the authorities for the generic names are very often shortened, and a list of all those, with the country in which they rose to celebrity, will be subjoined. Again, the descriptive peculiarities of species are classed in seven columns, in which the colours of the flowers, - the month during which they commonly blossom, - their habitude, whether as concerns the temperature they receive, their duration, or general nature,-their native climate, and the year in which they were first introduced to Britain,-are all duly registered. Where either or several of these circumstances are omitted, it is to be inferred that they have not been accurately ascertained. In the case of Epiphytes, Palms, and Grasses, they are simply noted as such, since their habits are universally the same. All other trifling particulars are regularly and efficiently interpreted in the catalogue of abbreviations.

Having thus specified the objects, classification, and utility of the work, we have only to commend it to the kind indulgence of the public, convinced that, whatever may be its failings-and in such an extensive compilation some defects must naturally be anticipated - they are neither glaring, momentous, nor, notwithstanding the smallness of the type, equal to those of any similar production. To the gardener, and all who cultivate or delight in acquainting themselves with plants, either for enrichment or amusement; but emphatically to such persons as wish to study the nature and history of vegetation in the garden, where alone they can hope these features to be permanently impressed on the memory, the Botanical Pocket Dictionary has claims which nothing at present existing or likely to be issued can supplant or diminish.

JOSEPH PAXTON.

\section{Chatsworth,}

July, $1 \times 40$. 



\section{AUTHORITIES FOR GENERIC TITLES.}

Ach. for Acharius. A Swedish botanist and examiner of Lichens. Adams, F. A Russian botanist and traveller in Siberia.

Adanson. - A French traveller and botanist.

Afuelitus. A professor in Sweden, and traveller in Sierra Leone.

Agardh. A Swedish professor, bisliop, and writer on Algaceous plants.

(itom.

The manager of the Royal Kew Gurdens.

Albertini. Author of some dissertations on Fungi.

Allioni. A botanist of Italy.

Anderson. A London writer on Peonies.

Andr. for Andrews. An eminent English botanical artist.

Andrzejowski. A Russian botanist.

Aublet. A Frenehman who travelled in Guiana.

Bancroft. A physician resident in Jamaica.

Banks. A celebrated English traveller and promoter of science.

Bartl. for Bartling. A botanist of Gottingen.

Barton. Once a professor at Philadelphia.

Bauhin, Caspar. A German botanist of the sixteenth century.

Baumgarten. A botanist of Transylvania.

Beauvois for Palisot de Beauvois. A French botanist and traveller in Africa.

Benth. for Bentham, An English botanist, and secretary to the Iondon Horticultural Society.

Bergius. A Swede, and writer on Cape plants.

Berkley. An English clergyman and writer on Fungi.

Bernhandi, A botanist of Italy.

Bertolini. A writer on Italian plants.

Besser. A professor in Russia.

Bieberstein. A Russian botanist, and writer upon the plants of Caucasus

Blunie. A Dutch botanist and traveller in Java.

Boerhaave. An ancient botanist and physician.

Bohmer. A German and writer on botany.

Bojcr. A botanist of the Mauritius.

Borkhausen. An examiner of the plants of Hesse Darmstadt.

Bory for Bory de $S$. $V$ incent. A French botanist and traveller. Bot. Reg. for Botanical Register. A botanical monthly periodical, commenced by Ker and now conducted by Lindley.

Bot. Rep. for Botanical Repository. A botanical periodical, formerly conducted by Andrews and others.

Bridel. Á German author on Mosses.

Brignoli, A botanist of Verona.

Brongniart. A botanist of France.

Browne, Patrick. An Irish botanist and writer on the plants of Jamaica.

Broun, $R$. An English botanist and traveller in New Holland.

Bulliard. A Frenchman and investigator of Fungi.

Burmann. A Dutch writer on botany and patron of Linnæus.

Carmichael. A Scotch botanist.

Cassini, $H$. A French writer on Composite plants.

Cavanilles, A botanist at Madrid.

Chamisso. A German traveller and botanist.

Choisy. A botanist of Switzerland.

Colebrook. An English writer on the Flora of India.

Colladon, J. F. A botanist of Genera.

Commelin. A botanist of Holland.

Commerson. A French traveller and botanist.

Corda. A German botanist.

Correa for Correa de Serra. A Portuguese botanist, diplomatist, and writer on botanical subjects.

Coulter. An Irish physician and traveller in Mexico.

Crantz. An Austrian Botanist.

Cunn. A. for A. Cunningham. A British collector for the Kew Gardens.

Cusson. A Swiss observer of Umbelliferæ.

Cyrilli. Au Italian botanist.

Dec. for Decandolle. A French botanist now resident as professor at Geneva.

Desfon. for Desfontaines. A French traveller and botanist in Algiers.

Desmazicres. A hotanist of France.

Desverux, A French botanist.

Dickson. An English examiner of Cryptogamia.
Dillenius. A German writer on botany, especially Mosses, settled in England when he was gardener to Gerard, at Eltham.

Dillwyn. An English investigator of Conferræ.

Ditmar. A botanist of Holland.

Don, $D$. Librarian to the Linnæan Society and botanist.

Don, $G$. An English botanist and traveller.

Douglas. A collector of plants in North America for the Horticultural Society of London.

Dryander. A Swedish botanist and long a librarian to Sir Joseph Banks.

Dumont, for Dumont Courset. A French gardening author.

E. Botany for English Botany. A periodical contrining coloured figures of British plants by Sowerby and Sir J. E. Smith. Ehrhart. A botanist of Germany.

Elliot. An American botanist who wrote on the plants of Carolina.

An English writer on marine plants.

Endlicher. A German botanist.

Fenzl. An Austrian botanist.

Feuille A French Jesuit who wrote on the plants of Chile.

$F$ ischer. A Russian botanist, and director of the Botanical Garden, St. Petersburg.

Flora Peru, for Flora Peruciana. A work on the plants of Chile and Peru by Ruiz and Pavon, two Spanish botanists.

Flugge. A German writer on Grasses.

Forskahl. A Danish naturalist who travelled in Arabia.

Forster. A traveller in the South Pacific Ocean.

Fougeroux for Fougeroux de Bundaroxa. A French botanist of the last century.

Fries. A writer on Fungi in Sweden.

Gartner. A German writer on the structure of fruit and seeds.

Gaudich. for Gaudichaud. A French botanist and voyager.

Gingins. A French botanist.

Gmelin. A Russian botanist and traveller in Siberia.

Gre: ille. An English author on Cryptogamic botany.

Gronotius. A Dutch botanist.

Haller. A botanist and physician of Switzerland.

Hamilton. A Scotch botanist and Indian traveller, sometimes ealled Buclianan.

Harvey. A writer on Cryptogamic and Cape plants.

Haworth. An English author on sucenlent plants.

Hedivig. A German writer on Cryptogamic plants.

Herbert. An English writer on Amaryllidaceous planis.

Hilaire. A Frencl botanist and traveller in Brazil.

Hill. An English botanical writer.

Hoffmann. A German botanical author.

Hooker. A professor of botauy at Glasgow.

Hort. Kew. for Hortus Kevensis. A catalogue of the plants in the Royal Kew Gardens.

Host. An A ustrian botanical writer.

Hudsom. An investigator of British plants.

Humboldt and Bonpland. Botanists and travellers in America, \&c.

Jack. An English writer on the plants of the Indian Archipelago.

Jackson. An English botanist.

Jacq. for Jacquin. An Austrian botanist.

Jussicu. A French systematical botanist.

Kampfer. A traveller in Japan.

Kalm. A Swedish pupil of Linnæus who travelled in N. America.

Kaulfuss. A German writer upon Ferns.

Ker. A A describer of plants in Bot. Reg.

Knowles and Westcott. Editors of the Floral Cabinet.

Koch. A professor of botany at Erlangen.

Konig. A German naturalist who travelled in the Eabt

Kunth.

A Prussian botanist who assisted in the arrange ment and publication of the plants found in America by Humboldt and Bonpland. 
Kunze. A German writer upon minute Crgptogamic plants.

Labillar, for Labil ardiere. A French botanist, and traveller in Syria, New Holland, \&ce.

Lagasca. A botanist of Spain.

Li Llare. A Mexican botanist.

Lamarck. A French naturalist who wrote largely upon botany

about the end of the eighteen th century.

Lambert, A. B. An English patron of botany.

Lamouroute. A French writer upon marine plants.

Lehmann. A Gerinan botanist and director of the Botanical Garden of Hamburgh.

$L^{\prime}$ Herit, for $L$ 'Heritier. A French botanist.

Lindley. Professor of botany in University College, London.

Link. $\quad$ A botanist of Prussia.

Limn. for Linnous. The great Swedish naturalist.

Llex. for Llexarza. A Mexican botanist.

Leeffing. A Swedish traveller and botanist.

Loureiro. A Portuguese monk who wrote on the plants of Cochinchina.

Lyngbye. A Danish writer on submarine Cryptogamic plants.

Marcgraav. One of the early naturalists who explored Brazil.

Martius. A Bavarian naturalist and traveller in Brazll.

Medicus. A German botanist.

Merat. A French writer on the flowers of Paris.

Meyer. A botanist of Germany.

Mich. for Michaux. A French botanist who wrote on the plants of North America.

Micheli. A Florentine microscopical botanist.

Mikan. A German author on the Brazilian Flora

Miller. One of the ablest scientific English garden botanists.

Mirbel. A French physiological botanist.

Monch. A German systematical botanist.

Mohring. A writer on Cryptogamia in Germans.

Molina. An Italian naturalist who wrote upon the flowers

of Chile.

Necker. A Germın hotanical writer.

Nees. A German botanist and profesanr.

Noronha. A Spanish butanist who visited the Philippines.

Nuttall. An American traveller and botanist

Ortega. A botanist of Spain.

Pavom. One of the authors of the Spanish Flora Peruviana

Pers. for Persooin. A F rench botanist.

Pling: An ancient naturalist.

Plumier. A Frenes botanist and traveller in the West Indies.

$P$ Phl. A botanist of Germany who travelled in Brazil

Poiteats. A French artist and botanist.

Poppig and Endlicher. German botanists, the former a traveller in South America.

Presl. A German systematical botanist.

Pursh. A Prussian gardener who wrote a Flora of North America.

Rafin. for Rafinesque-Schmalz. A North American botanical

writer.
Ranomd. A French botanist who wrote concerning the flowers of the Pyrenees.

Reich, for Reichard. A German botanist.

Reichenbach. A botanist of Germany.

Retz. A German botanist who wrote on the flowers of Scandinavia.

Rheede. A Dutch gentleman under whose orders the Hortus Malabaricus was published.

Rich. for Richard. A French botanist and traveller in Demerara. Ririnus, A German botanist.

Robil. for Robillard. A French botanist.

Rochel. Superintendant of the garden at Pesth.
Rolander. A botanist of Sweden.

Romer and Schultes. German botanists, and editors of the Systema Vegetabilium of Linnæus.

Roscoe. An English botanical author.

Roth. A German writer on botany.

Rotboll. A Danish botanist.

Rox, for Rarburgh. A botanist of India, formerly in charge of the botanic garden Calcutta.

Rudge. An English botanical amateur.

Ruiz and Pacom. See Flora Peruviana.

Rumphius. A botanical author of the Herbarium Amboinense.

Salis, for Salisbury. An English botanist.

Salm Dyck for the Prince of Salm Dyck. An illustrious German Salmateris.

Sati. A botanist of Italy.

Schlech, for Schlechtendahl. A German botanist.

Schmidt. A Bohemian botanist.

Schousb, for Schousboe. A Danish consul at Tangiers, author of a work on Moroceo plants.

Schrader, A German botanist.

Schreler. A botanist of Germany.

Schunvacher. A Danish botanist, who described many Sierra Leone plants.

Scopoli. A botanist of Italy who wrote on the flowers of Curniola.

Seringe. A French botanist.

Sibthorp. An English traveller in Greece, and botanist.

Sims. An English garden botanist.

Smith, Sir J. E. An English botanist, founder of the Linnzean Society.

Solander. A botanist of Sweden who sailed round the world with Banks and Cook.

Sonnerat, A French traveller in the East Indies.

Spach. A writer in the Annales des Sciences Naturelles.

Sparmann. A Swedish traveller at the Cape of Good Hope.

sprengeh. A German botanist and antiquary.

Stackhouse. An English writer on marine plants.

Sternberg. A noble botanist of Germany.

Swartz. A Swedish botanist who visited the West Indies, and published an account of the native plants.

Aneet. An English garden botanist.

Thowars for Du Petit Thouars. A French physiologist and traveller in Madagascar.

Thun, for Thunberg. A Swedish botanist and traveller.

Tode. A German author on Fungi.

Toumefort. An ancient French traveller and botanist.

Trentepohl. A botanist of Germany.

Trinius. A Russian writer on Graminea.

Turpin. A French botanist and draftsman.

Turra. A botanist of Italy.

Vahl. A Danish botanical author.

$V$ aillant. A French traveller and botanist.

$V$ andelli. A botanist of Portugal who wrote on the plants of

Vauch, for Vaucher. A Swiss writer on Confervæ.

Vela.

Velloza. A Brazilian botanist.
Ventenat. A French garden botanist.

Villars. A botanist of France who wrote on the plants of Dauphiny.

Wallich. Superintendant of the Calcutta botanic garden.

Walter. A writer on the plants of Carolina.

Weber. A German Cryptogamic botanist.

Wendland. A German garden botanist.

Willd. for Willdenonv. A Prussian botanieal writer.

Zeu.

A botanist of Spain. 


\section{ABBREVIATIONS.}

FIRST COLUMN.

COLOURS OF THE FLOWER.

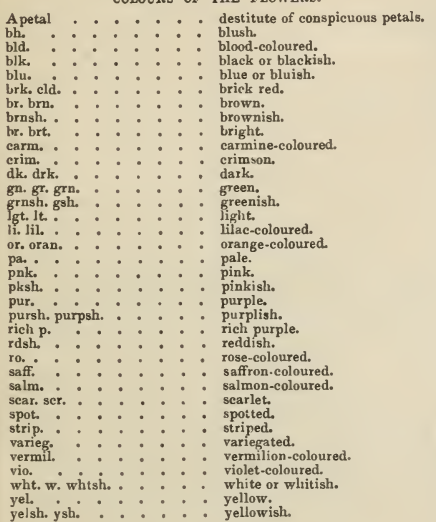

\section{SECOND COLUMN.}

PERIOD OF FLOWRRING.

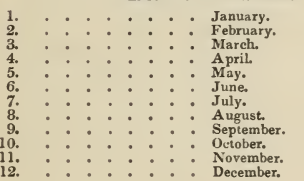

THIRD COLUMN.

TEMPERATURE REQUIRED.

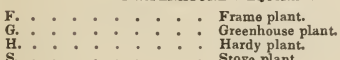

H. . . . . . . . Hardy plant.

\section{FOURTH COLUMN.}

HABITUDE.

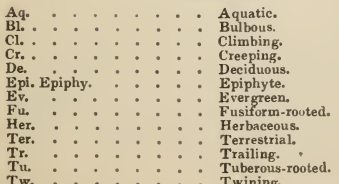

FIFTH COLUMN

HABIT AND DURATION.

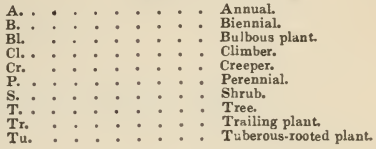

\section{SIXTH COLUMN.}

NATIVE COUNTRY.

Adriat Is.

Alp. Eur.

European Alps.

A . . . American hybrid.

. . Asia Minor.

A renipel. : : : : : : : A Arecian Arehipelago.

Asiatic G. : : : : : A siatic Gulf,

Baff. B. : : : $:$ Baflin's Bay.

Barba. : : Barbary

B. Ayres . . . . Buenos Ayres.

C. California.

Cappadoc. * . . . Cappadocia.

Carthag. * *... Carthagena.

Casp. Sea : : : : : Caspian Sea.
Casp. Sho,

Carpa. Mo. : : : Carpathian Mountains.

C. G. H. : : : : : Cape of Good Hope.

Che son. : : : : Chersonesus.

Coromand. : . . . Coromandel.

Cordill. : : : Cordilleras.

E. Ind. : : : : East Indies.

Eng, hyb. : : : : English hybrid.

Falk. Is. . : : Falkland Islands.

Ft. Vancou. : : : Fort Vancouver.

Guayaq. . . . . . Guayaquil.

Huds. B. : : : : : Hudson's Bay.

I. France : : Isle of Frauce.

I. Skye . . . : Isle of Skye.

Kamtsch.. . . . Kamtschatka.

K. Geo.'s Sd. : : King George's Sound.

Louisia. . . . . . Lmuisiana.

Madagas. . . . . Madagascar.

Magel.. . . . . . Magellan.

Maran, : Maranha.

Martiniq. : : : : Martinique.

Mediterr.. : : . : Mediterranean Islands.

Montpel. . . . . . Montpelier.

Moreton B. . . . . Moreton Bay.

Mosambi. . . . Mosambique.

M. Video : : : Monte Video.

N. Afriea : : : North Africa.

N. Amer. : : : North America.

N. Caledon. : : : New Caledonia.

N. Eur. : : : North Europe.

Newfoundl. . . . Newfoundland.

N. Grenada . . . . New Grenada

N. Holl, New Holland.

N. Patag. : North Patagonia

N. Spain . New Spain.

N. S. w. : : : New South Wales

N. Zeal. . : : New Zealand.

Organ Mts. : : : Organ Mountains.

Pennsyl. . . . . Pennsyivania.

Philadel.. . . . . Philadelphia.

Rio Jan. : Rio Janeiro.

S. Amer. : : : : South America.

San. Cruz. : : : Santa Cruz.

Scandin. . . . . Scandinavia.

S. Austral. . . . * * South Australid

S. Carol. . . . . South Carolina

S. France : : South France

S. France : * * : : South France

S. Leone . : : : : : : Sierra Leone.
St. Domin.

St. Vinc, : : : : : St. Vincent.

S. Sea Is.

Switz.

Sw. River, Swan R : : Swan River.

Tranqueb. : : : Tranquebar.

Valpar. V. L. D. Die. I. : : : Van Diemen's Land.

W. Ind. West Indies

W. Ind. Is. : : : : : West India Islands, 



\section{A PCCKET}

\section{BOTANICAL DICTIONARY.}

ABI ACA

$\bar{A}$ BǏES, see Pinus.

A A mildaAñRdīa, Vahl. After Professor Abild. gaard, of Copenhagen. Linn, 3, Or. 1, Nat. Or. Cyperacee. Worthless dwarf species of grass-like plants; increased by division, and grown in any common soil.

movostrichỹa . Apetal . . 6, Grass. N. Holl. . . 1819

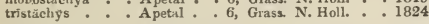
A antion, imperfact or untimely development.

AвRо̄мĂ, Linn. From $a$, privative, and broma, food; unfit to be eaten. Linn. 18, Or. 1, Nat. Or. Sterculiacece. Handsome free-flowering species of easy culture, delighting in a compost of loam and peat. Propagated with ease from seeds, or cuttings. The bark of $A$. augusta furnishes a very tough fibrous tissue, suited for manufacturing into cordage.

augŭstă . . . Purple . . 8, S. Ev. T. E. Indies . 1770 fastuōsă. : Purple : \&, S. Ev. T. N. S. W. : 1800 A вRōxY̌, Jussieu. From abros, delicate; referring to the involucrum. Linn. 5, Or. 1, Nat. Or. Nyctaginacea. Handsome trailing plants, multiplied by division, and grown in sandy peat. Synonyme: 1. Tricratus admirabilis.

mellifery . . White - 7, H. De. Tr. California . 1826 umbellată, 1 : Red : 4, H. Ev. Tr. California : 1823 A BRUzt, blunt, broken off.

A bru ptix-pInNatr. Pinnateleaves, terminating without an odd leaflet.

$\bar{A}$ BRŬs, Lirn. From abros, soft; in allusion to the delicacy of the leaves. Linn. 17, Or. 4, Nat. Or. Leguminosce. This pretty climbing species (Wild Liquorice) must have a strong heat to enable it to flower well. It delights in loam and peat, and is propagated readily from cuttings, in sand, under a glass. The roots have the property of the liquorice of the shops, while the seeds, if eaten in any quantity, produce violent headache.

precatórŭús . . Pa. pur, . 4, S. De. ch. W. Indies . 1680

AвŪTǍ, Aublet. From Abouta or Abuta, its name in Guiana. Linn. 22, Or. 10, Nat. Or. Menispermacea. An ornamental everoreen climber. Loam and peat, divisions. From the branches of this plant a drink is made by the natives of Cayenne, and used by them against obstructions of the liver.

raféscēns . . Grn. Yell. . . S. Ev. cl. Guiana . . 1820

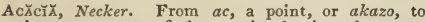
sharpen; many of the species having thorns or prickles. Linn. 23, Or. 1, Nat. Or. Leguminosa, Mimosec. Very ormamental plants of neat growth, and elegant foliage. All grow well in sandy loam and peat, and cuttings taken off at a joint root freely in sand, under a glass; portions of the strong roots planted in soil, in heat, leaving the points out, produce young plants; but the best plants are obtained from seed. The hardy species require to be slightly protected in serere weather. The bark of some species furnishes the tanning principle in a great degree, particularly $A$. aralica ; the bark of which is largely used in tanning leather, and is in India regarded as a powerful tonic. Gums are [i]

ACA ACA

yielded in considerable quantities by some species; and in India an intoxicating principle is obtained from other species. Synonymes: 1. A. acicularis. 2. Nimosa tortuosa. 3. A. strigosa. 4. $\boldsymbol{M}$. giraffa. 5. A. prostrata. 6. A. viscosa. 7. A. stolonifera. 8. M. marginata. 9. A. floribunda. 10. A. linearis. 11. A. mollissima. 12. A. impressa. 13. M. nigricans. 14. A. ambigua. 15. M. verticillata. 16. M. verticillata.

abietin: acahthocarpă $:$ Pa. red. acanthŏlōbä * White affinis alstå : : : Yellow amãră : : White amōenă $: \vdots$ Yellow āncēps : : Y Yellow angulătă : Yellow angustifatia : Yellow aräb̌că. : White arböreă: : : Yink arezósă: : armâtă . : Yellow Arrophala . asparagoidés âspèrà

Bancroftiānă:

. Yellow

bivenỏsă : Yellow

brachvacănthă

brasiliengis

brevifoliă : : Yellow

brêvǐpés : Yellow

Brōwnēī, 1 Yellow

Brunōnì $:$ Yellow

brexifilix: : Y Yellow

Burmanniānă, 2

cēsià : Yellow,

câfră : Y Yel, wht.

calamifolra : Yellow

canaliculată Yellow

caracasañă - Purple,

cassioĩdess . White

Cātéchú : Pa. yel.

centrophylla : White :

clirysōstīichy̆s:

ciliătă, 3

: Yellow

Yellow

concinnă : White

Coneordiānà :

conférta : Yellow

contortă: White

copallină : :

coriāceă : Yellow cornǐgĕră : : Pa. yell

coronillafrira, 4 .

Conırrantiână

crassicårpă : Yellow

crassiúscúlă : Y Yellow Cyclóprs : : Yellow daviesifolia : Yellow dealbătă : Yellow decipiéns: Yellow proment Yellow decurrēna. : Yellow
5, a. Ev. S. N. Holl.

S. Ev, S. N. Spain: 1899

S. Ev. S. S. Amer. : 1823

S. Ev. S. Acapulco 1825

5, G. Ev. S N. Holl. : 1822

S. Ev. T. E. Ind. : 1816

5, G. Ev, S. N. Holl. : 1820

5, G. Ev. S. N. Holl. : 1820

6, G. Ev. S. N. Holl. .1820

4, G. Ev. S. N. S. W. • 1816

S. Ev. T. E. Ind. . 1820

S. Ev, T. Jamaica : 1768

S. Ev. S, Caraceas: 1816

5, G. Ev. S. N. Holl. $: 1803$

G. Ev. T. Nepal. . 1818

- 5, G. Ev. S. N. Holl. : 1818

5, G. Ev. S. N. Holl. 1824

S. Ev. T. Jamaica

5, G. Ev. S. N. Holl.

. 1803

S. Ev. T. S. Amer. : 1824

S. Ev. T. Brazil : 1825

5, G. Ev. S. N. Holl. : 1820

G. Ev. S. N. S. W.

G. Ev. S. N. S. W. : 1796

5, G. Ev. S. N. Holl. : 1824

4, G. Ev. S. N. Holl. 1824

S. Ev. S. Ceylon : 1818

S. Ev. T. E. Ind. : : 1773

G. Ev. T. C. G. H. : 1800

5, G. Ev. S. N. Holl : 1823

G. Ev. S. N. Holl. 1824

S. Ev, S. Caraccas * 1817

S. Ev. T. 1820

S. Ev. T. E. Ind * : 1790

S. Ev. T. S. Amer. : 1800

S. Ev. T. Maurit. : 1824

. 5, G. Ev. S. N. Holl. - 1803

5, G. Ev. S. N. Holl. • 1824

5, G. Ev. S. N. Holl. 1818

S. Ev. S. E. Ind. . 1823

S. Ev. T. E. Ind. * - 1818

S. Ev. T. Brazil. : 1825

S. Ev. T.

. 5, G. Ev. S. N. Holl. : 1825

S. Ev. T. S. Amer. 1692

S. Ev. S. N. Africa 11817

G. Ev. T. Canaries : 1818

4, G. Ev. S. N. Holl. : 182

- 5, G. Ev. S. N. Holl. 1824

5, G. Ev. S. N. Holl. : 1824

6, G. Ev. S. N. Holl. : 1817

5, G. Er. S. N. Hioil. : 1823

4, G. Ev. S. N. Holl : 1803

5, G. Ev. S N. Holl.

- 5, G. Ev. S N. Holl. 1830 


\begin{tabular}{|c|c|c|c|c|c|c|c|}
\hline $\mathrm{ACA}$ & \multicolumn{3}{|c|}{$\mathrm{ACA}$} & \multicolumn{2}{|l|}{$A C A$} & \multicolumn{2}{|c|}{$A C A$} \\
\hline 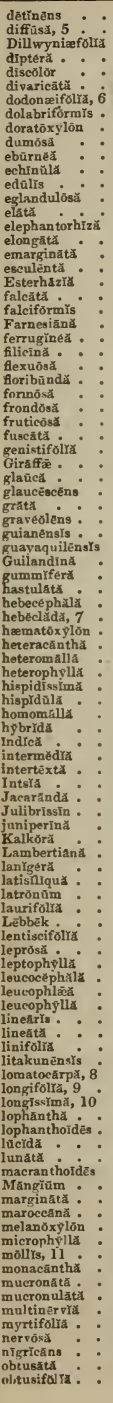 & 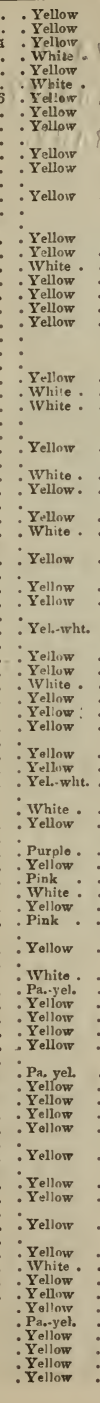 & 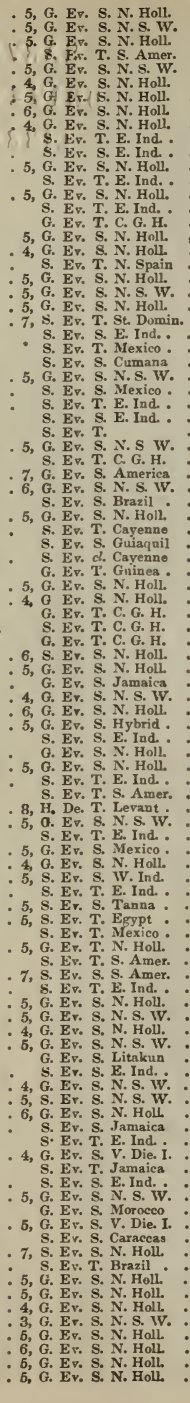 & 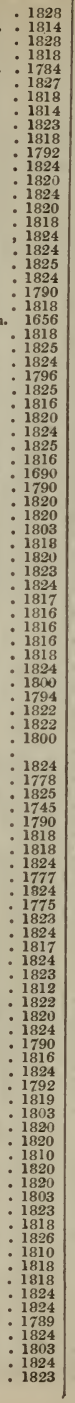 & 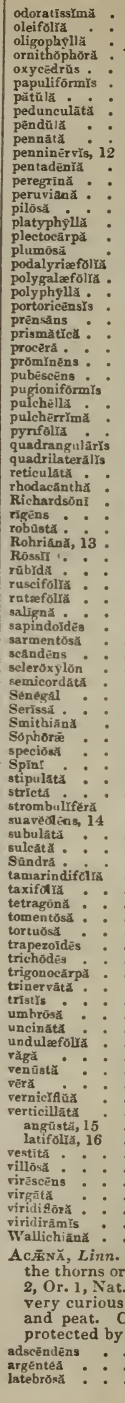 & 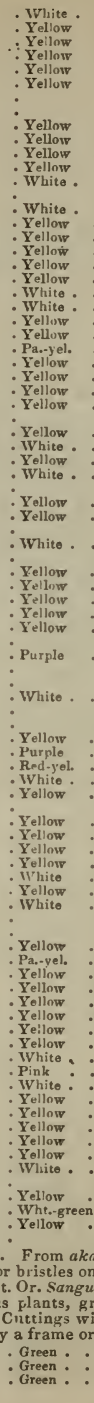 & 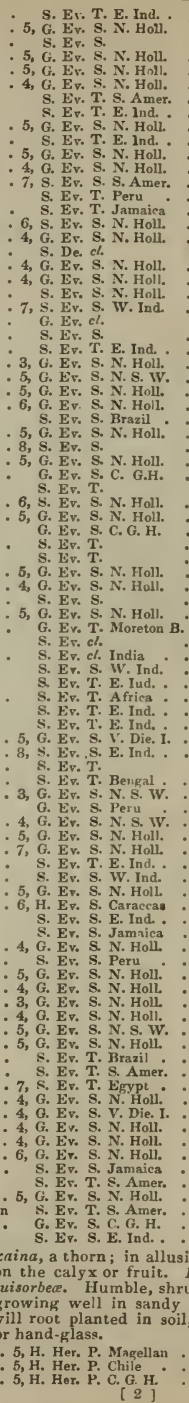 & 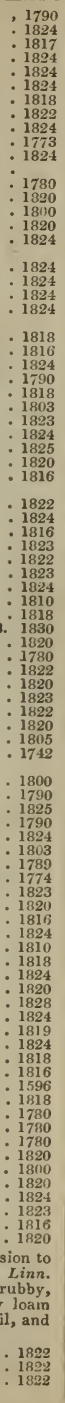 \\
\hline
\end{tabular}




\begin{tabular}{|c|c|c|c|}
\hline \multicolumn{2}{|l|}{$\mathrm{ACA}$} & \multicolumn{2}{|c|}{$\mathrm{ACE}$} \\
\hline 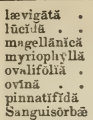 & $\begin{array}{l}: \text { Green } \\
: \text { Green } \\
: \text { Gellow } \\
: \text { Green } \\
: \text { Green } \\
: \text { Green } \\
\text { : Green }\end{array}$ & $\begin{array}{l}\text { 7, G. Her. P. Magell. } \\
\text { 5, H. Her. P. Falk. Is. } \\
\text { 5, G. Her. P. Magell. } \\
\text { 5, H. Her. P. Mendoza } \\
\text { 5, H. Her. P. Peru } \\
\text { 6, H. Her. P. N. Holl. } \\
\text { 5, G. Her. P. Chile. } \\
\text { 6, H. Her. P. N. Zeal. }\end{array}$ & $\begin{array}{r}1790 \\
: 1777 \\
: 1833 \\
: 1828 \\
: 1802 \\
: 1818 \\
: 1822 \\
: 1796\end{array}$ \\
\hline
\end{tabular}

ACĂLY̌ and aphe, touch. Linn. 21, Or. 1, Nat. Or. Euphorfor which see genus Abildgaardia-alopecuroĩdĕă, brachystăch y̆ă, caroliniānă, ciliütă, cuspiäată, diver-

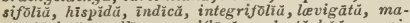
crostăch y̆ă, mollis, paucifloră, polystăchy̆ă, pruni-

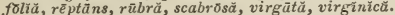

ACAN THOPHippí̀, Blum. The meaning of the name is not explained. Linn. 20, Or. 1, Nat. Or. Orchidacea. A. bicolor is a very curious and rather rare plant; in habit it mucli resembles $A$. geodorum, only it has pseudo-bulbs instead of tubers, while its rich flowers are produced from near the base of the shoots. A. striatum is described as being very much inferior. They will thrive well with the
same treatment as Bletia, provided they have a great deal of heat and moisture during the growing season.

bícölör • • Yel.-red . 6, S. Epi. Ceylon • . 1833 striătŭm : : Whito $: 6$, s. Epi. Nepal

sylhetense : : W White $\vdots 6$, S. Epi. Sylhet

1837

AcĀnthüs, Linn. From akantha, a spine, some of the species being spiny. Bear's Breech, Linn. 14, Or. 2, Nat. Or. Acanthacea. Coarse, yet stately, herbaceous plants, flourishing in almost any soil or situation, and are increased by divisions or by seed with great facility. A. mollis is said to be emollient; and it is conjectured that the leaf of this plant furnished the ancients with the elegant Acanthus leaf of their architecture.

carduifolin̆s . - Blue . . 8, G. Her, P. C. G. H.

hispānı̌cŭs : White . 8, H. Her. P. Spain

ilicifoliǔs : : S. Ev. S. E. Ind.

mollow : Pur wht 8 , Ev. S. E. I

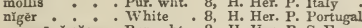

1816

spinôsús. . : Pur. wht., 8, H. Her. P. Italy . : 1629

ACÃrnă, Willäenow. Theophrastus describes a thistle under that name. Linn. 19, Or. 1, Nat. Or. Compositce. Insignificant plants, void of any known me-

rit. For culture aud propagation, see genus Abuta.

Synonyme: 1. Atraetylis cancelluta-cancellätä 1 , gummifera.

AcAulls, without a stem.

Accessary, something added to the usual number of organs.

ACCRETR, grown together.

AcCUMBENT, lying on something else.

Ač̃ , Linn. The word, in Latin, signifies vigorous, or sharp, and comes from ac, meaning a point, in Celtic. The name is used to designate this genus on account of the wood having formerly been much sought after for manufacturing into heads of pikes and lances. Linn. 23, Or. 1, Nat. Or. Aceracea. For the most part beautiful trees, of considerable size, generally employed in forming avenues or the back of shrubberies. The soil they delight most to grow in is open sandy loam, in which also, cuttings will strike freely in the open air; or by layers put down in the autumn they may be increased; but all the best plants are obtained from seed, which should be sown soon after gathering. From the sap of $A$. saccharinum the North Americans make a very good sort of sugar, in considerable quantities; other species possess, more or less, in the sap this saccharine property. Synonymes: 1. A. eriocarpon. 2. A. sempervirens. 3. A. spicatum. 4. A. striatum, hybridum.

nustrĭấm Green . 5, H. De. T. Austria

barbătūm : Grn. yel. : 4, H. De. T. N. Amer. : 1812 campéstrě . : Grn. yel. . 5, H. De. T. Britain collīnum * Grn. yel. 5, H. De. T. France . variegãtūm Grn. yel. 5, H. De. T. Britain

circinătūm . Grn. yel. 4, H. De. T. Columbia : 1827

. 5, H. De. S. Levant . 1752

dasycărpüm, $\mathbf{b}$ Grn, yel. 4 , H. De. T. N. Amer. : 1725

heterophȳllüm, 2 Grn. Yel. . 5, H. Ev. S. Levant : 1759

hybridūm . ?. Green. : 4, H. De. T. Amer. hyb. 1790

iberícūm : : Green : A H. De. T. Asiatic G. . 1826

lobătūm : $:$ Green: $:$ H. De. T. Siberia : : 1820

macrophȳllũm . Green . . 5, H. De. T. N. Amer. • 1826 montanúm, 3 . Grn. yel. . 4, H. De. T. N. Amer. : 1750 monspessulānūm Grn. yel. . 5, H. De. S. France . 1739 nĭgrüm . Grn. yel. 4 H. De T N Amer. 1810 oblongūm : : Grn, wht. ${ }^{\circ}$ F. Ev. T. Nepal : 1824 obtusătûm . Grn. yel. . 5, H. De. S. Hungary : 1825 obtusifóliüm . Grn. yel. . 5, H. De. S. Crete opalifóliúm : Grn. yel. . 5, H. De. S. France : 1823 opalŭs . . Grn. yel. . 5, H. De. T. Italy : 1752 palmătūm . Green . H. De T. Japan pennsylvānĭcừm, 4 Grn. yel. . 5, H. De. T. N. Amer. 1755 platanoidüs laciniātūm: : Grn. yel. 6 , H. De. T. Europe : 1683 Lobelyi : : Gra. yel. : 6, H. De. T. Europe variegātūm :Grn. yei. : 6, H. De. T. Europe Pseũdó. Flätănŭs Grn. yel. : 4, H. De. T. Britain purpũreúm . Purple :5, H. De. T. subobtūsūm Grn. yel. .5, H. De. T. Britu Vuriegatum. yel. 4 , H. De. Grn * Red * 4, H. De. T. N. Amer. 1656

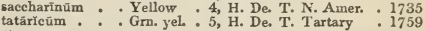
Áč̆RĀs, Robert Bronn. From a, privative, and keras, horn, on account of the spur being absent. Linn. 20, Or. 1, Nat. Or. Orchidaced. A very curious species, rather troublesome to cultivate. A light loamy soil, mixed with chalk, delights it most, and it can only be increased by seeds.

anthropð̋hơră . Green . . 6, H. Tu. P. England

secundifioră : Violet : 7, F. Tu. P. S. Eur. . 1829

Acerătīōm, Decandolle. Derived from $a$, privative, and keras, a horn; implying that the authers are destitute of horns. Linn. 11, Or. 1, Nat. Or. Elvocarpacea. An interesting species, grown in peat and loam; multiplied from cuttings.

opposit:fölrum . White . . S. Ev, S. Amboyna

1818

ACrrose, fine and slender, with a sharp point.

ACETAR1Ocs, any thing belonging to the salad tribe of plants.

ACETOse, sour, tart, acid.

AcHul.̄̄ă. Linn. Named after Achilles, a pupil of Chiron, and the first who used the plant so called in medicine, Linn. 19, Or. 2, Nat. Or. Asteracea, or Compositae. Showy, free-flowering species, succeeding well in any common soil, and readily increased by dividing the roots. A. tomentosa is, by its bright yellow flowers, well suited for ornamenting rock-work. The dried leaves of $A$. Ptarmica, powdered, and taken up the nostrils, excite sneezing. A. moschata is sudorific and acrid, and makes a wholesome food for cattle. Synonymes: 1. A. serrata. 2. A. ambigua. 3. A. filicifolia. 4. $A$. ochroleuca. 5. A. helvetica.

Yellow 7, H. Her P. Ierant ægyptiăcă : : Pa. yel. : 8, G. Ev. S. Levant Agérătūm * . Yellow * 9, H. Her. P. S. Eur. - * 1570 alhǐdda. : : PA yel. : White H. Her. P. Siberia: 1731 anglìcă, $1^{\circ}:$ : Wlite $: 8$, H. Her. P. Hritain angireá, 1 - White 8 , H. Her. P. anthemöidēs : Pa.yel. 7, H. Her. P. N. Amer. 1803 aspleniföliă : Pink : 7, H. Her. P. N. Amer. 1803 atráta : : : White : 8, H. Her. P. Austria : 1596 auriculata : : Yellow :7, H. Her. P. A. Minor: 1827 biserrătă : White 6, H. Her. P. Albania : 1820 chama melifoira White

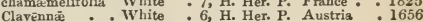
clavennnä : : White : 6, H. Her. P. Austria : 1656

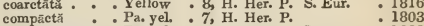
coronopifơllă : Pa. yel, : 7, H. Her. P. Levant . 1823 crétícă : White : 7, H. Her. P. Candia : 1739 cristãtă . White 7, H. Her. Y. Italy : 1784 crithmifora White $7 . \mathrm{H}$ Her P. Hungary 1804 decolōrāns : : Whit. yel. 7, H. Her, P. decümbēns : : Yellow 7, H. Ev. Tr. Kamtsch. 1816 Eupatơrǐum, 3 : Yellow : 7, H. Her. P. Casp. sho. : 1803 falcătă : : Pa. yel. : 7 , H. Her. P. Levant : 1739 Gerbērī : : Pa, yel. : 7, H. Her. Y. Siberia : 1821 glomerătă : Yellow 7, H. Her. P. Caucasus: 1818 grandiflöră: White 7, H. Her, P. Caucasus 1818 Herba-rotă : White : 7, H. Her. P. France . 1640 holosericés : White : 8, H. Her. P. Panisssus . 1817 imbricătă : Yellow 7 H. Her P. Persia: 1818 impătiēns : Yellow * 7. Her P. Persia : 1759 impatiens : lanătä 1 : White ligūsțeă $:$ White lingulati: : White macrophyliax White micrānthă Yellow microphylla: : White Millefoliūm: : White mengơlíå : : Whito

7 , H. Her. P.

7 , H. Her. P. Tauria : 181

7, H. Her. P. Italy - I791

7, H. Her. P. Hungary .1815

7, H. Her. P. Italy * . 1710

8, H. Her. P. Levant . 1805

8 H. Her P. Sprin : 1840

8, H. Her. P. Britain

7, H. Her. P. Siberia . : 1818 


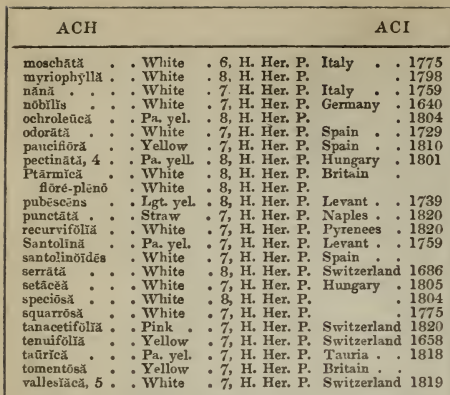

Bannătǐcă, dentifera, distans 2, dubia, heterophy̆llă, intermedia, magna, Millefolĩum rubrum, montana, polyphȳllä, rosea, stricta.

Áchlrs, Decandolle. From achlys, meaning obscure, in allusion to the obscurity of the genus. Linn. 13,

Or. 1, Nat. Or. Berberacea. A tuberous-rooted plant, of little beauty, multiplied by cuttings, and grown in sandy loam.

triphyllă . . White . . 5, H. Ev. T. N. Amer. 1827

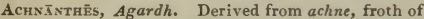
the ocean, and anthos, flower. Linn. 24, Or. 7, Nat. Or. Algue. Curious aquatic productions, said to separate by degrees into fragments: between every articulation or joint is one or more crystalline points-brěvǐpēs, longǐpēs, unipunctätă.

Achnodōnōon, Palisot de Beauvois. From achne, a chaff, or husk, and odon, a tooth. Linn. 3, Or. 2 , Nat. Or. Graminaced. Very insignificant plants, of the easiest culture, for which see Abildgaardia. Synonyme: 1. Phalaris bellardi. Bellārdī I. tènūeè.

AcнRĀs, Linn. The Greek name for the pear, or from ac, meaning a point, in Celtic, in allusion to the stiff spines with which the tree is covered. Linn. 5, Or. 1, Nat. Or. Sapotaceo. These plants, in this country, possess little merit, but in the West Indies the fruit produced by some of the species is much esteemed. $A$. sapota yields a fruit as large as a quince, the flesh of which is as yellow as a carrot; it has an agreeable smell, and very rich taste; the seeds, two in number, are aperient and diuretic; rich loamy soil; cuttings.

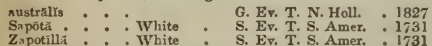

ACHYRĀNTHĒs, Linn. Achuron, chaff, and anthos, a flower, in allusion to the chaffy nature of the floral leaves. Linn. 5, Or. 1, Nat. Or. Amarantacea. Uninteresting species, of easy culture. A. pörrigēns is the most handsome species.

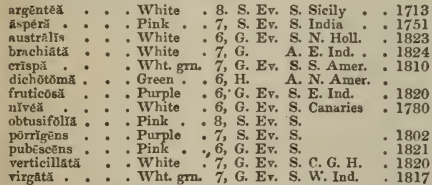

AchYRŏñ̆ Willd. From achuron, chaff, in allusion to the chaffy hairs on the branches and leaves. Linn. 17, Or. 4, Nat. Or. Leguminosa Papilionacea. The species is of easy culture.

villosă . . . Yellow • 7, G. Ev. S. N. Holl . 1819

Acrýr̆́rŏ́ŭs, D. Don. Achuron, chaff, anc̀ phoreo, to bear; the receptacle being chaffy. Linn. 19, Or. 1, Nat. Or. Composita. Mere weeds, of the easiest culture and propagation. Synonymes: 1 Hypocharis helvetica. 2. $\boldsymbol{H}$. maculati. 3. $\boldsymbol{H}$. radicata-helvêtícă 1 , maculätă 2 , radicātă 3 .

A c1̄̄NTHŬs, Robert Bronin. From akis, a point, and anthos, a flower; in reference to the bristly tips of

the flower. Linn. 20, Or. 1, Nat. Or. Orchidacea. Brown, small-flowered, tuberous-rooted plants ; multiplied by divisions, and grown in loam and peat. caudătŭs . - Brown * 5, G. Ev. Tu. N. Holl. 1824 exsértǔs : : Brown : 6, G. Ev. Tu N. Holl : 1329 fornicātŭs: : : Brown : 5 , G. Ev. Tu. N. Holl. : 1822 Aсісйнрнӑ, Jussieu. From akis, a point, and karphe, palea; on account of the palea being spiny. Linn. 19, Or. 4, Nat. Or. Calyceracea. A curious dwarf species, succeeding in peat and loam; propagated from divisions.

AcĭcŭL $\mathbf{A} \mathbf{R}$, needle-shaped.

Acıōtōn, Swartz. From akidotos, pointed ; in allusion to the stinging hairs on the leaves. Linn. 2!, Or. 9, Nat. Or. Euphorbiacea. A worthless species, easily grown and propagated :- ârēns.

ACINĀCǏ́ōRM, scimitar-like shaped.

Acıōtřs, D. Don. From akis, a point, and ous, an ear; in allusion to the petals. Linn. 10, Or. 1, Nat. Or. Melastomacece. Pretty species, particularly aquatica ; may be propagated and grown the same as the genus Melastoma. Synonymes: 1. Rhexia aquatica. Melastoma aquatica. 2. Melastoma discolur.

aquátică, 1. . Wht red 6, S. Ev. S. S. Amer. - 1793 discolor, 2: : Wht. red 6, S. Ev. S. Trinidad : 1816

Áčs, Salisbury. Taken from Acis, a shepherd, the son of Faunus. Linn, 6, Or. 1, Nat. Or. Amaryllidacea. This is a genus of pretty, dwarf, bulbousrooted plants, delighting in sandy soil, and multiplied by offsets. Synonymes: 1. Leucojum autumnale. 2. L. roseum. 3. L. tricophyllum.

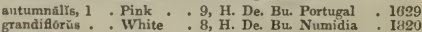

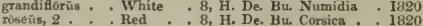

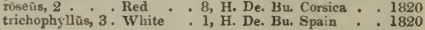

ACIsanthēer,$J$ ussieu. Taken from akis, a point, and anthos, an anther, on account of the anthers being pointed. Linn. 10, Or. 1, Nat. Or. Melastomacere. A curious evergreen shrub, for propagation and culture may be referred to Melastoma. Synonyme: 1. Rhexia acisanthera.

quadrătă, 1 . * S. Ev. S. Jamaica 1804

ACMADẼĬ aden, a gland; in allusion to glands on the anthers. Linn. 5, Or. 1, Nat. Or. Rutacea. A handsome little species, for culture and propagation, see Diosma. Synonyme: 1. Adenandra tetragone.

tetragúnă, 1 . . White . 6, G. Ev. S. C. G. H. - 1798 Acsêtı̌̆, Rich. Taken from akme, a point; in allusion to the pricking taste of the foliage. Linn. 19 Or. 2, Nat. Or. Composita. Uninteresting dwarf, trailing species; for culture, \&c., see genus Galin. sogea. Synonymes: 1. Spilanthes Acmella. 2. S. repens.

occidentálís - Yellow . 7, H. Tr. A. S. Amer. - 1825 repenns, 2 : : Yellow : 7. H. Tr. A Carolina : 1818

Mauriłiānă, 1.

A çї́ñ , Decandolle. Derived from Acmena, a nymph of Venus. Linn. 12, Or. 1, Nat. Or. Myrtacea. An ornamental species; for culture, \&c., see Tris tanea. Synonyme: 1. Mctrosideros floribunda.

floribūndx, 1 . White . 7, G. Ev. S, N. Holl, 1788

$\bar{A}$ CNĬDĂ, Linn. Taken from $a$, privative, and knide, nettle; the plant being like a nettle, but without stings. Linn, 22, Or. 6, Nat. Or. Chenopodiacea. An uninteresting species; for culture, \&c., see Cannabis:-cannabĩnă.

A CōnĪTŪM, Tournefort. The name is given on account of some species heing found plentiful about Acone, a town in Bithynia. Linn. 13, Or. 3, Nat. Or. Ranunculacee. Ornamental, tall, free-flowering, very hardy plants, succeeding well under the shade of trees; increased by division or by seeds. All the species are to be dreaded, being highly poisonous. $A$. napellus, and cammarum, are diuretic, and acrid in a high degree. The aconite has, however, become of great service in many very troublesome disorders. In Sweden favourable operations have been effected by an extract of the juice of the leaves of A. napellus in cases of rheumatism and intermittent fevers, applied in doses of from a grain to a scruple twice a day or of tener. A much larger dose has also been safely administered. Synonymes: 1. A. inclinatum. 2. 


\begin{tabular}{|c|c|c|c|}
\hline $\mathrm{ACO}$ & \multicolumn{3}{|c|}{$\triangle \mathrm{CO}$} \\
\hline \multicolumn{4}{|c|}{$\begin{array}{l}\text { A. altissimum. 3. A. pyrenaicum. 4. A. strictum. } \\
\text { 5. A. pallidum. 6. A. Cammarum. 7. A. Napcllus } \\
\text { pubescens. 8. A. laxum. }\end{array}$} \\
\hline acuminatūm & . Blue & [u. Switz. & . 1819 \\
\hline acūtūm . & - Blue . & . 6, H. De. Tu. S. Eur. & . 1821 \\
\hline albriciūm . & - White & . 6, H. De. Tu. Europe & . 1824 \\
\hline àlbūm & . White & - 7, H. Her. P. Levant & . 1752 \\
\hline $\begin{array}{l}\text { amǣnūm . } \\
\text { ampliftorùm : }\end{array}$ & . Blue . & - 6, H. De. Tu. S. Eur. & \\
\hline $\begin{array}{l}\text { ampliflorũm } \\
\text { angustifolrūm }\end{array}$ & m: Blue : & $\begin{array}{l}\text { 6, H. De. Tu. Austria } \\
\text { 6, H. De. Tu. Europe }\end{array}$ & . 1823 \\
\hline Antloora & - Pr. yel. & $: 7$, H. Her. P. Pyrenees & \\
\hline Antlıoroĩdéeûm & im, i Pa. yel. & . 7, H. Her. P. Jura . & . 1821 \\
\hline austrälé $\cdot$ : & - Purple & - 7, H. Her. P. Denmark & .1821 \\
\hline Barbatum & î̀m Blue ${ }^{*}$ Pa, & $\begin{array}{l}\text { 6, H. Her. P. Siberia } \\
\text { 6, H. De. Tu, Europe }\end{array}$ & $\begin{array}{l}1807 \\
.1824\end{array}$ \\
\hline biflōrūm . & - Pa. blue & - 6, H. De. Tu Siberia & .1817 \\
\hline $\begin{array}{l}\text { Brăunñ } \\
\text { callybơtrýón }\end{array}$ & $\begin{array}{l}\text { Blue : } \\
\text { Blue : }\end{array}$ & $\begin{array}{l}\text { 7, H. De. Tu. Switzerl. } \\
\text { 6, H. De. Tu. S. Eur. }\end{array}$ & 1821 \\
\hline Cămmărǘm . & - Purple & 8, H. De. Tu. Austria : & 1752 \\
\hline earpaitǐcũm . & - Purple & . 7 , H. Her. P. Carp. mo. & \\
\hline cอยrnŭ & - Blue . & . 7, H. De. Tu. Switzerl. & .1800 \\
\hline flexicaūlẻ . & - Blue & . 7, H. De. Tu. Switzerl. . & 319 \\
\hline $\begin{array}{l}\text { paūciflōrūm } \\
\text { ramósũm . }\end{array}$ & m . Blue. & - 7, H. De. Tu. Switzerl. . & 1821 \\
\hline ramósūm : & - Blue . & - 7, H. De. Tu. & \\
\hline $\begin{array}{l}\text { chinnĕnse : } \\
\text { Clũsĩi. }\end{array}$ & : Blue : & - 9, H. Her. P. Ch & \\
\hline clùsĩi commutătùm $^{*}$ & $\therefore$ : Blue : & $\begin{array}{l}\text { 7, H. De. Tu. Switzerl. } \\
\text { 6, H. De. Tu. S. Eur. }\end{array}$ & $\begin{array}{l}1819 \\
1823\end{array}$ \\
\hline Cynōetónūm, & 2 . Pa. yel. & 7, H. Her. P. France & $: 1820$ \\
\hline Decandölli. & - Pa yel. & . 7, H. Her. P. Siberia & . 1823 \\
\hline decōrûm * & - Blue . & . 6, H. Her. P. Pyrenees. & - 1824 \\
\hline delphinifolrūm & im . Blue & . 6, H. De. Tu. N. Amer. & 1804 \\
\hline elātūm . & - Biue & . 6, H. De. Tu. Europe . & . 1822 \\
\hline ẽminnēns • • & . Blue . & . 6, H. De. Tu. Europe & - 1800 \\
\hline moñ • & - Blue & . 6, H. De. Tu. Eu & \\
\hline eũlōphûm & - Pa, yel. & . 6, H. Her. P. Ca & . 1821 \\
\hline tächyon & - Blue . & . 6, H. De. Tu. Eu & . 1824 \\
\hline exaltātủ̆m & - · Blue & . 6, H. De. Tu. Siberia & . 1819 \\
\hline flāecǐdūm & - Blue & . 7, H. De. Tu. Siberia & . 1822 \\
\hline Florkeãnūm & - Blue & - 7, H. De- Tu. Sib & - 1822 \\
\hline $10 \mathrm{r}$. & - Blu. wht & 6, H. De. Tu. S & 01 \\
\hline formősūm . & . Blue - & - 6, H. De. Tu. S. & - 1824 \\
\hline Fūnkñ . & - Blue & - 6. H. De. Tu. Sy & . 1825 \\
\hline เซ็น̄m . & - Blue & . 6, H. De. Tu. Hu & - 1 \\
\hline gibbơsũm . & - Blue & . 7, H. De. Tu. Ca & 18 \\
\hline Gmelin & . Blue . & - 7, H. De. Tu. Siberia . & . 1821 \\
\hline grăcīlé * * & - : Blue : & - 7, H. De. Tu. Sv & .1821 \\
\hline $\begin{array}{l}\text { Erantiflörûm } \\
\text { Hăllēerì . . }\end{array}$ & Pa. yel. & - 7, H. Her. P. Ju & \\
\hline $\begin{array}{l}\text { Hăllerì } \\
\text { bícolor : }\end{array}$ & : Blue : & . 6, H. De. Tu. S & . 1821 \\
\hline hamatūum & - Pa. blue & $\begin{array}{l}\text { 6, H. De. Tu. Switzerl. } \\
\text { 7, H, De. Tu. Italy }\end{array}$ & \\
\hline gnum : & : Purple & $\begin{array}{l}\text { 7, H, De. Tu. Italy } \\
\text { 7, H. De. Tu Switzerl. }\end{array}$ & - 1810 \\
\hline multĩfî̉ ūm & m Purplo & $\begin{array}{l}\text { 7, H. De. Tu. Switzerl. } \\
\text {. }\end{array}$ & .1819 \\
\hline . . . & - Blue & 6, H. De. Tu. S. Eur. & $: 1823$ \\
\hline dūm . & - $\mathrm{P}$ & . 6, H. Her. P. Siberia & $: 1823$ \\
\hline pII & . Blue & - 6, H. De. Tu. Carinthia . & . 1823 \\
\hline İtūm • • & - Blue & - 7, H. De. Tu. & . 1821 \\
\hline èdrūm & - Blue & - 7, H. De. Tu. & - 1820 \\
\hline & - Blue & - 6, H. De. Tu. Eu & . 1822 \\
\hline$i \cdot \cdot$ & & - 7, H. Her. P. Austria . & 00 \\
\hline & & H. De. Tu. Jap & - \\
\hline $\begin{array}{l}\text { gerǔlétìm } \\
\text { lleănum . }\end{array}$ & $\begin{array}{l}\text { Blue } \\
\text { - Blue }\end{array}$ & - 7, H. De. Tu. J & \\
\hline nะ்กัm & $\therefore$ Blue : & $\begin{array}{l}\text { 6, H. De. Tu. S. Eur. } \\
\text { 6, H. De. Tu. S. Eur. }\end{array}$ & - 1820 \\
\hline Kôhlêri . & - Blue & $\begin{array}{l}\text { 6, H. De. Tu. S. Eur. } \\
\text { 6, H. De. Tu. Europe }\end{array}$ & . 1822 \\
\hline sũm . & - Blue & - 7, H. De. Tu. Switzerl. & $: 1820$ \\
\hline la & - Blue & . 6, H. De. Tu. S. Eur. & .1820 \\
\hline ckīi, 3 & - $\mathbf{P}$ & - 7, H. Her. P. Py & - 1 \\
\hline im. & & - 7, H. Her. P. Switzerl. & \\
\hline im: & - Blue & . 6. H. De. Tu. S. Eur. & - 1820 \\
\hline $\begin{array}{l}\text { Eanthüm : } \\
\text { ieidūm }\end{array}$ & : Pa,yel. & $\begin{array}{l}\text { 6, H. De. Tu. } \\
\text { 7, H. Her. P. Eu }\end{array}$ & - 1823 \\
\hline ūm : & - Purple & $\begin{array}{l}\text { 7, H. Her. P. Europe } \\
\text { 7, H. Her. P. Alp. Eur.. }\end{array}$ & - 1821 \\
\hline llūm & $\mathrm{m} \cdot \mathrm{P}$ & ; 7 , Her. P. & . 1596 \\
\hline & - To & - 7, H. De. Tu. K & . 1 \\
\hline & & . 6, H. De. Tu. & 1821 \\
\hline & $\cdot \mathbf{B}$ & . 6, H. De. Tu. Swi & \\
\hline vǐcūm & - & Molda & \\
\hline & - Blue : & - 7, H. De. Tu. & - 1 \\
\hline apellius . & & $\begin{array}{l}\text { 6, H. De. Tu. Europe } \\
\text { 6, H. De. Tu. Switzerl. }\end{array}$ & - 1596 \\
\hline & White & $\begin{array}{l}\text { 6, H. De. Tu. Sv } \\
6, \text { H. De. Tu. Sv }\end{array}$ & \\
\hline & - Plue & $\begin{array}{l}\text { H. De. Tu. Sw } \\
\text { H. De. Tu. Sil }\end{array}$ & \\
\hline$t \bar{m} \mathbf{m}$ & $\begin{array}{l}\text { - Purple } \\
\text { Pa. yel. }\end{array}$ & $\begin{array}{l}\text { H. De. Tu. Siberia } \\
\text { H. Her. P. Caucasus . }\end{array}$ & 18 \\
\hline aūm & - Blue . & $\begin{array}{l}\text { 7, H. Her. P. Caucasus } \\
\text { : 7, H. De. Tu. Europe }\end{array}$ & $\begin{array}{l}1823 \\
1799\end{array}$ \\
\hline gẽnsê, & - Blue & $\begin{array}{l}\text { - 7, H. De. Tu. Europe } \\
\text { - 6, H. De. Tu. S. Eur. }\end{array}$ & $\begin{array}{l}1799 \\
1822\end{array}$ \\
\hline & & - 6, H. De. Tu. Switzerl. & 1825 \\
\hline & & ler. P. N. Amer. & \\
\hline & & $T$ Turne & \\
\hline & & e. Tu. Europe & - 1823 \\
\hline โล̄กùm • & - Pa vel. & H. De. Tu. Europe & \\
\hline $\begin{array}{l}\text { Pallásn } \\
\text { panieulātũm }\end{array}$ & $\begin{array}{l}\text { Pa. yel. } \\
\text { Pa. blue }\end{array}$ & $\begin{array}{l}\text { 7, H. Her. P. Siberia } \\
7, \text { H. De. Tu. France }\end{array}$ & $\begin{array}{l}1821 \\
1815\end{array}$ \\
\hline cãtūm . & - Blue . & 6, H. De. Tu. Switzerl. & 1825 \\
\hline tūm & - Blue & . 7, H. De. Tu. Siberia & 1821 \\
\hline & Blue & H. De. Tu. Europe . & - 1824 \\
\hline renă̌eūm • & Yellow & H. Her. P. Pyrenees & \\
\hline $\begin{array}{l}\text { recognitūm : } \\
\text { réetũm }\end{array}$ & - Plue yel. & $\begin{array}{l}\text { H. De. Tu. } \\
\text { H. Her. P. Europe }\end{array}$ & 18 \\
\hline & & & \\
\hline
\end{tabular}

ACO

ACR

rĭğdũm . . Blue . . 6, H, De. Tu. Switzerl. . 1825

grandiflōrum : Blue : 6 , H. De. Tu. Siberia : 1826

rostrátĩm : Blue : 7, H. De. Tu. Switzerl. : 181

pilosiusscưlum,6Purple : 7, H. De. Tu. Carpa. mo. 1800

rabieuñũum . Purple . 7, H. Her. P. Siberia 1819

rhynchåntlıum . Pur. blu. 7, H. De. Tu. Switzerl. 1821

bicőlör * . Wht. blu. 7, H. De. Tu. Switzerl. 1819

Schleichēri, 7 . Blue * 6, H. De. Tu. Switzerl. 1821

semigaleatûm. Blue: 6, H. De. Tu, Siberia 1818

septentrionalé : Blue : 7, H. Her. P. N. Eur. : 1800

speciōsūm - Blue : 7, H. De. Tu. 1823

Sprengèlñ : Blue : 6, H. De. Tu. Europe : 1824

squarrōsūm * Blue * 6, H. De. Tu. Siberia 1822

strictūm

taūrīcûm, $8:$ : Blue: $: 6, \mathrm{H}$. De, Tu. Tarria: 1752

theriơplrǒnûm : Pa. yel. 6, H. Her. P. Europe : 1824

tortuôsûm - Pur. blue 6, H. De. Tư : 1812

tõxǐcūm * - Blue * 6, H. De. Tu. Switzerl. : 1825

tragōetōnūm $\quad$ ra. yel. 7, H. Her. P. Switzerl. 1822

unbrósūm : Blue * 7, H. De. Tu. Switzerl. 182

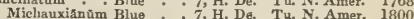

variegătūm . Pur. wht. 7, H. De. Tu. S. Eur. . 1597

albiflörūm : Pur, wht. 7, H. De. Tu. S. Eur. * 1597

bicolor. : Wht. blu. 7, H. De. Tu. Switzerl. 1821

corn̆léñm . Blue . ‥ H. De. Tu. Switzerl. 1819

venūstūm - Blue : 6. H. De. Tu. Switzerl. . 1823

versǐcó̄or - Blu, yel - 8, H. Her. P. Siberia . 1820

virgătūm . . Blue . 6, H. De. Tu. S. Eur. . 1822

rolubilé: : Blue: 7, H. De. Tu, siberia : 1799

Vulpária : : Pa.yel. : 7, H. Her. P. Alp. Eur. 1821

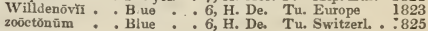

ĂcŏRŭs, Linn. Derived from $a$, privative, and kore, pupil of the eye, in reference to its medical properties. Linn. 6, Or. 1, Nat. Or. Acoracea. Marshy plants, of the easiest culture. $A$. Calamus is extremely useful, and Linnæus say's, the roots powdered, might supply the place of foreign spices; it is very aromatic and stimulant.

Călămuัs • . Apetal. . 6, H. Aq. P. Britain

gramineǔs : : A petal. 2, H. Her. P. Ohina

graminěŭs : : A petal. : 2, H. Her. P. Ohina
terrëstris : A petal. 6, H. Her. P. China

1796

Acremбкі̃̄ , Link. Derived from akremon, a branch, in reference to the clustered thecr. Linn: 24, Or. 9, Nat. Or. Fungi. Very curious plants, found growing generally upon dead sticks-fūscūm, verticillatum.

$\bar{A} \mathbf{C R} \breve{E}$, sharp, pungent.

AсRосйрнĂLUs, Bentham. The name is derived from akron, summit, kephale, head; on account of the flowers being on the top of the branches. Linn. 14, Or. 1, Nat. Or. Labiata. A plant of little beauty; increased from slips, and grown in sandy loam. Synonyme: Lumnitzera capitata.

capitătŭs, 1 . . White . . 7, H. A. China . . 1806

A crocŏmॅ̆, Martius. The leaves are in tufts, hence the derivation of the name, akros, top, and kmme, tuft. Linn. 2], Or. 6, Nat. Or. Palmacea. This genus comprehends a portion of those majestic species of palms which, by their towering stems and gigantic foliage, soar to the height of thirty or forty feet, and give a feature of exguisite grandeur to the character of the countries they inhabit. They prefer a light sandy loam; and to grow them well, an atmosphere very moist and warm is indis. pensable. They are increased from suckers. $\boldsymbol{A}$. aculeata is reported to have a trunk the size of a man's body, and the leaves prickly and longer than those of the Cocos. It produces a fruit the shape and size of a crab, with a thin, sweetish, astringent pulp, within which is a nut inclosing a white sweet eatable kernel. Synonymes: 1. Cocos aculeata. 2. C. fusiformis. 3. Bactris glohosa-minor.

\section{aculeăta, 1}

fusiformis, 2

globōsă

guianensis

mơrriñù 3

sclerocărp
tenuifolìi mit, and glochin, spear point. Linn. 21, Or. 1, Nat. Or. Chenopodiacece. An insignificant species, grown in any common soil, and increased from suckers. Synonyme: 1. Amaranthus Acroglochin-chenopodiỡidés 1.

A CROPERA, Lindley. From acros, the extremity, and pera, a small sack, because of the saccate appen. 
dage at the apex of the labellum. Linn. 20, Or. I, Nat. Or. Orchidacea. A very singular and rather pretty plant, producing its pale yellow and spotted purple flowers in pendent racemes. For culture and propagation, see Stanhopea. Synonyme: 1 . Maxillaria galeata.

Loddigesii . . Y Yel. \& spot. 8, S. Epi. Mexico . . 1828 Acrospīrmüu, Tode. Derived from akros, summit, and sperma, seed, in reference to the tumids on the apex of the plant emitting sporules. Linn. 24, Or. 9, Nat. Or. Fungi. Interesting and minute productions, existing as parasites upon decayed vegetables-comprëssüm, cornũtũm.

Acrosporrĩô, Nees. This word is taken from akros, top, and spora, sporule, implying that the latter occupies the summit of the filaments. Linn. 24, Or. 9, Nat. Or. Fungi. Minute species found upon the leaves of grasses and rotten oranges-fasciculätūm, moniliỡà̃és.

Acrostíchūm, Linn. Supposed to refer to the beginning of a verse, on account of the back surfaces of the leaves being so lined as to resemble in some degree the commencement of lines in poetry. Linn. 24, Or. 1, Nat. Or. Polypodiacea. Very interesting species of tropical ferns, delighting mostly in a mixture of loam and peat. They may be increased either by dividing at the roots, or by seed. $A$. a ureum sometimes grows to the height of four, five, and even six feet. A. alcicorne is a curious species common in our plant houses.

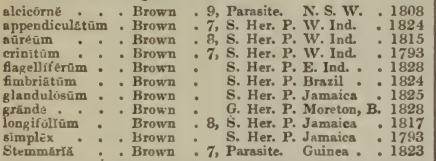

ACRŎTRÍchẽ, Robert Bronn. Derived from akros, a point, and thrix, hair; in reference to the hairy corolla. Linn. 6, Or. 1, Nat. Or. Epacridaced. Very ornamental but dwarf species; for culture and propagation, see Achyronia.

cordati
divaricata : : White ovaliforră : : Whito : 5, G. Ev. S. N. Holl : 1823

Acr $\bar{\AA} \tilde{A}, L i n n . ~ A k t a r a$, an elm, in allusion to the resemblance the leaves bear to those of the elm. Linn. 13, Or. 1, Nat. Or. Ranunculaced. Dwarf species of little beauty, for culture \&c., see Aconitum. Synonymes: 1. A. brachypetala, Americana. 2. A. brachypetcla, rubra.

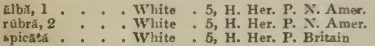

Activocīrpuัs, Robert Brown. The derivation of the naine is froin aktin, ray, and karpos, fruit, in allusion to its radiated appearance. Linn. 6, Or. 4, Nat. Or. Alismacea. Interesting floating aquatics, thriving only in water, or in moist situations. $A$ minor is a native of New South Wales, and grows well in a pot of sandy peat immersed in water; seeds. Syncnymes: 1 Alisma Damasonium, Damasonium stcllatum.

\section{Damasŏnน̌ŭ, 1 . White . 7, H. Aq. P. England}

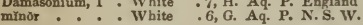

Actinochlöă, Willd. The name is derived from aktin, a ray, and chloa, grass, resemblance to grass. Linn. 3, Or. 2, Nat. Or. Graminea. Weeds of the simplest culture. Synonymes: 1. Chondrosium procumbens. 2. C. tenue.-Hirsütă, procumbens 1; prostrata, těnŭĭs 2.

Aстıхо̆мӗRĩs, Nuttall. The name is taken from aktin, ray, and meris, part; alluding to the radiated appearance peculiar to these plants. Linn. 19, Or. 3, Nat. Or. Compositce. Ornamental species; for culture, \&c., see Calliopsis. Synonymes: 1. Coreopsis alata. 2. C. procera. 3. C. alternifolia, Verbesina Coreopsis.

alătă, 1 . Yellow helianthrides : Yellow procẽrå, 2 . Yellow

7, H. Her. P. S. Amer. , 1803 7, H. Her. P. S. Amer. : 1825 9, H. Her. P. N. Amer. : 1766 squarrósă, 3 : : Yellow : 7, H. Her. P. N. Amer. : 1640

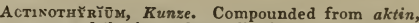
a ray, and thyrion, a door, alluding to the radiated integument of the sporidere, Linn. 24, Or. 9, Nat. Or. Fungi. The species appears in the early part of the year upon the culms of grasses, and is orbi. cular, and almost black.-Gräminis.

Acrinōrǔs, Labillar. Derived from actinotos, radiated, in reference to the rayed appearance of the involucrum. Linn. 5, Or. 2, Nat. Or. Umbellifera. An interesting plant with curious leaves, increased by dirisions, and grown in loamy soil. Synonyme: 1. Eriocalia major,

Helin̈nthI . . White . 6, G. Her. P. N. Holl. . 1821 Acutangur.ar, having sharp, or acute angles:

Acumasars, cuspidate, having a long tapering point.

Acure, terminating abruptly in a sharp point.

Acrsors, Persoon. The name is supposed to be the Greek name of a balsamic plant. Linn. 14, Or. 1, Nat. Or. Labiato. Most of the species are handsome, particularly $A$. vulgaris. For culture \&c., see Thymus. Synonymes: 1. Thymus grandiflorus. 2. T. herba-baroni. 3. T. acynoides, heterophyllus. 4. T. suaveolens. 5. T. acynos.

alpintis . . Purple . 8, G. B. Austria . 1731 grandiftōrǔs, 1 : Purple : 7, H. Tr. B. Austria: 1810 graveolens : Purple :7, H. Ev. S. Crimes : 1820 herbatbaroni, 2 : Purple : 7, H. Ev. S. Corsica : 1820 heterophyllus, 3 . Purple : 6. H. A. Italy : 1822 patavinŭs . . Flesh . 7, H. B. S, Eur. . : 1776

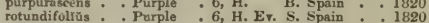

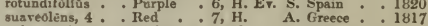

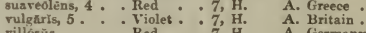
villósũs : : : Red : : 7, H. A. Germany : 1817

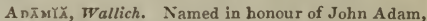
M.D., of Calcutta. Linn. 14, Or. 2, Nat. Or. Saxifrasacee. An ornamental species cultivated in peat and loam, and propagated from cuttings in sand, under a glass.

cyăneă.

6 s. Ev. S. E. Ind. . . 1829

A DA M's needle. See Yucca.

A Dansōnīă, Linn. Dedicated to Michael Adanson, a celebrated French botanist. Linn. 16, Or. 8, Nat. Or. Sterculiacea. The largest tree in the world is the Adansonia or Baobat-tree, the trunk of which has been found with a diameter of thirty feet; but its height is not in proportion. "It is emollient and mucilaginous in all its parts. The leaves dried and reduced to powder constitute Lalo, a favourite article with the Africans, which they mix daily with their food, for the purpose of diminishing the excessive perspiration to which they are subject in those elimates, and even Europeans find it serviceable in cases of diarrhoea, fevers, and other maladies. The fruit is, perhaps, the most useful part of the tree. Its pulp is slightly acid and agreeable, and frequently eaten; while the juice is expressed from it, mixed with sugar, and constitutes a drink, which is valued as a specific in putrid and pestilential fevers."-Hooker, Bot. Mag. 2792. It delights in rich loamy soil, and cuttings of the large ripened wood, strike best in a pot of sand, in a moist heat under a glass.

digitat . . White S. Ev, T. Guinea , 1724 ADDER's-ToNour. See Ophioglossum.

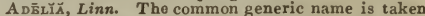
from the minute parts of fructification, and is derived from $a$, privative, and delos, visible. Linn. 22, Or. 13, Nat. Or. Euphorbiacee. Ornamental shrubs, cultivated in peat and loam, and increased from cuttings.

Acidatōn - . Grn, wht. . 6, S. Ev. S. Jamaica . 1768 Bernădra: : Green: 7, S. Ev. S. Jamaica: 1763

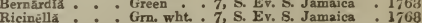

A DRXÃDR , Willd. The derivation is from aden, a gland, and aner, a male, or stamen, in allusion to the appearance of the stamens. Linn. 5, Or. 1, Nat. Or. Rutacer. Berutiful little shrubs with a pleasing appearance, succeeding well in sandy peat, mixed with a little turfy loam, and propagated easily by cuttings from the young branches planted in a pot of sand, under a glass, but not plunged. Synonymes: 1. Diosma linearis. 2. D. marginata. 3. D. villosa.

[6 6 


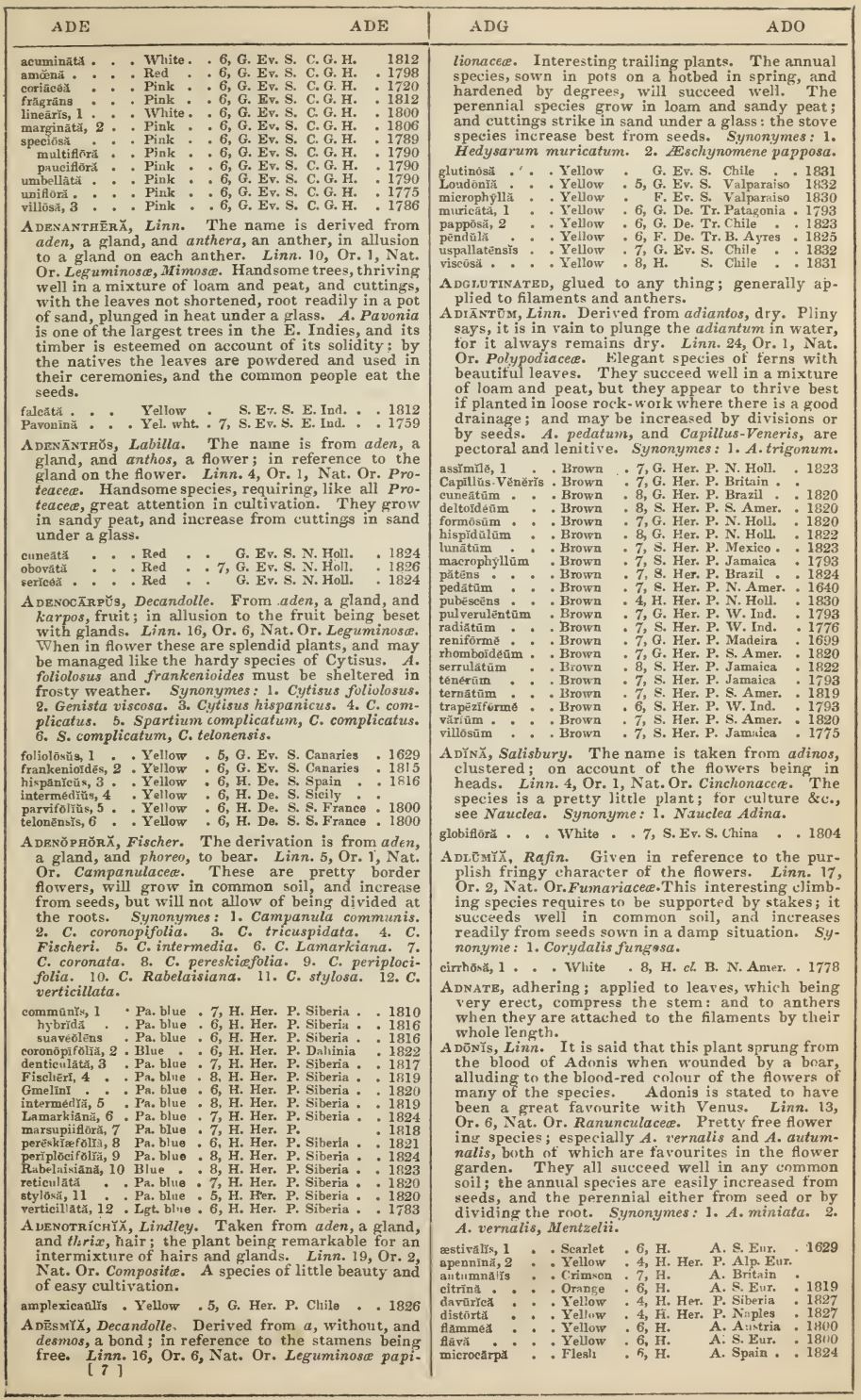


pyrenă̌ĕ . - Yellow * 7, H. Her. P. Pyrenees : 1817 sibirica. : : Yellow : 4, H. Her. P. Siberia : 1827 vernalis : : Yellow :3, H. Her. P. Europe 1829

A Dōx glory; alluding to the want of show in the flowers, these being ot the same colour as the leaves. Linn. 8 , Or. 4, Nat. Or. Oraliacea. The plaat is very dwarf and interesting, flourishing best under the shade of trees; it is increased by offsets.

Moschatellină . Grz yel. . 4, H. Tu. Her. Britain .

Aduxr, full grown.

ADoncous, crooked, twisted, or hooked.

Ecīpičn, Pers. 'Taken from aikion, a wheel, and êtos, like; like pustules. Linn. 24, Or. 9, Nat. Or. Fungi. These plants are found upon the leaves of other vegetables, and one of them is known to agriculturists under the name of red gum. This species usually grows inside the glumes of the calyx, under the epidermis, which, when the plant is ripe, bursts and emits a powder of bright orange colour. It does not appear to be materially injurious to the grains; and it has been found upon branded leaves. Before the cuticle which covers the fungus bursts, it has much the appear. ance of a pustule upon the human body.-Loudon's Ency. of Plants.-Albëscęns, Allit, Berbërildis, Binnī, Cīltha, confértim , cornatam, Epilobii, Grossulärice, Jacobate, lacerütam, Leguminosīram, leucospërmam, Mentha, Pcriclÿment, Pinĩ, Prenänthis, Primulie, Ranunculaceäram, Rhamni, rubellam, Turäxüct, Thalictri, Tussiläginìs, Urtíca, Violäram.

Eốlóps, Linn. Supposed to possess a remedy for a disease of one corner of the eye; hence the name. Linn. 23, Or. 1, Nat. Or. Graminea. Uninteresting hardy species of grass of the simplest culture. Synonyme: 1. E. triuncialls.-Caudata., cylindrica, hystrix, ovata, squarrosa, triaristatal, triuncialis.

Egk̄rîră, Personon. Derived from aigeiros, a poplar; the species being first discovered on it. Linn. 24, Or. 9, Nat. Or. Pungi. Exceedingly minute productions found generally on dead wood-candida, setosa.

Eoĺpalıx, $\boldsymbol{L}$ inn. A favourite of goats, hence the name, aix, a goat, and philos, dear. Linn. 4, Or. 1, Nat. Or. Verbenacce. Handsome species delighting in open loamy soil, and propagated from cuttings in sand in heat, under a glass.

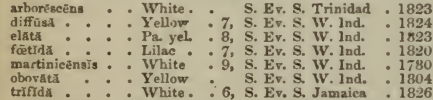

Bat $\bar{B}$, Correa. The word is from agle, one of the

Hesperides. Linn. 13, Or. 1, Nat. Or.Aurantiuceue.

The fragrant flowers of this ornamental shrub (the Bengal Quince) are succeeded by a fruit resembling an orange, which is thus spoken of by Mr. Don,_"The fruit is much larger than that of Feronia elephantum, and is very delicious to the taste, and exquisitely fragrant. It is not only nutritious, but possesses an aperient qualito which is particularly yerviceable in habitual costiveness; it containa a large quantity of exceed. ingly tenacious transparent gluten, which may be drawn out when fresh into fine threads, two or three yards in length." From the rind, the Dutch in Ceylon prepare a perfume.

Mărmelōs . . . Wht, red. . S. Ev. S. E. Ind. . . 1759

Esopŏnīù, Linn. The resemblance of the leaves to a foot, hence the derivation, from aix, a goat, and podion, a little foot. Linn. 5, Or. 2, Nat. Or. Umbelliferc. Common goat-weed. A troublesome weed: the leaves smell like Angelica, and may be eaten in salads.

\section{Podagräriă . White . 6, H. Her. P. Britain}

variegata
- : White : 6, H. Her. P. Bngdand

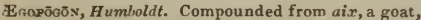
and pogon, a beard. Linn. 3, Or. 2, Nat. Or. Graminea. Curious species of grass of easy culture.

p.เsillŭs . . Apetal. . . 7, Grass. S. Amer.

1829

trisetǔs.: A A petal. : 7, Grass. S. Amer.

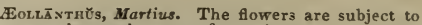
vary, hence the name from aioll ${ }_{G}$, to vary, and anthos, flower. Linn. 14, Or. 2, Nat. Or. Labiata. This interesting species delights in sandy loam, and is increased freely from seeds.

suaveöléns. . White . 7, S. A. Brazil . . 1825

Equilatirat, equal sided.

AERÃNrnus, Lindley. From aer, air, and anthos, a flower; in allusion to the manner in which the plant grows. Linn. 20, Or. 1, Nat. Or. Orchidacez. This is a very singular plant, with large, solitary, and sientless flowers. It requires the same treatment as Vanda.

grandiflora . . Y Yell. Gra. . 6. S. Epi. Madagase. . 1893

ARRIDRs, Loureiro. Named from aer, the air, becanse it possesses the power of living aimost entirely upon the matter which it absorbs from the atmosphere. Linn. 20. Or. 1, Nat. Or. Orchidaced. The flowers produced by some of the plants are delightfully fragrant, as A. odorata, the flowers of which are a rather delicate, light flesh coluur, and disposed in a loose, droping spike, from six inches to a foot long, which grows from the axils of the leaves. For culture and propagation, see $\boldsymbol{V}$ anda. Synonymes: 1. Epidendrum subulatum. 2. Aerides cornuta. affine

eylindricum, 1

odontéchilum.

o lor $a_{t a}, 2$

Vightianum
S. Epi, Sylhet

S. Epi. E. Ind

S. Epi, E. Ind.
S. Epi. Sylluet
1837

1837 1800 1800
E̊ũ̃, Forskahl. Taken from eroua, its Arabic name. Linn. 5, Or. 1, Nat. Or. Amarantacea. Interesting little plants of easy culture. Synonyme : 1. Celosia lanata.

jaranteă . . White . 6, S. Her. P. E. Ind. . 1768 Lanats, $1: \vdots$ White : 6, S. Her. P. E. Ind. : 1691 Erugrous, having a colour like verdigris.

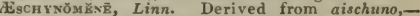
supposed to be a little sensitive. Linn. 17, Or. 4, Nat. Or. Leguminose, Papilionaceo. Ornainental plants requiring, Sweet says, "a strong heat to preserve the species through the winter; good loam suits them best, and cuttings root in heat under a glass." Synonymes: 1. E. viscidula. 2. AE. prostrata.

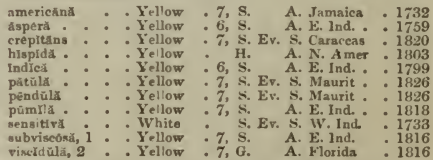

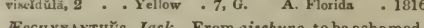

Ascriysaxtrǘs, Jack. From aischuno, to be ashamed, and anthos, a flower. Linn. 14, Or. 2, Nat. Or. Cyrtandracee. These are truly beautiful plants, and deserving a place in every collection. E. r randi. flora produces its beautiful deep scarlet flowers, at the extremity of the young shoots, in clusters of from twenty to thirty flowers in each cluster, and contrasting well with the thick, fleshy, dark-green leaves. It is an epiphyte, and is found to thrive best in chopped moss, and broken pots; it will also grow freely upon the old stumps of trees prepared for the purpose. AE. Roxburghii requires a mixture of equal portions of very turty loam and fresh leaf monld, with a little sand. and to be kept in a moist shady stove. They are easily increased by cuttings.

grandifiora . . Searlet . 8, S. Epi. E. Ind. . . 1837 Roxburghii : Scarlet: 7, S. Er. E. Ind. : 1137

Escǔrǔs, Linn. The name is given to a kind of oak which bears an edible fruit, ant is derived from esca, food or nourishment. Linn 7, Or.1, Nat. Or. Asculacea. Showy trees of considerable magnitude, well adapted for planting singly in parks or lawns, having at all times a pleasing appearance, but more especially when in flower. A deep loamy soil suits them, and they may be increased either by layering, grafting, or budding, and some produce good seed, by which they can be 
with advantage increased. The bark has been used successfully in intermittent fevers, and with gond success in dyeing yellow colours. Synonyme

1. A. carnea.

glâbrà

Hippocăstănūm

variegātūm

ohiotènsiss

pallyda

5, H. De. T. N. Amer.

1812

White.

, De. T. Asia

White

5, H. De. T. N. Amer.

Grm yel. 6, H. De. T. N. Amer.

6, H. De. T. N. Amer.

fresh horse droppings as free from straw as pos sible, lay it in an open shed in a heap or ridge here it will heat violently, and in consequence should be now and then turned for sweetening after this has subsided to moderation, it will be in a fit state for forming into a bed. In the process of making the bed, the dung should be put on in small quantities and beat firmly and equally together until it is the required size: in this state let it remain until the highest degree of heat to which it is capable of coming is ascertained, which may be readily done by inserting a heat-stick and pressing it with the hand: if not found violent, the spawn may be broken up into pieces of two or three inches square, and put into holes about three inches in depth, by six inches asunder, over its surface: after this throw a very small quantity of well-broken droppings over the whole. In this state let it remain for two or three weeks, when loamy soil may be put on about an inch or an inch and $\mathrm{a}$ half thick and gently patted with the spade. If the temperature of the house be kept about sixty or sixty-five degrees, mushrooms may be expected in six weeks. It is not well to water the beds much, particularly when bearing; it is much better to throw a little water over the path and flues, which will both improve the colour and flavour of the mushrooms without being attended with those bad effects frequently resulting from watering, viz. that of destroying the young stock and turning brown those already fit for table. Synonymes: 1. A. auratus. 2. A. spongiosus. 3. A. puniceus. 4. A. clavatus. 5. A. agrestis. 6. A. rheoides. 7. Viridarius. 8. A. varius, proliferus. 9. A. pileolarius. 10. A. croceus. 11. Resupinatus. 12. A. cornutus. 13. A. adustus. 14. A. flexuosus. 15. A. scariosus. 16. A. caseus. 17. A. reticulatus. 18. A. fulvus. 19. A. rosellis. 20. A. serosus. 2]. A. rubescens. 22. A. coronatus. 23. $A$ adnatus. 24. A. ficoides, 25. A. alumnus. 26. Merulius androsaceus.-Acrìs, adōnìs, adhesîvus, adūstǔs, a.elephantīnŭs, ademătōpŭs corallōĩès, aruginōsŭs, as tūūns, alho-brünnēŭs, ālbūs, alcatīnǔs, alliācě̉̆s,

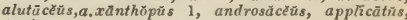
ăqūilüs, armenūăcŭs, aromătǐcŭı, āspĕr, asprēllūs, atro-älbŭs, atro-rüfüs, auranti-ferrugīnēus, auran-

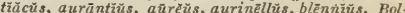
tōnī, bombycīnŭı, brūnnē̌̆s 2 , bulbōsŭs, caspitōsǔs, callochroüs, callossŭs vărǔŭs, camürophÿllŭs, campess-

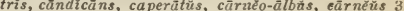

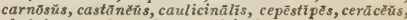
chalȳběŭs, chry̆sðdōu, ciliciō̄dès, cinnamöměŭs, clävŭs, clypeolärĭŭs felīnŭs,c.Meleāgrĭs, coccĭněŭs, cochleătüs, collinītǔs, collīnŭs, columbēttă, cơlŭs, com-

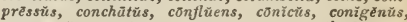
conspërsŭs, constrīctŭs, controvërsŭs, corticālĭs, oretācẽŭs, cristätŭs, cruēntŭs, cücŭmĭs, cuspidätŭs,

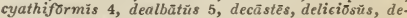
pällēns, deprēssūs, diatrētŭs, disseminätüs, dr.̆̈iñüs,

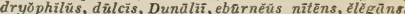
emëtícǔs Gēorgīi, epichy̆sīam, epiphÿllūs, epiptery̆-

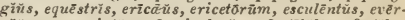
nĭùs, excoriätŭs, fasciculäris, fastībilis, fērtīlis, fīlüla, fülìpẽs, fimbriätüs, fimipütris, flabellîformis,

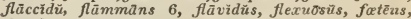
fatìũs, frăgrāns, fucūtŭs, fülvũs, furcūtŭs, furfiu-

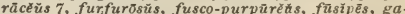
lēopǔs, galericulütũs 8, gambōsǔs, geophüllŭs,

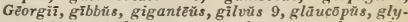
cyōsmǔs, gräcĭlìs, grammopōdĩus, granalōsūs io, griseocy̆ănuัs, homătðpuัs, haustellütūs 11, hēlvơlŭs, helvǔs, hippopīnŭs, hortēnsīs, Hudsōnī, hy̆brīdūs,

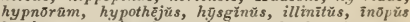
12, inornütüs, involütũs 13, juncícólă, laccütŭs ame. thȳstǐnŭs, lachrymabūndŭs, Lüctēŭs, lanuginōsŭs,

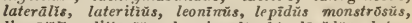
lignätīlis, littōrêus, longicaūlìs 14, lürǐdūs, luteoalbŭs, latĕŭs, majälǐs, marĭtimŭs, mastrucūtŭs, me-

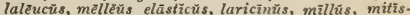
simŭs, möllìs, mūcìdūs, murüliss, muricâtŭs 15, inequälis, murinācĕŭs, murīmǔs, muscārĭ̌s, mutībǔlìs, Myơmūcēs, Myosotǐs, nebulärïs 16, necūtōr

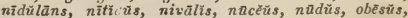

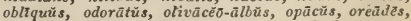
ostreätŭs, ovalǐs, ovīnüs, pällĭdŭs, phallotdēs verrucōsŭs virëscēns, palmütŭs, pantherīnŭs, papilionäcĕus, papyräcéus, parasĩtícŭs, päscŭūs, peliänthĭnus, pelculture, preparing spawn, formation of houses, \&c., is laid down. Collect a sufficient quantity of [ 9 ] 


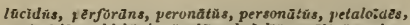
pezizoìdés, phleböphorŭs 17, pholidiüs, pîlīpěs, pipe-

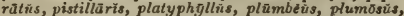

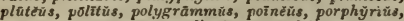
porrigêns, präeđox appendiculütüs, p. delícütüs, prasinǔs, prdiensìs $18, p$. clavaformis, p. erícēüs, pro-

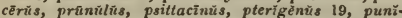
cễus, pürüs, pyrogülñs, pyxidâtūs, quietŭs 20 , racemosūs, radicātūs, rameülis, rhodophöliūs, rimösǔs,

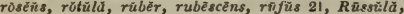

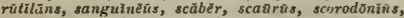
scrubiculätñs, sejunctūs, semiglobātŭs, semiovātũs 22 ,

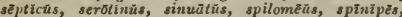
splëndëns, spumōsūs, squamōsüs, squarrosis, stellütũs, stercorüriñs 23 , stipütñs, stîptĭcŭs 24 , strobilinũs, stylobătŭs, subdūlcis, sublanütüs, sulphürēñs, tana.

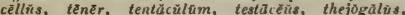

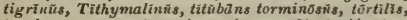
torulosŭs, torvŭs, tremŭln̆s, tuberosins 25 , turbinätr̃s, turfosūs, turgìdŭs, ulmüriūs, ustälis, Qvidūs, vacc⿱一兀ữs, vaginätüs fulvŭs, $v$. hyalinn̆s, v. plümbeñs, $v$.

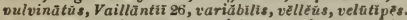

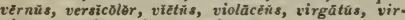
gineüs, vîridis, vulgâris, vulpīnüs.

A $G \bar{\Lambda} s t$ Ăснг̆s, $\boldsymbol{R}$. Bronn. So named in reference to its fine finwers. From agastos, admirable, and stachys, a spike. Linn. 4, Or. 1, Nat. Or. Proteacea. A pretty species, for culture, \&c. see Persoonia.

odorătă . - Pa yel. 6, G. Ev. S. N. Holl.

1826

Acasqulis, Sprengel. The Greek name for the Ammoniac plant. Linn. 5, Or. 2, Nat. Or. Umbelliferce. An uninteresting species of easy culture. Synouymes: 1. Cachrys latifolia, Siler caucasicum. - Caucắsícă 1.

A anthẽ cellent; on account of its beautiful flowers. Linn. 19, Or. 2, Nat. Or. Composita. For culture, \&c. see Cineraria. Synonyms : 1. Cineraria amelloīdes. 2. C. linifolia.

coelestrs,

Blue

6, G. Ev. S. C. G. H.

1759 linifolif, 2
6, G. Ev. S. C. G. H.

A बӑтнб̆риг̆цй, Jussieu. The name refers to the pleasant clove-like smell of the leaf, and is derived from agathos, gond, and phyllon, a leat. Linn. 11, Or. 1, Nat. Or. Lauraceue, Madagascar Nutmeg. This nrnamental tree grows well in good peat, or open rich loam; it is propagated from cuttings with ease, in sand, in heat. The bark and dried fruit are aromatic, especially the latter.

aromătřcūm . White . . S. Ev. T. Madag.

1823

AgAthósmă, Willden. Derived from agathos, guod, and osma, smell. Linn. 5, Or. 1, Nat. Or. Rutacea. The plants are ornamental, and smell like Diosmas. For culture, \&c. see that genus. The Hnttentots use the dried and powdered leaves of A. pulchella, with the grease of which they anoint their bodies; this according to Thunberg, gives them aluost an unbearable smell. Synomymes: 1. Diosma ambigua. 2. D. orbiculāris. 3. Bucco prolifera.

\begin{tabular}{|c|c|c|c|c|c|}
\hline & & & . & et & 5, \\
\hline 18 & A, 1 & & • & - White & - 5, G. Ev. S. C. G \\
\hline revifol & lia & - & - & - Purple & G. Er. S. C. G. \\
\hline Bruniă & dẽs & - & - & - Purple & Ev. S. C \\
\hline efoli & & - & . & - White & 7. S. C \\
\hline liăta & . & . & . & - White & 8. $\mathrm{C}$ \\
\hline ecta & & • & . & - Blue wht. & \\
\hline hirtà & & • & - & - Purple & 7. S. C. \\
\hline exsic & eata & & - & - Purple & . S. C. \\
\hline purp & urea & & - & - Purple & 3. $\mathrm{C}$ \\
\hline Vent & renat & tian & & - Purple & S. $\mathrm{C}$ \\
\hline ispīdả & & & - & - Violet & S. C. \\
\hline abricā & & & - & - Pink & c. \\
\hline foliz & & & - & - White & C. \\
\hline cula & aris & & - & - White & S \\
\hline infer & 3 & & $\cdot$ & - White & 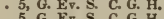 \\
\hline Eses & ins & & . & - White & S, \\
\hline ō:sष & : & • & • & White & \\
\hline & - & & & - White & .3 \\
\hline & & & & & S. C. \\
\hline
\end{tabular}

1812

1810

1818

1820

1774

1774

1816

1794

1794

1794

1794
1786

1774

1823

1800

1790

1798

1820

1790

1824
1786

Aڤnthissǔs, D. Don. The flowers are very pretty, hence the name is derived from agathos, pretty, and thyrsus, a thyrse. Linn. 19, Or. 1. Nat. Or. Compusita. For culture, \&c., see Sonchus. Synonymes: 1. Sonchus agrestis. 2. S. alpinus. 3. S. cacaliafulius. 4. S. cyaneus. 5. S. floridanus. 6. S. lupponicus. 7. S. Plumieri. 8. S. sibiricus. 9. S. tataricus.

alpinüs, 2 . Blue - 7, H. A. Scotland cyănèut, 4 : Blue : 7, H. Her. P. Nepal foridanŭs, 5 . Blus * 7, H. B. Tberia * 1820 lappōnicŭs, 6 . Blue : * 7, H. Her. P. N. Amer. : 1713 Plumieri, 7 : Biue: 8, H. Her. P. Lapland: 1804 sibĭrìcǔs, 8 : Blue 8, H. Her, P Prenees: 1794 tatăricŭs, $9:$ Blue: 8, H. Her. P. Siberia: 1764

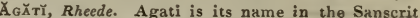
lanuruage. Linn. 17, Or. 4, Nat. Or. Leguminose. Tall orvamental species. For culture, \&c., see Sesbania. Synonymes: 1. Sesbinea coccinea. 2. S. grandiflora.

coccinè, 1 - Red * 8, S. Ev. T. E. Ind.

8, S. Ev, T, E. Ind, . 1820

A $\Theta \bar{A} \mathbf{v}, \operatorname{Linn}$. The name has been altered from agawos, admirable. Linn. 6, Or. 1, Nit. Or. Amaryllidacea. To this highly interesting genus be. longs the $A$. Americana, or American alne. This plant has been said to flower only once in a hundred years, but it is now known to flower sooner or later, according to the treatment it receives. The readiest way to throw it into flower is to apply bottom heat, and treat it as the pineapple. All the species thrive well in rich loamy soil, mixed with a very little rotten dung, decayed vegetable mould, and brick rubbish; they require but little water, and are propagated by suckers from the root. Synonyme: 1. A spicata.

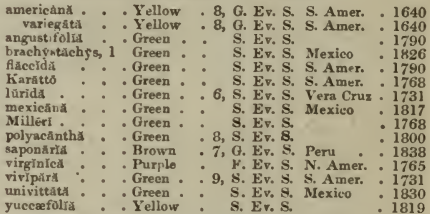

AGǨRĂTÛM, Linn. The colours are constant, or as might be rendered, always clear; hence the name is compounded of $a$, privative, and geras, old. Linn. 19, Or. 1, Nat. Or. Composita. The species are ornamental, and grow freely in light rich soil; cuttings root freely in soil under a glass. Synonyme: 1. A. obtusifolium. . White 7 , G. A. W. Ind, . 1800 - Lgt.blue . 7. H. A. America : 1714 Istifolfüm . . White $.7, \mathrm{H}$. A. Peru * 1800 mexichnüm : Blue : 6, H. A. Mexico :
strictūm :

Agglomgrats, $\}$ collected into a heap or head.

AgGrigatr, \}gathered together, applied to the inAogr rantid, $\}$ florescence.

A Or. not known, Nat. Or. Proteacea. This is a most beautiful plant, on account of its erect clear growth, and large interesting pinnatifid foliage. It thrives well in sandy peat, but must not be over-watered, and probably may be increased by cutting 3 .

binuata

G. Ev. T. Moren. Bay. 1830

A GRIMONia, Tournefort. Given by the Greeks to a plant supposed useful in the cataract of the eye; from argos, white. Linn. 11, Or. 2, Nat. Or. Rosacea. Ornamental species of easy culture. A decoction of $A$. Eupatoria makes a wholesnme garglt.

dahūrèca - Yellow . 8, H. Her. P. Dalıuria , 181 Eupatōriả - Yellow 6, H. Her. P. Britain nepalinsIs: : Yellow :6, H. Her. P. Nepal : 1820 odoráta * : Yellow $* 7$ H. Her. P. Italy : 1640 parviflóră . - Yellow - 7, H. Her. P. N. Amer. 1766 pilosă * Yellow $*$ 7, H. Her. P. Siberia 1819 rēpēns : . Yellow . 8, H. Her. P. Levant. 1737 striatr. White 7, H. Her. P. N. Amer. sunvedéns : Yellow : 7, H. Her. P. Virginia . 1810

Agrimony, see Agrimonia.

AGRöpzinč $M, P$ alisot de Beauvois. Derived from agms, a field, and pyros, wheat. Linn. 3, Or. 2, Nat. Or [ 10 ] 
Graminea. Mere weeds, of the simplest culture. Synonymes: 1. Triticum giganteum, $\boldsymbol{T}$. elongatum. 2. T. panicum. 3. $T$. pectinatum. 4. $\boldsymbol{T}$. repens.Acūtūm, angustifolium, caū̃nūm, cristâtūm, dasyänthūm, densiflorūm, desertóñ̄m, dīstīchūm, elon-

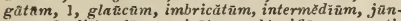
cĕ̃um 2, littorälé, muricãtâm, obtusifloram, pectinätA $m$ 3, pectiniförmé, prosträtū $m$, pūngēus, rēpēns 4, arvēnsě, capillārě, dumetōrūm, Leersiānūm, subu-

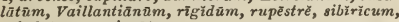
subulūtũm, variegātūm.

AGRostêмMĂ, Linn. Derived from ayros, a field, and stemma, a crown; in reference to the beauty of the flovers. Linn. 10, Or. 4, Nat. Or. Silenacec, Rose Campion. The species are well adapted for flower borders, where, when in flower, they are very ornamental. They grow well in any common soil, and increase by divisions or seed. Synonymes: 1. A. perennans. 2. Lychnis pyrenaica.

decuimbins, 1

Scarlet

7, H. Her. P. Russia

1834

pyrenălệ, 2 . Pa. rose

7, H. Her. P.

8, H. Her. P. Sw den 1824

Agrōsrĭs, Linn. This is the Greek name for all grasses, from agros, a field. Linn. 3, Or. 2, Nat. Or. Graminea. Bent Grass. Plants of simple cul ture.

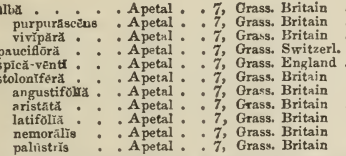

824

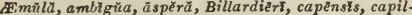

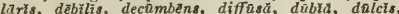
Forsteri, frondosa, gigantēa, hisplda, interrūptă, Juressi, latifoliă, maritimă, neglëctă, pallidă, pătŭlă, plebēiă, purpŭrẻa, retrafrāctă, spariă, sylvătĭcă, tenellă, Tenörit, tenuifolĭă, valentīnă, vărĭă, ver sìcolor, verticillätŭ, virgǐnžcă, vulgärìs, variegät ì.

A Grösi, a name given to any kind of lemon by the Italians.

A GyNĒJ $\breve{A}, \operatorname{Linn.}$ Possessed of neither style nor stigma, hence the name from $a$, privative, and gyne, a female. Linn. 21, Or. 1, Nat. Or. Euphorbiacea. Uninteresting plants, succeeding in loam, and increased readily from seeds or suckers-impobes, puber.

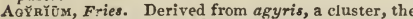
gpecies being generally found in crowds or clusters. Linn. 24, Or. 9, Nat. Or. Fungi. Curious dot-like productions, appearing like crusty spots upon dead wood-cüsiñm, rüfüm.

A IIĀNTữs, Willdenow. Derived from ailanto, (tree of heaven); the name of one species in the Moluccas, " $A$. glandulosa is a tree which may be compared to y gigantic stag's-horn sumach; it has very large leaves, unequally pinnate, with footstalks from on to two feet in length; and numerous flowers in a terminating pedicel, which exhale a disagreeable odour. The tree grows very fast, and on very poor soil, especially if it be calcareous. If the bark be wounded a resinous juice fiows out, which hardens in a few days. The wood is hard, heavy, glossy, like satin, and susceptible of a very fine polish. It is propagated by cuttings of the rnots. In general the trees bear only male flowers, but in France it has produced both male and female flowers, and fruit twice in ten y ears."-Loudon's Ency. of Plants.

excêlsă. . - Green - H. Ne. T. E. Ind. . 1800 Aīn temulentum, in reference to the deleterious qualities of that plant. Linn. 3, Or. 2, Nat. Or. Graminee (irasses of the simplest culture. Synonyme: 1. Phalaris semineutra

arundinācěă . A peț_ . 6, Grass. Cumana 1817 semineūtră, 1 : A petal : : 7, Grass. Hungarỳ : 1812

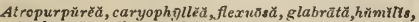
lendrgéră, pällēins, pulehella, refiräctă, versīcolor. $[11]$
A IRZPSis, Desvaux. Named from its resemblance to the genus aira; from aira, hair-grass, and opsis, like. Linn. 3, Or. 2, Nat. Or. Graminea. For culture, \&c., see Aira. Synonymes: 1. Aira brevifotia. 2. Poa agrostidea, Aira agrostidea.

brevifolin̆, 1 . A petal . . 7, Grass. Missouri . 1818 CandolleI 2 : A petal: :7̈, Grass. \$. Eirr. : 1820

Globossă, obtusuta.

Air-plant, see Aerides.

A rтö̌ř̆, Linn., Junior. In honour of Mr. William Aiton, the king's head gardener at Kew. Linn. 16, Or. 5, Nat. Or. Meliacea. A pretty and interesting species, thriving well in loam and peat. Cuttings if taken off when young will ront in sand, under a glass in heat, if not suffered to remain damp.

capünsłs . - . Pink . 7, G. Ev. S. C. G. H. . 1777

$\triangle 1 z \bar{\delta}$, Linn. These plants live under almost any treatment; hence the name is derived from aei, always, and zoon, alive. Linn. 12, Or. 2, Nat. Or. Tetragoniacere. Not worth growing, except in botanieral collections. For culture, \&c., see Mesembryanthemum.

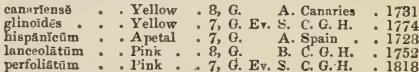
privative, and zugon, a yoke. Linn. 14. Or. 1, Nat. Or. Labiate, Bugle. These dwarf species have a pretty appearance when in flower, planted near the front of borders, \&c. They are easily cultivated, and increased by divisions or seeds.

alpină . . Blue - . 8, H. Her. P. England .

austrälǐs : Blue : 7, H. Hur. P. N. Holl.

Chrmäpits's : Yellow 7. H. A. England

foliōsă : Blue : 8, H. Her. P. Switzerl. 1826

genevēnsis . Flesh . 7, H. Her. P. Switzerl. 1656

integrifolia : Blue *6, H. Hex. P. Nepal 1821

orientalis

, Her. Lerant

reptāns : Blue : 5, H. Her. P. Britain

ulbã - White :5, H. Her. P. Britain

rübră : . Red - 5, H. Her. P. Britain

A KRR-TrRr, see Blighia sapida.

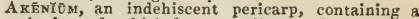
single seed, which does not adhere to it.

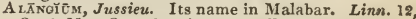
Or. 1, Nat. Or. Alanglaceg. Tall ornamental trees, thriving in light sandy loam, or loam, mixed with peat. Cuttings strike in sand, in heat, under a glass.

decap̌̉tălūm •. Pa. pur. . S. Er. T. E. Ind. • . 17\%9 hexapetălum Purple S. Kv. T. E. Ind. : 18:V

Albūcă, Linn. The name is given, somewhat injudiciously, to the colour of the flowers, from allus, white; only a few of the species having white flowers. Linn. 6, Or. 1, Nat. Or. Liliacea. The species are handsome, and thrive well in sandy oam mixed with a little peat. The suckers from the old bulb, or leaves taken off with a scale from the old bulb, will produce young plants. Synonymes: 1. Anthericum exuviatum. 2. A. fragrans.

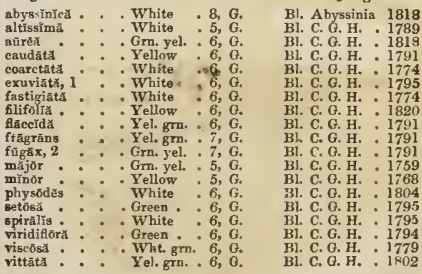

Az testa of seeds, surrounding the embryo. 
Ariserrxūm, the young wood before it comes to a proper consistence.

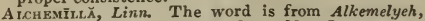
its A rabic name. Linn. 4, Or. 1, Nat. Or. Rosacede. Many of the species are ornamental, and well adapted for planting near the front of borders, or for adorning rock-work. They succeed well in any common soil, if not over-wet, and may be increased from seeds or divisions. A. vulgaris is astringent, and slightly tonic. Synonymes: 1. A. arvensis, Aphanes arvensis. 2. Alchemilla montana.

alpInă : : Green : : 6, H. Her. P. Britain capendiss: : Green : : 6, G. Her. P. C. G. H. hybrìda, $2:$ Green: : 7 , H. Her. P. Britain pentapliglla: : White: 7 , H. Her. P. Switzerl. pubëscēns : Green : 7. H. Her. P. Caucasus serīé̉ : Green : 7, H. Her. P. Caucasus Sibbaldiæfólfă: White : 6, G. Her. P. Mexico. vulgárís : : Green : 7, H. Her. P. Britain variegata: : Green: : 7, H. Her. P. Britain .

Aphŭnēs 1, cornucopioides.

Aucisä, Cavanilles. Named in honour of Fr. Ign. Alcina, a Spanish naturalist. Linn. 19, Or.4, Nat. Or. Composite. A species of little interest and easy cultivation-Perfoliatü.

A tcyoxípiom, Agardh. So called, from Halkioneion, the foam of the sea, among which the plants referred to this genus are naturally produced. Linn. 24, Or. 7, Nat. Or. Alga This also is supposed to be the nidus of animalcula. Lamouroux, who originally fixed it here, afterwards referred it to Zoophites; in which last opinion, Gaillon agrees with him, declaring that he has actually seen the animalcula nestling in it. D'Orbigny and Fillis consider it the ova of a testaceous animal. Defrâctîm, diăphănam, flavẽscāns.

A uDKh, see Alnus.

ALDROVINDĂ, Linn. In honour of Ulysses Aldrovandus, an old Itaiian botanist. Linn. 5, Or. 5, Nat. Or. Droseraces. We refer for culture, \&c. of this curious little aquatic, to Actinocarpus.

resiculōsa . . White . 7, H. Aq. P. Italy . 1823

A LECTŌRY̌, Acharius. The name is derived from Alektor, unmarried, hecause of the uncertainty respecting the male flowers. Linn. 24, Or. 8, Nat. Or. Lichenes. A. jubata occasionally supplies the rein-deer with food; for which purpose the Laplanders cut down the trees, that the lichen may be devoured from the topmost branches.Jubütäj.chalybiiformìs, sarmentosŭ.

A LемнIс, a vessel acting like a still.

A L.s.rRis, Linn. The whole plant appears covered with a powdery dust; hence the propriety of the name, from Aleton, meal. Linn. 6, Or. 1, Nat. Or. Liliacea. Interesting species, delighting in a shady situation, and peat or leaf soll. They are increased from offsets. A. farinosa has bitter roots, which act as a tonie and stomachic given in small doses, but a mixture of twenty grains produces much natusea, with a tendency to vamit. Synonyme: 1. A. alba.

añréa . . . Yellow . 7, H. H. P. N. Amer. . 1811 fainosă, 1: : White i. if. He P. N. Amer. : 1768

A.gunīišs, Forster. Derived from aleurites, mealy; in ailusion to the farinaceous substance with which the whole plant is covered. Lirn. 21, Or. 10, Nat. Or. Euphorbiacece. Handsome plants, succeeding well in loamy soil, and increased from ripe cuttings with the leaves left on, in a pct of sand, in heat, under a glass.

trîlöba . . . Apetal . . S. Ev. T. Society Is. . 1793

A I.EXANDRIAN LAURET, see Ruscus racemosus.

ALHĀGİ, Tournefort. The Arabic name of the piant. Linn. 17, Or. 4, Nat. Or. Leguninosa. Minna. These interesting plants must have the protection of the greenhouse in winter. They grow best in sandy loam and peat; and young cuttings in sand under a glass in heat, will root; but seeds when obtainable, sown in a hutbed, make the best plants. Manno is a natural exudation from the leaves and branches of $A$. vaaurorum, and is yielded only in hot weather. Synonymes: 1. Hedysarum Pseudo-Alhagi. Nann a caspica. 2. H. alhagi Manna hebraica.

camelörūm $\quad$. Red . . 7, F. Her. P. Siberia * . 1816 maurorüm. . Red̆ : 7, G. Ev. S. Egypt : 1714

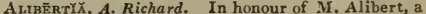
famous French chemist. Linn. 5, Or. 1, Nat. Or. Cinchonaced. An interesting tree, which may be referred to Hamelia, for culture and propagation. Synontyme: Mlelanopsidium nigrum.

edullís . . . Cream-eld. S. Ev. T. Guiana . . 1823

A t.ìsmă, Linn. The name is of Celtic origin, from alis, water. Water Plantain. Linn. 6,Or. 4, Nat. Or. Alismaceas. Pretty little aquatics; for culture, \&c., see Actinocarpus. A. Plantago is recommended in hydrophobia.

cordifoliă . White . 7, S. Aq. P. W. Ind. . 1810 lanceolâtă : Pur. whth 7, H. Aq, P, Britain.

nátăns . White 7, H. Aq. P. Wales

parnassiefcira : White: 7, F. Aq. P. Italy : 1890

parviflörā.: White 7. H. Aq. P. N. Amer. 1816

Plantago : Pur, wht 7, H. Aq. F. Britain.

ranunculoidess. Purple 8, H. Aq. P. Britain

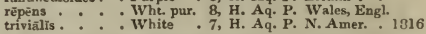

Alkali, any substance which mingled with acid produces fermientation.

ALLAMÃNDX, Willdenon. Named in memory of $\mathrm{Dr}$. Frederic Allamand, professor at Leyden. Linn. 5 , Or. 1, Nat. Or. Apocynacea. This handsome and free-flowering plant delights in rich loamy soil and may be multiplied freely from cuttings in sand in moist heat. An infusion of the leaves makes a valuable cathartic.

cathartice̊ . . Yellow . 7, S, Ev, S. Guiana . 1786

Azr.antōdĭñ, Bot. Reg. The cylindrical indusia resembles a kind of pudding called a sausage, hence the derivation of the name, from alluntos, a sausage. Linn. 24, Or. 1, Nat. Or. Polypodiacea. Ornamental species of Ferns; for culture, \&c., see Polypodium. Synonymes: 1 Polypodium axillare. 2. P. umbrosum. nustralls
axillaris, 1: : : Brown : 7, G. Pler. P. V. Die. L. : 1820
: axilaris, : Brown: 7, G. Her. P. N. Holl: 1820

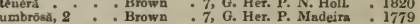

AlLLĀRǏx, Adanson. The name refers to the strong garlic smell; and is derived from allium, garlic. Linn. 15, Nat. Or. Crucifera. Mere weeds, of the simplest culture. Synonyme: 1. Erysimum alliaria -brachycärnä, officinalis, 1.

Arrıōxín, Linn. In memory of Charles Allioni, a botanist at Turin. Linn. 4, Or. 1, Nat. Or. Nyctagynacee. These interesting annuals delight in sandy peat or loam.

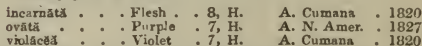

Árriôn, Linn. Derived from the Celtic all, signifying hot, or burning. Linn. 6, Or. 1, Nat. Or. Liliacea. Most of the species are pretty. They stcceed in common soil, and increase abundantly from offsets. The Onion, Leek, Garlic, Shaliot, Chives, \&c., all agree in their stimulant, diuretic, and expectorant seffects, differing in degree of activity. Synonymes: 1. A. carneum. 2. Amaryllis caspia. 3. Allium campestre. 4. A. flavescens. 5. A. fatidum ti A.baiculense, spirale, senescens. 7. A. roseum, ambiguum. 8. A. paniculatum. 9. A. monspessulanum. 10. A. tataricum. 11. A. virescens. 12. A. scorodoprasum. 13. Scilla paradoxa. 14. A. paniculatum. 15. A. vineale. 16. A. stellatum album, angulosum. 17. A. bisulcum. 18. A. tenuifolium. 19. A. glaucum, palustre. 20. Ornithogalum gramineum. 21. A. deflexum. 22. A. ambiguum, graminifolium, ericetorum. 23. A. cikiatum. $24 . A$. Ampeloprasum.

acutàngưlūm . Red • 6, H. Bl. P. 1816 acutiforũan 6 H BL P France Red : . 1819 * White 6, H. Bl. P. Crimea 1820 amónũa 1 . Red $* 5$, H. BL P. France . 1821 ampelóprăsūm : Purple : 7, H. BL P. England : 1818

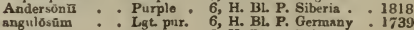
renărium : Purple. ascalonicūn : : Purple: 6, H. Bl. P. Palestine : 1546 măjǔs : - Purple : 7, H. Bl. P. S. Eur. asperum : Purple: 8, H. Bl. P. S. Eur. : 1800 ncropurpureúm : Drk. pur. 7, H. Bl. P. Hungary : 18\%1 aruireúmureum : Dru. pur. 10, H. Bl. P. Hungary : brarehtm : * : Blue * 10, H. Bl. P. Europe: 1830 canadenss. : Purple: 6, H: Bl. P. N. Amer 1739 carinatam: : Grn yel. 5, H. Bl. P. England. 


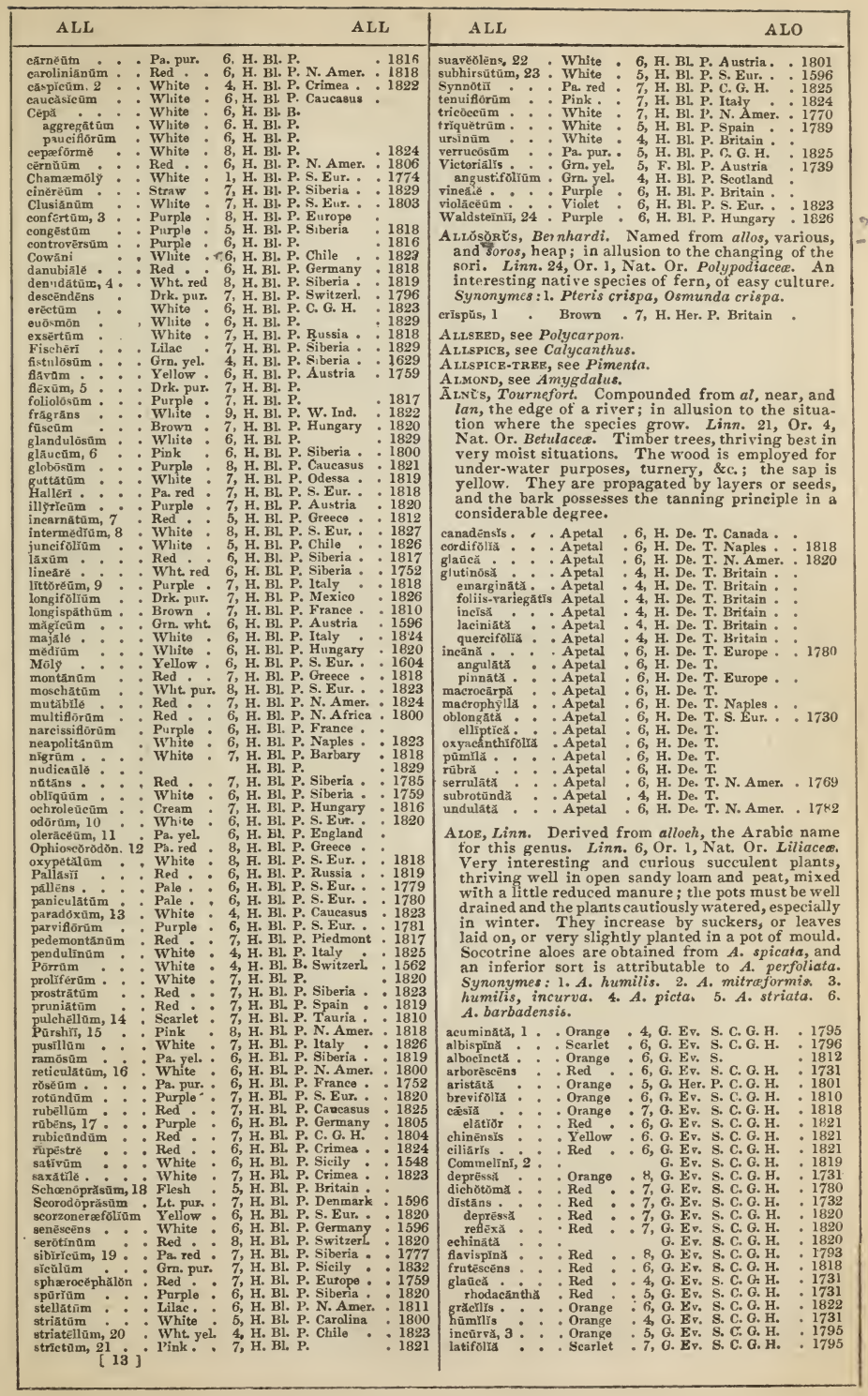




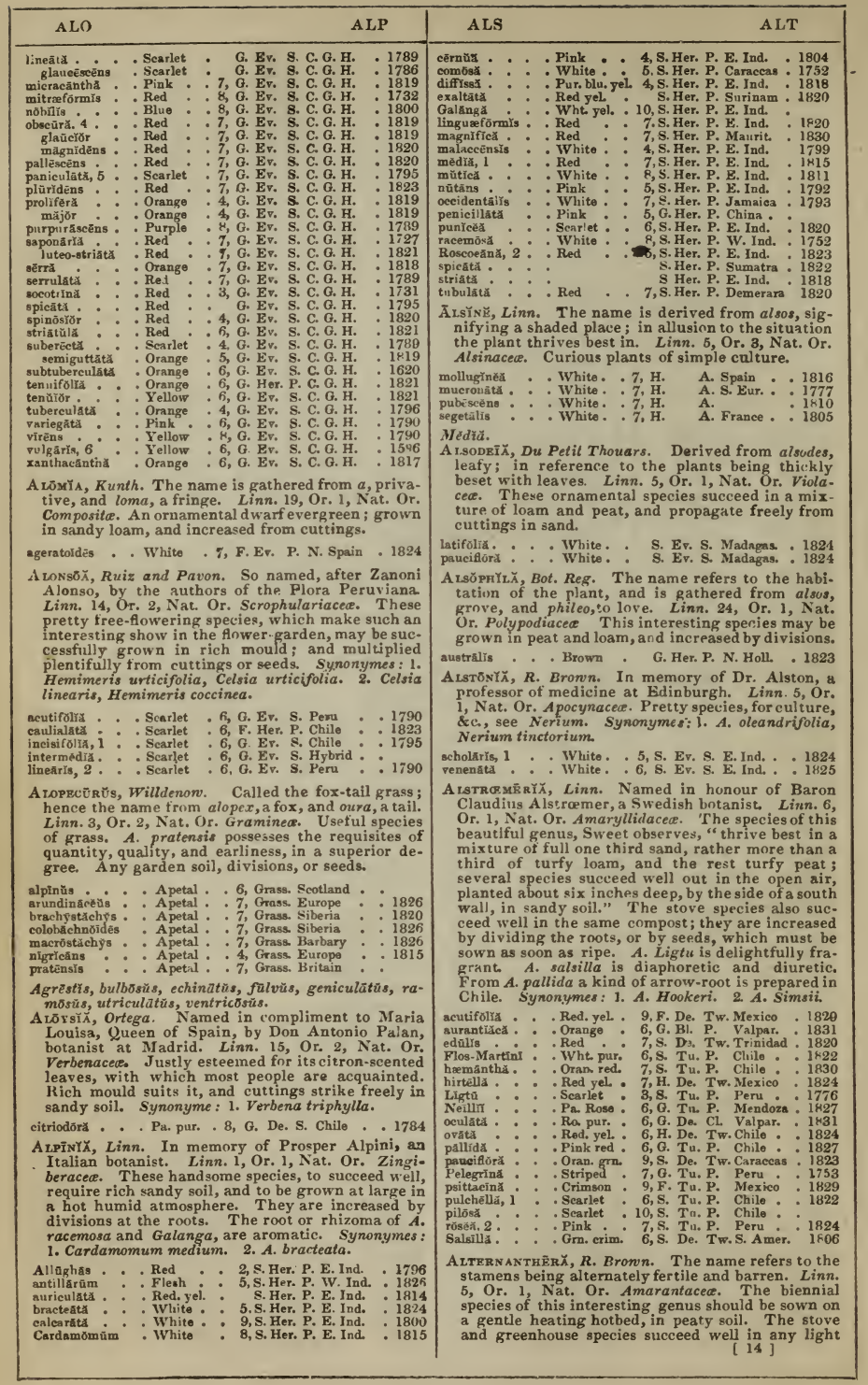


rich soil, and propagate freely from cuttings. Synonyme : 1. A. axillaris.

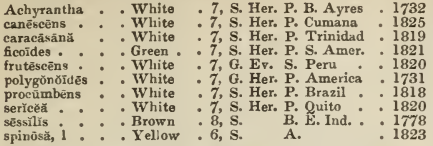

A ITRRNATrNG, alternate with anything mentioned.

Alth $\mp \Lambda, L i n n$. Derived from altheo, to cure; from the medicinal qualities of some of the species. Linn. 16, Or. 8, Nat. Or. Malvasee. Tall free-flowering plants: the biennial and annual kinds should be sown in the open border in spring, and transplanted when sufficiently strong. The herbaceous kinds may be increased by dividing the roots, or by seeds. $A$. rosea, the parent of the many beautiful varieties of Hollyhock, yields a blue colouring matter equal to indigo. Synonymes: 1. A. leucantha. 2. A. grandiflora.

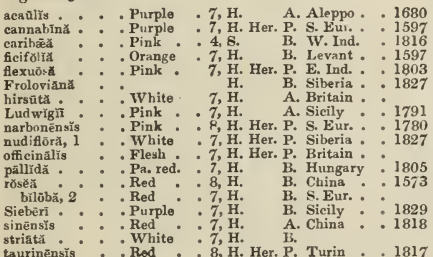

taurinënsis worthy German botanist. Linn. 22, Or. 13, Nat. Or. Coniferc. These handsome-growing trees attain a great magnitude and height, especially $A$. excelsa, which averages one hundred feet in height ; they prefer deep loamy soil; and young plants may with care be struck from portions of the fullyripened wood taken off at the joints, and planted in a pot of sand, under a glass, but not plunged or exposed to the sun. Seeds, when such can be obtained, produce the best plants. Synonyme: 1. Araucaria excelsa.

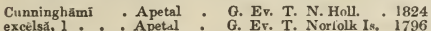

A LTīssĭmă, tallest, highest.

Alveolate, having the appearance of honey.

Arvise, belonging to the intestines.

Alysicărpưs, Necker. Derived from alysis, a chain, and karpus, a fiuit; in allusion to the chain-like appearance of the legume. Linn. 17, Or. 4, Nat. Or. Leguminose. Plants of the simplest culture. Synonymes: 1. Hedysarum bupleurifolium, grami neum. 2. H. nummularifolium. 3. H. styracifolium. 4. $\boldsymbol{H}$, vaginale.

$\begin{array}{lll}\text { buplenrifölīus, 1. Purple } & \text { - 7, S. Her. P. E. Ind. : } 1793 \\ \text { monilifer } & 1816\end{array}$ monilifer . - Purple . 7, S. Her. P. E. Ind. .

Nummularifolius 2. Styracifolius 3. vaginālìs 4.

A LỸssūm, Linn. Derived from $a$, privative, and lyssa, rage; from a notion among the ancients of the plant possessing the power of allaying anger. Linn. 15, Or. 1, Nat. Or. Cruciferc. These neat and interesting species are well adapted for ornamenting rock-work, or the front of flower-beds. They increase readily either fron seeds, cuttings, or divisions, and grow well in any common soil. Synonyme: 1. A.alpestre.

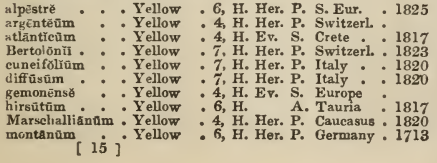

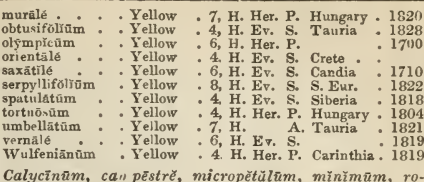
strütr̃m.

ALFxĭ, R. Brown. Taken from alyxis, anxiety in allusion to the heavy aspect of the plant. Linn. 5, Or. 1, Nat. Or. Apocynacec. Curious species of easy culture, growing well in sandy loam mixed with a litcle peat, cuttings of the ripened wond planted in a pot of sand under a glass, plunged in heat, will root freely. Synonymes: 1. Gynopogon Aly.xia, Alyxia Forsteri. 2. A. Ricliardsonia.

daphnoides White 4, G. Ev. S. Vorfolk Is.

Is. 1831 Forstērì * * White - G. Ev. S. Norfolk Is. 1831 White : G. Ev. S. Norfolk Is. 1831 ruscifölï, 2 : White :7, G. Ev. S. N. Holl. 1820

Alzatē̆, Ruiz and Pavon. Named in honour of Joseph A. de Alzaty, a Spanish naturalist. Linn. 5, Or. 1, Nat. Or. Celastracere. An ornamental tree, for culture, \&ce. see Celastrus.

verticillătă

G. Ev. T. Peru

1824

A MABILR, pleasing, amiable.

A MARĀNTHǓs, Linn. Derived from $\boldsymbol{a}$, privative, and mxiraino, to wither; in reference to the length of time some of the flowers retain their bright colours. Linn. 21, Or. 5, Nat. Or. Amarantreed. Some spe cies of this genus are pretty; the hardy kinds merely require sowing in the open border; the less hardy should be sown in a gentle-heating hotbsd, and when old enough, potted off singly, observing to give plenty of pot-room, good rich soil, and water. $A$. obtusifolia is diuretic. Synonymes: 1. Chenopodium caudatum.

atropurpŭrĕs̆s . Purple . 9, H. A. E. Ind. 1890 - Red grn. $8, \mathrm{H}$.

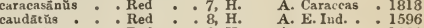
māxImŭs : Red : 8, H. celosioĩdès . . Red : 7, H. A. S. Amer. 1818 cruẻntǔs - Drk. red. . 7, H. A. China : fasciātǔs : $7, \mathrm{H}$ A. E. Ind. : 1816

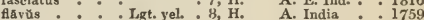

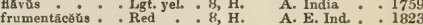
hẻeticŭs : Pink: : 8, H. A. E. Ind. : 1823 hypochondriăcŭs Dark red: 7, H. A. Virginia : 1684 larceæfólĭus . Red . 7, H. melanchōlicŭs . Purple $7, \mathbf{H}$. olerāceǔs,$P$ a, red $, 7, \mathbf{H}$. olerăceũs * Pred paniculătŭs $:$ Gieen : : 8, H. A. N. Amer. 1798
sanguĩnés speciōsǔs : : Red : $:$, H. A. A. Nepal : 1819 trícolor. : : Red yel. : 8, H. A. E. Ind. : 1548

Albŭs, angustifolǐŭs, Berchtoldð̃, Blītūm, bullātũs, campesstris, cauliflorŭs, chloröstächy̆s, curvifoliūs, de-

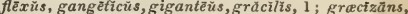
hy̆brìdüs, inamänŭs, incömtüs, interrūptūs, lētús,

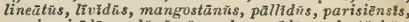
persicarioz̄dēs, poly̆gămŭs, polygonoz̄dēs, polȳstăchy̆s,

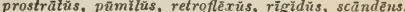
speciosūs, spicätüs, spinosñs, strīctũs, sylvēstrĭs, tenuifolīüs, trīstǐs, vĭrìdis, zanēnsis.

A MARYLI.Is, Linn. The name of a nymph celebrated by the poet Virgil. Linn. 6, Or. 1, Nat. Or. Amaryl lidacea. This interesting and beautiful genus of bulbous plants, may be successfully grown in the following manner. The bulbs of the stove species should be turned out of the pots in autumn, and laid on a shelf or other dry place till spring, when they should be potted and introduced into the hothouse, giving then, as they progress, plenty of water. A. reticulata and striatifolia will not bear turning out, as they flower better by remaining in the pot all the year. The greenhouse species must also be turned out of the pots and dried, and in the spring potted, and encouraged to flower. The soil should comprise equal portions of turfy loam and peat, with a fair quantity of sand; the pots should be drained well. They are increased by offsets 


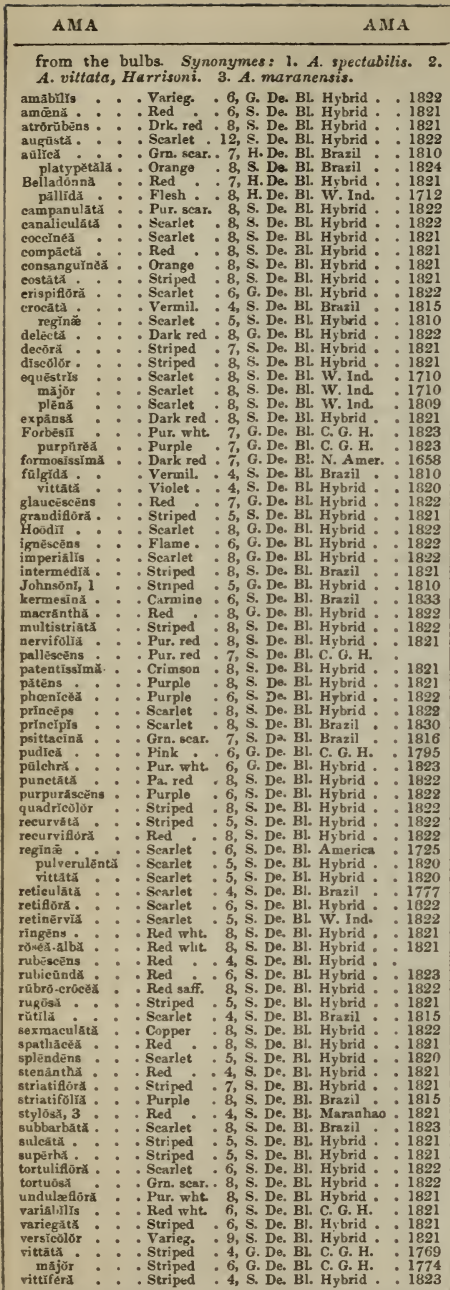

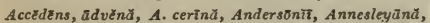
attenuātă, blāndă, bracteātă, breviflōră, brevifoliză, calyptrātă, carnēscěns, Colvīlli, consobrīnă, cūprěă,

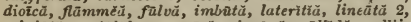
miniätă, mutäbilis, nervősă, obscürŭ, pällidă, pallii-

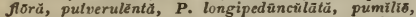
solandraftōrä, S. purpurāscēns, S. rübröstriātă, tatārīcā, trícólor, Vallētă, venosă, Wellsiänă.

A AsōNî̃, Linn. In meinory of Thomas Amason,

an American traveller. Linn. 14, Or. 2, Nat. Or. Verbenacec. These are interesting plants, and may be successfully grown in sandy loam, and increased from suckers. Synonyme: 1. Talygala campestris.

eréetă, 1 - - Yellow .9, S. Her. P. Maranh. 1893 A мвIGUous, doubtful or uncertain.

A мвRósı̃̃ , Linnaus. A poetical name, expressive of the food of the heathen gods. Linn. $\mathbf{1}$, Or. 5 , Nat. Or. Composita. Uninteresting species, of the simplest eulture. Synonyme: 1. A. absinthifoliaartemisicefoliă, cumanēnsé, elätiōr, heterophy̆llä 1,

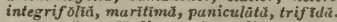

A MréANChİ̈, Medicus. According to Clusius, this is the only Savoy name for the Medlar. Linn. 12, Or. 2, Nat. Or. Pomacex. These ornamental freeflowering bushes, make a gay display when standing in the distant part of pleasure-ground. For culture, \&c., see Cotoneaster. Synonymes : It Mespilus canadensis, Pyrus sanguinea. 2. Mespilus Amelanchier.

Botryăprüm . . White. . 5, H. De, S. N. Amer. . 1746 ovalis . : White : 5, H. De. S. N. Amer. : 1800

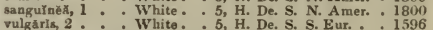
A rर̄̌cǔs, Willdenon. Emplnyed by Virgil, for a tine flower found on the banks of the river Mella. Linn. 19, Or. 2, Nat. Or. Composito. Interesting species, succeeding well in a loamy soil, and cuttings planted under a glass roet freely. Synonymes: 1 . Sideranthus spinulosus. 2. S. villosus.

Lychnitrs. . Violet . - 7, G. Ev. T. C. G. H. . 1768 spinulosus, 1: : Yellow : 8, H. Her. P. Mi Hsouri: 1811 A sizNr, A catkin, mode of inflorescence; as the A mentuM, $\}$ Hazel and Willow.

AmRrican ALor, see Agave Americana.

A M RRICAN CowsLIP, see Dodecatheon.

A mKRīmiñ $M$, Putriek Bronne. A Greek name for the house-leek : derived from $a$, privative, and merimna. care; in allusion to the little attention the plant requires. Linn. 16, Or. 6, Nat. Or. Leguminose. Ornamental shrubs; for culture, \&c., see Pterocarpus.

Brōwnę * * White. * S. Er. T. W. Ind. 1793

AмвтRSTKă, Willdenow. The name is given in allusion to the colour of the flowers, from anethystos, the amethyst. Linn. 2,Or. 1, Nat Or. Labiatie. A pretty blue-flowered annual; it grows in peaty soil, and matures an abundance of seed.

carūleă. . Blue . . 7 , H. A. Siberia . 1759 A METHYsTTNovs, violet-coloured.

A MHËrstîn, Wallich. In honour of the $\mathrm{Rt}$. Hon. Countess Amherst and her daughter Lady Sarah Amherst; the zealous friends and promoters of every branch of Natural History, but especially Botany. Linn. 17, Or. 4, Nat. Or. Leguminosce. This truly noble object first became known to Dr. Wallich, through the medium of a Mr. Crawford, in Angust 1836, who originally discovered it in Martaban, the E. Indies; the former gentleman afterwards found it, as he himself states, "prowing near a decayed Kioum, (a sort of monastery,) together with numerous individuals of Jonesia Asoca and Mesua ferrea; it was profusely ornamented with pendulous racemes of large vermilion-coloured blossoms, unequalled in the flora of the $\mathbf{E}$. Indies, and perhaps not surpassed in magnificence and elegance in any part of the world."-Wallich's Plante Asiatica Rariores. The ground, he states, was strewed even at a distance with its flowers, which are daily offered to the images in the adjoining caves. He transported it to the Botanic Garden, Calcutta, where it was seen by Mr. J. Gibson, who very fortunately succeeded in bringing a plant alive to the collection at Chatsworth. It appear3 to delight in a rich strong loam, and may be propagated by cuttings of the half-ripened wood, planted in sand, under a glass, in heat; or by ringing the stems of the old plant.

nóblis . . . Rieh ver. . S. Ev. T. E. Ind. . 1837 A Mĩč̌, Humboldt and Bonpland. In memory of $\mathrm{J}$. B. Amici, a noted physician. Linn. 16, Or. 6, Nitt. 
Or. Legminosa. This interesting evergreen climber delights in open loamy soil, and increases readily from cuttings.

zigùmerìs. . Yellow . 6, S. Ev. Sh Mexico . 1826 A Miröră, Persoon. Derivation unknown. Linn. 21, Or. 9, Nat. Or. Sapirdacec. An ornamental tree, thriving in peat and loam, and inereased from cuttings in sand. Synonyme: 1. Lagunea nitida.

nİtĩdă, 1

$$
\text { S. Ev. T. Peru }
$$

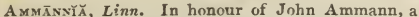
physician and botanist at Petersburgh. Linn. 4, Or. 1, Nat. Or. Lythraced. Species of no beauty; for culture, \&c., see Balsamina.

verticillată .. White . 8, H. A. Guinea . . 1819

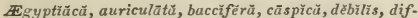

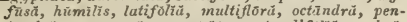
tündră, racemósia, ramīsior, rotundifolüu, rübră, sanguinolètü, vîrídis, Wormskioldī̄.

$\bar{A}$ мm, Linn. The plant delights to grow in sandy places, hence the name from ammos, sand. Linn. 5, Or. 2, Nat. Or. Umbellifere. Weeds of the simplest culture. Synonyme: 1. Bunium acaule.

Acaūlĕ 1, anethifoliam, Boebëri, daucifölīum, ferulcefölīūm, glaucifolīum, mäjūis, Visnägă.

Аммойй, $\boldsymbol{R}$. Brown. Derived from ammos, sand, and bio, to live; in reference to the situation where it grows. Linn. 19, Or 1, Nat. Or. Composite. Pretty species of the easiest culture.

alâtũm. . White . 6, F, Her. P. N. Holl. 1829 plantaginěum " White : 8, G. Her. P. N. Holl. . 1827

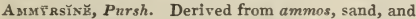
myrsine, a myrtle. Linn. 10, Or. 1, Nat. Or. Ericacex. These interesting species should be grown in peat, and sheltered in winter in a frame or pit. They increase from layers. Synonymo: 1. Ledum buxifolium, Leiophyllum thymifolium.

buxiforlæă, 1 . .White . . 5, H. K₹. S. N. Amer. . 1836 prostrătï . :White . 6, H. Èv. S. N. Amer.

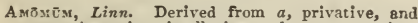
nomos, impurity; in allusion to the counter-poison qualities some speties are supposed to possess. Linn. 1, Or. 1, Nat. Or. Scitamina. Ornamental stove-plants, requiring similar treatment to Alpinia. In Bengal, the fruit of $A$. aromaticum is used, and the greater sort of Curdamums is yielded by $\boldsymbol{A}$. Grana-Paradisi.

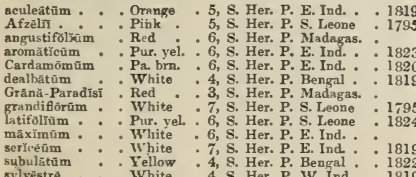

subulatūm * . Yellow * 4, 8. Her. P. Bengal . 182

А мо̆врнӑ, Linn. The name is derived from $a$, privative, and morpha, form; alluding to the deformity of the corolla. Linn. 16, Or. 6, Nat. Or. Leguminosic. Elegant free-flowering shrubs, thriving well in common soil, and increased by layers, or cuttings taken off at a joint, and planted early in at:tumn, in a sheltered situation. The more tender species require the protection of a mat in severe weather. Synonymes: 1. A. nana. 2: A. pubescens.

canéscễns

crôcéolangi: * Blue

Purple 7, F. De. S. Missour - 1819

7. De. S. N. Amer. . 182

fruticōsx : : Purple :7, H. De. S. Carolina : 1724 emarginatia : Purple :7, H. De. S. Carolina : 1724 microphyllă : Purple : 6, H. De. S. Carrlina

gläbrä... : Purple

herbace

Purple 7, F. Her. P. N. Amer. 1818

Lewĩsĩ

microphylla: Purple

7, F. Her. P. Carolina : 1803

Purple 8, F. De. S. Missouri : 1811 hence the name from ampelos, a vine, and opsis, resemblance. Linn. 5, Or. 1, Nat. Or. Vitacea. This genus of interesting plants comprehends the Virginian creeper, so well known for its adaptation to cover walls, bowers, and trellis-work. They grow in common soil, and increase from layers or cuttings. Synonymes: 1. Cissus amptopsis. 2. C. guiaquefolius.

bipinnătă - . Pur. grn. . 8, H. De. S. N. Amer. cordāti, 1 Pur. grn 5, H De Cl N. Amer. - Pur. grn. . 5, H. De. Cl. N. Amer. 1803 hederăcés, 2 - Pur. grn. - 7, H. De. Cl. N. Amer. 1729 hirsüta . . Pur. gra. . 5, H. De. Cl. N. Amer. : 1806

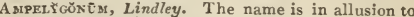
the grape-like fruit. Linn. 8, Or. 3, Nat. Or. Polygalacea. This species is very interesting, and will thrive in sandy loam and a little peat, and will readily increase from seeds. This is one of the spe cies from which indigo of fine quality is obtained.

chinēnsě . . Yelsh. wht. 7, G. Her. P. E. Ind. . 1837

AMphERĒpHis, Kunth. Derived from ampherephis, well covered; in allusion to the double involucrum. Linn. 19, Or 1, Nat. Or. Composite. Pretty annuals, of easy culture.

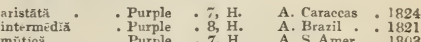
mŭticä. Purple $7, \mathrm{H}$ A. S. Amer. 1803

A MPFIBIOUs, growing either in or out of the water.

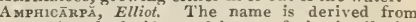
amphi, on both sides, and karpus, fruit; in allusion to the fact of the plants bearing pods both on the roots and on the stems. Linn.17, Or. 4, Nat. Or. Leguminosa. Ornamental deciduous twiners; for culture, \&c., see Clitoria. Synonymes: 1. G. comosa. 2. G. monoica. 3. G. fiusa, sarmentosa.

monóică, 2 - Apetal . 9, H. De. Tw. N. Amer. . 1781 sarmentỏsă, 3 . A petal 9, H. De. Tw. N. Amer. 1820

Comōsă, 1 .

Aмтнісно̆rdă, Fries. Compounded from amphis, sig. nifying on either or each side, and chorda, a chord. Linn. 24, Or. 9, Nat. Or. Fungi. A dusty or porous substance, found on rotten trunks under ground in the autumn-farinäcĕ $\vec{u}$

A мipнĭcómē, Royle. From amphi, around, and kome, hair; in allusion to the structure of the seeds. Linn. 14, Or. 2, Nat. Or.Bignoniacea. Dr. Lindley describes this as a very elewant and rather slender perennial, probably hardy enough to stand out if planted in any dry situation or on rock-work, and protected during winter from the wet and nost severe frosts. It thrives best in loamy soil mixed with a little sandy peat. and may be increased by seeds or cuttings of the young shoots.

argütă . . Lilac . . 8, F. Ev. P. Hinalaya Mts.

A MPHI.ŏвYū, Kunth. Derived from amphi, round, and lubos, a pod; in allusion to the round fruit. Linn. 14, Or. 2, Nat. Or. Bignoniaced. A pretty evergreen climber; for culture, \&c., see Bignonia. Synonyme: 1. Bignonia paniculata.

paniculatūm, 1 . Purple * S. Ev. Cl. W. Ind. . 1738

A MPH1EĀRP's, round-fruited.

A м⿻нтро̄Gō, $\boldsymbol{R}$. Brown. Compounded from amphi, round, and pogon, a beara. Linn. 3, Or. 2, Nat. Or. Graminea. A curious species of grass of the easiest culture.

strretŭs . . . A petal . . 6, Grass. N. Hot].

1823

A siphispórīèm Link. Compounded from amphi, on either or each side, and sporia, a sporule. Linn. 24, Or. 9, Nat. Or. Fungi. Yellow particles observable on hyacinths grown in glasses-Versĩcólör.

A MPLEXICAUIrs, stem-clasping.

Amsōnĩ , Walter. In memory of Charles Amson, a traveller in America. Linn. 5, Or. 1, Nat. Or. Apocynacea. Pretty species, succeeding well in common soil, and increased freely from cuttings under a glass, or by dividing at the ronts, synonyme: 1. Tabernamontana Amsonia.

angustifclia . . Blue . . 6, H Her. P. N. Amer. . 1774 latifolin, $1:$ Blue: : 6, H. Her. P. N. Amer. . 1759 salicifolia .: Blue: 6, H. Her. P. N. Amer. : 1812

A MริGDĂLǏs, Linn. Derived from amysso, to lacerate ; in allusion to the fissured shell. Linn 12, Or. 1, Nat. Or. Rosacea. The tall and coarse portion of these ornamental early-flowering plants may be advantageously disposed of in large plantations, and the dwarf kinds in small shrubberies at the front of the large ones. The common way of increasing them is by budding on the plum stock, or [ 17 ] 
on the bitter almond. Rich mould is a proper medium for them. They are most valued for producing their showy pink blossoms early in the season, sooner than al most any other shrubs. Synonyme: 1. Prunns sinensis.

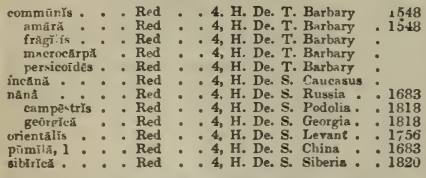

AmxuAczous, possessing the properties of starch.

Amris, Linn. From $a$, intensive, and myron, balm, or myrrha, myrrh; in allusion to the strong perfume of the species Linn. 8, Or, 1, Nat. Or. Amy. ridacec. Ornamental trees, succeeding well in an equal mixture of loam and peat, and are propagated from cuttings in sand under a glass. A. tozifera is poisonous. Synonymes: 1. A. elemifera. $2 A$. balsamifera.

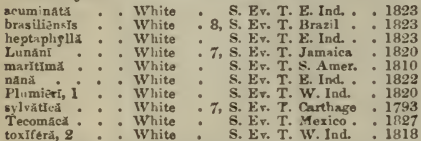

A ลัหล̆รั̆s, Linn. Equisitum, was so named by the

Greeks. Linn. 5, Or. 2, Nat. Or. Chenopodiacece.

Curious species of the simpleat culture. Synonyme: 1. Salsola articulata.

aphellä, 1 : . Green . 7, G. EV. S. A. Minor . 1817 flöriłă *. Green . 7, H. A. Theria * 1817

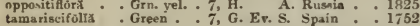

ANAC̄̄MPsĔ̊ōs, Ehrhart. Compoinded from anakampto, to induce to return, and eros, love; the name of a plant to which the ancients atiributed the quality of restnring the passion love. Linn. 11, Or. 1, Nat. Or. Portulacacede. A genus of curious succulent plants; for culture, \&c. see Aloe. Synonymes: 1. Rulingia polyphylla. 2. Talinum anacampseros, Rulingia Anacampseros. 3. R. varians. sngustifollia - Pink - 7, S Ev. S. C. G. H. - 1820 sngustifoliä - Pink - 7 , arachnoidés : Pink - 8, G. Ev. S. C. G. H. 1790 filnmentosA : Pink - 9, G. Ev. S. C. G. H. 1795 intermediA : Pink . 7, G. Ev. S. C. G. H. 1824 lanceolata . : Pink . 9, G. Ev. S. C. G. H. 1796 polyphylla, 1 : Pink : 8, G. Ev. S. C. G. H. 1818 rotundifollă, 2 . Pink * 8, G. Ev. S. C. G. H. : 1732 rtubêns . - : Red * 8, G. Ev. S. C. G. H. 1796

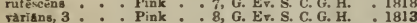

ANACX̄MPrIs, Richard. Named from anacampto, to turn back; in allusion to the retiexed state of the pollen masses. Linn. 20, Or. 1, Nat. Or. Orchidacece. An interesting native species, very similar to our orchis; cultivation simple. Synonyme: 1. Orchis pyramidalis.

pyramidalis . Red . . 7, H. Ter. Britain

Anacantrous, spineless.

ANACĀRIT́M, Roxburgh. The name refers to the form of the nut; hence the derivation from ana, like, and kardia, heart. Linn. 23, Or. 2, Nat. Or. Anacardiacece. These ornamental trees thrive in light loamy soil, and cuttings with their leaves on, taken from the ripe wood, will strike in sand, in heat, under a glass. A. occidentale is thus spoken of by Mr. Sander:-"This elegant tree, bearing panicled corymbs of sweet smelling flowers, succeeded by an edible fruit of the pomme kind of a yellow or red colour. This fruit or apple has a sub-acid flavour, with some degree of astringency." occidentālé
Indǐcūm. : : Grn. red. Gr. red. . S. Ev. T. W. Ind.
S. E. Ind. : 1699

Asaç̄clüs, Linn. Derived from $a$, privative, and anthos, a flower, and kyklos, a circle; in allusion tn the rows of ovaries placed round the disk Linn. 19, Or. 2, Nat. Or. Composito. Hardy annuals, requiring only to be sown in the open ground. $S y$ nonymes: 1. Santolina anthemoides. 2. Anthemis valentina.

aûrüls . . . Yellow : $8, \mathrm{H}$

A. Barbary : 1810

radistüs, 2. . Yellow 8, H. A. S. Eur. . : 1596

Anthemotdès I, creticus, divaricarus, orientülis, valen tinus.

A:ADĒNY̌x, R. Bronn. Named from $a$, privative, and aden, a gland; the nectariferous gland is wanting. Linn. 4, Or. 1, Nat. Or. Proteacere. A hand some species, cultivated in peat and loam, and multiplied by cuttings in sand under a glass.

pulchelli . . Yellow * G. Ev. S. N. Holl. . 1824

ANAGÄLLǏs, Tour nefort. The power of removing de. spondency is attributed to this genus, hence the name from anagelao, to laugh. Linn. 5, Or. 1, Nat. Or. Primulacea. Very pretty interesting species, of easy culture. Sow the hardy annuals in the open ground, and the biennials in pots in the greenhouse or a frame, and plant them out when strong enough. They increase from cuttings planted in any common soil under a glass. Orfila destroyed a dog by making him swallow three drachms of the extract of $A$. arvensis. Synongmes: 1. A. phanicea. 2. A. collina.

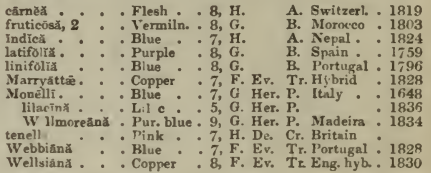

\section{Arasists, 1 ; cerulea.}

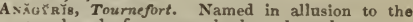
curved pod; from ana, backward, and gyros, a circle. Linn. 10, Or. 1, Nat. Or. Lesuminosic. Ornamental trees, growing in peat and loam, or any light rich soil, and multiplied from cuttings or seeds. The seeds of $A$. fotida, if eaten in any quantity, produce headach.

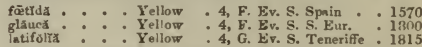

A vavisš, Thunberg. From nanas, the Guiana name. Linn. 6, Or. 1, Nat. Or. Bromeliacece. The plants that yield this very superior fruit, so mrch esteemed for its sweet aromatic flavour, were first cultivated in this country at Sir Matthew Dickeris, at Richmond, where fruit was first produced in 1715 . There are now as many as thirty distinct kinds described in our gardens, but of these only a few merit cultivation ; these are the common broadleaved Queen, Ripley Queen, and Lemon Queen, Black Jamaica, New and Old Providence, Antigua,

Montserrat, and two or three othera of vers good quality. There are many ways of cultivating these plants; our experience dictates the following Young plants should be potted in a compost of open sandy loam, mixed with a small proportion of either deer, sheep, or horse-droppings; the pots should be well drained and plunged into a tan-bed at about 75 degrees of heat; as the plants increase give them additional pot-room, using the same soil as before. In fine weather admit air the first thing in the morning -7 o'clock, and close the house early in the afternoon 3 o'clock; when the paths should be watered and the plants syringed over the tops, which will cause the atmosphere to be very moist, in this state the plants will thrive surprisingly. Fruiting plants must not be grown in an over-moist atmosphere, but should have when such can be given a freer circulation of air, or the fruit will be of an inferior flavour. The temperature in winter should be 70 or 75 degrees, in summer 80 or 85 degrees, and when closed in the afternoon 100 or 110 degrees. The best plants are obtained from suckers, but new or very rare sorts are often obtained from the crown of the fruit. After the fruit is cut, the stools should be plunged in a strong bottom heat, and strong suckers equal to year-old plants may be soon taken off. Synonymes. 1. Bromelia lucida. 2. B. ananas 
bracteãta . Crimson . 4, S. Her. P. Brazil . . 1820 debrlis : : Crimson . 4, S. Her, P.

locid i Pink S. Her P. S. Amer.

gativin, 2 : : Purple": S. Her. P. S. Amer. : 1690

ANĀNThĭRīx, Nuttall. Derived from $a$, without, and antherix, an awn, the appendage being wanting. Linn. 9, Or. 2, Nat. Or. Asclepiadaced. An interesting species; for culture, \&c., see Asclepias. Synonyme: 1. Asclepias viridis.

virrờis, 1 Grn. yel. 8 H. Hor. P. N. Amer. . 1812

ANARrhīnôm, Desfont. The name is gathered from $a$, privative, and rhin, nose; the plants being allied to Antirrhinum, but the flowers quite different. Linn. 14, Or. 2, Nat. Or. Scrophnlariacea. These pretty biennials succeed well if sown in the open borders.

bellidiföliūm . Blue - * 7, H. B. France . 1629 fruticossum : : White : 8, H. B. B. Eur. : 182 frubescẽns: : White : 8, H. B. S. Eur. . : 1818

AnastätícA, Lınn. This plant, however dry, will recover its original form, if immersed in water; hence the name from anastasis, resurrection. Linn. 15, Or. 1, Nat. Or. Cruciferc. Rose of Jericho. A curious dwarf species, of easy culture.

hierochûntină . White. . 7, F. A. Levant . 1597

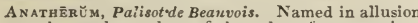
to the awnless valves of the calyx, from $a$, privative, and ather, awn. Linn. 23, Or. 1, Nat. Or. Graminea. Uninteresting species, of easy culture. Synonymes: 1. Andropngon muricatus, squarrosus. 2. A. muticus-Muricātūm 1, muticum 2, virginicum. ANAstomosing, unitiny of vessels, veins, or nerves. Anatomicum, dissected, laciniated.

Ancisps, two-edged.

A кснIËr Ẽ, Hill. In memory of P. Anchietea, a Brazlian writer on plants. Linn. 5, Or. 1, Nat. Or. Violucee. An ornamental species; for culture, \&c. see Calyptrion. Synonyme: 1. Culyptrion pyrifolium.

pyrifolia, 1 . White . 7, S. Ev, Cl. Brazil . . 1822

ANCHOvY-PRAR, see Grias cauliflora.

ANCHÉsă, Linn. A. tinctoria was auciently used for staining the skin; hence the name, from agchoresa, paint for the skin. Linn. 5, Or. 1, Nat. Or. Bora: ginea. The hardy annual and biennial species of this ornamental genus succeed well sown in the open borders. A. capensis should be raised in a frame, and treated as a greenhouse plant. The roots of $A$. tinctoria and virgtniea furnish a reddish brown substance used by dyers. Synonymes: 1 Myosotis obtusa. 2. A. angustifolia. 3. Myosotis macrophylla. 4. A. zeylanica.

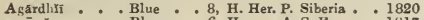
Blue 6, H. A.S. Kur. 1817 angustifólia: : Purpla" :5, H. Her. P. S. Eur. : 1640 asperrimå : Blue : 5, H. B. Egypt *: 1817 Barreliêri, 1 : Biue: 7, H. Her. P. S.Eur. : 1820

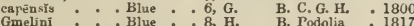
hispidă : Blue * 8, H. Her. P. Kodolia: 1817 hybrida : Whe blue 7, H. A. ltaly : 1820 inearnata : : Flesh - 8, H. Her. P. S. Eur. : 1816 incarnata : : Flesh : 8 , H. Her. P. S. Eur. : 1816 leptophyllä, 2 : Purple : 8, H. Her. F. Europe : 1640 longifülä . . Blue . 7, H. Her. P. Italy . : 1819

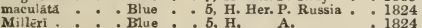
myosotidiföră, 3 . Pink : : 8, H. Her. P. Levant . $\quad 3713$ offinalis : . Blue : 8, H. Her. P. Tauria : 1825 ochroleủeă : Purple : 7, H. Her. P. Britain.. 1810 italǐ̌că : Pa. yel. : 8, H. Her. P. Caucasus : 1810 paniculătă : : Red $:$ : 5, H. Her. P. S. Eur.
procêră : 1597 rupéstris : : Blue: : 7, H. Her. P. Galicia : 1824 serícé . . Pur. yel. . 7, H. Hex. P. Siberia . 1802 stylosa : : Blue: :5, H. A. Siberia: : 1802 tinctōrla : : White : 8, H. Her. P. Montpel: 1596 undulata : . Purple * 7, H. Her. P. Spain ? 1752 verrucoss: : Blio :7. H. A. S. Bur. : 1821 Lycopsō̃dēs.

Andrasōnĩă, $\boldsymbol{R}$. Bronn. In memory of Messrs. W. A. W. and G. Anderson, great promoters of Botany. Linn. 5, Or. 1, Nat. Or. Epacridacea. A very pretty species, multiplied from portions of the young shoots, in sand, under a glass, and grown in sandy peat soil carefully watered.

spreugeloidés . . Pink . .6, G. Ev. S. N. Holl. 1803

A NDĪRĂ, Lamarck. Its Brazilian name. Linn. 17, Or. 4, Nat. Or. Leguminosa. Large ornamental [ Nat. trees; for culture, \&c, see Geqffroya. Synonymes: 1. Geoffroya inermis. 2. G. racemosa.

inërmYs, 1. Purple . S. Ev, T. W. Ind racemōsă, 2 : Purple : S. Ev. T. Trinidad : 1818

ANDR $\bar{c}$ chNē, Linn. The name of the Purslain in Greece, Linn. 21, Or. 10, Nat. Or. Euphorbiacea. Bastard Orpine. A weed, of simple culturetelephiōidës.

ANDR $\bar{\hbar} . \bar{A}$, Hedwig. Named in honour of J. G. R. Andreæ, a German professor. Linn. 24, Or. 5, Nat. Or. Musci. This remarkable genus ditfers from all other mosses, in having a thread, which splits into four valves, cohering at their ends by means of the persistent lid; it agrees with $\mathbf{S p h a g n u m , ~ i n ~ h a v i n g ~}$ no footstalk, but in its room an elongated recepta cle, and appears to be a transition from Musci to Hepatice. This is, however, only apparent. All the species are natives of rocks or molintains, and are remarkable for their nearly black, or darkbrown colour.-Loudon's Encyclopadia of Plantsalpĩnă, nivälis, Röthī, rupēstris.

AxDrogrsots, producing male and female flowers on the same plant, or on the same spike, or head.

Andreōskĩa, Decandclle. In memory of Ant. Andrzejowski, a Russian botanist. Linn, 15, Or, 1, Nat. Or. Cruciferce. Mere weeds, of the simplest culture. Synonymes: 1. Sisymbrium Sieversianum. 2. S. integrifolium. 3. S. pectinatum, Hesperis pinnata. 4. Cheiranthus pinnatifidus,-eglandulosa, 1 ; integrifolia, 2, pectinata, 3 ; pinnatifida, 4.

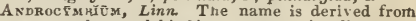
aner, anther, and kimbion, a sancer, in allusion to the peculiar form of the stamens and their appendages. Linn. 6, Or. 3, Nat. Or. Melantha:e⿻. Interesting bulbous-rooted plants; for culture, \&c. see Melanthium. Synonyme: 1. Melanthium eucomoides.

eucomöidés, 1 . Green • . 4, G. Bl. P. C. G. H. * . 1794 melanthioides: White : 7, G. B1. P. C. G. H. : 1823 volutare White 4, G. BL P. C. G. H. : 1316

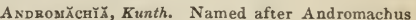
a physician to Nero. Linn. 19, Or. 2, Nat. Or. Cumposita. An uninteresting species of easy cul. ture-Igniärix.

ANDRŏmїD̆, Linn. Named after the virgin An. dromeda. Linn. 10, Ór. 1, Nat. Or. Ericacce. Very ornamental and interesting species, desighting in peat soil, and increased plentifuliy from layers and seads. The seed should be sown in pots, and very thinly covered, for if deep in the soil they will rot; the young plants should be planted out in the spring. Synonymes: 1.A.lucida, populifolia, reticulata, laurina. 2. A. Walteri. 3. A. spinulosa. 4. A. nitida, lucida. 5. A. polifolia, latifolia. 6. A. paniculata. 7. A. pubescens.

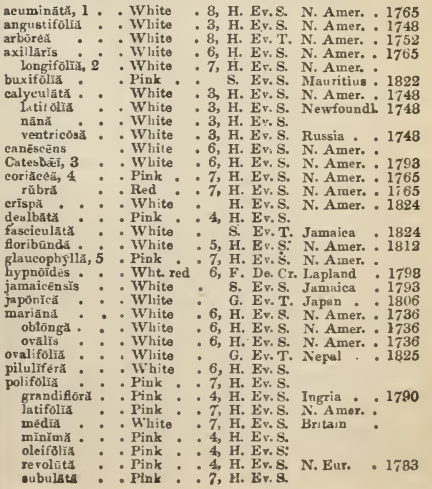




\begin{tabular}{|c|c|}
\hline A.NE & ANE \\
\hline 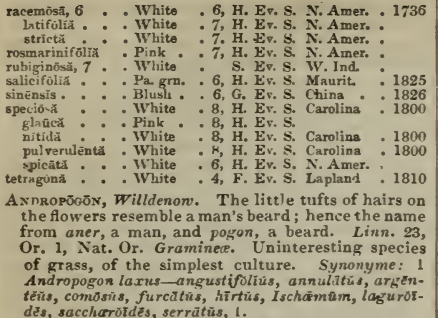 & 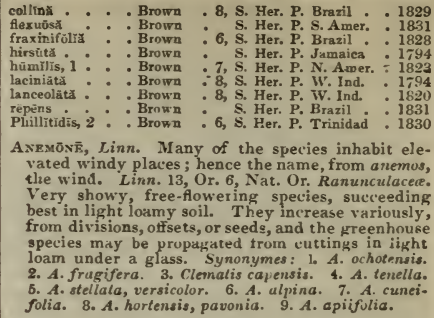 \\
\hline $\begin{array}{l}\text { ANDRosAcE, Lisn. Named in reference to the resem- } \\
\text { blance of the round hollow leaf to an ancient buck- } \\
\text { ler; from aner, a man, and sakos, a buckler. Linn. } \\
\text { 5, Or. 1, Nat. Or. Primulaces. Pretty species, suc- } \\
\text { ceeding well in small pots, in a mixture of turfy } \\
\text { loam and peat, cautiously watered. They increase } \\
\text { from seods, or by divisions. }\end{array}$ & 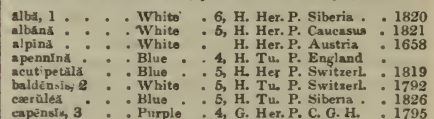 \\
\hline 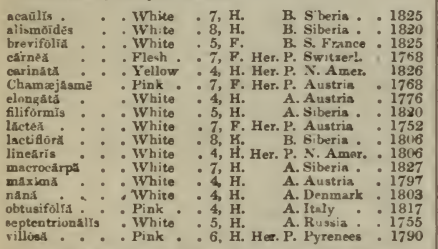 & 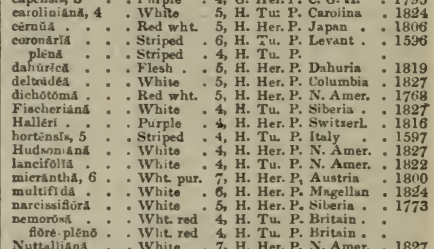 \\
\hline 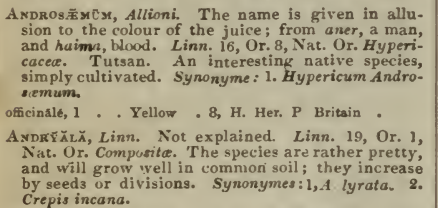 & 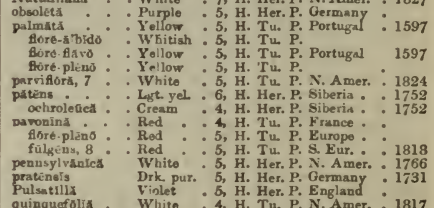 \\
\hline 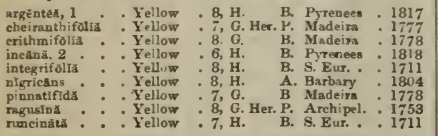 & 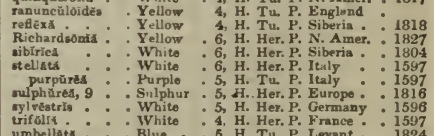 \\
\hline $\begin{array}{l}\text { A NEILEMA, } R \text {. Brown. The involucrum is wanting; } \\
\text { hence the name from a, without, and eilema, in- } \\
\text { volucrum. Linn. 3, Or. 1, Nat. Or. Commelinacee. } \\
\text { Interesting species; for culture, \&c. see Com- } \\
\text { melina. }\end{array}$ & 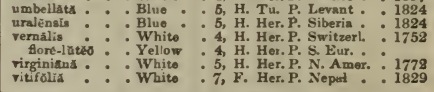 \\
\hline 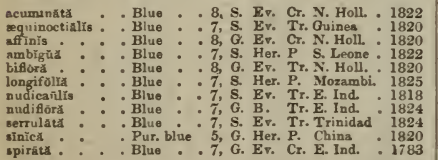 & 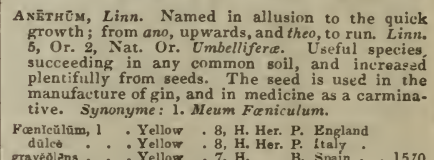 \\
\hline 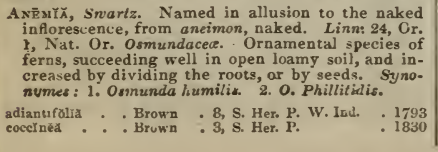 & 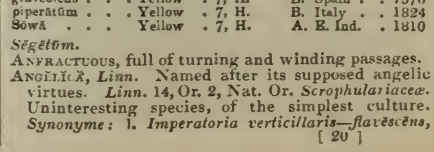 \\
\hline
\end{tabular}


lucida, Razoulii; sylvēstrĭs, triquinata, verticillaris, 1.

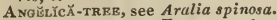

ANGEŌNİ̃, Kunth. From angelon, its name in the Caraccas. Linn. 14, Or. 2, Nat. Or. Scrophulariaces. An elegant flowering species, thriving in ligkt rich soil or turfy loam and peat, carefully watered. Cuttings planted in the same kind of soil, under a glass, root freely if a little air is occasionally admitted to them.

salieárīäfoliă . . Lgt. blue . 8, S. Her. P. S. Amer. • 1818 AxgiĀnthŭs, Wendland. Compounded from aggos, vessel, and anthos, a flower. Linn. 19, Or. 5, Nat. Or. Composita. An ornamental species; for culture, \&c., see Cassinia Synonyme: 1. Cassinia aurea.

gurěŭs, 1 - Yellow * 7, G. Her. P. N. Holl. 1803

Anaroxīion, Greville. Derived from aggeion, a vessel, and eilos, like. Linn. 24, Or. 9, Nat. Or. Fungi. A minute production, found upon dead sticks and other decomposing vegetables in autumn. Synonyme: 1. Reticularia sinuosa-sinuosam, 1.

A кобрно̆ the fruit; from aggos, a vessel, and phero, to bear. inn. 12, Or. 4, Nat. Or. Myrtacee. Ornamental species; for culture, \&c., see Metrosideros. Synonymes: 1. Metrosideros hispidus. 2, M. costatus.

cordifolin, 1 - Yellow . 8, G. Ev. S. N. Holl. . 1789 lanceolath, 2 : Yellow : 8, G. Ev. S. N. Holl. : 1816

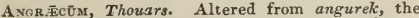
Malayan name of such plants. Linn. 20, Or. 1 , Nat. Or. Orchidacea. Some fine plants are described as belonging to this genus, among which A. eburnum is the most beautiful; it is a very rare plant, and not, as we are aware, possessed by more than three or four individuals in this country. It is a remarkably slow-growing plant, and has only flowered once in the country. For culture and propagation see Vanda.

caudātûm . - Wht, grn. 8, S. Epi. S. Leone * 1834

distrchūm

S. Ka. Madagas. 1826

lürǐdūm - Brown: 9, S. Epi. S. Leone 1822

mierānthüm : White . 10, S. Epi. S. Leone

odoratissimüm

teretifoliŭm : White - S. Epi. S. Leone

Anguzatr, cornered, having sharp angles.

Axguilläriá, R. Brown Named in allusion to the twisted seed; from anguilla, an eel. Linn. 6, Or. 3, Nat. Or. Melanthacea. Interesting dwarf species, growing well in sandy peat, and are multiplied from offsets.

biglandulōsa . Purple . 5, P. Her. P. N. Holl. . 1826 dioică . . Purple . 5, F. Her. P. N. \&. W. . 1896 indiea : : : Drk pur. 6, F. Her. P. Tranqueb. 1818

A NGUTNBA, signifying a snake.

ANGULAR, forming angles.

A NoularLY-TOothis, toothed so as to form angles.

A NGŪRĬ̈, Linn. A Grecian name for the cucumber. Linn. 21, Or. 2, Nat. Or. Cucurbitacea. Interesting species of the easiest culture.

pedati . Yellow * 7, S. Ev. Cl. S. Amer. 1820

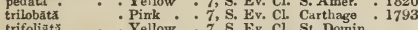

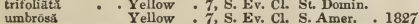

umbrosă Yellow • 7, S. Ev. Cl. S. Amer. • 1827

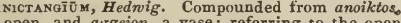
open, and aggeion, a vase, referring to the open nature of the theca. Sinall mosses, found in small depressed tufts in summer on rocks, \&c. Synonymes: 1. Gymnostomum ciliatum. 2. G. imberbe.-Ciliätūm, 1. imberbe, 2.

ANıgoz Ānthōs, R. Brown. Named in allusion to the long conspicuous scapes upon which the flowers are raised. Linn. 6, Or. 1, Nat. Or. Hamodoracea. Interesting species, succeeding in sandy peat, well watered, and increased by dividing the roots. Synonyme: 1. Schnagrichenia flavida.

flăvYă, 1 • : Yellow : 7, G. Her. P. N. Holl. 1808 * - Green * 5, G. Her. P. S. River - 1833 - Grn. red . 7, G. Her. P. N. Holl. 1836 Antmal oat, see Avena sterilis.

A NisАсд̄ equa], and akantha, a spine. Linn. 4, Or. 1, Nat.
Or. Chenopodiacea. A very curious species, of easy culture.

divarieătı.

G. Ev. 8. N. Holl. 1824

ANIsĀNTHƯs, Willdenow, Named from anisos, unequal, and anthos, a flower. Linn. 18, Or. 1, Nat. Or. Iridacea. Ornamental bulbous-rooted plants; for culture, \&c., see Antholyza. Synonymes: 1 . Antholyza Cunonia. Gladiolus Cunonia. 2, Gladiolus quadrungularis. G. abbreviatus.

Cunōniá, 1 . Scarlet * 6, G. B1. P. C. G. H. 1756 quadrāngŭlărĭs, 2 Yellow *4, G. Bl. P. C. G. H. : 1700 plëndens . . Scarlet . 6, G. BL P. C. G. H. : 1828

ANisk, see Tragium Anisum.

ANISERD-TRRE, see Ilicium.

ANısochī Lŭs, Wallich. Derived from anisos, unequal, and cheilos, a lip. Linn. 14, Or. J, Nat. Or. Labiate. An ornamental species; for culture, \&c., see Lavan. dula. The juice mixed with powdered sugar candy, is prescribed in India in cynanche. Synonyme: 1. Lavandula carnosa.

carnősă . . . Lilac . . 8, S. Her. P. E. Ind. . . 1778

ANǐsŏnŭs, Link. Named in allusion to the unequal divisions of the calyx; from anisos, unequal, and odous, a tooth. Linn. 5, Or. 1, Nat. Or. Solanacece. Synonymes: 1. Nicundra anomala. 2. Whitleya stramonifolia.

lūridǔs, 1 . . Lurid . 9, H. Her. P. Nepal . 132 stramónífólíŭs, 2 Yel. grn. 9, H. Her. P. Nepal : 182

ANısŏмธ̌тйs, R. Bronu. Named from anisos, unequal, and melos, a member. Linn. 14, Or. 1, Nat. Or. Labiate. Ornamental species; for culture, \&c. see Nepetu. Synonymes: 1. Ajuga furcata. 2. Nepeta mulaburica.

furcātă, 1 . - Blue * 8, G. Ev. S. Nepal . . 1824 malabarică, 8: $:$ Violet : 8, S. Ev. S. E. Ind. : 1823 moschata . Purple . 8, S. Er. S. N. Holl. : 1824 ovātă : : Pink. : 8, S. A. E. Ind. : 1823

Annulatrons, rings or circles.

ANNULAR, circular, producing a ring or circle.

A Nō̄Á, Cavanilles. Named in reference to the impervious capsule cells; from anodos, signifying impervious. Linn. 16, Or. 8, Nat, Or. Malvacea. Uninteresting species; for culture, \&e see Sida. Synonymes: 1. Sida hastata. 2 S. cristata. 3. S. crenatiflora. 4. S. deltoides. 5 . S. cristata.-Acerifolĭă 1, Dilleniānă 2, hastātă, incarnată, parviflēră 3 , triangulärǐs 4 , triľbbä 5 .

Anodōnī, Decandolle. From $a$, destitute, and odontos, of a tooth, alluding to the stamens. Linn. 15, Or. 1, Nat. Or. Cruciferae. Ornamental species; for culture, \&c. see Alyssum. Synonymes: 1, Alyssum dasycurpum. 2. Al. edentulum. 3. Al halimi. folusm. 4. Al. macrocarpum. 5. Al. rupestre. 6. Al. spinosum.

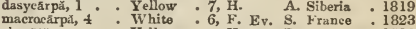
obovãtä. . Yellow H. Her. P. Hrance: 1830 spinôst, 6 : : White : 6, F. Ev, S. S. Eur. : 1683

edëntŭlă 2, halimifouliă 3 , rupēstrĭs 5 .

A noscrocrílǔs, Blume. Supposed to be from anoiktos, open, and ckeilos, a lip; in allusion to the spreading apex of that organ. Linn. 20, Or. 1, Nat. Or. Orchidacee. This is a very interesting little plant, with rather inconspicuous flowers and very handsome leaves, which are admirably and singularly painted with transverse yellowish lines upon a rich brown purple ground. The plant is described as a native of Java and Ceylon, but his Grace the Duke of Devonshire's collector found it on the Khoseea Hills, from whence he bronght living plants in 1837, and which are thriving in great beauty in the orchidere house at Chatsworth. It requires the same treatment as the other East Indian terrestrial orchidaceæ.

setăcĕ̃̄s . . Wht. grn. . 6, S. Ter. E. Ind. . . 1836

A NomAtrīč̆, Ker. Named fron anomos, singular, and theca, a capsule. Linn. 3; Or. 1, Nat. Or. Iridacea. Very interesting free-fiowering species, succeeding in common soil, and multiplied plentifully from seeds. $A$. cruenta makes a pretty show when planted in a bed by itself in the Hower-garden, where its neat blossoms are produced in abundance. cruēntă . . Blood . . 7, F. Bl. P. C. G. H. - 1830 jûncéă: : Lila : 5, G. BL P. C. G. H. : 1791 [21] 
ANomరDరs, Hooker. Compounded from anomos, irregular, and odous, a tooth; in allusion to the singular nature of the peristome. Linn. 24, Or. 5, Nat. Or. Musci. The plants have dark, blackish green, long cylindrical, straggling stems, and are found on the wilds of Dartmoor. Synonymes: 1. Necker curtipendula. 2. Hypnum viticulosum, curtipendulum 1 , viticulosum 2

A NōNǍ, Adansun. From Menona, its Banda name. Linn. 13, Or. 6, Nat. Or. Anonacee. An interesting genus, comprising for the most part fruit-bearing plants, preferring a moist heat and rich loamy soil, well watered. Ripened cuttings, in sand, under a glass, root readily; and fresh seed obtained from the tropics, sown in pots, and plunged in a strong hotbed, will speedily furnish good plants. The fruit is a pretty berry of a sub-acid taste, often as large as an orange, but in general more like a plum. A. cherimolia produces a succulent fruit of a dark purple colour, containing a soft sweet mucilage, and is much esteemed by the Peruvians. $A$, reticulata yields a yellowish, sometimes reddish fruit of the consistence of custard, and is much esteemed by some people. A. palustris bears a large, smooth, heart-shaped, sweet-scented fruit, of an ayreeable taste, but is a strong narcotic; the wood of this plant is so remarkable for its soft, spongy, nature, as to be employed in Brazil as a substitute for corks. Synonyme: 1. A. tripetala.

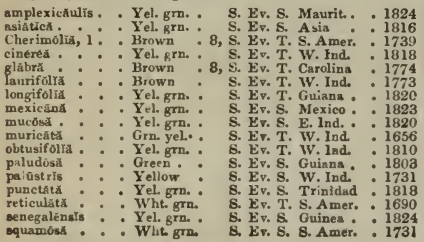

A NSERINous, relating to greese.

A NTKNNÁtiá, $\boldsymbol{R}$. Bronn. In reference to the down of the pappus, which is like the antennæe of some insects. Linn. 19, Or. 2, Nat. Or. Composita. Mostly interesting species; for culture, \&ce., see Gnaphalium. Synonyme: 1. Gnaphalium alpinum.

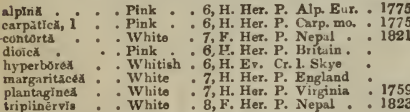

ANTRR10R, growing in front of any thing.

ANThelmLNTic, capable of killing worms.

A NTH К̆ Lis, Linn. In allusion to the great production of flowers; from anthemon, a flower. Linn. 19, Or. 2, Nat. Or. Composita. These species are more useful than ornamental, and may be grown in common soil, and increased from seed. $A$. nobilis is a very useful herb, and is employed medicinally as a tonic carminative anodyne, and when taken in large doses it proves a powerful emetic. Synonymes: 1. A. naritima. 2. A. saxatilis. 3. A. peregrina. 4. A. incrassata. 5. Pyrethrum orientale. alpiñ . . White , 7, H. Her. P. Austria . 1824 7, H. Her. A. A S. Eur. : 1731 apifolia : : Whito : 7, G. Her. P. China : 1819 austriácă : : White : 8, H. Her. P. Austria : 1759 austriāeă : : Whiteléri : : 8 , H. De. Tr. Italy : 1825

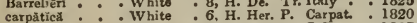
carpatica : : White : 6, H. Her. P. Carpat. : 1820 Chamomilla : White : 7, H. Her. P. S. Eur. : 1807

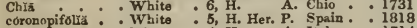
cota : : White $: 4, \mathrm{H} . \quad$ A. Italy : 1714 discoided: : Yellow : 6 , H. A. A. Ataly : 1825 fruticulósa : : White : 8, H. Her. P. Caucas, : 1820 fuscatal - : White 7 , H. Her. A. Pertugal : 1805 globonăh.j: : White : 7, H. Her. P. S. Eur. : 1825

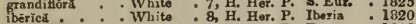

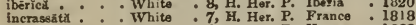
Fitzibelin, $\dot{2}:$ : White : 6 , H. Her. P. Hungary : 1823 maritrma

Marshalitána . Yellow * 7, H. Her. P. Cnncus. - 1816 melumpodia: : White :8, H. Her. P. Egypt. : 1819 mixta : White : $8, \mathrm{H}$. A. France : 173 montána : . Purple * 7, H. Her. P. ltaly. . 1759 nobrlǐs

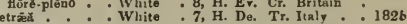
pubēscèns . . White . 7, H. Her. P. 8. Eur. . 1803 punctata : : White : 8, G. Ev, S Barbary : 1818 Pyrethrüm : : White : 5, H. Her. P. S. Eur. : 1570 rigéseêns : White : \& H. Her. P. Caucas. : 1805 Rudolphiănă, 5 . Yellow : 7, H. Her. P. Caucas, : 1824

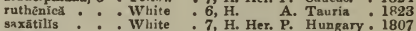
tinctōriă : : Yellow 6 , H. Her. P. Britain : tomentós: : : White : 7, H. Her. P. Levant : 1795

Anglica 1, arvensis, Cotula, nicaensis 3 , pedunculata 4, peregrina, racemosa, retusa, secundiramea.

A Nтиӗтно̆вй, Schreber. Compounded from anthos, a flower, and phureo, to bear. Linn. 3, Or. 2, Nat. Or. Graminea. An interesting species of grass, of easy culture. Synonymes: 1. Tripsacum hermaphroditum, Cenchrus levigatus.

elegăns, 1 . . A petal . 8, Grass. Jamaica. 1776

Anthŭrīcūx, Linn. Applied by the Greeks to the stem of the asphodel. Linn. 6, Or. 1, Nat. Or. Liliacec. This interesting genus comprises both bulbous and shrubby species, and all may be grown in a mixture of loam and peat, with the addition of a little sand. The shrubby species propagate readily from cuttings; and from the bulbous kinds offsets may be obtained. Most of them perfect seed. None of the species will thrive if overwatered, and the bulbous kinds should not have any water in winter. Synonyme: 1. Scilla pomeridiana.

albueoidés . White. 7, G. Her. P. C. G. H. 1788 bipedunculatom : White: : 5, G. Her. P. C. G. H. : 1825 casaliculatum . Wht. grn. 5, G. Her. P. C. G. H. 1774 rüfüm - Capper 6, G. Her. P. C. G. H. róc $¥ 0 \mathrm{~m}$ White. 6, F, Her. P. C. G. H. White 7 G. Her P C G falcatum : : White: : 5, Q. Her. P. C. G. H. filifolrom : : White.: 4 G. Her. P. C. G. H. hliforme $: \cdot$ Alexifoliũm : : White.: 6, G. Her. P. C. G. H. fragrans : : White: : 5, G. Her P. C. G. H. graminifolrum: White. 6, G. Her. P. c. G. H. hirsútūm : White. 7, G. Her. P. c. G. H. longifolrūm : White. 7, G. Her. P. C. G. H. pilorum . White. . 7, G. Her, P. C. G. H. White 3, F, Her, P, Chile pomerhlianùm, 1: White revolūtūm. . White :10, G. Her. P. C. G. H. : 1731 serotrnúm : : White. 7, H. Her. P. Britair. spirald . . White. S, G. Her. P. C. G.H. tynameñm . White . 7, G. Her. P. C. G. H. sutphŭreũm - Pur yel. 7, H. Her. P. Hungary : 1823 triforrūm : Whito. Y,G Her. P. C. G.H. 1789 rndulatüm. White: : 6,G. Her. P. C.G.H. : 1825 vespertinúm: : Whito: : 6, G. Her. P. C. G.H. : 1802 villosom : White:

ANTHERIYrRous, bearing anthers.

Axtrkns, the male parts of a flower, containing the fecundating matter.

ĀNтніی Ă, Fries. Derived from anthinus, florid; referring to the colour. Linn. 24, Or. 9, Nat. Or. Fungi. Minute productions, found on the decayed and decaying leaves-miniätã.

ANrulstirî, Willdenon. Named in allusion to the very stiff stubble, from anthisteri. Linn. 23, Or. 1, Nat. Or. Graminea. Uninteresting species, of simple culture. Synonyms: 1. Andropogon quadrivalvis -australis, ciliata.

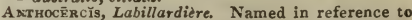
the radiated corolla, from anthos, a flower, and kirkis, a ray. Linn. 14, Or. 2, Nat. Or. Scrophulariacec. Thesepretty species succeed well in a mixture of loam and peat, with the pots well drained, and the plants carefully watered; cuttings root in sand under a glass.

albicăns * . White . 6, O. Ev. S. N. Holl. • 1824 littōrea : : : White : 6, G. Ev. S. N. Holl. : 1803 viscös L̆ : White : 5, G. Ev. S. N. Holl. : 1822

Aлтнб̆сйво̆s, E. Botany. From anthos, a flower, and keroeis, a horn; alluding to the horn-like form of the theca. Linn. 24, Or. 7, Nat. Or. Hepesticue. Small frondose plants, with long, slender, twovalved theca, in habit resembling Jungermannia, major, multifidus, punctatus.

Antroclisistâ, Afselius. From anthos, a flower, and 
cleistos, shut up. Linn. 5, Or. 1, Nat. Or.A pocynacer. An ornamental tree, thriving well in peat and loam, and increased trom cuttings.

macrophylla . . White * S. Ev. ' T. S. Leone - 1820

ÅNTuð̋ Dơ, Ruiz and Pavon. Derived from anthos, a flower, and odous, a tooth, Linn, 3, Or. 1, Nat. Or. Hippocrataced. Interesting evergreen species, growing in rich loam and peat, and propagated from cuttings in sand under a glass.

ellīptīeüm . . . Yel. grn. . S. Ev. S. Rio Jan. . 1818 paniculatūm : : Yel. grn. . S. Ev. S. Rio Jan. . 1818

Aктнодомаั, La Billardière. Named from anthos, a flower, and loma, a fringe. Linn. 13, Or. 1, Nat. Or. Marcgraaviacese. A beautitul tree, preferring rich loam, mixed with a little peat; ripened cut. tings root in sand under a glass.

montånă . . . . . . S. Ev, S. N. Holl. • 1810

Aмтнб̆рнб̆в stamens, and ovary are seated.

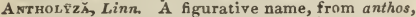
a flower, and lyssa, rage; the flowers look like the mouth of an animal ready to bite. Linn. 3, Or. 1, Nat. Or. Iridacec. An interesting genus of bulbous plants, thriving well in sandy soil under a south wall; the roots should be planted deep enough so as to be out of the reach of severe frost; they increase easily from offsets. Synonyme: 1. A. athivpica vitigera.

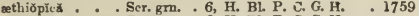
montana : : Brown : 6, H. Bl. P. C. G. H.

præăltă, 1 : : Orangø : $2, \mathrm{H}$, Bl. P. C. G. H

ANтнogpérmū M, Linn. From anthos, a flower, and sperma, seed. Linn. 22, Or. 4, Nat. Or Rubiacece. Amber Tree. An interesting species, delighting in loam and peat, and cuttings strike freely in soil.

æthiơpleūm . . Gm. wht. 6, G. Evv. S. C. G. H. . 1692

Anthoxス̃тнū xanthus, yellow. Linn. 2, Or. 2, Nat. Or. Graminere. Spring Grass. In teresting species of grass, of the simplest culture. It is the dried herbage of $A$. odoratum that gives the sweet peculiar fragrance in meadow hay, said to depend on the preseme of benzoic acid.

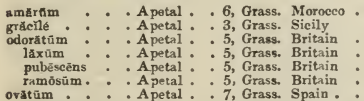

A by Pliny resembling Scardix. Linn. 5, Or. 2, Nat. Or. Umbelliferce. Uninteresting species, of the simplest culture. Syponyme: 1. Scandix Anthriscus -fumarioũdēs, hĩspĩdä, nemorôsă, nodosă, tāurīă, trichospêrmă, tuberculätă, vulgăris 1 .

ANThïllis, Linn. From anthos, a flower, and ioulos, down; in reference to the flowers being usually downy. Linn. 16, Or. 6, Nat. Or. Leguminosce. Beautiful free-tlowering species, proper for ornamenting rock-work. The hardy perennial and annual kinds thrive well in a warm situation and light soil. The greenhouse and frame kinds succeed best in sandy loam and peat, and increase plentifully from seeds, and sometimes from cuttings. Synonymes 1. Vulneraria rubriflora. 2. A. corni. cina. 3. Vulneraria polyphylla. 4. A. rustica.

8. H. Her. P. Britain.

anpalathi : Yellow : 7, G. Ev. S. C. G. H. : 1824

Hârbå Jôvis: : Pa, yel. : 4, G. Ev. S: S. Eur. : 1640

cornicina : White.: 7, H. A.Spain : 1759

evtisoĩdés: White: 6, G. Ev. S. Spain : 1731

Dillëñi, 1: : Red : 7, H. Her. P. S. Eur. : 1816

echinstä :Purple $6, G, E v, S$, S Eur.

$5, F$ Ev Spar.

Gerardi. :

hamösă, 2 Pa. yel. $\quad 7, \mathrm{H}$. A. Barbary : 1821

Hermãnnīâ * Yellow: 7; F. Ev. S. Levant. : 1739

heterophylla - Pink . 7, G. Ev. S. S. Eur. . 1768

lotoides : : Yellow :7, H. A. Spain : 1739

albä.: White. 7, H. Her. P. S. Eur. : 1759

onobrycholdés : Yellow 7, H. Her. P. Spain : 1817

polycéphala : Yellow 7 H Her, P. Barhary

polyphrla 3 Yellow $7 \mathrm{H}$ Her $\mathrm{P} . \mathrm{S}$.

Yellow . 7, H. Her P. S. Eur. . 1816

[23 ]

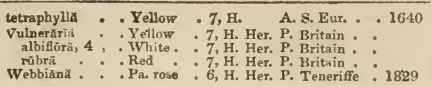

ANT1-APHKODIsIACAI, any thing which checks the desire of sexual intercourse.

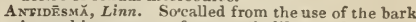
in making ropes; from anti, like, and desmos, bond. Linn. 22, Or. 5, Nat. Or. Stilaginacee. Plants requiring a rich loamy soil ; ripened cuttings with their leaves on, root in sand, in a moist heat.

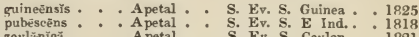
zeyläniea : : A petal : S. Ev. S. Ceylon : : 1821

Alexitērĭă, paniculata.

Ant1-prstilential, efficacious against pestilence.

A str-phrasis, the use of words in a sense opposite to that of some neighbouring parallel sentence.

AntrRrhīnūx, Linn. Derived from anti, similar, and rhin, nose; the flowers of most of the species bear a perfect resemblance to the snout of some animal, Linn. 14, Or. 8, Nat. Or. Scrophulariacece. Very pretty flowering species, succeeding well in common soil, and increased plentifully from cultings or seeds.

angustifolrüm . Pink . . 8, H. Her. P. Europe . 181 A sarīna : White: 7, F. Ev. Tr.Italy : 169 calycinúm : : Red : $7, \mathrm{H}$. Apain : 1810 glandulōsüm : Ro. yel. : 9, H. A. Californ. : 1834 măjŭs : Pink : 7, H. Her, P. England bıeölör: : Scr, wht. 7, H. Her. P. England. caryophylloidés Seur. stpd. 7, H. Her. P. Gard. hyb. coccineús . Scarlet. 7, H. Her. P. England flörë-plēnō: : Flesh . : 7, H. Her. P. Eugland variegãtùm. Red . 7, H. Her. P. Englaud mèdiūm - Pink : 8, H. Her. P. Eurnpe meonánthüm : Pink 8, H. Her. P. S. Eur. 182 mollé . White. 8, F. Ev. F. Spain - 1817 montevidēnsé: : Red : 7, H. A. Nt. Video. 1829 montevideñé : Red : : 7, H. A. Mt. Video
Orôntiûm : : Flesh : 8, H. A. Britain sempervirens : Pink : 8, H. Her. P. Pyrenees: 1821 sỉcülūin. - : White: 7, H. Her. P. Sícily * 1804

ANтRŏph ̌̌̃ native places of halitation, from antron, a cavern, and plio, to grow. Linn. 24, Or. 1, Nat. Or. Pctypodiacea. An interesting species of fern, of easy culture. Synonyme: 1. Hemionitis lanceolata.

lanceolātūm, 1 . Brown . 8, S. Her. P. W. Ind. - 1793

ANTI-scrophULOUs, efficacious against scurvy, antiscorbutic.

A NT1SEPTIC, efficacious against putrefaction.

AnTWRRP HotLYHock, see Althcea ficzfolia.

A « nychia. Linn. 5, Or, 1, Nat. Or. Illecebracec. An ornamental species; for culture, \&c. see Paronychia. Synonyme: 1. Queria canadensis.

dichŏtơmă . . Green . . 7, H. B. N. Amer. . 1806

Aōtǔs, Smith. The ear like appendages are want ing; hence the name from a, privative, and ous, ear. Linn. 10, Or. 1, Nat. Or. Leguminosa. Pretty greenhouse species; for culture, \& \&., see $P$ ultencea.

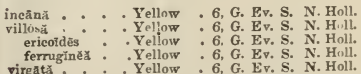

irgata. Yellow 6, G. Ev, S. N. Holl. 182

A pX̃rẵa, Scopoli. A name applied by the Greeks to a plant notw unknown. Linn. 19, Or. J, Nat. Or. Cumpositce. Herbaceous plants, of simple culture. Synonyme: 1. A. cichoracca.

aurantiăcă. . . Orange . 6, H. Her. P. Hungary . 1816 alpina, aspera, caucasica, coronopifolia, crispa, crocea, dubia, fasciculata 1, Gonani, hastilis, hispida, hyoseruides, incana, macrorhiza, strigusa, Tararaci, Villarsi.

A рвївӑ, Margraav. A name given by the natives of Brazil, to Apeiba Tibourbou. Linn. 13, Or. 1, Nat. Or. Tiliacece. Beautiful trees, with large leaves and fine yellow flowers, thriving well in loam and peat, and propagated by cuttings of the ripened wood, in sand, in heat, under a glass, carefully watered. The best way to make them flower in this country, is by ringing the large branches, and by this means checking the flow of the sap. Synonymes: 1. A. hispida. 2. A. hirsuta. 


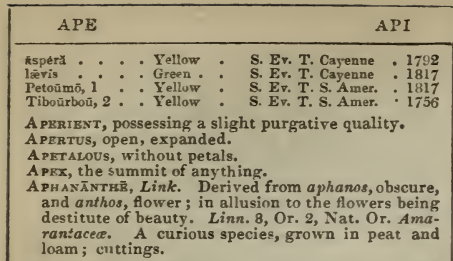

celosioidés . . . Wht. grn. 7, G. Ev. S. Brazil . . 1813

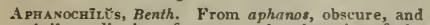
cheilos, a lip, in reference to the obscurity of the lip of the flower. Linn. 14, Or. 1, Nat. Or. Labiato. An ornamental species; for culture, \&c., see Mentha. Synonyme: 1. Mentha blanda.

incisŭs. . . White . 9, H. Her. P. Nepal . 1824

A PHEL $\bar{A} N D R \bar{A}, \boldsymbol{R}$. Bronn. From apheles, simple, and aner, a male; the anthers being one-celled. Linn. 15, Or. 2, Nat. Or. Acanthacese. This splendid stove species, to succeed well, should have a good turfy loam and peat, and be grown in proportioned sized pots, judiciously drained; when the plant is in a growing state, it should have a good supply of water at the roots, and frequently a powerful sy ringing on the leaves, \&c. Synonymes: 1 . Ruellia cristata, Justicia pulcherrima.

cristät, 1 . . Searlet - 8, S. Er. S. W. Ind. - 1733

A phrıễxis, D. Don. From apheles, simple, and exis, habit; in reference to the habit of the species. Linn. 19, Or. 2, Nat. Or. Compositc. Ornamental species; for culture, \&cc., see Elichrysum. Synonymes: 1. Elichrysum ericoides. 2. E. fasciculatum. 3. $E$. spectabile, pinifolium. 4. E. sesamoides.

Xeranthemum sesamoides.

fasciculátã, 2: Pur yel 6, G. Bv S. C. G. H. Alba . : : White. 7, G. Ev. \&. C. G. H. rübră : : Red : 7, G. Ev. S. C. G. H. hưrlis 3 .: : Pink : 5, G. Ev. S. C. G. H. H. sesamoides, 4 : : Pur, wht: 5, G. Ev. \& C. G. H.

Арнтнut 8, resembling something covered with little ulcers.

A PHYLLÃNГHĒs, Linn. Its stems are like a rush, and bear on their summit a little tuft of flowers; hence the nanie from aphyllos, leafless, and anthos, flower. Linn. 6, Or. 1, Nat. Or. Liliacee. This pretty species delights in peat that is somewhat sandy, and increases by dividing the roots or by seeds.

monspeliêrsis . Red . . 6, F. Her. P. France . 1791

Apícrã, Willdenow. Derived from apikros, nnt bitter; probably in allusion to the taste not being like bitter aloes Linn. 6, Or. 1, Nat. Or. Liliacece. Very interesting species of succulents; forculture, \&c. see Aloe. Synonymes: 1. Aloe spiralis. 2. Apicra pseudo rigida.

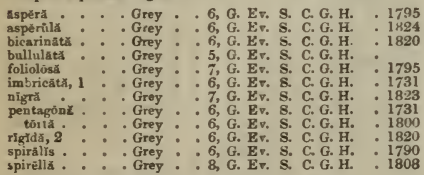

A piculatus, the flowers resembling a bee.

Apiculate, $\}$ terminating in a little point.

A PIFBR A, like a bee.

ĂpIōs, Boerhaave. From apion, a pear; in reference to the form of the roots. Linn. 17, Or. 4, Leguminose. An ornamental species; for culture, \&c. see Clitoria. The roots may be eaten with safety. Syncryme: 1. Glycine apios.

tuberōsa . . . Brown pnk. 8, H. Tı. P. N. Amer. . 1640

Aprux, Linn. Derived from the Celtic word apon, water; in allusion to the place where the plants grow. Linn. 5, Or. 2, Nat. Or. Umbellifere. The
APL

mode of cultivating these plants is so well known, that we need not mention it here.

graveléns. . White. - 7, H. B. Britain .

fractophyllum, prostratum, romanium, ternatum.

A PLË̄́trūM, Nuttall. From $a$, without, and plektron, a spur; the flower is spurless. Linn. 20, Or. 1, Nat. Or. Orchidacee. A curious little plant yrowing freely in sandy peat, and increased by offsets.

hiemale . . . Brown - H. Ter. N. Amer. . 1827

ArtophīLlēr, Jussien. From aploos, simple, phyllon, a leaf. The leaves are simple. Linn. 10, Or. 1, Nat. Or. Rutacece. Uninteresting species, of easy culture. Synonymes: 1, Ruta dahurica. 2. R. linifolia. 3. R. patavina. 4. R. pubescens. 5. $R$. suaveolens. 6. $R$. villosa-Burbaumii, dahurica 1 , linijolium2, potarinum 3, pubescens 4, suaveolens 5, tuberculatum, villosum 6 .

ArLüDA, Linn. Derived from apluda, chaff; the resemblance of the involucres to chaff. Linn. 23 , Or. 1, Nat. Or. Graminece. An uninteresting species, of the easiest cultivation. Synonyme: 1. Andropogon involucratus -aristātă, 1 .

A pücřxūx, Linn. Derived from apo, away, and kyon, a dog; supposed to be mortal if eaten by dogs. Linn. 5, Or. 1, Nat. Or. A pocynaced. Plants of little beauty, but easy culture; A. androsiomifolium is acrid, and blisters the skin. The stalks of A. cannabinum afford the North American Indians a substitute for hemp, of which they make twine, bags, fishing-nets, and lines, also linen for their own wear.

androsamifoliam striped . 8, H. Her. P. N. Amer. . 1688

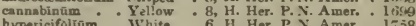
hypericifolium : White : 6. H. Her. P.N. Amer. : 1758 venetúm "White :6, H. Her. P. Adrint. Is. 1690

A poschintōx, Thun. The name is derived because of the specles growing in water; from the Celtic apon, water, and the Greek word geiton, near. Linn. 6, Or. 3, Nat. Or. Snururacere. Interesting aquatics, succeeding weil if planted in loam and peat, and placed in a tub of water. Offsets or seeds.

ungustifolrum, White. . 7, G. Aq. P. C. G. H. . 1788 erikpum : White: : 8, s, Aq. P. Ceylon. : 182 listachpon. : White. 6, G. Aq. P. C. G. H. : 1788 wonostichyỏn. : Pink : 9, S. Aq. P. E. Ind. : 1803

A roprrsirs, a swelling beneath the theca of mossos.

A rōrōs, Blume. From aporux, a running-shoot; from the appearance of the plant. Linn. 20, Or, 1 , Nat, Or, Orchidacere. This genus possesses little to recommend it to the lovers of this beautiful tribe. Its insignificant flowers are produced from the axils of its bright green leaves. It thrives well with the same treatment as Vanda. Synonyme: 1 . Dendrobium anceps.

ancēps, 1 . . . Yelsh, all . S. Epi, E. Ind. . . 1826

A pPENDAGr, that which is attached.

APPRNDANT, \} hanging, approaching, pendulous.

A ppendicuiate,

APPENDICULATRD, \}furnished with appendages.

APPENDIX, anything attached.

A PPKBSSED, pressed close to any thing.

A pproximate, $\}$ near together.

Āprérous, without the membranous margins, by botanists called wings.

AquĀRTín, Jacq. In honour of B. Aquart, Jacquin's companion in America. Lixn. 4, Or. 1, Nut. Or. Solanacea. A species of little beauty, and easy culture.

tomentósa . . . White. . S. Eq.S. S. Amer. . 1819

Aquatic, growing in water.

AQUIr $\bar{A} R \bar{I}$, Linn. The wood is called bois d'aigle, or eagle wood, in Malacea; hence the name froni aquila, an eagle. Linn. 10, Or. 2, Nat. Or. Aquilariacer. An ornamental evergreen shrub, succeeding in loam and peat, and propagated from cuttings, under a glass, in heat. Synonyme: 1. A. ovata.

malaccęnšs . . Wht. grn. . S. Ev. S. Malseen . 1823

AQU1L.̌̆Ğ̌x, Linn. From aquila, an eagle; alluding to the form of the petal. Linn. 13, Or. 5, Nat. Or. Rarunculaces. The species of this ornamental genus may be grown in common soit, and increased plentifully from seeds. Synonymes: 1. A. glan[24 i 
dulesa. 2. A. atropurpurea. 3. A. alpina grandiflora. 4. A. bicolor. 5. A. vulgaris, dahurisa.

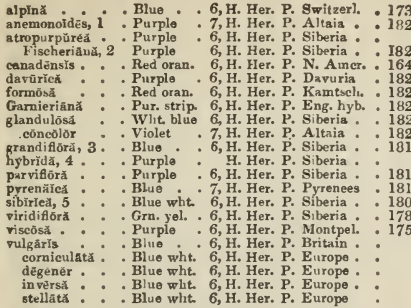

AQưrīisŭs, like an eagle.

$\widehat{A}_{\mathbf{R A n}} \mathbf{s}$, Linns. Originally from Arabia, but this name is not very precise, as the species are found in many parts of the world. Linn. 15, Nat. Or. Crucifere. Mostly interesting species, adapted for ornamenting rock-work; they are propagated from seeds or cuttings. Synonymes: 1. A. caucasica. 2. Turritis stricta. 3. A. aspera. 4. Turritis patula. 5. Turritis alpina. 6. A lellidifolia, ciliaris. 7. Hesperis verna.

albrdă, 1 . White. 7, H. Ev, Tr. Caucasus 1798

alpéstry's . White . 7, H. B, Switzerl. 1819

alpina . Wht yel. 5, H. Ev. Tr. Switzerl. : 1596

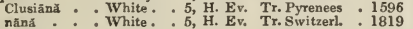

nañă : : White: : 7, H. H. Hite.

bellidifolra: Wha vel. 6, H. Her. P. Switzerl. : 1773

cerăleă : : Pa blue. 6, H. Her. P. Switzerl. : 1793

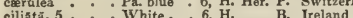

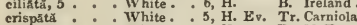

curtisniquă : White.: 6, H. W. B. N. Eur.

dasycárpå : White: 6. H. Her. 1. Podolia

lasioloba. : White. 6, H. B. Mexico.

longifolia: : White. 6. H. Er. Tr. Persia

lúcidx. . White. 6, H. Her. P. Hungary

variegata . White. 6, H. Her. P. Gardens

mollys. . White. 6, H. Ev. Tr. Cancasus

nūtanss : : White. : 6, H. Her, P. Switzerl.

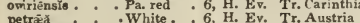

petrēå
hastulátă:

hispiuã : White. 6, H. Bv. Tr. Seotland

prẽeox

variegătă : White. .6, H. Ev. Cr. Gardens

procürréns : White. 6, H. Ev. Tr. Hungary

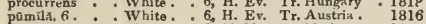

retrofracta : Blush : 6, H. Her. P. N. Amer. . 1867

rüséă . : Rose : : 2, H. Her. P. Calabria : 1832

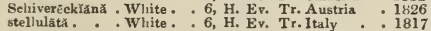

stenopetălă: : White: : 6, H. Ev. Tr.Italy : 1818

stolonîferd : White : 6, H. Ev. Tr. Carniola : 1818

strietă. : Cream. 5, H. Her. P. England

toxophylla : White: 7, H. B. Volya : 1823

undulăta . White. : 6, H. Ev: Tr. S. Eur. : 1810

vërnă, 7 : Purple $: 5, \mathrm{H}$. A. France : 1710 $A$. recta, canadensis, cebennensis, collina, Halleri, hirsuta, incana, lavigata, lyrata, muralis, Patriniana, pendula, procox, pubescens, sagittata, S. longisiliqua, S. oblongata, S. ovata, subylabrata, saxa. tilis, serpyllifGlia, spatulata, Thaliana, $\mathrm{T}$. parviflura, Turrita, $T$. pendula, $T$. umbrosa.

AnÄchřs, Linn. From $a$, privative, and rachis, a branch; the plant bears no branches. Linn. 17, Or. 4, Nat. Or. Leguminosce Casalpiniea. This very singular plant has the property of forcing the fruit or pods as they increase in size into the earth, where they ripen their seeds, hence the trivial name earth-nut. It grows in sandy loam singly in pots, and is multiplied from offsets. In South Carolina the seed is roasted, and used as chocolate; it further affords a thin limpi-d oil proper for lamps, a purpose to which it is applied in Cochin-China.

hypogax . . Yellow .6, S. A. S. Amer. . 1812 A RAchNorntus, covered with capillary filaments.

$A_{R} \bar{A} L \check{L} \breve{\Lambda}, L i n n . A$ name of unknown meaning, under which one species was sent to Fagon from Quebec in 1764, by a French physician. Linn. 5, Or. 5, Nat. Or. Araliacea. These fine species succeed well in common soil, and cuttings, cut off at a joint where the wood is ripe, and planted in a sheltered situation, soon strike root. A. nudicaulis is used in North America as a substitute for sarsa. parilla, Synonymes: 1. Hedera aculeata, 2. $H$. arborea. 3. H. capitata. 4. Panax fragrans. 5. Aralia hispida.

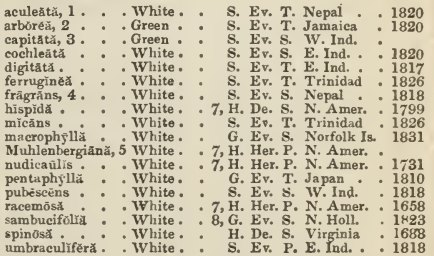

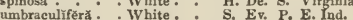

1818

ARANIFEROU,, resembling a spider. canos, its name in Chile Linn, 22, Or. 13, Nat. Or. Coniferc. This, says Sweet, may be termed the handsomest genus of plants with which we are acquainted. A. imbricata in particular is certainly one of the grandest plants known. It will thrive well in the open air, with the protection of a mat or two in very severe weather, and when got pretty large will no doubt be perfectly hardy. Rich open loam suits them well; and propagation may be effected in the same manner as recommended for Altingia.

brasilian丸 . . A petal . G. Ev. T. Brazil . . 1819 imbricātă . Apetal : G. Ev, T. Chile : 1796 Arborrus, being a tree, as distinguished from frutescent.

A r borkscent, having a tendency to become a tree. A rbor-vit.玉, see Thuja.

ĀRBŬTŬs, Linn. From the Celtic arboise, austerebush, rough fruit. Linn. 10, Or. 1, Nat. Or. Ericacee. Elegant shrubs, especially $A$. unedo, which is covered with blossoms, and sometimes with fruit throughout the months of October and November. They succeed well in open loamy soil, mixed with a little sandy peat, and increased by seeds, or by budding and inarching on each other: the dwarfer kinds root readily by layers. From the flowers of A. unedo an agreeable wine is prepared in the island of Corsica. The fruit when taken in any quantity is narcotic. Synonyme: $1, A$. hybrida.

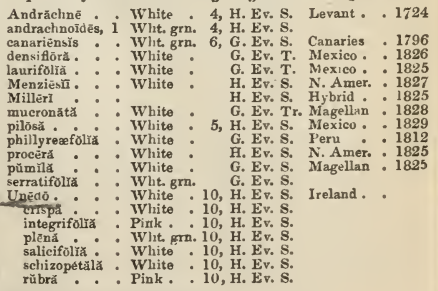

ARChaNGer, see Lamium

ARCHANGEI, see Archangelica officinalis.

A RCHANGËLİX̆, Hoffman. From arche, chief, and angelica. So named, from its supposed archangelic virtues. Linn. 5, Or. 2, Nat. Or. Umbelliferce. Ornamental species; for culture, \&c. see Angelica. Synonymes: 1. Angelica atropurpurea. 2. A. archangelica.

officinălı, 2 . . Green . . 7, H. B. England .

Atropurpârĕ 
ĀRetYứm, Linn. From arktos, a bear; in allusion to the rough bristly fruit. Linn. 19, Or. 1, Nat. Or. Compositce. Mere weeds, of the simplest culture. The seeds of A. Bardana are diuretic, diaphoretic, and gently purgative. Sijnonymes: 1. A.tomentosa. 2. A. major-Bardānü 1, Läppă 2, minŭs.

A RCrōpưs, Linn. From arktos, a bear, and pous, a foot; alluding to the spines which beset the plant, and which have been compared to the claws of a bear. Linn. 23, Or. 2, Nat. Or. Umbelliferce. An interesting species, which should be grown in a mixture of pert, sand, and luam, and it may be inereased by dividing the plant or by seeds.

echinătŭs . . Green . . 5, G. Her. P. C. G. H. . 1774

ARCtostăphr̆ bear, and staphyle, a grape; in allusion to the roughness of the fruit. Linn. 10, Or. 1, Nat. Or.

Ericacer. Interesting species; for culture, \&c. see Arbutus. Synonymes: 1. Arbutus alpina. 2. A. Uva-ursi.

alpinnă, 1 . . Flesh . . 4, H. De. Tr. Scotland

Uvä-ûrsI, 2 : : White: 4 , H. Ev, Tr. Britain

tomentüsí. White. H. Ev. S. N. Amer. : 1826

A Rctothīĕ , Wendland. From arktos, a bear, and theke, capsule; so named from the roughness of the fruit. Linn. 19, Or. 3, Nat. Or. Composite. Ornamental species, grown in turfy loam, or loam and peat, and increased by divisions. Synonyme: 1. Arctotis scapigera.

hirta * * Yellow * 7, G. Her. P. C. G. H. . 1820

A Rсто̄т19, Linn. Derived from arktus, a bear, and ous, an ear; shaggy fruit. Linn. 19, Or. 4, Nat. Or. Compositce. Showy interesting species; for culture, \&c. see Arctotheca.

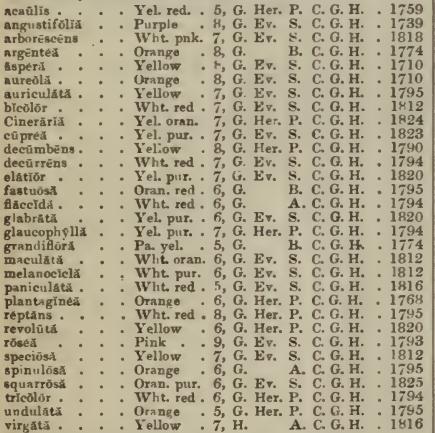

A RCUATE, ? bent like a bow, forming an arch.

A RCCATED, , bent like a bow, forming an arch.

A Reřriă, Persoon. So called from arkys, a net; alluding to the net-like appearance of the fibres. Linn. 24, Or. 9, Nat. Or. Fungi. Extremely small productions, found upon rotten wood. Synonyme: 1. Trichia denudata, flava, incarnata, leucocephala, punicea 1.

$\bar{A}$ RDENS, bright, glowing, burnished.

Arpǐsı̃ , Swartz. A name derived from ardis, a spear-point; alluding to the acute segments of the corolla. Linn. 5, Or. 1, Nat. Or. Myrsinacee. Mostiy handsome free-flowering species, of easy culture, succeeding well in a mixture of loam and peat; cuttings root freely in sand, plunged in heat, under a glass; or they may be increased from portions of the root, planted in a pot of mould leaving the points oitt, and plunged in a brisk bottom-heat. Synonymes 1. Icacorea guianensis. 2. Ardisia cre nata. 3. Myrsine Heberdenia. 4. Ardisia crenulata. 5. A. umbelluta. 6. A. pyramidalis.

senminătă, 1 7. S. Ev. S. Guians . 1803 eanaliculinta 7, S. Ev. S.

1821

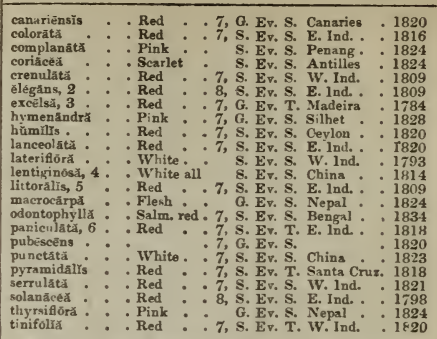

A rdūină, Linn. In honour of Pietro A rduini, curator of the economical garden of Padua. Linn. 5, Or. 1, Nat. Or. Apocynacer. This pretty species may be treated as recommended for Carissa.

bispinösă . . . White. . 6, G. Ev. S. C. G. H. . 1760

A Rēex, Linn. When an old tree, it is called in Malabar areec, when quite young, Perynga. Linn. 21, Or. 10, Nat. Or. Palmacea. This most beautiful genus of palms succeeds best in light sandy loam, and can be increased only from seeds. The well-known Betel Nut is the fruit of $A$. Catechu, and remarkable for its narcotic or intoxicating power; from the fruit is prepared a kind of spurious Catechu. Ainslie, 1-65. It seems to me, however, doubtful whether the intoxicating effect of the Betel Nut, which is cut in slices, folded in the aromatic leaves of the Betel pepper Nut (Piper Betel), and chewed in the mouth like tobacco, is not owing to the Piper leaf, in which it is wrapped when eaten, rather than to any special property of its own.-Lindley's Introd. to the Nat. Syst., 2nd Edit.

Cátéchũ . . . White . . Palm. E. Ind. . 1690 crinită : : White : Palm. S. France : 1824 Palm. W. Ind. 1893 hŭmllis : . White : Palm. E. lnd. : 1814 lutescëns: : Whito: Palm 1. Franee : 1824 Mánieoút: : : Whito : Palm S. Amer. : 1822 monteña : : : : Palm. S. Amer. 1822

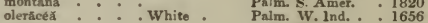

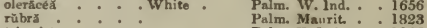
triândră : : : Palm. E. Ind. : 1825

AREMônĩn, Decandolle. Said to be altered from Agrimonia. Linn. 8, Or. 2, Nat. Or. Rosacer. Merely ornamental; for culture, \&c. see Agrimonia. Synonyme: 1. Agrimonia agrimonoides.

agrimonőidés . Yellow . 7, H. Her. P. Italy . . 1739

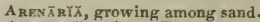

ArRVÁRIÄ, Linn. From arena, sand; referring to the sandy situation in which most of the species are found. Linn. 10, Or. 3, Nat. Or. Alsinaces. Diminutive plants, of the easiest culture. Synonymes: 1. A. Villarsii. 2. A. macrocarpa. 3. A. sibirica. 4. A. fastigiata. 5. A. liniflora. 6. A. filifolia. 7. A. gluberrima. 8. A. marginata. 9. A. marına. 10. A. androsácéd. 11. A. eherlerifolia. 12. A. heteromüllă. 13. A. pungens. 14. A. viscosa.

a ustrĭăcă, 1 baleärīeă

brevicaûlis cespitōs calyeīnă

calyculat canadēnsis

canéscēns, 2

capilläcéă

capilläriss, 3

cherlerioìdês

cherlerio

coimbrieënsĭs

đabûrĭcă

dëns:

fasciculätă, 4 .

White.

7, H. Her. P. Austria - $\mathbf{1 7 9 3}$

White. 7, H. Ev. Tr. Majorea . 1787

White. 7, H. Her. P. Alp. Eur.. 1823

White . 7, H. Her. P. Switzerl. . 1+26

White. .7, H. A. Barbary : 1816

White. 7, H. Her. P. Hungary . 1817

Red : 7, H. A. N. Amer. . 1812

White: 7, H. Her. P. Piedmont 1817

White. 7, H. Her. P. Siberia

White: 7, H. Her. P. France

White. 6, H Her. P Ireland

White : 7, H. A. Portugal : 1817

White 7, H. Her. P. Dahuria: 1824

White. 7, H. Her. P. Hungary : 1824

White

formōsa

Gerărdì, 5

glandulōsa

White

7, H. Her. P. Arabia

6, H. Her. P. Dahuria - 182

A. Franeo 1822 glomerătă : : White.:7, H. A. Tauna : 1818 


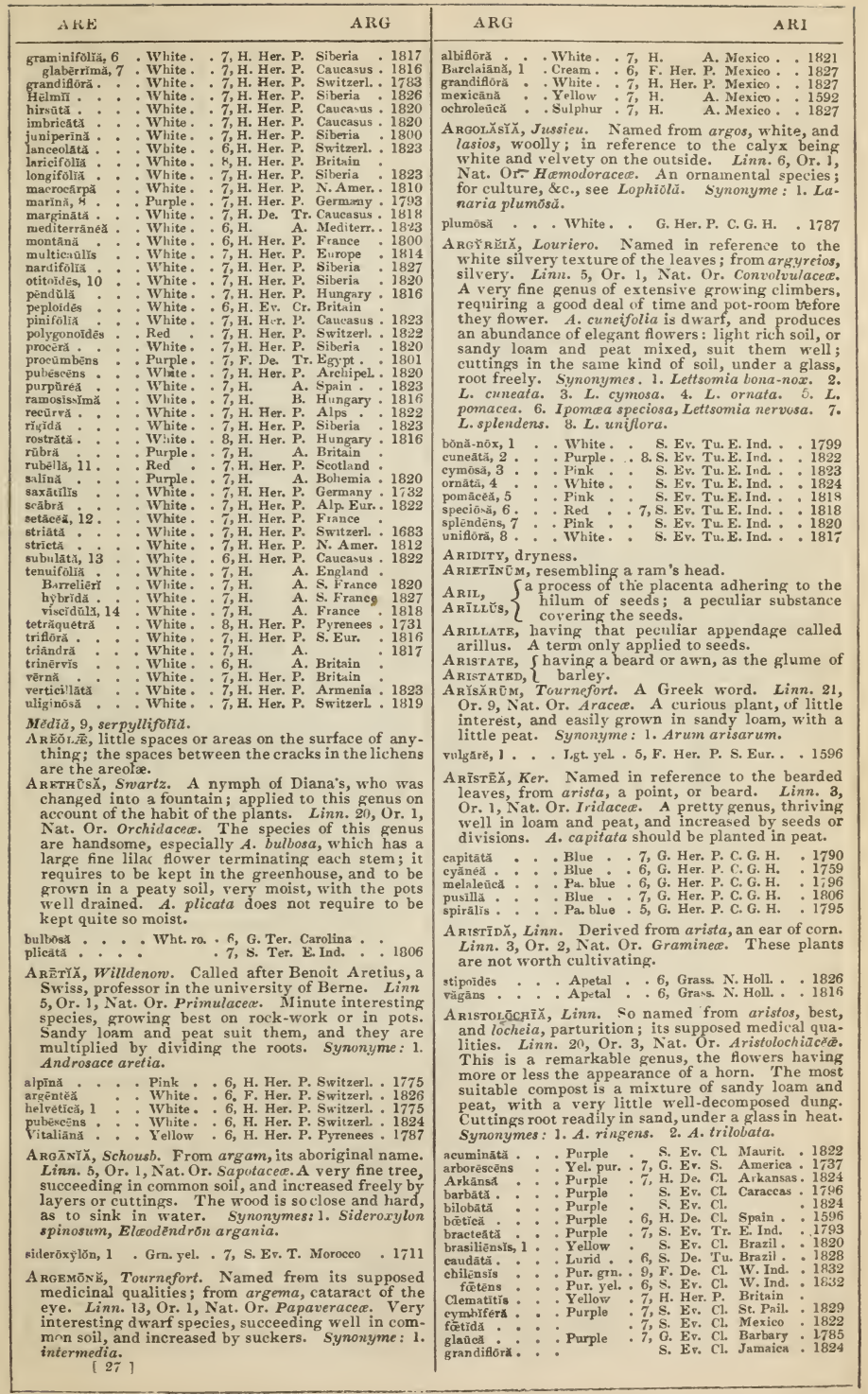




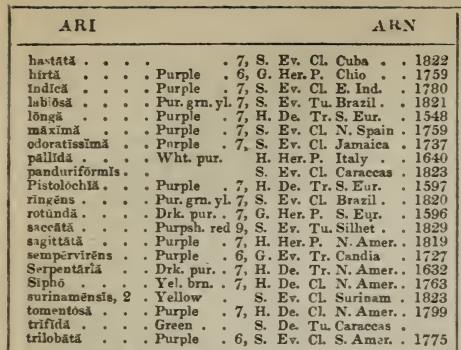

A RISTOTËI Y̌, Willdenow. In memory of the celebrated Aristotle. Linn. 11, Or. 1, Nat. Or. Philadelphaceu. This as a shrub is showy, but its flowers have little beauty. In a warm situation it grows freely, in common soil, and ripened cuttings soon take, as do also layers. It produces a berry.

Mäequí. . . Wht, grn. 5, H. Ev. S. Chile • . 1735 variegata : Wht. gra. 5, F. Ev. S. Gardens

A Rмв드̆că, Tournefort. Named from the apricot being originally from Armenia. Linn. 12, Or. 1, Nat. Or. Amygdalec. A genus of valuable fruit trees, as is at once apparent from its containing the well-known apricot. The species all thrive well in a rich loamy soil, and are best increased by budding on kind free-growing plum stocks. $A$. vulgaris, or common apricot, produces a round, yellow, firmish-fleshed fruit, little less esteemed than the peach or nectarine; it is used fresh from the tree at the dessert, and is also made into jellies, preserves, \&c.; from the clarified juice the Chinese make lozenges, which, dissolved by water, yield a grateful beverage; the nut yields a kind of oil, and the young shoots a fine golden colour to wool. Synonymes: 1. Prunus brigantiaca. 2. P. dasycarpa. 3. P. sibirica. 4. P. armeniaca. brigantisce, 1 . Pink . 3, H. De. S. S. Eur. dasycârpa. 2 White: $4 \mathrm{H}$ De persicifolra: : Pink: 4. H. De T. siblrĩă, 3 .: : Pink : : 4, H. De. $\mathrm{S}$ : siberia

vulgario 4. White: 4, H. De. T. Lerant eordifolli: : White. 3, H. De. T. Levant ovalifolla : : White: : $3, \mathrm{H}$. De. T. Levant

1819

1800

1800

1788
1548

1548

1548

ARM $\bar{R} \mathbf{I} \tilde{A}$, Willdenow. Armeria is the Latin name of Sweetwilliam. Linn. 5, Or. 5, Nat. Or. Plumbaginacea. These plants though dwarf are handsome, and well adapted for ornamenting rock-work ; they may also be grown in pots, in sandy, open, rich soil. A. vulgaris, or common thrift, is considered next to box the most valuable for edging walks, borders, \&c. Synunyme: 1. Statice armeria.

alliacéa .

alpină

arenaria

cephalōtẽs

denticulätă

diantholdẽs

hirta

hümกlı: :

juniperiforia

latifólix.

littoralirs

maritioñ

montână

pinifolia

plantagin

vulgăris. : : Red

White.

6, H. Her. P. S pain

7 , H. Her. P. Carinthis

Pink : 6, H. Her. P. France

Flesh: $: 6$, H. Her. P. Naples

Pink : 6, H. Her. P. Europe

7. G. Her. P. Europe

Pinkle : 7, H. Her. P. N. Africa

Pink : : 6, H. Her. P. S. Eur.

Pink 6, H. Her. P. Spain

Lgt, red : 7, H. Her. P. Algarbia

7, H. Her. P. S. Eur.

Red : 7, H. Her.P. Britain

Pink: 6, H. Her. P. Portugal

6, H. Her. P. Portugal

6, H. Her. P. S. Eur

6, H. Hex. P. S. Eur.

1798

ARMILLĀRIs, like a bracelet.

ĀRNíč̆, Linnaus. Derived from arnakis, a lamb's skin, because of the likeness of the leaves. Linn.19, Or. 2, Nat. Or. Compositce. The species are dwarf and interesting. A. montana is a powerful sternutatory, and has besides many and important medicinal properties. Synonyme: 1. A. montana.

Clasir . . Yellow

cordata: : : Yellow

córsìcă. Yellow

7, H. Her. P. Switzerl,

7, H. Her. P. Switzerl.

7, H. Her. P. Austris

1819

1819

1824
AR.V

ART

glaciälis . - Yellow . 7, H. Her. P. Switzerl. . 1823

helvetica, $1:$ : Yellow :7, H. Her. P. Switzerl. 1819

lanigera : Yellow : 7, H. Her. P. Italy : 1827

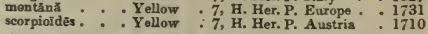

A RNopōoōs, Willdenow. Taken from arnos, lamb, and pogon, beard; in allusion to the bearded seeds. Linn. 19, Or. 1, Nat. Or. Composita. These are pretty flowering plants, and easily cultivated; the seed merely requires sowing in the border, and treating as other annuals. Synonymes: 1. Urospermum capense. 2. U. Dalechämpĩ.

åspèr * - Yellow : 7, H. A. Montpel. 1774 capinsis, 1: : Yellow : 7 , H. A. C. H. H. 1818 Dalechãmpir, 2 : Lgt yel. - 7, H. Her. P. S. Eur. : 1739

Arracācnă, Bancrof. The name given to the plant by the Spaniards in South America. Linn. 5, Or. 2, Nat. Or. Umbelliferc. Perennial South American herbs of a salubrious quality, extensively cultivated for culinary purposes, and propagated by planting pieces of the root, in each of which is an eye or shoot. Synonyme: 1. Conium arracacha.

esculēntă, 1 * Brnsh . . 7, S. Tu. P. Santa Fe.

1823

Aró $M$, the spicy quality of a thing.

Arr Henathérom, Palisot de Beauvois. Derived from arrhen, male, and ather, a point; the male spikes being furnished with awns. Linn. 23, Or. 1, Nat. Or. Graminea. Species of grass, of great use, though but little beauty; cultivation easy. Synonymes: 1. Holcus avenaceus, Avena elatior. \&. Holcus bulbosus, Avená bulbosa.

a venăcetūm, 1. . A petal . .6, Grass. Britain . mûtYeủm : A petal: $:$, Grass, Scotland bulbôsúm, 2: : A petal : : 7, Grass. Germany

ARRōsǔs, gnawed, bitten.

AR Row-GRAs, see Triglochin.

A RROW-HRAD, see Sagittaria.

AR Row-Roor, see Muranta.

A RTス̈вŏтR Y̌s, R. Bron'n. This name was suggested by the curious tendril belonging to the peduncle, by which the growing fruit is suspended on the nearest support; from aratao, to suspend, botrys, grapes. Linn. 13, Or. 6, Nat. Or. Anonaced. This species is very ornamental, growing about six feet high, and is easily cultivated in sandy loam, mixed with a little peat, and propagated from ripened cuttings in sand, under a glass. Synonyme: 1. A. hexapetala.

odoratbssima . . Brown . 7, S. Ev. S. China . . 1758

ARTANẼMĂ, D. Don. A tooth is borne on one side of each of the longer filaments; whence the name, from aratao, to support, nema, a filament. Linn. 14, Or. 1, Nat. Or. Scrophulariacea. This is an interesting plant, with the aspect of a mimulus, producing large showy blossoms. It has been treated in the greenhouse, but will snceeed in the open border in summer, in loam and peat; seeds. Synonyme: 1. Torenia scabra.

fimbriâtüm . . Pa blue . 8, G. Ev. S. Moreton B. 1830

ARTËrǏ Swedish naturalist, one of the first who attempted to divide umbelliferous plants into genera. Linn. 5, Or. 2, Nat. Or. Umbellifera. An uninteresting species, of the simplest culture-squamata.

ARTBMǏsĩ A, Linnous. Artemis, one of the names of Diana; the plant is said to have been named after Diana, on account of its being used in bringing on precocious puberty. Linn. 19, Or. 1, Nat. Or. Composila. Some species of this genus are pretty, others merely ornamental, while some are wholly uninteresting; their silvery leaves have a showy effect in rock-work, for which places they are well suited; they grow in almost any soil, and are increased readily from divisions, cuttings, and seeds. $A$. chinensis, and some other species, yield the moxa of China, a substance used as a cautery, by burning it upon parts affected with gout and rheu. matism. In India $\boldsymbol{A}$. indica is considered a powerful deobstruent and antispasmodic; and the leaves of $A$. maderaspatana are esteemed a valuable stomachic medicine. Synonymes: 1. A. caucusica. 2. A. leucanthemifolia. 3. A. nutans, cernua. 4. A. rupestris. 5. A. Redowskii. 6. A. inodora. 7. A. glacialis, rupestris. 8. A. rupestris. 9. A. splendens. 


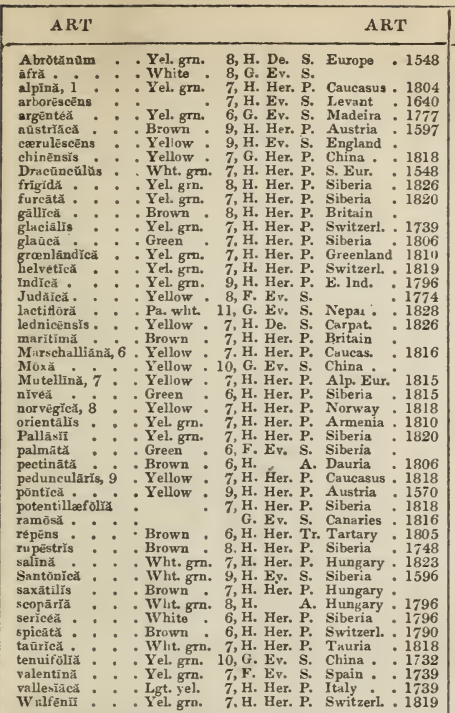

Absīnthtūm, albida, ambigua, anethifolīă, annua, armeniaca, arragonensts, Bulsamita, biennis, camphorütă, campestris, c. alpina, cünă, canadënsīs, canëscēus, caucăsĩcă, caudātă, chamuemeliffoliä, coarctütă, crithmifóliă, desertórūm 2, dracunculoìdés 3, fasciculātă, frägräns, gnaphalioĩdēs, herbācěă, hirsūtă, his-

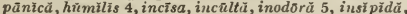
integrifoliăa, Japonnică, laciniātă, longifoliă, mexicànü, mollissímă, monogy̆nă, montevidênsis, negléctă, nūtūns, odoratíssimmü, palūstrǐs, parviflơrä, pauciflorä, pruceră, procrimbēns, serrätä, Sieversiänä, subcanēscēns, tanacetifóläă, viridífolīă, vulgārīs.

А RTнӧNїй. The meaning unexplained. Linn. 24, Or. 8, Nat. Or. Lichenes. Curious species, growing from a quarter of a foot to three feet high, and found chiefly on the bark of old trees.-Astroiddéu, impolżtă, lỹncěă, obscûră, Swartziañă.

Arthrĩtícưs, gouty, swollen.

Arthropódĩ̀, $R$. Brown. Derived from arthron, a joint, and pous, a foot; the foot-stalks of the flowers being jointed. Linn. 6, Or. 1, Nat. Or. Liliacece. Some species of this genus are very pretty, viz. A. minus and fimbriat um; others are ornamental; and the whole succeed in sandy loam and peat, and increase freely by divisions or seeds. Synonymes : 1. A. minus. 2. Anthericum pendulum.

eirrătūun . . White . . 6, G.Her. P. N. Zeal. fimbriatūm : Wǐnüs White. 7, G. Her. P. N. Holl. : 1822 manǔs :ulátūm, i : White. : 7, G. Her. P. N. Holl, : 1823 pendūlūm, 2 : White. : 7, G.Her. P. Teneriffe : 1816

Arthrostēman̆, Pavon. From arthron, a joint, and stemon, a stamen; their stamens or connectives being jointed. Linn. 8, Or. 1, Nat. Or. Melastomacea. A beautiful plant, about two feet high, with palish lilac-coloured flowers; it grows in loam, mixed with a little peat, and increases from cuttings. Synonyme: 1. Rhexia versicolor.

versǐrolour, 1 . Pink . . 8, S. Ev. S. Brazil • 1825

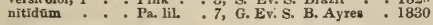
ARtichoke, see Cynara.

A rticulatk, A jointed, having joints.

Articulations, the places where one thing is jointed with another.

ART

ASA

Artocārpŭs, Linn. From artos, bread, and carpus, fruit; in allusion to the well-known name and uses of the bread-fruit. Linn. 21, Or. 1, Nat. Or. Urticacea. To this genus belongs the bread-fruit tree of the Sonth Sea Islands They are difficult to cultivate in this country; a light rich loamy soil is best adapted to them. Sweet says, "they have been generally treated too tenderly, and not allowed sufficient air. They appear to be of the same nature as the fig, to which they are nearly allied. Large cuttings root freely in a pot of sand, plunged under a hand,glass, in a moist heat, with all their leaves entire; if the leaves are shortened, it is a great chance if they succeed." For further particulars respecting this very valuable genus, see Loudon's Encyclopiedia of Plants.

incissă . . . Wht. grn. S. Ev. T. S. Sea Is. 1793 nuciféră: : : Wht. grn. S. Ev. T. E. Ind. integrifơliă. : Wht. grn. 6, S. Ev. T. E. lnd. : : 1778 heterophylla. Wht grno

$\bar{A} R \bar{C} M$, Linnoeus. Formerly aron, supposed to be an ancient Egyptian word. Linn. 21, Or. 9, Nat. Or. Aracer. This genus contains some very handsome species, while others are only useful on account of their medicinal qualities; the flowers are generally very disagreeable, hence they are not favourites; they all succeed in any common soil, and increase with little trouble from offsets. Synonymes: 1. Tacca phalifera. 2. A. gramineum.

atrō.rŭbẻns - . Brown * 7, H. Her. P. N. Amer. . 17.58 bulbriférūm. Purple : 4, H. Her. P. Bengal : 1813 campanulätūm, 1 Purple : 5, S. Her. P. E. Ind. : 1817 Colocásiă * . Green . S. Tu. P. Levant . 1551 crinīūm . - Brown. . 4, F. Her. P. Minorca - 1777 divarieātūm * Green . 7, S. Tu. P. E. lnd. * 1759

6, H. Her, P. N. Amer. 1759

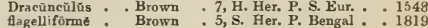

graminēūm : $\quad 6$, H. Her. P.

hederácēum : : Purple : 6, Epiphy. W. Ind. :1793

indǐeūm * : Brown * S. Ev. S. China * 1824

integrifólium : Green : 6, S. Ev. S. 1825

lingulătūm : Epiphy. W. Ind. 1793

marginatúm S. Her. P. E. Ind. , 1820

macrorhizón : :Green . S. Tu. P. E. Ind. : 1803

minũtüm . : Purple . 7, S. Tu. P. E.lnd. . 1802

obtusīlőbũm - . $\quad$ S. Her. P. Tauria 1824

orientalé - : Purple 6, H. Her. P. Sauria . 1820

palmatūm: : ${ }_{\text {H. Her. P. }}$ : 1825

pedātùm : S. Her. P. S. Amer. : 1820

pentaphyllūm: : S. Her. P. E. Ind. . : 1818

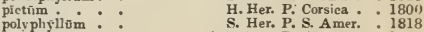

probosciđexúm : : 7, H Her. P. A penn. : 1818

ramōsūm * : 6, S. Ev. S. $\quad 1810$

rĩngēns _. * 6, G. Her. P. Japan • . 1800

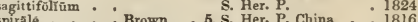

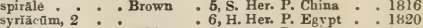

tenuiföliüm : White . 6, H. Her. P. S. Eur. : 1570

ternatúm . Purple : 7, F. Her. P. Japan : 1774

trilobătũm : . Purple . 6, S. Tu. P. Ceylon : 1714

auriculàtúm Purple

- Brown 6 . 6. Her

venōsūm $\quad:$ : Purple : 3, S. Her. P. $\quad: 1794$

maculātūm.

ARUNDiNĀČ̌̆ ră, reed-like.

ARUNDINÁR̆́, Michaur. An alteration of the word arundo, a reed. Linn. 3, Or. 2, Nat. Or. Arundinacea. These plants are only fit for general col. lections; their culture is simple, and young plants are obtained from seeds. Synonymes: 1. Ludolphia glaucêscē̃ns. Pãnīcâm glaucēscēns.

glaucēscẽns, 1 * A petal . . Grass. E. Ind. . 1818 macrospermă : : Apetal : :6, Grass. N. Amer. : 1809

ARŪNDó, Beauvois. An ancient name of doubtful origin, supposed by some to be from the Latin arundo, a reed; and by a recent author to be from the Celtic aru, water. Linn. 3, Or. 2, Nat. Or. Graminea. These are mere weeds. A. Donax, var. versicolor, is regarded by some on account of its striped leaves. A. Donax is grown in France and Italy for fishing-rods, fence-wood, training vines to, \&c.

Dơnâx . . . Apetal . . 7. Grass. S. Eur. . . 1648 vernícólór: : : Apetal : : 7, Grass. S. Eur. : : 1648 festucücěă, tenax.

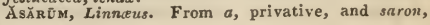
[ 29 ] 
feminine; the application of the term unexplained. Linn. 11, Or. 1, Nat. Or. Aristolochiacec. This is a remarkable genus of dwarf plants, on account of their curious flowers, which are frequently overlooked among the leaves; it is best to plant them near the front of borders, on account of their dwarf character, any common soil suits them, and portions of the root make young plants. The leáves and roots of $A$. europoum are emetic, cathartic, and diuretic.

arifŏliōm . . Brown .6, H. Her. P. N. Amer. . 1823 canadēnsè : : Brown : 6, H. Her. P. Canada . : 1713 europééum: : Purple :5, H. Her. P. Eneland grandifóliúm : Brown :5, H.Her. P. N. Amer.

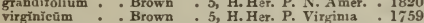
Ascaricīŏ, Cassini. Derived from ascaris, an intestinal worm, and ccedo, to kill, because of its medical properties. Linn. 19, Or. 1, Nat. Or. Compositce. Interesting, dwarfish annuals, easily cultivated, with the treatment in common practice for stove annuals. Synonymes: 1. Vernonia anthelmintica. 8. $\boldsymbol{V}$. triplinervia.

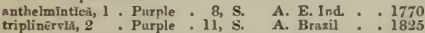
Ascrspevi, \} at first trailing on the ground, then A scBNDING, $\}$ rising erect, forming a curve.

$\bar{A} s c \bar{r}$, small tubes, which contain the sporules of cryptogamous plants.

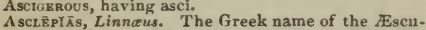
lapius of the Latins. Linn. 5, Or. 2, Nat. Or. Asclepiadacer. This is a genus of tall-growing herbaceous plants, which thrive best in peat, or any very light soil. They require a good deal of room to show their characters, and are readily propagated by seeds, or dividing the roots. $A$. syriasa is very odoriferous, and in Canada, when in flower, charms the traveller, especially when passing through woods in the evening. The French there eat the tender shoots in spring, as we do asparagus. The natives make a sugar of the flowers, gathering them in the morning, when they are covered with dew, and collect the cotton from the prods to fill their beds. On account of the silkiness of this cotton, Parkinson calls it Virginian silk. The roots of $\boldsymbol{A}$ decumbens are diaphoretic and sudorific, and have the singular property of exciting general perspiration, without increasing the heat of the body; it is used in Virginia against pleurisy. $A$. tuberosa is used in the United States as a mild cathartic, as a remedy for a variety of disorders. Synonymes: 1. A. laurifolia. 2. Cynanchum Ipecacuanha. 3. A. connivens. 4. A. purpurascens. 5. A. hybrida.

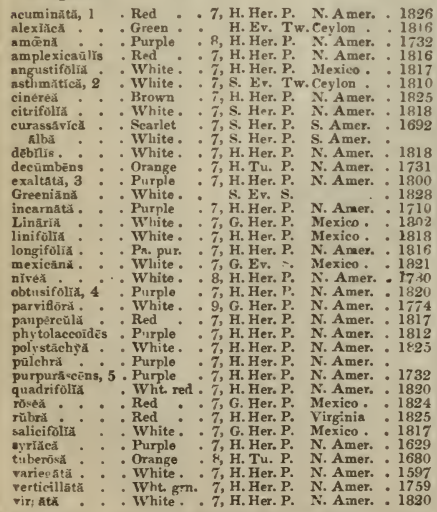

Ascŏbŏlěs, Persoon. From askos, a bladder, and ballo, to eject; in allusion to the principal pecu. liarity of the genus. Linn. 24, Or. 9, Nat. Or. Fungi. A curious production found chiefiy on old cow soil-furfurācêũs.

Ascōphōră, Tode. From askos, a term used to denote a peculiar kind of receptacle of sporules, and phoreo, to bear. Linn. 24, Or. 9, Nat. Or. Fungi. This is mere mould, as seen upon old paste, \&c. -mथcědo.

A scร̃ồ hard; plants soft to the touch. Linn. 16, Or. 8, Nat. Or. Hypericaced. The species are dwarf and curious, and succeed well with the treatment given to Hypericums.

amplexicaülè - - Yellow * 8, G. Ev. S. N. Amer. . 1823 crûx-Andreā : Yellow * 7, G. Ev. S. N. Amer. 1759 hypericoídes : Yellow 8, G. Ev. S. N. Amer. 1759 púmnlum . . Yellow . 7, F. Her. P. Georgia. - 1806 Ash-trek, see Fraxinus.

Astatic porson-BUL.B, see Crinum asiaticum.

Astañs̆, Adanson. A name of Canadian origin, meaning unknown. Linn. 13, Or. 6, Nat. Or. Anonaceie. Ornamental shrubs, from one to three feet high; they succeed best in peat and loam, and are of easy propagation by layering the branches. Synonyme: 1. Anosa triloba.

grandiflóra . . White. . 6, H. De. S. Georgia . . 1820 parviflora : : Brown :5, H. De. s. N. Amer. 1806 pygmāa : : White. : H. De. S. N.Amer. : 1819 trilóha, 1 . Pa. pur. 8, H. De. S. China : 1822 Aspắñ̆thǔs, Linnieus. Said to be derived from $a$, privative, and span, to extract ; in reference to the thorns. Linn. 16, Or. 6, Nat. Or. I.eguminose. "All the species are rather ornamental when in flower. A mixture of loam, peat, and sand, is the soil best adapted for them; and young cuttings of all will strike in sand, under bell-glasses, but the glasses must be wiped occasionally, or the cuttings are very liabe to damp off." - Don's System of Gard. and Botany.

\begin{tabular}{|c|c|c|c|c|c|c|}
\hline ffinis & & & Yellow & 7, G. Ev. S. & C. G. H. & .1822 \\
\hline Ibene: & . & & - White. & - 7, G. Ev. S. & C. G. H. & .1774 \\
\hline ane⿰冫а & - & & - Yellow & - 7, G. Ev. S. & C. G. H. & 95 \\
\hline rgenteal & & 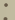 & - Yellow & - 7, G. Ev. S. & C. G. H. & 59 \\
\hline sparagoid & & • & Yellow & . 7, G. Ev. \&. & C. $G$. & - \\
\hline astroitis & • & - & low & - 7, G. Ev. S. & C. $G$ & 1818 \\
\hline Illósa : & • & & $w$ & Ev & C. & 1812 \\
\hline eăns & - & & - Ye & & C. & • \\
\hline Iraç & - & & - Yellow & . 7, G. Ev. S. & C. G. H. & \\
\hline pitáta & • & & - Yellow & . 7, G. Ev. 8. & C. G. H. & 182 \\
\hline poda & . & $\bullet$ & - Yellow & 7, G. Ev. & C. G. H. & - \\
\hline ciliârio : & - & - & - Yellow & . 7, G. Ev. S. & C. G. H. & • \\
\hline crasaif olia & $\cdot$ & - & ellow & S. & C. $G$ & • \\
\hline ericifolia & - & * & rellow & • & C. & \\
\hline dests & $\dot{0}$ & $\dot{.}$ & Yrllow & 7 , G. Bv. S & C. G. & $\because$ \\
\hline globónd. & 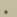 & & Orange & , G. Ev. \&. & C. G. H. & $\begin{array}{l}1802 \\
.1802\end{array}$ \\
\hline hispida. & $\cdot$ & 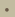 & . Yellow & 7, G. Ev. S. & C. G. H. & .1 \\
\hline hystrix . & - & - & - Yellow & G. Ev. S. & C. G. H. & . 1 \\
\hline indioa. & - & - & - Red & G. Ev. S. & E. Ind. - & .17 \\
\hline laricipX . & $\cdot$ & - & - Yellow & G. $\mathbf{E}$ & C. G. H. & . 1 \\
\hline nā & & • & ow & $\mathbf{E}$ & C. G. H. & \\
\hline pedunculá & & - & $\begin{array}{l}\text { Yellow } \\
\text { Yellow }\end{array}$ & 5 & C. & 18 \\
\hline quinquefol & & : & Yellow & 7, G. Ev. S. & C. G. H. & \\
\hline sericéa. & 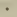 & - & - Yellow & G. Ev. S. & C. G. H. & \\
\hline 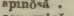 & • & - & - Yellow & Ev. S. & C. $\mathrm{G}$. & - 1 \\
\hline rrósax & $\cdot$ & - & Yellow & S. & C. G. H. & . \\
\hline subulāta & $\cdot$ & - & - Yellow & S. & C. G. H. & - \\
\hline thymifolix & • & - & - Yellow & , G. EV. S. & C. G. H. & \\
\hline & & - & & & 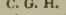 & \\
\hline
\end{tabular}

A sPă sparasso, to tear, some of the species being armed with strong prickles. Linn. 6, Or. 1, Nat. Or. Liliacer. The character and mode of treating this favourite genus is known by all; suffice it to say, that they are most successful in good rich light soil, and may be multiplied by seeds or divisions.

acutifoliǔs . . Wht. grn. F. Ev. S. Spain . 1640 æethiōpǐeǔs. : White. G.Ev. S. C. G. H. : 1816 albǔs . . White. F.Ev. S. S Sain . 1541 amårŭs: * Green . 7, H.Her.P. France 1824

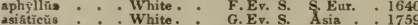
Broussonêtı : : Wher. P. Canaries: 1822 capensis : : Green . 4, G. Ev. S. C. G. H. : 1691 dahurícŭs: : :Green : : 4, G.Hv. Her.P. Dauria : 1893 declinatŭs: : Wht. grm. F. Hes.P. C. G. H. : 1759 decūmbëns. : Whi. grm. 4, G. Her.P. C. G. H. : 179 dependens : : White. 6, G. Fv. Tw. C. G. H. : 1819 faleatus : : Wht grm. S. Ev. S. E. Ind. 


\begin{tabular}{|c|c|}
\hline$A S P$ & $A S P$ \\
\hline 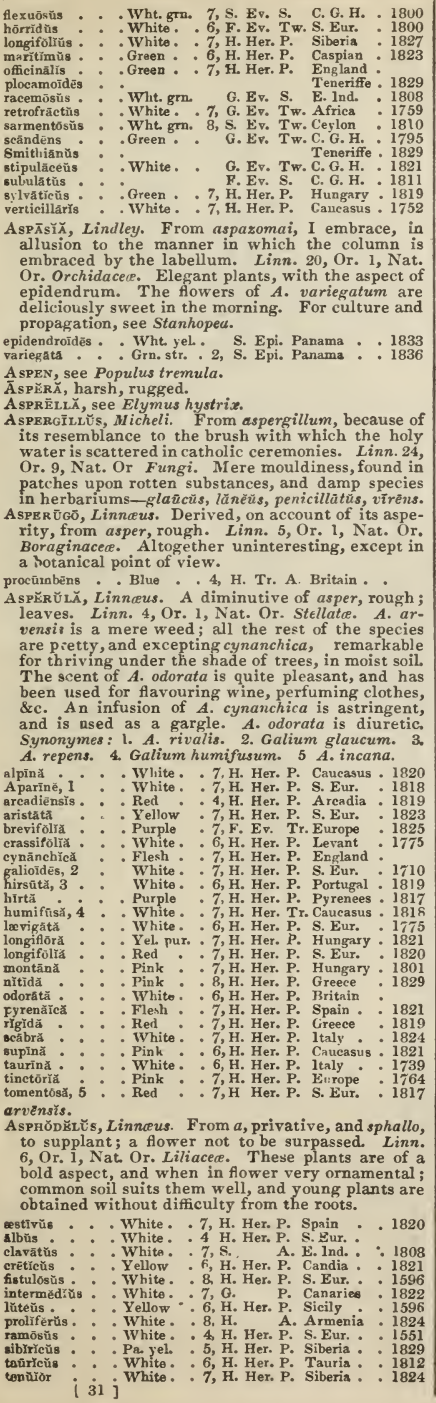 & 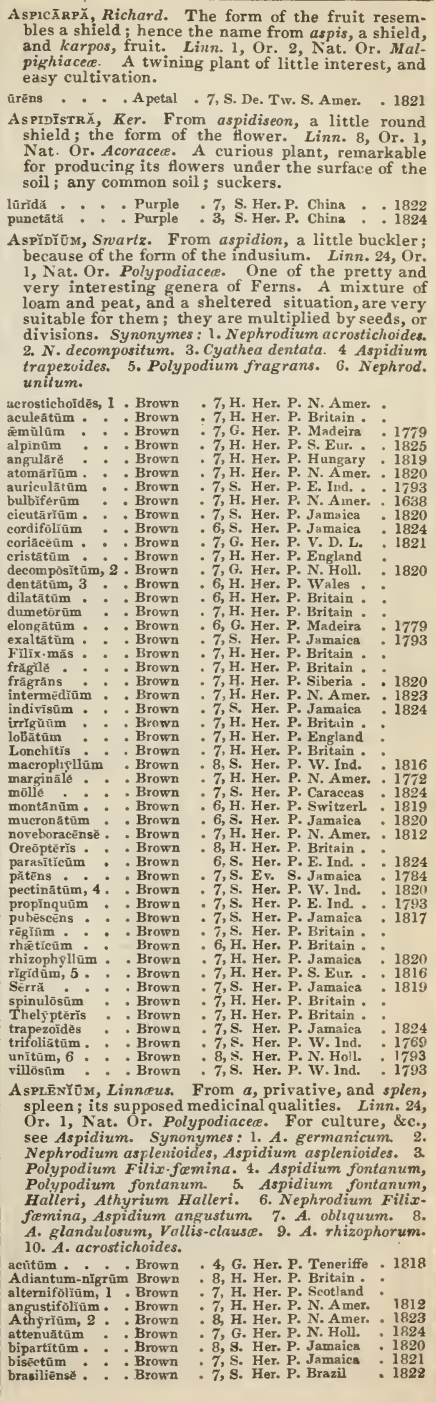 \\
\hline
\end{tabular}




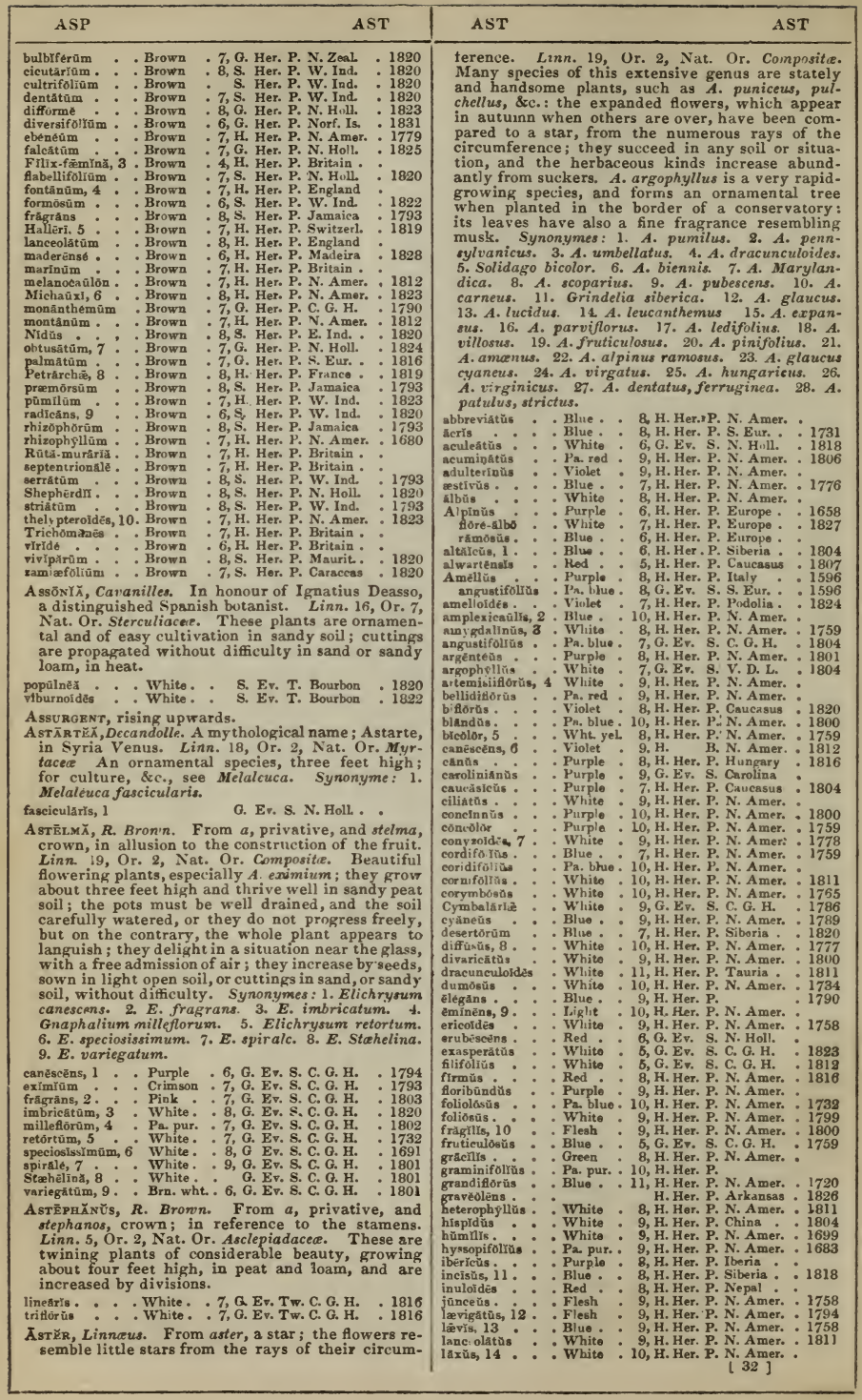




\begin{tabular}{|c|c|c|c|}
\hline $\mathrm{AST}$ & & AST & AST \\
\hline 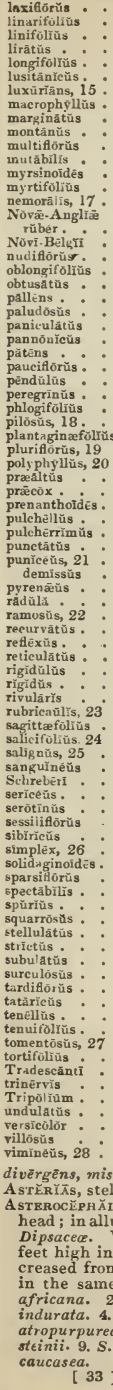 & 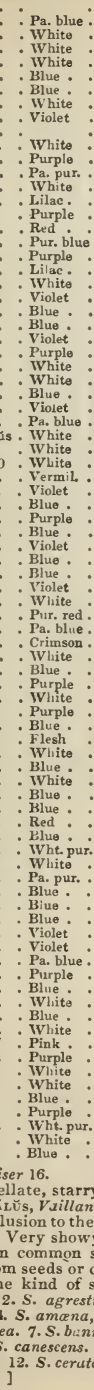 & 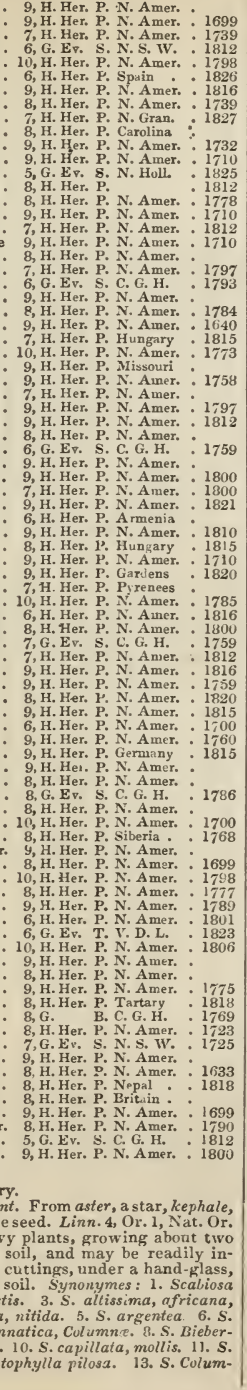 & 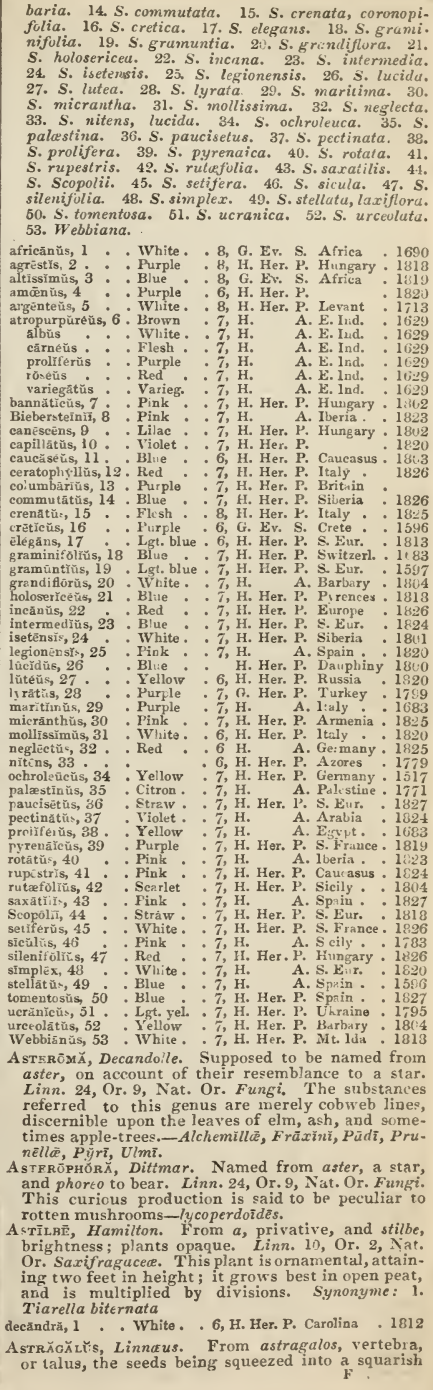 \\
\hline
\end{tabular}




\begin{tabular}{|c|c|c|c|}
\hline AST & AS'T & AST & AST \\
\hline 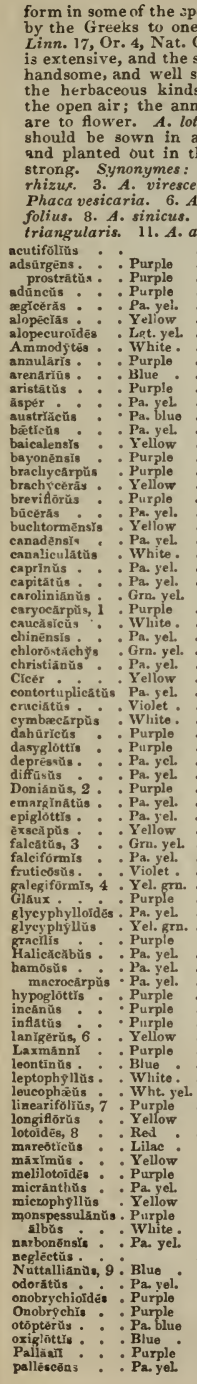 & 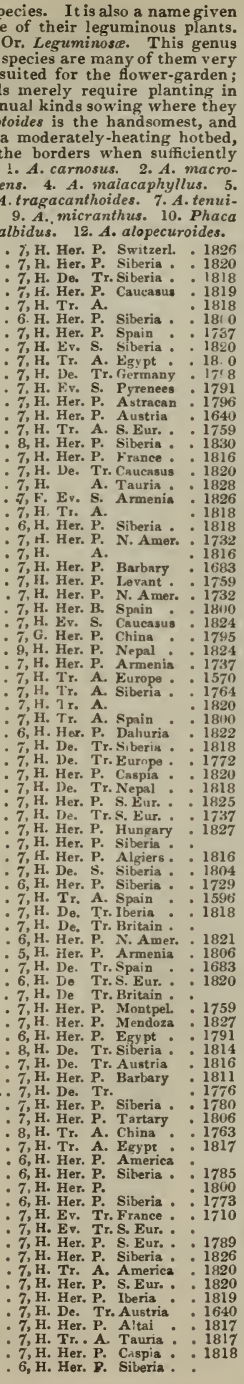 & 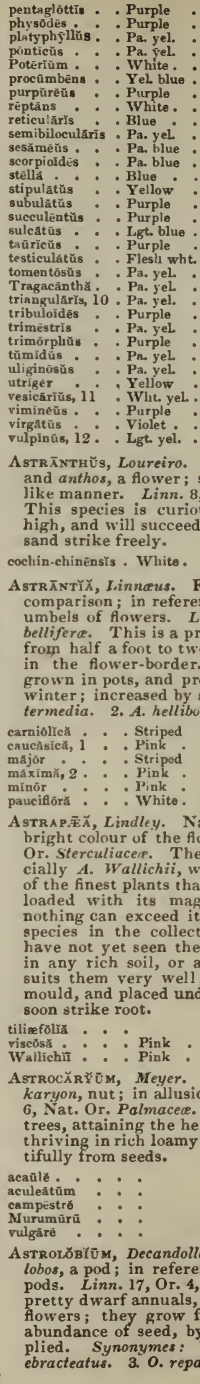 & 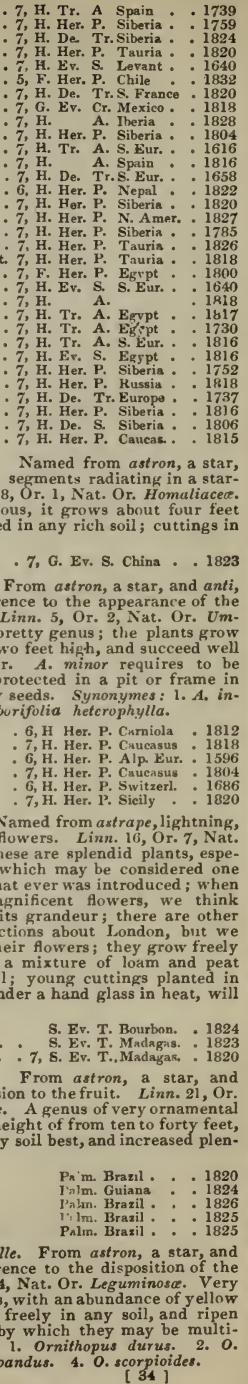 \\
\hline
\end{tabular}




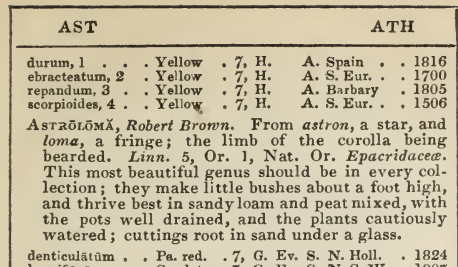

humifûsūm : : Scarlet :7, G. Ev. S. N. S. W.

1807

Astrospŏвīū Kunze. From aster, a star, and spora, a sporule, alluding to the form of the sporules. Linn. 24, Or. 9, Nat. Or. Fungi. A minute curious

black substance, discovered on dead beech branches -Hoffimänni.

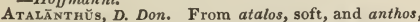
a flower ; in reference to the softness of the flowers. Linn. 19, Or. 1, Nat. Or. Compositce. These are species of little beauty, and easy cultivationarbðrěus, pinnatus, spinosus.

A TAI.̄NTİ̈, Correa. The fruit of this shrub is of a golden yellow colour, whence the name from Atalanta the daughter of Schonus; so swift that she promised to marry him who outran her, and by casting three goldeu apples in her way, she was overtaken by Hippomenes. Linn. 10, Or. 1, Nat. Or. Aurantiacea. This species is represented as being ornamental, and attaining four feet in height it succeeds in any rich soil, and increases freely from cuttings in sand under a glass in heat. Syno. nyme: 1. Limonium monophyllum.

monophylla, 1 . White. . 7, S. Ev. S. E. Ind. . . 1777 Aтамāscórilly, see Zephyränthës Atamäsco.

Aтнама̄ntă, Koch. Some of the species are found upon Mount Athamas in Sicily; whence the name. Linn. 5, Or. 2, Nat. Or. Umbelliferce. These are chiefly weeds, of very easy culture. Synonymes : 1. Ligusticum Cervaria. 2. Cachrys panacifolia.

condensãtă. : White. - 8, H. Her. P. Siberia - 1773 macedonica : White. 7, H. Her. P. Greece : 1596 $\underset{\text { tortuōaz̆ }}{\text { Mathiol : : White. : 7, H. Her. P. Carniola : } 1802}$

Annŭŭ, carviforă, Cervărăăl, cretēnsïs, incănă, lasiānthă, panacifóliă 2 , sibirĭcă, sicǔlŭ.

A thañ̆š̃, Cassini. From $a$, privative, and thanatos, death; in allusion to the length of time the flowers last. Linn. 19, Or. 1, Nat. Or. Composito. This is a genus of Cape plants, growing from half a foot to two feet high; some of them are very pretty, and all succeed well in loamy soil, and increase from cuttings in sand under a glass. Synonyme : 1. A. lanuginosa.

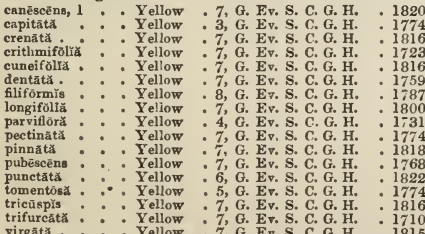
virgâtata : : Yellow : G. Ev, S. C. G. H. 171

Athropōoon, Willdenow. From ather, awn, and pogon,. a beard; on account of the awns being bearded. Linn. 23, Or. 1, Nat. Or. Gramineos. This is a species of grass said to be very pretty the cultivation and propagation simple. Synonyme 1. Chloris curtipendula, Dinébră curtipēndülă.

spludoỉdés, l . . A netal . 8, Grass. S. Eur. 1768 Aтнеrospērmă, Labillardiere. From ather, awn, sperma, seed; the seeds being furnished with awns. Linn. 21, Or. 8, Nat. Or. Atherospermacea. An ornarnental tree, attaining the height of twenty two feet; it grows in loam and peat, and may be increased from cuttings.

moschatx . White. . 6, G. Ev. T. N. Holl. . 1824

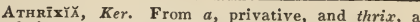
hair ; the receptacle being without hairs. Linn. 19, Or. 2, Nat. Or. Composito. This is a rather low, ornamental Cape shrub, succeeding in a loamy soil, and increased from cuttings.

capeñsis . . . Red . . 4, G. Ev. S. C. G. H. . 1821

A tractóвŏrŭs, Tode. The bladder which contains the sporules is fusiform, and is ejected from the base of the capsule as soon as the operculum is thrown off; whence the name, from atracktos, a spindle, and boleo, to eject. Linn. 24, Or. 9, Nat. Or. Fungi. Merely a white powdery substance found on wood, stones, \&c.-ubiquitärīus.

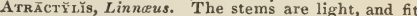
to make spindles; whence the name is derived from atraktos, a spindle. Linn. 19, Or. 1, Nat. Or. compositce. This species is fit only for general collections; culture and propagation easy-hümilis. ATrĂĞ̌NE, Linnceus. A name given to a species of Clematis by Theophrastus. Linn. 13, Or. 6, Nat. Or. Ranunculacere. 'This is a valuable and handsome genus of climbing plants, well adapted for training like Clematis, over bowers, trellis-work, and places where climbing plants are desirable; they grow in any common soil, and young plants may be obtained from cuttings under a glass, or layers. Seeds are sometimes produced, which should be sown in pans, and potted off, and attended. Synonymes: 1. Clematis verticillaris. 2. Atragene alpina, Clematis alpina. 3. Clematis occidentalis. 4. C. ochotensis. 5. C. sibirica.

americ Ana, 1 Purple 6, H. De, Cl. N. Amer obliqua : : Purple : 6, H. De. Cl. N. Amer. austrĭač, 2 : Brn. yel. : 7 , H. De. Cl. Austria occidentalis, 3 . 6, H. De. Cl. Siberia AтrAphĀxYs, Linnąus. Derived from $a$, privative, and trepho, to nourish, a plant yielding no nourishment ; a name given by the Greeks to the Atriplex of the Latins. Linn. 6, Or. 2, Nat. Or. Polygonacoc. The species of this genus are curious; they grow about two feet high, and thrive in a loamy soil, and increase from layers.

spinōsa . - Apetal . 8, F. Ev. S. Levant . 1732 undulat: : : Apetal : 6, F. Ev. S. C. G. H. : 1732 Atrĭplēx, Linnaus. From ater, black; the same name as Atraphaxis. Linn, 23, Or. 1, Nat. Or. Chenopodiacec. These are straggling plants of little beauty, and the simplest cuiture and propagation. Synonymes: 1. A. nitens. 2. A. rosea. 3. A. tutarica. 4. Calligomum canescens. 5. A. prostrata. 6. A. patula. 7. A. hastata. 8. A. incisa. 9. Obione sibirica.

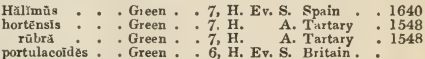

Acuminätă 1, älbă 2, albĭcāns, angustifoliă, campēstrĭs

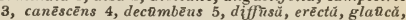
hastātă 6, incānŭ laciniată, linifólüă, littorälis, microspērmă, montevidēenš̆s, oblonyifilĭă, obtusütŭ, par. vifolīă, pätülä 7 , pedunculätä, prostrütă, reniformis, ròsĕă 8 , sibĩrĭcă 9 , sulcātă, tatărícă, trianguläris, venätă, verticillätă, virgätă.

Атяо̆рӐ, Linnceus. In allusion to the very poisonous fruit; from Atropos; one of the Fates, whose duty it was to cut the thread of human life. Linn. 5, Or. 1, Nat. Or. Solanaece. Both poisonous species, only fit for botanical collections. The leaves of A. Belladonna are narcotic and exciting. arborēscēns : White . : 7, G. Ev. S. Jimaica
Belladónnă

1733

AtralẼă, Humbcldt. Derived from attalus, magnificent; in allusion to the beauty of the trees. Linn. 21, Or. 9, Nat. Or. Palmaced. A fine genus of ornamental Palm trees, attaining the height of from ten to seventy feet; they thrive in any rich soil, and increase from seeds.

\section{cơmptă}

excēlsă

funifera

hŭmilìis

Ross:i

speciôsă

specthbllis
Pain. Brazil . , 1820

Paim. Brazil

Palm. Brazil

Palm. Brazi?

Palm. Prazil

Palre. Brazil

Puim Brazil
189

1821)

1825

1826 
AtrRnuatr, Atreviapering gradually to a point.

A UBRİETTİ, Adanson. In honour of M. Aubriet, a famous French botanical draughtsman. Linit. 15, Nat. Or. Crnciferce. These are very ornamental either in the flower-garden or on rock-work, as they produce their purple flowers for such a length of time; they delight in an open dry situation, and are multipiled by dividing the roots, or cuttings, under a glass. Syninymes: 1. Farsetia delioidea, Alyssum deitoideum. 2. Draba hesperidiflora. 3. Arabis purpurea.

deltoidén, 1 . Purple . 4, H. Ev. Tr. Juevant . . 1710 hesperiditloră, 3 : Purple : 3, H. Ev. Tr. S. Eur. : : 1893 purpürén, 3 . : Purple : 4, H. Ev. Tr. Greece : . 1820

A ฮैсŭвй, Kстpfer. The name of the shrub in Japan. Linn. 21, Or. 4, Nat. Or. Cornacee. This is a fine hardy shrub, and its beautiful blotched leaves make it generally admired, particularly as it is clothed with leaves all the year; it is proper for standing singly on a small grass-plot, or in clumps amongst other shrubs in a conspicuous place. Cuttings root readily under hand-glasses, in the common garden soii.

japōiňeă . . Apețl . 6, H. Ev. S. Japan . . 1783

AUCUPĀRTŭs, having a tendency to attract birds.

A UDIRF̄r Ť̃̆, Bentham. In honour of $M$. Audibert, of Tarascon, a celebrated nurseryman. Linn. 2, Or. 1, Nat. Or. Labiate. An interesting little plant about a foot and half high, and bearing palish-blue flowers; it grows in any common soil, and increases from seeds. Synonyme: 1. Salvia carnosa.

ineđ̆nă . . Pa. blue . 8, H. Ev. S. Columbia . 1827 A Unoư̌x̌n, Brongniart. In honour of $\mathrm{V}$. A udouin, a profound entomologise and friend of Brongniart. Linn. 5, Or. 1, Nat Or. Bruniacer. An ornamental genus; for culture, \&c., see the genus Diosma. Synonyme: 1. Diosma capitata.

capitätĩ . Purple . 6, G. Ev. S. C. G. H. . 1790 A UGŪsrǔs, grand, stately, magnificent.

A ŨI.̄̄x, Bergius. Named from aulax, a furrow; the under side of the leaves of the nriginal species being furrowed. Linn. 22, Or. 4, Nat. Or. Proteacea. This is a pretty genus, the species attain from one to two feet high and bear yellow flowers; they succeed best in a very sandy loam, with a gond drainage; ripened cuttings taken off at a joint, and planted in a pot of sand, will strike root readily under a hand-g!ass.

pinifölix : : Yellow $\quad 8$, G. Ev. S. C. G. H. $\quad 1780$ A URíç̇ǔs, a head or tuft like hair, of a gold colour. AUR:CUT.ATB,

AvRicUt.ATED, Shaving ear-like appendages.

AURICIED,

A URICUIATELT-SAGITATk, eared at the base, so as to give the leaf the appearance of the head of an arrow.

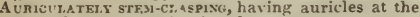
base of the leaves, clasping the stem.

A พี̃ลĀ, Linnaus. A name of obscure origin, supposed to be from the Ceitic aten, from etan, to eat ; whence our word oat has been cbtained. Linn. 3, Or. 2, Nat. Or. Graminea. The species of this genus are easy of cultivation, and uninteresting in point of beauty.

$$
\text { nưd: }
$$

ntidis * A petal.

pratensis Apetal.

pratensis . . A petnl.

leucosperma : : A petal. melanospêrina : A petal.

stêrülis. . . A petal

6, Grass.

6. Grass.

6, Grass. Britain

6, Grass.

6, Grass

6, Grass. Barbary

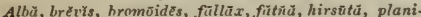

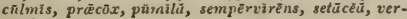
sicñlor.

A vẼNs, see Genm.

Av FRPnŌ, Linneus. In honour of Averrhoes, of Cordora, in Spain, a celebrated physician, Linn. 10, Or. 4, Nat. Or. Oxalidacere. The species are evergreen trees, singular for the fruit growing frequently on the trunk itself below the leaves: the flowers grow in racemes; the fruit is a fivecelied pomme. A. Bilimbi is a beautiful tree, with a green, fleshy, oblong fruit, the thick zess of the finger, flled with a grateful acid juice; the sub. stance and seeds not unlike those of the cucumber. Both species form handsome plants in our stoves, growing freely; and ripened cuttings root readily in sand, under a hand-glass.

BilimbI . . . Red yel. . 8, S. Ev. S. E. Ind. . • 1791 Carâmbülă . : . Grn. red : S. Ev. S. Ceylon : . 1733

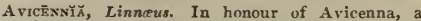
celebrated Persian philosopher and physician. Linn. 14, Or 2, Nat. Or. Myoporacce. The bark of $A$. tomentosa is in great use at $\mathrm{Rio}$ Janeiro for tanning, but it is not worth culture in this countrytomentosă.

A vicular, fit for bird's meat.

AWL-SHAPED, narrow-pointed, like an awl.

A wNED, terminating in an awn, or sharp point.

Awsedx-ACUM1NATED, tapering to a point, and terminating in an awn.

Awss, the beard of any thing.

Axır. $\quad$ literally the arm-pit; in plants applied to $A \times \bar{I} L \bar{A},\{$ the angle formed by the union of the leaf Axit-pIow and stem.

Axiltary, placed in the axils or axillye

$\bar{A} \times 1$ s, the line real or imaginary that passes through any thing; the axis of a spike of flowers is the stem to which the flowers are attached.

Axosōpüs, Beauvois. Derived from axon, axis, and pous, a font; in reference to the structure of the plant. Linn. 3, Or. 2, Nat. Or. Graminea. Species of grass, possessing little that is interesting.

cimieinǔs . . A petal . . 7, Grass. India

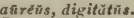

ĀxĭRĩs, Linneus. From axyros, rough; on account of the leaves, Linn. 21, Or. 3, Nit. Or. Chenopodiacere. The species of this genus are mere weeds, of the easiest culture, \&c._amaranthoides, hgbridä, prostritus.

$\Lambda$ rĩnīa, Linnons. In honour of the Duke d'Ayen, of the house of Noailles. Linn, 5, Or. 1, Nat. Or. Sterculiacec. The species are curious and grow fiom one to two feet high, producing purple and suarlet flowers in rich soil, and are multiplied by cuttings in sand.

lærigatá * . Searlet • S. Ev. S. Jamaica

Az tion of the plant. Linn. 5, Or. 1, Nat. Or. Ericacec. This is a beautiful genus, universally admired for its white, orange, purple, scarlet, and variegated flowers, which are invariably produced in great profusion. They all thrive best in sandy peat or very sandy loam; and cuttings taken off close to the plant will root in sand, under a glass placed in heat, or they may be multiplied from seeds, \&c. $A$. indica is a greenhouse plant of great beauty, it should stand out in the open air in summer in a partially shaded situation, and in the winter in a cool part of the greenhouse; the beautiful varieties require the same treatment. De. S. N. Amer. 1818 - Searlet . 6, H. De. S. N. Amer. . 1734 canescéps . Red 6, H. De. S. N. Amer. 181 calendulấęa : Orange $6, \mathrm{H}$. De. S. N Amer 1806 clirysolacts Yellow $6, \mathrm{H}$. De S. N Amer. crucex

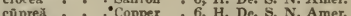
cûpreà " "Copper flímmen :- Ked : 6, H. De. \&. N. Amer. grandiflürà * Orange 6, H. De 8. N. Amer. ignéscēns •. Red • 6, H. De. S. N. Amer, lépìdă * Varieg. . 6, H. De. S. Hybrid . splēndēns *. Orange .6, H. De. S. N. Amer. Stapletoniăna . Rosy : 6, H. De. S. Hubrid. subcüprë : Copper : 6, H. De. S. Hubrid triûmphañs. Orange :6, H. De. S. N. Amer. Danielsiănà̆: Carmine glaūcă : : : Wlite hispida: : : White:

6, H. De. S. N. Amer. : 1734

6, H. De. S. China : 1830

6, H. De. S. N. Amer. - 1734

6, G. Er. S. Clina

4, G. Ev. S. China

4, H. Ev. S. China

4, G. Ev. S. China

6, G. Ev. S. China

, G. Ev. S. China

4, G. Ev. S. China

5, H. De. S. Hy brid

Copper . 6, H. De, S. Hybrid .
White. $\quad 4$ H. De, S. N. Amer.

6, H. De. S. N. Amer.

[. Ame 


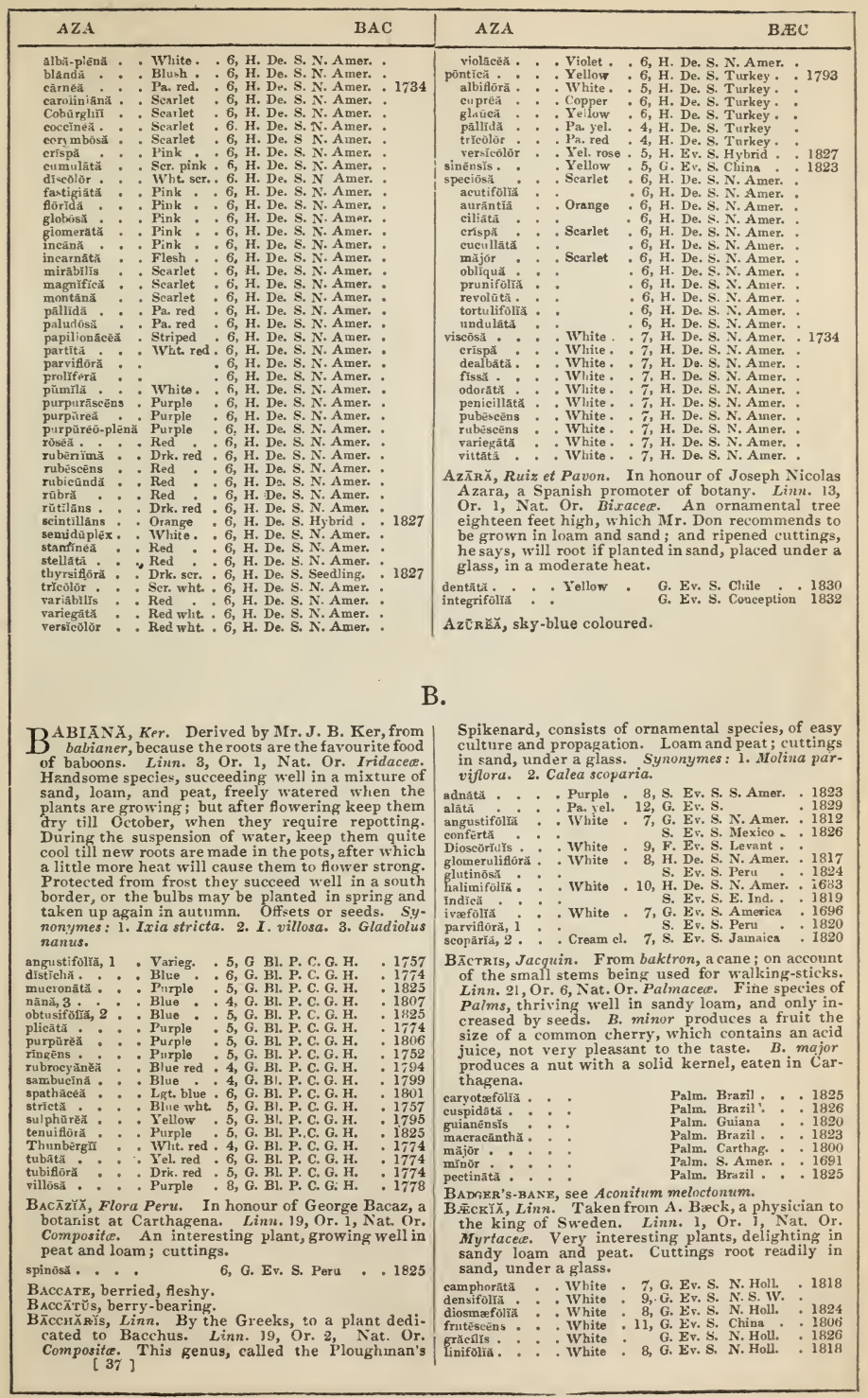


ramovissima , White

saxícola : White

virgāta. : : Whito

G. Ev. S. N. Holl. 7, G. Ev. S. N. Holl. : 1824

Derived from baios, small, and mykes, fungus; the resemblance of the fructifi. cation to a fungus. Linn. 24, Or. 9, Nat. Or. Fungi. The species appear like some small kinds of Agaricus or Hclvella, and are generally found upon heath, oaks, or sandstone-caspititiǔs, microphy̆llüs, rosĕùs, rîfüs.

B AGOED, swelled like a sack, or bag.

BALÃNTĩù, Kaulf. From balantion, a purse; on account of the form of the indusium. Linn. 24, Or. 1, Nat. Or. Polypodiacece. An interesting species of fern, growing in peat and loam, and increased by divisions. Synonyme: 1. Dicksonia culcita.

culcĭtă, 1 . . Brown . 8, S. Fern. Madeira.

BAlBĭsĭă, Cav. In honour of John Baptist Balbis, a writer on botany. Linn. 10, Or. 5, Nat. Or. Oralidacee. A handsome plant, succeeding best in the greenhouse, in loam and peat. It must be watered with great caution; cuttings. Synonymes: 1. Ledocarpum pedunculare. Cruickshanksia cistiflora.

peduneuläris, 1 . Yellow . 8, G. Ev. S. Chile * . 1825

BAI.L, applied to the round central part of the flower of Stapelia.

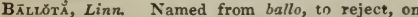
account of its offensive odour; hence the trivia name. Stinking Horehound. Linn, 14, Or. 1, Nat. Or. Labiata. Mere weeds, of the easiest culture Synonyme: J. B. fätidă-älbü, distīchä, niggrä, 1, vulsiris.

BALM, see Melissă.

BaLM of GILBAN, see Dracocēphülam canariēnsê.

BAISAM, see Impătiēns.

BALsA M A PPLE, see Momordică balsaminëă.

BAtsămTxĂ, Rivinus. Called balassan by the Arabs, from which most probably the name balsamina has sprung, Linn, 5, Or. 1, Nat. Or. Balsaminacer. That beautiful and popular annual the garden balsam, with its white, red, pink, purple, lilac, and finely-variegated carnation-like flowers, be longs to this genus. All the species are ornamental, and may be grown with success by the following mode of treatment, recommended in Don's Miller's Gard. Dic. :- "The seeds of these plants should be sown on a moderate hotbed, in spring, and when the plants are about two or three inches high, they should be planted in separate small pots, takin care to shade them until they have taken fresh root, replacing them in the hotbed, after which they should have a moderate share of free air admitted to them when the weather is favourable, to prevent their being drawn up tall and weak they should then be shifted from size to size of pots, until the plants have grown the size required, and when in flower they may be placed in the greenhouse, where they will make a very showy appearance, and seed freely." A light, very rich soil, composed of rotten dung, loam, and leaf mould, with a little sand, suits them best, plentifully watered. They do not root readily by cuttings; but may be increased abundantly from seeds, which in general ripen. The juice of the balsam used with alum is employed by the Japanese to dye their nails red. Synonyme: 1. Impatiens balsamina.

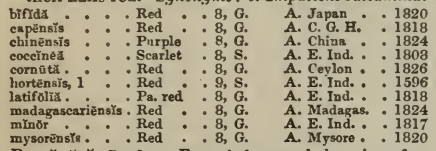

BAI From balsamon, balm; ence to its strong balsamic smell. Linn. 19, Or. 1, Nat. Or. Compositae. Plants of little interest, and easy culture. Synonyme: 1. Tanacētüm ännüūm. grandiflörג - Yellow . 7, F. B. Algiers . 1821 rulgărís. : : Yel, grm. 8, H. Her. P. Italy : 1568 ageratifoliă, annua 1 , virgata.

BALSA MODĒNDRōn, Kunth. From balsamon, balsam, and dendron, tree. Linn. 8, Or. 1, Nat. Or. Burseracea. An ornamental tree, growing well in sandy loam and peat, and ripened cuttings root freely in sand, under a glass, in heat. This tree yields the gum elemi of the East, which is distinct from the American elemi. Synonyme: 1. Amyris zelanica.

zèylănịūm, 1 . . $\quad$ S. Ev. T. Ceylon .

Baltııōră, Linn. In honour of Lord Baltimore, proprietor of Maryland. Linn. 19, Or. 4, Nat. Or. Compositce. Uninteresting species, of easy culture - alba, recta.

Baisam uf CAPBvi, see Coparféră.

BAISAM TREB, see Clũstü.

BAм ноо cANE, see Bambisă.

BAмвũsă, Schrader. From bambos, its name in India. Linn. 6, Or. 1, Nat. Or. Graminea. This genus contains the bamboo-cane ; the species are interesting, and in rich loamy soil they grow rapidly to a great height in our stoves if well watered; they increase by offsets. B. arundinacee is very useful for a very great variety of domestic purposes; in the $\mathrm{E}$. Indies, cottages are almost entirely made of it, bridges, boxes, cups, baskets, mats, paper, and masts for boats, are also made of it. It is likewise employed for fences for gardens, \&c., and it is commonly used instead of pipes for conveying water. The substance called tabasher, is a secreted siliceous matter, found at the joints of the bamboo.

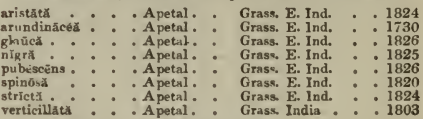

BANANA TRER, see Mnsal sapiēntum.

BANB-BRRRY, see Actād.

BAsDs, applied to the spaces between the lines, or ribs of the fruit of unibelliferous plants.

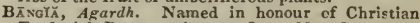
Frederick Bang. Linn. 24, Or. 7, Nat. Or. Algea. Curious productions, appearing on marine rocks about the sea coast-atropurpürĕŭ, fusco-purpürĕŭ, calophgllü, Laminārīe.

Banisteriä, Linn. In memory of the Rev. John Banister, a diligent botanist. Linn. 10, Or. 3 , Nas. Or. Malpighiacea. Interesting species, with beautiful foliage, as $B$. splendens. They succeed in loam and sand, or a mixture of loam and sandy peat; ripened cuttings root in sand, under a glass, in heat. Synonyme: J. B. heterophylla, B. fulgens.

\begin{tabular}{|c|c|c|c|}
\hline 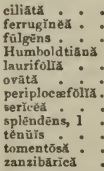 & $\begin{array}{l}\text { Y Yellow } \\
\text { : Yellow } \\
\text { : Yellow } \\
\text { : Yellow } \\
\text { : Yellow } \\
\text { : Yellow } \\
\text { : Yellow } \\
\text { : Yellow } \\
\text { : Yellow } \\
\text { : Yellow } \\
\text { : Yellow }\end{array}$ & $\begin{array}{ll} & \text { S. Ev. Tw. } \\
\text { S. Ev. } & \text { S. Ev. } \\
\text { S. Ev. } & \text { S. } \\
\text { S. Ev. } \\
\text { : 7, S. Ev. } \\
: 7, \text { S. Ev. S. } \\
\text { : 7, S. Ev. Tw. } \\
\text { S. Ev. S. } \\
\text { G. Ev. Tw. } \\
\text { G, S. Ev. Tw. } \\
\text { S. Ev. Tw. }\end{array}$ & $\begin{array}{l}\text { Brazil } \\
\text { Brazil : } \\
\text { W. Ind. } \\
\text { 8. Amer. } \\
\text { Jamaica } \\
\text { St. Domin. } \\
\text { Porto Rico } \\
\text { Brazil } \\
\text { S. Amer. } \\
\text { B. Ayree } \\
\text { S. Amer. } \\
\text { Zanzibar }\end{array}$ \\
\hline
\end{tabular}

BÃNš̌x, Robert Broven. In honour of Sir Joseph Banks, Bart. Pres. R.S.; a distinguished patron of science in general, particularly Natural History. Linn. 4, Or. 1, Nat. Or. Proteaced. This is a handsome and interesting genus. The species, to succeed well, must be treated in the following manner recommended by Sweet. "The pots must be well drained, which should be done in the following manner:-place a piece of potsherd about half way over the hole at the bottom of the pot, then lay another piece against it that it may be hollow, afterwards put some smaller pieces all around them, and some more broken very small on the top of these. All plants belonging to the Proteacec should be drained in the same manner, as the roots are very fond of running amongst the broken potsherds, and there is not so much danger of their being overwatered; care must be taken not to let them flag for want of water, as they seldom recover if allowed to get very dry; they should also be placed in an airy part of the greenhouse when in doors, as nothing is more beneficial to them than a free circulation of air. Cuttings are generally sup. posed to be difficult to root, but they will root 
readily if properly managed; let them be well ripened before they are taken off; then cut them at a joint, and plant them in pots of sand, without shortening any of the leaves, except on the part that is planted in the sand, where they should be taken off quite close, the less depth they are planted in the pots the better, if they only stand firm, when the sand is well closed round them: then place them under hand-glasses in the propagating house, but not plunge them in heat, the glasses must be frequently taken off to give them air, and dry them, or they are apt to damp off; when they are rooted, the sooner they are potted off in small pots the better, as the sand is liable to canker their roots, if left too long in it; when potted off they should be placed in a close frame, but not on heat, as a bottom-heat will destroy their roots, when they must be hardened to the air by degrees. Plants raised in this way have better roots, grow faster, and flower sooner, than plants raised from seeds : in raising them from seeds, they should be sown in the same kind of soil as the plants are grown in, and placed in the greenhouse, or if it is in summer they will come up sooner, if placed out in the open air; they will soon make their appearance, when they should be potted off in small pots, for if left in the seed pots too long they are apt to die, and are more difficult to move with safety." Synonymes: $1 . B$. ledifolia, $B$. littoralis.

ǣmŭlä : • - Green . . 8, G. Ev. S. N.S. W. . 1788

attenuătă - Yellow * G. Ev. S. N.S. W. . 1794

australiss - G Green . . G. Ev. S. N. S. W. : 1812

Baūerī : : : G. Ev. S. N. Holl

Baxtēri : : : G. Ev. S. N. Holl

Căleyī . : * Scarlet

coccinéa : : Scarlet

collină: : : Y Yellow

Cunninghảmir, 1 : Pa. yel.

dentāta. . Y Yellow

deprêssã : Y Yellow

dryandroídés : Yellow

elatior * * Yellow

Gōōdî́

Grōondī : : : Y Yellow

insulārǐs : Yellow

integrifolia: Y Yellow

latifolia . : Green.

littorălis . . Orange

marcēscēns. - Yellow

marginātă * - Yellow

mūtãns: : : Yellow

oblongifóliă : Y Yellow

occidentălis : Yellow

paludōsa : : Yellow

prostrāta . . Yellow

pulchëllă . Y Yellow

quercifoliă : Y Yellow

répúns : : : Yellow

serrảtā

G. $\mathrm{s}, \mathrm{N}$. Holl

G. Ev. \&. N. Holl

G. Ev, S. N. S, w.

G. Ev. S. N. Holl

G. Ev. S. N. Holl

G. Ev. S. N. S. W

G. Ev. S. N. Holl

G. Ev. S. N. Hol.

G. Ev. S. N. Holl.

G. Ev, S. N. S. W.

G. Iv. S. N. Holl.

G. Ev. S. N. Holl

G. Ev. S. N. S. W.

G. Ev. S. N. S. W

7, G. Ev. S. N. S. W

G. Ev, S. N. Holl.

7, G. Ev. S. N. S. W.

G. Ev. S. N. Holl.

6, G. Ev, S. N. Holl.

G. Ev. S. N. S. W.

G. Ev. S. N. Holl.

3, G. Ev. S. N. S. W.

G. Ev. S. N. Holl.

G. Ev. S, N. Holl.

G. Ev. S. N. Holl.

8, G. Ev. S. N. S. W

G. Ev. S. N. Holl.

1830

1830

1830

1830

1803

1800

1824

1822

1822

1824

1824

1789

1830

1794

1794
1822

1822

1788
1802

1803

1794

1804

1824

1803

1803

1805

1824

1805

1805

1803

1788

1830
1805

, G. Ev. S. N. Holl. : 1805
G. Ev. S. N. S. W. : 1788
G. S. N. Holl. 1803

G. Ev. S. N. Holl. : 1803

spinulosáa

BAOвAв TRER, see Adansoñŭă.

ВА̄pHǏx, Afzelius. Taken from baphe, from its use in dyeing. Linn. 10, Or.1, Nat. Or. Leguminosa. The genus yields what cabinet -makers call ring wood.

nłťdä . . . White. . 8, S. Ev. T. S. Leone . 1793

Baprĭsĭă, Robert Brown. From bapto, to dye; in allusion to the dyeing properties possessed by some species. Linn. 10, Or. 1, Nat. Or. Leguminosa. Ornamental border plants, succeeding in common loamy soil, and multiplied by divisions. The roots and leaves of $B$. tinctoria are antiseptic and astringent. Synonyme: 1. Podalyria uniflora.

albă . - . White . 6, H. Her. P. N. Amer. . 1724

australis . . Blue . . 6, H. Her. P. N. Amer. . 1758

exaltăta : . White. 6, H. Her. P. N. Amer. 1724

lanceolātă, 1 Yellow : 7, H. Her. P. N. Amer. : 1818

mǐnór : : Blue : 6, H. Her. P. N. Amer. : 1829

mollis : : : Blue : 6, H. Her. P. N. Amer. : 1824

perfoliata : Yellow : 8, F.Her.P. Carolina: 1732

tinctőriz : Y Yellow : 7, H.Her. P. N. Amer. : 1750

villosả : : Yellow 6, H. Her. P. N. Amer. 1811

BARBAcĒñ̆ Vandelli. From Barbacena, the governor of $M$ inas Geraes. Linn, 6, Or. 1, Nat. Or. Bro[ 39 ] meliacea. An interesting species, growing in sandy loam, and multiplied by divisions.

purpŭrĕa . . Purple . 7, S. Her. P. Brazil

1825

BARBADOEs CEDAR, see Junīpĕrŭs barbadēnsĭs.

Barbadofs cherry, see Malpighĭă.

BARbadoks gooskberry, see Peréskïă.

BARBADORS LILY, see Amaryllís equēstris.

BARBĂR Ĕ, Robert Bronn. On account of its being formerly called the herb of St. Barbara. Linn. 15, Nat. Or. Cruciferce. Plants of easy culture. The genus is called the Winter Cress. Synonymes: 1. Cheiranthus ibericus. 2. Sisymbrium Barbarea. 3. Erysimum pracox. 4. E. Burbarea.

prācôx, 3 . Xellow . 10, H. Her. P. Ergland

vuilgārìs, 4 : : Yellow: 7, H. Her. P. Britain

ibērǐcă 1 , plantagĭnĕă 2 , tařrĭcă.

Barbiérî, Decan. In compliment to J. B. G. Bar. bier, M.D. Linn. 17, Or. 4, Nat. Or. Leguminosa. An ornamental species, grown in sandy peat, and multiplied by cuttings. Synonymes: 1. Clitoria polyphylla. Galactia pinnata.

polyphŷllă, 1 . . Purple . S. Ev. S. S. Amer. . 1818 BARLĒRIA, Linn. In honour of the Rev. James Barrelier, a Dominiean, and M.D. of Paris. Linn. 14, Or. 2, Nat. Or. Acanthaceo. These interesting dwarfish plants flower freely if grown in loam and peat, mixed with a little rotten dung; and strike readily from cuttings made of the young wood, planted in soil, and placed under a glass. Synonymes: 1. B. mitis, Justicia flava, Eranthemum flavum. 2. Dicliptera spinosa.

albă . . . White . . . S. Ev. S. N. Holl

7, s. Ev. S. E. Ind.

7, S. Ev. S. E. Ind. 1768

cristātă . Blue • 7, S. Ev. S. E. Ind. • 1796

dichŏtơmă . Purple * 7, s. Ev. \&. E. Ind. : 1823

flàvă, 1. Yellow 7, S. Ev. S. E. Ind. : 1816

longifoliă : White : 8, S. B. E. Ind. : 1781

longittōă . * . S. Ev. S. E. Ind. * 1816

lup:lină, 2 - . Yellow - 8, S. Ev. S. Mauritius - 1824

Prionitis * : Orange * 7, S. Ev. S. E. Ind. : 1759

solanifolix: : Blue . S. Ev. S. W. Ind.

strigósăă Blue 7, S. Ev S, E. Ind. 1820

BARLIEY, see Hördēum.

BARNĀRDĨ, Lindley. In honour of E. Barnard, F.L.S. Linn. 6, Or. 1, Nat. Or. Liliacea. This pretty species succeeds well in peat and loam mixed, and increases by offsets.

scilloĩdés . . Pa.blue . 5, F. Bi. Siberia . . 1819

BARRED, marked in spaces with a paler colour, re. sembling bars.

BARR BN-Wort, see Epimĕdǐ̃um.

Barrixgtónï, Forster. Dedicated to the Hon. Daines Barrington, F.R S . \&c. Linn. 16, Or. 8, Nat. Or. Myrtacea. This very handsome, lofty-growing species, is rather scarce in our stoves, and somewhat difficult to preserve in a healthy state. It must be grown in a moist, warm atmosphere, not by any means under 60 degrees, and planted in loam and peat mixed. Cuttings in a moist heat, root in sand, under a glass. B. speciosa yields a reddish-brown drupe, the seed of which, mixed with the bait, inebriates fish.

speciósă. . . Scarlet. . S. Ev. T. E. Ind. . . 1786

Bartholixi, R. Bromn. In memory of the great Danish anatomist and physiologist Thomas Bartholin. Linn. 20, Or. 1, Nat. Or. Orchidacea. A singular species, very difficult to preserve in our collections. It requires a very sandy loam, and a light part of the greenhouse; it is very probable, that if thev had more light in their growing season, they would be much easier preserved. Synonyme: 1. Arēthũsă pēctǐnütŭ.

pẹctǐnătã . . . Lilac . . 11, G. Ter. C. G. H. . 1787

Bartönť, Pursh. In honour of Dr. B. S. Barton, a botanist in Philadelphia. Linn. 12, Or. 1, Nat. Or. Loasacea. Beautiful plants with large yellow and white flowers, which open in the night, and eff use around them a delightful odour. Sweet says, they should be raised in a gentle hotbed, and when up, potted, and protected in the greenhouse in winter. Synonyme: 1. B. decapetala. 


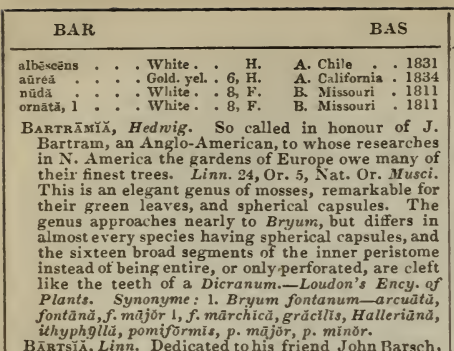

Barrsia, Linn. Dedicated to his friend John Barsch, Curious plants, of difficult cultivation. They succeed best in a shady bog border, or in pots kept moist; they also do pretty well in a muderately exposed situation sown in sandy soil.

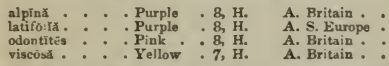

BaryösMñ, Willd. From the powerful scent of the leaves. Linn. 5, Or. 1, Nat. Or. Rutacee. Pretty species; for culture, \&c., see Diosma. Synonymes: 1. Diosma latifolia, D. serratifolia, D. odorata, Bucco crenata. 2. Diosma tinifolia. 3. Agathosma latifolia. 4. Agathosma pulchella.

betulin

crenulatx i Hhice. 6, G. Ev. S. C. G. H.

. Blitish. 4, G. Ev. s. G.

datifolla, 3 : : : White. : 7, G. Ev, s. C. G. H.

: White. : 5, G. Ev. S. C. G. H.

pu'chẹllă, 4 : : Purple : 6, G. Er. S. C. G. H.

1790

1816

1789

1790

BAsẽLl. , Linn. Its Malabar name. Linn. 5, Or. 3, Nat. Or. Chenopodiacece. Some species are pretty $B$. lucida when in fruit is very interesting. The seed should be sown on a gentle hotbed, or in pots in the hothouse, and afterwards planted out singly in small pots, and placed among the tender annuals. The species furnish a summer spinach in Paris and China.

slba

Ilba

cordifou

lacidă

nigrid

rnmósă

rŭbră

- White.

8,5 .

B. E. Ind.

Pa, nur.

8, S. CL. B. E. Ind.

8, S. Cl. B. E. Ind.

7, S. Tw. B. Mexico

8. S. Cl. B. China

8, S. Ev. Cl.

White.

8. S. Cl. B. E. Ind.

Purple

9 , S. Tu B. S. Amer.

1688

1802

1802

1824

1822

1731

BAsiL, see Ocyัm

BAsirar, at the base of anything, usually the embryo when situated at the bottom of the seed.

BĀssĭ̌, Linn. In honour of Ferdinando Bassi, Curator of the Botanic Garden at Bologna. Linn. 11, Or. 1, Nat. Or. Sapotacee. Handsome loftygrowing trees, thriving well in light loam and peat, mixed; ripened cuttings in sand, under a glass, strike root freely. B. butyracea yields a thick oil-like butter, and $B$. longifolia is prescribed in rheumatic affections.

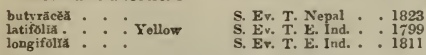

Bastard AcĀcĭă, see Robĭnŭă Pseudo-acãcĭŭ.

Bastard AcmĒLlī, see Spilënthēs Pseudo-acméllă.

Bastard atōcrón, see Silene Pseudo-atóción.

BASTARD BALM, see Melittis.

Bastard box, see Poly̆gălă Chamaebũxŭs.

BastaRd CABBAGE-TREE, see Gedfroyŭ.

BAstaRd CED +R, see Guazamá.

Bastard cherry, see Cérăsŭs Pseudo-cĕrăsŭs.

Bastapd crnnamon, see Cinnamōmūm Cāssiü.

B ASTARD CORK-TRER, see Quërcŭls Pseudo-sübër.

Bastard crāccă, see Viciă Pseudo-crāccă.

Bastard cypẽrũ̃s, see Cãrẻx Pseudg-cypẽrǘs.

Bastard dictāmứs, see Beringerïă Pseudo-dictamnus.

BAstard GRound-PINR, see Teũcrĩum Pscudo-chamapitỹs.
BAS

BAU

BAstard harg's-kar, see Phyllis.

BAstard a issop, see Teücriúm Pseudo-hyssópüs.

Bastard indigo, see Amórphä.

Bastard JAsMine, see Andrösä́cé chamajūismè.

BASTARD LUPINE, see Trifóliūm Lupinästēr.

Bastard maxchineri, see Camerā riă.

Bastard mousz-kar, see Hierüciūm Pseudo-pilosvllă.

Basta rd ō1.Bĭă, see Lavatérū Pseudo-ólbiă.

Bastard orpine, see Andrüchne.

BA8TARD PIMPERNEL, see Centūncŭlŭs bicơrnĭs.

BAstaRn quince, see Py̆rūs-chamueméspilüs.

Bagtard Rocket, see Brüssícă Pseudo-erucūsträm.

BAgTARD TOAD-rLAX, see Thësiüm.

BAstarin vervain, see stachytürphetä.

Bastard vetch, see Phäcá.

Bastard wiNdflower, see Gentiānă Preudo-pneumoneinthe.

Bastard woodsage, see Teũcríam Pseudo-scorodoniă.

BatrMĩNsĩă, Lindley. In compliment to James Bateman, Esq. of Kny persley Hall, Cheshire, an ardent collector and successful cultivator of Orchidaces, and author of that splendid work, the "Orchidaceæ of Mexico and Guatemala." Linn.20, Or. 1, Nat. Or. Orchidaced. A very pretty species, well deserving a place in every collection : it somewhat resembles a Maxillaria, with a pendulous raceme of flowers from the base of the pseudo-bulbs ; the sepals and petals are brownish-purple within, green without, and a white labellum. It requires the same treatinent as Stanhopea, and other similar genera.

Colleyi . . Pur. grn. . . 8, S. Epi. Demernara . 1834

Batrachospēracì, Agardh. From batrachos, frog, and sperma, seed. Name refers to the situation where the species grow. Linn. 24, Or. 7 , Nat. Or. Alga. The species are interesting, having more or less the appearance of a necklace, especially $B$. moniliforme; they grow mostly in marshes-monili. formé, M. detersin m, M. purpuräscęns, M. simpliciūs, M. stagnãle : văgam, V. teıuissimam.

Вїтsснї, Michaux. In honour of John George Batsch, a professor of botany in Germany. Linn. 5, Or. 1, Nat Or. Borayinacea. Pretty dwarf species, succeeding in common soil, and increased by seeds or divisions. Synonymes: 1. Lithospermum canescens. 2. L. hirtum, Batschia carolinensis.

caniscceñs, 1 - Yellow . 7, H. Her. P. N. Amer. . 1826 GmelinI, 2. Yellow :6, H. Her. P. Carolina 1812 longifora . . Yellow .6, H. Her. P. Missouri . 1812 sericefi: Yellow 7. H. Her, P. N. Amer. 1825

Battārr Battarra. Linn. 24, Or. 9, Nat. Or. Fungi. A very curious plant, found only in Britain, where it is very rare. The volva or wrapper, is about the size of a hen's egg, originally in three slightly coriaceous layers, hollow internally, which rises suddenly to its full height of about twelve inches; the stalk carries up on its summit full half the innermost layer of the volva, which is white and smooth within, and covered externally with copious brown sporules, intermixed with fibre.-Loudon's Ency. of Plants-phallozides.

BAf̈R, Andr. In memory of Francis and Ferdinand Bauer, botanical draughtsmen of the highest celebrity. Linn. 13, Or. 2, Nat. Or. Baueracea. Pretty, free-flowering species, of easy culture; a mixture of sand and peat suits them, and young cuttings root readily in sand or soil, under a glass.

hŭmirs. . . . Red * . 9, G. Ev. S. N. S. IV. . 1804 rubirfóliă: : : Pink : 9, G. Ev. S. N. S. W. : 1793

BAUнǏx̆, Plumier. In memory of John and Caspar Bauhin, botanists of the sixteenth century. Linn. 10, Or. J, Nat. Or. Leguminose. Showy interesting species, some of them particularly so when in bloom; they succeed well in a mixture of sand, loam, and peat; and cuttings taken when the wood is neither ripe nor very young (observing to dress off the leaves), and planted in sand, under glass in moist heat, will strike root. The dried leaves and young buds of $B$. tomentosa are prescribed in dysenteric affections; the bark of $B$. variegata is used in tanning and drying leather, and that of $B$. racemosa is employed in makiny rope. Synonymes: 1. B. anguina. 2. B. retusa, divaricata. 3. B. aculeata.

[40] 


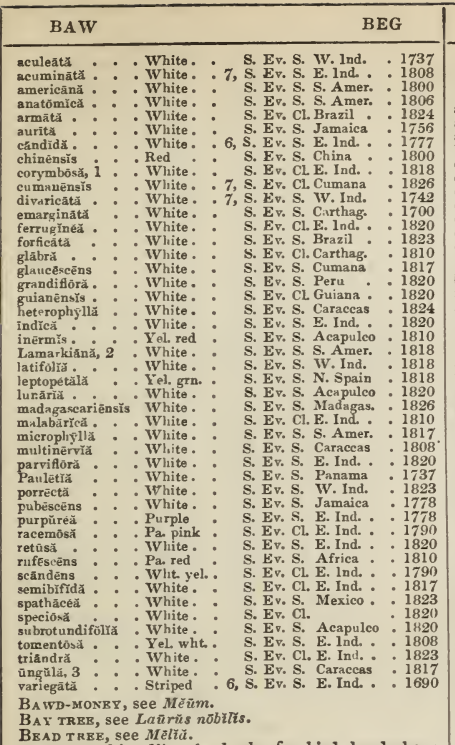

BEAK, anything like the beak of a bird, hard sharp points.

Bran, see Făbă.

BEAN CAPER, see Zygophyllūm.

BraN TREFoll, see Anügüris.

BrARRIND, see Calystëgiü.

BEARDLET TED, possessed of small awns.

BEAR's-8RERCH, see Acãnthüs.

Brar's-kAR sanicue, see Cortũsă.

BrAR's-Foot, see Hellëborrǔs fä́tĩdŭs.

BEAR's-GR APE, see Arctostaphy̆lös ũvă ârsĩ.

BEAST's-BANE, see Aconītūm theriophonūm.

Braupõrtĭ̌, Robert Bronn. In compliment to Mary, Duchess of Beaufort, a botanical patroness. Linn. 18, Or. 2, Nat. Or. Myrtacea. Very splendid and desirable species; for culture, \&c., see Tristania.

carinátä - . Scarlet . G. Ev. S. N. Holl. • 1823 Dumpieri : : : Pink : 5, G. Ev, S. Hartoe's Is. decussătă : : : Scarlet : 5, G. Ev. S. N. Holl : 1803
sparrsä. splendéns: : Red - G. Gv. S. N. Holl : 1830

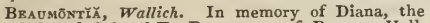
lady of Colonel T. Beaumont, of Bretton Hall. Linn. 5, Or. 1, Nat. Or. A pocynacece. Beautiful species, especially $B$. grandiflora. They succeed well in loam, or loam and peat mixed, and are propagated from cuttings, or seed, in sandy soil under a glass.

grandiflōră. . . White. . 6, S. Ev. Tw. E. Ind. . 1820 longifơlză: : White: 6. Sv. Tw. E. Ind. : 1818

BвскмĀNNĭ̃ Host. Dedicated to Mr. Beckman, the author of "The History of Inventions." Linn. 3, Or. 2, Nat. Or. Graminea. An uninteresting species, of the simplest culture. Synonyme: 1. Cynosurus erucaformis, eruciformis 1 .

BED-sTRAw, see Gälïum.

BEech, see Fägŭs.

B EЕT, see Bêtă.

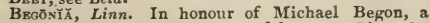
Frenchman, and promoter of botany. Linn. 21, Or. 9, Nat. Or. Begoniacea. An interesting, somewhrt succulent genus, peculiar for the leaves being oblique at their base. They succeed well in very [41]

BEJ

BEL

rich soil, and cuttings root readily. Some species are useful in cases of scurvy. Synonymes: $1 . B$. maculata. 2. Evansiana. 3. Glabra.

acuminátã . - White. - 7, S. Ev. S. Jamaica . 1790 acutifolia : . White. . 8, s, Ev, S. W. Ind. 1816 argyrostigmă, i . White . 8, S, Ev, S. Brazil : 1819 bulb̧̌feră ? : Wht. pul. 7, G. Her. P. Peru : : 1827 dichötómă : : White. : 7, S. Ev. S. Caraccas : 1800 dipetälä . Pink . 7, S. Ev. S. Bombay : 1827 dipteră ${ }_{\text {discolór, } 2 \text { : : : White. : 6, S. Ev. S. C. G. H. : } 1822}$ distichă : : White: : 9, s. Her. P. Brazil : : 1819 điversifólıă : Pink : 7, s. Her. P. Mexico: 1829 dūbĩă : White: 7, S. Her. P. Brazil.: 1818 Fischëri : : 6, s. Ev. S. s. Amer.: 1835

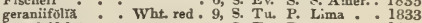
heracleifoliă: : Wht red. 9, Tu. P. Lima : 1833 hirsūtă. : : White. . 6, S. Tu. P. W. Ind. : 1789 hirtellă. . White. 9, S. Her. P. 1824 hŭmilis . . . White. 9, S. B, W. Ind. 1788

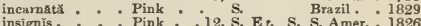
7. S. Er. S. Mexico . 182 lūeidä : : White: : 8, S. Ev S. W. Ind. 1816 macrophrlla: : White: : 7, S. Ev. S. Jamaica : 1793 Martiānă : : Pink: : 9, S. Tu. P. Brazil. : 1899 monntera .: : White: : 8, S. Tu. P. Brazil: : 1829 multibulbillōsă : White. S. Tu. P. Brazil. : 1830

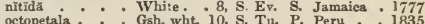
odoratal : White 9 S Her P. Pers palmáta : : White : 8, S. Ev. P. Nepal. : 1819 papillösă : : Pink :

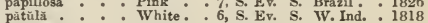
pauciflôră : : : White. : 6, S. H. S. P. W. Ind. : 1818 petaloides : : Ro. wht. : 5, s. Ev. S. Brazil : 1832 píctá platanifolra : - Pink : 9, S. Ev. S. Brazil. * 1829 pulchêla : : White: : 7, S, Ev A. Brazil. : 1823 sanguìneă : : S. Ev. S. Brazil: : 1829 scanguinea $3^{\circ}$ : : White. 8 , S. Ev. Cl Grazina: : 1829 semperflorēns : : Pink : S. Ev. S. Brazil : 1829 spatulatả . . White. 9, S. Her. P. W. Ind. 1819 suavēoléns . : White. 8, S. Ev. S. W. Ind. 1816 tuberōsă : : White. 8, S. Tu. P. Amboyna 1810 undulátí : . White: 7, S. Ev. S. Brazil. : 1825 villồü Pink : 7, s. A. S. Amer.

BRJARİ̆, Mutis. In memory of M. Bejar, a Spanish botanist. Linn. 11, Or. 1, Nat. Or. Ericacea. Beautiful species, of easy culture, succeeding well in loam and peat; and cuttings root readily under a glass in heat.

glaũcă . . . Purple . 6, S. Ev. S. N. Grena. 1826 racemō8ä: : Purple : 6, G. Ev. S. Florida : 1810 Belladonna iriy, see Amarȳllis Belladonnă.

BrLleisle cRess, see Barbürëă prä́cór.

Berleviárî́, La Peyrouse. In memory of P. R. Belleval, a French botanist. Linn. 6, Or. 1, Nat. Or. Liliacer. An interesting species, succeeding in common soil, and increased by suckers. Synonymes: 1 . Scilla romana, Hyacinthus romanus.

operculata, 1 . . White. . 5, H. Bl. P. Italy . . 1596

Bell ylower, see Campānülă.

BKLLidiāstrūa, Micheli. From bellis and astrum, resembling a daisy. Linn. 19, Or. 2, Nat. Or. Com. posita. An ornamental species, succeeding in peat and loam, and increased by divisions. Synonyme : 1. Arnica Bellidiastrum.

Micheliii . . . White . 6, H. Her. P. Austria . 1570 BĒLlǐs, Linn. In allusion to the pretty flowers. Linn. 19, Or. 2, Nat. Or. Composito. This comprehends the common daisy, the meritsand theculture of which must be familiar to every one.

ānnŭă . . . White. . 5, H. A. S. Eur. . 1759 hybrida : : White. 4, H. Her. P. ltaly. : 1824 perënnǏs : White. 6, H. Her. P. Britain

fistulösă. - Red - 6, H. Her. P.

hortensiss' - Red . 6, H. Her. P.

prolitéră : : Whía : 6, H. Her. P. Portugal . 1797

BĒLYYô, Linn. From bellis, daisy; the flowers being similar to those of the daisy. Linn. 19. Or. 2, Nat. Or. Compesito. Pretty species, succeeding best in sandy peat, or peat and common soil mixed; seeds or divisions.

bellidioìdēs . White. 7, H. A. Italy . 1796 crassifölǐü $\therefore$ : Wht. yel. 6 , F. Er. P. Sardinia: 1831 minútũm . : White. . 8, H. Her. P. Levant : 1772 BeLopěrŏNe, Nees. Named in reference to the arrow- 
shaped connectivum; from belos, an arrow, and perone, a band, or strap. Linn. 2, Or. 1, Nat. Or. Acanthacer. A pretty species, easily cultivated, and multiplied by cuttings.

oblongātă . . . Ro. pur. . 9, S. Ev. S. Brazil . . 1832

Brngal quincr, see Aglẽ mãrmẽlōs.

Brincàsă, Savi. From Count Benincasa, an Italian nobleman. Linn. 23, Or. 1, Nat. Or. Cucurbitacere. A worthless species, of the easiest culture. Synonyme: 1 . Cucurbita cerifera-ceriferéa 1 .

BENJAMin TREx, see Fĩcŭs Benjamïnă.

Benamin trez, see Lañŭs Bénzoin.

BrNT-GRAss, see Agróstĩs.

BENTHĀMĨ, Lindl. In honour of George Bentham, secretary of the London Horticultural Society. Linn. 4, Or. 1, Nat Or. Cornacere. A very hand some plant, sufficiently hardy to bear our severest winters, if guarded from the cold cutting winds, and unusually sharp frosts, by a mat. The flowers, which appear in profusion during summer, are succeeded by an abundance of large, globular, reddish-yellow, eatable fruit, of an insipid though not unpleasant taste. It succeeds best in common garden loamy soil, and is easily increased by seeds or layers. The best situation for it is against a south wall, where it grows freely, and looks well.

fragiferă . . . Ysh. red . 8, H. Ev. S. E. Ind. . . 1825 BgrĀRDY̌x, Villars. Named after Mr. Berard, a botanist of Grenoble. Linn 19, Or. 1, Nat. Or. Compositce. A pretty species, of very easy culture. Synonymes: 1. Brunia paleacea. 2. B. phylicoides.

paleăceă, 1. . . White - . 7, G. Ev. S. C. G. H. 1791 plyylicoides, 2. White : 7, G. Ev, S. C. G. H. 1805

BËrš̌ris, Linn. From berberys, its name in A rabia Linn 6, Or. 2, Nat. Or. Berberacea. This genus comprises the common berberry, and the species are very ornamental whilst growing plants. They thrive in any common soil, but prefer one rather light; cuttings or layers take freely in the open ground. The fruit makes an agreeable jelly, and, as a medicine, is considered an agreeable and grateful astringent acid. The bark of the roet boiled is used in Poland to dye yellow; the colour is best when boiled in ley. Synonymes: 1. Chitria. 2. Vulgaris iberica.

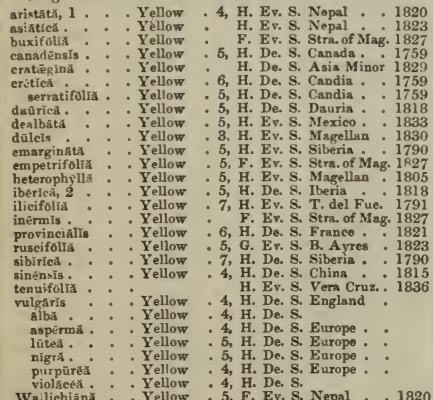

\section{BERBERRY, see Berberrĭs.}

ВеRсн в̆мї , Necker. In honour of M. Berchem, a French botanist. Linn. 5, Or. 1, Nat. Or. Rhamnacer. The species succeed in sandy loam and peat, and are interesting. They increase either by cuttings or seeds. To the roots of $B$. volubilis, antisyphilitic virtues are ascribed. Synonymes: 1 . Rhamnus lineatus, Enoplia lineata. 2. Rhamnus volubilis, Enoplia volubilis.

lineătǔs, 1. . . Green . . 6, G. Ev. Cl. China . . 1804 volübilis, 2 : Green : 6, H. De. Tw. Carolina : 1714

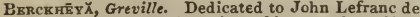
Berckhey, a Dutch botanist. Linn. 19, Or. 3, Nat.
Or. Composite. The species are ornamental, and succeed well in a mixture of loam and peat; cuttings planted in common soil, root readily under a glass.

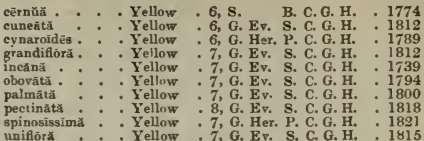

\section{Bergamot, see Menthă odorātă.}

BRRGẼ R, Krnig. In compliment to C. J. Berger, a botanist at Kiel. Linn. 10, Or. 1, Nat. Or. Aurantiacer. Curious and interesting species, sucreeding in sandy loam, and multiplied by layers or cuttings. The leaves of $\boldsymbol{B}$. Krnigii are stomachic and tonic, and an infusion of them toasted allays vomiting.

integērrĭmă . - White . . 6, S. Ev. S. W. Ind. 1823 Konisil. . . White . 6, S. Ev. S. E. Ind. . . 1820

BĒroY̌, Linn. In honour of P. J. Bergius, M.D.

Linn. 10, Or. 4, Nat. Or. Elatinacer. This curious

little species may be grown in sandy soil, and increased plentifully by seeds.

verticillata . . Wht, red , 6, H. A. Egypt . . 1820

BrRINGK̄rǐn, Necker. From Beringer, supposed to be a man's name. Linn. 14, Or. 1, Nat. Or. Labiate. Ornamental species; for culture, \&c., see Marrubium. Synonymes: 1. Marrubium acetabulosum. 2. M. africanum. 3. $\boldsymbol{M}$ cinereum. 4. $\boldsymbol{M}$. crispum. 5. M. hirsutum. 6. M. hispanicum. 7. M. orientale. 8. M. Pseudo-dictamnus.

acetabulósa, 1 . Purple . 7, F. Ev. S. Candia . 1676 afrieññ, $\mathbf{2}$ : : Purple: 8 , H. Her. P. C. G. H. : 1710 cinereñ, 3.: : Pa, pur : 7, H. Her. P. Spain 1823 crispa, 4 : : : Pa pur. . 7, H. Her. P. S. Eur. : 1714 hirsüt, $5:$ : Pa pur. : 6, H. Her. $\mathrm{P}$.

hispanlex, 6 . Purple 7, H. Her. P. Spain . 1714 orientalis, 7 : Purple : 7, H. Her. P. S. Eur. 1821

BERKRI. ẼX̆, Greville. In honour of the Rev. Mr. Berkely, an English eryptogamist. Linn. 24, Or. 7, Nat. Or. Algece. A very small, interesting marine production-frügilis.

BERMUDA CEDAR, see Junīperrŭs bermudiānũ.

BERRYA, Rox. In memory of Dr. Berry, who first introduced it into Calcutta. Linn, 13, Or. 1, Nat. Or. Tiliaceo. An ornamental tree, succeeding well in rich loam and peat mixed; cuttings planted in sandy soil root well under a glass. B. amomilla furnishes the fine light timber employed in making the Massoola boats of Madras, and called Trincomalee.

amomillă

7, S. Ev. T. E. Ind. . . 1800

ВввтйRō̆, Dec. Named in compliment to C. $J$. Bertero, an esteemed friend of Decandolle's. Linn. 15, Nat. Or. Crucifere. The species are ornamental, and of easy cultivation: sandy soil suits them, and young plants are obtained either from seeds or cuttings. Synonymes: 1. Farsetia incana. 2. Far setia mutabilis.

incañă, 1 . White . 7, H. B. Europe * 1640 mutäbilis, 2 : Wht. pnk. 7, H. Her. P. Levant: : 1802

BRRthol. L̇tĭ̌̆, Humb. and Bonp. In memory of L. C. Berthollet, a meritorious chemist. Linn. 13, Or. 1, Nat. Or. Lecythidacece. This tall ornamental tree yields the nuts known in shops under the name of Brazilian nuts. It succeeds in sand, peat, and loam, and may be increased by cuttings in sand, or in a sandy soil.

excēlsă

S. Ev. T. Para

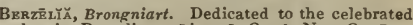
chemist Berzelius. Linn. 5, Or. 1, Nat. Or. Bru niacer. These pretty species delight in a mixture of rather sandy peat and loam. Cuttings take readily in sand, under a glass. Synonymes: 1. Brunia abrotanoides. 2. B. lanuginosa.

abrotanoides, 1 . White. . 6, G. Ev. S. C. G. H. . 1787 lanuginösă, 2 . : White. : 7, G. Ev. S. C. G. H. : 1774 BrsLēeř̆, Linn. Named in memory of Basil Besler, 
an apothecary at Nuremberg. Linn. 14, Or. 2, Nat. Or. Gesneriaeeu. A pretty and interesting genus, delighting in very light rich soil. Sweet says, cuttings strike freely by merely sticking them, without protection, in the tan-bed. Synonyme: 1. B. bicolor.

coccinnèa . : Yellow

eristat

dìchruá:,

grand follì

hirtélla.

incarnāt.

luteă

melittifoliž

móllis

pulchellă

serrulata

violāceă

Yellow

Red yel.

S. Ev. S. Guiana

1819

$6, \mathrm{~S}, \mathrm{Ev}, \mathrm{Cl}$. W. Ind. . 1739

7, S. Ev. S. Brazil.

8, S. Ev. S. Brazil.

, S. Ev. S. Brazil

S. Her. P. Guiana

7, S. Ev. S. Guians

, S. Ev. S. Guiana

S. Ev. S. S. Amer.

Ev. S. Triniclad . 1806

S. Ev. Cl. W. Ind. 1806

B ̌̆r alluding to the red colour of the roots. Linn. 5, Or. 2, Nat. Or. Chenopodiacea. The beet-root is the type of this genus; the uses of which are well known; the species succeed well in common garden soil, treated as other culinary roots. $B$. patula does best kept in the greenhouse. $B$. cicla is used as spinach; and in Germany and Switzerland the midrib of the leaf is boiled, and eaten with gravy or melted butter.

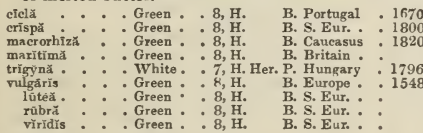

Betla nut, see Pipĕr Betle.

Brтónícă, Linn. From beutonic, its Celtic name. Linn. 14, Or. 1, Nat. Or. Labiata. These handsome dwarf species are well adapted for ornamenting the margins of flower-borders, or rock-work. They grow in any common soil, and increase plentifully from suckers. B. officinalis when fresh intoxicates, and the dried leaves excite sneezing.

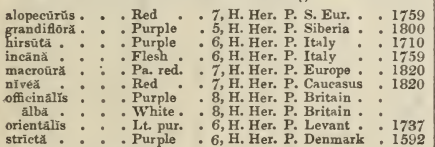

BrTony, see Betónĭcă.

BвтоNY, see Teũcrĩn betơnīcũm.

BĒtŭLĂ, Linn. From betu, its Celtic name. Linn. 21, Or. 4, Nat. Or. Betulacea. This is a popular genus, and best known by its common name, the beech. The species are for the most part loftygrowing trees, and very ornamental. $B$. pendula has a graceful and pleasing growth; the species pumila and nana are dwarfer-growing kinds, but very pretty and interesting. They thrive in any soil, and are commonly increased by grafting or budding on the larger and more plentiful kinds, the latter being raised from seed; the dwarfest species are best when produced from layers. Synonyme 1. Alnus vĩridiss.

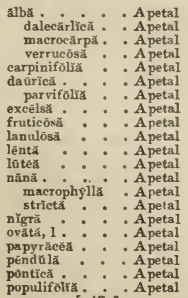

4, H. De. T. Britain .

5, H. De. T. Europe

6 , H. De. T. Europe

4, H. De. T. Britain.

7. H. Ev. S. N. Amer. 1759

7, H. De. T. Siberia.

7, H. De. T. Siberia :

7, H. De. T. N. Amer. : 176

6 , H. De. S. Siberia . 1818

7, H. De. T. N. Amer. - 1817

7, H. De. T. N. Amer. : 1759

5, H. De. T. N. Amer.

5, H. De. S. N. Amer.

5 , H. S. Switzerl: 1819

5, H. De. S. Siberia

7, H. De. T. N. Amer. : 1736

5, H. De. S. Hungary - 1820

6, H. De. T. N. Amer. : 1750

6, H. De. T. Britain .

H. Ev. S. Turkey

7, H. Ev. T. N. Amer. 1750 pubéscēns . Ape:al

pŭmîlĭ

rubrå : : : Apetal

tristis : : : A petal

6, H. De, T. Germany - 1819

$5, \mathrm{H}$. De S. Amer. : 1769

BıАцĀTĂ, two-winged.

Bícēps, having two heads.

Bicōrxis, two-horned.

BiDRNTATE, having $t w i n$, or a double row of, teeth.

BikNNial, of the continuance of two years. A plant is said to be biennial which takes two years to mature its fruit, and then dies.

Bifarious, disposed in two rows.

B1Fm, opening with a cleft nearly divided in two.

Bídêns, so called from bis, twice, and dens, a tooth alluding to the seed. Linn. 19, Or. 1, Nat. Or. Composita. These species are mostly uninteresting; a few, however are worth cultivating. They grow readily in common soil, and increase from seeds, suckers, or divisions, according to their habits and duration. Synonymes: 1 . Coreopsis coro nata. 2. B. odorata. 3. B. tripartita.

Berteriană, 1 - Yellow - 5, S. Her. P. Porto Rico 1787 bipinnătă : Yellow: 7, H. A. N. Amer. 1687 crithmifollă : Yellow : 6, G. Her. P. Mexico : 1824

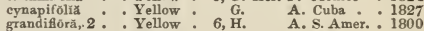
heterophylla: Yellow: 6, G. Her, P. Mexico: 180 leucornth macrospërmă

odorata.

Yellow

procēră : : Yellow

White $: 7$, H. A. S. Amer.

Yellow 6, H. A. Siberia .1819

11 , H. Her. P. Mexico : 1822

sambueifolia: : Yellow: 7, H. Her. P. S. Amer. : 1801

Angustífolīă, bullätă, cērnŭă, chinensǐs, connätă, chrysänthă, chrysanthemō̇dēs, foliōsă, frondōsă, helianthoides, hirtella, luxŭriäns, ntudifloră, parvifloră, pilosă, procūmbêns, reflēxă, striātü, tripartītü.

Bífóris, Sprengel. The name is compounded from bis, double, or two, and foris, a tlap; in reference to the shape of the fruit. Linn. 5, Or. 2, Nat. Or. Umbellifera. Uninteresting species, of the simplest culture. Synonymes: 1. Coriandrum testiculatum. 2. C. testiculatum-radīcāns 1 , testiculätām 2.

BifrenArí, Lindley. So named from bis, twice, and frænum; in allusion to the double strap or frænum that connects the pollen masses with their gland. Linn. 20, Or. 1, Nat. Or. Orchidacea. A genus of very pretty plants when in flower, especially $B$. aurantiaca, the flowers of which are deep orange yellow, mottled with deep brown spots. For culture and propagation see Maxillaria, to which the genus is near akin. Synonyme: 1. Maxillaria atropurpurea.

atropurpŭręa, 1. . Drk. pur. - S. Epi. Rio Jan. 1828

BīFrōns, two-faced.

Bı̈L̄̄vĩ̃, see Borrērǐă.

B1GRMrNATB, twin, each division bearing a pair of leaflets.

Bigrandurar, having two or double glands.

BiGLồ Mis, having two husks, or chaffy scales.

Bignōnia, Linn. In memory of Abbé Bignon, librarian to Louis XIV. Linn. 14, Or. 2, Nat. Or. Bignoniacea. The species are trees or shrubs, inhabitants of hot climates. The leaves are opposite, pinnate, ternate, or conjugate; the flowers in panicles, large and handsome, of various colours, red, blue, yellow, or white, and eminently beautiful. The stove sorts grow freely in loam and peat, and young cuttings root in sand under a handglass. The species grow in any soil, but will not flower well unless the situation be warm; they are increased by cuttings of the roots, by layers, or by young cuttings in a gentle heat, under a handglass or frame. B. radicans is a well-known muchadmired species, capable of living in the open air in this country against a wall.-Loud. Ency. of Plants. The young shoots of $B$. Chirere are sometimes manufactured into wicker-work. Synonymes : 1. Jacaranda alba. 2. B. heterophylla. 3. Jacaranda echinata. 4 Tomentosa. 5. Millingtonia hortensis. 6. Incarvillea-tomentossă.

albă 1 . . White

alliācéa: : Yellow

amc̄ēnă . . Yellow

apurēnsĭs : Yellow

requinoctialis : Yellow

S. Ev, Cl, Guiana

$S$.

E. Ind. : 1828

6, S. Ev. Cl. Guiana : : 1768 


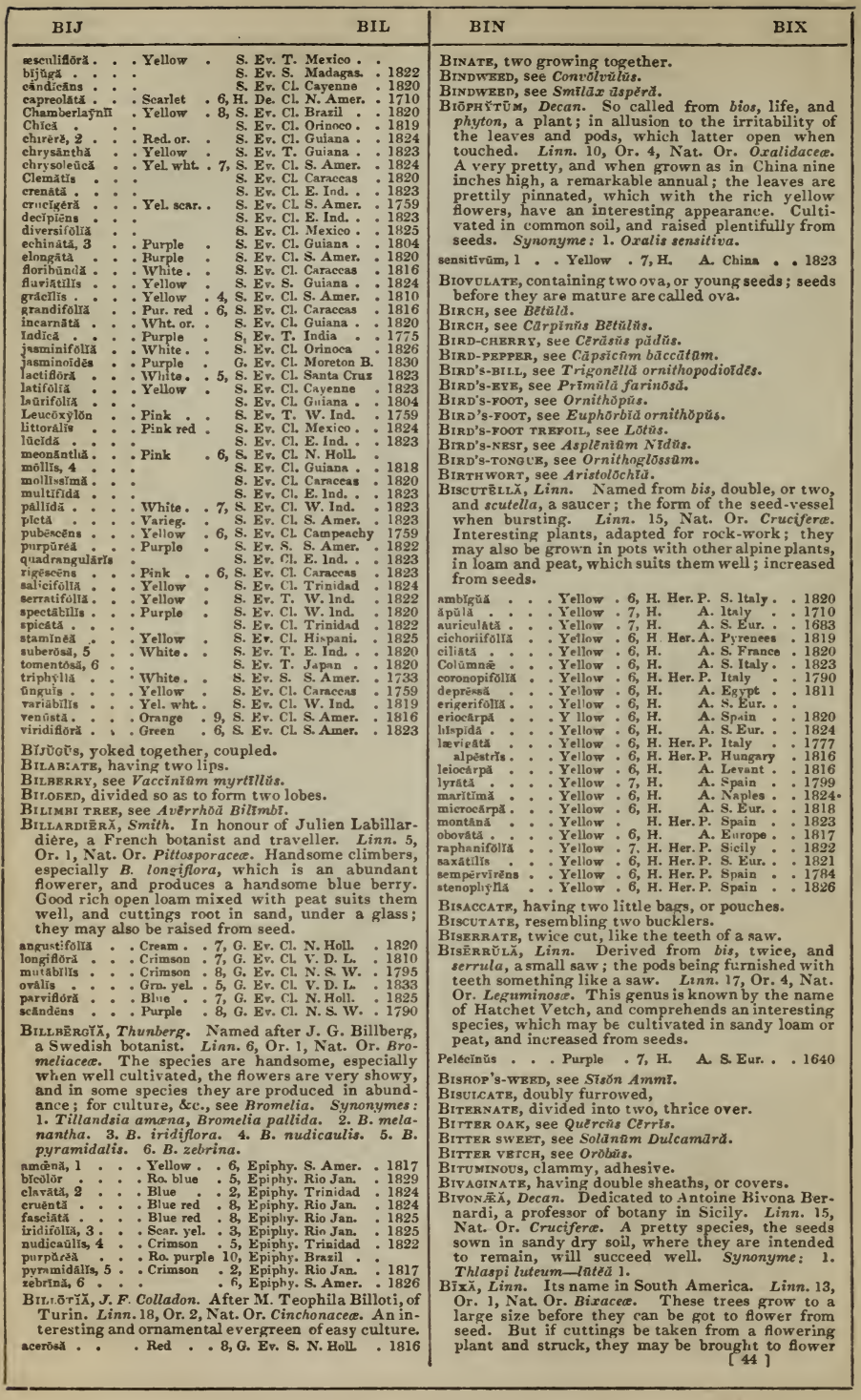


when small plants. Loam and peat suit them well, and cuttings root freely in sand, under a glass, in heat.-G. Don.

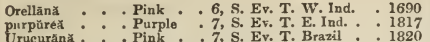

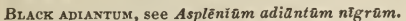

BLAck Bryony, gee Tămús.

BLACK SALTWORT, see Glañx maritímă.

BLACK VARN1SH TREE, see Melanorrhäă.

BцACKwẼLlĭ, Commelin. In compliment to Elizabeth Blackwell, a botanical artist. Linn. 11, Or. 5, Nat. Or. Homaliacer. The foliage of these plants is pretty, but the flowers have nothing to recommend them. They delight in sandy peat, and are propagated with facility from cuttings.

axillărǐs

axillăris

integrifölią

padiflōră

paniculatá

White.

White

White

S. Ev. S. Madag.

8, G. Ev. S. China

S. Ev. S. Madag.

White

G. Ev. S. Chile
S. Ev. S. Boiurbon

1824

1824

1823
1827

$182 i$

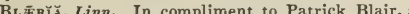
physician at Boston, in Lincolnshire. Linn. 4, Nat. Or. Ericect. The species are interesting, and may be cultivated the same as the genus Erica.

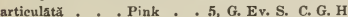

articulată * : Pink * 5, G. Ev. S. C. G. H.
ciliăris . : White. : 6, G. Ev, S, C. F. H

deprëssa : 6, G. Ev. S. C. G. H.

dumōsă

6, G. Ev, S. C. H.

ericoídès : . Purple . 9, G. Evv. S. C. G. H.

fasciculātă . . 6, G. Ev. S. C. G. H.

glabellă. : 6, G. Ev. S. C. G. H.

muscóst: Pink : 7, G. Ev, S, C. G

paucifoliă : : Pink : 6, G. Ev S. C. G. H

purpŭreă : : Purple : 5, G. Ev. S. C. G. H.

scābrã - . Purple 5, G. Ev. S. C. G. H.

1795

1795

1816

1806

1774

1812

1816

774

812

179

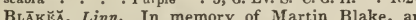
active promoter of useful knowledge. Linn. 11, Or. 1, Nat. Or. Melastomacea. These species are said to be among the most beautiful plants of the W. Indies. They grow well in peat, $o r$ peat and loam mixed; cuttings taken from quite ripenec wood, planted in sand, and plunged in a moist heat, root readily.

quinquenërv̌ă . White. . 6, S. Ev. S. Trinidad * 1820

BrANering, making white, by being grown in a dark place, or by being covered with any thing.

BIAND, fair, beautiful.

Brandrōnnĭ, Smith. Dedicated to George, Marquis of Blandford. Linn. 6, Or. 1, Nat. Or. Liliacece. These beautiful species grow freely in an equal mixture of sandy loam and peat, and thrive planted out in a conservatory, much better than when grown in pots. They increase from suckers or seeds.

prandiflōră . . Crimson . 7, G. Her. P. N. S. W. . 1812 nóbilis : Orange : 7, G. Her. P. N. S. W. : 1803

Blaträrĭŭs, relating to moths, like moths.

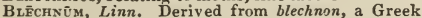
name for a Fern. Linn. 24, Or. 1, Nat. Or. Polypodiacea. Very interesting species of Ferns, they delight to grow in the openings of rockwork, in sandy loam and peat mixed; they divide readily at the roots, and may very readily be increased by seeds. Synonymes: 1. canadense. 2. stramineum.

\section{sustrăle}

braziliēnše, 1 Brown 1 S. Her, P. Brazil 1890

braziliense, 1.. Brown : 6, S. Her. Prazil. 182

cartilagineum. . Browa . \%, G. Her. P. N. Holl.

glandulósŭm *. Brown * 4, S. Her. P. Brazil * 1823

grảeilé * : Brown : 11, S. Her. P. Brazil : : 1830

lavigátūm : Brown : 7, G. Her. P.N. Holl. : 1821

longifoliūm Brown: 7. S. Her. P. Caraceas : 1820

occidentalé : Brown: 8. S. Her. P. Brazil : 1823

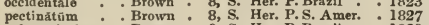

polypodioñdés : . Brown : 9, S. Her. P. Brazil : 1829

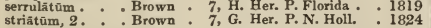

BцĒchūM, Jussieu. Taken from the Greek name of a plant resembling marjoram. Linn. 14, Or. 2, Nat. Or. Acanthacea. Species of considerable beauty; for culture, \&c., see Justicia.

angustifolīũm . Blue . . 6, S. Her. P. Jamaica . 1824 Braziliěnsø : Blue : 6, S. Her. P. Brazil : 1824 Brownèi : : 6 , S. Her. P. W. Ind : 1780 laxiflörüm . . White. 6, S. Her. P. Jamaica . 1818

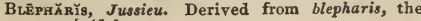
[ 45 ] eyelash; in allusion to the bracteas of the calyx. Linn. 14, Or. 2, Nat. Or. Acanthaceo. The species are ornamental, and may be referred to Acanthus for culture, \&c. Synonyme: 1. Acanthus caqensis.

boerhaaviæfoliă . Blue . 7, S. A. E. Ind. . 1821 rapensïs *. Blue : 7, G. B. C. G. H. 1816 fureãtă : : : : G. Ev. S. C. G. H. : 1816 linearifölĭă: : Blue : 7, S. A. Guinea: : 1823

BLEPHǏL̆ eyelash; the sepals being fringed. Linn. 2, Or. 1, Nat. Or. Labiate. These species are ornamental, and for culture, \&c., may be referred to Monarda.

ciliātă . . . Red . . 7, H. Her. P. N. Amer.

hirsūtă : Purple 8, H. Her. P. N. Amer. 1798

Bı.ÊTĬ, Ruiz and Pavon. In honour of Don Louis Blet, a Spanish physician and botanist. Linn. 20, Or. 1, Nat. Or. Orchidacea. This is, when in flower, a handsome genus of tuberous-rooted plants. They succeed well when grown in a mixture of sandy peat and light loam, with the pots well drained, and treated as follows:-As soon as the leaves die down, remove, the plants to a cooler house, where they should be kept dry for three or four months; then they must be repotted, and placed in a brisk moist heat; and when growing freely, liberally supplied with water. They are easily increased by dividing the roots, which should be done at the time of potting. Synonymes: 1. B. pallida, Cymbidium floridum. 2. C. hyacinthinum. 3. C. altum, Limodorum altum. 4. B. Shepherdii.

acutipétălă . . Purple . 9, G. Ter. Ameriea

6. Ser IV Ind.

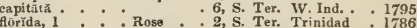

Tose 2, Ter. Trinidad

guinnénsǐs: : Pelsh. pur. 6, S. Ter. Nexico * 1830

hãvānënš̃s . Purple * 4, S. Ter. Havannah: 1835

hyä̌inthïnă, 2 . Ro. pink : 4, S. Ter. China : 1802

pâtŭlä Purple S. Ter Hayti

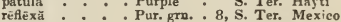

verecûndă, 3 : Purple : 3, S. Ter. WV. Ind. : 1733 Sliepherdri, 4 : Ro. purple 9, S. Ter. W. Ind. : 1788

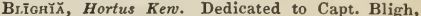
who first carried the bread-fruit to the W. Indies. Linn. 8, Or. 1, Nat. Or. Sapindacee. This is called Akee Tree, and is a plant much esteemed in Africa and the W. Indies on account of its fruit, which is as large as a goose's egg, and of a reddish, or yellow colour; the aril is eatable, of a sub-acid flavour, and considered very grateful, particularly in the W. Indies. It grows in loam and peat; and cuttings, with the leaves not taken off, root in sand, under a glass.

săpidda

White $\quad$ S. Ev, T. Africe 1793

Bughr, a vague term, signifying a pestilence amonyst plants, caused by the attack of insects, or parasitical fungi; or by some epidemic affection of the atmosphere.

BuIstBRED, the surface being raised, as the skin is when blistered.

Bцйт̄̄ M, Linn. The derivation is doubtful, but it is most probably taken from bliton, insipid. Linn. 1, Ur. 2, Nat. Or. Chenopodiaceo. These plants are only worth cultivation for the strawberry-like fruit which succeeds the flowers; hence the trivial name Strawberry Blite; they succeed well sown in the open ground.

capitatüm * A petal *7, H. A. Austria 1633 $\underset{\text { virgätũm }}{\operatorname{marìm}}$ : : A petal $: 7$, H. A. A. S. Eur. : 1680

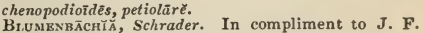
Br.usiznsācrĭ, Schrader. In compliment to J. F.
Blumenbach. Linn. 19, Or. 1, Nat. Or. Loasacea. The speciesareornamental; for sulture, \&c., see Loasa. Synonyme: 1. Loasa palmata.

insignnis, 1 . White. 7, H. Tr. A. Monte Vi. 1826

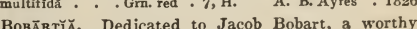
professor of botany at Oxford. Linn. 3, Or. 1, Nat. Or. Iridacece. The species are rather showy, and may be referred to Marica for culture, \&c. Synonymes: 1. Marica gladiata, Mora gladiata. 2. Monara spathacea.

aurantrăcă . . Qrange gladiātă, 1: : Yellow spathäcéă, 2 : : Yellow

3, H. Her. P. Belgia 1827 
BoccōnĬ monk, named Paolo Boccone, M.D. Linn. 11, Or. 1, Nat. Or. Papaveraces. The species are ornamental, and $\boldsymbol{B}$. frutescens has pretty foliage. They are easily cultivated in loamy soil, and increased from cuttings in sand, in a gentle heat, placed under a glass.

fritêscēns . . . Wht. yel. 2, S. Ev. S. W. Ind. . 1739 integrifolia : : White. . 2, S. Ev. S. Mexico. : 1820

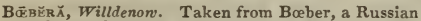
professor of botany. Linn, 19, Or. 2, Nat. Or. Compositc. The species are pretty, and of easy cultivation Synonymes: 1. Dyssodia glutinosa. 2. D. porophylla.

chrysanthemoĩdés, 1 Yellow - 10, H. A. Carolina . 1821 incănă . . . Golden : 9, G. Ev. S. Mexico : 1828 porophÿllă, 2.

Baнммёİ, Jacquin. In memory of George Rudolph Bohmer, a German botanist. Linn. 21, Or. 4, Nat. Or. Nyctaginacere. The species are uninteresting, and of the easiest culture. Synonyme: 1. Urtica arborea.

nubéscèns, 1 . . Green . . 4, G. Ev. S. Canaries . 1779 castaneŭfolìă, caudätă, cylindriccă, elongată, frondösă, frutèscēns, hîtü, interra ptă, lateriflöră, macrophȳllä, platyphyllă, ramiflorä, rotund ifüliü, salicifoliü.

BorRH AĀvĭn̆, Linn. So called in honour of the famous Dutch physician, who is said to have been the first of the many friends and patrons of Linnæus. Linn. 1, Or. 1, Nat. Or. Nyctaginacee. The species are of very simple cultivation, and possess but little beauty.

\begin{tabular}{|c|c|c|}
\hline 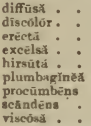 & $\begin{array}{l}\text { White } \\
: \text { Red } \\
\text { White: } \\
\text { Red } \\
\text { Scarlet } \\
: \text { Red } \\
\text { : Red } \\
\text { : Green } \\
\text { Searlet }\end{array}$ & $\begin{array}{l}\text { 9, 8. Ev. Tr. Guia } \\
\text { 8, S. Her. P. Guayaq. } \\
\text { 7, s. Her. P. India } \\
\text { 6, s. Ev. S. S Amer. } \\
\text { 6, S. Ev. Tr. Jamaica } \\
\text { 8, S. Her. P. Sppin } \\
\text { 8, S. Ev. Tr. E Ind. } \\
\text { 8, S. Ev. Cl. Jamaica } \\
\text { 6, S. Ev. Tr. Peru. }\end{array}$ \\
\hline
\end{tabular}

Bot.mophritè $\mathrm{M}$, Thouars. From bolbos, a balb, and phyllon, a leaf: the leaves universally rise from a pseude-bulb. Linn. 20, Or. 1, Nat. Or. Orchidacer. This is a most singular and interesting genus of plants, which to thrive well must be grown in a strong damp heat, potted, and otherwise treated as the genera Epidendrum, Stanhopea, \&c. Synonymes: 1. Anisopetalum Careyanum. 2. Tribrachia pendula.

bărbigêruim .

bracteolătũm

Carềyañŭm, 1

eocoinūm

eũ préũm

recūrvūm

saltatôrĭum

setigerêum

tetragōnūm

$$
\begin{aligned}
& \text { Crimson. 6, S. Epi. S. Leone } \\
& \text { Yel. pur. } 7 \text { S. Epi. Demerara } \\
& \begin{array}{l}
\text { Bra. pur. 10, S. Epi. Nepal } \\
\text { Flesh . 10, S. Epi. S. Lenne }
\end{array} \\
& \text { Copper : 10, S. Epi, S. Lenne } \\
& \text { Ysh. grn. S. Epi. E. Ind. } \\
& \text { Grn. wht. 9, S. Eipi. S. Leone } \\
& \text { 12, S. Epi. S. Leone } \\
& \text { Purple : S. Epi. Demerara } \\
& \text { Yellow . S. Epi. E. Ind. }
\end{aligned}
$$

1835

1836

1823

1835

1837

1822

1835

Bōı Dōñ, Lagasca. In memory of D. Boldo, a Spanish bntanist. Linn. 3, Or. 1, Nat. Or. Nyctaginacere. Ornamental species, succeeding in sandy peat, and propagated by cuttings. Synonyme: 1. Salpianthus arenarius.

lanceolătĭ, 1 . . Purple . 6, S. Ev. S. W. Ind. . 1824 purpurascéns : : Varieg. :6, S. Her. P. Cuba . : 1820

Bole, trunk of a tree.

Bōtētǔs, Dillenius. Named from bolos, a mass, in reference to its massy or globular form. Linn. 24, Or. 9, Nat. Or. Fungi. Curious productions, found in woods and groves, pastures, or on old trees. The species are succulent, and have their parts in the greatest perfection of any Fungi. B. granulatus is eatable, as is B. sub-tomentosus, and B. edulis is excellent when cooked. The Boleti when wounded, heal much in the same manner as the flesh of animals. Synonymes: 1. B. rubeolus-cyanēscēns,

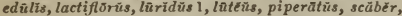

S. aurantīăcŭs. S. bovīnŭs, subtomentठ̋sŭs, S. sanguinēǔs, variegaturs.

Bôr.š̄ı, Desvaux. The name is taken from the round pods; and is derived from bolos, a ball. Linn. 15, Nat. Or. Cruciferce. An ornamental species, succeeding best in rather sandy peat; it ripens seed, from which it may be plentifully increased. Synonyme: 1. Vella aspera.

ãspèrüm . . . Cream . . 6, F. Ev. S. Spain . . 1818 Bourvärĭ, Schlech. The name is given in honour of the great Bolivar. Linn. 2, Or. 1, Nat. Or. Jasminaced. $\Lambda \mathrm{n}$ interesting species, delighting in a mixture of loam and peat, and propagates readily from cuttings.

triffida . . . Yellow . 6, G. Ev. S. Chile . . 1828

BoltōsY̌̆, L. Herit. Dedicated to J. B. Bolton, an English professor of botany. Linn, 19, Or. 2, Nat. Or. Composite. Very interesting species. so much like some of those of the genus Aster, that they may be referred for culture, \&c. to that genus.

sateroidës . . Flesh . . 9, H. Her. P. N. Amer. . 1758 glastifoliă : : Pink : : 9, H. Her. P. N. Amer. : 1758 Во̄мвйx, Linn. The name is derived from bombax, cotton; in allusion to the wool in the pods. Linn. 16, Or. 8, Nat. Or. Sterculiacere. The genus is trivially named the Silk Cotton Tree, and the species thrive well in a sandy loamy soil; half-ripened cuttings taken off at a joint, and planted in sand, under a glass, in a moist heat, root readily. The seeds of many of the species are enveloped in long hairs, like those of the true Cotton; it is found, however, that they cannot be manufactured, in consequence of no adhesion between the hairs. The woolly coat of the seeds of some of the species is employed in different countries for stuffing cushions, \&c. The trunk of $B$. Ceiba is spiny, and said to be one of the highest trees in both Indies; the wood is light and of little value, but is sometimes used for canoes. The wood cut into boards, and steeped some time in lime-water, will endure the action of the air many years. The cotton in which the seed is enveloped, is used by the poor inhabitants for stuffing chairs, pillows, \&c., but is seldom or never used for beds, it being thought unwholesome to sleep upon. Synonymes: 1. quinatum. 2. heptaphyllum. 3. heptaphyllum.

Celba, 1 . . . White. . S. Ev. T. S. Amer. . 1692 S. Ev. T. Guiana , 182 malabarieôm, 2 . Scarlet - S. Er. T. Malabar

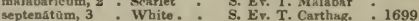

Bonaptrtě̃̆, Ruiz and Pavon. In memory of Napo. leon Bonaparte, Linn, 6, Or. 1, Nat. Or. Bro. meliacea. This species has a singularly graceful appearance, by the naturally drooping tendency of its rush-like leaves. It grows well in sandy rich loam, and increases without difficulty from seed.

grăcilis. . . . Epiphy. Mexico 1828 jüncéa : : : : Blue . Epiphy. Peru : 1800

Boxātǚ̆, Willdenow. In honour of M. Bonat, a celebrated botanist and professor at Padua. Linn. 20 , Or. 1, Nat. Or. Orchidacea. A curious species, with remarkably formed green and white, slightly fragrant Howers. For culture and propagation, see Bletia. Synonyme: 1. Orchis speciosa.

speciosa. . - . Grn. wht. . 5, S. Ter. C. G. H. . . 1820 BoNnäy, L ink. In memory of Bonnay, a German botanist. Linn. 2, Or. J, Nat. Or. Scrophulariacec. The species are dwarf-growing plants of considerable interest; for culture, \&c., see Gratiola. Synonyme: 1. Gratiola veronicafulia.

brachiata . . White. . 8, S. A. Braxil . 1823 réptăns : : Blue : 7, 5. Ev. Cr. E. Ind. : 1820 veronicæefoliă, 1 : Pink : : 8, S Cr. B. E. Ind. : 1798 BonNemaisōnī , Agardh. Named in honour of $M$. Bonnemaison, a French cryptogamist. Linn. 24, Or. 7, Nat. Or. Alge. A very delicate, finelybranched species, much like asparagus, rather plen. tiful about the sea-shore-asparagoides.

BoNNẼTiñ, Schreber. In honour of C. Bonnet, a celebrated naturalist. Linn. 13, Or. 1, Nat. Or. Ternstromiacee. An elegant species, doing well in a mixture of loam and peat ; ripened cuttings in a moderate heat, root freely in sand, under a glas $s$.

palūstris . . Red . . S. Ev. T. Trinidad . 1819

Bostř̆, Linn. Dedicated to James Bont, a Imutch physician. Linn. 14, Or. 2, Nat. Or. Myoporacece. An interesting plant, with the appearance of a Daphne; it succeeds in loam and peat, and cuttings root readily in sand, under a glass, in heat.

daphnoídés . . Yel. pur. . 6, S. Ev. T. W. Ind. . 1690 
BŏRĂGō, Linn. So called from the nourishing qualities of the herb. Linn. 5, Or. 1, Nat. Or. Boraginacee. Pretty dwarf species, succeeding in any common soil, and are increased by divisions or seeds. The leaves of $B$. officiualis may be used as a salad, and has been much reputed as a cordial.

crassifolua . Pink . . 6, H. Her. P. Persia . 1822 crassifolua - Pink - . 6, H. Her. P. Persia. - 1822 crétícă : : Blue: : 5, H. Her. P. Crete * : 1823 laxiflora : : Blue: : 6, H. Tr. B. Corsica: 1813 longifolia : : Blue : : 7, H. A. A. Eur. offeinaliss: : Blue : : $8, \mathrm{H} . \quad$ A. England
albiflöră: : orientalis : Blue :6, H. Her. P. Turkey 1752

BorAssťs, Linn. The inmmortal Linnæus applied this name to the spatha of the date. Linu. 22, Or. 6, Nat. Or. Palmacee. This fine species grows upwards of thirty feet high, and yields a fruit the size and shape of a child's head; it thrives well in a nixture of loam and peat, and propagates from seeds. From the sap of the trunk a sugar and wine is made of considerable value.

flabelliformis . Wht. grn. - Palm. E. Ind.

1771

Borво̄к̃ð, Wildenon. Dedicated to Gaston de Bourbon, Duke of Orleans, son of Henry IV. of France. Lium. 16, Or. 6, Nat. Or. Leguminosce. The species are very showy when in flower, and thrive well in peat and loam; and cuttings of the young wood in sand, placed under a glass, root freely.

barbáta. . . Yellow . 7, G. Ev. S. C. G. H.

ciliăta - . Yellow *, G. Ev. S. C. G. H.

cordâtă : : Yellow : 8, G. Ev. S. C. G. H.

crenâtă : : Yellow : 7, G. Ev. S. C. G. H.

lancenlată: Yellow: 7, G. Ev. S. C. G. H.

ruscifóliă: Yellow: 7, G. Ev. S. C. G. H.

trinervia : : Yellow :7, G. Ev. S. C. G. H. : 1759
undulătá

1823

Borkha Ûš̆, Bohmer. Dedicated to Moritz Borkhausen, a German professor of botany. Linn. 19, Or. 1, Nat. Or. Compositce. Species of no beauty except B. alpina, which is rather pretty and interesting; they are all easily cultivated. Synonymes: 1. Crepis alpina. 2. Hieracium stipitatum. 3. Lagoseris bursifolia. 4. Crepis fatida. 5. Lagoseris intybacea. 6. L. leontodontoides. 7. Crepis nicaensis. 8. Lagoseris raphauifolia. 9. Crepis rubra. 10. C. senecioides. 11. L. versicolor.

alpină, 1 . . Yellow . 7, H. A. Italy . . 1739 apargioüdēs 2, äspěră, bellidifölĭa, bursifoliă 3, Candöllèt, caroliniānă, fätidă 4, gravěolēns, hîspĭdă,

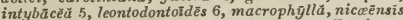
7 , raphanifuliă 8 , rłbră 9 , seneciozdès. Suffreniānă, taraxaciföliă, versicőlor.

Borōi Italian attendant of Dr. Sibthorp. Linn. 8, Or. 1, Nat. Or. Proteacere. A very pretty and interesting genus of New Holland plants. The species flower remarkably free, and some may be seen in bloom at almost any time of the year. They grow best in sandy peat mixed with a few broken shreds, and the pots, which should not be large, must be judiciously drained, as the plants are very liable to suffer from over watering. Cuttings taken at a joint, planted in sand, and placed under a glass in a frame, observing to dry up the damp now and then, will, if carefully tended, make roots.

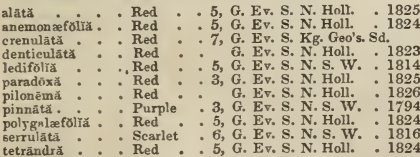

teträndră British cryptogamist. Linn. 24, Or. 8, Nat. Or. Lichenacea. An exceedingly interesting genus to the cryptogamist, on account of the natural habit of the species-atläntică, chrysophthälmă, ciliāris flävăcāns; furfurācěă, leucōmèlä, tenēllă.

Bornēẵ, Meyer. Derivation same as Borrera. Linn. 4, Or. 1, Nat. Or. Cinchonaced. Pretty little plants, of easy culture, in any common soil; and cutting of the perennial and shrubby kinds root readily in sand under a glass. B. stricta must be treated as a tender biennial. Synonymes: 1 . Spermacuce verticillata, Bigelovia commuta. 2. S. stricta, $B$. stricta. 3. S. verticillata, B. verticillata.

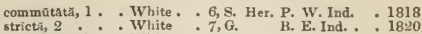
verticillátä, 3 : : White. : 7, S. Ev. S. Africa: : 1732

Bör ̌̆, Willdenow. Dedicated to Colonel Bory de St. Vincent, a French traveller and promoter of natural history. Linn. 22, Or. 2, Nat. Or. Liliacea. The species are uninteresting, and easily cultivated-acuminätă, ligustrīnă, nîtĭdă, porulösŭ, pri noìdés, retũsă.

Bōsč̃ Lamarck. Dedicated to Louis Bosc, a French professor of agriculture. Linu. 11, Or. 1, Nat. Or. Capparidacea. The species is ornamental, and may be referred to Cratava for culture, \&c. Synonyme: 1. Podoria Senegaleusis.

senegalēnsǐs . . $\quad$ S. Ev. S. Senegal . 182

Bōš̆̆, Linn. In compliment to Ernest Gottlieb Bose, a professor of botany in Germany. Liun. 5, Or. 2, Nat. Or. Phytolaccacea. An ornamental species, succeeding in loam and peat mixed; and cuttings in sand, under a glass, placed in heat, strike readily

Yervamōră - Rufous . . G. Ev. S. Canaries . 1728

Boswēllı̆, Roxburgh. Dedicated to Dr. John Boswell, of Edinburgh. Linn. 10, Or. 1, Nat. Or. Burseracee. Ornamental trees of easy culture, thriving best in loam and peat, and are propagated with facility from cuttings in sand, under a giass. The genus is called the Olibanum Tree. B. serrata yields a resin called olibanum, which yields a grateful incense, and possesses stimulant, astringent, and diaphoretic qualities. $\boldsymbol{R}$. glabra furnishes a coarse resin, used for pitching the bottom of ships. The resin of both species is used in India as a frankincense and as pitch.

glăbră . . P Pa. yel. . S. Ev. T. Cornmand. . 1823 serrātă : : Pa yel. : S. Ev. T. E. Ind.

BotANX BAх TREz, see Smīlăx glycyphūllă.

Botr Y̌cünAs, Willdenom. So called from botrys, a raceme, and keras, a horn; the horn-like raceme. Linn. 4, Or. 1, Nat. Or. Aguifoliacee. An interesting species; for culture, \&c., see Banksia.

laurīnūm . . . $\quad$ G. Ev. S. N. Holl.

1823

ВотR г̆снйем, Swartz. The derivation is from botrys, a bunch; in reference to the form of the fructification, which is much like a bunch of grapes. Liun. 24, Or. 1, Nat. Or. Ophioglossiacece. The genus is well known by the name of Moonnort. The species are curious and interesting plants; see Adiantum for culture, \&c. B. virginicum is the largest of the American ferns, and is named the rattlesnake, on account of its generally being found growing where those reptiles abound. Synonymes : 1. Gracilis. 2. Osmunda Lunärĭă.

austrälé . Brown . 6, F. Her. P. N. Holl. funarioídēs: Brown : 7, H. Her. P. Carolina: 1806 Lunärĭă, 2.: Brown :5, H. Her. P. Britain obliquũm * : Brown : 8, H. Her. P. N. Amer. : 1821 virgiñı̆cûm : Brown : 8, H. Her. P. N. Amer. : 1790

Botr Y̌ris, Michaux. Name alludes to the little round seeds, or seed-vessels, resembling a bunch of grapes, and derived from botrys, a cluster of grapes. Linn. 24, Or. 9, Nat. Or. Fungi. Minute productions. $B$. parasitica is found on that plant called the Shepherd's Purse, viz. Capsēllă Bürsü püstōrís -agaricīnŭ, dēnsă, diffūsă, effùsă, leucospóră, macrospбrăa, murīnă, nīgră, parasītǐcă, polysporă.

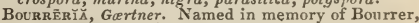
an apothecary of Nuremberg. Linn. 5, Or. 1 , Nat. Or. Cordiacec. Ornamental trees of easy cultivation; for the mode of which, see the genus Ehretia. Synonyme: 1. Ehretia Bourrērĭü.

exsūecă *. White. . S. Ev. T. W. Ind. exsuccă
sueculëntă, 1 : White. White:

BoūssǏxgat̃ur̃̌ , H. B. and Kunth named this genus in honour of J. B. Boussingault, a celebrated natiralist and traveller. Linn. 6, Or. 1, Nat. Or. Chenopodiacece. This is described as a most desirable stove plant, of rapid growth, and bearing copious and graceful racemes of deliciously fragrant flowers. It grows in any common garden soil, and 
may be increased by seed. At Glasnevin, near Dublin, the plant has stood the winter in the open air, planted at the bottom of a wall.

bāselloides. . . White . . 7, F. Bl. P. S. Amer. . 1836

Bouvāadū, Salis. In memory of Dr. Bouvard, superintendant of the royal Paris botanic garden. Linn. 4, Or. 1, Nat. Or. Rubiacea. This is a beautiful genus, worthy of extensive cultivation. $B$. triphylla is a free flowerer, and thrives in a cool part of the greenhouse; $\boldsymbol{B}$. versicolor is rather more tender, and thrives best in a warmer situation in summer, but requires to be cool in winter. They grow in a mixture of loam and peat, and young plants may be obtained from cuttings, which strike in the same kind of soil, in heat; they may also be propagated by pieces of the root, planted in good soil, in heat. Synonyme: 1. B. Jacquinii, Houstonia cuccinea.$$
\text { longiflôră }
$$

triphella 1 - White.

puhesecing - Searlet

glabri Scarlet

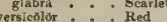

S. Er. S. Mexico

1827

, G. Ev. S. Mexico.

, G. Evis.

B, G. Ev. S. S. Amer.

1794

1794

1794

Bovístñ, Persoon. Latinised from its German name bofist. Linn. 24, Or. 9, Nat. Or. Fungi. Striking productions. Bulliard mentions having seen many of eighteen, twenty, and twenty-three inches in diameter; and on the authority of others, affirms them to attain the enormous bulk of nearly nine feet in circumference. B. gigantea is the largest of the genus or order, measuring two feet in diameter. The,flesh is at first white, afterwards of a greenish-yellow, lastly of a brown grey, the outer peridium cracks, and peels off in large flakes on being handled.-Loudon's Ency. of Plants-gigäntea, nige èscēns.

Bôwiě̃ , Hanorth. In memory of $\mathbf{J}$. Bowie, a collector of plants for the Kew gardens. Liun. 6, Or. 1, Nat. Or. Liliacece. Curious plants, succeeding in fibrous sandy peat, and multiplied by offsets or suckers.

Africañă . . . Red grn. - 10, G. Ev. S. C. G. H. - 1823 myriacinthă : Red grm. . 5, G. Ev. S. C. G. H. : 1823

Bowl.̄sY $\breve{A}$, Romer and Schultes. Named in honour of Mr. Bowles, an Irish botanist. Linn. 5, Or. 2, Nat. Or. Umbelliferce. A minute curious plant, will grow in any common soil, and is increased by divisions.

tenera . . . . Grn. yel. . 7, F. Ev. Cr. M. Video . 1827

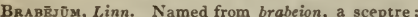
applying to the racemes of flowers Linn. 23, Or. 1, Nat. Or. Proteacer. An ornamental tree, succeeding best in open sandy loam and peat; cuttings of the ripened wood root without difficulty, in sand, under a glass.

stellatũm . . . White . . 3, G. Ev, S. C. G. H. . 1731

Brachiatr, having arms or branches usually placed opposite to each other at right angles with the main stem, and crossing each other alternately.

Br AcIIYLúñ̌, R. Bromn. From brachys, short, and lana, cloak; in allusion to the form of the calyx. Linn. 19, Or. 2, Nat. Or. Composita. An ornamental plant, for the culture of which, see Baccharis. Synonymes: 1. Baccharis nereifolia, Tarchonanthus dentata.

nereifolia, 1 - White. . 9, G. Ev. S. C. G. H. . 1752

BrachYpódīūM, Beauvois. Taken from brachys, short, and pous, a foot; in reference to the short stalks of the spikelets Linn. 3, Or 2, Nat. Or. Graminea. Mere weeds, of the simplest culture. Synonymes: 1. Triticum ssperum, Festuca rigida. 2. Triticum loliaceum. 3. Bromus pinnatus. 4. B. rupestris. 5. B. sylvaticus. 6. Brachypodium närdŭs-äspērăm 1 , brunciālé, brevisețtum, caspitossam, distăchÿon, Hăl-

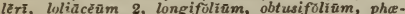

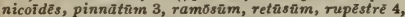
strigôsûm, sylvăticūm 5 , tenẻllūm 6 , Tenoriānūm, tennicūllàm, tenuiflorūm, uniolotdēs, unilaterālé.

BRACHYSĒMĂ, R. Brown. Derived from brachys, short, and sema, standard; the flowers having a very short standard. Linn. 10, Or. 1, Nat. Or. Legu. minosa. Very handsome clinbing species, especially $B$. latifolia, thriving well in an equal mixture of sandy loam and peat; they are increased by layers, or cuttings planted in sand, under a glass, in heat, root freely. They may also be increased by seeds, which are sometimes produced. These plants are well suited for training up the columns of the conservatory or greenhouse.

latifolinum * * Crimson - 5, G. Ev. Cl. N. Holl. - 1803 undulātüm. : Green . . 3, G. Ev. Cl. N. S. W. : 1820

BraснуттйLмג̆, $\boldsymbol{R}$. Bronn. Named from the word brachys, short, and stelma, a crown; in allusion to the short coronal processes of the flowers. Linn. 5, Or. 2, Nat. Or. Asclepiadacee. A curious plant, grows well in sandy loam, and is increased by cuttings.

crispěrüm • - Br. yel. 9, S. Tu. P. C. G.'H. - 1829 tuberosūm : : Purple : 6, S. Tu. P. C. G. H. : 1821

Bractras, small leaves placed near the caly $x$ on the peduncle or pedicel

BRĀDLĔJ Ǎ, Gaertner. In honour of Richard Bradly, a professor of botany at Cambridge. Linn. 21, Or. 10, Nat. Or. Euphorliacea. Curious plants, of little interest. They succeed in loamy soil, and multiply from cuttings.

nitida

S. Ev. S. E. Ind. . 1820

7, S. Ev, S, China: : 1816

$\mathrm{B}_{\mathrm{R}} \overline{\mathrm{A}} \mathrm{CT} \check{\mathrm{A}}$, small leaves placed near the calyx, on the peduncle or pedicel.

BRACTEATR, furnished with bractea.

BrACTẼó s.̄é, little bractea.

BRAssãvöı, Á, R. Brơvn. Named after Antonio Musa Brassavola, a noble Venetian, and one of the most enlightened botanists of his day. Linn. 20, Or. 1, Nat. Or. Orchidacea. The plants of this genus are deserving a place in every collection of orchidacea, having, when in flower, a delightfully fragrant odour.' They require to be propagated, and otherwise treated, as Stanhopea. Synonymes: 1. Epidendrum cucullatum, Cymbidium cucullatum. 2. C. nodosum, E pidendrum nodosum. ungustati - . Ysh. grn. . 6, S. Epi. Demerara

cucullata, 1: : White. 6, S. EpL W. Ind. : 1790

elegans 1.0. Lilac

nodost 8 - Llac grn."

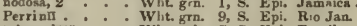

1830

tuberculata . : Wht yel. 7, S. Epi Brazil. 1827

$B_{R} \bar{x} s Y_{Y} \tilde{A}, R$. Brovn. In commemoration of the late $M r$. Brass, a skilful botanical traveller and draughts. man. Linn. 20, Or. 1, Nat. Or. Orchidacea. This is a fine genus of plants, all of which are delight. fully fragrant when in flower. The flowers are mostly yellowish green, spotted with purple. For culture and propagation, see Stanhopea. Synonymes: 1. Epidendrum caudatum, Malaxis caudata.

caudată, 1 . . . Ysh. grn. . 2, S. Epi. W. Ind. - 1823 Lanceanx . . Ysh. spot. 1, S. Epi. Surinam. 1833 måcröstachy̆a : Grn. brn. \& \&. Epi. Demerara : maculatia : : Wht spot 4, S. E pi Jamaica : 1806

$B_{R} \bar{A} s s i c h$, Linn. From bresic, the Celtic name of the cabbage. Linn. 15, Or. 2, Nat. Or. Crucifere. In this genus we have the well known cabbaze, with its many varieties, and many other familiar potherbs and roots. It is wonderful to look upon the common cabbage ( $B$.oleracea) with its varieties, and observe the exceeding great difference in appearance and qualities, particularly when we compare the original types as found on our shores, with wavy sea green leaves tending to no head, and flowering like wild mustard or charlock, with the caulifiower and red cabbage, \&c. As their culture is generally well known, we sball dwell upon it here as briefly as possible; the cabbage and its varieties require a very strong rich soil, or they will not come to a good size. The turnip also does well only in good rich soil, and indeed the whole tribe thrive best in open loamy soil, enriched with manure. They all pruduce an abundance of seeds, which must be sown at those periods which experience has shown to be the best, for bringing their produce to perfection at certain seasons. Synonymes: 1. B. sempervirens. 2. Raphanus cheiranthifolia. 3. Sisymbrium valentinum-baleärica 1, campēstrīs, C. nāpă Brässică, C. commãnťs, C. rustabãgă, c. oleỉferă, $c$. pabuläriă, cheiranthifoliă 2, cheiränthøs, chinēnsis, elongätä, E. rucüstrüm, fruticulösă, Gravină, Helèniänă, hümilis, incānă, lavvigãuă, monēnsis, montānă, Näpŭs, N. esculēntŭs, $N$. 


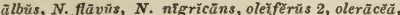
O. asparagoz̃des, O. cauliflöră, O. commūnǐs, $O$

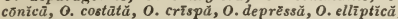
O. gemmǐfêră, $O$. mäjör, $O$. obovätă, $O$. oblongă, $O$. palinifoliă, $O$. quercifoliă, 0 . ramōsă, $O$. rūbră, $O$.

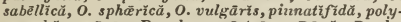
mörphă, prḗcóx, Pseudo-erncāstrūm, Räpă, $\boldsymbol{R}$. deprêssă, $\boldsymbol{R}$. oblōngă, $\boldsymbol{R}$. oleǔfëră, repändä, Richêrīi, subulürǐă, Tournefortīĩ, valentīnă 3 , violäcěă.

$\mathrm{BR}_{\mathbf{A} \mathbf{x}}$, Sternberg. In memory of Count Bray, a German botanist. Linn. 15, Or. 2, Nat. Or. Cruciferc. Curious minute species, with purple flowers. They thrive best in loamy soil mixed with a little fibrous peat, and are multiplied by seeds.

alpină . - Purple • 6, H. Her. P. Carinthia . 1823 pilósă : : Purple 5, H. Ev. S. N. Amer. : 1827

Brigmontển, Dec. In memory of M. Bremontier, an agriculturist. Linn. 17, Or. 4, Nat. Or. Leguminosc. An ornamental interesting plant, thriving in sandy loam, and is multiplied by cuttings in sand, under a glass, in heat.

Ammoxỳlŏn - Purple . S. Ev. S. Mauritius . 1826

BRĒx̌̆, Noronha. Named from brexis, rain; on account of the protection afforded against rain by some of the large leaves. Linn. 5, Or. 1, Nat. Or. Brexiacea. Excellent stove plants, with very beautiful foliage. They all grow freely and look well planted in large pots, in turfy loam and peat mixed. Cuttings take readily in any state, except that the leaves must not be moved, planted in sand, under a glass, in heat. A bud at the base of an entire leaf will strike, and make a young plant, if put in a little sand, under a glass, and put in the propagating house. chrysophȳllă

nuadagascariēns̆s. Green

spinōsa

- Green

S. Ev, T. Mauritius .

S. Ev. T. Madagas.

1820 cologist, Professor Bridel. Linn. 23, Or. 1, Nat. Or. Euphorbiacea. Small shrubs or trees, with little beauty, and easily cultivated. Synonyme: 1 . Clusia scandens.

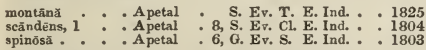

BRıGnōxĬ, Bertolini. Named in compliment to J. L. Brignoli, a professor at Vienna. Linn. 5, Or. 2, Nat. Or. Umbelliferce. A species of trifling beauty and easy culture. Synonyme: 1. Sium siculum.

panacifoliă, 1. . White . . 7, H. Her. P. Sicily . . 1686

BRISTLES, rigid hairs.

BrIsTLY-TOoThED, bristles like teeth, or with the teeth ending each in a bristle.

$B_{\mathrm{R} \overline{\mathrm{Z}} \mathrm{A}, L}$ Linn. Named from brizo, to nod, on account of the quaking character of the spikelets. Linn. 3, Or. 2, Nat. Or. Gramineœ. Although mere weeds, some species are pretty and interesting, as $B$. minor, rubra, Clusii, \&c. The whole are of easy cultivation.

Clūsī . . . . A petal . . 6, Grass, S. Eư. . . 1820

elátiōr . . A petal. * 7, Grass. Greece : 1817

geniculātă - * A petal - *, Grass. C. G. H. * : 1816

6, Grass, S. Eur. 1633

medlă . : A petal . 5, Grass, Britain

minoorr : A petal . 7, Grass. England

rübră : : : A petal: 6, Grass, S. Eur. : 1820

virēns : : A petal : 6, Grass. Spain : 1800

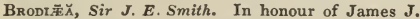
Brodie, a Scotch Cryptogamist. Linn, 3, Or. 1 Nat. Or. Liliacea. Very curions bulbs, with lilac, blue, and white flowers. They may be successfully grown in sandy peat, and increased chiefly by offsets of the root. Synonyme: 1. Hookeria coronaria.

congēsta - . Blue . . 7, G. Bl. P. Georgia . . 1806 grandifloră, 1: : Blue : 6, F. Bi. P. N. Amer. : 1806

BRомйı̆ц̆, Linn. So called after Olans Bromel, a Swedish botanist. Linn. 6, Or. 1, Nat. Or. Bromeliacer. This is a genus of very hand some plants, among which the Pine Apple was lately included. They are of easy culture providing they have a sufficiency of heat, and are potted in good rich open loamy soil; they must be watered carefully, that is, giving a good supply when grrwing, but in the winter a very little is sufficient. The pots should be well drained, and as the plants are, like the Pine Apple, subject to injurious attacks of the scale, \&c. they should be carefully looked over and washed; indeed, these plants may be said to do best with the treatment successfully applied to the of the genus in Brazil, called Grawartha.

acăngr.

S. Her. P. Brazil

bracteātă

discoloror.

exūdāns

fastuōsă

hümillis

Kărătăs

lingulātå

Pingŭin

semiserrătă

sylvēstrís

S. Her. P. Brazil .
Pink : 9, S. Her. P. Jamaica
Slue H. Her. P. Caraccas
Blk, wht. 8 , S. Her. P. Rio. Jan.
Pink : 4, S. Ev. S. S. Amer.
Yellow : 10, Epiphy. W. Ind.
Purple: 8, S. Her. P. S. Amer.
Pink : 3ink. S. Her. P.
Yellow:
5, S. Her. P. W. Ind.
Red : 5, S. Her. P. W. Ind.
Green : 3, S. Her. P. W. Ind.
Crimson: 7, S. Her. P. S. Amer.

1822

1785

1819

1824

1815

1789

1759

1822

1820 Pine A pple. Rope is manufactured from a species

chrysănthă

paniculīgèrà

BRо̆мบัs, Linn. So called from bromos, the Greek name for a wild oat. Linn. 3, Or. 1, Nat. Or. Graminea. The whole are uninteresting, and in point of culture simply managed. Synonymes: 1. Festuca gigantea. 2. F. triflora-Alopecūrūs, altissǐmŭs, arvënsǐs, äspěr, austrälīs, Biebersteīnŭĭ, ciliätŭs, commutătǔs, confertüs, elongātüs, erëctūs, festucoz̄dēs, Gaudīñ̄, gigäntēǔs 1, G. longifoliňs, G. triflorŭs 2,

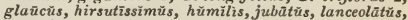
lanuginōsūs, lāxŭs, ligūstrīcŭs, longiflörùs, madritẻnsìs, müxĭmŭs, möllis, multiflorūs, parviflörŭs, pendulīnŭs, pilossŭs, pratēnsis, pubēscēns, pârgāns, rucemōsă, rĭgĩdūs, scaběrrìmǔs, scopārīŭs, secālinnùs, squarrōsŭs, stenophȳllŭs, stērĭlĭs, tectorūm, tơrtīlis, variegätŭs, velutīuŭs, vestītŭs, volgēnsĭs.

Brongniārtĭ, Humb. Bonpl. and Kunth. In honour of M. Adolphe Brongniart, a French botanist. Linn. 17, Or, 4, Nat. Or. Leguminosa. A valuable species, having flesh-coloured flowers. It is cultivated best in loam and peat, with a little sand; and increased by cuttings in sand, in heat, under a glass.

podalyrioidès . . Flesh . . 9, G. Ev. S. N. Spain . 1827 BRösĭmūm, Swartz. Named from brosimos, good to eat; in allusion to the eatable fruit. Linn. 23, Or. 2, Nat. Or. Urticacea. Alicastrum is common in the woods of Jamaica; the timber is not despicable, but the leaves and young branches are more useful, and a hearty fattening fodder for all sorts of cattle. The fruit, boiled with salt fish, pork, or beef, or pickle, has frequently been the support of the negroes and poorer sorts of white people in times of scarcity, and proved a wholesome and not unpleasant food; when roasted, it eats something like our common chestnut, and is called bread nut. The leaves and young shoots are full of gum, which renders them disagreeable to most cattle at first; but they soon grow very fond of them. B. spurium is also common in woods in the W. Indies; but its timber is of little value. In our stoves both species thrive well, and like loamy soil, and old cuttings with their leaves on, root in sand, in moist heat. -Lou. Ency. of Plants.

Alicăstrūm * Apetal * S. Ev. S. Jamaica $\quad 1776$

Bross胥Ă, Linn. Named after Gui de la Brosse, physician to Louis XIII. Linn. 5, Or. 1. Not sufficiently known to be referred to any natural order. As far as we know of this plant, it is a shrub, like a cistus, with scarlet flowers half an inch long. It will no doubt grow in sandy peaty soil, and raise from cuttings in sand.

coecinnèă - . Searlet - S. Ev. S. S. Amer.

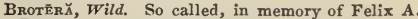
Brotero, a Portuguese botanist, and professor at Coimbra. Linn. 19, Or. 5, Nat. Or. Compositde. An interesting plant, with blue flowers, grows in loam, mixed with peat, and propagates by dividing the roots. Synonyme: 1. Onobroma corymbosa.

corymbßsă . . Blue . . 6, H. Her. P. S. Eur. . 1640

BroughtōNĭ, Brown. In honour of Mr. Arthur Broughton, an English botanist. Linn. 20, Or. 1, Nat. Or. Orchidacea. B. sanguinea, the only species 
we have seen flower, is a very desirable plant, producing its fine crimson flowers in terminal racemes. They require a free supply of water when in a free-growing state. For culture and propagation see Stanhopea.

nǐţ̃da . . . . Red . . 6, S. Epi. E. Ind. • 1824 sanguinēea : Crimson : 8, S. Epi. Jamaica . 1793

Broussonētř̆, Ventenat. In compliment to P. N. V. Broussonet, a French naturalist and traveller. Linn. 22, Or. 4, Nat. Or. Urticacea. Ornamental and fast-growing fruit trees, with large, various-shaped leaves, which differ in the male and female plants, so much as not to be easily distinguished one from the other. The fruit is no larger than peas; and in China and Japan B. papyrifera is cultivated for the sake of its young shoots, which are used in the same manner as osiers here; the onter bark, when separated from the wood and inner bark, will make tolerably good paper. The juice is also used in China as glue in gilding leather and paper. From the bark of this tree is made the finest and whitest cloth, worn by the highest ranks in Otaheite and the Sand wich Islands. The cloth of the breadfruit tree is inferior in whiteness and softness to it, consequently worn by the commoner people. They grow in any open soil, and increase readily by cuttings. Synonyme: 1. Morus papyrifera.

papyrrferră, 1 . : Apetal :6, H. De. T. Japan * : 1751

BrowALlY̌̆, Linn. Named in honour of J. Browallius, bishop of A bo. Linn. 14, Or, 2, Nat. Or. Scrophulariacece. Very handzome plants, on account of their blue and white flowers. They are easily cultivated in common soil, if sandy, much the better, and increased by seeds. Synonyme: 1. B. lactea.

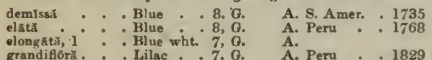

BRס̄WNĔñ, Wild. In memory of Dr. Patrick Browne. Linn. 16, Or. 3, Nat. Or. Leguminosa. This, though rare in our collections, is a splendid genus. The species succeed in sandy loam and peat, if the pots be well drained, and the soil carefully watered, particularly in winter. Cuttings of the ripe wood in sand, put in a moist heat under a glass, may be brought to root. Synonyme: 1. B. speciosa.

\begin{tabular}{|c|c|c|}
\hline 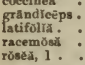 & $::$ : Red & $\begin{array}{l}\text { S. Ev. S. Caracess } \\
\text { S. Ev. S. Trinidad } \\
\text { S. Ev. S. Caraecas } \\
\text { 7, S. Ev. S. Trinidad }\end{array}$ \\
\hline
\end{tabular}

BRowsLowǐn, Roxburgh. In compliment to the late Lady Brownlow, daughter of Sir A. Hume. Linn. 13, Or. 1, Nat. Or. Tiliacce. A large, tall-growin tree, of considerable beauty, thriving in a sandy, loamy soil, and increased by cuttings without difficulty.

elntă . . . Yellow . S. Ev. T. E. Ind. . . 1820

BrūcěA, L. Héritier. In memory of J. Bruce, the traveller in Abyssinia. Linn. 12, Or. 4, Nat. Or. Zanthoxylacea. Evergreen ornamental shrubs, thriving in an open loamy soil mixed with a little peat ; and propagated from half or wholly ripened cuttings, in sand or soil, under glass.

ferrugithěă . . Green . . 4, S. Ev. S. Abyssinia - 1775 grüeilis . : : Yel grn. : S. Ev. S. E. Ind. . : 1820 sumatrănă : : Green . : 5, S. Ev, S. E. Ind. : 1820

Brugatassť̆, Persoon. Named in honour of Professor S. J. Brugmans. Linn. 5, Or. 1, Nat, Or. Solanacea. The species of this genus are among the greatest ornaments of our conservatories; $B$. arborea in particular; this species never thrives well but when planted out in a border, and must be plentifully watered, allowing plenty of room for the branches; thus treated, the number, size, and fine white colour of the flowers will be surprising. All the species are great feeders, and require good soil, and a deal of room to grow them fine. They are easily propagated from cuttings; or the eyes taken off, like vines, and put in good soil in heat, will strike readily. Synonymes: 1. San. guinea. 2. Datura arborea 3. D. arborea.

bǐcolor, 1 . . Dk, red . 8, G. Ev. S. Peru : 1833

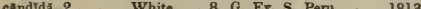

suavérlèns 3 . White. . 8, G. Ev. S. Perm * 1733 Waymănī . . . Wht. pur. 5, S. Ev. T. S. Amer. . 1827 BrũNĬ L̆, Linn. In memory of Cornelius Brun, a traveller in the Levant and Russia. Linn. 5, Or. 1, Nat. Or. This, observes Mr. Sweet, is a pretty Cape genus; its species are pretty bushy shrubs, with heath-like leaves, and are handsomest while young. The flowers are not so showy as in many other genera, but some of them are very elegant. A sandy peat soil suits them best, with a moderate supply of water; young cuttings, planted in sand under a bell-glass, strike root freely.-Bot. Cult. 153.

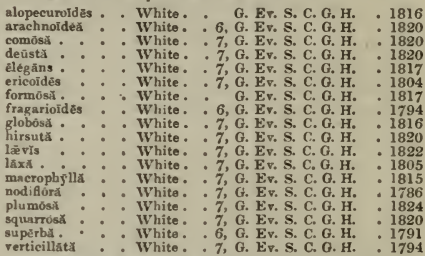

BRuvxīcaY̌, Banks Named in memory of one $F$ Brunnich, a Danish naturalist. Linn. 10, Or. 3, Nat. Or. Polygonacee. An evergreen climber, of some merit; it grows readily in a loamy soil, and roots freely from cuttings.

cirrhosă . . . Pink . . 7, G. Ev. Cl. Carolinn . 1787 BRUNōNIXX, Smith. Named in compliment to Robert Brown, Esq., D.C.L., \&c. \&c. Linn. 5, Or. 1, Nat. Or. Brunoniacece. A most interesting fragrant perennial; for the growth of which, a frame or cool greenhouse is recommended.

australis . . Blue . . H. Her. P. N. Holl, . 1834

Brunstētš̌ , Linn. In memory of Otho Brunsfels, of Mentz, a carthusian monk and physician. Linn. 14, Or. 2, Nat. Or. Scrophulariaced. Handsomegrowing, fine-flowering shrubs, with neat foliage, and showy white or purple flowers. They succed well in a good rich soil; and cuttings root readily in sand or soil under a glass in heat.

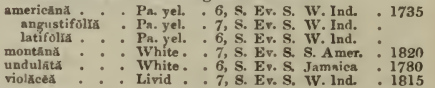

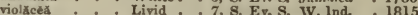

BRUNsvYGỸ, Ker. So called in honour of the family of Brunswick. Linn. 6, Or. 1, Nat. Or. Amaryllidaced. This, observes Mr. Sweet, is a beautiful bulbous genns, "some of the bulbs grow to a great size, and require large pots to have them flower in perfection; or if planted out in the open borders in spring, there will be a better chance of their flowering; taking the bilbs up again in autumn, and keeping them through the winter; or the best way to succeed well with them is to have a pit built on purpose, so as to be occasionally covered with the lights to keep off too much wet, and to be covered close in severe weather, as they cannot bear the frost; the mould must be made for them of full one-third sand, more than one-third of turfy loam, and the rest peat; all well mixed together, but not chopped too small, as the roots run better through it for being rough and hollow; when in full growth and flower they require a frequent supply of water, but none while dormant; all the greenhouse species of Amaryllidece will succeed best in this way."-Bot. Cult., 180. Synonymes: 1. Homanthus ciliaris. 2. Ammochuris coranica. 3. Amaryllis coranica, pallida. 4. Disticha, Buphane disticha. 5. Ammocharis falcats. 6. Amaryltis lati. coma, Nerine laticoma. 7. Amaryllis orientalis. 8. Hormanthus toxicarius.

ciliâris, 1 * - Black - 8, G. BL. P. C. G. H. coränīcă, 2 : : Pink : : 9, G. BL P. C. G. H. pällidă, 3 : : Pale : : 9, G. Bl, P. C. G. H. distichă, 4 : Red: O. BL P. C. G. H. : 1823 falerit, 5 : : : Red : : 5, G. Bl. P. C. G. H. : 1774 


\begin{tabular}{|c|c|c|}
\hline BRY & \multicolumn{2}{|c|}{ BUC } \\
\hline 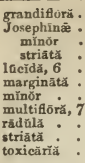 & 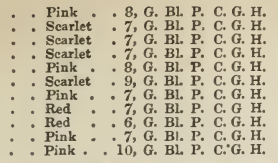 & $\begin{array}{l}1827 \\
: 1814 \\
1814 \\
: 1823 \\
: 1818 \\
: 1795 \\
: 1822 \\
: 1752 \\
: 1790 \\
1823 \\
1774\end{array}$ \\
\hline \multicolumn{3}{|c|}{$\begin{array}{l}\text { BR Y̌, Brown. From the word bryo, to sprout; so } \\
\text { named on account of the germination of the seed } \\
\text { commencing while on the plant. Linn. 16, Or. } 6 \text {, } \\
\text { Nat. Or. Leguminosa. Tallish evergreen orna- } \\
\text { mental shrubs, succeeding well in very rich soil, } \\
\text { and increased readily by cuttings or seed in heat. } \\
\text { Synonyme: 1. Amerrimum Ebenus. }\end{array}$} \\
\hline
\end{tabular}

Eběnǔs, 1. . Y Yel. grn. . 7, S. Ev. S. Jamaica • 1713

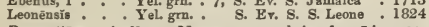

BrxōBīūM, Lindley. Name not explained. Linn. 20, Or. 1, Nat. Or. Orchidacea. A plant of no beauty, and very easy culture.

pubescêns . . Green . . S. Epi. E. Ind. .

BRYöNĬ growth of the stems, from bryo, to sprout. Linn. 21, Or. 10, Nat. Or. Cucurbitacece. Straggling plants of little interest, and easy culture. "The root of Brypnia is powerfully purgative, but if properly cooked, becomes wholesome; those of $B$. rostrata are used in India internally, in electuary, in cases of piles, it is also used in the form of powder as a demulcent; $\boldsymbol{B}$. cordifolia is cooling, and useful in expectorants. The root of $B$. Epigae was once considered to be the esteemed Calomba Root, on account of its nearness in quality. The young shoots and leaves of $B$. scabra, after roasting, are aperient._Lind. Intro. Nat. System-africānä,älbă, cordātă, crētīică, dīožcă, dissēctă, divīsă, epigēeă, ficifóläă, filifơrmìs, Gärcīñ̄, grāndīs, laciniosă, latebrosă, nütìdă, palmütă, pinnatîfídă, quinquělobă, scäbră, scabrêllă, tenellă, trilobätă, verrucosă.

BRYOPHYLLEM, Salisbury. So named from bryo, to grow, and phyllon, a leaf; in reference to the circumstance of the leaf when laid upon damp earth emitting roots, whence arise young plants. Linn. 8, Or. 4, Nat. Or. Crassulacee. Of this curious plant, Mr. Loudon observes, it requires very little water, and the pots to be well drained; it flowers best plunged in $\tan$ heat; rich loamy soil suits it best. Synonymc: 1. Cotyledon calycinum.

ealycinūm, 1 . . Grn pur. . 6, S. Ev. S. E. Ind. . . 1800

Bryorsǐs, Aghardh. The little branches resemble moss; hence the name bryon, moss, and opsis, resemblance. Linn. 24, Or. 7, Nat. Or. Algœ. Interesting marine productions, growing in fine feathery tufts-compositĭă, plumōsă.

BR Y̌̃, Hednig. Named from bryo, to abound; abounding in great plenty. Linn. 24, Or. 5, Nat. Or. Musci. Dwarf species, generally found growing in wet places. $B$. triquetrum has been only met with upon the border of some lakes in the north of Ireland. Synonymes: 1. Mnium androgynum. 2. Bryum stellare. 3. Compactum. 4. Aureum. 5. Nigricans. 6. Linum, cubitale-alpīnūm, andrŏgỹ-

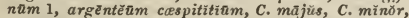
capillărē 2 , cārnam, cradūm, cuspidātūm, deal-

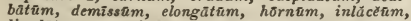
ligulātūm, marginātâm, nûtāins 3 , palâstrě, punctâtūm, pyriformě 4, roseūm, rostrătüm, Tozeri, trichơdēs, triquētram, turbinätûm 5 , ventricōsūm 6 , ZiErīi.

Bü̉ōn, Linn. Named from boubon, signifying the groin; in allusion to its medicinal qualities. Linn. 5, Or. 2, Nat. Or. Umbellifere. Curious plants, of little beauty and easy cultivation. Synonymes: 1. Selinum gallanum. 2. Farula lavigata.
2.

galbănüm, 1 - Y Yel. grn. . 7, G. Ev. S. C. G. H. 1596 gummíférüm: Pa. yel. : 7, G. Ev. S. C. G. H. : 7731 levigătūm, 2 : Yellow : 8, G. Ev. S. C. G. H. : 1774

Búchañ̄Nĭ, Roxburgh. Named in honour of F. Buchanan, now Hamilton, M.D. Linn. 10, Or. 4, Nat. Or. Anacardiacee. Fruit-bearing trees of no particular value; they grow well in light loamy soil; and cuttings root in sand, under a glass, in heat. Synonymes:1. Mangifera axillaris, Spondias axillaris.

[51]

BUC

BUL

angustifoliă, 1 . White. - S. Ev. T. E. Ind. . 1820

latifoủiả . . White. S. Ev. T. E. Ind. : : 1820

Buchnêră, Linn. After J. G. Buchner, a German naturalist. Linn. 14, Or. 2, Nat. Or. Scrophulariacea. Species of little interest; they grow in loamy soil, and are increased by seeds. Synonyme: 1. Biflora.

americãnă . . Blue • . 7, H. Her. P. N. Amer. 1733 hispădă, urticaefolăă 1 .

Būč̆DĂ, Linn. Named from bous, an $0 x$; the fruit being like an ox's horn. Linn. 10, Or. 2, Nat. Or. Combretacea. A fine tree, of considerable value on account of its useful qualities; it grows best in loam and peat ; and ripened cuttings planted in sand, and plunged in heat, under a glass, root readily. The bark is greatly esteemed by the tanners.

Būcèrēs . . Yel, wht. . 8, S. Evv. T. Jamaica . 1793

BuD, the flower, or leaves before expansion, are said to be in the bud.

BUDDLẼ, Linn. In memory of Adam Buddle, an English botanist. Linn. 4, Or. 1, Nat. Or. Scrophulariacea. A genus of very handsome shrubs, especially $B$ : globosa, which flowers freely in the open air of Britain, providing it has a warm situation; one against a south wall is best. $B$. Neemda is one of the most beautiful plants of India, bearing a profusion of handsome white flowers. They delight in a loamy soil, mixed with a little peat, and young plants are obtained by laying the branches, or from cuttings, which root in sandy mould with. out difficulty.

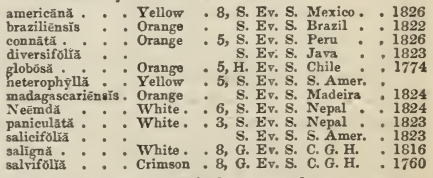

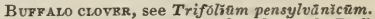

Buprōñ̆, Wild. Named after Count de Buffon, the noted naturalist. $\operatorname{Linn}, 4, \mathrm{Or}, 2$, Nat. Or. Alsinacee. Dwarf curious species, of easy culture. Synonyme : 1. B. annua.

perênnís . . White. . 6, H. Her. P. France . . 1817 tenuifolia, i : White : 6, H. A. England

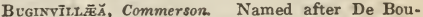
gainville, a French navigator. Linn. 8, Or. 8, Nat. Or. Nyctaginacee. A showy evergreen climber, succeeding in loam, and increased by cuttings.

spectābilis . - Pink . . S. Ev. Cl. S. Arser.

1829

Bugtr, see $A j u ̈ g a ̆$.

Buglnss, see Anchüsă.

Bugwort, see Cimicŭfügă.

Bunbīn Ĕ, Wild. From bolbos, a bulb. Linn.6, Or. 1, Nat. Or. Liliacea. The species are showy, fragrant, and of easy culture; and increase rapidly by cuttings,-Lou. Ency. of Plants-Synonymes: 1. Anthericum annuum. 2. Bulbosum. 3. Asphodeloides. 4. Hispidum. 5. Latifolium. 6. Nutans. 7. Pramorsa. 8. Scabrum. 9. Semibarbatum. 10. Triquatrum.

aloüdès

ānnuัă, 1

asphodeloīdès, 2

australis, 3 .

bisuleãt

ciliātă

frutéscēns

glaûeả

gramìnëă

latifoliă, 5

latifoliă, 5 : : Yhito

mesembryanthoìdēs Yellow

nūtăns, 6

præmôrsă, 7

rostrātă

scābră, 8

semiba

triquêtră, 10
Yellow

Yellow

Yellow

Yellow

Yellow

Yellow

White

Yellow

Yellow

Yellow

Yellow

Yellow

Yellow

Yellow

Yellow

Yellow

Yellow
6, G. Her. P. C. G. H. 5, H. Her. A. C. G. H. 7, F. Her. P. C. G. H. 6, G. Bu. P. N. Holl. 11, H. Bl. P. C. G. H. - 1823 6. G. Ev. S. C. G. H. : 1702 G. Bl. P. Chile: : 1828 5, G. Her. P. C. G. H. : 1824 5, G. Her. P. C. G. H. : 1774 7, G. Her. P. C. G. H. 1812 6, G. Her. P. C. G. H. : 1759 5, G. Her. P. C. G. H. - 1822 7, G. Her. P. C. G. H. - 1820 6, G. Her. P. C. G. H. - 1818 5, G. Her. P. C. G. H. - 1793 6, G. Ev. S. C. G. H. * 1812 6, G. Her. P. C. G. H. * 1825 7, G. Her. P. C. G. H. - 1820 G, G. Her. P. C. G. H. : 1825

1732 759 20 (1) 8 4
2 9

$$
\text { (n) }
$$


Bulaiferous, bulb-bearing.

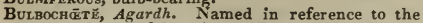
stiff bristly end of the primary filaments, from bolbos, bulb, and chaite, bristles. Linn. 24, Or. 7, Nat. Or. Alga. Found in autumn in delicate tufts about lakes and rivers-setigěră.

BuLns, under-ground buds, resembling roots, and consisting of numerous fleshy scales, placed one over the other.

BuLвocōDîư willd. Named from bolbos, bulb, and kodion, wool; the bulb being wrapped in a woolly covering. Linn. 6, Or. 1, Nat. Or. Melanthacere. Very beautiful dwarf species, worthy of careful cultivation: they grow best in sandy loam and peat; and young plants are obtained from the roots. Synonyme: 1. Colchicum versicolor.

vêrnúm . . Purple . 2, H. B1. P. Spain * 1629 versicőlori, $1^{*}$ : Purple : 8, H. Bl. P. Crimea : 1820

BULĞ̈rǏ, Fries. The species assume something the form of a bag; hence the name from bulga, a leather bag. Linn. 24, Or. 9, Nat. Or. Fungi. Minute species, frequent upon dead oaks and other decaying trees-inquinäns, sarcotdès.

BULlace TREg, see Pranŭs insititǐ̃ă.

BullatB, garnished with studs, like bubbles.

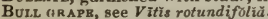

Bullīirdă, Dec. In memory of M. Bulliard, a French botanist. Linn. 4, Or. 3, Nat. Or. Crassulacea. A curious little annual aquatic. The soil for it is loam and peat; seeds.

Vaillantĩ. . White. 7, H. A. S. Europe . 1825

BuмĀLDĂ, Thunberg. In memory of J.A. de Bumalda, a botanist of Bologna. Linn, 5, Or. 2, Nat. Or. Staphyleacea. A curious evergreen, with little to recommend it ; any common soll suits it ; seeds. Synonyme: 1. Staphylea Bumalda.

trifolira

8, G. EV. S. Japan

1812

BumîLY̌̆, Swartz. The Greeks gave this name to the common ash. Linn. 5, Or. 1, Nat. Or. Sapotaced. These are plants of grand foliage, but no great beauty of blossom. Some of the species are robust enough to bear our winters in the open air, but they are rather tender, and require to be placed in a sheltered situation, or against a warm wall, and covered with mats during winter; cuttings root in sand, under a glass. The stove species are low W. Indian trees, and known there under the name of bully-tree. They thrive well in loamy soil, or loam and peat; and cuttings will root, but, according to Sweet, not freely, in sand under a hand-glass, being well ripened before they are taken off.-Lou. Ency. of Plants-Synonymes : 1. Sideroxylon lycioides. 2. Chrysophyllum macrophyllum. 3. Achras salicifolia. 4. Sideroxylon strigosum. 5. S. tenax.

\begin{tabular}{|c|c|c|c|}
\hline 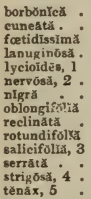 & & $\begin{array}{l}\text { White } \\
\text { White. } \\
\text { White. } \\
\text { White. } \\
\text { White. } \\
\text { White. } \\
\text { White. } \\
\text { White } \\
\text { White: } \\
\text { White. } \\
\text { White } \\
\text { White. } \\
\text { White. } \\
\text { White. }\end{array}$ & $\begin{array}{l}\text { T. Bourbon } \\
\text { T. W. Ind. } \\
\text { T. w. Ind. } \\
\text { S. Carolins } \\
\text { S. N. Amer. } \\
\text { T. Guiana. } \\
\text { F. W. Ind. } \\
\text { S. N. Amer. } \\
\text { S. Carolina } \\
\text { T. W. Ind. } \\
\text { T. S. Amer. } \\
\text { S. Missouri } \\
\text { T. N. Amer. } \\
\text { T. Carniola }\end{array}$ \\
\hline
\end{tabular}

Bonchöš̆, Jussieu. From bunchos, coffee; the seeds resembling that article. Linn. 10, Or. 1, Nat. Or. Malpighiacee. A genus of ornamental tallish shrubs; they thrive best in a mixture of loam, peat, and sand; cuttings of the ripe wood root very well in sand, in heat, under a glass. Synonymes: 1. Malpighia canescens. 2. Mr. glandulifora. 3. M. glandulosa. 4. MI. media. 5. MI. nitida. 6. M. polystachya. 7. M. tuberculata.

argêntě . . Yellow * 7, S, Ev. S. Caraccas canëscēns, $\mathrm{i}:$ : Yellow : 7, s. Ev. T. W. Ind cumanēnsis : : Yellow : 9, S. Ev. S. Cuman glandulfferă, 2 : Yellow $: 4$, S. Ev. S. W. Ind. glandulösa, 3. : Yellow : 4, S. Ev. S. W. Ind. media, 4, : Yellow: 7 , S. Ev. S. W. Ind. nitida, 5 : : Red : 7, s. Ev. S. St. Domin nitidar, 5 : : : Yellow : 7, S. Ev. S. Carthag. paniculată . . Purpla. . 6, S. Ev. S. Jamaica * 1820 polystāchỹa, $6^{*}$ : Yellow : 4, S. Ev. S. W. Wnd. : 1806

BĒxĪAs, Linn. Bunios, a hill; alluding to the habitation. Linn. 15, Or. 1, Nat. Or. Cruciferce. Hardy annuals, of no interest-äspěră, Erucägă, orientälis.

BūNĪò, Linn. Same as Bunias. Linn. 5, Or. 2, Nat. Or. Umbellifera. Mere weeds of the simplest culture. Synonymes. 1. Flexuosum. 2. Bulbucastanum-ammoides 1, Bulbosastanum, flexuosum 2, pyrenaum.

BUPLEŨ RŨ M, Linn. Not satisfactorily explained. Linn. 5, Or. 2, Nat. Or. Umbelliferoe. A very natural and remarkable genus, on account of the leaves being for the most part quite entire. They succeed in any common soil. The annual species merely require sowing in the open border early in spring; the perennial kinds may be increased by offsets, or seeds. S.ynonymes: 1. Tenoria canescens. 2. T. difforme. 3. T. frutescens. 4. T. fruticosim. 6. T. coriaceum. 6. T. plantagineum. 7. B. j«nceum. 8. T. spinosum.

argulōsūm . - Grn. yel. . 6, H. Her. P. Switzerl. . 1759 aûreủm.: : Yellow : 5, H. Her. P. Siberia : 1820 Burserifinüm : Grn yel. - 6, H. Her, P. Mt. Baldo 1817 canéscěns, 1 : : Yellow : 8, G. Ev. S. Barbary : 1809 carieifơlüun : Grn yel. : 7, H. Her. P. France : 1817 drfforme, 2.: : Yellow : 8, G. Ev. S. C. G. H. : 1752 exaltatüm: : Gmowel. : 7, H. Her. P. Tauria: 1807 exaltatūm : : Gm. yel. : 7, H. Her. P. Tauria $: 1807$
falcatúm frutéscëns, 3 : Yellow :8, H. Ev. S. Spain : 1752 fruticosūm, 4: Yellow : 7, F. Ev. S. S. Eur. : 1596 Gerârds. : Grn. yel. : 7, H. A.S. Eur. : 1804 Gibraltárieñ, 5 : Yellow 6 , F. Ev. S. Gibraltar: 1784 glaúcūm * - Grn. yel. 7, H. A. S. Eur. * 1819 grăclle : Grn. yel. : 7, H. A. Caraceas - 1820 graminifölyüm : Grn. yel. : 6, H. Her. P. Switzerl. 1768
heterophyllumm : Yellow : 6, H. jūnceum : : Grn yel. : 7, H. A. H. Eur. : 1779 lancifoliûm : Grn yel. $: 7, \mathrm{H}$ B. Tauria : 1820 longifóliúm : Grn. yel. : 6, H. Her. P. Switzerl : 1713 nodifloram. : Grn. yel. 7 , H. A. Greece 1823 nûdũm : * . Grn. yel. 10, G. Her. P. C. G. H. : 1778 Odontris : Gra. yel. - 7, H. A. Italy * 1749 panjiculatúm : Yrü yel. : 7, H. De. A. Pyrenees : 1819 $\underset{\text { petræum }}{\text { paniculatum : : Yellow : 7, H. De. P. Spain }} 1824$ petraim : Grne yel : 6, H. Her. P. Switzerl. 1768

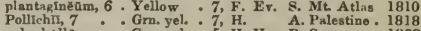
polyphyllúm : Grn. yel. : 5, H. Her. P. Caucasus : 1823 pyrenaicúm : Grn, yel. $H_{\text {. Her, } P \text {. Pyrenees }}$ ranunculoides: : Grn. yel. 7, H. Her. P. France rigrdom : Grn. yel. :6, H. Her. P. England remi-compositum: Grn. yel. : $7, \mathrm{H}$. A.Spain : 1778 sibiricum : Grn yel. : 7, H. Her. P. Siberia : 1826 spinósūm, 8 : : Yellow : 7, H. Ev. S. Spain . 1752 stellátum .: Grm, yel. : 6, H. P. SwitzerL: 1775 subovătūm : Y Yellow : 6, H. A. Spain : 1819

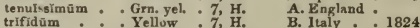

BuptrāıMũ semblance the disk of the flowers bears to an ox's eye, from bous, ox, and ophthalmos, eye. Linn. 19, Or. 2, Nat. Or. Composite. The plants of this genus are very showy and ornamental. The greenhouse species do well in a loamy soil; and increase from cuttings, under a glass: the herbaceous species thrive in common garden mould; and increase by suckers: the annual species only requite sowing in the open ground. Synonyme: 1. Coriaceum.

aquâticuัm .

grandiflórüm: Yellow

lavigătūm, 1 . Yellow

maritímūm Y Yellow

salicifóliūm : Yellow

serícě̉um : Yellow

speciosīssı̃m : Yellow

spinōsūm : Y Yellow

stenophylluim: : Yellow

7, H. A. S. Eur. 1731 8, H. Her. P. Austria : 1722 7, G. Ev. S. Teneriffo: 1800 8, F. Her. P. Sicily : 1640 9, H. Her. P. Austria : 1759 6, G. Ev. S. Canaries : 1779 7, H. Her. P. S. Eur. : 1826 7, H. A. Spain. : 1570

Bur, see Centathēcă Cappācĕă.

Burchārdí, R. Brown. In honour of Henry Burchard, M.D., a botanical author. Linn. 6, Or. 1, Nat. Or. Melanthacec. A species of considerable beauty, thriving best in sandy peat, or peat mixed with a little loam; offsets or divisions.

umbellãtă . . Wht. grn. 8, G. Her. P. N. Holl. . 1820

BuRChẼLLð̌, R. Brown. In compliment to W. Bur. chell, a traveller in Africa. Linn. 5, Or. J, Nat. 
Or. Cinchonacec. Handsome species, especially $B$. capensis; they require open rich soil, and to be carefully watered, and they will flower well. Synonyme: 1. Parviflora.

bubalină, 1 . . Searlet . 5, S. Ev. S. C. G. H. . 1818 oapēnsis : Scarlet : 3, S. Ev. S. C. G. H.

Burnocr, see Arctĩūm.

Burlingtóñ̌̆. Lindley dedicated this lovely genus to the amiable and accomplished Countess of Burlington. Linn. 20, Or. 1, Nat. Or. Orchidacea. The species belonging to this genus are of great beauty, each of which rivals the other in loveliness of colour and delightful fragrance of their flowers. The species belonging to this and some other genera grow best upon wood with a little moss on their roots, and fastened to the wood with tempered copper or metallic wire. Oak branches with several arms or forks protruding in different directions are the most suitable wood for them. B. rigida is a very curious-growing species, producing the small pseudo-bulbs at the end of the wiry-like rhizoma. When the plants make their growth a little moss should be fastened to the oak branch for the young shoots to root and fasten themselves to. Copious watering overhead and likewise a strong heat are necessary when the plants are growing, but when they are torpid they should be kept cool and dry. They are increased by dividing the bulbs.
eandrda . . . White
4, S. Epi. Demerara

rìgIdă Burnet, see Poterĭùm.

Burnet saxifrage, see Pimpinellla.

Bur parsuey, see Cañcălís.

BUR REBD, see Spargãnĩum.

Burry, covered with hooked stiff hairs, like the heads of bur or burdock.

BURSĀRĬ , Cavanilles. Named from bursa, signifying a pouch. Linn. 5, Or. 1, Nat. Or. Pittosporacea. A pretty species desirable for a greenhouse or conservatory, being an abundant flowerer, and very showy when covered with its elegant little white blossoms. An equal mixture of sandy loam and peat is the best soil for it; and young cuttings are not difficult to root in sand under a little glass.Bot. Cul.

spinōsă . . . . White . 10, G. Eq. S. N. S. W. . 1793

Bursēră, Jacquin. In memory of Joachim Burser, a botanist in Naples. Linn. 23, Or. 2, Nat. Or. Burseracec. Large trees of considerable value: they grow in loam and peat; and increase by cuttings or seeds. B. gummifera abounds in a watery balsamic fluid, which however soon becomes inspissated by exposure to the air. Hedges are made of it by the Spanish residents in S. America, who call it Almacigo. It is also said to possess identical properties with Quassia.

gummiferă : . . Wht. grn. . S. Ev. T. W. Ind. . 1690 serrati. . : : $\quad$ S. Ev, T. E. Ind. . : 1818

BuRtõñ̆, R. Bron'n. Named in honour of D. Burton, who collected for the Kew Garden. Linn. 10, Or. 1, Nat. Or. Leguminose. This pretty New Holland genus, says Mr. Sweet, requires more than ordinary treatment to keep it in good health; an equal mix ture of very sandy loam and peat is the best soil for it, and the pots to be well drained, with small potsherds, that the water may pass off freely, as nothing is more injurious to it than too much water. Young cuttings are not difficult to root, planted in sand under a bell-glass; it may also be raised from seeds, which are sometimes produced. -Bot. Cul. 181. Synonyme: 1. Gompholobium minus. confërtä . . Violet . 7, G. Ev. S. N. Holl. 1830

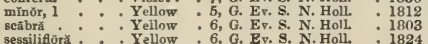

Butcher's nRоOм, see Rũseŭs.

BūTĔ, Roxburgh. In compliment to John, Earl of Bute, a lover and patron of botany. Linn. 17, Or. 1, Nat. Or. Leguminosce. This most splendid genus is rare in our collections, though easily grown, and not difficult to propagate. They grow best in loam and peat; and cuttings taken off at a joint, and planted singly in pots with their leaves on, will soon root, if not suffered to get damp, which should be continually guarded against. It is desirable to plunge them in a moist heat. The [ 58 ] flowers of $\boldsymbol{B}$. frondosa and superba yield a beautiful dye, and the roots are capable of being made into strong rope.

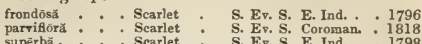
supërbă. Scarlet Bữŏмuัs, Linn. The leaves of this plant are said to cause the mouths of cattle to bleed that crop it ; hence the name from bous, ox, and temno, to cut Linn. 9, Or. 3, Nat. Or. Butomacee. This genus contains that beautiful plant the flowering rush, a native of the margins of our rivers, ditches, \&c. both species are aquatics, and may be increased with little difficulty.
latifoliñ
White.
6, H. Aq. P. Nepal

1823

ButTrR AND kgGs, see Narcíssŭs.

ButTRR BUR, see Tussilägð petasitēs.

Buttrerfly Plant, see Oncĩdíum Papĩlío.

BuTter-nut, see Jîgläns ciněrěă.

Butrer wort, see Pinguícülă.

ButTon FlowER, see Gomphiă.

Butron tree, see Conocärpūs.

Button-weed, see Spermacócẻ.

Butron-woon, see Cephalänthŭs.

BuxвA Ũ MĬ, Linn. In memory of J. C. Buxbaum, a German botanist. Linn. 24, Or. 5, Nat. Or. Musci. A most singular minute plant, without apparent leaves, more like a species of fungus than a moss, found generally in summer in fir-woods, \&c.aphÿllă.

Būxǔs, Linn. Supposed to have been taken from pyknos, dense; in reference to the wood. Linn. 21, Or. 4, Nat. Or. Euphorbiacee. This is an excellent genus of hardy evergreen shrubs; $B$. balearicus does much better however when it is slightly protected in severe weather. They thrive in most situations; and are propagated by suckers, or layers, without difficulty. The timber is very hard and smooth, and not apt to warp: it is used by the turner, engraver, mathematical instrument maker, comb, pipe, and flute maker; and the roots by the inlayer and cabinet maker. Wheels, skewers, pins, pegs for musical instruments, nut crackers, button-moulds, weavers' shuttles, hollersticks, bump-sticks, rollers, rolling-pins, tops, screws, spoons, knife-handles, combs, \&c., are made of it, as well as many other useful articles.

austrălì

baleărīcă

chinënsĭs

sempervirẽns angustifólia : Yel grn. $4, \mathrm{H}$. Ev, $\mathrm{S}$. Yel. grn. . 7, H. Ev. S. N. Holl.

Yel. grn. 10, G. Ev. S. China

Yel. grn. . 4, H. Ev. S. England

Bर̄BLIs, Salisbury. Byblis was the daughter of Miletus, Linn. 5, Or. 5, Nat. Or. Droseracec. A minute, very pretty aquatic; it should be planted in loamy soil, and immersed in water; seeds.

liniflōră. . . Blue . . 5, G. Aq. P. N. Holl. . 1800

BrRsōxĬмă, Richard. Derived from byrsa, hide; useful for tanning. Linn. 10, Or. 3, Nat. Or. Malpighiacea. These are handsome stove plants, thriving exceedingly in a rich soil, or loam and peat mixed suits them. Cuttings of the ripe wood planted in sand, under a glass, in heat root freely. Synonymes: 1. Malpighia altissima. 2. M. coriacea. 3. M. crassifolia. 4. M. lucida. 5. M. Moureila. 6. $\boldsymbol{M}$. macrophylla. 7. $\boldsymbol{M}$. pallida. 8. $\boldsymbol{M}$. verbascifolia. 9. MI. volubilis.

\section{altisš̆m} chrysophylla : Yellow: 8, S. Ev, S. Orinoco: 182 coriāeeã, 2. : White . 6, S. Ev. T. Jamaica: 1814 crassifolina, 3 . Yellow : 7, S. Ev. T. Guiana : 1793 laurifoliă . . Yellow . 7, S. Ev. T. Cumana . 1824 lücìda, 4 - . Pink * T, S. Ev, S. W. Ind. 1759 Mouréilă, 5 . Yellow . 8, S. Ev. T. S. Amer. . 1823 nervōsã, 6. Yellow 7, S. Ev. S. Brazil : 1820

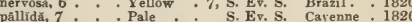
pallídä, 7 - Pale yel : F, S. Ev. S. Cayenne - 1820 reticulătă - - Pur. yel, - 7, S. Ev. S. Cayenne - 1823 spicâta $\cdot \dot{*} \cdot$ Yellow $\cdot 8$, S. Ev. S. Antilles . 1810

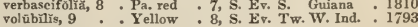
Brssoctănītu, Agardh. Compounded from byssos, fine flax, and klados, a branch; alluding to the fine branches. Linn. 24, Or. 7, Nat. Or. Algea. A singular production, said to grow in places overflowed with water, and on windows-fenestrüle. 
Bystropōgōn, Wild. The word alludes to the throat of the corolla being closed by hairs, and derived from byo, to close, and pogon, beard. Linn. 14, Or. 1, Nat. Or. Labiatce. The species are ornamental, and thrive best in a mixture of loam and peat; and cuttings put in sand or soil root readily.

canariênsis. . . Pa pur. . 7. G. Ev. S. Canaries origanifoliňs : . Pa pur. : 7, G. Ev. S. Canaries : 1815 plumósũs : : Pa pur. : 6, G. Ev. S. Canaries : 1779 puactātüs : : Pa. pur. : 8, G. Ev. S. Madeira
Byttnễĭn, Loeffling. In memory of S. A. Buttner, a professor at Gottingen. Linn. 5, Or. 1, Nat. Or. Sterculiacea. The species are not very interesting; for culture, \&c., see Commersonia. Synonyme : 1 . Commersonia dasyphylla.

dasyphylla, 1 . . White. . 6, G. Ev. S. V. D. L. - 1780 hermannifolia : : G. Ev. S. N. Holl : 1823 microphȳllă : Wht. pur. S. Ev. S. S. Amer. 1816 scâbră . . Purple . 7, s. Ev. S. W. Ind. "1793 catalpafolĭă, cordātă, grandifoliă, herbācěă.

C.

CACXLĬ and lian, exceedingly. Linn. 19, Or. 1, Nat. Or. Composita. A genus remarkable for the fleshy awkward-looking stems, and discoloured leaves of many of the species. They grow in a mixture of sandy loam, brick-rubbish, and decomposed dung well reduced; they require little water, especially when growing, and the pots must be well drained. Cuttings taken off, and dried for a few days to heal the wound, strike readily; when sufficiently struck, they should be potted off, using the same kind of soil recommended for old plants, and carefully watered. Synonymes: 1. Kleinia tomentosa. 2. C. tomentosa. 3. C. pugioniformis. 4. C. macrophyllum.

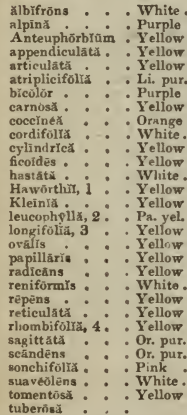

7, H. Her. P. Anstria - 1739 7, H. Her. P. Austria: 1739 2,G. Ev. S. C. G. H. ¿1596 G. Ev, S. Teneriffe: 1815 G. Ev. S. Teneriffe : 1815 9, G. Ev. S. C. G. H. $* 1775$
8, H. Her. P. N. Amer. 1669 7, S. De. S. E. Ind. 1804 6, G. Ev. S. C. G. H. : 1757 6, H. A. Mexico: 1799 6, H. Tu. P. Mexico - 1823 8, G. Ev. S. C. G. H. : 1710 8, H. Her. P. C. G. H. : 1710 G. Ev. S. C. G. H. : 1795 G. Ev. S. C. G. H. : 1795 9, G.Ev. S. Canariea : 1732
9, H. Her. P. S. Eur. 1819 9, H. Her. P. S. Eur. - 1819 , S. Ev. S. E. Ind. G. Ev. S. C. F. H. 172 7. G. Ev. Cr. C. G. H. : 1823 7, H. Her. P. N. Amer. 1801 7, G. Fv. S. C. G. H. 1759 G. Ev. S. C. G. H. - 1759 G. H. Her. P. Siberia : 1816 B. A. Java : 1823 4, G. Ev. Tw. C. G. H. : 1814 $7, \mathrm{~s}$. A. E. Ind. : 1768 8, H. Her. P. N. Amer. 1752 G. Ev. S. C. G. H. . 1795 8, H. Tu. P. N. Amer. 1812

\section{peltâtă, radulafólfă, runcinītă.}

CĀcнR \&s, Linn. Not satisfactorily explained, Linn. 5, Or. 5, Nat. Or. Umbellifere. The species are uninteresting, and the culture of them is easy. Symonyme: 1. Laserpitium ferulaceum-alätă 1, alpină, athamantõ̃dēs, crêtǐcă, Libanotĭs, microcärpä, Morisōnī, odontälgǐcă, seseloz̃dẽs, tẫrícă.

CÄcrüs, Linn. A name used by Theophrastus to describe a spiny plant. Linn. 12, Or. 1, Nat. Or. Cactacea. This genus is commonly called the melon thistle. The species are very interesting in appearance, and variable in structure. They suc ceed best in sandy loam, mixed with brick and lime rubbish, and a little peat, or rotten dung, at all times carefully watered. Cuttings root readily if a little dried before planting. Synonyme: 1. C. nobilis.

emrugatlus : : :

fnliosa ŭs.

redûctüs, 1

senilis $\cdot$.

CĀDIX, Forskahl.

Linn. 10, Or. 1, Nat, Or, Leguminesce. This rather curious species succeeds in light loamy soil, and cuttings root in sand, under a glass, in heat. Synonyme: 1. C. varia.

purpurexa, 1 . Wht. pur, 6, S. Ev. S. Arabia . - 1775 Cadưcǔs, falling off soon.
C fruestīnă, Cassini. Named from calestes, celestial; alluding to the sky-blue colour of the flowers. Linn. 19, Or. 1, Nat. Or. Composita. Showy species of easy culture, common open soil suits them; seeds. Synonymes 1. Eupatorium caruleum. 2. E. micranthum, Ageratum colestinum.

ageratordés . Blue . . 8, G. Her. P. N. Spain cærulex, 1 : Blue: : 7, F. Her. P. N. Amer. 1732 mierănthă, 2 . Blue : 7, F. Ev. S. S. Amer. : 1800

C AsNöprǩnìs, Bergius. Derived from kainos, new, and pteris, a fern. Linn. 24, Or. 1, Nat. Or. Polypodiacere. Small interesting ferns; peat mixed with a little loam suits them, and they are chiefly increased by divisions. Synonymes: 1. Asplenium laxum, Darea, Appendiculata. 2. Asplenium Odontites Darea, Odontites.

appendiculäta, 1 . Brown - 7, G. Ev. S. N. Holl. 1822 odontités, 2 : Brown 7, G. Ev. S. N. Holl. : 1822

Chesalpĩxĭ, Plumier. In memory of Andreas Cæsalpinus, chief physician to Pope Clement VIII. Linn. 10, Or. 1, Nat. Or. Leguminosa. This genus as a whole is of considerable importance, but the species in point of beauty have little to recommend them; they all grow well in sand, peat, and open loam mixed. C. Sappun yields the sappan wood of India. From the seeds of C. oleosperma an oil is expressed; and the Brazil-wood of commerce is obtained from the $C$. Brasiliensis.

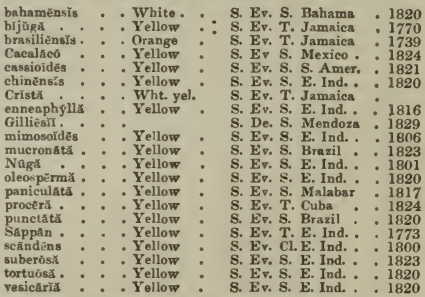

C $\bar{\AA} s i \check{A}, \boldsymbol{R}$. Broñ. In honour of Frederick Cresius. Linn.6, Or. 1, Nat. Or. Tiliacea. A showy species, sandy loam and peat suit it, and young plants are obtained from seeds.

vittăta . . Pa. blue. . 7, G. Tu. P. N. S. W. . 1816

\section{C.zsious, grey.}

Casprost, growing in little tufts.

ĊsŪLİ, Roxburgh. From casos, beaten; appearing as if trampled upon. Linn. 19, Or. 1, Nat. Or. Composita. Not interesting, culture simple. Synonyme: 1. Meyera orientalis-axillaris 1.

CAJÃŬs, Dec. From catjang, its name in Malabar. Linn. 17, Or. 1, Nat. Or. Leguminose. The species are highly useful for food in some places. They grow well in sandy loam; and increase from seed. The seed of $C$. flavus is much eaten by poor people, and negroes, and is esteemed a wholesome pulse. The plant is cultivated in Jamaica for feeding pigeons, whence its name; and in the island of Martinico, even the better sort of people hold it in estimation. Synonymes: 1. Cytisus Pseudocajan. 2. C. Cqjan. 
bicơlơr, 1 . * Yellow *7, S. Ev. S. E. Ind. . 1800 Aāuns, 2 : : Yellow : \%, S. Ev. S. E. Ind. : 1687 CĀKĬL plants. Linn. 15, Or. 1, Nat. Or. Cruciferce. Annual species of little beauty; cultivation simple. Synonyme: 1. Maritima sinuatifolia.

ægyptĩăcă, I - Purple . . $7, \mathrm{H}$. americānă : : Purple: : 7, H

A. Egypt America

A. America

marītímă - Purple.

CALABA TRER, see Calophy̆llūm Călăbă.

CALADẼNǏ̆, R. Bronn. From kalos, beautiful, and aden, a gland; in reference to the disc of the labellum being finely beset with glands. Linn. 20, Or. 1, Nat. Or. Orchidacee. A genus of pretty orchideous plants, growing well in a mixture composed of peat, loam, and sand in equal parts. They should be kept in a cool frame, and carefully watered, when not in a growing state; increased by dividing the roots.

alātã

ãlbä

caerüle:

6, F, Ter, N. Holl.

1823

testăeĕr

White.

F. Ter. N. Holl.

- 1810

Flesh:

F. Ter. N. Holl.

7, F. Ter. N. Holl.

1826

CALĀDǏ ŬM, Ventenat. Meaning not explained. Linn. 21, Or. 9, Nat. Or. Aracece. The species of this genus are interesting on account of having singufarly spotted stems, and pretty neat, often green foliage. Several grow best in water, and the whole grow well if planted in rich soil, and may be propagated from tubers. C. seguinum is a native of the W. Indies and S. America, and called the dumb-cane, and grows five or six feet high. This plant has the power, when chewed, of swelling the tongue, and destroying the power of speech. Dr. Hooker gives an account of a gardener who incautiously bit a piece of the dumb-cane, when his tongue swelled to such a degree, that he could not move it, he became utterly incapable of speaking, and was confined to the house for several days; he also adds, that it is said to impart an indelible stain to linen.-Ex. Bot. P. Brown states, that its stalk is employed to bring sugar to a good grain when it is too viscid, and cannot be made to granulate properly by the application of lime alone. Synonymes: 1. Arum cucullatum. 2. A. grandifolium. 3. C. seguinum maculatum. 4. C. grandifolium. 5. Arum virginicum. 6. A. xanthorhisum.

arboréscēns

arborë̌ñms * White.

arborém * White.

auritūm: White *

cucullátūm, 1: : Green

cucul

S. Ev. S. W. Ind. . 1759 S. Ev. S. Cumana : 1820 S. Ev. S. America : 1739 6, S. Her. P. Madeira : 1773 esculèntūm : "White.

fragrantissimüm . Red

grandifslǐum, 2 White

helleborifơlīum : White.

lăcèrūm

maculattrim, 3. Green

nymphæifölrūm: White.

odorātūm White.

odorãũm : White.

pedåtom: : White.

pinnatifídũm . White

pǔminùm .

sagittifoliūm - White.

scāndẽns - . White

seguinum * . White.

tripartītom

White.

S. Her. $\mathrm{P}$. Chiana

S. Her. P. America : 1739

Parasite. Demerara. 1839

6, S. Ev. S. Caraceas . 1803

6, S. Ev. S. Caraccas - 1796

S. Ev. S. Caraccas - 1822

9, S. Her. P. W. Ind. - 1828

3, S. Ev. S. S. Amer. . 1820

S. Her. P. E. Ind.

S. Her, $\mathbf{P}$, Pegu

S. Her. P. E. Ind." 1818

S. Her. P. Brazil. : 1824

S. Her. P. Caraccas - 1817

S. Her. P. Nepal . 1820

S. Her. P. W. Ind. - 1710

S. Her. P. Guinea 1822

3, S, Ev, S. America

S. Ev. Cl.

S. Ev. S. Caraccas - 1816

6, H. Her. P. Virginia - 1759

S. Her. P. E. Ind. : 1817
S. Ev. S. 1822

S. Her. P. Brazil

Canamagröstis, Adanson. Taken from calamos, a xanthorhizūm, 6 . White zamiæefölīum : Yellow reed, and agrostis, grass. Linn. 3, Or. 2, Nat. Or. Graminea. Mere weeds of simple culture. Syno3. C. sylvatica. 4. Arundo Calamagrostis 5. Agrostis Calamagrostis. 6. Arundo stricta. 7. C. arundinacea. 8. Arundo humilis-acutiflöră, confīnìs, effísă 1, glaūcă, Halleriānă 2, Hostīi 3, lanceolätă 4, Langsdórfĩ̄, läxă, littŏrěă, montānă, speciosă 5, stricta 6 , strigósă, sylvătǐcă 7 , tenèllă 8 , vărĭă.

CA LAMĀRI $\bar{s}$, plants resembling reeds. [ 55 ]

CALAmíórm̌́, reed or quill-shaped.

Calamint, see Calaminthă.

Calamĩnthă, Pursh. From kalos, beautiful, and mintha, mint. Linn. 14, Or. 1, Nat. Or. Labiatce. The species of this genus have little to recommend them; all that can be said is, that they are ornamental; they grow without difficulty in common loamy soil, and are increased by suckers. Synonymes: 1. Thymus caroliniana. 2. Melissa grandiflora. 3. Nepeta marifolia. 4. Melissa Nepeta. 5. M. calamintha, Thymus Calamintha.

albă . . . White . . 7, H. Her. P. Hungary . 1818 caroliniañă, 1 - Flame. 6, H. Her. P. Carolina : 1804 crètîcă : : Purple : 6, F, Ev. S. S. Eur. : 1596 fruticōsă
grandiflöră, $2:$. Purple variegată . Red . . 7, H. Her. P.

marifǒliă, 3 - Purple . 6, H. Her. P. Spain vepeta, 4 - Blue - 8 , H. Her, P. England

CalĀměris, D. Din. Compounded from kalos, pretty, and ampelis, a vine, its habit of growth being to ramble like that plant. Linn. 14, Or. 2, Nat. Or. Bignoniacea. This is a species of great merit, capable of enduring the open air; when in full flower it has an elegant appearance; the situation for it is against a south wall, trained up a pillar, over a vase, \&c. Any light loamy soil suits it ; and young plants from cuttings are readily obtained. Synonyme: 1. Eccremocärpŭs scāhĕr.

scăbră, 1 . . . Orange . 7, F. Ev. Cl. Chile . . 1824

C̆̆LĂMŬs, Linn. Taken from kalam, signifying a reed, in Arabic. Linn. 6, Or. 1, Nat. Or. Palmacea. This is a fine genus, holding a middle station between the grasses and palms, with the habit of the former and inflorescence of the latter. They succeed best in a moist atmosphere in rich sandy loam, and are increased by seed. The resin called dragon's-blood is obtained by wounding C. Draco. C. zalacca is cultivated for its fruit, which is about the size of a walnut, and covered with scales like those of a lizard; within these scales are two or three sweet yellow kernels.

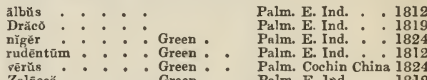

จêrŭs * * - Green - - Palm. Cochin China 182

CALANDRINĭ Humboldt and Bonpland. In honour of J. L. Calandrini, a German botanist. Linn. 11, Or. 1, Nat. Or. Portulacaced. The species of this genus are very pretty, and grow well in loam and peat carefully incorporated; multiplied from seeds or cuttings. Synonymes: 1. Talinum ciliatum. 2. T. paniculatum.

arenăriă

scēndēns : Purple : S. Her. P. Brazil

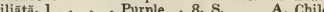

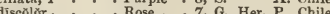

7, S. Her. P. Chile 1826 speciōsăă, 2 : Purple - 7, S. Her. P. S. Amer. 1816

CAI Āxt $\boldsymbol{R}$. Bronin. From anthos, a flower; literally a " pretty blossom." Linn. 20, Or. 1, Nat. Or. Orchidaced. This is a genus of very pretty plants when in flower. They require a light airy part of the honse, otherwise the flowers will not open freely, neither will their colour be so good. The plants must never be saturated with water; in every other respect they require the same treatment as is recommended for the Bletias.

bicŏlŏr

densiflöră

discōlor

furcătà

Sieböldi

CAITTY The name applies to the for the stigma, and is derived from kalathos, a basket or cup. Linn. 1, Or. 1, Nat. Or. Marantacea. The plants of this genus are interesting and ornamental. $C$. zebring is much admired on account of the stripes on the leaves, which resemble the marks on a zebra's back; whence the specific name. They grow well in the stove, in sandy 
peat; and are increased by divisions. Synonyme: 1. Maranta zebrina.

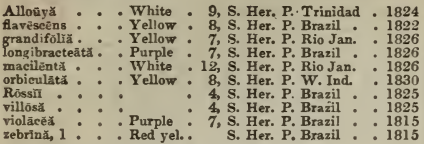

Calathian violer, see Gentiană pneumonānthe.

CALCARATB, spurred, having a spur.

CALCARzoUs, chalky.

CALCEIForM, like a little shoe.

CALcrolärï̀, Linn. Named from calceolus, alluding to the form of the corolla Linn. 2, Or. 1, Nat. Or. Scrophulariacece. This is a favourite genus, and contains some very showy species, from which an almost countless number of handsome hybrids have been raised and are raising. The herbaceous and shrubby kinds are chiefly cultivated. They thrive in a turfy loam, peat and sand mixed, or any kind of rich, open, sandy garden mould seems to suit them. The place most favourable to their successful growth is a pit or frame, where they must be potted and watered with judgment. Some cultivators turn them out in the flower-garden, where they make a brilliant display; others flower them in pots, with perfect success in the greenhonse; the latter way is generally preferred for the rare and superior kinds. Young cuttings planted in soil, under a glass, root freely; they are also increased from seed, which it is recommended to sow as soon as ripe. The annual species require to be sown in heat, and when up, potted off, and afterwards brought on for flowering in the greenhouse. Synonymes: 1. Tinctoria. 2. Diffusa. 3 Floribunda. 4. Anomala, pendula.

\begin{tabular}{|c|c|c|c|c|c|}
\hline \multirow{3}{*}{\multicolumn{2}{|c|}{$\begin{array}{l}\text { angustiflóră } \\
\text { arachnoldex }\end{array}$}} & \multirow{3}{*}{$\begin{array}{l}\text { Yellow } \\
\text { Purple } \\
\text { Yellow }\end{array}$} & & \\
\hline & & & $\begin{array}{l}\text { 6, G. Ev. S. } \\
\text {. 6, G. Her. P. }\end{array}$ & $\mathrm{Ch}$ & \\
\hline & & & , 7, G. Ev. S. & Cordill. & \\
\hline & & & & & \\
\hline & & & r. & & \\
\hline & - & & G. & e & \\
\hline & . & & G. & & \\
\hline & & & 5, G. & & \\
\hline & & & $\because 6, \mathrm{~F}$ & & \\
\hline & : & & 4, F. & & \\
\hline & $\vdots$ & & H. & & \\
\hline & & & & & \\
\hline & & & & & \\
\hline & & & & & \\
\hline & & & : & & \\
\hline & & & : & & \\
\hline ênsis & & & & & \\
\hline & & & & & \\
\hline & & & & & \\
\hline & & & & & \\
\hline & & & & & \\
\hline & : & w & A. & $\mathbf{P}$ & \\
\hline & & & & & \\
\hline & & & & & \\
\hline & & & & & \\
\hline & & & & & \\
\hline & & & & Ch & \\
\hline folix & & & & & \\
\hline & & & & $\mathrm{v}$ & \\
\hline & & & & & \\
\hline & & & & & \\
\hline & 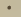 & & & & \\
\hline & & & & & \\
\hline & & & & & \\
\hline
\end{tabular}

Pale. 5, G. Her. D. Hybrid 1830

CAr.DĀsİ, Wild, In memory of J. Caldas, a Bo-
gotan naturalist. liferic. This very handsome species thrives well in sandy peat mixed with a little loam; seeds. Synonyme: 1. Bonplandia geminiflora.

heterophy̧llă . . Blue . . 7, S. A. N. Spain . . 1813 C̆̌Ľ̌̆, R. Brown. Derived from kalos, beautiful; in allusion to the showy flowers. Linn, 19, Or. 1, Nat. Or. Composita. The species are very showy, and easily cultivated; a loamy soil mixed with peat is best; cuttings take without difficulty in soil or sand. cordifolră . . . S. Ev. S. Jamaica . 1829 jamaicénsis : : Purple. 6, S. Ev. S. W. Ind. : 1739

Calrāctr̆, $\boldsymbol{R}$. Bronn. From kalos, beauty, and akte, sea-shore; the species being ornamental there. Linn. 19, Or. 1, Nat. Or. Composite. A showy species of easy culture and propagation. Synonyme: 1. Solidago urticafolia,

urticæfoliă, 1 . Yellow - 7, S. Ev. S. Vera Crus 1740

C $\bar{A} L \breve{k} \bar{A} \times \bar{A}, \boldsymbol{R}$. Bronn. In honour of George Caley, some time superintendant of the Botanic Garden St. Vincent. Linn. 20, Or. 1, Nat. Or. Orchidacere. A genus of pretty plants, requiring the same treatment as the Caladenias.

major . . . Grn. brn. . 6, G. Ter. N. S. W. • 1810 minor : : : Grn. brn. : 6, G. Ter. N. Holl. . : 1822

CALẼndŭLă, Linn. Named from calende, the first day of the month; there being flowers almost any month in the year. Linn. 19, Or. 4, Nat. Or. Com. posita. A genus of showy plants, among which is the old and well-known C. officinalis, or common marigold. This species was formerly used in soups and broths, but is now little regarded. The greenhouse species thrive well in loam and peat mixed; and cuttings root freely in sand, under a glass. The half-hardy annuals it is recommended to sow in a gentle heating hotbed, from whence they must be transplanted into the open ground; the hardy kinds merely require to be sown in the open borders. Synonyme: 1. C. agyptiaca.

arboréscēns -. Yellow . 12, G. Ev. S. C. G. H. . 177 arvénsis : Yellow: 6, H. A. Europe: 1597 chrysanthemifora Yellow : 4, G. Ev. S. C. G. H. : 1790 dentatax. * - Yellow * 5, G. Ev. S. C. G. H. . 1790 denticulatz - Yellow - 12, G. Ev. S. Barbary - 1821

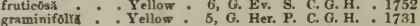
graminifolr : : Yellow : 5, G. Her. P. C. G. H. : 1731
hybrida. incána: : : : Yellow : $7, \mathrm{H}$. A. Barbary : 1796 mexicănă : Yellow : 8, H. A. Mexico : 1829 murieata : Yellow 12, G. Ev. S. C. G. H. nudicaunlrs : Wht. pur. 7, H. A. C. G. H. : 1731 officinslls : : Orange : 6, H. A. S. Eur. : 1573 plênă : Orange : 6, H. A

oppositifolra: : Yellow: 8, G. Ev. S. C. G. H. . 1774 pluvialis - White 6, H. A. c. G. H. : 1699 sánetí * - Yellow * 6, H. A. Levant - 1731 sicǔll: : . Yellow : 6, H. A. Sieily . 1816 stellatá : : Yellow : 7, H. A. Barbary : 1795 suffruticóa : : Yellow : 12, G. Ev. S. C. G. H. : 1823 Trăgŭs : : Wht. pur. 5, G. Ev. S. C. G. H. : 1774 viscóng. : : Orange: B, G. Ev. S. C. G. H. : 1790

CALRpìnă, Adanson. Not explained. Linn. 15, Or. 1, Nat. Or. Cruciferce. A curious annual, of easy culture. Synonyme: 1. Myagrum iberioides.

corvisi . . . White. . 5, H. A. S. Eur. . . 1816

CALİčùn, Acharius. The name is expressive of the organs of reproduction; and derived from knlypion, a little cup. Linn. 24, Or. 8, Nat. Or. Lichenes. Curious white or grey productions appearing in patches on wood or boards exposed to the airaciculürĕ, aruginosă, cantharëllım, capitellütūm, chrysocêphălum, claviculärě, cêrtüm, dëbīlę, ferrugīnēam, hyperellñm, inguĩnän, microcēphälü, rösĭdam, spharocêphălım, stigonëllam, terebinéllam, tigilläré.

CĀLLX̆, Linn. From kalos, beauty. Linn. 7, Or, 1, Nat. Or. Aracen. These species are showy and worth cultivation, they grow freely in any rich soil; and increase by seeds, or divisions. Synonyme: 1. Dracontium pertusum

sromăťeă . . White. - 7, G. Her. P. China • 1813 occulta : : White. 5, G. Her. P. China : 1817 palûstrǐs : : White. : 7. G. Aq. P. N. Amer. : 1768 CALLic̄̄RPă, Linn. Named in reference to the pretty berries; from kalos, beautiful, and karpos, fruit. Linn 4, Or. 1, Nat. Or. Verbenaced. The species of this genus are handsome, and succeed well in loam and peat mixed. Cuttings strike without difficulty in sand or soil. The bark of C. Lantana has a peculiar subaromatic and shightly bitter taste, and is chewed by the Cingalese, when they cannot obtain betle leaves; the Malays reckon the plant diuretic.-Lind. Nat. System of Botany. Synonyme: 1. C. tomentosa.

[ 56 ] 


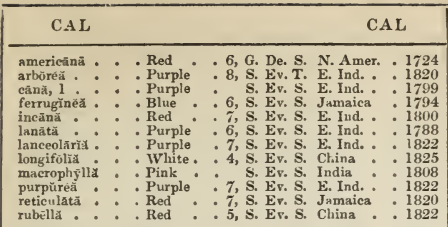

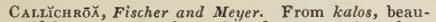
tiful, and chroa, colour; in reference to the colour of its flowers. Linn. 19, Or. 2, Nat. Or. Compositer. This little plant is well entitled to a place in every flower-border, as well on account of its dwarf and slender ha' as of its rich golden-coloured flowers. It grows rell in common garden soil, and is increased trom seed, which should be reared on a hotbed.

plaț̌glüssă. . Yellow . 10, H. A. California . 1835

CALLıcōar, Bot. Rep. The name is expressive of the pretty bunches of yellow flowers; and is derived from kalos, beautiful, and kome, hair. Linn. 11 , Or. 2, Nat. Or. Cunoniacee. A very showy plant, oultivated with ease in fibrous peat and sand; and cuttings root readily in sand, under a glass.

serratifolia. . Y Yellow .6, G. Ev. S. N. S. W. - 1793

CALLั̆GŏNŪM, Iinn. Derived from kalos, beautiful, and gonum, a joint; there being joints instead of leaves. Linn. 11, Or. 4, Nat. Or. Polygonacere. This species is showy, and requires sandy open loam to grow it well; cuttings.

Pallāšă. . . . Grn. wht. 8, H. Ev. S. Casp. Sea . 1780 CatLióprüa, D. Don. So called from Calliope, one of the Muses. Linn, 19, Or. 1, Nat. Or. Compcsite. This is a pretty dwarf genus, succeeding in any loamy soil, and increased by divisions. Synonyme 1. Leontodon aureun.

aûrěă . . . . Yellow . 6, H. Her. P. Italy . . 1789

CALliōpsìs, Reich. Derived from kallistos, beautiful, and opsis, eye; in allusion to the beantiful bright eye of the flower. Linn. 19, Or. 3, Nat. Or. Compositc. The flowers of these plants are extremely pretty, and well suited for the flower-garden. The perennial kinds grow in any loamy soil, and the annuals merely require sowing; the tender species should be sown in a slight hotbed, and afterward: transplanted. Synonymes: 1. Coreopsis tinctoria. 2. Coreopsis palmata. 3. Coreopsis rosea.

Atkinsoniana . . Yel. brn. . H. H. Columbia . 1826 bícōlor, 1 : Yellow : 6 , $\mathrm{H}$. A. Arkansas . 1829 palmáti, 2 : : Y Yellow :6, H. Her. P. Louisiana 1823 rüseă, 3 . : : Red : 7, H. Her. P. N. Casana 1778

Catilpróră, Lindley. Derived from kalos, pretty, and prora, a front; in allusion to its pretty appearance. Linn. 6, Or. 1, Nat. Or. Liliacece. This is a very handsome hardy bulbous species, succeeding well in a shaded peat border, and increased freely from offsets.

lūtéă . . . Yellow . 8, H. Bu. P. California . 1831

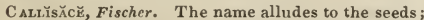
and is taken from kalos, beautiful, and sakos, a buckler. Linn. 5; Or. 2, Nat. Or. Umbelliferce. A species of little beauty, and easily cultivateddaharīcă.

CALLİII propriety of the name from kalos, pretty. Linn. 3, Or. 11, Nat. Or. Liliacer. This plant succeeds in sandy fibrous peat, and is increased by divisions.

rěpèns . . . Blue . . 6, S. Tu. P. W. Ind. . 1776

CALLISTÃ̄H Y̌s, Ventenat. The name is expressive of the fine spikes of flowers; and is derived from kalis, beautiful, and stachys, a spike. Linn. 10 Or. 1, Nat. Or. Leguminosie. Beautiful shrubs, of easy and free growth; sandy peat and loam is the best soil for them; and young plants ate readily obtained from cuttings, in sand.

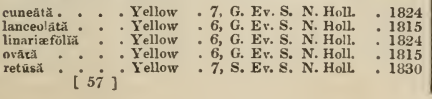

Calistämar, $R$. Bron:n. The name refers to the beautiful flowers; and is derived from kallistos, prettiest, and stemma, a crown. Linn. 19, Or. 2, Nat. Or. Compositue. The species of this genus are well known in the garden for the beauty of their flowers, and the little trouble required to bring them to perfection. The seeds should be sown in a gentle hotbed in spring, and the plants removed to the flower borders, or they may be sown as soon as the weather permits in the open air, where they are wished to flower. Synonymes: 1. Aster chi. nensis. 2. A. indicus.

\begin{tabular}{|c|c|c|c|}
\hline 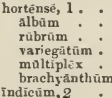 & $\begin{array}{l}\text { Blue } \\
\text { White: } \\
\text { Red } \\
\text { Varieg. } \\
\text { Varieg. } \\
\text { - Blue } \\
\text { Blue }\end{array}$ & $\begin{array}{l}\text { 7, H. } \\
: 7, \mathrm{H} . \\
: 7, \mathrm{H} \\
: 7, \mathrm{H} . \\
: 7, \mathrm{H} \\
: 7, \mathrm{H} \\
: 7, \mathrm{H} .\end{array}$ & $\begin{array}{l}\text { A. China } \\
\text { A. China } \\
\text { A. China } \\
\text { A. China } \\
\text { A. Clina } \\
\text { A. China } \\
\text { A. E. Ind. }\end{array}$ \\
\hline
\end{tabular}

CALI,IstĒmōn, $\boldsymbol{R}$. Brown. The name refers to the beautiful scarlet colour of the stamens of some species; and is derived from kallistos, beantiful, and stemon, a stamen. Linn. 12, Or. 1, Nat. Or. Leguminosie. These are species of great beanty, and should be cultivated in all conservatory or greenhouse collections; partieularly those with scarlet or crimson flowers. Loam, peat, and sand, is the best soil for them; and ripened cuttings strike readily in sand, or sandy loam, under a glass they are also sometimes increased from seeds. Synonymes: 1. Metrosideros citrinus. 2. M. lophanthus. 3. M. rugulosus. 4. M. salignus. 5. M. speciosus. 6. M. viminalis.

formōsŭs

- G. Ev. S. N. Holl, . Crimson , 6, G. Ev, S. N. Holl. Green 6, G. Ev. S. N. Holl. 1788 inearifollüs : Red : 5, G. Ev. S. N.S. W. 182 linearis. : Scarlet : 6, G. Ev. S. N. S. W. 1820 lophanthús, 2 : : Purple :6, G. Ev. S. N.S. w. 1788 G. Ev. S. N. S. IV. microphȳllŭs

mierơsticlıy̆m

microstąchy̆m

pūngēns

rigidüs

rugulôsŭs, 3

salignŭs, 4 .

scã ber

semperflồrēens

speciósŭs, 5

viminălis, 6

G. Ev. s. N. s.

Red . 3, G. Ev, S. N. Holl.

Green: : 6, G. Ev. S. N. S. WV.

5, G. Ev S. N. S. w.

Crimson : 4, G. Ev. S. N. S. W. W.

5, G. Ev. S. N. S. W

6, G. Ev. S. N. Holl.

Crimson : 7, G. Ev. S. N. Holl : 1820

Crimson . 4, G. Ev. S. N. S. WV.

Red 4, G. W. S. W 1822

Red * 4, G. Ev. S. N. S. W. * 1800

viridiflürūs. - Green * 7, G. Ev. S. N. Holl. • 1818 and thrix, hair; applied by Pliny to a plant, which had the colour of beautiful hair. Linn.1, Or. 2, Nat. Or. Callitrichacee. Plants not worth cultivating; the seeds do well thrown into a pond. Synonyines: 1. C.aquatica-autumnalis, pedunculata, verna 1, $V$. aquatica.

Callītrǐs, Ventenat. From kalos, beautiful ; in allusion to its beautiful appearance. Linu. 21, Or. 9, Nat. Or. Coniferce. This is a beautiful species, growing twenty or thirty feet high; like the rest of the family, it delights in sandy loam; and increases from seed. Synonymes: 1. Thuja articulala. 2. Cupressus triquetra.

cupressiformis

quadrivălvis, 1. A pețl . 2, G. Ev. T. Barbary

1826

4. G. E. T. 1815

Calrose, callous, hardened.

CALLOUSLY-GI.ANDUI.AR, having hardened glands.

CALLOUSLY SERRATED, having hardened serratures.

CАĪ̄CĔRĂ, Fries. Kalos, beautiful, and keros, a horn in allusion to the divisions of the plants. Linn. 24, Or, 9, Nat. Or. Fungi. These are remarkable productions found under the bark of various trees -cōrněă, tuberōsă.

CALOchĪL cheilos, a lip. Linn. 20, Or. 1, Nat. Or. Orchidace A genus of bulbous-rooted plants, very showy when in flower. The senals are yellowish-green, and the lip purple, covered with rich brown hairs. They will grow in the greenhouse; but they do best in the stove, treated as the Bletias.

campěstrīs . . Grn. brn. . G. Ter. N. Holl.

G. Ter. Noll. 1824

Calochōrtǔs, Pursh. From kalos, handsome, and chortus, grass. Linn. 6, Or. 3, Nat. Or. Liliacea. 
This is a splendid genus of plants. The soil most suitable for them is sandy peat, and a little loam; if the plants are grown in pots, they must be carefully drained, and the soil only watered as the growth happens to require it. In the winter they must be treated like other frame bulbs. When the roots recommence growing, shift them into new soil. They increase from offsets.

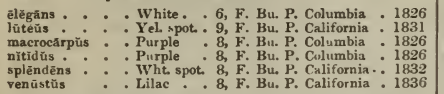

CALODĒxDRŌN, Thunberg. Derived from kalos, beau tiful, and dendron, a tree; in reference to the beauty of this plant. Linn. 5, Or. 1, Nat. Or. Kutacee. A tall-growing ornamental tree, succeeding in loamy soil; and increases from cuttings.

capense. . . . Pink . - G. Ev. T. C. G. H. . 1789

Сало̆рнйсӑ, Fischer. Taken from kalos, beautiful, and phake, lentil. Linn. 17, Or. 4, Nat. Or. Leguminosce. An ornamental species; it grows best in sundy loam; and is multiplied by seeds. Synonymes: 1. Cytisus niger, pinnatus, Wolgaricus.

Wolgtrǐę, 1 . Y Yellow . 5, H. De. S. Siberia . . 1786

CalōphăNes, D. Don. Taken fiom kal is, beautiful, and phaino, to appear; alluding to the flowers. Linn. 14, Or. 2, Nat. Or. Acanthaceo. This is an interesting addition to our hardy border flowers; it succeeds best in loam and peat; and is readily increased by parting the routs. Synonyme: 1 . Ruellia oblongifolia.

oblongifoltra . . Blue . . 8 , H. Her. P. Carolina . 1832

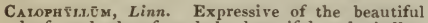
leaf; and taken from kalos, beautiful, and phyllon, a leaf. Linn. 15, Or. 1, Nat. Or. Guttifera. Largegrowing timber trees of considerable value. Sandy loam suits them best; and young plants are easily procured from cuttinge. Synonyme: 1. Calaba.

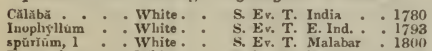
spúrín, 1. . White. . S. Ev. T. Malabar . 1800

CᄉLopōgös, R. Bron’n. From kalos, beautiful, and pogon, a beard; the lip is beautifully fringed. Linn. 20, Or. 1, Nat. Or. Orchidaced. This is a beautiful greenhouse plant, producing a few purple flowers on a stem, from twelve to eighteen inches high. It will grow well in peat and loam, and may be increased by dividing the tuberous roots. Synonyme: 1. Limodorum tuberosum.

pulchellǔs . . . Purple . 7, G. Ter, N. Amer. . 1771

Саноттйммӑ, R. Brown. From kalos, beautiful, and stemma, a crown; alluding to the flowers. Linn. 6, Or. 1, Nat. Or. Amaryllidec. These are handsome bulbous species, of tolerably easy culture; they thrive best in sandy loam and a litcle peat mixed; and are increased from offsets.

Albūm . . . White * 5, G. Bu. P. N. Holl

lūteüm : : Yellow : 11, G. Bu. P. N. Holl

purpäreūm : : Purple : 11, G. Bu. P. N. Holl

1824

CALотнймň̌s, Labillardière. So called from kalos, beautiful, and thamnos, a shrub. Linn. 18, Or. 2, Nat. Or. Myrtacece. Beautiful shrubs; they succeed well in sandy peat; and cuttings root freely in sand, or sandy mould, under a glass.

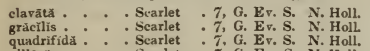

1824 gracilis : * . Scarlet * 7, G. Ev. S. N. Holl. 1803 vuadrifidasa : : : Searlet : T, G. Ev, S. N. Holl. : 1803

CALōThrīx, Agardh. The name applies to the beauty of the filaments; and is taken fram kalos, beautiful, and thrix, a hair. Linn. 24, Or. 7, Nat. Or. Algce. Minute, curions marine productions, found in little patches sometimes floating-confervicoulōr, distơrtŭ, fasciculātă, lanātă, L. fuscēscēns, lutēólü, mirăbĭliss, nivěă, scopulōrūm.

Carōris, R. Bronn. A derivation from kalos, beautiful, and ous, an ear; alluding to the palere of the pappus. Linn. 19, Or. 2, Nat. Or. Compasita. This species has wedge-shaped leaves, and is very pretty; it is multiplied by divisions, and grown successfully in any common soil.

cuneifóliă . . Blue . . 6, G. Her. P. N. Holl. . 1819 CAtōtrŏp̆ś, R. Brovn. Taken from kalos, beautiful, and tropis, a keel; alluding to the keel of the flower. Linn. 5, Or. 2, Nat. Or. Asclepiadacer. Any rich soil suits these beautiful species, young plants of which are readily obtained from cuttings, o1 seeds. Synouyme: 1. Asclepias gigantea.

gigăntẽă, 1 * White. * 8, G. Ev. S. E. Ind. . 1690 procéră . . White. 8, G. Ev, S. Persia . 1714

CĀITHĂ, Linn. A syncope of kalathos, a goblet; in allusion to the likeness of the form of the corolla to a golden cup. Linn. 13, Or. 1, Nat. Or. Ranunculacee. The species are showy, and do best in a moist situation, but will grow and flower in a common border. Seeds, or divisions. Synonyme: 1. Ficarioides.

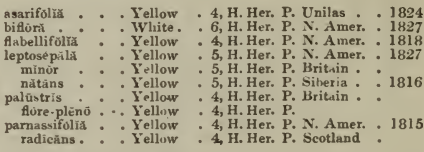

Caltrops, see Tríbũlüs.

CALYcĀNThés, Linn. From kalyx, a calyx, and anthos, a flower; in allusion to the colour of the calyx. Linu. 12, Or. 3, Nat. Or. Calycanthacee. This is a valuable genus, with delightful fragrant flowers. They succeed in open loamy soil, and multiply by layers.

fertilis . . . Brown . 6, H. De. S. Carolina . 1726 florídŭs. - Brown 6, H. De S. Carolina 1726 lævigatũ : Brown : 6, H. De. S. N. Amer. 1806 lavigatún pennsylvánieũs: Brown : 5, H. De. S. Pensyl. . : 1820 CALYCiYOR, formed like a calyx.

CALTCINE, of or belonging to the calyx.

CALYCULATE, i having bracteas resembling an exCAIYCU1,ATED, f ternal, or additional caly $x$.

Calrspōo. Salisbury. Said to be from kalypto, to conceal; in allusion to the habitat of the plant. Linn. 20, Or. 1, Nat. Or. Orchidacec. This is a small, but extremely pretty species, well deserving a place in every garden. It yrows best in sandy loam and peat, in a frame or warm border, by a south wall, and is increased by offsets from the bulbs. Synonyme: 1. C. americana.

boreălis . . . Ra. brn. . 1, F. Ter. N. Amer. . 1820

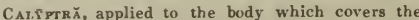
theca in mosses; anything in the shape of an extinguisher.

CAIIPTR ÃNuk̄s, Smartz. From kalyptra, a yeil, and anthos, a flower; in allission to the peculiar manner in which the united segments of the caly $x$ fall off. Linn. 12, Or. 1, Nat. Or. Myrtacede. Strong-growing ornamental timber trees, of easy management. Sandy peat suits them; and young plants are ob. tained by layering the branches.

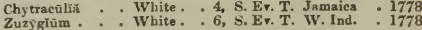

CALT̃ prRĪox, Gingins. Derived from kalyptra, a veil, and ion, a violet. Linn. 5, Or. 1, Nat. Ur. Violacea. Pretty species : peat and loam suits it; and young plants are procured from seeds. Synonymes: 1 . Viola Hybanthus, Ionidium Hybanthus.

Aublétīi, 1 . Cream . . S. Ev. Cl. Guiana . . 1823

Calystēoľx̆, Loureiro. Named from kalyx, calyx, and stega, a covering. Linn. 5, Or. 1, Nat. Or. Convolvulacece. Only a few of these species are interesting. They all succeed in common loamy soil, and are increased by divisions. Synomymes: 1. Convolvulus sepium. 2. Convolvulus spithamues. 3. Convolvulus stans.

dahürě̃ : Pink *. 7, H. De. Tw. Dahuria . 1823

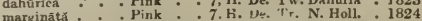
sépinim, 1: : Whit grn. 9, H. D. Tw. Australia: 1837 incarnăta : Med . 7, H. Ne. Tw. N. Amer. soldanella.: : Flame: 6, H. Ev. Tr. Britin

i 58 ] 
spithamæå. . . White. - 7, H. De. Tw. N. Amer. 1796

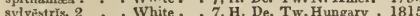
tomentōsă, 3 : : 6, H. De. Tr. N. Amer. 1818

Catesbeänă, paradōx̆, reniformǐs.

CALYTTHRIX, Labillardière. So called from kalyx, a caly $x$, and thrix, hair. Linn. 12, Or. 1, Nat. Or. Myrtacea, These are handsome evergreens, of easy culture; sandy peat and loam mixed suits them; and cuttings take readily in sand, under a glass.

ericoidēs

floribund

glä̆bră

pubèscēn

White.

Wlite.

White.

White.

G. Ev. S. N. Holl.

G. Ev. S. N. Holl.

5, G. Ev. S. N. Holl.

1824

G. Ev. S. N. Holl

1820

1824

CAmmuină, Crantz. From chamai, on the ground, and linon, flax; in allusion to its dwarf habit. Linn. 15, Or. 1, Nat. Or. Cruciferce. The species have but little beauty, and require to be sown in the open border. C. sativa is cultivated in some parts of Europe for the sake of the oil which is obtained from the seeds. Synonymes: 1. Myagrum sativum. 2. Cheiranthus sylvestris.

tīiă, 1

A. Britain .

strīācŭ, barbareafólăă, dentātă, microcārpó.

CÁL ̛̃ , the outer envelope of a flower.

CAMĀssí̄, Lindley. From quamass, or camass, its native name in N. America. Linn. 6, Or. 1, Nat. Or. Asphodelece. The flowers of this beautiful plant are nearly two inches in diameter. Dr. Lindley scarcely remembers to have ever seen a more strikingly handsome bulbous plant. It requires a peat border, under a north wall; increased by seeds.

esculēntă - . Purple . 7, H. Bu. P. Columbia . 1827

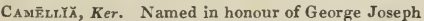
Kamel, or Camellus, a Moravian Jesuit, and traveller in Asia. Linn. 16, Or. 8 , Nat. Or. Ternstramiacec. "All the species of Camellia are universally admired by every collector of plants, on account of their beautiful rose-like flowers, and elegant darkgreen shining laurel-like leaves. They are very hardy greenhouse plants and are easy of culture, requiring only to be sheltered from severe frost. The best soil for them is an equal quantity of good sandy loam and peat. Messrs. Loddiges find that light loam alone answers as well, or better; and in the Comte de Vande's gardens at Bayswater, rotten dung is mixed with loam and peat. The pots should be well drained with pieces of potsherds, that they may not get soddened with too much wet, as nothing injures them more than overwatering, particularly when they are not in a growing state. When growing freely, they can scarcely have too much, and they should be watered over the leaves with a fine rose-pot; they are readily increased by cuttings, or inarching on the common kinds. The cuttings should be taken off at a joint as soon as they are ripened, and planted in sand, under a glass, where they will soon strike root; when this is the case they should be planted singly in small pots, and set in a close frame, and they must be afterwards hardened to the air by degrees."-Sweet. The season most proper to give the Camellias a general potting is February and March. After this, put them into a peach-house or vinery, or a warm greenhouse, and give the plants plenty of water while they are making their young shoots; when the season's growth is completed, and the flower-buds formed, the back of the greenhouse or even a well-sheltered north border will suit them, for they will be seriously injured if exposed to the rays of the sun. A regular succession of flowers may be obtained from autumn till July, if attention is paid to shifting the plants to the warm atmosphere of a vinery, or pinery, \&c., and to one a few degrees colder, and so on till they come to expand their flowers in the greenhouse, which in rough, bleak, cold weather, should be kept closed. The seeds of $c$. oleifera yield an excellent table oil.

euryoldès . . White. . 5, G. Er. S. China . . 1824

hỵbrìuă.

1824

[ $\left.59^{\circ}\right]$
Acutipètälă, Aisonīă, älbŭ, A. plēnă, A. semidūplēx, A. simplëx, A. variegätă, altheiflöră, Amhërstīă, amplīssimă, anemonefióră, $A$. älbă, A. cărnëă, $A$.

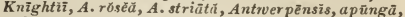
ārdëns, argēntĕa, atropurpŭrěă, atrōrŭběns, atro.

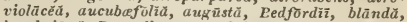
brooksiänă, Bruxellēnsìs, Buckliänă, burlesiānă, can. didíssìmă, Candolleānă, cardiuălīs, cärnĕă, cerăsīnă, Chamlērīi, Chandlērīin, Clintōniă, Cliveänă, cocciñĕă, cöllă, Colvîllīĭ, compäctă, C. rübră, Comptoniānă, conchifloră, concīnnă, cöncŏlòr, conspĩcŭă, corallīuă, coronätü, crassinērvìs, curvatifloră, Dahliaeflöră, decōră, delicatīssīmă, Derlıyānă, dilęectă, dianthifloră, Donkelaūrīī, Dorsêttīin, Eüertónīi, Eclīpsìs, elēctă, ēlęgāns, elegantīssīmă, Elphinstōnīi, excèlsă, exĭmĭă, fasciculärìs, fimbriätă, fioniānă fläc-

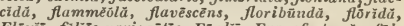
Floyīi, folits-variegâtis, Fordiz, Francfortensis, fül. gēns, gaussōnī, Gilēsī, gloriōsă, grandiflōră, Griffinīī, halēsīi, haylöckīi, hëlvớs, heptangulārīs, Herbërtiz, heterophy̆lla, hexangu'istris, Hibbèrtii,

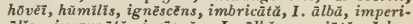
älīs, incarnätă, insīgnìs, I. älbă, tnvolūtă, Johnsōnī̄, Kermesĩnă, lāctēă, Lambērtĩă, Lancmānnĩu, latifoliă, Leěhĩi, Leeānă, Lefevreānă, Lehmännī, līndbrĭă, Lindleyānă, Lippóldĩ̄, longifoliă,

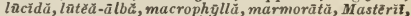
mūximă, minată, mutäbĭlìs, myrtifolìă, nänă, nannetēnsĭs, nǐvěa, nobilīssimmă, ochroleūcă, vrnätă, oxo. niēnsìs, paeonifloră, pa paverü cěă, paradoxă, Pärksīi, parthoniānă, parvifloră, penicillătă, perféctă, picturātă, platypètălă, plumăriă, pompönĩă, prägnăns, Pressī̄, prîncēps, pulchëllă, pulchērrīmă, punctätă, rununculifloră, Reevẽsīi, regīnōe, resplēndēns, Rivĩnī̄,

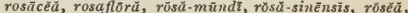
ruseīnă, Rössīi, rotundifolǐă, roulīuĩ, rubicūindă, rūbră, rübră-punctäă, rubricañlis, rugosissīmä,

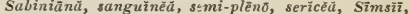
Soulangeãnă, spatulätă, speciōsă, spectälülis, Spofforthiänă, Spofforthīă-cārněă, spolófëră, staminèă,

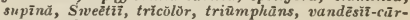
nĕă, vandẽsīî-supẽrbŭ, variäbìlìs, variegätă plēnō, V. sīmplēx, venōsă, versícōlör, Weimäriă, Welbankiänă, Wiltōnī̄, Woōsīĭ.

Kiss

oleîfera

White.

5, G. Ev. S. China

reticulātă

White

asănqŭă

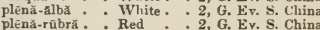

White.

5, G. Ev, S. China

4, G. Ev. S. China

semíplenă : Red : 2, G. Ev. S. China

1823

1819

1824

1824

1818

1811

CAMERÃRĬ, Linn. In memory of Joachim Camerarius, a physician and botanist of Nuremberg. Linn. 5, Or. 1, Nat. Or. A pocynaced. The species of this genus are handsome flowering plants, of easy culture; they succeed best in loam and peat mixed; and cuttings root in sand, under a glass, in heat. Synonyme: 1. Wrightia dubia.

angustifoliă $:$ White . 9, S. Ev. S. S. Amer. 1752
dübră, 1 : Orange

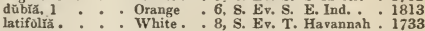

CAMPĀŇIX, Linn. The name is a diminutive of campana, a bell; on account of the resemblance thereto of the corolla. Linn. 5, Or. 1, Nat. Or. Campanulacea. This is a showy and well-known genus; some of the species are tall-growing handsome plants, while others scarcely rise more than a few inches from the ground. They are all of easy culture in the border of the flower-garden or shrubbery, where the hardy kinds merely require sowing; the less hardy kinds should be sown on a hotbed, or in the greenhouse, and when up potted off. The roots of $C$, Rapunculus are occasionally eaten. Synonymes: 1. Rupestris. 2. Roella decumbens. 3. C. capitata. 4. Neglecta. 5. Spatulata. 6. Speciosa. 7. Diffusa. 8. Betonicafolia. 9. Adenophora liliifolia. 10. C. baldensis. 11. Multiflora. 12. Glomerata petraa. 13 Lobelioides. 14. Gummifera. 15. Glomerata dahurica. 16. Planiflora. 17. Flexuosa.

\section{acuminåtă}

Adānni

affinis .

aggregàtă.

Alliōnî̃

alpină

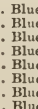

Blue
Blue
Blue
Blue
Blue
Blue
Blue
Blue
8, H. Her. P. N. Amer.

$\begin{array}{ll}7, \text { H. } & \text { B. Caucasis } \\ 7, \mathrm{H} & \text { B. S. Eur. }\end{array}$

G. H. Bur.

7 , H. Her. P. Caucasus - 1803

$T$, H. Her. P. S. France : 1820

7, H. Her. P. Switzerl. - 1779 


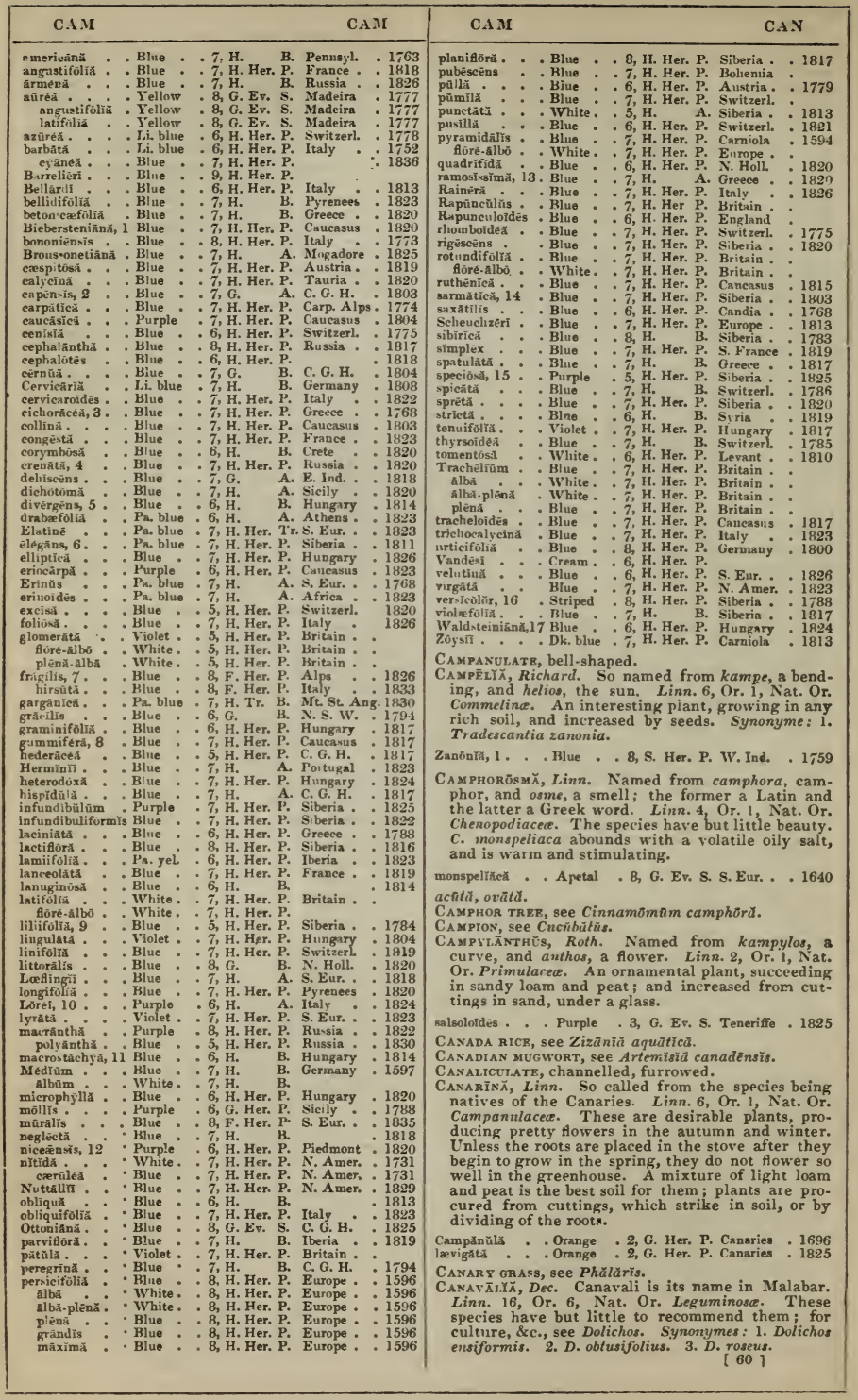


CAN ensifórmis, 1 : Purple : 7, S. A. F. Ind. : 1778 gladiat obtusifoliă, 2: : Purple. 7, S. Ev. Tw. E. Ind. : : 1820 emargiuātă Purple 7 S. Ev Tw. E. Ind 1800 rŏséă, 3. : Purple: T, S. Ev. Cr. Jamaica : 1812

Cancellatr, like lattice-work.

CANDIRBRRRY MYRTIE, see Myricü.

CANDōr.I.ẼA, Labillardière. In honour of Augustus Pyramus Decandolle, F.M.R.S. and L.S., Professor of Botany at Genera, author of many approved botanical works. He is one of the first botanists of the present age. Linn. 18, Or. 2, Nat. Or. Dilleniacea. A beautiful shrub, thriving best in a mixture of loam, peat, and sand ; cuttings, in the same kind of soil, root readily, under a glass.

cuneiförmis . Yellow . 7, G. Ev. S. N. Holl. . 1824

CANDY carrot, see Athamäntŭ Matthīoulă.

Candyturt, see Ibëris.

CANB-BRAkE, see Arundinñcẽă.

CANĒLl., P. Bronne. From canna, a reed; in allusion to the bark being rolled like cinnamon. Linn. 16, Or. 5, Nat. Or. Guttiferce. These are valuable and ornamental trees, about fifteen feet high, best cultivated in loam, peat, and sand; cuttings of the well-ripened wood taken off at a joint will root in sand in a moist heat; they must not be deprived of any of their leaves. Sweet recommends large old cuttings as the best. The bark is aromatic and pungent.

Albă . . . White. - S. Ev. T. W. Ind. . 1735 auriföliă: : White: : S. Er. T. S. Amer. : 1820 Cankscent, hoary, approaching to white.

CANĪNĂ, pertaining to dogs.

С̆̄NĂ, Linn. The Celtic name for a cane or mat. Linn. 2, Or. 1, Nat. Or. Marantacea. This, says Mr. Sweet, is a genus worthy of cultivation in all collections, as its lively flowers are produced in great abundance, and at all seasons; many species are now in our collections; the most splendid is iridiflora, which is amongst the handsomest plants of the stove; rich light soil suits the species best: they are propagated by divisions at the root, or by seeds, which they produce in abundance.-Bot. Cult. 43. Synonyme: 1. C. chinensis. angustifölia : Searlet 4, S. Her, P. S. Amer. angustifolia aurantiăcă . Orange - 12, S. Her. P. Brazil cärnèă : : Flesh : 12, S. Her. P. Brazil : cocciněă : : Scarlet : 12, S. Her. P. S. Amer
conıpacta : cröcea : : Red: : 5, S. Her. P

denudātá : 6, S. Her. Pr latifolià: : Red : 7, S. Her. P. Brazil discólör. : Scarlet: 11, S. Her. P. Trinidad edulis : Red: 9, S. Her. P. Peru

esculēnt: : Red : 12, S. Her. P. S. Amer.

excelsã. Scarlet: 2, S. Her. P. Brazil

flaccida: : : Red : 7, S. Her. P. S. Carol.

gigāntēi : : Red yel. . 12, S. Her. P.S. Amer

glaūeă - : Yellow : 7, S. Her. P. S. Amer.

rúfa : : Brown : T, S. Her. P. S. Amer.

Indícă : . . Scarlet : 12, S. Her. P. Indis

maculātă - . Red yel. . 12, S. Her. P. India

iridiflora : Red : 12, S. Her. P. Peru

jüncéa . : Red : 5, S. Her. P. Indies

lagunēnsìs: : Yellow: 9, S. Her. P. Laguna

LambertI : . Scarlet . 5, S. Her. P. Trinidad

lancenlâta : Red : 12, S. Her. P. Brazil

lanuginosă : : Scarlet: 4, S. Her. P. Marant

latifoliă. : Pink . 12, S. Her. P. Brazil

limbătä - * Red * 12, S. Her. P. Brazil

occidentalis : : Red yel. 6, S. Her. P. W. Ind.

occidentalis : Red yel. 6, 6 . Her. P. W. Ind.

flāvă. : Yellow: 6, S. Her. P. E. Ind.

pallidă: : : Pa. yel. : 6, S. Her. P. W. Ind.

latifölì : : Yellow: 6, S. Her. P. W. Ind.

pătēns

pedunculata

Red yel. 5, S. Her. P. Rio Jan.

Orange . 10, S. Her. P.

Red. . 12, S. Her. P. S. Amer.

Yellow: 5, S. Her. P. China

Red . 12, S. Her. P. W. Ind.

Red 5, S. Her. P.

Red : 12,S. Her. P. S. Amer.

12, S. Her. P. S. Amer.
8 , S. Her. P. S. Amer.

Red : 8, S. Her. P. S. Amer.

1829

182

1824

1822

1731

1820

1818

1818

1827

1820

$182:$

1820

1788
1809

1730

1570

1816

1820

1828

1819

1825

1823

1818

1629

1822

1820

1820

1820

1778

1820

1835

1820

182

1820

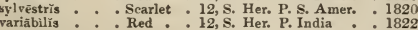

С̆̄nñ̆bĭs, Linn. So called from ganeh, its A rabic name, and from the Celtic appellation can, reed, and $a b$, small. Linn. 22, Or. 5, Nat. Or. Urticacea.
$\mathrm{CAN}$

CAP

One species of this genus produces the hemp. The hemp to which we owe so many of our comforts is C. sativa. Neither is handsome, and they require only to be sown in the open ground and keptciean. A most powerfully narcotic gum resin.

Indǐcă . . - Green . 8, H. A. E. Ind. . 1800 sativă : : Grn, wht. 6, H. A. India

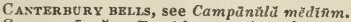

Cantharēilús, $F$. Adams. An alteration of the French name chanterelle. Linn. 24, Or. 9, Nat. Or. Fungi. Interesting productions. C. cibarius is one of the best of our eatable mushrooms. The best way of preserving them for use, is to string them in rows, and after they have become flaccid, to hang them in a dry place where they can have plenty of air. They then form a delicious ingredient in rich gravies, \&c. Synonyme: J. Merulius purpuratns, aurantiacus, cibarius, cinerens, cornu. copioides 1, lobatus, lutescens, nmbonatus, undulatus.

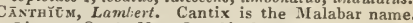
Linn. 5, Or. 1, Nat. Or. Cinchunaces. This is an ornamental shrub, and will grow in any rich soil cuttings.

dǔbřŭm . . . White. . 7, G. Ev. S. E. lnd.

CA PE JASMini, see Gardēnĩŭ flörĭdă.

CAPB rHILlyreA, see Cassiñè capēnsìs.

CAPER SPUtGB, see Euphōrbĭă Lüthy̆rĭs.

CAPER TREE, see Cäppărís.

$\left.\begin{array}{l}\text { CAPLLLARY, } \\ \text { CAPILLACEOUS, }\end{array}\right\}$ very slender, like a hair.

CAPILI.ARY-MuLtrin, divided in slender hair-like segments.

Capiliate, hairy, stringy.

CAP1TATE, growing in a head; a stigma is capitate,

when it is large, round, and blunt.

Cafitritiate, ?

Capitula , $\}$ growing in small heads.

Cархорнгцíd, Gertner. So called from kapnos, smoke, and phyllon, a leaf. Linn. 5, Or. 2, Nat. Or. Umbellifere. A mere weed. Synonymes: 1. Conium africanum, Rnmia capensis-africänă 1.

CÄРPăRIs, Linn. So called from the Arabic kapar, capers. Linn. 13, Or. 1, Nat. Or. Capparidacee. This is a genus of ornamental low shrubs; they grow well in a mixture of loam and peat : and cuttings root in sand, in heat, under a glass. C. $s p i-$ nosa is a good free-flowering species, when allowed plenty of room. The flower-buds of the caper form a well-known pickle; they are stimulant, antiscorbutic, and aperient; and the bark is said to be diuretic. Synonymes: 1. acutifolia, acuminata. 2. Octandra. 3. Eontanesii. 4 Arborescens. 5. Uncinata.

acuminătă . . White. . S. Fr. S. E. Ind, . 1829 amrgdalină White . Whate. aphyllă . . White. S. Ev S. E. Ind. : 1822 auriculätå: : White : S. Ev. S.

Brāssĩi : White - S. Ev. S. Grld Coast 1793 Breynă: : : White. : S. Ev. S. W. Ind. 1752 chinēnsǐs, 1 . White . 7, S. Ev. S. S. Amer. 182 cynophallöphöră . Grn. whit. S. Ev. S. W. lnd. : 1752 ferrugineă, 2: : White. : S. Ev. S. Jamaica : frondôsă : : Green : S. Ev. S. Carthag. : 1800 herbăcēă : : White: $\quad$ F. Her. P. Tauria: 1818 jamaicēnsǐs : White , S. Ev. S. Jamaica: 1793 lineāris. : White.: S. Ev. S. W. lnd. : 1793 mariāna : : White : S. Ev. S. Timor : 182 odoratíssimă * White. S. Ev. S. Caraccas . 1814 ovătă, 3. . . White. . 6, F. De. S. S. Eur. peltâtă . . White * G. Ev. S. Trinidad: 1827 pulchērrĭmă, 4 . White * S. Ev. S. Carthag. : 1700 salignă. White S. Ev, S. Santa Cruz 1807 sepiariă : White. S. Ev. S. E. lnd. . 1823 spinōsä. . White . 6, F.De. S. S. Eur. : 1596 tenuisĩliquă * White. S. Ev. S. Caraecas - 1823 torulōsã, 5 . . White . S. Ev. S. W. Ind. 1829 triflöră . . White . S. Ev. S. S. A mer. undulata . White. - S. Ev. S

S. Ev. S. Carthagena 1820

CAPRÄR̆̌̆, Linn. The leaves of this genus are liked by goats; hence the name, from caper, a goat. Linn. 14, Or. 2, Nat. Or. Scrophulariaced. Uninteresting species, of easy culture-biflöră, cuneätă, hümilǐs, lanceolütŭ, undulätŭ.

CAPrgolate, having tendrils. 


CAP CAR

CAPripótí̃ á, Romer and Schultes. Called poetically goat-leaf; and is derived from caper, a goat, and folium, a leaf; in reference to the climbing and twining habit of the plant. Linn. 5, Or. 1, Nat. Or. Caprifoliacee. This is a genus of favourite climbing plants, well adapted for planting against walls, bowers, or trellis work Common soil suits them; and cuttings taken off early in autumn readily root in a shady border. Synonymes: 1 . Lonicera glabratum. 2. Cap. pubescens. 3. L. caprifolium. 4. Caprifolium japonicum.

\begin{tabular}{|c|c|c|c|}
\hline & & & \\
\hline 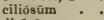 & $\mathrm{Ye}$ & & \\
\hline İūm. . & . Pu & $\mathrm{T}_{\mathrm{w}}$ & \\
\hline II & & H. De. Cl. N. A & 18 \\
\hline & . Or & H. De. Tw. Italy & \\
\hline 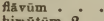 & $w$ & lina & \\
\hline 2. & & ier. & \\
\hline & & er. & \\
\hline & & & \\
\hline & yel. & ind & \\
\hline & & & \\
\hline & & & \\
\hline & & & \\
\hline & & & \\
\hline mènūr & w & De. Tw. Britain & \\
\hline is & red & I & \\
\hline & & $\mathrm{T}$ & \\
\hline & & & \\
\hline & & & \\
\hline & & & \\
\hline
\end{tabular}

CAPsÉtLĂ, Moench. So called from a diminution of capsule. Linn. 15, Or. 1, Nat. Or. Crucifere. Weedy plants. Synonyme: 1. Thlaspi liursa-pastoris -barsú-pastoris 1, a pétálü, $B$. coronopifoliua $B$. integrifüliü, B. minwör.

CÂPsícề, Linu. So named from kapto, to bite; on account of the hot, pungent qualities of the pericarp. Linn. 5, Or. 1, Nat. Or. Solunacer. This genus is ornamental, but chiefly cultivated for its fruit, which is much used in pickles; they are easily cultivated in any rich open soil; and readily inereased from seeds. Synonyme: 1. Cerasiforme.

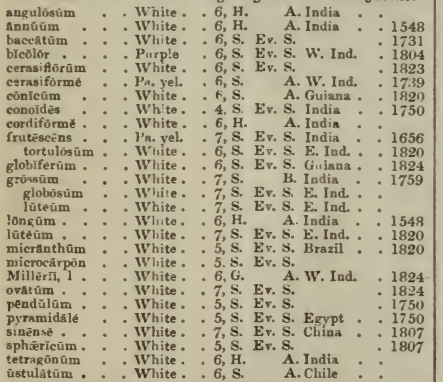
üstulâtūm. White. 6 . S A Chile

CaragāNĂ, A. B. Iambert. So called from carachana, its name in Tartary. Linn. 17, Or. 4, Nat. Or. Leguminosa. This is a handsome genus; most of the species are well adapted for shrubberies. A sandy open loam is the best soil for them; they are multiplied either by grafts, layers, or seeds. Synonymes: 1. Rubinia Altiguna. 2. R. Caragana. 3. $\boldsymbol{R}$. frutescens. 4. $\boldsymbol{R}$. mollis-tomentosa.

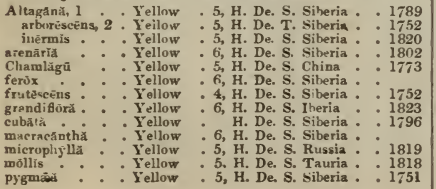

CAR CAR

Redowskt . . Yellow . 6, H. De. S. Siberia . . 1827 spinōsa . : Yellow : 5, H. De. S. Siberia : 1775 tragacanthoidés : Yellow :5, H. De. S. Siberia : : 1816

Caraguãtă, Plumier. Its name in S. America. Linn. 6 , Or. 1, Nat. Or. Bromeliaced. An interesting plant, but with no great beauty ; for culture, \&c., see Bromelia. Synonyme: 1. Tillandsia lingulata.

lingulāta . . Yellow . 6, Epiphy. Jamaica . . 1795

CARÃLLǏx, Roxburgh. From Carillie, the name of $\boldsymbol{c}$. lucida in the Telinga language in Hindoostan. Linn. 11, Or. 1, Nat. Or. Rhizophoracee. An ornamental stove tree, about twenty feet high, succeeding best in a mixture of sandy peat and loam, and may be increased from cuttings in sand, under a glass.

lúcỉdă . . . Y Yellow . S. Er. T. E. Ind. . . 1820

CARALlēyă, $R$. Bronn. Its Indian name. Linn. 5, Or. 2, Nat. Or. Asclepiaduces. This succulent genus of curious plants is allied to Stapelia; they vary in height from one to two feet. The best soil for them seems to be a mixture of loain and brick rubbish. The pots require to be well drained, and the plants cautiously watered, except about the tine of flowering, when they ought to have a liberal supply. Cuttings root freely, if they are allowed to dry before planted, till they begin to shrivel.

adscêndèns, 1 . Pink * 7, S. Er. S. E. Ind. . 1804

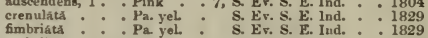
fimbriata : : Pa yoL. : S. Ev. S. E. Ind. : : 1829
umbellata : : Pink $:$ S. Ev. S. E. Ind. $: 1804$ CARĀPă, Aublet. From Caraipe, the name of $C$. gnianensis in Guiana. Linn. 10, Or. 1, Nat. Or. Meliacere. A fine genus of stove plants, not common in collections; they succeed best in loam and sandy peat mixed, and are increased readily by cuttings in sand, plunged in heat, under a glass.

guisnēnsis : . . Yellow * S. Er. T. Guians * . 1824 guineênsišs, i : Yellow : S. Ev. T. S. Leone : 1793

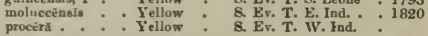

Caraway, see Caram Cärüt.

CARHONIzRD, burned to coal.

CARDÄMTNË, Linn. From kardia, the heart, damas, to subdue; stomachic quality of the plants, or perhaps a diminutive of kardamon, water'ress, the taste being similar. Linn. 15, Nat. Or. Cruciferce. An interesting genus, of the simplest culture and propagation.

amâră

sarifolia

belliditolia

alpiná, 1
Chelidōnià.

glaūeă

latifolia.

macrophylla

praténsis

plèná

thalictroidens

trifơlia

White. uliginón: : White

White. : 4, H. Her. P. Britain : 1710

White. 4, H. Her. P. Scotland

White. 4, H. Her. P. Austria : 1658

White. 6, H. Her. P. Italy : 1739

White. 6, H. Her. P. Calabria 1827

Purple 6, H. Her, P. Spain - 1710

Purple : 5, H. Her. P. Siberia : 1824

Purple 4 , H. Her. P. Britain

Purple : 4, H. Her. P.

White. $6, \mathrm{H}$. A. Piedmont 1818

White : 5, H. Her. P. Switzerl 1629

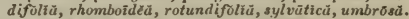
CARDIXAL Y LOWER, see Lobẽliü cardinülis.

CARDINĀrlis, principal, chief; scarlet.

CARDiospérMéM, Linn. From kurdia, a heart, and sperma, seed; in allusion to the shape of the seeds. Linn. 8, Or. 3, Nat. Or. Sapindaced. The species of this singular genus require to be sown in a hotbed frame, or in the stove in any light soil.

canéscēns

coluteoidès

Carind ûm

grandiförüm

Halicécébū

hìrsūtũm

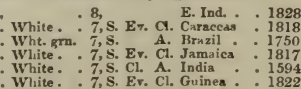
pubẽscēns : : Scarlet : 6, S. Ev. C1. N. Spain : 1823

\section{CARDoon, see $C$ ŭnŭră cardanncülüs.}

CARDÖ́ĀTé $x$, Jussieu. Carduns, a thistle, and patos, beaten path; in allusion to the appearance of the plant, and the place it inhabits. Linn. 19, Or. 1, Nat. Or. Composita. A n uninteresting herbaceous plant, of simple cultivation, and is increased by dividing the root-corymbosim. 
Synonymes: 1. Salmis angustifolia. 2. Ladovia funifera.

angustifülĭ i . Grn. yel. . S. Her.P. Peru . . 1818 funfiferd, 2. : White : S. Ev. Cl. Trinidad: 1824 jamuicēnsis : White.: S. Ev Cl. Jamaica : 1825 latifólı̈. : : Green : 7 , S. Her. P. Peru : 1818 palmáta : White. \% S. Her. P. Peru : 1818

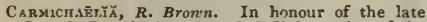
Captain Dugald Carmichael, F.H.S., author of the "Flora of Tristan da Acunha." Linn. 17, Or. 4, Nat. Or. Legnminosa. A pretty greenhouse shrub, sticeeeding well in sandy peat, and increased by cuttings in sand under a glass. Synonyme: 1. Lotus australis.

anstraliss, 1 . . Blue . . 6, G. Ev. S. N. Holl. . 1800

CARMiNatives, medicines which remove flatulence.

Carnation, see Diünthüs caryophȳllüs.

CARNosr, fleshy, thick substance.

CAROR trke, see Ceratōuiă.

CARor.İẼ̆A, Linn. In honour of Sophia Caroline, Margravine of Baden. Linn. 16, Or. 8, Nat. Or. Stercnliacea. Splendid species, growing from fifteen to twenty feet high; they delight in a rich loamy soil; and cuttings, not deprived of their leaves, toot in sand under a glass in heat.

alba . . . . White. . 7, S. Ev. T. Brazil . . 1817 insignils: : : Red : : S Ev T. W. Ind. : 1796

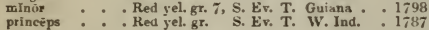
CARPËLI. A, 7 the small parts of which compound fruits CArpers, $\}$ are formed.

Cakpisié, Linn. From karpesion, a bit of straw, the appearance of the leaves of the involucrum. Linn. 19, Or. 1, Nat. Or. Composita. Plants of little beauty, and easy management in light rich soil; seeds-abrotanotales, cěrninam.

Carpints, Linn. From the Celtic, car, wood, pinda, head; the wood being fit for the yokes of cattle. Linn. 5, Or. 1, Nat. Or. Apocynacea. Ornamental trees, from twelve to thirty feet high; some of the species make good hedyes for shelter, as they grow quick, and are easily managed; they are raised from seeds or layers without difficulty.
americăna . A peta
Apetal
H. De, T. N. Amer.
3. H. De T. Britain

setủlüs

A petal

quercifolia : A petal

variegätí : A petal

orientalís.: A petal

3, H. De. T.

5. H. De. T. Europe.

3. De. T. Britain .

H. De T. Levant :

1739

Carpodĩnts, R. Brown. From karpos, fruit, and dinos, a circle; the fruit being round. Linn. 5, Or. 1, Nat. Or. A pocynacer. A fruiting shrub, attaining about eight feet high, and growing well in a mixture of open loam and sandy peat, and increased, without difficulty, from cuttings.

dülcls . . . . Green . . 6, S. S. Leone . . 1822

CARponōxtós, Labillardière. From karpos, a fruit, and odontos, toothed; the cells or carpels toothed at the apex. Linn. 13, Or. 6, Nat. Or. Hypericaced. An ornamental greenhouse plant, growing to the height of twenty feet; it thrives best in peat and loam mixed, and cuttings root freely in sand, under a ylass.

\section{lūcıัda}

G. Ev, T. N. Holl.

1820

CARPOIOGY, the science which treats of the structure of fruits and seeds.

CARrichtêră, Decandolle. Probably without meaning. Linn. 15, Nat. Or. Crucifere. This is a pretty annual, growing well when sown in the open ground in a dry situation. Synonyme: 1. Vella annua.

\section{Vella, 1 . Yellow .6, H. A. England}

Carrot, see Dauctis.

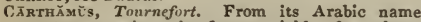
quortom, to paint; the flowers yield a fine colour. Linn. 19, Or. 1, Nat. Or. Compositc. Interesting annuals, requiring to be sown on a gentle hotbed, and afterwards transplanted where they are in: tended to flower.

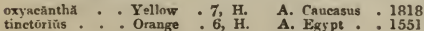
Carti.acinors, gristly.

CАвтокймӑ, R. Bronin. From kartos, shorn, and nema, a filament; in allusion to the stamens. Linn.
6, Or. 1, Nat. Or. Commelinaceo. A pretty annual, requiring merely to be sown in sandy peat, and treated in the stove.

spicâtūm . - Blue * . 7, S. Her. P. N. Holl. 1822 CĀrūM, Koch. From Caria, in Asia Minor, being originally found there. Linn. 5, Or. 2, Nat. Or. Umbelliferce. One species of this genus, $\boldsymbol{c}$. Carui, produces the seeds so generally known by the name of caraway seeds; they are hardy biennials, and require merely to be sown in the open ground.

eărŭĩ . . . White. . 5, H. Her. P. Britain .

simplex $x$.

CARUNCIE, a small protuberance.

CARUNCULĀrīă, Hanorth. Derived from caruncula, a fleshy protuberance; in reference to the flowers. Linn. 5, Or. 2, Nat. Or. Asclepiadacee. A curious succulent plant; for culture, \&c., see Stapeliú. Synonyme: 1. Stapelia pedunculata.

pedunculâtŭ, 1 . Br. pur. - 7, S. Ev. S. C. G. H. . 1790

CĂR ז̆, Nuttall. From caryon, signifying a nut; in allusion to the fruit. Linn. 21, Or. 9, Nat. Or. Juglandacea. A genus of timber-trees, growing about thirty feet high; they succeed in common soil, and increase by seeds or layers. Synonymes : 1. Juglans squamosa, alba. 2. J. amara. 3. J. compressa. 4. J. obcordata. 5. J. angustifolia, olivaformis. 6. J. porcina. $7 . J$. sulcata.

alba, 1 . . . Apetal — 4, H. De. T. N. Amer. - 1629 amårŭ, $2:$ : A petal $: 5$, H. De. T. N. Amer. : 1800 comprëssă, 3 : . A petal : 4, H. De. T. N. Amer. : 1730 laciniósa . . Apetal * 4, H. De. T. N. Amer. microcärpå :- Apetal 4, H. De. T. N. Amer. obcordát, 4: A petal : 5, H. De. T. N. Amer. . - Apetal . 4, H. De. T. N. Aruer. porcină, 6. . Apetal . 5, H. De. T. N. Amer. 1799 glábră : A petal . 5, H. De. T. N. Amer. sulcátr, 7 : A petal : 4, H. De. T. N. Amer. : 1804 tomentosar: : A petal : 4, H. De. T. N. Amer. maximă: : A petal :5, H. De. T. Philadel.

Carvōcār, Linn. From karyon, a nut; the species bear large frnit, containing an eatable nut. Linn. 13, Or. 4, Nat. Or. Rhizobolaced. A genus of fruit. bearing trees, attaining the height of a hundred feet; in our stoves they thrive best in sandy open loam or a mixture of loam and peat, and may be increased by cuttings in sand, under a glass. Synonyme: 1. Pekea tuberculata.

gląbrūm * - Green . - S. Ev. T. Guians . 1820 nuciferũm : Red. yel. S. kiv, T. Guiana tomentósũm, $1^{*}$ : Wliite.: S. Ev. T. Guiana : 1820

Caвqophistis, Linn. From karyon, a nut, and phyllon, a leaf; referring to the appearance of the flower-buds. Linn, 12, Or. 1, Nat. Or. Myrtaced. The species aromaticus grows to about twenty leet high, and produces the article known as cloves. It grows best in a mixture of sandy peat and loam in a strong steady heat. The species is rather scarre, owing to the difficulty of keeping them in winter cuttings in sand root readily under a glass, in a moist heat.

aromătřcŭs . . . Yel, wht. . S. Ev. T. Moluceas . 1797

CARYัб̄xă, Linn. The Greeks applied this name to a cultivated date Linn. 21, Or. 9, Nat. Or. Palmacea. A noble and beastiful genus of palms, growing to the height of twenty feet; the best way of treating them is in sandy loam, and a warm moist atmosphere; increased by seeds.

pärridx. S. Amer. . 1823

mits : White : Palm S. Amer. : 1890

urëns: : : White: : Palm. E. Ind.: : 1788

CAsBĀrĭn, Jacquin. In honour of $J$. Casearius, the co-operator of $\mathrm{Rheede}$ in the Hortus Malabaricus. Linn. 10, Or. 1, Nat. Or. Samydaceo. Interesting stove shrubs, growing from four to eight feet high; they all thrive well in sandy loam, and are increased by cuttings in sand under a glass in heat. Synonyme: 1. C. decandra. 2. Iroucana guiancnsis.

hirsūta . . Yel. RTr. . S. Ev. S. Jamaica . 1825 parviflöră, i : Yel. grn.: S. Ev. S. S. Amer. : 1818 S. Ev. S. Martiniq. 1827 S. Ev. S. Guiana : 1824 serrulata :Wht. grn. S. Ev. 8. Jamaica: 1818 serrulata : : Whitestris : Wrn. CAsREW-NUT, see Anacūrdîñm.

$[64]$ 
C.Ass̄̃VĂ, see Jünĭphă Mänžhōt.

CĀsš̆ă, Linn. According to Olaus Celsus, this name is to be traced to the Hebrew Ketzioth, and latinised by Cassia. Linn. 10, Or. 1, Nat. Or. Leguminose. This is a numerous genus of ornamental plants, growing from one to fifteen feet high; they delight in a light, loamy soil, or loam and peat mixed; some produce seed in abundance, but cuttings strike freely in sand under a glass in a little heat. Synonymes: 1. C. acuminata. 2. C. flexuosa. 3. C. crispa. 4. C. grandiflora. 5. C. 8. C. cermua. 9. C. arborescens. 10. C. multiglandulosa. 11. C. chinensis. 12. C. dimidiata.

acapulcêns's . Y Yellow * 6, S. Ev. S. Acapulco 1823

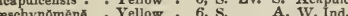
eschytur Yellow cegyptiăcă : Yellow : Yellow alàta angustissYmă. : Yellow apoucoustă, 1 : Yellow artemisioides "Yellow asperrǎ. : Yellow atomäria : : Yellow suriculată": : Yellow australis . : Yellow : aversifiōră : Yellow bacillarrǐs : Y.llow Barclayănă * Yellow Berterí : Yellow bifforă bifoliata: : Yellow bracteata . Yellow brevifoliă: : Yellow

BurmánnI, 2: Yellow capensis : : Yellow chamrerista: : Yellow chinennsIs . : Yellow ciliarrys: : Yellow ciliată: Yellow coromandeliăn . Yellow eorymbōsă - Yellow cuspidata . . Yellow diphylla . . Yellow dispăr . . . Yellow elliptǐcă : - Yellow eniarginata . Yellow fastigiătă : : Yellow flexuôsă : Yellow floribūndx - Yellow

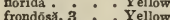
geminifloră : Y Yellow glandulosă : Yellow Blaũeă - : Y Yellow Blutinósă: : Yellow grăcills : : Yellow Herbertiānð : Yellow hirta : : Yellow hirsutta : : Yellow italineă : : Yellow lavigata, 4 : Yellow lanceolată, 5 : Yellow ligustrină : : Yellow lineâriss : : Yellow lineátă : Yellow lotoidés macranthểră Yellow marginătă :Yellow mexicānà : : Yellow microphyilix: : Yellow mimosoides: Yellow mollissima : Y Yellow níctĩtāns : : Yellow niggrǐeāns : Yellow obovătă, 6 - Yellow ocidentaliss . Y Yellow Parkeriänă: Ya. yel pătǔlă . Yellow pēndǔlă : : Yellow pentagōnă : Yellow pilōsă . - Yellow planisiliquă : Yellow polyphyllä : Yellow prostrătă : : Yellow pulchêllă: : Yellow pŭmñă, 7 : Yellow purpŭréă . Yellow quiaquangulārìs Yellow reticulată. : Yellow
Richardiañ : Yellow [ 65 ]
6, S. A. W. Ind. , G. Ev. S. Egypt 7, S. A. E. Ind. S. Surinam : 1820 7, S. Ev. S. Maypures - 1819 6, G. Ev. S. N. Holl. 7, S. A. Georgia . 1818 S. Ev, S. E. Ind 7, G. Ev. S. N. Holl 7, S. Ev. 8. Brazil S. Ev. S. Foril. 7, G. Ev. S. N. Holl. : 1827 6, G. Ev. S. W. Ind. 5, G. Ev. S. W. Ind. 8, G. Ev. S. W. Ind. 6, G. Ev. S. Brazil 8, G. Ev. S. W. Ind. 6, F. A. C. G. H. 1810 6, G. Bv. S. C. G. H. : 1816 7 , America : 1699 6, G. Ev. S. China - . 1807 6, S. Her. P. E. Ind. - 1817 6, S. Ev. S. Cuba • 1820 6, S. Ev. S. Coroman. - 1823 7, S. Ev. S. B. Ayres 1796 6, S. Ev. S. W. Ind. : 1781 S. Ev. S. S. Amer. 1824 6. S. Ev. S. Trinidad : 1818 5, S. Ev. S. Jamrica : 1759 6. S. Ev. S. E. Ind. . : 1818 7, S. A. Brazil : 1810 6, S. A. New Spain 1818 4, G. Ev. S. W. lnd. 6, S. Ev. S. Mexico . 1824 S. 6, S. Ev. S. W. Ind. 6, G. Ev. S. N. Holl. 6, S. Ev. \$. Orinoeo 11, S. Ev. S. Barba. 8, S. Ev. S. N. Amer. 7, S. Ev. S. America 6, S. B. S. Amer. 7, S. Ev. S. iv. STain 7, S. Ev. S. Levant 7, S. Ev. S. Ev. S. Bahama 7, G. Ev. S. Carolina 6, S. Ev. S. Jamaica 6, S. Ev. S. . WV. Ind. 6, S. Ev. S. Trinidad 6, S. Ev. S. Brazil

6, S. Ev. S. Surinam 9, H. Her. P. N. Amer. 6, S. Ev. S. Mexico. 7, S. A. San. Cruz 7, S. A. Ceylon. H. Ev. S. S. Aner. 182 7, s. A. Egypt : : 1640 6, S. Ev. S. W. Ind. : 1759 6, S. Ev. S. S. Amer. : 1818 8, S. Ev. S. Demerara - 1817 8 , S. Ev. S. W. Ind. : 1778 7, S. Ev. S. S. Amer. - 182 6, 8. Her. P. Peru : 170 6, S. Her. P. Jamaica : 1818 6, S. Ev. S. W. Ind. : 1822 6, S. Ev. Tr. S. Amer. : 1819 6, S. Ev. S. S. Amer. : 1819 7 , G. Ev. S. Mauritius . 1825 6, S. Tr. A. E. Ind. . 1814 7, S. Ev. A. E. Ind. . . 182 8, S. Ev. S. Casenne : 1818 7, H. E. Ev. S. N. Amer. : 1800 7, S. Er. S. Cumana : 1823

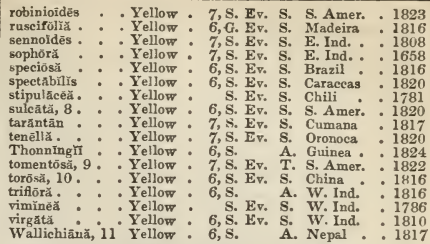

Absŭs, ligustrinō̃lẽs, obtusifolǐă, procūmbēns, serĭcĕă, sulphñrĕă 12, Tagẽră, Toră.

CAssîn, Linn. The name applied to it by the Indian of Florida. Linn. 5, Or. 3, Nat. Or. Aquifoliacer. An ornamental genus, from one to six feet high and one species, $C$. excelsa, grows eighteen feet high. They thrive in a composition of loam and peat, and cuttings of the matured wood root freely in sand under a glass.

æthiŏpică . - White. . 7, 0. Evv. S. C. G. H.

bārbără . : White. 7, G. Ev. S. C. G. H.

Côlpōoñ.: : White: : G. Ev S. C. G. H

excēlsă : : G. Ev. S. Nepal

Maurocēniz: : White. : G. Ev. S. C. G. H.

1818

1629

1820

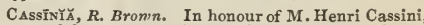
a celebrated French botanist. Linn. 19, Or. 5, Nat. Or. Compositae. The species of this genus are pretty, and may be successfully cultivated in a mixture of loam and peat; they are multiplied by dividing at the root, by cuttings, and by seed, without difficulty.

affinis

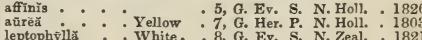
- White . 8, G. Ev. S. N. Zeal. : 1821 - Yellow 5, G. Holl. 182

CAssioberRy bush, see Vibūrnūm lovigātâm.

CÄss Y̌thă, Linn. The Greek name of the Cuscuta, which it much resembles. Linn. 9, Or. 1, Nat. Or. Cassythacee. This is a curious parasite, resembling very much the habit and character of the genus Cuscuta, and will succeed with the same treatmont which see.

filiformis . . White . . 5, Parasite. E.Ind. . . 1796 glabēllă. White . 5, Parasite N. Holl. 182

CAstănگ̆ă, Gartner. From its being originally found in the territory of Castanea, in Thessaly. Linn. 21, Or. 9, Nat. Or. Corylacea. Ornamental timber trees, of variable heights, from ten to fifty feet some are raised from seed; the varieties are frequently multiplied by grafting on the common kinds. Synonyme: 1. Fagus Castanea.

americāna . . Green . . 5, H. De. T. America

chinënsìs . Green . 5, H. De. T. China

Indīer : S. Ev. T. E. Ind.

6, H. De. T. Europe

mëdrărếs: Green: 6, H. De. T.

Castanospērmũu, Hooker. The seeds taste like chesnuts; whence the name, from castanea, chesnut, and sperma, a seed. Linn. 10, Or. 1, Nat. Or. Leguminosce. An ornamental fruit-tree, growing upwards of forty feet high, and delights in any loamy soil, and may be increased by layers.

austrālĕ . Saffron G. Ev, T. N. Holl. , 1828

CAst̄̄L K̆Ă, Turpin. After M. Castel, author of a poem upon plants, Linn. 8, Or. 1, Nat. Or. Och nacea. An interesting stove shrub, four feet high it requires a mixture of peat and loam to grow in, and is increased by cuttings in sand, in heat under a glass.

erēctă $\quad$ S. Ev. T. W. Ind. . 1821

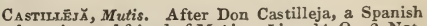
botanist, and friend of Mutis. Linn. 14, Or. 2, Nat. Or. Scrophulariacea. A genus of ornamental plants, of easy management; the stove species succeed 
well in a mixture of loam and peat, and are in creased by cuttings; the herbaceous and annual kinds may be grown in sandy peat, and increased by dividing the roots or seeds. Synonyme: 1 . Bartsia pallida.

\section{integrifolia . . S. Ev. S. S. Amer. . 1825 moranēnsı̆s : S. Ev. S. Mexico : 1825} pallìdă, 1 . : Lgt pur. . 7, H. Her. P. Siberia. 1789 septentrionalls : Wht. grn. 8, H. A. Labrador : 1824

\section{CAstor-orl PLANT, see Ricĭnŭs comminnis.}

CAsuARĩnă, Linn. Supposed to be named from the resemblance the leaves bear to the feathers of the Cassonary, of the same country. Linn. 21, Or. 1, Nat. Or. Casuaracer. These are very interesting plants, on account of their rush-like, frequently drooping, appearance; they grow from ten to fifteen feet high, and are very desirable, from the circumstance of their flowering so late in the season; they grow very well in a mixture of sandy loam and peat, and cuttings root in sand under a glass.

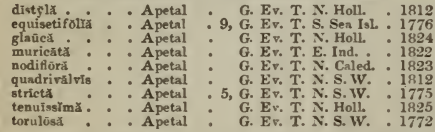

CAтABRర̄să, Beauvois. Derired from katabrosis, signifying food. Linn. 3, Or. 2, Nat. Or. Graminea. A curious aquatic genus of grasses, that require to be grown in a cistern, or pan of water; dirisions. Synonyme: 1. Aira aquatica.

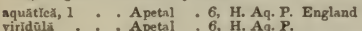

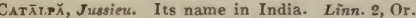
1, Nat. Or. Bignoniacea. C. syringafolia is excellently adapted for planting singly on lawns, or about the skirts of pleasure-grounds; it grows freely in a mixture of loam and peat, and is propagated readily by means of seed, layers, or cuttings. Synonyme: 1. Bignonia microphylla.

longIssima microphrllă, 1

S. Ev. T. W. Ind.

- 1777 : White 7. H. De. T. Hispaniola . 1820

Сатамスхснй, Linn. Katanagke, strong incentive; used by the women of Thessaly in philtres and love potions. Linn. 19, Or. 1, Nat. Or. Composite. A pretty genus, that succeeds well in common soil, and may be increased by seeds, or dividing at the roots.

carūleğ . - Blue * . 8, H. Her. P. S. Eur. - 1596 bieolor : : Wht blue 8, H. Her. P. Gardens : 1827
latez

CAтA PHR $\overline{A C T A ̆, ~ c l o t h e d ~ i n ~ m a i l . ~}$

CATARRAAL, of or belonging to a cold.

CAtasêtūa, Richard. Not explained. Linn. 20, Or. 1, Nat. Or. Orchidacea. All the species of this genus are strong, rapid-growing plants, and from the singular formation of the flowers, they well deserve a place in every collection. They should be kept cool and dry when torpid, forced gently into growth, and when growing freely, kept in a strong heat, and copiously supplied with water: this treatment should be applied to all plants of a similar habit. They require to be potted in the same kind of soil, and in a similar manner to the Stanhopeas and Gongoras. Synonymes: 1. C. Claveringi. 2. C. floribundum.

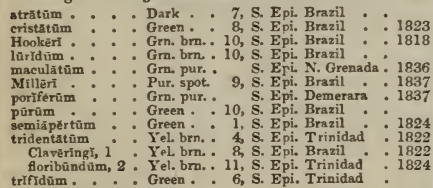

trifrdüm . 6, S. Epi. Trinidad

Catchipì, see Silēnè.

CATERPILLAR, see Scorpiûrŭs.

CATBsB $\bar{A} \bar{A}$, Gronovius. After Mark Catesby, author of the Natural History of Carolina. Linn. 4, Or. 1,
Nat. Or. Cinchonacece. An ornamental genus, the species of which attain from two to twelve feet high; they thrive best in light turfy loam, and peat soil. Being very subject to the attacks of insects, great watchfulness is required to keep them clear, or the plants never succeed or flower. Cuttings root in sand under a glass, in heat.

latifoliă . . Yellow - 6, S. Ev. T. W. Ind. . 1823

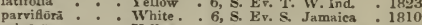
spinosa . : Yellow 6, S. Ev. S. I. Psovi. : 1726

Catharănthès, Don. From katharos, pure, and anthos, a flower; on account of the neat and beautiful flowers. Linn. 5, Or. 1, Nat. Or. A pocynacec. The species of this genus are well worth cultivating in every collection of plants. C. roseus and its varieties succeed well in common garden soil, and are readily increased by cuttings or seeds. The seeds of $C$. pusillus should be sown in a pot full of light rich soil, and placed in a hotbed, and afterwards treated as other tender annuals. Synonywies: 1. Vinca pusilla. 2. $V$. rosea.

pusillūs . . Blue . . 8, S. A. Tranquebar 1778 röseûs : : : Rose eld. : 5, S. Ev. S. E. Ind, * 1726 albŭs : : White. 6, S. Fv. S. E. Ind. ocellătūs : Wht. pur. 6, S. Ev, S. E. Ind.

CAthartic, purgative.

CATHour, generally useful, excellent in a medicinal sense.

CATK1x, inflorescence of the natural order Amentacea, as the willow.

Сатмит, see Nèpétă.

CAT's BA R, see Hypochärĭs.

CAT's rait, see Ty̆phă.

Cat's-tail grass, see Phlëbm.

Cат тнумв, see Telcriñm märam.

С АттлїуA, Lindley. In honour of William Cattler, Esq., of Barnet, Hertfordshire, a famous patron of betany, and one of the most ardent collectors of rare plants of his day. Linn. 20, Or. 1, Nat. Or. Orchidacece. Some of the species of this splendid genus of plants are most magniticent when in flower, as C. crispa, labiata, and Mossia; and these three vie with each other in the beauty of their flowers: when they are well grown, each of these has generally from four to six flowers on a spike; in $C$. crispa the sepals and petals are pure white, the latter much curled, while the lip or labellum is purple in the inside, and white outside. The flowers of $C$. labiata are very large and showy, the sepals and petals being a delicate rose-colour, and somewhat curled; the outside of the labellum is also rose-colour, and the inside blotched, and striped with deep carmine. The flowers of $\boldsymbol{C}$. Mossic very much resemble those of labiata, only they are larger, the circumference of the flower being about twenty-four inches. All the other species are highly deserving of cultivation, if only for the splendour of their flowers. For culture and propagation they may be referred to the Stanhopeas.

bicolor . . . Olive grn. . 9, S. Epi. Brazil . . 1837

crispa : : Wht pur. 9, S. Epi. Brazil : 1826

elatiér: : : Grne pur. : S. Epi. Brazil : 1827

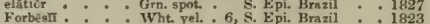

guttata : : : Grn. spot. 4, S. Epi. Brazil : : 1827

Russelliăna: : Grn spot. 8, S. Epi. Brazil : 1838

Harrisonï̌̈.: Vio yel : 4, S. Epi. Brazil

intermediă : : Via yel : 4, S. Fpi. Brazil : 1824

palludä - . I.gt. red *6, S. Epi, Brazil - 1833

labiātă . . Crim. lilac. 5, 8. Epi. Brazil . 1818

LoddigësII - Vio, lilac . 8, S. Epi. Brazil •. 1815

Móssiăe . Crim. lilac. 7, S. Epi. La Guayra : 1836

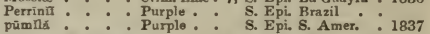

CAŪcX̃rîs, Hoffmansegg. A name used by Hippo-

crates and Theophrastus. Linn. 5, Or. 2, Nat. Or. Umbellifere. The plants have little beauty, and are easily managed by merely sowing the seed in the open ground_-daucotdës, gläbră, hĩspždă, latifüliă, leptophy̆llă, mauritünżeă, púmălă.

CAUDATB, talled, being like a tail.

CAẼDĒx, the trunk or stem of a tree.

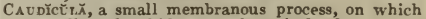
the pollen of orchidaceous plants is fixed.

Caur.rscent, acquiring a stem.

Cautialata, wing-stemmed.

CAoricurs, the little stem of the embryo which unites the cotyledons with the radicle.

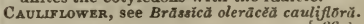


C AULINE, belonging to the stem.

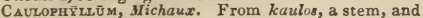
phyllon, a leaf; being so terminated by the stalks, its leaves appear a continuation of the stem. Linn. 6, Or. 1, Nat. Or. Berberacec. A singular plant that requires to be grown in sandy peat, and is increased by dividing the roots. Synonyme: 1 Leontice thalictroides.

thalictroides, 1 . Yel. grn. . 5, H. Tu. P. N. Amer. . 1755

Caustrc, having a burning quality.

C.̃vŭs, hollow, full of holes.

Cвaxōthŭs, Linn. From kenteo, to prick; a name used by Theophrastus to denote a spiny plant. Linn. 5, Or. 1, Nat. Or. Rhamnacea. A genus of showy plants, growing from one to twenty feet high; they thrive well in peat and loam; cuttings strike in sand, under a glass. Synonymes; $1 C$. caruleus. 2. Rhamnus capensis. 3. R. lavigatus. 4. R. mystacinus. 5, R. spharospermus. 6, Celastrus zeylanicus.

americănŭs - White. - 7, H. De. S. N. Amer. azürěŭs, 1 : Pa. blue : 4, G. Ev. S. Mexico capēnsis, 2 White. 6, G. Ev. S. C. G. H Light , 7, H. Ev. S. N. Amer, 1827 infëstũs - - S. Ev, S. Mexico * 1824 intermedrŭs . White. . 6, H. De. S. N. Amer, . 1812

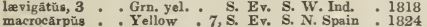
macrocărpŭs : : Yellow : 7, S. Ev. S. N. Spain : 1824 Mociniānŭs : : S. Evo S. Mexico : 1824 mystucinŭs, 4; Wht grn, 11, S. Ev. S. Africa : : 1775 nepalensis. : Yellow H, De. S. Nepal: 1820 ovătŭs : : White : 7, H. De. S. N. Amer. : 1818 perénnIss - . White. 8, H. Her, P. Carolina 1822 sanguhneěuss *. White. 6, H. De. S. Missouri - 1812 tardifórŭs tardiflörŭs zeylänicŭs, 6 : : White.: 9, H. De. S. N. Amer. 1820
S. Ev. T. Ceylon * 1818 CrcrōpǏ, Linn. After Cecrops, king of Athens, whose logs were fabled to be snakes. Linn. 22, Or. 2, Nat. Or. Urticacea. Beautiful plants, attaining upwards of fifteen feet high, they have five peltate leaves, which give the plant a fine appearance; a mixture of loam and peat suits them, and strong cuttings planted in sand, under a glass, with a little heat, root freely.

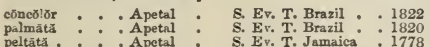

CEDAR of GOA, see Cuprëssũs lusitänǐcă.

CrDAR of Libanos, see Cêdrŭs Libănĭ.

CEDRĒLA, Linn. From cedrus, the cedar-tree; the wood has an aromatic resinous scent like it. Linn. 5, Or. 1, Nat. Or. Cedrelacea. A genus of tallish timber trees, they do well in open loam, and young plants are procured from cuttings in sand, under a glass.

odorätð. - . Pink * . E. Ev. T. W Ind. . 1739 Toōnă: : : Yellon : S. Ev. T. E.Ind. : 1823 velutină S. Es, T

CẼDrưs, Miller. Found plentifully on the banks of a brook in Judxa, named Cedron; whence the name. Linn. 21, Or. 10, Nat. Or. Coniferce. The two species of this genus are not only ornamental but highly valuable for the fine timber they yield, and grow ninety feet high; they delight in sandy loamry soil, and are increased by seeds generally, but $C$. Deodara takes readily grafted upon the common larch. Synonyme: 1. Pinus Cedrus.

Deodäră . . Apetal . 5, H. Ev. T. Nepal . . 18202 Libăñ .: Apetal : 5, H. Ev. T. Levant : 1683

Celāstrŭs, Linn. From celas, the latter season; the fruit remains on the tree' all winter. Linn. 5, Or. 1, Nat. Or. Celastracea. This is a genus composed of ornamental plants, varying in height from two to twenty feet; the species thrive best in a mixture of sandy loam and peat; the ripened cuttings root freely in sand, under a glass. The leaves of $C$. edulis and nutans are said to be stimulant, and are used in medicine. Synonymes: 1. C. emarginatus. 2. Cassine lavigata.

bullatŭs - . White. - 7, H. De. Cl, Virginia . 1759 buxifolrus to thite. cassinoĩdes: : White: cassinoides: : White.: 8, G. Ev. S. Canaries: 1779 cymúŭs. * * White. : 5, G. Ev. S. C. G. H. : 1817 cymósŭs
emarginatŭ: * White. * 7, G. Ev. S. C. G. H.
G. Ev. S. C. G. H. 1815
$\quad 1820$

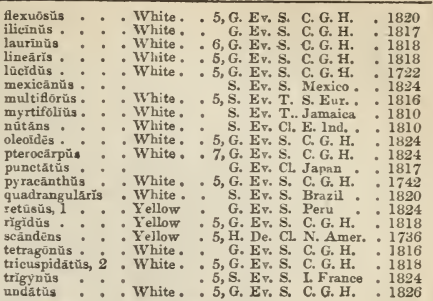

CFLANDiNr, see Chelidōnĩum.

Crilanding, see Boccöntä frutéscẽns.

CrLery, see Apīüm gravěolēns.

CELt, the hollow part of a capsule, in which the seeds are lodged, and the part of the anthers which contains the pollen.

CELLULAR, composed of cells.

CвLös̆ă, Linn. From kelos, burnt; the flowers of some of the species appear as it were singed or burnt. Linn. 5, Or. 1, Nat. Or. Amarantacea. These are all ornamental or curious plants, growing from one to five feet high; the species should be sown in a hotbed frame, or in a hothouse, and when of a sufficient strength, they should be transplanted into single pots, and placed amongst other hothouse or greenhouse annuals.

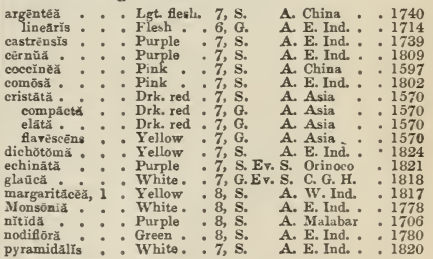

CẼrs̆̌̆, Linn. In honour of Olaus Celsius, D.D. professor of oriental languages in the university of Upsal, and friend of Linnæus. Linn. 14, Or. 2 , Nat. Or. Scrophulariacee. This is a genus of ornamental plants, from two to six feet high; its species must be raised on a mild hotbed, and then transplanted in pots, as it is necessary they have the protection of a stove or greenhouse during winter.

\begin{tabular}{|c|c|c|c|}
\hline 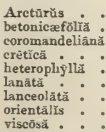 & $\begin{array}{l}\text { Yellow } \\
\text { : Yellow } \\
\text { Yellow } \\
\text { : Yellow } \\
\text { Yellow } \\
\text { : Yellow } \\
\text { Yellow } \\
\text { - Brn, yel. } \\
\text { - Yellow }\end{array}$ & $\begin{array}{l}8, \mathrm{~F} . \\
: 7, \mathrm{~F} . \\
: 7, \mathrm{~S} . \\
: 7, \mathrm{~F} . \\
: 7, \mathrm{~F} . \mathrm{Ev} . \\
: 7, \mathrm{~F} \\
: 7, \mathrm{H} . \\
7, \mathrm{~S} .\end{array}$ & $\begin{array}{l}\text { B. Candia . } \\
\text { B. N. Afries } \\
\text { A. E. Ind. } \\
\text { B. Crete : } \\
\text { B } \\
\text { S. } \\
\text { B. Levant . } \\
\text { A. Levant : } \\
\text { A. }\end{array}$ \\
\hline
\end{tabular}

CẼLsŭs, upright, stately, tall.

CÉLTis, Linn. One of the ancient names given to the Lotus. Linn. 23, Or. 1, Nat. Or. Ulmacea. This is an ornamental genus of trees and shrubs, varying in height from six to fifty feet; the most of them do very well in any common garden soil, and are very suitable for the back of shrubberies and plan. tations; increased by seeds or layers. Synonyme:

1. C. cordifolia.

aculeătă . . Green austrāịs crassifoliă, lavigātă

$\lim$ occidentilis

cordätă : Green

scabriūscúla, 2 Green
orientâlis . . Grn. yel
S. Ev. T. Jamaica

5, H. De. T. S. Eur.

4, H. De. T. N. Amer.

H. De. T. Louisiana

8, S. Ev, T. Jamaiea

- 1739

4, H. De. F. N. Amer.

4, H. De. F. N. Amer.

S. Ev. T. E. Ind. ? 1820
1791

1796

1823

656 


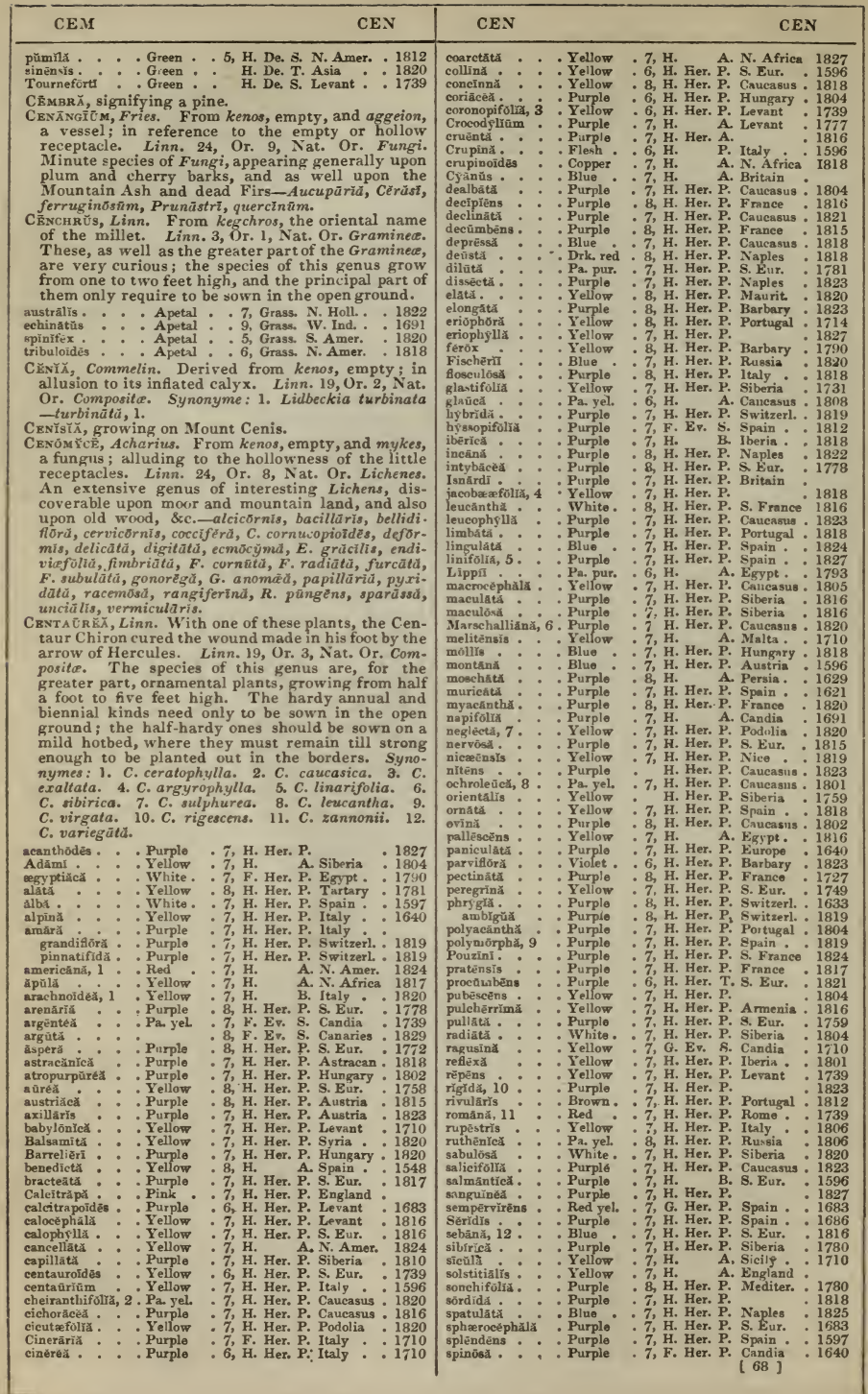




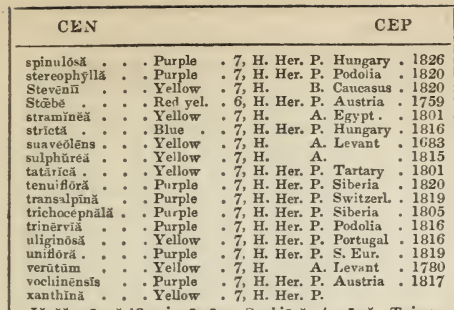

Jăcěă, nīgră 13, nigrëscēns, Scabiōsă, tagānă, Triumfêtti.

CвмтотнйcA, Desfontaines. From kenteo, to prick, and theca, a sheath; in reference to the prickly sheath. Linn. 3, Or. 2, Nat. Or. Graminea. A curious grass, of the simplest culture. Synonyme: 1. Cenchrus lappaceus.

lappãcè̃, 1 . . Apetal . . 7, Grass. E. Ind. • . 1773

Crntral-placknta, a column in the centre of fruits to which the seeds are attached.

Centrantruťs, Decandolle. From kentron, a spur, and anthos, a flower; the corolla being furnished with a spur at the base. Linn. 10, Or. 1, Nat. Or. Valerianaced. The plants are ornamental, growing from one foot to one and a half high; they succeed in any common garden soil, in the open borders; seeds. angustifolius . Crimson . 6, H. Her. P. S. Eur. . 1759 calcítrăpă *: Purple : 6, H. A Portugal : 1683 rüber : : Crimson : 6, H. Her. P. Britain flôrĕ-ălbó : White. : 6, H. Her. P. Britain

Cвntrocārphă, D. Don. From kentron, a sharp point, and karphe, chaff; the palex being bristly. Linn. 19, Or. 3, Nat. Or. Composite. An interesting genus of herbaceous plants, that thrive well in common soil, and are increased by dividing the roots, and by seeds. Synonymes: 1. C. acutifolia, Rudbeckia Nenmani.

chrysōmèlă, 1 . Yellow • 8, H. Her. P. S. Amer. . 1821

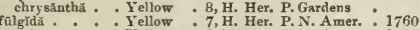

gräcilis: : : Yellow : 9, H. Her. P. N. Amer. : 1825

grandiflöră: : : Yellow :9, H. Her. P. N. Amer. : 1830

hirti: Y Yellow

rädülă: : Yellow

spathulata: : : Yellow

subtomentōsă . Yellow : 8, H. Her. P. N. Amer. : 1809

Centrocininióm, D. Don. Derived from kentron, sharp point, and kline, a bed. Linn. 19, Or. 2, Nat. Or. Composita. A genus of ornamental stove plants, succeeding best when grown in a light vegetable soil; seeds.

apprëssūm . . R Roøy . . 1, S. Ev. S. Peru . . 1830 refléxüm : : Rosy : 8, S. A. Peru: : 1830

Centrospērmūm, Sprengel. From kentron, a spur, and sperma, a seed; alluding to the spiny points of the pappus. Linn. 19, Or. 2, Nat. Or. Composito. A pretty annual, that requires sowing in the open border, in common garden soil.

chrysănthăm . Yellow . 7, H. A. Spain . . 1823 Crntaurv, see Centañurĕ.

CentêncŭLưs, Linn. The name applied by the Romans to a small plant, found in cultivated land. Linn. 4, Or. 1, Nat. Or. Primulaced. A curious annual, of easy culture in sandy loam.

miñmŭs . Flesh . 6, H. A. Britain .

Cerpateris, Swartz. From kephale, a head; the flowers disposed in heads. Linn. 5, Or. 1, Nat. Or. Cinchonacea. An ornamental genus of plants, from one to fifteen feet high; they thrive well in a mixture of peat and sandy loam, and cuttings strike root freely under a glass. Synonymes: 1. C. calycina. 2. Tapagomia purpurea. 3. $T$. violacea.

axillärĭs, 1. . White. . 4, S. Ev. S. Brazil . . 1816 elátă : : Purple : S. Ev. S. Jamaica : 1793 involucrătă : White.: 7, S. Ev, S. Guiana : 1826 pedunculata : White. 2, S. Ev. S. S. Leone punicéă. : : White.: 7, S. Ev. S. Jamaica : 1820 purpürĕa, 2 - Wht pur. 5, S. Ev. Tr. Trinidad : 1821 tomentōsă. : Brown. 8, S. Ev. S. Trinidad : 1825

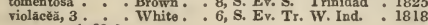

Crpha1.AnthĒră, Richard. From kephale, a head, and anthera, an anther. Linn. 20, Or. 1, Nat. Or. Orchidacer. A genus of very pretty plants, succeeding well in peat and loam, and increased by dividing the roots. Synonymes: 1. Epipactis cnsifolia. 2. E. pallens. 3. E. rubra.

ensiföliă, 1 . . White . . 6, H. Ter. Britain palléns, 2: : : White: : 6, H, Ter. Britain

CePHa1.ĀNThŭs, Linn. From kephale, a head, and anthos, a flower; referring to the flowers being disposed in globtuar heads. Linn. 4, Or. 1, Nat. Or. Cinchonacea. An ornamental shrub, growing seven feet high; the soil best for it is a mixture of sandy peat and loam; propagation is easy, the ripened cuttings root readily under a glass, or by layers.

occidentalis . - White. . 8, H. De. S. N. Amer. - 1735 brachy̆podŭs : White. 8, H. De. S. N. Amer.

Cephalic, medicinal to the head.

Cвpнalŏphóră, Cavanilles. From kephale, a head, and phoreo, to bear; the flowers are united in little heads. Linn. 19, Or. 1, Nat. Or. Composite. An annual of little beauty, and easy culture. Synonymes: 1. Hymenopappus glaucus, Grämĭ́̆ aromătĩcă - gla ũcă, 1.

Cephatotríchüm, Link. From kephale, a head, and thrix, a hair; the heads being covered with hairs. Linn. 24, Or. 9, Nat. Or. Fungi. A minute fungus discernible in general on decayed or decaying branches-nanum.

Cephalötüs, R. Bron'n. Fromkephalotes, headed; its filaments of stamens are capitate. Linn. 11, Or. 6, Nat. Or. Cephalotacece. A most curious little plant of rather difficult management, it should be potted in chopped moss, and boggy soil, mixed, the pots well drained, and the plants carefully watered. A glass should be placed over it at all times, and if allowed plenty of light and a temperature of 65 or 70 degrees, offsets treated in the same manner will speedily make roots.

folliculärls. . White. . G. Her. P. N. Holl. . 1822

CrRacrous, wax-like.

CERĂMĨ̃ M, Rochel. Derlved from keramion, a pitcher from the resemblance of the capsules. Linn. 24, Or. 7, Nat. Or. Algae. An extensive genus of seaweeds-arbūscǔlă, Borrērī, corymbōsūm, Davièsīin, diaphănūm, D. pilōsūm, florĩdūlūm, Hookērī, interrīptūm, lanuginōsâm, pătēns, pedicellätūm, pin-

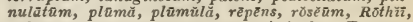
rūbrūm, tetragōnūm, têtrīcam, thujoüdēs, Turnēri, versĭcolठ̈r.

Cerranthēră, Beaurois. From keras, a horn, and anthera, an anther; the lobes of the anthers being terminated by a bristle. Linn. 5, Or. 1, Nat. Or. Violace. An ornamental genus of stove plants, growing about six feet high; it must be grown in sandy loam, and will increase by cuttings in sand, under a glass in heat.

subintegrifölǐ . White • . 6, S. Ev. S. Guinea . . 1824

CKR Ascrnous, deep red, cherry-coloured.

CrRĀstĩû, Linn. From keras, a horn; because many of the species have capsules like an ox's horn. Linn. 10, Or. 4, Nat. Or. Alsinacer. A genus of little interest; they vary in height from half a foot to two feet high. The herbaceous kinds have a pretty appearance on rock-work. Any light loamy soil suits them; seeds or suckers.

alpīnüm - . . White. . 6, H. Ev. Tr. Britain

glaciālě. : White : 6, H. Ev. Tr. Switzerl. : 1814 grandiflorum : White: : 6, H. Her. Tr. Siberia : 1818 lanatūm . : White. 6, H. Her. Tr.Alps * : 1819 latifolium : White : 6, H. Her. Tr. Britain pusillūm : : White :6, H. Her. Ar. Siberia : 1824 sylvãticūm: : White: 6, H. Her. Cr. Hungary I820

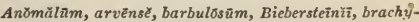
pětălūm, campanulātūm, caucāsīcūm, dahūricūm,

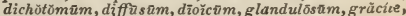
hîrsūtūm, holosteoìdēs, inflätūm, māritīmūm, matrēnsĕ, mäxĭmūm, nemorãlë, ovälĕ, ovätūm, pauci-

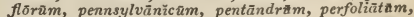
pilosūm, pubēscēns, ruderātūm, rupēstrě, semidecūndram, serpyllifotżum, Sprengētżi, stellarioüdes, strīctūm, S. suffruticōsīm, taūrícâm, Tenoriänam, tetrāndrūm, tomentōsūm, viscōsūm, vulgātūm.

Č̈răsưs, Jussieu. Reported to have been first 
brought from Cerasus, a town of Pontus, in Asia. Linn. 12, Or. 1, Nat. Or. Rosacee. A valuable genus of fruit trees, that grow well in any common soil, and are increased by seeds, budding, or grafting, with perfect ease. Synonymes: 1. C. macrophylla. 2. Prunus rubra. 3. P. pubescens. 4. C. salicina. 5. Prunes serrulata.

ธviǔm . Whito 4, H. Be. T. England macrocārpă : : White : 4, H. De. T. Switzerl multiplex : : White: 4 , H. De. T pallidä. : White : 4, H. De. T

sylvestriss : Whito : 4, H. De. T. Britain .

boreallis : White 5, H. De. T. N. Amer.

canadënsis : : Whito : 5 , H. De. T. Canada.

caproniănå : : White : 4, H. De. T. S. Eur.

cordigeră: : White : 4, H. De. T.

gobbetta : : Whito $4, \mathrm{H} . \mathrm{De}$ T

griotta : : White 4 , H. De. T.

Montmorencys̊n White 4 , H. De. T

mültiplex. Whito : 4, H. De. T.

palles êns : Whito : 4, H. De. T.

persicitolia : White 4 H. We. T

polygyna : White : 4 , H. De. T

caroliniână : : White : 5, H. Ev. T. Carolins . 1759

Chamæeêrăsŭs : White : 5, H. De. S. Autstria. : 1597

chicâsă. : White : 4, H. De. S. N.Amer. 1806

depréssă : : White : 5, H. De. S. S. Eur. : 1805

durăcină . : White , 4, H. De.T. S. Eur. .

cordigera, White , 4, H. De. T.

mammillaris, 1: White : 4, H. De. T.

obtusata White

hyemălis : : Wlite

japōniceă. . Pink,

mültriplēx : Prnk :

Juliảnă

péndŭlà : Whit : W

Laurocèrăsǔs: Whito

lusitâñ̌că * . White

Mahalè̉b : White

früctâ-fiàvo . White

latifolia - White

nepalēnsis: : White

Pecidentalis: : : White

bracteốsă: : White

parvillora

rūbră, 2

vulgárís

"White

, White

persicifolră : Whito

proutrât

Pseadó-cĕrăsús

pubéscēns, 3

pümilä

pygmāă, 4 .

mperfiơrêns

sessiliflóx

serruláta, 5 .

spherocârpa
virginianal.

5, H. De. S. N. Amer. . 1805

4, H. De. S. Japan : 1810

4, H. De. S. Jnpan : 1810

4, H. De. T, S. Eur, :

4, H. De. T.

4, H. De. T. S. Eur. . . 1821

4 H. Ev. S. Levant : 1629

5, H. Ev. S. Portugal : 1648

4, H. Ev. T. Austria , : 1714

5, H. De. T. S. Eur.

6 H. De. T. S. Eur. : F. De. T. Nepal

S. Ev. T. Jamnica

4, H. De. T. Britnin

4, H. De. T. N. Eur.

4, H. De. T. Britain .

4, H. De. T. Britain

5, H. De. T. N. Amer,

5, H. De. S. N. Amer.

4, H. De. S. Crete

4 H. De. S. China

, H. De. S. N. Amer 182

5, H. De. S. N. Amer. 1756

5, H. De. S. N. Amer.

4, F . De T China 1829

4, H. De. T

6, H. De. T. N. Amer. 1629

4, F. De. S. China ? 1822

6, S. Ev. S. Jumaica : 1820

5, H. De. T. Virginia : 1724

Cerratiór in allusion to the stigma having the appearance of a horn. Linn. 21, Or. 2, Nat. Or. Empetracee. This is a very pretty greenhouse under-shrub, that should be grown in a sandy peat, and may be increased by cuttings potted in sand, under a glass.

ericoídēs . . Brown . 6, F. Ev. S. N. Amer. . 1826

Cerătĭūm, Albertini. From keration, a little horn; because the plants resemble small horns. Linn. 24, Or. 9, Nat. Or. Fungi. These are minute plants, generally found growing on dead wood in the form of little horns-hydnozdés.

CERATocärpüs, Linn. From keras, a horn, and karpos, fruit ; in reference to the caly $x$ being two-horned. Linn. 21, Or. 1, Nat. Or. Chenopodiacee. An uninteresting annual, only requiring to be sown in the open border-arenäriũs.

CRRA toč̃phäLťs, Manch. From keras, a horn, and kephale, a head; on account of the end of the seeds in the heads of the capsules being horned. Linn. 5, Or. 6, Nat. Or. Ranunculacea. A somewhat curious genus of plants, only requiring to be sown in the open border, and treated as other hardy annuals. Synonyme: 1. Ranunculus falcatus.

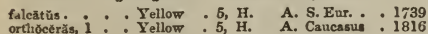

Ceratōchlŏă, Decandolle. From keras, horn, and chloa, grass; in reference to the seeds having three little horns, Linn. 3, Or, 3, Nat. Or. Graminea.
An uninteresting grass, requiring only to be sown in common soil. Synonyme: 1. Festuca unioloidesuniolōides 1.

CeratōnǏ̃, Linn. From keration, a horn or pod, in allusion to the shape of the pods. Linn. 23, Or. 2, Nat. Or. Leguminose. Scarcely worth cultivating, except for botanical collections; it grows to the height of fifteen feet, in a mixture of loam and peat; cuttings in sand will strike under a glass.

snlquă . . . . Red yel. . 9, G. Ev. T. Levant. . 1570

Ceratopľtălüm, Smith. Derived from keras, a horn, and petalon, a petal; in reference to the form of the petals. Linn. 10, Or. 1, Nat. Or. Cunoniacea. A fine greenhouse plant, growing best in a sandy loam, and increased by cuttings in sand under a glass.

gummiferrùm * Yellow . G. Ev. T. N. Holl. . 1820

CRRATOPhȲLLÔM, Linn. From keras, a horn, and phyllon, a leaf; the petals are cut so as to appear like a stag's horn. Linn. 21, Or. 9, Nat. Or. Ur ticacea. Uninteresting water plants, thriving in any pond, and easily raised by seeds-demersim, submêrsüm.

CRRATOPHY̌LŬs, leares like the upper part of a stag's horn.

Crratosānthēs, Jussieu. From keras, a horn, and anthos, a flower; referring to the inner segments. Linn, 21, Or. 10, Nac. Or. Cucurbitacece. A climbing plant, of no beauty, and grows in any common soil? increased by dividing the roots. Synonymes: 1 . Trichosanthes tuberosa, corniculata-tuberōsă 1.

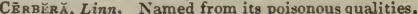
in allusion to the dog Cerberus, whose bite was poisonous, Linn, 5, Or. 1, Nat. Or. Apocynacea. An ornamental genus of stove plants, succeeding well in a rich mould, and cuttings in sand root freely under a glass in heat. The fruit of $\boldsymbol{C}$. Ahouai is a deadly poison. The Indians put small stones into the empty nuts, with which they ornament their legs; and the bark of C. Odallam is purgative.

Ahooal . - Yellow 6, S. Ev. T. Brazil * 1739 fruticosa: : Red : 5, S. Ev, S. Pegu : 1819 maculäta : : Whito: : 6, S. Ev. T. Bourbon : 1782 maculata : : Whito. : 6, S. Ev. T. Bourbon : 1782 Thevetia : : : Yellow $: 6$, S. Ev. S. N. Spain $: 1735$ thevetiorde: : Yellow :6, S. Ev. S. N. Spain : 1800

CrRbgra, see Tanghiñu.

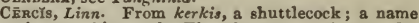
given to this tree by Theophrastus. Linn. 10, Or. i, Nat. Or. Leguminose. This is a beautiful genus of ornamental trees, flowering early in spring, and looking very pretty planted singly on a lawn, or trained to a wall or trellis; they grow to the height of twenty feet, and prefer an open loamy soil : plentifully increased from seeds.

canadēnsǐs . - Pa. red • 5, H. De. T. N. Amer. 1730 siliquăstrüm : : Red : 5, H. De. T. S. Eur. : 1596 flöré-albo : : White: : 5, H. De. T. S. Eur. : : parviflórum : Purple : 5, H. De. T. Bucharia : 1827

Cgrāsiñ, Pergoon. From the goddess Ceres, the inventor of tillage. Linn. 3, Or. 2, Nat. Or. Graminece. This is a very pretty grass, that requires to be grown in a greenhouse, and succeeds in any common soil; increased by seeds. Synonyme. 1. Paspalum membranaceum.

elĕgăns . . . A petal . 7, G. Her. P. Peru . . 1816

CĒrĚŭs, Decandolle. From cereus, signifying pliant,

like wax; referring to the shoots of some of the species being easily bent. Linn. 12, Or. 1, Nat. Or. Cactacer. A most beautiful genus, belonging to $\mathrm{Cac}$ tacea ; some of the species produce the most splendid flowers that are grown in our stoves; they succeed well in a sandy loam, the pots being well drained; in winter they require little or no water, but as soon as the flower-buds appear, they should have a good supply; increased by cuttings, which should be laid to dry a few days before being planted.

Ethrops . . S. Ev. S. Brazil . . 1829 affinĩs $: \vdots$ White. . S. Ev. S.

albisetosǔs: : : White. S. S. Donin. . 1816 albispinŭs : : $\quad$ S. Ev. S. St. Domin.. 1816 amblÿgónŭ: : * S. Ev. S. B. Agres : 1836 вrcuátís: : : Whito. . S. Ev. S. Agred: 1835 $\begin{array}{ll}\text { breuatis : : Whito. } & \text { S. Ev. S. }\end{array}$

[ 70 ] 


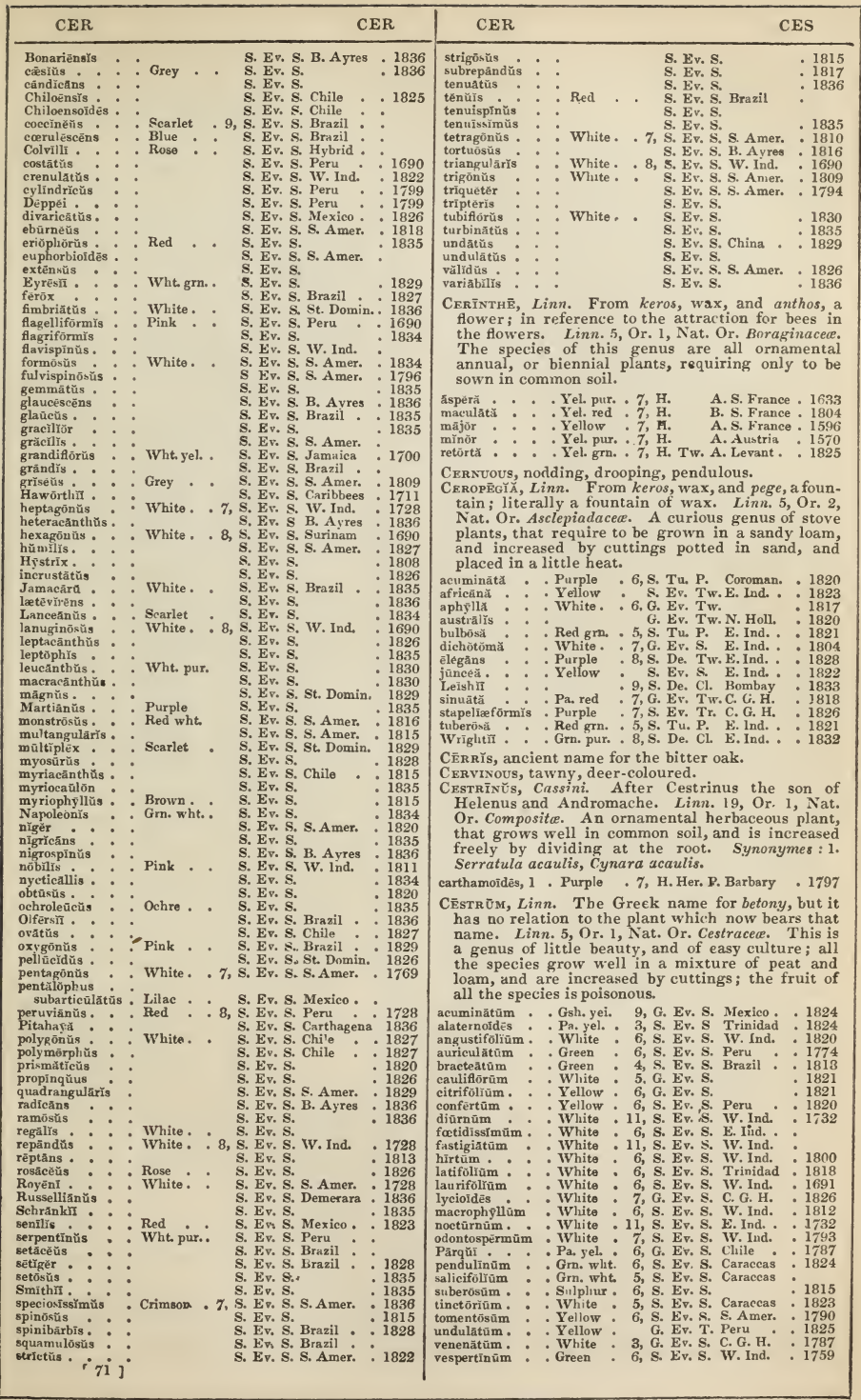


CETRĀRǏ , Acharius. From cetra, a buckler; in reference to the receptacle being buckler-shaped. Linn. 24, Or. 8, Nat. Or. Lichenes. Is a genus of lichens; some of the species are used for food in Iceland and Lapland. C. islandica and nivalis are used as tonic, demulcent, and nutrient-glañcă, G. fāllāx, isländīcă, juniperină, J. Pinüstrī, nivālis, sepincőlă.

CвUtröspŏră, Fries. From keutho, to hide, and spora, a sporule; in allusion to the sporules being hidden. Linn. 24, Or. 9, Nat. Or. Fungi. A genus of very minute fungi, found on decaying holly, larrel, and other leaves-Laūri, phacidiożes, phaeócones.

С 1 , Nat. Or. Orchidacee. This is described as a most singular plant, but no figure of it has yet appeared. It will most probably be found to succeed

when treated as is recommended for the genus Vanda.

\section{Barkěri}

$$
\text { S. Epi. Para }
$$

Снжтлснцақӑ, D. Don. From chaite, a bristle, and chlaina, a covering; the points of the involucre being covered. Linn. 19, Or. 2, Nat. Or. Compositce. This is an ornamental, greenhouse, herbaceous plant, succeeding best in sandy loam; seed.

odorătă. . . Red . . 8, G. Her. P. Chile . . 1830

Chжrophȳter, Hoffmansegg. From chairo, to rejoice, and phyllon, a leaf; alluding to the smell of the leaves. Linn. 5, Or. 2, Nat. Or. Umbelliferce. An uninteresting genus of plants, varying in height from one to three feet; the annual and biennial species are best sown in the open ground in common soil. Synonyme: 1. Myrrhis bulbosa.

aromarteūm * . White . 7, H. Her. P. Germany - 1726 tenuifólrüm : White. . 5, H. hler. P. S. Eur. . 1818

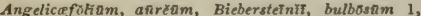
capensē, cicutäriam, colorātam, divaricâtım, hirsá-

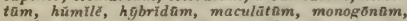

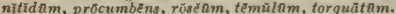

Chatanthêră, Ruiz el Pavon. From chaite, a bristle, and anthera, an anther; because the anther is furnished with a hairy tuft. Linn. 19, Or. \&, Nat. Or. Comporito. This is a pretty genus of herbaceous plants, which thrive best when sown in a mixture of peat and loam, increased by dividing at the roots. Synonyme: 1. Perdicium Chilense.

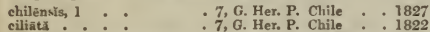

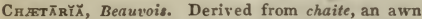
or bristle. Linn. 3, Or. 2, Nat. Or. Graminec. This is an interesting genus of grasses, that grow well if sown in any coinmon soil. Synonyme: 1 . Aristida adscensionis-adscensionis 1, carulescens, divaricata, hystrix.

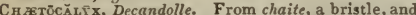
kalyx, calyx; the caly $\mathrm{x}$ is covered with bristles. Linn. 17, Or. 4, Nat. Or. Leguminose. Is an ornamental stove climber, that thrives well in a mixture of peat and loam; increased by cuttings. Synonyme: 1 . Glycine vincentina.

vincentină, 1 . Yellow . 6, S. Ev. Tu. St. Vincent 1823

С натоgĀstră, Decandolle. From chaite, a bristle, and gaster, a belly; alluding to the tube of the calyx being covered with hairy scales. Linn. 10, Or. 1 , Nat. Or. Melastomacere. Interesting plants, succeeding well in a mixture of peat and loam, and increased by seeds.

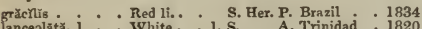

Снатӧміั $\mathrm{M}$, Kunze. Named from chaite, a bristle; in allusion to the hairy appearance of the plants. Linn. 24, Or. 9, Nat. Or. Fungi. This is a minute species of Fungus, found growing on damp straw, \&c. - - elätũm.

Снжто̄PHŐ́R̆, Agardh. From chaite, a bristle, and phoreo, to bear ; the filaments being terminated by a bristle-like point. Linn. 24, Or. 7, Nat. Or. Alga. This is a curious genus of Alge, found growing on marine rocks, in lakes, ditches, \&ce.-endiviceföliă, E. crässă, peliñtü, pisiförmǐs 1, tuberculōsă.

С̆дег̈spóră, Agardh. From chaite, a bristle, and spora, a seed; the sporules are placed on fine divisions of the filaments. Linn. 24, Or. 7, Nat. Or.
Alga. A fine genus of Alga, found growing on the sea-shore-Wiggit.

Снжтōspó Ră, $\boldsymbol{R}$. Brown. From chaite, a bristle or awn, and spora, a seed. Linn. 3, Or. 1, Nat. Or. Cyperacee. An uninteresting genus of grasses, that grow well in a boggy situation; increased by dividing at the roots. Synonyme: 1. Schenus ferrugineus.

turbinătă . . Apetal . 7, Grass. N. Holl. . . 1820

\section{ferruginěă, 1 .}

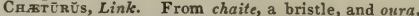
a tail; in reference to the silky appearance of the panicles. Linn. 3, Or. 2, Nat. Or. Graminea. An uninteresting grass, that grows in any common soil-fasciculätrus.

ChAFp-rLower, see Altcrnanthëră Achyrănthă.

CHAFT, bearing processes like chaff.

Сн ALLLËTİ̆, Decandolle. In honour of Mr. Chaillet, Swiss botanist. Linn. 5, Or. 1, Nat. Or. Chailletiacec. A poisonous greenhouse shrub, that grows about five feet high, succeeding well in a mixture of peat and loam, and increased by cuttings potted in sand, under a glass.

toxicāriă . . . White . . 6, G. Ev. S. S. Leone . 1824

CrazazA, a spot on the seed, indicating where the vessels of the raphe terminate.

Chaмғдӧrüă, Willdenow. From chamai, dwarf, and dorea, a gift; supposed to refer to the flowers being near the ground. Linn. 22, Or. 6, Nat. Or. Palmacca. An ornamental genus of Palms, growing from eight to ten feet high; they thrive best in a sandy loam in a moist hea?. Synonyme: 1. Numezia fragrans.

frägrans, 1 . . White . Palm. Trinidad . 1820 gracilis : : Wht grn. : Paim. Caraceas : 1803

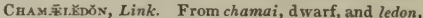
a kind of cistus; from its having the appearance of a cistus. Linn. 5, Or. 1, Nat. Or. Ericaced. This is one of the most interesting of our native plants it delights in a sandy peat, and may be increased by layers. S.ynouymes: 1. Azalea procumbens, Loiseleuria procumbens.

procūmbẽns, 1 . Pink . . 4, H. Ev. S. Britain .

Снамfifritsy, Willdenow. Derived from chamai, ground, and leirion, a lily ; on account of the appearance of the plant. Linn. 22, Or. 6, Nat. Or. Melanthacee. An ornamental herbaceous plant that grows best in a mixture of peat and loam, and is increased by dividing at the roots. Synonymes 1. Veratrum luteum, Helonias lutea, dioica, Melanthium densum.

carolinianúm, 1 . Yellow - 7, H. Her. P. N. Amer. 1759

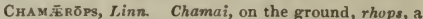
twig; alluding to the low growth of the plants. Linn. 23, Or. 2, Nat. Or. Pulmacer. A handsome genus of the Palm tribe, attaining thirty feet in height, and delighting best in a rich loamy soil, and with the exception of $\boldsymbol{C}$. guianensis and gracilis, they do very well in a common greenhouse. Syno. nyme: 1. Corypha palmata.

excilsx : lo excerilis : : : : Gm. wht. guianēnsǏs : : Grn. whit. : Palm. Guiana: 1824 hŭmilis . : Grn wht. 2 , Palm. S. Eur. : : 1731 hystrix : : Grn. wht. ${ }^{\circ}$ Palm. Georgia : 1801 serrulatä, : Grn. wht. : Paim. Carolina : 1809 С намissō misso, the companion of Kotzebue, Linn, 5, Or. 1, Nat. Or. Amarantacee. This is a beautiful stove plant, attaining the height of five feet; it thrives well in common soil, and may be increased from cuttings. Synonyme: 1. Achyrauthes altissima.

altissimñ, 1 . Yellow . 7, S. E . S. Jamaics . 1816

Chamosiris, see Anthĕmis.

CrANXEL-LBAVED, folded together, so as to resemble a channel for conducting water.

C нартїIÄ, Ventenat. In honour of M. Chaptal, a celebrated French chemist. Linn. 19, Or. 4, Nat. Or. Compositio. This is a pretty hardy herbaceous plant, that succeeds well in common soil, and increases by dividing the roots. Synonyme: 1. Tussi. lago integrifolia.

tomentôsă, 1 . White . 5, H. Her. P. N. Amer. . 1806 
CHĀR̆, Linn. From chairu, to delight; in allusion to its habitation. Linn. 24, Or. 7, Nat. Or. Alga. $A$ curious and interesting genus, requiring to be grown in ponds or cisterns, in a peat soil-üspěră, hìspĩdă, vulgärìs.

Charlas's sceptre, see Pediculärĭs Scēptrūm carolī nūm.

CHARLOCK, see Sinãpĩs arvēnsũs.

CHARLWoōnY̆, Sweet. In honour of G. Charlwood, F.L.S., an enthusiastic English botanist. Linn. 6, Or. 1, Nat. Or. Liliacece. This is a beautiful stove genus, that attains the height of ten feet; the species thrive well in a mixture of peat and loam, and are increased by cuttings in sand, under a glass, in heat. Synonymes: 1. Dracana australis. 2. D. indivisa. 3. D. stricta. austrälišs, 1 : : Blue wht.
congestä S. Ev. T. N. Zeal. : 1823

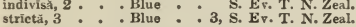

Charred, blackened by fire.

Chasmónî́, Presb. From chasmao, to gape wide; in reference to the calyx being spread open. Linn. 14, Or. 1, Nat. Or. Labiatce. An ornamental annual, that only requires sowing in common soil Synonyme: 1. Moluccella spinosa.

inciš̆, 1 . . Pink . . 7, H. A. Levant. . 1596

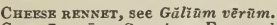

Cheisánthēs, Swartz. From cheilos, a lip, and anthos, a flower; in allusion to the form of the indusium. Linn. 24, Or. 1, Nat. Or. Polypodiacea. This is a beautiful genus of ferns, that succeed best when grown in a mixture of peat and loam, and increase by dividing the roots. Synonymes: 1 . Polyporium fragrans. 2. Pteris gracilis. 3. Notholona cheilanthoides. 4. Adiantum pteroides. 5. Nephrodium lanosum.

\begin{tabular}{|c|c|c|c|}
\hline 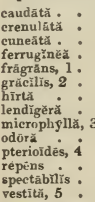 & $\begin{array}{l}: \text { Brown } \\
: \text { Brown } \\
: \text { Brown } \\
: \text { Brown } \\
\text { Brown } \\
: \text { Brown } \\
: \text { Brown } \\
\text { Brown } \\
\text { Brown } \\
: \text { Brown } \\
: \text { Brown } \\
: \text { Brown } \\
: \text { Brown } \\
: \text { Brown }\end{array}$ & $\begin{array}{l}\text { 6, G. Her. P. N. Holl } \\
\text { S. Her. P. } \\
\text { S. Her. P. } \\
\text { 6, S. Her. P. } \\
\text { 8, G. Her. P. Madeirs } \\
\text { 7, H. Her. P. N. Anner. } \\
\text { 6, G. Her. P. C. G. H. } \\
\text { 6, S. Her. P. N. Spain } \\
\text { 6, G. Her. P. W. Ind. } \\
\text { 6, F. Her. P. Switzerl. } \\
\text { 7, G. Her. P. C. G. H. } \\
\text { 7, S. Her. P. W. Ind. } \\
\text { 9, S. Her. P. Brazil } \\
\text { 8, H. Her. P. N. Amer. }\end{array}$ & $\begin{array}{l}: 1824 \\
: 1831 \\
: 1831 \\
: 1816 \\
: 1878 \\
: 1806 \\
: 1823 \\
: 1819 \\
: 1775 \\
: 1824 \\
: 1819\end{array}$ \\
\hline
\end{tabular}

Cheirāxthŭs, Linn. Derived from its A rabic name kheyrey, and anthos, a flower. Linn. 15, Nat. Or. Cruciferce. These are all ornamental dwarfish plants, and the common kinds thrive well in light soil, the rest require it somewhat richer, and the protection of a frame or greenhouse in winter. Synonyme: 1, C. dubius.

5. C. E. S. Earo 01810 arböréŭs : : Yellow : 5, G. Ev. S. Egypt : 1827 Cheiri $:$ Orange : 5, F. Ev. S. S. Eur. : : 1573 ferruginęùs: : Brown : 5, F. Ev. S. S. Eur.: : 1573 flavéscéns: : Yellow : 5, F. Ev. S. S. Eur. flöré-pléñ : Yellow : 5, F. Ev. S.

grandifiorns : Yellow : 5, F. Ev. S. S. Eur. . 1573

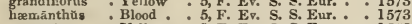

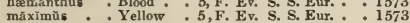

pàtŭlüs. : Yellow : 5, F. Ev. S. S. Eur. : : 1573

sanguineùs: . Drk, brn. . 5, F. Ev. S.

serrătăs : : Yellow : 5, F. Ev. S. S. Eur. . 1 1573

thyysoìdés : : Blood * 5, F. Ev. S. S. Eur. : 1573
văriús

fIrmŭs : : : Yellow : 6, F, Ev, S. Europe : 1873

fruticulósŭs : Yellow 5 , H. Her. P. Britain :

linifơlǐ̌s : : Purple : 4, G. Ev. S. Spain

mutábills : : Yel. pur. : 4, G. Ev. S. Madeira

longifölin̆s: : Wht. pur. 9, G. Ev. S. Madeira

1815

1777

1815

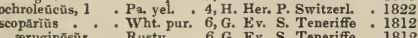

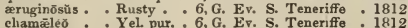

semperfioréns: : White. : G. Ev. S. Barbary : 1815

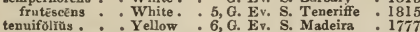

Chetrostémōn, Humboldt and Bonpland. From cheir, the hand, and stemon, a stamen; on account of their having five stamens, and the flaments united at the base. Linn. 16, Or. 6, Nat. Or. Sterculiacece. This is a very handsome plant, on account of its five-lobed leaves; it grows about thirty feet high, [ 73 ] in a sandy loam, and cuttings with their leaves entire, potted in peaty soil, plunged in heat, root freely.

platanoìdēs

S. Ev. T. N. Spain . 1820

ChgLrDõnūūm, Linn. The plant is said to flower at the arrival and dry up at the departure of the swallows; whence the name, from cheledon, a swallow. Linn. 13, Or. 1, Nat. Or. Papaveracece. The species of this genus are interesting, and succeed well in common garden soil. Synonyme: 1. C. dahuricum.

grandiflòrüm, 1 . Yellow * 5, H. Her. P. Dahuria . 1820 laciniátūm. . Y Yellow : 5, H. Her. P. S. Eur.

mäjüs.

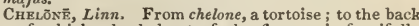
of which, the helmet of the flowers is fancifilly compared. Linn. 14, Or. 2, Nat. Or. Scrophulariacee. This is a beautiful hardy herbaceous genus, that ought to have a place in every collection; the species succeed well in a mixture of peat and loam, and are increased by dividing the roots. Synonyme: 1. C. major.

barbätă . * Scarlet * 7, H. Her. P. Mexico 1794 . Searlet 9. Her. P. California . 1834 gentianoildẽs - Oran. scar. 7, F. Her. P. Mexico . 1825 glābră * * . White - 8, H. Her. P. N. Amer. - 1730 Lyōnī, 1 : : Purple : 8, H. Her. P. N. Amer. - 1812

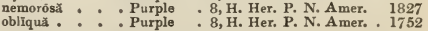
ChвNör.̄̄a, Linn. Supposed to be derived from chen, a goose, and leia, prey. Linn. 5, Or. 1, Nat. Or. Chenopodiacece. The beauty of this plant consists in its silvery leaves; its height is seldom more than one foot, and any rich light soil will suit it; cuttings root freely placed under a glass.

diffusă . . . Green . . 8, G. Ev. S. C. G. H. . 1758

CheNopōdūum, Linn. From chen, a goose, and pous, a foot; in reference to many of the species having leaves similar to the webbed feet of the goose. Linn. 5, Or. 8, Nat. Or. Chenopodiacea. A genus of so little beauty, that its species are for the greatest part only grown in botanical collections; when grown they require to be sown on a sandy soil in the open border. Synonymes - 1. Salsola fruticosa. 2. S. divergens. 3. C. erosum. 4. Salsola salsa. 5. C. fatidum. 6. Salsola salsa.

ambrosiol̃ễs . Green . . 8, H. A. Mexicn . . 1640 fruticosum, 1: Green: 8, H. E . S. England

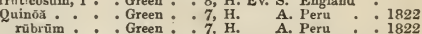
acuminātūm, acutifolîùm, àlbūm, A crassífolīūm, $A$.

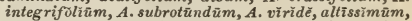
anthelmintīcūm, aristütūm, atrīplīcīs, Biebersteiniānūm, blitoĩdēs, Bonǔs-Henrīcŭs, botryoīdēs, Bötry̆s, Carthaginēnsé, caudütūm, chrysomelanospērmũum,

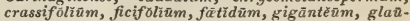
cūm, gravěðlēns, guineēnsĕ, hirsūtūm, hortēnsě 2, humifüsě, hybridūm, incīsūm, lanceolütūm, laterălĕ,

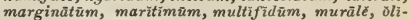
dūm, opulifoliūm 3, Pallasiānûm, parvifolīūm, pătŭlūm, petiolärĕ, polyspẽrmūm, punctulātūm, radiātūm, rhombifolīūm, rūbrūm, sīlsūm 4, Schraderiānūm 5 , sēpĩum, serotīnūm, setügěrūm, spicātūm 6, suffruti. cơsîm, ürbīcûm.

Chrerérĩ, Haller. In honour of John Henty Cherler, who assisted John Bauhin in his history of plants. Linn. 10, Or. 3, Nat. Or. Alsinacer. This is an ornamental plant, and has a good effect upon rockwork; it grows best in a sandy loam and peat, and may be increased by dividing the roots, or by cuttings.

sedoidess - . Yel, wht. 7, H. Fler. P. Scotland

Cherry, see Cèrăsĭs.

Chervil, see Dañcŭs Gingždĩtm.

Chervin, see Charophÿllüm.

Chesnut, see Castãnẽă.

Chicasaw plum, see Cĕrŭsŭs chicäsă.

ChickliNg veтcH, see Läthy̆rŭs sativeřs.

СНICK PEA, see Cïcěr.

CHICKWEED, see Alsiñ̌.

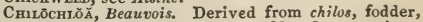
and chloa, grass. Linn. 3, Or. 2, Nat. Or. Graminece. A genus of grasses of no particular beauty, that only require to be sown in the open ground. Syno. nymes: 1. Phleum annuum. 2. P. arenaria. 3.P. 
prniculatum. 4. P. Behmeri-annua 1, arenaria 2, aspera 3 , Boehmeri 4, cuspidata.

Cнтй̄ĭ,$R$. Brown. From cheilos, a lip, and odous, a tooth; alluding to the lip being toothed. Linn. 14, Or. 1, Nat. Or. Labiate. The species of this genus are ornamental greenhouse shrubs, that succeed well in a mixture of peat and loam, and increase by cuttings potted in sand, under a glass. australis . . Violet * 7, G. Ev. S. N. Holl.

scutellarioidas: : Violet: : 9, G. Ev. S. N. Holl: 1899

Chiloglötrĭs, $R$. Bron'n. From cheilos, a lip, and glotta, a tongue; alluding to the tongue-like appendage to the lip. Linn. 20, Or. 1, Nat. Or. Orchidacece. An ornamental bulbous-rooted plant, growing well in a mixture of light turfy loam, turfy peat, and sand; and kept either in the greenhouse or in a frame.

diphylla . . . Red . . F. Ter. N. Holl. .

СатмйтнйLи, Pursh. From cheina, winter, and phileo, to love; the plants are green in winter. Linn. 10, Or. 1, Nat. Or. Pyrolacece. This is a genus of ornamental and medicinal plants, but difficult of cultivation; they succeed best planted out in peat soil, and there left to remain, as they cannot bear to be disturbed ; cuttings. Synonymes : 1. Pyrola umbellata. 2 P. maculata.

corymboran, 1 . . White. . 6, H. Her. P. N. Amer, - 1752 maculáta, 2 : Pink . 6, H. Her. P. N. Amer. . 1752

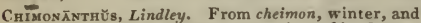
anthos, a flower; alluding to the time of its flowering. Linn. 12, Or. 3, Nat. Or. Calycanthacee. This genus is deserving of a place in all collections, on account of its delightful fragrance; it wil endure our winters in the open air, but when grown in the conservatory it is seen to the most advantage, as the flowers are liable to be injured when unprotected. It will grow in any soil, but prefers a mixture of loam and peat; increased by layers or young cuttings potted in sand, under a glass, plunged in a little heat. Synonyme: 1 . Calycanthus pracox.

frägrans, 1. . . Yel. red . 12, H. De. S, Japan . . 1766 grandifiorǔs : Yellow : 12, H. De. S. China

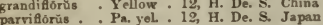
parvilórŭs. Pna yel. . 19,

('HINA Rosk, see Hibiscŭs ròsil-sinënsis.

Chingsk trek, see Páonlä Moutān.

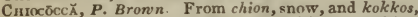
a berry; referring to the berries, which are white, hence the name snowberry. Linn. 5, Or. 1, Nat. Or. Cinchonacee. Ornamental plants growing from three to six feet high; they thrive well in a mixture of loam and peat, and are increased by cuttings in sand, placed under a glass. C. anguifuga is a violent emetic and purgative.

anguifrüğ̃ . . Wlite. . 7, S. Ev. S. Brazil . 1824 racemósá : : White: : 2, S. Ev. S. Jamales : 1729

Crîñ̄NTHUัs, Linn. From chion, white or snow, and anthos, a flower; the flowers are pure white. Linn. 2, Or. 1, Nat. Or. Oleacee. An ornamental genus of plants, varying in height from seven to thirty feet; the best plants are raised from seeds, but they may be increased by budding or grafting on the common ash.

axillärts . White. . 6, s. De. s. E. Ind. . 1810 maritis : White: 6 , H. De. $\mathbf{S}$. N. Amer. 1736 virginicắ : : White: 6, H. De. T. N. Amer. : 1736

CHIRONİ, Linn. After Chiron, one of the fathers of medicine and botany; he is represented to have been the son of Saturn. Linn. 5, Or. 1, Nat. Or. Gentianacer. The species of this genus are pretty, growing to the height of two feet: peat soil, or peat with a little loam mixed, suits them best; they onght to be frequently raised from cuttings, as the species are not long-lived plants; cuttings strike freely in peat, placed under a glass.

Red 7, G. Ev. S. C. G. H. decussätã : : Red frutếscēns: : : Red albilioră. - White. jnsminoidès linoìdés .

lyehnoidés: Purple Red G. Ev. S. C. G. H. 7. E. S C. G. H , G. Ev. S. C. G. H. 5, G. Ev, S. C. G. H. 8, G. Ev. S. C. G. H. 5, G. Ev. S. C. G. H nudicaúlis
1800 1759 1789 1756 1812 1812 1787 1816 peduneularis . Purple serpyllitolía - Yellow : 8, G. Ev. S. C. G. H. 1829 T, G. Ev. S. C. G. H. . 183') Cпाто̄xĭ, D. Don. From chiton, a coat of mail. in allusion to the seeds being covered with scales. Linn. 10, Or. 1, Nat. Or. Melastomacee. This is a genus of ornamental stove plants, growing from three to twenty feet high; they succeed well in a mixture of peat and loam, and are increased readily by cuttings planted in sand under a glass. Synonymes: 1. Molustoma albicans. 2. M. Fathergilla, Fothergilla mirabilis. 3. M. pyramidais. 4. $\boldsymbol{M}$. Tamoniana, M. Swartziana.

lbǐcāns, 1. * White . S. Ev. S. Mexico • 1815 Fothergilla, 2: : Purple : S. Ev. T. S. Amer. : 1815 macrophyllă: White.: S. Ev. S. Trinidad : 1820 pyramidälis, 3
Tamóniă, 4 : White: $:$ 7, S. Ev. S. Trinidad : 1817

Cнгіrs, see Altinm Schanopräsñm.

ChLDANThǔs, Herbert. From chlideios, delicate, and anthos, a flower; alluding to the delicate texture of the flowers. Linn. 6, Or. 1, Nat. Or. Amaryllidacee. This is a pretty plant, requiring to be grown in a composition of two-thirds sandy loam, and one-third sand and peat; bulbs that are planted out in the spring will flower in summer, but they should be taken up in the autumn. Synonyme: 1 . Pancratium luteum.

frăgrăus, 1. . Yellow - 5, G. Bu. P. B. Ayres - 1820

Chlotstrês, R. Brown. Named from chloa, grass, and anthos, a flower; on account of the green flowers. Linn. 14, Or. 2, Nat. Or. Verbenacee. An ornainental genus; the species grow to the height of two feet, and require a mixture of loam and peat; cuttings, when young, root freely in the same soil, under a glass.

glandulosă . . . Grm yel. . 7, G. Ev, S. N. Holl. Grn. yel. . 7, G. Ev. S. N. Holl : 1824 Stächälly. . Grn. yel. : 7, G. Ev. S. N. Holl. : 1822

Снцвй̆, Linn. From chloros, green. The flowers of c. perfoliata are a perfect green when dried, but yellow when fresh; hence the name Yellow-wort. Linn. 8, Or. 1, Nat. Or. Gentianacea. This is a pretty genus, and the species well worth cultivating as hardy annuals; they only require to be sown in the open borders as soon as the seeds are ripe. Synonyme: 1. C. dubia.

imperfoliată, 1 . Yellow . 6, H. A. Italy Yellow . H. Ataly. . 1823

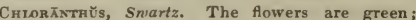
whence the name, from chloros, green, and anthos, a flower. Linn. 1, Or. 1, Nat. Or. Chloranthacere. This is a very curious yenus of plants, not growing more than a foot, or a font and a half high. They grow well in a mixture of isam and peat, and suttings root freely in peat under a glass.

inconspicǔŭs . A Aptu] . 5, S. Ev. S. China . . 1781 monandér : : A pets1 :6, S. Ev. S. Citina : : 1817 monóstichy's: A petal 4, S. Her. P. China : 1819

Chtorĩñixy. Link. From chloros, pallid, and eidos, appearance; alluding to the appearance of the plants. Linn. 24, Oy. 9, Nat. Or. Fungi. Insignificant plants, growing on decay ed wood-grisetum.

Снtб̈R̆s, Svartz. From chloros, green; alluding to the colour of the herbage. Linn. 23, Or. 1, Nat. Or. Graminea. The tender species should be raised on a hotbed, and require altogether to be grown with other tender annuals. Synonyme: 1. C. Durandiana. barbatå : : : A petal : : 6, Grnsk, E. Ind. : : 1777 comprëssá : : : A petal : : 8, Grass Jamaica : $: 1779$ dolichostăchy̆a: : A petai : : 7, Grass Phil. Is. : 1822 êlegăns : : A petal : 7, Grass. S. Amer. : 1818 fasciculăta : : A petal : 7, Grass Brazil . 1827 grácillis, 1 : A petal : 7, Grass. Bre California : 1824 pallia : : Apetal : Apetal : Grass California : 1826 polvdäetylă: : A petsl : 7, Grass, Jamaica : polvactyá.: A Aetsl : 7, Grass. Jamaica. : 1810 radiáta . Apetal . . ., Grass. IV. Ind.. . 1739 Roxburgbiảnà : : A petal : : 7, Grass. B. Ayres : 1824

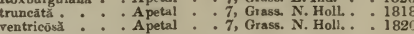
Chyorocōccū M, Greville. Derived from chlnros, green, and kokkos, a berry; on account of their appear- 
ance. Linn. 24, Or. 7, Nat. Or. Alge. This is a very curious genus, belonging to Alga, found growing on trunks of trees and old walls. Synonyme 1. Lepraria botryoides-murorum, vulgare 1 .

Chloróphürūm, Ker. From chloros, green, and phyton, a plant; referring to the appearance of the plants. Linn. 24, Or. 7, Nat. Or. Algae. A curious genus, growing from one to two feet high; they do best in a compost of turfy loam, peat and sand. Synonyme: 1. Anthericum alatum.

elătūm, 1 . . White. . 8, S. Her. P. C. G. H.

inornătüm : : White. 7 , s. Her. P. S. Leone

orchidāstrüm .

White

S. Her. P. S. Leone

1822

Chrorosis, the green sickness; a disease so called.

Снцово̄хйLón, Decandolle. From chloros, green, and xylon, wood; on account of the green or deep yellow colour of the wood. Linn. 10, Or. 1, Nat. Or. Cedrelacea. This is a fine timber tree, growing to the height of one hundred feet; it grows well in our stoves, in a mixture of loam and peat; cuttings. Synonyme: 1. Srietenia chloroxylon.

Swietēnĭă, 1 . White . . S. Ev. T. E. Ind.

1820

Chocolate-NuT, see Theobrömă

CHō̄s botanist. Linn. 10, Or. 1, Nat. Or. Rutacee. This is an ornamental shrub, growing about six feet high; it thrives well in a mixture of peat and loam, and may be increased by cuttings in sand under a glass.

ternātă . . . White. . 7, S. Ev. S. Mexico .

1825

CНоке, see Cërăsŭs hyemälis.

Снб̄ко̄, see $\mathbf{s e ̄} \operatorname{chūūm}$.

Сномецї, Jacquin. After J. B. Chomel, M.D., physician to Louis XV. Linn. 4, Or. 1, Nat. Or. Cinchonacer. The species are ornamental plants, growing from five to twelve feet in height; they thrive well in a mixture of loam and peat, and cuttings root freely under a glass in heat. Synonymes: 1. Ixora fasciculata. 2. I. spinosa.

fasciculătă, 1 . White. - S. Ev. S. W. Ind. spinosă, 2.: White: : S. Ev. S. W. Ind

1825

СнōNDRĬ, Agardh. From chondros, a cartilage; on account of the fronds being cartilaginous. Linn. 24, Or. 7, Nat. Or. Alga. A curious genus, belonging to $A \lg \mathscr{2}$; all the species are found growing in the ocean-articulată, clavellosă, dasyphy̆llă, kaliformìs, obtūsă, ovālīs, pinnatîfĩdă, tenuĩssìmă.

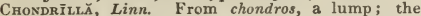
plants bear lumps of gummy matter on the stems. Linn. 19, Or. 1, Nat. Or. Compositc. Uninteresting plants; the species grow best planted in a sandy soil, and are increased by dividing the rootsgramĭnĕă, jînncĕă, latifolĭă.

C HorDĀRĨ , Link. Named on account of the resemblance of the plants to a cord, from chordea, a cord. Linn. 24, Or. 7, Nat. Or. Alga. A very remark. able genus of $A \lg a$, found growing in the oceanflagelliformis.

CHordorhīză, cord-rooted.

СноRĪspర̈ră, Decandolle. From choris, separately, and spora, a seed; the seeds are separated from each other in the pods. Linn. 15, Nat. Or. Cruciferce. The species of this genus are pretty, and only require sowing in the open ground, and treating like other hardy annuals. Synonymes: 1. Raphanus tenellus. 2. R. arcuatus.

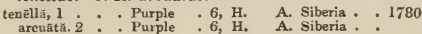

ibērǐcă, sibĭrĭcă.

CमоRо̄zцй. From choros, a dance, and zema, a drink; this name was suggested to Labillardière,

who originally discovered the plant upon the south.

west coast of New Holland, at the foot of the mountains, near a spot, where, after finding many salt springs, his party met with an ample supply of fresh water. Linn.10, Or. 1, Nat. Or. Leguminosa. This is a very pretty genus, C. Henchmanni is beautiful; they grow from one to two feet high, and succeed best in an equal mixture of peat, loam, and sand, and increase from cuttings, but the best plants are obtained from seed, which ripen in abundance.

cordātă . - * Red * . 4, G. Ev. S. N. S. W.

ilicifolitani . Scarlet . 5, G. Ev. S. N. Holl. : 1824 [ $7 \dot{5}]$ nānă . . . Yel red . 4, G. Evv. S. N. Holl. . 1803

ovātă * - Scarlet 8. G. Ev. S. N. Holl : 1830

rhómběă * - Yellow . 5, G. Ev. S. N. Holl. 1803

spartioidēs. - Yel. red . 8, G. Ev. S. N. Holl : 1832

trianguláré. : Scarlet: 4, G. Ev, S, N. Holl

Chrtstmas rose, see Hellěbrriñs nĩgěr.

Christ's BYE, see Inula Ocülüs Christī.

Christ's thorn, see Paliñrüs.

ChRōōtĕpis, Agardh. From chroos, skin, and lepo, to decorticate; in allusion to the change undergon by the inner membrane, which becomes powdery. Linn. 24, Or. 7, Nat. Or. Alga. This is a curiou genus of Alge, found growing on rocks, trees, and old walls-eběněŭs, jolīthũs, lichenícölü, odorätũs, rubicūndŭs.

CHRYSALIS-IIKE, like the chrysalis of an insect.

Chrysanthēllüm, Richard. A diminutive of Chry santhemum. Linn. 19, Or. 2, Nat. Or. Composita. An uninteresting stove annual, that will grow well sown in any common soil. Synonyme: 1. Verbesina mutica, Collęu procumbens-procūmbēns, 1.

Chrysanrhŭmōm, Linn. From chrysos, gold, and anthemon, a flower; alluding to the colour of som of the flowers being yellow. Linn. 19, Or. 2, Nat. Or. Composita. The species and varieties of thi genus are very numerous and of great beauty, when a large quantity of them are grown together the greenhouse species thrive well in any light soil, and young cuttings root freely taken off young, and potted in sand under a glass. Synonyme: 1 C. indicum.

absinthiifolǐum

Achīllēex .

anomalom

āretícūm

argēntéūm

atratũm

lobătūm

carinàtūm

coronārítum

daucifoling

heterophyllūm

indieûm

itulǐcūm

lanceolātữ

leucànthénūm

mexicānūm

monspeliēns

montānùm

paludōsũm

paludōsủm

pinnatĩfidūm

pŭmilūm

radieãns

rotundifơliñum

sclvèstrĕ

tanacetifoliūm

White

H. Her. P. Italy

1824

P. Kamtseh.

Wht pur. 7, H. Her. P. Switzerl. 1819

Yellow 8, $\mathrm{H}$. A. Birbary

White 7, H. Her. P.

White 6, H. Her P Montpel

White. 7, H. Her. P. Switzerl. 1806

9.

6. Her. China

.6, H. Her. P. Hungary . 1817

6, H. Her. P. Britain

8 , H. Her. P. Mexico.

$7, \mathrm{H}$. Her. P. Montpel. 1739

6, H. Her. P. France . 1759

Yellow $.7, \mathrm{H}$ A. Italy . 1775

- 6, H. Her. P. Barbary . 1810

. 6, H. Her. P. France . . 1825

White. - 7, G. Ev. S. Madeira - 1777

White. : 8, H. Ev. A. Spain : 1806

White. 7, G. Ev. S. Spain : 1818

Yellow 7, H. A. Britain.

Varieg. . 10, H, Her. P. China

White. 6, H, Her. P.

1764

tripartīûm, 1 Yellow 10, H. Her. P. E. Ind. 1800

Chrysērs, Lindley. After Chryseis, a celebrated Homeric beauty; alluding to the colour of the flowers, Linn. 13, Or. 4, Nat. Or. Papaveracere. The species of this genus are very handsome when in flower, and on that account well deserving of a place in every flower-garden. They succeed well in any rich soil, and must be annually raised from seed sown on a gentle hotbed early in spring, and afterwards planted out in the open border, where they will produce their flowers and seeds in auturnn. If there is any convenience for protecting the young plants during winter, the seed should be sown in autumn, as by that ineans the plants will flower much earlier and produce seeds with greater certainty. Synonymes: 1. Eschscholtzia Californica. 2. E. crocea.

ealiförníca, 1 - Yellow . 9, H. Tu, P. California . 1826 compảetä *. Yellow : 8, H. Tu. P. California . 1833 8, H. Tu. P. California . 1833

СhrysrphĬ a goblet; in allusion to the golden cup-like flowers. Linn. 6, Or. 1, Nat. Or. Amaryllidacea. This is a pretty genus of bulbs, that require to be grown in a light loam, and are increased by offsets. Synonyme: 1. Stenomison flava.

crocèa - Conper 5, G. Bu, P. S. Amer. 1820 crocidenta : Copper 10 G. Bu P. Peru : 1825

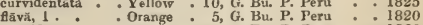
panciflöră : . Orange : 5, G. Bu. P. Peru : : 1822 
ChrysobăLĂnŭs, Linn. From chrysos, gold, and balanos, an acorn; some of the species bear yellow fruit. Linn. 12, Or. 1, Nat. Or. Chrysobalanacea. A genus of fruiting shrubs, succeeding best when grown in a mixture of loam and peat; increased by layers or cuttings in sand, under a glass. In the $W$. Indies the fruit of $C$. Icaco is eaten, under the name of cocoa-pluin.

\section{İễcō} White.

S. Ev. S. W. Ind.

1752

5, G. Ev. S. Georgia . 1812

СнRуš̆сŏмӑ, Decandolle. From chrysos, gold, and kome, hair; the stems are terminated by tufts of yeliow flowers. Linn. 19, Or. 1, Nat. Or. Compositu. This is an ornamental genus of plants, the species growing trom half a foot to six feet high; they succeed best in a mixture of loam and peat, and cuttings taken off when ripe, root freely under a glass.

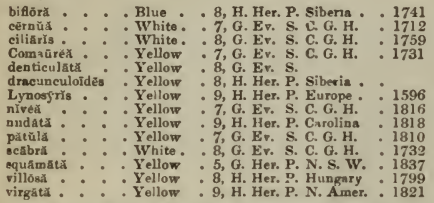

C月RYsŏ́ŏnī $x$, Linn. From chrysos, gold, and gonu, a knee or joint; the flowers are generally produced at the joints of the stem. Linn. 19, Or. 4, Nat. Or. Composito. This is a very pretty herbaceous plant, that thrives best in peat and loam, and is increased by dividing the roots.

virginianum - Yellow . 5, H. Her. P. N. Amer.

Chrysoptiflu, $M$, Linn. From chrysos, gold, and phyllon, a leaf; in allusion to the under surface of the leaves being covered with dense shining hairs of a bright yellow colour. Linn. 5, Or. 1, Nat. Or. Sapotacex. This is a fruit-bearing genus; the species grow from fifteen to fifty feet high, and one species, C. macrophyllum, attains the height of one hundred feet, with most splendid foliage; they do well in a mixture of loam and peat; and cuttings of the ripened wood root freely in sand under a glass, with a good moist heat.

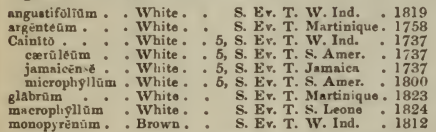

ChrYsopögón, Trinius. From chrysos, gold, and pogon, a beard; in allusion to the yellow awns. Linn. 23, Or. 1, Nat. Or. Graminer. An uninteresting grass, that only needs to be sown in any common soil. Synonymes: 1. Andropogon gryllus,

Holcus gryllus, Pollinia gryllus-gryllus 1.

Chrysosplēicit, Linn. From chrysos, gold, and splen, the spleen; in reference to the colour of the flowers, and the supposed medicinal virtues of the plant. Linn. 10, Or. 2, Nat. Or. Saxifragacea, This is a curious and rather pretty genus; they require a moist situation. Our native species are found in the greatest perfection upon the banks of small rivulets; increased by dividing the roots.

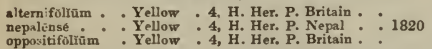

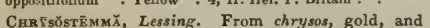
stemma, a crown; alluding to the coloir of the flowers. Linn. 19, Or. 3, Nat. Or. Composite. This very pretty species deserves to be cultivated in every flower-border. For culture and propagation see Coreopsis. Synonyme: 1. Coreopsis tripteris.

triptéris . . Yellow . 8, H. Her. P. N. Amer. . 1837

Chrysur ǔs, Persoon. From chrysos, gold, and oura, a tail; alluding to the compact heads of flowers. Linn. 3, Or. 2, Nat. Or Graminea. This is a genus of grasses, some of which are very ornamental; they only require to be sown in any common soil. Synonymes: 1. C. cynosuroides, Cynosurus aureus. 2. Cynosurus elegans.

effüsǔs . . . A petal * . 7, Grass, S. Eur. . . 182 elégans. 2 : : : A petal : : 7, Grass, S. Eur. : : 1824 Aarěrus 1 , echinätŭs.

Chrsis, Lindley. From chusis, a melting; because the pollen-masses are as it were fused together. Linn. 20, Or. 1, Nat. Or. Orchidacece. This is a splendid but very rare species. In its native country it is found growing suspended by long fibrous roots from the branches of trees, so that the pseudo-bulbs, which grow to a great length (and are also very brittle when growing), hang downwards, and wave in the wind. The flower is very showy, the colour being very bright, its texture firm, and its surface even and waxy. The labellum is beautifully marked with crimson veins. It succeeds well with the treatment recommended for the genus Vanda.

aûrea . . Y. Yellow . 5, S. Epi, Venezuela . 1834 Ciнarious, good for food, esculent.

CrrórȲō , Kaulfuss. From kibotion, a little chest; in reference to the form of the indusium. Linn. 24, Or. 1, Nat. Or. Polypodiacea. This is a beautiful tree fern from N. Holland, where it grows to the height of thirty feet; it requires to be grown in a mixtere of loam and peat, and is increased by dividing the roots. Synonyme: 1. Dicksonia antarctica.

Billardiêrt, 1 . . Brown. . G. Ev. T. N. Holl. . 1824

Cícc, Linn. Supposed to be a man's name. Linn. 21, Or. 4, Nat. Or. Euphorbiacea. Is a fruit tree, growing to the height of twenty feet; it thrives best in sandy loam, and strong cuttings root freely if planted with their leaves on in sand, under a glass. distrehă . . Green . . S. Ev. T. E. Ind. . 1796 CY̌č̆R, Tournefort. From kykis, force, or strength; in reference to its qualities. Linn. 17, Or. 4, Nat. Or. Leguminose. This genus is cultivated in the south of Europe for the same purpose as the lentil in this country; it only requires to be sown in common soil, but it is too delicate for field culture in this country.

arietinûm . . Purple - 7, H. A. S. Eur. . 1548 Cicnoriồ, Linn. The Greeks adopted this name from the Egyptians. Linn. 19, Or. 1, Nat. Or. Composita. This is a genus of uninteresting plants, with the exception of $C$. Endivia, which is very valuable as a salad; the tender species should be sown on a hotbed, and afterwards transplanted.

Fndriă . . Blue . . 7, H. A. E. Ind. . 1548 Intybüs. : Blue : 7, H. Her. P. Britain :

divaricātım, pümilım, spinฮีఃm.

Crcūtă, Linn A name of doubtful meaning, used by Pliny. Linn. 5, Or. 2, Nat. Or. Umbellifere. The species of this genus are of little interest, growing from one to three feet high; they delight in a humid situation, and are easily raised from seeds. The roots of $C$. virosa are poisonous.

maculatr . . Whito . 7, H. Her. P. N. Amer. . 1759 virosa . : White. 7, H. Her. P. Britain .

bulbłferă, dånrǐcă.

Cri1 $\tilde{I} \overline{\mathbb{N}}$, hairs like those of the eyelash.

CiLIATBD, $\}$ eyelash-haired.

CrLATELY-TOOTHED, having teeth like the hairs of the eyelash.

CILIARY-sCABRoUs, having rough ciliated margins.

Chliately-plumose, having long hairs on the edges, like the feathers of a quill.

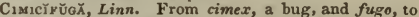
drive away; referring to the virtues which the plants are supposed to possess. Linn. 13, Or. 5, Nat. Or. Ranunculacee. A curious genus; the species grow from two to four feet high. They thrive well in any common soil, and are increased by seeds, or dividing the roots. Synonymes: 1 . Achae podocarpa. 2. A. Cimicifuga.

americănz, 1 . . Wht. yel. . 7, H. Her. P. Carolina . 1824 cordifolra : : Wht yel. . 6, H. Her. P. N. Amer. : 1812 fütridă, $2: \vdots$ : Lqt yel. 6 , H. Her, P. Siberia : 1777 palmata : : Whit yeL. 7, H. Her. P. N. Amer. : 1812

[ 76 ] 
Cıмchōnă, Linn. In honour of the Countess de Cinchon, vice-queen of Peru, who was cured of a fever in 1638 by this remedy. Linn. 5, Or, 1, Nat. Or. Cinchoneceer. It is from this genus that the celebrated Peruvian bark is obtained; it is not common in collections, owing to its being rather difficult to keep. The best soil for it is loam and peat ; and cuttings, if taken off when ripe, and planted in a pot of sand under a glass in heat, will strike.

officinaliss . . . Red . . 7, S. Ev. T. Peru . . 1810

scăbră

Cinchinōtǔs, Beanvois. From kigklis, lattice, and odous, a tooth; the ciliæ of the peristome are united in parcels, in a peculiar netted manner. Linn. 24, Or. 5, Nat. Or. Musci. A pretty genus, belonging to $M$ Iusci, found growing in streams of fresh water. Synonyme: 1. Fontinalis minor - fontinaloz̄dès 1 .

Cineräriă, Linn. From cineres, ashes; referring to the soft white down which covers the surfaces of the leaves. Linn. 19, Or. 2, Nat. Or. Compositce. This is a pretty genus of plants, the species of which grow generally from one to three feet high they thrive best in a mixture of loam and peat, and young cuttings root freely under a glass.

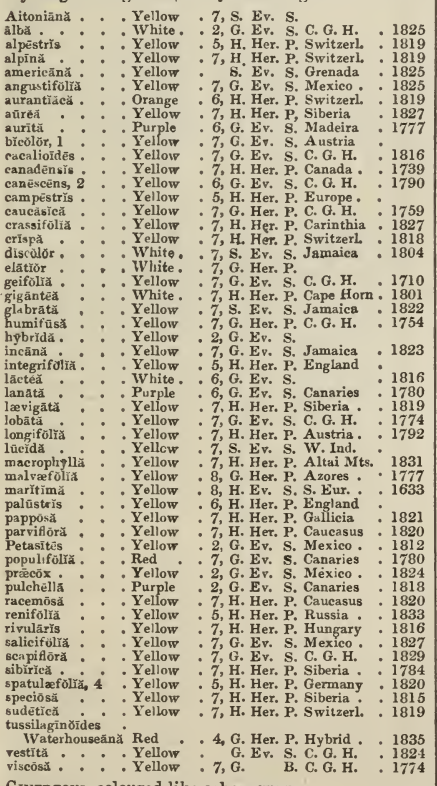

Cingrious, coloured like ashes, grey.

CinereousLy-CANescrest, between white and ashcoloured.

Cinergously-graucous, between sea-green and ashcoloured.

Crnkreusly-pubescent, covered with grey pubescence.

CINGALESE, inhabitants of, or belonging to Ceylon.

Cĩnsă, Linn. The ancient name of a grass growing in Cilicia. Linn. 1, Or. 2, Nat. Or. Graminea. This is a curious grass, that succeeds well sown in any common soil.
Cinnamōmūm, $\boldsymbol{R}$. Brown. Derived from the Arabic, kinamon, cinnamon. Linn. 9, Or. 1, Nat. Or. Lauracea. This is a genus of stove plants of considerable beauty, and some of them are highly valuable. It is from the inner bark of $C$. verum that the cinnamon of commerce is obtained; and c. camphora is the plant from which camphor is prepared. All the species succeed well in a mix ture of loam and peat; and cuttings of the ripened wood root freely in sand under a glass. Synonymes: 1. Laurus Beiolyota. 2. L. camphora. 3. L. cassia, L. cinnamomum. 4, L. Culiluban, 5, L. dulce, L. Burmanni. 6. L. glauca. 7. L. gracilis. 8. L. Malabatrum. 9. L. montana. 10. L. nitida. 11. L. cinnamomum, cassia.

Beiolgōtă, 1 - Yel. grn. . S. Ev. T. E. Ind. Grn. wht. 5, S. Ev. T. Japan : 1727 Cassiā, 3 . . Yel. grn. . 6, S. Ev. T. Ceylon . 1763 Culilābăn, 4 - Yel. grn. . S. Ev. T. E. Ind. . . 1823 dũleé, 5 * : : Wht. yel. . S. Ev. T. E. Ind. : 1820 glancūm, $6:$ Pa yel. : S. Kv. T. Japan : 1800 Malabatrūm, 8 : Yel. grn. S S. Ev, T. E. Ind, 182

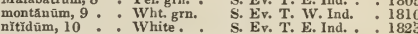
vērūm, 11 . : Green : 7 , S. Ev. T. E. Ind. : : 1768

CrnNamon, see Cinnamōmūm.

Cinqueroil, see Potentíllă.

Circēé, Linn. After Circe, the famous enchantress the fruit, from being covered with hooked prickles, lays hold of the clothes of passengers, as Circe is said to have done by her enchantments. Linn. 2, Or. 1, Nat. Or. Onagracee. Ornamental species, growing in any common soil, and increased by offsets. alpīnă

intermedix 0 Red

lutetiānã : : Red : 7 , H. Her. P. Britain

1821

Circinst B, curled round like a sheep crook.

Cincinal, resembling a circle.

Circinatbly-REVOLUTE, curled round like a circle.

CIRRHA $\tilde{A}$, Lindley. The part of the flower called the rostellum is prolonged in the form of a small tendri or cirrhus; hence the name. Linn. $20, \mathrm{Or}, 1$, Nat. Or. Orchidacea. This is an interesting genus of orchideous plants. The flowers of all the species are of a green or yellowish colour; and in some, the sepals and petals are beautifully spotted with rich orange. For culture and propagation see Stanhopea. Synonymes: 1. Cymbidium dependens. 2. Gongora viridi purpurea.

fuscoluteeă . . Yel. grm. . 7. s. Epi. Brazi Loddigěsin, i : Yellowish : 5, S. Epi. Brazii tristis - Pur. grn. 6, S. Epl, Mexico : 1834 viridipurpũrēă, 2 . Pur, grn. . 6, S. Epi. Brazil : Warreană . Yelsh. grn. 6, S. Epi. Brazil

Cirrhifrrous, bearing tendrils, or claspers.

Cirrhopétălǜ, Lindley. From cirrhus, a tendril and petalon, a petal in allusion to the form of the flowers. Linn, 20, Or. 1, Nat. Or. Orchidaces. C. Thouarsii is a most singular species, with long, strap-shaped sepals, growing from one side of the flowers, while the petals are very small, yellow, spotted finely with red. The rhizoma of this species elongates very much, and is in a growing state always at the extremity; on this account it is requisite, in potting, to keep the active part nearest the side of the pot from which it grows away. The other species have much smaller flowers, without any thing striking about them. For culture, \&c. they may be referred to Stanhopea.

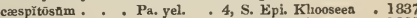
cornūtūm : : Purple : 8, 8. Epi. Khooseea : 183 Thouärsīi : : : Yel. red. : 7, S. Epi, So. Isles. : 1836 $\left.\begin{array}{l}\text { Cirrhosk, } \\ \text { Cirrhous, }\end{array}\right\}$ tendrilled, having claspers, like the pea. CİsǏü M, Vaillant. Fromkirsos, a swelled vein; from its supposed healing properties. Linn. 19, Or. 1, Nat. Or. Compositoe. This is an ornamental genus of hardy herbaceous plants, that succeed well in any common soil, and are increased by dividing the roots, or by seeds. Synonymes: 1. Cnicus acarna, Carlina acarna. 2. Carduus pratensis. 3. C. arvensis, Serratula arvensis. 4. Cnicus horridus. 5. Cirsium horridus. 6. Cnicus nivalis. 7. Carduus cichoraceus. 8. Cnicus cynaroides. 9. Carduus fimbriatus. 10. Carduus giganteus, Cnicus firma. 11 Cnicus elatior. 12. Cnicus hoteromallus. 13. Cnicus 
hybridus. 14. Carduus igniarius. 15. Cnicus inerme. 16. Cardurs italicus. 17. Cnicus lanceolatus. 18. Cnicus leucocephalus. 19. Carthamus mareoticus. 20. Cnicus medius. 21. Cnicus glaber. 22. Cnicus orientalis. 23. Cnicus paludosus. 24. Carduus palustris. 25. Carduus paniculatus. 26. Cnicus pauciflorus. 27. Cnicus pazcuarensis. 28. Cnicus pinnatifidus. 29. Carduus polyanthemus. 30. Cnicus pungens. 31. Carduus pyrenaicus. 32. Cnicus salisburgensis. 33. Carlina echinus. 34. Cricus strictus. 35. C. Verutum. 36. Cardus virginianus.

acaūlé

altissimun

Purple

ambǐgūũm

angulátūm

srachnoideūm.

Bertolini, 4

cânûm

carniolǐcūm

cassabōnä

eẼmnūùm

cichorácéúm, 6

ciliătūm

cynaroídés, 7

dealbatũm

desertōinum

diacânthûm

discolor :

echinocé phàán

elâtrũs, 8

erióphórūm

Erisithäles

ferox

fimbriatŭm, 9 .

Rigântêum, 10

glutinósūm

helenioldes.

heterophyllim

horridum 12

horridum, 12.

ikniarirum, 14.

ineล̃กūm

inërme, 15

itălicûm, 16

lascteumm $\dot{1}$; 17

lanifórùm

lnppaceũum

leucocéphăluăm. 18

mareótíūm, 19

midre

monspessulänún

munitüm

mūtleûm, 21 :

neglèctūn.

nudiflórûm.

obvallâtūm.

ochroleūcūm

olerăcéūm.

orgyElo

orentălé, $2 \dot{2}$

paludósúm, 23

paniculatùm, 25

paniculatótùm, 25 : Purplo 26 . Purplo

pazcuarẽnsé, 27 . Purflo

pinnatifídūm, 28. Purpl

polyăntliemûm, 29 Pink

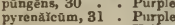

rigêns

rivularé

ruféscêns

Salisburgēnšx, 3

sclerānthūm, 33

semipecțnátûn

serratuloídés

serrulatūm

setósūm

spinosíssĭmūm

squarrósūm

stellãtūm strictũm, 34

strigôsũm .

syrĭậ̂m

tatăricūm

tuberōsūm

uliginōsûm

verūtūm, 35
virginiănüm, 36
8, H. A. Spain

7, H. Her. P. Britain

6, H. B. Barbary

7, H. Her. P. M. Cenis

7, H. Her. P. Switzetl.

7 , H. Her. P. Tauria.

7, H. Her. P. Italy

7, H. Her. P. Spain

7, H. Bl. P. Austria :

7, H. Her. P. Carniola

7, F. B. S. Eur.

7. H. B. Mexico

8, F. B. Naples.

8, H. Her. P. Siberia

7, H. Her. P. Crete

7, H. B. Caucasus

7, H. Her. P. Siberia

6, H. B. Nyria Amer.

8, H. Her. P. Barbary

7 , H. Her. P. Caucasus

8, H. Her. P.

7, H. B. Britain .

7, $\mathrm{H}$. Her. P. France

7, H. B. S. Eur.

7, H. Her. P. Cnucasus

7, H B. Sicily

7, H. Her. P. S. Eur.

7, H. Her. P. S, Eur.

H. Her. P. Siberia

7, H. Her. Nepal
7, H. Her. Prin

8. H. Her. Iberia

7, H. Her. P. Switzerl 1823

$7, \mathrm{H}$ B. Russia

$7, \mathrm{H}$. B. Caucasus

7, H. Her. P. Italy : 1824

7. H. Her. P. Switzerl. 1819

$7, \mathrm{H}$. Ber. Britain.

7, H. Her. P. Tauria

7, H. B. Caucasus

7, H. Her. P. Crete :

H. Her. P. Piedmont 1810

7 , H. Her. P. Siberia . 1820

6, H. Her. P. Montp. . 1596

7, H. Her. P. Caucasus - 1816

7, H. Her. P. N. Amer. . 1820

7, H. Her. P. Siberia . 1827

8, H. Her. P. Switzerl : 1817

7, H. Her. P. Caucasug : 1816

7 , H. Her. P. Europe : 1570

7, H. Her. P. 1823

7, H. B. Asia Minor 1827

7, H. Her. P. Switzerl. : 1819
6, H. S. Eur. . 1781

7. H. B. Hungary : 1816

7. H. B. Mexico

$7, \mathrm{H}$.

A. Spain

7, H. B. S. Eur.

7 , H. Her. P. Pyrenees

7, H. Her. P. Switzerl

7, H. Her. P. Hungary

7, H. Her. P. Pyrenees

7, H. Her. P. Europe

7, H. Her. P. Siberia

8, H. Her. P. Siberia

7, H. Her. P. Tauria

6, H. A. Silesia

7, H. Her. P. Switzerl.
7, H.
B. Siberia

$6, \mathrm{H}$. A. Italy

8, H. Her. P. Naples

8, H. B. Caucasus

7, H. Her. P. Levant

7, H. Her. P. England

6, H. Her. P. Caucasus 7, H. Her. P. Nirginia

änglícūm 2, arvênsĕ 3, Forstêri, palüstrĕ 24

CissāmpйLos, Linn. From kissus, ivy, and ampelos, a vine, having the character of the ivy in its rambling branches, and that of the vine, from the fruit being in racemes. Linn. 22 , Or. 13 , Nat. Or. Menispermacee. This is a genus of beautiful stove climbers; the species thrive well in a sandy peat, and are increased by cuttings planted in sand, under a glass.

caapĕbă. . . Green . . 7, S. Ev. Tw. S. Amer. 1733 capénsis : : Green : G. Ev. Tw. C. G. H. 175 hirsúta. : Yel. grn.: G. Ev. Tw. Nepal. : 1819 mauritiānă. : Yel. grn. . S. Ev. Tw. Mauritius 1824 microcirpă. : Y Yel. grm. . S. Ev. Tw. W. Ind. 1823 Pareiri : Green 7, S, Ev, Tw. S. Amer. . 1733

CIssũs, Linn. From the Greek, kissus, ivy ; said also to come from the Arabic word, qissos, signifying the same plant. Linn. 4, Or. 1, Nat. Or. Vitacece. This is a genus of climbers, some of the species of which are very ornamental; they are free growers, and delight in a light rich soil. Cuttings are easily rooted under a glass in a moist heat.

ăcida Green S. Ev. Cl. Tnmnica 1699

antáretied . : Green . . 7, G. F.r. Cl. N. S. W. : 1790

capensis *. Green : . G. Ev. Cl. C. G. H. : 1792

diversifólin, 1: Green:

elongati : Green: : G. Ev. Cl. E. Ind. . : 1818

glandulosa : : Green: S. Ev. Cl. E. Ind. : 1819

glaūea : : Green:: S. EY. Cl k. Ind : 1818

ovata : : Green: : Ev. Cl. Guadaloupe 1822

pentaphylla : Green : 7, G. Ev. Cl. Japan - 1790

puncticulosă . Green - S. Ev. Cl. Cayenne 1818

quadrangularis . Green * . S. Ev. Cl. E. Ind. * 1790

quinata . * Green * 7, G. Ev. Cl. C. G. H. . 1790

Sicyoldes : - Green - S. Ev. Cl. Camaica - 1768

trifoliata : Green : 7, S. Ev. Cl. E. Ind.: 1822

trilobati $:$ : Green : 7, S. Ev. Cl. E. Ind. : 1822
vitigines

adnātă, alăta, angustifolıd, auriculată, carnōsă, lati.

follă, microcärpă, orientälǐs, quinguefolid, rëpęns, smilacind.

CIIstũs, Tournefort. From the Greek, kistos, which is derived from kiste, meaning a box or capsule; on account of the remarkable shape of the capsule. Linn. 13, Or. 1, Nat. Or. Cistacere. This is a beautiful genus of plants, varying in height from one to four feet ; they are considered hardy, but there are some of them that require protection in winter, either in a greenhouse or cold frame, but most of the species will pass the winter in the open air, if the weather be not very severe; but it is the best plan to keep some of all the sorts in pots, that they may be more easily protected from severe weather, when they may be turned out in the borders in spring, where they will flower freely. They do well in common soil, and are increased by layers, or ripened cuttings placed under a glass, or seeds. Synonymes: 1. C. salvifolius. 2. C. laduniferus, stenophyllus. 3. C. undulatus. 4. C. villosus, virescens. 5. C. ladaniferus, undulatus.
acutifolrŭs, 1. White.
- 8, H. Ev. 8. S. Eur. .

asperifolrüs : White. 6, H. Ev. \&. s. Eur.

oandidissimŭs: Pa. red :6, H. Ev. 8 . Canaries

canêscếns : : Red : 6 , $\mathrm{H}$. Ev

Clüsins : : Red White:

complicắtŭs : : Bed

Corboriénsis : White

cordifolrüs .

crétícǔs :

taūrǐcǔs

crispüs.

cymósŭs : Purple

cŷprĭŭs, 2 - White

Dunaliănŭs, 3

6, H. Ev. S. Spain . . 1810

6, H. Ev. S. Spain : : 1818
6. Ev. S. Spain : 1656

6, H. Ev. S. $\quad 1800$

7, H. Ev. 8. Lerant - 1731

6, H. Ev. S. Portugal : 1656

6, F. Ev. S. Sicily.

6, H. Ev, s.

6, H. Ev. S. Greece . . 1800

5, H. Eี $v$. S.

6, H. Ev. S. Italy

Purple : 6, H. Ev. S. Algiers.
White. 6, H. Ev. S. Portugal

1825

hirsũtús

Purple 7. H. Ev. 8. S. Eural 1656

incānǔs. * * Purple

daniferùs White. 6, H. Ev. S. Spain

White. 6, H. Ev. S. Spain

maculatŭs . White.

latifolrŭs . . White

6, H. Ev. S. Spain

6, F. Ev. S. Barbary

1699

White:

6 , H. Ev. S. Spain

1700

laurifoliŭs :

lāxús : : : White : 6, H. Ev. S. Spain : : 165

longifoliǔs White. 6, H. Er. S. S. Eur. . 1800

monspeliēnsis White. 6, H Ev S. S Eur. 1656

oblongifolrüs White. 6, H Ev S. Eure?

obtusifoliüs : White $6, \mathrm{H}$

parvifiôrǘs. : : Pa.red : 6, H. Ev. S. Crete

Crete 78 ] 


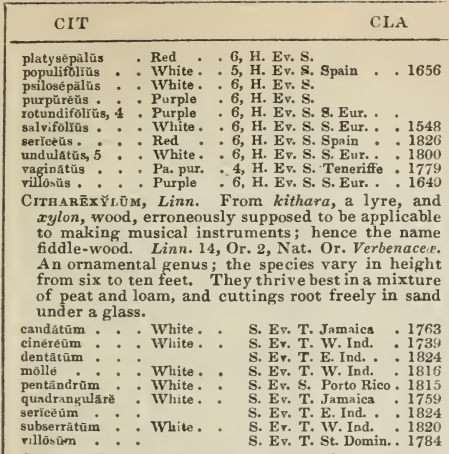

CIтrरовĀTŭs, Cunningham. Derived from citros, citron, and batos, a thorn; in reference to the small orange-coloured fruit, which resembles an orange ; hence it is called by the colonists orange thorn. Linn. 5, Or. 1, Nat. Or. Pittosporacea. The species of this little known genus will probably be found to succeed best in sandy peat, and a little loam, well mixed. The pots should be carefully drained.

multiflorŭs .

G. Ev. S. N. Holl

G. Ev. S. N. Holl

1818 paueiflórüs

Cítrōn, see Citrus.

CĩTrŭs, Linn. This genus is said to have its name from the town Citron, in Judea. Linn. 18, Or. 2, Nat. Or. Aurantiacea. This is an ornamental genus of fruit trees, growing from three to fifteen feet high; they thrive best in a good loamy soil, mixed with a quantity of rotten dung. They do not like much pot-room, nor too much water, when in a growing state. The different kinds are procured by budding or grafting on common stocks, which, as soon as operated upon, should be placed in some close frame, in a moderate dung heat. Stocks for working upon are raised from any oranges, lemons, \&c. They are sometimes raised from cuttings, in which case they produce fruit when very small plants.

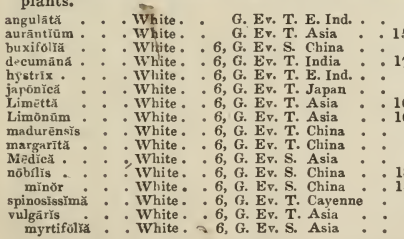

CladĀNTHǓs, Cassini. From klados, a branch, and anthos, a flower; referring to the situation of the flowers. Linn. 19, Or. 2, Nat. Or. Composita. Interesting dwarf plants, of simple culture. This is a pretty annual, growing about a foot and a half high; it only requires to be sown in common soil. Synonyme: 1. Anthemis arabica.

arăbǐcŭs, 1 . Yellow * 7, H. A. Barbary . 1759 canēscéns .: Yellow 6, F, Ev. S. Canaries : 1829

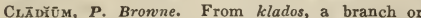
twig; referring to the appearance of the plant. Linn. 2, Or. 1, Nat. Or. Cyperacee. The species are curious, and best cultivated in wet boggy soil. Syncnyme: 1. Schøenus acutus.

glonerātūm . . A petal . . 6, Grass. N. Holl. . . 1816 jūncéüm : A petal : 7, Grass. N. Holl. : 1820 schcenoides, 1 : A petal : 7, Grass, N. Holl. : : 1823 germān ̌̆câm.

Cladospórî̀ M, Link. From klados, a branch, and
CLA

CLA

spora, a sporule; on account of the sporules being attached to the branches of the fungi. Linn. 24, Or. 9, Nat. Or. Fungi. Minute species of Fungi, found most frequently upon old decaying woodherbārūm, velutīnūm.

Cradostāch x̌s, D. Don. From klados, a brancli, and stachys, a spike, in reference to the manner of its flowering. Linn. 5, Or. 1, Nat. Or. Amarantacer. The species possess little beauty. For culture, \&c., see Achyranthes. Synonymes: 1. Achyranthes alternifolia, Desmochata alternifolia. 2. A. muricata, Chamissoa muricata.

alternifollă, 1 . . Purple . 9, G. B. E. Ind. . 1789 frútëscêns, 2 : : Green . 9, S. Ev. S. E. Ind. : : 1777 Cradostēphǔs, Agardh. From kiados, a branch, and stephos, a crown; in reference to the whorled branches. Linn. 24, Or. 7, Nat. Or. Alga. Marine productions, of an interesting character-myriophÿllūm, spongiossŭs.

Crammx, viscid, sticky.

CLANDEstink, hidden, secret, private.

CıĀrkĩă, Pursh. In honour of Captain Clarke, who accompanied Captain Lewis in his journey to the Rocky Mountains. Linn. 8, Or. 1, Nat. Or. Onagracer. A genus of annuals, which make a beautiful display in the flower-borders during summer. They succeed well merely sown in the open ground, where they are to flower; seeds ripen in great plenty.

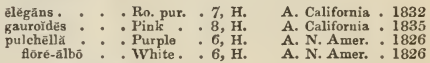

Clary, see Sălvăă Sclärěă.

Clathrate, latticed, divided like lattice-work.

CrĀ̄sẼĂ, Burmann. The meaning unexplained. Linn. 10, Or. 1, Nat. Or. Aurantiacea. An ornamental tree, growing upwards of twenty feet high, and cultivated best in rich loam. Cuttings may be rooted in sand, under a glass. Synonyme: 1. $\mathrm{Li}$ monia pentaphylla.

pentaphyllă, 1 . White. . 7, S. Ev. T. Coroman. . 1800

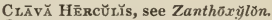

Ci.avãĭ Vaillant. From clava, a club; in reference to the form of the species. Linn. 24, Or. 9, Nat. Or. Fungi. Striking species of Fungi, growing from the eighth of an inch to a foot high, but the majority average from one to three inches. They are found upon trees of various kinds, sometimes in meadows, and at others, in dense shady places, where the soil is damp-abietină, acută, Ardeñ $\breve{a}$,

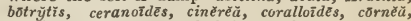
corniculātă, cristātă, fimbriātă, flãvă, frăgilìs,

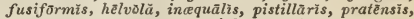
rugōsă, sētīpēs, stríctă, unciālìs, vermiculärìs.

Chavate, Shaped like a club, the thick end upper-

Clavated, most.

Claveriose, having club-like processes.

CL. $\mathbf{A} v$ Ǔs, a name for the ergot, a disease in corn.

CrAvĩJA, Ruiz and Pavon. In honour of J. Clavijo Faxardo, a Spanish naturalist. Linn. 5, Or. 1, Nat. Or. Myrsinacea. A very ornamental genus, growing in peat and loam, and cuttings might strike in the same kind of soil, under a glass, in heat. The trees grow about twenty feet high. Synonymes : $\begin{array}{ll}\text { 1. C. macrophylla. 2. Theophrasta longifolia. } & \text { 2. }\end{array}$

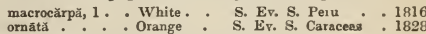
CLAws, the narrow end of petals.

Cцатто̄Nĭ , Linn. In honour of John Clayton, a collector of plants in Virginia, which were published by Gronovius in his Flora Virginica. Linn. b, Or. 1, Nat. Or. Purtulacacea. The species of this genus are very pretty; the penennial species grow best in a border of peat soil. The annual kinds only require sowing in the open border, in peaty soil. Synonymes: 1. C. virginica. 2. C. bifida. acutifolia . . White . H. Tu, P. Siberia . . 1827 acutiflōră, i : White : 5, H. Tu. P. N. Amer. alsinoídēs : : White: 5, H. A. England caroliniānă : Pink : 4, H. Tu. P. N. Amer. : 1789 grandiflōră. - Pink * 4, H. Tu. P. N Amer. gypsophrlōidēs : Pink : 10, H. A. California : 1835 Joanneānă. : White: 6, H. A. A. Siberia : 1818 lanceolata: : White: 4, H. Tu. P. N. Amer. 1812 longifólix: : White: 4, H. Tu. P. N. Amer. : 1827 


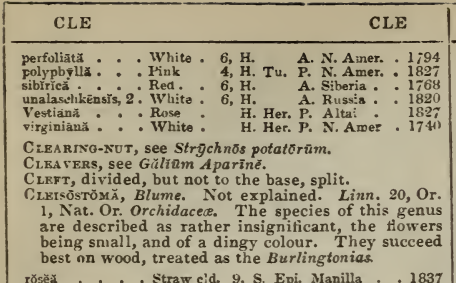

rơséă . . Straw cid. 9, S. Epi. Manilla . . 1837

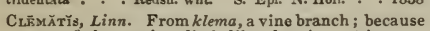
most of the species climb like the vine. Linn. 13, Or. 6, Nat. Or. Ranunculacer. A numerous and highly ornamental genus of, for the most part, climbing plants. The greenhouse species are very desirable where climbers are wanted; they grow well in any light soil, or loam and peat; cuttings root freely under a glass. The same treatment is required for the stove kinds. The hardy kinds grow in any common garden soil, and are well adapted for trellis-work, or for training against a wall. They are readily increased by laying the young shoots in July or October. The herbaceous kinds are increased by dividing the plants at the root early in spring. Synonymes: 1. C. calycina. 2. C. australis. 3. C. fragrans. 4. C. cirrhosa. b. C. cordata. 6. C. bracteata.

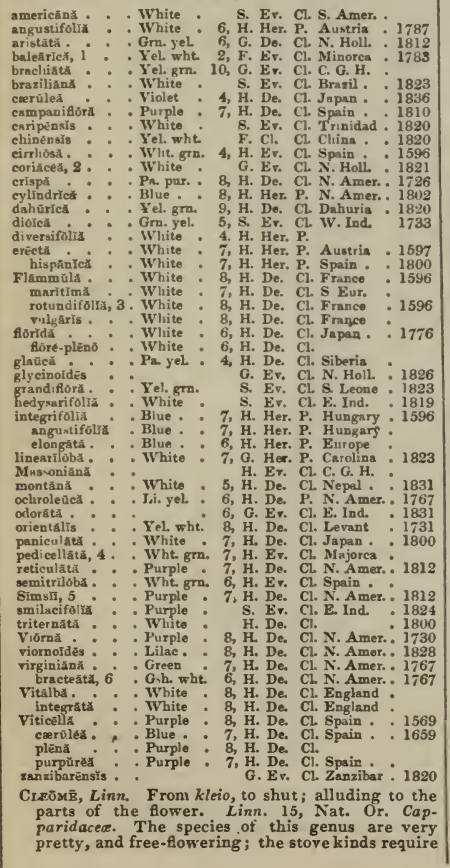

CLE

CLE

a rich light soil, and cuttings root freely under a glass. Some of the annual species require sowing in a hotbed frame, or in a hothouse, and when potted off, to be placed among the tender annuals. The hardier kinds may be sown on a hotbed, and when of sufficient size, planted out in sheltered situations in the flower-borders. Synunymes: 1 .

C. ornithopodioides. 2. C. spinosa.

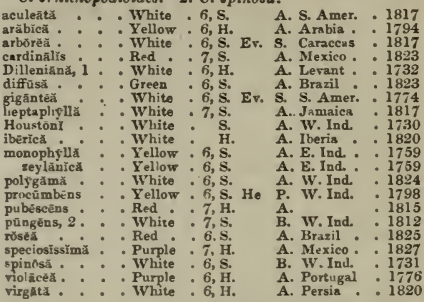

Clē̃̄ĩ Linn. A Greek name, employed by Theophrastus. Linn. 14, Or. 1, Nat. Or. Labiata. This pretty species merely requires sowing in the open border, and treating as other hardy annuals.

lusitarñeă . . Li.blue .6, H. A. Portugal . 1710

CzrRodêxprêx, Linn. Kletos, lot, and dendron, a tree; in allusion to the uncertain medicinal properties of the species. Linn. 14, Or. 2, Nat. Or. Verbenacea. A beautiful genus, varying in height from three to eight feet; they succeed best in a rich soil, composed of loam, rotten dung, and sandy peat. Young cuttings root freely in sand or soil, under a glass. C. speciosissimum is the most splendid. Synonymes: 1. Volkameria buxifolia. 2. C. uvatum, V. madagascariense. 3. V. angustifolia. 4. Leucosceptrum canum. 5. Siphonanthus indica.

angustifoliûm . : S. Ev. S. Maurit

S. Ev. S. Maurit. 1824 buxifotum : White

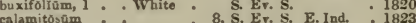
cërnǔũm : S. Ev. S. E. Ind. : 1823 coromandeliănüm $2 \quad$ S. Ev. S. Maurit. 1823 costatūm $\quad$ S. Ev. 8. N. Holl. : 1823 costatüm : : : White . 2, 8. Ev. S. Madagass. 1822 emimênse : : Wilite : 2, S. Ev. S. Madagas. : 1822

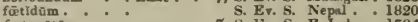
fortunatúm: : : wht red 7, s. Ev. S. E. Ind. 1784 frăgrâns . Whe red 10, S. Ev. S. China . . 1790 S. Ev. S E. Ind : 1790 glaūeúm. * : White 6. S. Ev. S. E. Ind. - 1825 helianthiforim " White. 6. S. Ev. S. E. Ind. : 1825 helianthifolrum
heteruphyyllum, 3 : White * 8, S. Ev. S. Maurit. : 1805 inerrme : White infortunatum S. Ev. S. E. Ind. Leucosciptrûm, 4 : White - S. Ev, S. Nepal : 1826 ligustrinum. : Whito : 9, s. Kv. S. Maurit : 1789 Livaum macrophy̆llum : : White . 11, S. Ev. S. E. Ind. : 1825 nûtáns
odorătúm : : : White : 11, S. Ev. S. E. Ind. : 1825
S. Ev. S. Nepal. 1823 paniculatūm : : Red : carlet : 8, S. Ev. S. Nepal : : 1823 phlomoldes. : : White : 8, S. Ev. S. E. Ind. : 1820

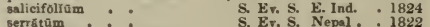

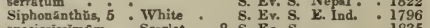
speciosissimum. : Scarlet : 8, S. E⿰. S. squamátūm . : : Scarlet : 8, S. Ev. S. China . : 1790 squamátūm : - Scarlet . 8, S. Ev. s. China : 1790

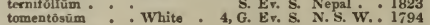

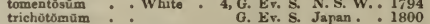
urticæfolrum : : S. Ev. S. E. Ind. : 1824 verticillatūm : : White . 8, S. Ev. S. Nepal . : 1818 riolácetum : Violet : S. Ev. S. E. Ind 1822 volübIle . : : Whito : S. Ev. Cl. Guinea : 1823

Сı.йтнӑ, Linn. From klethra, the Greek name of the alder; on account of the resemblance it bears to that plant. Linn. 10, Or. 1, Nat. Or. Ericacea. All the species of this genus are ornamental, growing from two to ten teet high. The greenhouse kinds are well suited for conservatories, succeeding best in peat earth, or light sandy loars; cuttings taken off, not too ripe, will root freely in sand, under a 
glass. The hardy kinds, where the soil will suit them, are well adapted for the front of shrubberies, and require the same kind of soil as the greenhouse speeies. It is usual to increase them by layers; but cuttings root readily in sand, under a glass. All the kinds may be raised from seeds.

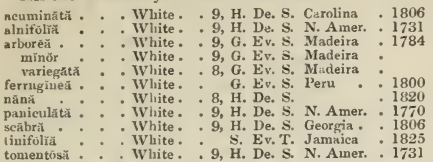

$\mathrm{C}_{\text {I.KYFิR }}$, Thmuluerg. In honour of Andrew Cleyer, M.D., a Dutch botanist, once resident at Batavia. Linn. 13, Or. 1, Nat. Or. Ternstromiacee. An ornamental greenhouse plant, about five feet high; it grows well in sandy peat, and is increased by cuttings under a glass.

japōnè̃eă

G. Ev. S. Japan

1820

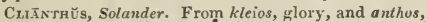
a flower: in reference to the noble appearance of the species of this genus. Linn, 17, Or. 4, Nat. Or. Legrminose. A very elegant plant, resembling the Sntherlandia frutescens when in flower; it attains the height of eight or ten feet; it grows well in an equal mixture of loam, peat, and sand; it does best when planted in the border of the conservatory, and will also flourish against a south wall when pro. tected from frost and cold; cuttings root in the kind of soil recommended for growing it, when placed under a glass.

punīeeŭs, 1 . . Crimıon . 5, F. Ev. S. N. Zeal. . 1832

Cı, botanist. Limn, 10, Or, L, Nat, Or. Melustomacere.

The species of this genus are not very showy. For culture and propagation, see MIelastoma. Synonymes: 1. Melastoma alata. 2. M. cernua. 3. M. elegans. 4. $\boldsymbol{M}$. hirta. 5. M. rubra. 6. $\boldsymbol{M}$. velutina. aggregãtă . . Wlite. . 7, S. Ev, S. Peru . . 1820 ngrestis: * - White. 7, S. Ev. S. Griana * 1822 cêrnñă, 2 . White. . 7, S. Ev. S. Peru * 1820

elégans, 3 . . White. . 7, S. Ev. S. Maran. . 1822

hiirtí, 4 . : Purple : S. Ev, S. Jamtica : 1740

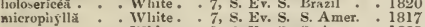

nǐveá : : White: 7, S. Ev s. S. Amer. : 1823

rübră, 5 : : Purple : 4, S. Ev. S. Guiana. : 1783

spicâta, $0^{\circ}$ : White . 7, s. Ev, S. Guiana . I 1793

Cr.iprōrtǐn, Linn. In honour of George Cliffort, a merchant of Amsterdaun, and one of the patrons of I.innieus. Linn. 2:2, Or. 12, Nat. Or. Rusacee. These species are only worthy of cultivation on account of their singular habit; they succeed well in an equal mixture of peat and loam, and cuttings of the young wood root freely in sand, under a glass.

cinerèt

cordifoli:

crenätă.

cuneñtiิ.

ericxefỏin

falcata

ilicifolia:

obcordáti

obliquá

pulchella

ruscifölī

sarmentös̆̃

strobilifieră.

ternăti.

tridentati

Grn. whit.

6, G. Ev. S. C. G. H.

Gin. whit. . 6, G. Evv. S. C. G. H.

Grn. wht. . G. Ev. S. E. Ind.

Grn, whit. - 4, G. Ev. S. C. G. H

Grn. whit. - 7, G. Ev. S. C. G. H.

Grn. wht. * 6, G. Ev. S. C. G. H.

Grn. whit. : 6, G. Ev, S. C. G. H.

Grn, whit. - 7, G. Es, S. C. G. H.

Grn. whit. : 6, G. Ev. S. C. G. H.

Grn. wht. . 6, G. Ev, S. C. G. H.

White 7, G, Er, S, C, G, H.

Gru. wlit. . 6, G. Ev. S.

Gru. wht. . 6, G. Ev. S. F. G. H.

Grn, wht, . 7, G. Ev, S. C. G. H.

trifoliāti : : Grn. whit. . 6, G. Ev. S. C. G. H. : 1752

. 1800

1820

- 1787

1799

1818

1714

1790
1816

1795

1752

1818

1818

Cr.INĀNDRỸ $\mathrm{Cr}$, that part of the column of orchideous plants in which the anther lies.

Crixopúntũm, Linn. From kline, a bed, and pous, a foot; the flowers have been compared to the castor of a bedpost. Liniz 14, Or. 1, Nat. Or. Labiute. Rather ornamental plants, growing about a foot high; they do well in auy common soil, and increase frealy by division of the roots, or by seeds.

apyptiaction - J'urple * 7 , H. Her. P. Egypt * . 1759 origanifoliñm : l'ink * 7, H. Her. P. S. Eur. . : 1825 vilgare.
Chintōnĭă, Douglas. In honour of De Witt Clinton, late governor of the state of New York. Lim. 16, Or. 2, Nat. Or. Lobeliacec. Very pretty border plants, producing an abundance of flowers; the seeds merely require sowing in the flower-borders in spring; they produce an ctbundance of seeds.

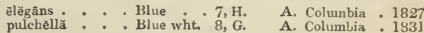

ClitŏR İ, Linn. From clitoris, an anatomical term a resemblance to the configuration of which has been fancied to exist in the flower. Linn. 17, Or. 4, Nat. Or. Leguminose. The species of this genu are mostly climbers, with large elegant peaflowers: they succeed best in a mixture of loam, peat, and sand; cuttings will root under a glass, in heat, but the best method of increasing them is by seed, which sometimes ripens in this conntry. The annual species requires the same treatment as other tender annuals.

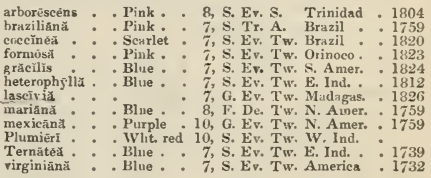

Crīvĭ L, Lindley. Named in honour of the Duchess of Northumberland. Linn. 6, Or. 1, Nat,. Or. Amaryllidacece. A beatutiful plant, requiring a warm part of the greenhouse, or a cool part of the stove; the soil it grows best in is a rich loam, with about a third part sand; when growing freely, it requires a plentiful supply of water; it may be increased by divisions, or seeds. Synonyme: 1. Imatophyllnm Aitoni.

nöbīlǐs, 1 . . . Red yel. . 7, G. Ev. Bl. C. G. H. . 1823

Crosed, that which is closed up, leaving no aperture ; pressed together, not spreading.

Clost-PRBssibD, when any thing lies quite close upon a suiface.

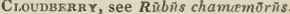

Crove, see Diūntlı̆̃s caryophỹllūs.

ClovEN, forked.

Clover, see Trifolîtim.

Clover-traE, see Caryophỹllŭs.

CI.OWN's ALI.HEAL, see Stăchy̆s palñstrĭs.

Club grass, see Corynēphorñs.

Clun moss, see Lycopŏdiũm.

Ci,UB RUSk, see Scirpŭs.

Cıêstă, Lim. In honour of Charles de l'Ecluse, of Artois, a celebrated botanist, who died in 1609. Linn. 23, Or. 1, Nat. Or. Guttiferce. A very ornamental genus of trees growing, under cultivation, thirty feet high; they require a light sandy loam, and the pots must be well drained. Cuttings root freely in sand, under a glass. In tropical climates they are found growing on other trees.

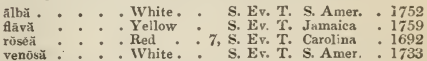

Clusterad, disposed in clusters:

CuvẼrĭĂ, Aiton. Named after Outgers Cluyt, a Dutchman, who was professor of botany at Leyden. I,inn. 22, Or. 3, Nat. Or. Euphorbicice. Ornamental species, thriving in a mixture of loam and peat; cuttings of the young wood root freely in sand, under a glass.

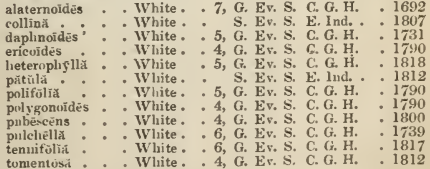
tomentusi . . White. .

CIY PẼ́r.Ă, Gaertner. From clypens, a buckler; in 
allusion to its buckler-like silicle. Linn. 15, Nat. Or. Crucifere. Pretty annuals, which only require sowing in the open ground, and to be treated as other hardy annuals.

Ion Thláspi : Yellow . 6, H. A. S. Eur. . . 1710 eriophora . : White. 6, H. A. Spain : 1820

CNвmidostāchY̌s, Martius. Derived from knemis, the spoke of a wheel, and stachys, a spike. Linn. 21, Or. 3, Nat. Or. Euphorbiacea. A worthless stove annual, growing in sandy peat-Chamelø̃ă.

CNRōRū M, Linn. Theophrastus gave the name cneoron to some shrub resembling an olive. Linn. 3, Or. 1 , Nat. Or. Surianacece. Beautiful species, delighting in a mixture of peat and loam, and cuttings ront freely in sand, under a glass.

pulverulēntūm : Yellow : 6, G. Ev S. Madeira : 1892

CnĒstǐs, Jussieu. From knao, to scratch; in reference to the prickly capsules. Linn. 10, Or. 4, Nat. Or. Connaracea; Ornamental shrubs; see Connarus, for culture and propagation.

corniculata - Purple * S. Ev. S. Guinea : 1793 gläbri : : Wht grn. S. Ev. S. Maurit: : 1823 polyphylla: : Purple . S. Ev S. Maurit. : 1823 CNYDř ûx, Cusson. The ancient name of Orach. $L$ inn. 6, Or. 2, Nat. Or. Umbelliferce. Worthless herbaceous plants; for culture and propagation, see Séselt. Synonymes: 1. Smyrnum atropurpureum. 2. Selinum canadense. 3. Angelica Fischeri-atropurpureum 1, canadense 2, Fischeri 3, Monnieri, pyrenceum.

COADUNATB, united, soldered together.

Cō̄GŬLĀNs, congealing together.

Conrctatr, pressed together.

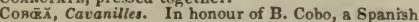
botanist. Linn. 5, Or. 1, Nat. Or. Polemoniaced A very fast growing climber, well adapted to a conservatory ; it thrives well in the open air in summer, and looks well growing up by the side of a house; if the wall be rough on which it runs, the tendrils will catch fast hold of the crevices and support the branches without any assistance; it may be increased by cuttings, which will root under a glass, in a little moist heat, but it is best to raise it from seeds, which ripen in abundance.

scandens . Purple 8, F. Ev. Cl. Mexico. 1798

СовёRGRĬ , Herbert. In honour of Prince Leopold of Saxe-Coburgh, now King of Belgium. Linn. 6, Or. 1, Nat. Or. Amaryllidacea. Handsome species, requiring the same treatment as Pancratium. Synonyme: 1. Pancratium incarnatum.

fillva - . Tawny - G. Bu. P. \& Amer. - 1829

СовтвнввD, covered with louse hairs, as if with cobweb.

Coccocīpš̌zUี M, Swartz. From kokkos, fruit, and kypsele, a vase; alluding to the shape of the berries. Linn. 4, Or. 1, Nat. Or. Cinchonaced. An uninteresting stove herbaceous plant, growing in sandy loam, and multiplied by cuttings in sand, under a glass-rëpẽns.

Coccrros a lobe; in allusion to the character of the fruit. Linn. 8, Or. 3, Nat. Or. Polygonacede. The Seaside Grape is an ornamental genus, varying in height from fifteen to eighty feet, the species are remarkable for their large leaves. They prow well in a mixture of loam and peat, and cuttings of the ripened wood, taken off at a joint, will root freely under a glass, in sand; the leaves of the cuttinus must not be shortened. Synonyme: 1 Coccoloba parviflora.

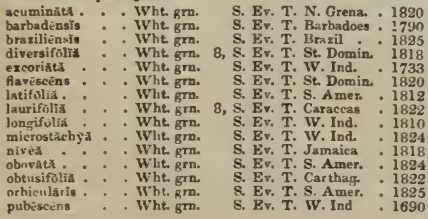

punctier . . Wht. gm. S. Ev. T. W. Ind. 1733 S. Ev. T. W. Ind 1690 rirěns ? : Wht. grn. S. Ev. T. W. Ind. : 1825

CōccŭLôs, a kind of cell, which opens with elasticity. Cóccŭnūs, Decandulle. Derived from coccos, the systematic name of the cochineal; given to this genus because most of the species bear scarlet berries.

Linn. 22, Or. 6, Nat. Or. Menispermacea. An interesting genus of plants, remarkable for their medicinal virtues. The species do well in a mix. ture of loam and peat, and cuttings root freely under a glass. C. crispus is used in intermittent fevers and liver complaints; a poisonous principle called picrotoxia has been detected in the seed of C. suberosus. Synonyme: 1. Menispermum coculus.

cordifơliǔs . : Wht. grm. S. Ev. C. E. Ind. . 1820 crispüs : : : Wht grm. S. Bv. Cl E. Ind. : 1822 S. Ev. C. E. Ind. : 1820 laurifoliŭs . : Wht. grn. S. Ev. Cl. E. Ind. : 1816 orbiculatūs . . Grn. yel. . S. Ev. Cl. E. Ind. : 1790 palmătŭs * Whe grn. S. Ev. Cl. E. Ind. . 1800 Plukenëtī, 1 : Grn. jel. S. Ev. Cl. E. Ind. . 1790 rotundifoliǔs "Whe grm. S. Ev. Cl. suberōsūs tomentósǔs: : : Whit. grn. S. Ev. Cl. E. Ind.: 1819 villosûs : : Grn yel. S. Ev. Cl. E. Ind. : 1800 hirsūtús: : : Grn yel. : S. Ev. Cl. E. Ind. : : 1800

Соснтвйrй, Tournefort. From cochlear, a spoon; the leaves are hollowed like the bowl of a spoon. Linn. 15, Nat. Or. Cruciferce. Plants of little interest with the exception of $\boldsymbol{C}$. Armoracca, the common Horse-radish, which should be planted in February or October in a deep rich soil; the best way of increasing it is by slips from the root. The smaller perennial kinds do best in pots or rock. work. The annuals and biennials merely require sowing in the open border, which should be done directly after the seeds have ripened. Synonymes : 1. C. pusilla. 2. Myagrum saxatile.

snglleă . Whito. 5, H. A. Britain

Annorices . White. 5 , K. Pa. P. England

fenentratia: : : White: : 5, H. B. Greenland : 1820 gronlandiea : Flesh . . 5, H. B. Scotland

integrifulis , White. 5, H. B. Siberia : 1822

offeinalis . . White. 4, P. B. Britsin .

minur

pyrenates. : White: 4, H. B. Pyrenees: 1820

acaūlts 1, suriculată, glastifoliŭ, macrocārpă, saxütilis 8 .

Cоснцият, $t$ wisted to resemble the shell of a snail.

CochlospērmūM, Kunth. From kochlo, to twist, and sperma, a seed; alluding to the somewhat twisted seeds. Linn. 16, Or. 8, Nat Or. Ternstromiaced. Magnificent trees, attaining the height of sixty feet, the best soil for them is loam and peat, cuttings not too ripe, taken off at a joint, will root in sand, under a glass, in a moist heat. Synonymes 1. Bombax Gossypium, B. grandiflorum. 2 B. viti. folium.

Gossýpiúm, 1 . Yellow . 5. Ev. T. E. Ind. . 1824 serratifolium, 2 . Yellow

Cоск's-CoмB, see Colosiă.

Соск's-сомв, see Rhinānthüs Crīstă-gällt.

Соск's-сомв, see Erythrină Cristă-gälli.

Cock's-Foot, see Echinochlö Crüs-gülli.

Cock's-Yoor Grass, see Dacty̆lis.

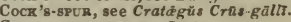

Cocon-NUT Trek, see Cócös.

CocoA rLUM, see Chrysobălănŭs.

Cōcōs, Linn. From the Portuguese word coco; the end of the nut resembles a monkey's head. Linn. 21, Or. 6, Nat. Or. Palmacea. The cocoa-nut tree belongs to this elegant uenus. The species grow upwards of fifty feet high, and are cultivated best in a mixture of loam and peat or light sandy loam, in a warm moist atmosphere. They do not succeed well in our collections, probably from being too much exposed to the sun, as they thrive best in the shade in their native country. Synonyme: 1. C. comosa.

flexuôs: Palm. Brasil : 1825 nucíféră : : : Pa grm. : Palm E. Ind. : : 1690 plumösă, i : : Pagrn. : Palm. Brazil : : 1825 Conйrĩux, Solander. Derived from kodarion, a leathern pouch; in reference to the pods. Linn. 2 , 
Or. 1, Nat. Or. Leguminose. Ornamental trees, from twelve to tiventy feet high. For culture and propagation, see Copaiférŭ.

acutifoliúm ． Pa. red 2, S. Ev. T. S. Leone 1800 obtusifóliúm : : Pà red :2, S. Ev. S. S. Leone : 1824

CōDřù , Stackhouse. From kodion, a skin; on account of the appearance of the species. Linn. 24, Or. 7, Nat. Or. Alye. Marine productions of little interest-būrsũ, tomentosũm.

CODLINS AND CRRAM, see Epilobĩñm hirsūtĩm.

Cōpōs, Linn. From kodon, a little bell, referring to the shape of the corolla. Linn. 10, Or. 1, Nat. Or. Hydrolacez. A curious plant, thriving in a mixture of loam and peat; it requires to be kept with the greenhouse plants.

Royēnĩ . . . White . . 9, G. B. C. G. H. . 1801 CoDonōpно̆вӑ, Linn. From kudon, a little bell, and phoreo, to bear; alluding to the flowers. Linn. 14, Or. 2, Nat. Or. Gesneracea. Ornamental plants. For culture, \&c., see Gesięriă. Synonymes : 1. Gisnera pasinata. G. tomentosa.

grandifloră, 1 . Scarlet *6, s. Ev. S. Brazil . 1818 lanceolátă, 2 . : Scarlet : 6, S. Ev. S. S. Ancer. : 1752 C̄̄LĽ̆ L̆, Lindley. Not explained. Linn. 20, Or. 1, Nat. Or. Orchidacea. This is described as being a very curiously formed plant, and requiring the same treatment as Stanhopea. Synonymes:1.Cymbidium tripterum, Epidendrum tripterum.

Bauērănă . • . White . . 6, S. Epi. Janaics . . 1790

CøL a female; in allusion to the form of the stigma. Linn. 20, Or. 1, Nat. Or. Orchidacer. The species of this genus are all very handsome when in flower and therefore deserve to be in every collection of Orchideous plants. From most of the species having been introduced but a short time, they are rather rare in most collections. They should be grown in a hot damp heat, and otherwise treated as the Stanhopeas. synonyme: 1. Calogyne punctulata.

barbata . . Wht yel. 12, S. Epi. Khooseea . 18

$\begin{array}{ll}\text { eristata } & \text { S. Epia Nepal : : : } 1837 \\ \text { S. Epi. Khooseea : } 1837\end{array}$

S. Epi. Khoosees

Gardneriañă: : White: : 13, S. Epi. Khooseea : 1837

interrūptă. : White. S. Epi. Khooseea : 1837

longicăuliss : : Wht. yel. $\quad$ S. Epi. Khooseea : 1837

S. Epi. Khooseea : 1837

S. Epi, Khooseea : 1837

nitida $: \vdots: \vdots$ Yellow $\quad$ S. Epi. E. Ind. . : 1822

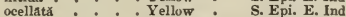

Wht bri 10 s. Epi. E. Ind

proliféră : : : Yellowish $\quad$ S. Epi. Khooseea : 1837

rigida $:$ : Yellow S. Epi. Khooseea : 1837

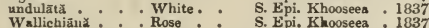

Cors̄̄̄, Linn. Named from Coffee, a province of Narea in Africa, where it grows in abundance. Linn. 5, Or, 1, Nat, Or. Cinchonaceu. The Coffeetree is a very ornamental plant, succeeding well in peat and loam, and if kept clean and free from insects it will flower and fruit abundantly; to grow well, it must have a good supply of water and plenty of pot-room; cuttings of the ripened wood root readily in sand, under a glass, in a moist heat. Coffee is the roasted seeds of this plant, and owe its character to a peculiar chemical principle called Caffein. Synonyme: 1. Totramerium paniculatum.

arăb̌că . . . . White. . 9, S. Ev. S. Yemen. . , 1696 paniculată, i : White: S. Ev. S. Guiana : 1822

COFFEE-TREE, see Coffeŭ.

COGW OOD TRBE, see Laũrŭs Chloroxy̆lön.

COHERTNG, connected.

Cōix, Linn. A name applied by Theophrastus, to a reed-leaved plant. Linn. 21, Or. 3, Nat. Or. Gra minea. A genus of curious tropical grasses, growing freely in light rich soil; they produce both flowers and seeds in great plenty.

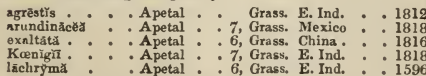
Cōr. Ă, see Stercaliăa acuminätă.

CоLвË́тr̈̆, Salishury. In honour of John Baptist $[83$ ]
Colbert, Marquis of Seignelai, a famous French statesman and patron of botany: died 1683. Linn. 13, Or. 5, Nat. Or. Dilleniacea. A beautiful genus of trees, resembling Dillenia, to which genus they may be referred for culture and propagation.

coromandeliañă, 1 Yellow . 4, S. Ev. T. Coroman. . 1803 seabröllă . Y Yellow S. Ev. T. Nepal . 1820

Сӧцнйсоัм, Linn. Named after Colchis, its native country. Linn, 6, Or. 3, Nat. Or. Melanthacece. An ornamental genus of bulbs, growing best is light loamy soil, and increased by offsets from the bulbs, or from seeds. Synonyme: 1. Merendera montana. arenam * Purple - 7, II, Bu. P. A pennin. - 1820 arenariumm : Purple 9, H. Bu. P. Hungary 1816 album

foliss-variegátis Purple 9, H. Bu. P. Britain

flörè-plēnō? Purple : 9, H. Bu. P. Britain

byzāntiumm.: : Purple : 9, H. Bu. P. Levant

chionense : : Purple : 11, H. Bu. P. Chio.

crociflorūm : Purple: 8, H. Bu. P. S. Eur.

montanūm, 1 : Purple : 8, H. Bu. P. S. Eur.

tessellatūm : Purple : 8, H. Bu. P. S. Eur.
umbrōsūm : Pink. 9 , H. Bu. P. Crimea

variegātüm : : Purple : 9, H. Bu. P. Greece

1819

CoLDẼNY̌, Linn. In honour of C. Colden, a zealous North American botanist. Linn. 4, Or. 3, Nat. Or. Boraginaced. A pretty stove annual, requiring the same treatmerit as other tender annukals.

procūmbëns . . White. . 7, S. Tr. A. E. Ind. . . 1699

CoLEBRōōKĬă, Smith. In honour of H. T. Colebrooke, an accomplished botanist. Linn. 14, Or. 2, Nat. Or. Labiata. A beautiful genus of shrubs, growin about three feet high, succeeding best in a mixture of peat and loam; increased by cutlings in sand, under a glass.

oppositifolra . . White. . G. Ev. S. Nepa] . . 1820 teruifolia : : White: : G. Ev. S. Nepal : 1820 CoLnon̄̄Mă, Bartling. From keleosa, a sheath, and nema, a filament; in allusion to the manner in which the filaments are fixed. Linn. 5, Or. 1, Nat. Or. Rutacea. A very beantiful little shrub. For culture and propagation, see Adenāndrü. Syno. nyme: 1. Diesma alba.

albă, 1 . - . . White . . 6, G. Ev. S. C. G. H . 1798

CoLeorhīzĂ, a little sheath, which tips the radicle in cruciferous plants.

CŏLĚŭs, Loureiro. Derived from koleos, a sheath referring to the manner in which the stamens are united. Linn. 14, Or. I, Nat. Or. Labiate. Shrub of some merit, requiring to be grown in a mixture of loam and peat, and increased by cuttings in sand, under a glass, in heat. Synonymes: 1. C. am. boinicus, Gesnera odorata. 2. Plectanthus barbatus, P. Forskohldi, 3. P. fruticosus.

\section{aromătĭcŭs, 1 . $5, \mathrm{~S}, \mathrm{EV}, \mathrm{S}$. Indi}

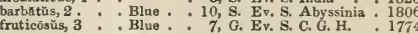

CoLLA PSING, the act of closing or falling together.

CoLLĒMă, HUffmann. From the Greek kolla, glue ; all the species are gelatinous. Linn. $24, \mathrm{Or}, 9, \mathrm{~N}$ at. Or. Lichenes. A rather extensive genus of Lichenes, varying from half an inch to three inches high, found in a variety of situations, some being on the trunks and roots of trees, some on rocks, and others on old walls and dry banks, \&c,-Burgēssīi, cheîlēêum,

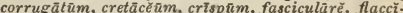
dūm, fluvialē, frōgrāns, fūrvūm, grunulätūm, lücêrūim, melē̉nūm, M. marginālé, multipartītūm, muscĭcơlă, nigrëscēns, nīgrâm, palmätūm, plicūtîlë, saturnīnùm, Schradērī, scotīnūm, S, sinuñtūm, spou

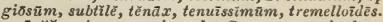

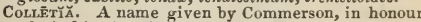
of his friend and countryman M. Collet, a write upon the plants of Brest. Linn, 5, Or, 1, Nat. Or. Rhamnacee. Ornamental shrubs, vary ing from two to five feet high. For culture and propagation, see Retanillŭ. Synonymes: 1. C. ferox. 2. C. horrida.

hörrưdă, 1 . . Gsh. wht. 5, F. Ev. S. Chile . . 1832 serratifóliă : Y Yellow .6, s. Ev, S. Perv : : 1822 spinōsă, 2 : : A petal $\vdots$ 6, S. Ev. S. Peru $\vdots 182$ Collguař, Moling. The name given to it by the natives. Linn. 21, Or. 10, Nat. Or. Euphorbiacece. 
A shrub of considerable merit, though little known in cultivation.

odoriferă . . . Yol, wht. . G. Ev. S. Clile . . 1831

Cot.īssĩ president of the Academy of Natural Sciences, Philadelphia. Linn. 14, Or. 2, Nat. Or. Scrophulariacex. A most elegant genus of hardy annuals: the seeds of the different kinds need only to be sown in the borders of the flower-garden early in spring, they will then flower beautifully durin summer, and ripen plenty of seeds; to obtain flowering plants early in spring, the seed must be sown in autumin.

bĭcūlor . . . Pur, wlit. 6, H. A. California . 1833 grandiflốră: : : Pk. blue $, 6, \mathrm{H}$. A. Columbia : 1826

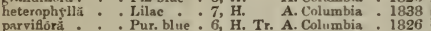
vêrnă : : Pur. blue : 6, H. Tr. A. N. Amer. : 1826

Cor.trvsōxǐn. Named by Linnæus in honour of his friend Peter Collinson, F.R.S., a distinguished promoter of botany. Linn. 2, Or. 1, Nat. Or. I,ahiate. A genus of pretty plants, growing upwards of three feet high; they succeed well in cormmon garden 8oil, particularly if they are planted in a moist situation; they are increased by dividing them at the roots.

\begin{tabular}{|c|c|c|}
\hline 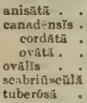 & 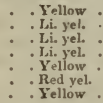 & $\begin{array}{l}\text { 10, H. Her. P. Carolina } \\
\text { 9, H. Her. P. N. Amer. } \\
\text { 9, H. Her. P. A. Amer. } \\
\text { 9, H. Her. P. N. Amer. } \\
\text { 8, H. Her. P. Carolina } \\
\text { 8, G. Her. P. E. Flor.. } \\
\text { 8, H. Tu. P. Carolina }\end{array}$ \\
\hline
\end{tabular}

Cor.ı̄мй ferring to the seeds. Linn. 5, Or. 1, Nat. Or. Polemoniacece. A genus of annuals, possessing little beauty in their flowers; they require the same treatment as Collinsia. Synonyme: 1. C. laterita.

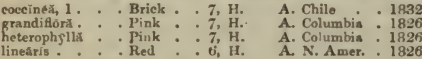

CoLoñ̄xIñ, Kunth. In honour of the family of Cologan, of Port Orotavo in Teneriffe, from whom the men of science visiting that island experience the greatest hospitality. Linn, 17, (0r. 4, Nat. Or. Leguminosce. A beautiful genus of climbers. For culture and propagation, see Clitoria. Synonyme 1. Clitoria Broussonetii.

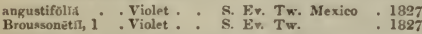

CoIopHōNǏ

France is Bois de Colophone. Linn. 6, Or. 1, Nat. Or. Burseracee. An ornamental tree, scarcely known in collections. For culture and propagation, see Bosnellia.

mauritinnă. . Purple . S. Ev. T. Mauritius . 1826 CoL̄̃RAss, changeable, coioured.

Coloratr, coloured, painted.

CōLP̄ōón, see Fusūnüs.

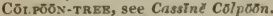

Cout's-roor, see Tussilag $\delta$.

ColuBRīñ, Richard. From koluber, a snake; alluding to the appearance of the twisted stamens. Linn. 5, Or. 1, Nat. Or. Rhamnacer. Plants of little beauty, and scarcely worth cultivating except in general collections; loam and peat suits them, and cuttings of the young wood root readily in sand, under a glass. Synonymes: 1. Ceanothus asiaticus. 2. C. cubensis. 3. C. colubrina. 4. C. reclinatus.

asiátieñ, 1 . . Pa. tel. , 7, G. Ev, S. Ceylon

cubēnsìs, 2: Crimson : S. Ev. S. Cuba

ferruginósă, 3 . Green : 7, S. Ev. T. Bahama reclinätă, 4 : Green : : 8, S. Ev. S. Jamaica : 1758

CoLUBR̄̄Nă, relating to snakes.

Columbink, see Aquileggĭa.

CoLumbints, resembling a dove in shape or colour.

ColumÉLİ̃. Named by Jacquin after the celebrated Geoponic writer, L. J. M. Columella, a Spaniard, who flourished about forty-two years A.C. Linn. 19, Or. 2, Nat. Or. Columelliaced. A worthless greenhouse biennial, growing in any common soil. Synonyme: 1. Nestlera biennis-biēnnis 1 .

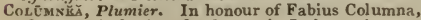
of the noble family of Colonna, in Italy. Linn. 14,
Or. 2, Nat. Or. Gesneracece. Pretty flowering plants, growing well in a mixture of loam and peat, andstrikingreadily from cuttings: the plants must be carefully watered or they will soon rot; they require a dry part of the house.

hirsñtă . . . P . pur. - 9, S. Ev, S. Jamnica 1780 rütrlans: : : Purple :, S. Ev. S. Jamaica : 1780 scandēns : : Scarlet : B, S. Ev. CL. W. Ind. : 1759 trifuliătă : : Blue . 9, S. Ev. S. W. Ind : 1823

Colếrĭ , R. Brown. From kolouros, deprived of a tail ; in reference to the seed wanting that appendage. Linn. 12, Or. 3, Nat. Or. Rosacee. A pretty species, thriving best in a mixture of peat and loam, and increased by divisions. Synonyme: 1 . Geum potentilloides.

potentilloìdès, 1 . Orange - 6, H. Her. P. Siberia . . 1780

Colvtěn, Linn. Supposed to be from koluo, to ampu. tate; they are said to die if the branches are cut off. Linn. 17, Or. 4, Nat. Or. Leguminosd. All the species of Bladder-Senna, on account of the great profusion of flowers, and their continuing in flower the most of the season, are well adapted for the shrubbery; they thrive in any common soil, and are increased by seeds, or cuttings planted in the autumn. C. arborescens is purgative. Synunyme: 1. C. Pucockii.

arborêscäns *. Yellow * 7, H. De. S. France * 1548 eruénti. Scarlet $: 6, \mathrm{H}$. De, s. Levant : 1710 lialéppīcă, i : Yellow : 8, H. De. S. Levant : I 1753 médíf * Orange 7, H. De. S.

8, н. De, S, Nepal 1829

Colvīlı k̆ñ, Bojer. In honour of Sir Charles Colville, Governor of the Mauritius. Linn. 10, Or. 1, Nat. Or. Leguminose. A splendid tree, from forty to fifty feet high; nothing is at present known of its cultivation.

racemonal - . Scarlet - S. Ev. T. Madagas, .

СомĀNDRă, Nuttall. Derived from kome, hair, and aner, anther; in allusion to the tuft of hair attached to the anthers. Linn. 5, Or. 1, Nat. Or. Santalaced. A hardy plant of some merit, thriving in a mixture of loam and peat, and increased by divisions. Synonymes: 1. Thesium umbellatum, Hamiltonia umbellatum.

umbellată, 1 . . Green . . H. Her. P. N. Amer. . 1789

Cossarōps Ys, Richard. From komama, the comarum, and opsis, appearance; because of its resemblance to Marsh Cinquefoil. Linn. 12, Or. 3, Nat. Or. Rosaces. Pretty lierbaceous plants. For culture and propagation, see Geum. Synonymes. 1. Dalibardu fragarioides, Waldsteinia Doniana. 9. D. fragarioides.

Douifina, 1. . Yellow . 5, H. Her. P. N. Amer. . 1800 fragarioldés, $2^{\circ}$ : White. : 5, H. Her. P. N. Amer. : 1803 Cомйrī M, Linn. Derived from kumaton, the arbutus ; on account of the similarity of its fruit. Linn. 12, Or. 3, Nat. Or. Rosacec. An interesting plant, growing in any moist soil, and increased by divisions. Synonyme: 1. Potentilla comarum.

palastre, 1. . Purple . 6, H. Her. P. Britain .

Сомйтеัs, tufted.

Сомнвётём, Laffling. A name given to a climbing plant by Pliny. Linn. 8, Or. 1, Nat. Or. Combre. tacea. Plants surpassed by few in the elegance and brilliancy of their blossoms; they all thrive well in loam and peat, and cuttings of the young wood root readily in a pot of sand, in a moist heat, with a glass over them. The climbing species are well adapted to training up the rafters, or covering the trellis-work in a stove. Synonyme: 1. C.laxum.

élegăns . . Senrlet : 5, S. Er. Cl. Brazil •. 1820

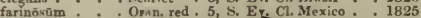

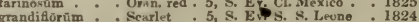

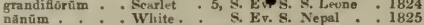
nanūm paniculatúm : : White. : 9, S. Ev. \&. Ci. Guineal : : 1825 racemônúm : White. 5, S. Ev. Cl. Benin : 1426 secūndüm, 1 : : Yel. str. : 5, S. Ev. Cl. Trinidad : 1818

Сомкрйямй, Labillardiere. From kome, the hair of the head; and sperma, a seed; alluding to the tuft of hairs at the end of the seed. Linn. 14, Or. 5 , Nat. Or. Polygalacea. These species are well worthy of cultivation, succeeding best in sandy loain and peat, and young cuttings will root freely in sand, under a glass.

(84) 
cordifolia . - Purple . 6, G. Ev. \&. N. Holl. . 1822 ericinit : Yurple :6, G. Ev. S. N. Holl. 1829

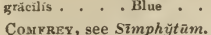

Соммет, İ, Linn. In honour of $J$. and G. Commelin, famous Dutch botanists. Linn. 3, Or. 1, Nat. Or. Commelinacea. Some of the plants of this genus are very handsome; the stove kinds grow freely in a mixture of sundy loam and peat, and are increased by divisions or seeds. The hardy kinds thrive in common garden soil, and are increased by offsets from the roots, or by seeds; the annual species require the same treatment as cther hardy and tender annuals.

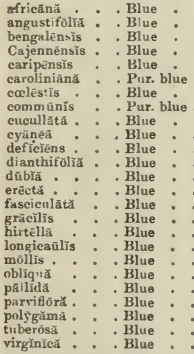

7, G. Ev. Tr. C. G. H.

6, F. Ev, Tr. Carolina

6, S. Ev. Tr. Bengal

6, S. Ev. Tr. Bengal

$6, \mathrm{~S}$. Her. P. Trinidad

H. Ev, Tr. America

6 , S. Her. P

6, $\mathrm{H}$. A. Americ

7. G. A. Brazil

7, G. Ev. Tr. N. Holl

8, S. Ev. Tr. Brazil

7, S. Tw. P.

7, S. Tw. P.

6, H. Her. P. Virginia

8, H. Her. P. Virgin

7, G. Her. P. Lima

6, H. Her. P. N. Amer.

8 , S. Ev. Tr. Caraceas

8, S. Ev. Tr. Caraceas

6, S. Ev. Tr.

6, S. Ev, Tr. Trinidad

6, S. Ev. Tr.

6, S. Ev. Tr.

6, S. Her. P. Mexico

1759

1827

1794

1823

1826

1732

1813

1732

1825

1820

1823

1816

1818

1732

1817

1830

1820

1806

1804

1820

1820

1824

1818

1732

Commrasōxĭ, Forster. In honour of Philibert Commerson, M.D., a French botanist and traveller, who died in 1774 . Linn. 5, Or. 5, Nat. Or. Sterculiucea. These ornamental shrubs thrive well in a mixture of peat and loam, and cuttings of the ripened wood will root readily in sand, under a glass, in heat.

echinātă . . White . . S. Ev. S. Moluceas . 1820 platyphȳllà : White: 6 , S. Ev. S. Moluceas : 1806 Cомminuted, pulverised, pounded.

Comoctünî̆, P. Bronne. From kome, a tuft, and klados, a branch; the leaves being crowded at the tops of the branches. Linn. 3, Or. 1, Nat. Or. Anacardiacea. Ornamental trees, from fifteen to twenty feet high, succeeding well in a mixture of peat and loam, or any light rich soil ; ripened cuttings will root in sand, under a glass, in heat.

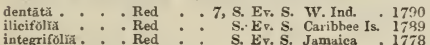
integrifoliă . Red

Comparêtrĭ, Poppig and Endlicher. Named after Andreas Comparetti, professor at Padua, and an eminent writer upon vegetable physiology. Linn. 20 , Or. 1, Nat. Or. Orchidacea. This is a splendid but a very rare genus of plants, well worth cul. tivating for the brilliant colour of the flowers, and their very curious structure. They will be found to succeed well potted in good fibrous peat, and the pots efficiently drained with broken potsherds, which should be carried up the centre of the peat. The plants showld be raised above the pot according to their size, in the same way as the Stanhopeas.

coccinéă . . . Scarlet . . 8, S. Epi, Brazil . . 1838

Complanate, flattened.

Cомplicats, folded together.

Compound, used in botany to express the union of several things into one.

Compressid, pressed together, flattened.

Coмpтōn Lord Bishop of London, an ardent cultivator of exotics. Einn. 21, Or. 3, Nat. Or. Myricacea. A pretty shrub, growing about four feet high in light sandy loan or peat soil; increased by layers.

aspleniforra - Brown . 4, H. De. S. N. Amer. - 1714

Conanthêră, Ruiz et Pavon. From konos, a cone, and anthera, an anther; the anthers being united into a cone. Linn. 6, Or. 1, Nat. Or. Liliaced. A pretty genus of bulbs, growing best in light sandy loam; increased by offsets. Synonyme: 1. C. bifolia.

bifölī̄.

Simsī, i

Blue

4, G. Bu, P. Chile

1823

CoNcave, hollow.

Conckntric, points, or lines, at equal distances from a common centre.

CoNCRETB, formed into one mass, joined together.

CondēLĬ Cavanilles. In honour of $\mathrm{A}$. Condal, a Spanish botanist. Linn. 5, Or. 1, Nat. Or. Rhamnacea. A curious plant, growing about two feet high; cultivated in any common soil, and increased by cuttings. Synonyme: 1. Zizyphus myrtoides.

microphyllă, 1 . Green . . F. Ev. S. Chile . . 1824

Condensate, bundled, growing close.

Condylocārpts, Heffman. From kondyle, a knob, and karpos, fruit; in allusion to the fruit. Linn. 5, Or. 2, Nat. Or. Umbelliferc. Worthless weeds, of the simplest culture. Synonymes: 1. Tordylium apulum. 2. T. humile. 3. T. officinale-apulum 1, humile 2 , officinale 3.

Cone, a particular kind of compound fruit.

ConfrRruminatB, united together so as to be undis tinguishable.

CoNpËrvă, Agardh. Derived from the Latin conferrumino, to consolidate; because of the close coherence. Linn. 24, Or. 7, Nat. Or. Alga. A very extensive and interesting genus of $A \lg \mathscr{E}$, found chiefly in the ocean, lakes, pools, ditches, \&c. -

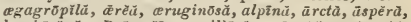

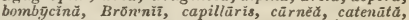
colläbëns, cougregätă, crässä, crispätă, cürtă, dis. š̉liēns, dīstüns, ericetōrüm, fasciätü, ferruginnéă,

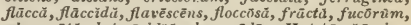

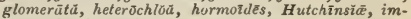
plëxă, intricãtă, isogōnă, lanōsă, līñ̄m, melogōnẵ̄m, mucōsūm, pütēns, $\boldsymbol{P}$. prolüfèrü, pellūcĩdü, refrīictü, ripürïü, rivulūrís, $R$. änglică, rupēstris, serícẽü, stellüris, tortuósŭ, tumīdülü, vaucheriafornìs, vcsi. cütü, $V$. fuscēscēns, Youngână, zonätü.

CoxplueNT, running into one another at the base or apex.

Congrutrati, glued together into one mass.

Contcal, shaped like a cone.

CoNICARLY-SUBULATE, between cone and awl-shaped, thickest at the base.

Coxico-cYindiricat, form of a cylinder, but tapering to a point.

Conico-súbulatr, awl-shaped and conical, tapering to a point.

Conic-ovate, between egg-shaped and conical.

Conjugate, joined in pairs ; thiefly applied to leaves.

Conīex. Derived, according to Linnæus, from konis, dust or powder; the application of the term is not evident. Linn. 5, Or. 2, Nat. Or. Umbellifera. The annual species of this genus merely require sowing in the open ground in autumn; the stove species delights in a rich mould, and is increased by dividing the roots. In the south of Europe $C$. maculutum is a dangerous poison, while in Russia and the Crimea it is innocuous and eatable.

croătřcūm

maculatüm

White
White

7, H. Her. P. Hungary

1818

CōNNĂR Ŭs, Linn. From connaros, the name of a tree described by Athenæus. Linn. 16, Or, 6, Nat. Or. Connaracea. The species of this genus are ornamental plants, growing from six to eight feet high; they succeed best in a mixture of peat and loam, and increase by cuttings of the ripened wood in sand, under a glass, in heat.

nǔtr̆dús. White.

panieulātŭs Wh W. Silhet . 1824 pubézcêns : : White. : S. Ev. S. Guiana.? 1822

CoNNĀTǓs, joined together at the base.

Conniving, converging, lying close together.

ConocArrús, Linn. From konos, a cone, and karpos, a fruit; the fruit is so closely imbricated in a head as to resemble a fir cone. Linn. 5, Or. 1, Nat. Or. Combretacec. Ornamental shrubs. For culture and propagation, see Bucida. The bark of $C$. racemosus is much used in Rio Janeiro for tanning.

S. Ev, S. S. Amer. 1894

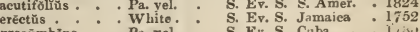

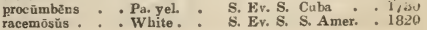
[85] 
Conoč̆pHătưs, Blume. From konos, a coue, and kephale, a head; referring to the form of the flowers. Linn. 21, Or. 4, Nat. Or. Urticacea. A curious plant, growing about ten feet high; cultivated in peat and loam, and increased by cuttings in sand, under a glass, in heat.

naucleiflōrŭs, 1 . Yellow . S. Ev. S. Chittagong , 1820 Coxom, cone-shaped.

ConopönĪ Ũ Koch. From konos, a cone, and podion, a little foot; form of flowers. Linn. 5, Or. 2, Nat. Or. Umbelliferce. Plants of little beauty; may be grown in any common soil, and increased by dividing the roots. Synonymes: 1. Sison canadense. 2. Myrrhis Claytoni. 3. Bunium denudatum.

Claytoni, 2. . . White . . 7, H. Her. P. N. Amer. . 1806 canadēnsĕ 1 , denudātom 3.

CoNōPš̌̃̆M, resembling a gnat.

CovospẼR MŨ Smith. From konos, a cone, and sperma, a seed. Linn. 4, Or. 1, Nat. Or. Proteacec. An ornamental genus of plants, thriving well in sandy peat, and readily increased by cuttings in sand, under a glass.

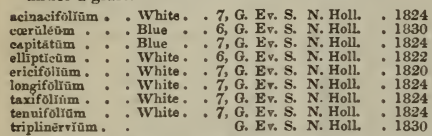

CoNōstǒm ÛM, Srvarts. From konos, a cone, and stoma, a mouth; the teeth of the theca are united. Linn. 24, Or. 5, Nat. Or. Musci. A curious species of moss, found during summer on some of the Scotch mountains. Synonyme: 1. Grimmia conostomaborealle 1 .

Conostřls, R. Bronn. From konos, a cone, and stylos, a style; the styles are united. Linn. 6, Or. 1, Nat. Or. Hamodoracea. Rather an ornamental genus, growing about a foot high; sandy peat suits them, and they are increased by dividing the roots.

aculeăta

serrulata

G. Her. P. N. Holl.

G. Her. P. N. Holl

- 1820

vetigeră

G. Her. P. N. Holl

- 1824

Conspërsư̌s, scattered, or sprinkled.

CoNstricted, tightened, or contracted in some particular place.

Contorteplicats, $t$ wisted in plaits.

Contractis, narrowed in some particular place.

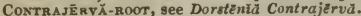

Convaliârix, Linn. From the Latin convallis, a valley; in allusion to the situation where it grows. Linn, 6, Or. 1, Nat. Or. Liliacer. The Lily of the Valley is a sweet little plant, thriving in any common soil; it will do well in any shady situation where few other plants will succeed; it is multiplied by dividing the roots.

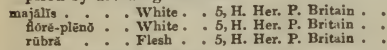

Cosvex, rising in a circular form.

Convoutre, rolled tngether, or over each other.

ConvóLvŭLuัs, Linn. Derived from the Latin convolvere, to entwine or wind about; in reference to the habit of the plants. Linn. 5, Or. 1, Nat. Or. Convolvulacex. Being mostly showy plants, the tender species are well adapted to stoves and conservatories: they are best cultivated in loam and peat, and cuttings strike very freely in sand, under a glass; the half-hardy annual kinds should be sown on a gentle hotbed, and when of sufficient size planted out into the open border, the hardy kinds only require sowing in the open ground; the stove and greenhouse annuals and biennials require to be sown in the stove, and treated as other stove and greenhouse annuals and biennials. The roots of C. arvensis and macrocarpus abound in a milky juice which is highly purgative, and the roots of C. floridus and scoparius are used as sternutatories. Synonymes: 1. C. Pseudo-siculus. 2. C. decumbens.

albivēntŭs - Pa pink . 6, S. Ev. Cl. Algoa . 1823 althreoldes : Pink * 6, H. De. Tw. Levant : 1597 arboréscéns : : Pink *. 6. Ev. S. Mexico : 1818 bleçlór. : Wht pur. 7, S. Tw. A. Isle Fra. : 1818 bieuspidatús: : Purple .6, H. De. Tw. Davuria : 1818 bonariénsiss . White. . 7, H. De Tw. Chile . . 1817 bryoniæfollüs : Pink : 7, G. Be. Tw. China : 1802 eanariensis . . Pink : 6, G. Ev, Tw. Canaries . 1590 cantábricǔs : Pink : 6, H. De. Tr, S. Eur. : 1640 chinēnšis. : Purple : 7, H. De Tw, China: 1817 eiliătŭs : : Pink : 7, S. Ev, Tw, Cavenne 1816 Cneōrūm: : : Pink : : 6, G. Ev. S. L. Lavenñ : 1816 córsieŭs *. Pinks . 6, H. De. Tw. Corvica : 1824 Dorgenīmm : Flesh : 7 , H. De. Tr. Levant : 1806 ebricteătũs : . White. : 7, H. De. Tr. 1819 elongâtũs, 1 . Whitēe : 7, H. Tw. A. Canaries : 1815 emarginatŭs : Purple : 7, H. De. Tw. Canaried: 1817 emarginatús : Purple : 7, H. De. Tw.
erubescens evolvoluides, 2 . Red : : 7, G. Tw. A. N. S. W. 1803 farinōsuns ? : Pink : : 5, G. Ev. Tw. Madeira : 1777 floridüs . : Pink : 8, G. Ev. Tr. Canaries : 1799 Gerardi : : Pink : 6, H. De. Tr. S. Eur.

gläher. : * White. : 5, S. Ev. Tw. Cayenne : 1806

guianēnsǐs * - White. * 7, S. Ev. Tw. Guiana : 1823

Hermănnī̄e - White * 8, G. Ev. Tw. Peru • 1799

hirtŭs . * Blue : 7, S. Tr. A. E. Ind. 1804

lmperătí : Yellow : 7, H. De. Cr. Naples : 1824

lineâris : : : Pinite : : 7, G. Bv. S. S. Eur. : 1770

lineătŭs : Purple : 6, H. De. Tr. S. Eur. : 1770

macrocärpŭs . Purple . 7, S. Tw. A. S. Amer. . 1752

mãximǔs. - Pink * 7, S. Ev. Tw. Ceylon 1799

ochrăcê̆ŭs. - Yellow : 7, S. Ev. Tw. Guinea : 1825

. Blue . G, G. Ev. Tw. Canaries . 1805

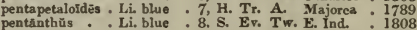

pentanthüs
quinquefolras

rêptāns : Purple : 7, S. Ev. Cr. E. Ind. : 1806

salvifolrŭs : Pink * 7, H. De. Tr. Palestine : 1825

saxatulis . . White. - G. Ev. Tr. S. Eur. : 1796

Scammonid . Wht pux. 7, H. De. Tw. Levant 1596

scoparius . White. 8, G. Ev. Tr. Canaries: 1733

scrobiculatŭs: : Pa. red. : S. Bv. Tr. S. Amer. 1825

SibthōrpI : White. : 7, H. De. Tr. Franer. 1823

sīcǔlŭs : : Li. blue : 7, H. Tr. A. S. Eur. : 1640

suffruticðsũs: : Pink : 7, G. Ev. Tw. Madeirs : 1788

tiliǎceǔs : : Purple : 7, G. Ev. Tw. Brazil. : 1820

albifórüs: : Whito. : 7, H. A. A. S. Eur. : 1629

verticillatǔs: : Blue : 8, S. Ev. Tw. W. Ind. : 1819

arvênsìs, bogotênš̌s, dentūtǔs, filicaūliss, hirsatǔs, in-

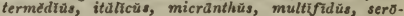
tintus.

CoŅ̌n̆, Linn. From konis, dust ; because it was sup. posed to have the power, when it was powdered and sprinkled, of driving away flies, whence the name Flea (Fly)-bane. Linn. 19, Or. 2, Nat. Or. Compositc. Plants of no beauty. The stove and greenhouse shrubby kinds grow well in loam and peat; young cuttings root under a glass. The hardy herbaceous kinds grow in any garden soil, and increase by divisions or seeds. The hardy and tender kinds require the same treatment as other hardy and tender annuals. Synonyme: 1. Conyza candida.

genistellordë: . Yellow • S. Ev. S. S. Amer. * 1824 odorkt3 . . : Purple : 7, S. Ev. S. India . : 1759 agyptiăeă, amảnă, amplexicåగis, arborëscëns, aurzlă, axilläris, balsamiféră, büfrōns, camphoratā, cündidă, carolinensis, chinēnsis, cinèrěa, fastigiată, fätidä, geminiflöră, glomerată, Gouäñ̄, hirsütü, incisă, inu-

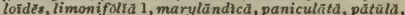

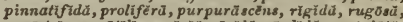

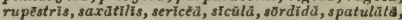
squarrossa, Tenorit, thapsoides, verbascifoliam, virgätà.

Со̆кї̆, Sonnerat. In memory of the celebrated circumnavigator Capt. James Cook, R.N., who was killed in the Sandwich Islands in 1779. Linn. 10, Or. 1, Nat. Or. Aurantiacea. An ornamental stove tree, requiring to be cultivated in a mixture of loam and peat, and cuttings of the ripened wood with their leaves on will root in sand, under a glass, in a moist heat. A fruit called wampee, which is highly esteemed in China and the Indian archipelago, is the produce of this tree.

punctătă . . White, . S. Er. T. China * . 1795

CoOPĒrY̌̆, Herbert. In compliment to Mr. Joseph Cooper, one of the most zealous and successful cultivators of rare plants in this kingdom, and who has had, for upwards of twenty years, the management of the botanic garden at Wentworth House, the property and residence of Earl Fitzwilliam. Linn. 6, Or. 1, Nat. Or. Amaryllidacer. Very interesting flowering bulbs; a sandy compost appears to suit them well, with a copious supply of water 
they inerease freely from seed. The flower is fragrant, smelling like a primrose, and is produced at night.

chlorōsōlēn . Wht. grn. . G. Bı. P. Mexico * 1835 Drummondn . : Whit red : G. Bu. P. Mexico： 1835

CopaĬF̆̌́̆ copaiba, and fero, to bear. The balsain of Capevi is the produce of this genus. Linn. 10, Or. 1, Nat. Or. Amyridacece. Valuable species, because of their medical properties. They are best cultivated in sandy loam; ripened cuttings will root in sand, under a glass, in heat.

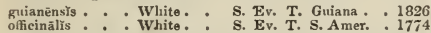

Coprīxús, Persoon. Named from kopria, dung; species found on dunghills. Lim. 24, Or. 9, Nat. Or. Furgi. The species of this genus are found on dunghills, trunks of trees, shady dainp places, \&c.

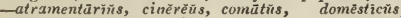
ephēměrürs, Lagöpŭs, micaceus, vĩrēns, pilacěñs, plicätriliss, rueliūtüs.

Cóprǐs, Salisbury. From kopto, to cut; in allusion to the divisions of the leaves. Lim. 13, Or. 6, Nat. Or. Runnnculacece. A pretty species, well worthy of a place in every garden, succeeding well in a bed of peat soil, or grown in pots, and protected in severe weather, increased by divisions or seeds. In the United States, the root of this plant is a popular remedy for apthous affections of the mouth in children. Synonyme: 1. Helleborus trifolius.

trifoliatix, 1 . . Brown - 5, H. Her. P, N. Amer. . 1782

Coralitord, like coral.

CORAL TRER, see Erythrīnă coralloulēndrŏn.

CoRAt.ŏRHİz̆, Swartz. Said to be from korallion, a coral, and rhiza, a root. Linn. 20, Or. 1, Nat. Or. Orchidacee. A genus of curious, bulbous-rooted, perfectly hardy plants. They grow well in peat and loam, and are readily increased by divisions.

innătă . . Green . . 6, H. Ter. Scotland

multiflöră : Green : 6, H. Ter. N. Amer.

odontorhiză: : Green : 6, H. Ter, N. Amer

182

Coranıc porsoN-Bur.B, see Brunsviğgü corümĭcŭ.

Corbert. Ārǔa, Haworth. From corbula, a little basket: in reference to the shape of the nectary. Linn. 6 , Or. I, Nat. Or. Amaryllidacea. An ornamental species, thriving best in a light loamy soil in a shel tered situation; it also suceeeds well in pots treated as a bulbous frame plant. Synonyme: 1. Narcissus bulbococium.

serötīna, 1 . . . Yellow . 3, H. Bu, P. Portugal . 1629

CōrchŏRŭs, Linn. From kore, a pupil, and koreo, to purge; in allusion to the laxative qualities of $\boldsymbol{C}$. olitorins. Linn. 13, Or. 1, Nat. Or. Tiliacece. A genus of stove shrubs and annuals, of easy cultivation. In India, fishing lines and nets, rice bags, and a coarse kind of linen are made from $C$ c $p$ sularis.

hïrtǐs * * . Yellow * 7, s. Ev, S. S. Amer. - 1820 pilölobŭs - Yellow : 7, s. Ev. S. S. Amer. 1818 trídēns . : Yellow : 7, s. Ev. s. Senegal. : 1824

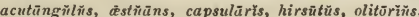
siliquऍ̄sūs, triloculäris.

Connate, formed like a heart.

CoRvATB, when joined by a hyphen to another word, signifies a figure between the two, as cordate-reniform, a figure between heart-shaped and kidneyshaped : cordate-auriculate, having auricles at the base, so as to give the leaf the figure of a heart.

CōrdĪA, Lina. In honour of $\mathrm{E}$. Cordus, a German botanist of the sixteenth century. Linn. 5, Or. 1 , Nat. Or. Coreliacec. An ornamental genus, many of the species being fine timber-trees, upwards of sixty feet high; best cultivated in loam and peat, and cuttings root freely in sand, under a glass, in heat. The flesh of the fruit of C. Myxa and Sebestena is succulent, mucilaginous, and emollient. Synonymes: 1. Varronia alba. 2, V. alnifolia. 3 V. augnstifclia. 4. V. monosperma. 5. V. bullata, V. globosa. 6. V. lineata. $7 . V$. martinicensis. 8 . $V$, mirabiloides.

Al: ${ }^{2}, 1$. . . Wlite . S. Ev. S. Trinidad , 1820 aluifölцӑ, 2 : White: S. Ev, s. Trinidad: 1818 angustifóliz̆, 3 : White : $\quad$ S. Ev S. Santa Cruz 1308 collocüetŭ . . Green . S. Ev. T. Jamaica , 1759 cory mbüsă, 4 : White. : S. Ev. T. Caraceas : 1800 dentatล

dentati.

dieliotorm

dillenis .

domestic

flavèscēns

Geraschãnthŭ

globōsน̆, 5

grandiflōră

l̇ēìs

lineâtă, $\dot{6}$

macrophȳll

martinicēnsiss, 7

micrãnthă

nıonoīeà

Mỹxa

nervōsa

nodōsã

obliq̨uă

parviflöră

reticulāta

rugōsă

Sebestēnă

spinēscêns

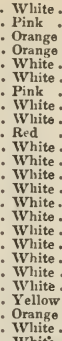

S. Ev. T. Curacoa

S. Ev, T. N. Holl,

4, S. Ev, T. Baliama

S. Kv, T. E. Ind. 1820

S. Ev, T, W, Ind

S. ${ }_{V}$ S. Guiana

5, S. Ev. T. W. Ind. : 1789

8 , S. Ev. S. Jamaica: 1818

9. G. Ev. S. S. Amer. 1827

7, S. Ev. r. Trinidad : 1827

S. Ev. S. W. Ind. 3793

S. Ev. T. W. Ind. 175

8, S. Ev, S. Martiniq. 1795

S. Kv. T. Guiana

9, S. Ev, T. Hispaniola . 1798

4, S. Ev. T. E. Ind.

S. Ev. T, E. Ind. : 164

S. Ev. S. Guiana : 1820

6, S. Ev. S. Guiana : 1803

S. Ev. T. E. Ind. : 1818

S. Ev. T. Jamaica . 1819

S. Ev. T. E. Ind. * 182

7, S. Ev. T. W. Ind.

S. Ev. T. E. Ind. . 1824

CoRDİ(:ӖRĂ, heart-lipped.

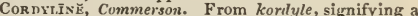
club. Linn. 6, Or. 1, Nat. Or. Liliacea. Ornamental shrubs, cultivated in a mixture of peat and loam, or any light vegetable soil; readily increased by suckers.

\section{cannæefōlì.}

S. Fv. S. N. Holl

1820 hemiclirs?

S. Ev.

1893

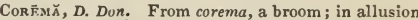
to the habit of the plant. Limn. 22, Or. 3, Nat. Or. Empetracece. An ornamental dwarf shrub, succeed. ing well in sandy peat, and increased by layers.

albă, 1 . . Apetal . 4, H. Ev. S. Portugal . 1774

Corf̂mîn, Nees. From korema, filth; found there.

Linu. 24, Or. 9, Nat. Or. Fuugi. A very minúte fungus, fourfd on old paste, \&c.-glañcरिm.

Conzópsis, Linn. From koris, a buy, and opsis, ap pearance; because of the resemblance of the seeds. Linn. 19, Or. 3, Nat. Or. Compositue. A very pretty genus of plants, the stove perennial kinds grow freely in any rich light soil, and cuttings root under a glass; some of the hardy kinds are tall growing plants well adapted to the back of flower borders, or vacant places in the shrubbery, some of the smaller species are very handsome, and may be planted near the front ; they are increased by divisions of the roots. The hardy and tender annuals and biennials require the same treatment as other hardy and tender annuals and biennials. -lb

älbă Wlite

angustifolia . Yellow

auriculătă

chrysāntlıă

coronätă

erassiforli:

diclıŏtōmă

diversiforlia

ferulæfóli:

filifólià

grandiffôră

ineis:

integrifolīa

lanceolată

latifolīă

lōngīpęs

rēptãns

senifolla

tenuifolyă .

trichuspërma

Yellow : 7 , H. Her. P. N. Anter. 1778

Yellow, 8, H. Her. P. Carolina

Yellow 7, H. Her. P. N. Amer. 1785

V. Ind. 1799

Yel. brn. 7, H. Her. P. Mexico 1835

Yellow 9, H. Her. P. Camelina 178

Cartina. 178

Yellow . 9, H. Ker. P. Carolina . 182

Yellow: 10, F. Her, P. Mexico 1799

Yellow: 8, H. A. Texas : 1835

Yellow: 8, H. Her. P. N. Amer. 1820

Yellow: 10, S. Ev. Tw. W. Ind.

Yellow: 7, H. Har. $\mathbf{P}$. Carolina

Yellow : 8, H. B. Carnlina 1724

Yellow 8, H. Her. P. N. Amer. 178

Yellow 4 H Her.

Fellow: 7, S. Tw. A. W. Ind. : 1792

Yellow - 9, H. Her. P. N. Amer. 181

Yellow : 7, H. Her. P. N. Amer. 1780

Yellow . 8, H. B. N. Jersey 1818

amplexicañlĭs.

CoREOPsis, see Chrȳsostêmmü.

Corracrous, thick, tounh, like leather.

Cortaxner, see Curiüudrîm.

Cortâxdrìm, Huflinann. Fromkoris, a buy; alluding to the smell of the leaves. Linu. 5, Or. 2, Nat. Or. Umbellifierc. A species of little beauty, which only requires to be sown in the open ground. 'The fruit is a well-known warm, and agreeable aromatic.

sativūm . . White . 6, H. A. England .

Contārix, Linn. Frım corium, a hide. Linn. 22 Or. §, Nat. Or. Coriariaceu. Ornamental shrubs, 
the hardy species succeeds well in the open border, and is readily increased by cuttings of the roots, or by suckers. The other species thrives well in a mixture of sand, loam, and peat, and cuttings under a glass, in the saine kind of soil, will toot freely. c. myrtifintia is not only used in tanning leather, but also for staining black. Its fruit is poisonons. myrtifolina . . . Green . . 6, H. Ev. S. S. Eur. . 1629 sarnentōŏ : : Green : : 6, G. Ev. S. N. Zeal. : 1893 Cǒrǐs, Linn. A Greek name, used by Dioscorides. Linn. 5, Or. 1, Nat. Or. Primnlaceie. An ornamental little plant, rather of a succulent nature, growing in peat and loam, with the pots well drained and a limited supply of water; it produces seeds in great plenty.

monspeliensis . . Lilac . . 6, G. B. S. Eur. . 1640

Corispírmèm, Linn. From koris, a bug, or tick, and sperma, a seed. Linn. 1, Or. 2, Nat. Or. Chenopodiaceve. Worthless hardy annuals, which merely require sowing in the open ground-canéscẽus, glomerätñm, hyssopiföliñm, intermédī̄m, Marschüllï,

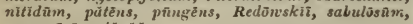
squarrñsüm, těnūé.

CORK-TREE, see Quērcñs sñbèr.

CORKWOOD, see Auōnü palñstrīs.

CoRs-Cockn.E, see Lychnis Githingr.

Corntutan cuerry, see Cörnǘs mäscŭla.

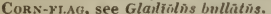

Corsiculatev, furnished with little horns.

Corsicuñ̄̃ǘ, Acharins. From corniculus, a little horn; referring to the divisions of the thallus, Linn. 24, Or. 9, Nat. Or. Lichenes. A genus of Lichenes found on mountains and alpine rocks

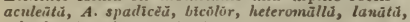
ochroleñcü, pubēscēns, tristis.

CORNiaH MONEIW'TRT, see Sibthörpld europäd.

Cornucópĩ $\overline{4}$, Linu. From cornu, a horn, and copia, plenty; the spike inclosed in the involucrum resembles the horn of plenty. I,iun. 3, Or. 1, Nat. Or. Graminea. This is an innual grass, that only requires to be sown in the open groind.

cucullàtím . . A petal . 8, Grass Jevant . . 1788

Cōrsčs, Tournefort. Derived from cornu, a hoın; the wood being thought as hard and durable as horn. Linn. 14, Or. 1, Nat. Or. Connacer. This is an ornamental genus, consisting principally of trees and shrubs, that succeed well in any coinum soil ; they are increased by seeds or by layers, the herbaceons species are generally grown in pots, but they grow well in a bed of peat, and are increased by dividing the roots. The bark of $c$ : florida and sericea is said to rank among the best tonics of $N$. America.

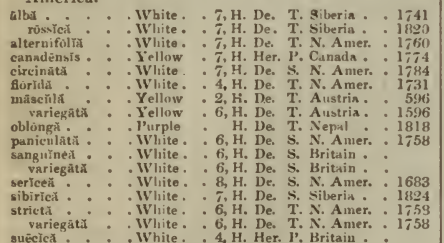

\section{CoRNētă, horned, furnished with horns.}

Cornêtĩ̄, Limu. Nauned after Jacques Cornutus, a French physician and traveller. Linn. 2, Or. 1, Nat. Or. Verbenucece. An ornamental shrub growing about six teet high, stcceeding well in a mixture of loam and peat; cuttings strike freely in sand, under a glass.

pyramidătă - Blue . . 7, S, Ev. S. Mexieo. . 1733 CurNwren, see Bisērrülă Pelecinüs.

Corot.t.A, the coloured part of a flower, composed of a petal or petals. The term is only applied when the caly $\mathbf{x}$ is persistent, otherwise it is called a perianth.

CoRóx $\tilde{A}$, a crown; in botany applied to the crown. like sup, which is found at the orifice of the tube of the corolla in Narcissus, Pancratium, and some others.
Coronīt.r. Ă, Necker. Derived from corona, a crown; in reference to the arrangement of the flowers. Linn. 17, Or. 4, Nat. Or. Leguminosce. An interesting genus: several of the greenhouse species are very pretty flowering shrubs, and grow well in a mixture of peat and loam, and may be increased by cuttings or seeds, which ripen in abundance; the herbaceous species are some of them best grown in pots, such as $C$. coronata and minima, as they require the protection of a frame in severe weather; increased by seeds or dividing at the roots: the hardy annual kinds only require to be sown in the open ground.

argēntea . . Yellow . 5, F. Ev. S. Crete . 1664

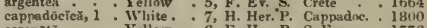
coronati . : Yellow 6, F. Her. P. S. Eur. . : 1776 crëtici. : : : Striped 6, H. A. Cuadia : 1731 glaûcă : : : Yellow : 7 , F. Ev. S. France : : 1722 variegåia: : Yellow : 8, F. Ev. S, Gardens slobisagáta: : White.:9, H. De. Cr. Crete: 1800 plobisad : : White : 9, H. De. Cr. Crete : 1800 jünceã : : : Yellow : 7, H. De. Tr. 1beria : 1822 ninimă $:$ Yellow : 7, F. Her. P. S. Eur. : 1658 montină, 2 : Yellow 6, 6. Her. P. Switzerl. : 1776 Pentaphy * Yllow . 6, F. Ev. S. Algiers - 1700 virínat: : Pink : 9, H. De. Cr. Europe : 1597 valentină, 3 : : Yellow : 8, F. Ev. S. S. Eur. : : 1596 viminalis. : Yellow : 8, F. Ev. S. Mogad. : 1798

Corpuscr.r, a sinall body, a particle of anything.

Corr.æ. A, Smith. In honour of Joseph Correa da Serra, a distinguished Portuguese butanist. Linn. 8, Or. 1, Nat. Or. Rutacer. The species of this genusare pretty greenhouse shrubs, yrowing from three to six feet high; they succeed best in a mixture of equal parts of sand and loain; the species are increased by cuttings, which should not be planted too thick, as they are liable to dump off. C. specinsa, which is allowed to be the most difticult, may be increased by inarching upon the cuininon sorts.

Elliwi

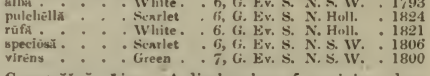

CoRrugrŏı Ă, rimn. A diminutive of corrigia, a leathern thong; from the halpit of the plants. Linn. 5, ()r. 3, Nat. Or. Illicebrucere. These are pretty annuals, only requiring to be sown in the open groutind, and to betreated as other hardy anuuals.

capinsis - . . White - 7, H. Tr. A. C. G. H. . 1819 littualis : Wlite. \%, H. Tr. A. England.

Corromorant, strengthening.

Corrosivg, having the power to eat away.

CORRuGarki, wrinkled, or shrivelled.

Cortical, belonging to the bark.

Corticate, like bark.

Cortüsă, Linn. In honour of J. A. Cortusus, professur of botany at Padua. Linn. 5, ()r. 1, Nat. Or. Primulacet. This is an ornamental plant, that succeeds well grown in a pot in a mixture of ренt and loan, but requires to be protected in severe weather; it is increased by dividing the roots, or by seeds.

Muthlióli . . Red . . 4, H. Her. P. Anstria . 1596

Corvisãrtỹ. Nauned by Merat, in honour of Mr. Corvisart. Linn. 19, Or. 2, Nat. (1r. Compositie. Plants not remarkable for much beauty, that grow well in common soil, and are increased by dividing the ronts. Synonymes: 1. Inula cuncusica. 2 I. Helenium.

caučsiea 1 . Yellow - 7, H. Her. P. Caucasus . 1818 Helenĩim, 2 : Yellow : 7 , H. Hev, P. Britain .

CоRхт̃тне̄s, Hooker. From korys, a helmet, and anthos, a flower; in allusion to the large helmetlike appendage to the lip of the flower. Lin:t. 20, Or. 1, Wat. Or. Orchilaceic. 'The species of this renus ought to be extensively cultivated, because of their splendid and very curionsly-finrined flowers. The nost extraordinary species of this genus is C. macrantha, of which the following is an abridged description, extracted from the Botanical Register. "The plant has the nabit of a Stanhopeu, ard pushes forth from the base of its pseudo-bulos a pendulous scape, 
on which two or three flowers are developed; each flower is placed at the end of a long, stiff, cylindrical-furrowed ovary, and when expanded, measures something more than six inches from the tip of one sepal to that of the opposite one. The sepals and petals are nearly of the same colour, being of an ochrey yellow, spotted irregularly, with dull purple. The lip is as fleshy and solid in its textrre as the sepals and petals are delicate; it is seated on a deep purple stalk, nearly an inch long, this stalk terminates in a hemispherical greenish-purple cup or cap; and the latter contracting at its front edge, extends forward into a sort of second stalk of a very vivid blood-colour, the sides of which are thinner than the centre, turned back, and marked with four or five very deep, solid, sharp-edged plaits. These edges again expand and form a second cup, less lobed than the first, thinning away very much to the edges, of a broadly conical figure, with a diameter of at least two inches at the orifice; this second cup is of an ochrey yellow, streaked and spotted with pale crimson, and seems intended to catch a watery secretion, which drips into it from two succulent horns, taking their origin in the base of the column, and hanging over the centre of the cup." -Bot. Reg. vol. xxii. t. 1841. The genus requires the same treatment as is recommended for Stanhopea. Synonymes: 1. Gongora macrantha. 2. G. speciosa.

macränthă, 1 - Brn. yel. . 6, S. Epi. Caraceas . maculātă : Yel. spot. 6, S. Epi. Demerara speciósă, 2 : : : Yel. srn. : 5, S. Epi. Brazil : : 1826

Corycārpǔs, Zea. From korys, a helmet, and karpos, a fruit; in allusion to the shape of the fruit. Linn. 2, Or. 2, Nat. Or. Gramineo. A curious grass, only requiring to be sown in any common soil. Synonyme: 1. Festuca diandra.

arundinācěŭs, 1 . Apetal . . 4, Grass. N. Amer. . 1810

CōR Y̌cīū, Snartz. From korys, a helmet; appearance of the flower. Linn. 20, Or. 1, Nat. Or. Or chidacer. The species of this genus will succeed well in an equal mixture of sandy loam and peat, planted out in a pit or frame. They will also grow, when planted about six inches deep, in a warm border, and protected by some slight covering, in frosty weather, but to be exposed when the weather is fine and mild; increased by divisions.

crispüm . . . Yellow . 7, F. Ter. C. G. H orobanchờiēs: : Yellow : 7, F. Ter. C. G. H.

CoR F̌ñLLIs, Decandolle. One of the Greek names of Fumitory; from korydalos, a lark; because the spur of the flower resembles the spur of that bird. Linn. 17, Or. 2, Nat. Or. Papaveracea. This is a beautiful genus, the species of which grow from one to six feet high; the delicate kinds thrive best in a mixture of peat and loam, and are very ornamental in fiower-borders; the annual kinds only require sowing in the open border; seeds. Synonymes: 1. Fumaria solida. 2. F. fabacea. 3. F. sempervirens. 4. $F$, pauciflora. 5. F. cava albiflora.

acaüls

Pa. yel. . 7, H. A. Hungary . 1825 \% $\mathrm{T}$ P 6, H. B. N. A mer. bracteata: : Pa. yel.:2, H. Tu. P. Siberia.: 1820 bicalcarātă : Pink : 6, H. Tu. P.

breviflōră : Pa. yel. 6, H. A. Kamtsch. 1824 bulbosă, 1 Pink 2, H. Tu, P. Britain caproìdés . White. 7, H. B. S. Eur. caveasică, 2 Puple caucasica, 2. Purple * 2, H. Tu. P. Caucasus . 1823 elaviculātă . Wht. yel. 6, H. Cl. A. Britain fabricéa - Purple 2, H. Tu. P. German

glaúcă, 3 . Yel pur. . 7, H. A. N. Amer. : 1683 impătiens. - Yellow :5, H. A. Siberia : 1823 lutez * Yellow : 7, H. Her. P. England longiflöră . Pa. rose 4, H. Tu. P. Altai Marshalliānă : Purple : 2, H. Tu. P. Tauria: : 1824 nôblis. : Li, yel, : 5, H. Tu. P. Siberia: : 1783 pæoniæfoliă . Purple . 2, H. Her. P. Siberia * 1820 pauciflöră, 4. - Purple . 2, H. Tu. P. Siberia * 1819 sibirică : : Yellow : 7, H. Her. P. Siberia: : 1810
strictă $:$ Yellow : 6, H. tuberōsă : : Purple : 2, H. Tu. P. Europe : : 1596 albifiōră, 5 . White :2, H. Tu. P. Europe : 1596 uralēnsìs . Pa. yel. : 8, H. B. Kamtseh. : 1824

Cŏn Y̌uťs, Linn. From korys, a helmet; referring to the calyx enwrapping the fruit. Linn. 21, Or. 9, Nat. Or. Cupuliferc. The species of this genus are $[89]$ generally cultivated for the sake of their fruit ; they will thrive well in any common garden soil, and may be raised from seed; but to have any variety true to its kind, they must be raised from suckers or iayers.

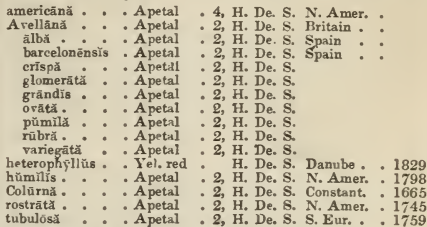

Conyмв, a raceme or panicle, in which the stalks of the lower flowers are longer than those of the upper, so that the flowers are all on the same level.

Cor rmbosely-cymose, between a corymb and a cyme. Corymbulosi, formed of many small corymbs.

CoRYNĒPHŏrĂ, Agardh. From koryne, a club, and phoreo, to bear; the last articulation of the jointed beard is club-shaped. Linn. 24, Or. 7, Nat. Or. Alga. Curious plants, found growing on the sea shore. Synonyme: Rivularia tuberiformis-marina 1.

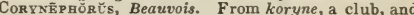
phoreo, to bear; the last articulation of the jointed beard is club-shaped. Linn. 3, Or. 2, Nat. Or. Graminee. Uninteresting species of grass, requiring only to be sown in common soil. Synonyme: 1 . Aira canescens.

\section{articulātŭs}

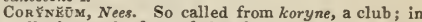
allusion to the form of the plants. Linn. 24, Or. 8 , Nat. Or. Fungi. Very minute species of Fungi, discernible upon old decaying branches-pulvinätn $m$.

CoRYNOCĀRPĽs, Forster. This name is derived from koryne, a club, and karpos, a fruit ; in reference to the form of the seed-vessel. Linn. 5, Or. 1, Nat. Or. Myrsinacee. An ornamental plant, of easy culture and propagation.

lævigatŭs

G. Ev. T. N. Zeal,

1823

CoRГPHA, Linu. From koryphe, the summit; the leaves are only on the top of the trees. Linn. 6 , Or. 1, Nat. Or. Palmacea. This is a beautiful genus of the Palm tribe, growing in their native country from 15 to 1.50 feet high; they should have a strong moist heat, and a sandy loam to grow them well.

lis A petal . Palm. N. Holl . 1824

Palm. E. Ind * 1824

glaucēscēns : : A petal : : Palm. E. Ind. : 1820

heterophyllús : A petal. Palm. Danube: 1829

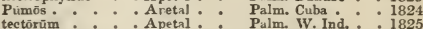

umbraculifera : Anetal : Palm. E. Ind.: 1742

Utān : A petal: Palm. Moluceas: 1825

Corysāntrīs, R. Brown. From korys, a helmet, and anthos, a flower; in allusion to the large helmetlike appendage to the flower. I.inn. 20, Or. 1, Nat. Or. Orchidacee. The species of this genus are well worth cultivating; for which, see Corycium.

bicalcărātă . . Drk, brn. . 7, F. Ter. N. Holl. . . 1823 fimbriātă : Drk. brn. : 7, F. Ter. N. Holl. : : 1824 unguicúlată : : Drk. brn. : 7, F. Ter. N. Holl. : : 1829

Coscĭx̌̃̂m, Colebrooke. From koskinion, a little sieve; in reference to the cotyledons being perforated. Linn. 22, Or. 6, Nat. Or. Menispermacea. This is a climbing plant of pleasing habit, that grows well in a mixture of loam and peat, and is increased by dividing the roots. Synonyme: 1. Menispermum fenestratum.

fenestrātūm, 1 . Yel. grn. - S. Ev. Cl. Ceylon * . 1800 Cōsmк̌̃, Willdenon'. From kosmos, an ornament; in allusion to the ornamental flowers. Linn. 19, Or. 2, Nat. Or. Composita. The species of this genus are mostly pretty annuals, that require to be sown on a gentle hotbed, and when large enough transplanted into the greenhouse or open borders. 


\begin{tabular}{|c|c|}
\hline $\cos$ & COT \\
\hline 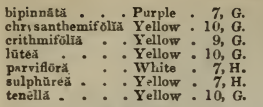 & $\begin{array}{l}\text { A. Mexico: : } 1799 \\
\text { A. S. Amer. } 1826 \\
\text { A. Mexico: : } 1825 \\
\text { A. Mexico: }: 1811 \\
\text { A. Mexico: : } 1800 \\
\text { A. Mexico: : } 1799 \\
\text { A. Mexico.: } 1824\end{array}$ \\
\hline $\begin{array}{l}\text { Cosmsilin, R. Brown. From } k \\
\text { reference to the beauty of th } \\
\text { Or. 1, Nat. Or. Epacridacea. } \\
\text { plant, growing about a foot } \\
\text { succeeds best in a sandy peat } \\
\text { creased freely from cuttings in }\end{array}$ & $\begin{array}{l}\text { meo, to adorn; in } \\
\text { flowers. Linn. 5, } \\
\text { This is a pretty } \\
\text { d a half high; it } \\
1 \text {, and may be in- } \\
\text { he same compost. }\end{array}$ \\
\hline
\end{tabular}

rũbrå . . Red . G. Ev. S. N. Holl. . 1826

Cosmrtic, beautifying.

Cōsmuัs, Cavanillles. From kosmos, beautiful ; in allusion to the appearance of the species. Linn. 19, Or. 2, Nat. Or. Composite. This is a genus of very beautiful plants, well deserving of extensive cultivation. The flowers are not very much unlike those of a single dahlia, to which the genus bears a close resemblance; and the perennial species requires exactly the same treatment. C. tenuifolius being an annual, the seeds must therefore be sown on a hotbed early in spring, and planted out in the flower-garden about the end of May; but a few plants should be kept in the greenhouse, from which the seeds shonld be gathered.

diversifolrŭs . . Lilac . . 9, H. Tu. P. N. Amer. . 1835 scabiosódes: : Scarlet :9, G. Tu P. Mexico:

Cossĩonǐn, Commerson. In honour of M. Cossigny, a French naturalist, who presented Commerson with an herbarium of the plants of Coromandel. Linn.6, Or. 2, Nat. Or. Snpindacece. This is a pretty stove plant, growing well in a mixture of peat and loam; and cuttings, in sand, root freely under a glass.

borbðnૉea . . $\quad$ S. Ev. S. Maurit. . 1824

CostatB, ribbed, having longitudinal elevations.

Costmary, see Balsamitn.

Cõstưs, Linn. Derived from its Arabic name, Gosth. Linn. 1, Or. 1, Nat. Or. Scitaminea. This is an ornamental genus of plants, growing well in a mixture of peat and loam, and are increased by dividing the roots, or by seed. Synonymes: 1. C. afer hirsutus. 2. C. speciosus angustifolius. 3. Alpinia spiralis.

\begin{tabular}{|c|c|c|}
\hline 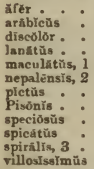 & $\begin{array}{l}: \text { White } \\
: \text { White } \\
: \text { White } \\
: \text { White } \\
: \text { White } \\
: \text { YeL pur } \\
: \text { Whimon } \\
: \text { Yellow } \\
: \text { Scarlet } \\
\text { : Yellow }\end{array}$ & $\begin{array}{l}\text { 6, S. Her. P. \&. Leone } \\
\text { 8, S. Her. P. Indies } \\
\text { 6, S. Her. P. Maran. } \\
\text { 5, S. Her. P. S. Amer. } \\
\text { 7, S. Her. P. S. Leone } \\
\text { 7, S. Her. P. E. Ind. } \\
\text { 7, S. Her. P. Mexico } \\
\text { 6, S. Her. P. Mrran. } \\
\text { 8, S. Her. P. E. Ind. } \\
\text { 6, S. Her. P. W. Ind. } \\
\text { 11, S. Her. P. St. Vincent } \\
\text { 11, S. Her. P. St. Vincent }\end{array}$ \\
\hline
\end{tabular}

Cotoneñstür, Medicus. From cotoneum, a quincetree ; in reference to the downy leaves of this genus being similar to the quince. Linn. 12, Or. 8, Nat. Or. Rosacea. These are hardy ornamental shrubs, growing about four feet high; they thrive well in any common soil, and are increased by layers. $S y-$ nonymes: 1. Pyrus Missia. 2. P. microphylla, uvaursi. 3. Mespilus Cotoneaster.

acuminsta - Pink . 4, H. De. S. Nepal 1890 acuminata : : Pink : : 4, H. De. S. Nepa! : 1820

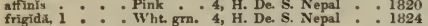

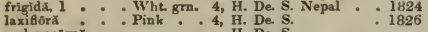

melanochirpi : : H. De. S

microphylla : White. 4, H. De. S. Nepal * 1825

nummuláriă : : Wht. grn. 4, H. De. S. Nepul : 1824

rotundifolia, $2^{*}$ : White. 4, H. Ev. S. Nepal : : 1820

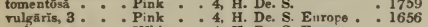

depressa : : White: 4, H. De. S. Europe

erythrocárpa : White. 4, H. De. S. Europe

melanocarpa : White: 4, H. De. $\mathrm{S}$. Europe

Corron, see Gossỹpiñm.

Corron GRAss, see Eriophðrim.

CotTon RO`B, see Filägő pygmåă.

Cotron thistrz, see Onopordìm.

CǒTữ $\breve{A}, L i n n$. A diminutive of cota, an old name of a species of Anthemis. Linn. 19, Or. 2, Nat. Or. Composito. This is a genus of very little interest; the tender species require to be sown on a gentle cot

cow

hotbed, or in the stove, but the hardy kinds need only be sown in the open air.

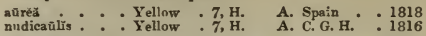
anthemoìdes, coronopiforiă, spheränthă, tanacetifólīu, viscossă.

CoTYLEDōis, seed leaf, the first leaf from seed.

CorY LĒDōn, Linu. From kotyle, a cavity; in allusion to the cup-like leaves. Linn. 10, Or. 4, Nat. Or. Crassulacea. A numerous and rather ornamental genus of succulents; they succeed best in a sandy loam, and the pots must be well drained, as they do not thrive with too much water at their roots. Cuttings taken off and dried in the sun for a few days root freely. Synonymes : 1. C. purpurea. 2. c. papillaris. 3. Onostachys malacophyllum. 4. C. ramosissima. 5. C. mucronata.

altērnăns

cacaiioindés

canaliculáta

corüseāns

erassifólià

cristata.

cuneâtă .

cuneiformis

curviforă, 1

decussată, 2

7, G. Ev. S. C. G. H. . 1816

Yellow: 5 G. Ev. S. C. G. H. 1816

elât:

fascieuliris

gräerlis

hemispluärică.

interjêcta

jasminiflora

maculats

maculat
Malacophyliūm, 3 Pa. yel. 6, H. Ev. S. C. G. H. 1818
S. Danuria : 1815

Yellow: 5, G. Ev. S. C. G. H. : 1818

mammilläris. Whi. pur. 6, G. Ev. S. C. G. H. : 1818

oblonga . : Red : 8, G. Ev. S. C. G. H. 1690

orbiculată : : Red : : 7. G. Ev. S. C. G. H. : 1798

ovata - . Red - 8, G. Ev. S. C. G. H. . 1789

papillarls : . Red . . 6, G. Ev. S. C. G. H. . 1822

ramồs, 4 - * 6, G. Ev. S. C. G. H.

ramosissimă - - 5, G. Ev. S. C. G. H. * 1816

rhombifolia - 6, G. Ev. S. C. G. H. 1823

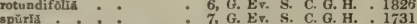

trieuspidita: : 7, G. Ev. S. C. G. H. : 1823

triflór . : : Pk. wht. 6, G. Kv. S. C. G. H. . 1821

tuberculösa - Onange * 7, G. Ev. S. C. G. H. . 1820

undulaer, 5 - 6, G. Ev. S. C. G. H. . 1818

ungulate - * 5, G. Ev. S. C. G. H. : 1818

CoUch GRAss, see Agropqrnm rëpëns.

CouttF̂rix, Humboldt and Bonpl. In honour of Thomas Coulter, M.D., a botanical author. Linn. 10, Or. 1, Nat. Or. Leguminosc. An ornamental genus of stove shrubs, from twelve to fifteen feet high; they grow well in a mixture of peat and loam, and are increased by seeds. Synonyme: 1. Poinciana tarra, Casalpina tinctoria.

hơrrìa . . Orange . S. Ev. S. Carthage . 1824 tinetôriá, i : : Orango : S. Ev. S. Carthage : 1822

Courgô̄RDE, see Lagenärĭă vulgärìs; var.

Coutārüñ, Aublet. Derived from coutari, the name applied to it in Guiana. Linn. 5, Or. 1, Nat. Or. Cinchonacea. This is a beautiful plant, growing to the height of twelve feet, and thriving best in sandy peat; increased by cuttings. Synonyme: 1 . Portlandia hexandra.

speciōsă, 1. - Purple - 8. Ev. 8. Guiana . . 1803

Coutour $\check{\mp} \check{n}$, Aublet. The name given to it in Guiana. I.inn. 4, Or. 1, Nat. Or. Gentianacere. The species of this genus require a mixture of peat and loam; increased by seed, which must be sown in a hotbed frame, or in the stove. Synonymes: 1. Exacum ramosum. 2. E. spicatum. 3. E. verticillata, Gentiana verticillata.

ramōs̆̆, 1. . White. . 7, S. A. Brazil - . 1824 spieâtă, 2 : : White : 7, 8. $\quad$ B. Maran. : 1823 verticillată, 3 : : White: : 7, S. B. Trinidad : 1818 Cow $\bar{A} \times \bar{I}$, D. Don. In commemoration of the services rendered to botany by the late Mr. James Cowan, a merchant who visited and introduced a number of plants from Mexico and Peru. Linn. 12, Or. 3, Nat. Or. Rosaced. A very beautiful and interesting shrub, about two feet high, with large showy blossoms resembling the rose; if it should prove sufficiently hardy to endure our winters, it will be [90'] 
a very great acquisition to the ornamental shrubbery. It requires to be grown in sandy peat, and may be increased by divisions, though it has, as yet, been found extremely difficult to propagate. plicata . . . Red . .6, H. Ev. S. Mexico.

Cowbank, sea Cicūtü.

Cowrerry, see Vaccīnǐūm Vìtis Idāă.

CowDIE PINE, see Dammără austrāliss.

Cow-aRAss, see Trifóliūm mĕdīum.

CoW-HERB, see Sa ponäriă vaccārĭă.

Cow-1TCH, see Mucūnă.

Cow-parsLry, see Herāclēũm pănăcẽs.

Cow-parsnep, see Herāclēũm.

Cowslip, see Prīmñlă vēris.

Cow-WHEAT, see Melümpürūm.

Cв. $\overline{\mathrm{A}} \overline{\mathrm{B}}$, Tournefort. The Greek name for Sea-kale, or Sea-cabbage. Linn. 15, Nat. Or. Crucifera. Some of the species are much valued, and cultivated as vegetables. They require a good rich soil, and may be increased by dividing the roots, or by seed.

cordifoliä . . White . . 5, H. Tu. P. Caucasus . 1822 maritIma : White. 5, H. Tu. P. Britain

1754

āspĕră, filiformĭs, fruticősă, hispänǐcŭ, orientälìs, pinnatĭfidă, reniförmìs, strigosă.

CRANBERRY, see Oxycóccüs palustrǐs.

CraNe's-R1LL, see Gerăniũm.

Craniolārĭ̃, Linn. Derived from kranion, a skull; on account of the fancied resemblance in the capsules, Linn. 14, Or. 2, Nat. Or. Pedaliacer. A greenhouse species, growing about two feet high, and succeeding in any light sandy soil, in which it merely requires sowing. Synonyme: 1. Martynia craniolaria.

ãnnŭă, 1 . . White. . 7, G. A. S. Amer. 1733

CRASPǨDĬ, Forster. Derived from craspedon, a fringe ; in allusion to the flowers. Linn. 19, Or. 1, Nat. Or. Composite. Curious plants, preferring a light loamy soil, and propagated readily by cuttings in sand, under a glass. Synonyme: 1. Richea glauca.

glaûcă, 1 . Y Yellow . 4, H. Her. P. N. Holl . 1836 macrocephala: : Ysh. wht. F. Ev. P. V. D. L. 1834 plebera . - . G. Ev. S. N. Holl. 1823

CRĀssǔlă, Linn. A diminutive of crassus, thick; in reference to the fleshy leaves and stems. Linn. 5, Or. 5, Nat. Or. Crassulacea. Succulent species, thriving best in a mixture of sandy loam and brick rubbish, care being taken to have the pots well drained; cuttings taken off and laid for iwo or three days in the sun to dry, take root freely. $s y$ nonymes : 1. Turgosia aloides. 2. T. capitellata. 3. $\boldsymbol{T}$. pertusa. 4. T. linguafolia. 5. $\boldsymbol{T}$. obovata. 6. T. tomentosa. 7. T. turrita.

acutifoliă . . White. . 7, G. Ev. S. Greece . 1795 White 6, G. Ev. S. C. G. H. 1800

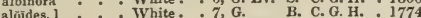

arboréscēns : Pink : 5, G. Ev. S. C. G. A. . 1739 bibracteát: White: 8, G. Ev. S. C. G. H. 1823 mäjor : White : 8, G. Ev, S, C. G. H. : $1 d 23$

biconvēxa . . White . . 8, G. Ev. S. C. G. H. • 1800

biplanâta : White: : 9, G. Ev. S. C. G. H. : 1823

capitellată, 2 . White. - 7, G. B. C. G. H. . 1774

centauroídés. Pink : 5, G. B. C. G. H. 1774

ciliata : : Yellow : 7, G. Ev. S. C. G. H. : 1732

media: : : Yellow : 7, G. Ev. S. C. G. H. : 1818

mĭnŏt Yellow :, G. Ev. S. C. G. H. : 1818

coccinella : : Searlet :7, G. Ev. S. C. G. H. 1823

culumnărīs. : White. : G. Ev. S. C. G. H. - 1789

concinnă - " Pink G. Ev. S. C. G. H. . 1818

cordată - . Pink - 6, G. Ev. S. C. G. H. . 1774

corymbūiōs̆ 3 . White - 11, G. B. C. G. H. 1818

cotylēdōnis . . White . - G. Ev. P. C. G. H. . 1800

deféctă - - White - 7, G. Ev. S. C. G. H. - 1820

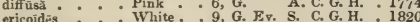

ericoides : : White: 9, G. \$v. S. C. G. H. : 1820

filicaúlis : White : 8, G. Ev. S. C. G. H. : 1820

fruticulōsa: : White : G. Er. S. C. G. H. :

glabră, 1 : White: : : G. White. A. C. G. H. : 1774

imbricata : White : 6, G. Er. S. C. G. H. : 1760

läctéa : - White. . 9, G. Ev. S. C. G. H. 1774

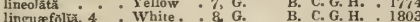

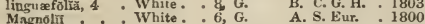

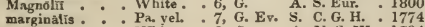

mesehátå $; 9 i$. White. :9, G. A. N. S. W. . 1794 obliqŭă . . Ked

White . 6, G. B. C. G. H. : 1818

G. Ev, S. C. C. H. : 1818

orbiculārĭs: Pink . 8, G. Her. P. C. G. H. 1731

perfilātă * Pink . 9, G. Ev. S. C. G. H. 1785

pellúcida - - Pink * 8, G. Ev. S. C. G. H. - 1732

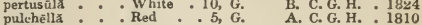

punctătă : Vhite.

ramōsă - - Pink - . 7, G. Ev. S. C. G. H. = 1774

ramuliflòrá . . White . . 6, G. Ev. S. C. G. H. . 1822

retroflexă - . Yellow . 6, G. A. C. G. H. . 1788

revölvēns . . White. . 8, G. Ev. S. C. G. H. . 1820

rosuläris . . White. . 7, G. Her. P. C. G. H. . 1819

rotundifolià : White. - 8, G. Ev. S. C. G. H. - 1820

scabră : : : Pa. yel. : 6, G. Ev. S. C. G. H. : 1730

scabrellä : * G. Ev. S. C. G. H. 1810

spārsă - - White. - 6, G. B. C. G. H. * 1774

squamulōsá : White. 8, G. Ev. S. C. G. H. 1774

6, G. Ev A. C. G. H.

telephioĩdess : White : 7. G. Ev. S. C. G. H. : 1818

tetragōnă : White. 8, G. Ev. S. C. G. H. 171

tomentoša 6 : White: 4, G. B. C. G. H : 1818

tũrrìt, 7 : : White: : 3. G. $\quad$ B. C. G. H. : 1818

verticillăris": Pink : 7, G. A. S. Eur. : 1788

CRAssזrŏL㑔, thick-leaved.

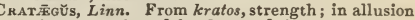
to the strength and hardness of the wood. Linn. 12, Or. 2, Nat. Or. Rosacea. A very ornamental genus, chiefly composed of low, hardy trees, or shrubs. Young plants may be obtained from seeds, and they may also be multiplied by buds, or grafts. Synonymes: 1. C. glandulosa. 2. C. indentata. 3.

Coccinea spinosa. 4. Mespilus linearis. 5. M. nana. 6. Cratagus lobata. 7. Pyrus cratagifolia. 8. Cratagus Oliveriana. 9. C. laciniata. 10. C. edulis. 11. C. incisa. 12, C. Celsiana.

alpină . . . White. . 5, H. De. T. Italy

a piiföliă

Aroniă

Azarōlŭs

carpätic

coccinéa

glandulôsà, $\mathrm{i}$

White.

5, H. De. T. N. Amer. 1812

5, H. De. T. S. Eur. * 1810

White. 5, H. De. T. N. Amer.

White 5 . W. Amer.

mate . N . Amer.

coralina White. 5, H. De. T. France.

crenulätä: : White. : 5, H. Ev S. N. Ame

Crūs-gâllī : White. 5, H. De. T. N. Amer.

lineảrǐs, 4 : White. 5, H. De. T. N. Amer.

nana, 5 thifira White. 5 ,

pyracanthifolra White.

spleirolia - White. W

pouglasiris : White: 5, H. De. T. N. Amer.

Douglast

ellipticá

flabellăta

fâvă .

lobată, 6

florentină, 7

flōrìdă

clābră

heterophỹa

laciniātă

latifoli:

maroceãnă

melanocărpă

mexicānă

monógȳnă.

nigra

odoratīssim

orientalis

oxyacantha

aūrex

mājor

White

White.

plena * * White

pracóx : - Scarlet

rōséa 9 Red

oxyacanthoides : White

parvifülĩa

grossulariæfolrà White.

pentagỹă. - White.

Poiretiana * White.

prunellifolĩ

prunifolra : White.

punctA $=$ : White

purpirea : : White.

5, H. De. T. Amer.

5, H. De. T. Britain

5, H. De. T.

5, H. De. T. S. Kur.

5, H. De. T. N. Amer.

6, H. De. S.

5, H. De. T. N. Amer.

5, H. De, T N A

5, - H . De T. N A

5, H. De. T. Sicily : 1816

5, H. De. T. N. Aner. : 1820

5, H. De. T. N. Amer.

5, H. De. T. Barbary

- 1822

5, H. De. T. Tauria * - 1820

5, H. De. T. Siberia

5, H. De. T. Hungary : 1819

5. H. De. T. Crimea

5, H. De. T. S. Eur.: : 1810

5, H. De. T. N.Amer. . 1810

5, H. De. T. Britain

5, H. De. T.

5, H. De. T. Asia Minor, 1820

$5, \mathrm{H}$. De. T.

5, 4. De. T.

5, F. De. T.

5 , H. De. T.

5, H. De. T. France . 1822

5, H. De. T. N. Amer. - 1704

6, H. De. T. N. Amer.

5 , H. Fe. T. Hungary : 1820

5, H. De. T. Hungary

1810

5, H. De. T.

5, H. De. T. N. Amer. 1818

H. De. T. N. Amer. : 1746

5, H. De. T. N. Amer. : 1746 


CRA CRI

Pyracanthă * White. . 5, H. Ev. T. S. Eur. . - 1699

pyrifólta, 10： : White.: 6, H. De. T. N. Amer. : 1765

sanguineñ . : White. 5, H. De. T. Siberia . 1810

spanguineñ : : : White.: 5, H. De. T. N. Amer. : 1805

spinosissimi

tanacetifoli

White. 5, H. De. T. Europe

H. De. T. Greece

1789

Leednă, iI

White. 5. H. De. T. Germany

1800

raûried, 12 . White. 7 , H. De. T. Tauria : 1800

Cratê̆ Á, Linn. After Cratzevus, a Greek botanist, who lived in the time of Hippocrates. Linn. 11, Or. 1, Nat. Or. Capparidacea. Ornamental stove trees, growing from twelve to twenty feet high; they prefer a rich strong soil, and may be propagated by cuttings in sand, under a glass, in heat. Synonymes: 1. Capparis trifoliata. 2. C. trifoliata.

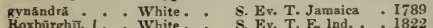
Koxburghn, 1: : White : : S. Ev. T. E. Ind. : 1822
S. Ev. T. India : 1752 tapioidés, 2 : : White: : S. Ev. T. S. Amer. : 1820

CratērīūM, Trentepohl. Derived from krater, a cup; in reference to the form of the peridium. Linn. 24, Or. 9, Nat. Or. Fungi. Curious minute species, found growing on mosses in damp places. Synonyme: 1. Cyathus minutus-leucocèphàlam, vulgärẽ 1 .

CREKPING, spread upon the ground, and rooting at the joints.

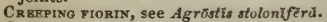

CRĔpIs, Linn. A name given to a plant by Pliny, of which he gave no description. Linn. 19, Or. 1, Nat. Or. Composita. Uninteresting species, succeeding in any common border soil, in which they merely require sowing. Synonymes: 1. C. Gmelini. 2. Prenanthes hieraciafolia. 3. Lagoseris taurinensis. 4. C. graminifolia-agrêstis, bannätică, biennis,

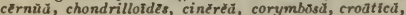
diff usă, Dioscüridhs, heterospérma, hieracioldés, lä-

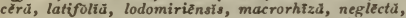
parviflorä, pinnatjüida, palchrì 2, rhagadiolotdes, rigêns, rigidä, scäbră, ségetam, Sprengeriänă, taurinëusis 3 , tectorom, tenuifolid 4 , viréns.

CRBNATE, having round notches.

CrBNULATK, having small round notches.

Crracentiă, Linn. In memory of Pietro Crescenti, of Bologna, an agricultural author of the sixteenth century. Linn. 14, Or. 2, Nat. Or. Bignniacec. A genus of handsome stove trees; they will thrive in a mixture of leam and peat, and cuttings of the ripened wood root freely in sand, in heat.

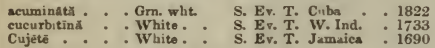

\section{Crras, see Lepidinm sativam.}

CREssX̃, Linn. From cressa, a native of Crete; the plant is plentiful there. Linn. 5, Or. 2, Nat. Or. Convolvulacee. This is a curious annual, prowing about six inches high, and should be sown in sandy peat.

erétiex Purple . 7, H. Tr. A. Levant . . I822

Crkss rockrt, see Vella.

CRRST, applied to some elevated appendage, terminating a particular organ; a stamen is crested when the filament projects beyond the anther, and becomes dilated.

Cratacrously-PRUinose, covered with whiteglittering spots, or pustules.

CrRTAN CARRot, see Athamäntä creticŏ.

CrIBRĀrî̀, Schrader. From cribrum, a sieve; in reference to the upper part of the peridium being perforated. Linn. 24, Or. 9, Nat. Or. Fungi. A small species, found on pine bark, \&c-micröpŭs.

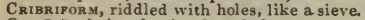

CRINĪTũs, hairy, having long hairs.

CRĩcos, Linn. From krinon, the Greek name of the lily. Linn. 6, Or. 1, Nat. Or. Amaryllidacer. This is a fine genus of bulbous plants; many of the species are very beautiful. The flowers of most of them are delightfully fragrant, and are produced freely in large umbels. They prefer a mixture of rich loam, peat, and sand, and are increased by offsets, which are produced in abundance. Synonymes: I. C. superbum. 2. campanulatum. 3. toxicarium. 4. brevifolium. 5. Amaryllis longifolia. 6. C. capense, viridilorum. 7. A. ornata. 8. C. rubrolimbo. 9. A. australusica. 10. A. giganteum. I1. A. revoluta, C. revoluta. 12. A. insignis. 13. A. moluccanum. 14. A. zeylarica

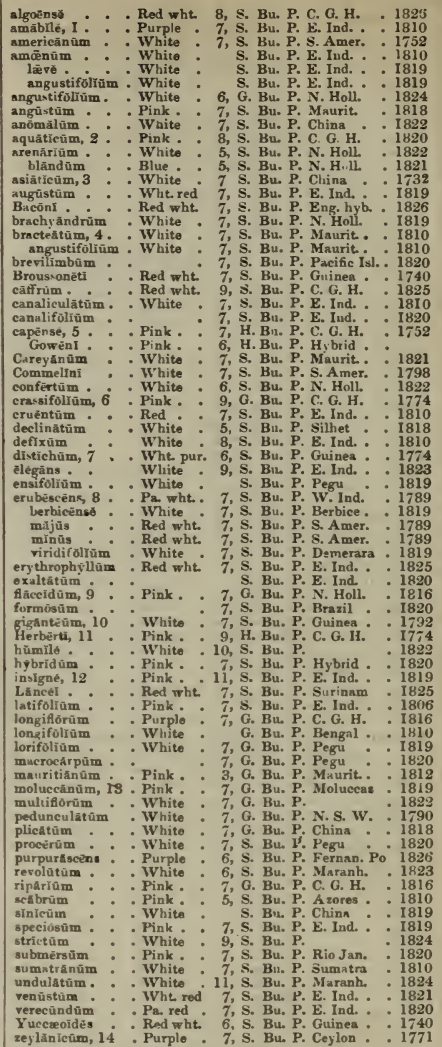

Crisp, curled, much undulated.

CRIstĂRL̆̈, Cavanilles. From crista, a crest; in reference to the form of the capsules. Linn. 16, Or. 8, Nat. Or. Malvaced. A pretty little hardy herbaceous plant, requiring to be planted in peat soil; to thrive, it may be increased by division or seeds. Synonyme: 1. Malva coccinea.

cocěnéă, I. . . Scarlet . 8, H. Her. P. Missouri . 1811

CRISTATR, crested, tufted.

CRітнмй ж, Tournefort. Derived from krithe, barley; in allusion to the singularity of the seeds. Linn. 5, Or. 2, Nat. Or. Umbellifere. Curious species, not succeeding well under any enltivation. Sandy or gravelly soil is best for them, with a plentiful supply of water, to which a little soda should be added now and then; increased by division. Synonyme: 1 . Tenoria canadensis.

latifoliñm, 1 . - Yellow * 7, G. Hex. P. Canaries - 1780

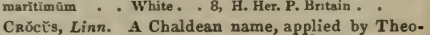


phrastrs. Linn. 3, Or. 1, Nat. Or. Iridacee. This is a well-known and much-admired genus. The species and varieties are very pretty and ornamental in flower-beds, borders, \&cc. They will grow well in any light sandy soil, and may be increased by offsets or seeds.

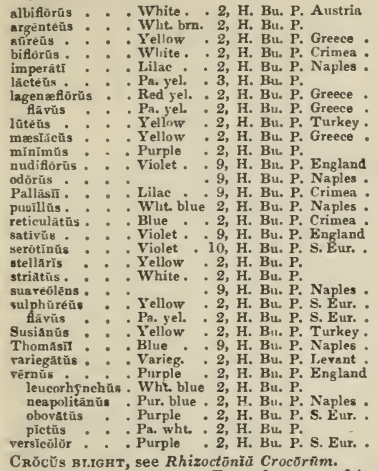

Cross $\bar{A}$ TDR Ă, Salisbury. From krossos, a fringe, and aner, a male, or anther; in reference to the anthers being fringed. Linn. 14, Or. 2, Nat. Or. Acanthacea. A beautiful, free-flowering stove shrub, succeeding well in any light rich soil, and easily propagated by cuttings in sand. Synonyme: 1. Harrachia speciosa, Ruellia infundibuliformis.

undulæfölru, 1 . Or. Scar. . 3, S. Er. S. E. Ind. . 1800 Crosswort, see Crucianẽ llă.

Crosswort, see Valantĩă cruciät $\breve{u}$.

Crotal. $\bar{A} R \bar{A} A, L i n n$. Derived from krotalon, a castanet; the seeds are in inflated pods, and rattle when shaken. Linn. 16, Or. 7, Nat. Or. Leguminose. This is a numerous genus, some species of which are very ornamental. C. juncea is said to be a valuable fodder; they require a mixture of loam and peat. The perennial kinds may be increased by cuttings ir sand, under a glass. The annual and biennial kinds merely require sowing. Synonymes: 1. sericea. 2. hirta. 3. Trifoliastrum. 4. chinensis. 5. lavigata. 6. stricta, anthylloides. 7. carulea. 8. incanescens. acuminātă . . Yellow -7 , F. A. C. G. H. 1820

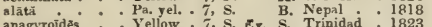
anagyroidés : Yellow : T, S. Er. S. Trinidad : 1823 anthylloìdés argēntéé

argenteá ${ }^{\circ}$. Yellow

Berteriandă : Yellow

bialāta

bifâriā.

bracteată

Brownéă ;

cajanifơliă .

calycină

chinēnsis

cubēnsise, 2

cytisoídes

diehơtớmã

foliōsă

fruticos

fūlvă

glaūca

hirsūtă.

Langsdorfin

linifôlya

medicagine ă, 3

Yellow

Yellow

Yellow

Yellow

Yellow
Yellow

Yellow

Yellow

Yellow

Yellow

Yellow

Yellow

Yeliow

Yellow

Yellow

Yellow

Yel. grn.

Yellow

Növẽ Hollinndīê . Purple

obscūră : : : Yellow
ovalis

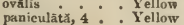

pellitá . Yeliow

péndülã

[93]

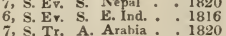

6, Sr. A. Arabia

6, G. Ev. S. C. G. H.
7, F. 6, S. Ev. S. Java
7. S. Ev. S. Jamaica - 1820 - 1823 - 1820 - 1810 . 1820 - 1820

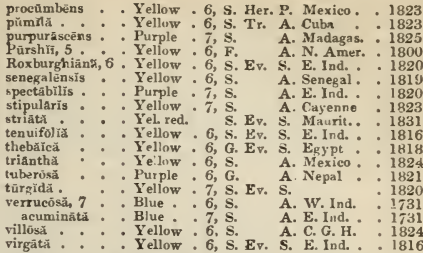

angustifôliă, arborēscēns 8 , axillārīs, benghalēnsìs, bi-

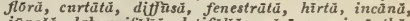

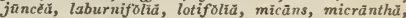
nepalēnsis, orixēnsis, pāllìdă, parviftōră, Paul̄̄nä, platycärpă, prostrütă, pulchêlld, pulchërrimă, pülchrủ, purpưrẽă, quinquefoliŭ, retūsũ, rubiginōsă,

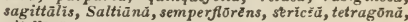
vitelliña.

CRỏnōn, Linn. From kroton, a tick : in reference to the resemblance of the seeds. Linn. 21, Or. 10, Nat. Or. Euphorbiacer. A genus (with the exception of one or two species) of little interest. The bark of C. cascarilla is aromatic; and the seeds of c. Tiglium are purgative. They will all succeed in a mixture of three parts loam, and one peat ; and cuttings, with the leaves left on, root freely in sand, under a glass, in heat. Synonymes: 1. digitata. 2. Aleurites ambinux.

Eleuteriz: Wht grn. 7, S, Ev. S. Jamaica 17 t8 glabellä: : : Wht. grn. 3 S. Ev. S. J Jmaies : 1778 inearis. : : Wht grn. 7, 8. Ev. S. W. kud. : 1773 picta

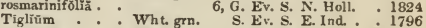
variegătă : : Wht. grn. S. Ev, S. E. Ind. 1804 crispă : : Wht grm. 7 , S. Ev. S. E. Ind. : 1804 Wht. grn. 7, S. Ev, S. E. Ind. . : 1804

argēnteă, aromätĭcă, astrGïtēs, cascarilllă, castaneafoliă,

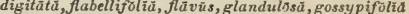

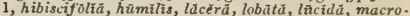

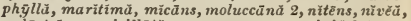
palüstris, penicillätă, pũngens, rosmarinifouliă, tomentosŭ, xalapēnsis.

CRסW Norwich, an excellent British botanist, and a great collector of willows. Linn. 10, Or. 1, Nat. Or.

Rutacer. Delightful greenhouse shrubs, producing their beautiful purple flowers throughout the greatest part of the year; they succeed in loam and peat, and cuttings root freely in sand, under a glass. latifoliă . - Purple . 7, G. Ev. S. N. S. W. - 1825 salignã. : : Purple : 9, G. Ev. S. N. S. W. : $179 \mathrm{C}$

CRowroot, see Ranancr̆ltss.

Crow's-YOOT, see Echinбchlōă crñs cōrvĩ.

CROWNED, terminated by anything.

Crozōphöră, Necker. The meaning is not explained.

Linn. 21, Or. 10, Nat. Or. Euphorbiacer. An annual species, of simple culture, succeeding in any !ight soil. The preparation called turnsol is chielly ob. tained from this plant. Synonyme: 1. Croton tinctoria.

tinctôrŭ̃ă, 1 . Whit. grn. 7, H. A. S. Eur. . . 15\%0

Crucianéti. Linn. A diminutive of crux, a cross;

alluding to the leaves being placed crosswise. Linn. 4, Or. 1, Nat. Or. Stellato. The greenhouse species of this genus grow freely in a mixture of loam and peat, and may be increased by cuttings; the annual kinds merely require sowing in the open border.

7$$
8
$$

6, S. Her. 1. N. Hoh glomer

latifolíă.

maritima

molluginoĩdés

monspeliảeă

pảtūlá.

pubèscēn

stylūsă

tuberculosa

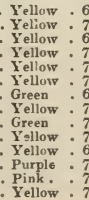

. $6, \mathrm{H}$.

G. Av A. Egypt .

6, H. A. France.

7, H. Her. P. Caucasus

7, H. A Lerant

6, H. Ev. A. France

7, H. Her. P. Caucasus

7. H. A. France

6. H. A. Spain

7, H. Her. P. Candia .

$7, \mathrm{H}$. Her. P. Persia
7, H. Her. P. Iberia
1800

1780

1658

1805

1824

1640

1800

1791

1798

1826 
CRUciatr, a flower is eruciate when four petals are placed opposite each other, at right angles.

CrucrFrous, the name of a particular family of plants bearing cruciate flowers.

$C_{R} \vec{Y} B \breve{K}$, Lindley. From krubeis, concealed; in allusion to the manner in which the column is hidden by the floral envelopes. Linn. 20, Or. 1, Nat. Or. Orchidacea. This plant is only remarkable for never expanding its singular, club-shaped, rosecoloured flowers. It requires the same treatment as Bletia.

rōsęa . . . Rose . . 6, S. Ter. Mexico . . 183-

CRFpsis, Aiton. From krypto, to conceal; referring to the flowers being concealed among the leaves. Linn. 3, Or. 2, Nat. Or. Graminea. Üninteresting species of grass, merely requiring to be sown in any common soil. Synonyme: 1. Heleochloa alopecuroides, Phalaris crypsoides-aculeàtŭ, alopecuroĩdēs 1 , schanoidês.

CRYPTÁNDRA, Smith. From kryptos, hidden, and aner, a man; alluding to the stamens being concealed. Linn. 5, Or. 1, Nat. Or. Rhamnacer. A singular genus; the species grow well in sandy peat, and young plants may be obtained from cuttings.

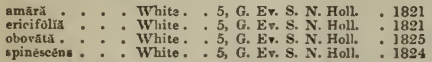

Crtptarrhênă, $\boldsymbol{R}$. Bronn. From kryptos, hidden, and arren, a male. Linn. 20, Or. 1, Nat. Or. Or-
chidacea. The small, yellowish-green flowers of this species are produced on a loose spike. For culture and propagation, see Bletia.

lanătz . . . Yelsh. grn. S. Ter. Jamaica . . 1815

CRYPToch̆R Y̌, R. Bronin. From kryptos, hidden, and karya, a nut; alluding to the fruit being covered. Greenhouse shrubs, growing about sixteen feet high; they will succeed in sandy peat, and plants may be obtained from cuttings.

Blaucesscérs - Wht. yel. 4, G. Ev. S. N. Holl. - 1818 oborata. : Whe yel. 4, G. Ev. S. N. Holl. : 1820

CRYptochīuťs, Wallich. From kryptos, hidden, and cheilss, a lip; the labellum is not easily seen, on account of the contraction of the mouth of the calyx. Linn. 20, Or. 1, Nat. Or. Orchidacere. A very interesting species, well worth a place in every collection of orchideous plants. It produces its brilliant scarlet flowers on a one-sided spike. For culture and propagation, see Stanhopea.

sanguInèa . . Scarlet . 6, S. Eipi. Nepal

CRy ptřr.ěpìs, R. Brown. From kryptes, hidden, and lepis, a scale; in reference to the seeds. Linn, 5, Or. 1, Nat. Or. A pocynacea. An interesting climbing species, growing well in a mixture of peat and loam, and multiplied by cuttings under a glass, in sand.

elểgüns .

S. Ev. Tw. Bratil . 1824

CRYptŏmšck̄s, Greville. Derived from kryptos, hidden, and mikes, a small fungus; alluding to the smallness of the plants. Linn. 94, Or. 9, Nat. Or. Fungi. A curious species found on willow branchesWanchir.

Cruptospírmōm, Persoon. From kryptos, hidden, and sperma, a seed; in allusion to the seeds being concealed in the involucrum. Linn. 4, Or. 1, Nat. (). Cinchonacer. A plant of little merit, growing freely, and increased by cuttings. Synonyme: 1 Opercularia pa'eata-Yoñngit $\mathrm{l}$.

Crvprosrẫŏ , R. Bronn. From kryptos, concealed, and stege, a covering; referring to the corona being concealed within the tube of the corolla. Linn. 5, Or. 2, Nat. Or. Asclepiadacee. Beautiful, climbing plants, succeeding in a mixture of lcam and peat. and cuttings will root freely in sand, under a glass, in heat.

grandiflōră . . Pink * . 6, S. Er. Tw. India * 1818 madagaseariēnšs. Pink : : 7, S. Ev. Tw. Madag. : : 1826

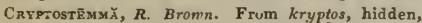
and stemma, a crown; the crown of the grains being concealed in wood. Linn. 19, Or. 3, Nat. Or. Compositi. Annual species, requiring to be sown in a gentle hotbed, and, when of a sufficient strength, planted out in the open borders, where they will flower, and look very well.

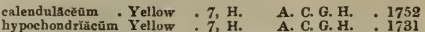

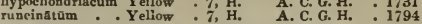

Cryptōstřllis, R. Bronn. From kryptos, hidden, and stylos, a style. Linn. 20, Or. 1, Nat. Or. Orchidacee. The species of this genus are curious, and succeed best in an equal mixture of turfy loam, peat, and sand; divisions.

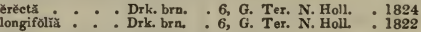
Crystarurns, resembling crystals.

Cũrǐcưs, cubical, die-shaped.

CUскоO-F towER, see Lychnis floscŭcŭlí.

CUcKoo-rLTWER, see Cardămănĕ pratënsis.

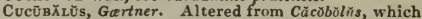
is derived from kakos, bad, and bolos, a shoot; meaning a plant which is destructive to the soil. Linn. 10, Or. 3, Nat. Or. Silenacea. A common plant, of little interest, thriving in any common soil, and increasing either by seeds, or division-bāccifêr.

Cucullats; a leaf is cucullate when its edge is curved

inwards, so as to resemble the cowl of a monk.

Cucumarr, see Cũcümis.

Cứcừis, Linn. Derived from curvus, crooked; referring to the shape of the fruit. Linn. 21, Or. 10 Nat. Or. Cucurbitacee. This is a well-known and extensively cultivated genus, chiefly for culinary purposes. The $\boldsymbol{C}$. colocynthis prodices the colocynth of the shops. The whole of the species require to be sown in a hotbed, and, when of sufficient size and strength, to be planted out in frames, or under a hand-glass, in a good rich soil. Synonyme: 1. Cucurbita citrullus.

\begin{tabular}{|c|c|c|c|}
\hline & & & \\
\hline 18 & & & 68 \\
\hline ton & : & $\begin{array}{l}\text { Tr. A. } \\
\text { Tr. A. }\end{array}$ & \\
\hline lus 1 & $\boldsymbol{v}$ & Tr. A. S. & \\
\hline & v & Tr. A, & \\
\hline Pastecal. & $w$ & rr. & \\
\hline his & & H. & \\
\hline . & - & L. & \\
\hline 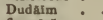 & . & - & \\
\hline is. & . & Cr & \\
\hline Girü: & : & r. A. & \\
\hline & : & & \\
\hline & - & . & \\
\hline & $\therefore Y$ & $\therefore$ & \\
\hline & & Tr. A. & \\
\hline ä́ă & : & F. $T r$ & \\
\hline & & & \\
\hline & & - 7, F, Tr. A. & \\
\hline Ion & $w$ & . & \\
\hline rüm & $: \mathbf{Y}$ & , 7, F. Tr. A. Le & \\
\hline ins. & .1 & & \\
\hline ativ & $w$ & E. Ind. . & \\
\hline filt & Hlow & & \\
\hline & & & \\
\hline & & & \\
\hline & & & \\
\hline & & & \\
\hline
\end{tabular}

Cucūraĩră, Linn. From curvitas, crookedness; in allusion to the shape. Linn. 21, Or. 10, Nat. Or. Cucurbitacea. For culture, \&c., see Cucumis, to which genus this is nearly allied.

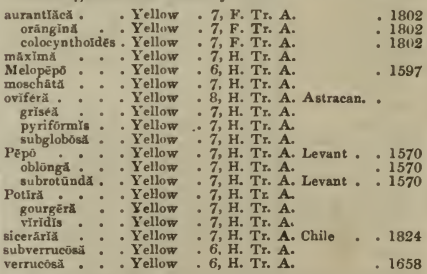

CorcĩTr̄̄u, Humboldt and Bonpland. From culcitu, a stuffed bed; referring to the heads of paleæ. Linn. 
19, Or. 1, Nat. Or. Composite. An ornamental, greenhouse plant, growing well in any common soil, and propagated by cuttings. Synonyme: 1. Cacalia salicina.

salicinúm, 1 - Yellow * 6, G. Ev. S. N. Holl. 1820 CиLlūmĭă, R. Bronn. In honour of Sir Thomas Cuillum, Bart., F.L.S., a great promoter of botany. Linn. 19, Or. 3, Nat. Or. Composite. Curious species, growing well in a mixture of peat and loam, and cuttings will strike root in soil, under a glass, in heat.

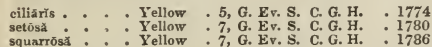
Cul, , the stem of grasses, scitamineous plants, and the like.

CULM1FEROU, producing culms.

$\left.\begin{array}{l}\text { Cultrate, } \\ \text { Cultriform, }\end{array}\right\}$ shaped like a pruning-knife.

CuMin, see Cuminñm.

CuMns, see Lagoëcřă.

Cumínês, Bauhin. Altered from quamoun, its A rabic name. Linn. 5, Or. 2, Nat. Or. Umbelliferce. A plant of little beauty, and merely requires to be sown in any open border, to succeed.

Cymrnnum . . . White. . 6, H. A. Egypt . . 1594 СuмmікĞ̌̆, D. Don. In honour of Lady Gordon Cumming, of Altyre, near Forres, Scotland. Linn. 6, Or. 1, Nat. Or. Liliacea. Pretty frame bulbs, with blue flowers; a mixture of loam and peat suits them, and they are multiplied by offsets. Synonyme: 1. Conanthera campanulata.

campanulâtã, 1 . Blue . . 8, F. Bu. P. Chile tenêlla.. Blue: 11, F. Bu. P. Chile trimaculata : Blue : 12, F. Bu. P. Chilo : : 1829

Crmulate, heaped, overflowed.

CUNEATE, wedge-shaped.

CUNRIForM-ovatr, between wedge-shaped and egg. shaped.

CONĭL̆, Linn. The derivation of this word is doubtful; by some botanists it is supposed to be from konos, a cone, and by others, to be from Cunila, the name of a town. Linn. 2, Or. 1, Nat. Or. Labiate. Pretty species. C. coccinea requires the heat of a greenhouse, and will succeed in a mixture of loam and peat. C. mariana will thrive in the open border, in any common soil; they may both be increased by division. C. mariana is used beneficially in slight fevers and colds, with a view to excite perspiration.

cocciñă . . Searlet . 9, G. Her. P. N. Amer. • 1823 mariänă : : Red : 9, H. Her. P. N. Amer. 1759

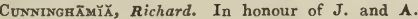
Cunningham, botanists and travellers in New South Wales. Linn. 21, Or. 10, Nat. Or. Conifera. This is a very handsome species; it succeeds best in a mixture of peat and loam, and may be propagated by cuttings, or seeds. It will grow freely planted out in a warm situation, if protected during the winter from severe frost. Synonyme: 1. Pinus lanceolata, Belis jaculiflora, C. lanceolata.

sinēnsĩs, 1 . A petal . G. Ev. T. China . 1804

Cuxōxǐn, Linn. In honour of John Christian Cuno, of Amsterdam, who described his own garden in verse, in 1750. Linn. 10, Or. 2, Nat. Or. Cunoniacee. An ornamental, greenhouse tree, attaining a height of twenty feet; it prefers a mixture of sandy loam and peat, and cuttings root in sand, under a glass, in heat.

capēnš̆s . . . White . . 8, G. Ev. T. C. G. H. . 1816 Cup, anything in the shape of a cup.

CUPĀNǐn, Plumier. In meniory of Father Francis Cupani, an Italian monk, and bntanical author, who died in 1710 . Linn. 8, Or. 1, Nat. Or. Sapin. dacer. An ornamental stove genus. The species vary in height from six to twenty feet; they flourish in a mixture of equal parts peat and loam, and young plants may be obtained from cuttings, under a glass, in sand. Synonyme: 1. Molinia canescens.

canêscēns, 1 . White - S. Ev. T. E. Ind. . . 1818 dentātă. : : White : S. Ev. T. Mexico: : 1824 excêlsă : : : White : S. Ev. T. Mexico： 1824 glábră : $:$ White : 5, S. Ev. T. Jamaica : 1822 saponarioidës . White * 4, S. Ev. S. W. Ind. 1810

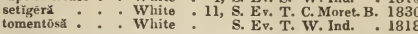

C Ū PHĚĂ, Jacquin. Derived from kuphos, curved; in reference to the form of the capsule. Linn. 11, Or. 1, Nat. Or. Lythracea. This is rather a pretty genus; the stove species require to be grown in sandy loam, and are propagated by euttings. The annual kinds should be raised in a gentle hotbed, and when strong enough, may be potted off, and kept in the greenhouse. Synonyme: 1. Melvillea speciosa.

circæoidēs . Purple

decāndră .: : Purple

grăeilis

lanceolát

Llă vĕă

Melvillă, 1

Purple

Purple

$9, \boldsymbol{c}$.

A. S. Amer.

1821

7, S. Ev. S. Orinoco : 1789

s. B. Mexico : 179

6, F. Ev. S. Mexico: : 183

Scarlet : 8, S. Her. P. Guiana : 1823

micropetălă . Purple - 7, s. Ev. S. Mexico - 182

multiflöră - Purple *9, S. Ev. S. Trinidad • 182

parvifloră. - . Pink . - 11, S. Ev. S. Demerara - 182

procūmbēns - . Pa. pur. - 8, S. N A. Mexico - 1816

racemósă. * Purple *6, S. Ev. S. W. Ind. - 1820

serpyllifoliă : : Red :
viscosissimă

virgảtă : : Purple : 8, G. A. Mexico : 1824

Cêpř̆ Decandolle. Cupi is the Malabar name of one of the species. Linn. 5, Or. 1, Nat. Or. Cinchonacea. The species of this genus deserve to be in every collection of plants, being very showy when in blossom, and the flowers very fragrant. For culture and propagation, see Rondeletia. Synonymes: 1. Webera coriacea. 2. W. corymbosa. 3. W. cymosa.

coriăcẻă, 1 * - White. . S. Fv. S. E. Ind. - 1828

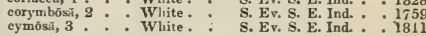

Cuprêssữs, Linn. From kuo, to produce, and parisos, equal; in reference to the branches being regular. Linn. 21, Or. 10, Nat. Or. Coniferce. The species comprising this genus are handsome, evergreen trees, varying in height from ten to forty feet. The hardy kinds are beautiful ornaments for lawns, grass plots, \&c. They prefer a good, rich, loamy soil, and are generally multiplied by seeds; but cuttings may be made to root, under a glass, in the shade. Synonymes: 1. glauca. 2. Thuja sphoroidea.

austrälrs * . Apetal * 4, G. Ev. T. N. Holl. baccifôrunis

lusitüñ̄eä, 1 .

pēndŭlă

sempervîrêns.

horizontălǐs : A petal

strictă : A petal

thyoldès, 2: : A petal

5, H. Ev. T

4, F. Ev, T. Goa

5, G. Ev. T. Japan : 1808

5, H. Ev. T. Candia: 1548

5, H. Ev. T. Nediter.

5, H. Ev. T. Mediter. : 1736

CŪPRĚŬs, copper-coloured.

C̄̃PŬLÃ, the cup of an acorn, and such -like fruits. CUPULATE, shaped like a cup, or a reversed bell.

Curatétr.ă, Linn. From kureno, to shave; in reference to the leaves being used in Guiana for polish. ing bows, sabres, \&c. Linn. 13, Or. 2, Nat. Or. Dilleniacer. Stove shrubs of some beauty, succeeding in sandy loam, and cuttings, made of the ripened wood, root freely in sand, under a glass.

alată * . White. . S. Ev. S. Guiana

CuRcuัLĬGó, Gartner. Derived from curculio, a weevil; the seeds have a process resembling the beak of that animal. Linn. 6, Or. 1, Nat. Or. Amaryllidacea. Pretty, herbaceous species, succeeding in a mixture of loam and peat, and increased by offsets.

brevifolia . . Yellow * 6, S. Her. P. E. Ind. . . 1804 latifollă : : : Yellow : 6, s. Her, P. Poolo Pin. : 1804 orchioides : : Yellow 6 , s. Her. P. E. Ind. : 1800 plieătă : Yellow : 6, G. Her. P. C. G. H. : 1788 gläbrà : : Yellow : 6, G. Her. P. C. G. H. : i 788 sumatrană: : Yellow : 7, S. Her. P. Sumatra : 1818

Cūrcưmă, Linn. Derived from kurkum, its Arabic name. Linn. ], Or. J, Nat. Or. Scitaminea. Interesting species, thriving well in a rich, light soil, and increased by offsets, from the root. Turmeric is obtained from $C$. long $a$; it is cordial and stomachic, and considered by the native doctors of India an excellent application in powder for cleansing foul ulcers. A kind of arrow-root is prepared from $C$. angustifolia. 


\begin{tabular}{|c|c|c|c|c|}
\hline CUR & & & & CYA \\
\hline æ & & & - o, s. Her. P. & 807 \\
\hline sda & & - $\mathrm{R}$ & - 4, S. Her. P. Bengal & $: 1819$ \\
\hline sngustifolra & & - Yellow & - 7 , S. Her. P. E. Ind. &.$\quad 1822$ \\
\hline aromätică . & & ellow & - 6, S. Her. P. E. Ind. &.$\quad 1804$ \\
\hline câsià . & 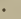 & Yellow & - 5, S. Her. P. Bengal . &. .1819 \\
\hline comúsă . & & - Red yel. & . 5, S. Her. P. E. Ind. & - 1819 \\
\hline elāta & - & - Crimson & . 5, S. Her. P. E. Ind. & .1 \\
\hline ferruginĕă & - & $\cdot \mathbf{Y}$ & r. P. E. Ind. & - 1819 \\
\hline $\begin{array}{l}\text { latifólia } \\
\text { leucorhiză }\end{array}$ & $\dot{\bullet}$ & $\begin{array}{l}\text { Y Yellow } \\
\text { : Red jel. }\end{array}$ & $\begin{array}{l}\text { 5, S. Her. P. E. Ind. } \\
\text { 5, S. Her. P. E. Ind. }\end{array}$ & $\begin{array}{r}. \quad 1820 \\
: 1810\end{array}$ \\
\hline lōng & - & $\cdot \cdot$ & 8, S. Her. P. E. Ind. &.$\quad 1759$ \\
\hline nă & - & U & 5, S. Her. P. E. Ind. & . 1824 \\
\hline parviflōră . & - & Wht rie & . 1, S. Her. P. Rome & - . 1828 \\
\hline petiolátă & - & - & - 8, S. Her. P. Pegu & . . 1822 \\
\hline reclinātă & : & - Pink & - 4, S. Her. P. E. Ind. & $: 1824$ \\
\hline $\begin{array}{l}\text { rubêscēns } \\
\text { rubricaülis. }\end{array}$ & & Y Yellow & $\begin{array}{l}\text { 7, S. Her. P. E. Ind. } \\
\text { 5, S. Her. P. E. Ind. }\end{array}$ & $: 1822$ \\
\hline virìliflōră & & . Yel grn. & S. Her. P. Sumatra & .1822 \\
\hline zedo & & . Red & $\begin{array}{l}\text { Her. P. A mboyn } \\
\text { Her. P. E. Ind. }\end{array}$ & - 1819 \\
\hline zerûmbét : & & . Yellow & . 7, S. Her. P. E. Ind. &.$\quad 1807$ \\
\hline
\end{tabular}

Currant, see Ríbess.

Curta, broken off, curtailed.

CURTİsİ, Aiton. In honour of the late William Curtis, the founder of the Botanical Magazine.

Linn. 3, Or. 1, Nat. Or. Aquifoliacea. This, in its native country, is a timber tree, attaining the height of eighty feet, and from which the Hottentots and Caffres make the shafts of their javelins. It succeeds in loam and peat, and cuttings strike readily in sand.

faginéă . . Pale - G. Ev. T. C. G. H. 1775

Curtŏgrise, Haworth. From kurtos, curved, and gyne, a style; referring to the gibbous ovaria. Linn. 5, Or. 5, Nat. Or. Crassulaced. Greenhouse species, flourishing in sandy loam, and propagated by cuttings, which should be laid a few days in the sun to dry. Synonyme. 1. Crassula undata.

undatx, 1 . . White . . 8, G. Ev. \&. C. G. H. . 1818 undulată : : : White: : 8, G. Ev. S. C. G. H. : 1797 undōsa . : : White. : 8, G. Ev. S. C. G. H. : 1824

CuscŭтĂ, Linn. Derived from its Arabic name, kechout. Linn. 5, Or. 2, Nat. Or. Cuscutacee. A genus of curious parasitical plants. They will grow on almost any plant they can lay hold of, producing, in the autumn, abundance of sweetscented flowers. Synonyme: 1. Reflexa verrucosa.

amerieănă . . . Wht. yel. . 8, Parasite. S. Amer. . 1816 australls : : White: 8, Parasite. N. Holl. 1818 chilensis : : White : $: 8$, Parasite Chile : White $: 1821$ chinēnsis : : White : 8, Parasite. China
E pithyomüm : White : 7, Parasite. Britain

Epithȳmüm : White : W, 7, Parasite. Britain : Britain

Hookérí, 1: : White: :9, Parasite. E. Ind.: 1823

verrucósă : : White : 8, Parasite. Nepal : 1821

Cưsōñ̄̆, Thunberg. In honour of Pette Cusson, a celebrated French botanist, and professor at Montpelier. Linn. 5, Or. 2, Nat. Or. A raliacec. Greenand loam, and cuttings root freely in sand, under a glass.

spicătă - : Green * - G. Ev. S. C. G. H. 1789 triptéris : : Green: : G. Ev. S. C. G. H. : 1816

CUSTARD APPI.s, see Anond.

Cutanrous, relating to the skin.

CuTICLs, the scarf skin, or epidermis.

Cut-roothsD, cut and toothed at the same time.

CұAмörsis, Decandolle. From kyamos, a bean, and opsis, resemblance; on account of the plant resembling a bean. Linn. 16, Or. 6, Nat. Or. Leguminosce. An annual species, of some beanty, growing freely in any common soil. Synonymes: 1. Dolichas psoralaoides, D. fabaformis, Psoralea tetragonolobus, Lupinus trifoliatus.

psoraloìdẽs, 1.. Purple . 7, H. A. Arabia . . 1813 CצANĒLLĂ, Linn. A diminutive of kyanos, blne; alluding to the flowers. Linn. 6, Or. 1, Nat. Or. Liliacea. These are pretty bulbous plants, thriving in a mixture of sandy loam and peat, and increased by offsets.

alba . . . White. . 7, G. Bu. P. C. G. F.

capensis * Blue : 7, G. Bu. P. C. G. H.

lineātă . . Striped . 7, G. Bu. P. C. G. H. : 1816

lüteă
orchidifōrmìs : : Yellow : 7, G. Bu. P. C. G. H. : 1788

Craxötris, D. Don. Derived from kyaños, blue, and ous, an ear; referring to the flowers. Linn. 6, Or.

1, Nat. Or. Commelinaces. Pretty species, requiring a good rich soil. C. barbata may be increased by division.

axillaris * * Blue . 8, G. B. E. Ind. . 1829 barbătă. : : Blue : 8, H. Her. P. Nepal : : 1824 cristãtă: : : Blue : : 8, G. Her. P. Ceylon : : 1770

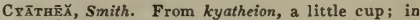
allusion to the indusium being cup-shaped. Linn. 24, Or. 1, Nat. Or. Polypodiacea. This is a genus of fine tropical ferns, mostly arborescent, growing from fifteen to twenty feet high. They succeed best in a mixture of peat and loam, and are increased by division, or seeds. Synonyme: 1. arborea.

arhøréa . . Brown . S. Ev. T. W. Ind. 1793 excēlsã, j : Brown : S. Ev. T. Maurit.. 1825 CYATHIFORM, cup-shaped, concave.

CYAтнōpēs, Labillardière. From kyathos, a cup, and eidos, like; because the nectary resembles that vessel. Linn. 5, Or. 1, Nat. Or. Epacridacece. Greenhouse shrubs, worth cultivating; they thrive in a mixture of peat and loam, and young plants may be obtained from cuttings.

acerósă . . . White. . 7, G. Ev. S. N. Holl. . 1823 glaniea . . . White. : 4, G. Ev. T. V. D. L. : 1818 Oxycédrŭs : : White. : 4, G. Ev. S. V. D. L. : 1822 C $\bar{Y} \mathrm{c} \bar{s}$, Linn. The Greek name of a palm, said to grow in Ethiopia. Linn. 22, Or. 12, Nat. Or. Cy cadacee. This is a fine ornamental genus of stove plants, requiring to be grown in good rich loam, with a liberal supply of water. Young plants may be obtained from suckers, which are sometimes produced. From the soft stem of $C$. circinalis a kind of sago is produced.

angulatr . . A petal • S. Her. P. N. Holl. . 1824 circinalis : : A petal : S. Her. P. E. Ind. : 1700 glaúeă : : : A petal : S. Her. P. E. Ind. : 1818 revolnta : : A petal : 7, S. Her. P. China : : 1737 squarrósa . . A petal : S. Her. P. E. Ind. . 1824

С ґсцймЕ̌, Linn. Derived from kyclicos, circular; referring to the round leaves. Linn. 5, Or. 1, Nat. Or. Primulacee. Pretty bulbous species, thriving well in a mixture of sandy loam and vegetable mould; they may be increased by seeds, which should be sown as soon as they are ripe. All the species are famous for their acridity, yet it is the principal food of the wild boars of Sicily, hence the common name of sowbread. Synonymes: 1. Clusii. 2. europaum.

ç̄̄m

colm . Li, red

uropāun , 1 . Li. red

albidúm. 2. Purple

purpurắcēns : Purple

ihểiceúm

latifőtrüm

lineariföltúm

neapolitånūm

përsícūm

albiflórūm

inodōrūm

odørătūm

laciniatuีm

repándūm

- Red

- Purple

Red

4. H. Tu. P. Inaly 1824

Red wht. . 2, G. Tu. P. Cyprus . . 1731

White. 2, G. Tu. P. Cyprus : 1731

Red wlit. 2, G. Tu. P. Cyprua : : 1731

Red wht : 2, G. Tu, P. Cyprus : : 1731

Стсцйтthŭs, Poiteau. From kyclos, a circle, and anthos, a flower; in allusion to the disposition of the flowers. Linn. 21, Or. 9, Nat. Or. Cyclanthacec. A curious stove perennial, flourishing in a mixture of loam and peat, and multiplied by suckers.

Plnmiérí . . Green . . S. Her. P. Trinidad . 1820

Сустовӧтнй, Sneet. From kyklus, a circle, and bothros, a pit; alluding to the sepals being circular. Linu, 6, Or. 1, Nat. Or. Liliacere. Beautiful species of bulbous plants, thriving well in an equal mixture of loam, peat, and sand. They may be readily increased by the little viviparous bulbs that are produced on the upper part of the stem. Synonymes: 1. Fritillaria barbata. 2. Cyclobothra barbata. 3. Fritillaria purpurca.

alba, 1 . . White. . 8, H. Bu. P. Califomia . 1832 harhăta. : Y Yellow 8, F. Bu. P. Mexico : 1827 lūteñ, 2. : Yellow 9, G. Bu. P. Mexico . 1827 pulchella : Yellow 8, H. Bu. P. California - 1832 Cұcuōplă, Ventenat. From kyclos, and pous, a foot; in allusion to the shape of the base of the pods. Linn. 10, Or. 1, Nat. Or. Leguminosa. Greenhouse 
shrubs, with little to recommend them; they grow freely in a mixture of peat and loam, and propagate freely by cuttings. Synonymes: 1. Sophora galioides, Aspalathus callosa. 2. Genista buxifolia.

galioidēs, 1 - Yellow * 7, G. Ev. S. C. G. H

genistoidès. . Yellow . 7, G. Ev. S. C. G. H

latifolină, 2 : : Yellow : 7, G. Ev. S. C. G. H

1820

1787

1820

Cテ̄cNōchвs, Lindley. From kyknos, a swan, and auchen, the neck; in allusion to the column, which is long, and gracefully curved, like the neck of a swan. Linn. \&0, Or, 1, Nat. Or. Orchidacea. The species of this genus are well worth cultivating, especially C. Loddigesii, which has large and delightfully fragrant flowers. The sepals and petals of this species are of a brownish-green colour, with darker spots, and bearing a strong resemblance to the expanded wings of a swan. They require a strong heat, and a plentiful supply of water when growing, and to be otherwise treated as the Stun. hopeas.

Loddigēš̀ * . Wht. grn. 5, S. Epi. Surinam - 1830 rentricōsă Grn. whi. S. Epi. Guatemala , 1835

CyдōnĬ Tournefort. Supposed to be named from its being a native of $\mathrm{Kydon}$, in the Island of Crete. Linn. 12, Or. 2, Nat. Or. Rosacea. A genus of fruit trees. C. japonica is one of the handsomest hardy shrubs, producing its beautiful scarlet, or white flowers, in great abundance. C. vulgaris, the quince, is well known, and cultivated for its fruit. They will thrive in any soil, and may be multiplied by suckers.

japônčč Scarlet all H. De, S. Japan - 1815 Jearlet all H. De. S. J ẩbă : : : White all . 5, H. De. S. China . . 1818 valgärìs : White: 5, H. De T. Austria : 1573 lusitănkă . White. 5, H. De. T. Spain maliförmiss: White: 5, H. De. T. oblōngă . . White. . 5, H. De. T. Europe .

CyLINDrical, cylinder-shaped, round.

CruindricallX-GLobose, a form between a cylinder and a sphere.

CyLindrospörî̀, Linn. From kylindros, a cylinder, and spora, a sporule; alluding to the cylindricalshaped sporule. Linn. 24, Or. 9, Nat. Or. Fungi. A minute species, growing on cabbage leaves-concēntrīcūm.

CyLîstä, Aiton. Derived from kylix, a calyx; in allusion to the very large calyx. Linn. 17, Or. 4, Nat. Or. Leguminosce. An ornamental climbing genus; the species grow well in a mixture of loam and peat, and cuttings of the young wood root well in sand, under a glass.

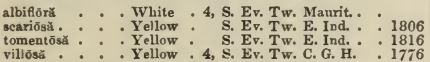
Yellow, 4, S, Ev, Tw, C. G. H, 1776

СумвйRĬ ferring to the shape of the fruit. Linn. 14, Or. 2 , Nat. Or. Scrophulariacea. This is a curious plant, growing about a foot high, and producing yellow flowers; it will flourish in any common soil, and may be increased by dividing the roots.

daürĭeă . . . Yellow . 6, H. Her, P. Tauria . . 1796

Cумві̃ ĩ̃̃, Swartz. From kymbos, a hollow recess ; in allusion to the labellum. Linn. 20, Or. 1, Nat. Or. Orchidacea. Several of the species of this genus are remarkably handsome when in fower, and therefore deserve to be extensively cultivated. The epiphytal kinds may be referred to Stanhopea, and the terrestrial, to Bletia, for culture and propagation.

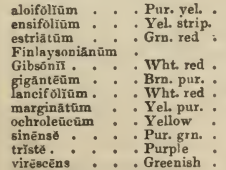

9, 5. Ter. E. Ind.

1789

S. Ter, E. Ind.

1780

S. Epi. Cochin Chin

1, S. Ter. Sylhet . . 1837 S. Epi. Nepal : : 183 , S Ter. Nepal : 1829 S. Epi. Brazil S. Epi. Trinidad

S. Ter. China

S. Ter. Nepal viréscēns $\cdot$ :

CrMmform, boat-shaped.

5, S. Epi. Japan 10 , S. Ter. China
Cумното̄gōn, Sprengel. From kymbe, a boat, and pogon, a beard; the valves of the caly $x$ are boatshaped. Linn. 93, Or, 1, Nat. Or. Graminea. A species of grass, remarkable for its fragrance; loam and peat suits it, in which it merely requires to be sown. Synonyme: 1. Andropogon Schonanthus.

Schænãnthŭs, 1 . Apetal . . Grass E. lnd. . . 1786

CyMr, a mode of inflorescence resembling a flattened panicle, as that of the Elder.

Cумго̄̄smă, Gartner. Kyminon, cumin seed, and osme, smell; the fruit smells like cumin seed. Linn. 8, Or. I, Nat. Or. Rutacee. Curious evergreen shrubs. They tourish in a mixture of loam and peat, and cuttings root freely in sand, under a glass. Synonymes: 1. Gela oblongifolia. 2. Jambolifera odorata. 3. J. pedunculata.

oblongifoliă, 1 . White . . 7, G. Ev. S. N. S. W. . 1824 odorătă, 2 : Green : G. Ev. S. China : 1818 pedunculătă, 3 : Green : : 6, S. Ev. S. E. Ind. : 1800

Cymose, flowering in cymes.

CYNAxchUM, Linn. From kuon, a dog, and agche, to strangle; alluding to its poisonous qualities. Linn. 5, Or. 2, Nat. Or. Asclepiadacea. Most of the species of this genus are perennial twiners, requiring the heat of the stove, or greenhouse; they may be grown in a good loamy soil, and will readily increase by cuttings. The hardy kinds thrive in any border soil. In Egypt, the leaves of $\boldsymbol{C}$. Arghel are used for adulterating senna. Synonymes: 1. Oleifolia. 2. Asclepias davurica. 3. A. villosa. 4. A. vincetoxicum. Gsh. wht. : 6, G. Her. P. Spain , 1596 White 7, G. Ev. Tw. C. G. H. 1831 H. De. Tw. erassifoliūm : Green * G. Ev. Tw. C. G. H. : 1816 excēlsūm White. 7, H. De. Tw. Barbary 1816 fimbriātūm Purple ${ }^{\prime}$ S, Ev Tw Cuman fūtidum : White. : W, S. Ev. Tw. Mexico : 1826 fuscatumm: : Brown : 7, S. Ev. Tw. Mexico : 1820

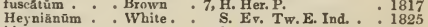
hirsutūm. . S. Ev. Tw. Trinidad : 1825 lūteum : : Yellow . 6, H. Her. P. Europe : 1596 médrũm : : White . 6, H. Her. P.

melanthōs - Purple * 7, H. De. Tw. 1818 monspeliacurm . White. . 8, H. Her. P. S. Eur. $1596^{\circ}$ mucronâtūm Green $7, \mathrm{~S}, \mathrm{Ev}, \mathrm{Tw}, \mathrm{Trinidad}$ nigrm Green. * 7, H. Tw. Trinidad 180 paucifiorum : : Green : 7, H. Her. P. S. Eur. : 1596 pilōsūm : White: 7. G. Ev. Tw. C. G. H. : 1726 róseum, 2: : Purple : 7, H. De. Tw. Davuris : 1818 sibīīeūm. . Green . 7, H. Her. P. Siberia : 1775 undātūm 3 : Green : 7, S. Ev. Tw. W. Ind. : 1803 Vincetóxǐcūm, 4 White: 7, H. Her, Pw. Europe : 182 viridifiórūm . Green 11, S. Ev. Tw. E. Iud. : 1814

CYNĀRĂ, Vaillant. From kuon, a dog; in reference to the spines of the involucrum. Linn. 19, Or. 1 Nat. Or. Compositce. This genus produces the artichoke, so much grown for culinary purposes. They all delight in a good rich soil, and may be increased by seeds. The Arabians consider the root of $C$. scolymus an aperient; the gum of it is called kun. kirgeed, and placed by them among their emetics. Synonyme: 1. Stobala glomerata.

cardūneŭlŭs . . Blue . . 8, H. Her. P. Candia . . 1658 féröx : Blue: $: 7$, H. Her. P. Italy : 1820 glomerătă, i : Blue : 8, F. Her. P. C. G. H. : 182 hórridà : Purple 8, G. Her. P. Madeira 1768 integrifoliă . . Blue . 7, H. Her. P. Spain pygmäă ... Purple 7, H. Her. P. spain 8 H Her P S Eur. spinosissimà : Blue : 7, H. Her. P. Sicily : 1826 hŭmĭlǐs.

C̄̄NŏDön, Richard. Derived from kuon, a dog, and odous, a tooth. Linn. 3, Or. 2, Nat. Or. Gramineas. Grasses, succeeding in any common soil, in which they merely require sowing. In India, a cooling drink is prepared from the roots of $C$. Dactylon. Synonyme: 1. Panicum Dactylon-Dācty̆lön 1.

Indieă . . A petal . 7, H. Cr. A. E. Ind.

Däcty̆lōn 1, lineārĭs, präcox, stellātŭs, virgätŭs.

Cynoglōssūm, Linn. From kuon, a dog, and glossa, a tongue; the leaves resemble a dog's tongue, whence the common name of the genus, Hound's Tongue. Linn. 5, Or. 1, Nat. Or. Boraginacea. The species are pretty border plants, succeeding in any common soil, and readily multiplied by 
division. Synonymes: 1. C. virginicum. 2.hirsutum. 3. Anchusa lanata.

amplezicañlé, 1 . Blue * . 6, H. Her. P. N. Amer. 1812 apennInūm : Red : $5, \mathrm{H}$. B. Italy : 1731 austrālēe : : Pa red : 6, G. Her. P. N. Holl. : 1820 bicollor : : Whe pur. 7, H. B. Germany : 1820 canēscēns, 2 Blue : 7. H. A. E. Ind. 1819 cheirifoliûm, 3 : Blue : 6 , $\mathrm{H}$. clandestīnúm . . Brown * $7, \mathrm{H}$. colñmnả . : Blue * 7, H. B. Apennines 1825 Dioscóridìs *. Purple * 7, H. B. France . 1820 elongătūm . Flesh . . 7, H. B. 1819 glomerātūm : $\quad 6$, H. B. N. Amer. 1812

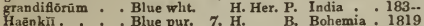
hirsũtūm: : : Blue pur. 7, H. H. A. A. G. H. : 1806 holoserícéüm: Violet: : $7, \mathrm{H}$. B. Siberia : 1821 magellénsé. : Purple 6, H. Her. P. Naples : 1823 officinălé : Pur. red . 6 , pietūm . : : Li, blue : $8, \mathrm{H}$ pylvătícứm: : : Blue : $6, \mathrm{H}$. umbellatom CrNomêtrh̆, Linn. From kyon, a dog, and metra, the matrix; referring to the form of the pods. Linn. 10, Or. 1, Nat. Or. Leguminosce. Stove trees, growing from twenty to thirty feet high, thriving well in a mixture of loam and sandy peat, and ripened cuttings will root in sand, under a glass.

cauliflöră • • Red • . S. Ev. T. E. Ind. * 1804 CรNōrchis, Thouars. From kuon, a dog, and orchis, Dog-orchis. Linn. 20, Or. 1, Nat. Or. Orchidacea. This species is one of the representatives in tropical countries of the terrestrial Orchises of Europe. It has a smell resembling that of Orchis mascula. It succeeds best in sandy loam, in a moist part of the house, and is increased by dividing the roots.

fastigiata . . . Red. grn. . 3, S. Ter. Is. of France - 1835 Cynosūrũs, Beauvois. From kuon, a dog, and ouva, a tail ; from its resemblance to a dog's tail, whence the name dog's-tail grass. Linn. 3, Or. 2, Nat. Or. Graminea. This species is esteemed one of the best fodder grasses in Europe; it will succeed in any soil.

eristatǔs . . A petal . 8, Grnss. Britain

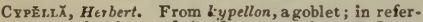
ence to the shape of the flowers. Linn. 16, Or. 1, Nat. Or. Iridacea. The species of this genus are rendered ornamental by their beautiful flowers; they delight in sandy peat, and may be multiplied by offsets. Synunyme: 1. Mora Herberti, Tigridia Herberti.

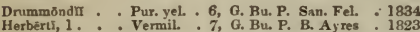

CYP̉̇ rũs, Linn. Supposed to be derived from $C_{y p r i s,}$ a name of Venus, from the roots of some of the species being aphrodisiacal. Linn. 3, Or. 1, Nat. Or. Cyperacea. A genus of grass-looking plants, many of them growing best in water, or a wet situation; any soil suits them, and they may be increased by division.

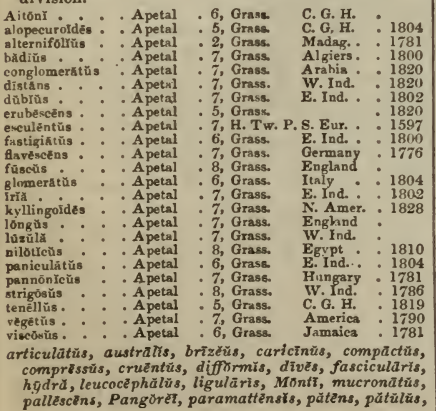

polycęphălūs, polystächy̆s, prostrūtǔs, rigidūs, tenuiflorūs, trisũlcūs.

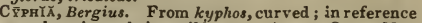
to the stigma being gibbous. Linn. 5, Or. 1, Nat. Or. Goodeniacea. A pretty genus; the species reQuire a mixture of peat, loam, and sand, and may be increased by taking off the young shoots as they begin to grow, and planting them in sand. The annual species merely require sowing. Synonymes. 1. Lobelia cardamines. 2. L. volubilis.

bulbôsã . . . Pa. blue . 8, G. A. C. G. H. . 1791 cardaminés, 1. : 7, s. Her. P. C. G. H. 1823 incisă . . Pa.red : 7, G. A. C. G. H. : 1819 Phyteūma
volübilis, 2 Cypress, see Cuprēssŭs.

CYPRIPẼdūm, Linn. From Cypris, one of Venus's names, and podion, a slipper; hence the name, Venus's, or Ladies' Slipper. Linn. 20, Or. 2, Nat. Or. Orchidaced. The Cypripediums are remarkably handsome when in flower, and on that account, they deserve a place in every collection. They are all of the easiest culture. The hardy species succeed well in peat soil, either kept in a frame, or planted out in a shady border. The species, natives of America, require to be protected from severe frost and rain. The stove kinds require the same treatment as other stove terrestrial orchidaceæ. Synonyme: 1. C. humile.

acaũlé, 1 . . . Ro. pur. . 5, H. Ter. N. Amer. - 1786 albūm : $:$ : Whice : 5, H. Ter. N. Amer. : 1800 arietInūm : : Grn. ro. : 4, H. Ter. Canada.: 1808 Caleeơlüs : : Ye:low : 6, H. Ter. England:

helvetĩcūm: : Yellow : 6, H. Ter. Switzerl. : 1825 es̆ndidūm : : White : 6, H. Ter. N. Amex. : 1826 Insigné : - Pur. grn. 6, S. Ter. Nepal - 1819 macruanthös. . . Purpie . 5, H. Ter. Siberia : 1828 parvifórüm - . Yellowish 6, H. Ter. N. Amer. * 1759 pubēscēns
purpurátúm

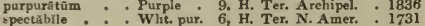

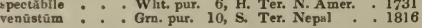

Cyrîtr. Ľ, Linn. In honour of Dominico Cyrillo, M.D., a professor of botany at Naples, and Fellow of the Royal Society of London. Linn. 5, Or. 1, Nat. Or. Celastracee. A genus of pretty shrubs, that grow well in a mixture of sandy loam and peat. Young cuttings root in sand, under a glass.

Antillarim . White 7, G. Ev. S. Antilles . 1824 caroliniană. : White : \%, G. Ev. S. Carolina : 1765

CyRtānthǔs, Aiton. Fromkyrtos, curved, and anthos, a flower; the tube of the flower is long and round. Linn. 6, Or. 1, Nat. Or. Amaryllidacere. Handsome Cape bulbs, succeeding in a mixture of turfy loam, sand, and peat, and a liberal supply of water, when in a growing state. They may be increased readily from offsets.

angustifoliñs - Orange . 5, G. Bu. P. C. G. H cârneús.: : Flesh . collinüs: : : Crimson: 6, G. Bu. P. C. G. H obliquūs : . Grn. or. . 6, G. Bu: P. C. G. H odōrüs Crimson 6, G. Bu. P. C. G. H. pяllidŭs : . Pink . 6, G. Bu. P. C. G. H. spiralis . : Scarlet : 6, G. Bu. P. C. G. H. striătŭs.: : : Orange : 7, G. Bu. P. C. G. H. : 1770

CYrTocinu, Kunth. From cyrtos, concave, and cheilos, a lip. Linn. 20, Or. 1, Nat. Or. Orchidacede. The species of this genus are small, but remarkably pretty when in blossom, and will probably be found to succeed best with the treatment recommended for the genus Burlingtonia.

hictoniěnsê . . Red . 10, S. Epi, Guatemala . 1836 flavëscéns : : Yellowish 6, s. Epi. Mexico • . 183.. maculstúm : Grn. pur. . S. Epi. Vera Cruz : 1837 mystacinûm : Yellowish 10, S. Epi. Peru . : 1836 СтRтб́р̆̌̆ L̆, Lindley. Not explained. Linn 20, Or. 1, Nat. Or. Orchidacea. This is a splendid species when in flower. It is easily cultivated with the treatment given to Stanhopeas, and the like: and it is readily increased by separating the thick stem, with a portion of the rooting rhizoma attached. Synanyme: 1. Cyrtopodium Woodfordii.

WoodfordI, 1. . Pink . . 9, S. Epi S. Amer. . . 1814

Cxrtoprotè, R. Bronn. From cyrtos, hollow, and yous, a foot; alluding to the curved stalk of the labellum of C. Andersonii. Linn. 20, Or. 1, Nat. [98 
Or. Orchidacee. This is a genus of plants well worth cultivating for the sake of their fine, sellow, sweet-scented flowers. They succeed well, treated as the genus Stanhopec.

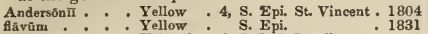
punctãtūm : : Yel, red : 4, S. Epi. Brazil

CYrtostY̌L̆̌, $R$. Brown. From cyrtos, convex, and stylos, a style. Linn. 20, Or. 1, Nat. Or. Orchidacer. A very curious species, succeeding well with the same treatment as is recommended for the genus Corycium.

renifōrmı̀s

6, F. Ter. N. Holl.

1823

Cysticāpnōs, Boerhaave. From kystis, a bladder, and kapnos, a Greek name for fumitory; in allusion to the bladdery capsules. Linn. 17, Or. 2, Nat. Or. Papaveracese. Annual species, requiring to be sown in a gentle hotbed, and afterwards trans planted into the open ground, where they will flower well. Synonyme: 1. Fumaria vesicaria. afrieană, 1. . . Wht. red . 6, H. Cl. A. C. G. H. . 1696 slexandrīua . Wht. red , 6, H. Cl. A. Alexan, 1827 Cystoseĩnă, Agardh. From kystis, a bladder, and seira, a chain; in reference to the upper parts of the fronds appearing like little bladders chained together. Linn. 24, Or. 7, Nat. Or. Alga. Species of sea-weed, found at all seasons of the year in the open ocean-abrotanifólăă, barbãtă, dīscors, ericō̃dēs, fibrōsŭ, granulätă, siliquosă, $S$, denudātă, $S$. mīnorr.

C זтїspóra, Fries. From kystis, a bladder, and spora, a sporule; the sporules appear like little bladders. Linn. 24, Or. 9, Nat. Or. Fungi. Minute species, growing on dead branches, leaves, \&c.-chrysospērmä, guttĭfĕră, leucospērmă, Rosārūm.

Cr̃Tisǔs, Linn. Derived from Cythrus, one of the Cyclades, one of the species being first found there. Linn. 16, Or. 6, Nat. Or. Leguminose. This is a very ornamental genus. The species are fine, hardy, free-flowering trees and shrubs, succeeding in almost any soil, and readily increased by seeds, layers, grafts, or buds. Synonymes: 1. Spartium multiflorum. 2. C. pauciflorus. 3. Spartium spinosum, villosum. 4. C. elongatus. 5. Spartium nubigenum. 6. S. patens. 7. s. spinosum.

\begin{tabular}{|c|c|c|}
\hline æeolǐ̌cŭs & & \\
\hline bùdùs & & Thite. \\
\hline lbŭs, 1 & & White. \\
\hline incarnāt & & lesh. \\
\hline alpĩnuัs . & . . & - Yellow \\
\hline argēntéus & - & - Yellow \\
\hline austrỉacŭs & . & - Yellow \\
\hline biflōrŭs. & & - Yellow \\
\hline calycinuัs, & & - Yellow \\
\hline capitātŭs & . & - Yellow \\
\hline ciliatŭs. & • & . Yellow \\
\hline êlègãns. & . & Yellow \\
\hline eiongatùs & • & Yellow \\
\hline faleâtús. & . & - Yellow \\
\hline glomerâtŭs & & - \\
\hline grandiflōrŭ & & Yellow \\
\hline hirsūtuัs & - & Yellow \\
\hline Labūrnūm & & Yellow \\
\hline $\begin{array}{l}\text { pux } \\
\text { länİgè }\end{array}$ & 18 & $\begin{array}{l}\text { urple } \\
\text { ellowy }\end{array}$ \\
\hline leucânthŭs & & Pa. yel. \\
\hline molliss $\cdot$ & & Yellow \\
\hline multiflorŭs & & Yellow \\
\hline nẫnŭs. & - & Yellow \\
\hline nīģrĭcāns & 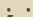 & Yellow \\
\hline nubiggénŭs, & 5 & Yellow \\
\hline orientalis & - & - Yellow \\
\hline pătēns, 6 & - & Yellow \\
\hline polỳtrichŭs & & Yellow \\
\hline proliférŭs & - & Yellow \\
\hline urpǔreǔs & & - Purple \\
\hline pygmǣus & - & Yellow \\
\hline racemōsŭs & - & Yellow \\
\hline ruthēnicŭs & . & Yellow \\
\hline seopă rǐŭg & - & Yellow \\
\hline âlbŭs. & - & White. \\
\hline $\begin{array}{l}\text { sessillitorüs } \\
\text { spinōsǔs, }\end{array}$ & & ellow \\
\hline supinuัs & : & ellow \\
\hline triflorrs & - & Yellow \\
\hline
\end{tabular}

5, H. De. S. Stromboli . 1836 6, H. De. S. S. Err.

5, H. De. S. Portugal : 1759

5, H. De. S. Portugal : 1752

6, H. De. T. Europe : 1596

8, H. De. S. France - 1739

7, H. De. S. Austria - 1741

5, H. De. S. Hungary , 1760

8, H. De. S. Tauria 1820

7, H. De. S. Austria 1774

7, H. De. S. Carpathia 1817

G. Ev S. C. H.

5, H. De. S. Hungary : 1804

7 , H. De. S. Hungary : 1816

S. Ev. S. Zanzibar : 1826

6, H. De. S. Portugal . 1816

7 , H. De. S. S. Eur. . 1739

5, H. De. T. Switzerl. 1596

7, H. Ev. T. Hybrid , 1828

6, F. Ev. S. Spain . . 1821

6, H. De. s. Hungary 1806

6, H. De, S.

6, H. De. S. Europe 1818

6, H. De. S. Europe : 1800

6, H. De. S. Austria : 1730

5, G. Ev. S. Teneriffe . 1779

6, H. De. S. S. Eur. : 1818

6, H. De, S. Portugal : 1752

6, H. De. S. Tauria . 181

4, G. Ev. S. Canaries . 1779

6, H. De. S. Austria

6, H. De. S. Austria

6, H. De, S. Galacea

7. H. Ev. S.

6, H. De. S. Russia : 1817

6, H. De. S. England

5, H. De. S. England

7, H. De. S. Italy .

6 H. Ev. S. S. Eur.

Сz̄̄скі̌̆, Andrezjouski. In honour of Andrezousk Czack, a Russian botanist. Linn. 6, Or. 1, Nat. Or. Liliacea. A pretty species, producing abundance of elegant flowers; it prefers a good rich loam, and an open situation. It is readily increased by seeds, or dividing the roots. Synonyme: 1. Anthericum liliastrum.

liliāstrüm, 1 . . White . . 5, H, Her. P. S. Eur. . . 1629

D.

DACRYDIOOM, Banks. Derived from dakru, a tear; in reference to the gummy exudation. Linn. 21, Or. 10, Nat. Or. Taxacece. These are ornamental plants, resembling the spruce in appearance, except that the branches are somewhat pendulous; hence the English name of $D$. cupressinum, New Zealand Spruce. A mixture of sandy loam and peat suits them, and ripened cuttings root in sand, under a glass. Synonyme: 1 . Juniperu. elata.

cuprểssĩnũm . .

G. Ev, T. N. Zeal.

G. Ev. T. Pulo Pen. : 1825

elátūm, 1 . :

DacrĭmY̌cēs, Nees. From dakru, a tear, and myke, a fungus; in allusion to the deliquescent nature of the plants. Linn. 24, Or. 9, Nat. Or. Fungi. Curious and minute species of Fungi, found usually upon dead and partially, rotten wood, in the early part of the season-moriformis, stillatus.

DACTYLICĀPNõs, Wallich. From dactylos, a finger, and kapnos, fumitory ; alluding to the berries being finger-shaped. Linn. 17, Or. 2, Nat. Or. Papaveracees. An interesting annual, of a climbing oharacter, succeeding in any sandy soil. Synonyme: 1. Dielytra scandens.

thalictrifólǐa, 1 . Yel. bm. . F. Ev. Cl. Nepal . . 1831 DĀctřĽs, Linn. From dactylos, a finger; the head is divided so as fancifully to resemble fingers. Linn. 3, Or. 2, Nat. Or. Graminece. An uninteresting genus of grasses, of easy culture and propagation.

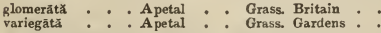

adscēndēns, cynosurō̃dēs, glaṽcă, glaucēscēns, hispa-

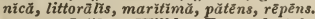

DActýoctēnî́m, Willd. From dactylos, a finger, [ 99 ] and kteis, a comb; alluding to the digitate spikes. Linn. 3, Or. 2, Nat. Or. Graminece. A plant of little merit, and of easy culture. Synonyme: 1. Cynosurus agyptiacus.

ægyptǐăcûm, 1 . A petal . . 8, Grass. Egypt . 1770

D AEnĂLǨ̆, Persoon. From daedaleus, artificial; artificial-like arrangement of sinuosities. Linn. 24 Or. 9, Nat. Or. Fungi. Very minute species of Fungi, found at all seasons on rotten wood, trunks of trees, \&c.-angustă, betulīnă, biēnnis, confrayōsă, gibbosă, quērcĩnă, unīcōlorr.

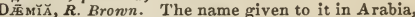
where the first plant was found. Linn. 5, Or. 2 Nat. Or. Asclepiadacee. An ornamental genus of twining plants, thriving best in a mixture of sandy loam and peat. Cuttings root freely in sand, or sandy soil, under a glass. Synonymes: 1. Cynanchum bicolor. 2. C. extensum. 3. Asclepias scandens. břcōlor 1 . White 7, S. Ev, Tw. E. Ind. . 1806 cordātă : : White : 7, s. Ev. Tw. Arasia : 1824 extēnsă, 2 : : White : 7, s. Ev. Tw. E. Ind. : : 1777 scăndēns, 3 : White : 7, S. Ev. Tw. Gambia : 1824

DAFrodru, see Narçssurs.

DĀHLǏ̆, Cavanilles. In honour of Andrew Dahl, a celebrated Swedish botanist, and pupil of Linnæus. Linn. 19, Or. 2, Nat. Or. Compositue. This exceedingly beantiful genus comprises almost an indefinite number of varieties, all more or less showy in the flower-garden in the autumn, when most other flowers have faded. They are all of easy cultivation, growing freely in almost any soil, particularly if of a sandy open nature. They may be raised plentifully from seeds, which should be sown early in the spring. After the flowering season is over, and the frost has damaged the leave and branches, the roots should bo taken up, and 
placed in a secure dry place, excluded from frost, till spring, when they should be divided and propagated, and brought on, by dung heat, in frames, for planting out in the flower-garden in May or June. Cuttings will root with great facility, by merely breaking or cutting off the young shoots, and planting them in small pots, in a warm frame heat; but this practice, as seeds grow so readily, except for very rare kinds, is more troublesome than profitable. Synonymes: 1. Dahlia frustraneafulgens. 2. Georgina pinnata.

Cervantésī
crocātă, 1 : Scarlet : 8, H. Her. P. Mexico

frustrānéă Scarlet in, H. Tu. P. Mexico

aurentiă. : Orange . 10, H. Tu. P. Mexico : 1802

eröcęă : Yellow : 10, H. Tu. P. Mexico : 1802

lúteă ${ }^{\circ}:$ : Sulphur : 10, H. Tu. P. Mexico : 1802

DAYs, Linn. The derivation of the name is unknown. Linn. 10, Or. 1, Nat. Or. Thymelacea. This is an interesting species, much like the Rhus cotinus, in its leaves; it grows in a mixture of peat and loam, and is increased from cuttings of the roots, kept in a warm situation, and sometimes from seeds.

cotinifolră . . Wht. grn. 6, G. Ev. S. C. G. H. . 1776

Darsy, see Bellis.

DALBẾrgĬ L Linn. In honour of Nicholas Dalberg, a Swedish botanist. Linn. 19, Or. 4, Nat. Or. Leguminusce. Ornamental stove species, delighting most in sandy loam and peat; cuttings strike, if planted in sand, under a glass.

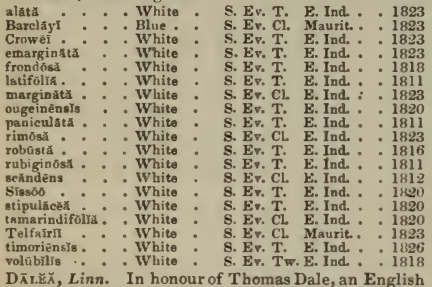

DĀL.̌̌̆, Linn. In honour of Thomas Dale, an English botanist of the last century. Linn, 16, Or, 4, Nat. Or. Leguminosa. All the species of this genus are almost destitute of interest; they grow best in loam and peat. The shrubby and perennial kinds are increased by cuttings planted in sand, under a glass. The tender annual species must be sown on a gentle hotbed, and, when of sufficient size, transplanted into the open borders. Synonymes: 1. Psoralea laxiflora. 2. P. leporina. 3. P. Dalea.

alopecuroides, 1, Pa. blue. 7, H. A. Mississippi 1812 aũrex . : Yellow: 7, H. Her. P. Louisiana 1811 breólö

blcolưr

Yel blue

$7, \mathrm{~s}$.

Pink. 10, $\mathrm{s}$

10, S. Her. P. S. Amex.

1817

Cliffortiānă

enneapliylla

Lagopas, 2

laxiflori, 3

White

aûtăns : Violet

reclinata. - Violet

rechinata. Violet

sericed : : Vinlet

7. H. A. Vera Cruz $: 1737$

7, S. Ev. S. W. Ind. $\quad 1772$

7, F. Her. P. Mexico : 1780

10, G. Her. P. Mexico : 18 is

7, S. Her. P. Mexico: 1824

7, G. Ev. S. Caraceas : 1819

7, S. Ev. Tr. Mexico . 1820

7, S. Her. P. Mexico: : 1824

7, S. Ev. S. Mexico : : 1824

tuherculat: . Purple . 7, S. Ev. S. Mexico * 1824 a celebrated French botanist, who died in 1588 . Linn. 2, Or. 1, Nat. Or. Euphorbiacece. Pretty climbing plants, thriving well in a mixture of loam and peat. Cuttings root freely in sand.

brasilięnsǐs. . . Grn. yel. . 7, S. Ev. Cl. Brazil • . 1824 ficifólia. . . Grn. yel. . 7, s. Ev. Cl. Brazil : 1820 scăndëns : : Grn. yel. :6, s. Ev. C. W. Ind. : 1739

DALrRĀrdă, Linn. Named after Denis Dalibard, a French botanist. Linn. 12, Or. 2, Nat. Or. Rosacea. A curious ulant, well suited for decorating rockwork, or the front of flower-borders; it requires protecting in severe weather, and is increased by division. Synonyme : $1 . D$. repens.

violæoides . . White . ., H. Her, P. N. Amer. . 1768
Dar.R FMPLü̆ă, see Turpĭnĭa.

DaItTónin. Named by Hooker in honour of the Rev. James Dalton, an excellent English muscologist. Linn. 24, Or. 5, Nat. Or. Musci. Pretty dwarf species of moss. D. splachnoides is only found growing, and that sparingly, by the side of a small stream on the Secawn Mountain, in the neighbourhood of Dublin. Synonymes: 1. Neckera heteromalla. 2. Neckera splachnoides-heteromallä 1, splachnotdes 2.

Damas̃̃Nİ̃ S, Schreber. From damazo, to subdue; in reference to its once supposed medicinal qualities. Linn. 6, Or. 4, Nat. Or. Hydrocharacece. Handsome aquatics. $D$. indicum is reputed to possess the power of removing the venom of the sea-dog.

Indĩeum . . White . 8, S. Aq. P. E. Ind. . 1800 ovalifơliúm : : White : 8, G. Aq. P. N. Holl. : 1824

DAMмӑR boyna. Linn. 21, Or. 10, Nat. Or. Conifere. A very handsome genus of Conifere, thriving well in a mixture of sandy loam, but of difficult propaga. tion. The only successful mode, is to take off the cuttings as soon as ripened, and plant them in a pot of sand, under a glass, in a gentle bottom heat. Liquid storax is thought to be yielded by the species of this genus. Synonyme: 1. Pinus Dammara, Agathis loranthifulia.

australis . . A petal. . S. Ev. T. N. Zeal. . 1821 orientälis, 1 : A petal: : S. Ev. T. Amboyna : 1804

DAтMAR pINR, see Dammürŏ.

DAMP1ERR $\bar{X}$. Named by Brown, in memory of Captain William Dampier, the celebrated circumnavigator. Linn. 5, Or. 1, Nat. Or. Scevolacee. Ornamental species, succeeding well in a mixture of peat and loam; cuteings of the young wood root freely, in sand, under a glass.

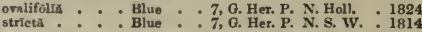

DAN茯X, Smith. In honour of Pierre Martin Dana, a writer on the plants of Piedmont. Linn. 24, Or. 1 , Nat. Or. Danceacee. An ornamental species of fern, growing well in a mixture of peat and loam, and increased by divisions of the root.

alătă . . . Brown . S. Her. P. W. Ind. . 1823

DANCrNo-gIRLs, see Mantžsiä Saltatoria.

DANDRLION, see Leötódon.

DANтrōñ̌n, Decandolle. In honour of M. Danthoine, a French botanist. Linn. 3, Or. 2, Nat. Or. Graminea. A worthless genus of grasses, of simple cultivation. Synumymes: 1. Avena provincialis. 2. A. semiannularis. 3. A. glumacea. 4. A. strigosacalycīnd, curvifoiă, longifoliă, macrüntha, pilosă, provinciälis 1, semiannuläris 2, sericed, spicätä 3 , strigosă 4.

DĀPHXĒ, Linn. From daio, to burn, and phone, a noise; it crackles when burning. Linn. 8, Or. 1, Nat. Or. Thymelace. All handsome dwarf shrubs, mostly evergreens, excellently suited for planting near the front of shrubberies. The branches of $D$. Cneorum are procumbent, stretching to a great dis. tance; whence it makes a beautiful rock plant. All the species prefer a peaty soil, and are readily increased by grafting on the common Spurge Laurel (D. Laureola), which may be plentifully raised from seed. In the South of Europe, $D$. Gnidium is used to dye wool yellow. The berries of $D$. Laureola are poisonous to all animals except birds. Synonymes: 1. D. Dauphinii. 2. D. collina, neapolitana. 3. D. cannabina. 4. D. olocfolia. 5. Passerina Tarton-raira. 6. P. villosa. 7.P.Thymelaa.

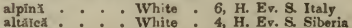
austrâlis : : : Pink. : 4, H. Ev. S. Naples chinêntis : Yellow: 5, G. Ev. \&. China Cneórūm : : Pink. 7. H. Ev. B. Austria: collin a Gnidiúm: : : White: 7, H. Ev. S. Spain

hybrưum, 1: : : Rhite : 7, H. Ev. S. Spain

hybridă, 1 : : Red : White: 6, G. Ev. S. Hybrid

Indied
Laurérlá : : : Green : ${ }^{6,}$ G. Ev. S. China
Et. S. Britain

Mezêreûm : : Pink : 3, H. De. S. England

allutim : 3 , H. De. S.

autumnaile : Red : 8, H. De. S. Europe

rûbrûm . : Pink. . 3, H. De. S England

neapolitánă, 2: : Purple : 3, H. Ev. S. Nsples

odora 1822

rüar. * . Pnk, wht. 7, G. Ev. S. China * . 177

variegăta : : White : 10, G. Ev. S. Japan : : 1830 oleoides. : : White : H. Fv. S. Crete : 1815
1759

[100 ] 
papyräceđ̆, 3 . White . 5, G. Eマ. S. Nepal • 1824 pơnticā. Grn. Jel. 4, H. Ev. S Pontus: 175 ríbră: : : Red Jel 4, G. Ev, S. Hybrid: : 1827 pubëscëns : Yellow: 4, H. Ev. S. Austria: 1810 serícéd, 4 . White * 4, H. Ev. S. Crete * 1820 striäta - Purple 5, H. Ev. S. Switzerl. 1819 Tarton-rairă, 5 . Whito 6, H. Ev. S. France - 1640

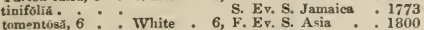
Thymelză, 7 : Yellow: 3, H. Ev. S. Spain: 1815

DARIingtóñ̌̆, Decandolle. In honour of Dr. Darlington, an American botanist. Linn. 5, Or. 1, Nat Or. Leguminosce. The soil best adapted to these pretty plants, is peat and sand, mixed with vegetable mould. They do best grown in pots, among the Alpine plants. They may be increased by dividing at the roots, or by young cuttings in sand under a glass. Synonymes: 1. Acacia brachyloba. 2. Mimosa glandulosa, Acacia glandulosa.

braclıylōhă, 1 . . White . . 9, F. Her. P. N. Amer. . 1803 glandulōsă, 2 : White : 9, F. Her. P. N. Amer. : 1806

DARNFI, see Lolĩūm temulēntūm.

DARWinİ, Rudge. In honour of Dr Darwin, the celebrated author of the poem entitled the Botanic Garden. Linn. 10, Or. 1, Nat. Or. Myrtacere These very singular plants grow well in a mixture of loam, peat, and sand, and cuttings of the young wood strike freely in sand, under a glass.

fasciculātă . . . 6, G. Ev. S. N. Holl. taxifoliă 6, G. Ev. S. N. Holl.
6, G. Ev. S. N. Holl.

1820 DASYcন̄RPǑs, hairy -fruited.

DAtz-palm, see Phänix.

DATB-pLUM, see Diōspy̆rós.

DAtíscă, Willdenon. Meaning unknown. Linn, 22 Or. 10, Nat. Or. Datiscacea. Hardy herbaceous plants, growing in any common garden soil, to the height of four feet. They are increased by divisions at the roots.

cannabĩnă . - Yellow . 8, H. Her. P. Candia • 1640 hirta: : Grn. yel. 6, H. Her. P. Pennsylv. : 1826

DAtûr tütorah. Linn. 5, Or. 1, Nat. Or. Solanacere. An ornamental genus, but chiefly composed of plants possessing very deleterious qualities. The seeds of D. ceratocaulon will sometimes remain in the ground for several years before they vegetate. The seeds of all the species require to be sown early in spring, on a hotbed, and when of sufficient size, they should be transplanted into a warm border, where they will flower better than if kept in pots. In the United States, the juice of $D$. stramonium is used in doses of from twenty to thirty grains, in cases of epilepsy, or of mania without fever.

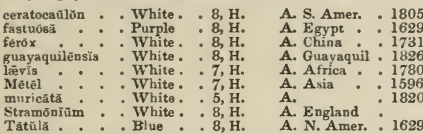

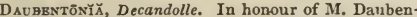
ton, a celebrated naturalist. Linn. 17, Or. 4, Nat. Or. Leguminosa. Very handsome plants; for cul ture and propagation, see Piscidia. Synonymes: 1. Eschynomene longifolia, Piscidia longifulia. 2. AEschynomene punicea.

lengifoliă, 1 : Yellow : 7, S. Ev. S. N. Spain 1820
punǐceă, 2. punìceă, 2 . - Vermiln. - 7, S. Ev. S. N. 8 pain 1820 Charles Daubeny, the present professor of botany at Oxford, and well known for his physiological researches. Linn. 6, Or. 1, Nat. Or. Liliacea. This is a very pretty, as well as a singular little plant, producing its beautiful yellow flowers in an umbel, larger than a crown piece. It will grow well in sandy loam and peat, and may be increased from offsets.

aūrěa . . . Yellow . 6, G. Bu. P. C. G. H. . 1832

DA Ūcǔs, Tournefort. From daio, to make hot; in allusion to its supposed effect in medicine. Linn. 5, Or. 2, Nat. Or. Umbelliferce. Some of the species of this genus are very useful, as $D$. Carota, and its varieties, yield the esculent root, so well known under the name of Carrot. They grow well in any common soil; the seeds require to be sown towards the end of March, or beginning of A pril.

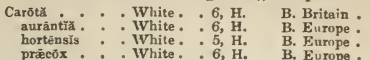

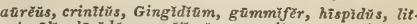

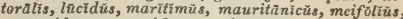
montevidēnsis, parviflorrŭs, poly̆gămŭs.

DAvĀLLĬ Smith. In honon- of Edmund Davali, Swiss botanist. Linn. 24, Or. 1, Nat. Or. Polypodiacec. This is a genus of very beautiful ferns. The rootstock of $D$. canariensis curves over the side of the pot in which it grows, and being covered with close brown hair, it very much resembles a hare's-foot; hence it is commonly called the hare's. foot fern. The species thrive well in a mixture of peat and loam, and may be increased by divisions at the roots, or by seeds. Synonyme: 1. Tricho. manes gibberosa.

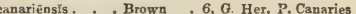
concavadénsis.: Brown : 6, G. Her. P. Canaries : 1699 dübră * : Brnwn : 6, G. Her. P. N. Holl. : 1826 èlegāns - : Brown . 6, G. Her. P. N. Holl. 1824 fläccidă: * Brown : 6, G. Her. P. N. Holl. : 1820 6, G. Her. P. N. Holl. DAviËš̃̆, Smith. In honour of the Rev. Hugh Davies, F.L.S., a Welch botanist. Linn. 10, Or. 1 Nat. Or. Leguminosa. The species are all very handsome plants when in flower; they do best in an equal mixture of loam, peat, and sand; cuttings nearly ripened, of all the species, will root readil in sand, under a glass. Synonyme: 1. Daviesia glauca.

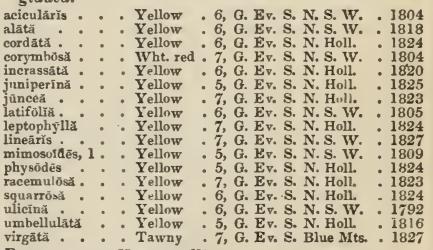

DAY LILY, see Hemerocallis.

DraDty CARROT, see Thäpsĭŏ.

DRADLY NIGHTSHADB, see Atrópă Belladōnnă.

DEAD NETTLB, see Galeóbdolon.

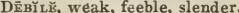

DECANDrous, having ten stamens.

DвcApHर̃LoŨs, ten-leaved.

Decrovous, falling off. Leaves which are shed annually are said to be deciduous; as are trees that annually lose their leaves.

Drcipuous cypress, see Taxodium distichum.

Dвсі̌p̆̄̌ss, deceiving, by resembling something else Declisate, curved downwards.

DFCoction, a preparation or digest, by boiling water. D ̌̆cŏ̀ŏs, Gmelin. From deka, ten, and odous (odontos), a tooth; referring to the calyx having ten teeth. Linn. 10, Or. 1, Nat. Or. Lythracec. This is a handsome border plant when in flower, growing in any common soil, and increased by dividing the plant at the roots. Synonyme: 1 . Nesca verticillata.

verticillătŭs, 1 . Purple . 8, H. Her. P. N. Amer. . 1759

DzсомтоuND : a leaf is said to be decompound when it is often pinnated; a panicle, when its branches ars also panicled.

DECORTICATED, disbarked.

Drcos $\bar{A} R$ Ĭ, Linn. From decuma, a tenth; in reference to the tenfold structure of some of the flowers and fruit. Linn. 11, Or. 1, Nat. Or. Philadelphacere. The species of this genus are ornamental, and well adapted to training against a wall or trellis; they grow well in any common soil, and may be increased by layers, or cuttings placed in sand, under a glass. barbăă White 7, H. De. Tw. Carolina . 1785 prostrăta: : White :7 H. De. Tr. N.Amer. : 1820 sarmentōsá: : White : 7, H. De. Tw. Csrolina : 1758 
Drcursive, having a tendency to run down.

Dscussark, when two right lines cross each other at right angles, they are said to be decussate.

DRRRINGIX, $\boldsymbol{R}$. Brown. In memory of Dr. Charles Deering, an English botanical anthor. Linn. 5, Or. 1, Nat. Or. Amarantaceu. Curious but weakgrowing plants. The seed requires to be sown in a hothouse, or hotbed, and when of sufficient size, the plants may be potted off, and placed among the stove plants.

celosioidès . . White . 9, S. B. E. Ind. . 1804 Indīcă : : : White : 10, S. B. E. Ind. : 1804

DRFLEXRD, turned downwards.

Deroix

DrorÁphis, Trinius. Derived from dis, twice, and grapho, to mark. Linn.3, Or. 2, Nat. Or. Graminea. Worthless species of grass, growing in any common soil, and increased by divisions at the roots. Synonymes: 1. Phularis arundinacea. 2. Arundo colorata-americănă 1, arundinacěă 2, variegātă.

DrнIscrNT, gaping; an expression applied to the mode in which the anthers or the fruit burst open, and discharge their contents.

Det.rssĒrĩ , Lamour. In honour of M. Benjamin Delessert, a famous French botanical patron. Linn. 24, Or. 7, Nat. Or. Algue. Beautiful species, of mostly deep green $A$ lga, found in tbe ocean, and on the sea-shore-alätă, $\boldsymbol{A}$. angustissimă,$A$. dilatătă, Bonnemaisont, glandulosă, hypoglossim, lacerätă,

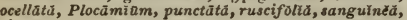
sin $u \bar{s}$ sä.

Ḋ̈r.Iмă, Linn. From delimo, to file, or shave off; the leaves are used for polishing. IIinn. 13, Or. 1, Nat. Or. Dilleniacea. Very fine climbing plants, growing best in loam, peat, and sand mixed; ripened cuttings root in sand, under a glass, in heat.

nitida

8. Ev. Cl, Trinidad .1830

sarmentósă, 1 : Fellow - S. Ev. Cl. Ceylon *: 1820

Defrquescent, melting away upon exposire to air.

Dвирнт́т̃ũ, Linn. From delphin, a dolphin; in reference to the supposed resemblance in the nectary of the plant to the imaginary figures of the dolphin. Linn. 13, Or. 3, Nat. Or. Ranunculaced. All the species of Larkspur are showy, and valuable as border flowers, especially $D$. Ajacis and Consolida, both of which are universally grown among the border annuals. The herbaceous and perennial kinds are increased by divisions, or seeds, and the annual and biennial kinds merely require sowing in the open border, where they will flower and seed freely. D. Consolida is regarded as a simple astringent. Synonymes: 1. D. tridactylon. 2. D. hirsutum. 3. D. intermedium. 4. D. junceum. 5. D. ambiguum.

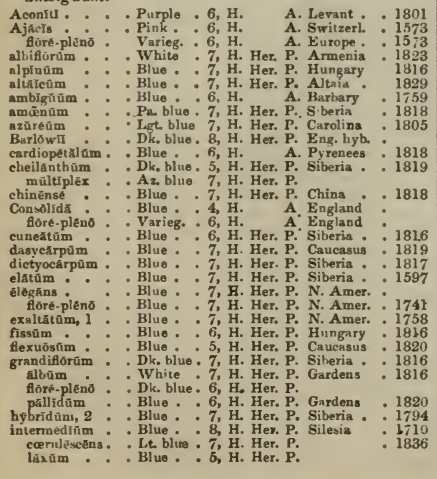

leptostăchy̆um 3 Blue . . 5, H. Her. P. Pyrenees palliridùm : Blue : 7 , H. Her. P. pilosissimũm: Blue: $7, \mathrm{H}$. Her. P. Siberis : 1836 ranunculiforram Blue: 7 , H. Her. P. Pyrenees:

sapphirinũm : Blue: : H H Her. P. Her. P. Siberia .

MenziësII : Blue : 7, H. Her. P. Siberia * 1826 mesoleñeũm : Blue - T, H. Tu. P. N. Amer. - 1826 mesoleūeũm : Blue * 7, H. Her. P. Switzerl. 1822 bracteósüm: : Blue : : 6, H. Her. P. Switzerl. : 1819 ochruleũcūm : Whito . 6, H. Her. P. Iberia 1823 Oliveriănùm . Blue : 6, H. A. S. Eur. : 1826 palmatifidûm . Blue . * 7. H. Her. P. Siberia . 1824 glahêllūm : Blue : 6, H. Her. P. Siberia : 1817 pentăg ‘nūm: Blue : 7, H. Her. P. S. Eur. : 1819 peregrinum, 4 : Blue: $:$, H. Her. P. Italy : 1629

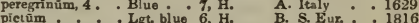

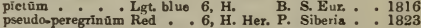
pubéscêns, 5 . . Blue: : 8, H. Her. P. Mediterr. : 1816 punícē̃m : : Purple: 7, H. Her. P. Siberia : 1785

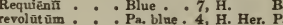

speciōsũm : : Blue : 7, H. Her. P. Caucasus . 1816 spŭriūm : Blue : 7, H. Her. P. Siberia : 1810 Staphisăgria: : I.gt. bluo 7. H. H. S. Eur. : 1596 tenuissimum : Purple 8 , H. A. Greece : 1835 tricơrné. : : Blue : 7, H. Her. P. N. Amer. : 1806 triste *. Blue: 7, H. Her. P. Dahuria 1819 urcenlatüm - Blue - 6, H. Her. P. P. Ply villosuin - Blue - 7, H. Her. P. Italy : 1819 vimin * Blue * 7, H. Her. P. Caucasus : 1818

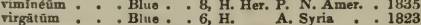
DĒLT Ă-I.RAvBD, shaped like the Greek $\Delta$.

DeLtỗ DẼs, triangular.

Dвмйтйе, Persoon. From a diminutive of dema, a bundle; in reference to the mode of growth. Linn. 24, Or. 9, Nat. Or. Fungi. An extremely minute species of Fungi, of a bluish colour, found on the stems of herbs in autumn-articulitnm.

DRMULCkNT, having the property of softening anything.

DrNDRŌBĪ̇, Swartz. From dendron, a tree, and bios, life; in the places of their natural growth, the species are generally found upon trees. Linn, 20, Or. 1, Nat. Or. Orchidaced. Noorchidaceous plants contribute more to the gaiety of the stove, than the species of this splendid genus. D. nobile, chrysanthum, Gibsonii, fimbriatum, densiflorum, and many others, are equalled by few, and certainly not surpassed, in the beanty of their flowers, by any other orchidaceous plants; and if the following directions be attended to, they will be found very easy of culture :-All orchidaceous plants require (to cultivate them successfully), a season of growth, a season of rest, and a season for flowering; all of which should coincide, as much as possible, with the corresponding seasons of those parts of the globe which they so profusely inhabit; and the species of this genus should especially be subjected to a change of treatment assimilating as much as possible to that before mentioned, without which, they will never flower in perfection. In India, three seasons only are known; the hot, or dry season, which is succeeded by the rainy season, and the cold, or winter season. In the hot season, all, or the greater part, of the plants belonging to this genus produce their flowers; in the rainy season, they make their shoots; and during the cold season, they have a period of repose. The different seasons being so well known, it is very easy to imitate them in our hothouses, and by attending to these simple rules, we should be enabled to flower the species of this more abundantly than those of any other orchidaceous genus, besides which, they might be easily induced to flower in this country at any season of the year. D. chrysanthum, Pie. rardit, and some others, grow well when fastened singly on pieces of wood, and treated as is recommended under Burlingtonia; but they all succeed well when potted in very turfy peat, raised above the pot, in the same way as is recommended in potting Stunhopeas. A strong moist heat is indispensable in the growing season, when they may be frequently slightly syringed over-head. They will be found to succeed best in a warmer part of the house than the Stanhopeds require. They are pro. pagated by detaching one or more of the stems while in a dormant state, taking care not to injure the roots, and potting it carefilly in turfy peat soil, and not nuch rsised above the pot, which 
must be carefully drained; the pot should then be plunged in a gentle bottom heat, where the plant will speedily produce new shoots. Synonymes : $\begin{array}{lll}\text { 1. D. cucullatum 2. D. pusillum. } & \text { 2. }\end{array}$

æmŭlùm amplüm. aūrêum carulêecēns calamiförmé ealceolârìa canaliculastüm cañdidūm

chrysđnthūm crumenātūm cûpréum . Dalhousiānuีm densiflorüm denưdâns fimbriátûm formōsûn GibsonnII .

heterocārpūm Wht brn. 12 , Straw eld.
Yellow. Yky blue Or. pink Epi. India .

S. Epi Ceyse S. Epi. Khooseea S. Epi.

6, S. Epi. E. Ind. S. Epi, N. Holl.

1823

White

Yellow

White

4. S. Epi. Khoosee

2, S. Epi. Nepal

4, S. Epi. Sumatra

6, S. Epi. E. Ind. S. Epi. Brazil 6, S. Epi. Nepal S, Epi. Khonse 5, S. Epi. Nepal

5, S. Epi. Khooseea 6, S. Epi. Khooseea S. Epi. Khooseea S. Epi, Khooseea S. Epi. Assam S. Epi. Assim Jènkinsit

linguæ̌form longicōrnú macrōståchy̆ūm moniliforme moschātūm multicáulá nôbĩlè

Pierărdĭ, 1

pulchellūm

pygmē̄um :

ramōsūm

rĭgĩdūm .

secūndūm

speciōsūm
stupōsũm

suleâtūm

teretifolinum

Pur, rose

Wht. gra.

Yhite

Orange

Yelsh. grn.

S. Epi. N. S. Nepal

Purple

White

Yellow

Blue

6, s. Epi. Ceylon

4, S. Epi. Japan

, S. Epi. E. Ind.

S. Epi. E. Ind

White

Gn. yel. pl.

Yellow

S. Ei F Ind

4, S Epi. E. Ind.

S. Epi. E. Ind.

S. Epi. E. Ind.

S. Epi. N. Holl.

7, S. Epi. Malacea.

5, S. Epi. Khooseea

Yel, wht.

White

Orange

4, S. Epi. Khooseea

7, s. Epi, N. Holl.

S. Epi. Nepal

1837

1837

1820

1837

1828

1823

1825

1837
1829

1837

1823

1837

1837

1837

1837

1810

1828
1829

1824

1837

1824

1828

1837

1837

Rose.

From dendron, a tree, and

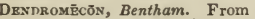
mekon, a poppy; alluding to the shrubby habit and affinity of the plant. Linn. 13, Or. 1, Nat. Or. Papaveracec. This is rather a remarkable plant, thriving in any common garden soil, and increased by seeds.

rìgĭdüm . . Yellow . 5, F. Ev. S. California . 1833

DĒnsũm, thick, tufted, bundled.

Dentärüă, Tourneforl. From dens, a tooth; alluding

to the tooth-like structure of the roots; whence the English name, Toothwort. Linn. 15, Nat. Or Crucifere. This is a genus of very ornamental plants, well worthy of cultivation in every garden. They succeed best in a light, rich, sandy soil, in a moist shady situation; they may be multiplied by divisions, or seeds.

bulbifera *. Purple . 4, H. Tu. P. England

digitáta. : : Pa. pur. :5, H. Tu. P. Switzerl. : 1656 diphyllă : : Wht pur. 5, H. Tu. P. N. Amer.

enneaphylla: : Pa. yef. . 5, H. Tu. P. Austria : 1656

glandulösă. . . Lgt. pur. . 5, H. Tu. P. Hungary : 1815

laciniătă . White . 5, H. Tu. P. N. Amer. 1822

maxima : - Pa. pur. - 5, H. Tu. P. N. Amer. - 1823

pinnnătă : Pa. pur. : 5, H. Tu. P. Switzerl. : 1683

polyphylla: : Purple : 5, H. Tu. P. Hungary : 1818

quinquefolta : Purple : 5, H. Tu. P. Tauria . 1820

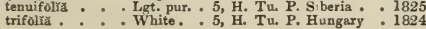

Dentate, having the margin divided into incisions, resembling teeth.

Dratatrily-ciritatrd, having the margin toothed, and tipped with hairs.

Dentately-sinuated, scolloged and toothed.

DeNTĒLlă, Forster. From a diminutive of dens, a tooth ; each side of the segments of the corolla is furnished with a small tooth. Linn. 5, Or. 1, Nat. Or. Cinchonacea. A small, creeping plant, the seeds of which require to be sown on a hotbed in spring, and when of sufficient size, they may be planted out into the open border. Synonyme: 1. Oldenlandia repens.

rèpēns, 1 . . . White . . F. A. E. Ind. . . 1802

DENTICULATB, the margins finely and slightly toothed. DeNTiculately-CiLIATED, having the margin so finely toothed as to appear edged with hairs.

Denticulations, very small teeth.

DexTIPorM, tooth-shaped. [ 103 ]
DrNTIPRICE, powder made to scour the teeth.

Deonstruknt, having the power of removing obstruc-

tions; a term in medicine.

DEPAUPERATB, impoverished, poor.

DEPENAR $\times$, hanging down.

DEPR RsseD, pressed downwards, low.

Depurated, purified, cleansed.

DEscēnDĒNs, growing downwards.

Drschā mPsĩa, Beauvois. In honour of M. Deschamps, M.D., a celebrated French botanist. Linn. 3, Or. 2, Nat. Or. Gramine. A genus of grasses, which will grow in any common soil, and is increased by divisions, or seeds. Synonymes: 1. Aira bottnica. 2. A. caspitosa. 3. A. lavigata. 4. A. montana. 5. A. paludusa.

bōttnīcă, 1 . Apetal . . 6, Grass. Bottnia

1816

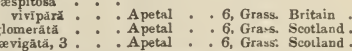

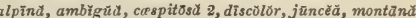
4, mĕdžă, paludōsă 5.

Desmāntet's, Willdenow. From desme, a bundle, and anthos, a flower; the flowers are collected into bundles, or spikes. Linn. 23, Or. 1, Nat. Or. Leguminosue. Some of the species of this genus are rather ornamental, while others are not worth cultivating. They like a mixture of peat and loam, and young cuttings root freely in sand, under a glass. The aquatic kinds require to be grown in large tubs, with five or six inches of soil in the bottom, and filled up with water. The tubs should be placed in a warm situation in the stove, where the plants will srow, and produce seeds, from which they may be increased.

callistãchýs * Red yel . 7, S. Ëv. S. Teneriffe - 1824

lacũstris : : White. : 7, S. Aq. P. S. Amer. : 1818

leptostāchy̆s : Whice. 7, S. Ev. S. Guinea : 1825

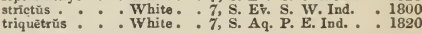

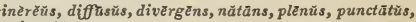
virgätüs.

DEsmílü M, Agardh. From desmos, a bond; on account of the parts cohering when in a state of dissolution. Linn. 24, Or. 7, Nat. Or. Algae. Two minute species of green Alga, found in summer in still waters. Synonyme: 1. Conferva dissiliens-cylindrica I, Snartioi.

Drsmocrëtĕ, Decandolle. From desmos, a bond, and chaite, a hair; in allusion to the coherence of the flowers. Linn. 5, Or. 1, Nat. Or. Amarantacec. This is a genus of ornamental plants, requiring a soil composed of a mixture of sandy loam and peat. They are variously increased by cuttings, seeds, or dividing the roots; the former root readily in sand, in heat, under a glass. Synomymes: 1. Achy. ranthes lappacea. 2. A. patula. atropurpŭrĕă, 1 . Purple $: 9$, S. Ev. S. E. Ind. 1759
flavéscẽns - Y : Yellow : 8, G.

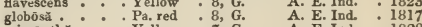
micrānthă . Yellow $: 7, \mathrm{G}$. A. E. Ind. 1820 pătŭlă, 2 - . White . 9, S. Her. P. E. Ind. . 1823 prostrátă - . Gm. pur. . 7, G. Ev. S. E. Ind. . 1793 tomentōsă : : White : 8, G. Ev. S. E. Ind. : 1818

Desmōntề, Decandolle. From desmos, a bond; alluding to the stamens being joined. Linn. 17, Or. 4, Nat. Or. Leguminose. A few species of this genus are very handsome, while the rest have little or no beauty. A mixture of sandy loam and peat suits them, and young plants may be obtained from cut tings planted in sand, under a glass, in heat, or by seeds. $D$. diffusum is a valuable fodder plant. Synonymes: 1. Hedysarum glutinosum. 2, H. aparines. 3. $\boldsymbol{H}$. adscendens. 4. $\boldsymbol{H}$. canadense. 5. $\boldsymbol{H}$. canescens. 6. H. cupitatum. 7. $\boldsymbol{H}$. cuspidatum. 8 . H. gangeticum. 9. $\boldsymbol{H}$. gyrans. $10 . \boldsymbol{H}$. latifolium. 11. H. maculatum. 12. H. malacophyllum. 13. H. marilandicum. 14. H. multiflorum. 15. H. obtusum. 16. $\boldsymbol{H}$. paniculatum. 17. $\boldsymbol{H}$. canescens. 18. $\boldsymbol{H}$. $\boldsymbol{s a}$ gittatum. 19. $\boldsymbol{H}$. serotinum. 2(1, $\boldsymbol{H}$. tomentosum. 2], H. tortuosum. 22. H. trigonum. 23. H. triflorum. 24. $\boldsymbol{H}$. triquetrum. 25, $\boldsymbol{H}$.umbellatum. 26. $\boldsymbol{H}$ viridiflor um.

acuminātūn, 1 . Purple - 7, S. Her. B. N. Amer. . 1805 alătūm angustifơlium: : Purple : 7, S. Et. S. Mexico: : 1824 


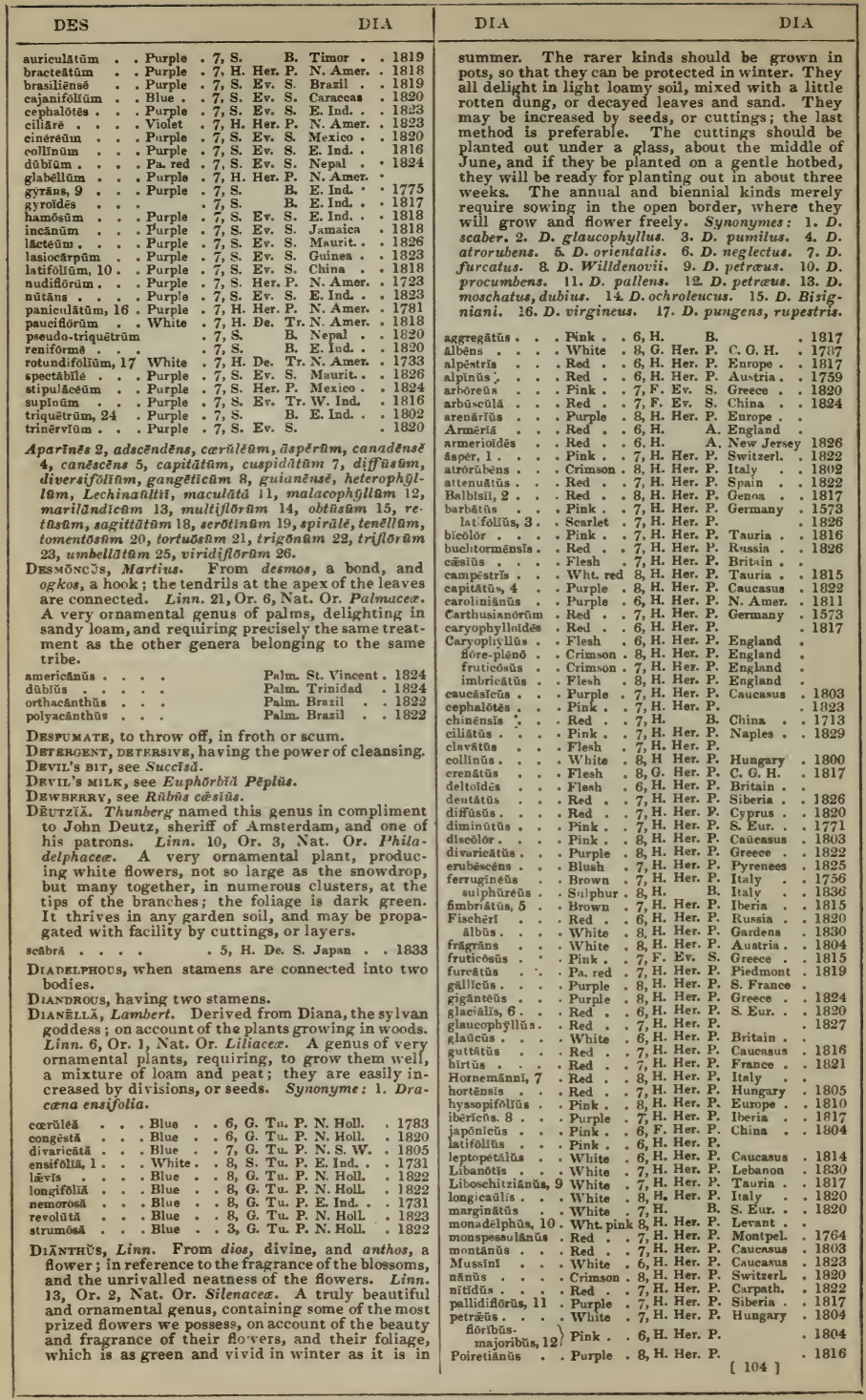




\begin{tabular}{|c|c|c|c|}
\hline DIA & & & IC \\
\hline 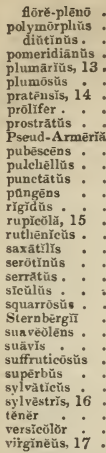 & 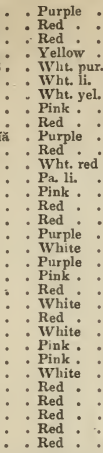 & 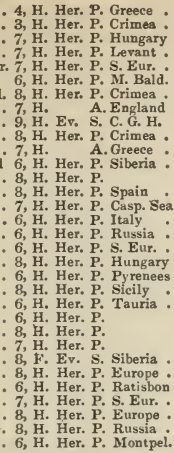 & $\begin{array}{r}1820 \\
: 1822 \\
: 1816 \\
: 1629 \\
: 1820 \\
: 1824 \\
: 1820 \\
: 1820 \\
: 1827 \\
: 1881 \\
: 1802 \\
: 1816 \\
: 1816 \\
: 1804 \\
: 1827 \\
: 1817 \\
: 1820 \\
: 1804 \\
: 1596 \\
: 1732 \\
: 1817 \\
: 1823 \\
: 1816\end{array}$ \\
\hline
\end{tabular}

DiAPĒNš̆ă. Named by Linnæus from diapente, composed of five; alluding to the flowers being fivecleft. Linn. 5, Or. 1, Nat. Or. Diapensiacee. A very pretty little alpine plant, but rather difficult to cultivate, as too much moisture is very apt to kill it. In its native country, it is continually covered with snow in winter, which protects it from the severe dry frosts. It succeeds best grown in small pots, in peat soil, with the protection of a frame in winter. It is increased by seeds, or divisions.

lapponīeă . . . White . 7, H. Her. P. Lapland . 1801

DiAPHaNous, transparent.

DIAPHORETIC, promoting perspiration.

Drāscĭ $\breve{A}$, Link. From dis, twice, and askion, a little bladder; because of the two protuberances at the base of the corolla. Linn. 14, Or. 2, Nat. Or. Scrophulariacere. A Cape annual, of no value-Bergiänă.

Dḯт̄́mÁ, Decandolle. From diatome, separation; the filaments are divided into joints. Linn. 24, Or. 7, Nat. Or. Alge. Very minute species of yellow and green Algo, found at all seasons of the year in the ocean, ditches, and on the sea-coast-Biddulphi-

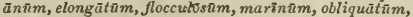
striātülüm, těnǔè.

D̆̈̌̌̆RĂ, Forster. From dis, double, and keras, a horn; the anthers are terminated by two horns, or bristles. Linn. 11, Or. 1, Nat. Or. Elcoocarpacere. A rambling shrub, growing to the height of about two feet. It succeeds well in a mixture of loam and peat; and cuttings of the ripened wood root in sand, under a glass. Synonymes: 1. Elcecarpus dentatus, Eriostemon dentatus.

dentátă, 1. . . White. . 7, G. Ev. S. New Zeal. . 1810

Dič̄rmă, Decandolle. From dis, twice, and erma, a prop; the calyx is propped at the base by two bracts. Linn. 17, Or. 4, Nat. Or, Leguminosa. A genus of very el egant shrubs, about three feet high, growing in a mixture of loam and peat ; they may be increased by young cuttings, planted in sand, under a glass, or by seeds. Synonymes: 1. Hedysarum biarticulatum. 2. Zornia elegans, Hedysarum elegans. 3. Zornia pulchella.

biarticulātüm, 1 . Yellow . 7, S. Ev. S. E. Ind. . . 1808

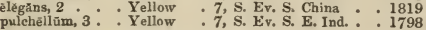

Drсн $\overline{\bar{s}} \bar{A}$, Lindley. From dich $\bar{z}$, in two rows; in allu. sion to the arrangement of the leaves. Linn. 20, Or. 1, Nat. Or. Orchidacee. This is a small, uninteresting little plant, succeeding best when treated as the genus Burlingtonia. Synonymes: 1. Cymbidium graminoides, Epidendrum graminoides.

graminð̋̈iēs . . Grn. yel. . 6, S. Epi. Demerara . 1823

Dichī̌ŭs, Decandolle. From dis, twice, and cheilos, a lip; in allusion to the calyx being deeply two[ 105 ]

lipped. Linn. 16, Or. 6, Nat. Or. Leguminose. A pretty little shrub; for culture and propagation, see Loddigesic.

Lebeckioìdēs . . Wht, yel. 4, G. Ev, S. C. G. H.

1826

DichōNDRĂ, Forster. From dis, twice, and chondros, a grain; in allusion to the form of the capsules. Linn. 5, Or. 2, Nat. Or. Nolanacece. Little creeping inconspicuous plants, seldom to be met with in collections; they grow well in peat and loam, and may be increased by cuttings.

argêntéă . . White . . 7, G. Ev. Cr. W. Ind. . 1800 carolinēnsis : White. . 7, F, Ev. Cr. Carolina : 1810 rêpēns * : White. . 7, G. Ev . Cr. N. S. W. . 1803 rotundifóliă . . White. * 7, G. Ev. Cr. 1819 sericeă . . White, 7, S, Ev, Cr. Jamaica 1793

DrchoRIzĀNDR $\check{A}$, Mikan. From dis, twice, chorizo, to part, and aner, an anther; in reference to the anthers being two-cleft. Linn, 6, Or, J, Nat. Or. Commelinacea. Beautiful herbaceous plants, resembling Commelina in their foliage, and may be referred to that genus for culture and propagation.

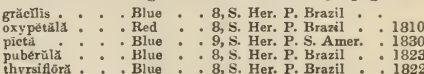

Dichōsмй. Derived from dicha, without, and osme, a smell. Linn. 5, Or. 1, Nat. Or. Rutacere. An ornamental species; for culture, \&c., see Diosma. Synonyme: 1. Diosma bifida.

bǐfíd . . . White . . 5, G. Ev. S. C. G. H.

Dichospŏrĭūm, Nees. From dicha, double, and spora, a sporule; in allusion to the double coat of the peridium. Linn. 24, Or. 9, Nat. Or. Fungi. An extremely minute species, found on the bark of oak trees in autumn. Synonyme: 1. Spumaria physaroides-aggregatum 1 .

Dichотомочs, a.stem that ramifies in pairs.

Drcoccous, having two cocci.

Dicksōñ̌̆ L' L'Heritier. In honour of James Dickson, a famous British cryptogamic botanist. Linn. 24, Or. 1, Nat. Or. Polypodiacece. A very ornamental genus of ferns, containing the tree-fern of St. Helena, which has often been brought in a living state to this country, but it rarely survives many months. The species do well in a mixture of loam and peat, and are readily increased by divisions, or seeds.

adiantoīës . Brown , 11, S. Ev. S. W. Ind. 1828 arborëscêns : Brown : 9, S. Ev. T. St. Helens : 1786 dissēctă * Brown * 8. S. Her. P. Jamaica : 1793 pilosiūscǔlă . Brown : 8, S. Her. P. N. Amer. - 1811

DreLĪ PTӖRĂ, Jussieu. From dis, double, and kleio, to shut; in allusion to the two-valived fruit. Linn. 2, Or. 1, Nat. Or. Acanthacee. An ornamental genus, nearly allied to Justicia, to which genus it may be referred for culture and propagation.

assūrgēns . . Red . 7, S, Ev S, WV. Ind. 1818 bivâlvis : : : Purple : 7, S. Ev. S. E. Ind. : 1818 chinênsĩs : . Pa. blue : 9, G. Her. P. E. Ind. : 1816 hexanguläris : Red : 7, S. A. S. Amer. : 1733 martiniceensis : Purple : 7, S. Ev. S. W. Ind. : 1818 pectinătă * : Blue * * 6, S. Ev. S. E. Ind. * 1798 resupinátă : : Wht. pur. 3, S. A. A. S. Amer. : 1805 retūsanátă : : Purple ${ }^{2}$ \%, S. Her. P. v. Ind. : 1821 scorpiotdès. : : T. Ev. S. Vera Cruz : 1802 verticillārìs : : Purple : 5, G. Ev. S. C. G. H. : 1826

DĩcrĂñ̄m, Hednig. From dikranos, two-headed; in reference to the divisions of the teeth of the capsule. Linn. 24, Or. 5, Nat. Or. Musci. A fine genus of mosses; many of the species form broad masses of turfy regetation, giving a beautiful character to the face of the earth where they grow. They are found at all seasons, and almost in every situation. Synonymes: 1. Hypnum adiantoides. 2. Dicranum viridulum, osmundioides. 3. D. pusillum, uncinatum. 4. Trichostomum piliferum. 5. D. flagellare. 6. Hypnum taxifolium. 7. D. callistomum. -adiantoides 1, bryoides 2, cerviculatum 3, crispum, falcatum, flavescens, flexuosum, fulvellum, glaucum, heteromallum, latifolium 4, longifolium, pellucidum, polycarpon, Schreberianum, scoparium, fuscescens. majus, Scottianum 5, spurium, squarrosum; Starkii, strumiferum, subulatum, taxifolium, undulatum, varium, luridum, rufescens, viride 7 , virens. 
Dicríptă, Lindiey. From dis, two, and cryptos, hidden; alluding to the structure of the four pollen masses. Linn. 20, Ur. 1, Nat. Or. Orchidacer. A curious species, with solitary flowers, requiring the same treatment as the Stanhopeas. Synonyme: 1. Heterotaxis crassifulia.

Bauẽrī . . . Yellow . 6, S. Epi. Jamaica . . 1823

Dicr $\mathrm{A}$ MNŬs, Linn. An ancient name supposed to have been given because the leaves resemble those of the Ash; hence the English name, Fraxinella. Linn. 10, Or. 1, Nat. Or. Rutccea. A genus of very ornamental plants, deserving a place in every flowerborder. D. Fraxinella, when rubbed, emits a fine odour, something like that of lemon-peel; this fine scent is strongest in the pedicels of the flowers. The species succeed well in any common garden soil, and may be increased by seeds, which ripen freely. The roots were formerly esteemed as a sudorific and vermifuge. Synonyme: 1 . D. albus.

albŭs . * White. . 6, H. Her. P. Germany . 1596 nngustifoliǔs : Lilac : 6, H. Her. P. Altni : 1821
Fraxinellä, 1 : Purple

Dictร̌̃ūōs, Schrader. From diktyon, a net, and eidos, similar; alluding to the resemblance of the peridium. Linn. 24, Or. 9, Nat. Or. Fungi. A very minute, black, pinheaded species, to be found at all seasons on rotten wood-cērnŭrim.

Didêltă, L'Heritier. From dis, double, and delta, the Greek letter equivalent to the English D; in refer. ence to the double receptacle. Limn.19, Or. 3, Nat. Or. Composita. Shrubs, with little to recommend them, growing well in peat and loam, mixed; and may be increased by cuttings-carnosum, spinosum.

Didêsmǔs, Desfontaines. From dis, twice, and desmos, a bond; the pod is jointed like two links of a chain. Linn. 15, Nat. Or. Cruciferc. Uninteresting annuals, of the simplest culture. Synonymes: 1. Myagrum agyptiacum. 2. Sinapis bipinnata-agyptiaca 1, bipinnata 2.

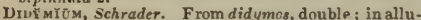
sion to the inner and outer peridium. Linn. 24, Or. 9, Nat. Or. Fungi. A very small species of Fungi, occasionally seen on dead leaves-globositm.

Didỹsódón, Hednig. Froun didymos, double, and odous, a tooth; the teeth of the fringe are in pairs. Linn. 24, Or. 5, Nat. Or. Musri. A genus of chiefly greenish mosses, found in spring and summer on mountain rocks and moist banks. $D$. inclinatum is only to be met with in this country, upon the mountains of Cunnemara, in Ireland. Synonymes: 1. Trichostomum capillaceum. 2. T. Jlexifolium. 3. Grimmia heteromalla. 4. G. inclinata. 5. G. atrovirens. 6. D. Bruntoni. 7. Bryum bipartitum, Dicranum Celsii, D. strictum, Trichostomum papillosum. 8. T, rigidulum. 9. T. trifarium, linoidescapillaceum 1, flexifolium 2, glaucescens, heteromallum 3 , inclinatum 4, nervosum 5, obscurum 6, purpureum 7 , rigidulum 8 , trifarium 9 .

Dinymous, two united; applied to the fruit when thcy appear twin.

Didynamevs, having two long stanens and two short ones in the same flower, each pair being collateral.

DIRLTTTRX̃, Borkhrusen. From dis, double, and elytron, a sheath; the base of the flower is furnished with two sheath-like spurs. Linn. 17, Or. 2, Nat. Or. Papaveracea. A genus of very desirable herbaceous plants. Any light rich soil suits them, and they are easily increased by divisions, or seeds. Synonymes: 1. Corydalis canadensis. 2. Fumaria cucullaria. 3. F. eximia. 4 Corydalis tenuifolia.

bracteosa . . White. . 6, H. Her. P. N. Amer. . 1823 canadènsise 1 : Whito: : 6, H. Her. P. N. Amer. : 1819 cucullaria, 2 : White : 6, H. Her. P. N. Aner. : 1731 eximiá, 3 : : Plesh : 6, H. Her. P. N. Amer. : 1812 formosâ.: : Ylesh : 6, H. Her. P. N. Amer. : 1796 lachenaliæflöra" : Purple" : 6, H. Her. P. Siberias. : 1826 peciöă. : Flesh . 6, H.Her. P. : 1810 spectăhlY̌s : : Purple : 6, H. Her. P. Siheria . 1810 tenuifoliă, 4 : : Pink *: 6, H. Her. P. Kamtch, : 1820

Drēxǐn, Lindley. From dis, two, and enia, a strap; in allusion to the attachment of the pollen-masses. Linn. 20, Or. 1, Nat. Or. Orchidacee. This is described as a plant of no beauty. Turfy peat soil, and an efficient drainage, will be found to suit it. cordstá . . Green. . S. Epi. Mexico . 1837 DiervĩLI, , Tournefort. In compliment to $\mathbf{M}$. Dier- ville, a French surgeon. Linn. 5, Or. 1, Nat. Or. Caprifoliacea. A very desirable plant for the front of shrubberies, growing from three to four feet high, in any common soil; it may readily be in. creased by cuttings, put into the ground in autumn and spring, or by suckers, which it throws up in great quantities from the roots. Synonyme: $1 . D$. canadensis, Lonicera Diervilla.

lũteă, 1 . . . Yellow . 6, H. De. S. N. Amer. . 1739

Dietrtics, relating to food, or diet.

Difform, different forms; used to express irregu. larity.

Diffuse, scattered, widely spread.

Dǐñês, Salisbury. From dis, twice, and etes, an associate; the genus is nearly related to Tris and Morce. 'Linn. 3, Or. 1, Nat. Or. Iridacee. The plants of this genus are very ornamental, and for culture, \&cc., may be referred to Iris. Synonymes: 1. Iris bicolor. 2. Morcea catenulata. 3. Iris moraoides, Morcea iridioides.

bǐcőlōr, 1 . . Yel, drk. . 6, F. Her. P.

catenulâtă, 2 : Wht brn. 6, F. Her. P. Madagas. 1826 iridioidés, 3 : Wht, brn. 7, F. Her. P. C. G. H. . 1758 DigrtäLYs, Linn. Derived from digitale, the finger of a glove; in allusion to the resemblance the flower bears to the finger of a glove. Linn. 14, Or. 2, Nat. Or. Scrophulariacea. The species are mostly very showy border flowers, growing in any common garden soil. The tender kinds are best planted in pots, so that they may have the protection of the frame in winter. According to Decandolle, the powdered leaves, or an extract of them, produce vomiting dejection, and vertigo, increase the secretion of saliva and urine, lower the pulse, and even cause death. Synonymes: $1 . D$. grandiflora. 2. parviflora. 3. intermedia. 4. ambigna. 5. erubescens.

amhY̌ŭd, 1 . . Lgt yel. . 7, H. Her. P. Switzerl. . 1596 nuีrẻ ả

eriostăchră

ferrugined

fugcésoin:

fülvă

laciniata

levigata

lanảt

leucophäà

lũteă, 2 .

lutéscéns

mediă, 3

micränthă

minorr

obscūră

ochroleñĕ̃, 4

orientalis

7, H. Her. P. Greece

Bro yel $7, \mathrm{H}$ R. Russia

Brown

Red : 7, H. Her. P. Hungary : 1823

Red $*$ 7, H. Her. P.

Yellow 6. H. Her. P. Spain ing

Yellow $: 7$, H. Her. P. Hungary : 1816

Yellow - 6, H. Her. P. Hungary — 1789

Wht, brn, 6, H. Her. P. Greece 1788

Lgt. yel. - 7, H. Her. P. France . . 1629

Yellow $7, \mathrm{H}$ Her $\mathrm{P}$

Yellow 6, H. Her. P. Germany - 1817

Yel, brn 7, H. Her. P. Switzerl. 1817

Purple: 7, H. Her. P. Apsin: 1789

Orange 6, F. Ev. S. Spaia : 1778

1820

Brown

purpuräscěns, 5 Pink 6. H. Her. P. Germany $: 1776$

purpüres̆ : Purple : 7, H. B. Britain .

alba : White 7, H. B. Britain .

rigida : : : Yel. red : 6, H. Her. P.

ThápaI: : Purple 6, H. Her. P. Spain • 1752 tomentós : : Red : 7, H. Her. P. Portugal : 1818 tubiföră : : Yellow : 6, H. Her. P.

Digrtaten, fingered, shaped like the hand spread open. DigITÃRİ̀, Schrader. Derived from digitus, a finger alluding to the singular manner in which the heads are divided Linn, 3,Or 2, Nat. Or. Graminea. A genus of grasses, all the species of which are uninteresting. They grow in any common soil, and may be multiplied by seeds. Synonymes: 1 . D. humifusa. 2. Milium filiforme-agyptiăca, affinìs, barbätă, bicörnis, biformis, ciliâris, criogónd, filiformìs, gläbră 1, lineîrìs, marginätă, paspaloĩdes, Roxbarghï 2, sanguinätis, villosă.

DigrrifoRs, formed like fingers.

Dior nous, two styles, or female organs.

Dilated, widened.

DiLĀTr İs, Linn. Meaning unexplained, Linn, 3, Or. 1, Nat. Or. Homodoracea. Ornamental plants, growing about a foot high in sandy peat; they aro readily propagated by seeds, or divisions.

corymbosă . : Purplo . 5, G. Her. P. C. G. H. . 1790 paniculata : : Blue : 6, G. Her. P. c. G. H. 1825 viscosal.: : Blue : : G. Her. P. C.G. H. : 1795 Dru, see Anetham.

DrLĽ̌xĩ, Linn. After the celebrated professor of botany at Oxford, John James Dillenlus, author of Hortus Elthamensis, \&ce. Linn. 13, Or. 6, Nat. Or. Dilleniacea. A splendid tree, which thrives well 
in the collections of this country. It grows best in a light loamy soil, or loam and peat; ripened cuttings, not deprived of any of their leaves, will root in sand, under a glass, in heat. The young calyxes are used in curriez by the inhabitants of Bengal.

speciôsă . . . Wht. yel. . S. Ev. T. E. Ind. . . 1800

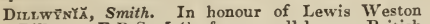
Dillwyn, F.R.S., L.S., \&c., a well-known British botanist. Linn. 10, Or. 1, Nat. Or. Leguminosce. Very elegant shrubs when in flower, and well worthy of cultivation in every collection. They grow from one to four feet high, in an equal mix ture of loam, peat, and sand, with the pots well drained. Cuttings of the young wood root freely in sand, under a glass.

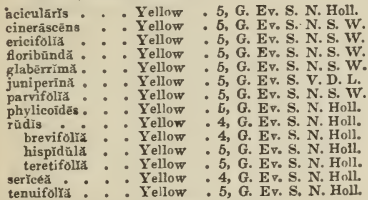

. 1826 1819 1794 1818 1800 1824 1824 1824 1824 1824 1824

DrMidiate, divided into two parts.

Dinērră, Beauvois. Its Arabic name. Linn. 3, Or. 2, Nat. Or. Graminea. An annual species, growing in any garden soil, and increased by seeds.

arabłcă . . . Apetal . . 6, Grass. E. Ind. . . $18 \cap 4$

DiNйм, Lindley, Not explained. Linn. 20, Or. 1, Nat. Or. Orchidacea. A very pretty plant; for culture and propagation, see Stanhopea. Synonyme: 1. Epidendrum polybulbon.

polybűlbōn . White . 12, S. Epi. Jamaica 1822

Drv̄̌rǔs, Snect. From dinetos, that may be twined ; in allusion to the habit of the plants. Linn. 5, Or. 1, Nat. Or. Convolvulacece. A very ornamenta. genus; the perennial species thrives well in any rich light soil. Young cuttings, in the same sort of soil, under a glass, in heat, will soon root. $D$. rucemosa grows very fast in a sheltered situation, and is well adapted to make a good covering for a temporary arbour. It is increased from seed, which is ripened in abundance. Synonymes: 1 . Porana paniculata. 2. P. racemosa.

paniculātă, 1 . White - 8, S. Ev. Tw. E. Ind. . 1823 racemósă, 2 : White : 8, H. Tw. A. Nepal : : 1823

Diठ̈cr, ӖӐ, $\boldsymbol{H}$. Bet. Kunth. In memory of Diocles Carystinus, an ancient Greek botanist. Linn. 17, Or. 4, Nat. Or. Leguminosa. A twining shrub, growing in any common soil, increased by cuttings in samd, under a glass, in heat. Synonyme: 1. Dolichos mollis-móllis.

DrŏDĭĂ, Linn. From diodos, a passage : many of the species grew by the way-sides. Linn. 4, Or. 1, Nat. Or. Cinchonacee. A genus of rather pretty trailing shrubs, of simple cultivation. A light soil suits them best; and cuttings, in the same kind of soil, root freely if placed in heat.

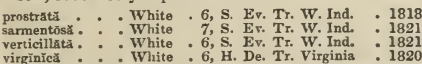

Drcerous, when a plant bears female flowers on one individual, and males on a nother.

DIOMĒDĚn, Cassini. Named after Diomeda, the daughter of Phorbas. Iinn. 19, Or. 2, Nat. Or. Composite. A genus of ornamental shrubs, with silvery leaves; they succeed well in any rich light soil; and cuttings root freely, in the same kind of soil, under a glass. Synonymes: 1. Bupthalmum frutescens. 2. B. arborescens.

argēntēa . . Yellow . 6, G. Ev. S. S. Amer. - 1824 bicientătă, 1 : Yellow : 7, G. Ev. S. W. Ind. 1696 glabrătă, 2. : : Yellow : 6, G. E.r. S. S. Amer. : 1699

DroN炛, Linn. Dione, one of the names of Venus. Linn. 10, Or. 1, Nat. Or. Cephalotacea. This is a very singular little plant in respect to its leaves, which are of an anomalous form, and have a curious motion, by which they catch insects; whence the

specific name, Muscipula, a fly-trap. The petiole of the leaf is winged. The extreme part is that which acts as a trap. As soon as the insect enters, the lobes of the leaf fold together, and remain so as long as the insect continues to struggle; but as soon as it is quiet, the leaf opens, and permits it to escape. The plant thrives best in small pots, in peat earth, and some dwarf species of moss placed underneath in the pot; the pots should then be placed in a pan of water, and set in a cool place in the stove, with a glass over them, but not close, else they will be liable to damp. Seeds are sometimes produced, by which they may be increased, but the readier way is to divide the plants at the root. It has also been found, that if a leaf be taken off, and placed on damp moss, it will emit a young plant from its edge.

Muscǐpunlă . . . White. . 7, S. Hex. P. Carolina . 1788 Dioscŏr ̌̆, Linn. Named after Pedacius Dioscorides, a famous Greek physician. Linn. 24, Or. 6, Nat. Or. Dioscrreacea. The $\mathrm{Yam}$ is cultivated in tropical climates for the sake of the roots, which are used in a similar way to potatoes, and are much esteemed by the natives. They are chiefly climbing plants; some of them have very handsome folisge. They succeed well in any light rich soil, and are readily increased by dividing their roots.

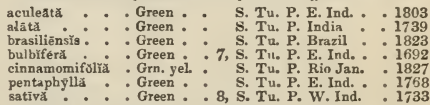
sativă 8 , S. Tu. P. W. Ind. : 1733

altīssīmă, ānguīnă, angustifoliă, atropurpŭrĕă, cori äcĕă, crispĩză, fasciculotă, gläbră, globossă, heterophyllă, leonēnsis, nepalēnsi̇s, Nummuläriăă, oppositi. foliă, piperifoliá, pulchēllă, purpūrēă, quaternātă, quinquẻlōbă, rubêllă, scãbră, trłf́idă, trifoliātă, triphȳllă, villossă.

Drōsmã, Linn. From dios, divine, and osme, smell the bruised leaves have an exquisite smell. I,inn. 5, Or. 1, Nat. Or. Rutacea. This is a genus of truly beautiful, heath-like shrubs, growing from one to four feet high. To grow them well, they must have a mixture of peat and sand, and a little turfy loam in the bottom of the pot, over the shreds. Young cuttings, planted in sand, with a glass over them, will root freely, without any heat.

cordãtă - White. . 5, G. Ev, S. C. G. H corymbōsă : White , 5 G Eq. S C G H cuprěssină : : Pink : 5, G. Ev. S. C.G. H ericoides $: \vdots$ : White: : 6, G. Eva S. C. G. H foctidissima : : White: 6 , G. Ev. S. C. G. H. foctidissiñmă : White : 6, G. Ev. S. C. G. H. hirsūtă : : : Pink : 5, G. Ev. S. C. G. H.
hybrĩdă : : White: 5, G. Ev, S. C. G. H. hybrīda:
longifóliă : : White : 5, G. Ev. S. C. G. H. oppositifolra : White : 6, G. Ev, S. C. G. H. pectinătă - Blue - 5, G. Ev. S. C. G. H. punctătä : : White : 6, G. Ev. S. C. G. H rūbrä : : Red : 3, G. Ev. S. C. G. H scopáriă : : Redite: 6, G. Ev S. C. G. H sphærocéphŭla : White: 5, G. Ev, S. C. G. H. squamósă. . 6 , G. Ev S. C. G.H subulata $: \vdots$ White . 6, G. Ev S. C. G. H. succulentä : White. 6, G. Er. S. C. G. H tenellä . : White . 5, G. Ev, S. C. G. H tenuissimă . - White. 7, G. Ev. s. C. G. H. tenuifolră : : White : 6, G. Ev. S. C. G. H tetragōnă : : White : 6, G. Ev. S. C. G. H. uliciñ : W White 5 , G E. S C. G. H ulicina : : : White : 5, G. Ev. S. C. G. H

1823 1818 1790 1756 1731 1731
1823

Dröspřrŏs, Linn. From dios, divine, and pyrus, pear; resemblance of the fruit. Linn. 23, Or. 2, Nat. Or. Ebenucee. Ornamental and highly valuable timber trees, from fifteen to thirty feet high. The species grow in any light loamy soil, and may be increased by ripened cuttinga. planted in sand, under a glass. The European species, $D$. Lotus, produced that famous fruit, which, according to the ancient romancers, caused oblivion. Some of the species are very remarkable for the hardness of the wood, such as D. Ebenus, Ebenoster, Mabola, and Melanoxylon, and for the eatable quality of the fruit; the former is well known under the name of Ebony and Ironwood. The bark of D. virginiana is said to be febrifugal. The fruit of $D$. Embryopteris is so glutinous as to be used in Bengal for paying boats. 


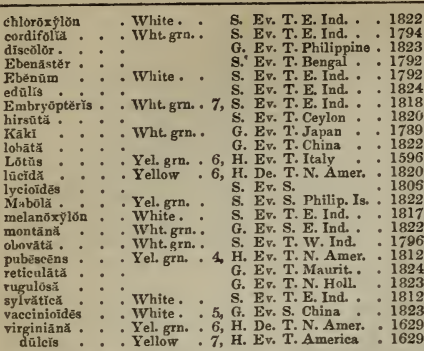

Drōrts, Schreber. From dis, double, and ous, an ear ; the flowers possess two ear-like appendages at the base of the florets. Linn. 21, Or. 4, Nat. Or. Chenopodiacec. Shrubs of little beauty, thriving in any light soil, and increased by layers, or cuttings, under a glass. Synonyme: 1. Atriplex pedunculata. ceratoídēs . . A petal . 3, H. De. S. Siberia . . 1780 atriplicĩnă 1, candidĩss̆mă.

Dīpнйcă, Loureiro. From dis, twice, and phake, a lentil, or pea; the pods are composed of two oneseeded joints. Linn. 17, Or. 4, Nat. Or. Leguminosa. An ornamental shrub, about eight feet high, nearly allied to Dalbergia. It requires the same treatment as other greenhouse plants. Synonyme: 1. Dalbergia Diphaca.

cochinchinēnsiss . White - G. Ev. S. China

Diphýleĩ Á, Michaux. From dis, double, and phyllon, a leaf; in allusion to the stems bearing only two alternate leaves each. Linn. 6, Or. 1, Nat. Or. Berberacea. A very pretty plant, growing freely in any rich light soil, and multiplied by divisions.

cymōsă. . . White. . 5, H. Her. P. N. Amer. . 1812

Diphřs, Jacquin. From dis, twice, and physa, a bladder; the pods are furnished with a membranous bladder on each side. Linn. 17, Or. 4, Nat. Or. Leguminosa. An ornamental shrub, from six to ten feet high; the soil best adapted to it is a mixture of loam, peat, and sand. Young cuttings will root in sand, under a glass, in heat.

carthaginênsis. . Yellow . S. Ev. S. Carthage - 1827

Diph Fscrūm, Weber. From dis, twice, and physkion, a vesicle; in reference to the shell of the theca being double. Linn. 24, Or. 5, Nat. Or. Musci. A very little plant, found in woods, and on rocks in Alpine situations. The stems are exceedingly short, and grow in densely matted patches. Synonyme: 1. Buxbaumia foliosa-foliostom.

Diplāchxî, Beauvois. From diploos, double, and achne, chaff. Linn. 3, Or. 2, Nat. Or. Graminee. An uninteresting species of grass, of simple culture. Synonyme: 1. Festuca polystachya-fusciculärís 1.

Diptăcưs, Nuttall. From dis, two, and plakos, a placenta; alluding to the splitting of the capsule, to each valve of which is attached a large placenta, and under its edges are found the slender subulate seeds. Linn. 14, Or. 2, Nat. Or. Scrophulariacee. A genus of very elegant plants, especially $D$. punicens, which will prove a very great ornament to our gardens, The species will succeed well in rich sandy loam, and may be increased by cuttings. $D$. puniceus is at present very scarce in this country. Synonyme 21. Mimulus glutinosus. glutinösŭs, 1 * Orange all * G. Ev. S. California $: 1794$
punicéŭs DiptăsǏ , Richard. From diplazo, to double; in reference to the glumes. Linn. 3, Or. 1, Nat. Or. cyperaced. A plant with little to recommend it, growing in any common soil, and increased by divisions.

karatifoliă . . Apetal . . 8, Grass. Guiana . . 1825

Diptãzîu, Snartz. From diplazo, to double; in allusion to the indusia being double. Linn. 24, Or.

1, Nat. Or. Polypodiaced. A very handsome and ornamental genus of ferns. D. auriculutum forms a tree about ten feet high. The plants succeed well in loam and peat, and may be either increased by seeds, or divisions; the latter is the more preferable method. Synonymes: 1. Asplenium arboreum. 2. Hemionitis esculenta. 3. H. grandifolia. 4. Asplenium ambiguum. 5. A. plantagineum.

arborēscēns . Brown . S. Ev. T. Maurit. . . 1826 auriculătüm, 1: Brown : 8, S. Ev. T. Caraccas : 1820 castaneæfơluñm . Brown : 7, S. Her. P. Guiana . 1824 esculēntūm, 2. Brown : S. Her. P. E. Ind. : 1822 grandifolium, $\dot{3}$ : Brown :8, S. Her. P. Jamaica: 1793

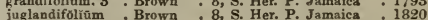
juglandifóliñm : Brown : 8, S. Her. P. Jamaica : 1820 malabaricum, 4 . Brown
plantagineúm, 5 : Brown seramporënsě . Brown : 8, S. Her. P. Serampore: 1820

Dipıōcŏsı̆, D. Don. From diploos, double, and koma, hair; the pappus is of two forms. Linn. 19, Or. 2, Nat. Or. Composita. A pretty plant, succeeding well in common garden soil. The plants require protection in winter, therefore it is best to grow a few plants in pots, to stand in the trame in winter, as those in the ground are apt to suffer if not well attended to; it may be increased by seeds, or divisions. Synonyme: 1. Doronicum villosum.

villösă, 1 . . . Yellow . 6, H. Her. P. Mexico • . 1826

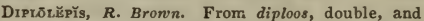
lepis, a scale. Linn. 5, Or. 2, Nat. Or. Asclepiadacece. An uninteresting genus of climbing plants, growing freely in any rich light soil; young cut. tings root in sand, under a glass, in heat. The root of $D$. vomituria is prized by the Indian doctors for its expectorant and diaphoretic qualities-apiculätŭ, ovätü, vomitoriă.

Diplop̄̄pPU's, Cassini. From diploos, double, and pappos, pappus; the fruit is furnished with a double row of bristles. Linn. 19, Or. 2, Nat. Or. Composita. A very handsome, shrubby species, growing to the height of about two feet, producing its flowers in heads, with the rays richlilac, and the disc a bright yellow. It succeeds well in sandy loam, and is increased by cuttings. It will grow and flower well in a hot exposed situation in the open ground, in summer, but requires the protection of a frame in winter.

incănŭs. . . . Lgt. yel. . 8, F. Ev. S. California . 1832 Diploph flutu, Lehmann. Derived from diploos, double, and phyllon, a leaf; in allusion to the twoleaved calyx. Linn. 2, Or. 1, Nat. Or. Scrophnlariaces. A border annual, the seeds of which need only be sown in the open border early in spring. Synonyme: 1. Veronica Crista-galli.

veronicæeformé, 1. Blue . . 4, H. Tr. A. Caucasus . 1813

Diplotāxǐs, Decandolle. From diploos, double, and taxis, a series; the seeds are disposed in two rows in each cell. Linn. 15, Nat. Or. Cruciferc. Uninteresting annuals, which merely require sowing in the open border, where they will grow, flower, and produce their seed in abundance. Synonymes: 1. Sisymbrium catholicum. 2. Sinapis crassifolia. 3. Sinapis erucoides. 4. Sisymbrium murale. 5. Sisymbrium pendulum. 6. Sisymbrium tenuifolium. 7. Sinapis virgata-Barrelieri, catholica 1, crassifolia 2 , erucoides 3, hispida, muralis 4, pendula 5, saxatilis, tenuifolia 6 , viminea, virgata 7 .

DIPLотнёмт̄ Martius. Derived from diploos, double, and thema, a spathe. Linn. 21, Or. 9, Nat. Or. Palmacea. Ornamental plants, growing to the height of about ten feet, and requiring the same treatment as Caryota, and other genera of the order. campéstre ... . Palm. Brazil . . 1893 maritümüm : : : $\quad$ Palm Brazil : : : 1823

Dipōdīe $\mathrm{s}, \boldsymbol{R}$. Bron'n. From dis, two, and pous podos, a foot; referring to the threads of the pollen masses. Linn. 20, Or. 1, Nat. Or. Orchidacea. A very curious, leafless plant, with rather pretty purplish flowers. For culture and propagation, see Bletia. Synonyme: 1. Dendrobium punctatum.

punctātũm . . Purplish . 12, S. Ter. N. Holl.

1822

Dīpsăcuัs, Tournefort. Supposed to be from dipsno, to thirst; in consequence of the leaves holding water; dipsakos is also the Greek name for the disease called diabetes, which is always accompanied by great thirst. Linn. 4, Or. 1, Nat. Or. Dipsacee. [ 108 ] 
Curious species, some of which are pretty flowering plants, especially $D$. pilusus. They grow well in any common soil, and are readily increased by seeds. $D$. fullonum is extensively cultivated in the west of England, the dried heads of which furnish the teasel used by fullers in dressing cloth.

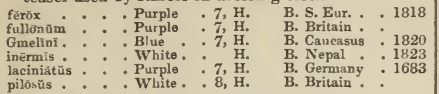

pilosús :

Diptérix, Schreber. From dis, double, and pterix, a wing; the two upper lobes of the calyx appear like two wings, Linn, 17, Or. 4, Nat. Or. Leguminose. An ornamental tree, attaining the height of sixty feet. It requires to be grown in a loamy soil, and ripened cuttings root in sand, under a glass, in a moist heat. The seeds of this tree are the Tongo, or Tonquin-beans, so well known as giving a pleasant scent to snuff. Synonyme: 1. Baryosma Tongo. odorătă, 1 . . Purple . S. Ev. T. Guiana . . 1793 DipTERous, applied to any thing which has two wings. DÏrcă, Linn. Derived from dirka, signifying a fountain; in reference to the habitation of the plant. Linn. 8, Or. 1, Nat. Or. Thymelacea. An ornamental little shrub, found growing in the marshes of North America. It succeeds well in sandy loam, and is propagated by layers, or seeds. It is so tough that the twigs are used for baskets, \&c. ; whence the English name, Leather Wood.

palüstrís . . Y Yellow . 3, H. De. S. Virginia . 1750

Dīsă, Linn. Meaning unknown. Linn. 20, Or. 1, Nat. Or. Orchidacec. A genus of interesting, tuberous-rooted plants, thriving well in an equal mixture of peat, loam, and sand, and increased by separating the roots. They require to be very carefiully watered when not in a growing state.

bracteátră * Green - 6, G. Ter. C. G. H.

chrysöståchy̆ă * Yellow . 6, G. Ter. C. G. H.

cornñă . . Pa blue . 6, G. Ter. C. G.H.

dracônĩs . . Wht. pur. 6, G. Ter, C. G. H.

ferruginëă : : Brown * 6, G. Ter. C. G. H.

graminifơliä : : Blue . G. Ter. C. G. H

grandiflöră : : Sesrlet : 7, G. Ter. C. G. H.

Gánér

maculătă Blue

prasingta

6, G. Ter. C. G. H.

1818

prasinata

Pa. blue

6, G. Ter. C. G. H.

1805

1823

1820

1823

1825

1826

1816

1815

DIs̄̄NDRĂ, Linn. Named from dys, difficult, and aner, an anther; the number of the anthers varies. Linn. 7, Or. 1, Nat. Or. Scrophulariacea. A pretty trailing plant, which, when raised, its pendant branches, and little yellow flowers, have a very pretty appearance. It will grow well in any rich light soil, and is propagated by divisions, or cuttings, with or without a glass, in a shady situation. prostrătă . . Y Yellow . 6, G. Ev. Tr. Madeira * 1771 Drschīnŭ, $\boldsymbol{R}$. Bromn. From dis, twice, and schizo, to split; application unexplained. Linn. 5, Or. 2 , Nat. Or. Asclepiadacer. Ornamental plants, growing in any light sandy soil ; and cuttings will root very freely in the same kind of soil, without any glass.

bengalennšs . . White. . 9, S. Ev. Tr. India

nummulariă. : White. : 8, s. Ev. Tr. Amboyna

Discorn, any thing dilated into something which may be compared to a disk.

Disces, or nisk, the fleshy annular process that surrounds the ovarium of many flowers; also the surface of a leaf; also the centre of a head of flowers of Composito.

Discutrins, having the power to scatter the matter of tumours.

DrsЁMMĂ, Labillardière. From dis, double, and stemma, a crown; the crown of the flower is double Linn. 16, Or. 2, Nat. Or. Passifloracee. A genus, comprising two splendid and curious shrubs, requiring the same treatment, in culture and propagation, as Passiflora. Synonymes: 1. Passiflora adiantifulia, Murucuia adiantifolia. 2. Passiflora Herbertiana, Murucuia Herbertiana.

adiantifólī̌, 1 . . Orange . T, S. Ev. Cl. Norfolk Is. . 1792 Herbertiănă, 2 : Grn. wht.: 7, S. Ev, C1. N. Holl. : 1821 DIsĒrmǏs, smooth, without thorns. $\left[\begin{array}{c}\text { smooth } \\ 109\end{array}\right]$
Disomorphous, two-shaped.

DŕspêRİ, Svartz. From dis, two, and pera, a pouch in allusion to the appearance of the two oute lateral segments of the perianth. Linn. 20, Or. 1, Nat. Or. Orchidscea. A tuberous-rooted genus, requiring the same treatment as Disa.

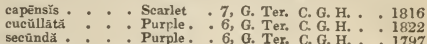

secūndă. : : Purple : 6, G. Ter. C. G. H. : 1797

D1sPĒRMŬs, two-seeded.

DīspónÔM, Salisbury. From dis, twice, and poros, a pore. Linn. 6, Or. 1, Nat. Or. Melanthacer. Pretty species, which may be successfully grown in two thirds peat, and one-third loam; they will succeed in a warm border, if carefully protected from severe frosts : they may be increased by dividing the roots, or by seeds. Synonyme: 1. Uvularia chinensis.

fülvūm, 1 * . Brown * 10, G. Her. P. China * 1801 parvifórüm : : Yellow : 7, G. Her. P. Nepal : : 1820

Drssêctă, laciniated, deeply cut into very fine segments.

Dissrpimants, the partitions by which a seed-vessel is divided internally.

Dīssǒnǒn, Greville. From dis, twice, and odous, a tooth. Linn. 24, Or. 5, Nat. Or. Musci. A genus of little, dark, and pale green plants, inhabiting, during summer, mountains and alpine bogs. Synonymes: 1. Splachnum Frolichianum, S. reticulatum. 2. Weissia splachnoides-Fraelichiänūm 1, splachnoìdés 2.

Drssolëxă, Ioureiro. From dis, double, and solen, a tube; in allusion to the double tube of the corolla. Linn. 5, Or. 1, Nat. Or. A pocynacea. A pretty species, growing in a rich light soil; and cuttings, planted in sand, under a glass, in heat, will soon root. Synonyme: 1. Cerbera chinensis.

verticillăta . . . G. Bv. S. China

1812

Distăсн Ү̌ŏ, two-spiked.

DistīNTǔs, distended, inflated.

Disтicнous, two-rowed; producing leaves or flowers in two opposite rows.

DrrtōLĂ, Fries. From dittos, double, and ioulous, down; in reference to the downy nature of the pubescence. Linn. 24, Or. 9, Nat. Or. Fungi. A species of Fungi, which grows upon dry wood, from the autumn till spring. It is one of the species of dry rot, and very injurious to the timber on which the plants vegetate $\rightarrow$ radicüta.

Ditrichoromots, divided into twos or threes; a stem continually divided into double or treble ramifications.

DitTANy of CRETE, see Origănūm Dictīmnũs.

DICRBTIC, having the power of promoting the flow of urine.

Drêrǐs, R. Brown. From dis, double, and oura, a tail; alluding to the lateral lobes of the labellum. Linn. 20, Or. 1, Nat. Or. Orchidacee. The species of this genus succeed well with the same treatment as Disa.

ăbă

auีréă.

elongâtă

longifolră

maculâtă

pedunculāta

White.
Yellow
Pink
Pink :
Yel, spot.
Yellow
Pa. yel.

6, G. Ter. N. Holl.

G. Ter. N. S. WV

5, G. Ter. N. Holl.

G. Ter. N. Holl.

5, G. Ter. N. Holl.

sulphŭréa . Pa. yel. 6, G: Ter. N. Holl.

1810

1822

1823

1826

1823

Drürūū, daily.

DIVARICATB, growing in a straggling manner.

DiverGENT, growing far asunder; applied to DIVERGING, $\}$ branches and leaves.

Dock, see Kŭmẽx.

DoD̄̄RTIẌ, Linn. In honour of F. Dodart, M.D., a French botanist. Linn. 14, Or. 2, Nat. Or. Scrophularincer. A species of little beauty, thriving in any light rich soil, and increased from seeds, or divisions.

orientălis . . . Purple . 7, H. Her. P. Levant . . 1752

DODDRR, see Cũscūtĕ.

DODECANDROU's, having twelve stamens.

DODвсĂтHĔón, Linn. From dodeka, twelve, and theos, a divinity ; twelve gods, or divinities of the Romans; a name absurdly applied to a plant, native of a world the Romans did not know, and resembling in no particular any plant of their writers, Linn, 5, Or. 1, Nat. Or. Primulaceie. Very ornamental plants when in flower, and well 
worthy a place in every collection. The species grow best in a light loamy soil, and are easily increased by dividing the roots.

integrifolīum . . Lgt. pur. . 4, H. Her. P. N. Amer. • 1829 Meădiá . : Lot. pur. 5, H. Her. P. Virginia: 174 albiflórũm: Whito. 5, H. Her. P. Gardens: 1824 eléğans : : Rnsy : 5, H. Her. P. Gardens : 189 Lilac - 5, H. Her. P. Gardens lilacinúm: Lilac: :5, H. Her. P. Gardens: 182-

Dodon育 known by the name of Dodonæus, a famous botanist and physician. Linn. 8, Or. 1, Nat. Or. Sapindacea. Plants scarcely worth cultivating, except in general collections. They thrive well in loam and peat, or any light soil; cuttings will root in sand, under a glass; those of the stove species must be placed in heat. Synunymes: 1. D. heterophylla. 2. D. viscosa, angustifolia. 3. D. angusti. folia.

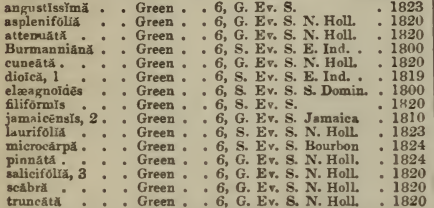

Lialätă, oblongifoliă, paulliniafouliă, triquětră, viscōsă.

Dog bRA MBLE, see Ribes Cynoshätr.

Dou porson, see Athûsă Cynăpiam.

Dog's-BANE, see Apöcūñm.

DoG's-сAввAGB, see Thelygōnam Cynocrämbz.

Doo's-TAIZ, GRAss, see Cynosintĭs.

Dog's-тоoтн vior.er, see Erythrönam.

Doowood, see Cornŭs.

DOLABRIFORM, axe-shaped

DólYchós, Linn. From dolichos, long; in reference to the long twining stems. Linn. 17, Or. 4, Nat. Or. Lcguminosc. D. Jacquiniti and $D$. lignosus are about all that are worth cultivating for ornament. Any rich light soil will suit them, and they may be increased by seeds, or cuttings; if by cuttings, they must be planted in sand, under a glass; the stove kinds in heat. Synonyme: 1. Phaseolus vexillatus.

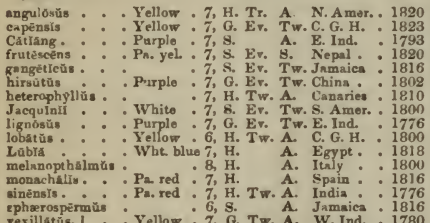
biflorüs, latcuัs, pilosĭs, reticulütǔs, sesquipedalis, setafoltǔs, tetraspêrmãs, tranquebăricǔs, unguiculātus.

DotrocĀrpŏs, Rolander. From dolios, deceitful, and karpos, a fruit; the fruit, tholigh beautifuI, is poisonous. Linn. 13, Or. 1, Nat. Or. Dilleniaced. An ornamental plant; for propagation and cultnre, see Tetracera. Synonyme: 1. Tetracera Calinea, Calinea scandens.

Calrnĕ, 1. . Yellow * S. Bv. Cl. Guiana . 1822

Dourzỹx, Cavanilles. In honour of Joseph Dombey, a French botanist and traveller in Peru and Chili. Linn. 16, Or. 7, Nat. Or. Sterculiacee. Ornamental plants, growing freely in sandy lnam and peat; cuttings of the young wood will root freely, if put in sand, under a glass, in a moist heat.

cannabină . - White. - 3, S. Ev. T. Mauritius.

cordifolla: : Red : S. Ev. S. E. Ind. : 1820

ferruginé: : White: : S. Ev. T. Mauritius : 1815

ováta * . White. S. Ev. T. Bourbon 1822

punctate * White. - S. Ev. T. Bourbon . 1820

tiliafolra * - White. S. Ev. T. Bourbon 1820
French botanist. Linn. 5, Or, 2, Nat. Or. Umbelliferc. A very pretty little plant, requiring an equal mixture of loam and peat; it may be increased by seeds, or divisions. Synonyme: 1. Astrantia Epipactis.

Epipáctis, 1 . Yellow . 4, H. Her. P. Alps . . 1823

Dобрї A, R. Brovn. In honour of Samuel Doody, a London apothecary, one of the earliest British cryptogamic botanists, Linn. 24, Or. 1, Nat. Or. Pulypodiacee. Very handsome ferns, growing well in loam and peat, and easily increased, either by seeds or divisions. Synonyme: 1. Woodnardia caudata.

aspéră * . - Brown . 6, G. Her. P. N. S. W. . 1818 caudătă, 1 : Brown : 6, G. Her. P. N. Holl. : 1820 medis : : Brown :6, G. Her. P. N. Holl. 1823

Doroxīcū M, Linn. Altered from Dorunigi, its Arabic name. Linn. 19, Or. 2, Nat. Or. Composite. An ornamental genus, and from the plants flowering early in spring, they are well deserving of cultivation; they grow in any garden soil, and may be increased with facility by dividing at the rout. Synonyme: 1 . D. orientale.

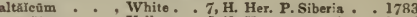
austri̊scûm Yellow 5, H. Her. P. Austria. austriacum 1 Yellow calúásicūm, 1. Y Yellow : 7, H. Her. P. Caucasus : 1815 Pardalianchés: Yellow :5, H. Her. P. Britain : plantaginéum: Yellow : 5. H. Her. P. S. Eur. : : 1570
ccorpioidés. : Yellow

DOReAl, growing on the back.

DorstëNî, Linn. In memory of Thcodore Dorsten, a German botanist. Linn. 4, Or. 1, Nat. Or. Urticacec. Very curious plants, growing freely in any light rich soil, and may be multiplicd with facility by parting the roots, or by seeds. brasiliénals : Green : 6, S. Her. P. Brazil : : 1792 ceratosinthès . Green . . 6, S. Her. P.S. A mer. 1826 cordifolia - Green * 6, S. Her. P. W. Ind. 1829 contrajérvă. Green . 6, S. Her. P. . A met. 1748 Drakenx Dreen. Grux . 1818

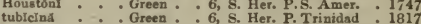

DoRтмйNx Dutch apothecary. Linn. 5, Or. 1, Nat. Or. Lobe. liacer. The species of this genus are singular and beantiful plants, but require a good deal of eare in cultivation. D. lacustris succeeds best planted in a pot of gravel, and placed in a pond or cistern, so that the plants may be about six inches under the water. The other species may be grown in a pot half filled with peat earth, and the rest with sphaynum, in which the plants must be set, and the pot placed in shallow water, so as not to immerse the plants. They may be increased by division. $S y-$ nonymes: 1. Lobelia Dortmanna. 2. L. paludosa.

lncťstrïs, 1 - P Plue - 7, H. Her. P. Britsin .

DoRyÃrmēs. Named by Correa de Serra, from dory, a spear, and axthe, flower; because of the long, straight flower-stem. Linn. 6, Or. 1, Nat. Or. Amaryllidaces. Rather an ornamental plant, re quiring a warm part of the greenhouse, or a cool part of the stove; the latter is preferable. It may be increased from suckers, which are seldom to be obtained, except by cutting a large plant down, or taking out the heart of the plant; in either case, it will throw out suckers.

excelsu. . . Cream. . 7, G. Her. P. N. S. W. . 1800

Dor rcvlom, Tournefort. From dory, a spear; the ancient plant was used to poison spears. Linn. 17, Or. 4, Nat. Or. Leguminosa. Very handsome plants, of sirple culture, succeeding best in a dry soil. They may be increased by seeds, which they ripen in abundance. Synonymes: 1. Lotus hirsutus. 2. D. ibericum. 3. L. parviflorus. 4. L. rectus. 5. L. subbiflorus. 6. D. monspeliense, Lotus Doryenium. 7. D. hirsutum, incanum, Lotus tomentosus, sericeus, affinis.

herbăceūm hirsatam, 1 latifoliūm, 2 parviflörûm, 3 : Yel. grn. : 7, H. Tr. A. S. Bıu. : 1810 réctūm, 4 . Red : 7, H. Ev. S. B. Eur. : 1640 subbiflôrūm, 5 : 7, H. Av A Spain : 1820 suffruticősunm, 6 . While. :7, G. Ev. S. S. Eur. : 1640 tomentósúm, 7 : Red wht. 7, H. Ev. S. S. Eur. : 1817 
Dотні̄DĔĂ, Fries. Derived from dothien, a tubercle, and eidos, similar. Linn. 24, Or. 9, Nat. Or. Fungi. Mostly dark species, growing upon stems of grass, and leaves of trees-älnēa, betulină, Gerănĭi, Hi mäntǐă, Ptěrĭdis, ribēsĩă, Robertiānă, Ulmī.

Dors-may be pellucid, resinous, or hairy.

Dougrissĩ. Named by Dr. Lindley, some years ago, in compliment to Mr. Douglas, whose zeal in collecting seeds and plants, and whose untimely end, have richly earned for him a niche in the long gallery of departed science. Linn. 5, Or. 1, Nat. Or. Primulacee. This is a very beautiful, but scarce, little plant, growing pretty freely in peat and sand, and ripening its seed in small quantity. Mr. Douglas transmitted the seed, from which this interesting plant was raised, from the Rocky Mountains, where he first found it among the snow, and afterwards from California.

nivălis . . Purple . 6, H. Her. P. Rky. Mts. . 1827

Dore's-FOOT, see Gerănǐum mơllè.

Down, soft, short hairs.

Dowsy-VILLous, covered with long soft hairs.

Dow:y-pUBEscent, soft, short down, closely pressed to the surface.

DR $\overline{\mathrm{A} A ̆}$, Decandolle. From drabe, acrid, biting; taste of the leaves. Linn. 15, Nat. Or. Cruciferc. Some of the species of this genus are very pretty, being well adapted for ornamenting rock-work, or growing in pots, among other alpine plants. A mixture of loam and peat suits them best, and they increase with lacility, either by dividing at the root, or by seeds. Synonymes: 1. D. aizoides. 2. D. incana. 3. D. androsucea. 4. D. lutea, longipes. 5. D. contorta. 6. D. androsacea. 7. D. hirta. 8, D. hirta. 9. D. hirta.

aizoîdès

Aizoon * Yellow. 5, H. Her. P. Carinthia 1823

pina * Yellow . 4, H. Her. P. Lapland 1820

silïcŭlǐs-pilosis Yellow

lasiocărpă: : White

$5, \mathrm{H}$. $\mathrm{P}$.
Yellow

austrǐ̆că White

brachystēmōn, 1 . Yellow

bruniæefóliă : Yellow

bryoídēs : Y Yellow

ciliaris . : Yellow

cinéréă - . White

confuisă, 2 * "White

crassifóliä: : Yellow

cuspidāta . : Yellow

daûrică . : White

ericæfólı̆ : Yellow

fladnisēnsìs, 3. White

zlacialis : Yeilow

Gmelini : : Yellow

gracilis, $4:$ : Yellow

hirtĭ. : White

incănă, 5 - White

neómptà : Yellow

lapponică, 6 : White

muraliss. : White

muricêllă, 7 - White

nemoralis : Y Yellow

oblongātă : : White

pilōsăâă : : : White

rêpēns : Yellow

rupēstrǐs, $8:$ Yellow

siliquōsă - • Whit

stellată, 9 : : White

H. Her. P. Greenland

H. B. Denmark

6.

P. Switzerl

, H. Her. P. Caucasu

3 , H. Her. P. Switzer]

7, H. B. Siberia

7, H. B. N. Eur.

, Her. P. Baff. B. .

3. $\mathrm{H}$ Her $\mathrm{P}$ Iberia

7, H. B. Dauria

, H. Her. P. Caucasus

6, H. Her. P. Switzerl.

6, H. Her. P. Siberia

6, H. Her. P. Siberia

8, H. Her. P. Switzerl.

6, H. Her. P. N. Eur.

5, H. B. Britain

4, H. Her. P. Caucasu

4, H. Her. P.

6; H. A. S. Eur.

6, H. A. England

6, H. Her. P. Lapland

6, H. A. Europe

6, H. Her. P. Siberia

6, H. Her. P. Siberia

6 , H. Her. P. Sentland

6, H: Her. P. Cancasu

6, H. Her. P. Pyrenees

1820

1824

1819

1820

1820

1731

1823

1826

1820

1824

1821

1819
1826

1823

1827

1823

1821

1810

182

1824

1810

1824

$1 \leftarrow 23$

1825

1818

1822

1820

nummulärĭă.

DrAc无NĂ, Linn. From drakaina, a female dragon; the inspissated juice becomes a powder, like the dragon's-blood. Linn. 6, Or. 1, Nat. Or. Liliacea. Very ornamental trees, well worthy of being cultivated in every collection of stove plants. They thrive well in a light, loamy soil; large cuttings root freely by being stuck in the tan, provided there be a strong heat. In Java, the root of $D$. terminalis is considered a valuable medicine in dysenteric affections. The substance called Gum Dragon, so well known in medicine, is the juice of D. Draco. Synonyme: 1. D. Marginata.

arbǒrĕă . * White. . B, S. Ev. T. S. Leone . 1800 braxiliênsIs: : White: S. Ev. S. Brazil : 1829 cẽrnŭă : : White: : 5, S. Ev. T. Mauritius

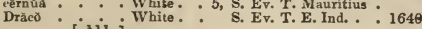

\begin{tabular}{|c|c|c|c|c|}
\hline ensifölia & & & S. Ev. S. & - \\
\hline rēă & * & te. & . 4, S. Ev. T. China & \\
\hline ins & - & $\cdot \pi$ & . 4, S. Ev. T. Africa & \\
\hline iptă & & ite. & . 6, S. Ev. S. S. Leone & - \\
\hline İs & & - $\mathrm{I}$ & S. Ev. S. S. Leone & \\
\hline วă & & - & - Ev. S. Mauritius & \\
\hline . & - & - Wh & S. & \\
\hline ns & - & . Wh & S. $N$ & \\
\hline irěă & & White. & 6, S. Ev. T. E. & \\
\hline - & & - W & . 6, S. Ev. S. Mr & \\
\hline riātă . & & $\cdot \mathrm{W}$ & - 4, S. Ev. B. C. & \\
\hline culôsă & - & Wh & v. S. S. & \\
\hline minălis & & White. & E. Ind. . & \\
\hline & & & S. Ev. T. Mauritius & \\
\hline Therata & & . White. & G. Ev. S. C. G. H. & \\
\hline
\end{tabular}

DRAсосйрHĂLёM, Linn. From drakon, a dragon, and kephale, head; the appearance of the heads of the flowers. Linn. 15, Or. 1, Nat. Or. Labiata. Most of the species are ornamental, and as such, they deserve a place in every garden. They succeed well in common garden soil. Some of the tende perennial kinds require the protection of a frame in winter, and, on that account, they ought to be grown in pots; they increase readily by dividing at the roots. The annual kinds merely require sowing in a rich, light soil, in the open ground, where they will flower beautifully. Synonyme: 1 D. grandiflorum.

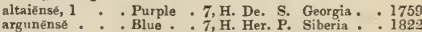
argunēnsé . . Blue . . 7, H. Her. P. Siberia . . 182

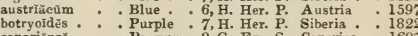
canariēnsĕ . . Pa. pur. . 8, G. Ev. S. Canaries : 169 canêscéns : Blue * 7, H. A. Levant . 171 ibēricūm moldāvicūm Blue: 7 H. Moldavia: 159 albifōrúm * Blue * 7, H. A. Noldavia * 1596 albifiórúm * W A. Moldavia - 159 origanoidēs: : 7, F. Ev. Tr. Siberia : : 1829 palmātūm : : Purple : T,H. Her. P. Siheria : 1815 parviflörü : Blue : 7, H. Her. P. N. Amer. : 182 peltátûm - Purple : 7, H. Her. P. Levant : 171 peregrinūm : Purple : 7, H. A. Siberia * 1759 sibirìcūm : Blue: 8, H. Her. P. Siberia: 1760 thymiflorum: Purple: 7, H. Her. A. Siberia: 1759 DRACōNis, spotted like a serpent.

Dracóntíum, Linn. From drakon, a dragon; the stems are spotted like the skin of a snake. Linn. 7, Or. 1, Nat. Or. Aracea. Curious species, delighting in a rich, light loam, and increased by dividing the roots. In India, the prepared root of D. polyphyllum is supposed to possess antispasmodic virtues, and is a valuable remedy in asthma.

polyphỵllūm - Apetal . 5, S. Ev. Cr. India * 1759 spinosum A A, S. Ev. Cr. Ceylon : 1759

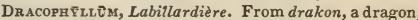
and phyllon, a leaf; the leaves resemble those of Drecana Draco, Linn. 5, Or. 1, Nat. Or. Epacridacee. Ornamental shrubs; for culture and pro pagation, see Andersonia.

capitatüm . . G. Ev. S. N. Holl recūndūm : White: 6, G. Ev. S. N. Hull. : 1824

Dragon, see Dracontiũm.

DRAGON's-HBAD, see Dracocēphălüm.

DrAGON-TREB, see Dracāenă Drăco.

Draparvär.pĭă, Bory de St. Vincent. In honour of J. P. R. Draparnald, a French botanist Linn. 24, Or. 7 , Nat. Or. Alga. Small, bright green plants, found at all seasons in pools and rivulets-glomerata, plumosa, tenuis.

Drastic, applied to purgative medicines which act violently

DrepanocĀrfŭs, Meyer. From drepanon, a sickle, and carpos, a fruit; alluding to the shape of the pods. Linn. 17, Or. 6, Nat. Or. Leguminose. Rather an ornamental shrub, from six to ten feet high. For culture and propagation, see Pterocarpus. Synonyme: 1. Pterocarpus lunatus.

lunătŭs . . . White. $\quad$ S. Ev. S. S. Amer. . 1792

DREPANOPHX̃LẼ, Kunth. From drepanon, a sickle, and phyllon, a leaf; alluding to the falcate leaves. Linn. 5, Or. 2, Nat. Or. Umbelliferce. A worthless, herbaceous perennial, growing in any soil; increased by divisions. Synonyme : 1. Sium Falcaria -agrēstè 1 . 
LRĪMĬ Jacquin. From drimys, acrid; the juice of the roots is so acrid as to cause inflammation when applied to the skin. Linn. 6, Or. 1, Nat. Or. Li. liacra. An ornamental genus, when the plants are in flower; they require a mixture of sandy loam and leaf mould, or peat soil. When not in a growing state, they require but little water, and when potted just before they begin to grow, they will flower freely. Synonyme: i. D. lanceofolia, Hyacinthus revolutus, Lachenalia reflexa.

acuminätă . . Brown . 8, G. Bl. P. C. G. H. - 1829 altissimă : : Wht. grn. 8, G. Bl. P. C. G. H. 1791 ciliärřs . : : Pur. wht. 8, G. Bl. P. C. C. H. 1800 elātå . * * Red g lancexfóliă : : Purple : 9, G. BL. P. C. G. H.

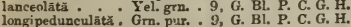
medfredunculatx. Grn. pur. : 9, G. Bl. P. C. G. H purpuräscens : : Purple : 8, G. BL. P. C. G. H. pusilllă . : Green . 5, G. BL. P. C. G. H. revolútă, 1: : Green : 8, G. Bl. P. C. G. H. revoluta, 1: Green :

viliosa . : : Grn. str. : 5, G. Bl. P. C. G. H. : 1826

DRĪMÝs, Forster. From drimys, acrid; the juice of the root causes inflarnmation when applied to the skin. Linn. 13, Or. 4, Nat. Or. Winteracea. Valuable trees, from twelve to forty feet high, requiring a mixture of loam, peat, and sand; ripened cuttings would probably root, if planted in sand, under a glass. The winter bark, which resembles that of cinnamon, is the produce of D. Winteri. Synonyme: 1. Wintera aromatica.

chilenšrs : * White. : G. Ev. T. Chile : 1829

DRINRRR's-NUT, see Strychnos potatöram.

DROPWORT, see SPirēă fúipēndūlü.

DRöš̃Rä. From droseros, dewy; the plants are beset with glandular hairs, which makes them appear as if covered with dew. Linn. 5, Or. 5, Nat. Or. Droseraced. This is a most singular and beautiful genus of plants, whose leaves are ornamented with red, glandular hairs, discharging from their ends a drop of viscid acrid juice. These hairs are so irritable as to contract when touched, imprisoning insects, after the manner of Dionara Muscipula. In their native state, they are found growing on mossy turfy bogs. The best way to grow them, is to plant them in small pots, about three parts full of peat earth, and some sphagnum planted on it; the plants should then be planted in the moss, and the pots placed in pans of water, and even then, the hardy species grow best in the greenhouse. They are all increased by seeds, which should be allowed to sow themselves, Synonyme: 1. D. intermedia.

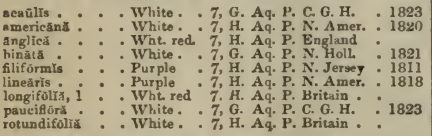

Drumiōndy̆ Decandolle. Named after Mr. Thomas Drummond, a well-known naeuralist, and zealons collector of plants, chiefly in the United States; he died at Havannah, in March, 1835. Linn. 5, Or. 2, Nat. Or. Saxifragaceo. This is a very pretty little plant, well adapted for the front of flower-borders, or to grow on rockwork. It grows most luxuriantly in peat, though it succeeds in any light soil; divisions. Synonyme: 1. Mitella pentandra.

mitelloīdés. . . Yellowish 6, H. Her. P. Rky. Mts. . 1827

DrUNKRn DARNRi, see Lotram temulentũm.

DRUPB, a kind of fruit, consisting of a fleshy, succulent rind, and containing a hard stone in the middle.

DR Ūs ̃̆, Decandolle. In honour of M. Le Dru, a French botanist and traveller. Linn. 5, Or. 2, Nat. Or. Umbellifere. A hardy annual, the seeds of which merely require sowing in a warm situation-oppositi, sliă.

DRYANDRX̆, R. Brown. In honour of Jonas Dryander, a distinguished Swedish botanist. Linn. 4, Or. 1, Nat. Or. Proteacea. A splendid genus of plants, nearly related to Banksia. All the species thrive well in an equal mixture of turfy loam, peat, and sand. The pots require to be well drained, and the potsherds broken very small, because the roots are fond of running among them. Cuttings taken off at a joint, in August or September, and planted in sand, without shortening the leaves, will readily root, if placed on a gentle hotbed, (but not plunged,) under a glass; bur they must be covered, so as the frost cannot injure them. As soon as rooted, they must be potted off, as the sand would injure the roots if they were too long in it; after being potted off, they should be placed in a close frame, and hardened to the air by degrees. The cuttings will do equally well if put in early in spring, just as they are beginning to push out young wood.

\begin{tabular}{|c|c|c|c|}
\hline . & : & ow & $\begin{array}{l}\text { nll. } \\
\text { oll. }\end{array}$ \\
\hline i. & - & - Yellow & s \\
\hline olia & - & - Yellow & \\
\hline$\overline{\mathbf{a}}$ & & & \\
\hline & - & Yello & 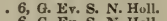 \\
\hline & - & & \\
\hline & . & & \\
\hline dà. & - & - Yellow & - \\
\hline & • & & \\
\hline & - & - Ye & \\
\hline$x$ & - & - Ye & - \\
\hline lătă & & - Y Ye & \\
\hline & 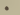 & - Yell & \\
\hline & & & 1. \\
\hline & & & \\
\hline ( & - & 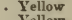 & \\
\hline folde. & & w & il. \\
\hline & & & \\
\hline
\end{tabular}

DRr̆s̄s, Linn. From dryades, or nymphs of the oaks; because the leaves bear some resemblance to those of the oak. Linn. 12, Or. 3, Nat. Or. Rosacer. A delicate genus of plants, which succeed best in a border of peat soil ; but they require to be protected in winter. They may be increased either from cuttings, seeds, or divisions. Synonymes: I. D. octopetala. 2. D. integrifolia.

Drummondi, 1 . White. . 7, F. Ev. T. N. Amer. - 1828 integrifolta . Whito. : 7, F, Ev. T. Greenland : 1824 octopetals . . White. : 7, H, Ev, T. Britain .

americhn̊ : White : 7, H. Ev. T. N. Amer. 1890 tenelli, 2 : : Whito: : 7, F, Ev. T. Canada : 1820

DRYMĀRIX, Willdenon. From drymys, a forest; habitation of the species. Linn. 5, Or. 3, Nat. Or. Illecebracece. Plants of no value; they need only to be sown on a hotbed early in spring. In the month of May, they may be planted out into a warm border. Synonyme; 1. Holosteum cordatum.

cordătă, 1 . . White. . 7, S. Ev. Cr. Jnmaica * 1800 grăcilys : : White. 7, s. Ev. Cr. Brazil . 1829

DRчมōxโ̌, Martius. From drumonia, woodland; the plant inhabits forests. Linn. 14, Or. 2, Nat. (Or. Gesneracea. An ornamental plant. For culture and propagation, see Besleria. Synonyme: 1. Besleria serrulata.

bleolör . . . Purp. yel. . S. Ev. Cl. WW. Ind. . 1806

DRYpĒTtîs. Named by $\mathbf{V}$ ahl, from drypto, to lacerate; plant spiny. Linn. 22, Or. 4, Nat. Or. Euphorbiacee. An ornamental shrub, about six feet high, growing in a mixture of loam and peat; cuttings will root in sand, under a glass, in heat. Synonyme: 1. Schofferia lateriflora.

cröcēă, l. . . 6, S. Ev. S. W. Ind. . 1820

Drípis, Linn. From dripto, to tear; the leaves are armed with stiff spines. Linn. 5, Or. 3, Nat. Or. Silenaces. This beautiful little plant is well adapted for ornamenting rock-work, in which situation it flowers in the greatest profusion. It may be increased by cuttings, planted in sand, under a glass, or by seeds, sown in an equal mix. ture of loam, peat, and sand, and when the plants get of sufficient size, they ought to be planted on the top of rock-work, where they must not be suffered to get dry till they are well established.

spinōsũ . . . Pa. blue . 6, H. Ev. 8. Italy . 1775

Duck's-yoor, see Podophyllüm.

DUCKWERD, see Lëmnü.

DûLč̌s, sweet, nectariferous.

Dunichīes, Persoon. The name of the island where the plant was first found. Linn. 3, Or. 1, Nat. Or. Cyperacea. A curious perennial species, growing in peaty soil, and increased by divisions.

spathăcêum . . A Apetal. . 7, Grass. N. Amer. . 1818 
DuMĀš̆, Decandolle. In honour of M. Dumas, one of the editors of Annales des Siciences Naturelles. Linn. 17, Or. 4, Nat. Or. Leguminose. Ornamenta plants; for culture and propagation, see Clitoria. putüscēns . . . Yellow * 10, G. Ev. Tw. Nepal . . 1824 villósă : : Pa. yel. : 10, G. Ev. Tw. Nepal： : 1824 DUмB CANe, see Calädĩum seguĩnûm.

DUMRRİlĩ̆, Leysser. In honour of M. A. M. Constant Dumeril, a French naturalist. Linn 19, Or. 1, Nat. Or. Compositce. Rather a pretty shrub, growing about three feet high, in any common garden soil, and increased by cuttings. Dusiose, bushy, shrubby.

DurÃNtă, Linn. After Castor Durantes, a physician and botanist, who died in 1590. Linn. 14, Or. 2, Nat. Or. Verbenacece. A very pretty and freeflowering genus, successfully grown in a mixture of loam ard peat. Cuttings root freely, planted in sand, under a glass, in heat. Synonymes: $1 . D$. microphylla. 2. D. dentata.

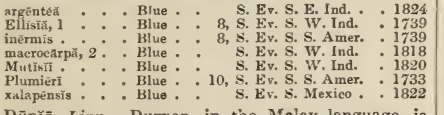

Dūrōo, Linn. Duryon, in the Malay language, is the name of the fruit. Linn. 18, Or. 1, Nat. Or. sterculiaced. This tree thrives well in a rich loamy soil ; and cuttinss, not too ripe, taken off at a joint, with their leaves entire, will root in sand, under a glass, in a moist heat. The fruit of this tree is about the size of a man's head, and is said to be the most delicious of all the fruits of India. The axil-like substance, which contains the kernel, is the eatable part of it, and most resembles cream; yet it is accompanied by such an intolerable stench, that, according to Rumphius and Valentyn, it is, by law, forbidden to throw them out, near any public path, in Amboyna. The smell is said to be similar to that of some putrid animal substances; yet, all agree, that if the first repugnance is once overcome, no fruit is more agreeable than the durion. The fouit is also used as a bait to entrap the civetcat; hence the specific name.

ribethinus. . White. . S. Ev. T'. E. Ind. . . 1825

DURÎ̃ scữ

Durmast, see Qnērcũs pubēscẽns.

Dũrǔs, hard, stubborn, rough.

Dutch Rush, see Equisêtr̃m hyemälé.

DuvāLŭă, Haworth. In honour of M. Duval, a celebrated French botanist. Linn. 5, Or. 2, Nat. Or. Asclepiadaceu. A curious genus of succulent plants, nearly related to Stapelia, to which they inay be referred for culture, \&c. Synonymes: 1 . Stapelia hirtella. 2. D. radiata. 3. Stapelia reclinata. 4. S. replicata.

paniculătă . . Purple . 8, S. Ev. S. Columbia . 1825

exespitōs - Purple - 5, S. Ev, S. C. O. H. - * Purple - 5, S. Ev. S. C. G. H empacta : : : Prown : 8, S. Ev. S. C. G. H. glomerātă : Brown : 8, S. Ev. S. C. G. H. hirtellă, 1 : : Purple : 8, S. Ev. S. C. G. H. Jacquiniãnă, 2 . Purple - 8, S. Ev. S. C. G. H. lavigatä - : Brown : 8, S. Ev. S. C. G. H. mastódês: : Brown: 8, S. Ev. S. C. G. H. radiates: : Purple: 8, S. Ev. S. C. G. H. radiata $\cdot *{ }^{*}$ : Purple $\quad 8$, S. Ev. S. C. G. H. reclinătà, $3 \quad:$ : Purple
replicătä, 4 , S. Ev. S. C. G. H. replicăta, 4 :
tubereuläta

- 1790 1800 1795 1804

Duv^ōă, Kunth. In honour of M. Duvau, a French botanist. Linn. 21, Or. 7, Nat. Or. Anacardiacea. Rather an ornamental genus; for culture and propagation, see greenhnuse species of Rhus.

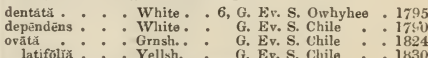

DWARY FAN-PALM, see Chamäröps hümilïs.

DWArf moly, see Allīun Chamuemōly̆.

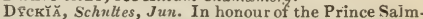
Dyck, one of the most liberal and intelligent patrons of science of the present day. Linn. 6, Or. 3, Nat. Or. Bromeliacece. A very handsome plant, agreeing in many particulars with the Aloe, to which genus it may be referred for culture and propagation. rariflōră . . Orange . 6, G. Her. P. Brazil . . 1832

DYRR's GREEN WEED, see Gëntstă tinctorĭŭ.

DYER'S LITTLE YELLOW WEED, see Rĕsĕdă lutěolü.

Dysoph₹LLĂ, Blume. From dysodes, fetid, and phyllon, a leaf; in reference to the smell of the leaves. Linn. 14, Or. 1, Nat. Or. Labiatie. Plants nearly related to Mentha, for which, see culture and propagation. Synonymes: 1. Menthu pumila, verticillatu. 2. M. quadrifolia.

pŭmĩlă, 1 . - Purple . 8, H. Her. P. Nepal * . 1826 quadrifoliă, 2 . Purple :7, G. Ev. S. Nepal : : 1820 Drspēpsĭ , difficulty of digestion.

E.

A A EN, having ears, or appendages.

H. EARTh Nut, see Bũñ̄um.

Earth tongur, see Geoglossūm.

EAs? Iñna mưwort, see Artemistŭ hirsntă.

EBǨNĔŬs, black, ebony-coloured.

EBk̆NŬs, Linn. From abnous, the Arabic name for ebony, or ebenus of the Romans. Linn. 16, Or. 6, Nat. Or. Ebenncere. These are pretty little dwarf plants, with pink flowers; they require a peaty soil, added to a little loam, to grow in, and are increased by seeds. Synonymes: 1. Anthyllis cretica. 2. A. pinnata.

crêtřĕ, 1 . . Pink . . 6, G. Ev. S. Candia . . 1737 pinnată, 2: : Pink: : 6, G. Ev. B. Barbary : 1786

EвоNх, see Diospy̆ross ëbĕnйs.

Ecasta PhÝlzom, P. Bronne. From hecastos, each, and phyllon, a leaf; the leaves of some of the species are composed of only one leaflet. Linn. 17, Or. 4, Nat. Or. Leguminosce. Ornamental shrubs, growing about ten feet high; they succeed in rich soil, and are increased by cuttings of the ripened wood, planted in sand, under a glass, in heat. Sy nonyme: 1. Pterocarpus Ecastaphyllum.

Brêwněi, 1 * . Wht. red . S. Ev. S. W. Ind. . 1733 Plumiēri : White - S. Ev. S. S. Amer: : 1820 Sieberi : : Wht. red: S. Ev. S. Guinea : 1824

EcaudatB, spikeless, without a stem.

Eccremocărpũs, Rviz et Pavon. From ekkremes, pendent, and karpos, fruit ; the fruit is pendent. Linn. [ 113 ]
14, Or. 2, Nat. Or. Bignoniucere. An exceedingls ornamental plant, well adapted for training over bowers, coitumns, trellis-work, \&c., like Clematis, Honersuckles, \&c. ; it should be planted in a mixture of sand, loam, and peat; cuttings root at once, in sand, or soil, with or without a glass.

longifōrŭs . . Orange . 7, G. Ev. Cl. Peru . . 1825

Echinvērĭ, Decandolle. In honour of $M$. Echeveri, author of the splendid drawings of the Flora Mexicana. Linn. 10, Or. 4, Nat. Or. Crassulacece. Amony succulents, this genus is one of great beauty. $E$. gibbiflora is disposed to grow rather straggling nevertheless, it is worthy of a place in every col lection, on account of its strong, shining luaves, and orangy-scarlet flowers. To yrow them well, they require a suil composed of sandy loam, and little peat, mixed with reduced rubbish of bricks, \&c. At all seasons they should be cautiously watered, particularly in winter. They increase from cuttings, dried a few day's before being put in the soil. Synonymes: 1. Cotyledun caspitosa. 2. C. coccinea.

cæspitôsă, 1 * Y Yellow * 7, G. Her. F. California . 1796 coccineđă, 2 Scarlet: 10,-G. Ev. S. Mexico . 1816 gibbiťōră : Yel. pink 9, G. Ev. S. Mexico : 1896 Trandifoliă: : Orange. 10, G. Ev. S. Mexico : 1828 lürídä: : scarlet: 7 , S. Her. P. Mexico: : 1830 racemóxả : Crimson : 10, S. Her. P. Mexico : 1836 secúndă . : : Scarlet : 6, S. Ev. S. Mexico : 1837

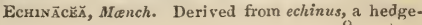


hog; the prickly scales of the receptacle give that appearance. Linn. 19, Or. 3, Nat. Or. Composita. These plants are ornainental, growing from one to two feet high, and of bold habits. For culture, \&c., see Coreopsis. Synonymes : 1. Coreopsis heterophyllu. 2. Rudbeekia napifolia. 3. R. purpurea. 4. $R$. serotina.

Dicksōni : . Lilac. • 8, H. Her. P. Mexico . heterophylli, $i$ : Purple : 10, H. Her. P. Mexico: : 1829 intermédĩă : Red : : 9, H. Her. P. Eng. hyb. : 1826

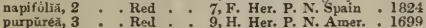
serótină, 4.: : Red : : 9, H. Her. P. N. Amer. : 1816

Echinatrd, covered with prickles, like an echinus, or hedgehog.

EchisĀrix, Desfontaines. From echinus, a hedgehog; the prickly heads may be fancied to resemble little hedgehogs. Linn. 3, Or. 2, Nat. Or. Graminex. A curious little annual, growing in any common soil, and increased by cuttings. Synonyme: 1. Cenchrus capitatus, Sesleria cchinuta.

capitătă, 1 . . . Apetal . . 7, Grass. S. Eur. . . 1771

Echrnk̃Llă, Agardh. From echinus, a hedgehog; bristly appearance of the plants. Linn. 24, Or. 7, Nat. Or. Alga. A very minute species of green $A / g a$, found in lakes, and, by some naturalists, believed to be animalcula-articulätä.

EchinocĀctǔs, Sulm-Dyck. From echinos, a hedgehog, and cactus; a name given by Theophrastus to a spiny plant. Linn. 12, Or. 1, Nat. Or. Cactacea. These are plants of yreat beauty and interest, on account of their singular and grotesque structure, the arrangement of their spines, and the beauty of their flowers. The soil best suited for them, is sandy peat, a little loam, and a little lime, or brick rubbish, all of which must be well mixed together. They must be watered very sparingly at all times, but more so in winter. They are increased from offsets, which must be dried a few days before being put in to strike. These plants, and Mammillarias, are sometimes much infested with red spider, which is very troublesome. The effectual way of exterminating them, is to shed a little dry sulphur over the plant infested, and they will soon disappear, and as soon return, if not carefully watched. Synonymes: 1. Cereus abnormis. \& E. platacantha, Cactus latispina. 3. Cereus cylindricus. 4. Cactus depressa. 5. Cereus gibbosus. 6. Cereus hystrix. 7. Cereus imbricatus. 8. Cactus intorta. 9. Cactus erinaceus. 10. Cactus parvispinus. 11. Cactus recurvus, nobilis.

aboōruīs,

acuatūs

acutangulărìs

Aneoniān

centeteriñs.

coccinéūs

cornigerüs, 2

corynồdés

erispátūs

cylindrieŭs, 3

dênsũs

Dẽpper

deprēssŭs, 4

echinatŭs

exculpt

Eyrésî́ :

glaūcŭs.

gibbùsús, 5

Gilliēsil

gladiătŭs

hamátŭs

hystrix, 6

imbricâtŭs, 7 .

infiatũs

intôrtǐs, 8

intricātús

erinảcéŭs, 9

Linkil

Mackieănuัs

maminillarioid

melocactiförm

meonacântlıũs

montevidensis

obvallatũ̉s .

orthacănthŭs

Ottōnis

oxyacãnthŭ

oxygonuns
White

Yellow

Yellow

Lii. red

Purple

Purple

7, S. Ev. S. S. Amer.

9 , S. Ev. S. M. Video

9, S. Ev. S.

S. Ev. S. Aneona

S. Ev. S. M. Video

9 , S. Ev. S.

9, s.

8, S. Ev. S. Mexico . 1803

9, S. Ev. S.

S. Ev. S. Mexico

S. Ev. S. Peru

S. Ev. S. Mexico.

S. Ev. S. Mexico

S. Ev. S. S. Amer.

9 , S. Ev. S. Mexico

9, s. Ev. S.

Wht yel. 9, S. Ev. S. Mexico.

Wht. grn. 7, S. Ev. S.

S. Ev. S. Mexien

7, S. Ev. S. Jamaica

9 , S. Ev. S. Mexico

7, S. Ev. S. Mexico

S. Ev. S. B. Ayres

S. Ev. S.

S. Ev. S.

S. Ev. S. Chile

Purple . 6, S. Ev. S. Antigua

S. Er. S, M. Video

7, S. Ev, S.

Yellow . 9, S. Ev. S. Mexien

Yel. wht. 10, S. Ev. S. Chile

Yel. red . 10, S. Ev. S. Chile

S. Ev. S. Niexico

S. Er. S. Jamaica

S. Ev. S. M. Video

Purple - S. Ev. S. Mexien
S. Ev. S. M. Video

Yellow

S. Ev. S.

S. Ev. S. Brazil

1818

1836

1836

1823

1835

1799

1829

1798

1830
1836

1829

1830

1808
1830

1833

1808

1820
1828

1768

1818

1835

1836

Pa. rose. pachycēntrŭs .

parvispintus, 10

platyacảnthüs.

polyacānthŭs

recūrvăs, 11

rhodānthüs

robūstŭs

Salmiãnǔs.

spinis-allbis

spinis-âlbis

sessilitör

spinosissimuns

spirális .

suhgihbòsŭs

subuliferǔs

sulcătǔs

tenuispinŭs

tephracānthōes

thelēpliorŭs

tuberculătús

tubiflōrŭs

Rosy.

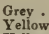

Yellow

S. Ev. S. Brazil

S. Ev. Brazil 1826

- $1836^{\circ}$

S. Ev. S. M. Video - 1826

S. Ev, S

S. Ev. S.

1834

S. Ev. S. Valparaiso - 1830

S. Ev. S. Mexico.

Ev. S. Mexico . 1829

S. Ev. S. Brazil . 1835

S. Ev. S. Brazil : 1825

S. Ev, S.

S. Ev. S. Mexien : 1826

S. Ev, S. Mexico: : 1836

S. Ev. S.

Eснихӧснго̆, Beaurois. From echinos, a hedgehog, and chloa, grass; alluding to the prickly lieads of flowers. Linn. 3, Or. 2, Nat. Or. Graminea. Hardy annuals, fit only to be grown in botanic gardens. Synonymes: 1. Panicum stagninum. 2. P. crus-galli.

crus-falli, 2 . A petal . . 7, Grass. Britain setigeri . : : Apetal : 7, Grass. E. Ind.

1820

commutätŭ 1, crus-cūrvĩ, cchinätŭ, erythrospẽrmŭ, intermédīü, stagniñü.

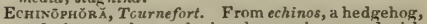
and phoreo, to bear; the involucrum is covered with stiff spines. Linn. 5, Or. 2, Nat. Or. Unbelliferce. Rather interesting plants, succeeding in any common soil, and increased by dividing the roots.

spinôs . . . Wlite. . 7, H. Her. P. England

tenuifoliă: White. 7, H. Her. P. A pulia. 1731

trichophyllă : White: * 7,H.Her. P. Levant : 1820

Echinopōcōn, Beauvois. From echinos, prickly, and pogon, a beard. Linn. 3, Or. 2, Nat. Or. Graminede. A mere weed, of the simplest culture. Synonyme: 1. Agrostis ovatus $\rightarrow$ vãtǔs.

Echīoôs, Linn. From echinos, a hedgehog, and opsis, aspect; in allusion to the hedgehog-like heads of flowers, Liun, 19, Or. 5, Nat. Or. Composito. Coarse plants, of conaiderable beauty, attaining from one to five feet high. They are well adapted for borders, on account of their stiff growth; any common soil suits them, and young plants are obtained by dividing the roots. In Spain, they use the flower of $\boldsymbol{E}$. strigusus for tinder. Synonyme: 1. E. persicus.

exaltătŭs . . White * 7, H. Her. P. Austria . 1817 horridus, 1: : Hlue.: T, H. B. Persia : 1818 hŭmilís : : Blue: : 7, H. B, Caucasus: 1816 lanuginósŭs : Blue : 7, H. B. Levant : 1736 panieulatus : Blue . 7, H. Her P. Spain : 1815 polycéphälüs : Blue . 7, H. Her. P. S. Bur. : 1816 Rítró . . Blue . 7, H. Her. P. Europe . 1570 ruthēnìcŭs : Blue . $7, \mathrm{H}$. Her. P. Russía . 1816 splıærocéphàlǔs : Lgt. blue 7, H. Her. P. Austria * 1596 spinठsŭs . . White * 7, H. Her. P. Egypt * 1397 strictũs. . - Pa, blue . 7, H. Her. P. Enrope . 1822 strigỏsūs : White : 7, H. A. Spain : 1729 taūricŭs : Blue : 8, H. Her. P. Russia: 1820 virgatŭs. : Blue: : 6, H. Her. P. S. Eur. : : 1820 viscósŭs : Blue: 8, H. B. Caucasus: 1818

Echinospēruêa, Snartz. From echinos, a hedgehog, and sperma, seed, the seeds are very prickly. $L$ inn. 5, Or. 1, Nat. Or. Boraginacee. These plants are not worth cultivating, except in general collec. tions. Synonymes: 1. Myosotis Lappula. 2. M. marginata. 3. M. virginica.

virginleùm, 3 . Blue. . 6, H. B. Virginia . 1699 barbütũm, deflẽxâm, Läppǜă 1, marginätam 2, pătălinm, Redónskit.

Eснӣт Es, Linn. From echis, a viper; referring to the smooth, twining shoots, Linn. 5, Or. 1, Nat. Or. Apocynacea. This is a most beautiful genus of evergreen twiners; they grow freely in a mix. ture of loam and peat, and are increased readily from cuttings in sand, under a glass. The bark of E. antidysenterica is astringent and febrifugal.

antidysentérĭă . Pink . . S. Ev. Tw. E. Ind. . 1821 biflor: : White : 7, S. Ev. Tw. W. Inl, : 1793 bispinôsă: : Pinle :G. Kv. S. C. G. H. : 1795 bispinosă : Pinle : 9, G. Ev. Tw. E. Ind. : 1812 caryophyllata . Pa. yel. 10, S. Ev. Tw. E. Ind. • : 1812 
difformis . Pa. vel. . 7, G. Er. Tw. Carolina . 1806

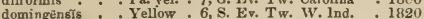
frutēscēns . grandiflöră. - Pink . S. Ev. Tw. E. lnd. . 1823 Heyni1 : . Yellow - 6, S. Ev. Tw. E. lnd. - 1818 longiflōră : : White 6, S. Ev. Tw. Brazil : 1816 malabärica. - Red * 6, S. Ev. Tw. Malabar - 1822 paniculatå . : Yellow * 7, S. Ev. Tw. S. Amer. : 1823 peltátă : : Yellow . 7, S. Ev. Tw. E. Ind. : 1818 Richārdī : : Yellow: 7, S. Ev. Tw. Guiana: : 1824 rubricaúlís: : Yellow: 7, S. Ev. Tw. Guiana: : 1824 stellāris. . . . Ro, yel. . 7, S. Ev, Tw. Rio Jan suberécti . Yellow . 7, S. Ev, Tw. Jamaica torósă * . Yellow * 7, s. Ev. Tw. Jamaica

EchĨ м, Linn. From echis, a viper; the seeds resemble the head of the viper. Linn. 5, Or. 1, Nat. Or. Boraginacec. This is a very pretty genus of shrubs, growing from two to six feet high, in a mixture of loam and peat. Cuttings will root in the same kind of soil, under a glass; but they are more readily increased by layers, which soon take root if laid down in the young wood, with a little nick cut in the shoot. Seeds are frequently produced, from which they may also be increased. Synonymes: 1. E. formosum. 2. E. grandiflorum. 3. E. hispidum, elegans.

aculeätūm . . White . 6, G. Er. S. Canaries Whito 6, G. Ev. S. Canaries ambĭgŭüm . . Wht. red 7, G. Ev. S. Canarie argèntéūm : : Blue - 6, G. Ev. S. C. G. H. austrälé. : : Purple 8, H. A. S. Eur. bifrōns : Wht. red 6, G. Ev. S. Canaries brachyanthùm . White . 6, G. Ev. S. C. G. H. cāndicāns . - Blue . 6, G. Ev. S. Madeira capitātūm . : Red : 6, G. Ev. S. C. G. H. candatum : : Red: : , G. Her. P. C. G. H crêtícûm : : Red : : 7, H. Her. P. C. G. H.

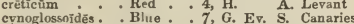

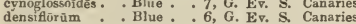

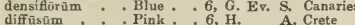
diffūsüm : : Pink : $:$, H. Ar A. Crete
fastuósũm : ferocissimuim : Blue :6, G. Ev. S. Madeir foliōsūm * White *, G. Ev. S. Canaries fruticoosūm. . Pink . . 5, G. Ev. S. C. G. H. gigāntēūm . : White * 6, G. Ev. S. Canaries glăntêm : : White : 5, G. Ev. S. C. G. H. glaucophyum : Violet : 5, G. Ev. S. C. G. H. glaucophy̆lūm
granditlórūm, 1 : Pink. : 6, G. Ev. S. Madeira

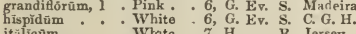
itülicūm lævigátūm lasiophyllam . lineātûm longiflōrūm longiflơrūm macrānthūin, macrophyllum marìtim ūm MertēnsII. micranthūm mölle

nervōsūm

nervôsūm

paniculātūm

parviflōrūm

plantaginoides

plantagineueum .

prostrătũm

pyramidātūm

pyrenāùm

salmånticonm

scāmañūn

scābrūm

sīmplēx.

spicátūm

strīctūm

strigösüm

tenưé

thyrsoidéñm

tuberculātüm

verrucōsūm

viviãcèù

virëstēns

vulgäré

forè-älbó

Whate

7, H. B. Jersey

Blue *

G. Ev. S. C. G. H.

White - 7, G. Ev. S. Canaries

Blue . 7, G. Ev. S. C. G. H.

Violet

7, G. Ev. S. C. G. H.
6, H.
A. S. Eur.

Violet

Blue

Blue

Blue
Violet

$7, \mathrm{H}$

A. Barbary

7, G. Ev. S: Canaries

6, H. Her. P. Spain

6, H. A. Barbary

White . 6, G. Ev. \&. Teneriffe

Purple : 7, G. Ev. S. Madeira

Pa.blue: 6, H. A. Levant

White \%, G. Ev. S. C. G. H.

Blue : 7, H.
White 6, H. B. Barbary

White

Purple

Red

$6, \mathrm{H}$.

7, H. Her. P. E. Italy

Blue . 7, G. Ev. S. C. G. H.

White

$7, \mathrm{G}$.
$7, \mathrm{H}$
$6, \mathrm{H}$.

B. Pyrenees

Pink

$6, \mathrm{H}$.

B. Hungary

A. Spain

Red

$6, \mathrm{H}$.

B. Europe

White

White
Blue.

6, G. Ev. S. Teneriff

Violet

7, G. Her. P. C. G. H.

6, G. Ev. \&. Canaries

8. G. Ev. S. C. G. H.

Blue

$7, \mathrm{H}$.

B. Sicily

Violet $8, \mathrm{H}$.

B. S. Eur.

White

7, $\mathrm{G}$.

B. Spain

Blue 6, G. E. S. C. G. H, 182

White: 7 , G. Ev. S. Canaries: 1820

Red

$\begin{array}{ll}7, \text { G. Ev. S. Canaries } \\ \text { H. H. } & \text { B. Britain }\end{array}$

7, $\mathrm{H}$.

B. Britain :

Ecrïpră. From ekleipo, to be deficient; the seedcrown and wing are wanting. Linn. 19, Or. 2, Nat. Or. Compositce. Uninteresting annuals and biennials of easy culture-erêctă, latifoliŭ, procūmb̋̉ns, prostrātŭ, punctātă, undulätă.

Ecostatr, having no nerves on the leaf.

EcrocARpẗs, Lyngbye. From ektos, outside, and

karpos, a fruit; the theca is not inclosed. Linn. [ 115 ]
24, Or. 7, Nat. Or. Alga. Mostly dark green marine productions, found in spring and summerbrachiütüs, granulösūs, tomentösùs, siliculossus atrŏvĭrēns-ferruginěrus.

Ectostrómă, Fries. From ektos, without, and strome, a hair. Linn. 24, Or. 9, Nat. Or. Fungi. Very minute species, to be met with during summer and autumn on the Iris, and decayed laurel leaves; whence their specific names-Irǐdis, Laûrí.

EDENTULîs, not toothed.

EDIBLE, eatable.

EDWĀRDsĩ̄, Salisbury. In hononr of Sydenham Edwards, a celebrated English botanical draughts man. Linn. 10, Or. 1, Nat. Or. Leguminose. A very ornamental genus of plants, which will survive our winters if planted against a warm wall, and protected from very severe frosts. 'They vary in height from four to twelve feet; they thrive best in sandy peat, and increase readily from cuttings. Synonyme: 1. Sophora sericea.

chilēnsiss . . Yellow . 5, G. Evv. T. Chile

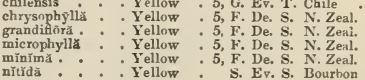

1822

1772

1818

Erruse, applied to inflorescence, and means a kind of panicle with a very loose arrangement.

EGg-hearkr, see Solünüm orìgĕnüm.

Eglantine, see $R$ Rosă lütěă.

EgLANTINE, see Rübǔs Eglanterrüu.

Egyptian Lotus, see Nymphäĕ Lotús.

Egyptian thorn, see $A$ cäcĭă vēră.

EhrÉtĭĂ, Linn. In honour of D. G. Ehret, a celebrated German botanical draughtsman. Linn. 5, Or. 1, Nat. Or. Ehretiacea. Stove plants, of much beauty, from eight to twenty-five feet high. They delight in loam and peat, and cuttings root in the same kind of soil, or in sand, under a glass, in heat. acuminătă . . White. . 7, G. Ev, T. N. Holl. 1820 asperä: : White: : S. Ev. T. E. lnd. : 179

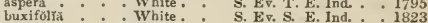

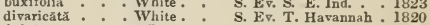
dübră : White. S. Ev. T. Jamaica : 1825 internōdis : : White. S. Ev. S. Antilles: 1819 lǣ̌rs - . White. - S. Ev. T. E. Ind. - 1823 lāxă * White : W. Wv. S. Bourbon - 1826 * White. * 7, S. Ev. S. E. Ind. • 1818 tinifollă : : White; ${ }^{*}$, S. Ev, T. Jâmaica: 1734

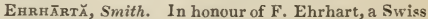
naturalist. Linn, 6, Or. 1, Nat. Or. Graminece. Plants which are only interesting in botanical collections. Synonyme: 1. Airacapensis.

panǐceă . . . A petal . . 7, Grass, C. G. H. . . 1790

calycīnă 1 , distichiphylla, gigantea.

EкввĒRĞ̌̆. Sparmann named this genus in compliment to C. Gustavus Ekeberg, captain of a Swedish East Indiaman, who took him out to China. Linn. 10, Or. 1, Nat. Or. Meliacea. A very ornamental tree, growing about twenty feet high; a mixture of loam and peat suits it, and young plants may be raised from cuttings, planted in sand, under a glass, in heat.

capēnsĩs . . White. . 7, G. Ev. T. C. G. H. $\quad 1789$

ELFĀGNŬs, Linn. From elaia, an olive, and agnos, a chaste tree; resemblance the tree bears. Linn. 4, Or. 1, Nat. Or. Elceagnacee. These are ornamental, largish-growing trees, or shrubs, of easy culture, thriving in any open soil, and are increased by layers or cuttings of the ripened wood, planted in a warm situation early in autumn. The fruit of $E$. urborea, and conferta, is eaten in Nepal; and in Persia the fruit of $E$. orientalis is used as a dessert, under the name of Zinzeyd.

acuminätr. . Apetal - G. Ev. S.

7, H. De, T, S. Eur. 1633 arböréa . . Apetal 7, G. Ev. T. Nepal : 1819 argēntéă - A petal H. De. T. N. Amer. . 1813 White H. De. S. Nepal . I I825

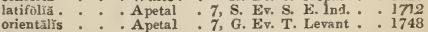

ËrĀis, Jacquin. From elaia, olive; the natives of Guinea express an oil from the fruit of this plant, is the Greeks do from their olives; whence the name Linn, 22, Or. 6, Nat. Or. Palmaceo. Beautiful species of palms, requiring a stroug heat, 
and rich sandy loam, to grow in, and may be increased by suckers. Palm oil is chiefly obtained from $E$. guineensis, and the best kind of palm wine is also said to be obtained from the same tree.

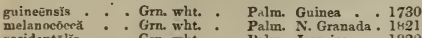
oecidentălis.: : Grn. whit. : Palm. Jamaica. : 1820

Er.zocĀrpǔs, Linn. From elaia, an olive, and karpos, a fruit; the fruit has been compared to an olive. Linn. 11, Or. 1, Nat. Or. Elaencarpacece. Very beautiful plants, from ten to twenty feet high. $E$. cy. aneus is excellently adapted for a conservatory They grow best in a mixture of loam and peat, and ripened cuttings strike in sand, or soil, under a glass, in a moderate heat; they are sometimes raised from seeds. Synonyme: 1 . E. reticulata.

cyăneŭs, 1 . . White. . 7, G. Ev. S. N. Holl. - 1803

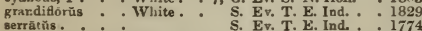

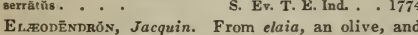
dendron, a tree; the fruit is like that of an olive, and the seeds are oily. Linn. 5, Or. 1, Nat. Or. Celastracere. This is an ornamental genus of plants, growing from three to twelve feet high; they delight in loam and peat, and cuttings root in sand, under a glass, in heat. Synonymes: 1. Portenschlagia australis, Lamarckia dentata. 2. Schrebera albens, Senacia glauca, Mangifera glauca. 3. Ru bentia olivina. 4. Cassine xylocarpa.

auctrālé, 1 . . . Gm. wht. . 7, G. Er. S. N. S. W. . 1796 glaūeúm, 2 : Green : S. Ev, S. Cevlon: 1824 integrifoliom: : Grn, whit.: 7, G. Ev. S. N. Holi. orientalé, 3 : Grn. yel. : S. Ev. T. Maurit.. : 1771 xylocârpúm 4 Grn. yel. S. Ev S. Antilles 1816

ElĀpHrỸō, Jacquin. From elaphros, contemptible; the wood being of no value. Linn. 8, Or. 1, Nat. Or. Burseriacer. A tallish-growing, ornamental tree, with white flowers; it succeeds well in peat and loam, and young plants are readily obtained from cuttings in sand, or sandy mould, under a glass, in heat. Synonyme: 1. Fagarn Elaphrium.

glăbrüm, 1. . . White. . S. Ev. T. Carthag. . 1818 ŁL̆̃T, Aiton. A name adopted from the Greeks. Liun. 21, Or. 6, Nat. Or. Palmacer. This is a fine palm, bearing fruit much like a wild plum. In the East Indies, the people chew it like the Areca nut, with the leaf of the betel, pepper, and quicklime. Elephants eat the fruit-stalks with avidity, on account of theirsweetness In our stoves, to grow the plant well, it must have a strong heat, and goud rich loam; increased by suckers.

sylvêstrìs . . Green . . 5, Palm. E. Ind.

1763

Eunts̄rücu, Linn. From elater, an impeller; in reference to the elastic seed-vessel. Linn. 91, Or. 10, Nat. Or. Cucurbitacee. A singular genus of plants, on account of the elastic seed-vessel; they have little beanty, and require the same treatment as Cucurbita.

earthaginènsé . Yellow . 6, H. Tw. A. Carthage - 1823 tamoides : Yellow：6, H. Tw. A. Mexico. : 1820

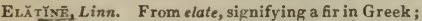
its Teaves have been eompared to those of the firtree. Linn. 8, Or. 4, Nat. Or. Elatinacea. Curious little aquatic plants, of no beauty; they merely require sowing by the side of a pond, or rivulet, in the open air. Synonyme: 1. E. triandra, hexandra, Hydropiper.

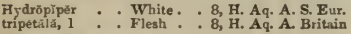

\section{ELDrR, see Sambñcŭs.}

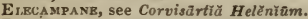

ElkctuÁRY, a medicine of conserves and powders, of the consistence of honey.

El,EGİ̃, Thunberg. From elegos, lamentation; in reference to the sad colour of the plants. Linn. 22, Or. 3, Nat. Or. Graminer. The species of this genus are only worth cultivating in botanical collections; they grow in a loamy soil, and are multiplied by divisions-junce̋̃ă, racemōsá.

Eletōtǐs, Decandille. From eleios, a dormouse, and ous otos, an ear; the leaves are shaped like the ears of a dormouse. Linn. 17, Or. 4, Nat. Or. Leguminosa. A stove biennial, of no interest whaterer.

Synonymes: Hedysarum sororium, Hallia sororia, Onobrychis sororia $\rightarrow$ sororia.

Eleōchăris, R. Brown. From helos, a marsh, and chairo, to delight; in allusion to the place where the plants delight to grow. Linn. 3, Or. 1, Nat. Or. Graminea. Mostly insignificant bog plants, which can only be recommended where there are botanical collections. Synonymes: 1. Scirpus acicularis. 2. S. multicaulis. acūtx.

geniculātă * A petal * 7, Grass. N. Holl. . 1819 glaucéscéns: : A petal : : 7, Grass. W. Ind. * 182: multicaúliss, 2 : A petal : 7, Grass Britain obtūsü Apetal : 6, Grass. N. Amer. 1818 ténıüs : : : A petal : : 7, Grass. N. Amer. : 1824

aciculärĭs 1, ovata, palustris.

ELEPH A NTİ̃sis, a species of leprosy, in which the limbs become prodigiously swollen.

Erephāxtōpuัs, Cassini. From elephas, an elephant, and pous, a foot; the radical leaves resemble an elephant's foot. Linn. 19, Or. 5, Nat. Or. Composite. The plants of this genus possess but very fittle beauty; they grow in any common soil, and are multiplied from seeds and offsets. On the coast of Malabar, a decoction of the leaves and roots of $\boldsymbol{E}$. scaber is given in cases of dysuria-anyustifolins, caroliniūnũs, mollis, nudicaũlis, nudiflorūs, scàbèr, spicātüs, tomentosüs.

Erisphant's-roor, see Elephäntopüs.

Erephant's-poot, see Testudinüriă Elephäntīpěs.

Enbusĩñ,, Guertner. Derived from Eleusis, one of the appellations of Ceres, Linn. 3, Or. 2, Nat. Or. Graminea. Species of grass, of little beauty, and easy culture. Synonyme: 1. Cynosurus indicus.

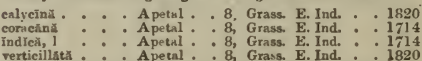

Eravated, any thing that rises above the surface.

Erichassex. From helios, sin, and chrysos, gold: in allusion to the brilliant flowers. Linn. 19, Or. 2, Nat. Or. Compositue. This genus is greatly admired on account of the beautiful flowers of some of the species. The soil in which they grow best, is a mixture of three parts peat, and one part saudy loam. Cuttings will strike in the same kind of soil, if they are taken off at a joint; some of the species seed freely, from which they may be increased. Synonymes: 1. Gnaphalium acuminatum. 2. G. angustifolium. 3. G. apiculatum. 4. G. arboreum. 5. G. arenarium. 6. G. candidissimum. 7. G. cephalotus. 8. G. congestum. 9. G. conicum, 10. G. cras sifolium. 11. G. crispum. 12. G. cymosum. 13. G. dasyanthum. 14. G. diosmofolium. 15. G. discolor. 16. G. divaricatum. 17. G. ericoides. i8. G. fatidum. 19. G. fluccidum. 20. Astelma fruticans, G. fruticans, grandiflorum. 21. G. grandiflorum. 22. G. graveolens. 23. G. helianthemifolium. 24. Elich-splendens. 25. G. ignescens. 26. G. italicum. 27. G. lasiocaulon. 28. G. maritimum. 29. G. odoratissimum. 30 . G. orientale. 31. G. patulum. 32. G. rutilans. 33. G. Stuechas. 34. G. tephrodes. 35. G. teretifolium.

acuminatūm, 1 angustifoliom, 2 . a piculatūm, 3 arboreûm, 4 arboreüm, 4 arenăriúm, argènt

bracteát đim

nvoluero-albrd candidīss Iñ ūxn, 6 cephalotés, 7 . congēstùm, 8 cỏnieûm, 9 crassifoliūm, io crīspüm, 11 eylindricóm cymôsūm, 12 dasyânthưm, i3 dealbätúm. diosmæf ðirūm, 14 discolorūm, 15 discolorüm, 15 . divarieåtùm, 16 ericoìdēs, 17 . fçetrdūm, 18 . frütieans, 20 . fülgĩdüm.
White Yellow Yellow White Yellow Yellow Yellow Pa yel. Yellow Pa. yel Pink Purple Yellow Yellow Pink. Yellow Yellow Yellow White White Brown Brown Wink. Pink . Lgt. yel Yellow Yellow : 7, G. Ev. S. C. G. H. . 1779
Yellow : 7, G. Ev. S. C. G. H. . 1774 [ 116 ]

7, G. Ev. S. C. G. H. . 1823 F. Ev. S. Naples

, Kv. P. V. D. L. . 180 , . . . . 1770 6, G. Her. P. C. G. H. 1800 7 . H. A. V. D. L. 1835 9, H. A. N. Holl. . 1799 7, H. H. A. Paspian 1833 6, G. Ev. S. C. G. H. 1789 6, G. Ev S. C. G. H 7 . E. S. C 179 B, G. Ev. S. C. G. H. . 1774 G. Her. P. C. G. H. . 1809 6, G. Her. P. C. G. H. . 1780 6, G. Her. P. Africa : 1731 7, G. Ev. S. C. G. H. 1812 6, G. Ev. S. C. G. H. 1819 $7, G$, S. C. H H 1815 6, G. Ev. S. C. G. H. . 1774 8, G. B. C. G. H. . 1699 7, G. Ev. S. C. G. H. . 1820 
grandiflörūm, 21 . White - 7, G. Ev. S. C. G. H. . 1731 gravēolẻns, 22 : Yellow. . 6, H. Her. P. Tauria . 1819 helianthemifolium 23 White : 7, G. Ev. S. C. G. H. . 1774 herbācēum, 24. Yellow: 7, G. Her, P. C. G. H. 1802 ignêscēns, 25 . : : Red : 8, G. Ev. S. C. G. H. . 1731 ignẽscēns, 25 * : Pa. yel. : 5 G. Her. P. V. D. L. . 1896 ităricūm, $26:$ : Yellow : 8, G. Her. P. Italy. : 1826

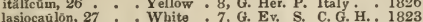
lasiocaūlôn, 27 : . White * 7, G. Ev. S. C. G. H. . 1823 marĭtĭmūm, 28 * ' ' 8, G. Ev. S. C. G. H. . 1772 microphyllum :. Whit. yel. 7, G. Ev. S. C. G. H. . 1823

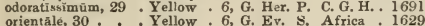
prientảlé, 30 : : Yellow * 6, G. Ev. S. Africa * 1629 patũlūm, 31 : : White : 5, G. Ev. S. C. G. H. . 1771 rĭgðūm rütilāns, $3 \dot{2}:$ : Red yel. : 6, G. Her. P. C. G. H. . 1731 rútilảns, 32 * * Red yel. . 6, G. Her. P. C. G. H. 1731

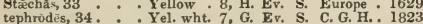

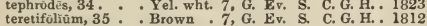

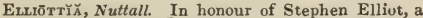
North American botanist. Linn. 8, Or. 1, Nat. Or. Ericacee. An ornamental species, succeeding best in a little sandy loam, mixed with peat; it is increased by layers.

racemósã . . . White . 6, F. Ev, S. Georgia .

Er.ı̄sĬ L̆, Linn. In honour of J. Ellis, F.R.S., a distinguished English naturalist. Linn. 5, Or. ], Nat. Or. Hydrophyllacea. A curious little species, of very easy culture.

Nyctelea . . White. . 7, H. A. Virginia . 1755

Ellzbocārpŭs, Kaulfuss. Detived from en, in, lobos, a pod, and karpos, fruit; in reference to the divisions of the fronds. Linn. 24, Or. 1. Nat. Or. Gleicheniaeea. An ornamental species of fern, of considerable beauty; it grows in a loamy soil, and is increased by dividing the roots.

olerăcěus . . . Brown . 8, S. Her. P. Tranqueb.. 1818

ELupsoid, like an ellipsis.

Elliptic-lancBolate, a form between elliptic and lanceolate.

Euš̄nă, Herbert. An ancient name of romance. Linn. 6, Or. 1, Nat. Or. Amaryllidacea. This splendid species will form a welcome addition to the cultivators of bulbous plants. It will no doubt be found to succeed well with the treatment commonly yiven to Pancratiums, and the like.

longipetală . . White . . 5, S. Bl. P. Lima . . 1837

ELM TREB, see Ulmŭs.

ELōDẽ Ă, Richard. From elodes, a marsh; the habitation of the plants. Linn. 3, Or. 3, Nat. Or. Hydro. characec. Interesting aquatics; for culture, \&c., see Plumieria.

guianēnsĩs . . White. . 7. S. Aq. A. Guiana . . 1820 pulanensis : : Whalle.
S. Aq. A. E. Ind. : 1831

Elongaten, lengthened.

Eıshōrtzĭa, Willdenow. In honour of J. S. Elsholtz, a Prussian botanist. Linn. 14, Or. 1, Nat. Or. Labiatc. The species are not ornamental, and may be referred to Hyssopus, for culture, \&c. Synonyme: 1. Hyssopus cristatus.

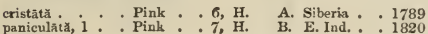
ocymoĩdés.

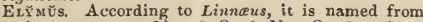
elyo, to cover. Linn. 3, Or. 3, Nat. Or. Graminec. The plants of this genus are of little beauty or interest, except in botanical collections; they grow in any soil, and are increased by seeds, or divisions. Synonyme: 1. Asperella hystrix.

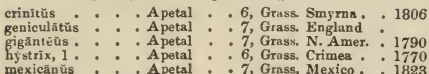

arenärĭǔs, canadēnsǐs, Caput-Medūsā, europāŭs, glaucifolīüs, hordeiformìs, intermědiùs, jūncēüs, philadēlphīcūs, pseudo-hȳstrīx, racemösŭs, sabulosūs, sibirĭcüs, st riātŭs, tēnër, villosŭs, virgǐnīcūs.

ELĪ Să, Schrader. Supposed to be from elyo, to cover. Linn. 3, Or. 1, Nat. Or. Graminea. A dwarf species of grass, of little interest, and very easy culture. Synonymes: 1. Carex Bellardi, myosuroides.

spicātā, 1 . . A petal . . 6, Gras6. Europe . . 1819

Elxträrĭ, Vahl. From elytron, an envelope; in allusion to the scaly stem. Linn. 2, Or. 1, Nat. [ 117 ]
Or. Acrinthacea. A genus of uninteresting stove biennials, growing in sandy peat. Synonyme: 1. Justicia acaulis - caulescens, crenata 1 , imbricuta, lyrata, marginata, ramosu, virgata.

EMARGINATB, having a small notch at the end.

EмBĒLIĂ, Linn. In Ceylon, the plant is called $\mathrm{Em}$ belia. Linn. 5, Or. 1, Nat. Or. Myrsinacea. fine East Indian tree, growing twenty feet high; loam and peat mixed suit it, and young plants are readily obtained from cuttings in sand, under a glass, in heat. The plant is said to be cathartic.

rohüstă . . . .Wht. grn. . S. Ev. T. E. Ind. . . 1823

Eмвцїс̆, Gartner. The name of the plant in the Moluccas. Linn. 21, Or. 10, Nat. Or. Euphorbiaces. Interesting, evergreen shrubs, growing from three to twelve feet high; a mixture of peat and sand suits them. Cuttings root readily in sand, under a glass, in heat. Synonymes: 1. Phyllanthus Emblica. 2. $P$. racemosus.

officinălis, 1 - Pa. yel. . 7, S. Ev. S. E. Ind. . . 1768 racemósã, 2 . . Grn. yel. . 7, S. Ev. S. E. Ind. . . 1798

Embossed, projecting from the surface, like the boss or umbo of a round shield, or target.

Eмвотнгі̄m, Forster. From en, in, and bothrion, a little pit; in allusion to tl.e anthers. Linn. 4, Or. 1, Nat. Or. Proteacea. This is described as a very handsome plant, growing about three feet high; like most of the Proteacea, it delights in sandy peat soil, and cuttings, in sand or soil, readily produce roots.

strobilinūm . . Grn. yel. . 4, G. Ev. S. N. Holl.

Emrracing; a leaf is said to embrace a stem when it clasps it round with its base.

EMET1c, that which produces vomiting.

$\mathrm{E}_{\mathrm{M} \overline{\mathrm{E}} \mathrm{x}}$ Necker. An anagram of Rumex. Linn. 6, Or. 3, Nat. Or. Polyyonacee. This species is only worth cultivating in general collections. sy. nonyme: 1. Rumex spinosus.

spinôsŭs . . Green . . 7, H. Tr. A. Candia . . 1556

Emmenagogur, any medicine that promotes menstruation.

Emollibit, softening.

EMPETREM, Linn. From en, upon, and petros, a rock alluding to the place of growth. Linn. 22, Or. 3, Nat. Or. Empetraced. These are interesting dwarf plants, of easy culture, delighting in elevated, particularly exposed situations, on dry, barren, moorish, or even boggy soil. The little berries they pro. duce are eaten by children, but are not wholesome if eaten in large quantities.

nĪgrūm . . Apetal . 4, H. Ev. S. Britain

rübrūm: : Brn. pur. H. Ev. S. S. Amer. : 183

Emplā̃ūu, Solander. From en, in, and pleuron, the membrane which envelops the lungs; the seedsare attached to a coriaceous membrane. Linn. 21, Or. 4, Nat. Or. Rutaces. A good greenhouse plant, with pretty pinkish flowers. It grows abuut three feet high; for culture, \&c., see Diosma.

serrulătūm. . Pink . . 6, G. Ev. S. C. G. H. . 1774

EmuLsions, medicines made of bruised oily seeds and fluid.

Enarthrocārpǔs, Labillardière. From ennea, nine, arthron, a joint, and karpos, fruit ; the pod has nine or ten seeds in the lower joint. Linn. 15, Nat. Or. Cruciferc. These are insignificant hardy annuals, only fit for botanical collections. Synonyme: 1 . Raphanus pterocarpus-arcuätŭs, pterocārpuัs 1.

ENCALT̄pră, Hedwig. From en, within, and kalypter, a covering; the calyptra is unusually large, entirely enclosing the thecæ. Linn. 24, Or. 5 , Nat. Or. Musci. Small, mostly greenish plants, found at all seasons on mountains, moist rocks, \&c. Synonyme: 1. Bryum extinctorium-ciliata, alpina, concolor, rhaptocarpa, streptocarpa, vulgaris 1.

Escĭlı̆ Adanson. Derived from egchelion, a little eel; in allusion to the appearance of the seeds. Linn. 19, Or. 3, Nat. Or. Composita. Very pretty dwarfish shrubs, growing best in loamy soil, or loam and peat mixed. Cuttings strike with ease in sand, under a glass, if not over-watered. Synonymes: 1. Pallasia halimifolia. 2. P. grandiflora.

canēscëns, 1 . . Orange . 7, G. Ev. S. Peru . . 1786 halimifölix, 2: . Yellow : 7, G. Ev. S. Mexico: I82i 
Encuanter's Nightshads, see Circẫu.

Exc̄̄êtū M, Agardh. From en, within, and koilos, hollow; the fronds are tubular and hollow. Linn. 24 , Or. 7 , Nat. Or. Algue. Plants found during the summer and autumn on the sea-coast. Synonyme: 1. Vlva fistulosa - bullosum, Lyngbyanum l.

Endivi, see Cichörīũm endĩvĩü.

ExDOCARP, the inner lining of fruits, which forms the cells.

ExDocãrpön, Hedwig. From endon, within, and karpos, a fruit; the receptacles are deeply imbedded in the leaf. Linn. 24, Or. 8, Nat. Or. Lichenes. Green and greyish species, found most plentiful in summer, on rocks. Synonyme: 1. Lichen fuscellus-complicātūm, Hedwĩgīin, lächnēūm, lepto-

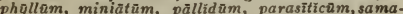

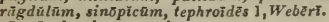

ENERVIs, having no veins.

ENGLISH MERCURY, see Chenopðdĩnm Bonús Henricŭs.

ENKIÃNThuัs, Loureiro. From enkous, pregnant, and anthos, a flower; the flowers are swollen. Linn. 10, Or. 1, Nat. Or. Ericacece. Most beautiful greenhouse plants, which Sweet says, " have been considered difficult to propagate. The difficulty is now removed, as ripened cuttings root readily, planted in pots of sand, and placed under a hand. glass, without bottom heat. The best soil for them is an equal mixture of sandy loam and peat, and care must be taken not to over-water them, when not in a growing state. When they become pretty large, they are the greatest ornament for the greenhouse, or conservatory."

quinqueflorŭs : Pink : 5, G. Ev. S. China
reticulatūs.

1812

1822

E`ōprs, without knots, smooth.

Exnopisū R $\tilde{h}$, the inner coat of seeds, under the spermodermis.

ENsate, or вNsifori, shaped like a sword, with a straight blade.

ENTÃDA, Adanson. The name given to one of the species in Malabar. Linn. 23, Or. 1, Nat. Or. Leguminosc. Ornamental stove climbers, of easy culture; loam and peat are the best soil for the plants, and sand for cuttings, in which they soon take root, if under a glass, in heat. The natives use the seeds of $E$. Pursctha for washing the hair. Synonymes: 1. Adenanthera scandens. 2. Mimosa scandens. 3. M. Entada. 4. M. polystachya. 5. MI. scandens.

Adenanthêrŭ, 1 White , S. Ev. CL, S. Sea Isl. , 1817 S. Ev. Cl. Gigalocium, 2, White: : S. Ev. CL. W. Ind. : 1819 monostachyd, 3 : White : S. Wv. Cl. W. Ind. : 1816 Pursietha, 5 . : White : S. Er Cl. E. Ind. . 1780

Entri.̃. $\tilde{X}, \boldsymbol{R}$. Bronin. From enteles; alluding to the stamens being all perfect. Linn. 13, Or. 1, Net. Or. Tiliacec. These plants are well worth cultiwith a little sandy peat, and are propagated by cuttings in sand.

arlırêscēns . White. . 5, G. Ev. T. N. Zeal. . 1820 palmâta

G. Ev. T.
G. Ev. S.

EPĀCRIs, Forster. From epi, upon, and akros, the top: in reference to the species growing on the tops of hills. Linn. 5, Or. 1, Nat. Or. Epacridacere. Very elegant greenhouse plants, growing in general from two to four feet high; they grow best in a very sandy peat soil, and the rougher and more turfy the soil is, the better the plants will thrive. If the plants are to be turned out of doors from the greenhouse in summer, they ought, just before, to be shifted into fresh pots and soil, otherwise, the roots being so fine, the hot sun against the pots is apt to destroy the points of them, and frequently kills the plant altogether. Cuttings taken from the tips of the young shoots, and planted in sand, under a glass, in autumn, winter, or spring, will root readily; but they will not strike so freely in summer. When rooted, they should be potted singly in small pots, and set in a close frame, and bardened to the air by degrees.

\section{apiculata}

. 5, G. Ev. S. N. Holl.

ceraflory
. Dp. blusk. 4, G. Ev. S. N. Holl.

glbr . White. 4, G. Ev. S. N. S. W.

exserta

White:

, G. Ev. S. N. S. W. grnndifloră: : Scarlet: 3, G. Ev. S. N. S. W. : 1803

4, G. Ev. S. V. D. L.

1825

1830

1830

1831

heteronēma . . White . . 6, G. Ev. S. N. Holl. . 1823

impréssa - Crimson : 6, G. Ev. S. N. Holl 1894

microphylla : $\quad$ G. Ev. S. N. Holl. : 1822

mucronulată : - Red * 5, G. Ev, S. N. Holl. : 1824

nivalis . : White: 2, G. Ev S. N. Holl. : 1899

obtusifolix: : White : 5, G. Ev. S. N. S. w. : 1804

onosmæföră : : Red : 6, G. Ev. S. N. Holl. : 1823

paludosa * . Pa red . 5, G. Ev. S N.Holl. : 1825

pulchểll : . . Pink . . 5, G. Ev. S. N. S. W. : 1804

purpurāscēns - Purple . 2, G. Ev, S. N. S. W. . 1803

ruscifoliă : : : 2, G. Ev. S. N. Holl. : 1803

spärsa $: \vdots$ : white. : 5, G. Ev. \& N. Holl : 1824

variabilis : : : Pink : 3, G. Ev. S. N. S. w. : 1829

EPHĒDR, Linn. The Greek name for the herb horsetail; because of the resemblance. Linn. 22, Or. 18, Nat. Or. Gnetacea. This is a curious genus of plants, succeeding in any common garden soil, and young plants are obtained by layering the shoots or branches. "The berries," says Mr. Loudon, "ripen in July and Angust; they are sweetish, mucous, and leave a little heat in the throat. They are eaten by the Russian peasants, and by the wandering hordes of all Great Tartary."

altissima . . A petal. F. Ev. Tw. Barbary . $1 \cap 25$

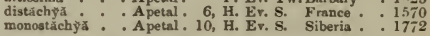

EPHL̄MǨrs, thing of a day's continuance.

Epicarp, the outside covering of a fruit.

EPIDENDRŨ M, Linn. From epi, upon, and dendron, a tree; the plants are usually found growing on the branches of trees. Linn. 20, Or. 1, Nat. Or. Orchidacex. This is a very extensive genus of epiphytes, many of which are highly deserving of culture, either for the beauty or delicious fragrance of their flowers. They thrive best when grown in a good strong heat, and a plentiful supply of water; they may be potted, and otherwise treated as the Stanhopeas. Synonymes: 1. Epidendrum ellipticum. 2. E. ciliare. 3. E. lineatum. 4. E. anceps. 5. Epithecia glauca. 6. Encyclia patens. 7. Hormidium uniflorum. 8. Encyclia viridiflora.

cemülam

altiss:mam

armenfỉcŭm

nromaticūin

asperám

aurantiacam

bicornūtūm

bifudūm.

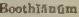

calsmiriom

cauliftorom

chlorĭnthūm

chlmroloúeñm

ciliarét

clavitam

cochleât tum

conopsentm.

crassifolrūm,

cucullatūn

cuspidátúm, 2

dichotómun

diffusũm

ellipticeúm

elongătûm

equitans

floribūndūm

frä́grâns, 3 .

fucătūm

fuscattūm, 4

glaũeณิm, 5 .

grăchlé

Hatrisonī

ionరิธmuีm

lăcêrnìm.

lividūm

longieollia

macrochilum

noctârnùm .

latifolium

nótśns

oolirăceùm.

odoratissimn

oncidioidés.

pachrsintham

papillósūm

pastoórís .

pătêns

primulinom

pygmāūm .

rlixophor rigidüm.

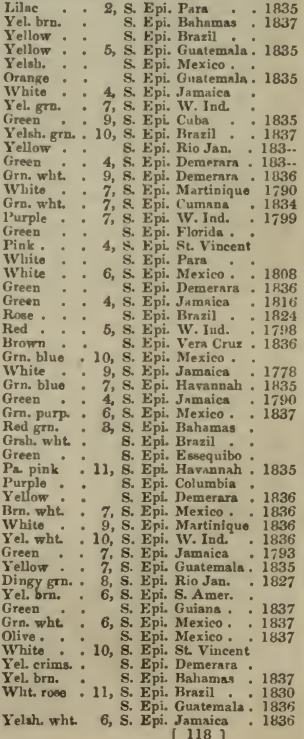




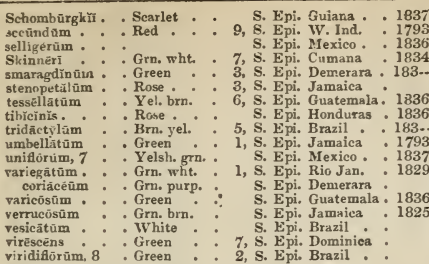

EPIDËrMis, the outer skin of a piant.

EpIGÆ̆, Linn. From epi, upon, and gaia, the earth; alluding to the trailing habit of the plant. Linn. 10, Or. 1, Nat. Or. Ericaces. These are very pretty trailing plants, and to grow well, they require a sandy peat soil, mixed with a very listle loam, and are most readily increased from layers.

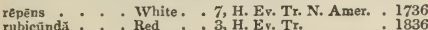

Epı̌ŏвīūm, Linn. From epi, upon, and lobos, a lobe the flowers have the appearance of being seated on the top of the pod. Linn. 8, Or. 1, Nat. Or. Onagraced. Many of the species of this genus are very ornamental, as $E$. angustifolium, while a few others, such as $E$. montanum, are mere weeds. They all grow well in common soil, and are either increased by seeds, or by dividing the roots. Sy nonymes: 1. E. Halleri. 2. E. molle. 3. E. squamatum.

slpëstrĕ

angustifơlinùm - Purple

ălbom

- Purple

6, H. Her. P. Switzerl.

1820

angustissimüm : Purple

colorătum . . Purple

crassifouliūm : Red

dahūricūm . : : White

Dodnnǣi, 1 : Purple
hirsūtūm

variegãtum - Rosy

lenceolätūm - Purp

obscūrūm : : Purple

parviflórûm, 2. Purple

rosmarinifolium, 3 Purple

spicátüm . . Purple

strictüm . . Purple

tomentōsūm : Purple

7, H. Her. P. Britain

7, H. Her. P. Britain

6, H. Her. P. N. Amer.

6, H. Her. P.

7, H. Her. P. France

7, H. Aq. P. Britain

6, H. Her. P. England

7, H. Her. P. Italy

6, H. Her. P. N. Eur.

7 , H. Her. P. Europe

7, H. Her. P. Britain

6, H. Her. P. N. Amer.

6, H. Her. P. N. Amer.

7, H. Her. P. Pennsyl

6, H. Her. P. Asia.

1775

1805

1829
1822

1700

1810

1779

1800

1817

1818

$1 \% 99$

alp̄̄nūm, alsinifolī̄m, montänūm, palūstrĕ, rǒsěûm, tetragőnūm.

Epimp̄ồ, Linn. From epi, upon, and Media; the plants were said to grow in Media. Linn. 4, Or. 1, Nat. Or. Berberacce. Elegant little plants, succeeding best in sandy peat soll, and may be in. creased by dividing the roots. $E$. grandiflorum requires to be grown in a cold frame, with the same kind of soil as recommended for the others.

alpinam

diphyllüm: : Red : 5, H. Her. P. Japan : 1830 grandiflorum : White. I F. Her. P. Japan : 1836 hexãndrüm : Lilac : $5, \mathrm{H}$. Her. P. N. Amer. 1827
violacēum

EPrPĀctís, Haller. From epipegnus, to coagulate; alluding to its supposed effect on milk Linn. 20, Or. 1, Nat. Or. Orchidacev. Pretty plants, thriving well in the flower-border, or in pots, in a mixture of peat and loam, very sparingly watered when in a torpid state. They are increased by divisions of the roots.

\section{Latiföliă . - Purple * 7, H. Ter. Britain \\ palũstris *. Purple . 7, H. Ter, Britain}

purpurătă . . Purple . . 6, H. Ter. England

\section{Ep1phylious, growing upon the leaves.}

EPIPHỸLlum, Haworth. From epi, upon, and phyllon, a leaf; alluding to the flowers growing from the flat branches, which appear like leaves. Linn. 12 Or. 1, Nat. Or. Cactacea. These splendid-flowering plants are the pride of every well-furnished garden. Their culture and propagation are the same as that recommended for Cereus, and the other genera of this order. Synonymes: 1. Cactus phyllanthus.
C. phyllanthoides. 3. C. speciosa, elegans. 4. C. truncata.

AckermännI . . Scarlet . 6, S. Ev. S. Mexico . 1829 alätūm . . White . 6, S. Ev. S. N. Amer, 1810 coccinéum * Scarlet , 6, s, Ev, S. Brazil - 182 , Ev. S. Brazil Hookērí, 1: : White. . 6, S. Ev. S. S. Amer. phyllanthoidẽs, 2. Pa red S. Ev. S. Jamaica phyllanthoíäs, 2. Pa red : White. S. Ev. S. Jamaica Phyllänthŭs ramulōsūm rhơmbeūm speciósūm, 3 S. Ev. S.

S. Ev, S. coccīnéŭm

Pink

6, S. Ev. S. Brazil

6, S. Ev. S. Brazil

Scarlet

6, S. Ev. S.

Ep1phyтks, plants which grow upon other plants without deriving any nutriment from them.

EPıstǒm ̌̌ Ŭs, spigot-shaped.

Equal, applied to petals and sepals when they are equal in size and shape with each other.

EQuĒstrĭs, fancied reseniblance to a horse's head.

Equidists̄int, equally distant.

Equilateral, having equal sides.

Equis̄̄tēm, Linn. From equus, a horse, and seta. hair; in allusion to the fine hair-like branches. Linn. 24, Or. 2, Nat. Or. Equisetacee. Although looked upon as mere weeds, they have a very interesting aspect when seen growing in their natural situations; they are found in boggy places, and multiplied by divisions-arvēnsě, Drummōndī, fluviätīlè, hyemale, limossũm, palūstrě, pratēnse, scirpoīdes, sylvătî́cūm, umbrōsūm, variegūtūm.

Equitant, a mode of arrangement of leaveg with respect to each other, in which the sides or edges al ternately overlap each other.

ERAgrōstis, Beauvois. From eros, love, and agrostis, grass; in allusion to the beautiful dancing spikelets; whence the English name, Love Grass. Linn. 3, Or. 2, Nat. Or. Graminea. Pretty species of grass, growing about a foot high, in any common soil. Synonymes: 1. Poa cynosuroides. 2. P. mexicana. 3. P. Eragrositis.

7. Grass. Egypt 1812

cynosuroides, $1^{\circ}$ : A petal : F, Grass. Egypt : 1824

decipiêns : . A petal : 7, Grass. 1819

mexicănă, 2 . A petal . 7, Grass.

pilōsă $\dot{3}$ - A petal * 7, Grass. Italy * - 1804

poæformis, 3 - Apetal * 7, Grass. Greece : 1699

punctata. * A petal * 7, Grass. Malabar . 1820

purpuráscẻns : : A petal : * 7, Grass, E. Ind. : 1817

tephrosanthếs : : A petal : : 7, Grass. Martinique . 1818

verticilläă . : A petal : 7, Grass. S. Eur. * 1820

Eranthŭmēm, R. Brown. From ear, spring, and anthos, a flower; applied by the ancients to their Anthemis. Linn. 2, Or. 1, Nat. Or. Acanthacea. The species of this genus are very pretty, and succeed well in sandy peat soil, and cuttings take readily in sand, tunder a glass, in heat.

ambĭgŭūm . . Red . 7, S. E v. S.

\%. Sucona : 1802

capensë. : Purple - 5, G. Ev. S. E: Ind. . 1818

crenulātūm . Lilac . 10, S. Ev. S. Nepal . 1824

êlègāns . . Scarlet . 6, S. Ev. S. Guinea . . 1824

fæcūndūm . - Lilae. * 6, S. Ev. S. Brazil * 1829

pulchellūm * Blue . 4, S. Ev. S. E. Ind. . . 1796

Red . 5, S. Ev. S. E. Ind. * 1820

spinósüm - * purple $:$ 7, S. Ev. S. W. Ind. 1733

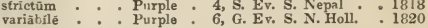

Erānthis, Salisbury. From erao, to love, and anthos, a flower; the bright yellow flowers are produced in winter. Linn. 13, Or. 6, Nat. Or. Ranunculacea. The species are dwarf, ornamental plants, of easy culture. Synonyme: 1. Helleborus hyemalis.

hyemălǐs, 1 . Yellow . 2, H. Tu. P. Italy . . 1596 síbirică : Yellow: 3, H. Tu P. Siberia : 1826

ErkctLy-Sfrkading, between erect and spreading.

ERRMÜrǓs, Bieberstein. From eremos, solitary, and oura, tail; spikes solitary. Linn. 6, Or. 1, Nat. Or. Liliacec. An ornamental species; for culture, \&c., see Asphodelus. Synonyme: 1. Asphodelus aitaicus.

spectäbřliss . . Yellow . 5, H. Her. P. Siberia . . 1800

Ěr̆, Lindley. From erion, wool; in allusion to the woolliness of the flower. Linn. 20, Or. 1, Nat. Or. Orchidacece. The species of this genus are very pretty when in flower. They require the [ 119 ] 


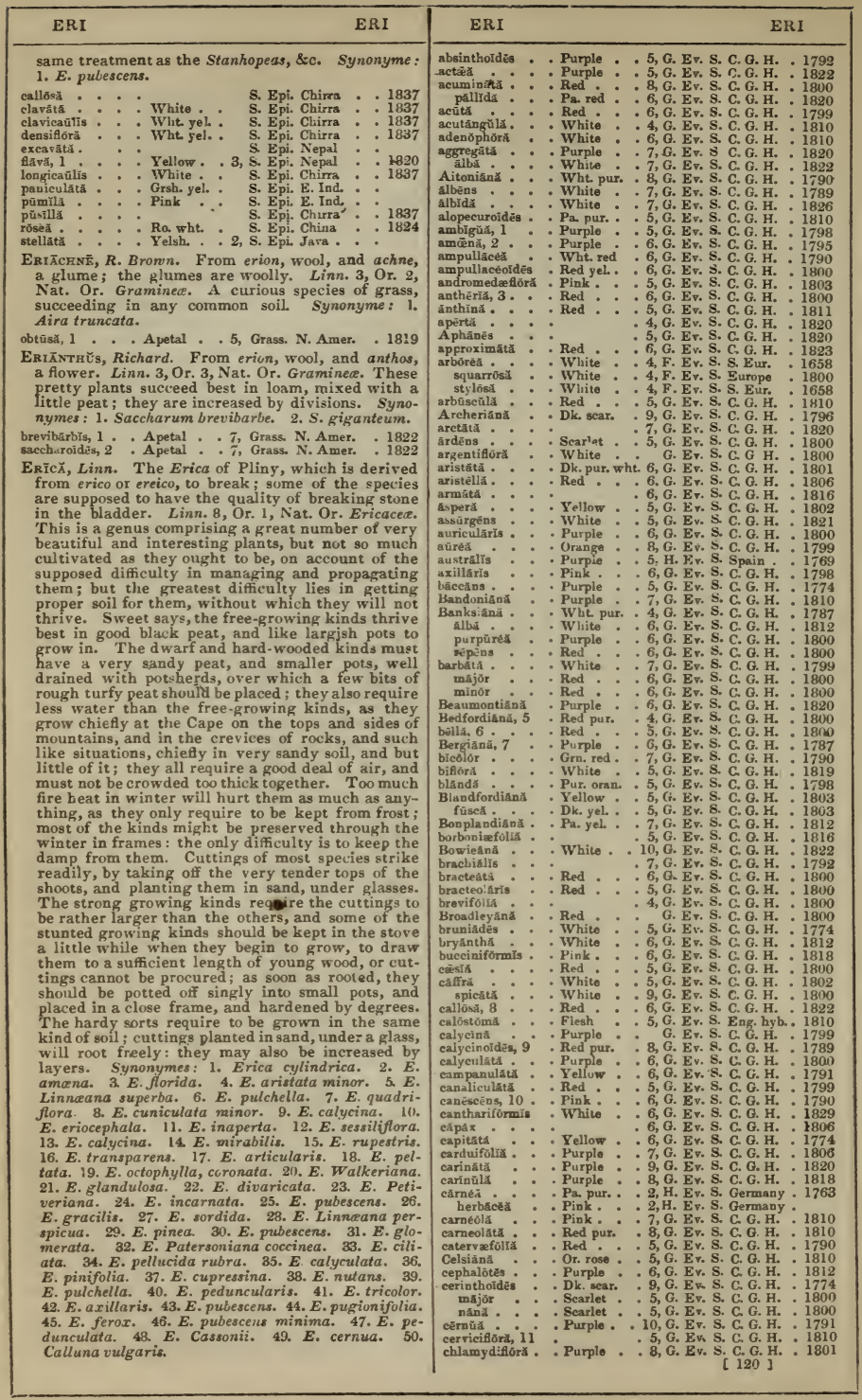




\begin{tabular}{|c|c|c|c|c|c|c|c|c|c|}
\hline \multicolumn{2}{|l|}{ ERI } & \multicolumn{3}{|c|}{ ERI } & \multicolumn{3}{|l|}{ ERI } & \multicolumn{2}{|c|}{ ERI } \\
\hline 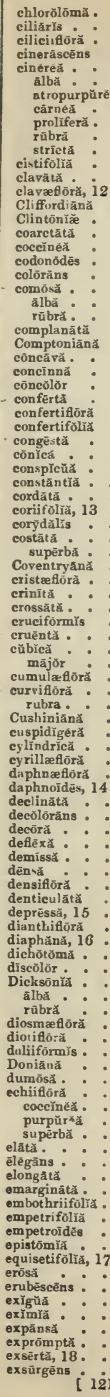 & 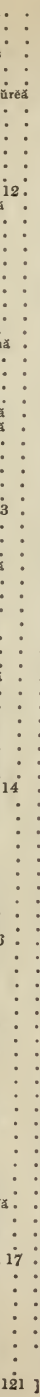 & 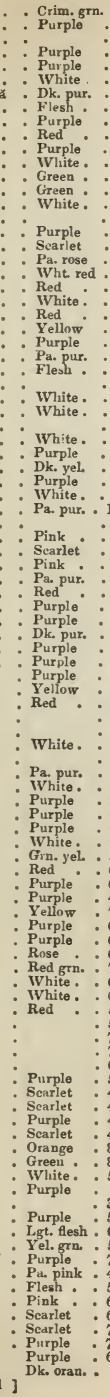 & 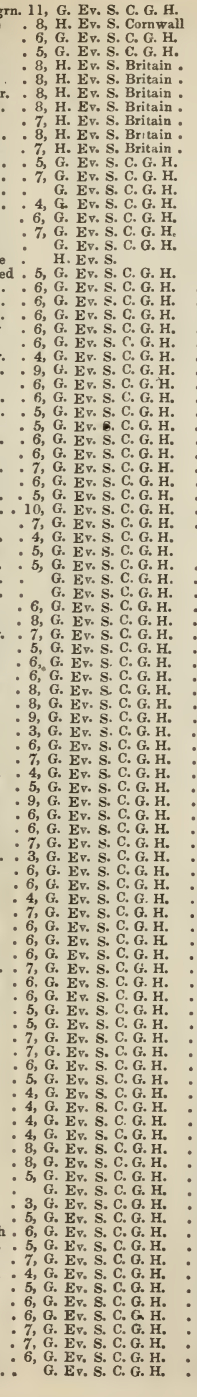 & 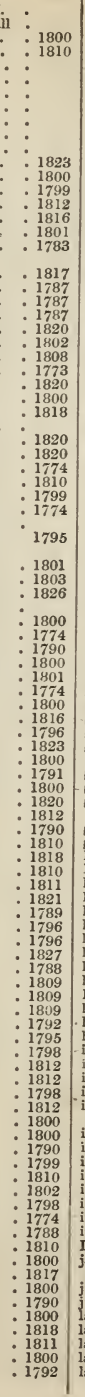 & 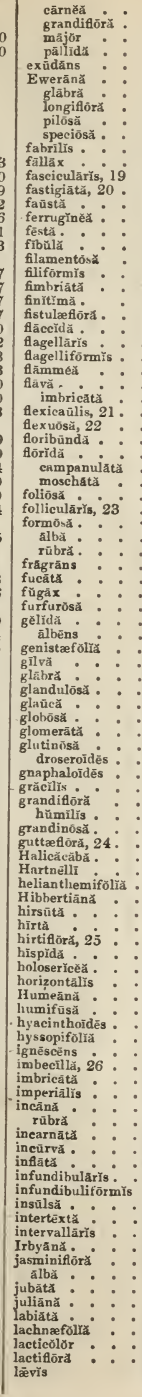 & 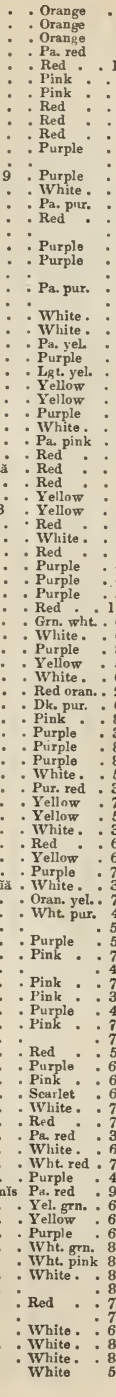 & 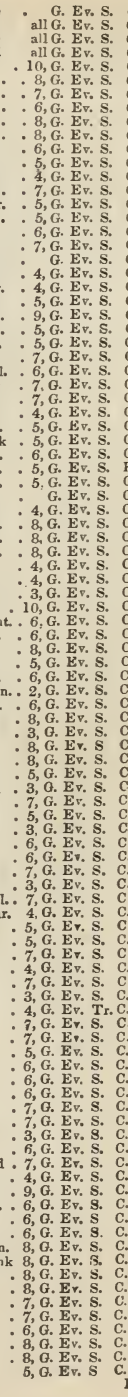 & 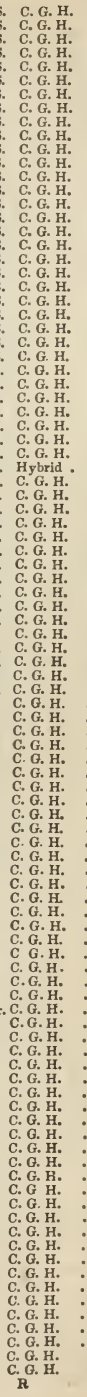 & 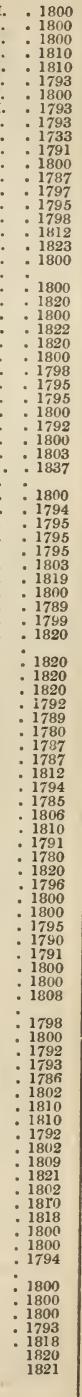 \\
\hline
\end{tabular}




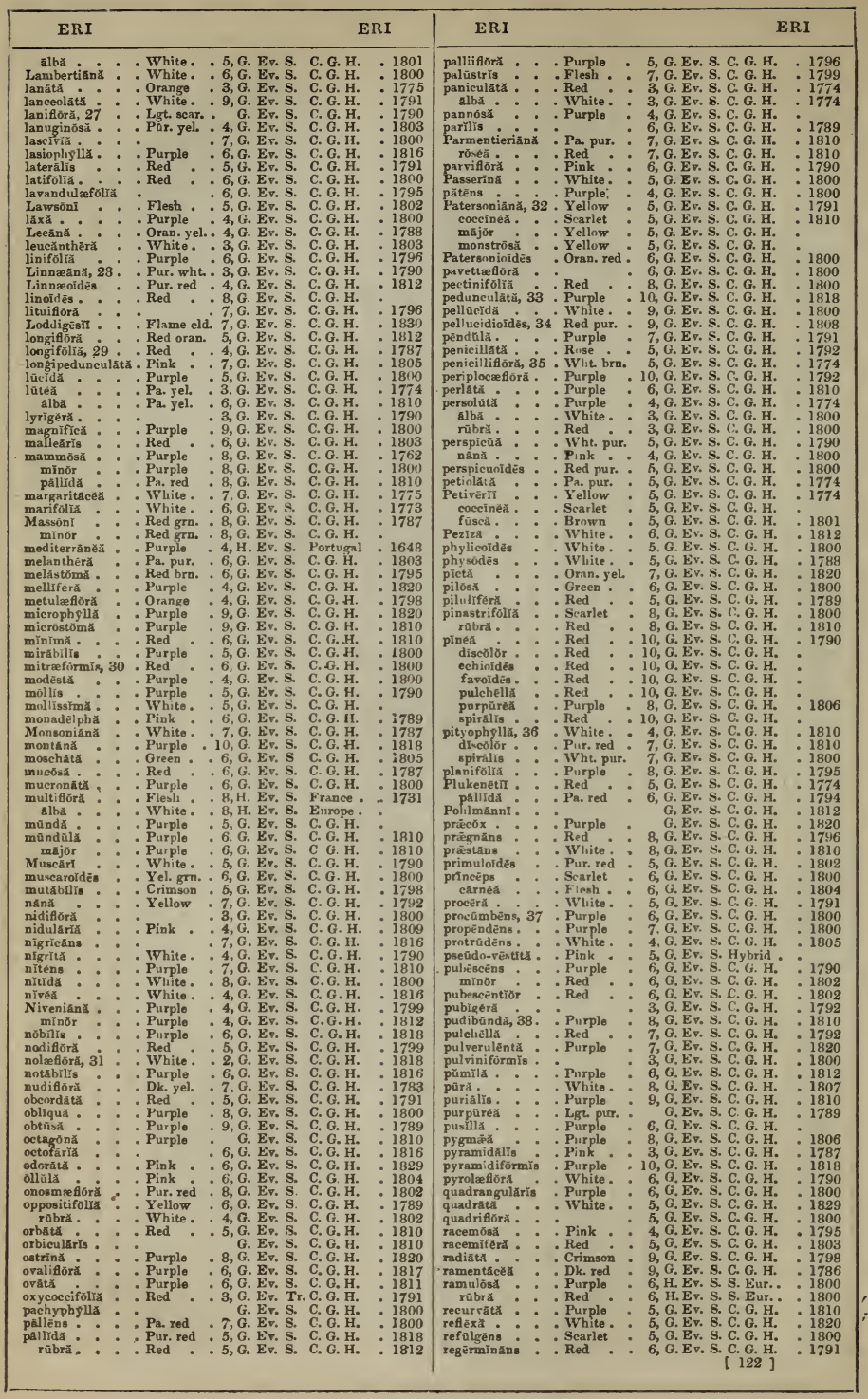




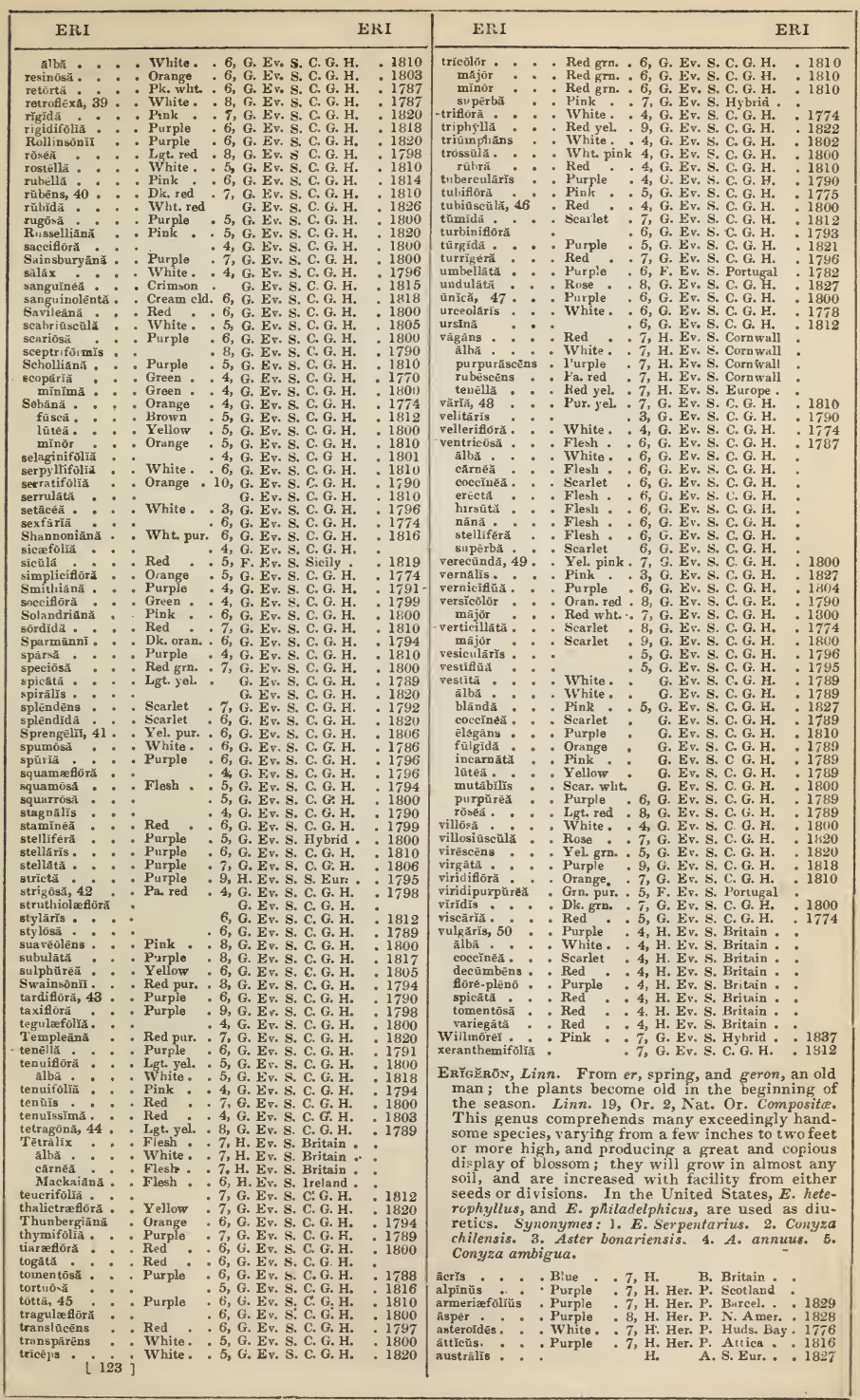




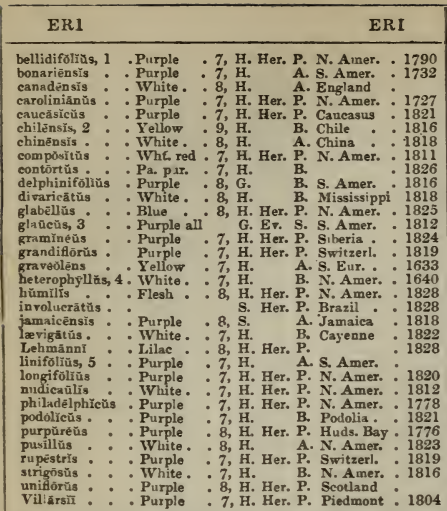

ERIN of its erinaceous appearance. Linn. 24, Or. 9, Nat. Or. Fungi. Very minute species, mostly brown or whitish; they are found growing in little tufts, on

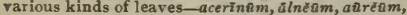

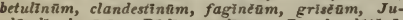
gländìs, lanōsam, Paddi, populinàm, Pseudo-plätănī,

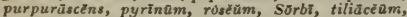
tortuosam, Vitis.

Enĩvĩs, prickly, rough.

ERivěs, Linn. Meaning unknown. Erinos is the wild fig-tree. Linn. 14, Or. 2, Nat. Or. Scrophulariacee. These are pretty d warf species, and should be in every collection of Alpines. If the soil is sandy, they will succeed well, and young plants are easily obtained from seeds, or divisions.

al pinǔs. . - Blue • - 3, H. Her. P. Pyrenees 1739 frâgrâns: : Wht yel 5, G. Ev. A. C. G. H. : 1776

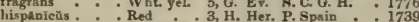

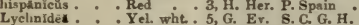
Lychinide : : Yel, wht. 5, G. Ev. S. C. G. H.
tristis : Purple : 5, G. Ev. S. C. G. H.

ERIobర̃tr Y̌x, Lindley. From erion, wool, and botrys, a bunch of grapes; the raceme is very woolly. Linn. 12, Or. 2, Nat. Or. Rosaced. E. juponica is the loquat tree of Japan, and is deserving of the most extensive culture, both as a plant of ornament and utility. The flowers are produced in terminal bunches in January, and the fruit ripens, and is fit for table, in A pril. Plants may be obtained from cuttings, seeds, or grafting. By cuttings, take off the young ripe wood in $J$ une, each cutting about two inches long, always cut off at a jount plant them in a pot of sand, under a glass, plunged up to the rim of the pot in a brisk heat, and they will soon root. By seeds, as soon as they are gathered, they must be sown in a pot of fine-sifted leaf-mould, and the pot plunged in a brisk heat; the soil should be covered with moss, to prevent the surface drying, and in about a fortnight young plants will make their appearance. When about an inch high, they should be planted singly into thimble pots, in a mixture of leaf and heath-mould broken very fine; plunke the pots again in a hotbed till they require another potting, after which, treat them as old plants. The best stock for grafting on is the Whitethorn, and for plants grown in the stove, the end of October is the best time for grafting, and if growing out of doors, grafting may readily be performed at the usual grafting season. Synonymes: 1. Mespilus cuila. 2. M.japonica.

elliptică, 1 • White - F. Ev. T. Nepal . . 1823 japonǐcă, 2 : White : 10, P. Ev. T. Japan : 1787

ERtocaūrơn, Linn. From erion, wool, and caulon, a stem; in allusion to the woolly stems. Linn. 3, Or. 3, Nat. Or. Restiaced. Very interesting plants, particularly $E$. septangulare, which flourishes ex

ceedingly well in Scotland, where, in some parts, it is found in abundance.

australlé. - : White : 6, G. P. N. Holl. 1820

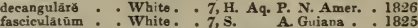
septanguláré : White : 9, H. Aq. P. Scotland

ERroç̆phăLUัs, Linn. From erion, wool, and kephale, a head; the woolly seeds are collected into heads. Linn. 19, Or. 4, Nat. Or. Compusita. Cape evergreen shrubs, of considerable beauty, sometimes growing to the height of six feet. They are cultivated with success in peat and sandy loam mixed, and cuttings root freely in sand, or sandy soil.

af́ricānuัs * - Yellow \&, G. Ev. S. C. G. H.

decussãtŭs : Yellow 4 G. Ev. S. C. G. H 1732 purpurzés: : : Purple : 4, G. Ev. S. C. G. H. : 1816 purpureús : : Purple : 4, G. Ev. s. C. : 1739

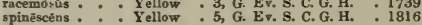

Ertochīlěs, R. Brown. Fromerion, wool, and cheilos, a lip; alluding to the disk of the labellum being pubescent. Linn. 20, Or. 1, Nat. Or. Orchidacee. This plant thrives best in an equal mixture of light turfy loam, peat, and sand, with the pots well drained, to let the water pass off readily : increased by divisions of the roots. Synonyme: 1 . Epipactis cucullata.

autumnalís . . Red . . 10, G. Ter. N. Holl. . 1823

ERIōcŏмx, Kunth. Derived from erion, wool, and kome, hair; alluding to the woolly palez. Linn. 19, Or. 3, Nat. Or. Composite. Very pretty Mexican shrubs, growing about three feet high, and cultivated in almost any common soil, and cuttings root freely in sand, or sandy soil.

floribūndx. . White . 10, F. Ev. S. Mexico . 1898 frägrains : : White : 9, F, Ev. S. Mexico. 1828 Ertods̄ndrón, Dccandalle. From etion, wool, and dendron, a tree; the capsule is filled with a fine, silky, woolly substance. Linn. 16, Or. 8, Nat. Or. Sterculiacea. These are noble plants, growing from fifty to a hundred feet high, in a strong, humid heat, and good rich loam and sandy peat mixed; they may be increased from seeds. The woolly cnat of the seeds of some of the species is used in different countries for stuffing cushions, and similar purposes. Synonymes: 1. Bombax pentandrum. 2. E. caribcum. 3. Bombax erianthos.

anfractuósũm, 1 . Scarlet * S. Ev. T. E. Ind. . . 1739

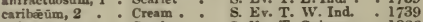
guineẻnsé : : Scarlet : S. Kv. T. Guinea : 1826 leianthérüm, 3 : Searlet : S. Ev. S. Brazil : : 1818

ErıŏGóxũx, Michaux. From erion, wool, and gonu, a joint; alluding to the stems being woolly at the joints. Linn. 9, Or. 1, Nat. Or. Polygonacea. The species of this genus are very pretty, and easily cultivated in loam and peat, and young plants are obtained with ease from seeds. Synonyme: $1 . E$. flavum.

compōisitūm . . Yel. wht. 6, H. Her. P. N. Allion .

longifolrüm : Yellow : 6, H. Her. P. N. Amer. 1829 pauciforūm : : Yellow : 6, H. Her. P. Lnuisiana : 1820 sericeúm, 1 : Yellow : 7, H. Her. P. Missouri : 1811

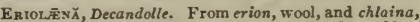
a cloak; the calyx is woolly. Linn. 16, Or. 8, Nat. Or. Sterculiacec. These plants are described as being pretty, growing in sandy peat, and multiplied from cuttings.

Candöllel . . Yellow . 12, G. Ev. T. Prome * 1828 Wallichn: : Red : : O. Ev. S. E Ind. : 1823

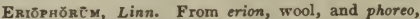
to bear; the seeds are covered with a woolly substance. Linn. 3, Or. 1, Nat. Or. Graminea. Very interesting plants, found in boggy situations, and may be increased by divisions. It is remarkable for having the seeds covered wish a wool-like cottony substance; whence the English name, Cotton Grass.

angustifolrūm . A petnl . 4, Grass. Britain . capitatũm : A petal : 8, Grass. Scotland : A petal : : \%, Grass. Sentland polystăchȳón - A petal . $\theta$, Grass. Britain pubéscêns : : Apetal : 3, Grass. England. raginătūm : A petal : 6 , Grass Britain rirginicum : : Apetal : 6, Grass. N. Amer. 1820 ERTōphürǐs, woolly-headed. 
Eriophȳluūm, Lagasca. From erion, wool, and phyllon, a leaf; in allusion to the silky, wool-like substance covering the leaves. Linn. 19, Or. 2, Nat. Or. Composite. The species are pretty, and will thrive in any common soil, and young plants grow well from divisions of the roots. Synonymes: 1 . Trichophyllum lanatum, Actinella lanata. 2. Trichophyllum oppositifolium.

eæspitôsūm, 1 - Yellow . 5, H. Ev. Tr. N. Amer. . 1826 appositifóliñm, 2. Yellow: H. Her. P. Missouri

Eriospérmō, Jacquin. From erion, wool, and sperma, a seed; in allusion to the woolly envelope of the seeds. Linn. 6, Or. 1, Nat. Or. Liliacea. Ornamental Cape bulbs when in flower; they grow freely in sandy peat, and may be increased from suckers. Synonymes: 1. E. latifolium. 2. Ornithogalum paradoxum.

Bellendèni, 1 . Lgt. blue . 7, G. Bl. P. C. G. H. fodiolíférūm Yel. grn. 7, G. Bl. P. C. G. H. 1806 lanceæfơlium : Lgt. hlue . 7, G. Bl. P. C. G. H. 1795 lanuginòsūm - W Wht. grn, 7, G. B1. P. C. G. H. - 1820 latifoirnm : : Lgt. blue : 7, G. Bl. P. C. G. H. $\quad 1800$
paradōxūm, 2 : parvifolǐnm : : Drk. blue 7, G. Bl. P. C. G. H. : 1796 pubescēns : : WVht. grn. 7, G. Bl. P. C. G. H. : 1820

ERiostīmōN, Smith. From erion, wool, and stemon, a stamen; because of the woolly stamens. Linn. 10, Or. 1, Nat.Or. Rutacer. Beautiful New Holland shrubs, varying from one to three feet high. They grow best in very sandy peat and a little loam mixed, and increase readily from cuttings in sand, or sandy soil.

buxiföliŭs . . Pink . . 5, G. Ev, S. N. Holl cuspidatǔs: : Red : : 5, G. Ev. S. N. Holl ericifoliǔs: : Red : 6, G. Ev. S. N. Holl. ràcilis : Lilac 7, G. Ev. S. N. Holl. lanceolātŭs : Red : 6, G. Ev. S. N. Holl. linearifollŭs: : Red: : 6, G. Ev. S. N. Holl. nyoporoìdés : TWhite : 9, G. Ev. S. N. Holl. ohovătŭs : Ked 5, G. Ev, S. N. Holl. alieifolĭ̌s . : Red :5, G. Ev S. N. Holl. squāméŭs . : Red :6, G. Ėv. S. N. Holl.

\begin{tabular}{|c|c|c|c|c|}
\hline 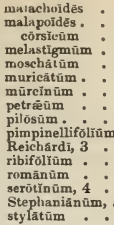 & 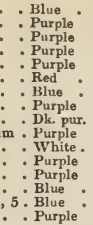 & $\begin{array}{l}\text { 7, H. } \\
\text { 6, H. Her. } \\
\text { 6, H. Her. } \\
\text { 6, F. Her. } \\
\text { 6, H. } \\
: 7, \text { H. } \\
\text { 7, H. } \\
\text { 7, H. Her. } \\
: 7 \text {, H. } \\
: 7 \text {, H. } \\
: 7, \text { F. Her. } \\
\text { 6, H. } \\
\text { 5, H. } \\
\text { 8, H. Her. } \\
\text { 6, H. Her. } \\
\text { 6, H. Her. }\end{array}$ & $\begin{array}{l}\text { A.S. Eur. } \\
\text { P. N. Africa } \\
\text { P. Corsiea } \\
\text { P. } \\
\text { A. England } \\
\text { A. } \\
\text { A. N. Africa } \\
\text { P. S. Eur. } \\
\text { A. France } \\
\text { A. S. Eur. } \\
\text { P. Minorca } \\
\text { A. C. G. H. } \\
\text { B. Rnme : } \\
\text { P. Siberia } \\
\text { P. Dahuria }\end{array}$ & $\begin{array}{r}1827 \\
1818 \\
.1640 \\
.1800 \\
\cdot 1800 \\
-1783\end{array}$ \\
\hline
\end{tabular}

bipinnätàm, chĭâm, cicōnžūm, cicutārĩũm, glaucophȳl-

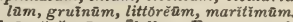

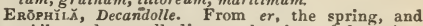
phileo, to love; alluding to the time of flowering. Linn. 15, Nat. Or. Cruciferc. Minute plants, one of which, $\boldsymbol{E}$. vnlyaris, is a native of Britain, and better known by the name of Draba verna; it is very pretty in spring when seen growing upon old walls, and other like places, where it is generally abundant. Any soil seems to suit these plants; but if it consists chiefly of loam, so much the better they will grow; seed is produced in abundance. Synonymes: 1. Draba pracox. 2. D. verna.

americãnă . . White. . 3, H. A. N. Amer. . 1816 prǣeōx, 1 : : White: : 3, H. A. Caucasus : 1820

Eross, gnawed, bitten; a term used to denote a particular kind of irregular denticulation.

EROSELY-TOOTHRD, the teeth are gnawed, or e rose.

ErrhiNe, promoting a discharge of mucus from the nostrils.

ERPĔtĭŏv, Decandolle. From erpetos, creeping, and ion, the Greek name for violet ; in reference to the creeping rooting stems. Linn. 5, Or. 1, Nat. Or. Violacee. Small, but pretty evergreen creepers, of much interest; they grow in sandy peat, and are multiplied by parting the roots. Synonymes: 1. Viola hederacea. 2. V. hederacea Elatines.

ERĪsmă, Rudge. From erisma, strife; so named fro the anomalous form of the genus, which is at so much variance with others. Linn. ], Or. 1, Nat. Or. Vochyacea. An ornamental plant, thriving well in a mixture of peat and loam, and cutting of the ripened wood will root in sand, under a glass, in heat.

floribūndă . . Blue . . 10, S. Ev. T. Guiana . . 1825

Erith Āis, $\boldsymbol{P}$. Bronne. From erithallo, to grow green; alluding to the deep green, shining leaves. Linn. 5, Or. 1, Nat. Or. Cinchonacea. A pretty genus of trees, succeeding well in the stove in a strong heat, and rich loam, mixed with a little peat; cuttings root readily in sand, under a glass, in heat.

fruticō๕ă . . White * 7, S. Ev. T. Jamaica . 1793 Tímōn. : S. Ev. T. E. Ind. : 1823

ERnöDйĂ, Swartz. From ernodes, branched; the plant is much branched. Linn. $4, \mathrm{Or}, 1, \mathrm{Nat}$. Or. Cinchonacea. This is, though a dwarf, a very pretty plant, and succeeds best in gravelly soil; young plants are obtained by dividing the roots. Synonyme: 1. Asperula calabrica, Pavetta fotidissima.

montänă, 1 . . Red . . 6, F. Ev. Tr. Sicily . . 1820

ERōdî̃u, L'Heritier. From erodios, a heron; the carpels resemble the head and beak of that bird. Linn. 16, Or. 2, Nat. Or. Geraniacec. An extensive genus of plants, of considerable beauty; they thrive well in any common soil, with the usual treatment. Synonymes: 1. E. alpinum. 2. E. graveolens. 3. E. chamadryoides, Geranium Reichardi. 4. E. multicaule, ruthenicum. 5. E. multifidum.

\section{alpinnùm}

. Red

caucalifóliüm, $i$ : Purple cicutifolium : Purple crassifóliūm: Scarlet glandulōsûm, 2 : Purple Gussōni. : Pa. pur. hirtúm . Purple hymenödês. - Pink incarnātūm : Flesh laciniảtūm : Red [ 125 ]
6, H. Her. P. Italy • 1814 $6, \mathrm{H}$. Her. P. Iberia . 1820 6, H. A. Italy : 1818 6 , H. Her. P. France : 1816 6, H. A. France : 1816 6, F. Her. P. Cyprus : 178 7, F. Her. P. Spain : 1798 7 , H. Her. P. Egypt . 181 7, F. Her. P. Barbary : 1789 6, F. Her. P. Crete 
mental and beautiful, more especially the hardier kinds, which are, on that account, particularly well adapted for the flower-border. They thrive best in a light sandy soil, though they will all grow in any cortmmon garden soil. The greenhcuse and frame kinds should be grown in pots, so that they may be sheltered in winter. They are readily increased by seeds, or dividing at the roots. The roots of $E$. campestre are slightly aromatic.

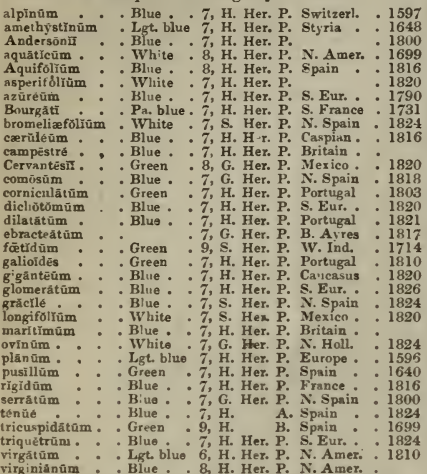

Er Y̌sim C̄M, Gertner. From erion, to draw, to cure; it is reckoned a powerful cure for a sore throat; it is also said to draw and produce blisters. Linn. 15, Nat. Or. Cruciferce. An extensive genus, of little merit. The herbaceous kinds thrive well in common soil, or in a mixture of loam and peat; they may be increased by cuttings, under a glass. The annual and biennial species mesely require sowing in the open border Synonymes: 1. Brassica alpina. 2. E. diffusum. 3. Cheiranthus virgatus. 4. Brassica austriaca. 5. Cheiranthus bicolor. 6. C. alpinus. 7. C. collinus. 8. C. decumbens. 9. C. dubius. 10. C. firmus. 11. C. helveticus. 12. C. armeniacus. 13. C.erysimoides. 14. C. leptophyllus. 15. E. grandiflorum. 16. E. grandiflorum. 17. Brassica orientalis. 18. Cheiranthus rhaticus. 19. C. guadrangularis. 20. C. siliculosus. 21. C. strigosus. 22. C. hieracifolius. 23. C. versicolor.

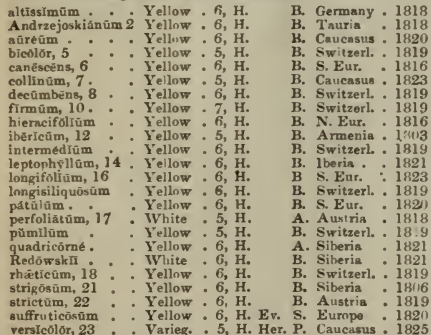

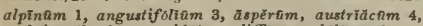
cheiranthō̃dēs, cuspidütūm, diffusam, dübiam 9 , ex.

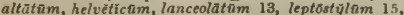

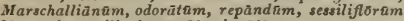
19 , sịcŭlñm, siliculossūm 20, virgätũm.

ER ऽsĭ $\overline{\mathrm{E}}$, Decandolle. The name given to mildew by the Greeks. Linn. 24, Or. 9, Nat. Or. Fungi. Very minute, mostly whitish species, found most commonly in autumn, on a great variety of plants, shrubs, and trees-adâncă, Popülī, Prunästrī, bicørnis, commünts, Cichoraceñram, Leguminosürũm, Po. lygoneârūm, Ranunculacē̄râm, Umbelliferärûm, di.

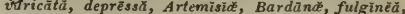
guttütă, corỵli, Ulmōrūm, lamprocärpă, penicillātă, Berbéridis, Grossulariă.

ERYTHRAর̆, Richard. From erythros, red; alluding to the colour of the flowers. Linn. 5, Or. 1, Nat. Or. Gentianacere. The species of this genus are pretty, but not easy of cultivation. The herbaceous species require an open, loamy soil, and may be increased by divisions. The annuals and biennials require sowing in the open border, in autumn, or they will not come up. Synonymes: 1. Chironia Centaurium, 2. C. littoralis. 3. C. pulchella.

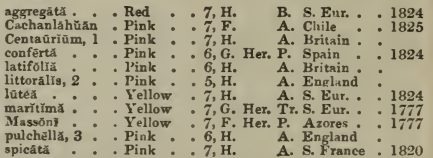

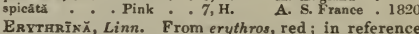
to the colour of the flowers. Linn. 17, Or. 4, Nat. Or. Leguminose. These are all splendid plants, with fine large leaves, and beautiful, brilliant, scarlet, or red flowers; the compost best suited for them is one part fresh maiden loam, one part sandy peat, and one part of horse-dung, well rotted and pulverised. The whole should be well incorporated and chopped, and also well exposed during frost in winter. A 3 soon as the plants have done growing, cut them down, and set them in a cool greenhouse, where they may be kept quite dry till the end of November, when they may be potted into fresh soil, and pots of a proper size. When potted, water, and set them in a house where the heat is about sixty degrees, and about March they will flower in perfection. When the plants are again out of flower, cut them down, as before, to five or six eyes, according to the strength of the stems; re-pot them, and place them in the stove until they have taken root, and made shooty from nine to twelve inches, when they must be removed to a house of the temperature of from fifty-five to sixty degrees, allowing them plenty of light; they must be frequently syringed, to prevent the attacks of the red spider. Continue this treatment till they show flower, then allow them plenty of air and moisture, and they will flower freely again in July, after which, it is advisable to give them their winter. Cuttings taken off at a joint, without depriving them of their leaves, root readily in sand, under a hand-glass, in a moist heat. E. Crista.galli, and E. laurifolia, will thrive and flower freely in warm sheltered situations out of doors; in such a situation, they are killed to the stump in winter with. out they are cut down to about four inches of the stem, and sheltered by an inverted flower-pot. Synonymes: 1. E. velutina. 2. E. arborea.

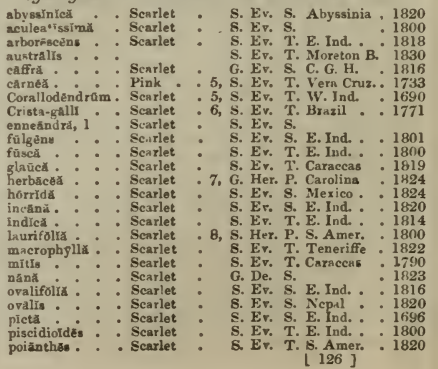




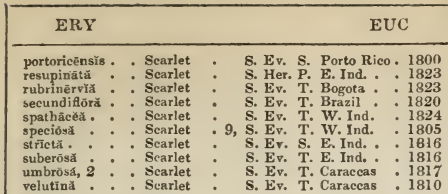

ErqthroL㐫nă, Sneet. From erythros, red, and chlcena, a cloak; alluding to the scales of the calyx. Linn.

19, Or. 1, Nat. Or. Composite. A very pretty Mexican species, producing its scarlet and orange flowers in abundance; it delights in a rich soil, and young plants are readily obtained from seed.

conspăcŭă . . Sear. oran. 9, H. B. Mexico . . 1825

ERYThrōxĩu, Linn. From erythros, red; in allusion to the colour of the leaves and flowers. Linn. 6, Or. 1, Nat. Or. Liliacece. These are handsome, though dwarf-growing plants. They all thrive in common garden soil, except E. lanceolatum, which requires a peat soil, or it will not succeed they are increased from offsets. Synonyme: 1. E. americanum.

albǐdūm

White.

4, H. Bl. P. Louisiana - 1824

Dẻns cănĭs

Red lilac

3, H. BI. P. Europe

1596 ălbidūm

Red lilac

3, H. Bl. P. Italy

1596

randifôrüm : Yellow : 5, H. Bl. P. N Amer. 1896

lanceolatum, 1 : Yellow : 4, H. BI. P. N. Amer. 1665

Eryth Rōpht. reference to the red juice which flows from the tree when cut. Linn. 10, Or. 1, Nat. Or. Leguminose. This is a lofty and an ornamental tree, growing about a hundred feet high. The natives of many parts of Western Africa use the red juice of the tree as an ordeal, to detect the guilt of those accused of any crime. The juice is taken in large draughts, and those who are not sufficiently strong to stand this ordeal, are pronounced guilty, and those who are, are considered innocent; whence the tree is called Gregre-tree, or Ordeal-tree. Syno. nyme: 1. Afzelia grandis.

guineēnš . . Pa. yel. . S. Ev. T. S. Leone . 1793

ERxthaōxĭLŏn, Linn. From erythros, red, and xylon, wood; the wood of the trees is red. Linn. 10, Or. 3, Nat. Or. Malpighiacea. These trees are not possessed of much beauty. They require to be grown in a mixture of peat and loam, and cuttings, not too ripe, will root in sand, under a glass, in a moist heat.

havanènsě . . Y Yel, grn. * S. Ev, T. Havannah . 1822 hypericiföliüm : Yel. grn. S. Ev, T. Maurit.. 1818 laurifơliúm .: Yel. gm. : S. Ev, T. Maurit.. : 1823

Escaltōnǐă, Mutis. In honour of Escallon, a Spanish traveller in South America, who first found the species in New Granada. Linn. 5, Or. 1, Nat. Or. Escalloniacece. All the species of this genus are very fine, evergreen, greenhouse shrubs, several of which are sufficiently hardy to stand our winters when planted against a south wall, with the protection of a mat in severe weather. They grow best in a mixture of peat, sand, and loam; cuttings taken off as soon as the wood is ripened, will root readily if planted in sand, under a glass. Synonyme: 1. E. bifida.

díscölor . . . . White. . S. Ev. S. S. Amer. . 1820 Glandulōsă : : Red : 9, G. Ev, S. Chile : 1827 montevidēnsiss, 1 : White. : 8, G. Ev. S. Monte Vid. 1827 pulveruléntă. . G. Ev. S. Chile . 1831

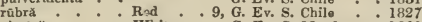
viscôsă : : : W White, : 9, G. Ev, S. Mendoza : 1829

EschaRotic, having the power to scar or burn the skin.

Eschsc日ōtrž̆

EscuLENT, good for food.

Етнёці̌̆, Cassini. Meaning unknown. Linn. 19, Or. 1, Nat. Or. Compositce. Stove annuals, not worth cultivating, except in botanical collections. Synonyme: 1. E. sinapifolia, brasiliensis, cony. zoides, divaricata, integrifolia 1 .

Eucal'̌rtũs, L'Heritier. From eu, well, and kalypto, to cover; the limb of the caly $x$ covers the flower before expansion, and afterwards falls off in the $[127]$

shape of a lid, or cover. Linn. 12, Or. 1, Nat. Or. Myrtacece. All the species of this genus are very tall and handsome, and as they grow fast, are wel adapted for conservatories. $E$. perfoliata will endure tne open air against a south wall, in which situation 1c looks very handsome, on account of its hoary, bluish foliage, and neat growth of the branches. They delight to grow in a mixture of peat, loam, and sand; and cuttings, not too ripe, root readily in sand, under a glass. A kind of gum, called kino, is got from $E$. resinifera, and sold in the medicine bazaars of India; and various other species yield a large quantity of tannin, which is extracted from the trees in New Holland, and sent to the English market, and is said to be twice as powerful in its operations as oak-bark. Synonyme : 1. E. curdata.

\section{alātă}

albicaūlis

amygdalin:

angustiföli

bocryoìdés

capitellātă

cornúta.

corymbosă

cotinifolia

elongāta

engenioìdēs

glöbǔlũs

hæmāstümă

heterophyllă

hirsüt

hypericifolia

incrassát í

media

microph ỳlla

mucronâtă

multiflōra

myrtifơlia

obliquă

orbiculārís

ovãtă

paniculātă

pauciffōrả

paucifor

persicifólix.

phillyreoides

piluläris

piperâtă

pulverulēntă, 1

pulvāgeră

purpuräscēns

resiniferă

reticulät

robūstă

rosträtă.

salīgnà

seābrà

stenophylla

strictă

triânthă

undulāta

verrucōsa

viminālì

virgãtă .
White.

White.

G. Ev. T. N. Holl.

G. Ev. S. V. D. L.

G. Ev. T. N. Holl

White. 6, G. Ev. T. N. Holl

White - G. Ev. T. N. Holl

White. - G. Ev. T. N. Holl

White - G. Ev. T. N. S. W.

White: G. Ev. T. N. Hull

White: G. Ev. T. N. Holl

White: G. Ev. T. N. Holl

White. G. Ev. T. N. Holl

White. G. Ev. T. N. Hol

White : G. Ev. T. N. Holl.

White - G. Ev. T. N. Holl

G. Ev. T. N. Holl

White. 6, G. Ev. T. N. Holl

White: : G. Ev. T. N. Holl

White: G. Ev T. N Holl

White: G. Ev T. N. Holl

White : G. Ev. T. N. Holl

White. G. Ev. S. N. Holl.

White. - 7, G. Ev. T. V. D. L

White. G. Ev. T. N. Holl

White, G. Ev T N Holl

White. G. Ev T. N. Holl

White: 7, G. Ev T. C. G. H

White: 7, G. Ev. T. C. G. H.

White. : G. Ev. T. N. Holl.

White.: G. Ev. T. N.S.W.

White.

White

White.

White.

White.

White.

White

White.
White.

White.

White.

White

White

White.

White

White.

IVhite.

White.

White

G. Ev. T. N. Holl

6, G. Ev. T. N. Holl.

G. Ev. T. N. Holl

G. Ev. T. N. HoIl.

G. Ev. T. N. S. W.

G. $\mathrm{T}$. $\mathrm{N}$.

G. Ev. T. N. Holl

G. Ev, T. N. Holl

G. Ev, T. N. Holl
White - G. Ev. T. N. Holl

G. Ev T. N.S. WV.

G. Ev. S. N. Holl. 1823

8, G. Ev. T. N. S. W. : 1794

G. Ev. T. N. Holl. : 1810

G. Ev. T. N. Holl. : : 1820

G. $\mathrm{T}$. $\mathrm{T}$. 1820

EuchariัDIั0ิM, Fischer and Meyer. From eucharis, agreeable; in allusion to the appearance of the plant. Linn. 8, Or. 1, Nat. Or. Onagraiea. A pretty little plant, nearly allied to Clarkia; it flowers about six weeks from the time of germina. tion, and is perfectly hardy.

concinnuam. . Purple . 6, H. A. N. Amer. 1836

Euchīlǔs, R. Bronn. From eu, well, or good, and cheilos, a lip; the upper lip of the calyx is very large. Linn. 10, Or. 1, Nat. Ori Leguminosce. A very pretty plant when in flower. For culture and propagation, see Pultenara.

obcordátŭs. . . Yellow . 4, G, Ev. S. N. Holl. . 1803

Eисквӧмӑ, Nuttall. From eu, well, or good, and chroma, a colour; alluding to the colour of the bracteas. Linn. 14, Or. 2, Nat. Or. Scrophulariacea.

Dwarf ornamental plants, of easy culture. Synonymes: 1. Bartsia coccinea, Castilleja coccinea. 2. Castilleja sessiliflora, grandiflora.

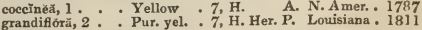
Ēûcrê, Linn. Derived from eukleia, glory; allud. 
ing to the beautiful evergreen foliage. Linn. 22, Or. 10, Nat. Or. Euphorbiacea. These are very ornamental shrubs, succeeding in peat and loam mixed, and multiplied from cuttings.

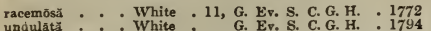

Eưchînūu, R. Brown. From eu, well, and kleidoo, to shut up; on account of the well-closed seedpods. Linn. 15, Nat. Or. Cruciferc. Plants which are only worth growing in general collections. Synonymes: 1. Bunias syriaca. 2. Vella tenuissima. syrẳăm, 1 . . White . . 7, н. A. Levant . 1778 tatärìeúm, 2 . White. . 7, H. A. Tartary . 1821

EīcŏmǏs, Linn. From eukomes, beautiful-haired; alluding to the tufted crown of the flower-spike. Linn. 6, Or. 1, Nat. Or. Liliacec. Ornamental plants, succeeding in any rich soil, and increased from offsets.

\begin{tabular}{|c|c|c|c|}
\hline 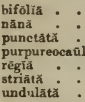 & âlis & $\begin{array}{l}\text { Lgt grn. } \\
\text { Brown } \\
\text { : Grn. brn. } \\
\text { : Grn. brn. } \\
\text { : Green } \\
\text { Green : } \\
\text { Green : }\end{array}$ & $\begin{array}{l}\text { 4, G. Her. P. C. G. H. } \\
\text { 5, G. Her. P. C. G. H. } \\
\text { 6, G. Her. P. C. G. H. } \\
\text { 4, G. Her. P. C. G. H. } \\
\text { 3, G. Her. P. C. G. H. } \\
\text { G. Her. P. C. G. H. } \\
\text { 4, G. Her. P. C. G. H. }\end{array}$ \\
\hline
\end{tabular}

EuCrŏsĭn̆, Ker. From eu, well, and krossos, a fringe; in allusion to the beautiful fringe of the flower, formed by the cup of the stamens. Linn. 6, Or. 1, Nat. Or. Amaryllidacee. This is a very pretty bulb, with orange-coloured flowers; it thrives in light loam, and is increased from offsets.

bǐcólơr . . . Orange . 4, G. BL. P. C. Horn . 1816

Eudēsmĭn, $R$. Bronn. From eu, well, and desma, a bundle : the stamens are connected into bundles. Linn. 18, Or. 2, Nat. Or. Myrtacea. An ornamental evergreen tree, about sixteen feet high, and producing an abundance of flowers; it thrives in sandy peat, and is increased by cuttings planted in sand, under a glass.

tetragónx . . . Red . . 7, G. Ev. T. N. Holl. . 1824

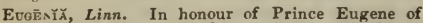
Savoy, a great patron of botany. Linn. 12, Or. I, Nat. Or. Myrtacee. A very ornamental and highly useful genus of plants, requiring the same treatment in culture and propagation as Jambosa.

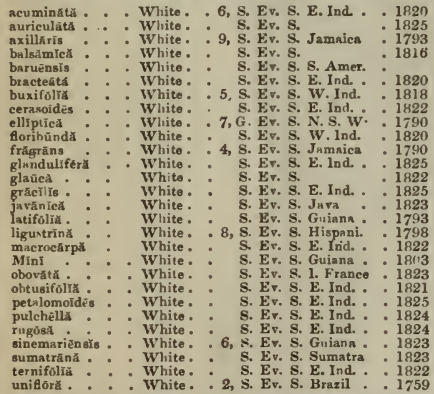

Eutōprĭă, R. Bronn. From eulophos, a handsome crest; in allusion to the labellum bearing elevated lines, or ridges. Linn. 20, Or. 1, Nat. Or. Orchidacese. This is a very pretty genus of tuberousrooted plants. They must be kept perfectly dry when in, a torpid state, and may be in every other respect treated as Bletias.

\begin{tabular}{|c|c|c|}
\hline 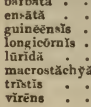 & : Y Yur. brn. & $\begin{array}{l}\text { G. Ter. C. G. H. } \\
\text { 9, S. Ter. S. Lenne } \\
\text { 7, G. Ter. C. G. H. } \\
\text { 1, S. Epi. S. Leone } \\
\text { 10, S. Ter. Ceylon } \\
\text { 6, G. Ter. C. G. H. } \\
\text { 7, S Ter. E. Ind. : }\end{array}$ \\
\hline
\end{tabular}

Eunŏmı̆, Decandolle. From eu, well, and nomos, order; because the leaves are opposite, and the seeds twin. Linn. 15, Nat. Or. Crucifera. This is a pretty little plant, growing freely in sand, loam, and peat, and increased by cuttings in the same kind of soil, under a glass, or by seed. Synonyme : 1. Lepidium oppositifolium.

oppositifollă, 1 . White . . 6, F. Hez. P. Syria . . 1827 Euŏxřsŭs, Linn. From eu, good, and onoma, a náme, well named. Linn. 5, Or. 1, Nat. Or. Celdstracea. This is a genus of largish and ornamental shrubs, well suited for large shrubberies. $E$. atropurpureus, and $E$. latifolius, are the most shows; any situation or soil will suit them. They increase by seed, or cuttings of the ripened wood, put in in autumn, will take root. Synonyme: $1 . B$. scandens.

americănŭs . Pink . . 6, H. De. S. N. Amer. . 1683 angustifoliuns: : Yel, red :6, H. Ev. S. N. Amer. : 1806 atropurpüréŭ: : Purple :6, H. De. S. N. Amer. : 1756 bullătŭs : Pink * 6, G. Ev. S. Nepal : 1828 chinēnsiss : Pink : 5, F. De. S. China : 1820 echinătŭs ... White. . 5, F. De. S. Nepal : 1824 europæùs : White * 6, H. De. S. Britain .

fóliss-variegătis White. 5 , H. Ev. T. Britain .

pŭmilüs. : : White: 6, H. De. $\mathrm{S}$.

grandiflörŭs : : White: : 6, F. Ev. S. Nepal . 1824 gुxôssŭs - * White. 5, F. Ev. S. Nepal : : 1824 Hamiltoniänüs : White. 3, F. Ev. T. Nepul : 1825 japoñicǔs *: Pink : 7, F. Ev. S. Japan : 1804 lúcídũs. : White, H. De. S. Nepal : 1820 micränthŭs : : White: : H. De. S. Nepal : : 1820 micrünthŭs : : White. - H. De. S. Caucasus : 1825 obovatŭs : Pink - 6, H. De. S. N. A iner. : 1820

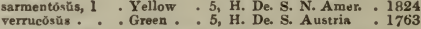

EUpatóñ̂̃u. Linnæus derived the name from Mithridates Eupator, who used it as a counterpoison. Linn. 19, Or. 1, Nat. Or. Compositce. Some species of this genus are very ornamental, as $\boldsymbol{E}$. floribundum, while others, as $\boldsymbol{E}$. coriaceum, are quite uninteresting. They require a mixture of peat and loam to grow in, and young plants are obtained from seeds without difficulty. $E$. $A y a-$ pana has been famed for curing the bite of serpents, and an infusion of its leaves forms excellent dietdrink, and when fresh bruised, are said to be very useful for cleaning the face of a forl ulcer. $E$. perfoliatum is tonic, stomachic, and febrifugal. Synonymes: 1. E. nepalense. 2. E. atriplicifolium. 3. E. molle, Ageratum guianense. 4. $E$. cordatum. 5. Eriopappus paniculatus. 6. E. Dalea. 7. E. atriplicifolium.

neuminatũm, 1 .

afbùm .

White

aink : Pink

canèscēns

cannäbinüm .

ceanothifoliumm

Pur. yel.

8. Her. P.

Pink. 6, H. Her. P.

White: 8, H. Her. P

chamædrifoltúm Blue : 8, S. Ev. S.

cos onopifóliún . White - 8, H, Her. P.

Daleă dehoideśn : Pink: : 8, S. Ev. S.

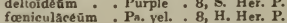

fœniculacéūm : Pa. yel. : 8, H. Her. P.

flnribūndûm : Blue : 7, S. Ev. S.

Frasérí

glandulosúm.

hyssupifơliūm

iresinoldēs

iræfolicum

lamiffollūm

lanceolatũum

linearifo:Iüm

macrophyllum

maculatúm 3 . Purple

melissinlés, 4 : White

montล̄nūm

nūtáns

odorătūm .

panieulatúm, 5

parviftōrúm, 6 .

perfoliatúm

pubéscénn.

punctătūm

purpüreúm

Whito

salviafültūm. Pink.
8, H. Her. P.

, H. Her. $P$.

N. Amer. : 1649

Tw. N. Gmonada 1820

Jamaica 1794

7. H. Her. P. N. Amer. : 1819

8, H. Her. P. N. Amer. : 1820

7 , S. Her. P. Jamaica : 1823

7, H. Her. P. N. Amer. : 1656

6, H. Her. P. N. Amer. : 1811

7, s. Ev. S. Jamaien : 1820

8, G. Her. P. Mexico. 1827

Pink . 8, \&. Ev. \&. Jamaica : 7752

S. Amer. : 1818

Jamaiea : 1826

N. Amer. 169

N Amer. : 1819

N. Amer. : 1815

N. Amer. - 1640

N. Amer. . 1699

N. Amer. 1814

[ 128 ] 


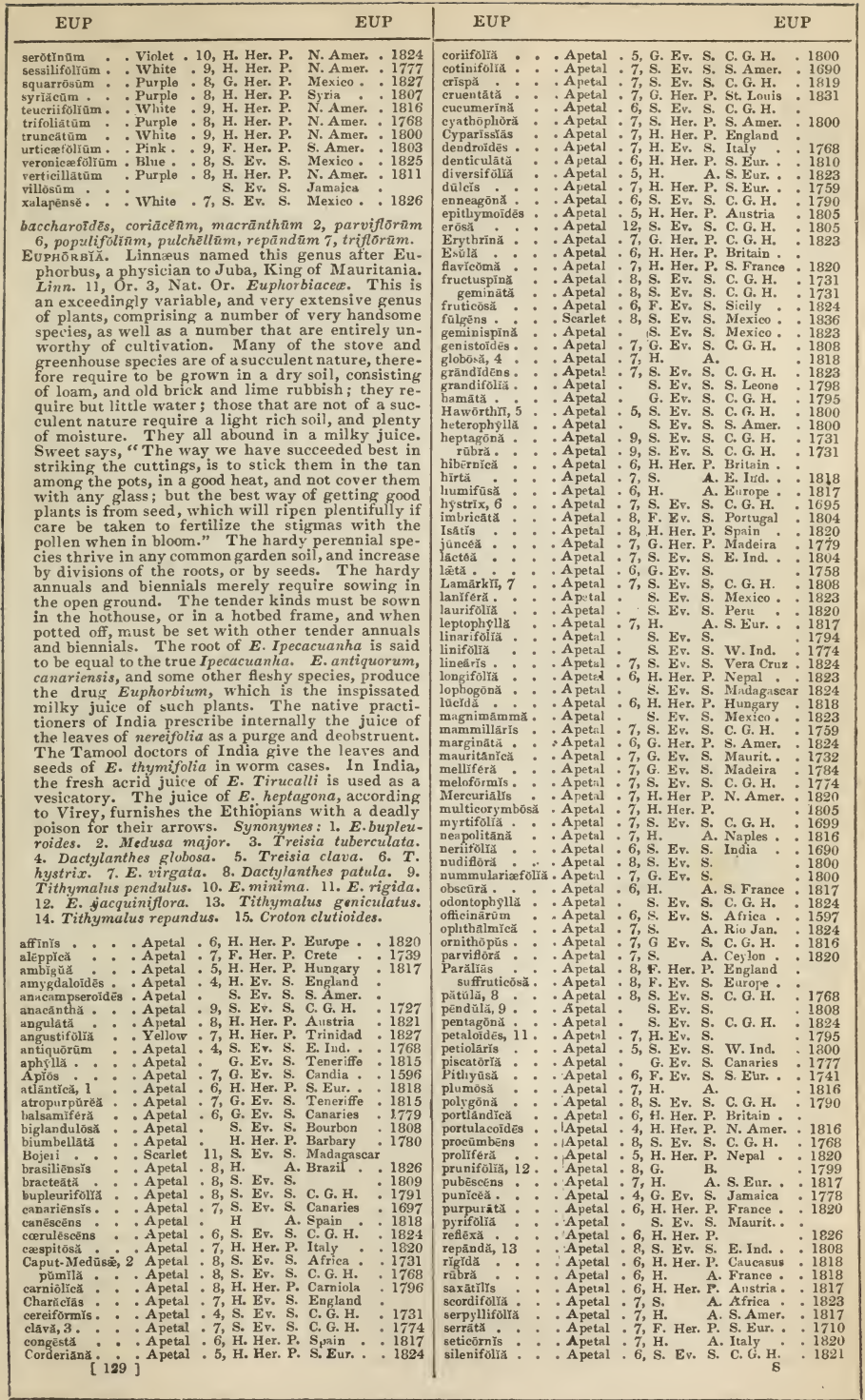




EUP EUR

glaũeă * Apetal * 7, S. Ev. S. C. G. H. - 1821 spathulæfoliă: :A petal : \&, G. Ev. S. G. H. 1800 spinósă . : A petal : 6, F. Ev. S. Lerant . : 1710 splēndéns : : Scarlet : 6, S. Ev. S. I. France : 1826 squarrós : A petal S. Ev, s.

stellæspină : A petal : S. Ev, S. C. G. H. 1824

tannēnsiss, 14 . A petal : 7, H. A. N. Heb.. : $1: 127$

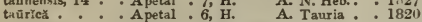

tauriénsis : : A petal : 7, H. Her. P. Italy : 1818

terracina : : A petal : 7, H. A. Europe : 1810

tessellãtă . A petal : 8, S. Ev. S.

tetragönă : A petal : s. Ev. S.

toxicãrĭ . A Aptal : 7, S. Ev. S. Guinea * 1793

trigönă . . A petal . \%, S. Ev. S. E. Ind. . 1768

trigonocărpa : A petal : 6, H. Her. P. 1823

truncítă
tuberculătă : : A petal

tuberosá . : A petal . 7, s. Fv. S. C. G. H. : 1808

uncinatå : : Apetal : 7, S. Ev, S. C. G. H. : 1794

uniflōră. : : Apetal * 7, S. Tu. P. S. Amer. : 1827

Valeriānă: : Apetal $: 7$, H. Her. P. Siberia : 1818

Parríns . : : A Aptal : 8, S. Ev. S. E. Ind.: : 1800

variegátå : : Apetal :9, H. A. Louisiana : 1811

villosa : : : Apetal $\because$ A, F. Fv. F. S. Europe $: 1820$

acuminātă, agrārīă, androscmifoliă, Apīss, bialātă,

Chamäsy̆́cé, ceratocārpă, condylocärpă, condénsă, co-

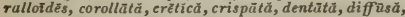

emarginātă, exiğüü, falcätă, fragíféră, Gerardiänă,

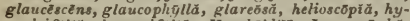

pericifoliă, hyssopifoliă, Humbóldtī, I pecacuänhă,

juncoũdes, Künzē, Lathyris, literätă, maculätă, mi-

cränthă, microphyllă. Myrsinītés, nicceènsis, ocymoìdéă, orientälis, pälídā, palı́stris, Péplis, Péplüs, peploz̃dẽs, pictă, pilossă, piluliféră, platy phȳllüs, polygonifoliŭ, procêră, prosträtă, provinciālis, pterocöccă, retæsă, röséă, silicifoliă, segetälis, serrulätä, strictă, sylvătică, thymifolid, uralënsis, valentină, verrucosau, virgātă.

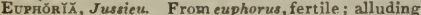
to the fruit. Linn. 8, Or. 1, Nat. Or. Sapindaced. A genus of fruit-bearing trees, attaining from fifteen to twenty feet high, and thriving in any rich mould; they may be increased either by layers or seed. Synonymes: 1. Dimocarpus Litchi. 2. D. Iongan. 3. Nephelium lappaceum, Scytalia Rambootan.

Litchi, 1 . . White . 5, S. Ev. T. China - . 1786

Longfnă, 2 : White. :5, s. Ev. T. China : 1786

Nepheliumm, 3: : White. : 5, S. Ev T. E. Ind. : 1809

EuphrāsǏ plant has been supposed to cure blindness. Linn. 14, Or. 2, Nat. Or. Scrophulariacec. These are interesting plants, particularly $E$. officinalis; they thrive with the most common treatment. E. Qfficinalis is slightly bitter and aromatic. Synonyme: 1 . E. saliaburgensis.

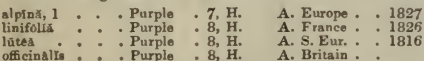

EupomärY̌̆, R. Brown. From eu, well, and pöma, a lid; the flower is covered before expansion, in the manner of an extinguisher. Linn. 12, Or. 3, Nat. Or. Anonacee. An interesting, laurel-like shrub, succeeding in sandy peat and loam mixed; it is increased by cuttings, or seeds.

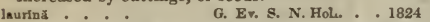

Eurötǐç $\mathrm{x}$, Link. From euros, the Greek name of a kind of mouldiness. Linn. 24, Or. 9, Nat. Or. Fungi. Yellow and white Fungi, found at all seasons on dried plants, and rose-bushes-herbariơrâm, Rosārùm.

EŨR̛̃̆, Thunberg. From eurys, large; alluding to the large flowers. Linn, 23, Or. 1, Nat, Or. Tern stramiacea. Evergreen shrubs, described as being very pretty; they succeed best in peat and loam, and are multiplied by cuttings in sand, or very sandy mould, under a glass, in heat.

chinénsı̌s . . White. . 6, S. Ev. S. China * - 1823 muitiflöră : White. F. Ev. S. Nepal 1823

Eur $\breve{X} \not \overline{\mathrm{E}}$, Salisbury. From Euryale, one of the Gorgons; alluding to the thorny menacing habit of the plant. Linn. 13, Or. 1 , Nat. Or. Nymphreaced. This is a very handsome plant, on account of its fine large leaves, which float on the surface of the
EUR

EUT

water, in which it requires to be constantly grown. The only way of propagating it is by seed, which is readily obtained by shaking the pollen on the stigma when the flowers are well expanded. $S y$ nonyme: 1. Anneslea spinosa.

féróx . . . Red . 8, S. Aq. P. India . 1809

EuRr̆вй, Cassina. From eurubies, wide-spreading; alluding to its creeping offsets. Linn. 19, Or. 2, Nat. Or. Compositce. Rather a pretty plant, each corymb usually consisting of numerous heads of flowers. For culture and propayation, see Aster. Synonymes; 1. Aster corymbosus, A. cordifolius.

corymbōsă, 1 . . White . 7, H. Hex. P. N. Amer. - 1765

Eurr̄clēs, Salisbury. From eurys, broad, and kleio, to close up; the perianth is shut up by the tube of the stamens. Linn. 6, Or. 1, Nat. Or. Amaryllidacex. Ornamental plants, growing about two feet high. For culture and propagation, see Pancratium. Synonymes: 1. Pancratium amboinense, Proiphys amboinensis. 2. P. australasicum. 3. Crinum nervosum.

amboinēnsǐs, 1 . White. . 5, S. Bl. P. Amboyna - 1759 australāsı̌eă, 2 : White. : 5, S. B1. P. N. Holl. : 1821 Cunninghämil : White: : 3, s. Bl. P. N. Holl. : 1826 Eustāchřs, Desfontaines. From eu, well, and stachys, a spike; alluding to the large flower spike. Linn. 23, Or. 1, Nat Or. Graminea. A pretty species of grass, of the easiest culture. Synonyme: 1. Chloris petraa, Agrostis complanata.

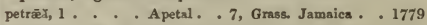

EustěgY̌, R. Bronn. Derived from eu, good, and stege, a covering. Linn. 5, Or. 2, Nat. Or. Asclepiadacee. This plant is described as being very ornamental; it will grow well in peat and loam, and is increased from cuttings in sand. Synonyme: 1 . Apocynum hastatum.

hastati, 1 . . White . 7, G. Ev. Tr. C. G. H. . 1816

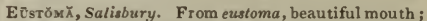
referring to the flower. Linn. 5, Or. 1, Nat. Or. Gentianacea. A very pretty annual, requiring to be sown on a gentle hotbed and transplanted into the open border, where it will produce flowers and seed in abundance.

silenifom . . White. . 7, H. A. I. Provid. . 1804

Eustrếphǔs, R. Bronn. From eu, well, and strepho, to twine; twining habit of the plants. Linn. 6, Or. 1, Nat. Or. Lilincea. These are very pretty evergreen twiners, and if carefully managed, they will succeed in sandy peat. Young plants are obtained from cuttings without any difficulty.

angustifollǔs. . Pa. pur. . 7, G. Ev. Tw. N. S. W. 1820 latifollŭs . : Pa. pur. : 6, G. Ev. Tw. N. S. W. : 1800 Eотихй, R. Brown. From eutaxia, modesty; in allusion to the delicate appearance of the plants when in flower. Linn. 10, Or. 1, Nat. Or. Leguminosa. The plants of this genus are very pretty, and thrive best in a mixture of loam and peat. To have handsome bushy plants, the tops should be frequently plucked off, and in potting, plenty of drainage should be given. Cuttings root readily planted in sand, under a glass. Synonyme: 1. Dillnynia pungens.

Baxiêr1. . Yellow •. Gr. S. N. Holl.

Baxterl. * Yellow - G. Er. S. N. Holl. * 1830 pingéns, 1: : : Orange : 5, G. Er. S. N. Holl. : 1825

EUTËRPĒ, Goertner. From euterpe, pleasing; alluding to the habit of the species. Linn. 21, Or. 6, Nat. Or. Palmacer. This is a fine genus of palms; some of the species grow upwards of forty feet high. To grow them well, they require a sandy loamy soil, and plenty of heat; they are increased from seed. Mr. Loudon has the following notice of $E$, oleracea : " It is the highest of the American palms. The sheaths of the leaves are very close, and form the green top of the trunk, a foot and a half in length. The inhabitants ent off this top, take out the white heart, of two or three inches in diameter, consisting of the leaves closely folded together, and eat it either raw, with pepper and salt, or fried with butter, like the artichoke." -Ency. of Plants. Synonymes: 1. Areca oleracea. 2. A. spicata. 
earibæă . . . . Palm. W. Ind. . . 1656 globōså : . . Palm. Maurit. . 1819

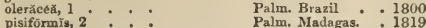
pisiförmǐs, 2

EuthäLês, R. Brown. From eu, well, and thaleo, to push, or sprout. Linn. 5, Or. 1, Nat. Or. Goodeniacea. This species is pretty, and will succeed well in loam and peat mixed; it is increased without any difficulty, by cuttings.

trinërviss • . Pur. yel. · 7, G. Her. P. N. Holl. . 1803

Euтнӓмїа, Nuttall. From eu, well, and thames, crowded; in allusion to the flowers. Linn. 19, Or. 1, Nat. Or. Compositce. Ornamental plants. For culture and prupagation, see Chrysocoma. Synonymes: 1. Chrysocoma graminifolia, Solidago lanceolata. 2. S. tenuifolia.

graminifoliă, 1 . Yellow . 9, H. Her. P. N. Amer. 1758 tenuifoliă, 2 . Yellow . 10, H. Her. P. N. Amer. . 1758

Euтŏc̆̆, R. Bromn. From eutokos, fruitful; alluding to the great number of seeds. Linn. 5, Or. 1, Nat. Or. Hydrophyllacee. The plants of this genus are very pretty. The seeds require to be sown in the flower-border early in spring, in light soil, where they will flower abundantly if not allowed to grow too thick.

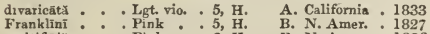

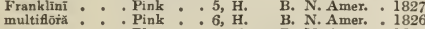

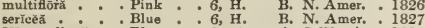
Wrangeliannă : : Blue : 8, H. A. California : 1835

Euxēñ̆ă, Chamisso. From eu, beautiful, and xenos, a stranger. Linn. 19, Or. 5, Nat. Or. Compositce. This is described as a very pretty plant, growing well in peat and loam, and increased from cuttings in sand, under a glass.

grätís . . Yellow . G. Ev. S. Chile . . 1825

EVEN; applied to a surface when it is not wrinkled or curled.

EvaNescrNT, quickly vanishing.

EvENING TLOWER, see Hesperänthă.

EvrRgregn thorn, see Cratāgŭs Pyracānthă.

Evirhastin(;, see Gnaphälīüm.

EvxrLAstiNg PEA, see Lathy̆rŭs latifũlizus.

EvễnĬă, Acharius. From eurnes, well-branched. Linn. 24, Or. 8, Nat. Or. Lichenes. A small bushy plant, of a greenish white colour; it is found at all seasons on heaths, and is used in dyeing. Synonyme: 1. Lichen stictoceros-Prunastri 1.

Evṑĭă, Forster. From evodia, a sweet snell; plant scented. Linn. 4, Or. 1, Nat. Or. Rutacec. An ornamental, evergreen, East Indian shrub, succeeding in sandy loam, and is increased from cuttings planted in sand, under a glass, in heat. $S y$ nonyme: 1. Fagara triphylla.

triphylla, 1 . . White. . S. Ev. S. E. Ind. . 1821

Evolved, unfolded.

EvōrvŭLŭs, Linn. From evolvo, to roll out, not twining, opposite to Convolvulus. Linn. 5, Or. 2, Nat. Or. Convolvulacea. All the species of this genus beat very handsome flowers. They are chietly plants of very easy culture. The annuals require to be raised on a moderate hotbed, and when potted off, to be treated like other tender annuals. Synonyme: 1. E. sericeus.

alsinoidēs : Blue * . 7, G. Tr. A. E. Ind. - 1817 emarginats . Blue * 9, S. Tr. A. E. Ind. 1816 gangeticüs. incanuัs, 1: : Biue: : 7, S. Tr. A. S. Amer. 1810 incanǔs, 1 : : Biue : W, S. Tr. A. S. Amer. : 1810 latifolins : : White : 6, S. Ev. Tw. Brazil * : 1819
linifoliŭs: nummulărĭŭs : Blue * 9, S. Tr. A. Jamaica : 1816 Nuttalliänŭs : Blue * 7, H. Tr. A. N. Amer. : 1824 serǐcěus. - White: 7, S. Tr. A. W. Ind. 1816 villōsŭs. Blue. 7, S, Ev. Tr, S. Amer. 1810

ExĀcũ $\mathrm{x}, \operatorname{Linn}$. From ex, out of, and ago, to drive; it is said to have the property of expeling poison. Linn. 4, Or. 1, Nat. Or. Gentianacea. These are pretty annuals, requiring to be sown in the open air, in peat soil, and a moist situation.

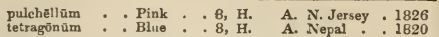

Exarillatr, without aril.

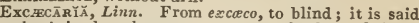
the juice has the power to canse the loss of sight. Linn. 29, Or. 13, Nat. Or, Euphorbiacece. Hand some, stove, evergreen species, thriving well in open loamy soil; they are increased by cuttings in sand, under a glass, in heat. The juice of $\boldsymbol{E}$ $\alpha$ galloch $\alpha$ affects the eyes with intense pain. Rumphius says, "When sailors have been sent ashore to cut fuel, and accidentally rubbed their eyes with the juice of it, they became blinded, and ran about like distracted beings, and some of them finally lost their sight."-Nat. Syst. Bot., p. 115.

Agallōehă . . . White. . 5, S. Ev. S. E. Ind. . . 1820

glandulōsă . : White. 5, S. Ev, S. Jamaica : 1821

serrätă . : : White. : 5, S. Ev. S. Chile : $1790^{\circ}$

Exscăpüs, without a stalk.

ExCENTRICAL, out of the centre.

ExcípưLă, Fries. From excipio, to catch, alluding to the roughness of the plant to the touch. Linn. 24, Or. 9, Nat. Or. Fungi. A minute species of black Fungi, found in autumn upon dead raspberry stems-Rübz.

Excīsă, bluntly cut off.

Excoriatr, stripped of the skin.

ExcuRRENT, projecting beyond the edge or point of any thing.

Exīiña, Fries. Froin exidio, to exude; alluding to the sporules exuding from the receptacle. Linn. 24, Or. 9, Nat. Or. Fungi. Brownish species, found in autumn and winter on various species of treesauriculätă, rubescenti-füscă, fläccĭdă, glandulosă, recīsă.

Exiñ̄ĭh, Greville. From exilis, slender; habit of the plants. Linn. 24, Or. 7, Nat. Or. Alga. Greenish, very minute species, found in summer in the sea, and various watery places-circulärĭs, fasciculätă, flabèllătă, fülgēns.

Exĭgữs, mean, small.

ExocĀroús, Labillardière. From exo, outside, and karpos, fruit; the seed is situated on a large fleshy receptacle. Linn. 21 , Or. 5, Nat. Or. Thymelacere. These are large-growing plants, especially $E$. cupressiformis, which is described as a timber tree. They require a mixture of peat and loam to grow in, and cuttings take freely in sand. under a glass.

cupressiförmis. Apetal - G. Ev. T. V. D. I. 1824 huiuifusŭs. : A petal : G. Ev. Tr. V. D. L. : 1824 strietüs.: : Apetal : G. Ev. S. N. Holl. : 1822

ExospŏRĩū, Link. From exo, outside, and spora, a sporule. Linn. 24, Or. 9, Nat. Or. Fungi. A very minute plant, found growing at any season on the lime-tree branches- $T \dot{T} l \bar{l} \bar{e}$.

Exоsте́mмă, Decandolle. From exo, without, and stemma, a crown; alluding to the exserted stamens. Linn. 5, Or. 1, Nat. Or. Cinchonacea. Trees, attaining from twenty to thirty feet high. $E$. floribund um is described as a timber tree. They all require to be grown in loam and peat, and are increased from cuttings in sand, under a glass, in heat.

brachycărpūm . White. . 8, S. Ev. T. Jamaica . 1823 caribæŭun . . White. 8, S. Ev. T. W. Ind. : 1780 floribūndūm : White. S. Ev. T. W. Ind. 1794 longiflörūm P.'̌k. White: 6, S. Ev. T. Caraceas : 1820

Exprctorant, anything that promotes the discharge of mucus from the chest.

Exserted, projecting much beyond something else.

Exsiccated, dried up.

Extra-axiluary, growing from above or below the axils of the leaves, or branches.

Exrra-) oliaciots, away from the leaves, or inserted in a different place from them.

Exsūccǔs, dry, sapless.

ExSURGENT, growing upwards.

Ex Ǔvı̆, whatever is cast off from plants.

Eysarioht, see Euphräsĭă. 
F.

F $X B A$, Decandolle. From phago, to eat; the escuTent seeds of the common bean are well known. Linn. 14, Or. 4, Nat. Or. Leguminosa. This species, and its garden varieties, are well known, on account of their seeds being so much used in cookery. They only require to be sown in the open ground. Synonyme: 1. Vicia Faba.

vulgārǐs, 1.: White. : 7, H. A. Egypt .

equina . . Purple $\tau, \mathrm{H}$ A.

ABAGo, Tournefort. From $f a b a$, a bean; resemblance of the leares. Linn. 10, Or. 1, Nat. Or. Zugophyllaces. This species thrives well in a light soil, and a dry situation; it is increased from seed. Synonyme: 1. Zygophyllum fabago.

mãjōr, 1 . . . Wht. saf. 7, H. Her. P. Syrıa . . 1596

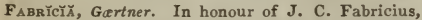
the celebrated Danish entomologist. Linn. 12, Or. 1, Nat. Or. Myrtucee. Ornamental plants, well adapted for conservatories, as they require to grow to a good size before they will flower. For culture and propagation, see Leptospermum.

lævieãta . . Yellow

myrifóllü: : : Yellow

. 6, G. Ev, S. N. S. W

G. Ev. S. N. Holl.

serices : : : Yellow : $\begin{aligned} & \text { G. Kv. S. N. Holl. } \\ & \text { stifer }\end{aligned}$ things; the albumen of some seeds.

FAGARA, see Xanthoxy̆lzm.

FAGÉrin, Necker. Supposed to be the name of some botanist known to Necker. Linn. 17, Or. 4, Nat. Or. Leguminosce. A very desirable greenhouse or conservatory plant, requiring the same treatment as Kennedyid. Synonyme: 1. Glycine biluminosa.

bituminôsă, 1 . Yel. pur. . 6, G. Ev $\Gamma$ w. C. G. H. . 1774

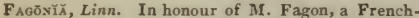
man, and great patron of botany. Linn. 10, Or. 1, Nat. Or. Zygophyllaced. These plants do not possess much to recommend them. They grow well in loars, peat, and sand, mixed, and cuttings root freely when planted in sand, under a glass.

arăbrea . . Purple . 7, G. Ev. S. Arabia : . 1759 erética : : Purple : 7, G. Ev. S, Candia : 1739 glutinúsa : : Red : 6,G. Ev. Tr. Egypt : : 1829

FAgrāex. Named by Thunberg, after his friend $J$. T. Fagræus, M.D. Linn. 5, Or. 1, Nat Or. Loganiacese. These are ornamental stove plants, thriving well in sandy loam and peat; cuttings of the young wood root readily in sand, under a glass, in heat. Synonyme: 1. Willughbeia zeylanica.

obovata . . . White. . S. Ev. T. Sillet . . 1816 zeylanica, i : : White : : S. Ev. T. Ceylou : 1816

FĩĞ̌s. From phago, to eat; in early ages the nuts of the Beech tree were used as food. Linn. 21, Or. 9, Nat. Or. Corylacece. Handsome and very ornamental timber trees, particularly $F$. sylvatica, which is one of the handsomest and best adapted of trees for planting singly in parks, or lawns. The Beech-tree thrives best in a chalky clay, or loamy soil, preferring a sheltered situation. They may all be increased by seed, budding, or grafting. The timber is brittle, but much used by turners, joiners, and millwrights.

antaretieã . A petal . H. De. T. Magellan . 1830 betuloides - Apetal * H. De. T. Magellan 1830 ferruginer: : A petal :6, H. De. T. N. Amer. : 1766 ferruginea : : Apetal $\quad$ : 6, H. De. T. Brituin.
sylvatiea atrôrŭbēns: : A petal : 6, H. De. T incisa : Apetal : 6, H. De. T.

$\left.\begin{array}{l}\text { Falcatr, } \\ \text { FaLCIFor },\end{array}\right\}$ bent like a sickle.

F $\overline{L K} \overline{1}$. Named by Linnæeus in honour of $J . P$. Falk, a Swedish botanist, who died in 1774 . Linn. 5, Or. 2, Nat. Or. Nolanacea. A desirable little creeper, which grows readily in a mixture of peat and loam, and young plants are easily procured from cuttings in the same kind of soil, under a glass.

répéns.

Pink . . 7, G. Ev. Cr. C. G. H.

.1774

FAise ARMERIA, see Diänthùs Pseudo-armëriă.

Falsedy TWo-valvid ; imperfectly two-valved, or having two valves with an origin different from that of ordinary valves.

FAx-NER VRD, the nerves disposed like a fan. FAn palm, see Corȳphá.

FAR $\bar{A} M \bar{X} \bar{A}$, Aublet. Meaning of the name not piven. Linn. 3, Or. 1, Nat. Or. Cinchonaced. This shrub is well deserving of culture on account of its sweetscented flowers, which are about the size of those of the jasmine. It succeeds well in a mixture of turfy loam, peat, and sand, and may be increased by ripened cuttings planted in sand, under a glass, in a moist heat. The plants require plenty of potronm, and a liberal supply of water. Synonyme: 1. Tetramerium odoratissimum.

odoratissimă . . White. . S. Ev. S. W. Ind. 1793

Farinacrous, full of flour.

FARINĂ, meal.

FARINACROUSLY TOMENTOSR, \} covered with a mealy FARIXOSELY-TOMENTOSE, $\}$ kind of down.

FARsËTĨ̆, Turra. In honour of Philip Farseti, a noble Venetian botanist. Linn. 15, Nat. Or. Cruciferc. The frame species of this interesting genus thrive well in any light soil, and cuttings strike readily in the same kind of soil, under a glass. The perennial kinds are well suited for rock-work, or for the front of flower-borders; they may be in. creased from cuttings planted under a glass, or from seed. The annual species merely require sowing where intended to flower. Synonymes: 1 . Alyssum cheiranthifolium. 2. F. ogyptiaca, Cheiranthus Farsetiu. 3. Alyssum clypeatum. 4. Lunaria groeca.

cheiranthifoliz, 1 Yelow . 7. H. A. Levant 1818 cheiranthoides, 2. Wht pur. \%, F. Ev. S. Levant : 17 48 clvpeâtă, 3. Yellow 7, H. Her. P. S. Eur. 1596 eriocarpa : Yellow 7, $F$. eriocarpa ${ }^{\circ}$. Yellow $\cdot 7, F$. Ev. S. Greece .1820 lunarinídes, 4 : Yellow : 7, F. Ev. \&. Archip. : 1731
suffruticōs

FAscrated, having pale bands or transverse spots.

FAscicled, in bundles, or parcels.

FAscici.rs, parcels, or bundles.

FAsciculATB, $\}$ arranged in bundles, or parcels.

FASCICLED-WHORYRn, arranged in parcels, but forming a whorl, or circle.

F ASCICLRD-RACEMES, racemes collected into parcels.

FASCICULATBLY-TUBRROUS, roots composed of parcels Fasciclad-tubarous,

FAstiatat, tapering to a narrow point, like a pyramid.

FAstigiatrly-branchiod, the branches becoming gradually shorter from the base to the apex.

FAúcšs, the gaping part of monopetalous flowers.

FAvosi, pitted, like the cells of a honeycomb.

FAvoskLy-scrobiculatr, excavated in little pits or hollows.

Frather-grass, see Stipa pennata.

FrATHRR-NERVED, the nerves disposed like the feathers of a pen.

FEBRTfugR, $\}$ efficacious in moderating fevers.

F BCULENT, muddy, thick with sediment.

F BCUNDATION, the act of making fruitful.

FËD̆̌A, Manch. Derived from fedus, an ancient word, signify ing a kid. Linn. 2, Or. 1, Nat. Or. Valerianacec. An extremely ornamental annual, the seeds of which merely require to be sown in the open border in spring.

cornucüpı̌̉ . . Red . . 7, H. A. S. Eur. 1796

FrLwort, see sinwis. Swertia

Frmale rers, see Asplēniūm Filix fümiñă. 
Fevnstrãur, having holes, or gaps.

Frnvil, see Anëthüm faenicülĩm.

P

Frvugreak, see Trigonellă.

Frrnandēzİ, Ruiz and Pavon. Named after George Garcias Fernandez, a Spanish botanist, who is unknown except through the medium of this genus. Linn. 20, Or. 1, Nat. Or. Orchidacea. Small plants not possessed of much beauty. They may be cultivated in good turfy peat, broken into small pieces, mixed with a few potsherds. The pots inust be well drained, and the plants kept in a hot damp stove.

acũtă * - * Yel. red. 6, S. Epi. Trinidad : 1834

Fervētũ , Commerson. After J. Fernel, physician to Henry II. of France, who died in 1558. Linn. 4, Or. 1, Nat. Or. Cinchonacer. Elegant little plants, with fine glossy leaves, well worthy a place in every collection. They succeed well in a mixture of turfy loam and peat, and cuttings planted in sand, under a glass, will root freely in the stove. Synonyme: 1. Coccocypselum buxifolium.

buxifolia, 1

S. Ev. S. I. France

1816 obovảtà .

FrRRĀrĬă, Linn. In honour of J. B. Ferrari, an Italian botanist. Linn. 16, Or. 1, Nat. Or. Indacea. Rather ornamental plants when in flower, succeeding best in a mixture of sandy loam and peat; when in a dormant state, they should be kept quite dry. As soon as they begin to grow they should receive a fresh potting, and a regular supply of water. If grown in a warm border, in sandy soil, the bulbs should be planted about six inches deep, and protected from severe weather; they are increased by offsets, or seeds. Synonyme: 1. Ferrariola viridiflora.

angustifolia Brown $6, \mathrm{G}, \mathrm{Bl}, \mathrm{P}, \mathrm{C}, \mathrm{G}, \mathrm{H},-1895$

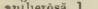

. par. 6, H. Bl. P. C. G. H.

elongàtà *. Drk. pur. . 7, F. Bl. P. M. Video - 1828

obtusifólǐ . . Brown * 6, G. Bl. P. C. G. H. 1825

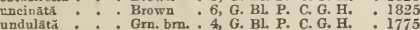

Ferrugrnous, iron-coloured, rusty.

FĔŭLă, Tournefort. From ferio, to strike; stems used as rods. Linn. 5, Or. 2, Nat. Or. Umbellifera. All the species of Ferula, or Giant-fennel, are strong-growing plants. They do well in any garden soil, and are easily increased by seeds. Synonymes : 1. F. nodiflora. 2. Peucedanum obtusifolium. 3. F. asafetida. 4. Peucedanum sibiricum. 5. Cicuto venenata.

asafōtrđă

campestris: : Yellow

capillărìs : Yellow

căspieă : : Yellow

commúnǐs : : Yellow

Feruago, $1:$ Yellow

longifolia: : Yellow

meoidés . : Yellow

nûdă $: \cdot$ Y Yellow

obtusifoliă, 2 . Green

orientâlís : : Yellow

pubéscêns : : Yellow

sibinrică, 4 : : Yellow

strictä : : Yellow

tingitānă : Y Y ellow

7, H. Her. P. Persia

6, H. Her. P. Tauria

, H. Her. P. Spain

7, H. Her. Palucasuo

7, H. Her. P. S. Eur.

7 , H. Her. P. Italy

7, H. Her. P. Siberia

7, H. Her. P Siberis

7, H. Her. F. Greece : 1819

7, H. Her. P. Levant : : 1759

8 , H. Her. P. Persia : 1782

7, H. Her. P. Siheria : 1820

7, H. Her. P. Siberia : 1816

6, H. Her. P. Podolia . : 1829

7, H. Her. P. Barbary - 1680

FerulāGō, Kach. From ferio, same as Ferula, Linn. 5, Or. 2, Nat. Or. Umbellifere. Plants very nearly related to Ferula, and requiring precisely the same treatment. Synonymes: 1. Ferula nodiflora. 2. F. thyrsiflora.

nodiflōtă, 1 * Yellow . 7, H. Her. P. S. Eur. . . 1596 thyrsiflôră, 2 : White. 6, H, Her. P. Crete : 1825

Frstūcă. Linnæus derived this name from the Celtic word fest, signifying pasture, or food. Linn. 3, Or. 2, Nat. Or. Graminee. This genus affords some valuable fodder grasses, grows best in a loamy soil, and is increased from seeds.

eãmbrìcă . . . Apetal . . 7, Grass. Wales eynosuroides : A Apetal : 7, Grass. S. Eur. [ 133 ]

duriñscŭlă . . Apetal . .6, Grass Britain

gläbra : : : Apetal : 7, Grass. Britain

glıúcă . . A petal . 7, Grass. S. Eur.

hirsută . . A petal : 7. Grass. Germung

lēviss.. . Apetal . 6, Grass. Russia

oviuă A petal 6, Grass. Rritai

tenuifólix: : A petal: 7. Grass Britain

văriă . : : Apetal: : 7, Grass, S. Eur.

vivipără : : : A petal : : 7, Grass, Britain

lpēstrǐs, alpānă, amethȳstinnă, äspěră, baleāriccă, bul-

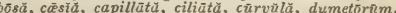
Fā̄uùs, fällàx, flavēscēns, glomerātă, grandiflöră, Hallēri, heterophȳllü, intermĕdiă, läxă, mexicā̃ă, nūtāns, pällēns, pannonică, pubēsiēns, rübëns, rübră, scäbră, serotină, strictă, tenëllă, trifloră, vaginătŭ, vallešăcă, xanthìnă.

Feveraw, see Pyrêthrum.

FEVRRIVORT, see Triostěũm.

Fibril.ose, covered with little strings, or fibres.

Fibrous, composed of fibres.

Fīвuัıı́ōris, button-shaped.

Fic̄̄ič̃a, Dillenius. Derived from ficus, a fig; the roots bear tubercles resembling little figs. Linn. 13, Or. 6, Nat. Or. Ranunculacea. These desirable plants succeed best if planted in any common soil, under the shade of trees. They are increased by separating the tubers in autumn. Synonyme: 1. F. ranunculoides.

vẽrnă, 1 - . Yellow $\quad$ 5, H. Tu. P. Britin . pallifa : Pa, yel. : 5, H. Tu. P. Gardens

plénă Yellow .5, H. Tu, P. B citain

Fîcès, Linn. The derivation of the name is unknown. Linn. 23, Or. 2, Nat. Or. Urticacece. This is an extensive but easily cultivated genus of plants, some of which are very desirable, especially $\boldsymbol{F}$ elastica, which is one of the most noted. They all thrive well in any light rich soil, or in loam and peat. Cuttings, with their leaves uninjured, root in sand; the stove species in heat. $F$. elastica is famed for producing a species of Indian rubber. The glutinous juice of $F$. indica is applied to the teeth and gums to ease the toothach; the Hindoos consider the bark a powerful tonic, and use it in diabetes. $F$. racemosa is slightly astringent, and the juice of the reot is also a powerful tonic. $F$. religiosa is the celebrated Banyan Tree of India the seeds of which are supposed to be cooling and alterative. Synonymes: 1. cerasiformis. 2. scabra, glandulosa. 3. nitida. 4. venosa, leucostictu. 5. virens. 6. scabra. 7. speciosa, indica.

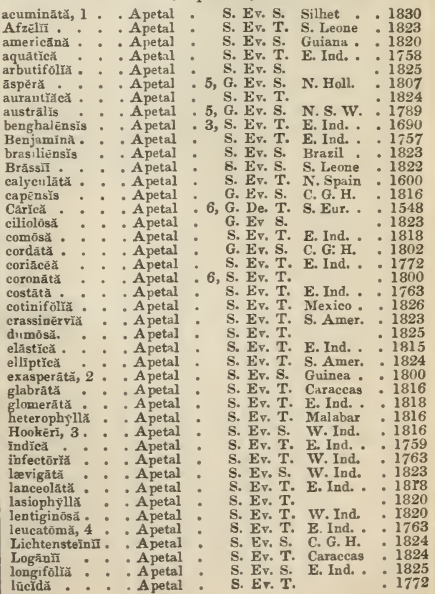




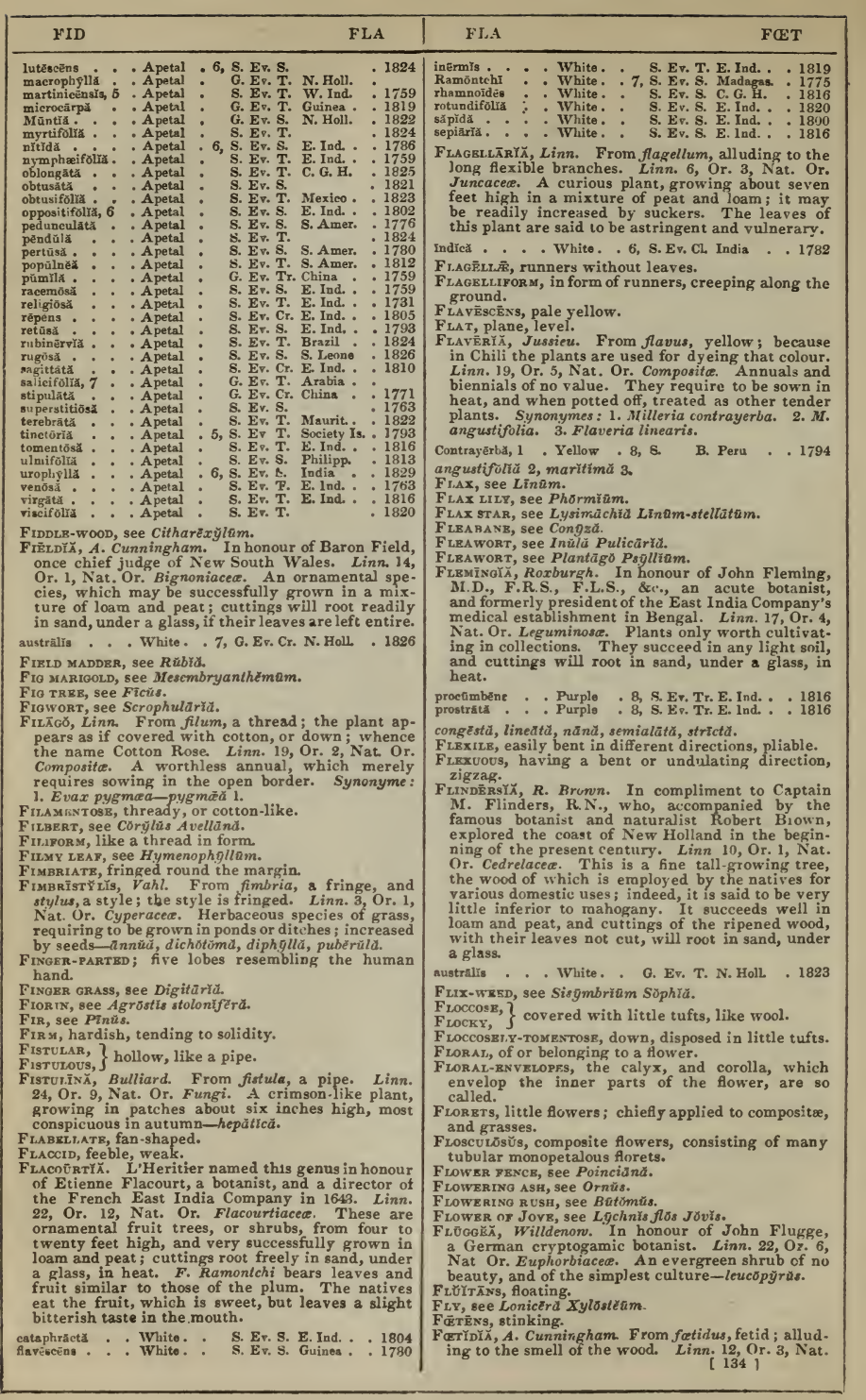


Or. Myrtacea. An ornamental tree, about twenty: five feet high; it requires a turfy loam, mixed with a little peat, and ripened cuttings will soon root if planted in sand, under a glass, in heat.

mauritiänã . . White. . S. Ev. T. Maurit. . 1825

Foliacrous, having the texture of leaves

Foliate; when a leaf is divided into leaflets, it is called $1,2,3,5$, or 10 -foliate, according to the number of leaflets.

FoirtcLe, a particular kind of two-valved seed-vessel, such as that of Proony.

Foldicular, like a follicle.

FontaNẼsia, Labillardière. In honour of the celebrated Desfontaines, professor of botany at Paris. Linn. 2, Or. 1, Nat. Or. Oleacece. If this very ornamental species is planted out in the open ground, it will require a little protection in severe weather. It thrives well in any common soil, and may be easily increased by layers, or cuttings, under a glass.

phillyræoĩdés . . Yellow . 8, F. De. S. Syria

1787

Fontrs̄̄IIs, Linn. From fons, a fountain; alluding to the place of growth. Linn, 24, Or. 5, Nat. Or. Musci. Greenish-looking plants, most conspicuous in the summer season. $F$. antipyretica is very common, floating in large masses in rivers an pools of water-antipyrêtĩcă, capilläcěă, squamôsă.

Fools' PARSLEY, see Fethūsă.

Footsta LKs, the stalks of leaves, \&c.

Forficātǔs, pince, or nipper-shaped.

ForMōsĂ, handsome, ornamental.

Fornicatr, arched.

Forsk ĀHLĬA, Linn. In honour of Peter Forskahl, a traveller in Egypt. Linn. 21, Or. 6, Nat. Or. Urticacer. Curious little plants, somewhat resembling the nettle. $\boldsymbol{F}$. candida thrives well in any light rich soil, and cuttings root readily in the same kind of soil, under a glass. The annual kinds require to be sown in a gentle hotbed, and when of sufficient size, transplanted into the open ground.

sngustifoliă * Wht. grn. 7, H. A. Teneriffe 1779 cāndìdă : : Wht. gra. 7, G. Her. P. C. G. H. : 1774 tenacissimă : : Wht. grn. 7, H. $\quad$ A. Egypt . : 1767

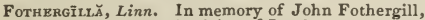
M.D., an eminent physician of London, and patron of botany. Linn. 13, Or. 2, Nat. Or. Hamamelacee. Beautiful shrubs when in leaf and flower, growing from three to six feet high, and bearing pretty, white, sweet-scented flowers. In the shrubbery, they thrive well in a peat soil, and may be increased by layers in spring or autumn, or by seed, which is annually imported from America. Synononymes: 1. F. Gardeni. 2. F. major.

alrifolia . . White. . 5, H. De. S. N. Amer. acüt̆ 1 White 6, acuta, $1:$ White. 6, H. De. S. N. Amer. 1765 serótină. : White. 8, H. De. S. N. Amer. 1765

Foveate, $\}$ pitted, full of little pits

FovĚ̃ L $\overline{\mathbb{E}}$, little pits, or hollows.

Foxrane, see Aconitam Vulpärüă.

FoxGrovk, see Digitäliss.

Fox-TAIL GRAss, see Alopecürŭs.

FrAGĀRǏ , Linn. From fragrans, fragrant; the perfumed fruit of the strawberry is well known. Linn. 12, Or. 1, Nat. Or. Rosacee. The cultivation and propagation of this plant is so familiar to every one, as are also the wholesomeness and deliciousness of the fruit, that neither need be particularised here any further than that seeds, sown early in spring, will generally fruit the same year very late in autumn. Synonyme: 1. grandiflora.

bonariênsis - Apetal . 6, H. Her. P. B. Ayres.

Whito 5 , H. Ayres.

Breslingin : White 0 , H. Her. P. France

calycina, 1 : White $: 4$, H. Her. $P$. France

canadēnsǐs. - White. 5, H. Her. P. N. Amer.

chilénsǐs . . White . 5, H. Her. P. S. Amer.

collină - . White . 6, H. Her. P. Germany

elâtĭor : * White .5 , H. Her. P. Britain

grandiflöră. - White 5 , H. Her. P. Surinam

indǐeă : . Yellow

majaúfeă : White

monophylla: - White

platanoïdès : Red : White

7, H. Her. Cr. India

5 , H. Her. P.

5, H. Her. P. . N. A mer.

5 , H. Her. P. Britain.

virginiañă: Whito : 4, H, Her. P. N. Amer. : 1629 [135]
Fragtr.ārĭă, Lyngbye. From fragilis, brittle; allud. ing to the nature of the plants. Linn. 24, Or. 7, Nat. Or. Alga. Green and brown tufts of Alga, found in rivulets and watery places-hyemalis, pectinālìs.

Francīsč̆ $\breve{E}$, Pohl. In honour of Francis, emperor of A ustria, a patron of botany. Linn. 14, Or. 2, Nat. Or. Scrophulariacea. An ornamental dwarfish shrub, requiring a mixture of peat and loam. Cuttings root in sand, under a glass, in heat. $S y$ nonyme: 1. F. Hopeana.

uniflôră, 1 . . Wht. pur. 7, S. Ev. S. Brazil

Francōă. Cavanilles named this genus after $\mathbf{F}$. Franco, a Valencian promoter of botany in the sixteenth century. Linn. 8, Or. 4, Nat. Or. Francoacere. Beautiful plants when in flower, and well worthy a place in every collection. They may be planted out in the open ground, in a warm sheltered situation, with a slight protection in severe weather. They can only be increased by seeds.

appendiculata. . Purple 7, H. Her. P. Chile * 1830 ramōsă . : White. 7, H. Her. P. Chile : 1831

FRANRENY̌. Named by Linnæus in honour of John Frankenius, professor of botany at Upsal, who died in 1661. Linn. 6, Or. 1, Nat. Or. Frankeniacees. Truly beautiful, little evergreen shrubs, or herbs. The hardy kinds are particularly well adapted for ornamenting rock-work, or they may be grown in small pots, and placed among the alpine plants. The greenhouse species should be placed on the front shelf in winter. All the species grow well in loam, peat, and sand, with the pots well drained; they are easily increased by cuttings planted in sand, under a glass, by seeds, or divisions of the roots. Synonymes: 1, hispida. hirsuta.

corymbôsă . . . Red . 7, H. Ev, Tr. Barbary . 1819 ericifoliă : : Red : 7, G. Ev. Tr. Canaries : 1816 hirsũtă, 1: : Li. blue : 7, H. Ev. Tr. Siberia : 1789 intermédră, 2 . White 7, H. Ev. Tr. S. Eur. : 1817 læ̌v̆s - Flesh : 7, H. Ev. Cr. England mollis : : Red : 7, H. Ev. Tr. Caucasus : 1824 nodiflöră : : Flesh :6, G. Ev. Tr. C. G.H. 1818 Nōthria : * Flesh : 7, H. Ev. Gr. C. G. H. : 1816 pauciflöră :- Pink. 7, G. Fv. N. Hol

FraNkincesse, see Pinnŭs $T \bar{a} d \ddot{d}$.

FrANZĒrY̌n, Cavunilles. In honour of Antony Franzer, a botanist. Linn. 21, Or. 5, Nat. Or. Compositce. Greenhouse shrubs of no interest. They grow in peat and loam, and may be increased by cuttingsambrosioz̄dès, artemisivīdēs.

Frasêră. Michaux dedicated this genus in honour of John Fraser, an indefatigable collector of North American plants. Linn. 4, Or. 1, Nat. Or. Gentianaceo. A very curious little plant, found in the morasses of North America, and successfully cultivated in peat soil, and increased by seeds, or divisions. The root of this plant is a pure and excellent bitter. Synonyme: 1. Walteri.

carolinēnsǐs, 1 . Grn. yel. . 7, H. P. Carolina . 1795

Frāxixŭs, Linn. From phraxis, a separation; the wood is used in making hedges. Linn. 23, Or. 2, Nat. Or. Oleacer. Most of the species are largegrowing trees, well suited for plantations. $F$. excelsior is one of the most useful of our native timber trees; its wood is much used by coachmakers, wheelwrights, and for many implements used in husbandry. Any of the kinds may be increased by budding or grafting on the common ash, but they are most frequently raised from seeds, which do not vegetate till the second year. The bark of several of the species yields a concrete dis. charge called manna, which is a sweet and gentle purgative. Synonymes: 1. discolor. 2. crispa. 3. simplicifolia. 4. nigra.

acuminătă . . Green . . 5, H. De. T. N. Amer. - 1723 ălbă . . : Green . 5, H. De. T. N. Amer. 1823 amarissimă : Green : 5 , H. De. T.

amerieãnă. : Green : 5, H. De. T. N. Amer. , 1723 appéndỉcă: : Green: 5 , H. De. T. appendiculătă : Green : : 5, H. De. T. Corsica . . 1825 argêntéă * Green - 6, H. De. T. Corsica atrōvirueñs : : Green : : 5, H. De. T. N. Amer. : 1783 cinërěa . : Green : 5, H. De. T. N. Amer. : 1824 


\begin{tabular}{|c|c|c|}
\hline FRE & FRI & FUM \\
\hline 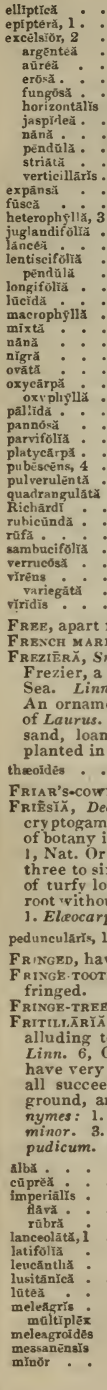 & 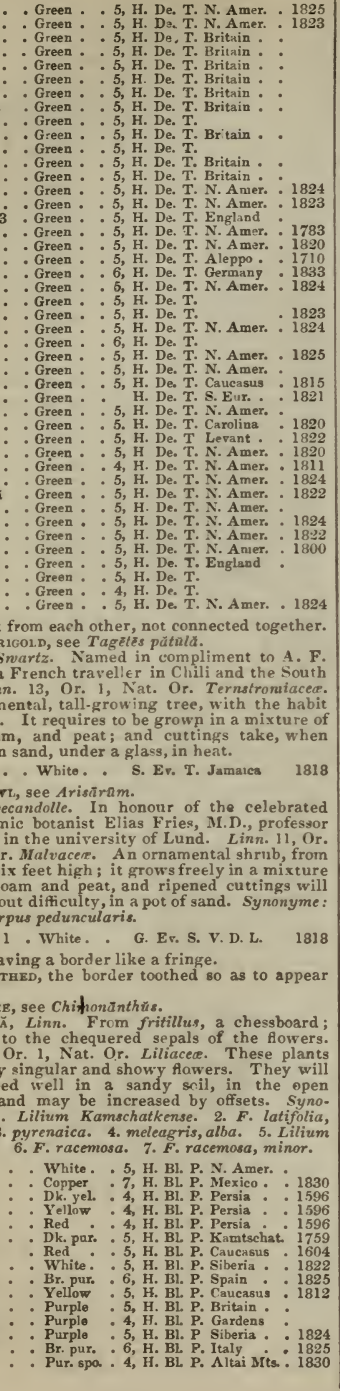 & 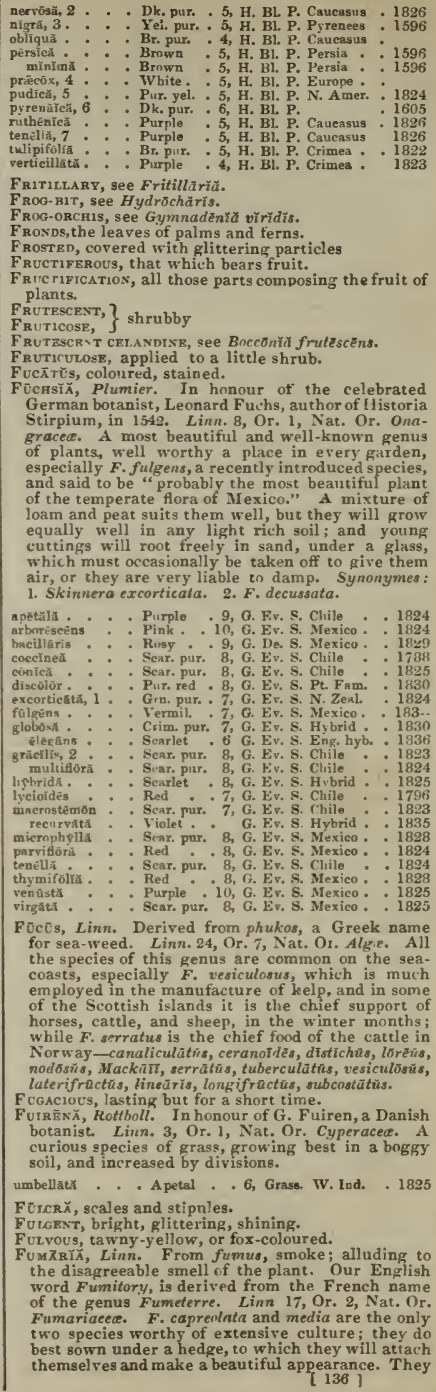 \\
\hline
\end{tabular}


only require sowing in the open ground. Synonyme: 1. F. capreolata.

\begin{tabular}{|c|c|c|c|}
\hline 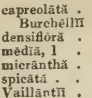 & $\begin{array}{l}\text { Flesh } \\
\vdots: \text { Pink } \\
: \text { Flesh } \\
: \text { Pink } \\
: \text { Flesh } \\
: \text { Pink }\end{array}$ & $\begin{array}{l}: 7, \mathrm{H} . \mathrm{Cl} . \\
: 4, \mathrm{H} . \\
: 7, \mathrm{H} . \\
: 7, \mathrm{H} . \\
: 7, \mathrm{H} . \\
: 7, \mathrm{H} .\end{array}$ & $\begin{array}{l}\text { A. Europe. } \\
\text { A. C. G. H. } \\
\text { A. Montpel. } \\
\text { A. Britain } \\
\text { A. Spain } \\
\text { A. S. Eur. } \\
\text { A. England }\end{array}$ \\
\hline
\end{tabular}

officinātis, parvifloră.

FUMITORY, see Fumāriă.

Fumösũs, strong-scented.

FUNÁR̆̃̆, Linn. From funis, a rope; alluding to the twisted formation of the fruit -stalks. Linn.24, Or. 5, Nat. Or. Musci. Minute species of moss, found growing in tufts on rocks and cottage roofs, during the winter and spring months-hiberrnică, hygromëtrĭcă, Muhlenbērgiñ.

Fungous, having the consistence of a mushroom.

Funicur, a little stalk, by which the seed is attached to the placenta.

FŨккї̆. Named by Sprengel in honour of Henry Funk, a German cryptogamist. Linn. 6, Or. 1, Nat. Or. Liliacea. Ornamental species, requiring a warm situation in the flower-garden, otherwise they will not flower well; they are easily multiplied by dividing the roots. Synonymes: 1. Hemerocallis lanceafolia. 2. H. carulea. 3. H. japonica.

albo-marginătă . Liiac . . 7, G. Her. P. Japan

lancerfolin 1 . Lilac

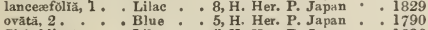

Sieboldiăna : : Lilac : : 6, H. Her. P. Japan : : 1830 subenrdătă, 3 : : White: : 8, H. Her. P. Japan : 1790

FuRcatr, forked.

FurCATELY-DIVIDED, divided in a furcate manner.

Furckllârî̀, Lamour. From furcella, a little fork; alluding to the arrangement of the fronds. Linn. 24, Or. 7, Nat. Or. Alga. A small plant, most conspicuous in spring and autumn-fustigiātă.

FURCRË.̆. Named by Ventenat, in honour of M. Fourcroy, a celebrated French chemist. Linn. 6, Or. 1, Nat. Or. Bromeliacere. A noble gerius of plants, resembling in a great measure the genus Agave, and requiring the same treatment. Syno. nyme: 1. Agave fietida.

\section{austrălís}

Căntŭlă

cubënxis

S. Her. P. N. Holl. S. Her. P. China

Gignten

mudagascariēnsìs.

rĭğ̀ă

S. Her. P. S. Amer.

S. Her. P. Madagas.

S. Her. P. S. Amer.

tuberösă : : Green . . 8, S. Her. P. S. Amer

1811

1739

1690

3895

1768
1739

Furfurackous, scaly, mealy, scurfy

FURROWRD, having longit!d dinal furrows, or channes,

FusĀxǔs, Linn. Derived from the French, fusain, a spindle tree; on account of the resemblance of the leaves and fruit. Linn. 23, Or. 1, Nat. Or. San. talacee. A worthless, evergreen, Cape shrub, requiring the same treatment as other Cape greenhouse shrubs-comprëssüs.

FUSĀrÝ̄M, Link. From fusus, a spindle; alluding to the shape of the sporules, Linn. 24, Or. 9, Nat. Or. Fungi. An extremely minute species, of a pinkish colour, found chiefly in spring on dead nettle stems-tremelloĩd $\vec{s}$.

Fuscous, blackish-brown.

Fusĩñ̄m, Fries. Fron fusus, a spindle; the sporidia are spindle-shaped. Linn. 24, Or.9, Nat. Or. Fungi. Whitish-coloured species, chiefly to be met with in autumn on dead beech leaves-cāndidūm, flavo. vйrêns, grisěũum.

Fusirorm, spindle-shaped, like the root of a carrot.

Fusric-wood, see Macläă tinctōriăh

G.

G ERTNER A, Lamarck. In honour of J. Gærtner, G M.D., F.R.S., a celebrated botanist. Linn. 10, Or. 1, Nat. Or. Lcganiacece. These plants are ornamental, and thrive well in a mixture of loam and peat, and cuttings root readily in sandy soil, under a glass, in heat. Synonymes: 1. Hiptage obtusifolia. 2. $\boldsymbol{H}$ mandablota.

obtusifơliă, 1 . White. S. Ev. Tw. Cluna * . 1810 racemosi, 2 . : Wht. yel.: 4, S. Ev. Tw. E. Ind. : : 1793 GĀĞ̌̆, Salisbury. In honour of Sir Thomas Gage, a botanical amateur. Linn. 6, Or. 1, Nat. Or. Liliacece. The species of this genus are very hand. some, and thrive well in any light soil, in the open ground, and may be readily increased from offsets. Synonymes: 1. Ornithogalum bohemicum. 2. 0. luteum. 3. O. lnteum, Gagea lutea. 4. O.pygmarum. 5. Anthericum serotinum 6. 0. minimum, arvense. 7. O. striatum. 8. 0. uniflorum.

bohëmǐ̀ă, 1 . . Yellow 4, H. Bl. P. Bohemia - 1825 bracteoláris, 2 : Yellow 4 , H. Bl. P. Eurnpe 5 , H Bl P. Tauria. 189 - 5, H. Bl. P. Turria . 1829

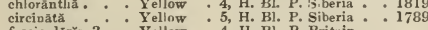
circinătă $\cdot 0^{\circ}$. Yellow

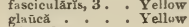
Liotărdi 4, H. Bl. P. Switzerl. 4, H. Bl. P. Switzerl. : 1825 5, H. BI. P. S. Eur. . 1825 podolǐcă : : pusilla . . Yellow pygmēex, 4 . Yellow 5erótĩnă, 5 - Yellow serotina, 5 . Y Yllow spathăcéă * : Yellow stellarřs, 6 : : Y Yllow
Sternbergit : : Yellow striâtå̀, 7 : : Yellow sylvàticā : Y Yellow uniflóră, $8:$ Yellow villösă

, H. Bl. P. Pudolia.

4, H. Bl. P. Bohemia

4, H. Bl. P. Spain - 1825

6 , H. Bl. P. Wales

5, h. Bl. P. Germany - 1759

5, H. Bl. P. Sweden 1759

7, H. Bl. P. Switzerl. : 1826

4, H. B1. P. Europe

5, H. Bl. P. Siberia : 1781

4, H. Bl. P. Caucasus : 1825

GaGnEBĪnǍ, Necker. The meaning unknown. Linn. 10, Or. 1, Nat. Or. Leguminose. Very ornamental evergreen shrubs, growing about six feet high. For culture and propagation, see Mimosa. Synonymes: 1. Mimosa pterocarpa. 2. Acacia tamariscina. axillārěs, 1. * Yellow . S. Ev. S. Maurit. . 1824 tamariscīnă, 2 : Yellow S. Ev. S. Maurit. . . 1824 GAILLARDǏn. Named by Fougeroux, in honour of [137]
M. Gaillard de Marentonneau, an amateur botanist. Linn. 19, Or. 3, Nat. Or. Compositce, Ornamental species, particularly G. bicolor; they grow well in any common soil, and increase readily by dividing the roots. Synonymes: 1. Virgilia helodes. 2. G. bicolor Drummondii.

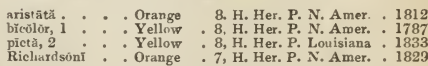

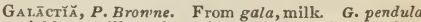
yields a milky juice when cut or broken. Linn. 17, ()r. 4, Nat. Or. Leguminosice. These are very handsome plants, especially $G$. pendula, which is a very desirable twiner. They require precisely the same treatment in culture and propagation as $\mathrm{Cli}$ toria, except that the North American species do not require to be grown in heat. Synonymes: 1 . Ervum volubile. 2. Hedysarum volubile

glabęllă, 1 . Purple . 7, H, De. Tw. N. Amer.

mollišs, 2. : Purple : 7, H. De. Tw. N. Amer. : 1827 péndülä : : Red : 7, s. Ev. Tw. Jamaica : 179 serǐcé̃ : : $: 7, \mathrm{~S}$. Ev. Tw. Bourbon $: 182$

Galactīrēs, Møench. From gala, milk; alluding to the white veins of the leaves. Linn. 19, Or. 3, Nat. Or. Composite. Very pretty annuals, which only require to be sown in the open border in spring. Synonyme: 1. Centaurea Galactites.

astrâlǐs . Purple : 7, H. A. N, Holl. 182 tomentôsă, i : : Purple : 7, H. A. S. Eur. . : 1738

GALACTODĒNDRōN, Kunth. Derived from gala, milk, and dendron, a tree. Linn. 23, Or. 2, Nat. Or. Urticacere. This is a lofty-growing tree, attaining the height of fifty feet; it may be grown in a mixture of peat and loam, and may probably be increased by cuttings.

\section{GaLANGale, see Kompferiu.}

S. Ev. T. Caraecas . 1829

Gar.̄̃Nthŭs, Linn. From gala, milk, and anthos, a flower; alluding to the milk-white fowers. Linn. 6, Or. 1, Nat. Or. Amaryllidaceo. These are dwarf, but very pretty species, of the simplest culture. 
nivalı̆s . . . . White. . 2, H. Bl. P. Britain .

plicătŭs: : : White. 2, H. Bl. P. Crimea : 1818

$\mathrm{G} \bar{A} \geq \bar{\Lambda} x$, Linn. From gala, milk; alluding to the whiteness of the flower. Linn. 5, Or. 1, Nat. Or. Pyrolacece. The species is pretty, and succeeds best in peaty soil, in a moist situation; it is readily increased by divisions. Synonyme.1. Blandfordia cordata.

aphyllă . . . . White . 7, H. Her. P. N. Amer. . 1786

GaL̄̄xı̆Ă, Thunberg. From galaktiao, to abound in milk. Linn. 16, Or. 1, Nat. Or. Iridacer. These are very pretty Cape bulbs, and grow best in a sandy peat soil; they are easily increased from offsets.

7, G. Bl. P. C. G. H

mucronularìs: : Pirple : T, G. Bl. P. C. G. H

ovāta

versicólór : : Purple : 7, G. Bl, P. C. G. H. : 1799

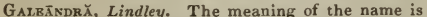
unexplained. Linn. 20, Or. 1, Nat. Or. Orchidacee. A pretty little plant, thriving well with the treatment given to the genus Bletiu. Synonyzne: 1 . Eulophia gracilis.

grăcììs . . . . Grn. yel. . 5, S. Ter. .1822

Gatrate, helmeted the upper lip of a ringent corolla is the galea of that corolla.

GALËĞ, Tournefort. From gala, milk; the plants are said to increase the milk of such animals as eat of them. Linn. 16, Or. 6, Nat. Or. Leguminose. Ornamental, tallish plants, well suited for flowerborders, provided they have plenty of room. They are readily increased by dividing the roots, or by seeds.

bhat

offinalis

Blue

White.

rientalis

perientális

lilacină

White

7, H. Her. P.

7. H. Her. P. Spain

1823

7. H. Her. P. Spain

1568

7, H. Her. P. Levant

1801

7, H. Her. P. Persin . 1826

6, H. Her. P. Peısia. . 1839

trìcờōr

Lilac: 6, H. Her. P.

1823

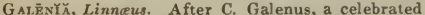
physician of Pergamus. Linn. 8, Or. 2, Nat. Or. Chenopodiacea. A species of little beauty, sueceeding in peat and loam; and young plants are readily obtained from cuttings.

africănă . White. , 7, G. Ev, S. C. G. H., 1752

Gateōrnŏtŏn, Hudson. From gule, weasel, and belolos, foetid smell; alluding to the smell of the species. Linu. 14, Or. 1, Nat. Or. Labiata. A pretty plant, found abundąntly in most parts of England in marshy places; increased by divisions.

lûtéŭm . . . Yellow . 6, H. Her. P. Britain

GaleõrsYs, Linn. From gale, weasel, and opsis, resemblance; the mouth of the corolla is gaping like that of the animal. Linn. 14, Or. 1, Nat. Or. Labiuto. Annual weeds, common in corn-fields, and therefore unworthy of cultivation. Synonymes

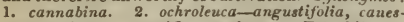
cens, Ladanutm, parviflora, pubescens, Tetrahit, versicolor 1 , villosa 2 .

GALERICUIATE, having a tuft or plume.

GALيsōoYñ, Ruiz and Pavon. In honour of M. M. Galinsoga, superintendant of the Madrid botanic garden. Linn. 19, Or. 2, Nat. Or. Compositc. A genus of little beauty; the seeds may be sown in the open border in spring.

balbisioides . Yellow 8, H. A. Mexico . 1825 parvifloră, trilobată.

GalipẼ A Aublet. The name given to the plant in Guiana. Linn. 2, Or. 1, Nat. Or. Rutacea. These plants are described as being handsome, and attaining the height of four feet. They succeed well in peaty soil, and are increased by cuttings in sand, under a glass, in heat.

odoratissymă . . White. . 5, S. Ev. \&. Fio Jan.

trifoliătă : : Green : : S. Ev. S. Guiana : 1816

Găs.̌̄u M, Linn. From gala, milk; the flowers of $G$. verum are used for curdling milk. Linn. 4, Or. 1, Nat. Or. Stellata. This is an extensive genus of plants, of very little merit. They all grow well in common garden soil. The herbaceous kinds are increased by dividing the roots, and the annuals need only be sown in the open groend. Synonymes: 1. glancum. 2. reflerum, Valantia trurica. 3. G. auisophyllum. 4 Valantia cucullaria. 5. G. vernum. 6. saxatile. 7. murale. 8. hispidum. 9. saccharatum, Valantia aparine.

campanulâtûm, 1 White * 7, H. Her. P. S. Eur. . . 1821 grëeüm. - Purple : 7, H. Her. P. Candia : 17 ! 18 liiısütūm : . Wlite : 8, F. Her, P. Teneriffe : 183 purpüreūm : Purple : 7, H. Hex. P. Switzerl. 1831 rúbrüm. Purple - H. Her. P. Italy suaventens : Purple - 7, H. Her P. Italy * 1597

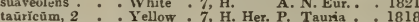

alpēstrĕ 3 , änglícûm, a parīnĕ, aristātūm, austrĭăcūm, baldènsé, Boccơñt, boreãle, brevifoliām, campéstrĕ,

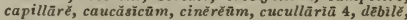
diffùsūm, divaricātūm, ellīptĩcūm, erēctūm, frügîtê,

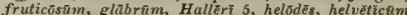
6 , infèstùm, leeve, linifoliūm, lithospermifoliūm,

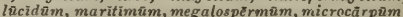

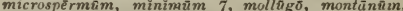
obliyaũm, palñstré, parisiēnsé, pilōsūm, pubēscēus, pŭmìlùm, pusillùm, rigidàm, rotundifoliñm, rubi-

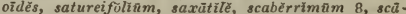

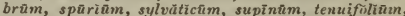

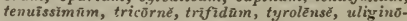
sūm, valantioūdēs, verrucősum 9 , vērūm, verticillatûm, Villärsiī, villōsūm, Witherīngì.

Galphìix, Cavauilles. An anagram of Malpighia. Linn. 10, Or. 3, Nat. Or. Malpighiacea. Handsome shrubs, thriving well in a mixture of loam aud peat, and cuttings of the ripened wood will root in sand, under a glass, in heat.

glaũeă * . - Yellow * S. Ev. Tw. Menico - 1829 hirsǔt : : : Yellow : 9, S. Ev. S. Mexico : 1824

GAMBOOR, see Garcina Gambogia.

GAMO-EPALOUS, when the sepals are joined at the edge. Garcisĩ M.D., F.R.S., an oriental traveller. Linn. 11, Or. 1, Nat. Or. Guttifere. This is a valuable and much admired genus of fruit-bearing trees. The plants thrive best in a light loamy soil with a little peat mixed : they require a strong moist heat to flourish well, and ripened cuttings will root in sand, under a glass, in a moist heat. In Loudon's Encyclopredia of Plants, the following description is given of $G$. Mangostana-" This tree bears a fruit which, in the East Indies, ranks with that of the pineapple. It rises with a taper stem, sending out many branches, not unlike a fir-tree, with oval leaves, seven or eight inches long. The flower is like that of a single rose; the fruit round, the size of a middling orange; the shell is like that of the pomegranate, the inside of a rose colour, divided by thin partitions, as in oranges, in which the seeds are lodged, surrounded by a soft juicy pulp, of a delicious fuvour, partaking of the strawberry and the grape, and is esteemed one of the rickest fruits in the world. According to Dr. Garcin, it is esteemed the most delicious of the East Indian fruits, and a great deal of it may be eaten without any inconvenience; it is the only fruit which sick people are allowed to eat without scruple. It is given with safety in almost every disorder; and we are told that Dr. Solander, in the last stage of a putrid fever in Batavia, found himself insensibly recovering by sucking this delicinus and refreshing fruit. The pulp has a most happy mixture of the tart and sweet, and is no less salutary than pleasant."

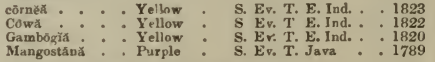

GARDEN BAIsaM, see Justiciă pectorälis.

GARDẼNIA, Ellis. Named in compliment to Alexander Garden, M.D., of Charleston, Carolina, a correspondent of Ellis and Linnzeus. Linn. 5, Or. 1, Nat. Or. Cinchonacea. This is a splendid genus of plants, producing their sweet-scented flowers very freely. They require a mixture of loam and peat ; and the stove kinds, a strong inoist heat and plenty of water at the roots. Cuttings of all root readily if not too ripe when taken off, planted in sand, under a glass, in a moist heat, with the pots plunged. Synonymes: 1. Mussanda spinosa. 2. Canthium corunatum, Posoqueria dumetorum. 3. [ 138] 


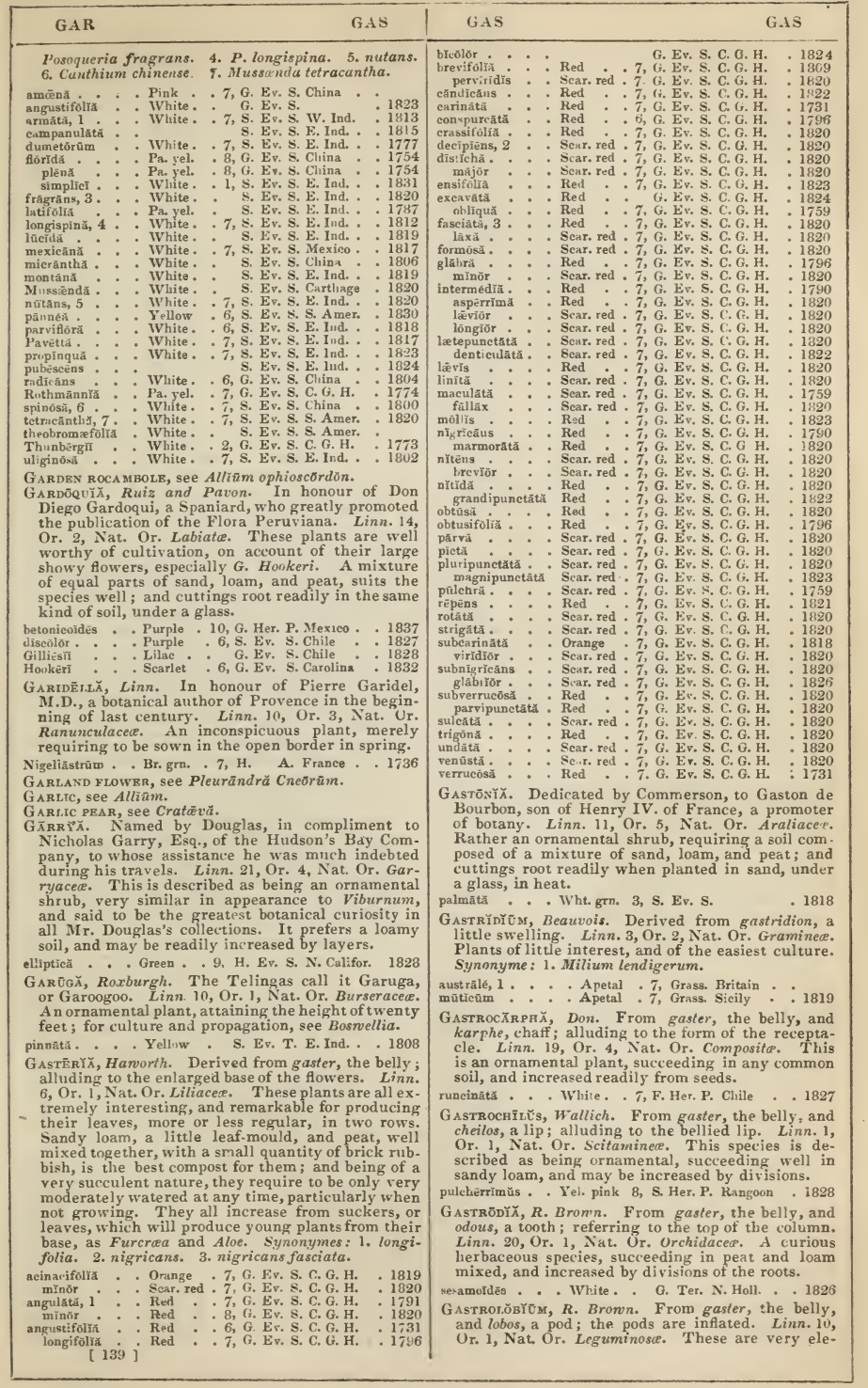


gant little shrubs. For culture and propagation, see Pultencea.

bĭlŏbûm - . Yellow . 5, G. Ev. S. N. Holl. • 1803 retûsûm : : : Or. scar. : 5, G. Ev. S. N. Holl. : 1830

GastrosīMă, Herbert. From gaster, the belly, and nema, a filament; the flaments are inflated. Linn. 6 , Or. 1, Nat. Or. Amaryllidacee. This is a very pretty plant; for culture and propagation, see Cyrtanthus. Synonyme: 1. Cyrtanthus uniflorus.

clavâtûm . . White. . 5, G. Bl. P. C. G. H. . 1816

GaUdichaUdĬ, $\boldsymbol{H}$. B. and $K$ unth. In honour of Charles Gaudichaud, the naturalist, who accompanied Freycinet in his voyage round the world. Linn. 5, Or. 1, Nat. Or. Malpighiacec. An ornamental plant, succeeding best in light turfy loam and peat mixed; cuttings, if ripened, root well in sand, under a glass, in heat.

cynanchoidĕs. . Yellow . S. Ev. Tw. Mexico. . 1824 Gaudīnİ, Beauvois. In honour of M. Gandin, a Swiss botanist. Linn, 3, Or. 2, Nat. Or. Graminee. Uninteresting, and easily cultivated. Synonyme: 1. Avena fragilis-frägitis 1.

GAUıтнёR and botanist of Canada. Linn. 10, Or. 1, Nat. Or. Ericacea. These are highly ornamental shrubs, thriving best in a peat soil. The greenhouse kinds should be treated the same as other hardy greenhouse plants. They are all readily increased by layers. The succulent fruits of $\mathrm{G}$. procumbens and G. shallon are sometimes used as food.

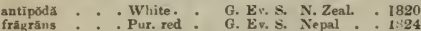

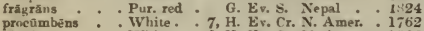
Shallon. : White. : 5, H. Ev. S. N. Amer. : 1826

Gẫră, Linn. From gauros, superb; in reference to the beautiful flowers of some of the species. Linn. 8, Or. 1, Nat. Or. Onagraces. All the species of this genus are well worthy of extensive cultivation. G. fruticosa, and the perennial kinds, thrive well in any light rich soil; the former may be increased from cuttings, and the latter by seed. The annuals and biennials require the same treatment as other hardy and tender annuals and biennials.

\begin{tabular}{|c|c|c|c|}
\hline 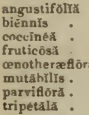 & $\begin{array}{l}\text { Pink } \\
\text { : Red wht. } \\
\text { Searlet } \\
\text { : Red wht. } \\
\text { : Purplo } \\
\text { Yellow } \\
\text { Yellow } \\
\text { : Pink . }\end{array}$ & $\begin{array}{l}\text { 8, H. Her. } \\
9 \text {, H. } \\
9 \text {, H. Her. } \\
\text { S. Ev. } \\
\text { 7, H. } \\
7, \text { F. } \\
\text { 8, H. } \\
8, \text { H. }\end{array}$ & $\begin{array}{l}\text { B. N. Amer. } \\
\text { P. Louisiana } \\
\text { S. S. Amer. } \\
\text { B. S. Amer. } \\
\text { B. N. Amer. } \\
\text { B. N. Amer. } \\
\text { A. Mexico. }\end{array}$ \\
\hline
\end{tabular}

GAż̄xૉ̌, Gertner. From gaza, riches; alluding to the splendour of the flowers. Linn. 19, Or. 3, Nat. Or. Compositue. Very showy and interesting plants, of easy management. Peat and loam suits them best, and young plants are obtained from cuttings in sand, under a glass. G. subulata may also be increased by dividing the roots. Synonyme: 1 . Gorteria rigens.

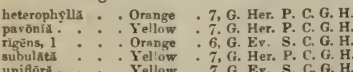

1812 uniflōră. Yellow 7, G. Ev. S. C. G. H. 1816

Grästrī̀, Michaux. From ge, the earth, and aster, a star; star-like appearance of the plants. Linn. 24, Or. 9, Nat. Or. Fungi. Small, mostly brownish species, found most plentiful in pine-woods and pastures during the autumn months. Synonyme: 1. Lycoperdon recolligens-coliforme, multifidumi, quadrifidum, Woodrvardi.

Grissomŭrî̀, Lindley. From geisson, a tile, and meris, a part; in allusion to the imbricated caly $x$. Linn. 14, Or. 2, Nat. Or. Acanthaced. This is a very handsome species; rich soil, cornprising loam and rotten dung, suits it best ; and cuttings root without difficulty, either in sand or soil, under a glass, in heat.

longiflöră . . Scarlet . 7, S. Ev. S. Brazil . . 1826

Grıssornīză, Ker. From geisson, a tile, and rhiza, a root; shape of the root. Linn. 3, Or. 1, Nat. Or. Iridacea. Handsome Cape bulbs; for culture, \&c., see Galāxĭă.

\begin{tabular}{|c|c|c|c|c|c|}
\hline aris & & & & & \\
\hline เిă & - & & White . & 14.10 & 78 \\
\hline & . & & & B1. & \\
\hline cātã & * & - & g. & C. & \\
\hline & & & & . & \\
\hline tēì & & - & - $\mathrm{V}$ & . & \\
\hline & • & - & & 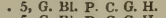 & \\
\hline 兽 & $\therefore$ & . & - W & & \\
\hline iscé & & & & & \\
\hline tâ & & - & & & \\
\hline & & 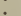 & & & \\
\hline & & & - Yel. bl & & \\
\hline
\end{tabular}

Gritonoptềî̄ M, Cunningham. From geiton, neighbour, and plesion, near; alluding to the scrambling habit of the plants. Linn. 6, Or. 1, Nat. Or. Liliacece. These are described as being curious and ornamental plants, requiring to be grown in a mixture of peat and loam, or sandy peat; and increasing by cuttings in sand, under a glass. Synonymes: 1. Luzuriaga cymosa. 2. L. montana.

\section{ăspèrūm . G. Her. P.} montänūm, 2 : Green : G. Rv. Tw. N. S. W. $\quad 1825$ G ̌̆l. A, Loureiro. From geleo, to shine; supposed to refer to the leaves. Linn. 8, Or. 1, Nat. Or. Rutacea. Ornamental plants, succeeding in sandy peat, and increased by cuttings planted in sand, under a glass. Synonyme: 1. Selas lanceolata.

lanceolătă, 1 - Yellow - G. Ev. S. Cochin-Ch. 1820 oblongifolia : : Wht grn. 6, G. Ev. T. N. Holl. . 1823 Gruating, jolly, a term in chemistry.

Griatinous, consisting of jelly.

GĚLĩ̃uัs, cold, frigid.

Gesōxî̉ M, Roxburgh. The meaning unknown. Linn. 22, Or. 2, Nat. Ur. Euphorbiacea. Uninteresting stove shrubs, of the easiest culture-bifariam, fas ciculätกm, lunceolatuีm.

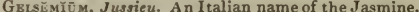
In America the species is known under the name of Carolina Jessamine. Linn. 5, Or. 1, Nat. Or. Bignoniacec. This species is not possessed of much beauty ; it thrives bast in sandy peat, and cuttings root readily under a glass. Synonyme: 1. Bignonia sempervirens.

sempërvirēns . Yellow . 6, F. Ev. CL. N. Amer. . 1640

Gвалатв, twin, producing flowers or leaves, in pairs.

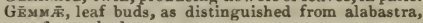
or flower-buds.

Grmaiferous, bearing buds.

GrNiculats, swollen jointed.

GrNípa, Plumier. From genepapa, the name of one of the species in Guiana. Linn. 5, Or. 1, Nat. Or. Cinchonacee. A genus of fruit-bearing trees. The fruit produced by $G$. americana is said to be excellent, and in much request in Dutch Guiana, where it is called Marmalade Box; for culture, see Gardenia. Synonyme: 1. Gardenia esculenta.

americână . . Pr yel. - S. Ev. T. S. Amer. . 1779 edūlIs : . White. - S. Kv. T. Guiana . 1824 esculēntă, 1 : S. Ev. T. China : 1823 Merianß : White. S. Ev. T. Cayenne : 1800 oblongifolra": Yellow: S. Ev. T. Peru : 1821

\section{GrNip-trek, see Geñ̃pă.}

Grsistă, Lamarck. Derived from the Celtic word gen, a small bush. Linn. 10, Or. 6, Nat. Or. Leguminose. These are all exceedingly ornamental, and free-flowering plants. The greenhouse and frame kinds thrive best in a mixture of loam, peat, and sand; and young cuttings planted in sand, under a glass, root very readily. The hardy spe. cies are particularly adapted for the front of shrubberies, on account of their generally low growth; they may be increased from layers, or seeds. Some of the species are purjatives, and others are diu retics. Synonymes: 1. Spartium athnense. 2. angulatum. 3. aphyllum. 4. cinereum. 5. sericeum. 6. congestum. 7. ferox. 8. linifolium. 9. monospermum. 10. parviflorum. 11. patens. 12. Genista prostrata. 13. Spartium purgans. 14. radiatum. 15. Genista januensis. 16. Spartium Scorpius. 17. spharocarpon. 18. umbellatum. 19. virgatum.

athnēnsis, 1 . Yellow * 7, H. Ev. S. Sicily * . 1816 angliea. : Yellow : 7, H. Ev. S. Britain angulata, $2{ }^{*}:$ : Yellow : 6, H. Ev. S. Maryland: 1739 anxantica . : Yellow : 7, H. Ev. S. Italy : 1818 aphylla, 3: : Violet . : 7, H. De. S. Siberia : 1800 [ 140 ] 


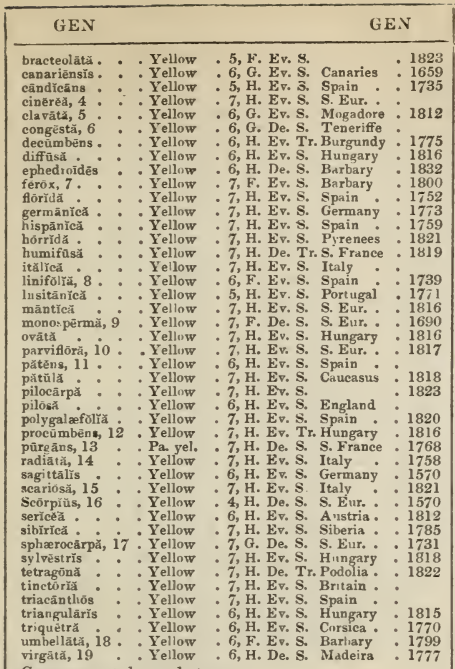

Groitais, styles and stamens.

GENTIAN, see Gentiāăă

GentrāNĂ, Linn. After Gentius, King of Illyria, who first experienced the virtues of the plant. Linn. 5, Or. 2, Nat. Or. Gentianacer. This is an extremely beautiful genus of plants; most of the herbaceous kinds grow well in a rich light soil, but some require to be grown in peat; indeed, all will grow much stronger in it. Some of the species should be grown in pots, and placed among alpine plants, and protected in winter; some of them may be increased by divisions. The annual and biennial kinds may be sown in a dry sandy situation, in the open border; but they must be sown as soon as ripe, because if left till spring before they are sown, they will not, very probably, come up till the second year. The stems and roots of most of the species, especially G. Amarella, campestris, cruciata, lutea, and purpurea, are tonic, stomachic, and febrifugal. Synonymes: 1. quinqueflora. 2. ciliata. 3. fimbriata. 4. ciliata. 5. amarelloides.

æstīä. . Blue . . 7, H. Her. Cr. Austria . 1818 aeañlís : Blue : 5, H. Her. Cr. Wales. angustifoliă : Blue: 5, H. Her. Cr. Alps : 1819 decûmbēns:- Blue - 7, H. Her. P. Siberia - . 1799

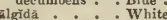
al pina altíziza : : : : Purpl

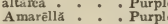

angulósă : : Purple

angustifoliri: . Purple

asclepiàdéá : Blue

aūreă, 1 : Yellow

barhátă, $2:$ Blue
bavãrică $:$ Blue

bilobă : Yellow

brachyphyllă : Blue

6 , H. Her. P. Siberia : : 1799

7 , H. Her. P. Siberia

7, H. Her. Cr. Alps

5 , H. Her. P. Stberia 1824

8, H. A. Britain

7, H. Her. P. Altai

7 , H. Her. P. A ustria

8, H. Her. P. Norway

8, H. B. Siheria .

$7, \mathrm{H}$. Her. P. Alps

Burseri . : Fellow

5, H. Her. Cr. Switzer]

7, H. Her. P. Pyrenees

7 , H. Her. P. Switzerl.

Purple: 8, H. Her. A. Britain

campēstrǐs : : Purple

8 , $\mathrm{H}$

A. Switzerl.

GEO

GER

\begin{tabular}{|c|c|c|}
\hline & & \\
\hline giacialis & - . & . \\
\hline $\begin{array}{l}\text { fumilis. } \\
\text { hybrida: }\end{array}$ & . & ple \\
\hline imbricătă & : & $\begin{array}{l}\text { rei. pu } \\
\text { Blue. }\end{array}$ \\
\hline carnãtă & $\dot{0}$ & Pink: \\
\hline ermédíă & $\therefore$ & Purple \\
\hline eăris . & - & - Blue. \\
\hline lūteă & . & . Yellow \\
\hline macropliȳll & la . & Blue . \\
\hline nivalis : & .. & Blue. \\
\hline ohtusifolliă &. & - Yellow \\
\hline ochroleûcă & . $\cdot$ & - Purple \\
\hline pannónǐcă & & - Purple \\
\hline Pneumonán & nthē & Blue. \\
\hline guttată & - & . Blue \\
\hline pratènsiss & . & Blue. \\
\hline udo-pn & & Blue \\
\hline $\begin{array}{l}\text { nanthe } \\
\text { pŭmîlă. }\end{array}$ & • & lue \\
\hline punetātă & . & Yellow \\
\hline purpuัréă & & Blue. \\
\hline fiōré-ālbo & & White \\
\hline pyrenăică, & & . Blue. \\
\hline quinqueflór & & Blue \\
\hline saponảriă & . & - Blue. \\
\hline flōrè-âlbo & & - White \\
\hline septēmfidả & . & Blue. \\
\hline guttātă & * & - Blue . \\
\hline iflóră . & • & Blue : \\
\hline $\begin{array}{l}\text { mbellâtă } \\
\text { trienlósă }\end{array}$ & & \\
\hline rnă. & & Blue. \\
\hline
\end{tabular}

\section{7 , $\mathrm{H}$.}

A. Alps

1819

A.Caucasus - 1824

Blue. . 7, H. Her. P. Switzerl. : 1819

Pink. 9, H. Her. P. N. Amer. 1812

- Purple. 9, H. Her. P. N. Amer. 1820

Yellow . 7, H. Her. P. Alps . . 1596

Blue . 7, H. Her. P. Siberia . . 1796

8, H. A. Sentland : 1826
7, H. A. Switzerl. 1826

8, H. Her. P. N. Amer. : 1803

7, H. Her. P. Alps

8, H. Her. P. England
8, H. Her. P.

$7, \mathrm{H}$.

8, H. Her. P. N. Amer.

5, H. Her, Cr. Switzerl.

1800

7, H. Her. P. Alps

7, H. Her. P. Adps

7. 1768

7. H. Her. P. Alps Eur. 1823

8, H. Her. P. N. Amer. : 1824

8, H. Her. P. N. Amer. : 1776

9, H. Her. P. N. Amer. - 1826

6, H. Her. P. Levant . 1804

7, H. Her. P. Siberia . 1807

6, H. Her. P. Caucasus

4, H. Her. P. S. Eur. : 1822

vêrnă : Blue 5, H. Her. Cr. Engtand

GronōRūM, Jackson. From ge, the earth, and doron, a gift. Linn. 20, Or. 1, Nat. Or. Orchidacea. These are rather interesting plants, succeeding well in a hot, damp stove, with the same treatment as is recommended for Bletia.

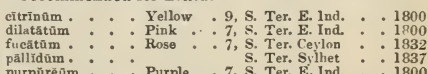

Geofrrōy, Jacquin. In honour of M. E. F. Geoffroy, author of Materia Medica, who died in 1731. Linn. 17, Or. 4, Nat. Or. Leguminosa. Stove trees, from twenty to thirty feet high; loam and peat mixed suit them well, and cuttings root freely in sand, under a glass, in heat.

spinösa. . - Yellow - S. Ev. T. S. Amer. - 1818

Groglōssề, Persoon. From ge, the earth, and glossa, tongue ; alluding to the form of the plants. Linn. 24, Or. 9, Nat. Or. Fungi. Small species of a brownish colour, found in autumn among grass, and in moist meadows; whence the English name Earth Tongue-gläbrüm, hirsũtūm, vĩrỉdĕ, vis. cosîm.

Gво̄Nŏмă, Willdenon. From geonomos, shilled in agriculture; the species are difficult to propagate. Linn. 22, Or. 6, Nat. Or. Palmacer. A tine genus of Palms, the species of which grow from four to twenty feet high. They require to be grown in a rich sandy loam, and a strong heat. They can only be increased from seed which, in this country, is seldom produced. acaūlǐs : * A petal * Palm. Brazil * 1823 pinnátífrôns: : A petal: Palm. Caraccas: 1821 Schnttiānă : : A petal : : Palm. Brazil : 1820 sīmplícífrons : : A petal : Paln. Trinidad : 1818 Spixiãnă : : A petal : : Palm. Brazil : 182

Grōphĭră, Don. From ge, the earth, and phileo, to love; alluding to the trailing habit of the plant. Linn. 5, Or. 1, Nat. Or. Cinchonacea. A minute species, of not much beauty, and easy cultivation. Synonyme: 1. Psychotria herbacea.

reniformǐs, 1 . Pa. red - 6, S. Her. Tr. W. Ind. . 1793

GrRănīè. Named by Linnæus from geranos, a crane; in allusion to the crane-like beak terminating the carpels. Linn. 16, Or.6, Nat. Or. Gerdniacea. Some species of this extensive genus produce very handsome flowers, while others are mere weeds. The greenhouse and frame kinds thrive in loam and peat, mixed with vegetable soil, and are easily increased from cuttings or seeds. The hardy kinds do well in the open border; G. argenteum, however, reguires to be protected in winter they ripen seeds freely, from which they may be irtreased. The annual kinds merely require to be

Blue. 7, H. Her. P. Germany H. Her. P.

Blue H. B. N. Amer. Dk. blue . 7, H. Her. P. Austria . 1596

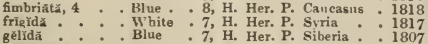

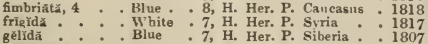

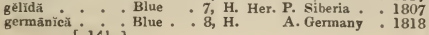


sown in the open border. In North America, they consider the root of G. maculatum a valuable astringent, and in North Wales, G. Robertiınum is used in nephritic complaints. Synonymes: 1. varium. 2. albanum. 3. prostratum. 4 Londesii. 5. pyrenaicum, nemorum. aconitirolium : White. 6, H. Her. P. Switzerl. althĩeûm . Pa. red 7, H. Her. P. Altai anemonefolrum : Red . 8, G. Ev. S. Madeira angulātũm argênteūm : : Striped argên téüm.: : Striped hatrachiō̃dés: : Blue :
Briceănūm : White: cœrŭlēüm : Blue canēscēns collinúm : Purple crivtatum, 2 : : Red dahúrícūm : : Purple
eriostēmón eriostèmōn : : Blue
pállým
: Pa. blu pállıdùm : Pa. blìe
fúscúm

gymnncaũion: Blue íberreúm : : Blue inodôrūm: : Pa. red L-mbërti : : Red

lancastriênsě, 3 : Striped tongroes, 4 . Lilac mácidúm : Pink macrorhizùm : Purple
maculatúm multítüüm: Red nemorósúm, 5 : Purple nepalēnsé nodioñus palústré :

phı̄eūm pilossūm praténké dหărǐcūm findertilbo

flóre-plènó 6, H. Her. P.

7, F. Her. P. S. Eur. 7, H. Her. P. Europe 6, H. A. Bristol 7, H. Her. P. Dahuria 6, F. Her. P. C. G. H. 8, H. Her. P. Pyronees 7. H. Her. P. Siberia 7, H. Her. P. Jberia 6, H. Her. P. Dahuria 7, H. Her. P. Siberia 8 , H. Her. P. Nepal 7. H. Her. P. S. Eur. 7 , H. Her. P. Iberia 7, H. Her. P. J,evant 6, F. Her. P. C. G. H. 6, H. H. Her. P. Nepal 6, H. De. Tr. Britain 7 , H. Her. P.

6, H. Her. P. Britain 6, H. Her. P. Ituly 6, H. Her. P. Ituly \&, H. Her. P. C. G. H. 7. H. Her. P. Italy Red : 6, H. Her. P. Nepal Purple : 7, H. Her. P. Germany Purple Purple Plack Blue Blue White

flore-rariegito Blue purpüréum . Purple pyrenäleúm : Purple re日Exúm . . Red sanguinéũm : Blood villosissimum Blond sibirileûm. - White sylvaticúm : Blue

tuberisum : Pink

ramúsûm : Purple

umbrôsûm - Purple

villosũm - Blue

Wallichiannum : Striped 6. H. Her. P. V. D. L. 5, H. Her. P. England 7, H. Her. P. N. Zeal. 6, H. Her, P. Britain 6, H. Her. P. Duuria 6 , H. Her. P. Britain 6, H. Her. P. Seotland 7, H. Her. P. Britain $7, \mathrm{H}$. A. Switzerl. 6, H. Her. P. Brituin. 7, H. Her, P. Italy 7, H. Her. P. Britain 7, H. De. Tr. Europe 7, H. Her. P. Siheria 8, H. Her. P. Italy 6, H. Her. P. Britain 7, H. Her. P. Italy 7, H. Her. P. S. Eur. 7, H. A. Italy 7 , H. Her. P. Nepal

177.5 1827 1788 1789 1817 1824 1787 1815 1820 1820

1822

1822
1759

1759
1814

1802

1701

1824 1823 1576 1732

1817

1821

1732 1816 1821 1818

buhëmicnm, Caroliniünom, colnmbinถm, dissēctum, divaricäinm, lncidum, molle, pällens, pusillom, Robertiānūm, rotundifolin $m$, villošum.

Grrardĩ, Linn. In honour of John Gerard, a famous old English botanist, and author of Gerard's Herbal, published in 1597. Linn. 14, Or. 2, Nat. Or. Scrophulariucea. These are handsome plants, growing well in a peaty soil. The perennial kinds may be increased by cuttings planted under a glass; but the best way of obtaining young plants is by seed.

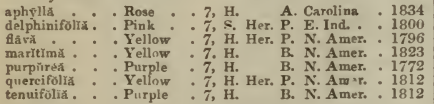

GrRnк̌ră. Gronovius named this genus in compliment to $\mathbf{J}$. Gerber, a naturalist and traveller in Russia. Linn. 19, Or. 2, Nat. Or. Compusite. A very pretty plant, of easy management; it thrives in a mixture of sandy loam and peat, and is increased the same way as other tender biennials.

crenăta . . . Purple . 7, G. B. C. G. H. 1822

GRRM, or GRRMRN, the old name of the ovary.

GRRMinAT1ov, the first act of vegetation in the seed.

GERMAN MADWert, see $A$ sperũgö.

GrRopöc0̄, Linn. From geron, old man, and pogon, a beard; alluding to the appearance of the seed. Linn. 19, Or. 1, Nat. Or. Compositc. Very pretty plants, of easy culture; they grow in any common soil.

calyculiatǔs - Pink $\cdot 7$, H. Her. P. Italy $: \frac{1774}{1704}$

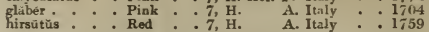

GrsNËrĂ. Named by Linnæus, after the famous botanist, Conrad Gesner, of Zurich. Linn. 14, Or. 2, Nat. Or. Gesnerucea. These are very hendsome species, thriving well in any light rich soil; and cuttings root readily in sand or soil, under a glass, in heat. Synonyme: 1. pendulina.

acaūlís.. . Scarlet - S. Her. P. Jamaica . 1793 allagophylla . Orange : 7, S. Her. P. Bruzil : 1834 Aggregată, $1:$ Searlet :6, S, Her. P. Brazil : 1816 bulbōsa . Scarlet ealyeinā

Cooperi . . Searlet : 1829

corymbösă . . Searlet . 7, S. Ev. S. Jamaics : 1822

* Red yel . 2, S. Her. P. Rio Jan. 1826

lorticilâtă. Crimson . 5, S. Her. P. Rio Jan. • 1835

*. Scarlet * 9, S. Ev. S. S. Amer. * 1835

hirsũta * - Scarlet * 7, S. Her. P. Brazil * 1833

lateritíă : : Searlet * S. Ev. S. Cuba * * 1834

Lindleyt : : Sear, yel. 7, S. Her. P. Brazil: : 1892

macrostachră : Scarlet S. Her P. Rio Jan. 1895

Marchil : Scarlet :9, S. Her. P. Organ Mits 1837

rupistris . . Scarlet . 8, \$. Her. P. 1835

seảbrä *. . Scarlet - 7, S. Ev. S. Jamaica . 1820

picát * - Scarlet 7, S. Her. Y. Brazil * 1835

Suttōnī.. Scarlet 7, S. Her. P. Rio Jan. 1833

tubifóră Scarlet 3, S. Her S S. Amer 1815

rutila : : Scarlet : 8, S. Ev. S. Brazil : 1895

GethFIIs, Linn. From getheo, to rejoice; alluding to the perfume of the flowers. Linn. 6, Or. 1, Nat. Or. Amaryllidacea. These small, ornamental, Cape plants, Sweet says, "thrive best in a mixture of sandy loam and peat, and require but little water when not in a growing state; they are in. creased by offsets from the bulbs, or by seeds."

Efri

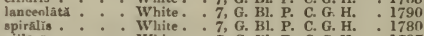
villösa White: 7, G. Bl. P. C. G. H. : 1787

GETōñ̌. Named by Roxburgh, who does not give the derivation. Linn. 10, Or. 1, Nat. Or. Combretacer. Ornamental evergreen climbers, succeeding in loam and peat, and multiplied from cuttings in sand, in heat, under a glass.

floribūndă . . . Yel. grn. . . S. Ev. Cl. E. Ind. . . 1815 nútün . : A petal : S. Ev. CL E. Ind. : 1816

Gīê, Linn. From geyo, to give a relish; because of the roots of G. urbanum. Linn. 12, Or. 3, Nat. Or. Rosacee. This is an ornamental genus, indeed some of the species, as $G$. coccineum, are extremely handsome. They all grow well in any rich light loamy soil, and are increased by dividing the roots, or by seeds. G. urhanum and rivale have been, for officacy, compared to Cinchona. Synonymes: 1 canadense. 2. coccineum. 3. sylvaticum. 4. incli natum. 5. Adamsia rotundifolia.

agrimonioidés . White. . 7, H. Her. P. N. Amer. . $181 \mathrm{~J}$ albūm, 1 : White. 7 , H. Her. P. N. Amer. 1730 atlāntı́m. 2 : Yellow : 7, H. Her. P. S. Eur. . 1810 brachypetilum. Yellnw 7, H. Her. P. , 1818

canadënse . Yellow 7, H. Her. P. Canada : 1810

chiloénsé, 3 : Copper : 7, H. Her, P. Chile : 1826 grandifữũm: Searlet: 7 , H. Her, P.

cilistūm * Yellow:7, H. Her. P. N. Amer. . 1818 heterophyllum : White. 7, H. Her. P. : 1816

hybridūm . . Red brn. 7, H. Her. P. Europe. internediūm * Yellow 7, H. Her. P. Vulhinia: 1794 macrophyllûm. Yellow 7, H. Her. P. Kamtsch, 1804 7 H. Her. P N Amer. 1895 Portenschlagiảnūm Yellow : 7, H. Her. P. 1820 pyrenăicūm, 4 . Yellow : 7, H. Her. P. Pyrenees : 1804
radiateüm

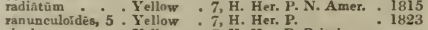
intermedrūm: Yellow : 7. H. Her. P. Britain : Hermany : 1794 rotundifólium, 6 . Yellow . 7, H. Her. P. Rusvia . 1820 strieturm striped urbânúm : : Yellinw $: 7$, H. Her. P. Britrin. 6, H. Her. P. N. Amer. : 1778

GHīrัX, Snartz. After Ghini, an Italian botanist. Linn. 2, Or. 1, Nat. Or. Verbenacac. A curious little plant, of easy culture in sandy open loam. The seeds require to be sown in pots, which must be placed in a huthouse, and when the seedlings are [142] 
of sufficient size, potted off, and treated as other tender annuals.

spinösă . . Purple . 8, S. A. W. Ind. . 1733

GiANT renNel, see Fĕrŭlă.

Gisвous, protuberant, swelled.

GíĽă, Ruiz and Pavon. In honour of P. S. Gil, a spanish botanist. Linn. 5, Or. 1, Nat. Or. Polemoniacea. This is an extremely pretty genus; all the species deserve a place in every flower-garden. The seeds merely require to be sown in the open borders in spring, where they will produce their pretty flowers in abundance. Synonymes: 1. pulchella, Cantua aggregata, Ipomopsis elegans. 2. I pomopsis inconspicua, Cantua parviflora.

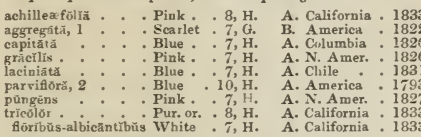

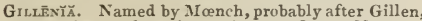
some obscure botanist. Linn. 12, Or. 2, Nat. Or. Rosacec. Ornamental plants; for culture and propagation, see spirca. The roots are emetic, and probably tonic. Synonymes: 1. Spircea trifoliata. 2. S. stipulacea.

stipuläcĕ, 2 . . Hed wht. . 7, H. Her. P. N. Amer. . 1805 trifoliati, 1 : Red wht. 7, H. Her, P. N. Amer. 1713

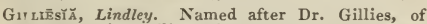
Mendoza, in Chili. Linn. 16, Or. 3, Nat. Or. Gilliesiacee. This species succeeds well in a warm border, consisting of loam and peat, with a little protection in winter; it is, however, scarcely worth cultivating. It is increased by offsets.

gramiñĕă . . Green . . 8, F. Bl. P. Chile . . 1825

GÍLVĂ, flesh, or ash-coloured.

GINGBR, see Zingüberr.

GivgerbReAd TRER, see Parinärīūm macrophȳllūm.

Ginseng, see $P \bar{n} n \bar{a} x$ quinquefoliñm.

GIRDED, surrounded by any thing.

Giš̄ KĩA, Linn. In honour of P. D. Giseke, a Danish botanist. Linn 5, Or. 5, Nat. Or. Phytolaccacece. A curious little plant, requiring the same treatment as other tender annuals.

pharnaceoìdés . Pa. grn. . 6, S, A. E. Ind. . . 1783

Glabrovs, smooth, destitute of hairz.

GLACı̄̄LIs, having a frozen appearance.

GraD1ATE, shaped like a short straight sword.

Gladiotěs, Linn. From gladius, a sword; alluding to the sword-shaped leaves. Linn. 3, Or. 1, Nat. Or. Iridacea. This is an extensive genus, consisting chiefly of beautiful flowering Cape bulbs. Sweet says, "the species thrive best in a mixture of very sandy loam, and decayed leaves, or peat soil, and require no water after they have done flowering till they begin to grow afresh. In the month of October, they should be taken out of their pots, and replanted in fresh soil, when they should be set in a cool frame, or some such place, as they require to be only protected from frost till such time as their pots are full of young roots-; then they may be set in a warmersituation, and watered regularly, and ther will flower freely. The hardy species thrive well in a light sandy soil, and are rapidly increased, as well as the tender kinds, by offsets from the bulbs; they require to be planted in a warm south border. If intended to remain in the ground all the winter, the smaller bulbs must be planted six inches deep, and the larger ones eight inches, so as to be out of the reach of frost; they should also be covered with a little dry litter in severe frost, or they may be taken up in autumn, and laid to dry all the winter where the frost cannot hurt them; they must then be planted early in spring, and they will generally flower well.'

\section{alätǔs} - Sear. yel. . 6. G. Bl. P. C. G. H. - Orange . 7, G. Bl. P. C. G. H. pictús White . 6, G. Bl. P. C. G. H. 7. G Bl. P. C. G. H. anguistŭs * - Yellow . 6, Bl. P. C. G. H. blẩndüs * * Flesh . 6, B1. P. C. G. H. hrevifölīs . . Pink * 5, G. Bl. P. C. G. H. byzantinus: : Red: 7, H. Bl P. Turkey: 1629 campanulătŭs . . I,gt. pur. - 5, G. Bl. P. C. G. H. cardinalis . : Red P. . . . . G. H. cärneŭs - . Flesh . . 6, G. B1. P. C. G. H. cochleătŭs . . Whtı red . 3, G, Bl, P, C, G, H.

Colvillī : Scar, yel. 7, G. Bl. P. Hybrid eărneŭs côncờlör cuspidatũs dêbilis eduliss flexuōsủs floribūnduัs

grăciliss.

hastātǔs

liirsūtŭs

hyঘlinüs

imbricătũs

involintưs

Millērl

Mortōnīus

namaquēnsis

natalênsis

permeäbrìis

recûrūis

sëgetum

tenellús

tenchs

trichonemifoliŭ

trimaculåtŭs

tristĩs

undulātŭs

cārneũs

pallizdūs

versicőlor

binērvǐs

tenǔior

viperatǔs

atsōniǔs.

Red , 7, H. Bl. P. S. Eur.

Flesh * 7, H. Bl. P. S. Eur.

Yellow - 6, G. Bl. P. C. G. H.

White. 5, G. Bl. P. C. G. H.

White - 6, G. Bl. P. C. G. H

Orange . 6, G. Bl. P. C. G. H.

Citron . 7, G. Bl. P. C. G. H.

5, G B P P. G. H.

Pink 6, G. Bl. P. C. G. H. 1795

Yel red: 6, G. Bl. P. C. G. H. 1895

Red 6, H. Bl.P. Russia : 1820

Pink : 6, G. BL. P. C. G. H. : 1757

Violet . 5, G. Bl. P. C. G. H. 1751

White * G. BL. P. S. Africa - 1837

Scar. yel. . 8, G. Bl. P. Natal River 1830

Orange , 6, G. Bl. P. C. G. F. . 1825

Striped 5, G. Bl. P. C. G. H. 1758

Purple 7 G. Bl P. S E

Pellow : 6, G. Bl. P. C. G. H. : 1825

Red 6, H. Bl. P. Tauria. 1823

Yellow 6, G. Bl. P. C. G. H. 1800

Red wht. . 6, G. B1. P. C. G. H. : 1794

Brn. red - 7, G. Bl. P. C. G. H. - 1745

Pink - 5, G. Bl. P. C. G. H. 1760

5, G. B. P. G. H. 176

Pink * 5, G. Bl. P. C. G. H. 17150

Prown 6, G. Bl. P. C. G. H, 1794

Vurieg. 6, G. Bl P. C. G. H. . 1779

Grn, wht. . 5, G. Bl. P. C. G. H. : 1787

Red wht. 4, G. Bl. P. C. G. H. 1801

GLADW1N, see Iris fatidissimă

GLAŃDULAR, furnished with glands.

GLANDULARLY-CRENATED, $\{$ havines crenatures or GLANDULARI,I-SERRATED, $\left\{\begin{array}{l}\text { serratures tipped with } \\ \text { glands. }\end{array}\right.$

GrandularLy-MURICATBD, covered with tubercles tipped with glands.

GlaNduLARLy-TOOTHED, margins toothed, with the teeth bearing glarts.

Grandelifrrous, bearing glands.

GIAREūsǔs, flourishing in gravelly soils.

Glasswort, see Salicörnía.

Grastonbury thorN, see Cratāgŭs Oxyacānthă, var.

Glauchscest, having something of a bluish hoary appearance.

GLAccĩy, Tournefort. From glaukos, glaucous; alluding to the colour of the plants. Linn. 13, Or. 1, Nat. Or. Papaveracea. Very pretty plants, some of which are paiticularly handsome in the flowerborders, where they flower and ripen seed in abundance, which has only to be sown in the open border. Synonymes: 1. G. luteum. 2. corniculatum.

- Yellow $\quad 8, \mathrm{H} . \quad$ B. Britain

phoenīceũm, 2. Purple $.7, \mathrm{H}$.

flaviflōrüm . Yeliow : 7. H. A. Tauria : 1823

rūbrūm.: : Red : 7, H. A. Greece: :1818

tricolor : Red $:$ A. Persia: 1828

Gravcot's, having a hoary grey surface.

Gr.A tx, Linn. From glaukos, grey; in allusion to the colour of the leaves. Linn. 5, Or, 1, Nat. Or. Primulaced. This is a pretty little plant, of easy management in open sandy loam; and is increased from seeds.

marīĭmă . . Flesh . . 6, H. Her. Tr. Britain

Gr.всно̄мӑ, Linn. Derived from the Greek glechon, signifying a sort of thyme. Linn.14, Or.2, Nat. Or. Labiatce. Plants requiring no particular manage. ment. G. hederacea is useful in the preparation of slightly tonic beverages.

lederãcéă * Blue * . 5, H. Ev. Tr. Britain

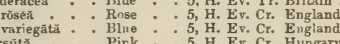

hirsuta : Pink: 5, H. Ev. Cr. Hungary

Gremitschĭ once a professor at Berlin, and a defender of Linnæus against Siegesbeck, and author of many botanical works. Linn. 23, Or. 2, Nat. Or. Leguminose. A most ornamental genus of trees, very remarkable for their acacia-like leaves, and the 
branching thorns which are produced on the stems of some of the species. They grow in any kind of soil, and are increased by seeds, which are usually procured from the native countries of the trees. A bed must be prepared, in which the seeds may be sown an inch deep, and if the spring is dry, they will not vegetate till the following year. Synonyme: 1. orientalis. 2. lavis.

brachycärpa . . Green . . 7, H. De T. N. Amer.

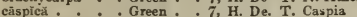

ferōx, 1: : : Green: : 7, H. De. T

hörríd

purpüręa : :Green : 7. H. De. T. China : $: 1774$

latisiliqua : : Green: : 7 , H. De. T

macrästhă: Green: : 7, H, De. T

mieracārthŏs .. Green .. 7. H. De. T.

mieracărthös: : Green: : T, H. De, T. N. Amer. . 1723

sinēnsis.

H. De, T. N. Amer.

H. De. $T$.

inermis Green

triacănthốs: Green

inërmis, 2

Gree

H. De. T.

7, H. De. T.

1819

Girichêxĭ Smith. In honour of the Baron P. F. Von Gleicher, a German botanist. Linn. 24, Or. 1, Nat. Or. Gleicheniacea. These are pretty plants, and will, in general, succeed in peat and loam, and increase from divisions of the roots.

\section{flabellăta}

puherecens: : Brown

spelúneä

7, S. Her. P. N. Holl.

7, s. Her. P. N. Holl

8, S. Her. P. Trinidad

8, S. Her. P. S. A mer.

8, s. Her. P. S. Amer

1823

1823

1824 the Maple. Linn. 11, Or. 5, Nat. Or. Ficoidea. A greenhouse annual, of simple culture-lotoìdës.

GLовввй, Roscoe. The name given to it in the MIoluceas.

Linn. 10, Or. 1, Nat. Or. Scitaminea. These are very pretty plants, especially $G$. Careyana. They attain from one to two feet high, and are cultivated in saudy open loam; they increase by parting the roots. Synonyme: 1. G. Hura.

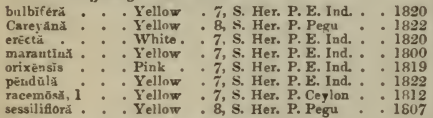

Globe ayarantr, see Gomphrend.

GLOBE FLOWER, see Tröliñs.

Giong Tristle, see Echinóps.

Glonose, \}routhir, $\}$ round or spherical.

GLOROsRLY-BLLIPTICAI, between spherical and oval.

Grosulosr, a diminutive of globose.

GLobuLĀrY̌̃, Linn. So named because the flowers a re produced in globnse heads. Linn. 4, Or. 1, Nat. Or. Globulariacea. This is a very handsome genus ; the rreerhouse species thrive well in a mixture of loam and peat, and the hardy kinds do well in sandy light soil. G. vulgaris is said to do best in peat. They increase freely by cuttings in sand or soil, or by seeds. Synonymes: 1. vulgaris. 2. salicina.

Alỵpũm - Pale . . 8, G. Her. P. S. Eur. . integrifolium . Pale : 8, G. Her. P. S. Eur.

bellidifolir . . Red : 7, H. Her. P. Italy

cordiforä: : Blue : 7, H. Her. P. Germany

linifolla, 1. Blue : 6, H. Her. P. Spain

Inngifoliax, 2 . White. . 7, G. Her. P. Madeira

năna

nudicañlis . . Blue

7, H. Her. P. France.

7, H. Her. P. Germany

6, H. Her. P. Spiin

6, H. Her. P. Burope

1640

1325

1 . 33

1818

1775

1824

1629

vulgaris Ble

GLoвīy. $\overline{\mathrm{E}}$, Haworth. From globulos, a globule, or globules. Linn. 5, Or. 5, Nat. Or. Crassulacea. These are interesting succulent plants, which may be successfully cultivated in sandy loam, and a little peat mixed with a small portion of brick rubbish. They require to be very carefully watered, especially when not in a free growing state. Cuttings, after drying a day or two, will root readily in the same kind of soil, or in sand. Synonyme: 1. Crassula cultrata.

atropurpŭrĕă - . Purple \& 8, G. Her. P. C. G. H. canésens : : White canéseéns : : White : 7, G. Her. P. C. G H capitãt i : : : White : 7, G. Her. P. C. G. H. hîspidă : White . 11, G. Her. P. C. G. H. imprëssă . . . . White . 8, G. Her. P. C. G. H. . 1820

minnör. : White \&, G. Her. P. C. G. H.

linguă : . White : 7, G. Her. P. C. G. H. : 1823

lingŭlă . White : G. Her. P. C. G. H. : 1823

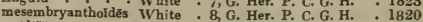

ālťór : . White : 8, G. Her. P. C. G. H. : 1820

möllis : : White : 8, G. Her. P. C. G. H. : 1774

nudicanliss . W White . 7, G. Her. P. C. G. H : 1732

obvallata. : : White : 7, G. Her. P. C. G. H. : 1795

radicañns . : : White - 7, G. Her. P. C. G. H.

subincana : White : W

eréctà : White : G. Her P. C. G. H 1823

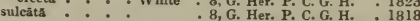

Groснmats, having hairs, the ends of whith are split and hooked back.

GLOMERATr, $\}$ gathered into round heaps, or heads.

GIORIōsă, Linn. Derived from gloriosus, glorious; because of the magniticent flowers. Linn. 6, Or. 1, Nat. Or. Liliacees. This is a truly handsome and curious genus of plants, well worthy of cultivation in every collection of stove plants. The following method of treatment is given by the late $\mathrm{Mr}$. Sweet:- "We have found them succeed best, and flower luxuriantly, by being planted in rather more than one-third turfy loam, full one-third white sand, and the remainder peat; as soon as planted, to be set in a hotbed frame till they have begun to grow; then move them to a warm part of the hothouse, and as they grow, train them up a stick, or wire, where they will flower, and if a little pains be taken to fertilize the stigmas with the pollen when in bloom, they will produce plenty of seeds, which should be sown as soon as gathered. After flowering, the stems must be let die down, and ther require no more water; the pots may then be laid on their sides, in a dry situation, and there left till the March following, when they should be planted." Young plants are generally obtained by dividing the roots; they are also raised from seeds. Synonyme: 1. simplex.

nepalénsis, 1 . Yellow . 6, F. Bl. P. Nepal - 1825 simplexx. : Blue : 7, S. Bi. P. Senegal: : 1756 superba: : : : Orange : $7, \mathrm{~s}$ RI. $\mathbf{p}$. E. Ind. : virêscêns : : Orange : 8, S. Bl. P. Mosambi : 1823

GLORIōš̃'s, superb, grand.

Glossōdî, R. Brown. From glossa, a tongue, and eidos, like; alluding to the tongue-like appendage within the flower. Linn, 20, Or. 1, Nat. Or. Orchidacec. Pretty plants, thriving well in sandy loam and peat, and increased by offsets from the roots. They require very little water when not in a growing state.

măjor . . . Blue . . 6, G. Ter. N. Holl. . 1810

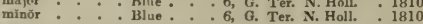

Grōssữ.$\grave{x}$, Lindley. From glossa, a tongue; in allusion to the tongue-like segments of the labellum. Linn. 20, Or. 1, Nat. Or. Orchidacea. A curious species, with very minute green flowers. It requires the heat of the stove, and to be otherwise treated like Glossodia.

tentaculata . Green . . 12, S. Ter. China . . 1824

Grorrīīü, Desfontaines. From glotta, a tongue;

the valves of the legume separate into two mem branes each, which have been compared to the superior opening of the larynx. Linn. 17, Or. 4, Nat. Or. Leguminosa A tall growing plant, the seeds of which require to be sown in peat and sand, and placed in heat, and when of sufficient size, planted singly in the same kind of soil, and shifted into larger pots as they grow, synonyme: 1. Phace floridana, Sesbania disperma, AEschynomene platycarpa.

floridănùm, 1 * Yellow * 7, G. A. Flonda , 1816 GLoxĩnī, L'Heritier. Named in honour of P. B. Gloxin, a botanist of Colmar. Linn. 14, Or. 2, Nat. Or. Gesneracea. A splendid genus of plants, well deserving of extensive cultivation; they thrive best in a rich soil, consisting of loam, peat, and sand, in equal quantities, with a little vegetable soil, well mixed together. In the summer, they should have a plentiful supply of water; in winter, ther require very little water. G. maculata is easily increased by divisions. The leaves of most of the others, if taken off close to the stem, and planted, will soon make young plants. 
caulēscëns . Purple 7, S. Her. P. Pernam. 1826 hirsútă : - Purplo * 7, S. Her. P. Pernam. : 1826 maculătä: : Purple :9, S. Her. P. S. Amer. : 1739 māima : : Pa. wht. 7, S. Her. P. Hybrid. : 1837 speciósă : : Purple: 9, S. Her. P. S. Amer. : 1815 : White. : 9 , S. Her. P. S Amer.

Grusacrou's; plants are said to be glumaceous when their flowers are like those of grasses.

Guvms, a part of the floral envelopes of a grass.

GLUTEN, glue.

Gluminous, $\}$ adhesive, gluey.

Glyck̆Rĭa, R. Brovn. From glykeros, sweet; alluding to the herbage. Linn, 3, Or. 2, Nat. Or. Graminec. An aquatic of no interest or beauty; it is of the simplest culture. Synonyme: 1. Festuca fluitans-flüitäns.

GuYcī $\breve{E}$, Linn. From glykys, sweet; the leaves and roots of some of the species are sweet. Linn. 17, Or. 4, Nat. Or. Legumincsa. A beautiful genus of plants, producing their pretty flowers in fascicles, or racemes, from the axils of the leaves; for cul. ture and propagation, see Clitoria.

bilobă Violet
Pa. yel. 11, G. Er. Mexico 1827 hedysaroz̄dēs . Purple heterophýlla. : Yellow , 7, G. Ev. Tw. C. G. H, minimă : : Purple : \%, G. Ev. Tw. N. Holl. minima : : Yellow: 7, S. Ev. Tw. W. Ind. secũndă: Y Yellow: 7, G. Er. Tr.

: Yellow: 7, S. Ev. Tw. S. Amer. 1823 1825

dêbilìs, parvifloră.

Guycōsmis, Correa. From glykys, sweet, and osme, smell; alluding to the sweet-scented flowers. Linn. 10, Or. 1, Nat. Or. Amarantacea. These trees are said to attain the height of twenty feet, and thrive well in a rich mould. They may be increased by cuttings in sand, under a glass, in heat. Synonyme: 1. Limonia pentaphylla.

arborěă . . . White. . 7, S. Ev. T. E. Ind. . . 1796 pentaphyllă, 1 White. 7, S. Ev, T. E. Ind. : 1790 GLycyrRh $\overline{\mathrm{I} z A}$, Tournefort. From glykys, sweet, and rhiza, a root; the sweetness of the root of the Liquorice is well known. Linn. 17, Or. 4, Nat. Or. Leguminose. A deep light sandy loam suits all the species of this genus, and they are readily increased by slips from the roots with eyes, and planting them in spring. The sweet, subacrid, mucilaginous juice is much esteemed as a pectoral. Synonymes: 1. aspera, hispida. 2. Liguiritia officinalis. aspêrrimă . . Blue . 7, H. Her. P. Siberia * \$795 echinată : Pale * 7, H. Her. P. Italy : 1596 fúetìa . : Pa, yel. \%, H. Her. P. Africa : 1817 glabra, $2:$ : Pa. blue:7, H. Her. P. Italy : 1569 glanduliféră : Pale : 7, H. Her. P. Hungary : 1805 hirsūtă. * * Pale - * 7, H. Her. P. Levant ; 1739 uralensis : : Pa blue : 7, H. Her. P. Siberia. : 1818

Glyphomītriǒn, Bridel. From glypho, to emboss, and mitrion, a little diadem. Linn. 24, Or. 5, Nat. Or. Musci. Small tufts of mo $s$, found on rocks in the spring. Synonyme: 1. Grimmia Daviesii, Encalypta Daviesii-Daviēsĩ .

GMELINA, Linn. In honour of George Gmelin, a celebrated German naturalist and traveller. Linn. 14, Or. 2, Nat. Or. Verbenacec. This is a genus of fine plants, though they seldom flower in this country. They grow best in rich loam, mixed with a little peat, requiring a very strong heat to grow them well. They may be increased without difficulty by cuttings, planted in sand, in heat, under a glass.

arbðréă . . Yellow . S. Ev. T. E. Ind. . 1824 asiātică : : Yellow : S. Ev. T. E. Ind: : 1792 parviflórà * : Orange : S. Ev. T. E. Ind. : 1817 speciosissina : White.: G. Ev, T. Neprl: 1823 villosi GNaphăLĨ̃ L, Linn. From gnaphalon, soft down; alluding to the woolly covering of the plants. Linn. 19, Or. 2, Nat. Or. Composite. Some of these are interesting plants, on account of the quality the flowers possess of retaining their colours after they are gathered from the plants. They grow in any rich light soil, and the shrubby and herbaceous kinds may be increased by cuttings and divisions. The annual and biennial kinds require the same treatment as other tender and hardy annuals and biennials. Synonymes: 1. Filago arvensis. 2. F. cephaloidea. 3. Gnaphalium spicatum, 4. F. gallica. [ 145$]$
5. germanion, 6. alpestris. 7. Lagopus, 8, montana. 9. G. spatulata. 10. F. pusilla. 11. pyramidata. 12. recta. 13. spharica. 14. G. alpinum.

15. $F$, sylvatica. 16. Gnaphalium multicaule.

albescens . . White. . S. Ev. S. Jamaica . 1793 involucrätūm Br. yel. 7, H. Her P. N. Zeal. : 1699 obtusifølrūm. Yellow : 7, H. A. N. Amer. 1732 purpüreum :- Purple : 7, G. B. N. Amer. : 1732 sanguinéũm : Crimson : 7, H. Her. B. Egypt : : 1768
undulátūm americānūm, arvēnsĕ 1, cephaloz̄děũm 2, coarctātãm 3 , decûrrēns, gallīcūm 4, germänǐcūm 5, Lagöpǔs 6, lūtēo-ālbūm, mīnimūm 7 , montānūm 8 , pensylvānĭcăm 9, pusīllūm 10, pyramidätñm 11, rēctūm 12, sphä.

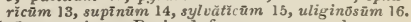
GNÊTūM, Linn. Derived from gnemon; the name given to it in the island of Ternate. Linn. 21, Or. 1, Nat. Or. Gnetacea. This plant will grow in sandy peat and loam mixed; it is multiplied by cuttings in sand, under a glass, in heat. In $\mathrm{Am}$. boyna, they eat the seeds roasted, boiled, or fried, and the tasteless green leaves form a favourite vegetable, in lieu of spinach.

Guēmonn

S. Ev. T. E. Ind.

Gxĭ̉̆, Linn. The ancient name of the Laurel. Linn. 8, Or. 1, Nat. Or. Thymelacece. The species of Gnidia are very pretty, and thrive well in a peat soil, if carefully watered, in which respect they require particular attention, as they have very tender roots. They are rather difficult to propagate, particularly $G$, radiata; the shoots should be taken off when young, planted in sand, under a glass, and placed where there is not much damp. Synonymes: 1. denudata. 2. acerosa.

argēntĕ $\mathrm{Pa}$ yel. 6, G. Ev. S. C. G. H bifîré - Pa. yel. 6, G. Ev. S. C. G. H. capitătä: : Pa. yel. 6, G. Ev. S. C. G. H. flavă. : : Yellow : 6, G. Ev, s. C. G. H. imbërbls : : Pa. yel. 6, G. Ev. S. C. G. H. imbricātă, i : Pa yel. : G, G. Ev. S. C. G. H. juniperifolia, 2 - Pa. yel. . 6, G. Ev. S. C. G. H. lævigãtă : : Pa. yel. : 6, G. Ev. S. C. G. H.

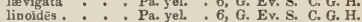
linoides : : : Pa. yel. : 6, G. Ev. S. C. G. H. ochroleŭcă : : Pa. yel. : 5, G. Ev. S. C. G. H. oppositifoliă : Pa yel : 6, G. Ev. S. C. G. H. radiata . : Pa. yel. : 6, G. Ev. S. C. G. H. serīcéă : P Pa. yel. 7, G. Ev. S. C. G. H. simpléxx. : - Pa. yeL * 7, G. Ev. S. C. G. H. tomentosa: : Pa yel. G, Ev, S. C. G H.

1826

1788 1825 1820 1810 1822 1824 1768 1820 1783 1818 1786 1818 GoAt-Root, see Onбñ̆s Nätrix.

GoAT's-BANE, see Aconitũm tragoctơnüm

GOAT's-BEARD, see Spiräă arüncŭs.

GoAT's-Foor, see Oxălis caprīnä.

GoAT's-origanUM, see Thyुmŭs Tragorigănn

GoAT's-rus, see Galëgä.

GOAT's-ThoRN, see Astrăgălüs Tragacinthă.

GoAT's-whвAт, see Tragopyram.

Goarweed, see Caprärĩă biflöră.

Godētǐ. Named by Spach, a German botanist, resident in Paris ; it is probably a Latinised proper name. Linn. 8, Or. 1, Nat. Or. Onagracea. Very pretty annuals, well worthy of a place in every garden; they are nearly related to Enothera, to which genus they may be referred for culture, \&c.

lepìdă * Pink . 8, H. A. Californ. 1835 rubicūndă: : Pa. flame : 8, H. A. Californ. : I835 Gopōy. Ruiz and Pavon dedicated this genus to Emmanuel Godoy, Duke of Arcadia, and Prince of the Peace, a noble Spaniard, and a protector of botany. Linn. 13, Or. 1, Nat. Or. Hypericacece. This is described as an elegant tree, thriving well in a mixture of peat and loam; and cuttings, if ripened, root freely in sand, in heat, under a glass. geminiflöră * Yellow . S. Ev. S. Brazil * . 1820

GoLDBĀchǏx, Decandolle. In honour of G. L. Goldbach, a Russian botanist, who communicated many observations on Cruciferce to Decandolle. Linn. 15, Nat. Or. Cruciferc. We know little of this plant, but it is described as ornamental, and doing well when sown in the open border, in common soil. Synonyme: 1. Raphanus larigatus.

lævigătă . . Pa. yel. . 7, H. A. Astracan . 1827

GOLDEN-HAIR, see Chrysocómă comaũrẻă.

GoLdEN-ROD, see Bסsĕä. 


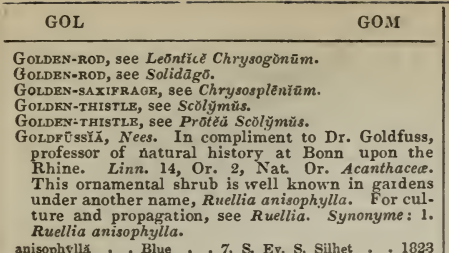

\section{GoLd or PLisasure, see Camelīnă.}

GoLDYLocks, see Chrysocömä.

Gomoprtalous, more properly Gasopetalots, mono. petalous.

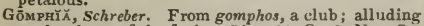
to the shape of the fruit. Linn. 10, Or. 1, Nat. Or. Ochnacer. A very pretty genus of plants, from three to five feet high; they thrive in sandy loam, and young plants are obtained from cuttings in sand, in heat, under a glass. Synonyme: 1. O'chna zeylanica.

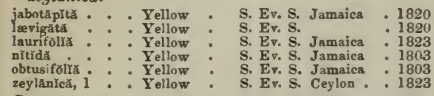

Gomphocãrpuัs, $\boldsymbol{R}$. Brown. From gomphos, a club, and karpos, a fruit; alluding to the club-shaped fruit. Linn. 5, Or. 2, Nat. Or. Asclepiadacce. This is a pretty Cape genus, succeeding in a mixture of loam and peat; and cuttings planted in sand, under a glass, in heat, will root freely. They are also sometimes raised from seeds. Synonyme: 1. Asclepias arborescens.

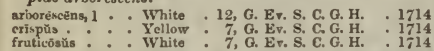

Gомрноцовїсм, Smith. From gomphos, a club, and lobos, a pod; the pod is club or wedge-shaped. Linn. 10, Or. 1, Nat. Or. Leguminosa. A splendid genus of New Holland plants, succeeding in sandy loam and peat; but they must be very carefully watered, or they will sicken, and die, as they are very delicate, and impatient of moisture. Cuttings take without difficulty in sand, under a glass. S.ynonymes: 1. fimbriatum. 2. fimbriatum.

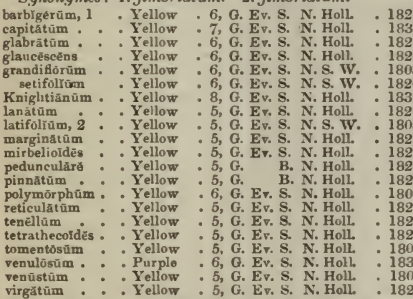

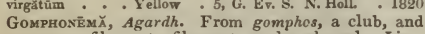
nema, a filament; filaments wedge-shaped. Linn.
24, Or. 7, Nat. Or. Alga. Minute plants, of a yellowish colour, found in lakes and alpine rivuletsgeminâtũ $m$, minutīssìmū $m$, paradox

GOMPHRẼNĂ, Linn. From gomphos, a club; alluding to the shape of the flowers. Linn. 5, Or, 1, Nat. Or. Amarantacea. The Globe Amaranth, which is the type of this genus, is well known for its round heads of purple and white flowers. They will succeed in rich mould; but to grow them very fine, they require a great deal of attention to shifting, watering, \&c.; they all increase from seeds, and the shrubby kinds from cuttings also.

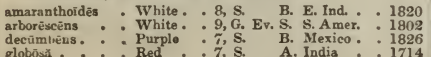

albæ . . White. . 7, S. A. India . . 1714 lastét : : : White.: 7, S. Ev. S. S. Amer. : 1823 perênnİ : : : White. : 7, G. Her. B. N. Holl. : 1824

Gömphŭs, Fries. From gomphos, a club; in reference to the shape of the plants. Linn. 24, Or. 9, Nat. Or. Fungi: Small species, found in pine woods during the summer and autumn months - glutinōsūe, rūtìlūs.

Gosūtūs, Rumphius. Its name in Malabar. Linn. 21, Or. 9, Nat. Or. Palmacer. This ois a fine palm, described as growing ipwards of forty feet high; it requires a strong heat, and rich mould, and can only be increased by seeds.

sacchđ̆rifer . . Palm. Moluccas . 1820

GongōrĂ, Ruiz and Pavon. In honour of D. Antonio Cabellero y Gongora, once Viceroy of New Granada, and a zealous patron of the celebrated Mutis. Linn. 20, Or. 1, Nat. Or. Orchidaces. The plants belong* ing to this genus are highly deserving of cultivation, as well on account of the extraordinary forms assumed by their flowers, as for their delicious perfume. For culture and propagation, see Stanhopea.

stropurpŭrëă - Dk, pur. *6, S. Epi. Trinidad * 1824 GoxiocĀRPǓs, Thunberg. From gonia, an angle, and karpos, a fruit; in allusion to the angular fruit. Linn. 4, Or. 3, Nat. Or. Onagracece. This is a somewhat curious species, merely requiring to be sown in the open ground.

micrānthŭs . . White. . 7, H. A. China . . 1806 Gosōนǒнŭs, Richard. From gonia, an angle, and lobos, a god; the pods are angular. Linn. 5, Or. 2 , Nat. Or. Asclepiadasece. Pretty twining plants; the stove and greenhouse species thrive well in loam and peat, and cuttings root readily in sand, under a glass. The hardy kinds grow best in a warm dryish situation, in any light soil, or in peat; they are increased by divisions, or seeds. Synonymes: 1. G. hirsutus. 2. Cynanchum discolor. 3. C. maritimum. 4. Gonolobus viridiflorus.

carolinênsìs, 1 . Purple . 7, G. De. Tw. Carolina - 1824

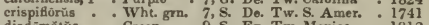
diadêmătüs : : Green : 9, S. Ev. Tw. Mexico : 1812 discolör, 2 : Green : 7, H. De. Tw. N. Amer. : 1809 echinátüs. S. Ev, Tw.

grandiflórŭs : Green * 7, s. De. Tw. Trinidad 1846 hirsútǔs : : Purple :6, H. De. Iw. N. Amer. : 1806 læ̌vis : Purple :6, H. De. Tw. N. Amer. : 1806 macrophyliŭs" : Yellow : 7, H. De. Tw. N. Amer. : 1822 maritimuss, 3 : Green : 6, S. Ev. Tw, Carthage : 1823 nigetr . Dk, piur. 10, S. Ev, Tw. Mexico. 1825 Nuttaliănŭs, 4 . Green . . 7, H. De. Tw, Mississippi 1822 obliquăs . 7, H. De. Tw. Carolina . 1818 planiflórŭs : . Green . 7, S. Ev. Tw. Trinidad : 1818 prostrütŭs : Green : 7, G. Ev. Tr. Mexico: : 1823 - 7, S. Ev. Tw. Caraccas - 1820 subernsǔs : : Green . 8, S. Ev, Tw. America : 1732

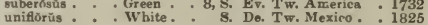

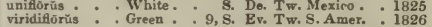

Goniosp̄̄mŏn, Haworth. From gonia, an angle, and stemon, a stamen; alluding to the shape of the stamens. Linn. 5, Or. 2, Nat. Or. Asclepiadacer. This is a genus of curious succulent plants, nearly related to Stapelia; which genus see for culture and propagation. Synonyme: 1. Stapeliu divaricata.

divaricatũs, 1. Flesh - 8, s. Ev. S. C. G. H. - 1793 pallidüs : : Pa blue : 8, S. Ev. S. C. G. H. : 1818 strietũs . Pa. blue : 8, S. Ev. S. C. G. H. 1814

GoodĒNİ̃. Named by Smith in honour of Dr. Good. enough, Bishop of Carlisle, and a botanical author. Linn. 5, Or. 2, Nat. Or. Goodeniacec. A very elegant genus of plants, requiring to be grown in a mixture of peat and loam; and young plants are freely obtained from cuttings in sand, under a glass; they are also raised from seeds.

bellidifarlua . . Yellow - 7, G. Her. P. N. Holl. - 1823 grăcills : * Yellow 7, G. Her. P. N. Holl. 1822 krandiflóră: : Yellow : 7, G. Ev. P. N. S. W. : 1803 tederácéa * . Yellow * 7, G. Her. P. N. Holl. • 1813 heterophyllä : Pa. red : 7, G. Ev. S. N. Holl. : 1826 panăa Good HenRy, see Chenopōdiūm Bonnüs-Henricǔs.

GoōDǐn, Salisbury. In honour of Peter Good, a collector of seeds in New Holland for the botanic [ 146 ] 
garden at Kew. Linn. 16, Or. 6, Nat. Or. Leguminose. This is a very elegant genus of little shrubs, succeeding in a mixture of loam und peat; and young cuttings root freely in sand, under a glass. They may be raised from seeds, which generally ripen in abundance.

\begin{tabular}{|c|c|c|}
\hline $\begin{array}{l}\text { Jatifoliä. } \\
\text { pulyspérmà } \\
\text { pubéscēns . }\end{array}$ & $:$ Y Yellow & $\begin{array}{l}\text { 6, G. Ev. S. V. D. L. } \\
\text { 6, G. Ev. S. V. D. L. } \\
\text { 6, G. Ev. S. V. D. L. }\end{array}$ \\
\hline
\end{tabular}

GOoD-NIGHT, see Argyreīă bönă-nőx.

GooDYẼ R̃, R. Brown. In honour of John Goodyer, a British botanist. Linn. 20, Or. 1, Nat. Or. Orchiduced. These are rather pretty free-flowering plants. The stove kinds do best in sandy peat, mixed with a little leaf-mould. The hardy kinds do best in sandy peat, and are readily increased by divisions of the roots. Synonyme: 1 . Neottia repens.

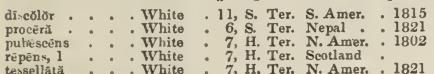

GooskBERRY, see Rībess Grossularĭă.

Goosz-coRN, see Juncüs squamósŭs.

Goose-root, see Chenopodiñm.

Goose-roor, see Aspalăthŭs Chenópordă.

Gooss-Tansy, see Potentīllă Anserină.

GORDōNদ̌, Ellis. In honour of Alexander Gordon, a celebrated nurseryman at Mile End, London, who lived in the time of Miller. Linn. 16, Or. 8, Nat. Or. Ternstromiacea. This is a genus of elegant plants, well deserving of extensive cultivation on account of their large and beautiful flowers. The plants are hardy enough to stand our British winters in the open air, yet the young shoots often get injured, owing to the shortness of our summer not suffering them to ripen the wood, or even to flower in perfection; they should therefore be treated as greenhouse plants. The best soil for them is peat, mixed with a little loan; they are readily in. creased by layers, or cuttings in sand, under a glass. G. Hamatoxyion requires to be grown in the stove; and cuttings of the ripened wood will root in sand, under a glass, in heat. Synonyme: 1. Lacuthea florida.

Franklini * White, - 9, H. De. S. N. Amer. 1774 Hæmatōxylön: White. S. Ev. T. Jamaica: 1820 Lasianthüs : Yellow:9, H. De. S. N. Amer. : 1739

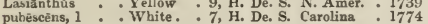
GortînǏă, Liñn. In honour of David Gorter, a Dutch professo: of botany at Hardewych. Linn. 19, Or. 3, Nat. Or. Crmposite. This is a dwarf Cape plant, or tittle beauty and easy culture.

personătă . Yellow . 8, G. A. C. G. H. $\quad 1774$ Gossร̌pĩu, Linn. From goz, or gothn, an Arabic word, signifying a soft substance; whence the Latin and Engiish name of the genus. The name of the Cotton-tree in Egypt is Gotnenseigiar. Linn. 16, Or. 8, Nat. Or. Malvacee. This is a highly valuable genus of plants, especially the species barbadense and herbaceum, the former being extensively cultivated in the West Indies, and the latter in the South of Europe. A light rich soil and moist heat suit all the species best. Cuttings of the shrubby kinds, if not too ripe, will root freely in a light soil, under a glass; they may also be increased by seeds. The annual and biennial species should be sown in pots in spring, and placed in heat, and when the plants are of sufficient size, they should be planted singly into small pots, and shifted as they grow.

\begin{tabular}{|c|c|c|c|c|c|}
\hline 1ătūm & & - Yellow & 7, & In & 1822 \\
\hline & . & - $\mathrm{Ye}$ & . 7, S. 1 & $\mathbf{T}$. & - \\
\hline & & .1 & .9 & B. Barbadues & \\
\hline (2) & - & & & A. & \\
\hline ūm & - & $\cdot 1$ & & er. & \\
\hline ūm & & I & & nd. . & \\
\hline oliūm & - & & . & & \\
\hline oling & - & $\nabla$ & 18 & Ind. . & \\
\hline süm & ${ }^{\circ}$ & - Yellow & 7,5 & P. India & \\
\hline foliùm. & " & Yellow & 7,8 . & A. E. Ind. . & \\
\hline
\end{tabular}

Goū̃NǏ, Linn. In honour of Anthony Gouan, once professor of botany at Montpelier, and author of the Hortus Monspeliensis. Linn. 23, Or. 2, Nat. Or. Ramunculacee. Interesting evergreen climbers, $[147]$ growing about ten feet high, and succeeding well in a mixture of peat and loam; cuttings root freely in sand, under a glass, in heat

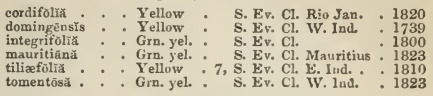

Gourd, see Cucūrbită.

GoutweED, see Egopodžam.

Govêñ̆ , Lindley. In compliment to J. R. Gowen,

Esq., the originator of some splendid hybrid $R$ ho-

dodendrons, \&c., at Highclere. Jinn. 20, Or. 1,

Nat. Or. Orchidaced. These are two remarkably

handsome plants when in flower. For culture and propagation, see Bletia.

liliâcéă . . White. . 7, s. Ter. Mexico superba : : : Yellow: 3, S, Ter. Xalapa

1828

Graвōwsкц̌. Schlechtendahl named this genus in compliment to Mr. H. Grabowsky, an apotlecary, and a botanical author of Ohlaf, in Silesia. Linn. 5, Or. 1, Nat. Or. Solanacee. A curious spiny, scrambling shrub, in appearance much like Atriplex Halimus. It is said to be sufficiently hardy to stand our winters when planted against a south wall. The soil best suited for it is a mixture of peat and loam, and it may be increased from cuttings without any difficulty. Synonymes: 1. Lycium boerhaavicefolium, Ehretia halamifolia.

boerhaaviæfóliă . Pa. pur. . 4, H. Ev. S. Peru . . 1780

GraIN-or-PaRAdIsE, see Amómūm Gränă-Paradīst.

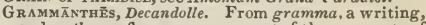
and anthos, a flower; on account of the segments of the corolla having the appearance of the letter $V$ on them. Linn. 5, Or. 5, Nat. Or. Crassulacea. The seeds of this pretty little succulent plant should be thinly sown in carefully drained pots, filled with loam and a little lime rubbish mixed. Synonymes: Vauanthes chloraflora, Crassula dichotoma.

chloræflöră - Yellow 7, S. A. C. G. H. 1774 Grammatophy̆lita, Blume. Name unexplained. Linn. 20, Or. 1, Nat. Or. Orchidacea. This is a fine species, but very rare in collections. It appears to grow well in a hot part of the house, treated the same as the genus Stanhopea.

multiflórūm

S. Epi, Manilua

1837

Grāngŭă, Adanson. Probably after Grange, some person known to A danson. Linn, 19, Or. J, Nat. Or. Compositce. Annuals of little beauty; they may be sown in the open border, or raised on a gentle hotbed, and transplanted. Synonymes: 1. Cotula latifolia. 2. C. cuneifolia.

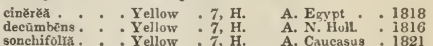
sonchifolra: : Yellow :7, H. A. Caucasus: 1821

břcőlör 1, chinēnš̃s 2 , maderaspatānă, mǐnǐmă.

Grangerĭ. Commerson dedicated this genus to $N$. Granger, a traveller in Egypt and Persia. Linn. 11, Or. 1, Nat. Or. Chrysobalanacea. A store plant, described as ornamental, and succeeding in peat and loam; it is increased from cuttings.

borbŏnYea . . White. . S. Ev. T. Bourbun . 1823

Graniform, formed like grains of corn.

Granular, $\}$ covered, as if with grains.

Granuliferous, bearing grains.

GRAPB, see Vitis vinifera.

GRAPR-HYAciNTH, see Muscärĩ.

GRAPE-PEAR, see Amelänchüér Botryăpĭtm.

GRÃPHis, Acharius. From grapho, to write; in reference to the a pothecia being like writing. Linn. 24, Or. 8, Nat. Or. Lichenes. Species found at all seasons of the year, chiefly on the bark of trees-

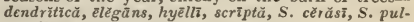
verulēntă, serpentīnă.

Grass-oy-Parnassus, see Parnāssiă.

Gratiól. L̆, Linn. From gratia, grace of God; on account of its supposed medicinal virtues. Linn. 2, Or. 1, Nat. Or. Scrophulariacea. Some species of this genus are very pretty free-flowering plants, thriving well in any rich moist soil, and are readily multiplied by divisions of the roots. The leaves 
and roots of $G$. officinalis act as purgatives and emetics.

\section{aūrea:}

latitolia

officinalis

quadridentáta:

tẹtragönă
Yellow

White.

6, H. Her. P. N. Amer.

7, G. Her. P. N. Holl.

7, H. Her. P. Europe . 1568

White. 6, Her. P. N. Amer.

Blue : 8, F. Her. P. B. Ayres
Yellow : 8, H. Her. P. Virginia
1820

1568

1830
1759

GRĀTUัs, grateful, agreeable.

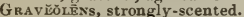

GrEAT BURNET, see Sanguisōrbŭ.

Great crNtaurea, see Centañēă Centaūrǔun.

GrBat macaw TREE, see Acrocómĩă fusiförmìs

Greek valerian, see Polemonĩum.

GrREN DRAGoN, see Arūm Dracōntĩum.

GrenNish-GLAucous, between a grey and green colour.

GrEEN LAVRR, see Ulvă Lactũcă.

GrRgarious, herding together.

Grevīllǐa, $R$. Brown. In honour of C. F. Greville, a patron of botany. Linn. 4, Or. 1, Nat. Or. Proteacee. This is a handsome genus of New Holland plants, which require to be grown in an equal mix. ture of sand, loam, and peat; and ripened cuttings root without difficulty in sand, under a glass. Seed is frequently produced by some of the species, by which young plants may also be obtained. Synonymes: 1. blechnifolia. 2, concinna.

acanthifolrä . Purple . 6, G. Ev. S. N. S. W. . 1824 acuminată : Red : 6, G. Ev. S. N. S. W. : 1805 arenăriă : Pink: 6, G. Ev. S. N. S. W. ăspèră $:$ Pink : 6, G. Ev. S. N. S. W. asplenifollă : Pink - 7, G. Ev. S. N. S. W. Bauér

Red: 6, G. Ev. S. N. Holl.

berberifolina . . Red * 6, G. Ev. S. N. Holl.

buxifolìa : Pink: 6, G. Ev. S. N. S. W.

Caleỹi, $1:$ : Red : 6, G. Ev. S. Moreton B.

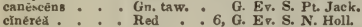

collina: : Pink : 6, G. Ev S. N s. W

concinnä : Pirple

dübĩn

Flindērsil

lieterophyll

juniperina

lineâris

Althe

incarnátá

montănă

mueronifolià

mueronulat

phylicoides

planifoliā, 2

podalyriafolr

podocar pifolra

pubēseēns

ripariž

robũstă

- Orange

. Red

sericễ . . . Pink

strictã : : : Pink

sulphunrè̃a : : Pa. yel.

6, G. Ev. S. N. S. W.

6, G. Ev. S. N. S. W.

Purple 6, G. Ev. S. N. S. W.

White. 6, G: Ev. S. N. Holl

Pink 6, G. Ev. S. N. S. Wv.

White. 6, G. Ev. S. N. S. W.

Flesh : 6, G. Ev. S. N. Holl.

Violet . 6, G. Ev S, N. S, w

Violet . . 6, G. Ev. S. N. S. W.

Red

Orange

6. G. Ev. S. N. S. W

Red : 6, G. Ev. S. N. Holl.

6, G. Ev. S. N. Holl.

6, G. Ev. S. N. S. W.

6, G. Ev. T. Pt. Jacik.

6, G. Ev, S. N. S. W.

6, G. Ev. S. N. S. W.

6, G. Ev. S. N. S. W.

6, G. Ev. S. N. S. W.

6, G. Ev. S. N. Holl.

1824

1806

1821

1790

1830

1824

1810

1824

1820

1824

1821

1822
1790

1790
1790

1790

1822

1824

1809

1823

- 1823

1821

1824
182.2

1822

1791

1829

1824

1890

1809

1824

GRĒwİ, Jussieu. In honour of Nehemiah Grew, M.D., F.R.S., a famous English vegetable physiologist, who died in 1711. Linn. 13, Or. 1, Nat. Or. Tiliacec. These are shrubs, with elm-looking leaves, but not possessed of any great beauty; they succeed in sandy loam and peat, and cuttings root in sand, under a glass, in heat. The fruit of $G$. asiatica is acrid and pleasant; it is much used in the manufacture of sherbet. Synonymes: 1. Mallococca crenata. 2. G. hirsuta.

affiniัs

asiaticeă

asperă

bicoolōr

bracteătă

carpinifolia

flíră.

hirsūtนี.

Mallocōecă,

Mierócós

obtusifölīa

occidentálīs

oppositifoli

orientălis

paniculată

pilosi

Rothir

salvifolia
Green

Purple

White.

White.

Wurpite

Yellow

Purple

$\mathrm{Pa}$. pur.

Green

Red

Purple

Purple

Parpla

White

White

White.

White.
S. Ev, S. China

7, S. Ev. S. E. Ind.

, S. Ev. S. E. Ind.

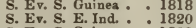

S. Ev. S. Guinea

S. Ev. S. C. G. H

S. Ev. S. E. Ind.

S. Ev. S. E. Ind.

S. Ev. S. C. G. H.

, G. Ev. S. C. G. H.

S. Kv. S. Nepal

7, S. Ev. S. E. Ind.

$S$. Ev. S. E. Ind.

S. Ev, S. E. Ind.

S. Ev. S. E. Ind.

8, S. Ev. S. E. Ind. serrulatæ.

White - 8, S. Ev. S. E. Ind. * 1818

White. S. Ev. S. E. Ind.. 181

liafoliä. White.: S. Ev. S. E. Ind. : 181

tomentōsă, 2 . Purple - S. Ev. S. Java * 1820

uimifoliă - - White - S. Ev. S. E. Ind. - 1816

villosa White, $8, \mathrm{~S}, \mathrm{E}, \mathrm{S}$. E. Ind. : 1816

GRĪA, Linn. From grao, to eat; the fruit is edible.

Linn. 13, Or. 1, Nat. Or. Myrtacec. This is an elegant fruit-bearing tree, from thirty to lifty feet high, with leaves about three feet long, and large flowers growing out of the stem and old branches; it thrives best in a loamy soil, and large cuttings will root under a hand rlass, in heat. In the West Indies, the fruit is eaten under the name of Anchovy Pear. It is of a brown russet colour, and the size and shape of an alligator's egg. It is pickled, and eaten in the same way as the East Indian mango, and is very similar to that fruit in taste. Donsays, " to grow it for fruit, it should be planted in a border, and trained near the light."

cauliflōră . . . White. . S. Ev. T. Janaica . 1768

GrIĒLề, Lınn. From grielum, old, grey; hoary aspect of the plants. Linn. 10, Or. 4, Nat. Or. Rosacea. Pretty Cape plants, said to thrive best in sandy gravel, with the pots well drained, as they are very impatient of water. Cuttings root with the greatest ease in the same kind of soil, with or without glasses.

humifūsûm - Yellow . 5, G. Her. P. C. G. H. 1825 laciništúm.: Yellow : 8, G. Her. P. C. G. H. : 1825

Grifrīxĩu, Ker. In honour of William Griffin, Esq., of South Lambeth. Linn. 6, Or. 1, Nat. Or. Amaryllidacea. These are very pretty bulbous plants, which, Mr. Sweet says, "succeed best in a mixture of rather more than one-third turfy loam, a third of white sand, and the rest peat, keeping them quite dry when in a dormant state; but as soon as they begin to grow, or show bloom, they must be well supplied with water. An airy situation suits them best; they may be increased by offsets from the bulbs, or by seeds."

hyaeinthina . . Blue - . 7, S. Bl, P. S. Amer. . 1815 intermedia : Blue: 4, s. Bl. P. Brazil: : 1823

Grirrīthš̃, Agardh. In honour of Mrs. Griffiths, of Devonshire, who has made many discoveries in marine vegetation. Linn. 24, Or. 7, Nat. Or. $A \lg \boldsymbol{c}$. Small, red-coloured species, found on the sea shore most plentiful in summer-barbàtá, corallíua, equi. setifoliă, multúlidă, setäcěă.

Grimmï, Hedrvig. In honour of J. F. Grimm, a German botanist. Linn. 24, Or. 5, Nat. Or. Musci. Small plants, growing in roundish tufts. G. pulvinata is very common on the tops of old walls and houses; it forms little cushion-like, brownish-green tufts, or lumps. Synonyme: 1. Dicranum ovaleapocărpă, nigra-virridis, strīctă, Doniānă, leucophäă, maritimă, ovätă 1, pulvinütă, saxícolă, -epiralis, torquätă, trichophÿllă, unicolor.

GrindĒLIA, Willuenow. Named after Grindel, a German botanist. Linn. 19, Or. 2, Nat. Or. Composite. Elegant plants, with very neat foliage and yellow flowers; they succeed without difficulty in loam and peat, and readily increase from cuttings in sand, under a glass. Synonymes: 1. Donia ciliata. 2. G. angustifolia. 3. Douia glutinosa. 4. D. squarrosa.

anmustifoll . . Sellow . 8, G. Her. P. Mexico . . 1822 ciliat, 1 . Yellow : 8, H. B. N. Amer. 1821 coronnpifoira. - Yellow : 8, G. Ev. S Mexico - 1826 Duvali, Y Yellow 8, G. Ev. S. Mexico r Duvali, 2 : Yellow ${ }^{\circ}$ : Yellow glutinósă, 3 - Yellow * G. Kexico . 1803 inuloidēs : : Yellow : 8, G. Ev. S. Mexico: 1815 spatulata : : Yellow: 8, G. Ev. S. Mexico: 1819 squarrōsă, 4 : Xellow : 8, G. Her. P. Missouri : 1811

Grīstüă, Linn. In honour of G. Grisley, a Portuguese surgeon, and botanical author. Linn. 8, Or. 1 , Nat. Or. Lythracea. Interesting stove shrubs, thriving best in a mixture of sandy peat and loam, and increased by cuttings in sand, under a glass, in heat.

secūnd

S. Ev. S. Cumana - 1820

tomentōsă : : Red . 6, 8. Ev. S. E. Ind. [ 148 ] 
GRōBY̌r, Lindley. Named in honour of Lord Grey, of Groby, a munificent patron of horticulture, and a most zealous cultivator of orchidaceous epiphy tes. He died in 1836 . Linn. 20, Or. 1, Nat. Or. Orchidacee. This is a very curious and pretty species, nearly allied to Cymbidium. The flowers are pale ochre colour, beautifully spotted with purple, and are produced on a pendulous raceme. For culture and propagation, see Stanhopea.

Amhērstř̆ . . . Oehre spot. 9, S. Epi. Brazil . . 1829

Gromwelt, see Lithospērmūm.

GroNōvǐ, Linn. In honour of J. F. Gronovius, a botanist of Leyden. Linn. 5, Or. 1, Nat. Or. Lousacece. Plants of little beauty, and easy cultivation; they are increased by seeds.

Humboldtiānă . Yellow . 7, S. CI. B. S. Amer. . 1820 scåndēns . Grn. yel. : 6, S. Cl. B. Jamaica : 1731 Grooved, furrowed, channelled, marked with grooves.

GRठ̃ssū M, thick, fat.

Ground-CHRRry, see Cĕrăsŭs Chamacěrăsñs.

Ground-cistus, see Rhododēndrŏn Chamarīstŭs.

Ground-crist A, see Cassiă Chamaerìstă.

GroUND-cripRESs, see Santolīnä Chamorcyparisstus.

GrouN D-IVY, see Glechōmă.

GroUND-PINE, see Ajūgă Chamapitty̆s.

GrOUNDSEL, see Seněč̌o.

GrouNDSEL, see Hyoscy̆ămŭs Seneciōnts.

GROVE-DOck, see Rüméx Nemolapăthūm.

Grumose, clubbed, knotted.

GR $\bar{Y} L L$ Ŭs, a cricket.

GuAíăcum, Linn. Guaiac is the South American name of the tree. Linn. 10, Or. 1, Nat. Or. Zygophyllacea. Lofty, ornamental-growing trees, cultivated in rich loam; ripened cuttings, taken off at a joint, will root in sand, under a glass, in heat ; but great care must be taken not to break the fibres when the cuttings are rooted, as they are rery brittle. The species are well known for their exciting properties. The bark and wood of $G$. officinale is bitter and acrid, and is chiefly used in sudorifics, diaphoretics, or alteratives. Synonyme : 1. Zygophyllum arboreum.

arboréūm, 1 . Blue * S. Ev. T. Trinidad . 1816 officinălë : : Blue : 8, S. Ev. T. W. Ind. : 1694 verticâlĕ : : Blue : : S. Ev. T. W. Ind. : 1820

GUĀR Ě̆, Linn. From Guara, the name given to one of the species by the natives of Cuba. Linn. 8, Or. 1, Nat. Or. Meliacea. These are tall-growing trees; the soil best adapted to them is loam, mixed with a little sand; and cuttings of the ripened wood, with the leaves not shortened, will root in sand, in heat, under a glass. Synonymes: 1. trichilioides. 2. trichilioides.

grandifloră, 1 . . White. . 6, S. Ev. T. S. Amer. . 1752 ramiflóră : : White. S. Ev. T. Porto Rico. 1824 Swartzi1, 2 : White. G, S. Ev, T. Jamaica 1818

Guattêrǐn, Ruiz and Pavon. In honour of John Baptiste Guatteri, an Italian botanist, and once professor at Parma. Linn. 13, Or. 6, Nat. Or. Anmacece. This is a splendid genus of plants, succeeding in a mixture of loam, peat, and sand. Young plants are readily obtained by cuttings planted in sand, under a glass, in heat. Synonyme: 1. Uvaria lanceolata.

cerasoidēs . . . Green . . S. Ev. S. E. Ind. . . 1820 laurifolia White S. Ev. S. Jamaica 1818 rūfă . : Brown 7, S. Ev. S. China : 1822 suberơsa : : White. : S. Ev, S. E. Ind. : 1820 virgata, 1 : : White: S. Ev. T. Jamaica : 1793

Guava, see Psĩdžam.

GuazüMă, Plumier. The name of the plant in Mexico. Linn. 18, Or. 1, Nat. Or. Sterculiacec. These are ornamental trees, described as growing from twenty to forty feet high; they thrive in a mixture of peat and loam, and increase from cuttings in sand, or soil, under a glass, in heat. $S y$ nonymes: 1. Bubroma guazuma, Theobroma guazuma. 2. Bubroma polybotryum.

polybottry̆ă, 2 . .

S. Ev. T. Brazil . . 1816

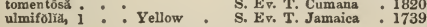

GURLDER-ROsE, see Vibūrnūm öpülǔs.

GURRNSEY-LILY, see Nerīnē sarniēns š̆s.

G DE rTĀBDĂ, V\&ntenat. In honour of Etienne Guettard, [. 149]

a French botanist. Linn, 21, Or. 6, Nat. Or, Cin chonacea. Splendid trees, attaining from upwards of twenty feet high; they succeed best in peat and loam mixed; and cuttings strike in sand without any difficulty. Synonymes: 1. Laugeria hirsuta. 2. L. lucida. 3. L. odorata. 4. Mathiola scabra.

hirsũtă, 1

luีcìdส, 2

odorātă

rugüsã

tomentōs

speciōiosă

S. Ev. T. Peru, 1890

S. Ev. T. Jamaica : 1818

S. Ev. T. Jamaics: 1818

S. Ev. T, w. Ind. 1793

S. Ev. T. Jamaiea: 1890

S. Ev. T. W. Ind. : 1818

GUilandīnă, Jussieu. In honour of Melchior Gui. landina, of Prussia, a great traveller, and a professor of botany at Padua, who died in 1589 . Linn. 10, Or. 1, Nat. Or. Leguminosa. These are pretty stove shrubs, of easy culture in sandy peat, mixed with a little loam; and young plants are obtained either by cuttings, or by seeds, withous difículty. The native practitioners of India suppose the kernels of G. Bonducella to possess powerful tonic virtues.

Bondũe . - Yellow - S. Ev. S. India . 1640 Bonducélla: - Yellow S. Ev. S. E. Ind.

1700

GuINEA-pEAch, see Sarcocēphalǔs.

Guinga-plum, see Parinärīūm excelsam.

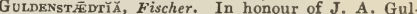
denstædt, a Russian natıralist. Linn. 17, Or. 4 Nat. Or. Leguminosa. A dwarf plant, of little beauty, and very simple culture. Synonyme: 1. Astragalus pauciflorus.

paucifloră, 1 . Red . . 7, H. Her. P. Sibena

GuM-Arabic trer, see Acāciă arăbĭcă.

GuM-c1stus, see Cîstǔs Ladanîfĕrŭs.

Gummiferous, producing gum.

GuM-succorx, see Chondrillă.

GUM-TRER, see Eucalȳptüs robastă.

GundËL̆̌̆, Tournefort. From Andrew Gundelscheimer, a German botanist, and first discoverer of the plant. Linn. 19, Or. 5, Nat. Or. Compositce. A curious plant, though possessed of no great beauty; it does best in sandy peat, and is readily increased by divisions.

Tournefōrtĩ . . Lgt. grn. . 7, H. Her. P. Levant . . 1739 GUNNĒră, Linn. In honour of E. Gunner, Bishop of Drontheim, a good botanist. Linn. 2, Or. 1, Nat. Or. Urticaceo. A curious Cape plant, growing best in rich mould kept moist; it is increased by divisions.

perpēnsă . Purple 7, G. Her. P. C. G. H. 1688 Günı̌̃, Lindley. In compliment to Ronald Gunn, Esq., a zealous investigator of the botany of Van Diemen's Land. Linn. 20, Or. 1, Nat. Or. Orchi. dacea. This is a curious little plant, with dingy purple flowers, succeeding well with the treatmen recommended for Burlingtonia.

pictă . . . Purple .6, S. Epi. Sidney 1837

Gustāv̆̃. Linnæus dedicated this genus to his patron Gustavus III. of Sweden, who presented a large collection of Indian plants to him. Linn. 16, Or. 8 , Nat. Or. Myrtacea. This is a truly splendid plant, growing upwards of ten feet high; it thrives well in any rich soil, and increases from cuttings in sand, in heat, under a glass.

augūstă. . . White. . S. Ev. T. Guiana . . 1794

GuzMĀnnì , Ruiz and Pavon. In honour of A. Guz man, a naturalist. Linn. 6, Or. 1, Nat. Or. Bromeliacea. This is a pretty species, and will do well in any rich mould; it is increased by suckers. trłeðlör . . . Grn. scar. 4, S. Her. P. S. Amer. . 1820

GyMNADÊNY̌, R. Brown. From gymnos, naked, and aden, a gland; in allusion to the gland of the pollen masses. Linn. 20, Or. 1, Nat. Or. Orchidacex. The plants of this genus do best in sandy loam and peat, and if grown in pots, they must be well drained, and very little water given to them when not in a growing state; they are increased by divisions of the roots. Synonymes: 1. Orchis conopsea. 2. $\mathrm{Ha}$. benaria tridcntata.

conōysěă, 1 . Purple - 6, H. Ter. Britain cucullătă : : White . 6, H. Ter. Podolia odoratissină White. 6, H. Tor. Switzer tridentatx, 2 White.6, H. Ter. Canada. 1824 
GYMNẼMă, R. Brown. From gymnos, naked, and nema, a thread; in reference to the stamens. Linn. 5, Or. 2, Nat. Or. Asclepiadacea. Interesting stove twiners, easily cultivated in loam and peat; cuttings take in sand, in heat, under a glass. The milky juice yielded by $G$. lactiferum is used by the Cingalese for food, who also use the leaves when boiled. Indigo of excellent quality is obtained from G. tingens. Synonymes: 1. Asclepias tenacissima. 2. A. tingens.

\section{lactiferūm . .} sylvëstré

tenacissimuin, $;$ Green S. Ev. Tw. Ceylon . . 1824 S. Ev. Tw. Ceylon : 1816 tingens, 2. Yellow: 7, S. Ev. Tw. E. Ind. : 1823

GצмNōctằǔs, Lamarck. From gymnos, naked, and klados, a branch; appearance of the branches. Linn. 22, Or. 9, Nat. Or. Leguminosa. A very handsome hardy tree, growing well in open loamy soil, and is propagated by cuttings of the roots.

canadēnsis. . . White. . H. De. T. Canada. . 1748

GyMnogräммӑ, Desfontaines. From gymnos, naked, and gramma, writing; alluding to the naked sori. Linn. 24, Or. 1, Nat. Ör. Polypodiacea. The species of this genus are among the most interesting of the Fern tribe, and not difficult of cultivation, growing well in a mixture of loam and peat; and young plants are obtained by divisions of the roots. Synonymes: 1. Acrostichum calomelanos. 2. A. chrysophylla. 3. A.leptophylla. 4. Hemionitis pedata. 5. H. rufa. 6. H. tartarea. 7. Acrostichum trifoliata.

calomělănŏs, 1 . Brown . 7, S. Her. P. W. Ind. 1790 chrysophyllă, 2 : Brown :7, \$. Hex. P. W. Ind. 1824 leptophylla, 3. Brown :7, H. Her. P. S. Eur. . 1819 myriophylla : Brown : S. Her. P. Brazil : 1824 pedáa, $4^{*}:$ Brown :6, S. Her. P. N. Spain : 1822 peruviăna : : Brown : 7, S. Her. P. Peru : 1822 rũfa, 5.: : Brown : 7, S. Her. P. Jamaica : 1793 rūfa, 5 : : Brown : 6, S. Her. P. Jamaica: 1793 sulphŭréa
tartáréa, $6 .:$ Brown tomentósa : : Brown : S. Her. P. Brazil : 1831 trifoliata, $7^{*}:$ Brown :7, S. Her. P. Jamaica : 1810

Gyмкогомй, Humbt., Bonp., and Kunth. From gymnos, naked, and loma, a border; in reference to the margin of the grains. Linn. 19, Or. 3, Nat. Or. Composita. An interesting genus of stove shrubs, particularly the species maculata, which is very pretty; they require a mixture of loam and peat, and young plants are obtained from cuttings in soil, under a glass, in heat, without difficulty. G. maculata is very readily increased by divisions of the roots.

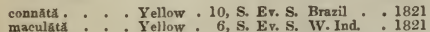
maculátä * : Yellow : 10, S. Ev. S. W. Ind. N. Spain : 1825

Gymnostāch צ̆s, R. Brown. From gymnos, naked, and stachys, a spike. Linn. 4, Or. 1, Nat. Or. Acoracee. This is a pretty plant, of easy culture in peat and loam, and is increased by suckers.

ăneêps .

$$
\text { 6, G. Her. P. N. Holl. }
$$

Gxмnostб̆мữ, Hednig. From gymnos, naked, and stoma, a mouth; alluding to the open orifice of the theca. Linn. 24, Or. 4, Nat. Or. Musci. A numerous genus of plants, growing in tufts and patches of various colours, found at every season, and in almost every situation. Synonymes: 1. luteolum. 2. stelligerum. 3. obtusum. 4. aruyinosum. 5. paucifolium. 6. intermedium. 7. Grimmia Forsteri-

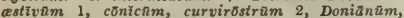
fasciculärě, Griffithsiānum, Heìmīi 3, lappōnīcūm, microstömüm, ovătūm, grăcílé, vulgīré, pyriformĕ,

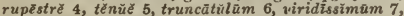
Wilsōnī.

GYNANDRópsis, Decandolle. From gyne, a female, aner, andros, a male, and opsis, resemblance; the stamens appear as if inserted on the top of the ovary. Linn. 15, Nat. Or. Capparidaced. These are very pretty plants; for culture, \&c., see Cleome. Synonymes: 1. Cleome candelabrum. 2. C. pentaphylla. 3. triphylla. 4. speciosa. 5. triphylla.

candelābrūm, 1 . Red . . 7, H. A..S. Amer. . 1824 pentaphyllă, 2 . White: 7, 5. A. E. Ind. : 1640

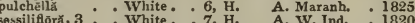
sessilifioră, 3 . White . 7, H. A W. Ind. 1820 speciósă, 4. . . White. * 7, S. B. Carthag. . 1818 triphyllă, 5 : White : 7, H. A. W. Ind. 1816 GYNANDRous, having the stamens and style combined in one body.

GxмовАsв, a fleshy receptacle, bearing separate fruits. GyNoBAsic, having a gynobase.

GrNopHoRE, a lengthened receptacle, bearing the petals, stamens, and pistils, but not the calyx.

Gryous; flowers are said to be $3,4,5$, \&c., gynous, when they contain so many styles.

GYpsōPhĬLĂ, Linn. From gypsos, chalk, and phileo, to love; in reference to the favourite habitat of the plants. Linn. 10, Or. 2, Nat. Or. Silenacea. The plants of this genus do not possess much beauty; they are all easily cultivated in any open soil, and the herbaceous kinds are increased by cuttings. The annuals need only be sown in the open border. Synonyme: 1. scorzonerafolia.

acutifolra . . White. . 7, H. Her. R. Siberia . 1820 adscēndêns : White: : 7, H. Her. P. S. Eur. : 1800 altissimă : Striped:7, H. Her. P. Siberia: 1759 arenärí White. 7 , Her. H. Hungary 189 White 7, Her. P Podgary - 1801 Whiter. P. Podolia . 1821 White. 7, H. Her. P. Crete . 1810 elégans: : White: 7, H. Her. P. Crimea : 1815 fastigiâta: : White: : 6, H. Her. P. Germany : 1759 glaủeă. - White. 8, H. Her. P. Caucasus . 1822 glomerăta : Pa, red : 7, H. Her. P. Tauria 1818 graminéa * Red * 8, H. Her. Tr. Greece 1810 musalls pariculst: : Red : 8, H. A. Germany - 1739 paniculata. White. 8, H. Her. P. Siberia . 1759 perfoliăă . Flame. . 7, H. Her. P. Spain . . 1732 prostrăta - . Red * 8, H. Her. Tr. Siberis . 1759 pubëscẻn: - White. 6, H. Her. P. Siberia : 1829 répëns : : Striped : 8, H. Her. Tr. Siberia : 1774 rigIdA : Pink : 7, K. Her. Tr. France : 1769 sabulösð, 1 . White. 7, H. Her, P. Tauria: 1817 Saxifräg : Pink : 7, H. Her. Tr. Germany: 177 serotina White: Steveñ. : : White: 7, H. Her. P. Iberia.: 1829 Strathium: : White: : 7, H. Her. P. Iberia. : 1822 tenella : White: 7, H. Her. P. Europe: 1816 tenuifolia: : : Red : $:$, H. Her. P. Calleasus: 1824 viscôsă . : White: 6, H. A. Levant : 1773 GrrocT̃Rús, Jacquin. From gyro, to turn round, and karpos, a fruit; in allusion to the fruit moving in the air. Linn, 23, Or, 1, Nat. Or. Illigeracea. These plants are described as being very ornamental, and of easy cultivation in loam and peat. Cuttings strike readily in sand, in heat, under a glass. Synonymes: 1. G. Jasquinii. 2. Jacquinii.

americănŭs, 1. Yellow - S. Ev. T. W. Ind. 1816 GrRöphŏn, Acharius. From gyros, a circle, and phoreo, to bear; alluding to the disk of the shield. Linn. 24, Or. 8, Nat. Or. Lichenes. Very interesting plants of the Lichen tribe, found growing chiefly upon exposed rocks, or granite stones; some of the species are peculiar to the Highlands of Scotland-cylindrĭcă, deũstă, erōsă, gläbră, polyphy̆llă, murĩnă, pellītă, proboscídĕă, ärctǐcă, pustulätă.

Grrosk, turned round like a crook.

Gyrostímōn, Desfontaines. From gyros, a circle, and stemon, a stamen; in reference to the concentric arrangement of the stamens. Linn. 22, Or. 12, Nat. Or. Euphorbiacece. This is described as being rather an ornamental tree, and thriving in loam and peat; it may be increased by cuttings in sand. Synonyme: 1. Codonocarpus austrulis.

attenuātŭs . . $\quad$ G. Ev. T. Moreton .1830 
$\mathrm{H}^{A}$

ABENĀRĨ̃, Willdenow. From habena, a rein, - or thong; in allusion to the long strap-shaped spur. Linn. 20, Or. 1, Nat. Or. Orchidacece: This place in every collection. The hardy kinds will grow well in the open border, with a slight protection for the American species in severe, frosty, or rainy weather. The stove species grow best in a mixture of leaf-mould and peat, placed in a hot, damp part of the house when in a growing state; but like the genus Bletia, after the plants have lost their leaves, and the roots become dormant, they require to be kept cool and dry until the roots begin to push, when the plants should be repotted, and again placed in a hot and moist heat. They are all increased by divisions of the roots. Synonyme: 1. Orchis foliosa.

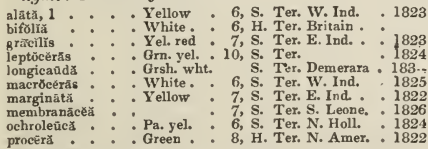

НАвіт, features, or general appearance of a plant.

HӐвІัт Ӑ, habitation, locality, native country.

HABLітzї, Bieberstein. In honour of C. Von Hablitz, a traveller, and author of Travels in the Crimea. Linn. 5, Or. 1, Nat. Or. Chenopodiacec. We know nothing of this plant; indeed, it is very possible it is not in the country. It may be increased by cuttings, or seeds.

tamnoidēs. . White . 9, H. De. Cl. Caucasus . 1828

Habrānthưs, Herbert. From habros, delicate, and anthos, a flower. Linn. 6, Or. 1, Nat. Or. Amaryllidacec. All the species of this genus are pretty when in flower. A mixture of three parts sandy loam, and one part peat, suits the various species of this genus. They may be increased by offsets from the roots, or by seeds, which are frequently produced in abundance.

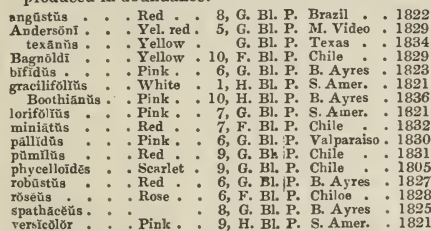

HamMadictžŏn, Lindley. From haima, blood, and dyktyon, a net; alluding to the colour of the veins of the leaves. Linn. 5, Or. 1, Nat. Or. Apocynaceœ. A very ornamental plant, with beautifully-veined leaves; the soil best adapted to it is a mixture of loam and peat, and cuttings of the young.wood root readily in sand, under a glass, in heat. Synonymes : 1. Echites sanguinulenta, nutans.

venōsūm, I . Yellow . 7, S. Ev. Tw. W. Ind. . 1821

H жмйNтhŭs, Linn. From haima, blood, and anthos,

a flower; colour of some of the flowers. Linn. 6,

Or. 1, Nat. Or. Amaryllidacec. A genus of fine bulbous plants; all the species succeed well in sandy loam, mixed with a little peat. They do not require to be watered when in a dormant state, in consequence of which, the bulbs ripen, and afterwards flower freely; increased by offsets.

albiflos . . . White . . 6, G. Bl. P. C. G. H. . 1791 amarylloídès : Pink : 8, G. Bl. P. C. G. H. 1825

(1)

cărnèŭs :

coarctătŭs

cocciñeús

crāssipès

hŭmillis.

hyalocârpuัs

lanceæefoliŭs

maculātŭs

moschātŭs

multiflorŭs

orbiculăris

pubèscēns

punǐcěus

quadrivālvis

rotundifơlrŭs

sanguinnès

tigriuน̆s.

Hrita Flame

Pink - 6, G. BI, P. C. G. H.

- Pink

- Pink

Red

8, G. BI. P. C. G. H.

2, G. Bl. P. C. G. H.

9 , G. Bl. P. C. G. H.

* 5, G. Bl. P. C. G. H.

Scarlet 9, G. Bl. P. C. G. H.

Red $\quad$ 7, G. Bl. P. C. G. H.

6, G. Bl. P. C. G. H.

Red : 9, G. Bl. P. C. G. H.

Scarlet : 6, S. Bl. Y. S. Leone

White . 7, G. Bl. P. C. G. H.

- 8, G. Bl. P. C. G. H.

Scarlet - 7, G. Bl. P. C. G. H.

Flame G, Bl. P. C. G. H.

Scarlet : 7, G. Bl. P. C. G. H.

Crimson G. Bl. P. C. G. H.

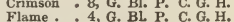

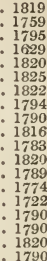

Hed-coloured. wood; logwood is well known for its red colour. Linn. 10, Or. 1, Nat. Or. Leguminose. The logwood tree attains the height of twenty feet; it grows well in a mixture of loam, peat, and a little sand, and it may be increased by cuttings in sand, in heat, under a glass, or by seeds, which are very frequently received in this country from the West Indies. The bark and the wood are slightly astringent. The wood is chiefly used in dyeing.

campechiānūm . Yellow . S. Ev. T. S. Amer. • 1724

Hamodōrūm, Smith. From haima, blood, and doron, a gift; colour of the flowers. Linn. 3, Or. 2, Nat. Or. Homodoracec. Ornamental plants, growing freely in loam and peat; they are readily increased by divisions of the roots.

planifolǐnm - Orange - 8, G. Her. P. N. S. W. . 1810 teretifolium : : Orange :8, G. Her. P. N. Holl. : 1822 HAIr GRAss, see Aĭră.

HĀK ĔA, Schrader. In honour of Baron Hake, a German promoter of botany. Linn. 4, Or. 1, Nat. Or. Proteacee. A genus of very desirable New Holland plants; they require to be grown in a soil composed of equal parts of loam, peat, and sand. It is necessary to drain the pots well, so that the plants are not injured by too much water. Cuttings of the ripened wood root without difficulty in sand, under a glass.

aciculârîs

angustifð̆ră

acanthophyllä

Baxtēri.

canēscēns

earduifölră

ceratophylla

clavátă

einéréa

dactyloidès

dactyloidēe

echinătā

epiglōttirs

ferruginéă

feexillis

flōrida

gíbbōsă

Lambërt

lanīgĕrĭ

latifólix.

laurīnă .

ineărís .

marginātă

nititida

nìtĩdă

oleifữĩa

părîlìs

pectinătà

petrophiloides

propinqua

prostrâtă
White.

White.

White.

White

White.

Brown

White

White

White

White

White

White

White.

White

White.

White.

White.

White.

White

White

White.

White.

White.

White.

White.

White.

White.

White

White.

White.

White.
6, G. Ev, S. N. S. W. 1790

G. Ev. S. N. Holl : 182

G. Ev. S. N. S. W. : 1821

G. Ev. \&. N. Holl. 1803

G. Ev. S. N. Holl,

7, G. Ev. S. N. Hodl. 1800

5, G. Ev. S. N. Holl. - 1825

$7, G$. S S N Holl.

- 1824

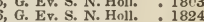

, G. Ev. S. N. Holl. : 1790

, G. Ev. S. N. Holl.

7, G. Ev. S. N. Holl. : 1794

G. Ev. S. N. Holl. : 1819

G. Ev. S. N. Holl.

G. Ev s. N. Holl 182

5, G. Ev. S. N. S. W. : 1790

B, G. Ev. S. N. Holl. - 1803

G. Ev. S. N. S. W. : 1825

, G. Ev. S. N. Holl. 1820

G. Ev. S. N. Holl. 1825

G. Ev. S. N. Holl. : 1830

5, G. Ev. S. N. Holl. : 1824

G. Ev. S. N. Holl.

5, G. Ev, S. V. D. L

6, G. Ev. S. N. Holl. : 1803

5, G. Ev. S. N. Holl. : 1803

6, G. Ev. S. N. Holl. : 1794

6, G. Ev. S. V. D. L. . 1796

5, G. Ev. S. N. Holl. . 1810

G. Ev. S. N. Holl. : 1825

5, G Ev. S. N. S. W. : 1824 [151] 
pugioniförmin . White. . G. Ev. S. N. S. W. - 1796

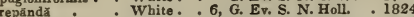
ruscifolia: : White: $:$, G. Ev S N. Holl : 1824 ruscifolia: White.: 4, G. Ev S. N. Holl. : 1791 saligná.: * White. 4, G. Ev. S. N. Holl : 179 subulata : : White: 5, G. Ev. S. N. S. IV : 1824 sulcãtă : : White : 5, G. Ev. S. N. Holl. : 1820 sulcătă . * * White * . 5, G. Ev S. N. Holl, S. N. Holl tubereulata : G. Ev, S. N. Holl ulicină : White . G. Ev. S. N.S. W undulāta : : White. 6, G. Ev. S. N. Holl

HaLBERD-WBaD, see Neuroleena.

HALËsix, Linn. In honour of S. Hales, D.D., F.R.S. a vegetable physiologist. Linn. 11, Or. 1, Nat. Or. Ebenacec. All the species of the Snowdrop tree are most beautiful and valuable shrubs, on account of their flowering so early in the season; they grow freely in any common garden soil, and mul. tiply by cuttings of the roots, or by layers.

tetrăptéră . . White. . 5, H. De. S. Carolina - 1756 partiflora - White H. De. S. N. Amer. 1809 diptéră. : : White.: 4, H. De. S. N. Amer. : 1758

HaLIMoDĒNDRō, Fischer. From halimos, maritime, and dendron, a tree; in allusion to the shrub grow ing in dry, naked, salt fields, by the river Irtis, in Siberia. Linn. 17, Or. 4, Nat. Or. Leguminose. These are very beautiful shrubs, well worthy of a place in every garden; for culture and propagation, see Caragana. Synonymes: 1. Robinia Halodendron, Caragana argentea. 2. Robinia triflora.

argëntěŭm, 1. . Pink . . 5, H. De. S. Siberia brachysémã. . Pink : 6, H. De. S. Siberia

Halisiris, Agardh. From hals, the sea, and seris, lettuce; in reference to the membranous fronds. Linn. 24, Or. 7, Nat. Or. Alga. I species, with some likeness of a Polypodium; it is olive-green, and found in the ocean at all seasons of the yearpolypodioides.

HALLEIA, Linn. In honour of Albert Haller, M.D., a distinguished botanical author. Linn. 14, Or. 2 , Nat. Or. Scrophulariacec. A genus of ornamental shrubs, requiring to be grown in a light rich soil cuttings root readily in sand, or soil, under a glass. They require an airy part of the greeuhouse, and plenty of water in summer.

elliptică * . Scarlet . 7, G. Er. S. C. G. H. . 1826 lūeida : : : Searlet :7, G. Ev. \&. C. G. H. : 1752

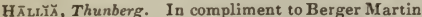
Hall, a pupil of Linnæus. Linn. 16, Or. 6, Nat. Or. Leguminosa. Herbaceous plants, with little to recommend them to the cultivator; they thrive best in sandy loam and peat, and cuttings of the young wood root freely in sand, under a glass. They sometimes ripen seed, from which plants may also be obtained.

imbricata . . Pink . . 8, G. Ev. S. C. G. H. 1812 alätă, asarīnă, cordătŭ, flüccĭdă.

HALoñ̄ars, Forster. From hals, the sea, and rhax, berry of grapes. Linn. 8, Or. 4, Nat. Or. Onagracea. These are rather curious plants, thriving well in a mixture of loam and peat, and increased readily by cuttings in sand, under a glass.

Cercódĭ . . . Grn. red . 6, G. Ev. S. N. Zeal. . 1772 prostrátă : : Grn. red . 7, G. Ev. S. N. Zeal. : 1820

HALхм Ǩn̆̌, Agardh. From hals, the sea, and hymen, a membrane; alluding to the membranous fronds. Liun. 24, Or. 7, Nat. Or. Alga. Interesting marine plants, with flat, membranous fronds. $\boldsymbol{H}$. edulis is the true, and $\boldsymbol{H}$. palmata the common Dulse, both of which are eaten in Scotland-edalis médiă, furccllâtă, ligulätă, Opūntĩă, palmätă-marginüférü-sarniēnsis, purpurāscēns-crispätŏ.

HА̄ MAMĒLIs, Linn. From hama, with, and melon, an apple; the fruit accompanies the flower. Linn. 4, Or. 2, Nat. Or. Hamamelacea. The species of Witch-hazel are ornamental trees, producing a fruit something like a nut. They succeed in any common soil, and are commonly increased by layers.

macrophylla . Yellow . 5, H. De. T. N. Amer. . 1812 virginies : : Yellow : 5, H. De. T. N. Amer. : 1812

HAMĒLI. Named by Jacquin, in honour of the distinguished botanist H. L. Du Hamel Du Monceau, who died in 1782 . Linn. 5, Or, 1, Nat. Or. Cin. chonacea. This genus consists of handsome, freeflowering shrubs, easily cultivated in peat and loam; and cuttings, planted in the same kind of soil, root readily in a moist heat, under a glass. Synonyme: 1 . H. odorata.

axillărĭs - . Yellow * 8, S. Ev. S. W. Ind. 1892 chrysānthă : : Yellow : 11, S. Eৃ. S. Jamaica : 1822 pătêns : : Yollow 7, S. Ev. S. Hispaniola. 1752 sphærocärpa : : Orange : 7, S. Ev. S. Mexico • 1811

HАмıтт̄хॅ̆, Roxburgh. In honour of Mr. Hamilton, of Woodlands, near Philadelphia, an eminent botanist, and the first to erect a conservatory in North America, for the preservation of plants of hot climates. Linn. 22, Or. 3, Nat. Or. Cinchonacece. These plants are very desirable on account of their producing flowers very freely, which are delightfully fragrant; loam and peat suit them best, and cuttings root readily in sand, under a glass, in a moist heat. Synonymes: 1. Spermadictyon azureum. 2. S. suaveolens.

seăbră, 1 . - Pa blue • 1, S. Ev. S. Nepal . . 1823 suaveóléns, 2 : White 10 , S. Eマ. S. E. Ind. ' 1818

HАмб̄sǔs, hooked, bent.

Hapalostéphİōa, Don. From hapalis, soft, and stephos, a crown; alluding to the hairy receptacle. Linn. 19, Or. 1, Nat. Ur. Compositce. The plants included in this genus are well adapted for rockwork, or the front of fower-borders; they grow freely in any light rich soil, and increase by dividing the roots, or by seeds. Synonymes: 1. Crepis austriaca. 2. Hieracium grandiflorum. 3. lyratum. 4. paludosum. 5. blattaricides, Lepicaune multicaulis. 6. Hieracium pyrenaicum. 7. sibiricum, Crepis sibirica. 8. Lepicaune spinulos/

austriăcúm, 1 - Yellow - 7, H. Her. P. Pyrenees : 1793 grandiftōrūm, $\dot{2}$ Yellow H Her, P. Switzerl granditörüm, 2 : Yellow : Hellow Her. P. SwitzerL: 1791 8. H Her. P. Britin

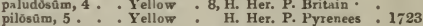
pyrenaricum, 6 : Yellow : H. Her. P. Pyrenees: 1723 sibiricum, 7 . Yellow: H. Her. P. Siberia : 1755 spinulosum, 8. Yellow : H. Her. P. Pyrenees: 1820

HARD-GRAss, see Ophiürŭs.

HARD-GRAss, see Scleróchlod.

HARDWíckIÁ. Koxburgh named this genus in com-

pliment to Major-General Thomas Hardwicke, F.R.S., L.S, \&c., of the East India Company's Artillery. Linn. 10, Or. 1, Nat. Or. Leguminose. Trees from forty to fifty feet high; a light loamy soil suits them well, and good sized cuttings root readily in sand, under a glass, in heat.

hinatd . . Yellow . 3, S. Ev. T. E. Ind. . 1820 pinnata: : : Yellow : 4, S. Ev. T. E. Ind. : 1818

HARBBELIS, see Campänŭlă rotundifoliă.

HARB's BAR, see Erȳsimñm austriücrim.

HARB'S-EAR, see Buplearím.

HARB's-70ot, see Ochromä Lagópũs.

HARE'S-FOOT FERN, see Davālliá canariènsís.

HARB's-TAIL GRAss, see Lagũrũs.

HaRicot D'ORLBANs, see Phasélús sphäricüs.

HanōNGă, $P$. Thouars. The native name of the species is Ronga. Linn. 18, Or.2, Nat. Or. Hypencacea. A tall, ornamental-growing shrub, thriving well in a mixture of loam and peat; plants may be obtained from cuttings of the ripened wood, planted in sand, under a glass, in heat. Synonyme: 1. paniculata.

madagassariênsis, 1 Yellow . 7, S. Ev. S. Madagas. . 1825 HARPĂLY̌č̆, Don. After Harpalyce, daughter of Lycurgus. Linn. 19, Or. 1, Nat. Or. Composita. The species of this genus are not possessed of much interest; they grow well in any garden soil, and the perennial kinds may be increased by seeds, or divisions; the annual species by seed, sown in the open border. Synonymes: 1. Prenanthes alba. 2 altissima. 3. cordata. 4. serpentaria. 5, virgata.

albă, 1 . - White - 7, H. Her. P. N. Amer. 1762 altissima, 2 - Yellow * 7, H. Her. P. N. Amer. • 1696 $\underset{\text { viminea }}{\text { cordată, } 3}:$ : Pa. yel. : 7, H. Her. P. N. Amer. : 1816
: : serpentäriă 4 , virgãtä 5 .

HARRISONIA. Hooker named this genus in honour of Mrs. Harrison, of Aighburg, near Liverpool, who first introduced the plant. Linn. 5, Or. 2, Nat. Or. $[152]$ 


\begin{tabular}{ll} 
HAR & HAW \\
\hline Asclepiadacere. An ornamental shrub, well worthy
\end{tabular}

Asclepiadaces. An ornamental shrub, well worthy tion, see Gomphocarpus.

loniceroidēs . . Searlet . 7, S. Ev. S. Brszil . . 1825

HARTōgǏn, Thunberg. In honour of J. Hartog, a Dutch naturalist and traveller at the Cape. Linn. 5, Or. 1, Nat. Or. Aquifoliacee. An ornamental tallish-growing shrub, nearly related to Myginda; for culture and propagation, see Cassine.

capēnsis 6, G. Ev. S. C. G. H.

1800

HART's-TONGUR, see Scolopendrĩum.

HART's-Tongue, see Polypũdîum Phyllitídis.

H ARTW $\vec{G} \breve{I}$, Lindley. In compliment to Mr. Theodore Hartweg, a successful collector of Mexican plants for the Horticultural Society of London, and who discovered this his genus. Linn. 20, Or. 1 , Nat. Or. Orchidacea. A curious little plant, with delicate purple flowers; it requires to be treated similar to other Mexican orchiadaceæ.

purpǔréă . . Purple . . 8, S. Epi. Vera Cruz . 1837 Hartwort, see Tordỹlinm.

HASSAGAY-TRRE, see Curtǐsĭă.

HAssetquístĩ . Named by Linnæus, in honour of his pupil Frederick Hasselquist, M.D., who travelled in the Holy Land, \&c., and died at Smyrna, in 1752. Linn. 5, Or. 2, Nat. Or. Umbellifere. Mere annual weeds, natives of Egypt; they grow in any common soil_agỹptiăcă, cordätă.

HAsTATR, formed like the nead of a halbert.

HASTATELY - LANCEOLATE, between halbert-shaped and lance-shaped.

Hastately-sagittate, between halbert-shaped and arrow-shaped.

HATCHET-VETCH, see Bisërrŭlü.

HauLM, dead stems of herbs.

HautBox, see Fragārĭa.

HAWKWEED, see Hieräcŭũum.

Hawōrthĭă. Prince Salm-Dyck named this genus in compliment to A. H. Haworth, F.L.S., a distinguished English botanist. Linn. 6, Or. 1, Nat. Or. Liliaced. Haworthia is a singular and highly interesting genus of succulent plants, nearly related to the genera Aloe and Gasteria, and they require the same treatment as those genera. Synonymes: 1. Aloe atrovirens. 2. A. margaritifera minima. 3. Haniorthia concava. 4. rigida. 5. Aloe margaritifera. 6. Haworthia fasciata. 7. Aloe rigida. 8. A venosa. 9. A. viscosa.

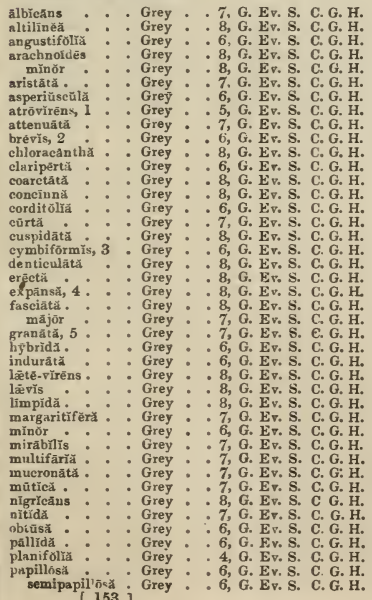

1795

1824

1824

1727

1819

1820

1818

1823

1790

1810

1820

1824

1821

1823

1817

1816

1819

1795

1819

1818

1795

1818

1820

1735

1821

1820

1819

1820

1819

1739

- 1795

1824

1820

1820

: 1822

: 1825

- 1824

- 1820

1824

1820
HA W

HED

părvă • - . Grey * . 5, G. Ev. S. C. G. H. 182

pŭmùlă Grey

ămǐla : : : Grey : : 5 , G. Ev. S. C G. H

, 8, G. Ev. S. C. G. H

pluriperlatai - Grey - 8, G. Ev. S. C. G. H.

pluriperlata: Grey : : 8, G. Ev. S. C. G. H.

recûrvă . : : Grey

Reinwårt5, 6 . Grey

reticulátã . - Grey

retūsá . . Grey

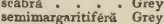

major : . Grey

minor : Grey

multiperlátả - Grey

semiglabrătă

tata

mãjör

médiă

nigrieẩ

sōrdida :

torquătă

tortellä

tortuōsă, 7

tūrgìdă .

venòă, 8

virêscêns

irêscèns

minör
viscôsă, 9

HaWthoRn, see Cratägŭs.

6, G. Ev, S. C. G. H

6, G. Ev. S. C. G. H

6, G. Ev. S. C. G. H

6, G. Ev. S. C. G. H

4, G. Ev. S. C. G. H

4, G. Ev. S. C. G. H

4, G. Ex. S. C. G. H

4, G. Ev. S. C. G. H.

6, G. Ev. S. C. G. H.

7, G. Ev. S. C. G. H

7, G. Ev. S. C. G. H.

2, G. Ev. S. C. G. H

7, G. Ev. S. C. G. H

6, G. Ev. s. C. G. H.

8, G. Ev. S. C. G. H

7, G. Ev. S. C. G. H.

7, G. Ev. S. C. G. H.

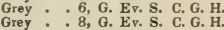

Grey : 6, G. Ev, S. C. G. H.

8, G. Ey, S. C. G. H

Grey : : 8, G. Ev. S. C. G. H.
Grey : 6 , G. Ev. S. C. G. H.

1818

1752

1805
1820

1825

1820

795

1820

1794

1720
1818

1819

1819

1819
1819

181

1820

182

1820

1820

1823

1823

1795

1819

1819
1819

1819
1727

HAWTHORN, see Rhūs Oxyacänthă.

HАYLŌCK ÎA. Herbert named this genus in honour of his very intelligent gardener Matthew Haylock. Linn. 6, Or. 1, Nat. Or. Amaryllidacea. This is rather a pretty bulb when in flower, and it may be successfully grown in sandy loam; it is easily increased by offsets from the bulbs.

pusilla . - . Straw . 9, F. Bl. P. B. Ayres - 1829

HAzEl, see Corỹlŭs.

HBART's-BASB, see Viollă trícǒlör.

Hrart-sked, see Cardiospermūm.

HEATH, see Erīcă

HeBristreftiă, Linn. In honour of $J$. E. Hebenstreit, M.D., professor of botany at Leipsic. Linn. 14, Or. 2, Nat. Or. Selaginacea. This is a genus of pretty under-shrubs, with very neat foliage and modest flowers; they thrive best in a mixture of sandy loam and peat, and young plants are readily obtained from cuttings in the same kind of soil, under a glass. Synonyme: 1. H. aurea.

albiflōră - . White. . 7, G. Ev. S. C. G. H

white. 6, G. Ev. S. C. G. H. 6, G. Ev. S. H. G. Ev. S. C. G. H. 1822 * - White * 6, G. Ev. S. C. G. H. . 1815 cordàtă - . White. - 7, G. Ev. S. C. G. H. . 1774 dentãta. - * White * 7, G. A. C. G. H. • 1739 erinoides - . White . 5, G. Ev. S. C. G. H. 1816 fruticosă : White. : 8, G. Ev. S. C. G. H. : 1816 integrifoliă, 1 : White: 5, G. Ev. S. C. G. H. : 1792

Heneỏmă, Persoon. Hedeoma is a Greek name for Mint. Linn. 2, Or. 1, Nat. Or. Labiatce. The seeds of these plants merely require to be sown in the open border in spring

pulegioidès - . Blue . . 7, H. A. N. Amer. 1777

HẼp̌ra Ă, Swartz. The name appears to be derived from hedra, a Celtic word, signifying a cord, and the English name, Ivy, is derived from in, a word in the same language, signifying green, from its being always green. Linn. 5, Or. 1, Nat. Or. Araliaced. The common Ivy is very often employed for covering naked buildings, or trees, which latter it invariably kills; it is increased by slips, taken otf, and planted where they are to grow. The tender kinds will grow in any soil, though they appear to grow better in a very light one.

canariênsis : Green : H. Ev. Cl. Canarie

ehrysocårpă - Green . - H. Ev. Cl. India

vulgăris : Green : H. Ev. Cl. Britain

HвDGE-GARIIC, see Alliărǐă.

HRDGR-HYSSOP, see Gratiolä.

HBDGB-MUSTARn, see Erȳsimûm. 
HEDGE-NBTTIE, see Stächy̆s.

HEDWTGYu, Swartz. In honour of John Hedwig, the celebrated muscologist, who died in 1799. Linn. 8, Or. 1, Nat. Or. Burseracea. A tall-growing ornamental tree, thriving in peat and loam, with a little sand mixed; cuttings root readily in sand, under a glass, in heat.

balsamüféră . . White . . 8, S. Ev. T. W. Ind. - 1820

Нвдйснї́м, König. From hedys, sweet, and chion, snow; alluding to the sweet-scented snow-white flowers of some of the species. Linn. 1, Or. 1, Nat. Or. Scitamined. The species of Hedychium, or Garland Flower, are all highly-prized flowering plants, more particularly $H$. angustifolium and $H$. coronarium; they are all well worthy of extensive cultivation. They all grow freely in rich light soil, and to flower them well, they require a large pot, with a plentiful supply of water when in a growing state; they are readily increased by diriding the roots. Synonymes: 1. angustifolium. 2. angustifolium.

acuminātūm . White angustifólīum . Searlet aurantiăcūm, 1 . Orange cārnéūm coccīné üm, 2 : Smarlet coronariüum : Yellow elátūm . : : Pa. red ellipticuin : : : White flavèscèns: Yellow flẫinm : . Yellow Gardneriānūm : Yellow glaūcūm . White. White

răcillè

heterumallum : Yellow longifoliùm

măxĭmūm . : White.

apeciōsūm

spicãtūm

thyriforme - White

urophyllüm - Yellow

7, S, Her P. $\mathrm{B}$. Ind

1820

8, S. Her. P. E. Ind. : : 1815

7, S. Her. P. E. Ind. : 1812

8, S. Her. P. E. Ind.

S. Her. P. E. Ind.

S. Her, P. E. Ind.

8, S. Her. P. E. Ind.

6 , S. Her. P. India

7 , s. Her. P. Nepal

7, S. Hex. P. E. Ind.

7, S. Her. P. E. Ind.

7, S. Her. P. India

6, S. Her. P. E. Ind,

8, S. Her, P. $\mathbf{S}$. Ind.

B, S. Her. P. E. Ind

. S. Her. P. India

4, S. Her. P. India

7, S. Her. P. Nepal

7, S. Her. P. E. Ind.

1823

1791

1818

1804

1822

1822
1819

1822

1823

1822

1820

1823

1810
1830

1818

1828

Hвруб̄Ťs, Linn. From hedys, sweet, and ous, an ear; alluding to the sweet-scented ear-like leaves. Linn. 4, Or. 1, Nat. Or. Cinchonacea. Stove annuals, of neither interest nor value; they are readily grown in peat and loam. Synonymes: 1. Spermacoce biflora. 2. Oldenlandia diffiusa. 3. o. ramo-

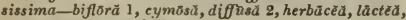
ramosissimả 3 , umbellātă.

HeDTrpsols, Tournefort. From hedys, sweet, and pneo, to breathe; in reference to its having the power of scenting the breath. Linn. 19, Or. 1, Nat. Or. Compositie. Hardy annuals, of no interest ; the species need only be sown in the open groundcoronopifoliă, crëtică, mauritānică, monspeliēnsìs, pēndrila, rhagadiolvidés, tubaformis.

HвnȲsĂRÜM, Linn. From hedysarnn, the name of a papilionaceous plant described by Theophrastus. Linn. 17, Or. 4, Nat. Or. Leguminosa. Almost all the species of this genus are very handsome flowering plants, producing racemes of very beautiful pea flowers, particularly adapted for flowerborders, or rock-work. They grow freely in a light rich soil, or loam and peat, and the herbaceous kinds are increased by dividing the roots in spring, or by seeds. The seeds of the annual and biennial kinds only require sowing in the open border in spring. Synonyme: 1. H. sibiricum. 2 H. alpinum. 3. $\boldsymbol{H}$. obscurum altaicum. 4. $\boldsymbol{H}$. humile.

alpīnūm, 1 . Purple pedicelare, 2. Purple altâìcūm . . Purple brachýsémūin, 3 Purpl candidùim ${ }^{\circ}$ - Purple hümile, 4. Purple carnōsúm : : Purpūm : Purple cousanguĩnăum : Purple coronariúm Scarlet cretâceúm : Purple fruticôsūm : Purpl grandiflörūm : Purple ihēricuñm . - Purple lasiocärpũm . Purple ohseūrūm . : Purpl pallidúm : Pa red păllidúm : : Pa. re
rờeúm
6, H. Her, P. Siberis

6, H. Her. P. Siheris

7, H. Her. P. Siberia

7, H. Her. $\mathbf{P}$, Siberia

5, H. Her. P. Tauria

6 , H. Her. P. Tuuria

7, H. Her. P. Barbary

7, H. Her. P. Caucasus

7, H. Her. P. Siberia.

$6, \mathrm{H}$. B. Italy

7, H. Her. P. Siberia

6, H. De. S. Siberia

7, H. Her. P Iberis

H. Her. P. Siberia

7, H. Her. P. Alps

$6, \mathrm{H}$. Her. P. N. A frica 8, H. Her. P. Caucasus
1798

1818

1817

1817

1820

1 1 20

1820

1596

1819

1782

1818

1816

1640

1800

1820
1803

rutidocărpūm - Purple - 8, H. Her. P. Siberia * 1826 splèndēns. Cream taūricūm. : Pa pur. : 7, H. Her. P. Tauria: : 1804 văriám : : White.: 7, H. Her. P. S. Eur. : 1820

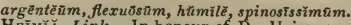

HĒMİ̃, Link. In hononr of Dr. Heim, a celebrated Berlin physician. Linn. 11, Or. 1, Nat. Or. Ly. thracea. These plants are very pretty when in blossom; they grow well in an equal inixture of loam and peat, with a little sand. They only require to be protected from frost in winter, which may easily be done if the plants are agrinst a south wall; if in pots, they should be removed into the greenhouse. Cuttings strike freely either in sand or soil, under a glass. Synonyme: 1. Nesca salicifolia.

linariæfolră *.Yellow - F. Ev. S. S. Amer. 1829 myrtifolia : Tellow : F. Ev: S. S. Amer. : 1826 salicifólıă, i . Yellow : 8, F. Ev. S. Mexico: 1821

Herstērǐa. Named by Linnæus, in honour of Laurence Heister, once professor of botany at Helmstadt, who died in 1758. Linn. 10, ()r. 1, Nat. Or. Olacacea. This is a tree which attains the height of about fifteen feet, and is cultivated in a mixture of loam, peat, and sand; and cuttings will root in sand, under a glass, in heat. The wood of this tree is the partridge-wood of the cabinet-makers.

coccīnĕă . . Scarlet . S. Ev. T. W. Ind. . 1822

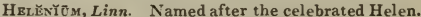
Linn. 19, Or. 2, Nat. Or. Compositce. Very pretty tallish-growing plants, well adapted for flower borders; they will grow freely in any common garden soil. The herbaceous species may be increased by dividing the roots. The annuals and biennials require the same treatment as is generally given to such species.

autumnălè . - Yellow - 9, H. Her. P. N. Amer. - 1729 canaliculâtūm . Yellow. 8, H. Her. P. N. Amer. . 1800 mexieanûm - Yellow . 8, H. Her. P. Mexico . 1825 pŭmeens * - Yellow * 8, H. Her. P. N. Amer. * 1776 purm . Yellow . 8, H. Her. P. 1818 quadridentátüm - Yellow $\cdot 8, \mathrm{H}$. A. Louisiana * 1790

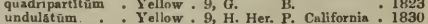

Нвціл̄тнйыст, Tournefort. From helios. sun, and anthemon, flower; in allusion to the yellow flowers. Linn. 13, Or. 1, Nat. Or. Cistaced. This is a very showy, free-flowering genus of plants, comprising some of the prettiest little shrubs in cultivation, for ornamenting rock-work. In winter, some of the species require the protection of a frame, or greenhouse, and on that account, require to be grown in pots; they all thrive well in a mixture of sandy loam and peat. The shrubby kinds may be increased by cuttings, under a hand-glass, in a sheltered situation, or by seeds, by which the annual species are also to be raised. Synonymes: 1. viscidulum. 2. roseum. 3. salicifolium. 4. sampsucifolium.

acuming

cuminatūm.

algarvēnse

alpéstré

Andersón] angustifoliūm a penninúm arảbỉcûm, 1 : atriplicifóliùm barbàtūm Barreliěri brusiliēnsé brusiliensi canadēnsé canêscêns, 2 cănūm . caruliniănüm - Yellow ciliátūm cinèreùm Yellow crassifoliūm . Yellow crōcéúm . . Yellow cū prēūm

Yellow

White Yellow Yellow

Yellow White Yellow Yellow Yellow Yellow

Yellow

Yellow

Yellow Red

Yellow Red ellow Red denticulātūn, 3 Yellow - Yellow ellipťcūm Yellow ericoidè̃s : : Yellow

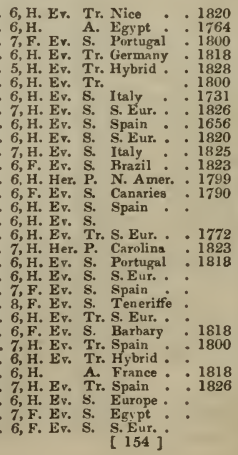




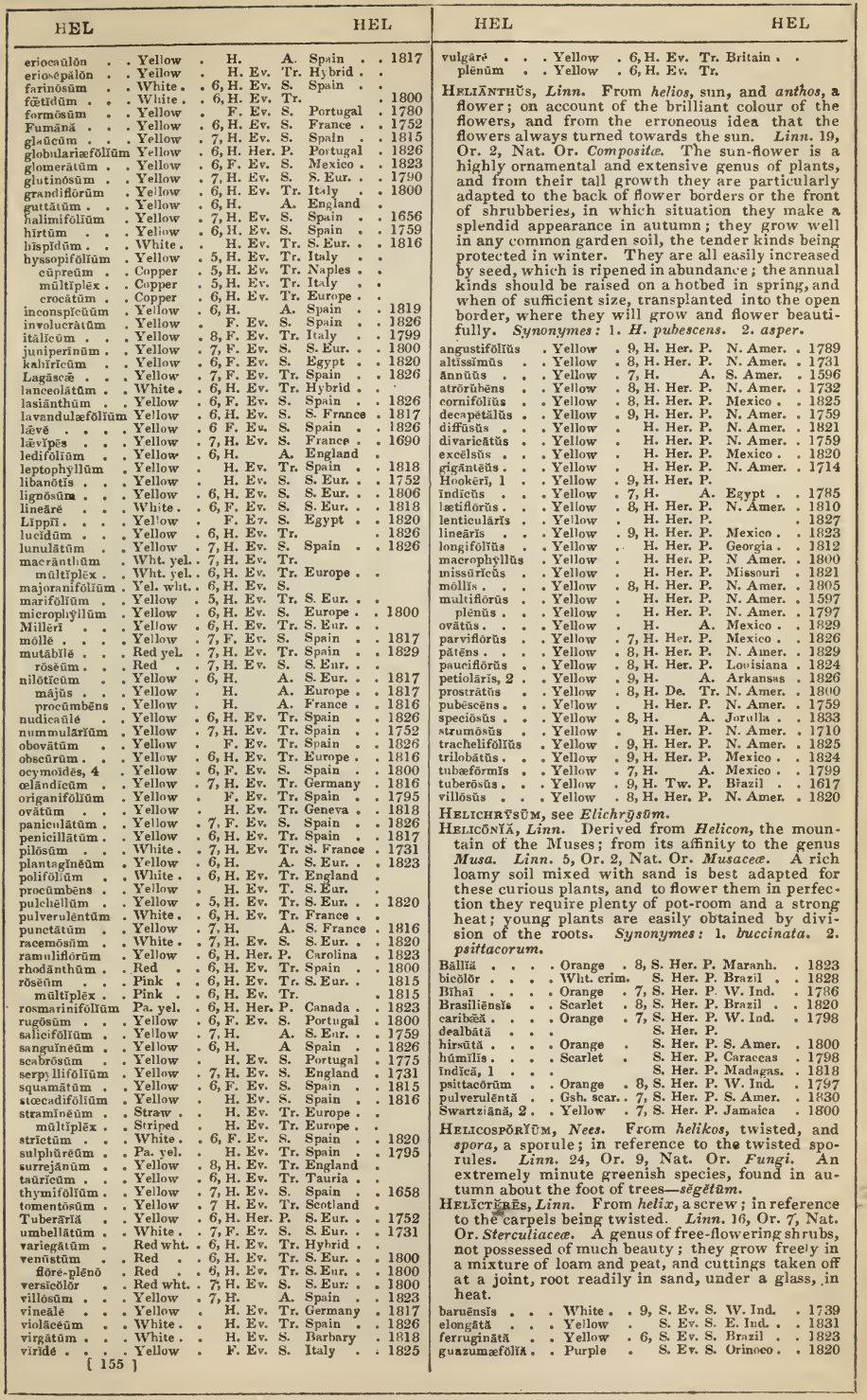




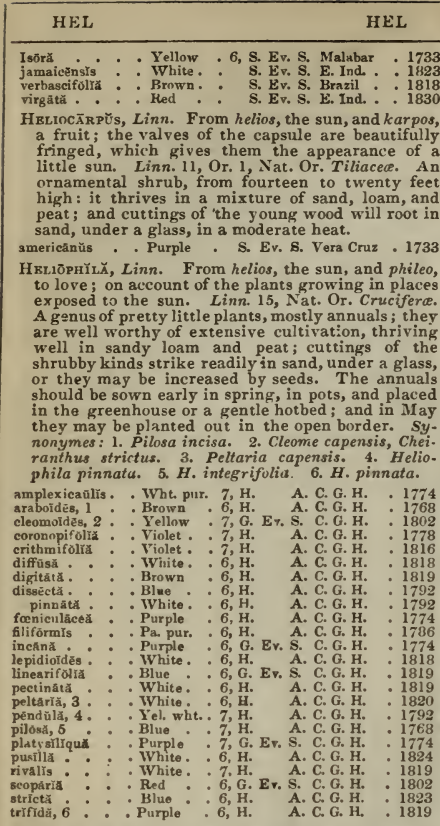

Hactōpšs, Persoon. From helios, the sun, and opsis, appearance; alluding to the brilliant colnur of the flowers. Linn. 19, Or. 2, Nat. Or. Composita. These are tall growing plants, well suited for the back of flower borders, where they flower beautifully in autumn. The annual kinds require the same treatment as those of the genus Helianthus; while the herbaceous kinds may be freely increased by dividing the roots. Synonymes: 1. Acmella bupthalmoides, Bupthalmum scabrum. 2. B. helianthoides.

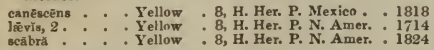
scăbră. : Yellow

HвLtotrópĩù, Linn. From helios, the sun, and trope, twining; the flowers are said to turn towards the sun. Linn. 3, Or. 1, Nat. Or. Ehretiacea. Some of the plants of this genus are highly valued for the fragrance of their flowers, and are therefore to be met with in most gardens; they succeed freely in any rich light soil, and cuttings of the shrubby kinds taken off when roung, readily strike in the same kind of soil. The annuals and biennials require the same treatment as other hardy and tender annuals and biennials. Synonymes: 1 . H. grandiflorum. 2. H. chenopodioides. 3. Myosotis linifolia. brevifolīum

brevifolium : : White com . White. A. S. Eur. corymbōsum, 1 : Lilac : : 7, G. Ev. A. Peru chenopodioĩdẻs 2 White. : $6, \mathrm{H}$. A. S.Amer. europêum . . White. linifoling 3 White. marecesnum oblungifoliñm: White: 6, S. Ev. S. W. Ind. i, H. A. S. Eur.
: White. H. A. C. G. H. S. A. E. Ind.
HEL

HEM

obovătūm . . Brown . 5, H. A. Nepal . . 1825

parvifloram : : White. : 8, S. A. Nepal * : 1825 peruviānüm : Lilac : : 7, G. De. S. Peru : 1757

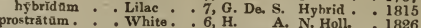
undulătūm * Li. hrn. * 7, G. Ev. S. N. Africa zeylānicum . . White. . S. Ev. S. Ceylon . : 1818

HeLLĔвöRuัs, Linn. From helein, to cause death, and bora, food; the poisonous qualities of the plants. Linn. 13, Or. 6, Nat. Or. Ranunculacece. These plants thrive well in any common soil, growing best under the shade of trees; and are readily in creased by divisions or seeds. The poisonous quali ties of this genus are well known. Synonyme: 1 . trifolius.

atrorŭbêns . . . Purple . 3, H. Her. P. Hungary * 1820 dumetörüm : Green . 3, H. Her. P. Hungary : 1817 fätidurs. : : Green: : 3, H. Her. P. England :

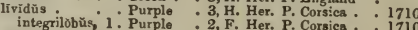
ninter rillobus, 1. Purple . 2, F. Her. P. Corsica . 1710 anguatifniliús Pink odōrüs purpuráscèns : Green $: 3$, H. Her. P. Hungary : 1817

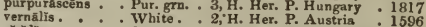

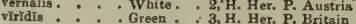

HвLLĒ professor at $\Delta$ bo. Linn. 1, Or. 1, Nat. Or. Scita. minec. Ornamental plants; for culture and propagation, see Hedychium.

abnōrmIs . . White. . 6, S. Her. P. China . . 1824 cærülea. : : White. : S. Her. P. N. Holl. : 1820

HzLM IT-SHAPED, see Galeate.

HzLмĩthĭ, Jussieu. From helminthion, a little worm; because of the resemblance of the rugose seeds. Linn. 19, Or. 1, Nat. Or. Compcsita. The seeds of this species only require to be sown in the open border. Synonyme: Picris echioides.
echioides
Yeliow. 6, H.
A. Britain .

HrLмispŏrYū, Link. From helmins, a worm, and spora, a sporule; shape of the sporiles. Iinn. 24, Or. 9, Nat. Or. Fungi. Patches of very minute black Fungi, found on dead wood, and branches of trees-macrocürpón, vclutinñm.

HвLōnĪs, Linn. From helos, a marsh; in reference to the habitat of the plants. Linn. 6, Or. 3, Nat, Or. Melanthacee. These are ornamental plants, delighting in peat soil and a moist situation, where they will grow and flower profusely; they increase readily by dividing the roots, or by seeds. Syno-

angustifoll . White . . 5, H. Her. P. N. Amer. . 1823 bullătă, 1 : Purple: 4, H. Her. P. N. Amer, 1758 ery throspërmă, 2 . White . : 6, H. Her. P. N. Amer. : 1770

Hetosciňdīù, Koch. From helos, a marsh, and skiadon, an umbel; an umbelliferous plant, inhabiting marshes. Linn. 5, Or. 2, Nat. Or. Umbelli. ferc. Mere weeds, growing in ponds or rivulets, like other hardy aquatics. Synonymes: 1. Sison Ammi. 2. S. bulbosum. 3. S. inudatum. 4. Sium nodiflorum. 5. Sison repens-ammi 1, bulbosâm 2, inundät $1 \mathrm{~m} 3$, nodiflorâm 4 , rëpēns 5 .

Hervēul. A, Linn. A name employed by Cicero, as the name of a fungus. Linn. 24, Or. 9, Nat. Or. Fungi. These species are found in spring and autumn in woods, fields, \&c.-elästică, esculëntă. īnfülă, leucophāa, mìtră.

Hemerocāllis, Linn. From hemera, a day, and kallos, beauty; alluding to the beauty and dura. tion of the flowers, Linn. 6, Or. J, Nat. Or. Liliacea. 'This is an ornamental genus of flowering plants, of the simplest culture, thriving well in any light loamy soil, and readily increased by divisions. fāva Yellow 6, H. Her, P. Siheris 1596 fülvi fūlvă * Fulvous - 7, H. Her. P. Levant - 1590

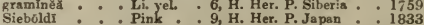

Hzмiclīĭ , R. Bromn. Supposed to be from hemisus, half, and kleio, to shut up. Linn. 4, Or. 1, Nat. Or. Proteacea. A fine greenhouse plant; for culture and propagation, see Dryandra. Synonyme: 1. Dryandra falcala. chinēnsis * White. S. Her. P. China S 1825 nymes: 1. $\boldsymbol{H}$. latifolia. 2. $\boldsymbol{H}$. leta.

distǐch - - Orange . 5, H. Her. P. China * 1798 7, G. Ev. S. C. G. H 6, G. Ev, S Moroce

Baxtērı, 1 . . Yellow . 6, G. Ev. S. Lucky Ray 1824 


\begin{tabular}{|l|}
\hline HEM \\
\hline Hrminessurs, R. Bronn. From hemisus, half, and \\
desmos, a tie; alluding to the filaments. Linn. 5, \\
Or. 2, Nat. Or. Asclepiadacea. A pretty clirabing \\
species, thriving well in a mixture of loam and \\
peat; young plants are very freely obtained by \\
cuttings planted in sand, under a glass, in a little \\
heat. A decoction of the roots is recommended by \\
European practitioners in cutaneous diseases, scro. \\
fula, and venereal affections. \\
indicŭs.
\end{tabular}

Hгмім ̌ris, Linn. From hemisus, half, and meris, a part ; the flowers appear as if parted. Linn. 2, Or. 1, Nat. Or Scrophulariacec. An ornamental plant, growing well in a mixture of loam and peat; and young cuttings, planted in the same kind of soil, root freely.

montānă * . $\quad$ 7, S. Her, P. C. G. H. 1816

Hвмroñ̄tĭs, Linn. From hemionos, a mule; the species is supposed to be barren. Linn. 24, Or. 1, Nat. Or. Polypodiacea. A very elegant little fern, thriving well in a mixture of sandy loam and peat, and readily increased by dividing the roots.

palmāta * * *

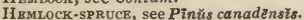

Hвмp, see Cännŭbìs.

HEMP-AGRIMONY, see Eupatoriñm cannabinñm

HEMP-NETTLE, see Galeópsis.

HEN-AND-CaICKENs, see Bellis perënnis prolifëră

HRNBANB, see Hyoscy̆ămŭs.

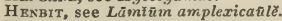

HENNA-PI.ANT, see Lansōnīă inērmĭs.

HерĂтİC̆, Linn. From hepaticos, relating to the liver; the lobes of the leaves have been compared to the lobes of the liver. Linn. 13, Or. 6, Nat. Or. Ranunculacea. These are very pretty plants, and on account of their being abundant flowerers, and the flowers of much variety in shade and colour, they are all universal favourites in the flower-garden. They grow best in a light loam or peat soil, and increase readily by dividing the roots in spring. Synonyme; 1. Anemone hepatica.

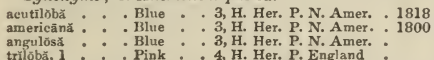

Hepaticous, liver-coloured, lobed like the liver.

HERAc̄̄NTHĂ, Link. From heros, noble, and akantha, a thorn; alluding to the beauty of the plants. Linn. 19, Or. 1, Nat. Or. Composita. Very pretty annuals; the seed should be sown on a gentle hotbed, and when of sufficient size, transplanted into the flower borders. Synonymes: 1, Carthamus armenius. 2. C. lanatus. 3. C. creticus. 4. C. tauricus, Onobroma dentata.

armeneñă, 1. . Yellow . 6, H. A. Armenia . 1816

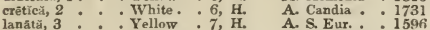

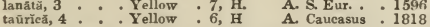
HrRĀct.̄ề, Linn. From Heracles, a plant sacred to Hercules, Linn. 5, Or. 2, Nat. Or. Umbellifera. Strong coarse growing plants, only worth cultivating in botanical collections; any common soil suits them; and they are all easily increased by seed. Synonymes: 1. H. angustifolium. 2. H. sibiricum. 3. H. gummiferum. 4. H. amplifolium. 5. $\boldsymbol{H}$. elegans, 6. $\mathrm{H}$. luctniatum.

alnīnûm *. White , 6, H. Her. P. Switzerl. 1739 alpinum * * White áspèrùm *. White . 7, H. B. Caucasus . 1818

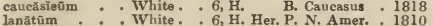
lanâtūm : * White. : 6, H. Her. P. N. Amer. : 1810
ligusticifóliūm : White. : 6, H. minimúm * : White. : 6, H. Her. P. S. France : 1810 pubëscēns, 3 . White . 7, H. B. Caucasus: 1823 pyrenāĭcûm *. White , 6, H. B. Pyrenees : 1798 speciōsum . : White: 6, H. B. Siberia : 1817 Sphondyliunm: White: 5, H. B. Britain: : 1800 elëgans, 5 . White : 5, H. B. Austria * 1800

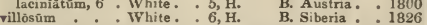
austrĭăcūm, flavěscēns, $F$. angustifólĩnm $1, \vec{F}$. latifo

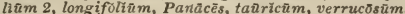

HвRBACROUS-PLANT, a plant, the stem of which perishes annually.

HrRbêrtĩ , Sweet. In honour of the Hon. and Rev William Herbert, of Spofforth, a distinguished botanist, and author of a Monograph on Amarylli( 157 )

\section{HER}

HER

daceæ, 1837. Linn. 16, Or. 1, Nat. Or. Iridacere. A very pretty species, growing well in an equal mixture of loam, peat, and sand; with protection in winter, the species will grow as well in the open border, as in the frame; it is increased by seeds.

pulchēlla . . . Blue pur.. 7, F. Bu. P. Chile . . 1827

Herb-paris, see Paris quadrifotiă.

HERB-ROBRRT, see Geräniūm Robertiānâm.

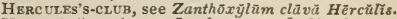

HERITIËră, Aiton. In honour of Charles Louis L'Heritier de Bautelle, a celebrated French botanist and author; he died in 1800. Linn. 21, Or. 10, Nat. Or. Sterculiacea. This genus, the Lookingglass Plant, consists of large handsome growing trees, and is easily cultivated in sandy loam and peat; large ripened cuttings root in sand, under a glass, in a moist heat.

littoraliss . . . Red . . S. Ev. T. E. Ind. . 1780 minör

HFRMĀXxǐ, Linn. In honour of Paul Hermann, botanist and traveller in Ceylon; he died in 1695. Linn. 16, Or. 2, Nat. Or. Sterculiacee. Pretty flowering plants, well worth a place in every garden; they all grow well in any light rich soil, and young cuttings will root readily in the same kind of soil, under a glass. Synonymes: 1. H. rotundifolia. 2. Mahernia grandiflora. 3. H. latifolia.

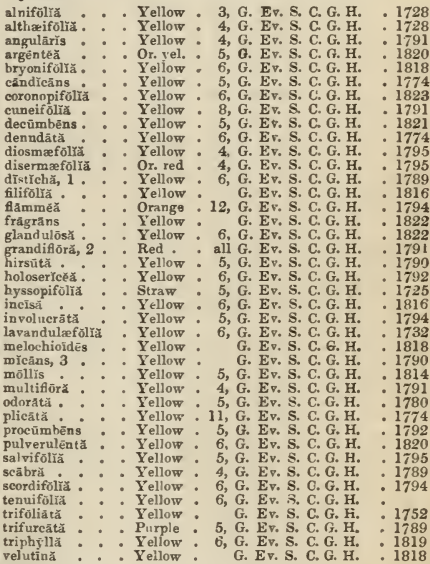

HERMAPHRODITE, consisting of two sexes.

Hêrass, Linn. The meaning of the name is un. known. Linn. 23, Or. 1, Nat. Or. Umbelliferce. This is a genus of inconspicuous, stunted-looking plants, thriving well in peat, sand, and loam mixed. They may either be increased by seeds, or cuttings. Synonyme: 1. $\boldsymbol{H}$. depauperata.

ciliătă Grn. yel, 5, G. Her, P. C. G.

Grn. yel. 5, G. Her. P. C. G. H. 1816 villüsă, 1 : : Green : : 5, G. Her. P. C. G. H. : 1795

HERMY̌xīm, $\boldsymbol{R}$. Bromn. The meaning of the name is not explained. Linn. 20, Or. 1, Nat. Or. Orchidacece. The species of this genus are pretty, and grow freely in chalky soil, or in a mixture of loam, peat, and sand; they increase by divisions of the roots. Synonymes: 1. Ophrys alpina, Chamorchis alpina. 2. Ophrys manorchis.

alpinnum, 1. . . White . 5, F. Ter. Switzerl. . 1824 congètūm: : Green 11, G. Ter. Madeira monōrchĩs, $2:$ : Green : 6, H. Ter. England

HRRNĀNDY̌, Linn. In honour of Francisco Hernandez, M.D., a Spanish botanist. Linn. 2l, Or. 
3, Nat. Or. Hernandiacea. The species of this genus are elegant and lofty-growing trees, succeeding well in sandy loam and peat; and ripened cuttings, not divested of their leaves, will root readily in sand, under a glass. The juice of the leaves of $\boldsymbol{H}$. sonora is a powerful depilatory; it destroys hair, withuut pain, wherever it is applied.

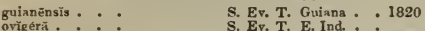
sonôriă : : S. Ev. T. E. Ind.

Herniārǐn̆, Linn. From hernia, a rupture; because of its supposed effect in curing it. Linn. 5, Or. 2, Nat. Or. Illeccbracec. The species of this genus are not of very much interest, but of the simplest culture. Synonyme: 1. hirsuta.

alpină . . . Green . . 6, H. De. Tr. S. Eur. . . 1822 annǔă : : Green: : 7, H. Tr. A. Spain : 1824 cinerea : : Green : 6 , H. Tr. A. Montpel. : 1823 fruticōsa : : Green : 6, H. Ev. S. Spain : 1814 glabrà : : Green: : 7, H. De. Tr. England ineână $\mathrm{i} \cdot$ Green - 7, H. De. Tr. England polygonotdés : Green

HrRon's-BILL, see Erōdiūm.

HrRpẼsrǐs, Gartner. From herpestes, anything that creeps; alluding to the habit of the plants. Linn. 14, Or. 2, Nat. Or. Scrophulariacea. Some of the species of this genus are very pretty; others are mere weeds. They all thrive well in a rich soil, and are readily increased by seeds, or divisions.

cuneifolră . - Blue - 8, H. Aq. P. N. Amer. - 1812

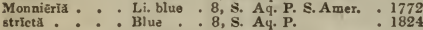
amplexicā̄lìs, Brơnnīi, micränthă, portulacūcĕă, rotundifoli.i.

Herrêtî̀, Ruiz and Pavon. In hunour of C. A. de Herrera, a Spanish agriculturist. Linn. 6, Or. 1, Nat. Or. Liliacee. These are handsome plants growing freely in a mixture of loam and peat, and are increased by divisions.

parviffôră . . Grn. yel. . 6, S. Ev. Tw. Brazil . . 1824 stellata : : : Grn. Jel. . 6, S. Ev. Tw. Chile : 1825

Hesper anthos, a flower; the flowers are produced in the evening. Linn. 3, Or. 1, Nat. Or. Iridaced. A genus of rather pretty towering bulbs; for culture and propagation, see Gladiolus. Synonyme: 1. Ixia angusta.

angūsț̆, 1

cinnamōmę̆ faleâtă pilosà Violet

5, G. Bl. P. C. G. H 4, G. BI. P. C. G. H 4, G. BI. P. C. G. H. 8, G. BI. P. C. G. H

4. G. B1. P. C. G. H.

1825 1787 1787 1808

1811

Hh̄spěris, Linn. From hesperos, the evening; the Alowers of most of the species of Rocket are more fragrant towards evening, Linn. 15, Nat. Or. Crucifere. The Rocket is a well-known flower in every garden. The herbaceous kinds do best in a lightrich soil, and attention must be paid to frequent transplanting and dividing, or they will not grew, particularly $\boldsymbol{H}$. matronalis and its varieties; the best time for doing it is when they begin to spring afresh from the root after flowering. The seed of the annual and biennial kinds merely require sowing in the open border. Synonymes: 1 . $\boldsymbol{H}$. sibirica. 2. $\boldsymbol{H}$. inodora. 3. $\boldsymbol{H}$. bituminosa.

aprical . . Purple . 5, H. Her. P. Siberia

eläthi

Pink

$6, \mathrm{H}$.

B. Europe

frärans

White

5 , H.

B.

heterophylla: : Red pur. 7, H. $\quad$ B. 1 . It $\quad$ B. Italy

laciniáta : Purple : 5, H. Her. P. S. France

matronalis : Purple : 6, H. Her. P. Europe

hortēnsIs : Purple . 6, H. Her. 1. Europo

albiflóră . White. 6, H. Her. P. Europe

albn-plëna . White. . 6, H. Her. P. Europe

foliiflóră : Green . 6, H. Her. P. Europe

purpureo-plēna Red: 6, H. Her. P. Europe

variegata . Whit, red : 6, H. Her, P. Europe

8 birlea, 1: Purple: 6, H. Her. P. Siberia

sylvêtrís, 2 : Pinkle : 6, H. Her. P. Britain

pulehêllă. : Red : 7, H. A. Levant

pygmä̀: :

ramosissima: : Red : 7, H.

repăndă : Purple $6, \mathrm{H}$.

A. Syria

A. Algiers.

1822

1824

1828

1820

1823

1816

15.97

1759
1759

1597

1597

1597

1800

1827

1828

1819

runcinata : : Wht pur. 6, H. bituminōsă, 3 Wht. pur. $6, \mathrm{H}$.

speciōsd . Ro. pur. 4, H. Her. P. Siberia . 1829 tristis .: : Purple : 5, H. Hor. F. Austria: : 1629

Hxsperoscõrnūx, Lindley. From hesperos, the west, and skordon, garlic; an alliaceous plant, growing in the western hemisphere. Linn. 6, Or. 1, Nat. Or. Liliacec. These are rather pretty species, growing well in light sandy soil, and increased by offsets, or seeds. $H$. hyacinthinum requires protection in winter. Synonyme: 1. Brodica grandiflora.

hyacinthĩn ūm, 1 . Blue . 7, F. Bl. P. 1826 läcteũm * : White. : 7, H. Bl. P. California : 1833

Hetrranthēră, Beauvois. From heteros, variable, and aner, an anther; the anthers are variable. Linn. 3, Or. 1, Nat. Or. Pontederacea. This is a genus of ornamental aquatics. The hardy species may be grown by the side of a pond or rivulet; the other kinds require the same treatment as other tender aquatics. Synonyme: 1. Leptanthes reniformis.

acūtă, 1 . * White . 6, G. Aq. P. Virginia • 1812 limôsă : : Blue : 7, H. Aq. P. N. Amer. 1842 reniformis: : Blue : 7, S. Aq. P. S. Amer. : 1824

HetrRomorpha, Chamisso. From heteros, diverse, and morpha, form; in allusion to the leaves. Linn. 5, Or. 2, Nat. Or. Umbelliferce. This shrub thrives well in any common garden soil, and is freely increased by cuttings. Synonyme: 1. Tenoria arborescens.

arborêscēns - Yellow . 8, G. Ev. S. C. G. H. . 1810

Hztenopōoōn, Persoon. From heteros, variable, and pogon, a beard. Linn. 21, Or. 3, Nat. Or. Graminea. Species of grass, not worth cultivating in any collection. Synonymes: 1. glaber. 2. Andropogon contortus-Alliónil 1, contortīs 2 .

HeTRRōptïrIs, $\boldsymbol{H}$. $\boldsymbol{B}$. and $\boldsymbol{K}$ unth. From heteros, variable, and pteron, a wing; the wings of the carpels are various in size and shape. Linn. 10, Or. 3, Nat. Or. Malpighiacea. The plants of this genus are for the inost part handsome climbers, thriving well in sand, peat, and loam; and cuttings of the ripened wood will root in sand, under a glass, in heat. Synonymes: 1. Banistcria brachiata. 2. chrysophylla. 3. nitida. 4. purpurea.

appendiculată . Yellow - S. Ev. Cl. St, Vincent 1820 brachiátä, 1 : Yellow : S. Kv. Cl. W. Ind. . 1759 Eærŭléa - Blue S. Ev. CL. W. Ind. 1893 clirysophyllä, 2 . Yellow - S. Ev. Cl. Brazil * 1793 floribündă : Blue : S. Ev. Cl. Mexico: 1824 nitidă, 3 : Yellow: S. Ev S. Brazil: 1809 rüfü. Yellow S. Ev s. Brazil : 1899 parviforia : : Purplo: S. Ev. Cl. W. Ind. : 1820 purpũrea, 4 : : Purplo: S. Ev. Cl. W. Ind. : 1759

Hetraospérmōm, Willdenow. From heteros, various, and sperma, a seed; alluding to the variable size and shape of the seed. Linn. 19, Or. 2, Nat. Or. Cumposite. An annual of little value; it requires to be raised on a gentle hotbed, and afterwards transplanted into the flower-border.

pinnătūm - . Yellow . 8, H. A. New Spain 1799

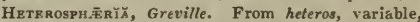
and sphaira, a sphere. Linn. 24, Or. 9, Nat. Or. Fungi. A black shining fungus, found growing on the stems of dead herbs-patelld.

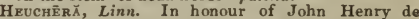
Heucher, professor of medicine at Wittenberg, and a botanical author. Linn. 5, Or. 2, Nat. Or. Saxifragacea. A genus of very neat, though not showy, American plants, growing well in any light garden soil, and very easily increased by dividing the plants at the root. $H$. americana is a powerful astringent.

americănă . . Purple . 5, H. Her. P. N. Amer. . 1656 cauléscéns: : Purple 5 , H. Her. P. N. Amer. 1656 cylindrácea : Grite * 6, H. Her. P. Carolina 1812 glabra - . Pink : 5, H. Her. P. N. Amer. 1827 hispida. . Purple 5, H. Her. P. Virginia 1826 micrāntha . Yal. prn. . 7, H. Her. P. Columbia : 1897

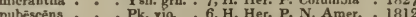
pubercens * Pk. via. 6, H. Her.

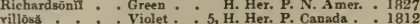
Hexagonal, six-sided.

HexaxmRous, having six stamens.

Hexangutir, six-angled.

Hexapetarous, having six petals.

Heyländī, Decandolle. In honour of M. Heyland, 
an artist employed by Decandolle. Lisn. 16, Or. 6, Nat. Or. Leguminosce. Stove shrubs, otherwise requiring the same treatment as Hallia. Synonyme: 1. Hallia monophylla-hebecarpa 1, leiocarpa.

HË a German botanist and traveller in India. Linn. 10, Or. 1, Nat. Or. Meliaceu. Ornamental-growing trees, about twenty feet high; they require to be grown in loam and peat, and ripened cuttings, with their leaves whole, will root in sand, under a glass, in heat.

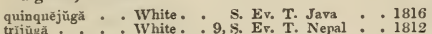

HıAss, gaping, opening wide.

HIB B F.R.S., L.S., once eminently distinguished for his love of plants; for a length of time he maintained Mr. Niven, a famous collector of plants, at the Cape. Linn 13, Or. 3, Nat. Or. Dilleniacere. All the species of Hibbertia are well worthy of a place in every collection of plants; they grow from one to three feet high, and succeed best in equal quantities of sandy loam and peat. Cuttings, put in in the same kind of soil, either in spring or summer, will root freely under a glass. Synonyme: $1 . H$. curifolia.

Yelow 6 , G. Ev. N. Holl Cunninghămi : Y Yellow * 6, G. Ev. S. N. Holl. 1826 Yentstow G. Ev, Tw. N. Holl. grussularizefliă : Yellow: 5, G. Ev. Tr. N. Holl. : 1816 lineăris . Yellow: 6, G. Ev. S. N. Hoil. : 1821 lineăris : : : Yellow: 6. G. Ev. S. V. D. L. : 1824 pedunculätă, $1^{\circ}$ : Yellow: 6 , G. Ev. S. N. Holl : 1821 salignă. : : Yellow: T, G. Ev. S N. Holl. : 1823 vireata . . Yellow : 7, G. Ev. S. N. Holl. : 1822 volúbilǐs : : Yellow : 6, G. Ev, Tw. C. G. H. : 1790

Hrsiscǒs, Linn. Said to be derived from ibis, a stork, which is said to chew some of the species. Linn. 16, Or. 8, Nat. Or. Malvarece. All the species of this extensive genus are very showy flowering plants, and therefore deserve to be extensively cultivated. The shrubby, stove, and greenhouse kinds all require the same treatment, growing best in a mixture of loam and peat; and cutting root readily in sand, under a glass, the stove kinds in heat. $\boldsymbol{H}$. syriacus thrives well in any common garden soil, and is easily increased by layers, or seeds, while its varieties may be grafted one on the other, or they may be raised from cuttings planted under a hand-glass. The hardy herbaceous kinds are particularly showy; they are marshy plants, and require to be grown in a rather moist soil, with protection in winter. The hardy annuals merely require to be sown in the open yround. The tender biennials and annuals require to be sown in pots, and treated as other tender annuals and biennials. The petals of $H$. rosa sinensis are astringent, and a few species, such as $\boldsymbol{H}$. sabdariffa and surattensis, are slightly acid. Synonymes: 1. H. palustris. 2. H. racemosus. 3. H. digitatus. 4. H. ficulneus. 5. $\mathrm{H}$. grandiflorus. 6. H. aculeatus.

Abelmöschŭs . Yellow . 8, S. Ev, S. India, 1640 acerifoliǔs.: Pink : 4, G. Ev. S. E. lnd. : 1798

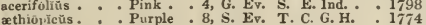
aquâticŭs, 1 : : White: 7, H. Her. P. S. Eur. : 1819 bàmíă: : Yellow: 7 , s. A. A frica: 1818 bifurcâtŭs : - Purple - 6, S. Ev, S. Brazil : 1825 borbōnfeŭs: : Yellow : 7, S. Ev. S. Buurbon : 182 Camerôni : : Rosy - 6, S. Ev. S. Madagas. : 1837 cannabinǔs : : Wht. pur. 6, G. F. B. E. Ind. : 1759

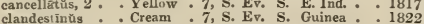
clypeãtŭs : : Yellow : 8, S. Ev. S. Jamaica : 1759

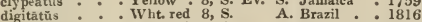

Keriānŭs, 3 : Wht red 8 , S. B. Brazil : 1816 divaricãtǔs. . Sulphur . 7, G. Ev. S. Moreton B. 1829 diversifolius, 4 Yellow - 6, S. Kr. S. E. lnd. - 1798 eriocårpŭs . Yellow - 8, S. Ev. S. Bengal . 1823 esculentŭs: Yellow . 6, S. A. W. Ind. 1692 ferruginèus : : Scarlet * S. Ev. S. Madagas, : 1824

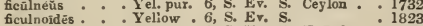
furcātŭs : : Yellow : 8, S. Her. P. E. Ind. . : 1816 GenēvII. . . Ruse . 7, s. Ev. S. Maurit.

gossypinŭs: : Yellow: 7, G. Ev. S. C. G. H. : 1818 heterophyllüs, 5 . Wht, red 8, G, Ev, S, N. S, W. 1803 hisplutüs Yel, brn, 7, G. Ev. S. C. G, H.

incânŭs : Yellow. 9, H. Her. P. Carolina: 1806 lâmpăs: : : Pink.:

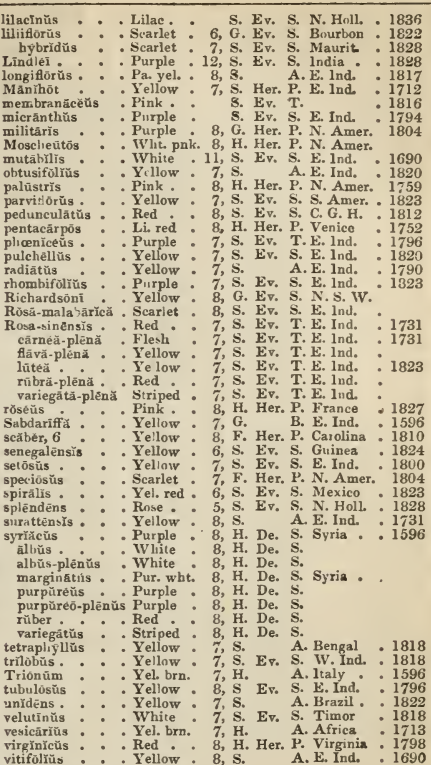

HICKORY-TRRE, see Căry̆ă ălbă.

HIEMTLis, pertaining to winter.

Hieräciố, Linn. From hierax, a hawk; being supposed to shar pen the sight of birds of prey. Linn.19, Or. 1, Nat. Or. Compositce. An extensive genus of pretty flowering plants; the dwarf herbaceous kinds are remarkably adapted for rock-work, or the front of flower-borders, the taller kinds at the back; they may either be increased by seeds, or divisions. $H$. fruticosum is readily increased by cuttings in mould, under a glass. The annual species need only be sown in the open border. Synonymes: 1 . H. verbascifolium. 2. H. auricula collinum. 3. H. sabaudum. 4. $\boldsymbol{H}$. prenanthoides. 5. $\boldsymbol{H}$. collinum. 6. $\boldsymbol{H}$. collinum cymosum. 7. H. montanum. 8. Lepicaune prunellofoliu. 9. $\mathrm{H}$. integrifolium. 10. Andryala lanata.

alpéstrĕ . . Yellow alpinūm : Yellow amplexicaūlé : Yellow pulmonarioidés Yellow andryaloidẽs Yellow andryaloide: Y Yellow angustifólium: Y Yellow aurantǐăeúm : Orange flāvūm : Y Yellow aurìcülă . . Yellow auriculātủm - Yellow Bauhini. : Y Yllow bifídüm. Yellow bifưrcum : : Yellow borezle, $3:$ Yellow bracteolø̄tūm Yellow calcăréūm : : Yellow canadēnsě . . Yellow canéscẻns : Y Yellow cerinthoidẻs Yellow chondrilloidès . Yellow ciliátūm Yellow collinūm: : Yellow

7, H. Her. P. Switzerl. 1822 7, H. Her. P. Britain 7, H. Her. P. Pyrenees : 1739 7, H. Her. P. Switzerl. . 1819 7, H. Her. P. Italy - 1816 7, H. Her. P. Switzerl. - 1819 7, H. Her. P. Switzerl. * 1819 6, H. Her. Cr. Scotland 6, H. Her. Cr.Switzerl. 1819 7 , H. Her. Cr. England 7 , H. Her. P.

, H. Her. Cr. Germany $6, \mathrm{H}$. Her. Cr. Germany 1816 6, H. Her, P. Hungary 6, H. Her. P. Tauria 7 , H Her P. N. Eur. 8 . H Her P Europe T. 7 Her P Canada 8 , H. Her. P. Switzerl. : 1820 8, H. Her. P. Scotland 6, H. Her. P. Austria 1640 Her. P. Crete • 1824 5 H. Her, Cr. Switzerl. 1819 


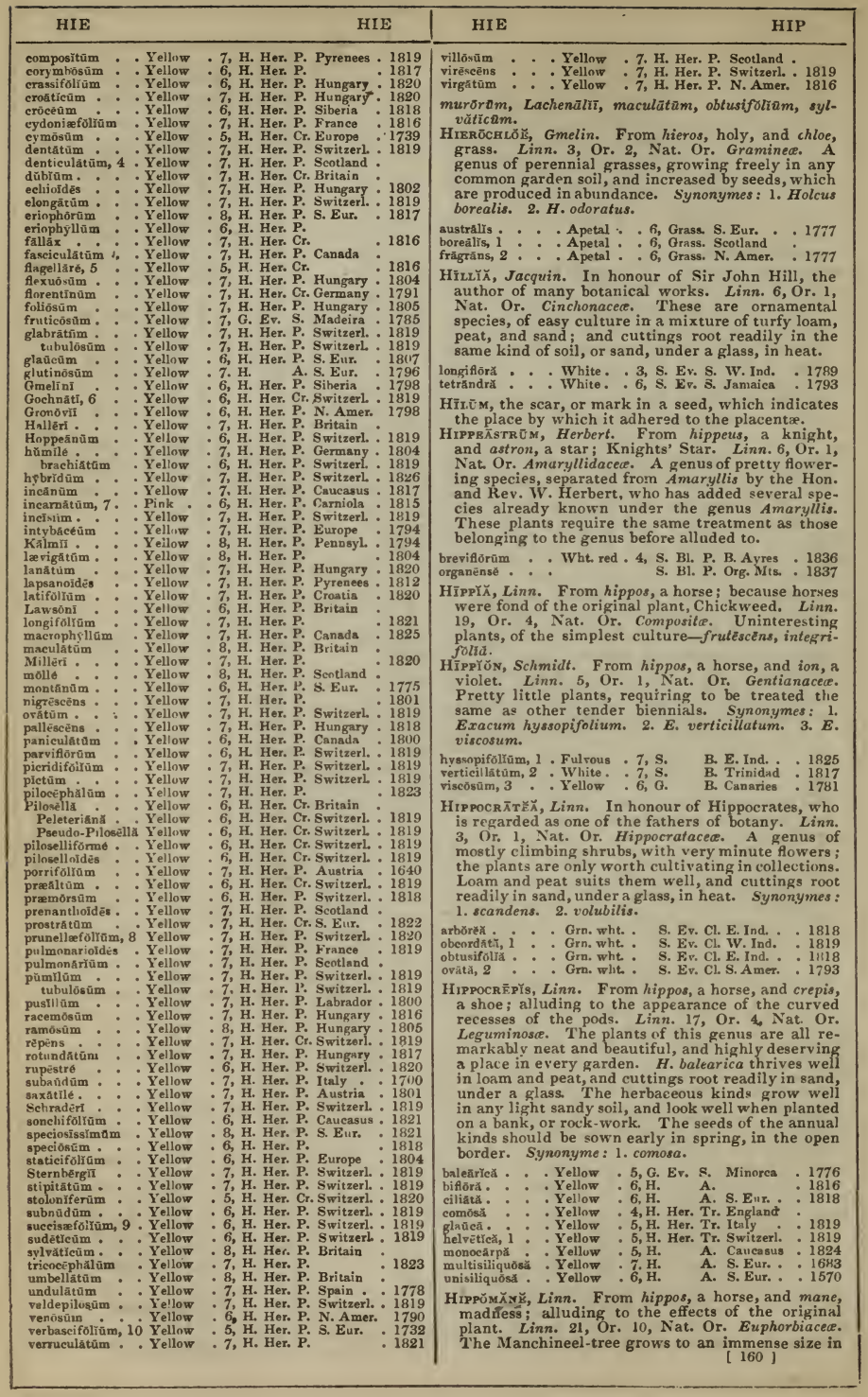


its native country, and abounds in a white milky juice, which is highly poisonous, therefore, it is very necessary in cutting the plant, not to let any of the juice touch the skin, as a single drop wonld be sufficient to make the hands swell and itch very much. A mixture of sandy loam and peat suits it, and cuttings root readily in sand, under a glass, in heat.

Muneınellă . Green . . S. Ev. T. W. Ind. 1690

Hippomărăthrūm, Linn. From hippos, a horse, and marathron, fennel. Liun. 5, Or. 2, Nat. Or. Umbellifere. A curious species, of very easy culture and propagation.

sicǔlūm * . . Yellow * 7, H. Her. P. Sicily • . 1640

HippōpHĂ to destroy; in reference to the supposed poisonous qualities of the seeds, Linn. 22, Or. 4, Nat. Or. Eloagnacer. Ornamental trees, growing in any common soil, and may be readily increased by layers, or cuttings of the root:

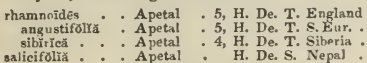

HrPpūrăs, Linn. From hippos, a mare, and oura, a tail : the stem resembles a mare's tail, from the crowded whorls of very narrow hair-like leaves. Linn. 1, Or. 1, Nat. Or. Onagracee. A curious aquatic, growing best in a ditch, pond, or marshy situation.

vulgarìs . . Apetal . 5, H. Aq. P. Britain

Hiræă, Jacquin. In honour of $\boldsymbol{J}$. N. de la Hire, a French botanist, who died in 3727 . Linn. 10, Or. 3, Nat. Or. Malpighiacea. These are pretty climbers, growing best in a mixture of sandy loam and peat; and cuttings of the ripened wood root readily in sand, under a glass, in heat.

Indice

White.

7, S. Ev. Cl. E. Ind.

1820

nũtâns: : White : 7, s. Ev. Cl E. Ind, : 1820 odorătă : : : Yellow : \&. E E. Cl. Guinea : 1823 reclinãtă: : Yellow : 7, S. Ev. Cl. W. Ind.

HIRSUTE, rough, with soft hairs.

HiRTÉLLA, Linn. From hirtus, hairy; the young branches. Linn, 5, Or. 1, Nat. Or. Chrysobalanacea. The flowers of these curious tropical timber trees are rarely seen in this country; they delight in a mixture of peat and loam, and cuttings will root freely in sand, under a glass, in heat. Synonymes : 1. americana. 2. paniculata.

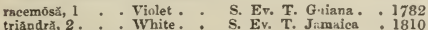

HīsPID $\check{A}$, rough, with stiff hairs.

HOARY, covered with white down.

HoFFMANSËGĞ̈, Cavanilles. In honour of J. C. Hoffmansegg, a distinguished naturalist, and with Link, author of the Flore Portugaise, Berlin, 1806 . Linn. 10, Or. 1, Nat. Or. Leguminosa. An interesting dwarf shrub, growing well in peat and loam and cuttings, if not too ripe, will root in sand, under a glass, in heat.

falcarriă . . Yellow . 7, S. Her. P. Chile . . 1806

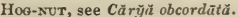

Hoo-PLUM, see Spondĩ̄s.

HoGWEED, see Boerhaũvĭă.

HoĪ rž̄ , Jussieu. Derived from Hoitzil, the name given to it in Peru. Linn. 5, Or. 1, Nat. Or. Polemoniacece. Handsome species, succeeding well in equal portions of sandy loam and peat; and cut tings root freely when placed under a glass, in the same kind of soil.

cærŭlén * * Blue * G. Ev. S. Mexico • 1824 coccineă . . Scarlet G. Ev. S. Mexico: 1824 glandulösă: : Pa red : G. Ev, T. Mexico: : 1825

Hōucǔs, Linn. From helko, to extract; the original plant was supposed to possess the power of extract ing thorns. Linn. 23, Or. 1, Nat. Or. Graminea. A genus of grasses, which delights to grow in light loamy soil ; increased by seeds, or divisions.

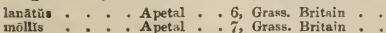

Holigārnă, Roxburgh. The name of the tree in the language of Karnata. Linn. 23, Or. 1, Nat. Or. \ $161 \uparrow$
Anacardiaceo. This species is a very tall-growing tree; for culture and propagation, see Anacardism. longifolla . . White . S. Ev. T. E. Ind. . 1828 HoLly, see Iléx.

HoLLYHock, see Althẽă rŏsĕă.

HoLMSK10̄LDĨ̄, Retg. In honour of Theodore Holm. skiold, a Danish botanical author. Linn. 14, Or. 2, Nat. Or. Labiatae. Rather curious and interesting plants, succeeding well in an equal mixture of loam, peat, and sand; and cuttings of the young wood root freely in the same kind of soil, under a glass, in heat. Synonymes: 1. Hastingia coccinea. 2. Hastingia scandens.

sanguĩneă, 1 . . Scarlet • S. Ev. S. E. Ind. . . 1796 scāndens, 2 : Scarlet : 5, S. Ev. Ci. E. Ind. : 1824 HoLosERİč̆

Horōstüūm, Linn. From holos, all, and osteon, a bone; applied by antiphrasis to this plant, which is soft and delicate. Linn, 3, Or. 3 , Nat. Or. Alsinacea. These species merely require to be sown in the open ground.

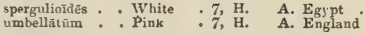

1829

\section{diändrūm.}

HomăLĪ̇M, Jacquin. From homalos, regular; the stamens are regularly divided into 3 -stamened fascicles. Linn. 18, Or. 4, Nat. Or. Homaliacea. The flower of this species is rather insignificant. The plant grows in a mixture of loam and peat; and cuttings, nearly ripened, root readily in sand, under a glass, in heat.

racemōsūm . . White. . 6, S. Ev. T. W. Ind. . 1816

Hosogeseous, having a uniform nature, principle, or composition.

Номввй father of epic poetry, Homer. Linn. 16, Or. 1, Nat. Or. Iridacese. This is a beautiful genus of bulbous plants; they delight to grow in an equal mixture of loam, peat, and sand. When they are in a dormant state, they should be kept free from moisture; but when growing, they should be plentifully supplied with water. They are increased by offsets from the bulbs, or by seeds. Synonymes:

1. Moraea collinn. 2. elegans. 3. collina exaltata.

4. collina miniata minor. 5. flexussa. 6. spicata. 7. virgata.

collină, 1

êlegăns, 2

exaltăı̆, 3

fláccĩdă, 4 : : Vermil

flexuōså, $5:$ : Yellow

lineătă

miniātă

porrifolīă

spicaté, 6

Vermil.

5, G. Bl, P. C. G. H

5, G. Bl. P. C. G. H.

$5, G$. B. C. G.

5, G. Bl. P. C. G. H.

5, G. Bl. P. C. G. H

5, G. Bl. P. C. G. H.

5, G. Bl. P. C. G. H.

Vermil. - 5, O. Bl. P. C. G. H.

Purple 5, u. Bl P. C. G.

НомеR's MOLY, see Alliam mägżcam.

HoNesty, see Lunäriă.

HoNey-Brrrey, see Melicöccŏ.

HOXEY-FLOWER, see Meliānthrs.

HoNeY-garlic, see Nectaroscordim.

HONEY-LOCUST TRER, see Gleditschiă triacanthos.

HONEY-PORE, the pore in flowers which secretes honey.

HONEY-SCALEs, the scales in flowers which secrete honey.

HoxвY-spots, the spots in flowers which secrete honey. HoNeystickLe, see Lonicēră.

HoNEYwort, see Cerinthĕ.

HONEYWORT, see STsjn.

HooDRD, being curved or hollowed at the end, into the form of a hood.

HOODED MIFFO1r, see Utriculärăă.

Ноок̄̌̃ Hooker, LL.D., F.R.S., \&c., the present professor of botany in the university of Glasgow, one of the most distinguished of modern botanists. Linn. 24, Or. 5, Nat. Or. Musci. This is described as a very beautiful genus of plants, resembling Fypnum. One of the species, $\boldsymbol{H}$. late-virens, has only been discovered as yet in a bog near Cork-laté-virens, lūcēns.

HoOP-AsH, see Celtis crassifötiă.

HOOP-PETTiCOAT, see Narcissŭ́s bulbocodiñm.

Hop, see Hŭmülüs.

Hop-HORNBEAM, see Ostry̆ă.

HOP-L1KB TREFor1, see D̉edicāgठ lupulină. 
HōRDĚ M, Linn. According to Bodrus, the name is derived from hordus, heavy; because bread made with barley is very heavy. Linn. 2, Or. 2, Nat. Or. Graminece. The species of this genus are among the most useful plants we possess; corn, like barley, are among their products. The seeds of the various species have only to be sown in the open ground.

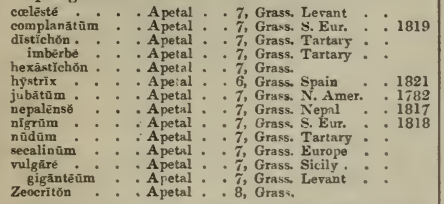

bulbosùm, capensē, marĭtĭmam, murīnñm, pratēıse, strictiom.

HoR BHOUND, see Marrabinm.

HorkēLl $\breve{A}$, Schlechtendahl. In honour of John Horkel, professer of botany at Berlin. Linn. 10, Or. 1, Nat. Or. Rosaceo. These are rather pretty herbaceous plants, growing freely in any common garden soil, and increased by seeds, or divisions.

congesta . . White. . 8, H. Her. P. Californis . $1820^{\circ}$ füscă : : Whit brn. 7, H. Her. P. N. Amer.

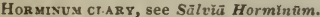

Hormíxúx, Linn. From hormao, to excite; medicinal qualities of the plant. Linn. 14, Or. 1, Nat. Or. Labiato. This is a very beautiful plant when in blossom; it grows well in the open border in summer, but if allowed to remain in that situation during winter, it is apt to be killed by damp; it is readily increased by divisions, or seeds.

pyrenălcūm . . Blue . . 6, H. Her. P. Pyrenees . 1820

Hors; any stiff awl-shaped process is called a horn. Honsbias, see Curyinüs.

Horniminnia, Willdenon. In honour of Professor Hornemann, of Copenhagen. Linn. 14, Or. 2, Nat. Or. Scrophulariacea. A little inconspicuous species, of greater rarity than beauty, and of simple culture. Synonyme: I. Gratiola goodeniafolia.

b[color, 1 . . Blue . . 8, S. A. E. Ind. . 1816

Hornerass, see Ceratichlö̆.

HORN OF PLENTY, see Fẽdiă cornucơ pră

HoRN-POPPY, see Glaficitim.

HORNWORT, see Ceratophyllom.

Horsz-chrstrut, see Escŭlüs.

HoRsz-POPPY, see Seseli Hippomăräthrnm.

Horse-RADIsH, see Cochleüriē armorüciü.

HoRSB-RADISH TREE, see Moringĭ.

HorsRshog v в тсH, see Hippбcrépis.

Horgbtall, see Equisetñm.

Horsetall treg, see Casuarina.

HorsB-THistLe, see Cirsiñm.

Hos $\bar{\lambda}$ скї. Named by Douglas in honour of David Hosack, M.D., F.R.S., professor of botany in the university of New York. Linn. 17, Or. 4, Nat. Or. Leguminuse. The plants of this genus are showy, and well adapted for borders and rockwork. They grow in common garden soil, and are increased by divisions, or seeds. Synonymes: 1. Lotus pinnatus. $2 \mathrm{~L}$. sericeus.

bĩcollör, 1. . . Yel, wht. 8, H. Her. P. N. Amer. . 1826 decũmbẻns : Yellow . 8, H. Her. P. N. Amer. : 1827 parviforin. : : Yellow : 8, H. He: P. N. Amer. : 1827 parvilina . : : Yellow : 8, H. He. P. N. Amer. : 1827

Hōsră, Jacquin. In honour of N. T. Host, a German botanist. Linn. 8, Or. 1, Nat. Or. Verbenacer. Handsome shrubs, growing freely in peat and loam, and increased by cuttings in sand, under a glass,

in heat. Synonyme: 1. Cornutia punctata.

coerulexa, 1. . Blue * 7, s. Ev. S. Mexico . . 1733 latifoliá. : : Blue : 7, s. Ev. S. Mexico： 1824 longifolla : : Blue : 7, s. Ev. S. Mexico：1826

HotTentot-bread, see Dioscórēă.

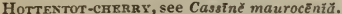

HottFntot-Fig, see Mesembryanthèmũ

Hoтtōxĩ , Linn. In honour of P. Hotton, a professor in the university of Leyden; he died in 1709. Linn.
5, Or. 1, Nat. Or. Primulacee. This is a singular and pretty aquatic species, producing its flowers in large bundles; it should be grown in a pond or ditch, and increased by divisions.

palūstrǐs . . Flesh . . 8, H. Aq. P. England .

Hound's-TONGUв, see Cynoglossam.

Hov'SEIEEK, see Sempervivam.

HoustõxĨ̃, Linn. In honour of William Houston, M.D., a famous British botanist; he died in 1733 . Linn. 4, Or. 1, Nat. Or. Gentianaced. The species of this elegant yenus are well adapted for ornamenting flower borders or rock-work; they grow best in a peaty soil, and increase freely by divisions. albifiōră . . . White . . 6, H. Her. P. N. Amer. - 1828 cerǔlea . Blue . 6, H. Her. P. N. Amer. : 1785 longifolra - Scarlet : H. Her. P. N. Amer. purpurrëă : Purple :7, H. Her. P. N. Amer. : 1800 serpyllifolia : : White. : 7, H. Her. P. N. Amer. : 1826

Houtrū̃ñ̌, Thunberg. After Houttuyn, the celebrated virtuoso of Amsterdam. Linn. 3, Or. 3, Nat. Or. Saururacese. The species are worth cultivating. They thrive well in any light rich soil, in a very moist situation, and increase by divisions or seeds.

cordātă . . . . Yel. grn. . 6, G. Her. P. Japan . . 1820 fëtrdă : : : Yel grn. : 7, G. Her. P. Japan : 1800 Hōvěñ, $R$. Bronn. In honour of Anthony Pantaleon Hove, a Polish botanist, and traveller in the Crimea and Persia. Linu. 14, Or. 6, Nut. Or. Leguminosie. The plants of this genus are truly elegant when in flower, and particularly well adapted for ornamenting the conservatory and greenhouse. They delight in a mixture of sand, loam, and peat, and may be increased by young cuttings in sand, under a glass. Synonyme: 1. Poiretia elliptica. 2. P. linearis. 3. H. lanigera.

apiculáti . . Purplish . 5, G. Ev, S. N. Holl. . 1894 acutifolua : Purple : 5, G. Ev. S. N. Holl. : 1823 Celsis Blie 6. G. Ev. S. N. Holl : 1818 लтїрй : : Purple : 2, G. Ev. S. Sw. River : 1837 ellipticar, 1: : : Purple : 4, G. Ev. S. N. Holl : 1817 Mllipticá, 1. : : Purple : 4, G. Ev. S. N. Holl : 1817 ManglésII. : : Purple
lanceolâtă lanceoláa
latifolia : : Purple : 5, G. Ev. S. N. Holl. $: 1805$
: linearris, 2: : Purple : 7, G. Ev. S. N. S. W. : 1796 longifolra : : Purple : 7, G. Ev. S. N. S. W. 1805 S, G. Ev. S. N. Holl. : 1824 - 5, G. Ev, s. N, Holl. 1824 pûngens : - Blue * G. Ev. S. Sw. River - 1837 purpurreă
rosmarinifoiră: : Purple : 6, G. Ev. S. N. Holl. : 1820
1894

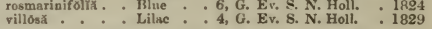

HovēNY̌̆, Thunberg. In honour of David Hoven, a senator of Amsterdam, who contributed to the success of the travels of Thunberg. Linn. 5, Or. 1, Nat. Or. Fhamnacece. These are small fruit-bearing trees, growing to the height of eight or ten feet, and producing a fruit which is said to taste like the Bergamot pear. They grow freely in a mixture of loain and peat; and cuttings of the ripened wood root freely in sand, under a glass. Synonymes : 1. $\boldsymbol{H}$. acerba, 2。 $\boldsymbol{H}$, dulcis.

dule Is, 1 . . White. . 7, G. Ev. T. Japan . 1812 inæqualys, 2 : : White: : G. Ev. T. Niepal : 1820

Hoร̃ , $\boldsymbol{R}$. Brown. In honour of Thomas Hoy, F.L.S. late gardener to the Duke of Northumberland, at Sion Honse; he died in 1821. Linn. 5, Or. 2, Nit. Or. Asclepiadacez. The plants of this genus bear very handsome waxy flowers, well known to all cultivators. They will grow in almost any soil, but loam, peat, and sand, suits them best; cuttings planted in a moist heat, will root freely; even a leaf, taken off close to the plant, and planted in mould, in a little heat, will root and produce a plant. Synonymes: $\mathbf{1}$. $\boldsymbol{H}$.lanceolata, $\boldsymbol{H}$. pallida.

austrälis . . White. . S. Ev. Tw. N. Holl. . 1820 carnósì . . Pink . 7, S. Ev. Tw. Asia . 1802 coriāceă : Wht. yel. 8, S. Ev. Tw. Manilla : 1838 S. Bv, Tw. China

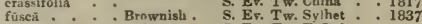

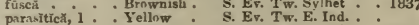
Potsil $:$ : Yellow : S. Ev. Tw. E. Ind. : 1824 trinerrvis : : Yellow : 7, S. Fv. Tw. China : 1824

HuDsōxโ̃̄, Linn. In honour of William Hudson, F.R.S., a London apothecary, and author of the Flora Anglica, 1778. Linn. 11, Or. 1, Nat. Or. [ 162 ] 
Cistacece. These are pretty little heath-like shrubs, rather difficult to cultivate; they grow best in a peat soil, in a shady situation. They require the protection of glass in winter, and should therefore be grown in pots They may either be increased by layers, or ripened cuttings, in sand, under a glass.

ericoidểs

Vuttalli

Yellow

6, F. Ev, S. N. Amer.

- 1805

Yellow : 7, F. Ev. S. N. Amer.
Y. Ev. S. N. Amer.

1826

Hū̄rNĭă, R. Bromn. In honour of Justus Huernius, an early collector of Cape plants, and from whose drawing the first account of Stapelia was taken. Linn. 5, Or. 2, Nat. Or. Asclepiadacece. These plants are related to the genus Stapelia; which see, for culture and propagation. Synonymes: 1. Stapelia ocellata. 2. S. reticulata.

barbātă .

- Whit stri. 8, S. Ev. S. C. G. H.

Yel. stri. 9, s. Ev. S. C. G. H.

S. Ev. S. C. G. H.

crispi:

guttâtă

hümillis .

lentiginósă

ocellẩ, i

reticulat.

Yel, stri. S. Ev. S. C. G. H.

Yel. stri. 9, S. Ev. S. C. G. H.

Yel. stri. 8, S. Ev. S. C. G. H.

Yel. stri. 9, S. Ev. S. C G. H.

Pnk. stri. . 8, S. Ev. S. C. G. H.

9, S. Ev. S. C. G. H.

. 1795

$\cdot 1795$

1795

1795

1795
1795

venuistä

1793

1795

HUGőxĭ, Linn. In honour of John Hugon, an English botanical author in 1771 Linn. 16, Or. 6, Nat. Or. Hugoniacea. The plants of this genus thrive well in a mixture of loam, peat, and sand; and cuttings of the ripened wood will root freely in sand, under a glass, in heat.

mystax . - Yellow . 6, S. Ev. S. Ceylon * 1818 serrata : : Yellow : 7, S. Ev. S. Maurit. . 1820 Humbir-plaNt, see Mimősă pudĩcă.

HŨ MĽ̃, Smith. In honour of the Lady of the late Sir Abraham Hume, bart. of IFormleybury, Herts. Linn. 19, Or. 1, Nat. Or. Compositce. An elegant species, flowering well in a warm situation in the open border; it requires to be raised on a gentle hotbed, and when of sufficient size, potted off, and treated as a greenhouse plant till the second year, when it may be turned out into the open border where it will grow and flower much better, than if confined in pots.

êlę̆ans . . Red . . 7, G. B. N. S. W. . 1800 H

Hivicis, humble; small, low.

HUัмuัLuัs, Linn. From humus, the ground; the plant, if not supported, creeps along the ground. Linn. 22 , Or. 5, Nat: Or. Urticacea. This is the wellknown Hop, which is so extensively cultirated in some parts of England. It looks well grown as a temporary arbour in summer, as its leaves are very larye, and make a fine shade; deep loamy soil suits it best, and it may be increased by divisions or seeds.

Lǔpülús . . Yellow . 7, H. Her. Cl. Britain .

HuNGaRtan Lötüs, see Nymphāă thermälis.

HuNNEMĀNNİ, Sweet. In honour of John Hunnemann, a zealous botanist, and to whom the British gardens are indebted for a great number of plants. Linn. 13, Or. 1, Nat. Or. Papaverace. This is a very handsome plant when in flower, requiring much the same treatment as $\mathrm{Humea}$

fumariæfoliă . Yellow . F. Her. P. Mexico . 1827

HERA, Linn. The name of the plant in South America. Linn. 21, Or. 11, Nat. Or. Euphorbiacea. The species of Sandbox tree grow well in a light loamy seil, or loam and peat mixed; large cuttings of the ripened wood will roet in sand, under a glass, in heat.

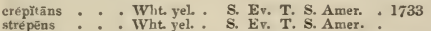

Husks, the dry envelopes of either flowers or fruits.

Hutchísš̃, R. Bronn. In compliment to $\mathbb{M}$ iss Hutchins, an accomplished Irish eryptogamist. Linn. 15, Nat. Or. Crucifere This is a genus of pretty alpine plants; the herbaceous kinds do best in sandy loam and peat, and are easily increased by cuttings under a hand-glass. The annual species delight in a dry situation on a rockery. Synony ves: 1. Lepidium alpinum. 2. calycinum. 3. [ 163 ] petraum. 4. procumbens. 5. Iberis rotundifolia. 6. I. stylosa.

alping, 1

brevistila

eal cina,

ceperfoli:

petræa, 3

procūmìa

rotundifólǐă, $\dot{5}$

stylösă, 6 .

White.

White

5. H. Her. P. S. Eur.

1775

- 6, H. Her. P. Carinthia . 1824

White. 4, H. A. England

5, H. A. England : 1823

6, H. Her. P. Caucasus: 189

Wht. pur. 6, H. Her. P. 8. Eur . 1759

Whit pink 6, H. Her. P. Cuucasus: 1824

Hracīnthěs, Linn. A boy killed by Zephyrus.

Linn. 6, Or. 1, Nat. Or. Liliaced. These berutiful

and well-known plants are easily cultivated in

light sandy loam, and readily increase by offsets from the bulbs. The hyacinth forces well, and few bulbs do better in water. Synonyme: 1. Zuccagnio viridis.

amethrstinŭs . Blue . 4, H. Bu, P. S. Eur.

1759

brumblis : Various 2, H. Bu. P

3, H. Bu. P. Levant

$159 f_{3}$

White - 3, H. Bu. P.

flavĭs *. Yellow . 3, H. Bu. P. 1596

mültiplēx : Varieg. 4, H. Bu. P. 1596

rüber. Red : 3, H. Bu. P. 1596

semiplēnŭs: : Varieg. : 3, H. Bu. P. 1596

spicatǔs - . Blush . 2, H. Bu. P. Zante - 1826

viridis, 1 : : Green: : 8, G. BL P. C. G. H. : 1774

HYACINTH, see Hyacĩnthüs.

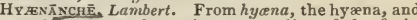
agcho, to strangle; poisonous quality of the fruit. Linn. 22, Or. 10, Nat. Or. Euphorbiacee. A shrub from six to eight feet high, of very easy culture. In the colony of the Cape of Good Hope, the pow dered fruit is used to poison hyænas. Synonyme 1. Toxicodendron capense.

globōsà, 1 . . Wht. grn. 6, G. Ev. S. C. G. H. 1783

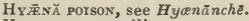

HYALINE, crystalline, transparent.

HYBRID, partaking of the nature of two species.

HFDŪm, Linn. From hydnon, a Greek word, sig nifying a truffle. Linn. 24, Or. 9, Nat. Or, Fungi. Some of the species of this genus are eatable, as $H$ coralloides; they are chiefly found under the trunks of trees, in moist situations-auriscālpĭam, bārbüJovis, coralloĩdès, crispüm, erinücéüm, ferrugino-

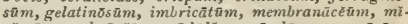
nĭmñm, ochräcēūin, rüdülŭ, repändūm-squamósūm, rufèscēns, spatulätūm.

HYDRÁngẽ, Linn. From hydor, water, and aggeion, a vessel; the capsule of some of the species has been compared to a cup. Linn. 10, Or. 2, Nat. Or. Saxifragacec, Dwarf shrubs, which are very pretty when in flower; they are well suited for the front of shrubberies, growing in any common soil; and ripened cuttings root freely planted in any sheltered situation. Synonymes: 1. Hortensia opu loides. 2. Hydrangea radiata.

arborēscēns - White. - 7, H. De. S. Virginia .1736 cordātă .

heteromáll

hortensis, 1

niัveă, 2

White.

Pink

H. De. S. Carolina

H. De. S. Nepal

5, H. De. S. China 182

quercifolia: : : White: 7, H. De. S. Florida : 1803

Hrdrafogur, any thing which removes dropsy.

HyDrĀstis, Linn. From hydor, water; plants grow ing in humid places. Linn. 14, Or. 1, Nat. Or. Ranunculacer. An ornamental species, succeeding well in a moist situation, in loam and peat, and increased by tubers of the roots.

canadēnsis . Green . . 5, H. Her. P. N. Amer. . 1759

HYDRöchărĭs, Linn. From hydor, water, and charis, grace ; a pretty aquatic. Linn. 22, Or. 8, Nat. Or. Hydrocharaces. This little plant is one of the prettiest ornaments of our still waters; it looks very pretty grown in a tub or cistern of water, and is readily increased by seeds, or runners, which root at the joints.

mồrsŭs-rảnǣ . White. . 6, H. Aq. P. Britain.

HYDRס̄снцо̆ , Link. From hydor, water, and chloa, grass; aquatic grass. Linn. 3, Or. 2, Nat. Or. Graminece. Mere weeds, of the simplest culture. Synonymes: 1. Poa aquatica, Glyceria aquatica. 2. P. aruadiuacea. 3. P. distans. 4. P. maritima, Glyceria maritima-aquātícă 1, arundiaūcěă 2, distīns 3 , maritimă 4.

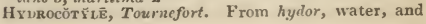


cotyle, a cavity; in reference to the plants growing in moist situations, and the leaves being hollowed like cups. Linn. 5, Or. 2, Nat. Or. Umbelliferce. Uninteresting plants, growing in peat soil in wet situations; increased by divisions. Synonyme: 1. $\boldsymbol{H}$. hirsuta-americānă, asiātīcă, bonariēnsìs, nepa-

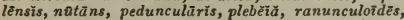
repändă, sibthorpiōides, trĭlobă, umbellätŭ, villosă, vulgärìs.

spicătă, 1 . . . Green . . 7, S. Her. P. India . . 1810

HYDRODīcr Y̌o, Kunth. From hydor, water, and dictyon, a net; reticulate structure of the plants. Linn. 24, Or.7, Nat. Or. Alga. A curious aquatic production, resembling a net-utriculätūm.

HХDRōLẼ̆, Linn. From hydor, water, and elaia, oil ; alluding to the situation and oily nature of the plant. Linn. 5, Or. 2, Nat. Or. Hydroleacec. Rather handsome plants when in flower, succeeding well in loam and peat; and cuttings will root in sand, under a glass, in heat. Synonyme: 1. caroliniana.

quadrivălvǐs, 1 . Pa. blue - 7, S. Her. P. Carolina . 1894 spinôsă . . Blue * 6, S. Ev. S. S. Amer. : 1791

HYDROPẼLtĭs, Michaux. From hydor, water, and pelte, a buckler; the plant grows in water, and the leaves are like a buckler. Linn. 13, Or. 6, Nat. Or. Nymphoacee. This very pretty plant is seldom to be met with in our gardens, it being very diffcult to grow; it requires to be kept in a cistern or pond of water, and may be increased by offsets. Synonyme: 1. Brasenia peltata.

purpüred, 1 . . Red . . 7, F. Aq. P. N. Amer. . 1798 HxDRophรLLŨM, Linn. From hydor, water, and phyllon, a leaf. Linn. 5, Or. 1, Nat. Or. Hydrophyllacea. Dwarf, neat-foliaged plants, inhabiting the marshes of North America; any rich soil suits them in a moist situation; and they may be in. creased by suckers.

canadênsĕ . . White . 5, H. Her. P. Canada - 1759 virginǐcŭm: : Blue. 6, H. Her. P. N. Amer. : 1739

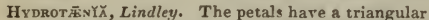
glandular bar at their base, which points upwards and secretes honey; whence the name. Linn. Or. , Nat. Or. Iridacere. A curious genus, found in mountain pastures, near the Real del Monte mines in Mexico. The plant looks like a Tigridia, and bears flowers resembling Fritillaria pyrenaica, only smaller. For culture, \&c., see Tigridia.

Meleâgrìs . . Yellow . 7, H. Bl. P. Mexico . . 1837

HroRōcrŏcrs, Agarih. From hygros, moist, and krokis, a little tuft. Linn. 24, Or. 7, Nat. Or. Algoe. These plants are only found in chemical solutions of vegetable matter, such as ink, rose water, \&c.-atramẽntī, barytică, pällïdă, Rơsā, sanguĭněă, typhlodērmă, vīnī.

HYGROMETRICAI, indicating the approach of water.

Hyoróprílă, R. Brown. From hygros, moist, and phileo, to love, alluding to the habitat of the plant. Linn. 14, Or. 2, Nat. Or. Acanthaced. A pretty plant, growing freely in a rich light soil; and young cuttings root freely in the same kind of soil, under a glass, in heat. Synonyme: 1. Ruellia ringens.

ringēns. . . S. Ev. Tr. E. Ind. . . 1820

HYMrN舫, Linn. From Hymen, god of marriage ; in reference to the two leaflets. Linn. 10, Or. 1, Nat. Or. Leguminose. The species of Locust-tree are highly ornamental; they delight to grow in loam and peat, and cuttings will root in sand, under a glass, in heat. Synonyme: 1. Trachylobium Mar. tianum.

Candolliānă . White. - S. Ev. T. Acapulco . 1824

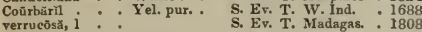
verrucōsă, 1 S. Ev. T. Madagas. * 1808
HrmenaxthËRă, R. Bronn. From hymen, a mem. brane, and anthera, an anther, the termination of the anthers. Linn. 5, Or. 1, Nat. Or. Polygalacea. An ornamental shrub, about six feet high; it grows freely in peat and loam, and cuttings root in sand, under a glass, in heat.

dentătă . . Yellow . 5, G. Ev. S. N. Holl. . 1824 Hrmenīlt , Fries. From hymen, a membrane; the plants are scaly. Linn. 24, Or. 9, Nat. Or. Fungi. Small productions, found on nettle stems-vulgüris. HYMenocãrpǔz, Savi. From hymen, a membrane, and karpos, a fruit; alluding to the membranous legumes. Linn. 17, Or. 4, Nat. Or. Leguminosa. Little inconspicuous plants, of the simplest culture. Synonymes: 1. Medicago circinata. 2. M. nummularia. 3. $M$. radiata.

circinătǔs, 1 - Yellow * 7, H. Tr. A. Italy . . 1640

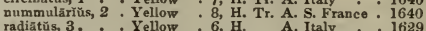

Hymanodīctř̆o, Wallich. From hymen, a membrane, and diktyon, a net; the seeds are girded by a reticulated membrane. Linn. 5, Or. 1, Nat. Or. Cin. chonaced. Ornamental trees, from twenty to thirty feet high; for culture and propagation, see Cinchona. Synonymes: 1. Cinchona excelsa. 2 C.thyrsiflora.

excellsūm, 1 . Grn. yel. . 7, S. Ev. T. E. Ind. . 1820 thyrsifforum, 2 : Grn. yel. : 6, S. Ev. T. E. Ind. : : 1819 Hумехо̆Ğ̌x, Haworth. From hymen, a membrane, and gyne, a woman. Linn. 12, Or. 2, Nat. Or. Ficoidece. A plant of no great beauty, and requir. ing the same treatment as other tender annuals. Synonyme: 1. Mesembryanthemum glabrum.

glăbră, 1 . . . Pa. yel. . 8, G. A. C. G. H. . 1787

HYMENOPĀPP's, L'Heritier. From hymen, a membrane, and pappos, a pappus, in reference to the membranous crown of the seeds. Linn. 19, Or. 1, Nat. Or. Composito. Half-hardy annuals, of little beauty, and easy culture. Synonyme: 1. Stevia pedata.

pedătŭs, 1. . . White. . 8, H. A. S Amer. 1803 seabioşứs: : : White: : 8, H. A. Carolina : 1816 tenuifol̆ŭs.

HYMeNophỸนlū S, Smith. From hymen, a membrane, and phyllon, a leaf; alluding to the leaves. Linn. 24, Or. 1, Nat. Or. Gleicheniacea. The species of this genus rank among the most elegant of the Ferns, and do best when grown in small pots, in a mixture of loam and peat, and increase freely by seed, or dividing the roots.

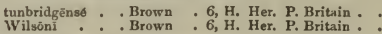

Н хоscรัх̆мัs, see Physochlažnă.

Hyoscrümús, Linn. From hyos, a hog, and kyamos, a bean; the fruit is eaten by the swine. Linn. 5, Or. 1, Nat. Or. Solanacea. The species of Henbane are all of the easiest culture. The shrubby and herbaceous kinds are well adapted for planting on rock-work during simmer, but in winter they require the protection of glass; and are increased by cuttings or seeds. The annual and biennial kinds merely require sowing in the open ground. Henbane has been long used as a medicine Synu. nyme: $1 . H$. niger annuus.

auriculātŭı * . Yellow * 6, H. A. Naples . , 1823 canariénsis : : Yellow : 12, G. Ev. \&. Canaries : 1816 Datūră. : : Yellow : 5, F. Ev. S. Egypt . : 1829 nłgér : : : Yel. pur. 6, H. ${ }_{\text {B. Britain }}$

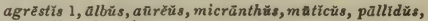
pusillür, Senecionǐs.

HYōš̆R 1̄s, Linn. From hyos, a hog, and scris, succory; swine's-succory. Linn. 19, Or. 1, Nat. Or. Compositce. Uninteresting herbaceous plants, of the simplest culture-arenarida, lacĭdă, radiătă, scābră.

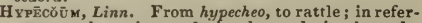
ence to the noise made by the seeds in the pods. Linn. 4, Or. 2, Nat. Or. Papaveracea. These are very pretty plants; the seed has only to be sown in the open ground.

erëctūm * . Yellow . 5, H. A. Siberia . 1759 pëndǔlüm * Yellow . 6, H. Tr. A. S. France . 1640 procũmbēns . Yellow . 7, H. Tr. A. S. Eur. . . 1596

HYPRRBOREUs, northern.

HYPERCATHĀsis, a medicine that produces too power. ful effects as a purgative.

HYPERİCUM, Linn. The name is said to be derived fromilper and eicon, an image; the superior part of the flower represents a figure. Linn. 18, Or. 2, Nat. Or. Hypericacea. The most part of the species of this extensive genus are showy plants. The greenhouse and frame shrubby kinds do well in 
loam and peat, and young cuttings root freely in sand, under a glass. The hardy shrubs are well fitted for the front of shrubberies, being dwarf and showy, and growing in any soil, and increased by divisions or seeds, as well as the herbaceous kinds, which thrive well in any common soil. The seeds of the annual species have only to be sown in the open ground in spring. Synonymes: $1 . H$. monogynum. 2. delphinense. 3. Kohlianum. 4. nervosum. 5. aspalathoides. 6. Elodea campanulata.

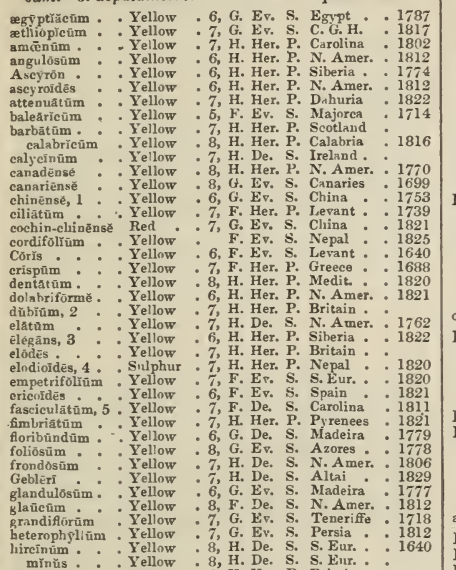

hirsũtûm: : : Yellow

humitũsûm : Yellow

hy×sopifólǐum : Yellow

involütŭm . Yellow

japōnīeũm : : Yellow

Kalmiânûm : Y Yellow
lævigătūm

Liottárdí . : Y Yellow

montãnūm : Yellow

myrtifólinum - Yellow

nudiflórüm : Yellow

oblongifơliūns : Yellow

olȳmpīeúm : Yellow

palud̃ōsũm : Y Yellow

pàtǔlūm . : Yellow

perforātūm : Yellow

procūmbēns : : Yellow

prolífĩeum : Yellow

pûlchrūm. - Yellow

pusillám : : Yellow

pusillúm : : Yellow

quadrángưlum : Yellow

quinquenêr vìum Yellow

rosmarinifôtūum Yellow

serpyllifolinm . Yellow

simplëx : : Yellow

triplinērvé : Yellow

urâlüm : : Yellow

verticillătūm : Yellow

virgatúm - . Yellow

virgiñ̌eūm, 6 : Yellow

H YPHĀ $\bar{x} \bar{E}$, Gertner. From hyphaino, to entwine;

alluding to the fibres of the fruit. Linn. 22, Or, 6,

Nat. Or. Palmacea. An ornamental palm-tree,

growing best in strung sandy loam. Synonyme: 1 .

Cucifera thebaica.

coriacéă, 1

Palm. Egypt.

. 1824

H TิPñ̄ M, Linn. Hypnos was a name used for a moss by the Greeks. Linn. 24, Or. 5, Nat. Or. Musci. This is the most extensive genus among mosses, and known without difficulty by the prostrate, pin- nated, bright green branches, $\boldsymbol{H}$, crista-castrensis is said to be the most rare and beautiful of all the British species. Syronymes: 1. serrulatum. 2. nigroviride. 3. dubium, fallax. 4. confertum. 5. fluviatile, adnatum. 6. alpinum. 7. implexum. 8, Stokesii, Swartzii. 9. recognitum. 10. illecebrum. 11. crenulatum. 12. subtile. 13. intricatum-abietĩnūm, adūncūtm-rugōsūm, ālbūcāns, alopecûrâm, alpēstrĕ, Blandōvĩ, bländam, brevirosstrë, catenulātūm, commutātūm, confērtūm 1 , cordifớliùm, crīstăcastrênsis, cupressiförmĕ 2-polyūnthẽs, curvätãm, cuspidātūm, denticulātūm angustifóliñm-obtusifolĩum, dimörphūm, filicīnûm 3, flagellārě, flūitāus,

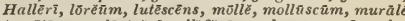

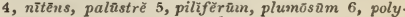

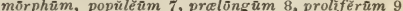
pūrūm 10, reflexum, ripārīum, rugulosūm, ruscifơlīùm, rutābūlūm 11, salebrösūm, Schrebērì, scorpiōidēs, sêrpēns 12, silesiänūm, splēndēns, squarrō-

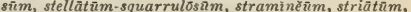
tcnēllūm, trifüriūm, triquetrūm, undulätūm, uncinätūm, velutĩnūm 13 .

HXPocalīptŭs, Thunberg. From hypo, under, and kalypto, to veil. Linn. 16, Or. 4, Nat. Or. Leguminose. A plant well worthy of cultivation. It thrives well in an equal mixture of sandy loam and peat; and young cuttings root readily in pots of sand, under a glass. Synonyme: 1. Crotalaria cordifolia.

obcordătǔs, 1 . . Purple . 6, G. Ev. S. C. G. H. . 1823

Нуроснікй, Linn. From hypo, for, and choiras, a pig; the plants are eaten by them. Linn. 19, Or. 3, Nat Or. Composita. Weeds of the easiest culture-arachnītēs, Balbīsīi, canēscēns, dimörphă, glñbră, hĩspìdă, macrorhiză, mīnimmă.

HYPOCRATERIFORM, salver-shaped.

Hypaiftrês, Richard. From elytron, a covering, and hypo, under; the bracteas are under the glumes. Linn. 3, Or. 1, Nat. Or. Cyperacece. A eurious species, succeeding best in loam and peat, and increased by divisions.

argēntěũm . . . Wht. pur. . 7, Grass. E. Ind. . . 1824

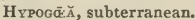

Hypogynous, situate below the ovarium.

HYPOẼstẼs, Solunder. From hypoestes, an under garment; in reference to the covering of the involucrum. Liun. 2, Or. ', Nat. Or. Acanthacec. Ornamental plants; for culture and propagation, see Justicia. Synonyme: 1. Micranthus cochinchinensis.

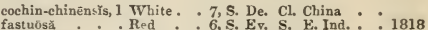
fastuōsã ${ }_{\text {involnerātă }}^{\circ}:$ Red : 6, S. Ev. S. E. Ind. : 1818 involuerātă : White. : 7, S. Ev. S. E. Ind. : : 1811
purpunreă sêrpéns . . 7, S. Ev. S. Australia : 1820

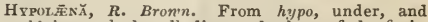
clalaina, a cloak; alluding to the base of the fruit. Linn. 22, Or. 2, Nat. Or. Restiacec. Curious plants, of very easy culture in sandy peat; and increased by divisions of the root.

exsũleă . - . Apetal . 6, Grass. N. Holl. .

1821

fastigiată . Apetal 6, Grass. N. Holl. . 1820

Hypolstrem, Vahl. From hypo, underneath, and elytron, involucrum. Linn. 3, Or. 1, Nat. Or. Cyperacec. Rather an interesting species, of simple culture, and increased by seeds.

senegalēnser . . A petal. . 7, Grass. Senegal . 1824 HYPOPHYLious, situated under the leaf.

HYpōxrs, Linn. From hypo, beneath, and oxys, sharp; referring to the base of the capsule. Linn. 6 , Or. 1, Nat. Or. Amaryllidacea. A genus of no great beauty, thriving well in sandy loam and peat, or decayed leaves. While dormant, they do not require any water, and when they begin to grow, they should be fresh potted, and regularly watered; they are easily increased by offsets from the roots. athe

albă

White.

6, G. Her. P. C. G. H.

1806

breviscăpă

carolinënsis

decūmbëns.

eréctä

hygrowétrìcà : Y Yellow
jüncéa. : Yellow

Yellow

Yellow : 6, G. Aq. P. C. G. H.

5, G. Her. P. Brazil

G. Her. P. Carolina

Yellow 7, S. Her. P. Jamaica - 1755

Yellow 6.1752

Yellow: G. Her, P.N. Holl. : 1820

jüncể . . Y Yellow : 6, F. Her. P.Carolina : 1787 [165 ] 


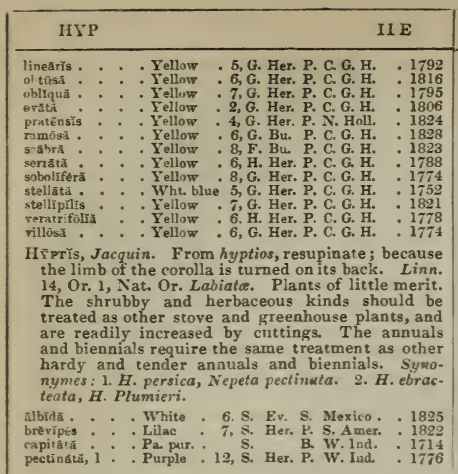

pectunátä, 1 : Purple . 12, S. Hex. P. W. Ind. : 1776
HYS

ILL

radiătă . Purple . 8, S. Her. P. Cirolina . 1690

\begin{tabular}{l} 
radiata \\
recurvătă . Purple : 8, S. Her. P. Carolina 1680 \\
\hline
\end{tabular} stachyoidés. $\quad 7, G$. Her. P. W. Ind. : 1824 chamǟdry̆s, Polyänthos, polystăchy̆ă, scopārĭă, spicätä, suavěrlēns, 2.

Hrssor, see Hyssópüs.

Hrssópüs, Linn. The derivation of this word is rather uncertain. By some it is said to be from the Hebrew, ezob; others assert it to be from the Arabic, azzof. Linn. 14, Or. 1, Nat. Or. Labiate. The cultivation of this genus is well known to everybody. Synonymes: 1. $\boldsymbol{H}$. orientalis. $2 . H$. Schleicheri.

officinālìs . . Blue * . 6, H. Ev. S. S. Eur. . - 1548 angustifuilüs, i Blue: $: 7, \mathrm{H}$. Ev. S. Caucasus

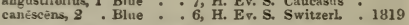

Hrstĕrĭț, Fries. From hysteresis, penury; alluding to its appearance on infested trees. Linn. 24, Or. 9, Nat. Or. Fungi. Minute plants, found growing upon the bark of trees, \&c.-angustätnm, arundinäcêm, conigënam, degěněräns, foližcolâm, Früxĭnt, graminēàm, Junipeerit, lineärĕ, maculärĕ,

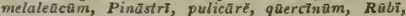
văriâm.

H $\vec{Y} s T R \bar{I} x$, bristly, like a porcupine.
TBẼĬS, Linn. From the country called Iberis, now Spain; on account of the original species being found there. Linn. 15, Nat. Or. Cruciferu. The species of this gęnus are all very pretty plants of easy culture, and well known in our yardens under the name of Candytuft. 1 . umbellata is a great favourite, and generally found in every flower-garden collection. Synonyme: 1. E. ceprefolia.

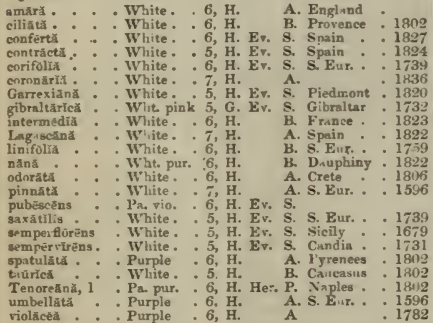

ICED, covered with shiny particles, like icicles.

ICR-DROPs, resembling icicles.

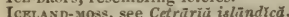

ICB-PI.ANr, see Mosembryünthémâm crystullinam.

IchxocÁrpes, R. Bronn. From ichnos, a vestige, and karpos, fruit. Linn. 5, Or. 1, Nat. Or. Apocynacece. An ornamental stove shrub, of easy management in peat and loam; and cuttings take in sand without difficulty. Synonyme: 1. Apocynum frutescens. trutièscēns . . Purple . 7, S. Ev. Tw. E. Ind. . . 1759 IČ̆ch, Aublet. The name of the plant in Guiana. Linn 10, Or. 1, Nat. Or. Burseracee. These are ornamental trees, attaining upwards of thirty feet high: for culture, \&c., see Amyris. Synonymes: 1. Anyris guianensis. 2. A. heterophylla.

enneăndr . . White. . S. Ev. T. Guiana guianēnsį 1: : White: : S. Er. T. Guiana heterophrlla, $\mathbf{2}$ : White: $\quad$ S. Ev. T. Guiana

1822 1823 S. Ev, T. Trinidad : 1819

I cosANnBous, having twenty or more stamens.

ILEx, Linn. Name originally from the Celtic, oc, or ac, signifying a point; un account of the prickly leaves. Linn. 4, Or. 3, Nat. Or. Ayuifoliaceu. A genus of trees and shrubs well known for their elegant character, evergreen prickly foliage, and their adaptation to lawns. Many varieties have resulted from culture, which are distinguished by the variegation and size of the leaves, and the colour of the fruit. They grow well in any soil, but best in a dryish situation, where there is a good depth of loam. They are increased by budding or grafting on the common kinds; but cuttings of the ripened wood will root under a glass, in a sheltered situation. I. parazuensis is used as tea, and yields the famous beverage called Maté in Brazil. Syno. nyme: 1. Iles nata.

angustifotra . . . W7inte . 5, F. Er. S. Caroline . 1806 Aquifoliúm : White : 5, H. Ev. T. Britain ulbo-marginatum White $5 . \mathrm{H}$. Ev. S. Britain aureo-marginătüm White 5 , H. Ev. \$. Britain crassifolrum . White $: 5$, H. Ev. T. Britain ferox . White: 5, H. Ev. S. Britrin flâsũm : White 5 , H. Ev. S. Britain het-rophyllũm . White .5 , H. Ev. T. Britain medió-pictüm. White : 5 , H. Ev. S. Britain recũrvüm : White : 5, H. Ev, T. Britain baleâries : : White 5 , H . T. Minorea canariènsìs : White 5, H. Ev. T. Canaries Cassine. . . White \& $\mathrm{H}$. Er. T. Carnlina chinensi's . . White . 7, G. Ev, S. China Dahoôn . . White . 5, H. Ev. S. Carolina laxiflöră : . White . 5, H. Ev. T. Carolina myrtifolr : : Whito : 7, s. Ev. S. W. Ind. opscis. White $5, \mathrm{H}, \mathrm{Ev}$. T. Carohing paraguêngits: : White: S, Er. S. Parrguay Perádó. : . Pink. 5, G. Ev. T. Madeira recürră, 1: White : 5, H. Ev. T.

salicifolra . . White

7, H. Ev. T. Florida. 1818

InL.̌̆č̌ra ŨM, Linn. From Illecebra of Pliny, which is derived from illicio, to allure; pretty enticing plants. Linn. 5, Or. 1, Nat. Or. Illecebracee. Interesting dwarf plants. I. verticillatum is found in England in bogyy places, and is very pretty. They grow in any soil, and increase from seed without difficulty. Synonyme: 1. Puronychia cymosa.

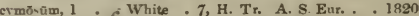
diffüsūm : White :6, G. Her. P. Trinidad : 1817 glomerătãm: : White: 6, S. Her. P. Bzazil : 1820 gmmphrenoides : White : 6, S. A. Peru : 1810 leueurum * White : 6, H. Tr. A. C. G. H. : 1818 verticillătūim: : Whito : 7, H. Tr. A. England

Itr.̆c̛̆̃ M, Linn. From illicio, to allure; because of the arreeable perfume of the species. Linn. 13, Or. 6, Nat. Or. Winteracece. The species of this useful genus thrive well in a light loamy soil, and are readily increased by layers. Cuttings of the ripened wood rnot readily in sand, under a glass, in heat. $\boldsymbol{J}$. anisalum and $\boldsymbol{I}$. floridanum are considered powerful stomachics and carminatives. 
anisâtüm * . Red * . 5, F. Ev. S. Japan * 1799 foridoñm 5. Fv. S. Florids. 1766 parviflōrum : Yellow 5, F. Ev, S. Florida : 1790

Illospörïts, Martius. From illo, to envelop, and sporos, a sporule. Linn. 24, Or. 9, Nat. Or. Fungi. A very small rose-coloured fungus, appearing in autumn on Borrera ciliaris, and some othersrŏsē̃um.

I $\operatorname{sB} B \bar{E} R \overline{1}$, smooth, without a beard.

ImBricATB, laid one over another, like tiles.

IMMARGIXATB, without a margin.

IMMERSED, buried, applied to the leaves of aquatics when they grow under the water, and to the ovary when buried in the disk.

IMPĂтĪ̄Ns, Rivinus. From impatiens, impatient; applied to this genus because the elastic valves of the capsules burst when touched, and throw the seed out with great force. Linn. 5, Or. 1, Nat. Or. Bnlsaminacese. This is a genus of very beautiful and singular plants, all deserving a place in every collection. I. natans should be grown in a large pot of water, in rich loamy soil, in a warm part of the store, and increased by seeds sown in spring. I. scapiflora thrives well in a light rich soil, with careful watering in winter. The frame species should be sown on a gentle hotbed in spring, and when about two inches high, they may be planted out into the open border. The seeds of the hardy kinds should be sown in the open border in a shady situation. Synonyme-1. biflora.

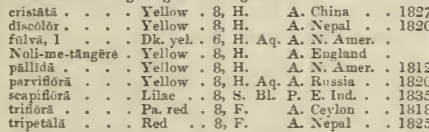

Impra Ātă, Cyrilli. After Ferrante Imperati, a Nea. politan botanist of ths sixteenth century. Linn. 3, Or. 2, Nat. Or. Gramineu. Pretty species of grass, of the commonest culture. Synonyme: 1. Saccharum spontaneum. arundinäcéa . : A petal . 7, Grass, S. Eur. * . 1817

IMPRRATŌRĬ. Named by Linnæus from its supposed forceful medicinal virtues. Linn. 5, Or. 2, Nat Or. Umbelliferc. Plants of no great beauty, and of the simplest culture; increased by divisions, except I. mexicana, which is raised from seeds.

angust fóliă . Purple - 7, H. Her. P. S. Eur. . . 1819 mexicánă : Gm, yel. . 7, H. Her. P. Mexico : 1818 Ostrüthrum : Pink: 6, H. Her. P. Scotland

IxpI.rxts, folded or plaited.

Isa møxus, unpleasant, disagreeable.

Ixcasts, hoary, mouldy-coloured.

Ixcisan, cut, separated by incisions.

INCLAUDENT, not closing.

I NOOMPIBTE, not full.

INcomprus, slovenly, rough, unpolished.

Iscossprccot's, obscure, ill defined.

IxcRAsSATED, becoming thicker by degrees.

I NCUMBRNT, lying upon any thing.

INcer $5 \mathrm{RD}$, bending inwards.

I NDEHISCENT, not dehiscing.

INDIAX BAт, see Laûrüs indīcă.

INDIAN Butr, see Nymphāă cyänēă.

INDIAN CORN, see Zéd.

INDIAN CRBss, see Tropā̄olñm.

IxDIAN ctcuMBER, see Medéulä virginfcŭ

INDIAN DOOB-GRAss, see Cy̆nödōn Indică.

INDIAN F1G, see Opūntzŭ.

INDIAN HAWTHORN, see Ruphiðrépìs.

INDLAN HRART, see Cardiospērmüm corindñm.

Ixdian Lorus, see Nymphäă Lótūs.

IxDIAN MADDFr, see Hedyotis.

IXDIAN MILIET, see Sorgham vulgärè.

Ixpias shor, see Cännä indičr.

Ixptas robacco, see Cünnäbls indică.

INDiGksots, native of a country.

IxDIGo, seee Indigðfĕră.

IxDIGŏF ̌̆R Ă, Linn. From indigo, a blue dyestuff, a corruption of Indicum, Indian, and fero, to bear most of the species produce the well known dre called Indigo. Linn, 17, Or. 4, Nat. Or. Leguminose. An extensive genus of rather elegant plants,

the shrubby kinds of which are well worthy of cultivation. The stove and greenhouse shrubby kinds thrive best in a mixture of sandy loam and peat, and may be increased without difficulty by cuttings of the young wood planted in sand, under a glass, in heat. The annual and biennial kinds must be raised from seeds sown in a hotbed in spring, and when the plants have grown a sufticient height, they may be planted singly into pots, and treated as other tender annuals and biennials. The powdered leaf of 1 . Anil is used in hepatitis. Indigo is produced from various species of this genus, especially from $I$. tinctoria. Synonymes - 1. I. tinctoria, brachycarpa. 2.I. filifolia. 3. I. hirsuta. 4. Lebeckia nuda. 5. I. angulata. 6. I. carulea.
amōenă
Purple

3, G. Ev. S. C. G. H

angustifolĩă: : Purpie : 8, G. Ev. S. C. G. H.

anil : : Purple : 7, G. Ev. S. W. Ind

argëntéă - Purple . 7, G. Ev. S. E. lnd,

uspalathoidès. Purple . 6, G. Ev. S. Ceslon

atropurpüreă. Purple 7, G. Ev, S. Nepal

auptrilis

australis. Pink . N. G. W.

căndicăns. . Red . 7. G. E

cytisoides

denudata.

diphyllã

divarieata

Purple

7, G. Ev. S. C. G. H.

Purple : 6, G. Ev. S. C. G. H

Purple

7, S. A. Africa

endrcaphrill

Scarlet

enneaphyllá . Purple

filifölis

Purple

filiformis: : Purple

frägrans : Purple

frutescēn

füsed

glabră.

glandulôsă

hedysaroides.

hirsuta

irsuta

incâdi

Lechenaultin.

leptostachya

linifollia

nûdă, 4

procümbeñs

psnraloides

rigidà

sarmentôsá

spinôsă

s)lvatier, 5

tinctoria,

trifoliata

trit:

violācēa

virgātă

Purple

Flesh

Red

Purple

Purple

Drk. pur.

Pink

Purple

- Purple

Red

Red

Burple

Red

Red

Purple

Purple

Risy lit.

Pink

Purple

Red

Purple

Red

7, S. De. Tr. Guinea

7, S. Tr. A. E. Ind.

8, G. EF. S. C. G. H.

7, G. Ev. S. C. G. H.

S. Ev. S, E. Ind.

?, G. Br, S. C. G. H

7 , S. A. Guinea

7, S. Tr. A. E. Ind.

7, S. $\mathrm{Av}$. E. Ind.

G. Ev, S E. Ind.

7, S. Ev. S. Guisea

8, G. Ev. S. C. G. H.

S. Tr. A. Guinea

7, G. A. E. Ind.

6, S. Er. S. E. Iud.

7, S. Tr. A. E. Ind.

6. G. Ev. S. C. G. H.

6, G. Her. P. C. G. H

8, G. Ev, S. C. G. H.

7, S. Ev. S. E. Ind.

, G. Her. P. C. G. H. 1816

6, G. Ev. S. Arabia . 1820

6, G. Er, S. N. Holl. . 1825

7, S. Er. S. E. lnd. . 1731

S. A. E. lnd. * 1816

6, G. Ev. 8. E. lnd. 1819

6, S. Ev, S. B Ind. 1890

$5,5 . \quad A . E$. Ind. : 186

jûncĕă $\mathrm{g}$, stipulä ris.

Ixpc RATrp, hardened.

IxDẼ $1 \bar{C}$, the membrane that incloses the thecre of ferns.

INĒRMis, smooth, unarmed.

IsFECTOR1Cs, dyeing, staining.

IxFER IOR, any thing placed below the ovary; the lowest of any thing.

INFLATED, blown up, full of air.

INFLEXED, bent inwards.

INFLORESCENCE, disposition of flowers

INPLXDIBUitirorM, funnel-shaped.

IxGÃ, Plumier. The South American name of $I$. ver $a$, adopted by Marcgraf. Linn. 23, Or. 1, Nat. Or. Leguminosa. The whole of these plants are described as ornamental, and as attaining eren thirty feet high. They are of easy culture in peat and loam, and are readily multiplied by cuttings in scil or sand, under a glass, in beat. $\boldsymbol{I}$. dulcis is well known for the sweet juice which flows from its leares when they are put into the mouth and bruised. Synonymes: 1. Acacia grandiflora. 2. I. marginata, Minosa fagifolia. 3. M. Houstoni, Acacia Houstoni. 4. I. afselioides. 5. Mimosa fagi. folia. 6. M. xylocarpa.

affinis

albĕ .

anômảlà, 1

Burgōni, 9

circinalis

comos

duleìs :

Pink :
White:
Red :
Pink :
Pink :
Pink :
Pink :
Purple

S. Ev. T. Brazil

, S. $F_{\mathrm{v}}$ T. Mexico

S. Ev. T. Guiana

S. Ev, T. W. Ind.

S. Ev. T. Jamaica

S. Ev. T. E. Ind.
1800

1804

1799

175

1818

1840

1825 


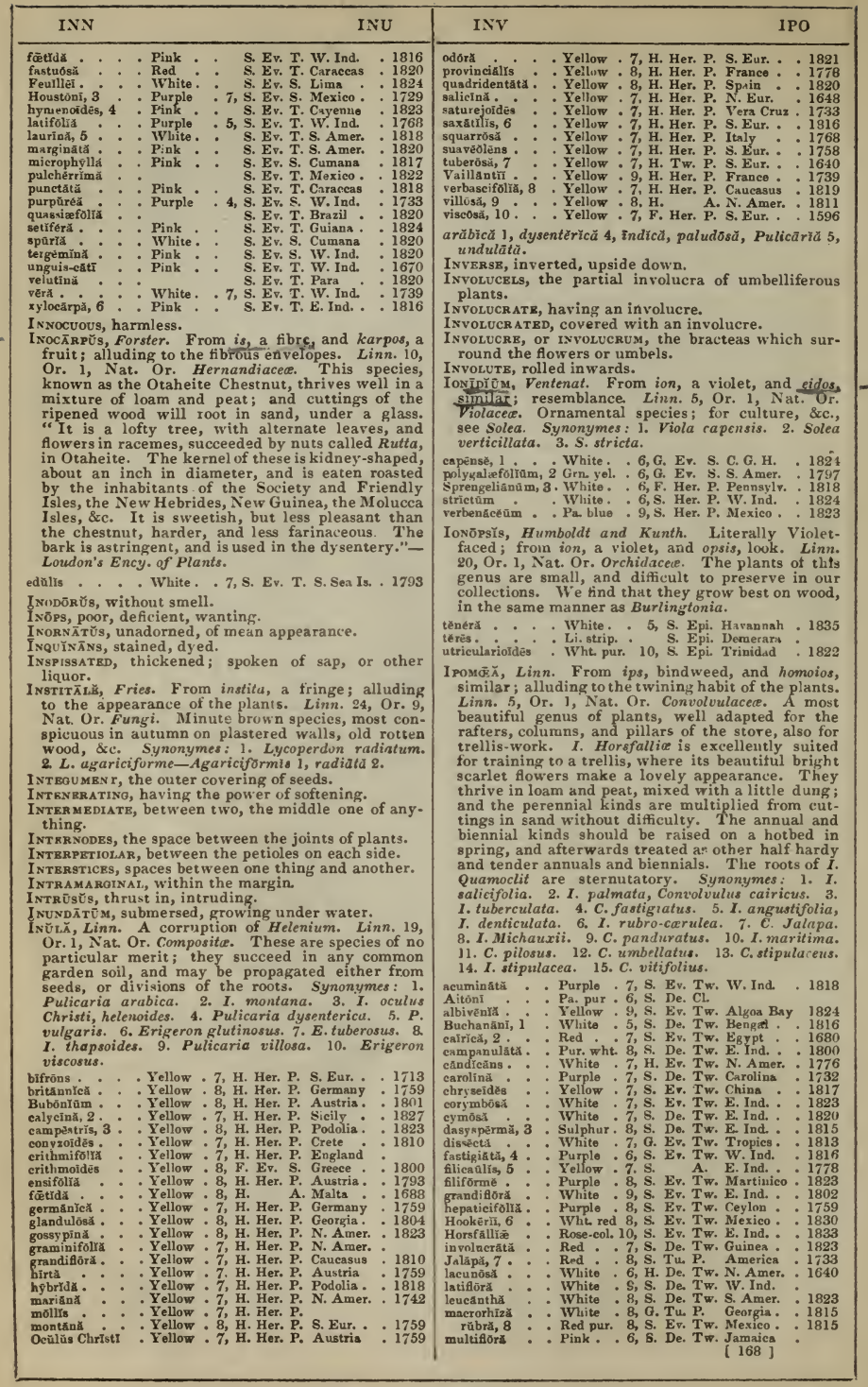




IPO IRI

muricătă . . Bl. pur. . 8, S.

mutärlis. Blue : 7, S. Ev. Tw. S. Amer.

mutabilis. - Blue .

noctiluca : : White : 8, s. Ev. Tw. L. lud.

ochrices : Yellow 8, S. De. Tw. Guinea : 1826

pandustă, 9 : Wht. pur. 6, H. De. Tw. N. A mer. . 1732

parvifioră. Purplish 7, S. De. Tw. WV Ind

péndülả . Pink , 7, G. Ev. Tw. N. S., W.

pes-tigridis . Red . 8, S. De. Tr. E. Ind.

pilosă, 11.: Pink: 8, s. De. Tw. E. Ind.

platensis : Violet 7, S. Ev. Tw. Plata

plateanis 18 Yellot

pudibũndă : Rose.col. 8, S. Ev, Tw. St. Vincent 1822

repāndă

Roxbürghì

Scarlet

7, S. Ev. Tw. S. Amer.

1822
1793
1806

Purple . 7, S. Ev. Cr. E. Ind.

sagittifolià

Sellơw

sepiarīa

sessiliflōră

, H. De. Tw. Carolin G. De. Cl.

setosá

Red

sibirica

Red

S. Ev. Tw. E. Ind.

White

8, S. Ev. Tw. Nepa

solanifolia

Fleăl

7, H. De. Tw. Siberia

H. Ev. Tw. Florida.

Pink.

S. De. Tw. America

stipulaceă, 13 . Purple . 9, S. Ev. Cr. E. Ind.

tambifolia * Blue * 7, S. De Tw Carolina

trichocarpa - Pa. pur. . 7, H. De. Tw. Carolin

triquetra.: Purple : 7, S. Ev. Tw. W. Ind

tuherculátă, 14 : 7, S. Ev. Tw. Bourbon

tuberósă : Pa yel.

uniflōra

Turpéthūm

tyrianthìnă

umbellata

White

8, S. Tu. P. W. Ind.

8, S. Tu. P. S. Amer.

1799

1819

1831

1817

1779

1813
1759

1759

1732

1732

1778

1818

1731
1731

1731
1752

. Scarlet.6, S. Ev, Tw, S. Amer.

violscea . . T'urple.8, S. De. Tw. S, Amer.

vitifollă, 15 : Yellow: 7 , S. Ev. Tw. E. Ind.

I POM $\bar{\alpha} \bar{A}$, see Batatas.

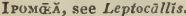

I ромйё, see Pharbitis.

I Pom $\bar{\alpha} \bar{A}$, see Quamoclit.

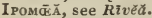

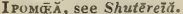

I poмōpsis, Micheli. From ipo, to strike forcibly, and opsis, sight; alluding to the dazzling colour of the flowers. Linn. 5, Or. 1, Nat. Or. Polemoniacea. A very beautiful genus of plants, but rather difficult to cultivate. The following is our mode of treatment:-A bout the end of July the seed should be sown very thinly in small pots, large sixties, well crocked, and filled with peat and loam, both sandy, and in equal parts, and placed in a cold frame, where the seed will soon vegetate, during which time the least possible water is given. When the plants begin to show signs of leaves, they are thinned out to three or four in each pot; in about a week after this, they should be removed into a rather light and airy part of the greenhouse, where they remain all winter. During winter, over-watering, and drips from the roof of the house, must be carefully avoided. In spring, they are shifted into forty-eight-sized pots, well drained, and the same kind of soil as before; in doing this, great care must be taken not to injure the roots. In this sized pot they will generally be found to

flower. Out of the four plants left after thinning, it is rare that more than two remain in each pot, one of which may be destroyed if the other appears healthy and well established; if not, let both remain. In the course of their growth, water cannot be too cautiously giren, especially just before the plants break into flower. Thus nourished, in an airy situation near the glass, they flower splendidly in July and August, and continue beautiful for a long time. Synonyme: 1. Gilia pulchella.

厄ૈęgāns . . . Searlet . 7, H. B. N. Amer. . 1820

IRĒsix Ĕ, Willdenow. From eiros, wool; referring to the woolly appearance of the branches. Linn. 22, Or. 5, Nat. Or. Amarantacee. The plants of this genus are very pretty, and may be cultivated in sandy loam and peat, mixed with a little decayed dung. They increase from seeds by merely sowing them on a gentle hotbed.

celosioidès . - White . 7, F. Her. P. S. Amer. 1733 diffûsă . : White : 7, F. Her. P. S. Amer. : 1818 elätior : : : White : 7, G. A. Antilles : 1820 elongata : : White : 7, F. Her. P. S. Amer. : 1822 flaréscēns . White . 7, F. Her. P. S. Amer. : 1824

InIs, Linn. From iris, the eye; alluding to the variety and beauty of the colours of the flower. [ 169 ]
IRI

IRI

Linn. 3, Or. 1, Nat. Or. Iridacee. The genus Iris has long been, as it still continues to be, a great favourite in the flower-garden. "The swordleaved sorts," says Sweet, "do best in a light loamy soil, and increase freely by suckers from the roots, or by seeds. The tuberous-rooted ones are more difficult to cultivate, and thrive best in a mixture of loam, peat, and sand, as does also the tribe to which $\boldsymbol{I}$. persica belongs, as $\boldsymbol{I}$. alata, cau casica, reticulata, \&c. The common bulbous species do well in common garden soil, the more sandy the better." I. tuberosa is purgative, and $\boldsymbol{I}$. versicolor and verna are used in the United States as cathartics. Synonymes: 1. I. gracilis. 2. Vieusseuxia iridioides. 3. I. spatulata. 4. I. tripetala. 5. 1. nepalensis. 6. I. paradoxa. 7. I. stenogyna. 8. I. aphylla. 9. I. tripetula. 10. I. pamila, I. violacea.

acũtă . . . Blue * . 5, H. Her. P.

alätă : : Blue : $:$, H. Bl. P. Plgier

amc̄nă $:$ Blue :

arenariă $\cdot$ Yellow

biflor

biglümis

bohèninică

Boltoniānă,

brachycũspis

caucăsica

clandestina

cœlestinza

crassifơlina

cristätă.

cuípréă

deflēxă.

dichơtomå

èlégárs.

flaveescêns

flavissīm

flexuōs

florentină

fortidissim

variegat

furcàtă

germānică

graminéă

Guldenstādtī

halōphñs

Hookẽ rì, 5

hưmìlis.

hungärīeã

ibêrică, 6

livĩdà

longiflōră

longifolia

longispatha

lüridd

lusit ānīcă

lutēscēns

Monniēri

neglēetá

nepalensis

nòthă

nudicaūlis

ochroleũeă, 7

odorátă .

orientális

Pallásii

chinénsis

pâlìdă

persice.

plicātă

prismat Ică .

pallìdă-flāy

pŭmilă

reticulāt

ruthenica

sambucina

scariōsă.

flơrè-ầbo

sordrda.

spathulaka

spūria

squảlēns

stendgỹnẽ

susiānn̆ .

Swẽrtill,

tangērî́a

taûrĩca

$\operatorname{ten} \delta x$

6, H. Her. P. Hungary

6, H. Her. P. Germany

4, H. Her. P. Siberia.

5, H. Her. P. Bohemia

5, H. Her. P. N. Amer.

7, H. Her. P. Caucasus

H. Her. P. Ching

6, F. Her. P. Brazil

Blue

Pa. blue

, H. Her: P. N. Amer. 1756

6, H. Her. P. N. Amer.

Nepal

7, H. Her. P. Russia

7, H. Her. P.

Yellow

Yellow

Yellow

White.

Livid

Livid

Blue

Blue

Yellow

Blue

Purple

Blue

Blue

Riole

Livid

Greenish

, H. Her. $\mathrm{P}$.

H. Her. P. Siheria

5, H. Her. P. Germany

5, H. Her. P. S. Eur?

6, H. Her. P. Britain

6, H. Her. P. Britain

3, H. Her. P. Tauria . 1822

, H. Her. P. Germany : 1573

6, H. Her. P. Austria - 1597

4, H. Her. P. Siberia * 1757

5. 1780

4, H. Her. P. Nepal * : 1822

4, H. Her. P. Caucasus : 1812

5, H. Her. P. Hungary : 1815

H. Her. P. Levant

Purple

- Brown

Yellow

Yellow

$\mathrm{Pa}$, blue

Blue

Blue

Blue

Lgt. ye

Blue

Lgt. blue

Blue

Blue

$\mathrm{Pa}$. blue

Whe yel.

Purple

Yellow

Ya. yel.

Purple

Blue

Lgt. blue . 6, H. Her. P. S. Eur. 1658 
tenuifölra . . Lgt. blue . 5, H. B1. P. Dauria . 1796 tridentátă, 9 : Blne - 5, H. Her. P. N. Amer. 1820 triföră . : Blue $: \vdots$, H. Her. P. Italy : 182 tuberōsă : : Grn. blue. 3, H. Bl. P. Levant : 159 variegata : : Striped 5 , H. Her. P. Hungary : 1597 ventricôsă : : Pa. blue * 6, H. Her. P. Dauria. 1800 vērnă : : Purple 4 , H. Her. P. Virginia 1748 violăcéă, 10 : : Violet. : 5, H. Her, P. S. Eur. . : 1800

viréscêns : : Yellow : 5, H. Her, P. Sur. : 1820

virêscêns : : Yellow : 5, H. Her. P. N. Amer. 1858

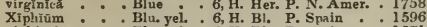
xiphioidés : : Blu. yel. : 6, H. BL P. Spain : 1571

IRtsh-HвATH, see Mensiesĭă polifotiă.

IRON-TREE, see Siderodēndrön.

IroN-WOoD, see Siderסxy̆lon.

IroN-WOOD, see Argünïü Sidcrōxy̆lŏn.

IRONWORT, see Sideritis.

Is $\bar{c}$ criš, $\boldsymbol{P}$. Bronne. From isos, equal, and achne, a glume. Linn. 3, Or. 2, Nat. Or. Graminec. A species of grass, of little interest, and common cultrure-austrïlis.

Is ÄNrHŬs, Micheli. From isos, equal, and anthos, a flower; in reference to the regularity of the corolla. Linn. 14, Or. 1, Nat. Or. Labiata. A somewhat interesting annual, cultivated in sandy peat, and propayated from seeds. Synonyme: 1. Trichostema brathiatum.

cœrŭlẹ̆s . . Blue . . 7, H. A. N. Amer. . 1818

Isর̄RĪ, Persoon. From isos, equal; on account of the regularity of the filaments. Linn. 24, Or. 9, Nat. Or. Fungi. A white species, found during the spring months on some species of Trichiamicroscòpícă.

Is $\bar{T}$ TIs, Caspar Bauhin. From isazo, to make equal; the plant was believed, by its simple application, to destroy all roughness of the skin. Linn. 15, Nat. Or. Crucifere. The species of this genus have not much beauty, and cannot be recommended except for general collections. They thrive with the commonest management, and increase from seeds. $\boldsymbol{I}$. alpins may be increased by dividing the roots. Synonymes: 1. I. megacarpa. 2. I. dasycarpa.

\begin{tabular}{|c|c|c|c|c|}
\hline aleppicat & & & & A. Levant \\
\hline & & - Yellow & - 6, H. Her. & P. Italy \\
\hline $\begin{array}{l}\text { armēnă } \\
\text { campéntrìs }\end{array}$ & & $\begin{array}{l}\text { Yellow } \\
\text { Yellow }\end{array}$ & : 7, Н. & $\begin{array}{l}\text { A. Levant } \\
\text { B Persin : }\end{array}$ \\
\hline canércèns. & & - Yellow & $5, \mathrm{H}$. & B. S. Eur. . \\
\hline iherică. & & - Yellow & & B. Theria : \\
\hline latisillq̣uă & - & - Yellow & $\mathrm{H}$. & B. Persia \\
\hline Jittoralís . & & - Yellow & & B. Tauria \\
\hline lusitanieă & . & Yellow & H. & A. Portugal \\
\hline 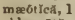 & & Yellow & $H$ & B. A zof \\
\hline o Wongată, & & - Yellow & H. & B. Brical : \\
\hline $\begin{array}{l}\text { prä́óx } \\
\text { taúrícă }\end{array}$ & & - Yellow & y. & B. Hungary \\
\hline $\begin{array}{l}\text { tauriaa } \\
\text { tinctorm }\end{array}$ & & $\begin{array}{l}\text { Yellow } \\
\text { Yellow }\end{array}$ & $7, \mathrm{H}$. & B. England \\
\hline
\end{tabular}

bannäfičă, hehecārpă, orientatis.

Isch开м ÜM, Beauvois. From ischo, to stop, and haima, blood; berause of its supposed medicinal qualities. Linn. 23, Or. 1, Nat. Or. Graminex. Uninteresting species, of the easiest culture-aristatum, austräle, rugosum.

IsẼTī Ǎ, Schreber. Named after P. E. Isert, a German surgeon, in the Danish service at Accra Linu. 6, Or. I, Nat. Or. Cinchonacee. This is described as a very showy species, succeeding in sandy loam and peat, and increased by cuttings in sand, under a glass, in heat. Synonyme: 1. Guettarda coccinea. cocčnęа . . Scarlet . 7, S. Ev. S. Guinea . . 1820

IsY̌rô, Acharius. From isos, equal; because of the small difference that exists between the podetia. Linn. 24, Or. 8, Nat. Or. Lichenes. Small species, found most plentiful in autumn and winter on rocks and trunks of old trees. I. Westringii is used in dyeing-coccōdes, coralliñum, microstīctícâm, phymalơdês, phraymä̃um, Westrîngĩ.

IsMĒLIA, Cassini. Origin of name unknown. Linn. 19, Or. 2, Nat. Or. Compositer. This is described as an elegant little shrub, from one to two feet high, succeeding best in a light sandy soil, and increased both by cuttings and seeds.

maderēnšs . . Straw. . 5, F. Ev. S. Madeira . 1834

IsmÊŇֻ, Herbert. Ismene the daughter of CEdipus and Jocasta Linn. 6, Or. 1, Nat. Or. Amaryllidacee. These species are all beautiful, and worthy of extensive cultivation; for which, see Amaryllis.
Synonymes: 1. Pancratium Amancaes, 2. P. calathinum.

Amancã ss, 1 . Yellow . 6, S. Bl. P. Peru * 1804 sulphüré : : Yellow $: 6$, S. Bl. P. Peru : 1804

calätlīnüm : White : 6, s. Bl. P. Brazil : 1800

Knightir : : White. : 3. S. Bl. P. Florida: : 1836

Macleānă : : White. 6, 5. Bl. P. Jima : 1837

IsNĀRDY̌, Linn. In memory of Antoine Dante Isnard, member of the Academy of Sciences. Linn. 4, Or. 1, Nat. Or. Onagracca. Mere weeds, found in marshy situations-alternifolżă, palüstrìs.

IsocĀrpH $\check{\Lambda}, \boldsymbol{R}$ Brovn. From isos, equal, and karphe, chaff; regularity of the chaff of the receptacle. Linn. 19, Or. 1, Nat. Or. Composita. An uninteresting plant, of common cultivation-oppusitifoliă. IsochĩLús, R. Bronn. From isos, equal, and cheilos, a lip. Linn. 20, Or. 1, Nat. Or. Orchidacece. The flowers produced by these plants are very insignificant. For culture and propagation, see Stan. hopea.

graminifoliũm . . Gm. yel. . 5, S. Epl. Jamaicn - . 1829 lineăré . : : Pink : 4, s. Epi. Martinique: 1791 lividūm : : : Livid : s. Epi. Mexico.

S. Epi. Jamaica: 1793

IsŏEัTẼs, Linn. From isos, equal, and elos, the year; plant the same throughout the year. Linn. 24, Or. 4, Nat. Or. Lycopodiacea. A curious little aquatic, found in some lakes in this country.

lacūstrìs . . Brown . 7, H. Aq. P. Britain .

Isōı.̣̌̆ı̌s, R. Brown. From isos, equal, and lepis, a scale: alluding to the regularity of the scales. Linn. 3, Or. 1, Nat. Ur. Cyperacea. Curious species, growing freely in any common soil, and increased by seeds, suckers, and divisions. Syno nymes: 1. Scirpus fuitans. 2. S. gracilis. 3. S. densus.

austrolis

anstralis :

fürtans, 1

Holnscliēnă

nodósix, 2

7, Grass. S. Eur.

A petal : 7, Grass. England

setacea $:$ A petal - 7, Gras4. Britain

1823

IsoptĒxis, Lindley. Derived from isos, equal, and pleco, to plait; on account of the upper segment of the corolla being eijual in length to the lip. Linn. 14, Or. 2, Nat. Or. Scrophulariacea. This is a genus of remarkably showy plants when in blossom. They grow well in a light rich soil, and may be increased either by cuttings under a glass, or by seed. Synonymes: 1. Digitalis canariensis. 2. D. sceptrum.

onnariênsIs, 1. Ye:low . 6, G. Ev. S. Canaries - 1698 scéntrūm, 2 : Yel. brn.: 7, G. Ev. S. Madeira : 1777

Isopб̆Gōn, R. Bronn. Derived from isos, equal, and pogon, a beard. Iinn. 4, Or. 1, Nat. Or. Proteacece. A fine genus of evergreen shrubs, invariably from New Holland; for culture, \&c., see Protea. Syno. nyme: 1. Protea divaricata. anethifolrŭs : Pale : 4, G. Ev. S. N. Holl anethiforùs : : Pale : : 4, G. Ev. S. N. Holl.

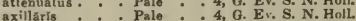

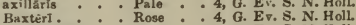
BaxtêrI. . Rose * 4, G. Ev. S. N. Holl ceratophŷllŭs . Pale : 5, G. Ev. S. N. Holl divariehtũs, 1. : Pale : 5, G. Ev. S. N. Holl. : 189 formösŭs : Rose : 4, G. Ev. R. N. Holl. : 1805 longifortrǔs. : Yellow : 4, G. Ev. S. N. Holl. 1823 LnudónI : . Purple * 6, G. Ev. 8. K. G.'s Sud. 1830 pulycĕphălüs . . Pale * 5, G. Ev. S. N. Holl. 1824 propinquйs 5, G. Ev, S. N. Holl spatulâris : : Purple : G. Ev. S.

lineârys: : : Purple : 9, G. Ev. S. K. G.'s Snd. 1830 teretifolras: : : Purple : 9, G. Ev. S. N. Holl : 1823 trilobŭs. : : Pale : : 5, G. Ev. S. N. Holl. : 1803

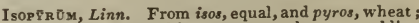
the Greeks gave this name to a plant resembling Nigella, the seeds of which have the same taste. Linn. 13, Or. 6, Nat. Or. Ranunculacere. Pretty plants, succeeding with the simplest cultivation in plamyil, and increased by seeds. I. thalictroides may be also increased by divisions.

fumarioldess . Wht grn. $6, \mathrm{H}$. A. Siberis . 1741 thalictroides : Wht grn. 4, H. Her. P. Italy ] [170] 
I TALIAN BERCH, see Quërcřs Escŭlŭs.

Iт巳̆, Linn. Itea is the Greek name of the willow, and applied to this genus on account of the quick growth of the species, Linn. 5, Or. 1, Nat. Or. Escalloniacea. An interesting North American shrub, cultivated in open fibrous sandy peat, and multiplied without great difficulty from layers.

virgIň̌că . . Whita. - 7, H. De. S. N. Amer. . 1774 IV̆. Supposed to be from $Y u a$, a name nsed by the older botanists; applied to this genus by Linnæus, because the smell of the plants resembles that of the ancient Iva. Linn. 19, Or. 5, Nat. Or. Composite. These species are not very interesting; they grow in any common soil, and increase from seeds. I. frutescens may also be increased by cuttings.

frutēscēns . . White. . 8, H. Ev. S. N. Amer. . 1711 ānnŭă, ciliătă.

Iv $\mathbf{x}$, see Hédërd.

Ixî̉, Linn. Ixia, bird-lime; because of the viscid nature of some of the species. Linn. 3, Or. 1, Nat. Or. Iridacee. A genus of very handsome plants when in flower. Sweet recommends them to be grown in a mixture of sandy loam and decayed leaves, or peat soil. When they have done flowering, they require no water till they begin to grow afresh. In October, they should be fresh potted, and set in a cool frame, as they only require to be protected from frost till their pots are well filled with roots; then they may be set on the shelves of the greenhouse, and watered regularly, and they will flower well. The species of this genus, and some other bulbous-rooted genera, succeed best in a pit, covered with lights in very cold or wet weather. Mrost of the species will grow well in a south border, in the open air, planted from five to six inches deep, in a light sandy soil, near a wall, and to be covered with dry litter in severe weather; they will then flower much stronger than if grown in pots, and they may be increased by offoets from the bulbs, or by seeds. añică : : Pink: : G. BI. P. C. G. H aũlică : : Pink : capillăriss : : Violet : 4, G. Bl. P. C. G. H. cupitătă
columellăry: : : Varieg. 8, G. Bl. P. C. G. H cōnié : : Orange 4, G. Bl. P. C. G. H crateroidę̣̂: : Drk yel, : 5, G. Bl. P. C. G. H crispà : : Blue : 4, G. BL P. C. G. H.

- 1822 1800 1774 1774 1780 1790 1757
1778 1778 dübra . . Red

derecta * Red * 4, G. Bl, P. C. G. H.

ncarnáta Flesh : 5, G. Bl. P. C. G. H.

lūteă. . Y Yellow 5, G. Bl. P. C. G. H.

flexuós̆ : Pink . 4, G. Bl. P. C. G. H.

furcâtá. . . Pink : 4, G. Bl. P. C. G. H.

hybridă. * W White. . 6, G. Bl, P. C. G. H.

incarnātă *. Flesh . 5, G. BL. P. C. G. H.

lineārìs : White. 4, G. Bl. P. C. G. H.

linearis :

ochroleñc: : Pur, Jel. 5, G. Bl. P. C. G. H.

monadelphä: Blue : 5, G. Bl. P. C. G. H.

cūrtă. : : Orange : 4, G. Bl. P. C. G. H.

ovătă : : : Red

pătēns : : : Purple

retâsă : : L L gt, yel

viridiffōr

Varieg.

4, G. BL. P. C. G. H.

4, G. BL. P. C. G. H.

4, G. Bl. P. C. G. H.

5, G. Bl. P. C. G. H. : 1780

Ixōpĭă, $R$. Brown. From ixodes, viscid; in allusion to the nature of the plants. Linn. 19, Or. 1, Nat. Or. Compositce. This is a pretty shrub, and may be successfully grown in a mixture of peat and sand, and propagated from cuttings of the young wood in sand, under a glass.

achilleoídès * . White . . S, G. Er. S. N. Holl. . 1803

Ixōră, Linn. After Iswara, a Malabar deity, to which the flowers of some are offered. Linn. 4, Or. 1, Nat. Or. Cinchonacer. A beautiful genus of East Indian shrubs, easily cultivated in our stoves. They require a sandy open soil, composed of loam and peat, in which they grow well provided they are kept clear of insects, which is easily effected by well washing the whole plant with a good syringe while growing. They propagate from cuttings in sand, or sandy soil, under a glass, in heat. Synonymes: 1. 1. Pavetta. 2. 1. alba. 3. 1 . parviflura. 4. I. longifolia. 5. I. coccinea. 1. flammea.

. Scarlet \& 8, S. Ev, S. E. Ind. : 1800 barbätr. . White . 7, S. Ev, S. E. Ind. : 1823 blāndă, 2 . White. 8, S. Ev. S. E. Ind. : 1768 brachiată * White * S. Ev. S. E. Ind. . 1823 cuneifolir : : Orange : 8, s. Ev s. China : 1822 decipiēns, 3 - White 8 , S. E. S, E. Ind 1806 flāvă fúva fúlgens, $4^{*}$. Orange * 8, S. Ev, S. E. Ind. • 1823 grandiflöră *. Red * * 8, S. Ev. S. E. Ind. . . 1814 incarnătă . . Purple *6, S. Evv. S. Moluceas - 1822 roséa

J.

ABORסSX, Jussieu. Derived from the Arabic, Jaborose; a name applied to the Mandrake, from its affinity to it. Linn. 5, Or. 1, Nat. Or. Solanaceos. Pretty little plants, thriving well in any light rich soil, and may be easily increased by cuttings or divisions.

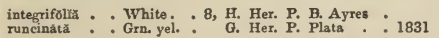

JACAR̄̄NDĂ, Jussieu. The name of $J$. brasiliana in Brazil. Linn. 14, Or. 2, Nat. Or. Bignoniacece. These are fine lofty trees, with the elegant habit of the fine leaved Acacias. The soil best suited for them is loam, peat, and sand; and cuttings, with the leaves whole, of the half-ripened wood, will root in sand, under a glass. The best way to get them to flower, is to keep the plants dry in winter. Synonymes: 1. Bignonia carulea.

B. procera. 3. J. Rhombifolia. 4. J. ovalifolia.

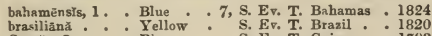
Copấ, 2 : : Biue : S. Ev. T. Guiara : 1793 Glicifoliă, 3 * Blue * S. Ev. T. W. Ind. 1800

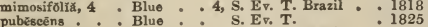

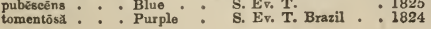
JACA TREE, see Artocārpuัs integ rifotĩa.

JACK-IN-A-BOX, see Hernändiă.

JACKsర̄Nĭ̈, R. Bron'n. In honour of George Jackson,

an atute Scotch botanist, once librarian to the dis. $[171]$ tínguished A. B. Lambert, Esq., F.R.S., V.P. LqS., \&re. Linn. 10, Or. 1, Nat. Or. Leguminosce. A genus of pretty plants, growing readily in light loam and peat, and easily increased by cuttings in sand, under a glass. Synonyme: 1. Daviesia reticulata.

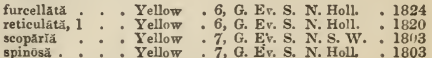

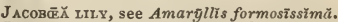

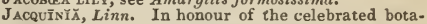
nist, N. J. Von Jacquin, professor at Vienna. Linn. 5, Or. 1, Nat. Or. Myrsinaceo. A genus of very desirable plants, on account of the beauty of their flowers. They are of easy culture in a mixture of sand and peat. It is thought that watering these plants occasionally with salted water, has a tendency to make them grow and flower more freely. Cuttings will root in sand, under a glass, in heat ; but they are by no means easy of propagation.

arbörĕă . . . White. . 7, S. Ev T. W. Ind. - 1829 armillărìs : White - 6, S. Ev. S. W. Ind. 1768 aurantrăcă lineăriss mearion. Ked 1823 macrocărpă
ruscifolra $J_{A G G B D}$, cut in a coarse manner.

JALAp, see Miräbälís Jaläpă. 


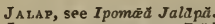

Jamaica DOGWOod, see Psĩdĭ Erythriñă.

JAMA1CA EBONY, see Bry̆ă Eběnŭs.

JAMAICA MILKWOOD, see Brósimūm spūrīûm.

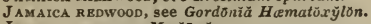

JAMAica Rose, see Meriänă.

JAMroLANA TRER, see Calyptränthēs Jambolānă.

JAMBŌsă, Rumphius. Altered from Schambu, the Malay name of one of the species. Linn. 12, Or. 1, Nat. Or. Myrtacea. The plants of this genus are possessed of some beauty, growing readily in loam and peat; but they do not produce their flowers till the plants attain a good size. Cuttings of the ripened wood root freely in sand, under a glass, in heat. Synonymes: 1. Eugenia amplexicautis. 2. $E$. aquea. 3. E. myrtifolia, $E$. australis. 4. $E$. macrophylla. 5. E. malaccensis. 6. E. Jambos.

amplexicaūlıs, 1. White. . 6, S, Ev. T. E. Ind. . . 1823 ăquẽă, 2 . . White. $\quad$ S. Ev. T. E. Ind. . 1820 auseral's, 3 : White. : 6, G. Ev. T. N. Holl. : 1800 macrophyllă, $\dot{4}$ : White.: S. Fv. T. E. Ind. : 1820 muluccensis : Scarlet : 7, S. Ev. T. $E$. Ind. : 1768 purpüré, $5:$ : Purple :6, s. Ev. T. E. Ind. : : 1768 vulgaris, 6. : Grn. yel. : 4, S. Ev. T. E. Ind. : 1768

JaxīpqX̆, Kunth. Derived from Janipaba, the Brazilian name of the plant. Linn. 21, Or. 1, Nat. Or.

Euphorbiaced. A genus of interesting plants; for culture and propagation, see Jatropka. Synonymes 1. Jatropha Laflingii. 2. J. Manikot.

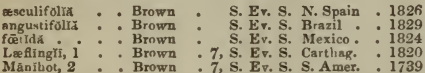
7, s. Ev, S. S. Amer 1739

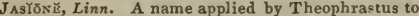
a wild pot-herb now unknown. Linn. 5, Or. 1, Nat. Or. Lobeliacece. The species of this genus are very eleyant when in blossom, and well adapted for ornamenting rock-work. They all prefer to grow in a peat soil, and require the protection of a frame in severe weather, and may be increased by divisions of the roots, cuttings, or seeds.

hŭmills. . . . Blue . . 7, H. Her. P. S. France - 1824 montana $:$ Hlue . 6. H. A. Brituin

perennís . Blae . 7, H. Her. P. France : 1787

JAsMiNg, see Jasmiñ̂m.

JAsmíñ M. Linnæus derives the name fron $i a$, a violet, and osme, smell; some assert that it is from ysmyn, the Arabic name of the plant. Iinn. 2, Or. 3, Nat. Or. Jasminaced. The species of this very elegant genus are familiar to every one. The stove and greenhonse kinds thrive well in a mixture of sand, loam, and peat; and cuttings of the ripened wood rout freely in soil or sand, under a glass, in heat. The hardy kinds thrive well in any common soil, and are easily increased by cuttings planted under a glass. They are remarkably well adapted for training over an arbour, or against a wall, or trellis-work. The genuine oil of Jasmine of the shops is the produce of $J$. grandiflorum and offici nale: but a similar perfume is ubtained from $J$. Sambuc. Synonymes: 1. J. Wallichianum. 2. J. flexile.

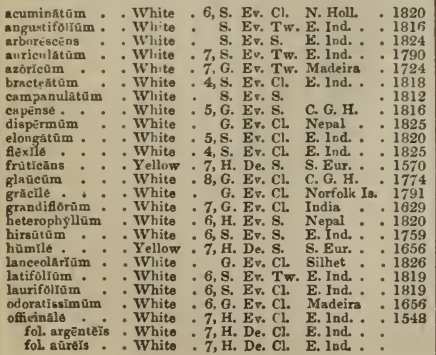

flōribŭs plēnis - White - 7, H. De. Cl. E. Ind. . : paniculātǔm : White I, S. Ev, Cl. Chins : 1818 pubĭgerūm, 1 : Yellow : 6, H. Ev. Cl. Nepal : : 1827 revolutūm . : Yellow : 6. S. Ev. Cl. E. Ind. : : 1810 Sảmbàc. : White all S. Ev. Tw. E. Ind. : : 1665 fơréplēnō . White all S. Ev. Tw. E. Ind. . 1700 trifoliâtūm. . White all S. Ev. Tw. E. Ind. . 1730 scāndēns . . White . 13, S. Ev. Tw. E. Ind. . . 1820 simplicifolūm : White : 6, S. Ev. Cl. S. Sess : 1800 tortuōsūm, 2 : White : 6, G. Ev. Cl. C. G. H. : 1818 trinervé. : White: S. Ev, Cl E. Ind. : 1804 undulátûm: : White : 1, s. Ev. CL China : : 1 H19

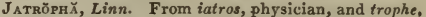
food; in allusion to the medicinal properties of the plants. Linn. 21, Or. 10, Nat. Or. Euphorbiacece. The species of this genus are coly valuable in a medicinal point of view. They thrive well in sandy loam and peat, in small pots, with little water. Most of the species ripen seed freely ir care be taken to fertilise the stigmas with the pollen. Cuttings root very readily stuck in the tan, in a strong heat. The seeds of $J$. Curcas are purgative and emetic; an oil is obtained from them, which is a valuable external application in itch.

austrális

cocined : Scarlet S. Ev. S. Cuba : 1824

Cürcăs Green . S. Ev. S. S. Amer. : 1731

frăgrảns : S. Ev. S. Cuba :

glandulōsa: : : S. Ev. S. Arabia: : 1824 goss:pifolia : : Green . 6, S. Ev. S. W. Ind. : 1690 herbäcea $:$ Green : $7, \mathrm{~s}$ A. Vera Cru2.. 1759 integerrimă * Scarlet .6, \&. Ev. S. Cuba * 1809 muliffida * Green * 7, S. Ev. S. S. Amer. : 1696 pandurafolia : : Scarlet : 7, s. Ev. S. Cuba : 1800 peltata . : S. Ev. S. S. Amer. : 1825 napaiforiă.

JEFPRREðXIXX. Dedicated by Barton, to Mr. Jefferson, the celebrated president of the United States. Linn. 8, Or. 1, Nat. Or. Ranunculaced. This is a pretty hardy plant, very curious, from the peculiar mode of dehiscence of its capsule. It thows well in any common garden soil, and may be increased by dividing the roots, or by seeds. Synonyme: 1 . Pudophyllum diphyllum.

diphyllz, 1 . . White . 5, H. Her. P. N. Amer. 1792

JER`EY THIsTi.e, see Centañ rẻă Isnärdi.

JERUSALEM ARTICHOKв, see Heliänthüs tuberósŭs.

Jerusalem saor, see Phlómis fruticosó.

JEW'B-RAR, see Exídĭă auricülä.

JOB'P TRARS, see COI $x$.

JӧнNí. Named by Roxburgh, in honour of the Rev. Dr. John, a missionary, once resident in Tranquebar. Linn. 3, Or. 1, Nat. Or. Celastracee. Very handsome shrubs, producing edible fruit. They do well in loam and peat; and cuttings of the ripened wood will root in sand, under a glass, in a moist heat.

coromnndelină . Yel. grn. . S. Ev. Cl. E. Ind. • . 1820 salacioìdés. . Orange : S. Ev. S. E. Ind. : : 1822

Jorsts, the places at which the pieces of the stem are articulated with each other.

JolLIFPY Ar. Named by Bojer, in compliment to his friend M. Jolliffe. Linn. 22, Or. 13, Nat. Or. Cucurbitaces. This is a splendid plant, producing its curious and beautiful flowers in great profusion; but it requires a large space to krow in, and to be frequently pruned in, before it flowers. It grows well in sandy loam and a little peat. It is much better to raise it from cuttings of the flowering shoots, as they will flower nuch earlier; they will root without difficulty in soil or sand, under a glass, in heat. Synonyme: 1. Telfairia peltata, Feuillea peltata.

africănă, 1 . . Purple - 7, S. Ev. Tw. Zanzibar . 1825 JoxĒğ̌̆, Roxburgh. In honour of the distinguished scholar and botanist, Sir William Jones. Linn. 7 , Or. 1, Nat. Or. Leguminose. The species of this genus are highly fragrant, and well worthy of a place in every collection. They thrive well in a mixture of sandy loam and peat; and large cuttings root freely under a glass, in heat. Synonyme : 1. J. pinnata.

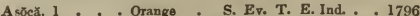

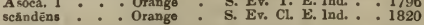
JossīxǏx, Commerson. The derivation not known [172 ] 
but most probably a man's name. Linn. 12, Or. 1, Nat. Or. Myrtacee. This plant is well worth cultivating for the sake of its beautiful foliage, independently of its handsome large flowers; for culture and propagation, see Psidium.

orbiculátă . . White . . S. Ev. S. Mauritius . 1823 Joutay, see Oūtěă.

JoVE's BBARD, see Hỹdnñm bārbă Jõvǐs.

Jovi's Frvir, see Laûrŭs Diospȳrós.

JUBर̄TǓs, crested, maned.

JUDAS TRBE, see Cêrcăs.

JUĀTŭs, coupled together.

Jestās, Linn. From Jovis glans; literasly the nut of Jove. Linn. 21, Or. 9, Nat. Or. Juglandacee. The well-known Walnut-tree is among the species of this ornamental genus. They are all tall, stately of this ornams, well adapted for parks and lawns. They grow freely in any rich loamy soil, and are raised from seeds. $J$. cinerea is esteemed anthelmintic and cathartic. Synonyme: 1. J. heterophylla, $\boldsymbol{J}$. filicifolia.

\begin{tabular}{|c|c|c|}
\hline 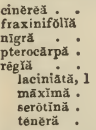 & $\begin{array}{l}\text { : Apetal } \\
: \text { Apetal } \\
: \text { A petal } \\
: \text { Apetal } \\
: \text { Apetal } \\
: \text { Apetal } \\
: \text { Apetal } \\
: \text { Apetal } \\
\text { : A petal }\end{array}$ & $\begin{array}{l}\text { 4, H. De. T. N. Amer. } \\
\text { 4, H. De. T. N. Amer. } \\
\text { 4, H. De. T. N. Amer. } \\
\text { 4, H. De. T. N. Amer. } \\
\text { 4, H. De. T. Persia : } \\
\text { 4, H. De. T. Persia : } \\
\text { 4, H. De. T. Persia : } \\
\text { 4, H. De. T. Persia : } \\
\text { 4, H. De. T. Persia : }\end{array}$ \\
\hline
\end{tabular}

JuLy flower, see Prosōp ̌̌s juliflöră.

Juncǔs. Linnæus derived the name, from jungo, to join; in allusion to the first ropes being made from rushes. Linn. 6, Or. 1, Nat. Or. Juncacee. All the species of Rush do best cultivated in a moist situation, some of them entirely in water, and others in a peat soil; they may be increased by seeds, or dividing the roots. In Japan, they cultivate $J$. effusus for making floor-mats. Synonymes 1. J. helodes, arcticus. 2. J. compressus. 3. J. gra. cilis, tenuis. 4.J. biglumis.

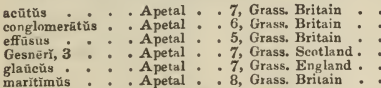

acutiflörŭs, ärctĭcŭs, aristätŭs, bältǐcŭs 1, biglämĭs, bottñ̄cūs, bufōnñŭs, bulbōsŭs 2, capitätŭs, castānĕŭs, canōsŭs, filifōrmìs, Jacguīnĩ 4, lampocärpŭs, monānthos, obtusiflorŭs, pauciflorŭs, planifoliủs, pleběiŭs, polycĕ phälŭs, pygmäūs, squarrōsŭs, subverticillätŭs, supīnùs, Tenagè̃ă, tènŭis, trìfidús, triglamis, uliginosüs, vaginätüs, valvätŭs.

JuNGERMĀNNİ, Nees. In honour of the German botanist, Louis Jungermann, who died in 1653 . Linn. 24, Or. 6, Nat. Or. Jungermanniacee. This is a very extensive genus of obscure plants, found at all seasons of the year, and generally in little patches, förmed by their creeping stems, upon trees, or rocks, or on the earth in damp places-albesscẽns, älbĭcāns, anōmälă, aspleniō̄dēs, barbātă, bicuspidātă, bidentätă, Bläsiă, byssācēă, calyptrifoliă, capitātă, ciliār rĭs, cochleariformìs, complanätă, comprēssü, concinnātă, connīvēns, cordifolǐă, crenulātă, cuneifoliă, curviföliă, decĭpīens, Dicksōñ̄, dilatätă, Doniänä, emarginätă, epiphȳllă, excīsă, exsēctă, Francīscī, furcātă, hamatifolìă, heterophy̆llă, hibērnìcă, Hookèri, Hutchīnsĭă, hyălĭnă, incīsă, inflätă, iulācěă, juniperīuă, lavigätă, lanceolātă, laxifoliăa, Mackăīi, minūtă, minutīssǐmă, multĭfídă, nemorósă, obtusífolı̆ă, orcadênsǐs, pīngŭis, planifolīă, platyphyllă, polyänthos, pubēscềns, pümìlá, pusīllă, rēptäns, resupinätŭs, scaläris, serpyllifolĭă, setācĕă, setiförmăs, spharocārpă, Spāgnī, spinulōsă, stipuläcĕă, Tamarīscī, Taylōĩ, tomentēllă, Trichomänìs, trichophȳllă, trilobätă, Turnērî, umbrơsă, undulätă, ventricosă,

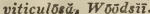

JUNipkr, see Junĭpĕrŭs.

JuNY̌pŭnưs, Linn. Derived from the Celtic, juniperus, rough, or rude; in allusion to the stiff habit of the shrubs. Linn. 22, Or. 13, Nat. Or. Coniferce. This genus is too well known to need to be particularised here. All the species will grow in sandy loam, and some in any common garden soil, as $J$. Sabina. They are mostly raised from seeds, though cuttings will strike when planted in a [ 173 ] sheltered situation, under a hand-glass. The stimulating and diuretic powers of the Savin $(\boldsymbol{J}$. Sabina) are well known. The berries of $\boldsymbol{J}$. communis are well known for the Havour they give to gin. Synonyones: 1.J. canadensis. 2.J. nana. 3. J. suecica. 4. J. alpina. 5. J. prostrata, J. repens. 6. J. tamariscifolia. 7.J. caroliniana.

\begin{tabular}{|c|c|c|c|}
\hline & & & \\
\hline ermūdiāna & & - & \\
\hline hinēnsis & - & & \\
\hline Smithin & & & \\
\hline ìs & & & \\
\hline lens & & & \\
\hline & & & \\
\hline ra & & & \\
\hline ă, & & & \\
\hline dürich & : & & \\
\hline rupācè̃ & 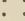 & & \\
\hline xcểlsă. & $\cdot$ & & \\
\hline peia & & . & \\
\hline lacrocărpà & & & \\
\hline xycëdrŭs & & . & \\
\hline honicea & & & \\
\hline $\begin{array}{l}\text { eürvă } \\
\text { abină }\end{array}$ & . & • & \\
\hline $\begin{array}{l}\text { bīnă } \\
\text { ã pīnă, } 4\end{array}$ & & & \\
\hline tă & & & \\
\hline & & & \\
\hline qua & & & \\
\hline quamōsă & & & \\
\hline urìférä & & • & \\
\hline vife & & & \\
\hline h & & & \\
\hline
\end{tabular}

F. Ev. T. W. Ind.

1759

5, F. Ev T. Bermudas - 1683

5, H. Ev. S. China : 1804

F. Ev. S. Nepal

5, H. Ev. S. Britain

5, H. Ev. S. Canada

5, H. Ev. S.

5, H. Ev. S. N. Eur.

5, H. Ev. S. Poland

H. Ev. S. Dauria

H. Ev. S. Syria

H. Ev. T. Siberia

H. Ev. S. S. Eur.
H. Ev. S. Greece

, H. Ev, S. Spain

5, H. Ev. S. S. Eur.

5, H. Ev. S. Nepal

5, H. Ev, S.

5, H. Ev. S. N. Amer.

H. Ev. S. S. Eur.

5, H. Ev. S. Europe

H. Ev. S. Nepal

H. Ev. S. Spain

H. Ev. S. C. Horn .

5, H. Ev. S. N. Amer.

$5, H$, S. N. Amer.

JUPITER's BEARD, see Anthȳllis Bärbă Jovis.

Jussi㱏.. Named by Linnæus, in memory of Antoine de Jussieu, demonstrator of plants in the Royal Gardens at Paris, and uncle of the celebrated Antoine Laurent de Jussien. Linn. 10, Or. 1, Nat. Or. Onagracea. Rather obscure aquatics, growing freely in a pot or tub of water, and readily increased by cuttings. The biennials are raised from seeds. Synonymes: 1. J. acuminata. 2. $J$. villosa.

\begin{tabular}{|c|c|c|c|}
\hline 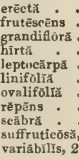 & & $\begin{array}{l}\text { Ye } \\
: \mathrm{Ye} \\
: \mathrm{Ye} \\
: \mathrm{Ye} \\
: \mathrm{Ye} \\
: \mathrm{Ye}\end{array}$ & $\begin{array}{l}\text { 8, S. Aq. B. S. Amer. } \\
\text { 6, S. Ev. S. } \\
\text { 8, G. Aq. P. Carolina } \\
\text { 7, S. Aq. B. S. Amer. } \\
\text { 8, S. Aq. B. N. Amer. } \\
\text { 7, S. Aq. B. S. Amer. } \\
\text { 8, S. Aq. B. E. Ind. } \\
\text { 8, S. Aq. P. W. Ind. } \\
\text { 7, S. Aq. P. S. Amer. } \\
\text { 8, S. Aq. P. India } \\
\text { 8, S. Aq. B. W. Ind. }\end{array}$ \\
\hline
\end{tabular}
Jusrīcĭă, Linn. In honour of J. Justice, an eminent Scotch horticulturist and botanist. Linn. 2, Or. 1, Nat. Or. Acantharec. An extensive, highly interesting and ornamental genus of plants, which mostly flower very freely. The stove and greenhouse shrubby and herbaceous kinds, grow well in any light soil, or loam and peat mixed, and may be multiplied by cuttings in sand, under a glass, the stove kinds in heat. The seeds of the annual and biennial kinds must be raised in pots, in a hothouse, or hotbed frame, and when transplanted, treated as other tender annuals and biennials. The flowers, leaves, and roots of $\boldsymbol{J}$. Adhatodu are said to possess antispasmodic qualities. $J$. Ecbolium is supposed to be diuretic. $J$. paniculata is the base of the French bitter tincture called Drogue Amère, which is highly valued for its stomachic and tonic properties. Synonymes: $1 . J$. guadrangularis, $2, J$. flavicoma. 3. eustachiana. 4. oblongata. 5. tinctoria.

Adhătơdă Purple S. Ev, T. Ceylon - Purple - S. Ev. T. Ceylon Albz ama ăbilis

aspèrūlă, 1

Betōnǐcă

bicalyculātá

calytrǐchă,

caracasānă

caracasảă

cärnĕă :haginēnsis

ciliaris

coccinéa S. Ev. S.

S. Ev. S. Indies

Pink.

White

Purple

Yellow

Violet

Flesh

Purple

Wurple

comătă : : : Purple

cuspidátà
8,8

S. E. Ind.

A. E. Ind.

2, S. Ev. S. Brazil

5, S. Ev. Tr. Caraceas

8, S. Ev. S. Rio Jan.

7, S. Ev. S. Carthag.

7, s. A. W. Ind.

2, S; Ev. S. S. Amer.

7, S. Her. P. Jamaica : 1795
7 , s. Ev. S. Arabia . 1820
1699 1816 


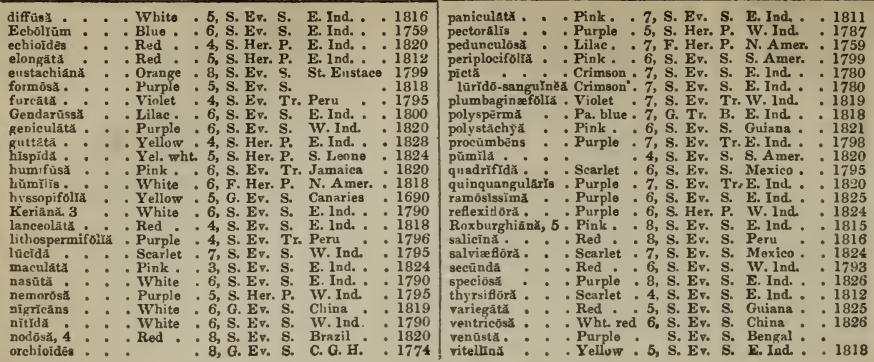

K.

T EMPFERİ, Linn. In honour of E. Kæmpfer, I a German naturalist, who deed in 1716 . Linn. 1, Or. 1, Nat. Or. Scitaminece. A curious genus of stemiless plants, easily cultivated provided they are carefully watered, requiring but little when not in a growing state. They grow best in sandy loam and peat mixed, and are easily increased by divisions of the roots.

(a) elégans : Purple Galángă * . Wht pur. 7, S. Her. P. E. lnd. : 1728 marginata : : Blue : 7 , S. Her. P. E.lnd. : 1822 ovalifolra. : B'ue 6, S. Her. P. Malacea : 1822 panduratá : :Purple : 10, S. Her. P. E. lnd. . : 1797 Rnscoelana : Whice. 10, S. Her. P. E. lnd. : 1827 rotūndă .: Red wht. : 7, S. Her, P. E. lnd. : : 1764

K AGENẾKǏă, Ruiz and Pavon. In honour of Count Frederick Kageneck, a patron of botany. Linn. 12, Or. 2, Nat. Or. Rosacee. This is described as a very tall ornamental-growing tree, succeeding in loam, peat, and sand; ripened cuttings will probably root in sand, under a glass, in a little heat.

cratægoídés . . White. . F. Ev. T. Chile • 1831

I ALANcho $\breve{E}$, Adanson. The Chinese name of one of the species. Linn. 8, Or, 4, Nat. Or. Crassulacece. This is a pretty genus of sicculent plants, requiring but little water when not in a free-growing state. They appear to do best in a mixture of loam and sand. They are very easily increased by cuttings, which should be taken off, and laid to dry a few days before planting; they will then root in a few days. Synonymes: 1. Verea acutiflora. 2. $V$, crenata. 3. Crassula rotundifolia.

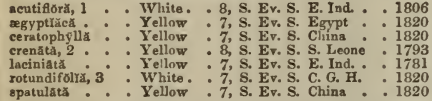

KAliforM, formed like Salsola Kali, a sea-coast plant. K̇̃LYY̌, Linn. In honour of Peter Kalm, professor at $\mathrm{Abo}$, in Sweden, and author of Travels in America, 1753 Linn. 10, Or. 1, Nat. Or. Ericacea. The plants of this genus rank among the most handsome of our hardy shrubs. They do best when grown in a peat soil, though they will grow in a very sandy loam; they may be increased by layers or seeds, and when raised from the latter, they require the same treatment as that recommended for $R$ hododendron. folrs-rariegits Red Red mInIma. Red : 6, H. Ev. S. N. Amer. minimă : : Red : : 6, H. Ev. S. N. Amer. orstä: : Red : 6, H. Ev. S. N. Amer. ovata. :- Red : : 6, H. Ev. S. N. Amer. rösęă . - Red • 6, H. Ev. S. N. Amer. .

rübră : . Red : 6, H. Ev. S. N. Amer.

Wlit red: 6, H. Ev. S. Carolina 1820 glaūer: : : Purple: 4, H. Ev. S. N. Amer. 1767 rosmarinifolig: Red : 4, H. Ev. S. N. Amer. : 1812 hirsūta * : : Red : : 8, H. Ev. S. N. Amer. : 1786
latifolra

KaLosāntrēs, Haworth. From kalos, beautiful, and anthos, a flower. Linn. 5, Or. 5, Nat. Or. Crassulacea. A truly handsome genus of succulent plants, well worthy of extensive cultivation for the beauty of their flowers; for culture and propaga. tion, see Globulea. Synonyme; 1. Crassula coccinea. biedlor : . . Yel. scar. . 6, G. Ev. S. C. G. H. . 1810 biconvèxă : : White. 7, G. Ev. S. C. G. H. : 1823 coccInế, 1. : Scarlet .7, G. Ev. S. C. G. H. : 1710 forre-ălbð : White. 7. G. Ev. S. C. G. H. : 1811 Ked * 8, G. Ev. S. C. G. H. .. White. 4, G. Ev. S. C. G. H. mediá : versicolor : : White: 5, G. Ev. S. C.G. H. : 1817

KANGURU viNR, see Cissüs antürcticŭs.

KaULFÛssî, Blume. In honour of Frederick Kaulfuss, M.D., professor of botany at Halle. Linn. 19, Or. 2, Nat. Or. Compositce. This is a pretty little annual, with bright blure flowers, succeeding well in any light loamy soil.

amellỡdēs . . Blue . . 7, H. A. C. G. H. . 1819

IKERL; when the midrib of a leaf or petal is sharp. and elevated externally, it is called a keel.

KRNNB̂DY̆Ă, Ventenat. In honoir of Mr. Kennedy, formerly of the firm of Lee and Kennedy, the once celebrated nurserymen of Hammersmith. Linn. 17, Or. 4, Nat. Or. Leguminosa. A very beautiful genus of conservatory or greenhouse climbers, succeeding well in sandy loam and peat, and easily propagated from cuttings of the young wood in sand, in a little bottom heat, with a glass over them. Synonyme: 1. K. dilatata. 2. latifolia.

apétala - Apetal - G. Ev. Tw.

petala - - Apetal - G. Ev. Tw. cocernexa : Comptoniānă : Blue : 4, G. Ev. Tw. N. Holl. : 1803 G. Ev. Tw. N. Holl. : 1824 inophyllă, 1.: Searlet - G. Ev. Tw. N. Holl. macrophyllä: Purple G. Ev. Tw. S. River Murryátí̄e : Scarlet 4, G. Ev. Tw. Australis: Marryattae * Scarlet * 4, G. Ev. Tw. Australia * 183 G. Ev. Tw. N. S. W. 1828 nìgriesens . Pur. grn. . 3, G. Ev, Tw. N. Holl. 1839 ovātă, 2 : Purple : 6, G. Ev. Tw. N. Holl. : 1818 parviflóră: : : G. Ev. Tw. N. Holl. : 1824 prostrata : : Scarlet $\quad 4$, G. Ev. Tr. N. S. W. : 1790 min $6 r$ : Red : 6, G. Ev. Cr. N. Holl. rubieündx : Dk. red : 6, G. Ev, Tw. N. S.W. : 1788 serleéa : Scarlet : G. Ev. Tw. N. Holl. 1824 Sterlingr: : : Scarlet : 5, G. Ev. Tw. S. River . 1834

KẼRRǏ, Decandolle. In honour of Mr. Kerr, some time superintendant of the botanic garden in Ceylon. Linn. 12, Or. 3, Nat. Or. Rosacea. This [174] 
truly beautifill plant is an old and well-known inhabitant of our gardens; it will grow in any common soil, and cuttings of the young wood taken off at a joint, will root readily if planted under a hand-glass. Synonyme: 1. Corchorus japonicus.

japóň̆că, 1 . . Yellow all H. De. S. Japan • . 1700

KIDNEY-BEAN, see Phasěðlŭs.

KIDNEX-vBrcH, see Anthy̆llis.

KroGELARIÁ, Linn. In honour of Francis Kiggelar, a Dutch botanical author. Linn. 22, Or. 9 , Nat. Or. Flacourtiacea. Plants only worth cultivating in general collentions : they are of common culture, and increased by cuttings.

af rieănă . . Wht. grn. 6, S. Ev. T. C. G. H. . 1683 integrifolia : : Wht. grn. 6, S. Ev. T. C. G. H. : 1819

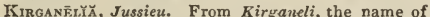
the plant in Malabar. Linn. 21, Or. 10, Nat. Or. Euphorbiacea. This plant will grow well in a mixture of loam and peat; and ripened cuttings will root in sand, under a glass, in a moist bottom heat. Syuonyme: 1. Phyllanthus kirganelia.

elęgâns . 7, S. Ev, S. Maurit. 1820

KrTAIBĒr.̌̆ Willdenon. In honour of Paul Kitaibel, M.D., professor of botany at Pest, in Hungary. Linn. 16, Or. 8, Nat. Or. Malvacea. A tall, mallowlike, herbaceous plant, succeeding in any common soil, and easily increased by seeds, which it ripens in abundance.

vit ifolǐă - . White. . 8, H. Her. P. Hungary . 1801

ILEINHōvั̆, Linn. In honour of M. Kleinhoff, formerly director of the botanic yarden in Java. Linn. 16, Or. 7, Nat. Or. Sterculiacec. A handsome species, flowering throughout the year, and seldom being without fruit, which is, however, of little value. It succeeds well in peat and loam; and cuttings root in sand, under a glass, in heat.

hóspĩtă. . . Pink all S. Ev. T. Moluecas . 1800

KI,Ē̄Ĩ. Named by Linnæus, in honour of James Henry Klein, a German botanist. Linn. 19, Or. 1, Nat. Or. Composita. The species of this genus are of very little interest, and of the simplest culture and propagation.

viridifióră . . Green . . 7, S. Ev. S. Mexico . . 1823 colorĩtă, Porophȳllàm, ruderālīs, suffruticōsă, tage$t, \bar{z}$ des.

KNĀPPİ, Smith. In compliment to Mr. M. Knapp, a writer on British grasses. Linn. 3, Or. 2, Nat. Or. Graminea. This is one of the least of the British grasses, and merely requires sowing in any common soil.

agrostidęa . . Apetal - 7, Grass Wales

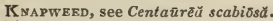

KNAPWERD, see Centū̃urēă Jücĕă

INA Ûrĭ, Coulter. In honour of C. Knaut, a physician, and botanical author at Halle, in Saxony, who died in 1694. Linn. 4, Or. 1, Nat. Or. Dip sacea. Plants of little beauty, growing in any soil or situation. Synonymes: 1. Scabiosa arvensis. 2. S. collina. 3. S. ciliata. $4 . \mathrm{S}$. diversifolia. 5. S. hybrida. 6. S. montana. 7. S. orientalis. 8. S. propontica. 9. S. sylvatica. 10. S. integrifolia. 11. S. longifolia.

arvenš̌s, 1 - Bl. pur. . 8, H. Her. P. Britain collină, 2 : Bluish : 8, H. Her. P. Europe vulgârřs : Bluish. 8, H. Her. P. Britain ciliată, 3 . White. 7, H. Her. P. Moravia : 1802 diversifolīă, 4 . Violet . 6, H. Her. P. Transylv. : 1826 hybríă, 5 - Pa, pur. : 6, H. A. S. Eur. : 1819 montānă, 6 : Whíte. : 7, H. Her. P. Caucasus : 1820 orientalis, 7. Red - 8, H. A. Levant - 1713 propontïă̈, 8 . Purple $\quad 8, \mathrm{H}$. A. Levant - 1768 ylvaticn, 9 * Red * 7, H. Her. P. Europe * 1633 ntegrifoliă, 10 Cream. . 7, H. Her. P. Europe . 1748 longifoliă, 11 Lilac . 7, H. Her. P. Hungary : 1802

\section{ISNAWEL, see Sclerānthŭs.}

K NEED, or KNKE-JO1NTRD, bent like the knee-joint.

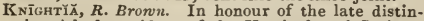
tinguished president of the Horticultural Society, Thomas Andrew Knight, Esq., F.R.S., \&c., who died in 1838. Linn. 4, Or. 1, Nat. Or. Proteacea. This is described as a fine ornamental tree, requiring much the same treatment as Hakea, and some other New Holland genera.

excżlsă . i $\dot{1}_{5}$ Flesh . G Gv. T. N. Zeal. . 1824

\section{KNOT-GRAss, see Illecēbrūm.}

KNowltōnİ̈, Salisbury. After Thomas Knowlton, once curator of the botanic garden at Eltham. Linn. 13, Or. 6, Nat. Or. Ranunculacea. Curious species, but of no great beauty. They succeed well in loam and peat, and are increased by dividing the roots, or by seeds. Synonymes: 1. Adonis hirsuta. 2. A. capensis.

daucifolit

dacrachis

gractis

rĭgìdă, 2

Yel. Grn. Her. P. C. G. H.

Yel. grn. 4, G. Her. P. C. G. H.
Yel. grn. : 4, G. Her. P. C. G. H.

Yel. grn. . 4, G. Her. P. C. G. H.
Yel. grn. . 4, G. Her. P. C. G. H.

Yel. grn. : 3, G. Her. P. C. G. H

1822

1820

1823

1780

$\mathrm{K}$ ōx̌r, Linn. In honour of Kobert $\mathrm{Knox}$

lived many years in Ceylon, and published a rela.

tion of it in 1781. Linn. 4, Or. 1, Nat. Or. Cin-

chouacea. The species of this genus are rather ornamental, and succeed well in sandy loam and peat; and young cuttings planted in mould or sand, under a glass, will root readily. Synonymes :

1. Spermacoce Roxburghii. 2. $K$. corymbosa, $\mathbf{S}$. sumatrensis. 3. K. umbellata, S.teres.

lǣพัs, 1. . Pink * . 7, S. A. Bengal . . 1818 sumatrēnsis, 2 . White. 7, S. Ev. S. E. Ind. - 1818

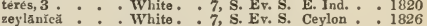

IKовRĒsı̌A, Willdenon. After Dr. Kobres, a German, and a great promoter of botany. Linn. 21, Or. 3, Nat. Or. Cyperacea. A mere weed, of the simplest culture. Syuonyme: 1. Scharius monoicacaric̄̄nă.

Köeнї, Roth. In honour of M. Koch, a German butanist. Linn. 5, Or. 2, Nat. Or. Chenopodiacea. The species of this genus are not possessed of much beauty. The seed has only to be sown in the open ground. Synonyme. 1. Chenopodium arenarium.

arenāriă, 1. . Wht grn. 5, H. A. Hungary 189

dasyānthã: : Green : $7, \mathrm{H}$. A. Caucasus : 1823 erióphŏrà Green 6, H. A. Spain

hyssopifolră: Green: $:$, H. A. Siberia: : 1801 muricātă : Green: :7, H. A. Egrpt: 1773 prostrātă : : Green : : 7, H. De. Cr. S. Eur. : : 1780 scoparriä: : Green : 6, H. A. Greece : 1629 sedoĩés : : Green: : 5, H. A. Crimea: 1821

KaLẼrĭ, Link. Named in honour of M. Kœhler, professor of natural history at Mayence. Linn. 3, Or. 2, Nat. Ur. Graminea. Mere weeds, of the commonest cultivation. Synonyme: 1. Aira cristata.

glābră, 1 . . Apetal . 7, Grass. Britain .

agyptĭăcă, brachystăchy̆ă, cristätü, glañcă, grandifloră, hirsată, hīspĩdă, lobätă, macrānthă, pennsylvānică, phleō̄dēs, pubēscēns, tuberossă, vallesiăcă, villōsă.

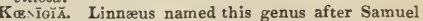
Kœnig, a Swiss mathematician. Linn. 3, Or. 3, Nat. Or. Polygalaces. This is a curious incon spicuous species, of greater rarity than beauty; it will grow sown in any common soil in the open border.

islandica . . Apetal . 4, H. A. Iceland. . 1773

KOLRRUTĒR̆ L̆, Linn. In honour of the celebrated German botanist, J. G. Kolreuter. Linn. 8, Or. 1, Nat. Or. Sapindacece. This is a very handsome plant, growing well in any common soil; it should be planted in a sheltered situation, as it will not flower if too much exposed; it is readily increased by layers or cuttings of the roots.

paniculătă. . Yellow . 7, H. De. T. China . . 1763

KoNīGĂ, R. Bronn. In honour of Charles Konig, F.R.A., I.S., superintendant of the natural histury department in the British Museum. Linn. 15, Nat. Or. Cruciferce. $K$. maritima variegata is a pretty little undershrub; it grows in any common soil, and may be increased by cuttings planted under a glass. $\boldsymbol{K}$. maritima is increased from seed sow 11 in the open border. Synonyme: 1. Alyssum maritimum, Adysetum maritimum, Glyce maritima. marĭtrmă, 1. . White. . 7, H. A England variegata : White. 7, G. Ev. S.

KRAMẼR̆ L̆, Lefling. In honour of J. G. H. and W. H. Kramer two German betanists, Linn. 14, Or. 2, Nat. Or. Polygalaceu. This is described as an ornamental shrub, succeeding in sandy loam 
and peat; cuttings will root in sand, under a glass, in heat. The species is tonic, and excessively astringent.

paucifiòra .

S. Ev. S. Mexico . 1824

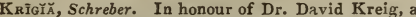
German botanist. Linn. 19, Or. 1, Nat. Or. Composite. $K$. virginica is rather a pretty little grassyleaved annual; it, as well as $K$. caroliniana, has only to be sown in spring, in any open loamy snil. The other species will grow well in the same kind of soil, and may be increased by divisions. Synonymes: 1. Troximum virginicum. 2. Hyoseris caroliniana. 3. Troximum Dandelion. 4 Hyoseris virginica.

virginìcă, 4 . Yellow . 6, H. A. N. Amer. . 1811 amplexicaũlís 1, caroliniānă 2, Dandētĩon 3 .

KrUBĒră, Hoffmann. After John Julius Kruber, M.D., a promoter of botany. Linn. 5, Or. 2, Nat. Or. Umbellifere. The seed of this species only requires sowing in a light soil in the open border, in spring. Synonyme: 1. Ulospermum dichotomum.

leptophylla . . White . 6, H. A. S. Eur. . 1596 K sylvania, a pupil of Linnæus. Linn. 19, Or. 1 Nat. Or. Composita. Ornamental little plants, succeeding well in a mixture of peat and sandy loam, and increased by divisions. Synonymes: 1 .
Critonia Kuhnia. 2. C. eupatorioides. 3. Kleinia linearifolia, Jaumea linearis.

Critōñ̌̆, 1. * White . · 7, H. Her. P. N. Amer. . 1816 eupatorioidés, 2 : White. : 7, H. Her. P. N. Amer. 1812 linearifoliě, 3.: 3 G. Her. P. Brazil : 1829 rosmarinifolia . White. . 7, G. Her. P. Cuba : 1828

K his friend Charles Sigismund Kunth, a famous Prussian botanist. Linn. 21, Or. 6, Nat. Or. Palmacece. This is described as an ornamental palm, growing in any rich mould, and increased only by seeds.

montā

Palm. N. Grenada . 1829

Kร̄ı̆Ă, Roxburgh. In honour of Colonel Robert Kyd, the first director of the Calcutta botanic garden. Linn. 16, Or. 7, Nat. Or. Sterculiacere. An ornamental genus, succeeding well in light turfy loam and peat, well mixed; and increased by cuttings, not too ripe, planted in sand, under a glass, on a bottom heat.

calycină * * White * . S. Ev. S. E. Ind. . . 1818 fraternă . White . S. Ev. S. E. Ind. . 1823

K YLLĪNGĬĂ, Linn. In hononr of P. Kylling, a Danish botanist, who died in 1696, Linn. 3 Or. 1 , Nat. Or. Cyperacea. Mere weeds, of the simplest culture-brevifoliă, intermèdiă, monocēphälä, polycèphălă, trĭcëps, uncinätō.

L.

TBELLCM, the front segment of an orchidaceous 1 or other flower, the lower petal, the lip.

LABIATR, having a lip, or lips.

LABIÖSĂ, large, or broad-lipped.

$L \bar{A} B L \bar{A} v 1 \bar{A}, A$ danson. Lablab is the Arabic name of Convolvulus, with which this has no affinity except in the twining habit. Linn. 17, Or. 4, Nat. Or. Leguminoser. The seeds of the annual kinds may be sown in pots, and kept in the hothouse until May, when, if the weather is fine, they mas be planted in a sheltered situation in the open ground, and supported in the same way as scarlet-runners. The greenhouse species are readily increased by cuttings. Synonymes: 1. Dolichos cultratus. 2. D. albus. 3. D. bengalensis, Lablab bengalensis. 4. L purpureus, D. purpureus. 5. D. Lablab.

cultrătă, 1 * White. . 7, G. Tw. A. Japan . 1816

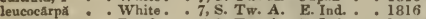
microcarpă : Purple , 7, S. Tw. A. E. Ind. : 1818 nankinicä: White. 7, G. Tw. A. China : 1714 perēnnāns, 2: : White. : 7, G. De. Tw. China : 1820 perénnăns, 2: : Violet: : 7, S. De. Tw. E. Ind. : 1794

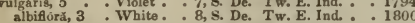
purpürę, 4 : Purple : 7, S. De. Tw. E. Ind. : : 1790

LACEBRAKB, see Lagêtlă linteă rĭă.

LACERATB, $\}$ torn, appearing torn.

LACRRATBLY-TOOTHBn, toothed in a coarse irregular manner.

LACHENĀLY̌̆, Jacquin. In honour of W. de la Chenal, a botanical author. Linn. 6, Or. 2, Nat. Or. Liliacec. This is a genus of pretty, though rather diminutive plants, seldom attaining a foot in height. They bear forcing remarkably weil, and may be made to flower at almost any season. The soil best adapted to the growth of these plants is a mixture of peat and sand. Care must be taken to give them little or no water when not in a growing state. They may be increased by offsets, or by seeds.

anguYnĕ - White . 4, G. Bl. P. C. G. H. angulnea *: White.: 4, G. BL. P. C. G. H. bifoliă bifoliă

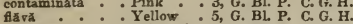
frăgrans : : Wht. red . 4, G. Bl. P. C. G. H. glaucina : Grn. wht. 5, G. Bl. P. C. G. H.

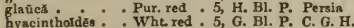
isopētălà : Wht. pur. 5, G. Bl. P. C. G. H. isopētăla ${ }^{\circ}: \therefore$ Wht pur. 5, G. Bl. P. C. G. H. lancerefolla
lilitifóră liliiflóră : : White: : 5, G. Bl. P. C. G. H. luteolå : : : Yel red : 3, G. Bl, P. C. G. H
1825

1793

1813

1774

1790

1798

1795

1825

1812

1804
1818

1818

1798

1774 maculat: mutabilis nervósă orchioldès pallida. pallirdă .

pãtūila

pêndülă

maculát

punetătà

purpurè

purpureo-ccerüles pusillix

quadrieolot

coloratá

racemósá

rosea

rübiar

sessilifion

tricollor

tricolor.

uniflōrả.

violâcé

\section{LACHN汫, Linn.}

Yel. red . 3, G. Bl. P. C. G. H. Mlue 11, G. Bl. p. C. G. H. H. 1810 Grn. wht. 3, G. BL. P. C. G. H. 1752 Pr. blue : 5, G. Bl. P. C. G. H. : 1782 Pa. blue : 5, G. Bl. P. C. G. H. : 1782
Pa. blue Wht pink 4, G. Bl. P. C. G. H. : 1795 Red yel. . 4, G. BL. P. C. G. H. : 1789 Red yel. 4. F. Bl. P. C. G. H. 1789 Purple . 5, F. Bl. P. C. G. H. : 1824 Purple 4, G. Bl. P. C. G. H. 1826 Purple 4, G. Bl. P. C. G. H. White. 6, G. BI. P. C. G. H. : 1825 Pur. grn. : 2, G. Bl. P. C. G. H. : 1790

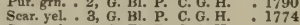
Sear. yel. : 4, G. Bl. P. C. G. H. : 1774 Wht. grn, 5, G. Bl. P. C. G. H. 1811 Pink 5, G. Bl. P. C. G. H. 1800 Red Pink 1803 Red : 5 , G. BL. P. C. G. H. 1804 Red yei. : 4, G. BI. P. C. G. H. : 1774

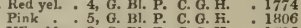
Wht blue 3, G. Bl. P. C. G. H. : 1795 Violet. 3, G. Bl. P. C. G. H. : 1795 the downy clothing of the corolla. Linn. 8 , Or. 1, Nat. Or. Thymelacea, Interesting Cape plants, with pretty woolly heads of white or purple flowers. They succeed well in sandy peat, with the pots carefully drained; and young plants may be obtained from cuttings in sand, under a glass. Synonymes: 1. Gnidia filamentosa. 2. Passerina conglomerata.

buxifờlin̆, 1

White. 5, S. Ev. S. C. G. H. 1800 conglomerăti, 2 . White - 6, G. Ev. S. C. G. H. $: 1773$ eriocephala - White - 6, G. Er. S. C. G. H. - 1793 purpüréd: : Purple : 4, G. Ev. S. C. G. H. : 1800

LACHNĀNTHẼs, Ellis. From lachne, wool, and anthos, a flower; in allusion to the flowers, which are woolly. Linn. 3, Or. 1, Nat. Or. Homodoracee. A pretty plant; for culture and propagation, see Dilatris. Synonyme: 1. Dilatris tinctoria, D. Heritiera.

tinctōrŭă, 1 . . Pink . . 7, G. Her. P. N. Amer. . 1812

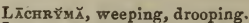

LACINI ATE, jagyed, cut.

LActücă, Linn. Derived from lac, milk; on account of the milky juice which exudes from the plants when broken. Linn. 19, Or.1, Nat. Or. Compositce. A mong others, this genus contains the well-known "Lettuce," with the culture of which every one is familiar. $L$. virosa yields an extract resembling [ 176$]$ 
opium in its qualities, but less likely to produce the oonsequences attending the use of that drug. synonyme: 1. sonchoides.

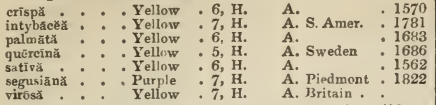

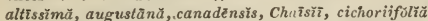

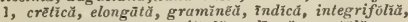
maculālă, perēnnis, sagittälă, salïgnă, scarioulă, sonchifolnă, strīctă, tenērrīmă, tuberosă, villōsă, vimĭnĕă.

LACTESCENT, yielding milky juice.

Lacū $\bar{A} \bar{E}$, little pits, or depressions; applied to vessels when they are full of air.

LAcunose, covered with pits, or depressions.

LAcustr1s, growing in lakes, or pools.

LADIES'-SLIPPER, see Cypripédiàm.

LADX's-sMock, see Cardamĩne.

LADıEs' TRACEs, see Neóttiă spiralits.

LADIES' TRACEs, see Spirānthès.

LADY FERN, see Aspidĩn Thelȳplĕram.

L $\bar{\mp}$ Ĭ. Named by Lindley, who does not give the derivation. Linn. 20, Or. 1, Nat. Or. Orchidacee. These are splendid plants, approaching in beauty to some of the finer Cattleyas. The sepals and petals of $\boldsymbol{L}$. anceps, and its variety, are pale lilac the central lobe of the labellum is a beautiful deep purple, and the mouth of the tubular part yellow and white. L. grandiflora has never flowered in this country, and is found rather difficult to grow. The others are of very easy cultivation, requiring precisely the same treatment as their rivals, the Cattleyas.

albĭdă

ảncēps

White.

S. Epi. Oaxaca

1838

Barkeriānă

autumnalis

furfurảcèa

Ro pur 19, E. Mi. Oaxaca.

Rurple : 12, S. Epi. Mexico

Red $\cdot 9$, S. Epi, Mexico * 1836

grandiflöra

Violet

S. Epi. Xalapa

S. Epi. Mexíco . 1838

1838

L. ATI Ă, Linn. In honour of Jean de Laet, of A ntwerp, who published a Latin history of America, dedicated to King Charles I. of England. Linn. 13, Or. 1, Nat. Or. Bixacea. Rather a pretty shrub; for culture and propagation, see Ludia.

Thāmnıัa . . White. - 7, S. Ev. S. W. Ind. 1824

LÆ̈Tǔs, cheerful, bright.

L.EviGÄTŬs, smooth, soft.

LAGAsc A, Cavanilles. In honour of Don Mariana Lagasca, professor of botany at Madrid. Linn. 19, Or. 1, Nat. Or. Composita. A pretty little plant, requiring precisely the same treatment as other stove annuals.

mőlliss . . . White. . 7, S. A. S. Amer. . 1815

LAGRNĀRĬĂ, Seringe. From lagena, a bottle; becanse of the bottle-shaped fruit of some of the species. Linn. 21, Or. 10, Nat. Or. Cucurbilaced. The wellknown vegetable, the "Gourd," is the produce of this species and its varieties; for culture, \&c. see Cucurbita. Synonyme: 1. Cucurbita Lagenaria.

Yellow

8, H. Tr. A. India

clavātã.

Yellow

8, H. Tr. A. India

depréssà.

Yellow

8, H. Tr. A. India

8, H. A. India

1597

1597

8, $\mathrm{T}$. A India

LAGBrstrōmĭ, Linn. In honour of Magnus Lagerstroem, of Gottenburgh. Linn. 23, Or. 1, Nat. Or. Lythracea. A most splendid genus of plants, especially $L$. regina, the flowers of which are produced in panicles; they are at first pale rose-coloured, and gradually deepen to a beautiful purple. The soil best adapted to these plants is a mixture of peat and loam. All the species, except $\boldsymbol{L}$. indica and its variety, are rather difficult to cultivate; they require a strong heat, and very little wate in winter. In summer, they grow freely, and require plenty of room to grow, with a good supply of water; cuttings root readily in sand, under a glass, in heat.

grandiflóră . . Red

indrea : Flesh

rơséa.: : Rose

parvifloră: White

$[177]$
7, S. Ev. S. E. Ind.

7, S. Ev. S. E. Ind.

S. Ev. S. E. Ind

S. Ev. S. Ind.

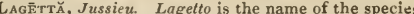
in Jamaica. Linn. 8, Or. 1, Nat. Or. Thymelace. This species grows well in loam and peat; and cuttings of the ripened wood root readily in sand, under a glass, in heat. Synonyme: 1. Duphne Lagetta.

linteărĭă

White

S. Ev. S. Jamaica

1793

LAGő̄č̄̌, Linn. From lagos, a hare, and oikos, a house; the seeds enveloped in the hairy involucrum have been compared to young leverets. Linn. 5, Or. 2, Nat. Or. Umbcllifero. The seeds of this plant should be sown soon after they are ripe, in autumn, because if deferred till spring, they commonly remain a year, and sometimes longer, before they grow

cuminoìdés . Grn. wnt. 6, H. A. Lerant . 1640

LAgonfchīü, Bieberstein. From lagos, a hare, and onychion, a little nail; in allusion to the spines on the plant. Linn. 10, Or. 1, Nat. Or. Leguminosa. This plant will succeed in a warm situation in the open border, if protected by a mat in severe weathe in winter. It may be increased either by seeds, layers, or cuttings, taken off at a joint when very young, and planted in sand, under a glass. Synonymes:1. Acacia Stephaniana, Mimosa micranlha.

Stephaniānŭm . Yellow . 7, F. Ev. S. Persia . 1816

LAGŌPǓs, resembling the foot of a hare.

LAGŌš̆Rİ, Bieberstein. From lagos, a hare, and seris, succory, Linn. 19, Or. 1, Nat. Or. Composiloe. Obscure plants, of the simplest culture. Syno. nyme: 1. Crepis nemausensis-nemausēnsťs 1, laürücă LAGŨN $\overline{\mathscr{A}}$ A, Cavanilles. In honour of Andreas Laguna a Spanish physician and botanist of the sixteenth century. Linn. 16, Or. 8, Nat. Or. Malvacea. Annuals of no interest; they will grow in any light loamy soil. Synonyme : 1.L. angulala-lobātă, sinuātă 1.

LAGŨRũs, Linn. From lagos, a nare, and oura, a tail; on account of the resemblance of its heads. Linn. 3, Or. 2, Nat. Or. Graminea. A mere weed, growing in any soil or situation.

ovâtŭs . . Apetal * . 6, Grass. N. Hou. . . 1820

LAHĀYĂ, Rąmer and Schulles. In honour of $\mathbf{M}$. Lahaye, a diligent botanical gardener. Linn. 5 , Or. 1, Nat. Or. Illecebracea. This is a genus of rather pretty plants. The shrubby and herbaceous kinds grow well in sandy peat, and may be increased by cuttings planted in sand. The annuals require similar treatment to other hardy and tender annuals. Synonymes: 1. Hayea alsinifolia. 2. Mollia aristata. 3. M. diffusa. Illecebrum divaricatum. 4. I. latifolium. 5. Hayea polycarpoides.

alsinffolia, 1 . White . 7, H. Tr. A. S. Eur. . . 1817 aristătă, 2 . White - 6, G. Ev. S. Canaries 1780 corymbósă . White 6, S. Er. S. Ceylon 1893

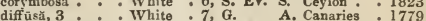
. White * 7, G. A. Canaries $\cdot 1779$ gnaphalioĩdēs . White . 6, G. Ev. S. N. Africa . 1818

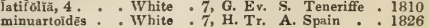
polyearpoidés, 5 : White : 7, G. Her. P. Sicily : : 1817 stellata . White : 7, S. Ev. S. Guinea: : 1820 tenuifoliă: : White:7, S. Ev. S. S. Leone : 1817

LĂLĂG dame, immortalized by Horace, and applied to this plant on account of its gay and lively-looking colours. Linn. 15, Or. 6, Nat. Or. Leguminosa. This is one of the prettiest of the New Holland leguminous plants. It requires an airy part of the greenhouse, and to be similarly treated to the genus Hovea.

omātă . . Yel. pur. 4, S. Ev. S. N. Holl.

1830

LAмвЕ̄RTĬ. Named by Smith, in honour of Aylmer Bourke Lambert, Esq., F.R.S., V.P. L.S., one of the most liberal botanists in Europe, and the possessor of a splendid herbarium, open to every man of science. Iinn. 4, Or. 1, Nat. Or. Proteacee. Very handsome plants, succeeding well in loam and peat, with the pots carefully drained. Water must, at all seasons, be very cautiously supplied; for if once the soil in the pots gets saturated, the plants will soon become sickly, and perish. Cuttings taken off at a joint, before they begin to push, will root in sand, under a glass, if secured from damp. 


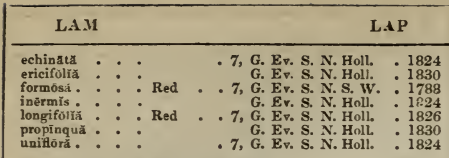

LAмв's L.BTTUCE, see Valerianêllă.

LAMBLLATB, \} divided internally by little plates.

LAMBLiosB, having little plates.

LİMINA, applied to a leaf of a plant considered without a petiole.

LAMINART̄A, Lamour. Named because of the sori upon the laminze of the fronds. Linn. 24, Or. 7, Nat. Or. Alga. Interesting species of sea-weed. In Iceland, an extract is obtained from $L$. saccharina, which is used by the poorer inhabitants as a substitute for sugar-agārūm, bulbơsă, dēbilits, digitätă, esculentă, latifoliă, Phyllitis, saccharinăbullätă.

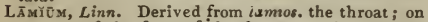
account of the form of the flowers. Linn. 14, Or. 1, Nat. Or. Labiatc. Plants of very little merit, if we except $L$. Orvala. They will grow in any common soil, and are increased by divisions and seeds. Synonyme : 1. L. maculatum.

birfaum . . White. . 6, H. A Britain .

flexnostim : :

hirsatum : Purple: 6, H. Her. P. S. Eur.

longifiórüm, i : Pink .: 3, H. Her. P. S. Eur. :

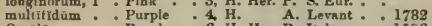

Orvala : : Purple : 6, H. Her. P. Italy : 1596

tomentôsuim : : White. $6, \mathrm{H}$. Her. A. Armenia

Lapsānă, Linn. From lapazo, to purge; in allusion

to its once supposed medicinal virtues. Linn. 19, Or. 1, Nat. Or. Compusita. Plants of little interest, and of the commonest culture. Syzonymes: 1 . Hyoseris futida, Arnoseris fatida. 2. H. minima, A. minima.

grandiflöră. - Y Yellow : 7, H. Her. P. Caucasus - 1816 commiñĭs, crīspă, fä́tidă 1, intermědiă lyrätă, pusillă 2. LARBRễ , Hilnire. Named after the Abbé Larbré, a botanical author. Linn. 10, Or. 3, Nat. Or. Alsinacea. A small uninteresting weed, succeeding in any common wet soil. Synonymes: 1. Stellaria aguatica, uliginosa-aquätică i.

LARCH, see Lârixx.

Lürīx, Decandolle. From the Celtic, lar, fat; on account of the tree producing an abundance of resin. Linn. 21, Or. 10, Nat. Or. Conifera. All the species of this genus are highly ornamental, and some of them are extensively cultivated for their timber, which is adapted to a variety of useful purposes. The lareh grows rapidly in almost any soil, and in any situation, yet its timber can only be brought to perfection when the trees are grown in a clear dry atmosphere, on a cold-bottomed soil, rather moist on the surface. Young plants are obtained from seed, which should be sown in April, on finely-prepared soil. After the seeds are sown, a light roller should be drawn over the bed, to press the seeds firmly into the earth, and they should then have a thin covering of soil. The plants are generally allowed to remain two years in the seed-bed, and afterwards planted into nursery lines, or where they are finally to remain. As the Larch vegetates earlier than most other trees, and suffers more if removed after it has begun to grow, it ought to be transplanted in autumn, or early in spring. We have adopted the names of the species and varieties as given by Mr. Loudon in his very valuable work, the Arboretum et Fruticetum Britannicum. Synonymes: 1. Pinus laricina, P. microcarpa, Abies microcarpa. 2. L. pendula, Pinus pendula, P. intermedia, Abies pendula. 3. L. prolifera. 4. $L$. microcarpa, $P$. microcarpa. 5. L. dahurica. 6. L. intermedia, P. intermedia. 7. L. sibirica, $L$. rossica, Pinus L. sibirica.

LAMPWICK, see Phlomis Lychnitis.

LANcAshtR B AsPHODEL, see Narthectam ossifragam.

LANCBOL.ATB, lance or spear shaped.

LANCEWOOD, see Guatterĩà virzāt

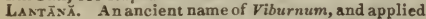
to this genus by Linneus because of its affinity. Linn. 14, Or. 2, Nat. Or. Verbenacee. These plants are rapid growers, forming small bushy shrubs, and producing their pink, yellow, orange, or changeable-coloured heads of flowers in great abundance, which have a somewhat agreeable aromatic flavour. Any loamy soil suits them; and they are increased readily by cuttings in sand, in heat. Synonyme: 1. parviforilu.

sculeâta . . Red . 6, S. Evv. S. W. Ind. . 1692

albá. : : : White: 6, s, Ev. S. S. Amer.

Annūir: : : : Flesh: : 7, s. S. S. Amer.

brasiliēnals: White: 6, \&. Ev. 8. Brazil

canmmara . Red or. 6, S. Ev. S. WV. led

caccinés : : Scarlet :6, S. Er. S. S. Amer.

crocea $: \vdots:$ Copper : 6, S. Ev. S. Jamaica

crocea : : : Pinker : 6 , S. Ev. S. Samaica

geminat: : : Purple : 6, S. Ev. S. Trinidad

birta

8, S. Ev. S. Mexico.

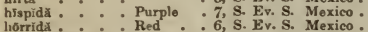

hơrrida

6, S. Ev. S. Mexico

6, S. Ev. S. W. Ind.

Red : 7, s. Ev. S. S. Amer.

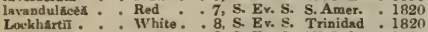

melissifolin : : Yellow : 8, S. Ev. S. W. Ind. : 1732

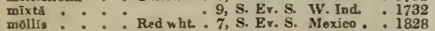

nireä : : : Whito.: 8 s. Ev. S. E. Ind.

mutabin: : Yel. rose : 5, S. Ev. S.

odorata. : : White. :5, S. Ev. S. W. Ind. 1758

odorata. Purple 7, S. Ev. S. Cuba

purpüre̊ : : : Purple : 7, s. Ev. S. Ev. S. S. Amer. : 1820

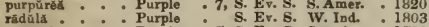

rectr, 1 : : : Purple 7, S. Ev. S. Jumaics : 1758

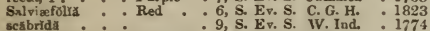

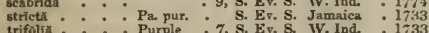

trifoliceă.: : : Vurplet. : 7, s. Ev. S. S. Amer. : 1818

Lasogrsõsuัs, woolly

LA PPĀGO, Schreber. From lappa, ourdock; because of its rough prickly flowers. Linn. 3, Or. 2, Nat. Or. Graminea. A plant of little beauty. The flowers are furnished with small prickles, similar to those of Arctium Lappa, or Burdock; whence the name. It will grow in any soil

ameriealnz, 1 - A petal - 3, H. De. T. N. Amer. 1739 pëndũlä, 2 : A petal : 3, H. De T. N:Amer. 1739 prolifera, $3:$ : Apetal $: 3$, H. De. $T$

rūbră, 4. : A petal : 3, H. De. T. N. Amer. . 1760

europáa : A petal : 3, H. De T. Germany : 1629

commūnl̀s - A petal - 3, H. De. T. Germany 1629

compáctá - A petal : 3, H. De. T.

dahüried, 5. Apetal 3, H. De, S, Dahuria 1827

flore-Albo : A petal : 3 H. De. T. Tyrol

flore-rübrő: A petal : 3, H. De. T. Germany: 1629

intermedra, 6 : A petal : 3, H. De. T. Altai : 1816

lâxă : Apetal $: 3, \mathrm{H}$. De T.

péndülă: A petal : 3, H. De. T. Tyrol

répêns : A petal 3, H. De. $\boldsymbol{T}$

sibiricat, $\dot{7}:$ Apetal : 3, H. De. S. Siberis . . 1824

LARKSPUR, see Delphininm.

LĀRrĚÁ, Cavanilles. In honour of John Anthony de Larrea, a Spanish promoter of the sciences. Linn. 10, Or. 1, Nat. Or. Zygophyllacee. A mixture of loam, peat, and sand, is best adapted to the growth of these pretty shrubs; and young cuttings will root freely in sand, under a glass.

divarichtă . . Yellow * 7, G. Ev. S. B. Ayres • 1829 nitidx : : Yellow : 6, G. Ev. 8. B. Amer. 1823

Laskrpiričc̀, Tournefort. From laser, its gum, and pix, pitch; the name of the ancient Silplium. Linn. 5, Or. 2, Nat. Or. Umbelliferc. Mere weeds, growing in any common soil. Synonymes: 1 . L. trilobum. 2. L. Libanotis. 3. Cnidium carvifolium. 4. L. Halleri. 5. L. pilosum-aquilegifoliam 1,

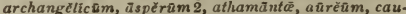
сăsicûm 3, güllïcôm, G. angustifoltam, hirsutam 4, hispĩdūm 5, latifoliūm, murginütam, meotdes, peucedanotdês, pilosũm, pruthenicum, scäbrüm, Sïlèr, triquetram.

LASRR WORT, see Laserpitĩum.

LASER WORT, see Thäpsĩu Laserpäth.

LAsiñNuRĂ, Decandolle. From lasios, hairy, and andros, a male; alluding to the hairy stamens. Linn. 10, Or. 1, Nat. Or. Melastomacere. This elegant genus of shrubs well deserves a place in every stove; their large purple blossoms are rather [178] 
freely produced in panicles. They require to be grown in a mixture of loam, peat, and sand; and cuttings of the young wood will root without difficulty, if planted in the same kind of soil, under a glass, in heat. Synonymes: 1. Pleroma holosericeum, Rhexia holosericea. 2. Pleroma Fontanesii, Melastoma granulosa.

argênteă, 1 . . Purple * 7, S. Evv. S. Rıo Jan. . 1816 Funtanesiānă, 2 : Purple : S. Ev. S. Rio Jan.

LAstoBōtrरัs, Kunze. From lasios, woolly, and botrys, a bunch of grapes. Linn. 24, Or. 9, Nat. Or. Fungi. This species is found beneath the epidermis of honeysuckle leaves: when mature, it is of a black colour, and generally situated on a paler or colourless portion of the leaf-Lonicērä.

LasiopǔtălūM, Cassini. From lasios, woolly, and petalon, a petal. Linn. 16, Or. 7, Nat. Or. Sterculiacea. These are small bushy shrubs, producing an agreeable contrast in the greenhouse by their ferrugineous leaves and woolly-petalled flowers. They grnw in loam and peat, and are increased by ripened cuttings, under a glass.

ferruğ̌něūm * Whito • 6, G. Ev. S. N. Holl parviliörūm : White 6 , G. Ev. S. N. Holl

1791

Lasiǒrǔs, Cassinz. From lasios, hairy, and pous, a foot; alluding to the woolly footstalks of its heads of flowers. Linn. 19, Or. 2, Nat. Or. Composita. This plant has little beauty to recommend it; any common soil suits it, and it may be increased by divisions.

sonchoỉdēs - • Yellow . 8, H. Her. P. Armenia . 1834

LAsiospērmūm, Lagasca. From lasios, woolly, and sperina, a seed; woolly texture of the seeds. Linn. 19, Or. 1, Nat. Or. Composite. Rather pretty plants, of the simplest culture and propagation. Synonymes: 1. Santolina anthemoides, 2. crithmi filia. 3. eriosperma. 4. alpina, erecta. 5, rigida.

anthemoides, 1 . Yellow $.8, \mathrm{H}, \mathrm{E}_{\mathrm{v}}$. Tr. Italy . 172 crithmifolrüm, 2: Yellow : 8. F. Ev. Tr. Macedon. : 1817 erinspérmũm, 3 : Yellow $: 8$, F. Ev. Tr. It ly $: 1816$ peduneulare, 4 : Yellow : 7, H. Ev. Tr. Italy : 1798 rigriūm, 5. : Yellow : 8, F. Ev Tr. Greece : : 1816

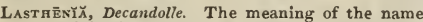
not explained. Linn. 19, Or, 2, Nat. Or. Compositos. These are rather pretty plants, well adapted for the beds of the flower.border. The seeds should be sown early in spring, or in the previous autumn.

californřcă . : Yellow : 5, H. A. California - 1834 LATANĬ plant in the Isle of Bourbon. Linn. 22, Or. 13 Nat. Or. Palmacere. A genus of fine middle-sized palns, with plaited fan-like fronds. They delight in a rich strong loam, with a tolerable supply of water. Synonyme: 1. chinensis.

borbēṇ̃̌̆, 1. . Orn, wht. . Pa.m. Bourbon . . 1816 glaueophylı: : : Grn. wht. : Palm. E. Ind. : : 182s rabrä. : : Grn. wht. Palm. Maurit. : 1788

LATERAI, on one side, or on the sides.

LAthr $\bar{A}$, Linn. From lathraios, concealed; in allusion to the plant being found in concealed places. Linn. 14, Or. 2, Nat. Or. Orobanchacere, A very curious little plant, furnished with white fleshy scales in the place of leaves. It is very shy of cultivation, and may be increased by carefully dividing the roots.

Squamăriă . . Green . . 4, H. Her. P. Britain .

LÄTHȲRŭs, Linn Fromla, augmentative, and thouros, anything exciting; in allusion to the medicina qualities of the seeds. Linn. 17, Or. 4, Nat. Or. Leguminosa. This genus is formed for the most part of yery handsome plants when in flower, the larger kinds being well adapted for arbours or shrubberies, where they must be supplied with branches to support them. Any common soil suits them; they are increased by seeds, and some of the perennial kinds by dividing the roots. The seeds of $L$. Aphaca produce intense headach if eaten in any quantity, while the roots of $L$. tuberosus are said to be wholesome food

alátŭs . . . Purple . $7, \mathrm{H}$. $\mathrm{Cl}$. A. Italy

. Italy . 1823 altăǐcŭs. : * H, Her. P. Altai : 1832 amphicárpǔs : Pink : 6, H. A. Levant : 1680
angulatŭ annuŭs . . Yellow , 7, H. Cl. A. S. Eur , 162: A phăcă: : : Yellow : 6, H. cl. A. Englund Armitageannŭs :Pur, blue 5, H. De. S. Brazil : 182 articulătŭs . . Fsh. wht. 7 , H. Cl. A. S. Eur. 1640 aurienlăttís : Purple * $7, \mathrm{H}$. Cl. A. S. Eur. . 1800 ealifơrnicǔs - Purple * $6, \mathrm{H}$. De, cl. Californ: : 1826 Cìcếră : Red . H. Cl. A. S. Eur. $8, \mathbf{H}$. A Naples Clymennum: : Blue : 6, H. Cl. A. Laples : : 1832 crnũtũs : : Purple: 7 , H. Cl. A. Levant . 1713 decaphsillis : : Red li. : 6, H. De. Cl. N. Amer. 1818 grandifforŭs: : Rose : 7, H. De. Cl. S. Eur. : : 181 helōdēs - Purple : 7, H. Cl. A. A. Eur. : : 1827 heteropliyllŭs: Flesh : 8, H. De. Cl. Europe : 1731 hirsũtŭs . Purple . 7, H. Cl. A. England hĩrtǔs . Purple 7, H. A. Europe neonspicǔŭs : Purple . 7, K. A. Europe . J800 Purple . 7, H. A. Levant . . 1739 intermédrüs : : Red : : 8, H, De. Cl. N. Eur.: : 1820 italícǔs. : : Pink: 8, H. Cl. A. Italy

latifolrŭs : : : 8, H. De. Cl. England albiflörŭs : White : 8, H. De. Cl. Gardens leptophyllux : Purple: 6, H, A. Caucasus : 1818 longipedunculâtǔs Red . : 7, H. A. A : 1817 usitânieǔs. - * 7, H. C1. A. Spain • 182 magellanicús : - Pur. blue 6, H. Da C. C. Horn. - 1744 micranthŭs : Purple * 7, H. A. S. France * 1816

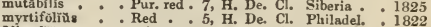
myrtifoling : : Red : 5, H. De. Cl. Philadel.
Nissoliå : : Crimson: 6, H. A. England odorătŭs : : Varieg. : 7, H. Cl. A. Sicily palūstrY̌s . . Paı pur. . 6, H. De. Cl. Britiin pisiförmiss . . Purple : 7, H. De. Cl. Siberia polymörphüs pur. 7, H. De. Missouri 1824 purpüréō-cæru- Pur. blue 8, H. De. Tw. Brazil • . 1836 purpüréř : : Purple . 7, H. Cl. A. Crete rơsěus : : Red : 7, H. De. Cl. Iberis : 1822 rotundifolrŭs : Rose. : 7, H. De. Cl. Tauria : 1822 satín̆̌s. - : White : H. Cl. A. S. Eur. : 1640 setifolī̌s : Red : 6, H. A. S. Eur. : : 1739 sphæ̋rıcŭs . : Crimson. 6, H. A. S. Eur. : 1801 spürīus. : : Purple 6, H. Cl. A. S. Eur. : 1815 stipuläcěŭs : Purple : 7, H. De. Cl. N. York : 1816 sylvéstrĭs : : Purple: 7, H. De. Cl. Britain. tenuifolins. - Blue . 7, H cl. A. N. Afries: 1820 tingIttanŭs : : Dk, pur. 7. H. Cl. A. Barbary : 1680 tūmY̌ns : : Red : : 7, H. C. A. Piedmnnt: 1817 venōsŭs. : : Whit. red 6, H. De. Cl. Pennsyl.

\section{LAUREL, see LaArŭs}

LAUREL CHRRRY, see Cêrăsñs Lxurocěrăsŭs.

LAURESTINE, see Vibărnam Tĩnŭs.

LAUROFHỸLŬs, Thunberg. From laurus, a laurel, and phyllun, a leaf; in allusion to the similarity of the foliage. Linn. 23, Or. 2, Nat. Or. Urticacere. A shrub of no great beauty, from six to seven feet high, producing its minute green flowers in panicles; it thrives in loam and peat, and may be increased by layers.

capēnsYs . . Green • . G. Ev. S. C. G. H. . 1801

LAūrưs, Pliny. From the Celtic word blaur, (laur, the $\mathrm{b}$ is dropped) signifying green, in allusion to the foliage of the plants. Linn. 9, Or. 1. Nat. Or. Lauracece. This is a very handsome and interesting genus of plants. The stove and greenhouse kinds do well in a mixture of sandy loam and peat, and ripened cuttings generally root freely in sand, under a glass; the stove species in a moist heat. Among the most interesting and valuable of the hardy kinds is $L$. nobilis, or bay-tree, which is injured by severe frost: it is, therefore, best to protect the plants with mats when young; they will grow freely in the common garden soil, and in the warmer counties where the weather does not hurt them, they attain the size of trees. $L$. Benzoin, L. Sassafras, and several others, are de. ciduous, and in some situations attain a great size. They may be increased by layers, or cuttings of the roots. The bark of $L$. Benzoin is stimulant and tonic, and in North America it is used in intermittent fevers. In $\boldsymbol{L}$. fatens an acrid red, or violet juice, is particularly abundant. All the species are more or less aromatic and stomachic. Synonymes: 1. Evosmus albidus. 2. Laurus Borbonia.

æestivalys • . Yellow • 4, H. De. S. N. Amer. - 1775 aggregătă : Grn. yel. : G. Ev. S, China : 1821 albida, 1 : : Yellow : H. De. S. Carolina : 1824 Bênzö̌n : : Yel. grn. : 4, H. De, S. N. A mer. : 1683 bullātă . : : Green : 6, G. Ev. S. C. G. H. : 1823 eanariênsĭs. : Yel. grn. G. Ev. T. Canaries : 1815 carolinënsǐs, 2: Yel. grn. : 5, H. Ev, T. N. Awer. 1806 


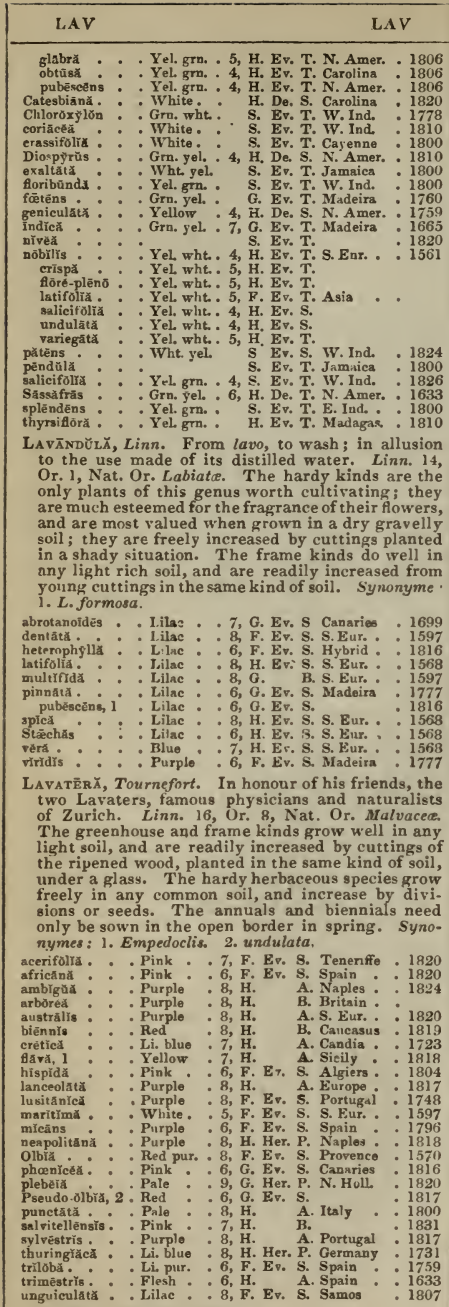

LAVBNDBR, see Lavãndŭlă.

LAvender cotron, see Santolīnü.

LAvẼnî, Snartz. Supposed to be of Cingalese origin. Linn. 19, Or. 1, Nat. Or. Compositue. Mere annual weeds, growing in any common soil-decambenns, erēctă.

LAVRÃǏx, Velloza. In honour of the Marquis of Lavradio, a distinguished patron of botany. Linn.

LAW

LEC

5, Or. 1, Nat. Or. Violacece. This is a very elegant shrub, requiring a mixture of loam, peat, and sand; and cuttings root freely under a glass, in sand, in heat.

montānă * . Purple , S. Ev. S. Brazil . . 1826

LAWsōxǏ̃, Linn. In honour of Isáac Lawson, M.D., author of a Voyage to Carolina. Linn. 8, Or. 1, Nat. Or. Lythracee. Ornamental trees, producing their flowers in panicles or racemes; for culture and propagation, see Lavradia. The Egyptian women obtain a paste from the powdered leaves, with which they stain their fingers and feet an orange colour; this they esteem an ornament. It will last for several weeks before there is oceasion to renew it. Synonyme: 1. L. inermis, L. spinosa. albă, 1 . . . White. . S. Ev. T. E. Ind. . 1759 purpüréă . . Purple \& S. Ev. T. E. lnd. : 1820

LAx, loose, supple.

LAxмĀNNĩA, $R$. Bromn. In honour of E. Laxman, a Siberian traveller. Linn. 6, Or. 1, Nat. Or. Liliaces. An interesting plant, growing freely in loam and peat, and readily increased by divisions.

grăeTis . . . . Pur. wlit. 6, G. Her. P. N. Holl. . 1824

LeADwort, see Plumbägr.

LEAFLBTs, small parts of compound leaves.

LBayY, covered with leaves, or of the consistence of a leaf.

Là̃NGî̄u, Link. From leios, smooth, and aggeion, a vessel; alluding to the peridium. Linn. 24, Or. 9, Nat. Or. Fungi. A genus of minute wart-like Fungi, found upon the leaves of mosses, and decaying trunks of trees-floriformé, Trevelyünz.

Lrather wood, see Dircă.

LRATHERY, thick, of the consistence of leather.

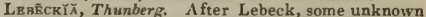
botanist. Linn. 16, Or. 6, Nat. Or. Leguminose. Plants of some beauty, sncceeding in sandy loam and peat, and multiplied by seeds, or cuttings in sand, under a glass.

contaminătă - Yellow

ey tisoidés. : . Yellow

sericeá . : Yollow : 4, G. Ev. S. C. G. H. : 1774

subnũda
subternătă : : : Yellow : 4. G. Ev. S. C. G. H. : 1824
Yellow

LRRrktōñ̌̃ , see Pavōnǎi.

LECAsōră, Acharins. From lekane, a basin; alluding to the form of the shields. Linn. 24, Or. 8, Nat. Or. Lichenes. This genus comprises some valuable plants. L. atra, hamatomma, parella, and turtarea, are used in dyeing, especially the latter, which is in much request for dyeing woollen yarn-albellă, a poehrẩă, argopholìs, ätră, brannněu, candelärěŭ, polyeärpă, carneo-lntĕă, cerỉnă, cervinnă, chloroleñcă,

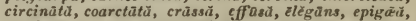

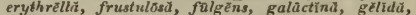

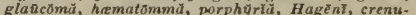
lītă, Hookerīi, hypnorüm, lentigeră, nuröram, oculată, parellă, pericleă, exigŭă, rñbră, rubricơsă, sali-

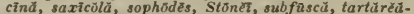
frigidä, tuberculósă, Turnērī, upsaliēnsis, väriă, ventøsă, virellă, vitellină.

Lвсн $\overline{\mathrm{A}} \tilde{A}, L i n n$. After $\mathbf{G}$. Leche, a Swedish botanist, who died in 1764. Linn. 3, Or. 3, Nat. Or. Cistacees. Small plants, of no beauty, and the commonest culture. Synonyme: 1. L. major.

mǔnör White . 7. H. Hex. P. Canndn . 1802 racemulosa ${ }^{*}$ : White: 7 , H. Her. P. N. Amer. 1816 tenuifolla . : White: : 6, H. Her. P. Virginia : 1823 thymifollid: : White. : 7, H. Hex. P. Canada. 1780 villösă, 1 : : White. : 7 , H. Her. P. N. Amer. 1812

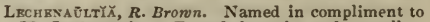
M. Lechenault, a French botanist and traveller. Linn 5, Or. 1, Nat. Or. Goodeniacea. Very elegant plants when in blossom. They grow best in a mixture of turfy loam, peat, and sand; and cuttings of the young wood root readily in the same kind of soil, under a glass. Synonyme: 1. L. Baxteri.

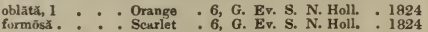

LFcīD̄̄ă, Acharius. From lekis, a saucer, and eidos, like in allusion to the saucer-like shields. Linn. 24, Or. 8, Nat. Or. Lichenes. A very extensive genus of Fungi, found in almost every situation, and at all seasons of the year. Syncnymes: 1. Lichen [180] 
escharoides, 2. Lichen atrocarpus. 3. Lichen calvus

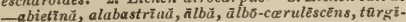
dă, anomălă, anthracīnŭ, aromătică, ätro-cinërĕă, ätrō-älbă, atrō-vīrēns, geogrāphīcă, atrō flävă, ātrō-

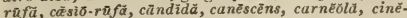
rế-füscă, citrinêllă, cōnflüēus, conspurcätă, cora. cĩnă, cortǐcōlă, dedalěă, decīpiēns, decōlōrâns, granulosă 1, dolosă, Ehrhartiānă, epipolīă, escharoūdẽs,

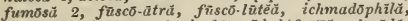
immérsă, incūnă, lapicĩdă, Lightfootīă, līcĩdă,

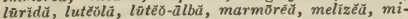
crophȳllă, miscéllă, EEdēri, orōsthĕă, parasēmă, peträă, pholidiōtă, polȳtrōpă, quērnēă, rivulosă, rubiformis, rupēstrĭs 3 , sabuletōrūm, geбchrōă, sanguinärīă, scabrōsă, scalārīs, silícēă, speīrēă, sulphürĕă, uliginosă, verruculōsă, vesiculärīs, viridēscēns.

Lесіттіs, Laffling. From lecythos, an oil-jar; in aIInsion to the form of the seed-vessels. Linn. 13, Or. 1, Nat. Or. Lecythidacee. The soil best adapted to these plants is a mixture of loam and sand, and they require to be kept in a strong heat. Cuttings of the ripened wood will root in sand, under a glass, in heat. The fleshy seeds of Lecythis are eatable, but leave a bitter taste in the mouth.

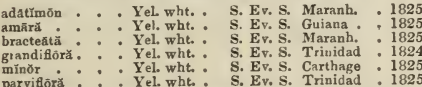

LRDkBŨR̆ L̆ Link. After M. Ledebour, a botanical author. Linn. 5, Or. 2, Nat. Or. Umbelliferce. $L$. hyacinthina is possessed of some beauty, and is of very simple cultivation. Synoayme: 1. Tragium tauricum.

hyacinthing . . Grash. wht. G. Bu. P. E. Ind. . . 1832 pimpinelloĩdēs 1.

LËDŏN GUM, see Cistŭs Lëdón.

LẼDù, Linn. From ledon, the Greek name for a plant now known as the Cistus Ledum. In foliage the present genus ayrees with the plant of the ancients. Linn. 10, Or. 1, Nat. Or. Ericacea. This is an ornamental genus of plants, well suited for the shrubbery, where they form a fine contrast to Rhododendrons. They thrive best in bog earth, and young plants are obtained from layers, treated in the same way as the Rhododendron. Synonyme: 1. I. graenlandicum.

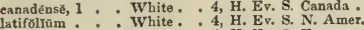

latifolium - White. - 4, H. Ev. S. N. Amer. 1763

palũstré *. White. * 4, H. Ev. S. Europe * 1762

decümbens . - White. - 4, H. Ev. S. Hud. Bay 1762 the the present proprietor. Linn. 5, Or. 1, Nat. Or. Vitacer. Plants only worthy of cultivation in reneral collections. A mixture of loam and peat suits them well, and good sized cuttings root freely in sand, under a glass, in heat.

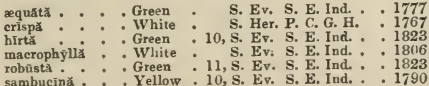

LEB CHBE, see Euphōrīă Lĩtchĩ.

LвEK, see Allīūm Pörrūm.

Lnērsĭ, Swartz. After J. D. Leers, a German botanist. Linn. 3, Or. 2, Nat. Or. Graminea. These plants possess little to recommend them. They grow readily in any common soil, and are increased by seeds.

austrälís oryzoīdēs : : : A petal
virginnică $:$ A petal

7, Grass. N. Holl. . . 1819 7, Grass, Levant: : 1798 7, Grass. N. Amer. : 1770

Legume, $\}$ a pod, the fruit of leguminous plants.

LEGUMiNous, plants which bear legumes, or pods, such as the pea, the bean, \&c.

LвIMĀNTHĪ̄M, Michaux. From leimon, a meadow, and anthos, a flower. Linn. 23, Or. 1, Nat. Or. IIelanthacece. These plants are worth cultivating. They thrive well in a peat soil, in a damp situation, and are increased by seeds. Synonymes: 1 .
Melanthium hybridum, latifolium, racemosum. 2. monoicum, polygamum. 3. virginicum, Helonias vir ginica, Veratrum virginicum.

hȳbridūm, 1 . White. . 6, H. Her. P. N. Amex. . 1822 monoícum, 2 : Brown 6, H. Her. P. N. Amer. 1817 6, H. Her. P. N. Amer. 1768

LRM $\bar{A}$ NĬĂ, Bory. In honour of M. Leman, a French botanist. Linn. 24, Or. 7, Nat. Or. Alga. This is rather a curious genus; the species are always found floating in fresh water rivers-fluviatiltsmĕdĭă, torulosă.

L $\overline{\mathrm{B}} \mathrm{MN}$, Linn. From lepts, a sca,e; in reference to the form of the plants. Linn. 21, Or. 1, Nat. Or. Pistiacea. Annual weeds, found floating in stag nant water, and known to most under the name of Duckweed-gībbă, minŏr, polyrhīă , trisulcă.

LRMON-GRAss, see Cymbopбgőn Schanänthüs.

LBNs, see Ervizm Lēns.

LENTICUIAR, lens, or pea-shaped.

ĹNTIGINōsüs, freckled, pimpled.

LiNTiL, see Ervūm Lëns.

LeocÄrp̌̌s, Link. From leios, smooth, and karpos, a fruit; in allusion to the smooth peridium. Linn. 24, Or. 9, Nat. Or. Fungi. This is found in clusters on rotten wood, and has the appearance of being varnished with vermilion. Synonyme: 1. Lycoperdon fragile-vernicōsŭs

Lволӧтц̌s, Persoon. From leon, a lion, and ous, an ear; in reference to the fancied resemblance in the corolla. Linn. 14, Or. 1, Nat. Or. Labiata. Fine ornamental plants. They require to be grown in loam and peat, and should have plenty of air to allow of their flowering in perfection. Cuttings root in sand, under a glass, in heat. $L$. nepetifolia requires the treatment commonly given to tender annuals. Synonymes; 1. Phlomis Leonurus. 2. P. Leonitis.

intermědiă . Orange 9, S. Ër. S. C. G. H. 1822 Leonūrús, i : : Searlet: 11, G. Ev. S. C. G. H. : 1712 nepetrefoliă : Orange : 9, S. A. E. Ind. : 1778 ofãtă, 2 . : Orange : 6, S. A. C. G. H. : 1713

LEŌNrĭč̌, Liñn. A bridged from Leontopetalon, which is derived from leon, a lion, and petaton, a leaf; because of the resemblance of the leaf of $\boldsymbol{L}$. leontopetalon to the impression of a lion's foot. Linn. 6, Or. 1, Nat. Or. Berberacea. Plants of little beauty, succeeding in any common soil, and increased by offsets, or seed's.

altăcă . . Yellow , 4, F. Tu. P. Siberia . 1829 Chrysogónum : Yellow :5, F. Tu. P. Levant: 1740 leontopetalon . Yellow . 4, F. Tu. P. Levant: 1597 odessãnă : : Yellow : 4, H. Tu. P. Odessa : 1828 vesicãriă : : Yellow : 5, F. Tu. P. Siberia : 1821

L RōNTódōn, Linn. From leon, a lion, and odous, a tooth; in allusion to the tooth-like divisions of the leaves. I.inn. 19, Or. J, Nat. Or. Composite. Herbaceous plants, of no value. They grow in any common soil, and increase freely by seeds, or divisions of the roots. Synonymes: 1. Prenanthes bulbosus. 2. Taraxacum ceratophorum. 3. T. glaucanthum. 4. T. bicolor. 5. Leontodon lividus. 6. L alpinus-alpīnūs, bessaräbǐcūs, bulbōsüs 1, cichoräcěus, ceratơphörüs 2, corniculätūs, eriopodŭs, erythrospērmũs, glaucănthös 3, glaucēscēns, lavigätüs, le ucānthơs 4 , nīgricāns, obovãtŭs, palūstrìs, serótíùts, Stevēnīi, $\operatorname{tar} \bar{a} x \tilde{u} c \bar{u} m$.

Leontopódī́m, $\boldsymbol{R}$. Brown. From leon, a lion, and pous, a foot; the heads of the flowers have been fancifully likened to a lion's foot. Linn. 19, Or. 2, Nat. Or. Compositce. This plant does best cultivated in peat soil; it is well suited for ornamenting rock-work, and is increased by seeds, or divisions of the roots. Synonymes: 1. vulgare, Gnaphalium Leontopodium.

helveticūm, 1. . Yellow . 6, H. Her. P. Austria • . 1776

LRonū Rǔs, Linn. From leon, a lion, and oura, a tail in allusion to the appearance of the spike of flowers. Linn. 14, Or. 1, Nat. Or. Labiata. The herbaceou species grow freely in common garden soil, and increase readily by seeds. The other kinds require to be treated similar to other hardy and half-hardy annuals and biennials. Synonymes: 1. L. crispus. 2. L. villosus, L. condeasatus. 3. L. heterophyllus. 4. L. altaicus, $L$. multifidus.

Cardfăcă . . Red . . 6, H. Her. P. Brituin .

crispuns, 1: Red : 7, H. Her. P. Siberia : 1658 


\begin{tabular}{|c|c|c|c|c|}
\hline LEO & . & & - & LEP \\
\hline 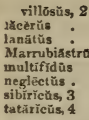 & $\therefore$ & $\begin{array}{l}\text { Purple } \\
\text { Pink } \\
\text { Pellow } \\
\text { : Purple } \\
\text { : Purplo } \\
\text { - Purple } \\
\text { : Red } \\
\text { Flesh. }\end{array}$ & 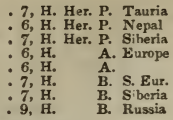 & 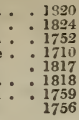 \\
\hline
\end{tabular}

\section{LropaRD's.BANB, see Dorōñ̌ç̄m.}

LEOPARn's-BANB, see Arnǐcă Dorönǐcă.

LBOPOLDINIÁ. Named by Martius, in memory of the late Empress of Brazil. Jinn. 21, Or. 6, Nat. Or. Palmacec. A fine palm, requiring similar treatment to other Brazilian palms.

pûlehră . . . Palm. Brazil . . 1825

Lxôtĭx, Hill. The meaning is not explained. Linn. 24, Or. 9, Nat. Or. Fungi. A genus of sery little interest, found on the ground in moist woods, or on trees-infundibuliformis, labrică, nänü.

LePĀNTHËs, Swartz. From lepos, bark, or lepis, small, and anthos, a flower; the plants of this genus have very small flowers, and grow upon the bark of trees. Linn. 20, Or. 1, Nat. Or. Orchidacea. This is one of the most pigmy of orchidex, with the habit of a Pleurothallis. It can only be grown under a bell-glass, among damp moss, in a cool part of the house.

tridentātă . . Yel. pur. . 1, S. Bpi. Jamaica

LEPBC нїIĬ, Willdenon. In honour of John Lepechin, a Russian botanist. Linn. 14, Or. 1, Nat. Or. Labiata. Rather pretty plants, growing well in a mixture of peat and loam, and increased by cuttings, planted under a glass. $L$. spicata require to be protected in frosty weather. Synonyme: 1 . Horminum caulescens.

chenopodifölí - Red • 7, H. Her. P. Siberin . 1818 spicâtă, 1 . . : Pa yel. : 7, F. Her. P. Mexico: : 1800 LeP1DĂGĂthIs, Willdenon. From lepis, a scale, and agathis, a ball. Linn. 14, Or. 2, Nat. Or. Acanthacee. This genus is nearly related to Justicia; it thrives well in any light rich soil; and cuttings of the young wood, planted in the same kind of soil, and placed under a slass, will root in a very short time.

cristătă

S. Her. P. E. Ind. . 1820

Lepĩñ̄y, R. Bronk. From lepis, a scale; in allusion to the shape of the pods, which appear like little scales. Linn. 15, Nat. Or. Cruciferce. Most of these plants are uninteresting, and none of them pretty. L. sativum is the well-known garden cress. They are all easily increased by seeds sown in the open ground. Synonymes: 1. Thlaspi campestre. 2. Cochlearia Draba. 3. Thlaspihirtum. 4. Lepidium graminifolium. 5. L. graminifotium.

sativüm - . White. 6 , H. A. Perara .1548

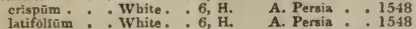

affīně, bonariensě, eampěstrě 1, cupęnsě, cardamiñěs, chalepensé, cordatum Cummingiānùm, cuneifoliam, densifloram, divari-

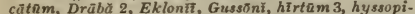
folinm, Ibērĭs 4, inctsâm, latifoliam, lineärè, lyrütüm, Menziêsī, micräntham, Nove-Hollīndiđ̄, olerācēum, perfoliatûm, Piscidiam, ruderäle, spinōsūm, subulütüm, suffruticơsam 5 , vesicäriam, virgiñicūm.

LzPIDOSPËRMă, Labillardière. From lepis, a scale, and sperma, a seed; in allusion to the scaly appearance of the seeds. Linn. 3, Or. 1, Nat. Or. Cyperacee. This plant is not possessed of much interest; it will grow in any kind of soil, and is increased by divisions.

gladiātă . . . A petal . . 7, Grass. N. Holl. . . 1819

LEPIDOTED, covered with scurfy dots.

LEPRART̃̆, Linn. From lepra, leprosy; the plants on which the species grow appear as if diseased with leprosy. Linn. 24, Or. 8, Nat. Or. Lichenes. Found most common on old pales, or rocks. They are generally of a yellowish east. $\boldsymbol{L}$. ochracea is one of the Lichens used in dyeing-chlorină, flävă, ochrücêu, virêscēns.

LEPROUs, covered with spots, or scales.

LEPROUSIY-sILVRRY, $\{$ covered with whits or silvery LEPROUSLY-siLVERY, $\left\{\begin{array}{l}\text { scales, or scurf, resembling } \\ \text { the leprosy. }\end{array}\right.$ Lrprousty-Tosgntosi, covered with shaggy down, having the appearance of leprosy.

LEP

LEP

Leptălētom, Decandolle. From leptaleos, slender; in allusion to the slender filiform leaves. Linn. 15, Nat. Or. Cruciferce. The seed of this annual species has only to be sown in the open ground. Synonyme: 1. Sisymbrium filifolium.

filifoliúm, 1 . Yellow . 6, H. A. Siberis * 1820

LEPTĀNDRX̆, Nuttull. From leptos, slender, and aner, an anther. Linn. 2, Or. 1, Nat. Or. Scrophulariacea. The plants of this genus are well adapted for ornamenting flower-borders, and are readily increased by divisions of the roots. Synonymes: 1. Veronica sibirica. 2. $V$. virginica.

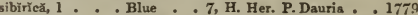
rirginied, 2 : White: 7 , H. Her. P.Virgiuis : 1714 incarnáta : : Flesh : 7, H. Her. P. Virginia : 1714

Leptāxthuัs, Michaux. From leptos, slender, and anthos, a flower; the tube of the flower is long and slender. Linn. 3, Or. 1, Nat. Or. Pontederacea. This species may be preserved in a peat soil, in a very moist situation; it is increased by offsets.

gramǐněŭs . . Yellow * 7, H. Aq. P. N. Amer. - 1823

Leptocarp. $\bar{x}$, Decandolle. From leptos, slender, and karpos, a fruit; in allusion to the slender fruitpods. Linn. 15, Nat. Or. Crucifere. The seed of this annual should be sown in the open ground early in spring. Synonymes: 1. Turritis Loeselii, Sisymbrium Loeselii-Loeselit 1.

Liptocāreưs, R. Brown. From leptos, slender, and karpos, a fruit. Linn. 22, Or. 3, Nat. Or. Restiacere. A mere weed, requiring to be grown in the greenhouse, and increased by divisions. Synonyme: 1. Schonodum tenax-lend $x$ 1

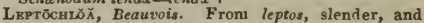
chloa, grass; in allusion to the slender habit of the plants. Linn. 3, Or. 2, Nat. Or. Graminece. This genus consists for the most part of annuals. They grow in any soil, and are increased bv seeds. Synonyme: 1. Poa chinensis.

cyuosuroides : A petal . . 5, Grass. E. Ind. * 1824 douningensta . * A petal * . 6, Grass. W. Ind. . . 1820 fliformis, 1. . A petal . . 7, Grass China . . 1820 procéră : : : A petal : 7, Grass. Brazil : : 1823

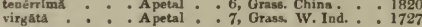

Lертомйrц̌, R. Brown. From leptos, slender, and meris, a part. Linn. 5, Or. 1, Nat. Or. Sintalaced. Ornamental plants, succeeding well in a soil composed of loam and peat in equal parts ; and cuttings of the ripened wood will ront readily in sand, under a glass. Synonyme: 1. Thesium drupaceum.

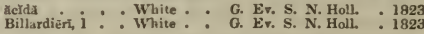

Lrpтōniтuัs, Agardh. From leptos, slender, and mitus, a thread. Linn. 24, Or. 7, Nat. Or. Alga. These plants are found floating in the water. They consist of very slender intertangled filaments, from the extreme fineness of which the generic name is contrived-clavūtūs, läctêùs, minutīssimûs. nānūs.

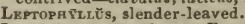

LEPTösīpHōn, Bentham. From leptos, siender, and siphon, a tube; in allusion to the slenderness of the tube of the corolla. Linn. 5, Or. 1, Nat. Or. Polemoniacer. These are very elegant annuals, well worthy of a place in every flower-border. The seed should be sown in a peat soil. Seeds sown in autumn will flower in April and May, and seed sown in spring will produce flowers in autumn.

androsăcễu . . Blue wht. 8, H. A. California . 1833 densiflorüs. : : Purple. 6, H. A. California : 1833 corólla-albă: "White. 6, H. A. California : 1833

Leptospī.ryēm, Forster. From leptos, slender, and sperma, a seed; in allusion to the small narrow seeds. Linn 12, Or. 1, Nat. Or. Myrtaces. All the plants of this genus are well worthy of extensive cultivation, as well for the neatness of their foliage as for the beauty of their blossoms. They thrive best in a mixture of loam, peat, and sand, and cuttings root in sand, under a glass; they may also be raised from seeds, but plants from cuttings are preferable, as they flower when young, and those raised from seeds do not flower till they become large. Synonymes: 1. Billotia flexuosa. 2. L. grandifolium. 3. B. maryinata. 4. L. stellatum. arachnoideüm. White. 6, G. Ev. S. N.S. W. 1795 attenuătúm : White. . 6, G. Ev. S. N. S. W. : 1795 


\begin{tabular}{|c|c|c|c|c|}
\hline LEP & & & L & Es \\
\hline 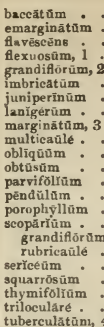 & 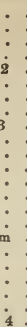 & $\begin{array}{l}\text { White. } \\
\text { White. } \\
\text { White. } \\
\text { White. } \\
\text { White. } \\
\text { White. } \\
\text { White. } \\
\text { White. } \\
\text { White. } \\
\text { White. } \\
\text { White. } \\
\text { White. } \\
\text { White. } \\
\text { White. } \\
\text { White. } \\
\text { White. } \\
\text { White. } \\
\text { White. } \\
\text { White. } \\
\text { White. } \\
\text { White. } \\
\text { White. }\end{array}$ & $\begin{array}{l}\text { 6, G. Ev. S. N. Holl. } \\
\text { 6, G. Ev. S. N. Holl. } \\
\text { 6, G. Ev. S. N. Holl. } \\
\text { 6, G. Ev. S. N. Holl. } \\
\text { 6, G. Ev. S. N. Holl. } \\
\text { 6, G. Ev. S. N. Holl. } \\
\text { 6, G. Ev. S. N. Holl. } \\
\text { 6, G. Ev. S. N. Holl. } \\
\text { 6, G. Ev. S. N. Holl. } \\
\text { 6, G. Ev. S. N. Holl. } \\
\text { 6, G. Ev. S. N. Holl. } \\
\text { 6, G. Ev. S. } \\
\text { 6, G. Ev. S. N. Holl. } \\
\text { 7, G. Ev. S. N. Holl. } \\
\text { 6, G. Ev. S. N. S. W. } \\
\text { 6, G. Ev. S. N. Zeal. } \\
\text { 7, G. Ev. S. Pt. Jack. } \\
\text { 6, G. Ev. S. N. S. W. } \\
\text { 6, G. Ev. S. N. S. W. } \\
\text { 7, G. Ev. S. N. Holl. } \\
\text { 6, G. Ev. S. N. Holl. } \\
\text { 6, G. Ev. S. N. Holl. } \\
\text { 6, G. Ev. S. N. Holl. }\end{array}$ & $\begin{array}{r}\cdot 1790 \\
: 1818 \\
: 1787 \\
: 1823 \\
: 1810 \\
: 1823 \\
: 1790 \\
: 1774 \\
: 1820 \\
: 1824 \\
: 1800 \\
: 1820 \\
: 1789 \\
: 1800 \\
: 1772 \\
: 1817 \\
: 1817 \\
: 1818 \\
: 1824 \\
: 1800 \\
1816\end{array}$ \\
\hline
\end{tabular}

Lrptostв̄цxă, D. Don. From leptos, slender, and stelma, a crown. Linn. 19, Or. 2, Nat. Or. Composita. This is a strong-growing plant, attaining the height of seven or eight feet; the flowers are produced in large panicles. It will grow well in a rich light soil, protected from severe frosts, and may be increased by seeds, or by separating the roots.

māxĭmūm . . Whitsh. . 9, F. Her. P. Mexico . . 1827

Leprostrōm ă, Fries. From leptos, thin, and stroma, a layer; in allusion to the thin consistence of the species. Linn. 24, Or. 9, Nat. Or. Fungi. These species are found on the stalks of ferns, and on the leaves of some plants-caricinūm, filicinūm, scirpinum, Spirāed.

LẾpTōtes, Lindley. From leptos, slender; in allusion to the leaves. Linn. 20, Or. 1, Nat. Or. Orchidacee. This is a pretty little species, growing rather freely among broken potsherds, decayed vegetable matter, and moss, and may be increased by divisions.

bǐcőlör . . . . Wlit red . 4, S. Epi. Brazil . . 1831

LePYRödŭĂ, R. Bronn. From lepyrodes, scaly; because the bracteas are within the scales of the spike. Linn. 22, Or. 3, Nat. Or. Restiacer. This plant requires the protection of the greenhouse. A mixture of light sand, loam, and peat, in equal portlons, suits it well, and it may be increased by dividing the roots.

grăcìlı̆s . . A petal . . 5, Grass. N. Holl. . . 1824

LĒRĬ. Named by Decandolle, in compliment to his friend M. Leri. Linn. 19, Or. 2, Nat. Or. Composite. Mere biennial weeds. They are natives of the West Indies. Synonyme: 1. Tussilago nutans-älbīcāns, nūtäns 1, primillü.

LËsK ̌̌̆ , Hednig. In honour of N. G. Leske, professor of natural history at Marburg. Linn. 24, Or. 5, Nat. Or. Fungi. A genus of mosses, some. times united to Hypnum, which it very much re. sembles in habit. They are found during spring and summer on the trunks of trees, \&c. Synonymes: 1. Hypnum atrovirens, attenuatum. 2. Pterogonium rotundifolium. 3. Hypnum medium, inundatum-complanātă, dendrō̃dēs, incurvātă 1 , iuläcĕă 2, polyānthă, polycārpă 3 , pulchêlla, rufëscēns, sericéă, trichomanoidés.

Lrspedēză, Michaux. In honour of M. Lespedez, once governor of Florida, and a great patron of botany. Linn. 17, Or. 4, Nat. Or. Leguminosie. Very showy plants when in flower. The herbaceous kinds grow $w \in l l$ in peat borders, and are increased by dividing the roots in spring. The shrubby kinds must be grown in a mixture of sand and peat ; and cuttings of the young wood root readily in sand, under a glass. The seeds of the annual kinds should be sown in a peat border, in a sheltered situation. Synonymes: 1. Anthyllis cuneata. 2. Hedysarum junceum. 3. L. hirtu. 4. L. divergens. 5. L. reticulata. 6. L. sessiliflora.

angustifolia . Pa pur. . 6, H. Her. P. N. Amer. 1800 cavitáa eríocārpă, 1: : Violet. : 7, G. Ev. S. Nepal : 1819

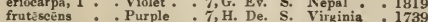
frutsscens : Purple : 7, H. De. S. Viruinia : 1739
glomerăã jüncé, 2.: White. 7, H. Ev. S. Siberia: : 1776 polyståchy̆ă [i White. : 7, H, Her. Y. N. Amer. : 1789

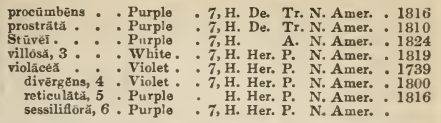

Lessērtǐ Ă, Decandolle. In honour of the Baron Benjamin Delessert, of Paris, a most distinguished promoter of botany, and author of the Icones, published at Paris in 1823. Linn. 10, Or. 10, Nat. Or. Leguminosa. The shrubby and herbaceous kinds are elegant little plants, requiring the same treatment as Snainsonia. The annual species should be sown in pots early in spring, and placed in the greenhouse, and when about two inches high, to be planted singly into small pots, and shifted into larger ones as they grow.

ănnŭă. - - Red • . 6, G. A. C. G. H. . 1731 annularis - P. G. A. G. H. 173 brachystächya : Purple :7, G. Ev. S. C. G. H. : 1826 diffús̆ : : Red * 7, G. Tr. A. C. G. H. : 1792 falciformis : Purple : 7, G. Ev. S. C. G. H. : 1826

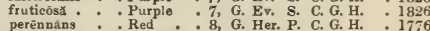
procúmbëns : Purple : 6, G. Her. P. C. G. H. : 1753 pülchră : : Red *: 5, G. Ev. S. C. G. H. : 1817

LEsTiBupēsIx, Thouars. In honour of F. J. Lestiboudois, a Flemish botanist. Linn. 5, Or. 1, Nat. Or. Amarantacea. These plants are not pos. sessed of much beauty. A light rich soil suits all the species well. Synonyme: 1. Celosia panicuiata.

paniculată, 1 . Pa. yel. * 7, S. B. Jamaica 1733 trigy̆ud : : : White.: 8 , S. B. Senegal.
virgată

Lеттs̄̄m Lettsom, M.D., F.R.S., a famous English natu ralist, and author of a work on the Means of Preserving Objects of Natural History in 1772. Linn. 13, Or. 1, Nat. Or. Ternstromiaced. A very beau tiful shrub. It must be grown in the stove, in the same kind of soil as recommended for Leptomeria.

tomentôsă . . White . S. Ev. S. Peru . . 1823

LeTruce, see Lactũcă.

LrUCADẼNDRōx, Linn. From leukos, white, and dendron, a tree; in allusion to the white leaves. Linn 14, Or. 2, Nat. Or. Proteacea. A genus of splendid evergreen shrubs, with handsome foliage, and heads of yellow flowers. L. argenteum, or the Silvertree, grows to the height of fifteen or twenty feet, with beautiful silky leaves; it is on that account admirably adapted for ornamenting conservatories. They grow best in loam and peat, with a small portion of sand, provided the pots are carefully drained, and not overwatered. Cuttings of the ripened wood will root readily planted in sand, under a glass. Synonyme: 1. Protea stellaris. adscēndëns : Yellow ämǔlüm : Yellow angustätũm - Yellow argèntéūm : Yellow buxifolium : Yellow cinereúm : : Yellow comósūm: : Yellow concinnuim : : Yellow concoilrr - Y Yellow corymbơsūm : Yellow decôrûm - Y Yellow decūrrëns : - Yellow floridum : Y Yellow fusciflórủm, 1. - Yellow glâbrûm - - Yellow Globulăriá: : Yellow grandifiōrūm : Yellow
imbrieătūm : Yellow imbrieátūm : Yellow Levisãnuัs : : Y Yellow linifoliñm : Yellow marginātûm * Yellow
7, G. Ev. S. C. G. H. oaudătūm . : Yellow ovālè . Y Yellow plistys pèrmûm . Yellow plumósūm : . Yellow pubëscéns . . Yellow retũsûm . . Yellow salignûm • - Yellow seábrúm : : Yellow 7, G. Ev. S. C. G. H. 7, G. Ev. S. C. G. H. 6, G. Ev. S. C. G. H. 8, G. Ev. S. C. G. H. G. Ev. S. C. G. H. 5, G. Ev. S. C. G. H. 7, G. Ev. S. C. G. H 5, G. Ev, S. C, G. H G. Ev. S. C. G. H 5, G. EV. S. C. G. H 4, G. Ev. S. C. G. H. G. Ev. S. C. G. H G. Ev. S. C. G. H 4, G. Ev. S. C. G. H. 5, G. Ev. S. C. G. H. 5, G. Ev. S. C G. H. 4, G. Ev. S. C. G. H G. Ev, S. C. G. H G. Ev. S. C. G. H 4, G. Ev. S. C. G. H. 5, G. Ev. S. C. G. H. 5, G. Ev. S. C. G. H. 5 , G. Ev. S. C. G. H. 5, G. Ev. S. C. G. H. 7, G. Ev, S. C. G. H. 4, G. Ev. S. C. G. H 5, G. Ev. S. C. G. H 5, G. Ev. S. C. G. H.
G. Ev. S. C. G. H. 5, G. Ev. S. C. G. H. : 181

1789

177 1789 1693 i812 1800 1774 181 1800 1774
1790 1790 1812 1795 serícéum $\cdot$ Yellow 


\begin{tabular}{|c|c|c|c|}
\hline LEU & \multicolumn{3}{|c|}{ LEU } \\
\hline spatulatūm & - Yellow & . 5, G. Ev. S. C. G. H. & .1818 \\
\hline squarrōsūm & - Yellow & G. Ev. S. C. G. H. & .1824 \\
\hline strīetũm . & - Yellow & - 6, G. Ev. 8. C. G. H. & - 1795 \\
\hline tōrtūm : * & - Yellow & - 6, G. Ev. S. C. G. H. & - 1790 \\
\hline $\begin{array}{l}\text { uligibosūm } \\
\text { venơsum }\end{array}$ & $\begin{array}{l}\text { : Yellow } \\
\text { Y Yellow }\end{array}$ & $\begin{array}{l}\text { 5, G. Ev. S. C. G. H. } \\
\text { 5, G. Ev. S. C. G. H. }\end{array}$ & $\begin{array}{l}1795 \\
.1816\end{array}$ \\
\hline virgâtūm . & . Yellow & - 6, G. Ev. S. C. G. H. & - \\
\hline
\end{tabular}

LeücĀs, Burmann. From leukos, white; because o the downy whiteness of the flowers. Linn. 14, Or. 1, Nat. Or. Labiata. These plants are not possessed of much beauty. They will grow freely in any common soil. Synonymes: 1. $\boldsymbol{L}$. Plunkenetii. 2. Phlomis chinensis. 3. P. zeylanica. 4. P. martinicensis.

biflöră . White . 8, G. A. Ceylon *. 1819 cephalötês: : White: 8, s. A. E. Ind. : 1818 clinênsis, 2 : White: 7 , S. A. China: : 1820 clinẻnsis, 2 : : White : 7, S. A. China : : 1820

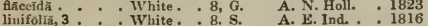
aspera 1 , indica, martinicensis 4, urticafolia, zeylanica. LeucocArpŭs, G. Don. From leukos, white, and karpos, a berry; in allusion to the white fruit. Linn. 14, Or. 2, Nat. Or. Scrophulariacec. A curious little plant, growing best in peat and loam. Synonyme: 1. Mimulus perfoliatus.

alātŭs, 1 . . Yellow . F. A. Vera Cruz. . 1830

LRUcocŏR $\breve{Y} \overline{\mathrm{B}}$, Lindley. From leukos, white, and koryne, a club; because of the white sterile anthers. Linn. 3, Or. 1, Nat. Or. Liliacer. These plants will succeed well in a light sandy soil, and increase by offsets from the bulbs, or by seeds. Synonymes 1. Brodica alliacea. 2. B. ixioides.

alliācę, 1. . White - F. Bl. P. Chile . 1825 ixioidès, : Lilac. 10, F. Bl. P. Chile: 1821 onurătă . : White : 8, F. BL. P. Vulparaiso. 1826

Lвûcódōn, Schweigger. From leukos, white, and cdous, a tooth; on account of the colour and shape of the peristome. Linn. 24, Or. 5, Nat. Or. Musci. A species of moss, with long stems, creeping over stones, the bark of trees, \&c. Synonyme: 1. Dicranum sciuroides-sciuroìdës 1 .

Leucŏjढ̆, Linn. From leukos, white, and ion, a violet; in reference to the colour of the flower ; whence the English name, Snow-flake. Linn. 6, Or. 1, Nat. Or. Amaryllidaced. Hardy bulbs, growing to the height of twelve or eighteen inches, and producing spikes of pretty white flowers, like the Snow-drop. Sandy loam suits them best, and they are increased by offsets from the bulbs.

ativum

pulchêllūm

Vërnúm

White.

5, H. B1. P. England

carpăthicūm

White

White. 4, H. Bl. P.

White. 2, H. Bl. P. C.r. M.

1596

Lrucopōgōn, R. Bronn. From leukos, white, and pogon, a beard; because of the white hairs with which the limb of the corolla is bearded Linn. 5 , Or. 1, Nat. Or. Epacridaced. These plants are well worth a place in every greenhouse. They will grow well in an equal mixture of sandy loam and peat, with the pots well drained, and care must be taken never to overwater them. The tops of the very young shoots, taken off, and planted in sand, under a glass, will root freely. Synonymes: 1. Styphelia obovatus. 2. S. Richei. L. parviflorus.

amplexicaũlìs . White . G. Ev, S. N. S. W. . 1815 apprëssŭs : White. 6, G. Kv. S. N. Holl. : 1820 collinuัs. White. 5, G. Ev. S. V D. L. 1824 Whito S, G. Ev. S. N S. W. White G, G. Ev, S N Holl juniperoides : : White. : 5, G. Ev. S. N. S. W.

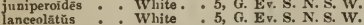
microphyllŭs: : White. :6, G. Ev. S. N. Holl obovătǔs, 1 : : White. polystaichy's : White: setigerar : White. 6, G. Ev. S. N. Holl.
6, G. Ev. S. N. Holl. 6, G. Ev. S. N. Holl.

nearly allied. Synonymes: 1. Protea candicans. 2. Leucodendron grandiflorum.

attenuảtûm - Yellow . 6, G. Ev. S. C. G. H. candícāns, 1 : Yellow conocārpûm : Yellow elliptrcum $:$ Yellow formósưm : : Yellow grandiflörüm, $\dot{2}$ : Yellow lyponpyllum . : Yellow lineáre : Yellow mèdĭum : : Orange parile : : Yelliow pătǔlúm : : Yellow puběrūm : : Yellow spatulătũm : Yellow tomentósüm : : Yellow
tōttúm : Yellow 8, G. Ev. S. C. G. H. 6, G. Ev. S. C. G. H. - 1774

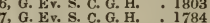
7, G. Ev. S. C. G. H. : 1784
6, G. Ev. S. C. G. H. 1800 6, G. Ev. S. C. G. H. : 1787 7, G. Ev. S. C. G. H. : 1774 7. G. Ev. S. C. G. H. 1794 8, G. Ev. S. C. G. H. 5, G. Ev. S. C. G. H. : 1774 6. G. Ev. S. C. G. H. : 1825 6, G. Ev. S. C. G. H. : 1789 LRUCORHĨz̆, white-rooted.

LвU costёммӑ, Bentham. Derived from leukos, white, and stemma, a crown; on account of the white downy seeds. Linn. 4, Or. 1, Nat. Or. Compositce. This is a very fine species, well deserving of exten. sive cultivation. It may be referred to Elichrysum for culture and propagation. Synonyme: 1. Eli. chrysum vestitum.

vestítüm, 1 . . White . . 8, G. Ev. S. C. O. H. . 1774 LEUcōx Y̌Lơ, white-wooded.

LEUZ $\overrightarrow{\mathrm{B}}$. Named by Decandolle, in honour of his friend De Leuze. Linn. 19, Or. 3, Nat. Or. Composita. These are dwarf ornamental plants, seldom exceeding nine inches in height, and producing large purple flowers. Any common garden soil suits them, and they may be increased by divisions of the roots, or by seeds. Synonymes: 1. Cnicus carthamoides. 2. Centaurea conifera. 3. Cirsium salinum, Centaurea altaica.

- P. Siberis. carthrmoides, i : Purple : 8, H. Her. P. N. Holl. : 1821 coniferă, 2. Purple 7. H Her, P. S Eur. 1693 salina, $3^{2}:$ : Purple : 6, H. Her. P. Siberia : 1817

Lzvistĩcōm, Koch. From levo, to assuage; the plant is said to relieve flatulency. Linn. 5, Or. 2, Nat. Or. Umbelliferc. This plant succeeds well in common garden soil, and is easily increased by seeds. Synonyme: 1. Ligusticum levisticum.

officinãlé, 1 - Pa. yel. . 6, H. Her. P. Italy • 1596

LRwīš̃, Pursh. In honour of Captain M. Lewis, who accompanied Captain Clarke to the Rocky Mountains. Linn. 13, Or. 1, Nat. Or. Cactacee. Light loam and brick rubbish is a good soil for this plant, and it may be increased bv dividing the roots, or by seeds.

redivivã . . Rose . . H. Her. P. N. Amer. . 1826

LEYSs̄̄RĂ, Linn. In honour of Frederick William Leysser, a famous German botanist. Linn. 19, Or. 2, Nat. Or. Composita. Ornamental plants, requiring to be grown in a peat soil, mixed with a little loam; and cuttings, planted in the same kind of soil, under a glass, will root without difficulty. Synonyme: 1. Stahelina gnaphalvides.

ciliata - Orange \& 8, G. Ev. S. C. G. H. gnaphaloīdés - Orange - 8, G. Ev. S. C. G. H. : 1774

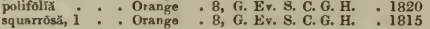

Lвтскят̄̄RIA. Wallich named this genus in honour of his friend William Leycester, once chief judge at Bengal, a munificent and zealous patron of horticulture. Linn. 5, Or. 1, Nat. Or. Caprifoliacea. This is an elegant and most beautiful shrub when in flower, from the contrast of the deep green hue of its stem and leaves, with the purple colour of the large bracteas and the berries. A light soil suits it best, and it is readily increased by cuttings taken off in autumn or spring, or by seeds. It is well adapted to the front of shrubberies. It will require the protection of a mat in winter.

formōsä. . . . Wht. pur. 8, H. Ev. S. Nepal . . 1824

LIÃTaÍs, Schreber. The meaning of the name is not known. Linn. 19, Or. 1, Nat. Or. Composita. These are very charming little plants, with spikes of purple or pink flowers. It is best to take them out of the border in winter, and preserve in pots of sandy loam and peat, and in spring they may be planted out in the open border in the same kind of soil. Young plants are easily obtained by divisions. [ 184 ] Linn. 4, Or. 1, Nat. Or. Proteacea. An interesting and terminal heads of yellow tlowers; for culture and propagation, see Protea, to which this genus is 


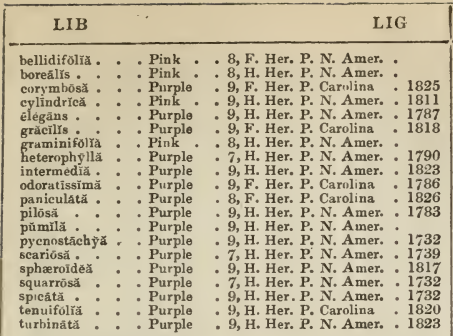

I, İĔR, the inner bark.

LiBẼRTİ, Sprengel. In compliment to Mademoiselle M. A. Libert de Malmédy, a Belgian lady, to whom the French Flora is indebted for a great number of new species. Linn. 16, Or. 1, Nat. Or. Iridacea. This ornamental species thrives well in an equal mixture of loam and peat, and may be increased by dividing the roots. Synonyme: 1. Sisyrinchium formosum.

formōsă. . . . White. . 5, F. Her. P. Chiloe . . 1831

Lїсй, Schrader. The meaning is not explained. Linn. 24, Or. 9, Nat. Or. Fungi. A species about the size of a pin's head, fuund chiefly on rotten wood-fragiformis.

LichīNĂ, Agardh. Derived from Lichen; on account of the resemblance. Linn. 24, Or. 7, Nat. Or. Alga. By some botanists, this genus has been referred to the Lichens, and by others they are said to be Alga in one stage of their existence, and Lichens in another-confinis, pygmäă.

Lichtensteĩix, Chamisso. In honour of M. Von Lichtenstein, a celebrated German botanist, and professor of medicine at Berlin. Linn. 5, Or. 2, Nat. Or. Umbelliferce. Pretty plants, with blue
flowers. They grow well in sandy loain, and young plants are readily obtained from seeds. Synonyme: 1. Cymation lavigatum.

lævigătă, 1. - Blue - . G. Her. P. C. G. H. . 1824 undulātă : : Blue : 7 , G. Her. P. C. G. H. : 1814

LrcuĀră, Rumphius. The name of the species in the Macassar language. Linn. 6, Or. 1, Nat. Or. Palmacea. These are very beautiful palms, requiring a sandy loam and strong moist heat to grow in. In Macassar, they make tobacico-pipes of the narrow leaves, while the middle broad one is used for wrapping up fruit, \&c.

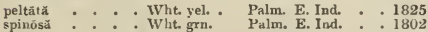

Lin, the calyx which falls off from the flower in a single piece.

LiпвёскіA, Berger. In honour of E. G. Lidbeck, an acute Swedish botanist. Linn. 19, Or. 2, Nat. Or. Composita. Urnamental plants; for culture and propagation, see Leyssera. Synonyme: 1. Cotula quinqueloba.

lobatit, 1 • . Yellow . 5, G. Ev. S. C. G. H. 1800 pectinată : Yellıw : 5, G. Ev. S. C. G. H. : 1744

Lignтғооттй, L'Heritier. In honour of the Rev. J. Lightfoot, author of the first Flora Scotica. Linn. 5, Or. 1, Nat. Or. Campanulacea. Ornamental under shrubs, growing freely in a mixture of loam and peat; and young cuttings root readily in the same kind of soil, under a glass. Synonymes: 1. tenella. 2. Campanula fruticosa, interrupta.

Loddigēsĩ, 1 - Pa.blue . 7, G. Ev. S. C. G. H. 1822 oxyencenidés: : Blue : 7, G. Ev. S. C. G. H. : 1787 subulātă, 2 : : Blue : 8, G. Ev. S. C. G. H. : 1787

L1GNōsŭs, woody.

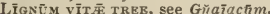

LígŭL.̆, the membrane at the top of the petiole of grisses.

LIGUlATE, strap-shaped.

Ligêsticồ, Koch. So named because of some of the species growing in Liguria. Linn. 5, Or. 2, Nat. Or. Umbelliferce. Hardy herbaceous and biennial plants not worth cultivating. They will grow in any soil, and are increased by seeds. Synonymes: [185]

LIG

LIM

1. Sison peregrinum. 2. Cnidium pyrenaicum. 3 Selinum Seguieri-alütūm 1, baleärĭcūm, cāndücäns,

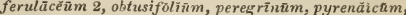
scóticūm, Seguiēri 3, Sprengēliž.

Ligūstrūx, Linn. From ligare, to tie; in allusion to the very flexible branches. Linn. 2, Or. 1, Nat. Or. Oleacece. These plants are well suited for making hedges, especially the evergreen varietie of $L$. vulgare. L. lucidum, and its variety, if grown in the open air, will require protecting in winter they are easily increased by cuttings. Synonyme: 1. $\boldsymbol{L}$. nepalense.

lūeiัduีm floribūndủm spicătūm, 1 vulgăré

chlornearrpüm

leucocārpûm semperrvirêns variegătûm .

White White.

White.

White.

White.

White.

White.

IVhite

White.

White

I1.Ac, see Syrīngă.

Līıīo M, Tournefort. Derived from the Celtic word $l i$, signifying whiteness; on account of the beau tiful $w$ hite flowers of the original species. $L i n u$. 6, Or. 1, Nat. Or. Liliacece, This is a fine orna mental and well-known genus; most of the species succeed in a light rich soil, but the American spe cies should be grown in peat. All the kinds are readily increased by offsets from the bulbs. In Kamtschatka, the root of $L$. Pomponium is cultivated the same as the potato is in this country Synonymes: 1. L. fulgens. 2. L. autumnale. 3. L. speciosissimum. 4. L.lancifolium. 5. L.lancifoliumroseum. 6. L. pennsylvanicum.

Andinūm . . Searlet . 7, H. Bl. P. N. Amer. - 1819 trosanguineúm, 1 Drk. red 7, G. B . P. Japan 7 F B P. J Pan aurantiacūm * Orange * 7, F. Bl. P. Japan: Drk. or. Alôré-plēnō . Drk. or. minŭs

varie_ātūm

bulbîférūm

minŭs

umbellâtūm

variegŭtūm .

Buschiãnūm

canadense

rubrūm

candǐdulm

spicät ûm

striâtūm

varięãtūm

Caroliniān ûm, 2

Catesbēi

Chalcedŏnīeủm

concőlór

corûseâns

crocēūm

eximiủm, 3

gläbrum

japuñ̌cūm

longifolinum

Martigon

albo-plēnố

pubésceens

sepālis - .5lbîs

sepi-is-plurïm

monadelpliûm

Nepulēnsé

penduliflórúm

peregrinūm

philadêlphỉeûm

umponiūm

flörè-plennó

pŭnilitim

pyrrenăicüm
floré-plén

speciั่-ūm, 4

punctātūm,

spectābille, 6

tenuifơlīūm

Thunbergiānūm

Orange

6, H. Bl. P.

Drk, or. 6 , H. Bl. P.

- 6, H. Bl. P. Ital

. 6, H. Bl. P.

Orange - 6, H. BI. P. Italy

Orange 6, H. Bl. P.

6, H. B1. P. Siberis

Lrt. or.

White

White.

6, H. Bl. P. Siberia.

7, H. Bl. D. N. Amer. - 162

7, H. B1. P. N. Amer. * 1629

6 , H. Bl. P

White. 6, H. Bl. P.

White. $6, \mathrm{H}, \mathrm{Bl}, \mathrm{P}$

Orange . 7, H. Bl. P. N. A mer.

Scarlet 7, H. Bl. P. China

7, H. Bl. P. China

7, H. Bl. P. China

Red

Searlet

, G. Bl. P.

rite

Orange

White

Orange

Thite.

Purple

White

Oringe

White

Purple

White

- 7 , H. Bl. P. Nepal

Cupper col. 6, H. Bl. P. N. Amer.

White. 6, H. Bl. P. C. G. H.

Seirlet 7, H. BI. P. N. Ame

Resl

Red 5, H. Bl. P.

Scarlet:7, H. Bl. F. Dauria

Drk, or. : 7, H. Bl. P. Pyrenees

Yellow . 7, H. BI. P

Y-llow - 7, H. Bl. P. Siberia

Orange

8, H. B'. P. Japan

Wlit. spot. 7, G. Bl. P Japan

Lat. or $6, \mathrm{H}, \mathrm{Bl}$ P. Duria

Searlet 6, H. Pl. P. Siberia

Or.scar, 7, G. Bl. P. Japin

Orange: 7, H. Bl. P. Clina

LIIY, see $L$ Lĭĩum.

LILy нуаспмт, see Scīllă Lĭľ̌o-hyacīnthŭs.

LILY-OF-THE-vAI1.EY, see Convallärĭa.

Li1. PINк, see Apluyllünthēs.

LILY THORN, see Catesbäa.

Limatr, having an expanded end; or being bordered by something. 
L1Mn, the border of a flower.

LiMs, see Cîtrŭs Limöniăm.

LiMR-TREe, see Tiliā.

LİßĚC $\Re$, Linn. From loimos, a pest; on account of the supposed poisonous qualities of the plant. Linn. 7, Or. 3, Nat. Ur. Illecebracee. A mixture of sandy loam and peat suits this species best; and cuttinge root readily under a glass.

africăuūm . . . White. . 6, G. Her. P. C. G. H. . 1774

LIMNĀNthēs, $R$. Bronn. From limne, a marsh, and anthos, a flower; in allusion to the habitat of the plant. Linn. 10, Or, 1, Nat. Or. Limnanthacee. This plant is well deserving of a place in every collection, on account of the elegance and beauty of its Howers, which are slightly fragrant. It requires to be grown in a moist and shady situation, and it is increased by seeds, which ripen pretty freely.

Dougläs! . . Wht. yel. . H. Tr. A. Californ. . 1833

LimNőchĂrัs, Bonpland. From limne, a pool, and chairo, to delight; in allusion to the habitat of the species. Linn. 13, Or. 1, Nat. Or. Commelinacec. Handsome aquatic plant8, of easy culture in a tub or cistern of water, and increased either by runners or seeds.

Humboldtil - Yellow . 5, S. Aq. P. B. Ayres . 1831 Plumierr : : Pa. yel. : \%, S. Aq. P. Brazil : 1822

LIмбัмі̆ the Citron. Linn. 10, Or. 1, Nat. Or. Alrantiacea. This genus is nearly allied to Citrus. The plants hould be grown in a mixture of loam and peat, with a little rotten dung added; and cuttings will root in sand, under a glass, plunged in a moist heat.

australls : : White.: : G. Ev. T. N. Hull. 1830
citrifolla :

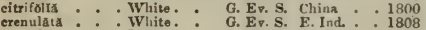
parviflora : . White. G. Ev. S. Clini

ocsndèns : : White. : G. Ev, cl. Clina

1800

Lrmogẽură, Linn. From limus, mud; in allusion to the habitation of the species; whence the English name Mudwort. Linn. 14, Or, 2, Nat. Or. Scrophulariucea. The seeds of this sub-aquatic should be sown near a pond or rivulet.

aquẽtǐcă . . . Flesh . . 8, H. Aq. A. Britain

Liмరsuัs, muddy, growing in mud.

LimpIDǓs, clear, transparent.

LiNXNThưs, Bentham. From linon, flax, and anthos, a flower. Linn. 5, Or. 1, Nat. Or. Polemoniacere. An ornamental annual, succeeding well when sown in the open border in spring.

dichơơmŭ . . Pink . . H. A. Californ. . 1833

Lixĩriñ, Tournefort. From linum, flax; on account of the similarity of the leaves. Linn. 14, Or. 2, Nat. Or. Srrophulariacea. This genus for the most part consists of annuals, well adapted for ornamenting rock-work. L. triornithophora is remarkable for the form of its flowers, which bears some little resemblance to three little birds seated in the spur. They thrive best in a light sandy loam, and are readily multiplied by seeds. Synonymes: 1. speciusa. 2. Antirrhinum lanigerum. 3. A. fruticans. 4. A. linarioides. 5. spurium. 6. A. Linaria. 7. A. odorum. 8. strictum. 9. L. striata. 10. Antir. lusi. tanicum, pedunculatum.

acutilobă. Purple \& H. Ev. Tr. Siberia . 1825 egrptiacă : : Yel. pur. : 7, H. A. Equpt : 177 . aquitrlloba : Purple : 6, H. Ev. Tr. Sardinia: 1829 alpina . : Blue * 7. F. Ev. Tr.Austria . 1570 alsiniforir : Blue : $6, \mathrm{H}$. A. Corsica: : 1824 amethy,tină : Blue yel. : 7, H. Tr. A. Spnin : 1728

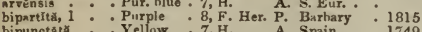

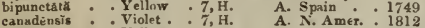

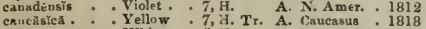
chalepensis: : White. :6, H. A. Levant : 1680 circinatas: : Yellow : 6, N. Africa : 1833 cirrhosa : : Pablue : 7, H. Tr. A. Egypt : 1771

erutáceă : : Violet : : 7, H. H. Ev. Tr. Enuland albalaria : : Whitet: : 5, H. Ev. Tr. Enyland variegáĭ : : Violet: : 6, H. Ev. Tr. Gardens dalmátică : Yellow : 6, F. Er. s. Levant. dealbatu, 2 . Yellow 1731 delphínioides : Blue : B. H. A. Russial : 1820 diffü : : 7, H. A. Spain : : 1826

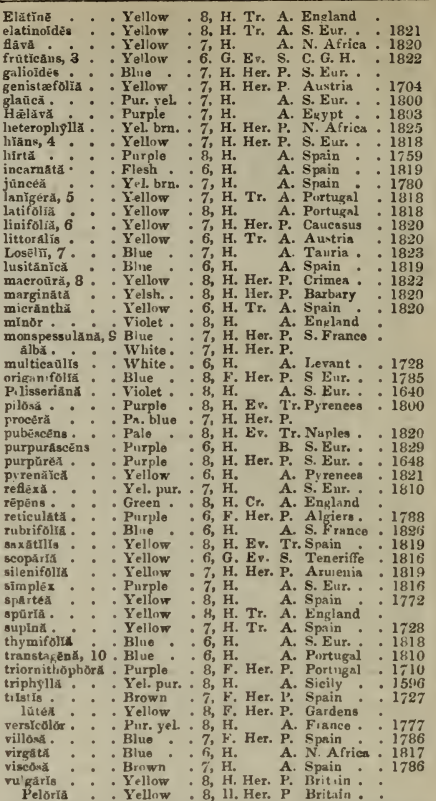

Liscō $Y$ X, Linn. Probably from Lincon, the name of some botanist. Linn. 5, Or. 2, Nat. Or. Bruniaced. Ornamental plants; for culture and proparation, see Diosma. Synonymes: 1. Divsma cuspidata. 2. deusta.

alopecurolded . White. . 5, G. Ev, S. C. G. H. 1816

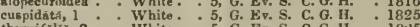
thymifolra, 2 : : White : 5, G. Ev. S. C. G. H. : 1825

LimpĒrNĭĂ, Linn. In honour of F. B. Von Lindern, M.D., of Strasburg, a botanical author. Linn. 14, Or. 2, Nat Or. Scrophulariaced. The seed of this plant has only to be sown in the flower borders.

Pyxidarín . . Blue . 7, H. A. S. Eur. . . 1789

LiNDs $\bar{A} \tilde{A}$, Dryander. In honour of $\mathrm{Mr}$. Lindsey, an

English writer on the germination of mosses. Linn. 24, Or. 1, Nat. Or. Polypodiacen. A very handsome genus of Ferns, which will grow well in an equal mixture of sandy loam and peat, and it may be increased by divisions of the roots, or by seeds, which must be sown on a pot of earth, watered, and covered over with moss, till they make their appearance.

falcatz. . Brown . 5, S. Her. P. Trinidad . 1819 lineáris: : : Brown : 5, G. Her. P. N. Holl. : 1820 wedra . Brown 5, G. Her. P. N. Hull. 1823 micrnphylla $_{\text {trapezæeformis }}:$ : Brown
Brown Livear, narrow, when the two sides are nearly parallel.

LiNED, having lines, or streaks.

LiNGUiform, $\}$ tongue-shaped.

LiNs A. D. D. J. F. Gronovins, with the concurrence of Linnæus, selected this little depressed, abject, early-flowering, long-overlonked northern plant, to transmit the illustrious name of Linnæens to posterity. Linn. 14, Or. 2, Nat. Or. Caprifoliacece. ( 186 ) 
tulipiferă - Yel red , 6, H. De. T. N. Amer. 1663 obtusifflix : : Yel.red . 6, H. De. T. Penusyl. : 1663

Lrsiñxthǔs, Linn. From lysis, dissolution, and $a n$. thos, a flower; in allusion to its being a powerful cathartic, Linn. 5, Or. 1, Nat. Or. Gentianaced. A mixture of loam, sand, and peat is the soil best suited for these ornamental plants. Cuttings of the shrubby and herbaceous kinds strike freely in sand, under a glass. $\boldsymbol{L}$. Russellianus is the most splendid of the genus; it was discovered by the lamented Drummond in Texas, who described it as " not excelled in beauty by any plant." The flower is large, handsome, borne in a terminal panicle; the corolla is as large as a tulip, of a fine rich purple, with a very deep eye in the centre. The flower continues perfect for tivo or three weeks. By forcing it early in the spring, and planting out in the open border, it will probably be found to flower as freely as Phlox Drummondii. It is figured as an annual, but is very likely to prove biennial. Synonymes; 1. Eustoma silenifolia. 2. L. angustifolius.

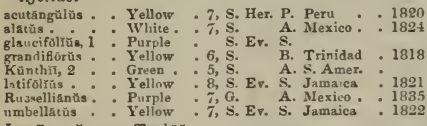

Lrsı̄̄NThǔs, see Tachð̆.

IIIss̄̃Ntrĕ, R. Bronn. From lissos, smooth, and anthos, a flower. Linn. 5, Or. 1, Nat. Or. Epacridacer. Fine ornamental shrubs, attaining the height of three feet, and producing numerous small white flowers ; for culture and propagation, see Epacris, to which this genus is nearly allied.

eliâtă - White. . 6. G. Ev. S V. D. L.

daphnnides : : White. : 6, G. Er. S. N. Holl.

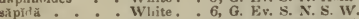

strios: : : White G, G. Er. S. N. W.

1825

1818

182

subulate : : White. : 5, G, Ev. S. N. S. W. : 1823

Listēră, R. Bron'n. In honour of Martin Lister, II.D., a famous English physician and naturalist. Linn. 20, Or. 1, Nat. Or. Orchidacede. Curious little plants, growing in peat and loam, and increased by divisions of the roots. Synonyme: 1 . Neottia ovata.

cordätă. . . Brown . 6, H. Ter. Britain

LithoNtriptic, having the power of breaking the stone.

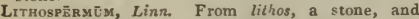
operma, a seed; the little nuts or seeds are extremely hard, and have a surface as smooth as a polished pebble. Linn. 5, Or. 1, Nat. Or. Borayinacere. The species of this genus are all of the easiest culture. The shrubby kinds are well adapted for growing on rock-work, or on the top of walls, where they $w$ ill speedily establish themselves if allowed to scatter their seeds; or they may be kept in pots among al pine plants, and increased by cuttings. Synonymes: 1. L-latifolium. 2. Anchusa tincturia.

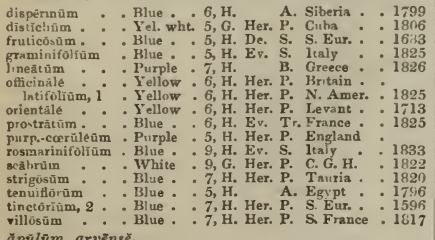

ăpuัlūm, arvēnsě.

LiTT $\bar{A} \vec{A}$, Brignoli. In honour of the Duke of Lytta, near Milan, a patron of botany. Linn. 6, Or. 1, Nat. Or. Amaryllidacee. This is a handsome plant, and was long confounded with Bonapartea juncea, but is now found to be a totally different plant. It grows well in sandy loam, and is increased by suckers. Synonyme: 1. Agave geminiflora. ด่minilară, 1 . Gresn 7 G. Ev. P. America
LrTTORĔLI.̆, Linn. From littus, the shore; in allusion to its place of growth. Linn. 21, Or. 4, Nat. Or. Plantaginacea. A pretty little sub-aquatic, with neat white flowers, and long tremulous stamens; it is increased by seeds.

lacũstrĭs . . White - 7, H. Aq. P. Britain . .

LrvistōnǏĂ, R. Brunn. In honour of Patrick Murray, of Livistone, near Edinburgh. Linn. 6, Or. 3, Nat. Or. Palmacede. This is a sulendid genus of palms; they require to be grown in a sandy loam, and strong heat.

hŭmǐlis

Palm. N. Holl. . 1824 inèxmìs Palm. N. Holl. : : 1824

Lizard's-TatL, see Saurürũs.

Lō̄să, Linn. The meaning is unknown. Linn. 18, Or. 2, Nat. Or. Loasucea. This is a genus of plants highly interesting from the beauty of their curiously formed flowers. They would all be invaluable in collections were it not for the abominable stinging property of some of the species, as L. Placei : on that account it is necessary to be very eareful in touching them. Any common loany soil suits thent, and they are easily increased by seeds. Synonymes: 1. ambrosiafolia. 2. tricolor. 3. acanthifolia.

Alba

White

hispidä, 1. Yellow

incână : : White

lateritia : : Red

nitida, $2:$ : Yellow

pầtŭlă

Plấcéi, 3

Yellow

Yel low

7, H. A. Chile : $: 1831$
G. A. Peru : $: 1425$
7, G. Tr. A. Lima : 1830
10, G. Ev. Tr. Peru : 1820
5, F. Cl. B. Tucuman $: 1835$
7, H. A. Chile : 1822
7, H. A. Chile : 1827
7, H. A. Chile : : 1822
6, G. A. Chile :

LовАтв, lobed, divided into a number of segments.

LiBATRLY-CREAATED, having deep crenatures, or in. dentations.

$\mathrm{L}_{\mathrm{B} B}$, a division.

LoBËLỸ , Linn. In honour of Matthew Lobel, author of various botanical works; he was a native of Lisle, became physician and botanist to James I., and died in London in 1616. Linn. 5, Or. 1, Nat. Or. Lobeliacece. This is an extremely interesting genus of plants, on account of the beauty of the blossoms. The greenhouse and stive shrubby and herbaceous kinds grow well in a mixture of peat and sand; the shrubby kinds are readily increased by cuttings in the same kind of soil, and the herbaceous species by dividing, and by seeds. The hardy herbaceous kinds do well in a lixht rich earth, or peat soil; bint in winter most of them require the protection of a frame. The greenhouse annuals and biennials inust be sown in pots, and treated as other greenhouse annuals and biennials. The seeds of the hardy kinds have only to be sown in the open border. $\boldsymbol{L}$. longiflora is one of the most venomons of plants. Barton says the Spanish Americans call it Rebenta Cavallos, becruse it proves fatal to horses that eat it, swelling them intil they burst. Taken internally, it acts as a violent cathartic, the effects of which no remedy can assuage, and which end in death. Synonymes: 1. $L$. erinoides. 2. L. gnodenioides, L. spicata. 3. L. crispa. 4. L. commutata. 5. L. maculata. 6. Isotoma axillaris. 7. L. pedunculata. 8. L. micrantha.

acuminâtă . . . Gm. tel. 6, S. Ev. 5. W. Ind. • 1822 alstả

. Blue

Blue : 7, H. Her. P. N. Amer. 1812

inceps . . Blue . 6, H. A. C. G. H. 1818

Blue : 9, S. Her. P. Chile : 1824

Ausurgêns : : Scarlet : 8, G. Ev. S. W. Ind. : 1787

atro-ccerúleă : Dk. blue 7 , H. Her. P. Hybrid . 1836

ntrosanquinea . - Black - 7, H. Her. P. Eng. hyb. - 1836 bellidifolra. : Blue. $7, G$. Hex. P. C. G. H. : 1790 bicolór . Pa.blue. 7, G. A. C. G. H. 1795 Bridgésil . . Pink . . 6, G. Hex. P. Chile * 1336 cœeruleă. : Blue : 6, G. Her. P. C. G. H. : 1824 campanulăts : Blue: 6, H. A. C. G. H. 1821 companuloises, 1: White 6. S. Hex. Chins 1820 cardinalis : . Scarlet: $7, F$, Her. P. Virginia : 1629

Millêrí : : Pink : 7 H. Her, P. Eng. hyb. : 1835

Cavanillesiana : Red : 6, S. Her. P. N. Spain : 1825

Claytoniână, 2 : Bine: : 6, H. Her. P. N. Amer. : 1824

Cliffortiâna : Pink: : 7, H. A. N. Amer.

coelēstis. : : Blue : : 7, H. Her. P. N. Amer. : 1831

colorātå: : : Orange : 8, F. Her. P. N. Amer. : 1839

colorătă crenătă. : : Blue : : 4, G. Her. P. C. G. H. : 1794 


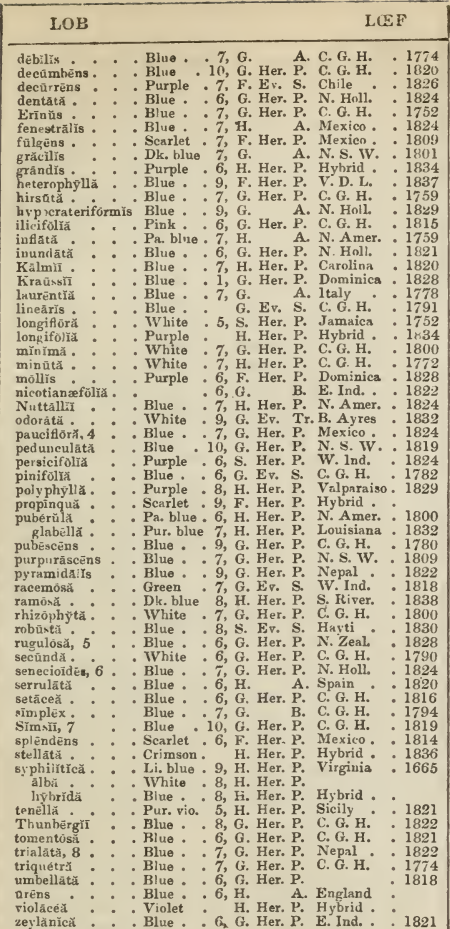

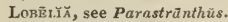

LoBĒrLǏ̃, see Prütřă.

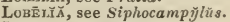

LOBĒLİ̃ă, see Tüpă.

Located, placed.

Locula MENTs, partitions or cells of a seed-vessel.

Locurar; a fruit is called unilocular if it contains but one cell, bilocular if it contains two cells, and so on.

LOCCST-TREE, see Hymenāă.

LoDniGẼsı̆Ă, Sims. In honour of Conrad Loddiges, the celebrated nurseryman at Hackney near London, and father of the present eminent proprietors. He died in 1820 . Linn. 16, Or. 6, Nat. Or. Leguminosa. This is an extremely interesting shrub, succeeding well in an equal mixture of sandy loam and peat; and cuttings of the young wood root freely planted in sand, under a glass.

oxalidifolla . . Pa. pur. , G, G. Ev. S. C. G. H. . 1802

Ludō̄c Ẽ Ă, Labillardière. Named after Laodice, the daughter of Priamus and Hecuba. Linn. 22, Or. 12, Nat. Or. Palmacea. For the culture and propagation of this palm, see Cocos. Synonyme: 1 . Cocos maldivica.

sechellārūm

Palm. Seychelles .

LGFLĪ̃GĬ. Named by Linnæus, in compliment to his disciple Peter Lofling, a traveller in Spain and America, who died on his travels in 1756 . Linn. 3, Or. 1, Nat. Or. Alsinucea. The seed of these plants need only be sown in the open ground where they are to remain.

hispănĩcă . . Green . . 6, H. A. Spain . . 1770 pentandră : : Green: : 6, H. A. S. Eur. : : 1820

LogÃNĨ, R. Brown. In honour of J. Logan, a dis. tinguished botanist, Linn, 5, Or. 1, Nat. Or. Loganiacea. Rather small but interesting shrubs, which produce their flowers in axillary or terminal bunches. They grow well in sandy loam and peat, and ripened cuttings root freely in sand, under a glass. Synonymes: 1. Euosma albiflora. 2. Exacum vaginule.

floribūndă, 1 . White. 4, G. Ev. S. N. S. W. 1797 latitolin, 2.: : White.: G. Ev. S. N. Holl. : 1816 ligustrină: : : Wlite. . G. Ev. S. N. Zeal. : 1837
revolută

LoGwood, see Hamatoxy̆lün.

Lotîn, Limn. From the Celtic, loloa, which in Latin is rendered lolium, Rye-grass. Linn. 3, Or. 2, Nat. Or. Graminea. This is a very valuable genus of grasses. L. perenne, or perennial Ryegrass, is one of the most esteemed fodder grasses, and is said to have been the first species that was taken into cultivation in Europe. They grow best in a good rich soil, and increase readily from seeds.

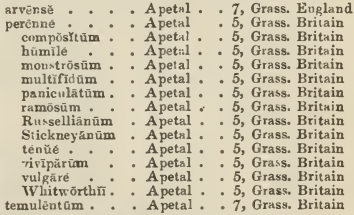

multîforūm, rĭgĭdũm, speciosūm, těnūĕ.

LosARǏ , Willdenow. Derived from loma, an edge; in allusion to the marginal position of the indusia. Linn. 24, Or. 1, Nat. Or. Polypodiacea. An interesting genus of ferns; for culture and propagation, see Lindsan. Synonymes: 1. Stegrnia falcata. 2. Acrostichum longifolium. 3. Stegania nnda, Onoclea nuda. 4. Stegania procera, Osmunda pracera. 5. Blechnum boreale.

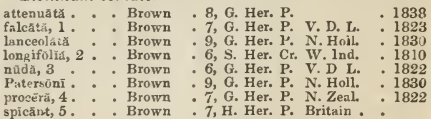

LomĀtră, R. Bronn. From loma, a border; in allusion to the winged edge of the seeds. Limn. 4, Or. 1, Nat. Or. Proteaced. This is a genus of very handsome plants, which thrire well in a sandy peat soil, and increase by cuttings in sand, under a glass.

dentātă. .

ilicifolră

longifơlǐa

silaifólia

tinctōrǐ̀

Lös̄s, Gartner. The meaning unknowa. Linn. 19,

Or. 1, Nat. Or. Composita. The seed of this plant has only to be sown in the open ground. Synonyme: 1. Athanasia annua.

inodōr, 1 . . Yellow . 7, H. A. Barbary . 1686

LoNchītês, Linn. From lonche, a lance; in allusion to the form of the fronds. Linn. 24, Or. 1, Nat. Or. Polypodiacea. This genus consists of two very handsome ferns, which grow best in a mixture of turfy loam and peat, and increase by divisions. Synonyme: 1. Pieris podophylla.

hirsũtaे . . Brown . 8, S, Her. P. W. Ind. • 1793 pedātă, 1 : : Brown : 6, S. Her. P. Jamaica : 1793 Loxchoc̄̄rpuัs, Hnmboldt, Bonp. and Kunth, From lonche, a lance, and karpos, a fruit ; in reference to the lance shape of the pods. Linn. 17, Or. 4, Nat. Or. Leguminosa, Ornamental shrubs, growing well in loam and peat, and increased by cuttings of the young wood planted in sand, under a glass, in heat. Synonymcs: 1. Dalbergia domingensis. 2. Amerimnum latifolinm, Pterocarpus latifolius. 3. [189] 


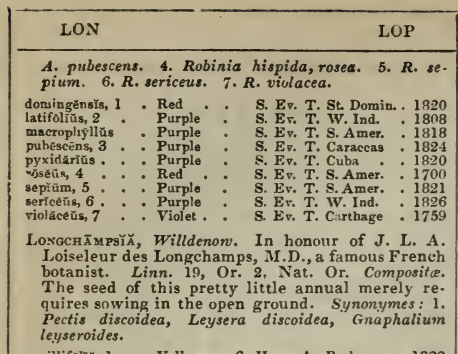

capilliföllă, 1 . Yellow . 6, н. A. Barbary . 1822

LONDON-PRIDE, see Saxifrăgă umbrósă.

I.ONDON-ROCKRT, see Sișymbriūm Irž̉.

LoNGicōRNô, long-spurred.

LoNicēr $\breve{h}$, Linn. Named after Adam Lonicer, a German botanist, who died in 1586 . Linn. 5, Or. 1, Nat. Or. Caprifoliaced. This is a genus of very ornamental shrubs, closely allied to the genus caprifolium. The species grow in any common soil, and are readily increased by cuttings taken off in autumn, and planted in a sheltered situation. Synonymes: 1. L. sibirica. 2. L. campaniflora. 3. Symphoricarpus puniceus.

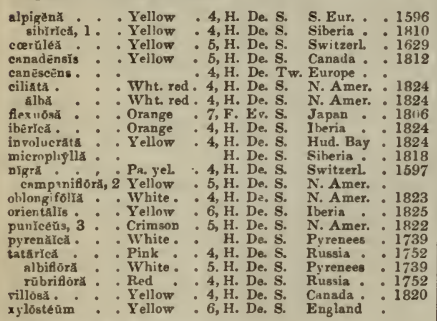

LOOKING gLAss pLANT, see Heritiéră.

Loosk-sTrire, see Lysimächră

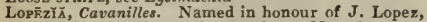
a Spanish botanist. Linn. 6, Or. 1, Nat. Or. Onagracea. This is a genus of very, elegant plants. The annual species should be raised on a gentle hotbed, and afterwards transplanted out into a warm border. The biennial kinds require to be kept in the greenhouse.

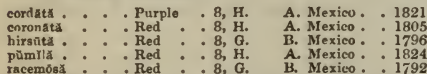

LOPHĀNTHŬs, Bentham. From lophos, a crest, and anthos, a Hower; in allusion to the crenated middle lobe of the lower lip of the corolla. Linn. 14, Or. 1, Nat. Or. Labiate. Very pretty plants, growing in common garden soil, and increased by dividing the roots, or by cuttings planted under a glass, or by seeds when those are produced. Synonymes: 1. Hyssopus anisatus. 2. H. Lophanthus. 3. Nepeta multifida. 4. $\mathrm{H}$. neptoides. 5. $\mathrm{H}$. scrophularioides. anisătŭs, 1. . . Blue . . 7, H. Her. P. N. Amer. . 1826 multifidurs, 3 : White: 7 , H. Her. P. Silieria: 1796 nepetiniders 4 dis 5 Yel, wht. 7, H. Her. P. N. Amer. 1692 urticefơliūs, 2 . Blue : : 7, H. Her, P. N. Amer. : 1826

Lopนйð̆ $\breve{A}, K e r$. A diminutive of lopha, a crest ; in reference to the crest of the sepals. Linn. 6, Or. 1, Nat. Or. Hamodoracece. This is a rare little herbaceous plant, growing in peat soil in a damp situation. It will also grow and flower well in pots placed in pans of water; it is increased by
LUP

LOT

dividing the roots. Synonyme: 1. Conostylis americana.

aūrể, 1 . . . Yellow . 6, H. Her. P. N. Amer. . 1811

LopHīră, Banks. One of the sepals is extended out into a ligulate wing or crest; whence the name from lophos, a crest. Linn. 12, Or. 1, Nat. Or. Dipteracea. This is a very fine low-growing tree. It has tap roots, and therefore requires to be planted in a very deep pot, in order to allow the roots to descend. It should be grown in sandy loam and peat, and kept rather dry; cuttings of the ripened wood will root in sand, nnder a glass, in heat. In Sierra Leone, it is called Scurby or Scrubby Oak.

africānă . . . White. . 6, S. Ev. T. S. Leone . 1822

LöрнйūM, Fries. From lophion, a little hillock. Linn. 24, Or. 9, Nat. Or. Fungi. These extremely minute plants are very similar to the valves of a bivalred shell-elatam, mytilinam.

Lophospŕry Ü, D. Don. From lophos, a crest, and sperma, a seed; the seeds are furnished with a crest-like wing. Linn. 14, Or. 2, Nat. Or. Scrophulariacea. This genus is composed of very elegant plants, with large purple, or rose-coloured flowers; for culture and propagation, see Maurandya. Synonyme: 1. Rhodochiton volubile, $L$. Rhodochiton.

atrosangurněũm, 1 Drk. pur. . 6, G. Ev. C. Mexico * · 1833 erubéscéns.? Rosy : 8, F. Ev, Cl. Talapa : : 1830

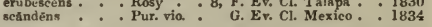

Lopìı̌n, Martius. From lopimus, signifying easy of decortication. Linn. 14, Or. 8, Nat. Or. Malvacere. This plant grows well in any rich soil, and is readily increased by young cuttings taken off at a joint, and planted in sand, under a glass, in heat. Synonyme: 1. Sida malacophylla.

malaenphyllă, 1 . Red . . 8, S. Ev. S. Bahia . . 1823

LORĀNTHŬs, Linn. From loron, a thong, and anthos, a flower; in allusion to the long linear form of the petals. Linn. 6, Or. 1, Nat. Or. Loranthacea. A genus of parasitical plants, with the habit of the well-known $\mathrm{M}$ istletoe.

européūs . . Greenish . Parasite. Europe . 1824

LORĀNTHŬs, see Noytsiă.

LoRATE, thong or strap shaped.

LORD ANSON's PRA, see Läthy̆rūs magellanicūs.

LōRĚ Ǔs, leatherY.

LorE, see Zizy̆phñs Lotñs.

Lõtǔs. From lotos of Theophrastus; the true Lotus is Zizyplus Lotus. Linn. 17, Or. 4, Nat. Or. Leguminosa. An ornamental genus of plants. The greenhonse and frame species grow freely in any light soil, and are increased by cuttings of the young wood planted in sand, under a glass, or they may be increased by seeds. The hardy kinds are well suited for ornamenting rock-work, or dry banks. The seeds of the hardy annual species need only be sown in the open ground in spring. $L$ corniculatus and $\boldsymbol{L}$. major are sometimes sown with white clover and cow-Rrass, in laying down permanent pastures. Synonymes: 1. L. diffusus. 2. Cytisus argenteus. 3. $L$. decumbens. 4. Trigonella indica.

angustissimbs, 1 Yellow . 5, H. Tr. A. Britain . anthylloidēs? . Drk. pur. : 6, G. Ev. S. C. G. H. : 1812

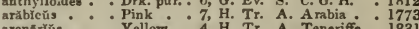
arenårłŭs: : Yellow : 4, H. Tr. A. Teneriffo: 1831 argênteús, 2 : Y Yellow : 6, F. Her. P. angustifollăs. Yellow . 7, F. Her. P. Tenerifo 1827 atropurpâreŭs . Drk, brn. . G. Ev. 8. Teneriffe . 1820 australls - . Pink - 7, G. Her. P. N. Holl. 1800

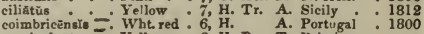
corniculátús - : Yellow : 6, H. De. Tr. Britain alpinū : : Yellow : 6, H. De. Tr. Switzeri. flóré-pléno : Yellow: 7, H. De. Tr. Gardens

tore-plenó : Yellow : 7, H. De. Tr. Gardens : 1812

crassifolyŭs * Yellow : 8, H. Her. P. S. Eur. * 1812

créteús * * Yellow * 6, G. Ev. Tr. Levant - 1580

cytisoidess. * Yellow * 6, H. Tr. A. S. Eur. . 1752

decūmbens : Yellow 7, H. Tr. A. Europe . 1816

depréssǔs.: : Yellow : 7, H. De. Tr. Hungary : 1819

edulis. : : Yellow : 7, H. Tr. A. Italy : 1759

flexuósŭs: : Yellow : 7, H. De. Tr. Europe: : 1816

Forsterr, 3 : Yellow : 7, H. De. Tr. Britain: : 1816

gebelix : : Yellow : 5, F. Ev. Tr. Aleppo : 1816

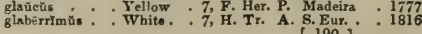




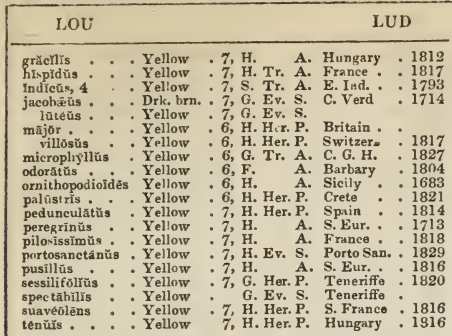

Loūrü̆̆, Necker. Unquestionably the name of some person. Linn. 17, Or. 4, Nat. Or. Leguminosa. These plants are worth cultivating; they require the same treatment as most other biennials. Synonyme: 1. Hedysarum vespertilionis.

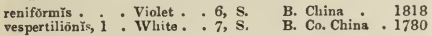

Loureīră, Cavanilles. In honour of John de Loureiro, a Portuguese botanical author. Linn. 22, Or. 13, Nat. Or. Euphorbiacece. These plants grow well

in a mixture of loam and peat; and cuttings root readily in sand, under a glass, in heat

cuneifsliă . . White. . 7, S. Ev, S. Mexico. . 1824 glandulösă: : : S. Ev. S. Mexico: : 1799

Lousewort, see Pedicnlārǐs

LOVAGE, see Ligũstīcūm.

Lovage, see Achillä̉ü Ligũst:"că.

LOVE-AFPI.E, see Lycopérsícūm esculēntnm.

LOVE-GRAss, see Eragrostis.

LOVB-LIES-BLEEDING, see Amaränthüs caudätŭs.

Lōw Ĭ Lowe, Travelling Bachelor of the University of Cambridge. Linn. 12, Or. 3, Nat. Or. Rosacea. This ornamental plant is found in its native country growing in saltish fields. Although it is an old inhabitant of our gardens, it is yet very scarce, being very difficult of cultivation. A mixture of loam, peat, and sand appears to suit it best, and it may be increased by seeds or layers. Synonyme: 1. Rosa berberifolia.

berberifoliă . . Yel. pur. . 6, F. Do. S. Persia • . 1790

LuBīnǏă, Ventenat. In honour of M. de St. Lubin, a French officer and botanist. Linn. 5, Or. 1, Nat. Or. Primulacea. This species grows freely in loam and peat, and young plants are readily obtained from cuttings.

atropurpürea . Purple F. Her. P. C. G. H. . 1820

LuRricate, slippery.

Lucren, see Medicāgð satĩvă.

Lûcřnǔs, shining, glittering.

LucūLü. Sneet. Luculi sva is the name given to the tree by the Nepalese. Linn. 5, Or. 1, Nat. Or. Cinchonacea. This fine tree is worthy of a place in every collection, as there cannot be a more beau. tiful object than this tree is when covered with its numerous cymes of pink-coloured, very fragrant, flowers. It grows well in an equal mixture of light turfy loan and peat; and cuttings will root in sand, under a glass, in a little heat. Synonymes : 1. Cinchona gratissima, Mussaenda Luculia.

gratīssimmă . . . Red . . 8, G. Ev. S. Nepal . . 1823

LucūMă, Jussieu. Lucuma is the name of the tree in Peru. Linn. 5, Or. 1, Nat. Or. Sapotaceue. Fruitbearing trees, cultivated in a mixture of rich loam, with a little light soil to keep it open; and cut. tings of the ripened wood root in sand, under a glass, in heat. Synonyme: 1. Achras mammosa. 2. A. Lucuma.

Bonplândiă * * White * S. Ev. T. Cuba • 1822 mammósū, 1 . . White. . S. Ev. T. S. Amer. . 1739

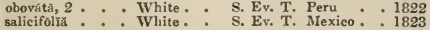

Lũ̃Ĭ , Lamarck. From ludo, to sport; the leaves of L. heterophylla assume various forms. Linn. 13, Or. 1, Nat. Or. Bixacea. Rich loam, and a little peat, suit these plants; and cuttings soon root in

sand, under a glass, in heat. Synonyme. 1.tuberculata.

heterophyllă . . Yellow . 7, S. Ev. S. Maurit.. . 1823 sessilitōră, 1 : Y Yellow : 7, s. Ev. S. Maurit. : 1820

LUDWĪGǏ, Linn. In honour of Christien Gottlieb Ludwig, professor of medicine at Leipsic and botanical author, in 1737. Linn. 4, Or. 2, Nat. Or. Onzgracea. Uninteresting plants, not worth cultivating except in general collections-parvijlörŭ, prustrūtă.

Lürfă, Cavznilles. Derived from louff, the Arabic name of L. agyptiaca. Linn. 21, Or. 5, Nat. Or. Cucurbitacea. A remarkable kind of gourd, pos. sessed of a very disagreeable odour; for culture and propagation, see Cucumis. Synonymes: 1. Cucumis acutangulus. 2. Momordica luffa.

acutángŭlă, 1 . Purple * 7, F. Tr. A. N. Amer. . 1692 æegyptĩacă, 2 : : Purple : 7, F. Tr. A. E. Ind. : : 1739 fótída. : : Purple :7, H. Tr. A. India : 1812

LUнц̆й, Willdenow. In honour of Charles Vander Luhe, a famous German botanist. Linn. 18, Or. 2, Nat. Or. Tiliacea. This is a very pretty plant, which thrives well in a mixture of peat and loam; and cuttings of the nearly ripened wood root readily in sand, under a glass, in heat. In Brazil, they use the bark of $\boldsymbol{L}$. paniculata for tanning leather.

paniculată . . Rosy . . S. Ev. Cl. Brazil . . 1828

Luĩš̌n, Gaudich. The meaning of the name not explained. Linn. 20, Or. 1, Nat. Or. Orchidacece. This is a pretty species, very scarce in collections, The sepals and petals are light green, and the labellum is strongly streaked internally with deep purple. The leaves of the plant bear a strong resemblance to those of an Aerides, and the plant requires precisely the same treatment as that genus. alpīnă . . . . Grn. pur. . 4, s. Epi. Silhet . . . 1837 LUMNitzēră, Willdenow. In honour of Stephen I.umnitzer, a botanical author. Linn. 14, Or. 1, Nat. Or. Combretacea. A pretty little plant, of common culture.

moschătă . . White. . 8, G. A. N Holl. - 1823 tenuiflöră . . . Pa. pur. . 7, S. Her. P. E. Ind. . . $17(13$

LUNĀrľ̆, Linn. From luna, the moon; in allusion to the appearance of the broad silvery silicles. Linn. 15, Nat. Or. Cruciferce. A genus of large, rather pretty plants, with cordate leaves, and purple or white flowers. Any common border soil suits them, and they are increased by seeds. $\boldsymbol{L}$. rediviva may also be increased by dividing. Synonyme: 1. añnua.

biēnnǏs, 1 . . Li. pur. . 5, H. B. S. Eur. . . 1570

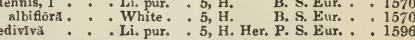

Lunate, shaped like a half-moon.

LUNGWort, see Pulmonārŭă.

LUNGWORT, see Hierāciūum pulmonäriă.

LUPINE, see Lupinñs.

Lupĩnũs, Linn. From lupus, a wolf; in allusion to its drowning or exhausting land. Linn. 16, Or. 6, Nat. Or. Leguminosa. The species of this genus are among the most beautiful of our annual and herbaceous border-flowers. They will flourish in almost any soil, but a rich loam suits them best. They perfect their seeds very freely, from which young plants are easily obtained.

albřfrōns . . Blue . . 9, F. Ev . S. California . 1833 albŭsōns : : White: : 7, H. Ev. A. California : 1833 angustifoliŭs : Blue : 7, H. A. Spain : 1686

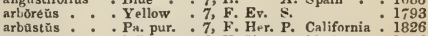
arbustŭs : : Pr.pur.: 7, F. Her. P. California : 1826

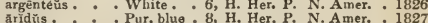

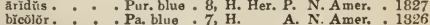

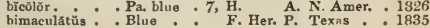
bractenlärss: : Blue : $7, \mathrm{H}$. A. Mideo : 1820 canaliculătŭs : Blue : 7, F, Ev. S. B. Ayres : 1828 Cruickshãnkil : Varieg.: 7, F. Ev. S. Peru : 1829 densiflörǔs : Whit. pnk. 7, H. A. California : 1833 èlégañns . Vio. rose . 6, H. A. Mexico. 1831 exaltătŭs : : . A. 1932

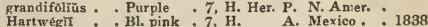

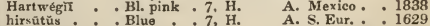

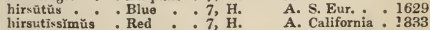
incătŭs : : Pa. li. : : 7, G. Ev. S. B. Ayres : 1830 laxiflörŭs: : Blue pnk.: H. Her P. Columbia : 1826 latifơlư̌s . Blue . 7, H. Her. P. California 1834 [ 191 ] 


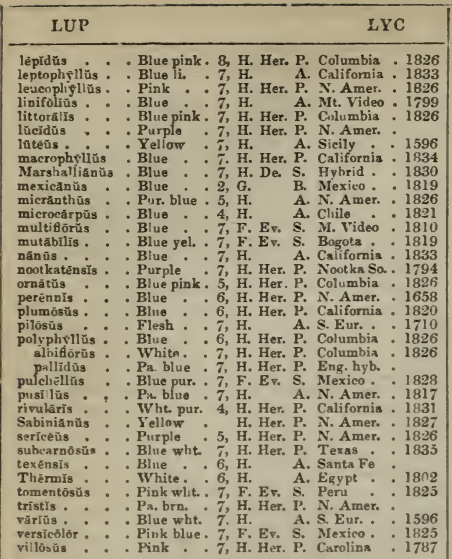

Lurin, between a purple, yellow, and grey colour.

LêzŭLĂ, Decandolle. From the Gramen Luzula of

Bauhin, the Glowworm.grass Linn. 6, Or. 1,

Nat. Or. Juncaceu. These plants are nearly related to Juncys, from which they are at once distin guished by their flat leaves. They possess but little beanty, and are of the easiest culture. Synonymes: 1. Juncus arcuatus 2.J. spadiceus.

Berthelöttil . . A petal . Grass Teneriffe . 1829

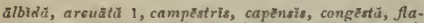

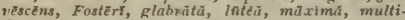
floră, nivēú, pediformis, pilosŭ, spadiceă 2, spicütă, sudêtică, vernälis.

Lrchiss, Decandolle. From lychnos, a lanip; on account of the brilliancy of the flowers of most of the species. Linn. 10, Or. 5, Nat Or. Silenacer. An extremely beantiful genus of plants, well meriting extensive cultivation for the brilliancy of their flowers. Among the most showy and esteemed of the border-flowers, is $\boldsymbol{L}$. Chalcedonica, the double varieties of which require some care to prevent them from returning to a single state. $L$. latter will zrow and flower well if planted out in the open border in spring, but it must be taken up in autumn, or the frost will kill it. They all grow freely in light rich loamy soil; but they must be frequently divided, or they will dwindle away, and the best time to do this is early in spring. The seed of the annual species has only to be sown in the oven border in spring. $\boldsymbol{L}$. Cali Rosa is very handsome. Syaonymes: 1. Viscaria alpina. 2. $\boldsymbol{L}$. brachypetaia. 3. Agrostemma coronaria. 4. A. corsica. 5. A. sylvestris. 6. A. Flos-cuculi. 7. Githago sesetum. 8, Viscaria helvetica. 9. V. neglecta. 10. Githago nicerensis. 11. Agrustemma pyrenaica. 12. A. sibirica. 13. A. dioica 14. Viscaria vulgaris.

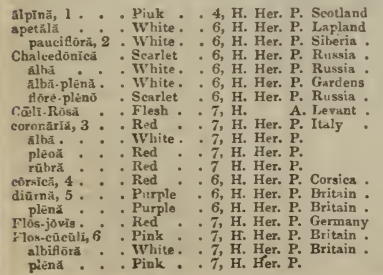

fülgẹns ${ }^{\circ} \cdot$ Scarlet .6 , H. Her. P. Siberia . . 1822

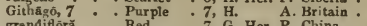
grandiflöră * Red * 7, G. Her. P. China : 1774 helvêtică, 8 : Red : 7 , H. Her. P. Switzerl. : 1814 läĕă * Flesh : H. Her. P. Portugal : 1778 neglêctă, $\dot{9}:$ White : 6 , H. Her. P.

nicrénsis, $10^{\circ}$ : Wht red: $6, \mathrm{H}$. Ner. Nice 1794 prrenăică, 11 : White. : 6, H. Her. P. Pyrenees : 1819

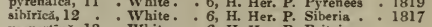
vespertiñ, 13 . White. 6, H. Her. P. Britain: multiplex. White. 6, H. Hex. P.

rơsea $0^{*}$. Wht red . 6, H. Her. P. Britain

Viscărina, 14. Pink : 5, H. Her. P. Brituin

plēeã : : Red : : 5, H. Her. P. Britain :

\section{apětălă, brachypětălă.}

LYcroser İssă, Ramer and Schultes. From lycium, and serissa, serissa-like lycium. Linn. 5, Or. 1, Nat. Or. Solanacea. A Cape shrub, which grows in peat and loam, and is increased by cuttingscapēnsis.

Lrciex, Linn. From lycion, a name given by Dioscorides to a thorny shrub, and applied to this genus because of its containing some thorny shrubs. Linn. 5, Or. 1, Nat. Or. Solanacea. The stove and greenhouse kinds require the same treatment as other similar plants. L. afrum, and some others of the Cape species, thrive and flower well ayainst a south or west wall, and are very handsome when in flower. The hardy species are admirably suited for training against trellis-work, or walls, or for covering arbours. They are all readily increased by cuttings of the ripened wood planted in sand, under a glass. Synonyme: 1. L. carnosum.

Afrüm . . . Violet. . 6, H. De. T. C. G. H.

carnliniañäm: : Blue : : 7, H. Ev. S. Curolina : 1896 chinénse : Purple 7, H. De. Cl. China cinêreúm : Vinlet . 6, G. Ev. S. C. G. H.

européüm : : Pink : 6, H. De. Cl. S. Eur.

chrisocârpüm

sphærocápuim hörrídũm

lanceolẻtüm micropliyllūm. rigidnim. 1 . ruthèricuina eaxpícúm

Shawn

tetrindrūm

Trewianūm

turbinatūnu

\section{White}

link

5, H. De. $\mathrm{Cl}$.

7, F. Ev. S. C. G. H

6, H. De. S. C. G. H

H, De. Cl. Siberin

7, H. De. Cl. Casp. Sea

Pink : 7, G. Ev. Cl. C G. H.

Violet. 6, F. Ev. S. C. G. H.

Violet. 6, H. De. Cl. C. G. H.
Purple : 6, H. De. Cl. China

6, H. De. Cl. Clina
6, H. De. Cl. Clina
1818

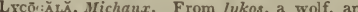
milk. Linn. 24, Or. 9, Nat. Or. Fungi. In the early stage of this plant's existence, it appears like a mass of thick cream. It is found upon rotten or decayed leaves-miniñtu.

LYcopî́RDós, Michaux. The meaning of the name is not explained. Linn. 24, Or. 9, Nat. Or. Fungi. This is a genus of roundish, tuber-like plants, which, when ripe, explode, and emit their sporules like smoke, and known among country people by the name of Puff-balls. They grow in pastures and on the stumps of trees-Bovista, excipuliforme, perlätom, pratênse, pyriforme.

I.YCOPERsT́cús, Tournefort. From lykos, a wolf, and persicon, a peach ; in ailusion to its aphrodisaical qualities. Liun. 5, Or. 1, Nat. Or. Solanacer. The Lycopersicon, or Love-apple, consists cliefly of annual plants, several of which are trained ayainst walls for the sake of their fruit, which is used for soups. They are generally raised in frames, or in a stove, and when of sufficient size, they are transplanted into the open border. Synonymes: 1. Solanum Pseudo Lycopersicum. 2. S. Lycopersicum. 3. S. pimpinellifolium.

1817

1596 cerasifórmĕ, 1 * Green - 7, H. A. Peru - 1800 commutatúm : : Green : 7 , H. H. A. A. Amer. : 1546 esculéntüm, 2 : Green : 7, H. A. S. Amer. : 15:6 chrýocārpüm . Green : 7, H. A. S. Amer, : 1596 erythuchirpum . Green : 7, H. A. S. Anier. 1596 leirencārpúm. Green: 7, H. A. S. A mer: 1596 Humboldtii : Yellmw: $8, \mathrm{H}$. A. S. Amer. 1822 Humholatil : : Yellmw : 8, H. Her. A. S. Amer. . 1822

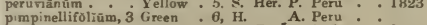

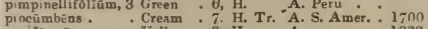
pyriformé : : Yellow : 8, H. A.
regularé . : Green : 6, H.

LycopódĪ̇ M, Linn. From lykos, a wolf, and pous, a foot; because of the resemblance of the roots.

[ 192 ) 

species of Club-moss require to be cultivated in peat soil, in a moist situation; some of them succeed in pots of water. They are readily increased by suckers.

\begin{tabular}{|c|c|c|}
\hline 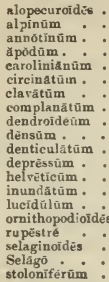 & $\begin{array}{l}: \text { Brown } \\
: \text { Brown } \\
: \text { Brown } \\
: \text { Brown } \\
: \text { Brown } \\
: \text { Brown } \\
: \text { Brown } \\
: \text { Brown } \\
: \text { Brown } \\
: \text { Brown } \\
: \text { Brown } \\
: \text { Brown } \\
: \text { Brown } \\
: \text { Brown } \\
: \text { Brown } \\
: \text { Brown } \\
: \text { Brown } \\
: \text { Brown } \\
: \text { Brown } \\
: \text { Brown }\end{array}$ & $\begin{array}{l}\text { 8, H. Ev. Tr. Britain } \\
\text { 8. H. Ev. Tr. Britain } \\
\text { 7, H. Ev. Tr. Britain } \\
\text { 8, H. Ev. Tr. N. Amer. } \\
\text { 8, H. Ev. Tr. Carolina } \\
\text { 7, S. Her. P. E. Ind. } \\
\text { 8, H. Ev. Tr. Britain } \\
\text { 8, H. Her. P. N. Amer. } \\
\text { 7, H. Her. P. N. Amer. } \\
\text { 8, G. Ev. Tr. N. Holl. } \\
\text { 7, H. Ev. Tr. Switzerl. } \\
\text { 8, G. Ev. Tr. C. G. H. } \\
\text { H. Aq. P. Switzerl. } \\
\text { : 6, H. Ev. Tr. Britain } \\
\text { 8, H. Ev. Tr. N. Amer. } \\
\text { 7, H. Ev. Tr. } \\
\text { 8, H. Ev. Tr. N. Amer. } \\
\text { 8, H. Ev. Tr. Britain . } \\
\text { 8, H. Ev. Tr. Britain . } \\
\text { 7, S. Her. P. Brazil : }\end{array}$ \\
\hline
\end{tabular}

stoloniférūm : Brown
Linn. 24, Or. 3, Nat. Or. Lycopodiacea. The hardy

ginea. 2. A. frondosa. 3. A. paniculata. 4. A. ferruginea.

capreafolita

ferruginex,

frondôsă, panieulătă, 3
rigidă, 4 .

White.

White

7, H. Ev. S. N. Amer. - 1812

IVhite.

White.

6, H. Ev, S. N. Amer. 1784

5, H. Ev. S. Virginia

7, H. Ev. S. N. Amer.

5, H. Ev. S. N. Awer. 1748

Yōssĭa, $R$. Bronn. In memory of Israel Lyons, author a botanical work, and from whom Sir Joseph Banks received his earliest instructions in botany. Linn. 5, Or. 1, Nat. Or. Gentianaceg. A pretty plant; for culture and propagation, see Echites.

stramǐneă . . Striped . 6, S. Ev. Tw. N. Holl. 1820

LYPERĀNThǓs, $\boldsymbol{R}$. Bronn. From lupe, sadness, and anthos, a flower; in allusion to the sombre appearance of the flowers. Linn. 20, Or. 1, Nat. Or. Orchidacea. A genus of curious, tuberous-rooted plants, thriving well in a mixture of loam and peat, and increased by divisions of the roots.

Lrcōpsis, Linn. From lykos, a wolf, and opsis, the face; some resemblance in the flowers. Linn. 5, Or. 1, Nat. Or. Boraginacece. The seeds of these plants have only to be sown in the open ground in spring. Synonymes: 1. Nonea arvensis. 2. Anchusa echioides, N. echioides. 3. N. obtusifulia. 4. Anchusa ovata. 5. A. variegata-arvënsis 1, calyciñă 2, echioũdès 3 , obtusifoliă 4 , orientälis 5 , variesătă 6 .

L Ȳcōpǔs. From lykos, a wolf, and pnus, a foot; in allusion to the resemblance of the leaves to the foot of that animal. Linn. 2, Or. 1, Nat. Or. Labiata. They succeed in the open ground, in any light rich soil, preferring a moist situation, and are readily increased by seeds, or divisions of the roots. Synonyme: 1. L. virginicus quercifolius.

australiss * . White. . 5, G. Her. P. N. Holl. . 1823 europerús : White. 7, H. Her. P. Britain . exaltátŭs : White: 7, H. Her. P. Italy : 1739 macrophyllŭs, i : White. : 7, H. Her. P. Europe . Her. P. N. Amer. : 1700 virgrnicús 1 : White: : 8, H. Her. P. Virginia : 1760

L Y̌GĒ M, Linn. From lygeo, to bend; on account of its flexibility. Linn. 3, Or. 1, Nat. Or. Graminea. A species of grass with rushy leaves. It is much used in Spain, Provence, \&c., for making ropes, baskets, nets, for filling mattresses, \&c. It grows in light loamy soil, and is increased by dividing the roots.

Spārtūm .

5, Grass. Spain

1776

LxGōDĨ̃ sion to the twining habit of the plants. Linn. 24, Or. 1, Nat. Or. Osmundacere. The Snake's-tongue is a climbing genus of ferns, which grows freely in a mixture of turfy loam and peat, and is readily increased by dividing of the roots, or by seeds sown in the usual way. Synonymes: 1. Hydroglossum hirsutum. 2. Osmunda scandens.

circinătūm . . Brown . 8, S. Ev. Cl. E. Ind. . - 1823 hastátūm .: : Bruwn : 8, S. Eq. Cl. Maranh. : 1820 mexieãnūm : : Brown : G. Her. P. Mexico.: 1831 polmátūm : Brown : 8, S. Ev. Cl. N. Amer. polynuorphüm, 1 Brown : 8, S. Ev. Cl. S. Amer. : 1820 scandens : Brown : 5, S. Ev. Cl. E. Ind. : 1793

LYME-GRAss, see Ely̆mŭs.

LXMPHATIC, belonging to lymph or sap.

LYNGKY Ă, Agardh. In honour of the famous Danish botanist H. C. Lyngbye. Linn. 24, Or. 7, Nat. Or. Alge. Curious plants, resembling some species of the genus conferva. They are found on damp earth at all seasons of the year-crispă, murülis, prolǐfěră.

LYōxĬ, Nuttall. In memory of John Lyon, an A merican collector of plants, who fell a pictim to a dangerous epidemic among those savage and romantic mountains which had so often been the theatre of his labours. Linn. 10, Or. 1, Nat. Or. Ericacee. Very ornamental shrubs, well worth a place in every garden. They grow best when planted in a peat soil, and may be increased by layers, or seeds; if by seeds, they must be sown in pots filled with sandy peat soil, and covered slightly over. Synonymes: 1. Andromeda ferru.

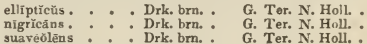

1824

suaveôlēns G. Ter. N. Holl.

1892

LYRATR, ly re-shaped.

LYsıмĀchİ, Linn. From lysis, dissolution, and mache, strife. Linn. 5, Or. 1, Nat. Or. Primulacee. A very pretty genus of plants, with mostly yellow flowers, L. Nummularia is a handsome free-Howering plant, and from its trailing habit, is well fitted for decorating rock-work. All the species are of the easiest culture, and may be propagated by divisions, except $L$. dubia and $L$. Linum-stellatum, which must be increased by seeds. Synonymes : 1. atropurpurea. 2. stellata. 3. quadrifolia.

aftīñ̌s . . . Yellow * 7, H. Her. P.

angustifoliza : : Yellow:7, H. Her. P. N. Aner. . 1803 atropurpǔréă : : Dk. pur. 8, G. Her. P. Levant : 1820 capitătă : Yellow : 6, H. Her. P. N. Amer. 1813 ciliata . . Yellow : 7, H. Her. P. N. Amer. 1732 dũbră, I * Y Yellow * 8, H. B. Levant . 1739 Ephẻměrŭm *. White . 8, H. Her. P. Spain : 1730 hybrida . Yellow . 7, H. Her, P. N. Amer. 1806 Lìnūm-stellătūm 2 Green : 6, H. A. Italy : 1658 némórūin : Y Yellow : 6, H. Her. P. Britain. Nummulăriă - Yellow * 6, H. Ev. Tr. Britain . punetátä . Yellow : 7, H. Her. P. N. Holl. : 1658 quadriföliă. . Yellow : 7, H. Her. P. N. Amer. : 1794 strictă . Yellow . 7, H. Her. P. N. Amer. 1781 thyrsiflöră . Yellow , 6, ri. Aq P. England verticillătă . Yellow: 7, H. Her. P. Crimea: 1820 vulgăris. : Yellow: 8, H. Her. P. Britain :

Lysin̄̄мă, R. Brown. From lysis, a freeing, and nema, a filament; in allusion to the stamens being free from the corolla. Linn. 5, Or. 1, Nat. Or. Epacridaced. A genus of very pretty plants, which thrive best in a very rough sandy peat soil, and are increased by cuttings of the nearly ripened wood, planted in sand, under a glass. Synonyme: 1 . Epacris rosea.

attenuătūm

conspicŭùm

lasiānthūm.

pentapétãlūm pũngēns

White.
Pink
Pink :
White:
Red

2, G. Ev, S. N. S. W 3 , G. Ev. S. N. Holl. 3, G. Ev. S. N. Holl. 3, G. Ev. S. N. Holl.

, G. Ev S. N. S. W. • 1804

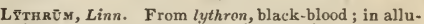
sion to the purple colour of most of the flowers. Linn. 11, Or. 1, Nat. Or. Lythracee. The hardy perennial species of this genus are very handsome. They tbrive in any common garden soil, and are readily increased by dividing the plants at the root. The seeds of the annual species should be sown in the open border in spring. Synonymes: 1. $\boldsymbol{L}$. Kennedianum. 2. L. diffusum. alătúm, 1. - Purple . 7, G. Her. P. A nerica 1812 Graffërí * Purple : 7, H. A. Italy : 1800

lanceolătũm, 2: Purple : 7, H. Her. P. Carolina : 1800 lineärelam, 2: Purple myrtifolīüm: : Purple Salieāriă : Purplo thesioides: Liluc thymifolium: Purple tumentosūm virgktūm . : Purple 7, H. Her. P. N. Amer. 1820 7, H. Her. P. Britain .

8, H. A. S. Eur. .

8, H. A. N. Amer. 1816 7, H. Her. P. Austria. 7, H. Her. P. N. Amer. : 1812 7, H. Her, P. Caumsus : 1808 azórícå. - Yellow. 6, H. Her. P. Azores: 1831 longifóliă, 3 . Yellow * 7, H. Her. P. N. Amer. 1798 maculātă * . Yellow : 6, G. Ev. Tr. N. Holl. 1822 
M $\bar{A} \mathrm{BA}$, Forster. The name applied to it in TongaTabu. Linn. 22, Or. 8, Nat. Or. Ebenacee. These plants are well worthy of cultivation; a of the ripened wood root freely in sand, under a glass. Synonyme: 1. Ferreola buxifolia.

buxifolin, 1 . Yellow * S. Ev. S. E. Ind. . 1810 laurină : : : 7, G. Ev. Tr. N. Holl. : 1824 MAcaw-TrRk, see Acrocōmĭă fusiformĭs.

MAcBRatB, to decompose by steeping in water, or other liquid.

MACIEĀEA, R. Bronn. In honour of Alexander M'Leay, F.R.S., L.S., a famous entomologist and colonial' secretary in New South Wales. Linn. 13, Or. 1, Nat. Or. Papaveracea. A very beautiful herbaceous plant, succeeding in any rich mould, and increased by dividing the roots in spring; is may also be propagated by seeds. Synonyme: 1 . Bocconia cordata.

cordata, 1 . . Red yel. . 6, H. Her. P China

MAcLŪră, Nuttall. In honour of William Maclure, a North American geologist. Linn. 21, Or. 4, Nat. Or. Urticaceu. A genus of very ornamental trees, attaining the height of thirty feet. They require to be grown in turfy loam and peat, and are increased from cuttings of the ripened wood planted in sand, under a glass. M. aurantiaca should be slightly protected in severe weather. Synonymes: 1. Morus Plumieri, Brosissonetia Plumieri. 2. M. tinctoria, B. tinctoria.

aurantǐ̌că . . Apetal . H. De. T. N. Amer. • 1818 Plumiêri, 1 : A petal : S. EःT. W. Ind. : 1804 tinetóră, 2 : A petal : S. Ev. T. W. Ind. : 1739

MacradénYă, R. Bronn. From makros, long, and aden, a gland; in allusion to the long caudicula of the pollen-masses. Linn. 20, Or. 1, Nat. Or. Orchidacee. This is rather a pretty genus, requiring a strong moist heat to keep the species healthy. They should be potted in turfy peat broken into small squares, and raised a little above the pot, which must have a good drainage.

lutescešns. . . Olive. . 11, s. Epi. Trinidad . . 1821

mătieă : : : Dingy wht. 8, s. Epi. Trinidad:
triandră : : WhL grn. 5, S. Epi. Surinam

M Acrocnēuō̌, R. Bronn. From makros, long, and kneme, a leg; in allusion to the long flower-stalk. Linn. 5, Or. 1, Nat. Or. Cinchonacee. Ornamental plants, succeeding in loam and peat, and propagated by cuttings in sand, under a glass, in heat.

jamaicẽnsè . . White. . S. Ev. T. Jnmaica 1806 tinctôrüüm: : Red : 9, S. Ev. T. Trinidad : 1820

MAсRот̆́tūm, R. Bronn. From makros, long, and pous, a foot; in allusion to the shape of the seedvessel. Linn. 15, Nat. Or. Crucifere. A light rich soil suits these plants well, and cuttings of the herbaceous species root readily in sand. M. laciniatum is readily increased by seeds. Synonyme: 1. Cardamine nivalis. laciniâtūm. : White : 7, H. Her. A. N. Amer. : 1827 M ACRORHīză, long, or large-rooted,

M ACROSTY̌LIs, Bartling. From makros, long, and stylis, a style; referring to the length of the style. Linn. 5, Or. 1, Nat. Or. Rutacea. This is an interesting genus of plants; for culture and propagation, see Diosma. Synonymes: 1. Agathosma barbata. 2. A. obtusa, Diusma ciliata.

barbată, 1 . . White. 5, G. Ev, S. C. G. H. : 1810 obtūăa, 2 : : Purple : 5, G.Ev. S. C. G. H. : 1774 lanceolats : : Purple : 5, G. Ev. S. C.G.H. : 1774 oblongă . : Puiple :5, G. Ev. s. C. G. H. : 1774 ovăta. : : Purple 5, G. Ev, S. C. G. H. : 1774

Macrōtrŏp̆̌s, Decandolle. From makros, long, and tropis, a keel; alluding to the long keel of the flowers. Linn. 10, Or. 1, Nat. Or. Leguminosa.
An ornamental plant ; for culture and propagation, see Anagyris.

fö̀tưda . . Yellow . 4, G. Ev, S. Chins . . 1820

MAcrōtřs, Rafinesque. From makros, long, and ous, an ear; resemblance in the long capsules. Linn. 13, Or. 1, Nat. Or. Ranunculacee. A pretty plant, growing freely in any good soil, and increased by divisions. Synonyme: 1 . Actica racemosa.

racemōsă, 1 . . White . 5, H. Her. P. N. Amer. .

MADAgAscar NUTMEg, see Agathophy̆llam.

Madagascar potato, see Solüntam inguini.

MAD APPLR, see Solänüm insäñm.

M ADDER, see $R$ übiáa.

M $\bar{A} \bar{\perp} \hat{A}$, Molina. Madi is the name of the original species in Chile. Linn. 19, Or. \&, Nat. Or. Composite. The seeds of these rather handsome plants should be sown in May or June, in a shady situation, in any common garden soil. They grow about two feet high, flower in about two months after being sown, and continue in beauty about six weeks or two months. Synonymes: 1. M. mellosa, M. viscosa.

elègåns . - Yellow * 8, H. A. N. W. Amer. 1831 eativă, 1 : : Yellow : 7, H. A. Chile. Amer. 1794

MADWoRT, see Algssim.

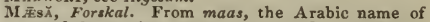
one of the species. Linn. 5, Or. 1, Nat. Or. Myrsinacea. These are ornamental plants; for culture and propagation, see Ardisia. Synonymes: 1 . Basbotrys indica. 2. M. tomentosa. 3. B. pubescens.

argèntéă . . White * 4, S. Ev. S. E. Ind. . 1818 Indică, 1 : White : 11, s. Ev. S. E. Ind. : : 1817 maerophylla, 2 : White : 6, s Ev. T. E. Ind. : 1818 pubéscēns, 3 . . White : 6, S. Ev. S. E. Ind. . : 1824

MagnōLr̆, Linn. After Pierre Magnol, professor of medicine at Montpelier, and author of several botanical works; he died in 1715. Linn. 13, Or. 6, Nat. Or. Magnoliaced. This is a genus of very elegant and showy plants when in flower, and all well worthy of extensive cultivation. The hardy kinds being remarkably handsome shrubs, should be planted in conspicuous situations, where they will flower profusely when they attain a good size. $M$. glauca and some others grow best in a peat $80 i l$ in a moist situation. They are generally increased by layers put down in spring or autumn, or by seeds; when the layers are first taken off, they should be potted in a mixture of loam and peat, and placed in a close frame till they have taken fresh root. None of the leaves should be taken off or shortened, nor any shoots be cut off, or their tops shortened, as they will not succeed so well; fur the more branches and leaves are on, the sooner they will strike fresh root. The Chinese kinds are often inarched or budded on $\boldsymbol{M}$. obovata, which takes readily. The greenhouse kinds thrive best in a mixture of peat and loam, and are also increased by inarching or budding on $\boldsymbol{M}$. obovata, one of the readiest growing kinds. $\boldsymbol{M}$. fuscata, and any of the weak-growing species, increase with facility from cuttings taken off as soon as ripe, and planted in a pot of sand, under a glass. The seeds of the North. American species are received annually from that country. They should be sown as soon as possible after their arrival in pots of light rich earth, covering them half an inch deep; these may be placed either in a hotbed or a warm sheltered situation, or they may be sown in the open ground, and when the plants are of suffi. cient size, they should be planted out singly into pots, and sheltered till they have taken fresh root, and they should be protected from the frost by a frame for two or three successive winters, giving them the benefit of the open air in mild weather. Synonymes: 1. M. gracilis, M. Yulan. 2. M. Soulangiana. 3. M. tomentosa. 4. M. umbrella. 
acuminătă . - Yel. grn. . 6, H. De. T. N. Amer. . 1736 Candöllī : Yelsh... 6, H. De. T. N. Amer. : 1736 māxină : : Yelsh. : 6, H. De. T. N. Amer. : 1736 auriculata : White. 4, H. De. T. Carolina 1786 conspicủă, 1 . White. 3, F. De. T. China * 1789 Alexandrina . White. 4, F. De. T. China . . 1831 citriodoră : White: 4, F. De. T. China: 1831

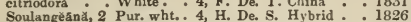
cordátă. Yel, wht. 6, H. De. T. N. Amer. : 1801 - Yel. whic . 6, He. T. N. Amer

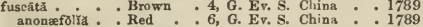
White: 7, H. De. T. N. Amer. - 1688 Burchelliănă White: 6, H. De. T

Gordonikna. White. 6, H. De. T.

longifolia White. 7, H. De. T. Hybrid

Thomsoniand White 7, H Thrid

: Purple: 4, H. De. S. Japar

grandiflöră :

angustifoira

crispà

elliptĩcă

exoniênsis

ferruginęa

lanceolăta

obovätă

præecóx

Kobüs, 3

macrophȳlia

obovātă .

discólor

purpŭrèă

pyramidätă

White 8, H. T. Carolina

White. 7, H. Ev, T. Paris

White. 6, H. Ev. T. N. Amer.

White. 8, H. Ev. T. Carolina

White. 8, H. Ev. T. N. Amer.

White. 8, H. Ev. T. N. Amer.

White. 8, H. Ev. T. Carolina

White. 8, H. Ev. T. Carolina

White : 8, H. Ev. T. N. Amer.

White

8, H. Ev. T. N. Amer.

Pur, wht. 7, H. Ev. S. Japan

White. 7, H. De. T. N. Amer.

Purple

Pur. wht

7, F. De. S. China

5, F. De. S.

4, H. De. S. Japan

White. 5, H. De. T. Carolina : 1811

1750

1817

1804

1734

1734

1734

1734

1804

1800

1790

790

1811

MAHĒRnĭ, Linn. An anagram of Hermannia, signifying affinity. Linn. 16, Or. 2, Nat. Or. Sterculiacea. These are extremely pretty plants. The soil best adapted to them is an equal mixture of loam and sandy peat; and young cuttings taken off at a joint, will soon root, if planted in the same kind of soil, under a glass. Synonymes: 1. It. pinnata. 2. M. odorata. 3. M. Burchellii. bipinnătă, 1 - Brown : 7, G. Ev. S. C. G. H.

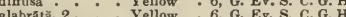
glabrátă, $2:$ : Yellow : 6, G. Ev. S. C. G. H.

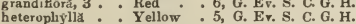

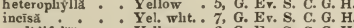

oxalidifolia pulchëlla resedafolra sessilifolià

vernickta

Yel, whit. Yellow 6, G. Ev. S. C. G. H. Reddish . 7, G. Ev. S. C. G. H. Yellow 7, G. Ev. S. C. G. H. Yel. wht. . 6, G. Ev. S. C. G. H. Vermil. - 7, G. Ev. S. C. G. H. verticillātă. : Yellow : 7, G. Ev. S. C. G. H.

\section{Mahoganx, see Swietēñ̌̆ Mahägơñ̆.}

M Анб̄Nǐ, Nuttall. In honoúr of Bernard M'Mahon, of North America, a lover of botanical science. Linn. 6, Or. 1, Nat. Or. Berberacec. A mixture of sand, peat, and loam, is the soil best adapted to the growth of these beautiful shrubs. They may be increased by layers, or by cuttings of the ripened wood planted in sand, in autumn, under a glass. Synonymes: 1. Berberis Aguifolium. 2. B. pinnati, $M$. diversifolia. 3. B. nervosa, $M$. glumacea. 4. B. repens.

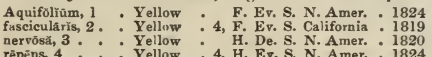

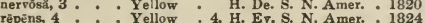

M AIDENHA1R, see Adiūntũm.

Maidenhair, see Passiflórä Adiäntum.

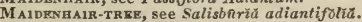

MAIDEN-L1P, see Echinospērmũm läppŭlă.

MAIDEN-PLUM, see Comoclädiă.

MAJorĀAn, Manch. An alteration of the Arabic name, Maryamych. Linn. 14, Or. 1, Nat. Or. Labi. atc. These plants succeed well in sandy soil and a dry situation. The species are all shrubby if protected during winter, and they are easily increased by slips or cuttings. Synonymes: 1. Ori. ganum Maru. 2. O. Majorana. 3. O. syriacum. 4. O. Onites, O. smyrnaum.

crassifolia, 1 . Purplish - 6, F. Ev. S. Levant .

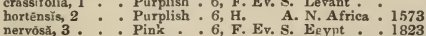

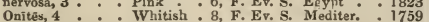

Malabar I.EAF, see Cinnamōmam Malabātrâm.

MAIABAR NightshaDE, see Baséllă.

Malabar nut, see Justǐciă Adhatodă.

Malabar Rose, see Hibíscŭs Rösă malabŭrĭcă.

MALAchodĒnDRón, Linn. From malachos, soft, and dendron, a tree. Linn. 16, Or. 8, Nat. Or. Sterculi- acea. This fine ornamental plant is highly deserving a place in every garden, on account of its large cream-coloured blossoms. The plant should be kept in the greenhouse, for though sufficiently hardy to stand our winters in the open air, the young shoots often get injured by frost, the summer not being long enough to ripen the wood, or even to flower it in perfection. The best soil for it is peat, mixed with a little loam; and it is readily increased by layers, or cuttings of the ripened wood, in sand, under a glass.

ovătũm . . . White . 7, H. De. T. N. Amer. . 1785

MaL̄̄chră, Linn. A name under which Pliny speaks of a Persian tree, which produces a gum. The name is preserved to designate plants analogous to mallow, from the similarity of the word malachra with that of malache, a mallow. Linn. 16, Or. 8, Nat. Or. Malvacer. Annuals of no interest; they require to be raised in a hothouse, and, when of sufficient size, to be planted singly into small pots, and placed among the stove plants. Synonyme: 1 . M. fasciata-alceófoliă, bracteätă, capitätă, fasciätă, heptaphȳllä 1 , radiätă, rotundifoliă, trĭlobă.

M ALA Y A PPLE, see Jambósă malaccẻnsĩs.

MaLÃxis, Snartz. Malaxis, delicate; in allusion to the textire of the species. Linn. 20, Or. 1, Nat. Or. Orchidacea. A pretty little plant, growing freely in sandy peat.

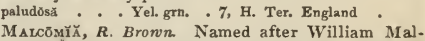
colm, F.L.S., a celebrated nurseryman and cultivator. Linn. 15, Nat. Or. Crucifere. These plants are not possessed of much beauty. They should be sown in the open border in spring; or by sowing at various times, they may be got to flower all the year, except in severe frosty weather. $S y$ nonymes: 1. Hesperis africana. 2. $\mathrm{H}$. arenaria. 3. Cheiranthus lyratus. 4. C. maritimus.

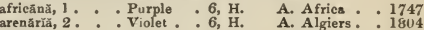
chră. . Purple 6, H. A. Chio: 1732 erōsă : 6, H. A. Portugal : 1818 incrassătă : Purple :6, H. A. Tenedos : 1820 lâcéră - . . Wht. yel. . 6, H. A. S. Eur. . - 1718 láxă. - - Purple . 6, H. A. Siberia * 1820 maritimă, 4 : : Violet : 6, H. A. Cyprus : 1820 parviflóră . Lilac . 6, H. A. S. Eur. . 1823 taraxacifoliă : Purple 6, H. A. Siberia : 1795

M ALR FRRN, see Aspídiūm Filit $x$-mäs.

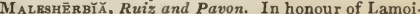
gnon de Malesherbes, an illustrious French patriot and agriculturist. Linn. 5, Or. 3, Nat. Or. Malesherbiacea. This is a very interesting genus, requiring the treatment common to most greenhouse annuals. Synonyme: 1 . M. coronata.

hrumilis. . White. - G. A. Chile

linearifoliă, 1 Pur blue 8, G. A. Chile * 1832

Matrow, see $M a ̈ l v a ̈$.

MALlow Rose, see Hibiscŭs moschätǔs.

MĂLŏp $\breve{~ L i n n . ~ F r o m ~ m a l o s, ~ t e n d e r ; ~ i n ~ a l l u s i o n ~ t o ~}$ the soft leaves. Linn, 16, Or. 8, Nat. Or. Malvaceu. These are very beautiful plants. The seed should be sown in the open border about the beginning or middle of April.

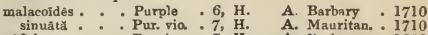

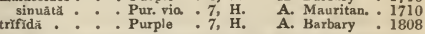

Malpīghĭ, Linn. In honour of Marcello Malpighi, once professor of medicine at Pisa, and author of many valuable works on natural history. He died in 1694. Linn. 10, Or. 3, Nat. Or. Malpighiacece. A genus of interesting plants, some of which, as $M$. Aquifolia, coccifera, and one or two others, are especially worth the cultivator's care. They thrive well in any light soil, and cuttings of the ripened wood root readily in sand, under a glass, in heat. $M$. glabra is known by the name of Barbadoes Cherry in the British West Indies. It is cultivated in all the West Indian Islands, and in many parts of South America, for its fruit, which is esteemed there, but is much inferior to our cherries. Syno. nyme: 1. M. punicifolia.

angustifolyx - Pink - * 7, S. Ev. S. W. Ind. $\quad 1737$

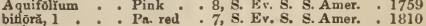
[195] 


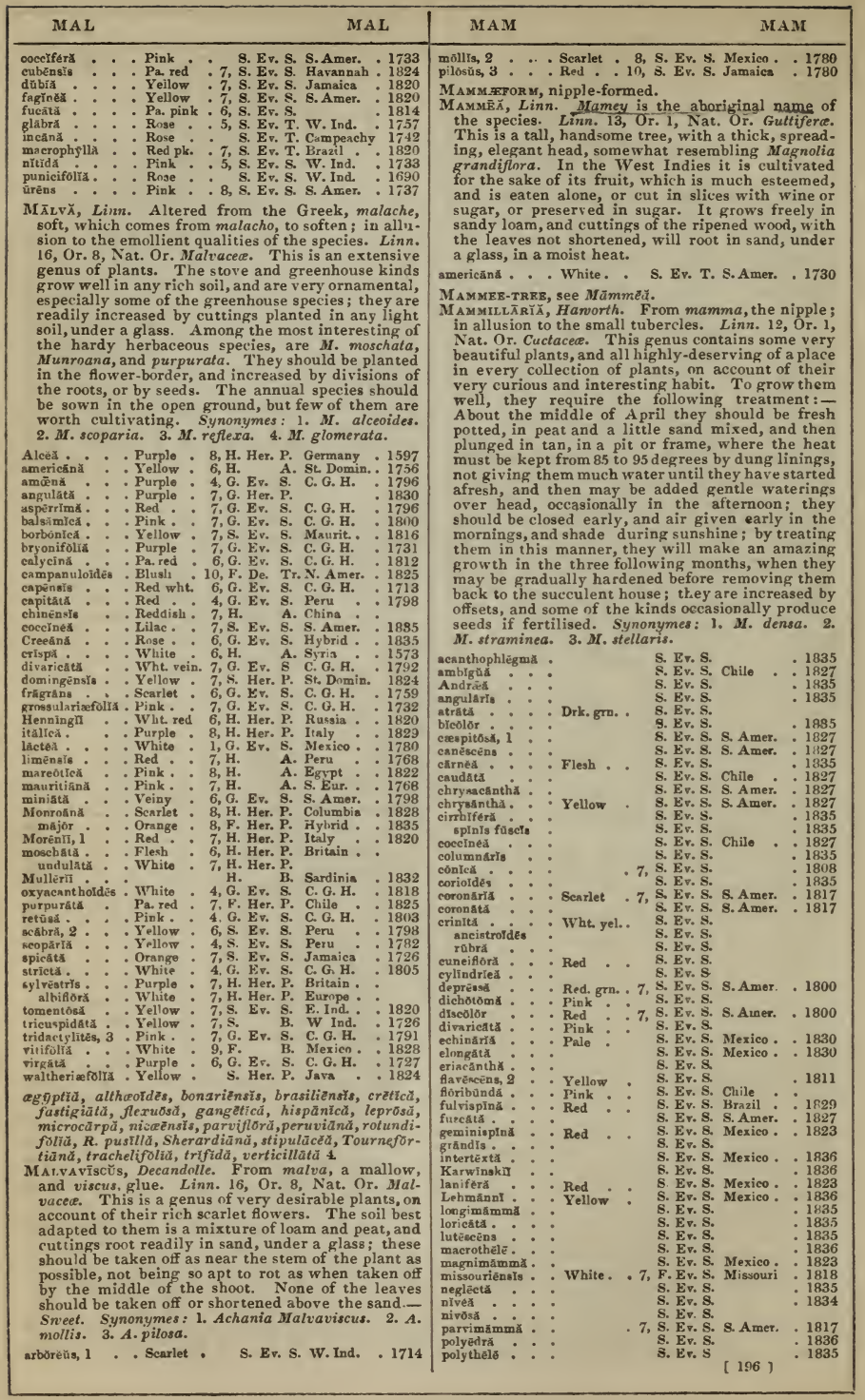




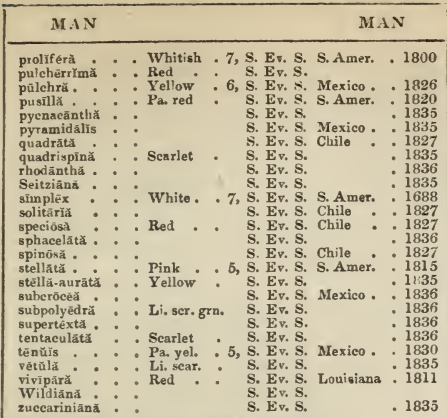

Manchineer, see Hippómănẽ Mancinellă.

MANchinker, see Säpĩüm Hippomănê.

MaNDARIN ORANGE, see Cítrǔs nobilis.

MANDrAgōră, Tournefort. The English name Mandrake, Is derived from mandra, an ox-stall, something relating to cattle, and agauros, cruel; on account of its poisonous effects on cattle when accidentally gathered with their fodder in the countries where the plants abouud. Linn. 5, Or. 1, Nat. Or. Solanaceo. These plants thrive well in a light soil, in a shaded situation. They can only be increased by seeds. The roots are very apt to rot during winter. Synonymes: 1. Atropa Mandragora. 2. M. efficinalis. 3. A. mandragora.

autumnalis, 1 . . Yel. wht. . 6, H. Her. P. S. Eur. .

negléctă : Yellow : 5, H. Her. P.

präcōx, 2 : : Fuscous : 3, H. Her. P. Switzerl. . 1819 vernal's, 3 : : White . 4, H. Her. P. Levant . 1548

Mandrake, see Mandragorŏ.

MANẼTtǏn, Mutis. In honour of Xavier Manetti, prefect of the botanic garden at Florence, and author of Regnum Vegetabile, 1756. Linn. 4, Or. 1, Nat. Or. Cinchonaced. These plants are well worth cultivating for the beauty and elegance of their flowers. The best soil for them is a mixture of loam and peat. They are easily increased by cuttings of the young wood in the same kind of soil, under a glass, in a moderate heat. Synonyme : 1. M. cordifolia.

coccinĕă - Scarlet . 6, S. Ev. Tw. Guiana , 1806

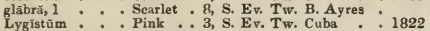
MANGĬFĔR̆ Linn. Derived from mango, the name of the tree, and fero, to bear. Linn. 23, Or. 1, Nat. Or. Anacardiacee. This is a genus of much esteemed tropical fruit trees, thriving well in sandy loam, or a mixture of loam and peat. The species are readily increased by cuttings of the ripened wood planted in sand, under a glass, in heat. Fresh seeds imported from the places of their natural growth, will vegetate freely. Within the tropics, they hardly eat any other fruit besides $M$. indica, or Common Mango, during the hot months; but if wine be not drunk with it, the Mango is apt to throw out boils, which are, however, conducive to health. The fruit of the finest $M$ angos have a rich sweet-perfumed flavour, accompanied by a grateful acidity.

fētíd̆ . . Red . . S. Evv. T. E. Ind. 1824 indica : : : White: : 7, S. Ev. T. E. Ind. : : 1690

Mango givorr, see Curcūmă Amādă.

Mangostan, see Garcinnuă Mangostānă.

MANGostan, see Amaränthŭs Mangostänă.

MANGo-rRkB, see Mangiffer $r \check{a}$.

YANGROVE, see Rhizophoră Mãnglē.

Manicāriă, Gartner. From manica, a glove ; in allusion to the spathe. Linn. 21, Or. 9, Nat. Or. Palmacea. This is a fine palm, which must be grown in a rich loam, and can only be increased by seeds.

sacciféră

Palm. E. Ind. . . 1823

Manisônis, Swartz. From manis, a scaly lizard, and oura, a tail; referring to the appearance of the

spikes. Linn. 3, Or. 2, Nat. Or. Graminec. A curions plant, of simple culture.

granulärís . . Apetal . . 7, Grass. E. Ind. . . 1821

I ANNA, see Alhāgt.

ManNa Ash, see Ornŭs rotundifolü.

MANTǏš̆, Sims. Name taken from the insect man-

tis; because of the resemblance of the flowers.

Linn. 1, Or. 1, Nat. Or. Scitaminece. These singular plants thrive well in a mixture of loam, peat, and sand, and are easily increased by dividing the roots.

saltatōrĭă * . Purple . 6, S. Her. P. E. Ind. . . 1878 spatılătă : Blue . 6, S. Her. P. E. Ind. : 1823

MANūtǔn̆, Linn. From manus, the hand; in allusion to the five divisions of the corolla. Linn. 14, Or. 2, Nat. Or. Scrophulariacece. Handsome plants, rarely to be met with in collections; they grow well in a mixture of peat and sand, or vegetable mould, and are propagated with ease either by cut-

tings or seeds. Synonymes: 1. Buchnera fatida.

2. B. capensis. 3. B. viscosa.

\begin{tabular}{|c|c|c|}
\hline 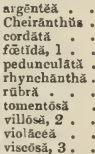 & $\begin{array}{l}\text { Yellow } \\
\text { Orange } \\
\text { : Red } \\
\text { : White: } \\
\text { : White: } \\
\text { : Yellow } \\
\text { : Red } \\
\text { Yellow } \\
\text { Y White. } \\
\text { : Violet: } \\
\text { Pink }\end{array}$ & $\begin{array}{l}\text { 7, G. } \\
\text { 8, G. Her. P. C. G. } \mathrm{H} . \\
\text { 7, G. Ev Tr. C. G. H. } \\
\text { 7, G. A. C. G. H. } \\
\text { 9, G. Ev. S. C. G. H. } \\
\text { 9, S. Her. P. C. G. H. } \\
\text { 6, G. Ev. S. C. G. H. } \\
\text { 8, G. Ev. S. C. G. H. } \\
\text { 6, G. } \text { A. C. G. H. } \\
\text { 9, S. Her. P. } \\
\text { 9, G. Ev. S. C. G. H. }\end{array}$ \\
\hline
\end{tabular}
ethisptcy, alternifuting capitatc linịotiă, oppositiforžă.

MAPLE, see Acẽr

MarĀNTĂ, Linn. After B. Maranti, a Venetian physician and botanist, who died in 1554. Linn. 10, Or. 1, Nat. Or. Marantacee. A genus of interesting plants, which grow well in any light rich soil; they are readily increased by dividing at the

roots. MI. arundinacea is esteemed in the East for the fæcula which abounds in the root, and on that account it is collected as a delicate article of food.

angustifolia $\quad$ Red 7, S. Her. P. W. Ind. 1820 arundinācēă : White: 7, s. Her. P. s. Amer. : 1732 bieôlör : : White: 7, S. Her. P. Brazil : 1823 minǒr : : White. : 4, S. Her. P. S. Anıer. : r828 cuspidătă * Y Yellow : 7, S. Her. P. S. Leone 1822 divaricătă. . White. . 7, s. Her. P. Brazil : 1818 purpurăscēns : White. 8, S. Her. P. Brazil : 1823 gibbã * * White. . 8, S. Her. P. E. Ind. . 1818 grắlilı̆s . . White. . 7, s. Her. P. Guiana . 1823

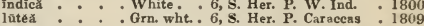
malaceēnsiss : : Grn. wht. 12, S. Her. P. E. Ind. : 1820 obliqquă. . : Red • . 7, S. Her. P. Guiana : 1803 petiolātă : : Yellow 7, S. Her. P. Guiana . 1818 sylvătǐcă : : Yellow : 7, S. Her. P. W. Ind. : 1800 7, S. Her. P. E. Ind. : 1819

MARĀTtǏ , Sn'artz. In honour of J. F. Maratti, of Vallombrosa in Tuscany, a writer upon ferns. Linn. 24, Or. 1, Nat. Or. Daneacede. This ornamental fern grows well in loam and peat, and is increased by dividing the roots, or by seeds.

alātă . . . Brown . 8, S. Her. P. Jamaica • 1793

Marcescent, permanent, when withered not falling off.

MARCGRAāvǐă, Linn. In honour of George Marcgraave, a German, who published a Natural History of Brazil in 1718. Linn, 13, Or. 1, Nat. Or. Marc. graaviacede. This is a genus of curious shrubby, creeping plants; they are found adhering by their fibres to the trunks of trees, though they are not strictly parasitical. They are well suited for covering the walls or rafters of stoves. They grow in turfy loam and peat; and cuttings root in sand, under a glass, in heat.

S. Ev S. Guiana umbellätă : : : White : : S. Ev. S. W. Ind. : 1792

M ARE'g-TaIL, see Hippūris.

Margaritaceous, pearl-bearing.

Marchántín, Corda. In honour of Nicholas Marchant, a French botanist. Linn. 24, Or. 6, Nat. Or. Hepatice. Creeping plants, with green. cellular, fleshy fronds, spreading over the surface of the ground in moist places-androgy̆nă, connčă, hemisphärĭcă, irrigũă, polymorphă. 
MARGN, edge or border.

MARGINATBD, having a border.

MARgYricārpǔs, Ruis and Pavon. From margaron, a pearl, and karpos, a fruit; resemblance of the fruit. Linn. 2, Or. 1, Nat. Or. Rosacere. This is rather a pretty plant, growing well in sandy peat, and increased by cuttings in sand, under a glass, in heat.

setósũs . . . Green . . S. Ev. S. Peru . . 1829

MĂRÍC̆, Schreber. From maraino, to become flaccid; in allusion to the flowers. Linn. 3, Or. 1, Nat. Or. Iridacee. Very beautiful and curious plants, delighting in a mixture of loam, peat, and sand, and increased by dividing the roots, or by seed, which ripens in abundance.

cçrǔléă . . Blue • . 5, G. Her. P. Brazil . . 1818

cœlēstrss : Blue 5 S. Her. P. Brazil : 1829

gráçlis. Yel. blue : 8, G. Her. P. Brazil : 1830

gracils. : Yellow 6, G. Her. P Brazil:

hümilis: * Yellow * 6, G. Her. P. Brazil • 1823

longifoliä : : Striped :8, S. Her. P. Brazil : 1830

Northiānaz. : : Yellow : 6, G. Her. P. Brazil : 1789

paludősã : : White. 7, s. Aq. P. Guiana . 1792

Sabini : Yellow : 8, G. Her. P. St. Thomas 1822

MARTGOLD, see Caléndülă.

Marîscưs, Vahl. From the Celtic word mar, signifying a marsh; in allusion to the plants growing in marshes. Linn. 3, Or. 1, Nat. Or. Cyperacea. Curious stove plants, growing in a lnamy soil well supplied with water, and inereased by dividing the roots.

nggregatŭs . A Apetal . 6, Grass. 1822 conflexŭs : A Apetal : 7, Grass Brazil : 1819 elâtŭs

lāvǐs, ovulärĭs, punīcěŭs.

MARJōR $\mathrm{A}$, see Origănnm.

Marsóróm, see Majorünă.

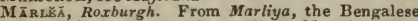
name of the plant. Linn. 8, Or. 1, Nat. Or. Alangiacere. A pretty plant, succeeding in peat and loam; and cuttings of the half-ripened wood root readily in sand, under a glass.

begonizefolra . . Yellow . G. Ev. S. China .

MarRóbĨ m. From marrob, a Hebrew word, signify ing a bitter juice; in allusion to the extreme bitterness of the plants. Linn. 14, Or. 1, Nat. Or. Labiatc. Any common garden soil will suit these plants, and they are readily increased by divisions of the roots, or by seeds. Synonymes: $1 . M$. affine. 2. M. creticum. 3. M. apulum.

Aleosim cretin 1597 Astracanicüm: : Pa pur. : 7, H. Her. P. Lerant : : 1816 eandidissimûm : White. 7, H. Her. P. Lerant : 1732 catarizfolium. : Purple : 7, H. Her. P. Jevant : 1819 leonurnídes, 1. Purple 7 , H. Her. P. Caucasus: 1819

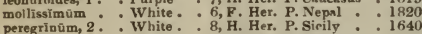
supinūm ? : Purple 9, H. Her. P.S. Eur. : 1714 vule réé : : White. 7 , H. Her. P.Britain lanatúm, 3 : : White.: 8, H. Her. P. Britain

MARgDĒNǏ, $\boldsymbol{R}$. Brown. In honour of William Marsden, F.R.S., late secretary to the Admiralty, and author of a History of Sumatra. Linn. 5, Or. 2, Nat. Or. Asclepiadacer. A genus of very interesting plants. M. flavescens is well suited for covering rafters, pillars, or trellis-work, in stoves or conservatories. They grow in a mixture of loam, peat, and sand; and cuttings root in sand, under a glass, in heat.

eréctă . * . White - 7, G. Ev. S. Syria • 1597 flavēseêns: : : Yelsh. : 8, S. Ev. Tw. N. Holl.": 1830 suavélêns : : White：7, S. Ev. Cl. N. Holl. : 1816 MARSHĀTr.Y̌̃, Schreber. In honour of Humphrey Marshall, a botanical author. Linn. 19, Or. 1, Nat. Or. Compositu. This is a genus of very handsome plants. They grow very well in a mixture of loam and peat, and are readily increased by cuttings.

angustifoliă - Purple . 7, F. Her. P. Carolina . 1800 crespitôsa : : Pur. wht. 7, F. Her. P. Texas . 1837 lanceolată : : Purple: 6, F. Her. P. Carolina : 1812 latifolia : : Pa pur. : 6, F. Her. P. Carolina : 1806

MARSH-cIVQUEFOIL, see Comărûm palıstrě.

M ARsh-MaLLow, see Althēea.

Marsh-marigoti, see Cãlthă.

MARSH-PENNYWORT, see Hydrocotỹtē vulgäris.

MARsîn $\overline{\mathrm{B}} \mathrm{A}$. Linnæus dedicated this genus to the Count L. F. Marsigli, founder of the Academy of Sciences, Bologna. Linn. 24, Or. 4, Nat. Or. Mar. sileucea. A curious aquatic plant, readily increased by divisions.

quadrifóliă.

. 7, H. Aq. P. Europe . . 1820

Marsypiñnthùs, Martizs. From marsupos, a purse, and anthos, a flower; because of the shape of the flowers. Linn. 14, Or. 1, Nat. Or. Labiata. This is not a plant of much beauty. The seed may be reared on a hotbed, and treated as other tender annuals. Synonyme: 1. Hyptis inflata.

hyptoīeses, 1 . Blue * 7, s. A. America . 1823

MART Yxĭ, Linn. In honour of John Martyn, F.R.S., professor of botany at Cambridge, who died in 1768 . Linn. 14, Or. 2, Nat. Or. Pedaliacere. Handsome annuals. The seed should be raised on a hotbed, and when transplanted singly into pots of light rich soil, they should be kept in the stove or green. house. Synonyme; 1. M. annua.

diändră. . . Red . 7, s. A. N. Spain . 1731 longiflöră : : Pa.pur. : 7, G. A. C. G. H. : 1781 proboscider, 1: : Lgt blue : 7, G. A. Arazil : 1825

MăR đ̊M, signifying a herb with a strong smell.

MAFVRL-of-PERU, see Miräbilis.

MAssōñ̄, Linn. In honour of Mr. F. Masson, author of Stapeliæe Novæ. Linn. 6, Or. 1, Nat. Or. Liliacea. A genus of very singular plants, flourishing in an equal mixture of loam, peat, and sand, and requiring no water when in a dormant state. They may be increased by offsets from the bulbs, or by seeds. They will grow very well in a frame. Synonyme: 1. M. pustulata.

anguatifolis - White. 4, G. B1. P. C. G. H. candrda. : : White. : 4, G. Bl. P. C. G. H cordat : : : White. : 5, G. Bl. P. C. G. H. cordata. : White. 5, G. Bl P. C. G. H. echinstă : White. 5, G. Bl. P. C. G. H. ensifolia : : Livid . 4, G. B1. P. C. G. H. grandiflora. : : Wht grn. 10, G. Bl. P. C. G. H. longifolr : White: 3, G. Bl. P. C. G. H. muricati White, 4, Bl P. C. H. paucifór : : White. : 4, G. Bl. P. C. G. H. scatrat, I: : White: 2, G. B. P. C. G. H.

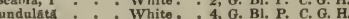
violácéă. : : White. : 5, G. BL. P. C. G. H. : 1800

MAstBRWORT, see Imperatólü.

M AsTERWonT, see Astrüntĩu.

MAstic, see Majorānä crassifoliă.

Mastication, grinding or chewing with the teeth.

M Astrch, see Thỹmüs Mastichinĕ.

M Astich-TRRB, see Pistācīà Lentisscùs.

МАтйвй, Aublet. From Matabaiba, the name of M. guianensis in French Guiana. Linn. 8, Or. 1, Nat. Or. Sapindacea. These trees at tain the height of sixty feet. They grow in a mixture of loam and peat, and cuttings of the ripened wood, not deprived of any of their leaves, will root in sand, under a glass, in heat. Synonyme: 1. Ephielis fraxinea.

quianēnšs, 1 . White . . S. Ev. S. Guiana • 1803 Patrisiană. White : S. Ev. S. Guiana : 1825

MAT-oRAss, see Nïrdüs.

Mat-grass, see Psämméc.

$M$ ATH, an old term for crop.

MATHIŏL $\breve{L}, R$. Bronn. In honour of Peter Andrew Mathioli, a famous Italian physician, and author of a commentary on the works of Dioscorides; he died in 1757. Linn. 15, Nat. Or. Cruciforce. This is a genus of old and well-known inhabitants of the garden. In order to obtain good double Stock-gilliflowers, Brompton and Queen-stocks, choice should be made of such single-flowering plants as grow near many double ones. The seed should be sown in May, and after they have reached two or three inches high, they should be thinned at least nine inches asunder, and the plants taken out may be planted at about the same distance apart in the flower-border; if the following winter be severe, they must be protected by mats, and in the follow. ing May and June they will flower beautifully. Desirable double varieties may be propagated by cuttings, which root readily by being planted under a hand-glass, and shaded. To have a succession of the Annual, or Ten-neek-stock, the seed should be [ 198 ] 
sown in February, March, A pril, and May, and the plants from the May sowing will continue to flower till Christmas. In preserving plants of the Stock.gilliflower, and Ten-week-stock, for seed, select only such single-flowering plants as have fine-coloured flowers. The biennial and hardy shrubby kinds should be treated in the same manner as the Stock-gilliflower, and all the annual kinds in the samp way as the Ten-neek-stock. The greenhouse shrubby species grow best in a mixture of light soil and sand, and cuttings root readily under a glass. Fine double stocks may be planted in pots, and kept in a frame during winter.

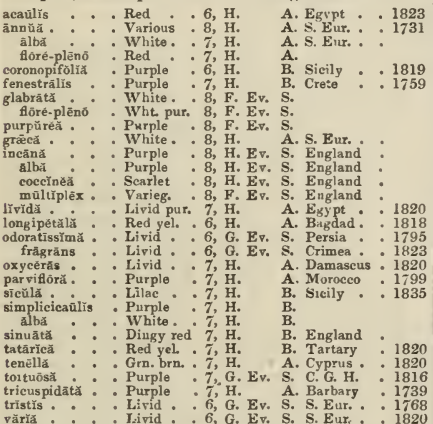

MATRICĀRĬ L Linn. From matrix, the womb. Linn.

19, Or. 2, Nat. Or. Composite. Hardy annuals, of no interest-capēnsǐs, Chamomällă, C. florĕ-plēnö, pusillă, suavěólêns.

MÁtRIx, a place where anything is generated or formed.

M $\bar{x} \operatorname{Tr} \tilde{A}$, Schultes. Supposed to be after some botanist. Linn. 5, Or. 1, Nat. Or. Boraginacere. Ornamental plants, growing well in any common garden soil, and increased by divisions.

lanãtă . . . Reddish . 6, H. Her. P. Levant . 1800 umbellătă : . Red . 5, H. Her. P. Hungary 1822

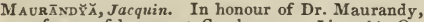
professor of botany at Carthagena. Linn. 14, Or. 2, Nat. Or. Serophulariacere. The species of this genus are very elegant, climbing, evergreen, or herbaceous plants, and are therefore well worthy of a place in every garden. During summer, they will grow and flower abındantly planted against a wall in the open air, or at the bottom of trelliswork; but they require the protection of a green. house in winter. A light rich soil suits them, and they are easily increased by young cuttings planted under a glass, or by seeds.

antirrhiniflōră . . Purple . 7, G. Ev. Tw. Mexico . 1814 Barclayañ : : Blue wht. 7, G. Ev. Tw. Mexico : 1325 senperflörêns: : Purple .7, G Ev, Tw. Mexico : 1796

MAvRITť̆, Linn. In honour of the Prince Maurice of Nassau, the pation of the celebrated Piso. Linn. 22, Or. 6, Nat. Or. Palmacere. This is a genus of splendid plants, growing well in a rich sandy loam in a good strong heat, with a copious supply of water when growing vigorously.

armâtă . . . Palm. Brazil . 1824 flexuösă . . . Wht grn, . Palm. Surinam . . 1816 viniferă : : Palm. Maranh. : 1823

Maxillīrĭ Ruiz and Pavon. So named in consequence of the resemblance between the column and labellum and the jaws or maxillæ of some animal. Linn. 20, Or. 1, Nat. Or. Orchidacece. This is an extensive and very elegant genus of plants, all of which are highly deserving of cultivation, either for the beauty or delicious fragrance of the flowers. $\boldsymbol{M}$. Steelii is not only a very remarkable, but a very beautiful plant; the flowers are large, of a fine yellow colour, irregularly spotted with dark purple. [ 199 ]
This, and several other species, as $M$. acicularis, imbricata, racemosa, and $M$. rufescens, should be grown on wood, on which a little moss should be placed, then the roots of the plant put on that, with a sufficient quantity of moss, and the whole fastened to the wood with some metallic wire. For the culture of the other species, see Stanhopea. Synonymes: 1. Maxillaria fuscata. 2. M. placanShera.

aromatica

atrơrúbēns

Barringtơn 㣞

Bōouthrì

chloranthă

Cölleyi

cristătă

décolòr

dēnsă

Déppĩ

dieryptoidès

foveãt :

galeătă

graminnéa

Henchmänni

imbricáta

longifoliă

macrophylla

mãdidă

ochroleũeă

pallidiflóră .

pärvǔlá.

Parikêrī.

pictă

porrēetă

puittacīnă

pưmina

punctată

Rollissônir

ruféseêns, 1

sinuōsă

squālēns

stapelioüdēs

Steelii

stenopêtălă

streptopétālă

tetragona

variäbìlis

unipunetät

virrìdǐs, 2

vitellina

Warreānă

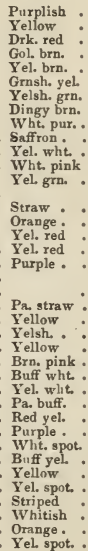

S. Epi. Brazil

5, S. Epi. Mexico.

7, S. E pi.

6, S. Epi. S. Amer.

4, S. Epi. Jamaica

S. Epi. Demerara 1837

9, S. Epi. Mexico : 1834

7, S. Epi. Trinidad

S. Epi. Rio Jan.

1, S. Epi. Jamaica

11. S. Epi. Mexico .

6, S. Epi. Xalapa

S. Epi.

S. Ei. Demerar

S. Epi. Demerar

S. Epi. Brazil

3, S. Epi. Mexico .

S. Epi.

6, S. Epi. N. Granada 1822

S. Epi. Columbia

S. Epi. Brazil

7, S. Epi. Rio Jan.

S. Epi. St. Vin

4, S. Evi Brazil

1896

4, S. Epi. Demerara : 1826

5. Epi. Brazil

S. Epi. Rio Jan.

1835

S. E pi, Demerara . 1835

6, S. Epi. Rio Jan. . 1826

8. S. Evi Rio Jan

12, S. Epi. Trinidad

10, S. Epi. Demerara : 1834

8, S. Epi. Brazil . 1822

6, S. Epi. Brazil : 1837 S. E pi.

Red. yel. 6, S, Eni. Vera Cruz, 1837 Pur. gru.wht. 7, S. Epi. Brazil . 1827 S. Epi. Demerara : 183Purple. 1, S. Epi. Mexico.

Yellow S. Epi. Mexico

5, S. Epi. Brazil

Orange
Whit. pur.: 6, S. Epi. Brazil
8, Epi. Brazil

S. Epi. Organ Mts.

Maximurānă, Martius. In honour of Maximilian Prince of Wied-Neuwied. Linn.23, Or. 1, Nat. Or. Palmacee. This is a very beautiful plant, requiring the same treatment as the genus Mauritia. rēgìa

Palm. Brazil

MAY-APPLE, see Podophy̆llūm peltãtũm.

MA ATẼ̃ŭs, Feuille. Miaiten is the Chilian name of one of the species. Linn. 23, Or. 2, Nat. Or. Celas. tracea. The species of this ornamental genus thrive well in a mixture of peat, loam, and sand; and cuttings of the ripened wood root readily in the same kind of soil, under a glass. Synonymes: 1. Celastris octagonus: 2. C. verticillatus.

White F. Ev T. Chile chilēnsís : : : Grnite yel. ${ }^{*}$ F, F. Ev, T. Chile Chile : 1822 octagonuns, i : White. 10, G. Ev. S. Peru : : 1786 verticillătu็s, 2 : White $: 10$, G. Ev. S. Peru ： 1823

MĀž̌s, Loureiro. From mazos, a teat; in allusion to the mouth of the corolla being closed by tubercles, Linn. 14, Or. 2, Nat. Or. Scrophulariacee. This is a genus of interesting annuals. They re quire to be raised on a gentle hotbed, and abont the end of May to be planted out into a warm sheltered situation in the open ground. Synonyme

1. Lindernia japonica.

pumYYō . * . Pa. pur. . 6, H. A. V. D. L. 1823 rugósŭs, 1 . Yel, pur. . 7, F, Tr. A. China . 1780

Mradow-grass, see Pöă.

MRADOW-RUR, see Thalīctrūm.

MEADOW-sAFrRon, see Colchĩcñm.

Mradow-saxirrage, see Sësétī.

Mradow-sWERT, see Spirä̋ă Ulmārĭă. 


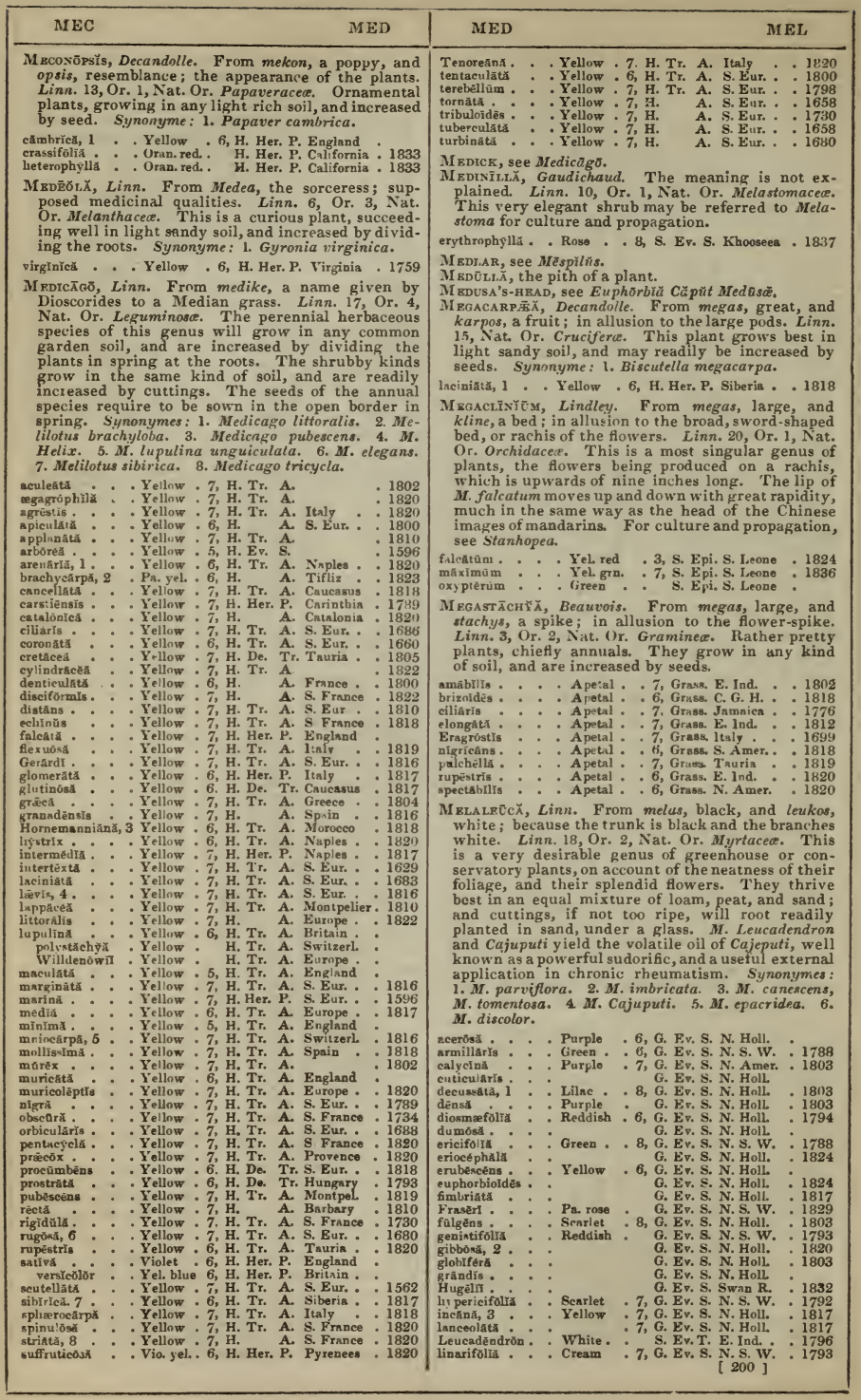




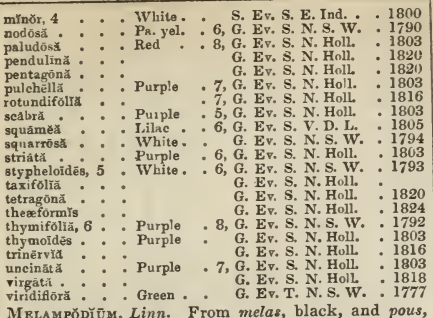

Mвzамғо̆рйŪм, Linn. From melas, black, and pous, a foot; in allusion to the seeds. Linn. 19, Or. 4, Nat. Or. Composite. Uninteresting plants; they require to be sown and treated as other tender annuals. Synonymes: 1. M. ovalifolium, Wedelia minor, Alcina onalifolia, Dyssodium divaricatumamericünūm, hĩspìdūm, hŭmillë, longifoliūm, paludosin l.

MrLaMPF̄ wheat. Linn. 14, Or. 2, Nat. Or. Scrophulariaced. Annual weeds, which require to be sown in the open ground-arvēnsē, cristätū $m$, nemorōsûm, pratẽnsē, sylvätïcūm.

MrLanĀithền̆, Richard. From melas, black, and anthera, an anther; alluding to the colour of the anthers. Linn. 19, Or. 1, Nat. Or. Composita. Uninteresting plants, growing in any common soil, and increased by divisions and seeds. Synonymes: 1. Calea aspera. 2. Bidens nivea-deltoìdēa 1 , has tätă 2, h. pandurätă.

Melancónîu, Link. From melas, black, and konis, dust; in allusion to the black dusty appearance of the species. Linn. 24, Or. 9, Nat. Or. Fungi. These are very minute plants, found on dead branches of trees-conglomerātūm, ovätūm.

MELANocaũLón, black-stemmed.

MrLaNorRh $\bar{\AA} A$, Wallich. From melas, black, and rheo, to flow; when wounded it yields a black juice. Linn. 23, Or. 2, Nat. Or. Anacardiacede. This splendid tree attains the height of a hundred feet; it grows in peat and loam, and cuttings of the ripened wood root freely in sand, under a glass, in heat The varnish of Martaban is obtained from this tree; it is known in that country by the name of Theet-see, or Kheu, and is extremely dangerous, as the skin, if rubbed with it, inflames, and become covered with pimples, which are difficult to heal.

usitatissimă . Red . . S. Ev. T. E. Ind. . 1829

Mrinanosilĩnō, Hofmansegg. From melas, black, and selinon, parsley. Linn. 5, Or. 2, Nat. Or. Um bellifera. 'This plant grows in any common soil, and is increased by divisions. Synonyme: 1. Selinum decipiens

decĩp̌èns . . White. . 6, H. Her. P. Madeira . 1785

MrLANöxY̌Lŏn, black-wooded.

MrLañnthŏn, dark-flowered. MrLĀnthīù, Linn. From melas, black, and anthos, flowers. Linn. 6, Or. 3, Nat. Or. Melanthacea. The plants of this genus deserve a place in every collection; for culture and propagation, see Massonia. Synonyme: 1. Tulipa Breyniana.

capense̊ . - Yellow . 5, G. Bl. P. C. G. H. 1768 ciliătūm : Pa. yei. :6, G. Bl. P. C. G. H. : 1810 gramineúm : Whíte: 5, G. Bl. P. Madagore: 1823 funcéūn : Pink : 9, G. Bl. P. C. G. H. : 1788 phalangioidẽs: White. : 6, G. Bl. P. Carolina : 1810 secundūm . "White. 9, G. Bl. P. C. G. H. 1812 sibrricúm $;:$ : Wht gl. P. Siberia : 1823

MBLAspr我ŬL a globule; dark colour of the bulbs. Linn. 3, Or. I, Nat. Or. Iridacea. These handsome plants re. quire to be treated similar to the Ixias. Synonyme 1. $M$. graminea.

gramineza . Green . 6, G. Bl. P. C. G. H. . 178 intermedră, 1 : Y Yel. grn. $: 6$, G. Bl. P. C. G. H. : iridifolră : Grn. yel. :6, G. Bl. P. C. G. H. : 1787 parviflör [201]
MruĀstōmă, Burmann. From melas, blaek, and stoma, the mouth: the black berries of some of the species are commonly eaten by children, whose mouths they stain black. Linn. 10, Or. 1, Nat. Or. Melastomacea. These plants are very showy when in flower, especially $\boldsymbol{M}$. elongata; indeed, this plant can hardly be excelled for beauty; in it native habitat its flowers are large, and vary from blue to purple and white. Loam, peat, and sand, mixed, suit all the species best; and cuttings of the young wood root readily planted in pots filled with peat, and placed under a glass, in heat. $S y$ nonymes: 1. Osbeckia grandiflora. 2. $M$. malabathrica.

$\begin{array}{ll}\text { affinis } & \text { S. Ev. S. E. Ind. * } \\ \text { Afzeliană : Red } & \text { S. Ev. S. S. Leone }\end{array}$

Afzeliănă . Red - S. Ev. S. S. Leon

åspèră : . Purple

Bănksĭ . . White - 9, S. Ev. S. N. Holl

căndỉdă . - Purple - S. Ev. S. China

corymbỏsă - - Purple - 6, S. Ev. S. S. Leone

cymōsa - - Purple - 6, S. Ev. S. S. Amer.

ecostătă. - - Purple - 7, S. Ev. S. Jamaica

macrocarpä, 2: : Purple : 6, G. Ev. S. Clina

macroearpa, 2.: Purple : 6, S. Ev. S. E. Ind.

sanguiněă : Purple: 9, S. Ev. S. China

1810
1824
1815
1824
1829
1792
1792
1793
1823
1793
1793

MEtĀstŏMă, see Plerömă.

MríĀGRIs, freckled, speckled.

M KLнĀnĭ, Forskahl. From Mount Melhan, in Arabia Felix, where the original species was first found. Linn. 16, Or. 2, Nat. Or. Sterculiacer. Ornamental trees, growing about twenty feet high. They thrive best in a mixture of sandy loam, and cuttings root readily in the same kind of soil, under a glass, in heat

Burchelli1 . - White - G. Ev. T. C. G. H. . 1818 Erythrōxylö́n: : White: : 7, S. Ev. T. St. Helena: 1772 Melanōxýlón : WVhite. : 7, S. Ev. T. St. Helena : 1800

M ̌̆L亡̆, Linn. The Greek name of the manna ash ; resemblance in the leaves. Linn. 14, Or. 10, Nat. Or. Meliacea. Fine trees, thriving well in a mix. ture of loam, peat, and sand; and large cuttings of the ripened wood, with the leares not shortened, will root in sand, under a glass; those of the stove species in heat. The root of $\boldsymbol{M}$. Azedarach is bitter. and is used as an anthelmintic in North America The fruit of $M$. Azadirachta is oily, acrid, and bitter, as is also the bark.

australis - . Lilac * G. Ev. T. N. Holl. - 1810 Azadirăchtă : White: : 7, S. Ev. T. E. Ind. : 1759 Azedarăch : Blue: 7 , G. De T. Syria: : 1656 Azedarăch : : Blue : 7 , G. De. T. Syria : : 165 composita : Wht red. 7, S. Ev. T. E. Ind. - 1810 excelsä : : Whineēnsì : : Wht red: 7, G. Ev. T. E. Ind. : 1819

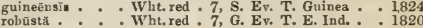
sempẹrvirēns : Brown : S. Ev. T. Jamaica: 1656 supübă. : : Wht red: S. Ev. T. E. Ind. : 1810

MELIĀNThŬs, Linn. From mel, honey, and anthos, a flower; the flowers are full of honey. Linn. 4 , Or. 1, Nat. Or. Zygophyllacex. Ornamental shrubs, thriving in any light rich soil; and cuttings root freely under a glass.

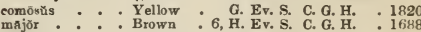
H. Ev. S. C. G. H.

MrLIC̆ L Linn. From mel, honey; the Italian name of the great inillet. Linn. 3, Or. 2, Nat. Or. Gra minea. Some species of this genus are worth growing; they are all of the simplest cnlture.

altissimă. . A petal . . 7, Grass. Siberia • . 1770 ciliata : A petal : 7, Grass. Europe: 1771 nūtans 6 , Grass. Burope unifóră : A petal * : 6, Grass. Britain

Bauhīni, glābră, pyramidālis, speciōsă, sylvătĭcă.

MrLIC-GRASs, see MIelícă.

Meñ̄chrưs, R. Brown. From melichros, honeycoloured; alluding to the colour of the glands of the flowers. Linn. 5, Or. 1, Nat. Or. Epacridacer. These are very pretty shrubs; for culture and propagation, see Epacris.

mĕdrŭs . . . Scarlet . 5, G. Ev. S. N. S. W. . 1824 6, G. Ev. S. N. Holl. 1824

MrLicôccă, Jussieu. From mel, honey, and coccos, a berry; the fruit is very sweet. Linn. 8, Or. 1 , Nat. Or. Sapindaceip. These plants are cultivated to a great extent in the West Indies for their eatable fruits. They grow well in a light loamy soil; and cuttings of the ripened wood will root in sand, 


\begin{tabular}{|c|c|c|}
\hline$M E L$ & & MEL \\
\hline $\begin{array}{l}\text { under a } \\
\text { trijuga. }\end{array}$ & glass in heat. & ne: 1. \\
\hline 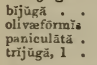 & $:$ Yellow : & $\begin{array}{l}\text { S. Ev. T. Antilles . } 1778 \\
\text { S. Ev. T. N. Granada } 1824 \\
\text { S. Ev. T. St. Domin. } 1820 \\
\text { S. Ev. T. Ceylon . } 1820\end{array}$ \\
\hline \multicolumn{3}{|c|}{$\begin{array}{l}\text { Mrúróp̌̆, Forster. From mel, honey, and kope, a } \\
\text { division; in allusion to the honey glands at the } \\
\text { base of the ovaries. Linn. 8, Or. 1, Nat. Or. Rutacea. } \\
\text { An ornamental shruo, growing freely in loam and } \\
\text { peat; and cuttings of the young wood root in sand, } \\
\text { under a glass. }\end{array}$} \\
\hline
\end{tabular}

under a glass.

\section{MrLinot, see Melilotüs.}

MrLíotũs, Tournefort. From mel, honey, and lotus; honey lotus. The plants are similar to the Lotus, and are the favourite haunt of bees Linn. 14, Or. 10, Nat. Or. Leguminosa. Very few of these plants are worth cultivating except in general collections. $\boldsymbol{M}$. arborea is readily increased by cuttings. The seed of the other kinds only requires to be sown in the open border in spring. Synonymes: 1. M. alba. 2. MI plicata. 3. Trifolium Kochianum. 4. Mr. vulgaris. 5. Trifolium Melilotus officinalis. 6. M. rugulosa. 7. M. mauritanica.

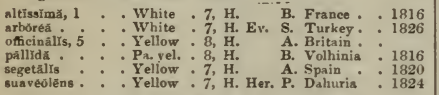

arvēnš̆s, Baumētț, Besseriānd̆ 2, dentātă, grăcillì, indícă, itülīcă, Kochīīnă 3 , leucānthä 4, lineärìs, macrorlitză, mela nospęrmă, messanēnsis, neapolitänd, palnstris, parvifióră 6, Petitpierreānă, polönícă,

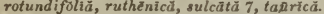

MrLīssã, Bentham. From melissa, a bee; the bees obtain a great quantity of honey from the Balm. Linn. 14, Or. 1, Nat. Or. Labiate. These plants will grow in common garden soil, and are readily increased by dividing the roots. Synonymes: 1 . $\boldsymbol{M}$. altissima, $\boldsymbol{M}$. cordifolia. 2. Horminum pyrenaicum.

cretica

officinalys variegàta villosi, 1

polyfinthös.: White. 7, H. Her. P. Prenees: 1820

Whe. pur.

6, H. Her. P. Candia .

1596

Mxtîtră, Linn. From melitta, a bee; a name synonymous with Melissa. Linn. 14, Or. 1, Nat. Or. Labiata. These are showy plants when in flower, and are, on that account, well fitted for ornamenting flower-borders and shrubberies. They are increased by dividing the roots in spring or autumn. Synonyme: 1. M. grandiflora.

Melissophy̆llūm' . Flesh . . 5, H. Her. P. England alpina . Flesh . 5, H. Her. P. Switzerl grandifióră, 1 : Wht yel. 5, H. Her. P. England

\section{M xLLTrkRous, honey-bearing.}

MrLocīctuัs, C. Bauhin. From melcs, a melon, and cactus; in allusion to the appearance of the plants. Linn. 12, Or. 1, Nat. Or. Cactrcee. This is a genus of grotesque-looking plants. They are well worthy of a place in erery collection of plants, and require precisely the same treatment as the $\boldsymbol{X I}$ ( $\mathrm{m}$ millarias. Synonymes: 1. Cactus Melocactus. 2. C. macracantha. 3. M. Besleri. 4. Echinocactus polyacantha. 5. E. Sellowii.

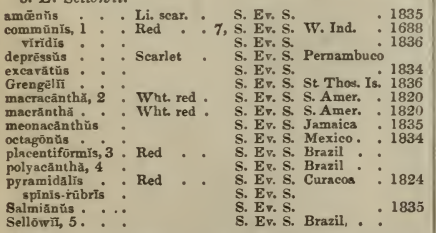

MrLocãnnă, Kampfer. From melon, an apple, and kanna, a reed. Linn. 6, Or. 1, Nat. Or. Graminea. This species is nearly allied to Bambusa; it is
MEL

MEN

readily increased by suckers. Synonyme: 1. Bambusa baccifera.

bambusoldés, 1 . A petal . . 7, Grass. E. Ind. . 1818

M вLōchĭ name of Corchorus olitorius, which is used in the East as a salad-plant. Linn. 16, Or. 2, Nat. Or. Sterculiacea. Plants of little beauty. Any light rich soil suits them; and cuttings root freely in the same kind of soil, under a glass, in heat.

parvifóră . . Purple . 7, S. Ev. S. Caraceas . 1820 parvifuliä : : White. 6, S. Ev. S. Trinidad : 1819 pyranuidata
tomentosea MrLodīsťs, Forster. From melon, an apple, and dineo, to turn round. Linn. 5, Or. 2, Nat. Or. A pocynacece. Ornamental plants, well worth cultivation for the sake of their showy flowers. They grow well in a mixture of loam and peat ; and cut. tings will root in sand, under a glass, in heat.

monôgynuัs . . White . 7, S. Ev. Tw. E. lnd. . 1820 scāndéns . : White : 7, s. Er. Tw. N. Caled. : 1775

MrLon, see Cŭcŭmis Mělo.

MrLoN-puMpkin, see Cucârbită Melopěpo.

M вL.ON-THIsti., see Melocâcrüs.

M RLON-TURK's-cAP, see Melocäctüs commants.

MrLosēírä, Agardh. From melon, a melon, and seira, a chain; shape of the filaments. Linn. 24, Or. 7, Nat. Or. Alga. Very minute species, found in salt marshes, rivulets, \&c.-discǐkěrü, lineütă, nummulotdes.

M EL̄̄THRĬ supposed to be Bryony. Linn. 2l, Or. 2, Nat. Or. Cucurbitacere. A mere weed; it grows in any rich soil, and is increased by seeds. Synonyme: 1. Trichosanthes fatidissima-fatida 1 , pendula.

Mrmaranacrous, or mrsuravous, having the texture of a membrane.

M RMBCr̆Lŏ, Linn. From memecylon of Dioscorides; the Greek name of the fruit of the Arbutus. Linn. 8, Or. 1, Nat. Or. Memecylaced. The soil best adapted to the growth of these plants is a mixture of peat, loam, and sand; and cuttings of the young wood root freely in sand, under a glass, in heat.

capitellatūm . . . 7, S. Ev. S. E. Ind. . . 1796 edulle..: Purple : S. Ev. T. Ceylon : 1820

Mรsıücŭs, Desfontaines. From mene, the moon, and okkus, the eve; supposed to refer to the shape of the seeds. Linn 15, Nitt. Or. Cruciferce. A pretty little annual, well fitted for ornamenting rockwork. The seed may be sown where it is to remain. Synonyme: 1. Alyssum linifolius.

linifolrüs, 1. . White. . 6, H. A. Caucasus . 1819 Mrnîscîê, Schreber. From meniskos, a crescent; alluding to the shape of the fructification. Linn. 24, Or. 1, Nat. Or. Polypodiacea. This is a very elegant genus of ferns. They thrive well in loam and peat, and are increased by dividing the roots, or by seeds. Synonymes: 1. Hemionitis prolifera. 2. Polypodium reticulatum. 3. Asplenium sorbifolium. proliferûm, 1 . . Brown . 5, S. Her. P. E. Ind. . . 1820 reticulátúm, 2 : Brown : 5, \&. Her. P. Martinique 1793 sorbifoliũm, 3. : Brown : S. Her. P. Brazil ? . 1823

Mrxispī́múa, Linn. From mene, the moon, and sperma, a seed; the fruit is kidney or half-moonshaped; whence the English name, Moon-seed. Linn. 22, Or. 10, Nat. Or. Menispermacea. This genus is chiefly composed of hardy plants, well adapted for covering arbours or trellis-work. They grow in any common soil, and may be increased by dividing the roots, or by cuttings planted early in spring in a sheltered situation, or by seeds. Synonymes: 1. M. virginicum. 2. Cissampelos smilacina. canadēnsé . . Grn. yel. . 6, H. De. Tw. N. Amer. 1691 lohâtúm, 1 : Grn. yel : 6, H. De. Tw. N. Amer. 1732 daũrieûm ? : Whe yel. 6 , H. De. Tw. Dauria : 1810

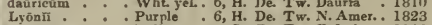

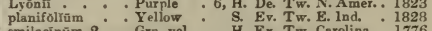
smilacinum, 2: Grn. yel. : H. Ev. Tw. Carolina : 1776

M Enonvilur.̌̆ , Decandolle. In honour of $\mathbf{M}$. Thiery de Menonville, an enterprising French naturalist. Linn. 15, Nat. Or. Cruciferce. Rather a pretty hardy plant, growing freely in light loamy soil, and is increased by seeds.

filifólia. . . . Grsh. wht. 8, H. A. Chile. . 1836

MẼNstrŭ̃̃ a liquor used as a dissolvent.

$[202]$ 
M daughter of Cocytus, as being turned into mint by Proserpine in a fit of jealousy. Linn. 14, Or. 1, Nat. Or. Labiata. The Mint is a well-known genus of useful herbs, with the culture and propagation of which every one is familiar. Synonymes: 1. M. pyramidalis. 2. $\boldsymbol{M}$. crispa. 3. MT. hirsuta, M. nepetvides. 4. M. paludosa, M. palustris. 5. $\boldsymbol{M}$. rivalis. 6. $\boldsymbol{M}$. agrestis. 7. $\boldsymbol{M}$. priecox. 8. $\boldsymbol{M}$. gentilis. 9. M. Badensis. 10. M. rubra. 11. M. acutifolia, MI. sativa. 12. M. austriaca. 13. M. borealis. 14. $M$. odorata. 15, $M$. gracilis. 16. $M$. macrostachya, $M$. rugosa. 17. M. capensis. 18. $M$. hirta. 19. $\boldsymbol{M}$. undulata. 20. $\boldsymbol{M}$. canescens. 21. $\boldsymbol{M}$. nemorosa, M. Niliaca. 22. M. gratissima. 23. M. brevispicata, M. lavigata. 24. M. crispata.

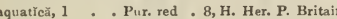
$\begin{aligned} & \text { crispa, } 2 \text { : Purple : 7, H. Her. P. Siberia } \\ & \text { lirsūtă, } 3\end{aligned}: \begin{aligned} & \text { Purple } \\ & \text { : P, H. Her. P. Britain }\end{aligned}$ liirsũtă, 3 : Purple * 8, H. Her. P. Britain rrënsis, 5. Purple * 8, H. Her. P. Britain agrêstis, 6 Purple 6, H. Her. P. Britain glábră, 7 Purple glabra, 7 - Purple gracilis, 8 - Purpl nītrdă, 9 : Purple
rūbră, $10:$ Purple rūbră, $10:$ Purple
sativă, $11:$ Purple sativă, 11 . Purple uriculăriă . Purple balsàmeă - Purple blāudă canadēnsǏs: : Purple glabrátã, 13 : Purple citrāăă, 14 . . Red pur coccinèa : : Scarlet dentítă : : : Purple divaricátă : . Purpl glabrătă : . Purple incảnă : Purple - Purple

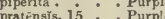

praténsis, 15 . Purple

pubèscēns : : Purple

RequiēnLilac 7, H. Her. P. Britail 7 , H. Her. P. Britain 9, H. Her. P. Britain 7, H. Her. P. England 7, H. Her. P. Germany 7, H. Her. P. E. Ind. 7, H. Her. P. Italy 9, H. Her. P. Nepal 8, H. Her. P. N. Amer. 7, H. Her. P. N. Amer. 7, H. Her. P. Britain 7, H. Her. P. E. Ind. 7, H. Her. P. Germany 7 , H. Her. P. Spain 7, H. Her. P. Egypt 7, H. Her. P. Greece 7, H. Her. P. Spain , H. Her. P. England , H. Her. P. England 7, H. Her. P.

H. Her. P. Britain 8, H. Hex. P. Corsica 8, H. Her. P. Britain
H. Y r. P. C. G. H. , H. Her. P. S. France salícīnă, 17

งนล̄ ป็s, 18 . . Red

sylvéstrís - Purplish mollissimă, 20 . Purpl nemorôsă, 21. Purple nemorôsă, 21. Purple
vulgăriss, 22: Purple těnǔis:. : Purple tênnŭiss : : : Purple villōsă $23:$ : Purple erīspå, 24 : Purple 7, H. Her. P. Britain 7, H. Her. $P$.

H. Her. P. Spain

7, H. Her. P.

, H. Her. P. Germany

7, H. Her. P. N. Amer. 9, H. Her. P. Britain 8, H. Her. P.

1640

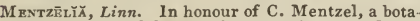
nical author of Brandenburg. Linn. 12, Or. 1, Nat. Or. Loasacer. These curious plants grow freely in a mixture of sandy loam and peat; and cuttings root freely in sand, under a glass, in heat.

asperå . - Yellow * 7, F. A. America 1733 hispìdă : : Yellow: 4, S. Her. P. Peri : 1831 hispidă:*ä: Yellow : 4, S. Her. P. Peru : 1831

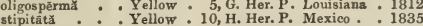

MBNyĀThĒs, Linn. From men, a month, and anthos, a flower; alluding to the duration of the flowers. Linn. 5, Or. 1, Nat. Or. Gentianacee. Plants of the simplest culture. M. trifoliata is bitter, tonic, and febrifugal. Synonyme: 1. M. americana.

trifoliâta : White. - 7, H. Aq. P. Britain .

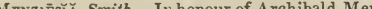
F.L.S., \&c., surgeon and naturalist to the expedition under Vancouver; he collected many specimens of plants on the North-west coast of A merica, New Holland, Van Diemen's Land, \&c. Linn. 8, Or. 1, Nat. Or. Ericacea. A very ornamental genus of plants; for culture and propagation, see Azalea. Synonyme: 1. Erica Dabaci.

ferrugraěa . - Brown ．5, H. De. S. N. Amer. - 1811 globulãris . Brown . 5, H. De. S. N. Amer. 1806 polifoliă, 1: Purple 7, H Fr. Ireland

atro 1 . Purple flòré-ālbō Alore- White longifoliă : Purpl 7, H. Ev. S. nănă. - Purple * 7, H. Ev. S. Ireland .

MEnzik̄sĩu, see Phyllodöce. $[203$
Mercl'RiĀLǏs, Linn. After Mercury, who is said to have first discovered the plant. Linn. 22, Or. 8 , Nat. Or. Euphorbiacea. Weeds of the simplest culture. The juice of $M$. perennis is emetic, while the seed is purgative, and highly dangerousamhigüŭ, äunŭă, ellīptică, perẽnnìs, tomentósă

MrRENDĒRă, Ramoud. A name given to Colchicum by the Spaniards, and applied to this genus because of its affinity. Linn. 6,Or. 3, Nat. Or. Melunthacea. This species thrives well in a light loamy soil, and is readily increased by seeds, or offsets from the bulbs. Synonymes: 1. Bulbocodium trigynum, Colchicum caucasicum.

caueăsĩcă, 1 . . Purple - 8, H. Bl. P. Caucasus - 1823

MERıAxĭ authoress of a work on insects. Linu. 10, Or. 1, Nat. Or. Melastomacea. This is a genus of very beautiful stove plants, which grow freely in sandy peat mixed with a little loam; and cuttings of the half-ripened wood root freely in sand, under a glass, in heat.

leucănthă . . White . . S. Ev. S. Jamaica S. Ev. S. Jamaica

MERĨSMă, Fries. From merismos, a division; because of the branched habit. Linn. 24, Or. 9, Nat. Or. Fungi. These plants are found in woods and damp places-cristātă, fātădä-anthocẽ phälă, tuberósă.

MertẼnsĭ , Willdenow. In honnur of F. C. Mertens, professor of medicine at Bremen. Linn. 23, Or. 1 Nat. Or. Urticacea. All the species of this genus are highly esteemed by the lovers of border plants for the brilliant colour of their blossoms. M. mari. tima and parviflora require to be grown in pots, in very sandy peat. The other species will grow in common garden soil, though they succeed much better when kept in a peat border; increased by divisions. Synonymes: 1. Pulmonaria dahurica. 2. P. denticulata. 3. P. lanceolata. 4. P. maritima. 5. P. paniculata. 6. P. parviflora. 7.P. virginica. 8. P. sibirica.

dahurǐcă, 1 Blue . 5, H. Her P. Dahuria 1818 denticulátă, 2: : Blue : : 6, H. Hes. P. N. Amer. : 1800 marginătă, 3 . Blue : 6, H. Her. P. Louisiana: 1813 maritimă, 4 . Blue . 7, H. Her. P. Britain . paniculātă, 5 : Blue : 6, H. Her. P. Hud.'s Bay 1778 parvitioră, 6 . Blue . 7, H. Her. P. Canada. 1827 pulmonarioïdẽ, 7 Blue . 4, H. Her. P. N. Amer. 1699 sibīīeă, 8 . Blue: H. Her. P. Siheria. 1801

MвRūLǏU, Haller. From meta, a pillar; because of the resemblance in the original fungus metulius. Linn. 24, Or. 9, Nat. Or. Fungi. This is one of the most important of parasitical fungi, being what is called the dry rot, so well known as the pest of wooden constructions-aurantīăcŭs, lächry̆mäns-ob7īqŭ̌s, tremellosŭs.

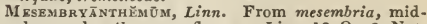
day, and anthemon, a flower. Linn. 12, Or. 2, Nat. Or. Ficoidece. This beautiful and well-known genus of succulents is very easily cultivated. If they are intended to remain in pots, a light sandy loam will suit them best; but if they are planted out in a dry hot border, they will flower more profusely. Many of the kinds are very beautiful objects for the flower-garden; for this purpose, cuttings should be struck in the autumn, and allowed to remain in the store-pots all winter. A dry pit or frame, where frost is excluded, is sufficient for their protection in winter. Cuttings of the most succulent kinds should be allowed to dry a little after planting before water is given, after which they root readily. $\boldsymbol{M}$. edule is the Hottentot-fig, the leaves of which are eaten. $M$. nodiflorum is used in making $M$ aroquin leather. Synonymes: 1. M. stellatum. 2. M. Candollei. 3. M. purpureo croceum. 4. M. dimidiatum. 5. M. parviflorum. 6. M. magnipunctatum.7. M. micranthum. 8. $M$. canescens. 9. M. hirsutum. 10. M. hispidum. abbreviātüm

acinaeifórmé lóngum . acuminátūm acutăngŭlūm acūtūm .

adscênndēns .

adūneūm

æquilaterẳ̇ āgninüm: : Yellow

Pink .

Pink :
G. Ev, Tr, N. Holl.

G. E. Tr, C, G. H.

- 8, G. Ev. Tr. C. G. H.

- 8, G. Ev. S. C. G. H.

G. Ev, S. C. G. H.

7, G. Her. P. C. G. H.

Yellow: 9, G. Her. P. C. G. H.

Pink 2, G. Ev. S. C. G. H

Pink 6, G. Ev, Tr. N. Holl.

6, G. Ev. Tr. N. Holl.
6, G. Her. P. C. G. H.
1825

1714

1820

1321

183

1795 


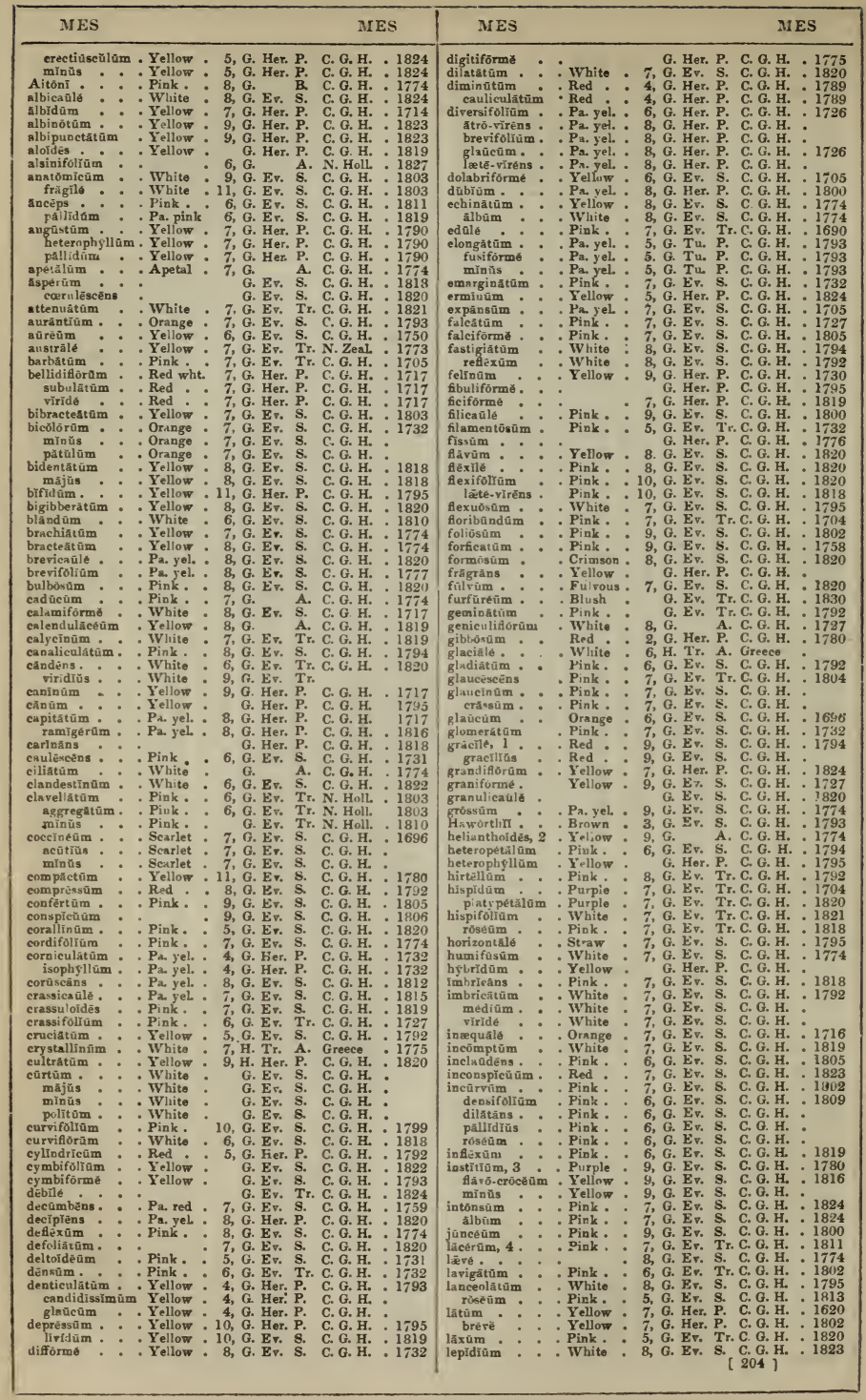




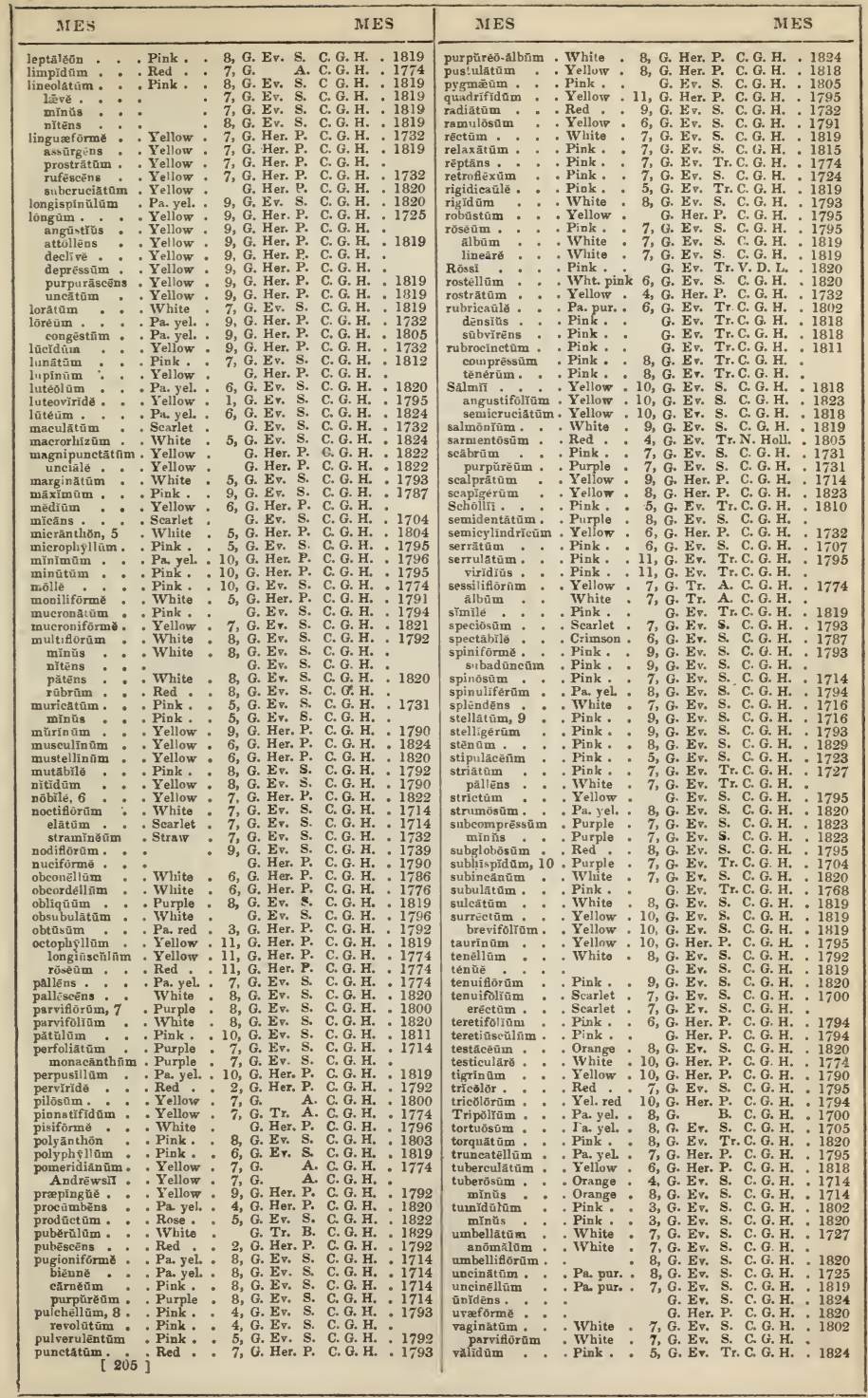




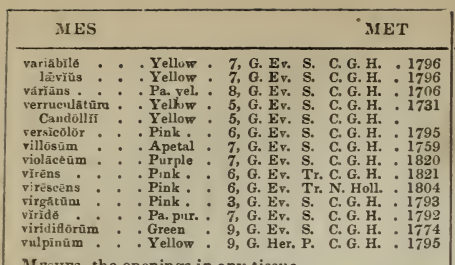

Mrshrs, the openings in any tissue.

MESOGLōĩ. Fr. From mesos, middle, and gloios, viscid; the spines of the branches are in a solid mass. Linn. 24, Or. 7, Nat. Or. Alga. This genus is entirely composed of marine plants. Synonymes: 1. $R$ ivularia verticillata. 2. $R$. vermiculata-capillūrìs, coccinnĕă 1, Hudsōni, multífidă, vermiculäris-coriäcĕă 2.

Mrspílüs, Linn. From mesos, a half, and pilos, a bullet; in allnsion to the resemblance the fruit $\zeta$ bears to half a bullet. Linn. 12, Or. 2, Nat. Or. Rosacere. The Mespilus, or Medlar, is a genus of low-growing trees; they are very ornamental, and are therefore worth a place in every shrubbery. Any common soil suits them, and they are readily increased by budding or grafting on the common Hawthorn, or they may be increased by seeds, which do not vegetate till the second year after sowing. Synunymes: 1. M. grandiflora, M. Smithit.

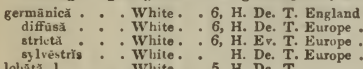

lobátż, 1 : White.: 5 , H. De. T

Mesirfschmīiľ, Linn. In honour of Dr. Messerschmid, a German botanist. Linn. 5, Or. 1, Nat. Or Ehretiacea. These plants are of easy cultivation in loam and peat, and cuttings root readily planted in sand, under a glass. Synonymes: 1. Tournefortia hirsutissima. 2. T. laurifolia. 3. T. scandens. 4 $T$, volubilis.

hirsutixsimä, 1 . Grn, yes. * 6, S. Ev. T. W. Ind. · 1818 Inurifolia, 2 : Yellow : 7, S. Ev. Cl. W. Ind. 1819
sesndens, 3 : Orn yel. scăndens, 3
volübilis, $\mathbf{4}$ : : Grn. yel. : 7, S. Ev. Cl. Peru : 7 , S. Ev. Tw. Jamaica 1816

MĒsŭ A, Linn. In honour of Mesue, the father and son, two celebrated A rabian physicians and botanists; they resided at Damascus, and flourished in the eighth and ninth centuries. The works of the son were published at Venice in 1581. Linn. 16, Or. 7, Nat. Or. Guttiferce. This tree is well de. serving of cultivation on account of its beautiful, orange and white, sweet-scented flowers, which contrast finely with the dark-green foliage. It attains the height of fifty feet, and grow's best in a mixture of strong loam, peat, and sand. Young plants are commonly obtained from seeds; cuttings will root in sand, under a glass, but not freely. The wood is used for a variety of purposes in the East Indies, being considered harder and more durable than most other Oriental timber. The dried blossoms may be found under the name of Nagkesur in every bazaar in India; they are used in medicine, and universally esteemed for their fragrance.

fêrrēêa . . . . White . 7, S. Evv. T. E. Ind. . . 1837

Mrtalŭsĭ , R. Bronn. From meta, a change, and lasios, hairy; supposed to refer to the leaves. Linn. 19, Or. 2, Nat. Or. Composite. These are pretty plants, growing about three feet high, in a mixture of three parts sandy peat and one part loam; and cuttings root readily in the same kind of soil, under 2 glass. Synonymes: 1 . Gnaphalium divergens. 2. G. fastigiatum.

divērgēns, 1 . . White. . 7, G. Ev. S. C. G. H. . 1816 fastigiata, 2 : White. : 6, G. Ev. S. C. G. H. : 1812 mucronata. : White. : 6, G. Ev. S. C. G. H. : 1824 muricătă
seriphioĩdés : : White. : 7, G. Ev. S. C. G. H.
G. Ev. S. C. G. H. 1816

M гтАsтёцй, $\boldsymbol{R}$. Bronn. From meta, instead of, and stelma, a crown. Linn. 5, Or. 2, Nat. Or. Asclepiadacea. This is a very ornamental twiner, well suited for covering the rafters or pillars of a stove.
It grows in peat and loam, and cuttings of the young wood root readily in sand, under a glass.

\author{
parvifōrūm . . Grn, wht. . S. Ev. Tw. W. Ind.
}

Mistrosidērŏs, Gaertner. From metra, the heart of a tree, and sideros, iron; on account of the hardness of the wood and pith of the trees. Linn. 12, Or. 1, Nat. Or. Myrtacea. These plants are well worth a place in every collection of greenhouse plants. They grow best in loam, peat, and sand, well in. corporated, and young plants are readily obtained from cuttings of the young wood planted in sand, under a glass. Synonyme: 1. Leptospermum am. biguum.

angustifoliŭs . - Yellow - G. Ev. S. C. G. H. . 1787 G. Ev. \&. C. G. H. : 1824 capitatüs : : Pink . G. Ev. S. C. G. H. : 1824 corifôliǔs, 1 . White. G. Ev. S. N. Holl. glomülifér. : Yel. grn. : 5, G. Ev. S. N. S. W. : 1805

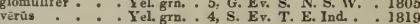
M $\overline{\mathrm{C}} \mathrm{M}$, Tournefort. From meion, small; in allusion to the leaves. Linn, 5, Or, 2, Nat. Or. Umbelliferce.

Hardy herbaceous plants, of no beauty-athamanticum, Bunius, Mutellina, sihiricum.

MrXican-MUOWORT, see Artemisiă mexicänŭ.

Mexican-tea, see Psorüléa glandulosä.

MEXICAN-TIGRR-FLOWER, see Tigrídiú pavoniă.

MRYĒRÄ, Sctreber. In honour of Gottlieb Andrew Meyer, a German botanist. Linn. 19, Or. 2, Nat. Or. Composito. A little inconspicuous plant, growing about a foot high, and of the easiest culture.

séssilis . . . Y Yellow . 7 , S. Her. P. W. Ind.

I rcaceous, glittering or shining

Mrc $\bar{E}$, glittering particles.

M IchazLMAs-DAIsr, see Astér.

MıнĀ̄xî́, L'Heritier. In honour of Andrew Michaux, botanist to Lou is XVI. ; he travelled in Syria, Persia, and North America. Linn. 8, Or. 1, Nat. Or. Campanulacea. This is a genus of handsome plants; the seeds merely require sowing in the open ground, and the plants are treated like other biennials. They should be slightly protected in winter. Synonyme: 1. M. decandra.

campanuloidés . Pa. red . 7, H. B. Levant . 1787 levigată, 1 . White.: $7, \mathrm{H}$. B. Persia : : 1827

Mrсні̄LYX, Linn. In honour of Pietro Antonio Micheli, a famous Florentine botanist, who died in 1757. Linn. 13, Or. 6, Nat. Or. Magnoliaced. This hand some tree attains the height of thirty feet, and prodices fragrant flowers, and an edible but not an agreeable fruit. It grows well in a light loam; and cuttings root freely planted in sand, under a glass, in heat.

Champăcă . . Yellow . S. Ev. T. E. Ind. . . 1779

Mı̄ōx̌̆, Ruiz and Pavon. In honour of D. Micon, M.D., a Spanish botanist. Linn. 10, Or. 1, Nat. Or. Melastomacece. The species of this genus are well deserving of a place in every stove. For culture and propagation, see Meriana. Synonyme: 1. Melastoma acinodendron. 2. M. grandifoliu. 3. M. lovigata. 4 M. levigata. 5. M. purpurea. 6. M. tetrandra. 7. M. trinervia.

Acinodēndrŏn, 1. Purple * S. Ev. S. Jamaica 1804 angustata . White. S. Ev. S. Trinidad 1890 decussta White S. S. S Guiana 1820 decussita ${ }^{\circ}$ : Whifolia, 2 White: : S. Ev. S. Trinidad: 1818 grandifolira, 2 : White: :
impetiolario $\begin{array}{ll}\text { impetiolârĭs : : White.: } & \text { S. Ev. S. W. Ind. : } 1822 \\ \text { levigáta, 3. : White. : } & \text { \&. Ev. S. W. Ind. } 1815\end{array}$ longifolră : : White: S. Ev. S. Guiana : 1817 präsinză, 4 . White. 7, 8. Ev. S. Januaics : 1817 purpuráscêns, 5 . Purple : S. Ev. S. Guiana : 1817 rubescēns * - White. - S. Ev. S. S. Amer. 1818 semicrenătă - White. - S. Ev. S. Guadaloupe 1817

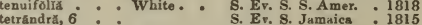
tetrándră, 6
trinérvià, 7

MrсRÃnthймём, Michaux. From mikros, small, and anthos, a flower. Linn. 2, Or. 1, Nat. Or. Scrophnlariacea. An ornamental plant, growing in sandy peat, and increased by divisions.

orbiculátùm . . White. . 5, F. Ev. Tr. Carolina . 1826

MírōcăLă, Link. From milkros, small, and kalos, pretty; in allusion to the small, pretty flowers. Linn. 4, Or. 1, Nat. Or. Gentianacea. A pretty little plant, of easy cultivation. Synonyme: 1 . Exacum filiforme.

[206] 


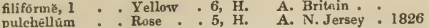

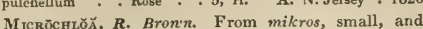
chlva, a grass; in allusion to the minute size of the plants. Linn. 3, Or. 2, Nat. Or. Graminea. A hardy annual. It grows in any common soil.

setācěă . . . Apetal . . 7, Grass. E. Ind. . . 1816

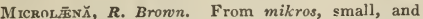
lenos, wool; in allusion to the small, woolly flowerstalk. Linn. 4, Or. 2, Nat. Or. Graminea. A greenhouse perennial species, growing in loam and peat, and increased by seed. Synunyme: 1. Ehrhartia stipoides.

stipoìdēs, 1 .

Apetal . . 7, Grass. N. Holl.

1822

Miсró̄̄mă, R. Brown. From mikros, small, and loma, a fringe; the flowers are fringed. Linn. 5, Or. 2, Nat. Or. Asclepiadacea. Small climbing plants, growing freely in a mixture of loan and peat; and cuttings will root readily in sand, under a glass. Synonymes: 1. Pcriploca linearis. 2. Ceropeyia sagittata.

lineare, 1. . White. . 7, G. Ev. Tw. C. G. H. . 1823 ragittátūm, 2 : Grn. pur. : 7, G. Ev. Tw. C. G, H. : 1775

Mіскомй́і̆ӑ, Bentham. From mikros, small, and meris, a part. Linn. 14, Or. 1, Nat. Or. Labiata. These plants will grow well in common garden soil, and are easily increased by cuttings. Synonymes: 1. Satureia approximata. 2. Mentha australis. 3. Satureia graca. 4. S. tenuifolia, S. congesta. 5. S juliana. 6. S. hirsuta. 7. Nepetamarifolia. 8. S. viminea. 2. Thymus Teneriffie. 10. $\boldsymbol{T}$. ericofolius.

approximätă, 1 . Purple . 6, F. E7. S. Mediter.

austrälis, 2 . . F. Ev. S. N. S. W.

grēề, 3 . Purple . 6, F. Ev. S. Greece * 1759

densiflōră, 4. Purple : 6, F. Ev. S. S. Eur. : 1822

juliãnă, 5 : Pa red. : 7, F. Evv. S. Mediter. : 1596

hirsūtă, 6 : Pirple * 6, F. Ev. S. Sicily * . 1822

marifóliă, 7 : : Blue * 7, F. Ev. S. Spain : 1800

Teneriffæ̈, $9:$ : Purple : 5, F. Ev, S. Teneriffe

vảriă, 10 : Purple : 7, F. Ev. S. Canaries : 1806

Mıсrōpǔs, Linn. From mikros, small, and pous, a foot. Linn. 19, Or. 4, Nat. Or. Compositue. Uninteresting annuals; the seeds need only be sown in the open ground-erēctũs, supīnüs.

Microspērmūm, small-seeded.

Micróstr̆Lís, Nuttall. From mikros, small, and stylos, a column; in allusion to the very small column. Linn. 20, Or. 1, Nat. Or. Orchidacea. A genus of plants possessing little to recommend them. The Mexican species should be kept in the greenhouse, and grown in sandy peat; they come up in spring when they flower, after which, the leaves die down, and the plants remain dormant till the following season; they are increased by dividing the roots.

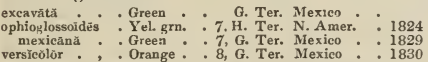

Mıско̆тц̌̆, Smartz. From microtes, smallness; in allusion to the very minute parts of fructification. Linn. 5, Or. 2, Nat. Or. Amarantacea. The seeds should be sown in loam and peat, and treated as other stove annuals. Synonyme: 1. Ancistrocarpus maypurensis.

débillis . . White. .6, S. A. Jamaica . 1816 maypurēnsiss, $1^{*}$ : White. : : $^{*}$ S. A. Trinidad : 1817 MicRöris, R. Brown. From mikros, small, and ous, otos, an ear; appearance of the anthers. Linn. 20, Or. J, Nat Or. Orchidacea. A curious genus of tuberous-rooted plants, which require the same treatment as Ccrycium.

albã : * : White : 6, F. Tex. N. Hous. 1826 parviflora - Green F. Ter. N. S. W. * 1823 MID-RIB, the middle vein of a leaf, which passes from the petiole to the apex.

Mignonertr, see $R e \overline{s e s} d \ddot{u}$.

MiKTNİ, Willdenon. In honour of Joseph Mikan, professor of botany at Prague. Linn. 19, Or. 1, Nat. Or. Composite. These plants grow well in any light rich soil, and are increased by cuttings, in sand, under a glass. In Spanish America, a [207] valuable antidote against the bite of serpents is obtained from $M$. guaco.

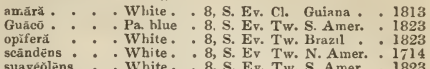
suaveölēns - White. 8, S. Ev Tw. N. Amer. * 1714

chenopodîfơlĭă, hastātŭ, Houstōnī, orinocēnsìs.

Milfoli, see Achillēă.

MiLiARY, granulated, resembling many seeds

MĭLĩũ, Linn. From mille, a thousand; in allusion to the immense number of seeds produced by it. Linn. 3, Or. 2, Nat. Or. Graminea. Hardy annuals and perennials, not worth growing, except in botanical collections. Any common soil will suit themconfēertūm, effīsūm, frutēscēns, gallecīcūm, microspērmīm, velutīnñ̄m, vernālĕ.

MiLK-PARSLEY, see Selīñ̄im.

Milk-veTch, see Astrăgălŭs.

Milkwort, see Polȳgălă.

MILK-WOOD, see Brósīmīm.

Mírlă, Cavanilles. In honour of Julian Milla, head gardener in the Royal Garden of Madrid. Linn. 6, Or. 1, Nat. Or. Liliacea. Two very pretty plants highly deserving of cultivation. They grow in light loam, and are increased by seeds.

bifföră • • . White. . 5, F. Bl. P. Mexico . . 1826 unifloră : Wht. li. 2, F. Bl. P. B. A yres : 1832

MinLĒrĭ, Linn. In honour of the celebrated Philip Miller, F.R.S., author of the Gardener's Dictionary. Linn. 19, Or. 4, Nat. Or. Compositce. Stove annuals of nobeauty. Any common soil suits them -biflóră, quinqueflóră.

Mullet, see Pänŭcûm.

MILLET-GRAss, see Mīlǐũm

Millingtônİ, Roxburgh. In honour of Sir T. Millington, professor of botany at Oxford. Linn. 14, Or. 2, Nat. Or. Millingtoniacea. An ornamentalgrowing tree. For culture and propagation, see Jacaranda.

simplicifỏǐă . Yel ow . S. Ev. T. E. Ind. . . 1828 Mито̄NĬ, Lindley. Thus named in compliment to Earl Fitzwilliam, one of the oldest and steadiest friends of Natural Science in this country, and a great lover of Orchidaceঞ. Linn. 20, Or. J, Nat. Or. Orchidacea. The flowers of these plants are strikingly handsome; the sepals and petals of $M$. spectabilis are delicate cream-colour, and the labellum, which is very large, is elegantly marked with various shades of purple, deepest towards the base. In $M$. candida, the sepals and petals are yellowbrown, and the labellum pure white, finely marked with pink. In potting these plants, the peat should be raised, for a well-grown, good-sized plant, two or three inches, in the same way as recommended for Stanhopeas; and the creeping stems, from which the pseudo-bulbs grow, ought to be entirely on the surface, and if necessary, they may be fastened to the peat with hooked pegs. The best way of pro. pagating the species of this genus is, first, to cut the stem half through, which will cause young plants to be sent out; and finally, to cut them through a month before dividing. They require a hot part of the house. Synonyme: 1. Macrochilus Fryanus.

căndida . White . 3, S. Epi.

. White . 3, S. Epi. 183-

M гмётёs, Salisbury. From mimos, a mimic; because of its resemblance to several other genera. Linn. 4, Or. 1, Nat. Or. Proteacer. This is a genus of very pretty shrubs. For culture and propagation, see Protea. Synonymes: 1. Protea cucullata, 2. Deastella vaccinifolia.

cuculată 1 Purple

divaricato Purple

divaricăt

Hartōg

palüstrĭs

pauciflōr White

G. Ev. S. C. G. H 7, G. Ev, S. C. G. H 7, G. Ev. S. C. G. H 7, G. Ev. Ev. S. C. G. H purpureă ${ }^{\circ}$. Purple . 11, G. Ev. S. C. G. H.

1789 1795 1824 1802 1802 1818 1789 of many of the species resemble animal sensibility. Linn. 23, Or. 1, Nat. Or. Leguminose. The leaves of several of the species belonging to this genus are more or less sensitive to the touch, but none so 


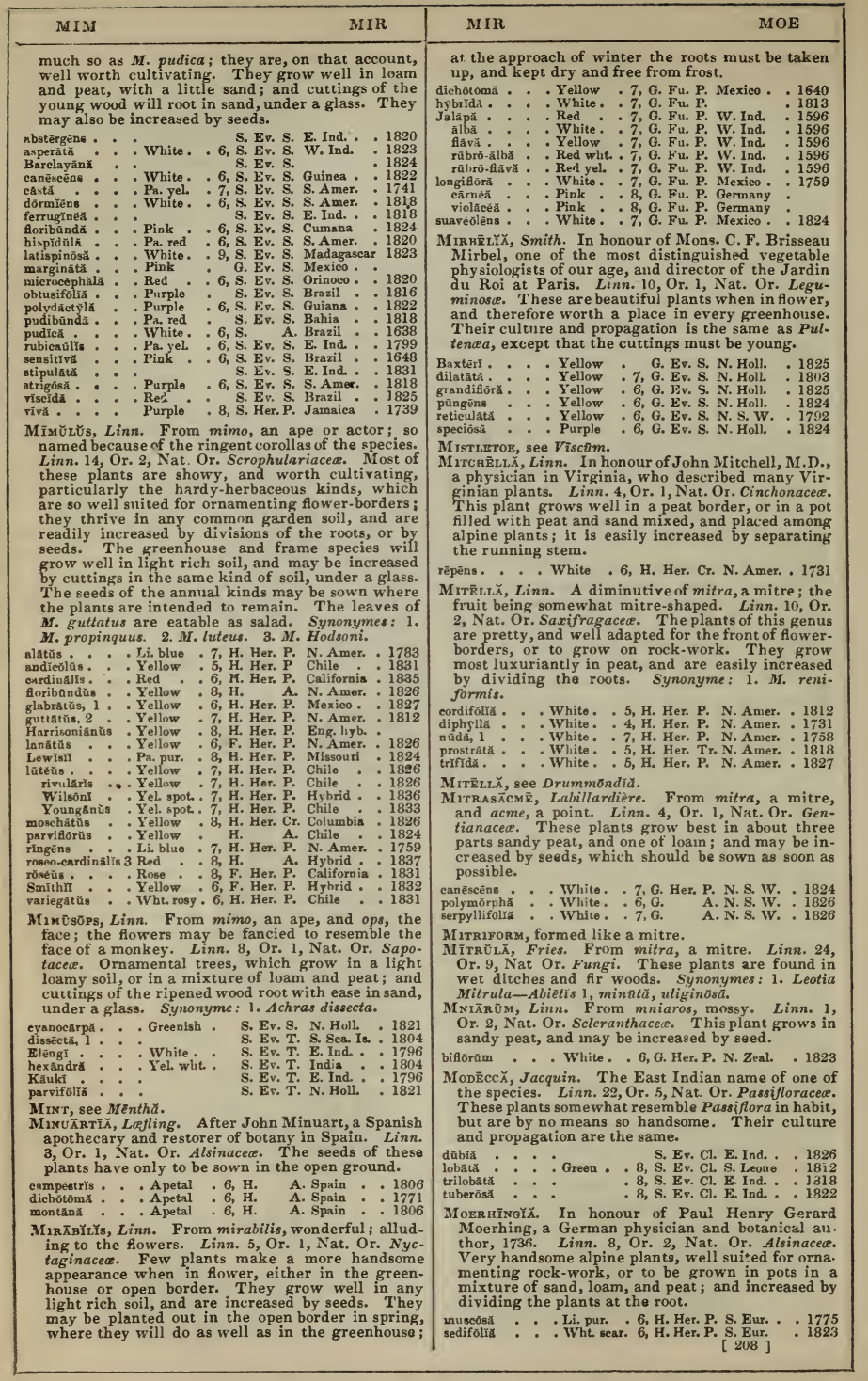


Mogiphāxīs, Martius. Name not explained. Linn. 5, Or. 1, Nat. Or. Amarantacea. This species may be successfully grown in sandy loam.

virgăta - . . Whitish . 9, S. B. Russia * . 1836 MoLdavian BaLM, see Dracocěphălṽm moldāvǐcūm.

Moninērlă, Colladon. After Ignatio Molineria, director of the botanic garden at Turin. Linn. 6, Or. 1, Nat. Or. Amaryllidacee. This little plant thrives well in peat and loam, and is increased by divisions,

plicătă . . . Scar. yel. . 8, S. Her. P. Java • . 1820

Afor.̄̄Ǐ̆, Mench. In honour of $J$. Molina, a writer upon Chilian plants, in 1782 . Linn. 3, Or. 2, Nat. Or. Graminea. Weeds not worth growing in any collection. Synonyme: 1. Melica carulea-carülëă 1, depauperatü.

MōıL $\vec{k}$, soft, fliable.

Moll. Çō, Linn. A name applied by Pliny to a plant supposed to be the same as our Galium Mollugo; given to this genus because of the resemblance of the species. Linn. 3, Or. 3, Nat. Or. Illecebracea. Stove annuals of no beauty. Synonymes: 1.M. dichotoma. 2. M. Linkii-hīrtă, oppositifolĭă, Schrānkīi 1, triphällă 2, verticillütă.

Molospermti, Koch. From molops, a stripe, and sperma, a seed; the fruit has the appearance of being striped. Linn. 5, Or. 2, Nat. Or. Umbellifera. This plant grows in any common soil, and is increased by dividing at the root, or by seeds. $S y$ nonyme. 1. Ligusticum peloponnesiacum.

peloponnesiăcūn. Pa yel. • 6, H. Her. P. Switzerl. . 1598 Monīcč̈-RA1M, see Moluccellă.

Molucc̄̄L1.Ă, Linn. The plants were supposed to be natives of the Molucea Islands. Linn. 14, Or. 1, Nat. Or. Labiata. The seed of these plants should be sown on a hotbed in spring, and when the plants are of sufficient size, they may be planted singly into pots, and kept under the glass till the end of May, when they may be planted out in a dry warm border, where they will flower and ripen their seeds freely.

lävřs *. Pa.pur. * 7, H. A. Svria * 1570 Marrubiăstrūm. Purple * 7, H. A. Siberia * 182 tuberúsă * Pa pur. * 7, H. Tu. P. Tartary - 1796 have the appearance of being bitten. Linn. 21, Or. 10, Nat. Or. Cucurbitacea. Stove and frame twining annuals and perennials, of neither interest nor beauty-Balsămīnă, charäntiă, dioīcă, Elatērīūm, mīxtă, muricatŭ, operculütă, senegalēnsĭs, tubifloră, umbellatŏ.

Monachānthuัs, Lindley. From monachos, a monk and anthos, a flower; in allusion to the labellum of $\boldsymbol{M}$. viridis, which is like a cowl: whence the English name of the genus, Monks'-flower. Linn. 20, Or. 1, Nat. Or. Orchidacea. Though not a handsome genus, it is rendered very interesting from the singular form of the flowers. They will grow and flower well when treated as the Catasetums.

díscǒlör . . . . Pa. yel. . 9, S. Epi. Demerara . 1834 fimbriảtús: : Grn. wht 10, S. Epi. Pernamb. 1837 10, S. Epi. Pernamb.

MosĀсH NĒ, Beauvois. From monos, one, and achne, a glume. Linn. 3, Or. 2, Nat. Or. Graminee. A stove annual, not worth cultivating-unilateralis.

Moxadrupous, having the filaments cohering into a tube.

MONANDROUS, having only one stamen.

MoNANThEs, Hanorth. From monos, one, and anthos, a flower. Linn. 11, Or. 7, Nat. Or. Crassulacea. This may be referred to Sempervivum for culture and propagation. Synonyme: 1. Sempervivum monanthas.

polyphy̆llă, 1 . . Red . . 8, G. Her. P. Canaries . 1777

MoNĀRDă, Linn. After N. Monarda, a physician of Seville, in the sixteenth century. Linn. 2, Or. 1, Nat Or. Labiata. These plants are of easy culture, growing well in any common soil; and readily increased by dividing the roots. $M$. aristata and $M$. punctata should be grown in pots, in a mixture of peat and sand. Synonymes: 1. M. citriodora. 2. M. Kalmiana. 3 M. affinis, M. altissima, $M$ media, $\boldsymbol{M}$. oblongata, $\boldsymbol{M}$. purpurea, $\boldsymbol{M}$. rugosa. 4. M. menthaefolia. 5. M. mollis. [209]

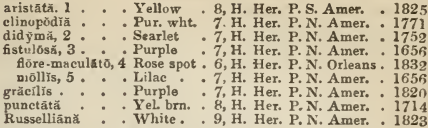

Mox flament; filaments simple. Linn. 24, Or. 7, Nat. Or. Alga. These plants are only to befound in the sea-apiculätūm, Dillnȳnī̃, obtūsūm, guadripunctätūm.

Moxе̄ rмă, Beauvois. From monos, one, and herma, a support. Linn. 1, Or. 2, Nat. Or. Graminea. A curious species, growing in any soil, and increased by seeds. Synonymes: 1. Psillurus nardoides, Rottboellia monandra.

monăndrūm, 1 . A petal . . 7 , Grass. Spain . . 1804

Mon̄̄т̆ ${ }^{\prime}$ 'Heritier. In honour of Monet de la Marck, a famous French botanist. Linn. 4, Or. 1, Nat. Or. Aquifoliacea. An ornamental shrub, growing about three feet high, and succeeding in loam and peat, and readily increased by cuttings in sand, under a glass, in a little bottom heat. Synonyme: 1 Azima tetracantha.

bar'eriuidês, 1 . Green . . 7, s. Er. S. E. Ind.

1758

MoNeYwoRt, see Dioscörĕă nummulärĭa.

MoNRYwort, see I,ysimăchřă nummulärĭă.

Monkywort, see Taverniēră nummulāriă.

Mosīulü, Persoon. From monile, a necklace; the filaments are articulated. Linn. 24, Or. 9, Nat. Or. Fungi. This fungus is found in autumn on dead wood_antennütă.

MoNil.rForm, formed like a necklace; that is to say, with alternate swellings and contractions, resembling a string of beads.

MoNkвY-FLowkR, see Mìnŭlŭs.

Mosk's-HOOD, see Acðnītîm.

Monk's-HOOD, see Dielȳtră cuculläržă.

Monn1̄̄er, Aublet. In honour of William le Monnier, once professor of botany in the Jardin du Roi, at Paris, Linn. 17, Or, J, Nat. Or. Rutaces. A stove annual, of no beauty-trifolĩă.

MonNīnă, Ruiz and Pavon. In honour of Monnino, Count de Florida Blanca, a Spanish promoter of botany. Linn. 17, Or. 3 , Nat. Or. Pulygalacee. An ornamental shrub, growing in peat and loam, and increased by cuttings or seed.

oltusifollă . . Red . . 6, G. Ev. S. Peru

1830

MoNocotruedonots, having only one seed-leaf or cotyledon.

Moserciovs, having the one sex in one flower, and the other in another, on the same plant.

Moxōdóră, Dumont. From monos, one, and dora, a skin; in allusion to the fruit being one-celled. Linn. 13, Or. 6, Nat. Or. Anonacee. This plant thrives in a light sandy loam; and ripened cuttings root in sand, under a glass, in a moist heat. Synonyme: 1. Anona Myristica.

Myrīstioă

S. Ev. S. Jamaica .

Monopetarous, having only one petal.

Monôpsís, Salisbury. From monos, one, and opsis, a face; the flowers are regular, not bilabiate. Linn. 5, Or. 1, Nat. Or. Lobeliacea. This little plant deserves a place in every garden because of its neat, elegant, deep-blue flowers. The seeds should be raised on a hotbed, and when the plants are about an inch high, planted singly into pots, in a mixture of peat and sand; or they may be planted out in a sheltered situation in the open border in May. Synonyme: 1. Lobelia speculum.

conspicŭă, 1 . . Blue * . 7, H. A. C. G. H. 1812

Monoserazous, having only one sepal.

MoNostăснй Ă, one-spiked.

Moxōtŏcă, R. Bronn. From monos, one, and tokos, a birth; the fruit is one-seeded. Linn. 5, Or. 1 , Nat. Or. Epacridacee. Very elegant plants; for culture and propagation, see Leucopogon. The pots must be well drained with potsherds. Synonyme. 1. Styphelia glauca.

àlbă * * * - White. . 6, G. Ev. S. N. S. W. . 1824 elliptică : . White. 6, G. Ev. S. N. S. W. . 1809 
lineätă, 1 . . . White. . 6, G. Ev. S. v. D. L. . 1804 scopériă : : White : 6, G. Ev. S. N. S. w. : 1825

MoNōtrŏpă, Linn. From monos, one, and tropeu, to turn; the flowers are turned one way. Linn. 10, Or. 1, Nat. Or. Ericacere. Curious parasitical plants, growing on the roots of beech and pine trees in shady moist places.

Hypöpitys . . . White . 6, H. Her. P. Britain .

unifloră. . . White . 6, H. Her. P. N. Amer. 1824

Mossōxĭă, Linn. In honour of Lady Ann Minnson, the assistant of Lee in his Introduction to Botany. Linn. 16, Or. 7, Nat. Or. Geraniacece. This is a genus of beautiful plants, delighting in a mixture of turfy loam and leaf-mould. M. ovata is increased by seed, and the others may be propagated by cuttings, or by dividing the roots. Synonyme: $1 . M$. speciosa.

\section{lohátã - . Purple - 5, G. Her. P. C. G. H.

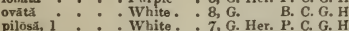 \\ Côlla : : Pa.red : 7, G. Her. P. C. G. H \\ speciós̆ : : Red : 5, G. Her. P. C. G. H. \\ 5, G. Her. P. C. G. H.}

Mostanōă, La Lave. After Montanoa, a Mexican patriot. Linn. 19, Or. 4, Nat. Or. Compositce, Greenhouse shrubs of no beauty, growing in any common scill, and increased by cuttings-grandifloră, tomentōsă.

Montrzēmã. Named by Mocino and Sesse, two Mexican botanists, in honour of Montezuma, a sovereign of Mexicu. Linn. 16, Or. 7, Nat. Or. Sterculiucere. An ornamental, large-growing tree; loam and peat suit it best, and cuttings of the halfripened wood will root in sand, plunged in heat.

speciosIssĭmă . . Red . . S. Ev. T. Mexieo . 1827

Mōrř̆, $L$ inn. In honour of Joseph Monti, Ph. D., professor of botany, and a botanical author, 1791 . Linn. 3, Or. 3, Nat. Or. Portulacacece. This genus is nearly akin to Claytonia. The plants are well. known British aquatic's - fontänd, rivuläris.

Moxtivĩ ; Linn. In honour of Laurence Montin, a Swedish botanist. Linn. 22, Or. 4, Nat. Or. Ona. gracer. This species is not possessed of much beauty; it thrives well in peat and loam, and is increased by cuttings.

earyophyllācea . White. . 7, G. Ev. S. C. G. H.

1774

MooN-sged, see Menispermnm.

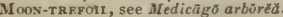

Moovwort, see Botrüchilum.

Moowwort, see Rümèx Lunărĭ̃.

MoR $\bar{\AA}$, Linn. In honour of R. Moore, a botanist of Shrewsbury. Linn. 3, Or. 1, Nat. Or. Iridacece. This is a very elegant genus of bulbous-rooted plants. For culture and propagation, see Ixia. Synonyme: 1. M. edulis lutescens.

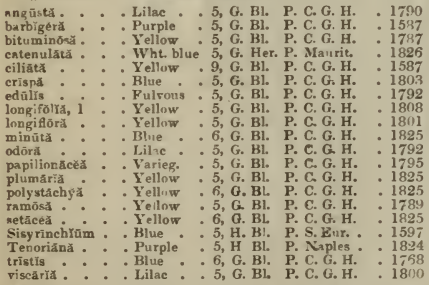

Morchêr.l. D̆, Dilln'yn. Derived from morchel, the German name of the plant. Linn. 24, Or. 9, Nat. Or. Fungi. A genus of eatable Fungi, found upon the gruund-esculēntă, e. rotūndü, e. vulgüris, hȳbridä, pátūlä.

MORTANT, that which enabies matter to receive dyes or colouring matter, and to retain them.

Morexón, $L a$ Lave. In honour of P. Moreno, a Mexican patriut. Iinn. 5, Or. 1, Nat. Or. Convolvulacer. Ornamental plants, growing in a mixture of peat and loam; and cuttings root readily in sand, under a glass, in heat. globōsă . . . Scarlet . S. Bv. Tw. Mexico . 1827 grandiflöră: : : Searlet : S. Ev. Tw. Mexico: : 1826 pátũlă . : : Scarlet S. Ev. Tw. Mexico: : 1826

Moric̄̄ndǐn, Decandolle. In honour of Stephen Moricand, an Italian botanist and author. Linn. 15, Nat. Or. Crucifere. A very pretty plant; the seed only requires sowing in the open ground early in spring. Synonyme: 1. Brassica arvensis.

arvënsis . . Violet . . 7, H. B. Europe . . 1739

MoRĩnă, Linn. In honour of L. Morin, a French botanist. Linn. 2, Or. 1, Nat. Or. Dipsacee. This is an ornamental plant, but seldom to be met with in collections; it grows well in a light rich soil, and is increased by seed.

pềrš̌eă . . . . Red wlit. . 7, G. Her. P. Persia . . 1740

MoRĩnd, Ventenat. Altered from Morus Indica, or Indian Mulberry, because of the shape of its fruit, and native country. Linn, 5, Or. 1, Nat. Or. Cinchonacea. Ornamental plants, growing freely in a mixture of loam and peat; and cuttings root readily in the same kind of soil, under a glass, in a moist heat.

angustifoliă . White. . 5, S. Ev. S. E. Ind. . . 1816 bracteátă : White.:5, S. Ev. S. E. Ind. : 1816 citrifolli : White. S. Ev. S. E. Ind. : 1793 jasminoides : : Pa buff, 4, G. Ev. Cl. PL. Jackson 1893

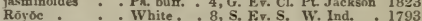

MoRingă, Burmann. Muringo is the name of the species in Malabar. Linn. 10, Or. 1, Nat. Or. Moringacee. This plant thrives well in light loamy soil, and cuttings root freely in sand, under a glass, in heat. The young roots of this tree are scraped, and used by the inhabitants of the places of its natural growth as horse-radish is in Europe, having much the same sharp taste. Synonyme: 1. Hyperanthera Moringa.

pterygnspersma . Yellow . S. Ev. T. E. Ind. . . 1759

Morīsı̌, Cassini. In honour of Professnr Moris, who discovered the species. Linn. 15, Nat. Or. Cruciferce. This plant is well fitted for ornamenting rock-work, where its bright yellow flowers contrast well with its deep-green polished leaves; it is increased by seed sown as soon as ripe.

hypogēă . . Yellow . 5, H. Her. P. Sardinia . 1833

Morisōnīn, Plumier. In honour of Robert Morison, a Scotchman, professor of botany at Oxford, who died in 1683. Linn. 16, Or. 8, Nat. Or. Capparidacea. An omamental plant, which grows well in a mixture of loam and peat; and cuttings of the ripened wood will root in sand, under a glass, in a gentle heat. Synonyme: 1. Capparis Morisoni.

americasnd, 1 . . White - . S. Ev. T. W. Ind.

1824

Morмōnēs, Lindley. From mormo, a frightful-looking object, a goblin; in allusion to the strange appearance of the flowers, Linn, 20, Or, 1 Nat Or. Orchidacec. These are very singular plants when in flower. For culture and propagation, see Cata. setum.

atropurpüreă . - Purple , 10, S. Eni. S. Main pardinä. . : : Redsh. pur.. 7 , s. E pi. Oaxaca

1834

Mörñ̆, Lizdley. Morna, a heroine of Northern romances. Linn. 19, Or. 1, Nat. Or. Compositce. This is a genus of very beautiful plants, well deserving of cultivation. They are half-hardy annuals, and may be had to flower in the greenhouse from May to the end of August, if sown at two different seasons. Plants intended to flower in Mar should be sown the preceding September, and plants for autumn tlowering should be sown in February. The seeds should be sown in pots, in sandy peat and leaf mould, and placed in the greenhouse; the young plants should be potted off when small into sixties, two plants in each pot close to the side, shifting them into larger ones as they require it, keeping them near the glass in a dry, airy part of the house. They must be very cautiously watered, as too much or too little will, in a few hours, destroy the healthiest plants; the pots should therefore be well drained, and the plants should not receive too great a shift at any time. If they are intended to flower in the open border, the plants must not be planted out before the end of May, as the least frost kills them. 


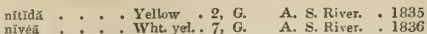

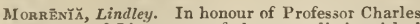
Morren, of Liege, one of the most distinguished vegetable anatomists of the present day. Linn. 5 , Or. 2, Nat. Or. Asclepiadacea. This is a very curious little plant, requiring the same treatment as the greenhouse species of Cynanchum.

odorătă . . . Green- . 7, G. Ev. Tw. B. Ayres . 1937 Mōrǔs, Linn. From the Celtic word mor, signifying black; in allusion to the colour of the fruit. Linn. 21, Or. 4, Nat. Or. Urticacea. 'The species of Morus or Mulberry, grow from ten to thirty feet high. A moist situation and loamy soil suit them best. $\boldsymbol{M}$. $n i g r a$ is in general cultivation for the sake of its fruit, which is well known. $M$. alba is extensively cultivated for food for the silk-worms. Synonymes : 1. M. sinensis. 2. M. alba ovalifolia. 3. M. pumila, M. nana. 4. M. sinensis. 5. M. pennsylvanica. slba

Columbăsså : A A petal

italiea, 1 : : A petal

macrophyllä : Apeta

Morettiánă . Apetal

multicaūlīs - Apetal

pŭmìlă, 3

rơsèă

sinēnsǐs, 4

A petal

A petal

A petal

câléar-gálìi . : Apetal

constantinopolitănă Apeta

indica

A peta

Apetal

nïgră.

A petal

laciniătă: A petal

rübrä, 5*: : A petal

tatărică : : : : A petal

6, H. De. T.

6, H. De. T. Italy

H. De. T. China

H. De. T

6, H. De. T

6, H. De. T. China

6, H. De. T. China

H. De. T

H. Ev. S. N. S. W

6, H. De. T. Turkey

S. Ev, T. E. Ind.

6, H. De. T. Italy

6, H. De. T.

6, H. De. S. N. Amer. . 1629

6 , H. De. T. N. Amer. : 181

6, H. De. T. N. Amer. - 181

Moschā̃ŭ, Ruiz and Pavon. From moschos, musk; on account of the smell of the plant. Linn. 19, Or. 1, Nat. Or. Composita. This pretty annual is found in sandy waste places in Chile; in this country, it requires the treatment common to half-hardy annuals.

pinnatĩfidă

7, H. A. Chile

1823

Moschater, see Adóră.

Moschōsmä, Reichenbach. From moschos, musk, and osme, a smell. Linn. 14, Or. 1, Nat. Or. Labiata. Interesting annuals; the seed should be sown in light rich soil on a hotbed, and afterwards planted out in the open ground, or potted, and placed among the stove plants. Synonymes: 1. Lumnitzera ocymoides. 2. Ocymum polystachyon, Lumnitzera polystachya.

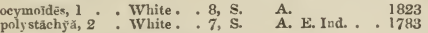

Moтн, see Verbascum Blattärăă.

MотнRR wort, see Leonūrǔs.

MotTLED, marked with blotches of colour of unequal intensity, passing insensibly into each other.

Movgrōtĩ., Agardh. After J. B. Mougeot, a cryptogamic botanist. Linn. 24, Or. 7, Nat. Or. Alga. These little plants are found in ditches-carulêscêns, genuflēxă.

Mouldixrss, see Aspergîllĭs.

Mountain-Ash, see Pýrís aucupärĭă.

Mountain-zBony, see Bauhinăă.

MountaIN-PARSIRY, see Selinūm oreoselīnūm.

Mountain-sorrat, see Oxgriü.

Mourírĭ, Jussieu. From Mouriri, the native name of $M$. guianensis. Linn. 10, Or. 1, Nat. Or Memecylacea. These plants require to be grown in mixture of loam and peat; and cuttings of the young wood will root in sand, under a glass, in heat. Synonymes: 1. Petaloma mouriri. 2. P myrtilloides.

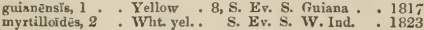

Mousk-kar, see Hierūtcīum pillosēllă.

MOUSE-TAR CHICKWWEED, see C'erüstĩùm.

MousE-TA1L, see Myosürĭ.s.

MousB-taII, see Dendrobiñm Myosürùs.

MoUse-THORN, see Centaürếi myacänthă.

Moving PrANt, see Desmódīum gȳrūns.

Mōxă, see Artcmiš̆ chinēnsĭs. [211] membranācè̃ . A petal

S. Ev. T. Mauritius. 182

Mouse-tail, see Mygalarüs.
Mucliagr, a turbid slimy Huid.

MŨeǒr, Michaux. From muceo, to be musty. Linn. 24, Or. 9, Nat. Or. Fungi. The plants grow on musty bread and vegetables-amethystĕŭs, caninŭs, clavätūs, delicatülūs, fusiggĕr, stercōriùs.

Mucronate, sharp-pointed.

M UCrose, a small sharp point.

M Ucronulats, having a little hard sharp point.

Mucûnă, Adanson. Mucuna-guaca is the Brazilian name of $M$. urcns. Linn, 17, Or, 4, Nat. Or. Leguminose. These plants are not possessed of mict beauty. A rich soil suits the species of Cow-itch, and they are readily increased by cuttings. The stinging effects of the hairs of the pods of $\boldsymbol{M}$. pru riens are well known. A strong infusion of the roots of the same plant, sweetened with honey, is used by the Indian doctors in cases of cholera. morbus. Synonymes: 1. Stizolobium altissimum. 2. Carpopogon giganteus. 3. C. imbricatus. 4. S pruriens. 5. S. urens, Dolichos urens.

altīssĭmă, 1 . Purple - S. Ev. Cl. Martinico . 1779 anguineá . P. Ev. Cl. E. Ind. : 1817 atropurpŭréă * . Purple - S. Ev. Cl. E. Ind. - 1820 S. Ev. Cl. E. Ind. : 1826 imbricãtă, 3 - Purple - S. Evv. Cl. E. lnd. - 1815 prüriêus, 4 . Purple * S. Ev. Cl. E. Ind. : 1680 ürèns, 5 : Yellow :6, S. Ev. Cl. W. Ind: 1691

gigāntēă 2, macrocerătĭdēs, mïtǐs, monospērmă, nǐvěă.

MUDWORT, see Limosellă.

IUGWORT, see Artemisžă vulgārĭs.

MulberRy, see Morŭs.

MuLch, a gardener's term for the placing manure about the roots of trees, on the surface of the ground.

MULI.BiN, see Verbäsctm.

Mullēeră, Linn. In honour of Otto Frederick Muller, a Dane, and one of the editors of the Flora Danica. Linn. 16, Or. 6, Nat. Or. Leguminosa. An ornamental tree, growing in loam and peat mixed; and cuttings of the young wood will root in sand, under a glass, in heat.

moniliformis . Yellow . S. Ev, T. Guiana • . 1792

MuLtreêspǐs, many-jointed.

MULTIFARIoUs, very numerous, or arranged in many rows.

Multiridet-pinnatifid; a leaf is so casled when it is pinnately-Iobed, and these lobes are again divided into many parts.

Multipartite, divided into many parts.

M Ũ LTîPı.̈. much multiplied.

MŨNDĬ Ă, Kunth. From mundus, neat; in allusion to the appearance of the plants. Linn. 17, Or. 3, Nat. Or. Polygalacee. This species, and its variety, are well worth cultivating for the sake of their flowers and fruit, which are very pretty. Sandy peat is the best soil for them; they are readily increased by young cuttings in sand, under a glass. Synonymes: 1. Polygala spinosa. 2. P. viminea.

spinbsă, 1 . White. . 3, G. Ev. S. C. G. H. - 1780 angustifóliă, 2. Purple : 3, G. Ev. S. C. G. H. : 1800

MUntīnglă, Linn. In honour of Abraham Munting, professor of botany at Groningen; he died in 1683 . Linn. 13, Or. 1, Nat. Or. Tiliacec. The flowers of this curious shrub bear a strong resemblance to those of the bramble, while the fruit is as like the cherry; it thrives well in a light loamy soil, and may be increased by cuttings in sand, under a glass, plunged in heat.

Calabūră . . White. . 6, S. Ev. S. Jamaica . 1690

MURĀrtĭă, Necker. In honour of John Von Muralt, a Swiss botanist. Linn. 17, Or. 3, Nat. Or. Poly. galacee. This beautiful genus of furze-like plant are highly deserving every care in cultivating them. A sandy peat soil suits them, and cuttings, taken from the young wood, will root in sand, under a glass. Synonymes: 1. Polygala alopecuroides. 2. $\boldsymbol{P}$. filiformis. 3. $\boldsymbol{P}$. Heisteria. 4. $\boldsymbol{P}$. humilis. 5. P. mixta.

alopecuroidès, 1 . Purple

ciliaris

diffüs

filiformis, 2

Heistërĭă,

hŭmilǐs, 4

juniperifolì

6, G. Ev, S. C. G. H. 1824 G. Ev S. C. G. H : 1800 Purple Purple Purple

1, G. Ev. S. C. G. H. : 1787

6, G. Ev. S. C. G. H. : 1810
MultiFid, cleft into many parts. 


\begin{tabular}{|c|c|}
\hline MUR & MUS \\
\hline 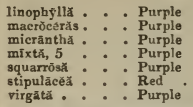 & $\begin{array}{l}\text { 6, G. Ev. S. C. G. H. }: 1816 \\
\text { G. Ev. S. C. G. H. }: 1812 \\
\text { G. Ev. S. C. G. H. }: 1800 \\
\text { G. Ev. S. C. G. H. }: 1791 \\
\text { 5, G. Ev. S. C. G. H. }: 1820 \\
: \text { 6, G. Ev. S. C. G. H. }: 1801 \\
\text { G. Ev. S. C. G. H. : } 1812\end{array}$ \\
\hline \multicolumn{2}{|c|}{$\begin{array}{l}\text { MURICĀRĬL, Desfontaines. From muricatus, full of } \\
\text { prickles; the pods are beset with prickles. Linn. } \\
\text { 15, Nat. Or. Cruciferce. A hardy annual, not worth } \\
\text { a place in any collection. Synonyme: 1. Bunias } \\
\text { prostrata-prosträtä l. } \\
\text { MUR1CATB, covered with short, sharp points. }\end{array}$} \\
\hline
\end{tabular}

MURICATBLY-HISPID, covered with short, sharp, stiff bristles.

MURRĀ̌̃̆, Konig. In honour of John Adam Murray, once professor of botany at Gottingen, and editor of some of Linnæus's works. Linn. 10, Or. 1, Nat. Or. Aurantiacea. These shrubs are well worthy of cultivation for the sake of their sweet-scented flowers. They thrive well in a mixture of turfy loam and peat; and cuttings of the ripened wood, not deprived of any of their leaves, will root in sand, under a glass, in a moist heat.

exotreă . . . . White . . 8, S, Ev. S E. Ind. . , 1771 paniculàtă : : : White. : 7, S, Er. T. E. Ind. : : 1823

Murucū̌̆, Tournefort. The name of the species in Brazil. Linn. 16, Or. 2, Nat. Or. Passifloraced. This is a genus of plants nearly allied to Passiflora, which see for culture and propagation. Synonymes : 1. Passiflora Micrucuia. 2. P. perfoliata.

ocellată, 1 . Scarlet $\cdot 7, \mathrm{~S} . \mathrm{Ev} . \mathrm{Cl}$. W. Ind. -1730 perfoliăta, 2 : : Purple : 7, s. Ev. CL w. Ind. : 1816 MŨs̆, Linn. Altered from the Egyptian Mauz, in honour of Antonius Musa. Linn. 5, Or. 1, Nat. Or. Musaced. To this genus belong those universally-esteemed fruits the Banana and Plantain, but from these plants growing to twenty-five or thirty feet high, they are rarely seen in perfection in this country on account of the quantity of room required; but the valuable species, $M$. Cavendishii, does not grow more than four or five feet high, so that any one possessing a moderate-sized house may, with a very little trouble, be rewarded by abundance of its excellent fruit, which is much superior to that of any of the other species. They all thrive best in a rich soil, requiring plenty of room and moisture; they are increased by suckers, which the old plants produce in abundance. It is considered that no known plant produces anything like the same quantity of nutriment from the same space of ground, as the Banana. It is indigenous to all the tropics, and from the numerous uses to which it is applied we may mention the following. The tops of the young plants are eaten as a delicate vegetable; the fermented juice of the trunks produces an agreeable wine. The fruit is served up both raw and stewed; slices fried are also considered a delicacy; and, finally, the leaves are used for thatching and basket-making.

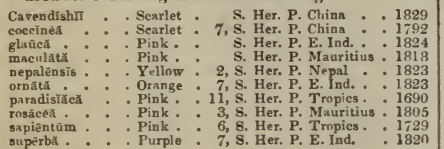

MU UscArí, Desfontaines. From moschos, musk; smell of the flowers. Linn. 6, Or. 1, Nat. Or. Lilizeea, Some of the species of this genus are very handsome, and should be planted near the front of flower-beds or borders; they thrive well in sandy loam, and are readily increased by offsets from the bulbs. Synonymes: 1. Mr. meschatum, flavum. 2. Hyacinthus moschatus.

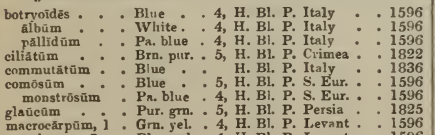

macrocăr pũm, i : Grn. yel. 4, H. Bl. P. Levant . 1596
MUS

pāllēns . . Pa. blue . 5, H. BL. P. Crimea . . 1822 parviflórûm : : Blue : 4, H. Bl. P. Sicily : 1827 pedunculärè : Blue . 4, H. Bl. P.

racemôsūm : Blue : $4, \mathrm{H}$. Bi. P. Europe 1780 minŭs : Blue : 4, H. Bl. P. Europe : 1780 MUsč̆̌̆̌R

MUscĭpứL

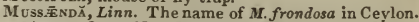
Linn. 5, Or. 1, Nat. Or. Cinchonacere. Some of these plants are very pretty. They all grow well in a mixture of loam and peat; and cuttings root freely in the same kind of soil, under a glass, in heat. Synonyme: 1. Macrocnemum coccineum.

arcuătă . . . . Yellow . S. Ev. S. I. France - 1822 chinēnsis: : : Y. Ev. S. Chinance : 1820 coccineã, 1 : : Red . . 8, S. Ev. T. Trinidad : 1825 frondósă : Yellow : 8, S. Ev. S. E. Ind. : 1814 gläbră * Orange : 7, s. Ev. S. E. Ind. : 1820 pubüscens : : Yellow : S. Ev. S. I. France * 1824 speciōsa : : Redow : 8, S, Ev. S. Trinidad : 1820

Mutable, changeable, inconstant.

MutATz, changed.

MutīsǏA, Linn. In honour of Celestine Mutis, a South American botanist, and discoverer of this his genus, Linn. 19, Or. 2, Nat. Or. Composite. Very pretty climbers, requiring to be grown in peat and loam; and cuttings root in sand, under a glass, in a gentle heat. Synonyme: 1 . M. specissa.

arachnoldéă, 1 , Red . . 7, S. Ev. Cl. Brazil . 1823 ilicifollä * . R G. Ev. Cl. S. Amer. : 1839 latifolia. : : Pnk. yel. . 9, G. Ev. Cl. Valparaiso: 1832

MYĀGR ŪM, Tournefort. From myia, a fly, and agra, capture; an ancient plant was so named from its properties of catching flies. Linn. 15, Nat. Or. Cruciferce. The seed of this pretty annual has only to be sown in the open ground.

perfoliătum . Pa. yel. . 6, H. A. France . 1648

MүйNтhǔs, Lindley. From myia, a fly; when the flowers are dried they look very much like a fly pressed flat. Linn, 20, Or. 1, Nat. Or. Orchidacede. This is a very curious genus of plants, and like other plants of a similar habit, they are easily cultivated, provided they are placed in a cool house and kept riry for some months, and afterwards vigorously forced in the same manner as the Catasetums.

barbătǔs . . Grn. pnr. . 2, S. Epi. Demerara immneulátǔs: :Grn pur. 3, S. Epi, Demerara: 1835 cẹrnūūs. . : Grn. pur. : 5, S. Epi. Brazil .

delwidés : : Grn. pink 10, s. Epi. Demerara : 1835

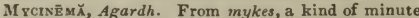
fungus, and nema, a thread. Linn. 24, Or. 7, Nat. Or. Alga. The plants composing this genus are found on rotten wood-arachnoĩdeam, folvnm, phos.

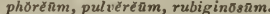

MYGALOURŬs, Link. From mygale, a field-mouse, and oura, a tail. Linn. 3, Or. 2, Nat. Or. Graminea. Mere annual weeds. Synonymes: 1. Festuca bromoides. 2. F. myurus. 3. F. uniglumis - alopecu-

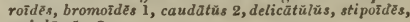
uniglümis, 3.

MYGINDĂ, Jacquin. In honour of Francis Von Mygind, a German botanist. Linn 4 , Or, 3 , Nat. Or. Aquifoliacee. These plants grow freely in loam and peat, and cuttings of the ripened wood will root in sand, under a glass; the stove species in heat. Synonyme: 1. Mlex Myrsinitis.

integrifolia . White. - S. Ev. S. Martinique 1826 latifoliá. * White. 4, 8. Ev. S. W. Ind. 1795 Ev. S. N. Amer. 1318

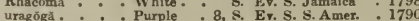
MYLoch́rí̃is, Willdenon. From myle, mill, and karyon, a nut; the seeds have four wings. Linn. 10, Or. 1, Nat. Or. Celastracea. An ornamental species, with the habit of Andromeda; it may be successfully grown in loam and peat, and cuttings will root in sand, under a glass. Synonyme: 1 . Cliftonia ligustrina.

ligūstrinnūm, 1 . White . . 5, F. Ev。 S. Genrgia .

M rŏpŏrẽ̀, Banks. From myo, to shut, and puros, a pore; in reference to the leaves. Linn. 14, Or. 2, Nat. Or. Myoporacea. Pretty shrubs, delighting in a mixture of loam and peat; and cuttings will root readily in sand, under a glass. Synonyme: 1 Pogonia glabra.

[212] 


\begin{tabular}{|c|c|}
\hline MYR & MYR \\
\hline 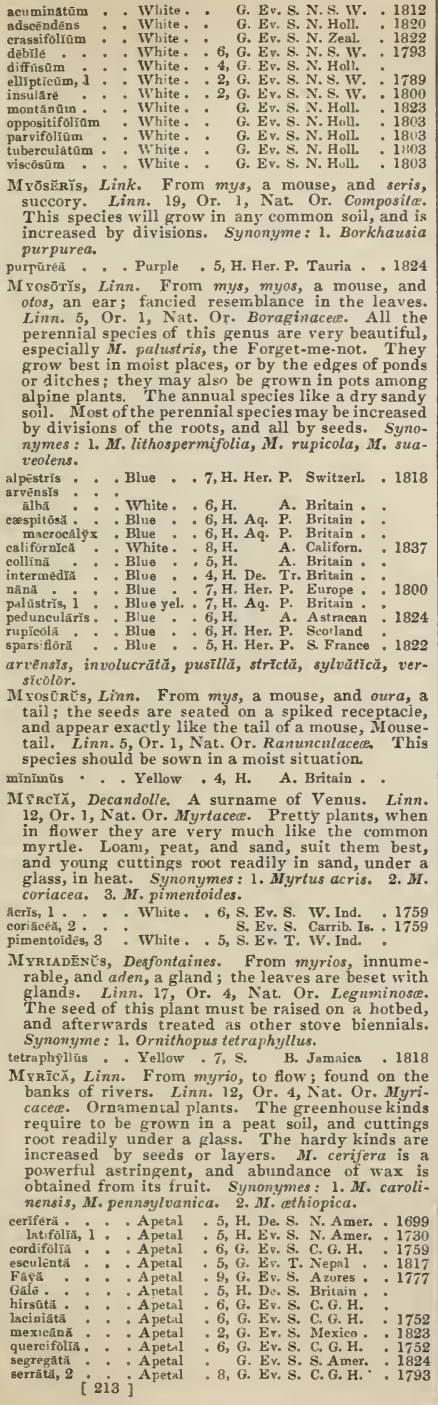 & 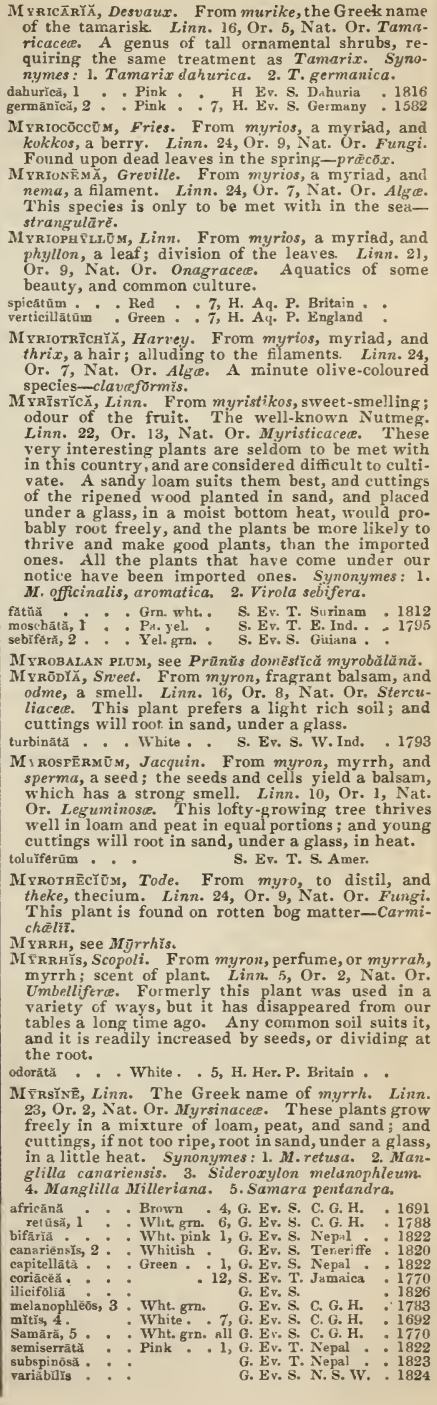 \\
\hline
\end{tabular}




\begin{tabular}{|c|c|}
\hline MYR & NAR \\
\hline
\end{tabular}

I YRSIPH T̃LLŨ $\mathrm{M}$, Willdenom. From myrsine, a myrtle, and phyllon, a leaf; resemblance of the leares. Linn. 6, Or. 3, Nat Or. Melanthacee. A genus of pretty twining plants, thriving well in sandy loam and peat, and readily multiplied by dividing at the root. Synonyme: 1. Medeola asparagoides. angustifoliam : Grn. wht. 7, G. De. Tw. C. G. H. : 1752
as paragoidẽs, 1 : Grn. wht. 6 , G. De. Tw. C. G. H. : 1702

MrRTLE, see Mỹrtŭs.

MYRTLE BILHRRRY, see Vacciniñm Myrtillüs.

M ̌̄RTǓs, Linn. From myron, perfume; myrtos of the Greeks; myrtus of the Dutch, and of almost every other European language. Linn. 12, Or. 1, Nat. Or. Myrtacece. The Iryrtle is a favourite and well-known yenus of plants, which grow well in sandy loam and peat; and cuttings, if not too ripe, will root freely either in sand or soil, under a glass.

affinìs . . Purple , 6, G. Ev. S. China . . 1823 bifốră : : : White. 5 , S. Ev. S. Jamaiea : 1759

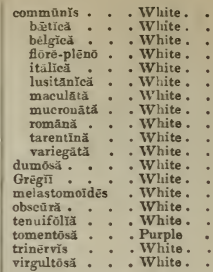

MYS

NAR

IYxotrīchīôs, Kunze. From myxa, gluten, and thrix, a hair; filaments. Linn. 24, Or. 9, Nat. Or. Fungi. This species is found on rotten branchescæsiūm.
N ÆMĀSPŎRA, Persoon. From nema, a thread, and spora, a sporule. Linn 24 , Or. 9 , Nat. Or. Fungi. Very minute plants, found on dead branches of Hornbeam, \&c._carpīnz̃, crö́č̃ă, filamentōsă, Ros

Namatēllă, Fries. From naima, gelatine, and ello, to contain; in allusion to the nucleus in the receptacle. Linn. 24, Or. 9, Nat. Or. Fungi. A curious flesh-coloured species, growing on partially decayed pine-wood-encephala.

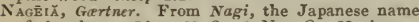
of the plant. Linn. 22, Or. 4, Nat. Or. Myricaces. A plant of very little interest, growing best in a good rich loam; and cuttings of the ripened wood root in sand, under a glass, in a strong heat.

Putranjivă . . A petal . S. Ev. S. E. Ind. . 1822

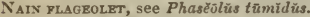

Nījās, Linn. From naias, a water-nymph; on account of the habitation of the plant. Linn. 21, Or. 5, Nat. Or. Fluviales. A curious plant, of very simple culture. Synonyme: 1. monosperma.

măjorr, 1

7, H. Aq. A. Europe.

NAKBD, without hairs, leaves, or branches, \&c.

NAKEDISH, nearly destitute of hairs, leaves, \&c.

NANDīNa, Thunberg. Nandin, or Nand-scokf, is the name of the shrub in Japan. Linn. 6, Or. 2, Nat. Or. Berberacea. This is a handsome plant, growing in a mixture of loam and peat; and ripened cuttings will root in sand, tunder a glass, provided the leaves are not shortened.

domëstică . . . Grn brn. . 7, G. Ev. S. China . . 1804

Naxôpīs, Lindley. From nanodes, pigmy; in allusion to the small size of both plant and flowers. Linn. 20, Or. 1, Nat. Or. Orchidacto. This is among the most curious of orchidaceous plants ; its flowers are completely embosomed by the leaves, and so sinilar in colour, that it would scarcely be observed to be in flower, even if every branch were blossoming. It is rather difficult to cultivate, but will be found to succeed best treated after the manner of Burlingtonia.

diveolor

Purpsl. grn. 8, S. Epi. Brazil

1827

NAPIFORM, formed like a turnip, tuberous.

N APOLRoN's WEEPING WILLOW, see Sülīx Na poleōnă.

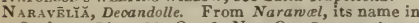
Cevlon. Linn. 13, Or. 6, Nat. Or. Ranunculacee. A mixture of sandy loam and peat suits this species, and cuttings of the young wood will root readily in sand, under a glass, in heat. Synenyme l. Atragene zeylanica.

zeylänieă - . Y Yellow • S. Ev. Cl. Ceylon • . 1796

NARcīssús, Linn. From narke, stupor; on account of the effects produced by the smell upon the nerves. Linn. 6, Or. 2, Nat. Or. Amaryllidacea. This is an old and very popular flower of great beauty, and some of the species are highly fragrant. They are all of very easy culture, growing well in any light sandy soil, or on glasses of water, and increased by offsets from the bulbs. $\boldsymbol{N}$. poeticus, and one or two more, are well known to be emetic. synonymes: 1. radipllorus. 2. triandrus. 3. orien. talis, var. 4. Corbularia conspicua. 5. Queltia concolor. 6. Narcissus praecox. 7. bicolor. 8. Ajax maximus. 9. Narcissus Tazetta. 10. trilobus 11. calathinus. 12. unicolor, nevius. 13. poeticus, majalis. 14. moschatus. 15. festalis. 16. Phylogyne minor. 17. calathinus, odorus, tripartitus.

ăjầx . . . Yellow . 3, H. Bl. P.

albieans : Pa. yel. : 3 , H. Bt $P$.

albús . : Wht. yel 4, H. BI. P.

plēnŭs: : : Sulphur . 4, H. BI. P.

plenús. : - Sulphur. 5 .

aputicorónă. : Yel, $m$. : 4, H. Bl. P. N. Afriea

auråntiüs: : Yellow: 3 , H. Bl. P.

plenùs-lutè ùs : Yellow: 3, H. BL P.

bicolor

biflords : - White 3, H. Bl. P. Britain :

bitlorus : : White $: 3$, H. Bl. P. Britain
bifrons :

Bulbocótióm Yellow 4 H. Bl P. Porturgi

căpāx : : Pa. yel. : 5, H. BI. P.

White $4, \mathrm{H} . \mathrm{BL}$. P.

çrnũŭs, 2 . Crm. whe 3, H. Bl. P. Spain

corond-plēna . Crm. wht. 3, H. Bl. P. Spain

citrinŭs, 3 . Whit. yel. 4 , H. Bl. P.

eomprếssǔs : . Li. yel. . 3, H. Bi. P. Spain

côneơlör : : Yellow : 4, H. Bl. P.

eonsploŭ ùs, 4 : : Yellow : 5 , H. Bl. P.

crenulätūs : : Wlite 4 , H Bl. P. Spain

Cýprì. : Whe yel. 3, H. Bl. P. Cyprus

corónă-plênă:" : Whit yel. 3, H. BI. P. Gardens

dǔbǐus

fistulōsǔs

floribündūs

galanthifolros

grăcilìs

grandiflörŭs.

Hawortliín, 5

plênưs-sul phŭrèù :

heminalis

incomparábilis

inflâtüs

infundibuia

interjéctüs

interjēetüs :

italicũs, 6

plênứs.

semiplènuัs

Jonquİa

flôré-pléno

latifoliūs.

lobulätũs.

lorifolluss, 7

ăncēps

brévilló

Lũnă

Macleăin

mäjōr .

maxĭmùs, 8

minor.

montånŭs

moschătūs
White 4, H. BL P. France

Wlit. yel 4 , H. Bl. P.

Wht. jel. 3, H. Bl. P. Spain

White. 5, H. Bl. P.

Yellow $4, \mathrm{H}$. Bl P.

Wht. yel 4, H. Bl. P.

Yellow 4, H. Bl. P

4, H. Bl. P.
4, H. Bl. P

Sulpliur : 4, H. B1. P.
Yellow : 3, H. Bl. P.

Yellow . 4, H. Bl. P. Portugal . 1629

Yellow: 3, H. BL P.

P. sulphur 3, H. BL. P. Spain . . 1696

Yellow . 3, H. BL. P.

Yellow: 4, H, BI. P.

Pat vel. : 3, H. Bl. P. Pyrenees

Pa yel. 3, H. Bl. P. S. Eur.

Cream : 3, H. Bi. P. Italy

Yellow : 4, H. BI, P. Spain: 1596

Yellow : 4, H. Bl. P.

Yellow: 3 , H. BL P.

Yellow: 3, H. Bl. P.

Yellow: 3, H. BI. P.

Yellow : 3, H. Bl. P.

Yellow $: 4$, H. Bl. P.
White 4, H. Bl. P.

White

Yellow : 3, H. Bl. P. Spain

Yellow : 4, H. Bl. P.

Yellow: 3, H. BL P. Spain

White : 4, H. Bl. P. Portugal

White: 4, H. B1. P. England

Yellow: 4, H. Bl. P.

[ 214 ]
Cream - H. Bl. P. Italy

Pa yel. . 4, H. B1. P. Spain : 1596 


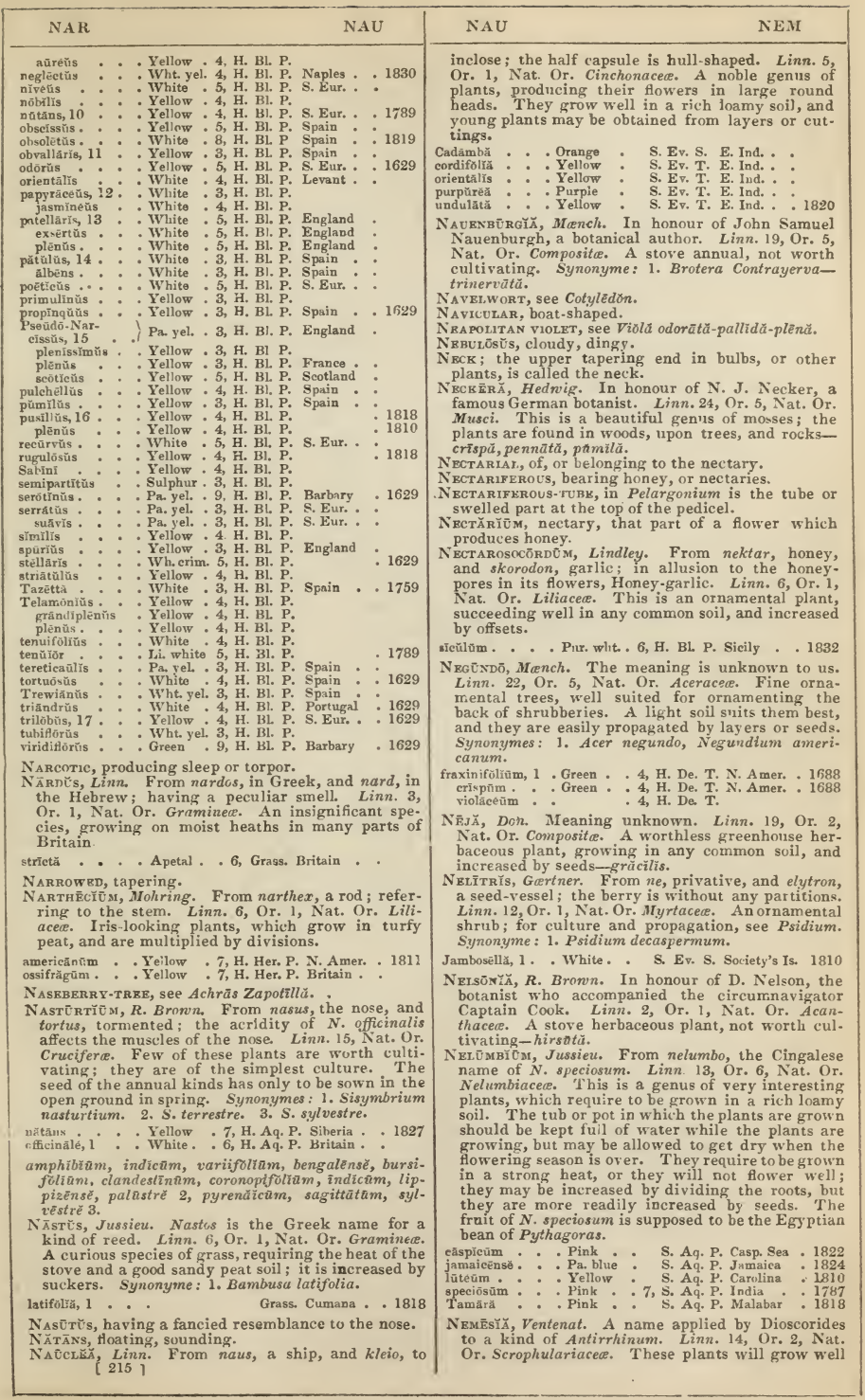


in any rich lipht soil. $\boldsymbol{N}$. bicornis may be treated as other tender or half-hardy annuals; the othe:s may be increased by cuttings of the young wood planted under a glass. Synonyme: 1. Antirrhinum macrocarpum. bicôrnìs.
chamædrifoiliă, 1: Purple : 7, H. G, Her. A. C. G. H. H. : 1774

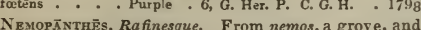
anthos, a flower; habitat of the plant. Linn. 22, Or. 5, Nat. Or. Aquifoliacea. This is an ornamental plant, thriving well in a peat soil, and readily increased by layers or seeds. Synonymes: 1. fascicularis, Ilex canadensis.

ennatensis

H. De. S. N. Amer. . 1812

NemōphǏц, Barton. From nemos, a grove, and phileo, to love; the plants delight in a shady situation. Linn. 5, Or. 1, Nat. Or. Hydrophyllacede. This is a genus of very pretty annuals, all of which are well worth cultivating; they grow and flower best in a moist shaded situation, and a peat or vegetable soil. If the plants are wanted to flower early, the seed should be sown on a hotbed, and afterwards transplanted; but if not wanted to flower before late in summer, they may be sown in the open border. Synonymes; 1. Hydrophyllum appendiculatum. 2. Phacelia parviflora, Eutoca parviflora.

\begin{tabular}{|c|c|c|c|}
\hline $\begin{array}{l}\text { atomaria : } \\
\text { aurita : } \\
\text { insignis : } \\
\text { paniculätă, } 1 \\
\text { parvifioră, } 2 \\
\text { phacelioidẽ }\end{array}$ & $\begin{array}{l}\text { : Wht pur. } \\
: \text { Purple } \\
: \text { Blue } \\
: \text { Pa blue } \\
\text { : Blie : } \\
\text { Blue : }\end{array}$ & $\begin{array}{l}\text { 8, H. } \\
6, \text { H. } \\
8, \text { H. } \\
\text { 5, H. Her. } \\
: \text { H. Her. } \\
\text { 7, H. Her. }\end{array}$ & $\begin{array}{l}\text { A. California } \\
\text { A. California } \\
\text { A. California } \\
\text { P. N. Amer. } \\
\text { P. N. Amer. } \\
\text { P. N. Amer. }\end{array}$ \\
\hline
\end{tabular}

Nemcrosťs, growing in the woods, or among trees.

Neörtřx, Linn. Veuttia, a bird's nest; in allusion to the interwoven fibres of the roots. Linn. 20, Or. 1, Nat. Or. Orchiducer. This is a pretty genus of orchidaceous plants. The hardy species will succeed well in chalky soil, or a mixture of loam, peat, and sand. The stove kinds may be referred to Bletia for culture; they are all increased by divisions. Synonymes: 1. Spiranthes bicolor. 2. S. elata. 3. S. picta. 4. S. pudica.

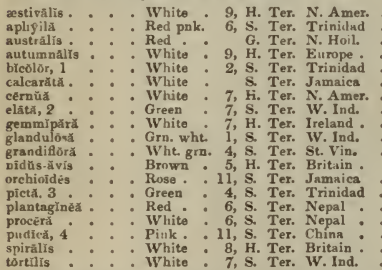

1892

826

$18-23$

1823

1796

1790

1829

1826

1805

1824

1819

1892

Nepīntak̄s, Linn. This is a name under which Homer speaks of a substance, probably opium; but in what way it is applied to this plant we do not know. Linn. 22, Or. 13, Nat. Or. Nepenthacec. $\boldsymbol{N}$. distillatoria is a most extraordinary and singular plant, and well known under the name of Chinese Pitcher Plant; it ought to be in every collection of stove plants. It attains the height of twenty or even thirty feet, when its appearance is inconceivably singular from the fine large pitchers which bang gracefully from the points of the strongest leaves. It is supposed by most cultivators to be extremely difficult of cultivation, but we have not found the least difficulty in cultivating it; indeed, we question whether the plants at Chatsworth are not finer than plants growing in and enjoying all the advantages of their native soil. Experience has clearly taught us that heat at the roots is as necessary to the successful growth of this plant as a heated atmosphere is indispensable to the stem and leaves. The plants should be potted in a com. post of a little coarse fibreus peat, mixed with a kreater portion of Hypnum Moss, and the pots to be then immersed in moss, the heat of which should not be less than eighty degrees, while the heat of the house need not be, except in summer, more than seventy. The moss in which the plants are plunged should be kept rather wet, so that a constant but gentle huridity is given off, which rises among the plants, and thus strengthens, while it promotes their growth. Offsets are thrown out from the base of the stem of old plants, which, when a few inches long, or when each offset has made three or four leaves,aretaken off, and potted singly into thirty-two-sized pots, using the same kind of compost, and plunging them in the moss, as before directed, and as the plants grow, and the rootlets in the pot become numerous, an additional sized pot should be given to each, using precisely the same materials as before, observing to secure a good open drainage at the bottom of each; young plants may also be obtained from seeds.

distillntörtă . . Grn. yel. all S. Ev. Cl. Chins : • 1789 Pliyllamphora : Gru. yel. . 7, S. Ev. Cl. Clina : 1820 Nepétă, Linn. From Nepet, the name of a town in Tuscany, where the plants were first found. Linn. 14, Or. 1, Nat. Or. Lubiate. Some of the plants belonging to this genus are very pretty, and well adapted for flower-borders, while others are not worth growing. They prefer to grow in a light dry soil, and are increased by dividing at the root in spring or autumn, or by seeds. Synonymes: 1 . arragonensis. 2. Melissa alba. 3. N. patella. 4. grandiflora. 5. Melissa cretica, Thymus marifolius. 6. N. longiflora. 7. amethystina. 8. pannonica. 9. paniculata. 10. Teucrium sibiricum.

Blie 7, H. Her. P. S. Eur. 1816 angustifolfă, $1^{\circ}$ : Purple 6, H. A. Spain : 1798

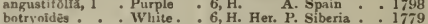

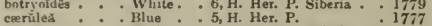
cataria .: : White: 8, H. Her. P. Britain. crispa : P*. blue : 7, H. Her. P. Levant: 1800 croâtı̌̆, 2 . : White. 7 , H. Her. P. Hungary : 1821 diffúsa : : Purple : T, H. Her. P. Siberia : 1824 fissa : : Blue : H. Her. P. Caucasus : 1831 grandiflóră: : Blue: $7, \mathrm{H}, \mathrm{Her}, \mathrm{P}$ Cauensus: 1817 graveolens, 3 : : Purple: 7, H. Her. P. S. Eur. : 1804 imbricata . Hlue * : \%, Her. P. Spain : 1820 incána . : White. 8, H. Her. P. Levant: : 1723 italied . Red wht. : 7, H. Her. P. Italy : 1640 latifolrd, 4. Purple - 7, H. Her. P. Pyrenees: 1816 longifoura . Vinlet . . 7, H. Her. P. Persia . 1802 macroüra Wlit. pur. 7, H. Her. P. Siberia . 1820 marrubioldès : Ked . 7, H. Her. P

multibracteati : Purple :7, H. Her. P. Algiers. . 1817

Mussinf, 6. . Violet . 7, H. Her. P. Siberia : 18114

Nepetella, 7 . Red * 7, H. Her. P. S. Eur. : 1758

nûda, 8. . White . . 7, H. Her. P. S. Eur. . . 1713

pannônică, 9 - Red * 9, H. Her. P. Hungary - 1683

pirviflörà . . Blue * 7, H. Her. P. Caucasus . 1820

Scordótiss.. Blue *. 7, H. Her. P. N. Africa . 1817

7, H. Her. P. Tauria . 1828

sibirică, 10 : Purple 7. H Her P. Siberia: 1804

suaveoléns.: Blue : 7. H. Her. P : 1817

supina . . Blue: 7, H. Her. P. Caucasus: 1816

tencrifolia - Purple : 7, H. Her. P. Armenia . 1816

teucrioidés. : Wlúte. : 7, H. Her. P. S. Eur. . . 1820

ucrăniar : Blue 7, H. Her. P. Ukraine 1798

violaceñ : Blue : 8, H. Her. P. Spain : 1798

colorūtă, lamiifollă, lanütŭ, malabūrǐcŭ, melissaeföliŭ, reticulätũ.

Niвндо̆мӑ, Acharius. From nephros, a kidney; in allusion to the form of the apothecia Linn. 24, Or. 8, Nat. Or. Lichenes. These plants are found amongst moss in stone quarries, \&c.-părilits, resupinätă.

NERINE, Herbert. After Nerine, the danghter of Nerius. Linn. 6, Or. 1, Nat. Or. Amaryllidacea. A genus of pretty bulbous plants. $N$. sarniensis, or Guernsey-lily, is a very popular autumnal flower. They flourish best in a rich sandy mould, and are readily increased by offsets, or by seeds. Synonymes: 1. Lycorus aurea. 2. Amaryllis curvifolia. 3. Lycorus radiala.

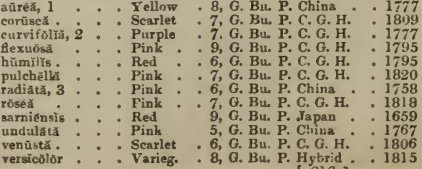
$[216]$ 
NF̄̌ habitat of the plants. Linn. 5, Or. 1, Nat. Or. Apocynaced. This is a genus of noble evergreen shrubs, of easy culture, and flowering freely the greater part of the year. $N$. Oleander and its varie ties bear forcing remarkably well, and although treated as greenhouse plants, yet they will not flower well unless they are kept in the stove; they grow well in any rich light soil, and young cut tings root in any soil if kept moist. The leaves of $N$. Oleander contain gallic acid, and the leaves and bark of the root of $N$. odorum are applied externally as powerful repellents by the Indian practitioners.

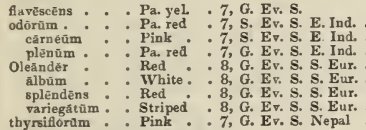

Nerveless, without nerves

Nerves, the strong ribs upon leaves or flowers.

NERvosi, or Nervous, full of nerves.

NERVOSELY-FURROWRD, Or STREAKRD, having nerves like furrows, or streaks.

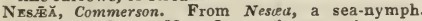
Linn. 11, Or. 1, Nat. Or. Lythracece. An orna mental plant when in flower, growing best in a mixture of loam, peat, and sand, and readily in creased by cuttings in sand, under a glass.

trifiōră . . Blue . . 8, S. Her. P. Mauritius . 1809

NĒst.̌̆, Desfontaines. The meaning not explained Linn. 15, Nat. Or. Cruciferce. A hardy annual, not worth cultivating. Synonyme: 1. Myagrum paniculatum-paniculätă 1 .

NETTED, having the veins reticulated.

Nistib, see Urtică.

Netrti-trib, see Céltis.

Neurocārpè, Desfontaines. From neuron, a netve, and karpos, a fruit; each of the valves of the pod is furnished with a longitudinal nerve. Linn. 17, Or. 4, Nat. Or. Leguminosa. These plants require to be treated like other stove plants. $S y$. nonyme: 1. Crotalaria guianensis.

guianēnsĕ, 1 . Purple - S. Ev. S. Guiana * 1826

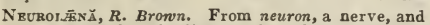
lana, a cloak; alluding to the calyx. Iinn. 19, Or. 1, Nat. Or. Compositce. A worthless stove shrub, growing in sandy peat-lobätä.

Nírolōmă, Andrzejonski. From neuron, a nerve, and loma, a fringe. Linn. 15, Nat. Or. Cruciferce. A plant of some beauty; it grows in any common soil, and is readily increased by divisions. Synonymes: 1. Arabis grandiflora, Hesperis arabidifolia.

arabidiflórúm, 1 . Purple . 5, H. Her. P. Siberia * . 1800

Neurospērmă, Rafinesque. From neuron, a nerve, and sperma, a seed; the seeds are articulated with anastomosing nerves. Linn. 21, Or. 1, Nat. Or. Cucurbitacea. For the culture and propagation of this worthless plant, see Cucurbita.

cuspidáta - Yellow - 7, H. Tr. A. Kentucky . 1827

Niuter, neither male nor female.

NEW JrRsey TEA, see Ceanôthŭs americānŭs.

NEw Zraland spiNach, see Tetragóniă expānsă.

NEW Z BALAND TEA, see Leptospërmūm scopärǔŭ.

Nicker-trar, see Guiländīnä.

Nicorsōxǐă, Decandolle. In honour of Mr. Nicolson, author of an "Essay upon the Nat. Hist. of St. Domingo." Linn. 17, Or. 4, Nat. Or. Leguminosa. For the culture and propagation of this plant, see Uraria. Synonyme: 1. Hedysarum barbatum.

barbătă, 1 . . Purple .6, G. Ev. S. Jamaica • 1818

NicorrāxĂ, Linn. In honour of John Nicot, of Nismes, ambassador from the King of France to Portugal, who procured the first seeds from a Dutchman, who had them from Florida. Linn. 5, Or. J, Nat. Or. Solanacea. The species of this genus generally grown as tobacco, are $\boldsymbol{N}$. T'abacum and $N$. macrophylla. The popular narcotic which it furnishes is probably in more extensive use than any other, and its only rival is the betel of the [ 217 ]

East. The herb for smoking was brought to England from Tobago in the West Indies, or from Tobasco in Mexico (and whence the name), by Sir Ralph Lane, in 1586 . Seeds were shortly afterwards introduced from the same quarter. Sir Walter Raleigh first introduced smoking; in the house in which he lived at Islington were his arms on a shield, with a tobacco plant on the top. "Tobacco as used by man," says Du Tour, "gives pleasure to the savage and the philosopher, to the inhabitant of the burning desert and the frozen zone; in short, its use either in powder, to chew, or to smoke, is universal, and for no other reason than a sort of convulsive motion (sneezing) produced by the first, and a degree of intoxication by the two last modes of usage." Don's Gard. and Bot. Many of the species are showy when in flower, and are well suited for decorating the flower-borders. The seeds require to be sown on a hotbed in spring, and when the plants have got two or three leaves, they should be planted into small pots, and placed in the frame, and planted out about the end of May, those for the open border in conspicuous situations, and those intended for leaves in rows three feet apart. Synonyme: 1. suaveolens.

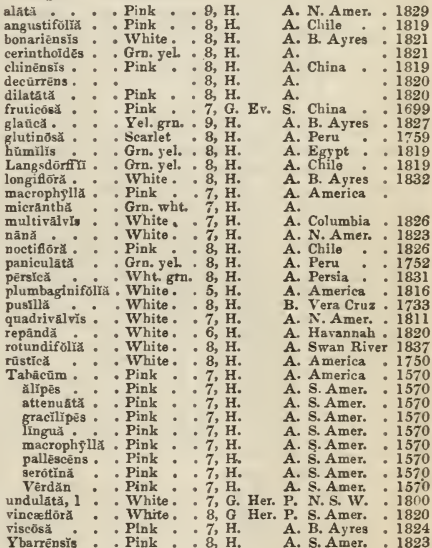

NidoraNt, nestling, as a bird in its nest.

NıDUrārǐă, Bulliard. From nidus, a nest; on account of the plants consisting of cups, which contain egg-like seeds, Linn. 24, Or. 9, Nat. Or. Fungi. Interesting plants, found on rotten leaves, shavings of wood, bark, \&c._campanulātä, Crucĭbülūm, striätā.

Nīứs, the nest of anything.

NıввёнRц̌, Decandolle. After Carslen Niebıhr, a traveller in Arabia. Linn, 13, Or. 1, Nat. Or. Capparidaced. 'These plants grow well in a mixture of loam and peat; and cuttings of the nearly ripened wood will root in sand, under a glass, the stove species in heat. Synonymes: 1. Cratava caffra. 2. Capparis heteroclita.

caffra, 1 - - White . - G. Ev. S. C. G. H. - 1818 madagascariennsiss. White. : S. Ev. S. Madagas. 1822

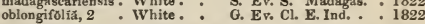

Nitrambêrgłă, Ruiz and Pavon. In honour of John

Eusebius Nieremberg, a Spanish Jesuit, author of a History of Nature, Antwerp, 1635. Linn. 5, Or. 1, Nat. Or. Solanacea. These very elegant plants may be referred to Petunia for culture and propagation. Synonyme: $1 . N$. linariafolia.

aristătă . . - Wht. pur. 7, H. A. Panama 1832 calycina : : White. . 7, G. Her. P. Uraguag : 1834 


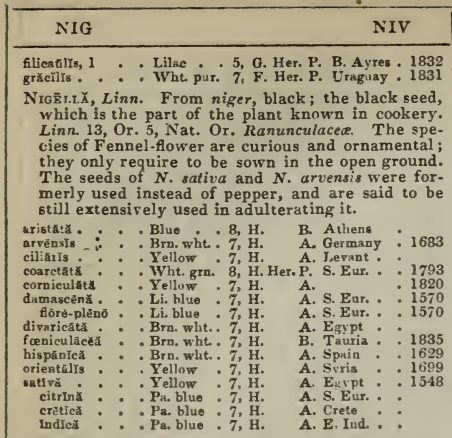

NrontвHAdz, see Silānūm.

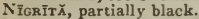

NigRITẼLLÃ, Richard. From niger, black; becaurse of the dark colour of the flowers. Linn. 20, Or. I, Nat. Or. Orchidacea. A curious tuberous-rooted species, growing freely in loam and peat, and increased by divisions of the roots.

angustifolia . . Drk, crim. . 7, H. Ter. Austria . . 1795

Nïn, Thunberg. The name of the tree in the Moluccas. Linn. 21, Or. 10, Nat. Or. Palmacer. A fine palm, requiring to be grown in a strong loamy soil and a hot, humid atmosphere.

frúticang . . White. . Palm. E. Ind.

1822

Nıрнбъб̆цйs, Kaulfuss. From niphobolos, covered with snow; the indusia appear as if covered with snow. Linn. 24, Or. 1, Nat. Or. Polypodiaced. A genus of very ornamental ferns, which grow well in sandy loam and peat in equal portions, and are increased by dividing the roots, or by seeds. Synonymes: 1. Polypodium adnascens. 2. confluens. 3. lineare. 4. lingua, Acrosticloum lingug. 5. P. pertusum. 6. P. rupestris.

adnăscéns, 1 - Brown - 5, S. Ev. Cr. E. Ind.

albieans Hrown 7, S. Her. P. Ceylon

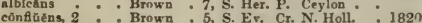

côntaúns, 2 - Brown . 5, S. Ev. Cr. N. Holl. 182

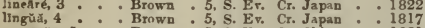

pertüsús, 5 : Brown : 5, S. Ev. Cr. China : 1821

rupestris, 6
sibensis.

Nippl.zwort, see Lapsänă.

Nissólı̌̃, Jacquin. In honour of Willian Nissole, a

diligent French botanist. Linn. 17, Or. 4, Nat. Or. Leguminost. Ornamental shrubs, which grow well in a mixture of loam and peat; and cuttings of the ripened wood will root in sand, under a glass, in heat.

sculeata

fruticōa

glabrata

S. Ev. Cl. Rio Jan. * 1824

micrỏptẻră. White. : z, S. Ev. S. Teneriffo: 1820

White. 7 , S. Ev. Cl. W. Ind. 1800

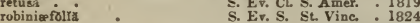

Nrrt̄̌llă, Agardh. From niteo, to shine; shining plants. Linn. 24, Or. 7, Nat. Or. Alge. Fresh water Alga; the plants are found in pools and rivulets. The stems are composed of simple tubes. Synonyme: 1. Chara flexilis-flexilis 1, gräcilìs, nìdı̇icicã, opäcă, translücēns.

Nirioues, shining, glossy.

NITR ĀRIÁ, Schreber. From nitrum, nitre; first found by Schreber near the nitre works in Siberia. Linn. 11, Or. 1, Nat. Or. Nitracea. Curious dwarfgrowing shrubs; they succeed well in a light sandy soil, and may be increased either by cut. tings or layers. Synonyme: 1. N. caspica.

Schober . . Pur. blue . 6, H. De. S. Siberia . . 1788 câspî̀că, $\mathrm{i}$ : : Whito. : 6, H. De. S. Caspian. : 1812 sibirică : : W. De. S. Siberia.

tridentati. : $\quad$ H. De. S. Barbarg

1820

NitTA-TREg, see Parkžă.

NIV̌̉A, covered with a pubescence re:embling snow.

NIV

NOR

NIVĒviă, R. Bronin. In honour of James Niven, a eminent collector of South A frican seeds. Linn. 4, Or. 1, Nat. Or. Proteacea. These shrubs are possessed of some beauty; they thrive in sandy peat and a little loam mixed, and cuttings of the young wood root freely in sand, under a glass; they may also be increased by seeds. Synonyme: 1. Protea spatulata.

crithmifóliă - . Pa. pux. - 7, G. Ev. S. C. G. H. Lakōpǔs : : Purple T, G. Ev. s. C. G. H. med.a . - Purplo 7, G. Ev. S. C. G. H. parvifo. iă, i : : Purple : 7, G. Ev S. C. G. H. : 1803 scéptrüm : . Pa. pur. : 7, G. Ev. S. C. G. H. : 1790 spathulàta. : : Purple : 7, G. Ev. S. C. G. H. $\quad 1790$
spicátă. : Purple spicátă. . . Purple 7, G. Ev. S. C. G. H. . 1786 professor at Pavia. Linn. 19, Or. 1, Nat. Or. Composito. Ornamental plants, growing in any common soil, and increased by cuttings. Synonymes: 1. Lagasca heliunthifolia. 2. L. rubra. 3. L. suareolens.

latifolĩă . . White . 8, F. Ev, S. Mexico . . 1826 rịgiď, 1 : Pink : 8, S. Ev. S. Mexico: 1825 rubrh, 2 . Red : 7, S. Ev, S. Nexico:: 1823 suareülens, 3 : Whito: 8, S. Ev, S. Mexico : 1825

Nopding, having a drooping position.

Nō̄in, the swelled articulations of stems, the place where one joint is articulated with another.

NoDose, having many nodi, or knots.

NōbǔLữs, a small, hard nodus, or knot.

Nois̄̄tTǏ̈, Humb., Bonp., and Kunth. In honour of Louis Noisette, an eminent French cultivator. Linn. 5, Or. 1, Nat. Or. Violacer. This species grows freely in any light rich soil, and young cuttings root in sand, undor a glass, in heat. Synonymes: 1. Ionidium longifolium, Viol is longifolia.

longifolka, 1 . C Cream . S. Ev. S. Cajenne . 1824

Nor.̄̄Nă, Linn. From nola, a little bell; because of the form of the corolla. Linn. 5, Or. 1, Nat. Or. Nolanacea. These plants are very showy when in flower, and are therefore well suited for orna. menting flower-borders. The seed ought to be sown on a gentle hotbed in spring, and transplanted to the open ground about the middle of May.

atriplicifoulua . Wht. yel. 7, H. A. Peru . 1834 grandiforă . Blue . 7, H. Tr. A. Chile : 1829 paradóxá : : Blue : 8, H. Tr. A. Chile : 1825 tenellaz : : Blue : 8, H. Tr. A. Chile : 1824

Nolīx , Michaux. After P. C. Nolin, an American botanist. Linn. 6, Or. 3, Nat. Or. Melanthacex. This is a very ornamental plant, succeeding in sandy peat, and increased by offsets. Synonyme: 1. Phalangium virgatum.

georgiănă, 1 . . Wlute . . 7, H. Her. P. Georgia. . 1812

Nonatêt.Ĭ , Aublet. The name of one of the species in Guiana Linn. 5, Or. 1, Nat. Or. Cinchonacea. A genus of ornamental plants; for culture and propagation, see Hamiltoniu. Synonymes: 1. Psychotria involucrata. 2. P. racemosa.

lotéa . . Yellow . 6, S. Ev. S. Guiana . 1823 offeinalrs, 1 : White. 6, S. Er. S. Cayenne : 1827 racemôs, 2 : White: : 6, S. Ev. S. Guiana - : 1818 violäcé . White. . 6, S. Ev. S. Guisna . 1824 NōEẼ, Decandolle. In honour of J. P. Nonne, a German botanist. Linn. 5, Or. 1, Nat. Or. Boraginacece. Plants of no great beauty; they grow well in the open border, where the seed has only to be sown. Synonymes: 1. Lycopsis lutea. 2. $L$. picta, Anchusa picta. 3. L. vesicaris. 4. Anchusa rosea. 5. A. versicolor. 6. L. vesicaria.

eiliata . . Yellow . 6, H. A. Levant . . 1804 Alavéscéns: : Yellow : 6, H. A. Russia : 1835 lũtéă 1 : Yellow $: 6, \mathrm{H}$. A. Crimea : 1805 nigricáns : : Dark : 5, H. Tr. A. Barbary : 1822 pietã, 2 : Varieg. $: 6, \mathrm{H}$. Tr. A. Tauria . 1800 püllă, 3 : Dark : 6, H. Her. Tr. Germany : 1648 rosen, 4 : : Pink : 6, H. A. Crimea : 1823 violacēar, 6 : : Purplo : 6, H. Tr. A. S. Eur. . : 1686 NorĀntěA, Aublet. From the Guiana name of $N$. guianensis, Gonora-antegri. Linn, 13, Or. 1, Nat. Or. Marcgraaviacee. These are singular and very beautiful plants; they grow well in a mixture of loam and peat, and cuttings root freely either in sand or mould, under a glass, in heat.

[218] 
brasilięnsǐs . . S. Ev. S. Brazil . 1820 griauēnsìs . : Violet. S. Ev. S. Guiana . : 1818 Norōхнй traveller in Madagascar. Linn. 2, Or. 1, Net. Or. Oleucea. For the culture and propagation of these plants, see the genus Olea. Synonymes: 1. Olea cernua. 2. O. emarginata.

cếrnŭă, 1 . . White * S. Ev. T. Mauritius . 1816 emarginătă, 2 : White : 8, S. Ev. T. Madagas. . 1825

Norway-spruce, see Pinus canadensĩs.

Nōstŏc, Vauch. Meaning unknown. Linn. 24, Or 7, Nat. Or. Algae. A genus of curious plants, found in lakes, and on rocks in moist sitrations

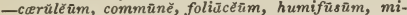
crosçpǐcūm, Muscōrūm, pruniformĕ, sphฮ̄ricum, verrucôsūim, vesicūrīūm.

NoTEL $\bar{x} \bar{A}$, Ventcnat. From notos, south, and elaia, an olive; in allusion to the genus being allied to Olea, and from its native country, Linn. 2, Or. 1, Nat. Or. Oleacece. These plants grow well in peat and loam, and cuttings of the ripened wood root readily in sand, under a glass.

lizustrīnă . . White. . 7, G. Ev. S. V. D. L. . 1807 longifolix: : White: 4 G. Ev S. N. S. W. 1790

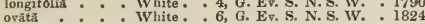
punctată : : White : 6, G. Ev. S. N. Holl. : 1826 rígidă : : White : 7, G. Ev. S. V.D. L. : 1821

NoтноснL水, R. Bromn. From nothos, spurious, and chlaina, a cloak; the sori are frequently only covered over by the palex of the frond. Linn. 24 , Or. 1, Nat. Or. Polypotiacece. This is a genus of very handsome stove ferns. They grow well in sandy peat soil, in a hot, humid atmosphere, and are increased by divisions, or by seeds, sown and treated in the usual manner. Synonymes: 1. Acrostichum vellenm, lanuginosum. 2. A. Marante. 3. Pteris piloselloides.

distäns . . . Brown . 7, G. Her. P. N. Holl

Eekloniaña : Brown : 8, S. Her. P

lanuginōsă, 1 : Brown : 8, G. Her. P. Madeir

Marantæ̃ 2 : Brown : 7, G. Her. P. N. Holl

nǐrä . White 7 , s. Her. P. Mexico

piloselloidés, 3 : Brown $: 7$, s. Her. P. E. Ind.

púmilă: : Brown :8, S. Her. P. N. Holl.

sinuátă: : : : Brown : S. Her. P. Perr

1893

1838

1778

1820

1822

Notöč̆R̆̌s, R. Bronn. From notos, the back, and keras, a horn; back of the pods. Linn. 15, Nat. Or. Cruciferce. Hardy annuals, not worth cultivating. Synonymes: 1. Erysimum bicorne. 2. E. quadricorne, Nazturtium quadricorne-canariēnsè 1, hispänĭcâm, quadricôrně 2.

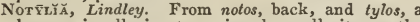
hump; in allusion to a singular callosity on the stigma. Linn. 20, Or. 1, Nat. Or. Orchidacee. Pretty little plants, well worthy of a place in every collection; for culture and propagation, see Burlingtonia.

Barkêrī . . . Straw • \&. Epi. Mexico . . 1837

inçिrră

ineûrvă
mierănthă $:$ : : Paraw yel

punctătă : : : Y Yel. grn.

S. Epi. Mexico

S. Epi. Demerar

S. Epi. Trinidad

S. Epi. Trinidad
S. Epi. Demerara

NÛCLEัŬs, the kernel of a nut.

Nucamentaceous, producing nuts.

NUDICAŨLĬs, naked-stemmed.

NUMMUL $\bar{A} R \bar{I} \breve{A}$, round, like a piece of coin.

NêPHĀR, Sibthorp. From naufar, or nyloufar, the A rabic name of Nymphoa. Linn. 13, Or. 1, Nat. Or. Nympharacea. This is a genus of very beautifu plants, admirably adapted for growing in ponds, cisterns, or lakes; and they are increased by dividing the roots, or by seeds, which have only to be thrown into the water where they are intended to grow. Synonymes: 1. Nymphaea advena. 2. $N$. lutea. 3. Nuphar minima.

ådvěnă, 1 - . Yellow * 7, H. Aq. P. N. Amer. - 1772 Kalmiånă : : Y Yellow : 7, H. Aq. P. Canada : 1807 lūten̆, 2.: Yellow 6, H. Aq. P. Britain

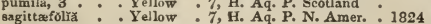
NūTĀss, nodding, drooping

NutMeg, see Myristǐcă.

NUTMEG, see Mionodoră myristĭcă

Nurs, seeds covered with hard shells.

NuträLLǏ, Dickson. In honour of Thomas Nuttall, F.L.S., professor of mineralogy at New Cambridge,

North A merica, an eminent botanist. Linn. 16, Or. 8, Nat. Or. Malvacece. A genus of very ele gant plants when in blossom, and, therefore, well worth cultivating. They grow in a sandy peat soil, and are increesed by seeds, and sometimes by dividing at the roots. They require a slight protection in severe weather.

cnrdâtă . . . Pink - . 8, H. Her. P. N. Amer. - 1835 digităth́. : Purple 8 , H. Her. P. N. Amer. grandiflor . . Pink . 8, F. Her. P. papaveräcéa : Red, pur. . 8, H. Her. P. Lnuisiana. 1833 pedátá : : Purple : 8, H. Her. P. N. Amer. : 1824

Nut-TREe, see Cŏry̆lŭs.

Nôyrsĩ,$R$. Bronn. After Peter Nuyts, a famous Dutch navigator. Linn. 6, Or. 1, Nat. Or. Loran thacea. This very singular tree requires to be grown in a mixture of loam, peat, and sand; young plants may probably be obtained from cuttings planted in sand, under a glass, Synonyme: 1 Loranthus floribundus.

floribūnda . . Sulphur . G. Ev. T. N. Holl. . 1831

NyстĀnтhēs, Linn. From nux, nuctos, night, and anthos, a flower; the flowers expand at night, and fall off at the break of day: whence arbor-tristis, the name of the species. Linn. 22, Or. 1, Nat. Or. Jasminacee. This tree is much valued on account of its very fragrant flowers, which are unfortunately seldom to be seen in this country. It grows in loam and peat, and is increased by cuttings, not too ripe, planted in sand, under a glass, in heat.

arbor-trīstǐs . . White . . S. Ev. S. E. Ind. . . 1781

Nycterisītřŏ, Ruiz and Pavon. From nykteris, a bat, and sition, food; bats feed on the flowers. Linn. 5, Or. 1, Nat. Or. Sapotacee. This plant grows well in light turfy loam and peat well incorporated, and is increased by cuttings of the ripened wood planted in sand, under a glass, in heat. Synonyme: 1. Chrysophyllum splendens.

ferrugrneūm, 1 - White . - S. Ev. T. S. Amer. : 1823 NyctĚrī̄̄M, see Solānūm.

NYмрн $\bar{A}$, Linn. From nymphe, a water-nymph; alluding to the habitation of the plants. Linn. 13, Or. 1, Nat. Or. Nymphaacere. These are beautiful plants, well worthy of cultivating in every collection. The stove species should be grown in tubs of water placed in a warm part of the house, with some rich loamy soil at the bottom. The hardy kinds may be grown in ponds, canals, \&c. They are all increased either by seeds, dividing the roots, or separating the tubers. The stems of $N$. alba are superior to oak galls for dyeing grey. Synonymes : 1. stellata, var. 2. cahlara. 3. esculenta, Castalia edulis. 4. C. mystica. 5. N. odorata minor. 6. carulea. 7. Lotus.$$
\text { albă }
$$

ean

bländă

ccerŭlèă,

edūlřs,

Lōtǔs, 4

minnŏr, 5

odorãta

pubēscēns

pygmæà

reniformls

rūbrà

rơsè̃

sentifolia, 6

stellata .

thermālis,

White

6, H. Aq. P. Canada.

White. 7, S. Aq. P. Jamaica 1801

White 7, S. Aq. P. Trinidad 1800

- Blue . 7, S. Aq. P. Egypt . : 1792

Blue 7, s. Aq. P. E.Ind. : 1809

Blue $:$, s. Aq. P. E. Ind.

Pink : 7, S. Aq. P. Egypt : : 1802

White. 7, S. Aq. P. N. Amer. 1812

White. 7, H. Aq. P. Siberia . 1809

White. 7, H. Aq. P. N. Amer. 1786

White. 6, S. Aq. P. E. Ind. . 1803

White. 7, H. Aq. P. China 1805

White 7, G. Aq. P. Carolina 1893

Red 3. A P. E. Ind

Red * 7, Aq. P. E. Ind. 1803

Blue: : 8, S. Aq. P. C. G. H. : 1792

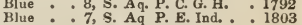

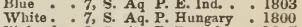

NȲssă, Linn. Supposed to be from the name of a water-nymph, on account of the habitat of the plants. Linn. 23, Or. 2, Nat. Or. Santalacea. These trees are well suited for large shrubberies; they grow in any common soil, but prefer a damp situation, growing best when planted on an island in a pond or river; they may be propagated by layers or seeds. Synonymes: 1. N. aquatica. 2. N. capitata. 3. N. denticulata, tomentosa. 4. N. sylvatica.

biflorră, 1 . Green . 5, H. De. T. N. Amer. - 1739 căndieãns, 2 : Green : H. De. T. N. Amer. 1806 grandidentăt 3,3 Green: 5, H De, T. N. Amer. 1735 villoga, 4 . Green: 5 , H. De. T. N. Amer. : 1824 


\section{0.}

\section{A K, see Quẽrcūs.
OAT-GRAss, see Avẽnă.}

Oв is used in the composition of Latin technicals to indicate that the thing is inverted, as obovate is inversely ovate.

ОввйтUัs, bottle-shaped.

OnCONical, inversely conical.

OBCORDATELY TWO-LOBED, inversely-cordate, with the indentation very deep, so as to appear of two lobes.

OnËš̆, Haworth. From obesus, fat ; alluding to the flowers. Linn. 5, Or. 2, Nat. Or. Asclepiadacee. This is an interesting genus of little plants; sandy loam suits them, and young cuttings root in sand, under a glass. Synonymes: 1. Stapelia geminata. 2. S. serrulati.

decoră * . . Yel. str. . 3, G. Ev. S. C. G. H. . 1795 geminată, $\mathbf{l}$ : Purplo : 3, G. Ev. S. C. G. H. : 1795 serrulată, 2 : : Purple : 7, G. Ev. S. C. G. H. : 1805

OrLIQURLY-REPAND; a leaf having a margin undulated, and unequally and obliquely dilated, is said to be obliquely-repand.

OBLiquBLY-TRUNCATE, cut off in an oblique manner.

OBLONG, when joined by a hyphen to another word, signifies a form between the two words, as oblongelliptical, oblong-linear, and so on.

OBLONG-Triougtrous, oblong and three-sided.

Orovatr, $\}$ inversely egg-shaped, with the broadest OBovord, $\}$ end uppermost.

Oвоvатв, when joined by a hyphen to another word, signifies a shape between the two words, thus, obovate-spatulate, a shape between obovate and spatulate.

OBOVATB-CUNBatzD,
OBоVAтвL-WRDG-SHAPED, $\left\{\begin{array}{l}\text { between obovate and } \\ \text { wedge-shaped, with } \\ \text { the broadest end up- } \\ \text { permost. }\end{array}\right.$

OBsoletr, hardly evident.

Ossoz.вTRLY-тоOTHED, scarcely toothed.

OBTUSB-ANGLBD, having blunt angles.

Onvoluts, having one part rolled on another.

Occingstal, coming from the west.

Oснкй, Schreber. From ochne, the Greek name of the wild pear-tree; there is some resemblance in the foliage. Linn. 13, Or. I, Nat. Or. Ochnacea. The species of this genus are said to be very ornamental; they grow from six to eight, and $O$. arborea to twenty, feet high. Sandy loam and peat mixed sitit them, and cuttings root in sand, under a glass, in heat. Synonyme: 1. O. squarrosa.

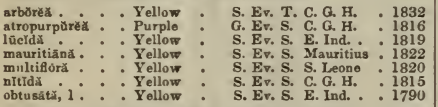

Oснгогестетs, pale yellow, ochre-coloured.

Oснго̄мй, Svartz. From ochros, pale; referring to the flowers, leaves, and wool of the seeds. Linn. 16, Or. 2, Nat. Or. Sterculiacer. Interesting plants, attaining from twelve to twenty feet high; they grow best in sandy loam, and young plants are raised from cuttings in sand, under a glass, in heat.

Lagōpŭs * : : White. * S. Ev. T. Jamaica : 1804 OchRōš̌̆, Jussieu. From ochros, pale; alluding to the wood. Linn. 5, Or. 1, Nat. Or. Apocynaced. A rather pretty shrub; for culture and propagation, see Cerbera. Synonyme: I. Cerbera borbonica. borbōnị̈̄ă, 1 . .

S. Ev. S. Bourbon . 1823

Ōchrŭs, Pcrsoon. From ochros, yellow; on account of the colour of the flowers. Linn. 17, Or. 4, Nat. Or. Leguminosa. A pretty annual, of easy cultivation in any common garden soil. Synonyme: 1 . Pisum Ochrus.

pâllìdă, 1 . . Yellow . 7, H. Cl. A. S. Eur. .

Ocrnóniox, Decandolle. From octhodes, warted; alluding to the warted surface of the pods. Linn. 15, Nat. Or. Cruciferce. A plant of little beauty and very simple culture. Synonymes: 1. Bunias agyptiaca, Rapistrum ægyptiacum.

æegyptrăcûm, 1 .Yellow . 8, H. A. Egypt . . 1787

OCTANDrous, having eight stamens.

Octogrnous, having eight styles.

Остомйлй, R. Bronn. From okto, eight, and meris, a part; in allusion to the pollen-masses. Linn. 20, Or. J, Nat. Or. Orchidacea. The species of this genus are not of a very interesting character; for culture and propagation, see Burlingtonia.

grăeillis ... - Yellow * S. Epi. Rin Jan..

graminifóĭă : : Wht yel. 5, S. Epi. W. Ind. . :

serratifolra . : : White 10, S. Epi. Rio Jan.: :

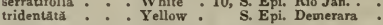

Oç̌мčs, Linn. From ozo, a smell; alluding to the powerful scent of the plants. Linn. 14, Or. 1, Nat. Or. Labiatc. Some of the species of Ocymum, or Basil, are much esteemed as herbs, and are of the simplest culture. Synonymes: 1. O. cristatum. 2. o. caryophyllatum. 3. O. thyrsiflorum. 4. O. cordifolium. 5. O. americanum. 6. O. grandiforum. 7. O. montanum. \& Plectranthus monachorum. 9. o. febrifugum.

adscêndēns, 1. . White . 8, H. Her. P. E. Ind. . 1822 albüm . : White : H. A. E. Ind. : 1816 basIlYcūm : White $: 8$, H. A. E. Ind. : 1548 glabrătūm, 2 : White : $7, \mathrm{H}$. A. E. Ind. : 1817

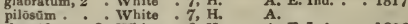
thyrsiflórum, 3 White: 6, H. A. E. Ind. 1806 BojêrI, 4 ?. White : S. Her. P. Madagas. : 1825 eănưm, 5 : White 7 , H. A. China : 1822 filamentosûm, 6 : White : 9, S. Er. S. Africa : : 1809 gratissimūm . White : 7, S. Ev. S. E. Ind. : 1751 menthoídés : White: $\mathbf{S}$. micrănthũm, 7 : Pa. pur. : 7, H. A. S. Amer. . 1816 minathm, 7 . Pa. A. Amer. - 1816

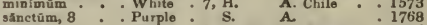
sănctûm, 8 : : Purple : 8, S. Ev. A. Madagas. : 1768

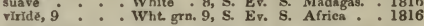
americănam, cănūm, cordifoliam, grandiflorâm, gratissimam, menthoüdẽs, micrünthâm, pilosam, sünctüm, suāve, vĭridè.

Odontarquв̄nă, Meyer. From odous, a tooth, and arrhen, a male; filaments. Linn. 15, Nat. Or. Crucifera. This pretty little trailer may be suc. cesstully cultivated in a mixture of loam and peat ; cuttings.

mierophy̆lla

H. Ev. Tr.

1832

ODontogrỏssūm, Humboldt and Kunth. From odous, a tooth, and glossa, a tongue; alluding to the labellum. Linn. 20, Or. 1, Nat. Or. Orchidacce. This plant is new to our collections. The flowers are described as very handsome, the sepals and petals being yellowish-green, richly blotched with brown. It will probably succeed well with the treatment given to Oncidiums, and the like.

cờdătūm . . . Grn. brn. . $\quad$ S. Epi. Mexico . . 1837

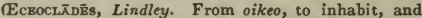
klados, a branch. Linn. 20, Or. 1, Nat. Or. Orchidacea. These are fine plants, well deserving a place in every collection; for culture and propagation, see Vands. Synonymes: 1. Angracum falcatum. 2. A. maculatum.

falcătă, 1 . . Whito * 4, S. Epi. China * 1815 maculatha , 2 : : Ro, wht. : 10, 8. Epi. Afriea : : 1819

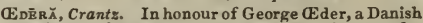
professor of botany at Copenhagen. Linn. 19, Or. 5, Nat. Or. Composita. A pretty shrub, succeeding in sandy loam, mixed with a little peat, and propagated in sand, or sandy soil, under a glass.

proliférď . . . Yellow . 5, G. Ev. S. C. G. H. . 1789 GкА̄хтй, Lamarck. From oinos, wine, and anthos, a flower; odour. Linn. 5, Or. 2, Nat. Or. Umbelliferce. These plants are mostly uninteresting, and of simple culture in any common soil. The juice of the leaves and stem of $E$. crocata is a violent 
poison for man and animals. Synonymes: 1. $\mathcal{E}$. gymnorhisa. 2. EE. approximata. 3. E. involucrata. 4. E. australis. 5. E. virgata. 6. E. glauca-apiifoliă, crocătă, fistulচsă, globulosă, inëbrăäns, interrūptă, Lachenâlīi 1, L. approximātă 2, L. involucrātă 3 , nodifloră, peucedanifríă, phelländriâm, pimpinel-

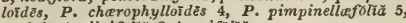
prolifĕră, silaifoltă 6 , tenuifólĭă.

ENocärpüs, Martius. From oinos, wine, and karpos, fruit; wine obtained from the fruit. Linn. 2l, Or. 6, Nat. Or. Palmacea. A fine palm, attaining twenty feer high, thriving in any rich mould in a strong humid heat, and is increased from suckers.

EvoтнйR̆, Linn. From oinos, wine, and thera, a catching; the roots of $\mathscr{E}$. biennis were formerly taken after meals as incentives to wine-drinking. Linn. 8, Or. 1, Nat. Or. Onagracea. The Evening Primrose is a genus of truly beautiful plants, well suited for ornamenting flower-borders; they will grow in any common garden soil. The perennial species are increased by dividing the plants at the roots, by seeds, and some by cuttings. The seeds of the annual and biennial kinds merely require to be sown in the open border. Synonymes: 1. $E$. spectabilis. 2. CE. ambigua. 3. CE. suaveolens. 4. E. concinna. 5. E. hirta. 6. E. alata. 7. E. striata. 8. E. undulata. 9. E. pinnatifida. 10. E. minima. 11. E. rhizocarpa.

acaūlìs

acaūlis

amōenă

biffrōns : : Purple

cheiranthifolia: Yellow

clasātă

corymbös. 1. Yhite

cruciātă : Yellow

decūmbēns: : Purple

densifióră : : Purple

dentãtă : Y Yellow

Drummōndūi : Y Yellow

elâtă

Frasẽr

Yellow

variegată - Yellow

uticỏsă : Yellow

ambĭgǔă, 2 Y Yellow

gauroìdés - : Yellow

glaūeà. :

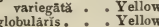

răcillis : Yellow

grandiflóră, 3 . Yellow

humifüsă, 4. Purple

hỵbrìă : : Yellow

incănă : : Y Yellow

lineäris : : Yellow

longiflöră . Y Yellow

macrocärpă - Yellow

médră $\cdot{ }^{\circ}$ - Yellow

micrănthă, 5 . - Yellow

missourēnsis, 6 . Yellow

mollissimă : Y Yellow

nervōsă: : Yellow

noctūrnă, 7 : Yellow

Nuttällin . White

odorātă, 8 : Yellow

pellida

parvifōră: : Yellow

pubëscëns : White

pŭmilla - . Yellow

purpūréă . . Purple

Pūrshĩ, $9:$ White

pusilla : Yellow

quadrivūlnèră : Pink

Romanzōvĭ : Purple

rösé ${ }^{z}$-albă : Red wh

salicifolix . Yellow

Sellowir

serrulată

minimă, 10 . Yellow

speciōsă . - White

triata i) $221^{\circ}$
7, F. Her. P. Chile

6, H.

$6, \mathrm{H}$.

B. N. Amer。

1821

7, H. A. N. Amer.

7, H. B. N. Amer.

8, H. B. Texas

G. Ev. S. N. Amer. - 1811

7, H. A. Mexico: 1823

9, H. B. Mexico : 1816

7, H. B. N. Amer. 1824

8, H. A. California : 1827

8, H. A. California : 183

8, F. Her. P. Texas : : 183

7, H. B. Mexico: : 1826

7. H. B. C. G. H. : 1828

6, H. Her. P. N. Amer.

8, H. Her. P. N. Amer.

7. 1737

7 . H. Her. P. N. Amer. - 1813

6, H. Her. P. N. Amer. : 1810

7, H. Her. P. Gardens

7, H. Her. $\stackrel{\mathrm{P}}{\mathrm{P}}$

7, H. B. N. Amer.

7, H. A Florida.

7, H. Her. P. N. Amer.

7. H. B. N. Amer.

8, H. A. N. Amer.

8, H. B. B. Ayres

6, H. Her. P. N. Amer. 181

$7, \mathrm{H}$. B. N. Anuer.

6, H. A. California

7, H. Her. B. B. Ayres

$\begin{array}{ll}\text { 7, H. } & \text { B. B. Ayres } \\ \text { 7, H. } & \text { B. N. Amer. }\end{array}$

7, H. Her. $\mathbf{P}$.

7, H. B. C. G. H.

6, H. Her. P. N. Amer.

6, H. Her. P. America

6, H. B. N. Amer.

7, H. B. S. Amer.

6. H. Her. P. N. Amer. - 1757

7, H. $\quad$ A. N. Amer. : 1794

7, H. Her. P. N. Amer. : 1817

9, H. A. N. Amer. : 1826

7, H. Her, P. Peru : 1817

5, H. A. Nepal : : 1827

7, H. B.

H. Her. P. M. Video - 1831

9, H. Her. P. N. Amer. : 1820

$7, \mathrm{H}$. B. Mexico . 1816

$7 ; \mathrm{H} . \quad$ A. N. Amer. . 1770

7, H. Her. P. N. Amer. : 1825

7, H. Her. P. N. Amer.

7, H. Her. P.

\begin{tabular}{|c|c|c|c|c|}
\hline 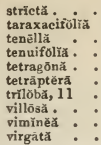 & $\begin{array}{l}\text { Yellow } \\
\text { White } \\
\text { : Purple } \\
\text { : Yurple } \\
\text { : Yellow } \\
\text { : Yhite } \\
\text { Y Yellow } \\
\text { Y Purplew } \\
\text { : Pur. wht. }\end{array}$ & 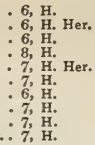 & $\begin{array}{l}\text { A. } \\
\text { P. Pern : } \\
\text { A. Chile : } \\
\text { A. Chile : } \\
\text { P. N. Amer. } \\
\text { A. Mexico - } \\
\text { A. N. Amer. } \\
\text { B. C. G. H. } \\
\text { A. California } \\
\text { A. Peru - }\end{array}$ & $\begin{array}{r}1822 \\
: 1825 \\
11822 \\
1828 \\
: 1820 \\
: 1796 \\
: 1822 \\
\vdots 1791 \\
: 1826 \\
11823\end{array}$ \\
\hline
\end{tabular}

OFricinat, any thing sold in shops.

$\mathrm{O}_{\text {GRCHER-LIMB, }}$ see $\boldsymbol{N} \bar{y} s s a ̆$ cāndicüns.

Ordîu, Link. From oon, an egg, and eidos, resem-

blance. Linn. 24, Or. 9, Nat. Or. Fungi. The species of this genus grow on decayed wcod, and the leaves of various plants-Erysiphoides, fruct̆̈gĕnūm, fülvâm, leucoconĩum.

OrL-NUT, see Hamiltōnŭŭ.

OrL-sERD, see Verbesinnă satĩvă.

Orly grarn, see Sěsămûm.

Orly Palsi, see Elüis.s.

OLĀx. Named by Linnæus from olax, a furrow; but how applied to this genus we are not informed. Linn. 3, Or. 1, Nat. Or. Oleacee. Ornamental climbers of simple culture in loam and peat; and young plants may be raised from cuttings in sand, under a glass, in heat.

imbricătă . . White . 12, S. Ev. Cl. E. Ind. . 1820 scändēns : : White 12, S. Ev. Cl. E. Ind. : 1820

OLDENLĀNDY̌̆, Liñn. In memory of H. B. Oldenland, a Dane, who collected plants at the Cape of Good Hope in 1695 . Linn. 4, Or. 5, Nat. Or. Cinchonacere. An interesting under-shrub, growing in loam and peat, and increased by cuttings in sand, under a glass, in heat.

Deppiānă . . White. . 6, S. Ev. S. Mexico . 1835 OLD-MAN's-BBARD, see Geropögōn.

ÓlĚ, Linn. From elaia, olive. Linn. 2, Or. 1, Nat. Or. Oleacea. The Olive is a very important genus of plants, on account of the oil, \&c., which is obtained, chiefly from some of the varieties of 0 . europaa. They are also much admired for the fragrance of their flowers, which render them worthy of a place in every collection. They grow well in loam and peat; ripened cuttings root readily in sand, under a glass. They may aiso be increased by grafting on the common privet. $S y$ nonymes: 1. O. undulata. 2, Phillyrea robusta. 3. o. europaea.

americānă . . White . . 6, G. Ev. S. N. Amer. . 1758 arbörë . . White. 8, G. Ev. T.

capennsis

8, G. Ev. T. C. G. H. 1825

nndulätă, 1 White 7, G. Ev. T. C. G. H

dioica . . White . 3, S. Ev. T. E. Ind. : 1818

excêlsă : : White: 5, G. Ev. T. Madeirs : 1784

frägräns : : Yellow : 7, G. Ev. T. China : 1771

lancéa . : White . 8, S. Ev. T. I. France : 1819

Oleăstér - . White. 7, G. Ev. S. Portugal . 1821

paniculätă * - White - 7, G. Ev. T. N. Holl. 1825

Roxburghiäna. White- 8, S. Ev. T. Sylhet : Ind.: 1820

sativă 3 : White: 8, H. Ev. T. S. Eur. : 1570

buxifölia : White. 7, F. Ev. T. S. Eur.

ferruginera : White , Z, F, Ev, T. C. G. H.

latifolia.: White: 7, F. Ev, T. S. Eur.

longifölĩ : : White. : 7, F. Ev. T. S. Eur.

obliqŭå . White. *, F. Ev. T. S. Eur.

verrucōsa White 4, G. Ev. S. C. G. H

1814

ŎĽ̆̆, see Norōnhĭă

OlBAGINous, having the qualities of oil.

OLRAstrR, see Eläägnŭs.

Oreraceous, esculent, eatable.

Oribanum-trib, see Bosnélliŭ.

OLrve, see Olĕă.

OLIVE-BARK-TREB, see $B \tilde{c} c \not{d} d \check{a}$.

Oeivērĭ Ventenat. In honour of M. G. L. Olivier, a celebrated French naturalist. Linn. 5, Or. 2, Nat. Or. Umbelliferce. A plant of little interest; the seed should be sown on a gentle hotbed, and afterwards transplanted.

decümbens . . Purple . 6, H. Tr. A. Bagdad . . 1816

OLIVE-wooD, see Elaodẽndrŏn.

OLȲNrhì, Lindley. From olynthos, signifying an unripe fig. Linn. 12, Or. 1, Nat. Or. Myrtacee. An ornamental species; for culture and propaga. tion, see Myrtus. Synonyme: 1. Myrtus disticha.

distǐchă, 1. . . White . 5, S. Ev. T. Jamaica . 1793

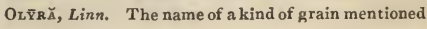


by the Greek authors. Iinn. 21, Or. 3, Nat. Or. Graminea. Worthless plants, of easy cultivation. Synonyme: 1. 0 . paniculata-latifotid 1, pauciflöră.

Omaz̄̃Ntraũs, Adrien Jussieu. From homalos, smooth, and anthos, a flower. Linn. 21, Or. 10, Nat. Or. Euphorbiacece. A pretty stove shrub, cultivated in peat and loam, and propagated from ripened cuttings in sand, under a glass, in heat.

populifơliă. . . White. . 8, S. Ev. S. N. Holl. . 1825

OMIMR-PI.ANT, see Plectränthüs ternātŭs.

OMPHĂL.̄̌̆, Linn. From omphalos, navel ; umbilicated anthers. Linn. 21, Or. 10, Nat. Or. Euphorbiacea. Interesting trees, from twelve to twenty feet high, cultivated in a mixture of peat and loam, and propagated from cuttings in sand, under a glass, in heat.

diăndră . . . Apetal - S Ev. T. W. Ind. - 1820

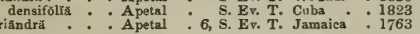

OMpharŏbĪ̃u, Gertner. From omphalos, a navel, and lobus, a pod. Linn. 10, Or. 1, Nat. Or. Legu. minosis. A genus of very pretty plants; for culture and propagation, see Schotia. Synonymes: 1. Connarus africanus. 2. C. asiaticus, Rhus Radalijavel.

africānūm, 1 . Pa. red . S. Ev. S. Guinea . 1822 indı̌ñm, 2.: : Pa red : S. Ev. S. Ceylon :

OмphaLǒmī̄m, see Schotĩă.

OMPHALODĒs, Tournefort. From omphalos, the navel, and eidos, like; the fruit resembles the navel whence the genus has been called Venus's Navelwort. Linn. 5, Or. 1, Nat. Or. Boraginacea. These plants are very elegant border-flowers, and of the easiest culture. The perennial kinds grow well under the shade of trees and shrubs, and are in. creased by division. The seed of the annual species should be sown in the open border in spring. Synonymes: 1. Cynoglossum brassicafolium. 2. C. linifulium. 3. C. nitida. 4. scorpioides. 5. Anchusa sempervirens. 6. C. omphalodes.

amplexicablis, 1. White 7, H. Her. P. Spain - 1823 linifolir, 2. : White: 7, H. A. Portugal : 1748 littoralrs : * White: 7. H. Her. A. France : 1826 mynsotorděs
nitidom 3 ${ }_{\text {sitidom } 3}$ : : Whioldes, 4: : Blue : : 7, H. Tr. A. Portugal : 1812 semperrvirens, 5 : Blue: : 6, H. Her. P. Britain . vérnă, 6 : : Blue : 3 , H. Her. P. S. Eur.

1633

Oncĭbǐūy, Swarlz. Derived from ogkos, a tumour ; the plants belonging to this genus have warts, tumours, or other excrescences at the base of the labellum. Linn. 20, Or. 1, Nat. Or. Orchidacea. This is an extensive and very handsome genus of plants, every one of which is highly deserving a place in every collection. $O$. papilio bears a striking resemblance to a butterfly on the wing. $O$. altissimum throws up from fifteen to twenty flowerspikes, producing as many as two thousand flowers, the colour of which is yellow spotted with brown, and there is the splendid 0 . Lanceanum, one of the most prized in this valuable genus; but to particularise, whereall are remarkable either for the beauty or the singularity of the flowers, would be invidious. The large-leaved kinds do best when grown in rustic baskets, which can readily be suspended from the rafters of the house; the basket should be made of small pieces of oak nailed together, or holes may be bored, and a piece of strong wire run through near the end of each, and fastened at the bottom. Some moss and rotten woor should be placed in the bottom previous to putting the plant in, in doing which, care must be taken not to insert the plant too deep. Moss and rotten wood must surround the roots of the plant, but should not on any account be raised higher than the roots of the leaves, or they will be liable to damp off. The small-growing kinds, as 0 . iridifolium, should be fastened on wood, and treated as the Burlingtonias. The other kinds, as $O$. papilio and $O$. altissimum, require to be potted similarly to the genus Stanhopea. Synonyme: 1. O.juncifolium.

altīssǐmūm . . . Yel. brn. . 3, S. Epi. Panama ampliātĩm : : Yellow : 3, s. Epi. Pankma : 1793

barbătúm : : : Yeli. brn. : 4, S. Epi

Bauêri : : : Yel, brn. 4, 4. Epi. Rio Jan 1830

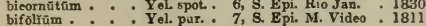

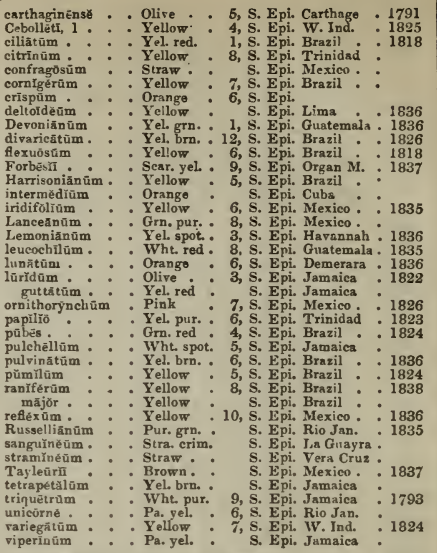

ONCoRHริм⿻и一ัs, Fischer and Meyer. Derived from onkos, tumour, and rhynchus, beak; alluding to the lip. Nat. Or. Scrophulariacece. The seed of this plant may be sown in any common garden soil.

renellŭs . . . .

Oxrox, see Allrâm Cępă. ONoвrōmă, Decandolle. Fromonos, an ass, and broma, food; fazourite food of the ass. Linn. 19, Or. 1, Nat. Or. Composite. Ornamental plants, succeeding in any common soil, and increased by cuttings, divisions, or seeds. Synonymes: 1. Carthamus arborescens. 2. C. caruleus. 3. C. cynaroides. 4. C. glaucus. 5. C. loucocaulis.

arborēscẻns, 1 . Yellow . 7, G. E ซ. S. Spain . 1731 ceerúleúm, , 2 : Blue : 6, H. Her, P. Spain : 1640 cynaroldes, 3 : : White: 6, H. Her. P. Caucasus : 1820 glaúcúm, 4 : : Purple : $7, \mathrm{H}$. A. Tauria : : 1817 leucocaúlon, 5 : White : 6, H. Her. P. Greece : : 1800

ONoBricnis, Tournefort. From onos, an ass, and brycho, to gnaw; plants grateful to the ass. Linn. 17, Or. 4, Nat. Or. Leguminosce. All the species of Saintfoin are very showy, and well suited for ornamenting rock-work or flower-borders. The herbaceous kinds grow best in pots, in a mixture of chalk, sand, and loam; they succeed best when raised from seed, which should be sown where the plants are to remain. Synonymes: 1 . 0 . orientalis. 2. O. picta. 3. Hedysarum Onobrychis. 4. H. saxatile.

arentir 0.7 . Her P. Siberia - 1818 arenarră : : Red Wite: : 7, H. Her. P. Hiberia P. Hungary : 1818 eăpŭt-gallir : : Flesh : $7, \mathrm{H}$. Her. A. France. : 1731 carpatiea .: : Purple : 7, H. Her. P. Carpat. : 1818 conferta : : Purple : 7, H. Her. P. 1beria : 1817 cornútă, 1": Red : :, F. Ev. S. Caucusus : 1817 cornuta, 1 : Red : T, F. Ev. S. Csucusus: 1816 Cristă-gallir - Flesh : 7, H. A. S. Eur. - 1710 echingta $:$ Flesh : : 6, H. Her. P. Calubria : 1831
Fontanésit : Fed glabră . : : Purple : 7, H. Her. P. Tauria : : 1816 grăcrilis : : Pa red :7, H. Her. P. Podolia : 1820 mareótičă : $\mathrm{Pa}$ red $: 7$, H. Her. P. Caucusus : 1820 Michaũxí, $2:$ Ph red $: 7$, H. Her. P. Levant . 1820 montana . Purple : 7, H. De. Tr. S. Eur. : 1817 Pallasi : : Pr yel. : H. Her. P. Iberia : 1820 Paltsin - : Pa yel. " H. Her. P. 1beria : 1820 procūmbẻns: : Purple, 7, H. De. Tr. Iberia : 1819

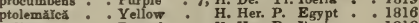

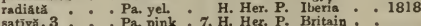
sativă, 3 : Pa. pink * 7, H. Her. P. Britain : : 1790 supină : : Pa red : H. Her. P. Switzerl. : 1819 tanałtı̆că: : Purple : 7, H. Her. P. Caucasus : 1817

ONōcrц̌̆, Linn. From onos, a vessel, and kleio, to inclose; referring to the apparent capsules. Linn. [222] 
24, Or. 1, Nat. Or. Polypodiacece. These plants grow well in loam and peat, or on rock-work they are increased by dividing at the roots, or by seeds.

obtusilnbãtă - Brown . 7, H. Fer. P. N. Amer. . 1812 sensibilis : Brown : 8, H. Her. P. Virginia : 1799

ONōNrs, Linn. From onos, an ass, and onemi, to delight; some of these plants are said to be grateful to asses. Linn. 16, Or. 6, Nat. Or. Leguminosa. All the plants belonging to this genus are of easy cultivation, and several of them are rather hand. some when in flower. Synonymes: 1. hircina. 2. spinosa, glubra. 3.fruticosa. 4. barbata, 5. Natrix. 6. arvensis. 7. reclinata.

albă

angustissimă White.

arboräscēns:

arenārẵ : Yellow

rragonèusis: : Yellow

biflöră. Y Yel. pur.

brachycărpă: Y Yellow

brevifơrä. Y Yellow

carensiss : Purple

cuspidătă: : Yellow

Denhārdtir . Yellow

diffūsă

emarginat

faleãta

Purple

cetida. Yellow

ruticós: : : Pink

microphyllă, 3 Pur. red

geniniflöră - Purple

glābrà̀ .

irtă . . Blue

hispānice

Yellow

longifolì

minutissina, 4

oligophylla

peduncularis . Wht ro.

pēndūlă . Purple

procūrréns

ramosissima

otundifolia : Pink

aristăk Pink

tribracteàtă: : Pink

tridentătă Purple

villōsă .

$7, \mathrm{H}$

A. Burbary

6, F.

S. Spain

9 , H. B. Naples

7, H. Ev S. S. France 1826

7, H. De. S. Spain : 1816

7, H. A. Barbary : 1818

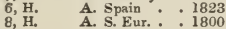

A. C. G. H. : 1800

H. Ev. Tr. Spain

6, F. Her. P. Algiers: : 1818

8, H. B. Naples : 1832

7, H. A. Italy : : 1820

S. Ev. S. Maurit. : 1825

$7, \mathrm{~F}, \mathrm{~S}$ S Eur.

6, H. A. Morocco : 1818

5, H. Ev. S. S. Eur. . : 1680

6, H. Ev. S. Arragon

7, H. A. Spain

7, G. Ev. Tr. C. G. H. , 1824

F. Eur. . 1816

7. F. Ev. S. Spain * 1799

7, F. Ev. S. Teneriffe: 1816

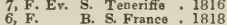

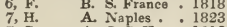

7, G. A. C. G. H. 1818

F. Ev. S. Teneriffe : 1829

F. Her. P. Barbary 1890

7, H. Her. P. Europe . : 1820

7, F. Ev, S. Sicily : 1819

5, H. Ev. S. Pyrenees : 1570

6, H. Ev.

7, H. A. Sicily . . 1817

6, H. Ev. S. S. Eur. : 1800

6, H. Ev. S. Sp.h Her. P. C. G. H. : 1752

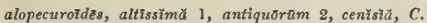
subaristūtä, cērnüă, Cherlèrīi, Colūmnā, críspă, mitissimă, monophȳllă, nätrīx, ornithopodiō̃dēs, pīngũis 5, pubēscēns, reclinätă, rẽpēns spinঠsă 6 , S. älbă, striätă 7 , vaginülis, variegātă, viscosă.

ONopórdŏn, Linn. From onos, an ass, and perdo, to explode; referring to the supposed effects on the ass. Linn. 19, Or. 1, Nat. Or. Composita. Rather interesting plants, of common cultivation.

acantlǐñ : : Purple : $7, \mathbf{7}, \mathrm{H}$.

acaülōn : : : White : $7, \mathbf{7}, \mathbf{H}$

cynaroIdês : : : Wurple : 7, H

elãtũm : : Purple : 7, H.

grǣeũm : : Purple $\quad 7, \mathrm{H}$

heteracănthưm

illy̆rĭcūm

macracinthum Purple $* 7, \mathrm{H}$

pyreñícúm : White. : 8, H.

tauีrǐcūm : Purple:7, $\mathrm{H}$

unifốrúm: : Wurple : $7, \mathrm{H}$

viréns : : Purple :7, H.

B. Britain .

B. Pyrenees

B. 168

B. Greece : 1823

A. Levan

B. S. Eur.

179

Eur. 1850

A. Barbary : 1798

B. Pyrenees 1820

B. Tauria : 1800

B. Spain : 1896

B. Nontpel. :1818

B. S. Eur. : 1818

Oxōsmă, Linn. From onos, an ass, and osme, smell; said to be grateful to the ass. Linn. 5, Or. 1, Nat. Or. Boraginacea. These are extremely pretty plants when in blossom, and are well adapted for grow ing on rock-work or wall-tops, in which places they should be sown, where they will afterwards maintain themselves if allowed to scatter their seeds. The stove and greenhouse species must be kept in pots. Synonyme: 1. O. arenarium.

divarieatũm * Yellow . 5, H. Her, P. Caucasus echioìdés: White: 5 , H. Her. P. S. Eur. - Yellow * 6, H. Her. P. Hungary : 1804 gigāntēūm . - Yellow - 4, H. Her. P. Tauria : 1818 Gmelini . - Striped . 6, H. Her. P. Altai : 1829 orientảlě - - Yellow . 5, H. Her. P. Levant . 1759 polyphyllūm : Yellow: 7, H. Her. P. Tauria : 1829 rĭgĭdūm

rupēstré

serīcēium

setōsūm

implicīssimūm

stellulātủm

aūrǐcūm

tricerospërmūm

trinērviüm .

from the similarity of the plants to those of Onosma. Linn. 5, Or. 1, Nat. Or. Boraginacec. Ornamental lants; for culture and propagation, see Onosma. Synonymes: 1. Purshia hispida. 2. P. mollis.

hisspìdūm, 1 - Yellow . 6, H. Her. P. N. Amer. - 1759 molle, 2 : White. 6, H. Her. P. N. Amer. 1819

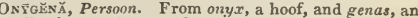
offspring. Linn. 24, Or. 9, Nat. Or. Fungi. This minute autumnal species is found on decaying hoofs and horns of animals-equinzi.

OPAQUB, dark, destitute of transparency.

OpĒGr ̌̆ to write; cracks upon the surface of the thal lus. Linn. 24, Or. 9, Nat. Or. Fungi. These plants are found on the bark of trees, on stones, \&c., at all seasons of the year-calcürëú, cerebrină. epipästŭ, microscðpičă, herpētǐcă, disparütă, maculãrǐs, nimbosă, nōthă, diāphöră, Persoōnēă, apürěă saxĭgěnă, stenocūrpă, denigrātă, sulcātă, tesserātă, venơsă, vulgãtă.

OPERA-GIRIs, see Mantisš̆ă saltatoriă.

Operculärî, Richard. From operculnm, a lid; in allusion to the operculate calyx. Linn. b, Or. 1 Nat. Or. Cinchonacea. Pretty plants, easily cul tivated in a mixture of loam, peat, and sand; and young plants are obtained from cuttings under a glass. Synonymes: 1. aspera, diphylla.

assperă * . White . 6, G. Her. P. N. Holl.

hispìdă, 1 White 7, G. Her. P. N. Holl. White 7, S. Her P. E. Ind . - White

Oprrculārĭă, see Pómäx.

OPERCULATE, covered with a lid.

OpẼrcǔLǘ, a lid.

OpRrCULATBD, covered with a lid.

OPHIOGLDSSŨM. From ophis, a serpent, and glossa, a tongue; the resemblance of the leaves. Linn. 24 Or. 1, Nat. Or. Ophioglossaced. These ferns wil grow well in a mixture of loam and peat, and may increased by divisions of the roots, or seeds. The hardy kinds should be planted in a moist situation.

bulbōsūm

enstätüm

graminèum

usitảnìcûm

petiolătūm

reticulātūm

vulgâtūm

- Brown

7, F. Tu. P. N. Amer.

Brown . 6, G. Her. P. N Holl

Brown 6, G. Her P. N. Holl.

Brown 6, H. Her. P. Portugal

Brown 3, S. Her. P. Jamaica

Brown : 6, 8. Her. P. W. Ind.

5 , H. Her, P Britain

1820

182

181

1793

OPHIOPŌGōx, Ker. From ophis, a snake, and pogon, a beard. Linn. 6, Or. 1, Nat. Or. Liliacea. An or namental genus, thriving well in sandy loam and peat, and increased by dividing at the roots. Synonyme: 1. Convallaria japonica.

jabürăn * * White . 7, F. Her. P. Japan

1830

. Li. yel 6, F. Her. P. Japan . 178

spicâtŭs Violet 10, F. Her. P. Nepal . 182

OphIorhīză, Forskahl. From ophis, a snake, and rhiza, a root; Snake-root. Linn. 5, Or. 1, Nat. Or. Cinchonaces. This shrub grows well in light loam soil, and cuttings of the young wood root in sand, under a glass, in a moist beat; it may also be increased by seeds.

Mūngõs . . . White . . 8, S. Ev. S. E. Ind. .

1820

OpHı̄̄x̌̆Lŏn, Burmann. From ophis, a serpent, and xylon, wood; alluding to the tortuous root and stems. Linn. 23, Or. 2, Nat. Or. Apocynacea. This plant is rather pretty ; for culture and propagation, see St, phanthus.

serpentinūm . . Whito . . 5, S. Ev. S. E. Ind. . . 1690

OpHIUิRǓs, Gartner. From ophis, a snake, and oura, a tail. Linn. 3, Or. 2, Nat. Or. Graminede. Curious annual grasses, growing in any common garden soil. Synonymes: 1. Roltboellia filiformis. 2. $\boldsymbol{R}$. incurvata. 3. $R$. cylindrica, Monerma subulata, Lep. turus cylindricus. 


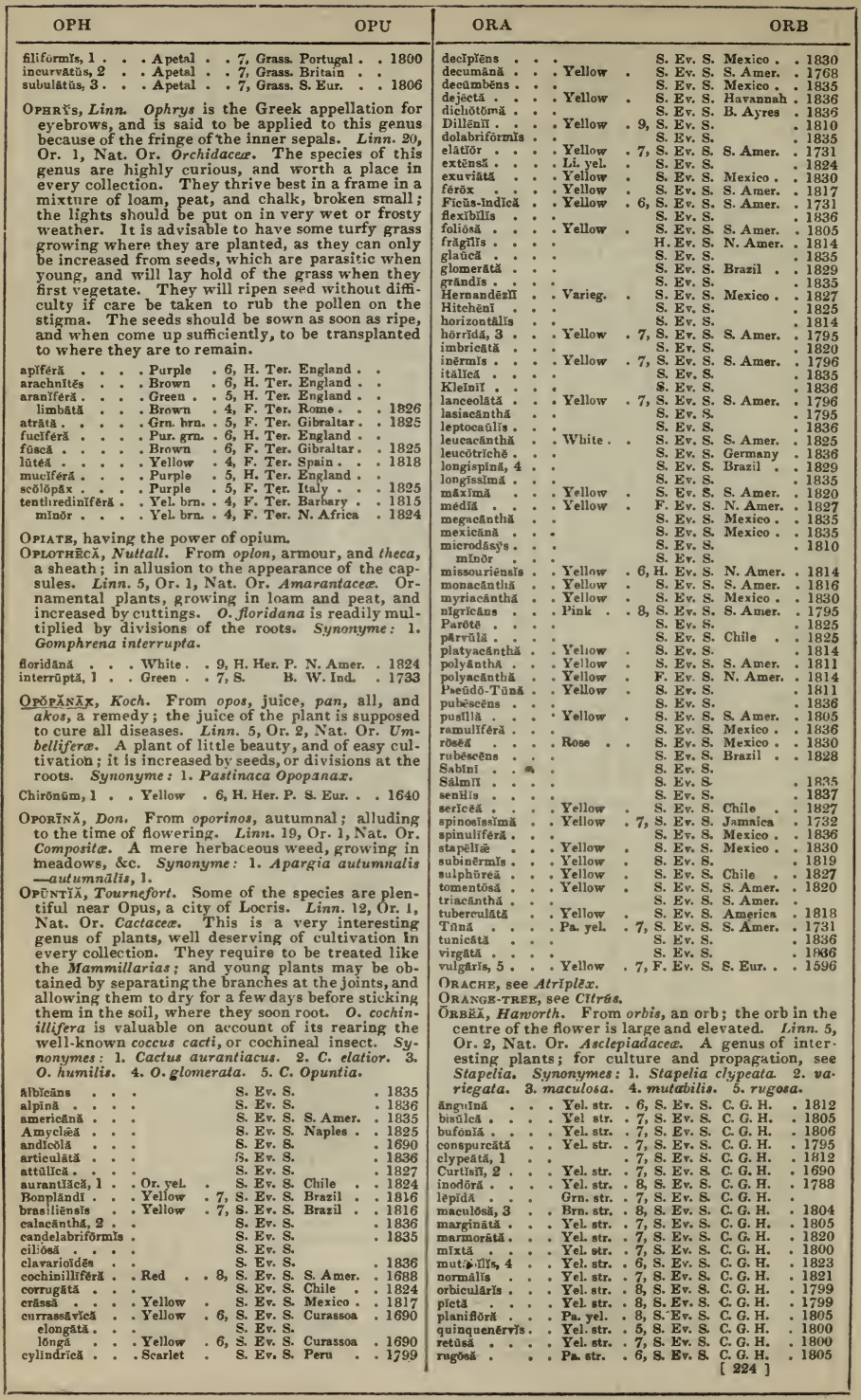


variegata *. Yel. str. . 8, S. Ev. S. C. G. H. $\quad 1727$ Wendlandiānă, 5 Yel. str. 8 , S. Ev. S. C. G. H. : 1818 ORBICUlate, circular, or spherical.

ORBICULATELY $\rightarrow$ DERESSED, spherical, but depressed on the top.

Orchall, see Roccêlla.

Orchits, Linn. Orchis, testis; frequent shape in the roots. Linn. 20, Or. 1, Nat. Or. Orchidacea. Some of the species of this genus are well known, and require the same treatment as the genus Ophrys. 0 . maculata, and several others, grow best in peat 8oil. Synonymes: 1. Orchis parviflora. 2. Gymnadenia angustifolia. 3.0 . palustris. 4. 0. tephrosanthos. 5. O. Rivini. 6. O. sulphurea. 7. O. Cyrilli. 8. O. Schleicheri. 9. Habenaria spectabilis. 10. O. similia. 11. O.tephrosanthos.

acuminatà, 1 Purple 5, F. Ter, Barbary 1815 coriōphöră : 6, H. Ter. Switzerl Brown foliōã : : Purple :5, F. Ter. Madeira

fūseă

: Brown

- Green * 6, H. Ter. N. Amer.

- Purple 6, H. Ter. Austria

Brown $6, \mathrm{H}$. Ter. England

ibērică, 2 . White. . 6, H. Ter. Caucasus .

latifolia

longibracteàtă : Purple
longicôrnìs : : Purple

måcră, 4 .

maculătă .

máscüla: : : Purple

Purple

vēră, 5 - : Purple

pálléns, 6 : : Pa. yel

papilionâcéă . . Purple

provinciălis, 7 : Pur. yel
pateifloră.

pseudo-sambucina . Purple

quadripunctătă : Purple

sambucină, 8 Yellow

spectäbilis, 9 : Pink

tephrosanthós, 10 . Purple

undulătă $:{ }^{-} \mathrm{Pa}$ pur.

6, H. Ter. Britain

5, H. Ter. Europe

5, F. Ter. Barbary

5, H. Ter. Britain

6, H. Ter. Britain

5, H. Ter. Britain

5, H. Ter. Switzerl.

5, H. Ter. Switzer

5, H. Ter. Britain

5, H. Ter. Switzerl.

6, H. Ter. Switzerl.

7, H. Ter. Italy

4, H. Ter. Italy

4, H. Ter. Sicily.

4, H. Ter. Switzerl.

6, H. Ter. N. Amer.

4, H. Ter. England

4, H. Ter. England

Pa. pur. 12, F. Ter. Sicily.
$\mathrm{Pa}$. pur. $5, \mathrm{H}$. Ter. Britin

ustulată : : : Purple : 5, H. Ter. England
variegăta. : Pa. pur. :5, H. Ter. S. Eur.

Oririck, an opening.

ORIGĂNÛM, Linn. From cros, a mountain, and ganos, joy; in allusion to the habitation of the plants. Linn. 14, Or. 1, Nat. Or. Labiato. Marjoram is a genus of well-known and easily cultivated plants; they grow in any light dry soil. The shrubby kinds are increased by cuttings or slips; the herbaceous species by dividing at the roots. $O$. Dictamnus is said to be tonic and stimulant. Synonymes: 1. 0. stoloniferum. 2. O. humile. 3. O. creticum, O. megastachyum. 4. O. oblongatum, 0 . virens.

regyptiăcüm . . Pink . * F. F. Ev. S. Egypt . . 1731 Dietámnǔs.: : Pink : 7, F. Ev. S. Candia : 1551 heracleōtǐeûm: : White: : 8, H. Her. P. S. Eur. : : 1640 Mărū Pink

normales : : Blue

sipy̆leúm : : Pink

6, H. Her. P. Nepal * 1819

Tourneforti *. Pink *. 8, F. Ev. S. Arnorgos : 1788

vulgâré, 1 . - Pink . 8, H. Her. P. Britain

flōré-ălbō . White. 6. H. Her. P. Britain

húmilé, 2 . Purple

prismătĩeūm, 3 White
vĩrēns, 4 . Purple

6. H. Her. P. Britain

6, H. Her. P. Asia

6, H. Her. P. Portugal

ORLĀ $¥ \check{A}$, Hoffinenn. In honour of John Orlay, M.D., secretary to the Medico-Chirurgical Society of Moscow. Linn. 5, Or. 2, Nat. Or. Umbelliferce. Worthless plants. The seed should be sown in the open ground in spring. Synonymes: 1. Cuucalis grandiflora. 2. C. maritima. 3. platycarpos-grandifloră 1, maritīmă 2, platycārpōs.

OrMocĀrǜ, P. Bronne. From ormos, a necklace, and karpos, a fruit; the pods are jointed, and appear like a necklace. Linn. 17, Or. 4, Nat. Or. Leguminosa. For the culture and propagation of this plant, see Pectitia. Synonyme: 1. Hedysarum sennoides-sennoídēs.

Ormōš̆, Jackson. From ormos, a necklace; the seeds of 0 . coccinea are strung for necklaces; they are red, and have a black spot at one end. Linn. 10, Or. 1, Nat. Or. Leguminosa. Ornamental trees, requiring to be treated the same as the stove species of Ednardsia. Synonyme: 1. Robinia coccinea. $[225]$ cocč̆nĕă, 1 . - Blue * . 7, S. E7. T. Guiana * . 1823 dasyeārpa : : Blue : : 6. S. Ev. T. WV. Ind. : 1793

Ornithī dīūm, Salisbury. From ornis, a bird, and eidos, like; the upper lip of the stigma is beak-]ike. Linn. 20 , Or. 1, Nat. Or. Orchidacee. This is a genus of rather interesting plants; for culture and propagation, see Burlingtonia.

albūm . . - White. . 9, S. Epi. Trinidad - 1833

ORNiтhoč̆phăLŬs, Hooker. From ornis, a bird, and kephale, a head; the column resembles a bird'shead. Linn. 20, Or. 1, Nat. Or. Orchidaced. A curious little epiphyte, requiring precisely the same treatment as the genus Burlingtonia.

gladiātŭs. : : Green : : 4, S. Epi. Trinidad
trichorhĩzŭs:

1823

OrnithŏgărüM. From ornis, a bird, and gala, milk.

Linn. 6, Or. 1, Nat. Or. Liliacece. An ornamental genus of plants, thriving well in sandy loam and peat; they require very little or no water when dormant, and are increased by offsets from the bulbs. When any of the tender kinds are planted out in the open border, they should be taken up in autumn, and placed in a dry room free from frost, and planted out again early in spring. Synonyme: 1. Scilla maritima.

WThite - 9, G. Bl P. Chile White : 9, G. BL P. Chile . 1821 arabicum : : Yellow : 6, F. Bl. P. Egypt: : 1629 barbātūm : White. 6, G. Bl. P. C. G. H. : 1795 Bērgì * . Wht. grin. 3, G. Bl. P. . 1816 biflórūm : White. 4, G. Bl. P. Peru : 1832 bifolĩum : White. 8, G. Bl P. Chile: 1831 brachystăehy̆s: White. 3, G. Bl. P. Dahuria : 182 bulbïférüm . White. 4, H. B1. P. Russia :1821 caudãtūm . . Wht. grn. 5, G. Bl. P. C. G. H. . 177 chloroleûcūm . Grn. wht. 7, G. Bl. P. Valparaiso. 1834 ciliātũm * - White. . 4, G. B1, P. C. G. H. * 1819 coarctătũm - Wht grn. 6, G. BL. P. C. G. H. 1804 comosum : White. T, H. B. Pustria 1797

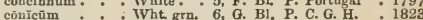
corymboumsúm : WVht grn. 6, G. Bl. P. Chile. : 1829 corymbösúm : - Wht grn. 5, F. Bl, P. Chile ** 1823 elätūm . : White: 3, F. BL P. Egypt : 1804 exscãpûm . . White. . 5, H. Bl, P. Italy . 1824 fimbriātum : White. : 2, H. B1. P. Crimea : 1820 fuseãtüm . Light. 6, G. BL, P. C. G. H. 1820 geminiflōrumm . Grnsh. wht. G. Bl P. Lima

hispidūm * : White. . 6, G. Bl. P. C. G. H. : 1824 ixioidês.: : White: : 5, F. Bl. P. California : 1796 juncifolinm : White: 7, F. Bl. P. C. G. H. 1794 lactéūm - White. 6, G. B1. P. C. G. H. 1796 latifoliūm . White. 6, F. B1. P. Egypt . 1629 longibracteătûm . White. . 5, G. Bl. P. C. G. H. 1817 maculātūm - White. 5, F. BL P. C. G. H. : 1823 miniātúm : - Yellow narbonense. : White: 7, H. Bl. P. S. Eur. : 1810

nireúm : : White. : 5, G. Bl. P. C. G. H. : 1774 notātûm nūt țing odorătưim ovātủm pilōsûm polyphyllûm prasintum pyramidale pyrenăcūm refrāctūm revolūtūm rupēstré secûndūm scilloỉdés Squilla, 1 stachyoĩdẽs suaveúlèns tenēllùm tenellum tenuifolinu hyrsoidēs flāvëscēn trĭgy̆nūm umbellătû̃m unifơliūm

7, G. Bl, P. C. G. H.

White. 6, H. Bl. P. Britain

Pa. yel. : 5, G. Bl. P. C. G. H.
White. 5, G. Bl, P. C. G. H.

White. 5, G, BI P. C. G. H.

White 6, G. BI, P. C. G. H.

$6, \mathrm{G}$ B P C G.

White 6, H BL P Spain.

Green 6, G. B1. P. England

White. 5, H. Bl P. Hungary: 1820

White. 5, G. BL P. C. G. H. 1795

White. 5, G. Bl. P. C. G. H. : 1795
White. 8 , G. Bl. P. C. G. H. 1826

White. 6, G. Bl. P. C. G. H. : 1795

White. 5, F. BL P. S. Eur. . 1829

Li. yel - 5, H. B1. P. S. Eur. * 177

White 6, G. BL P. C. G. H. 1818

White. 4. BL P. C. G. H. 1819

Yellow : 6, G. Bl. P. C. G. H. : 1757

Yellow 6, F. Bl. P. C. G. H. : 1800

Wht. grn. 6, F. BL P.

White. 5, H. B1. P. England

Green * 6, G. Bl. P. Gibraltar : 1805

Ornithoguōssũa, Salisbury. From ornis, a bird, and glossa, a tongue; resemblance of the petals. Linn. 6, Or, 3, Nat. Or. Melanthacea. Ornamental plants ; for culture and propagation, see Ornithogalum. Synonyme: 1. Melanthium viride.

undulătūm * - Green - 9, G. Bl. P. C. G. H. • 1825 viridé, 1 : : Green : 10, G. Bl. P. C. G. H. : 1788 


\begin{tabular}{|l|}
\hline ORN \\
\hline ORNTrHōpús, Linn. From ornithos, a bird, and pous, \\
a foot; the pods are like the claws of a bird. Linn. \\
17, Or. 4, Nat. Or. Leguminose. Plants of very \\
little beauty, The seed should be sown in the \\
open ground in spring. Synonyme: 1 . O. perpusillus \\
intermedius.
\end{tabular}

comprêssŭs . . Yellow . 6, H. A. S. Eux. . . 1737

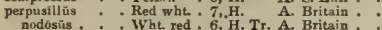

sativús, 1.: : Violet : 6, H. Tr. A. Pritain : 1818

Orvǔs, Scopoli. Oren, Hebrew, oreinos, Greek, ornus, Latin; names for the wild ash. Linn. 2, Or. 1, Nat. Or. Oleacea. All the species of Flowering Ash are ornamental and useful; they are easily cultivated, and may be raised from seeds, as those of Fraxinus, or they may be increased by budding or grafting on the common ash. Synonyme: 1 . Fraxinus striata.
americana
floribūnda: : : White.
rotundifoliă : White:
striatä, 1 : Whitisi
5, H. De. T. N. Amer.
5, H. De. T. Italy
5, H. De. T. Italy
5, H. De. T. Italy
4, H. De. T. N. Amer to strangle; supposed to kill the plants on which it grows. Linn. 14, Or. 2, Nat. Or. Orobanchacec. The Broom Kape is a genus of curious parasitical plants, none of which are properly cultivable. o. major is powerfully astringent.

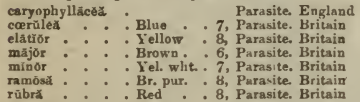

1820

1730

1622

Orǒ́ữs, Linn. From oro, to excite, and bous, an ox ; the Orobos of Theophrastus was the name of a plant used for fattening oxen. Linn. 17, Or. 4, Nat. Or. Leguminosic. The plants of this genus deserve to have a place in every flower-border, on account of their very elegant pea-blossoms. Any light soil suits them, and they are readily increased by dividing the plants at the roots in spring, or by seeds. Synonyme: 0 . Gmelini.

alpistris : Purple 6 , H. Her. P. Hungary

americănŭs . . Pat. pur. * G. Ev. S. Jamnica

angustifolrus. White. 4, H. Her. P. Siheria

atropurpureàs. Purple * 5, H. Her. P. Algiers

aurăntiữs. - Yellow .6, H. Her. 1. Iberia

coccineús.: : Scarlet 4, H. Her. P. Vera Cruz

unijügüs: : Scarlet : 4, H. Her. P. N. Amer.

divaricatus : Purple 6, H. Her. P. Pyrenees

erêctu็s

Fischęrĩ

formosurs: - Purple

formosuls: : Pux

hirsūtüs: : : Red Purple

Jordsing

İeteũs 1 : : : White

lagrigatŭs: : Yellow

lathyroides : Blue

laxitłórŭs. : Violet

luteūs : * Li, yel

multiflörŭs: : Parred

nígêr ochroleũeùs: : Yurple

pallèscéns : : White

prucifōrŭs

pisiformis : Purple

pyrenailicús: Purple

saxätrilis : Purple

sylvatiengs
tenuifoliús : : Purple

Purple 6, H. Britain .

Tournefórtir - Yel. pur. .6, H. Her. P. Hungary

tuberósŭs. : Purple : 6, H. Her. P. Britain,

variegatŭs: : Purple : 7, H. Her. P. Italy

vărüs. : Yel. red : 4, H. Her. P. Italy

venetūs: : Purple : 4, H. Her. P. Gernany

venósũs : . Blue . 6,. H. Her. P. Siberia .

vērnŭs : Purple: 3 , H. Her. P.

vicioídés : : Yellow : 6, H. Her. P. Hungary . 1819

Onōntiōm. Adopted from the Greek by Linnæus. Linn. 6, Or. 1, Nat. Or. Aracece. A curious aquatic, of easy culture.

aquătīcūm . . A petal . 6, H. Aq. P. N̦. Amer. 1775 OrPIAB, see Telëphifim.

ORPINB, see Sédüm Telēphĩum.
OrtĒGǏĂ, Linn. In honour of Casimir Gomez de Ortega, once professor of botany at Madrid. Linn. 3, Or. 1, Nat. Or. Illecebraceer. These plants should be grown on rock-work, or in pots well drained, in a mixture of loam, peat, and sand; they may be increased by cuttings or seeds.

diehōtōmă . . A petal . 8, H. Her. P. Italy . . 1820 hispânicá : . Apetal : 6, H. Her. P. Spain : 1768

ORTHōck̆Răs, R. Bronn. From orthos, straight, and keras, a horn; in allusion to the appearance of the outer sepals. Linn. 20, Or. 1, Nat. Or. Orchidncece. A curious little plant, requiring the same treatment as the genus Disa.

striátūm

C. Ter. N. Holl. , , 1826

ORthopōgōn, R. Brown. From orthos, straight, and pogon, a beard. Linn. 3, Or. 2, Nat. Or. Graminea. These plants.require the same treatment as other stove biennials. Synonymes: 1. Oplismenus africanus. 2. Orthopogon loliaceus.

hirtẽllús. . . A Apetal . . 6, Grass. W. Ind. . 1795

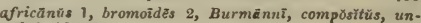
dulatifoliūs.

ORthō rRīchōm, Hedwig. From orthos, straight, and thrix, a hair; teeth of the peristome. Linn. 24, Or. 5, Nat. Or. Musci. An extensive genus of very minute plants, found on rocks, trunks of trees, \&c. Synonymes: 1. O. nudum, O. anomalum. 2.0. aristatum-affinè, mäjūis, pūmîlam, anomälùm, crispūm, cupulātūm 1, dia phänūm 2, Drummondĩ, Hutch. Insiü, Ludvigh, Lyēllit, pulchêllùm, rivuläré, rupicơlü, speciōsum, striūtam.

Orthrosinthì's, Sneet. From orthros, morning, and anthos, a flower; time of flowering. Linn. 16, Or. 1, Nat. Or. Iridacee. This is a very pretty plant, growing well in an equal mixture of loam and peat, and may be increased by offsets from the roots, or by seeds.

multifốrŭs . . Blıe . . 6, G. Her. P. N. Hol. . 1820

OR乏zณ̆, Linn. Derived from the Arabic name, eruz. Linn. 6, Or. 2, Nat. Or. Graminece. The species of Oryza, or Rice, should be sown in a pan or cistern of water, and kept in the stove.

latifolia . . Apetal . . 8, Grass. S. Amer. . 1820 nepalénsis : : Apetal : 8, Grass Nepsl : 1818 sativă. : : A petal : 7 , Grass, E. Ind. : 1546

Onyzōpsĩs, Richard. From oryza, rice, and opsis, appearance. Linn. 3, Or. 1, Nat. Or. Gramined. This species grows in any common soil, and is increased by divisions.

asperifolra . . A petal . . 7, Grass N. Amer. . 1822 OsAGR-APPLE, see Maclâră.

Osвīckǐn, Linn. In honour of Peter Osbeck, a Swedish elergyman and naturalist. Linn. 8, Or. 1, Nat. Or. Melastomacere. Theso shrubs are well worth cultivating on account of their beautiful flowers; for culture and propagation, sec Melastoma. Synonymes: 1. Melastomi osbeckioides. 2. Pleroma glomerata. 3. Rhexia glomerata. 4. Mielastoma nepalensis. chinẽnsIs, 1 *. Purple * 7, S. Ev. S. Chins : 1818 glomerăta, 2 : Pink * 7, S. De. S. Trinidad: 1818 albiflörd, 3 : White. 1, S. Ev. S. Braz! * 1821 nepalénsis, 4. Purple * 6, S. Ev. S. Nepal * . 182 stellatá : Pink: 7, S. Ev. S. Nepal: 1820

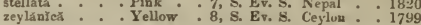

Oscrilarōrĩ, Vauch. Plants having an oscillatory motion. Linn. 24, Or. 7, Nat. Or. Alga. Minute plants, found on stones in rivers, pools, \&c. Synonyme: 1. rupestris-alütă, autumnälè, vaginată, contēxtă, cörīum, cyūnēă, decörtică, limbätă 1 , limosă,

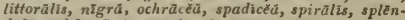
dìdä, subj йscü, těnüis, tenuissimä, turfosă.

OstFr, see Sülix viminülis.

Osuītés, Cassini. From osme, perfume; strong smell of camphor. Linn. 19, Or. 3, Nat. Or. Composita. Ornamental plants, thriving in any rich light soil, and increased by cuttings in sand, under a glass.

bellidiástrūm . . White. . 6, G. Ev. S. C. G. H. . 1816 camplionina : White. 5, G. Ev. S. C. G. H. : 1794 dentata. . White. 5, G. Lv. S. C. G. H. : 1820

Osstōndă, Linn. From Osmunder, one of the names of Thor, a Celtic deity. Linn. 24, Or. 1, Nat. Or. Osmundacea. Ornamental ferns, of easy culture. Synonyme: 1. regalis.

[226] 


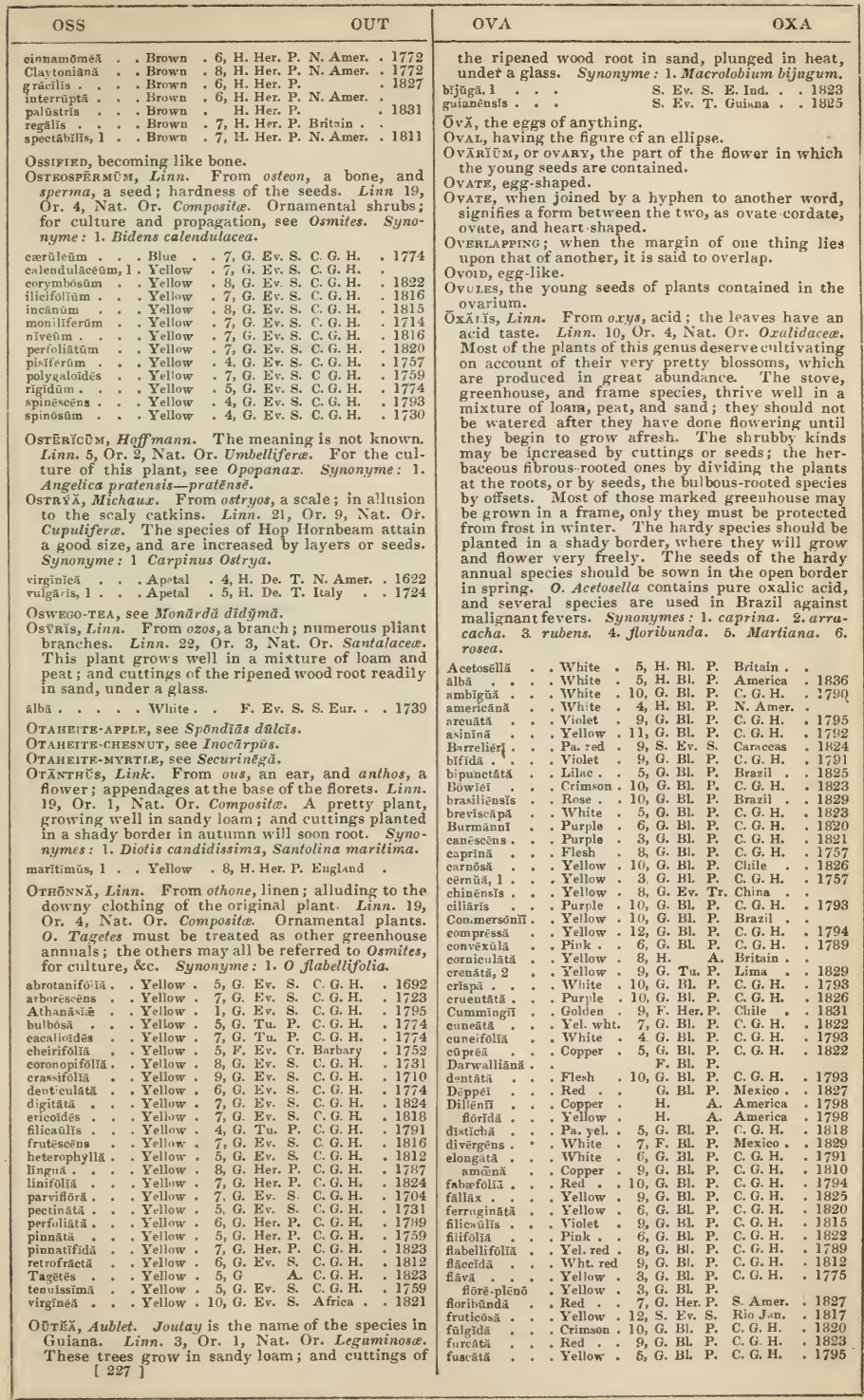




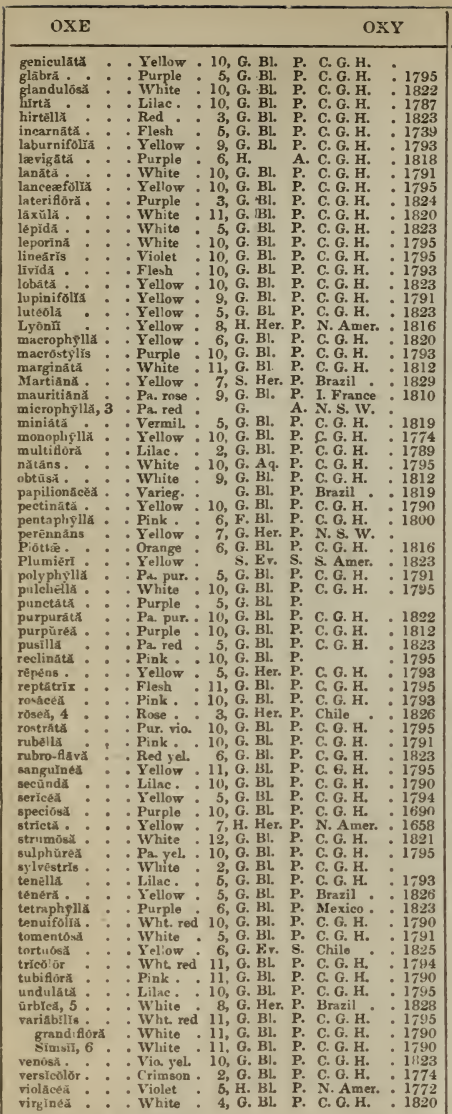

OXRYr, see Bupthälmam.

OхEYв DAIsv, see Chrysänthĕmam leucānthĕmam.

Oxr. EYA , Hooker. In honour of Mr. Oxley, late surveror-general of New South Wales. Linn, 10, Or. 1, Nat. Or. Cedrelaced. A fine tree, attaining the height of one hundred feet; it should be grown in loam, peat, and sand, and cuttings of the ripened wood will root in sand, under a glass, provided the leaves are not shortened.

xanthôxy̆lŏn

G. Er. T. N. Holl. . 1828

Ox-Lıp, see Prĩmũlă elātiǔr.

OxHorn, see Bácidă Būcérắs.

Oxtongur, see Pícris.

OxyãxtuŨs, Decandille. From oxys, acute, and anthos, a tlower. Linn. 5, Or. 1, Nat. Or. Cinchonacea. An ornamental plant; for culture and propagation, see the stove species of Gardenia.

speciōsŭs . . . Whito. . 7, S. Ev. S. S. Leone * 1789 Oxувス̄pHuัs, Jussieu. From oxys, acid, and baphe,

dyer's-colour. Linn. 3, Or. 1, Nat. Or. Nyctagi. nacea. This is a genus of curious plants, which succeed well in the open border in summer, but they should be taken up in autumn, and laid up in a dry room out of the reach of frost; they are readily increased by seeds, which ripen in abundance. Synonymes: 1. Allionia linearis, Calymenia angustifolia. 2. A. nyctaginea. 3. A. pilosa.

aggregătŭs . Pink • . 7, F. Her. P. N. Spain . 1811 angustifớrŭs, 1. Purple : 8, H. De. Cr, Louisiana 1812 Cerrantésî̀, : Purple : 6, F. Ev. Tr. Mexico, 1823 chilensĩs . Lilac . 9, H. Her. P. Chile . 1832 decūmbēns : Purple * 8, H. De. Cr. Missouri 1818 expânsǔs.: - Purple * 7, F. Ev. Tr. Peru * 1819 glabrifoliǔs . Purple * 7, F. Her. P. N. Spain . 1811 nyctaginēús, 2 : Purple : 8, H. De. Cr. Missouri , 1823 nyctagineús, 2 : Purple : 8, H. De. Cr. Missouri : 1823

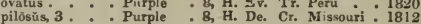
pilosŭs, 3 : : Purple : 8, H. De. Cr. Missouri . 1812
viscósus : Purple

Oxycôccuัs, Richard. From oxys, sharp, and kokkos, a berry ; sharp acid taste of the berries. Linn. 8, Or. 1, Nat. Or. Ericaced. The Cranberry is a wellknown genus of plants. $O$. palustris grows in most turfy mossy bogs in the mountainous parts of Britain, the berries being very much sought after. When the plants are grown for the sake of the fruit, they should be planted on an artificial bog, but when grown only for having specimens, they will do in pots well drained, and filled with peat and sand, with some sphagnum moss about their roots, and placed in pans of water. Synonymes: 1 . O. erythro. carpus. 2. Vaccinium macricarpus. 3. V. Oxycoccus.

eréctũs, 1 . . Pink * . 5, H. Ev. S. N. Amer. - 1806 macrocárpŭs, 2 . Pink : 5, H. Ev. Tr. N. Amer. : 1760 variegatüs : Pink : 5 , H. Ev. Tr. Gardens palüstris, 3 : : Pink : : 5, H. Ev. Britsin.

OxrLöвто, Botanical Repository. From oxys, sharp, and lobos, a pod; the legumes are furnished with a sharp pod. Linn. 10, Or. 1, Nat. Or. Leguminosie. Ornamental plants; for culture and propagation, see Podolobium.

arborescens - Yellow . 5, G. Ev. S. V. D. L.

G. Ev. S. Swan R.

6, G. Ev. S. N. S. W. . 1807

elliptreǔm - . Yellow * 7, G. Ev. S. V. D. L. • 1805

ferrugineúm * Y Yellow * 5, G. Ev. S. N. Holl. * 1820

obtusifollũm *. Searlet . 5, G. Ev. S. N. Holl. • 1824

Pultenádé. . . Drk. or. . 3, G. Ev. S. N. Holl. : 1824

retūsúm : : Orange : 5, G. Ev. S. N. Holl. : 1823

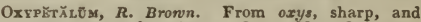
petalon, a petal. Linn. 5, Or. 2, Nat. Or. Asclepiadacea. An interesting plant, growing in peat and loam, and increased by cuttings in sand, under a glass, in heat.

S. Ev. Tw. Brazil . 1893

Oxînĩ , Hill. From oxys, acid. Linn. 6, Or. 2, Nat. Or. Polygonaces. The Mountain Sorrel grows well in common garden soil, and is increased by dividing at the roots, or by seedy. Synonymes: 1. Rumex digynus. 2. O. reniformis.

reniformls, 1 - Green. . 6, H. Her. P. Britain . amerieanŭs, 2 : Green. 6, H. Her. P. N. Amer.

OxystËrax̌, R. Brown. From oxys, sharp, and stelma, a crown; the foliola of the corona is acute. Linn. 5, Or. 2, Nat. Or. Asclepiadacere. An ornamental plant ; for culture and propagation, see Oxypetalum.

esculēntūm . Y Yellow . S. Er. Tw. E. Ind. . 1816

Oxร̃тrŏpIs, Decandolle. From oxys, sharp, and tropis, a keel; flowers ending in a mucrone at the apex of the keel. Linn. 17, Or. 4, Nat. Or. Leguminose. These plants are very handsome $n$ hen in flower, and are well adapted for ornamenting rock-work, or the front of flower-borders. The seed should be sown where the plants are intended to grow, as they seldom thrive after transplanting. The rarer kinds may be grown in pots well drained, in a mixture of peat, sand, and a little loam, and treated as other alpine plants. Synonymes: 1. Astragalus Halleri. 2. O. Gmelini. 3. Astragalus montanus. 4. A. dahuricus. 5. A. uralensis, O. sordida.

ambīgŭă - Purple . 6, H. Her. P. Siberia . 1817

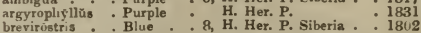
brevirostris : Blue : 8, H. Her. P. Siberia
campéstris cyāneã : : Blue . : 7, H. Her. P. Caucasus : 1818 


\begin{tabular}{|c|c|c|c|}
\hline OXY & & & \\
\hline 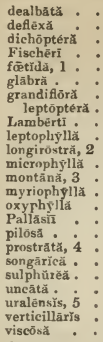 & 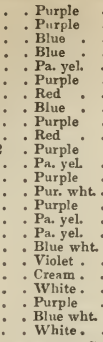 & 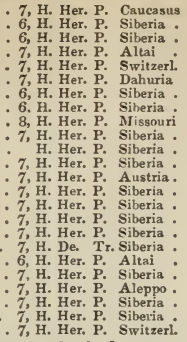 & $\begin{array}{l}.1803 \\
: 1800 \\
: 1815 \\
: 1817 \\
: 1819 \\
: 1823 \\
: 1820 \\
: 1818 \\
: 1811 \\
: 1818 \\
: 1820 \\
: 1819 \\
: 1581 \\
: 1818 \\
: 1816 \\
: 1818 \\
: 1732 \\
: 1820 \\
: 1824 \\
: 1820 \\
: 1768 \\
: 1800 \\
: 1819\end{array}$ \\
\hline
\end{tabular}

and oura, a tail ; but the application is not evident. Linn. 19, Or.2, Nat. Or. Composite. An ornamental plant, having somewhat the appearance of Chrysanthemum coronarium. It grows in any common soil.

chrysanthemoìdēs. Yellow - 7, H. A. California . 1834

Ozoñom, Persoun. From ozos, a branch; the filaments are branched. Linn. 24, Or. 9, Nat. Or. Fungi. This plant is found during autumn on decayed wood-aurĩçmũm.

Ozothāmsǔs, $R$. Bronn. From ozos, a branch, and thamnos, a shrub. Linn. 19, Or. 1, Nat. Or. Com posito. Ornamental plants, growing freely in an equal mixture of loam and peat; and cuttings of the young wood will root in a few days planted in sand, under a glass. Synonymes: 1. Chrysocoma cinerea. 2. Eupatorium ferrugineum. 3. E. rosmarinifolium.

ciněrěňs, 1. * Y Yellow - 7, H. Ev. S. V. D. L. - 1820 ferruginéŭs, 2 . Yellow * 7, G. Ev. S. V. D. L. . 1829

P.

DACHIDENDRŌN, Willdenon. From pachys, thick, and dendron, a tree. Linn. 6, Or. 1, Nat. Or. Liliacec. A genus of tree Aloes, thriving in a mixture of sandy loam mixed with old lime and brick rubbish; the pots in which they are grown must be well drained, that the moisture may readily pass off. They require but little water in winter, and are increased from suckers, or young side shouts, when they are produced; leaves taker off close from the stem, and laid to dry for a few days, then planted in pots of dry soil, will throw out young plants at their base. Synonymes: 1. Aloe africana. 2. A. angustifolia. 3. A. ferox. 4. A. principis. 5. A. pseudo-africana, africana angustior. 6. A. pseudo-ferox, subferox. 7. A. supralevis.

africănūm, l * Red * . 7, G. Ev. S. C. G. H. : 1819 angustifölium, 2 : Red : 7, G. Ev. S. C. G. H. : 1806 férox, 3 . Yellow : 5, G. Ev. S. C. G. H. 1759

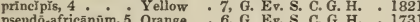
pseudo-africānumm, 5 Orange $\quad 6$, G. Ev. S. C. G. H. $: 1731$

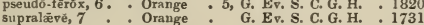

PAcriocībü, Berkley. From pachne, hoar-frost, and kybe, a head. Linn. 24, Or. 9, Nat. Or. Fungi. These substances are found on decaying plants of various sorts-acìcūlă, älbĭdă, ferrugĩnëă, grīsěă, subulātă.

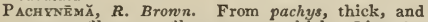
nema, a filament; filaments very thick. Linn. 10, Or. 3, Nat. Or. Dilleniacece. This little leafless shrub thrives best in a mixture of loam and peat; cuttings strike root freely in sand, under a glass.

$$
\text { complanātūm . . } \quad \text { G. Ev. S. N. Holl. }
$$

Pachypōoĩōm, Lindley. From pachys, thiek, and podion, a peduncle; thick footstalks. Linn. 5, Or. 1 , Nat. Or. Apocynacea. This succulent and tuberous-rooted genus succeeds in an equal mixture of light turfy loam, peat, and sand; as the plants require scarcely any water in winter, the pots must be well drained, that the moisture may pass off readily; cuttinge taken off, and laid to dry till the wound is dried up, then planted in a pot of dry soil in spring, will strike root, and produce tubers before winter. Synonymes: 1. Echites succulenta. 2. E. tuberosa.

succulēntũm, 1 . Wht. red . 5, G. De. S. C. G. H. - 1820 tuberösüm, 2 . Wht. red. 8, G. De. S. C. G. H. : 1 :13

Pachyrhĩzùs, Richard. From pachys, thick, and rhiza, a root; alluding to the thick tuberous roots of the plants. Linn. 17, Or. 4, Nat. Or. Legumi. nosa. The plants succeed weil in a light rich soil ; they may be increased from cuttings in sand, under a glass, by the tubers of the roots, or by seeds. s.ynonyme: 1. Dolichos bulbosus.

angulătǔs, 1 . . Purple . 7, S. Ev. Tw. E.Ind. . . 1781 PAchysāndră, Michaux. From pachys, thick, and [ 229 ] aner, a man; in allusion to the thickness of the stamens. Linn. 21, Or. 4, Nat Or. Euphorbiacere. This genus of dwarf growing plants thrives in any common soil, and may be planted near the front of flower-borders; it is increased freely by suckers from the roots.

coriācéă * . White. . 6, S. Ev. S. Nepa] . . 1822 proümbēns : : White. : 4, H. Her. P. N. Amer. : 1800

Papĩnă, Adanson. Derivation doubtful. Linn. 24, Or. 7, Nat. Or. Fungi. A small brownish-coloured species, found in the ocean-deñstĩ.

PÁDERĪa, Linn. From poederos, opal; in reference to the transparent berries. Linn. 5, Or. 1, Nat. Or. Cinchonacea. The species are remarkably free growers; any kind of light rich soil suits them, and cuttings root readily in the same kind of soil, under a glass.

foetrdă . . . Purple . S. Ev. S. China . . 1806

PAfDERōtă, Linn. The ancients applied this name to a species of Acanthus. Linn. 2, Or. 1, Nat. Or. Scrophulariacere. These pretty dwarf alpine plants are well adapted for rock-work; light sandy soil, or an equal mixture of peat, loam, and sand, will suit them very well; if grown in the open border, the situation should be dry and airy; increased from seeds.

Agëriă . . . Yellow . 5, H. A. Italy . 1824 Bonarôtå : : Blue : 5, H. A. Austria: : 1818

PææŏNĬ L Linn. The physician Pron was the first who used it in medicine. Linn. 13, Or. 2, Nat. Or. Ranunculacea. Beautiful flowering plants, mostly hardy enough to endure our winters. P. Moutan, and its varieties, though able to bear a moderate degree of frost, do not flower so well as when planted out in the border of the conservatory; they bear forcing well; a rich loamy soil suits them best. The shrubby kinds are increased from cuttings taken off in August or September, with part of the wood of the preceding year attached, and planted in a sheltered situation where they will root freely. The herbaceous species are increased by dividing the plants at the roots, taking care to leave a bud to each slip; the new varieties are obtained trom seeds. Synonymes: 1. P. Makoya. 2. P. laciniata. 3. P. tartarica. 4. P. dahurica. 5 . P. sessiliflora.

albiflöră

* . White. . 5, H. Her. P. S'heria .

candídă . Flesh . 5, H. Her. P. Siberia

festá, 1 pink 6, H. Her. P.

frägräns . . Red . 5, H. Her. P. China

1548

Hünễ

Pottsri : Crimson 6, H. Her. P. China

6, H. Her. P. China 1808

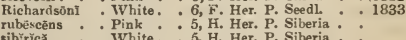

sib̌ričă : : White : 5 , H. Her. P. Siberia 


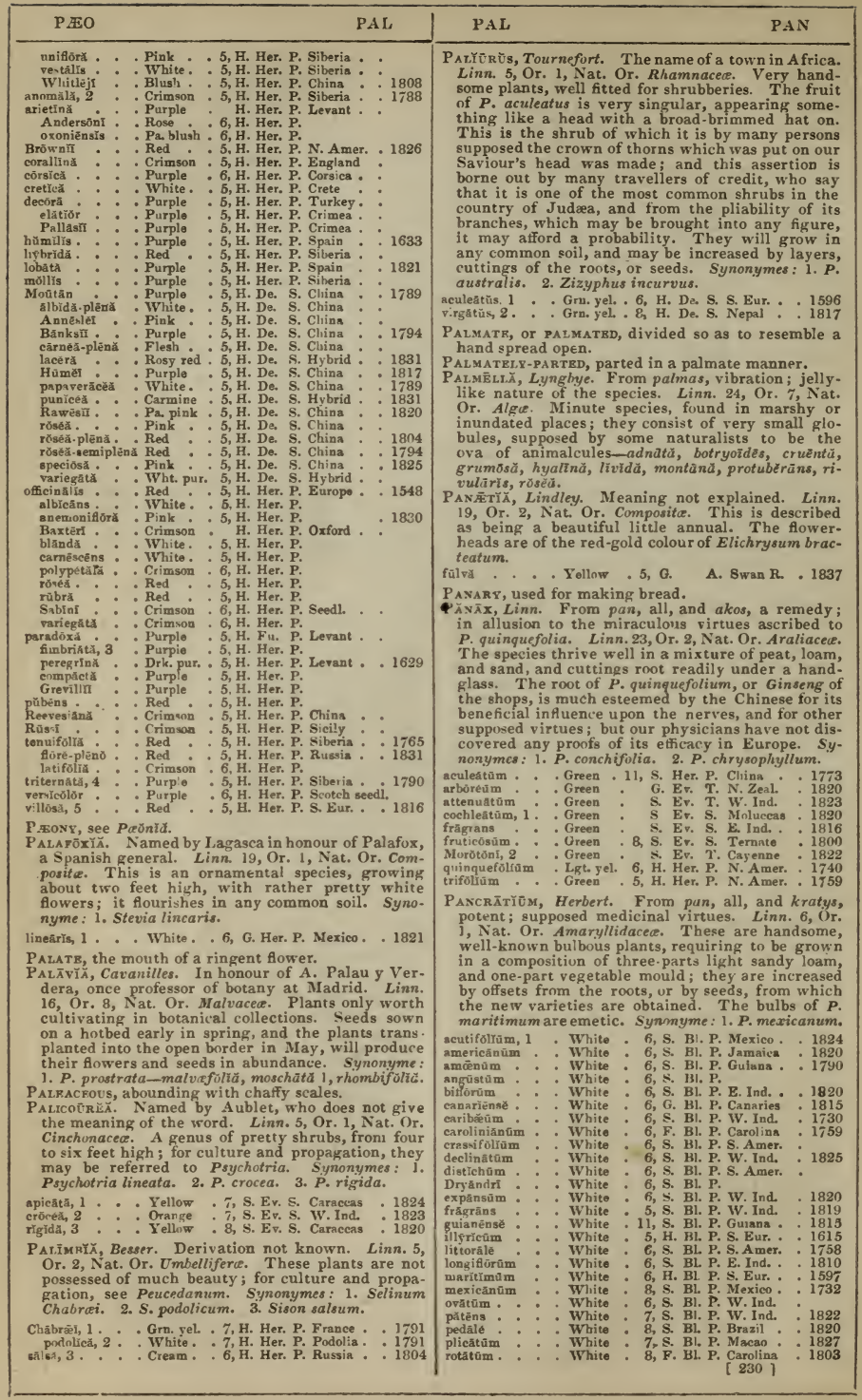


speciōsūm . . White . 7, 8. B1. P. W. Ina. . 1759 22, Or. 1, Nat. Or. Pandanacea. This stately, finelooking genus has received the English name, Screw-Pine, on account of the appearance of the plants; they thrive in a light loamy soil. Some of the species produce suckers, by which they may be increased.

ริlhŭs

âlhús . White

candelab:ùm .

ectulis * : White

fasciculăriss * White

furcātŭs

hưmiliss.

inërmis

integrifōinus

latifoliǔs

longiföliǔs .

marginátǔs

odoratissimūs

reflexŭs .

sẽssilis

S. Ev, T.

S. Ev. T. Guinea . . 1826

S. Ev. T. Madagas. • 182

S. Ev. T. E. Ind.

6. Ev. T. E. Ind.

S. Ev. T. E. Ind.

S. Ev. T. Manrit.

S. Ev. T. E. Ind.

S. Ev, T. E. Ind

S. Ev. T. E. Ind.

S. Ev. T. E. Ind.

S. Ev. T. N. Holl.

S. Ev. T. E. Ind.

S. Ev. T. E. Ind.

S. Ev. T. N. S. W.

S. Ev. T. E. Ind.

turbinâtūs . White

ütrils

Pandurate, fiddle-shaped.

PANiceous, eatable, good for bread.

Panic-grass, see Pānícūm.

Panic-urass, see Ehrärtă panĭcěă.

PANicle, a loose disposition of inflorescence, as oats.

PANicLED, or PANiculate, forming a panicle.

Paniculately-Branched, loosely branched.

Paniculately-RAcemose, a panicle formed by numerous racemes.

PĀxicồ, Linn. From panicula, a panicle, or panis, bread. Linn. 3, Or. 2, Nat. Or. Graminece. A useful genus of grasses. P. miliaceum is frequently sown for feeding poultry, and is sometimes used as a substitute for rice. $P$. arborescens is said by Linnæus to equal in height the loftiest trees in the East Indies, though the culm is little thicker than a goose's-quill; it grows in the woods and jungles. In cultivation, the species grow in any common soil, and are increased by dividing at the root, or by seeds.

bris

cölōnüm

A petal

7, Grass. E. Ind.

1801

faum . A petal . 8, Grass. E. Ind. . 1699

- Apetal . 6, Grass. Jamaica . . 1801

miliăceūm *: A petal : 7, Grass. E. Ind. : 1510

muricātūm: : : Apetal : : 6, Grass. E. Ind. : : 1805

oryzoídés : . Apetal : 8, Grass. W. Ind. : 1829

prolifériun : : Apetal : 7, Grass. N. Amer. : 1820

altīsš̌mūm, ส̃ncēps, arborēscēns, arundinācěûm, usperrĭmūm, attenuātūm, bücơlŏr, brevifóliūm, capillūrĕ, C. mĭnǒr, carthagiuēnsě, clandestīnūm, colorātũm, costātñm, decūmbēns, dichötōmūm, diffùsı̃m, divari-

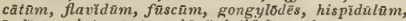

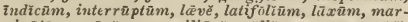

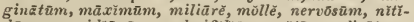
đūm, numidīānâm, palmifölīùm, pătēns, plicâtūm,

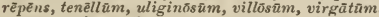

PAPĀV̌̆R, Linn. From papa, pap, or thick milk; the juice of the poppy was formerly used in chil dren's food to make them sleep. Linn. 13, Or. 1, Nat. Or. Papaneracece. P. somniferum is cultivated in the vicinity of London; the capsules are sold to the druggists for the opium which is obtained from them. The plants succeed in a light rich soil. The perennial kinds are increased by dividing at the roots. All the species are narcotic. Syno. nymes: 1. P. Burseri. 2. P. pulcherrimum. 3.P. aurantiacum. 4. P. alpinum.

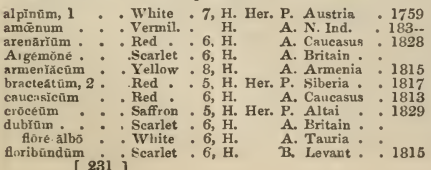

A. Persia . 1897

A. Africa . . 1835

A. N. Holl.

A. England

$6, \mathrm{H}$

6, H. A. Caucasus

, Her. P. Kamtsch. : 1824

7, H. Her. P. Siberia - 1730

4, H. Her. P. Hybrid : : 1820

H. Her. P. Siberia * : 1800

7, H. Her. P. Norway : 1800

5, H. Her. P. Armenia : 1714

6, H. Her P. S. Eur. . 1714

6, H. Her. P. S. Eur. . 1714

6, H. H. Africa : : 1828
6, H. Her. P. Persia : 1830

7, H. Her. P. Pyrenees

6, H. Her. P. Switzerl

6, H. A. Britain

6, H. A. Britain

$6, \mathrm{Fi} \quad \mathrm{A}$. Brituin

6, H. A. Britain

A. Britain

A. Britain

6, H. H. Her. P. Dahuria

A. S. Eur.

A. Britain

A. Britain

A. Britain

A. Britain

A. Britain

A. Britain
A. Hollaud

1823

1822
1824

Papaw-treE, see Carícă Papaỹă.

PAPER-Mulberry, see Broussonétžă papyrācěă.

Papilionackous, butterfly-shaped flowers, as the common pea.

PAPILI.E, small, soft excrescences.

PAP1Llose, or PApilious, having small glandular excrescences, like pimples.

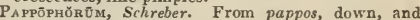
phoreo, to carry. Liun. 3, Or. 2, Nat. Or. Gra minece. Grasses of no interest; increased by seeds -nigrĭcāns, phleotilès.

PĀppús, crown of the fruit of compositæ, and similar plants.

PAPUI_E, round, soft, watery protuberances.

PApurose, covered with papulze.

Papyraceous, resembling paper.

PĂpĨrťs, Willdenow. From the Syrian, babeer whence the Egyptian word papyrus, paper. Linn. 3, Or. 1, Nat. Or. Cyperacec. This is a splendid genus, requiring to be grown in a tub or large pot of water, with rich mud at the bottom; increased from divisions, or by seeds. The famed Papyrus of the Egyptians was obtained from our Cyperus Pupyrus. Synonymes: 1. Cyperus elegans. 2. C. odoratus.

antiquōrūm * A petal . 8, S. Aq. P. Egypt * . 1803

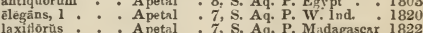
odoratǔs, 2 : : Apetal : 7, S. Aq. P. W. Ind. 1819

Paraboltcal, for $m$ of a parabola, longer than broad, tapering gradually to both ends.

Paraguay tra, see Ilēx paraguénsis.

Parastranthüs, Don. From parastrepho, to invert, and anthos, a flower; the flowers are upside down compared with those of other genera of the order. Linn 5, Or. 1, Nat. Or. Lobeliacea. These beautiful plants are easily cultivated in a mixture of loam, peat, and sand; increased by dividing at the root. Synonymes. 1. Lobelia lutea. 2. L. unideutata. 3. L. varifolia.

simplex , 1. . Yellow - 6, H. Her. P. C. G. H. . 1774

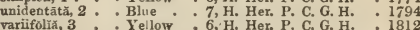
Pardānthěs, Ker. From pardus, a leopard, and anthos, a flower; alluding to the spotted flowers. Linn. 3, Or. 1, Nat. Or. Iridacea. A handsome genus, succeeding in light rich soil; when planted in the open border the plants require a little protection in severe weather; increased by divisions, or by seeds.

chinēnsǏs . - Orange . 6, H. Her. P. China * . 1759 nepalénsı̌s : : : Orange : 6, H. Her. P. Nepal : : 1823 Pareira brata root, see Cissampélos.

Parenchyma, parts of plants consisting of cellular tissue only. 
Partāná, Aublet. Its name in Guiana. Linn. 21, Or. 9, Nat. Or. Graminea. A curious under-shrub, growing in any common soil, and increased by divisions.

campéstrǐs . . Apetal. . S. Ev. S. Cayenne . 1803

Parietārĭ, Linn. From paries, a wall; they are commonly found on old walls. Linn. 23, Or. 1 Nat. Or. Urticacese Mere weeds, found on old walls, stony ground, \&c.; they are of no beauty, and the easiest culture. Synonyme: 1. Boehmeria urticifolix-crëtĭcă, floridānă, indīcă, judā̃că, lusitünǐcă, micränthă, officinälìs, pennsylvănĩcă, poly. gonoīdẽs, prostrütă, urticaéóliă 1 .

Pariktal, attached to the sides of the ovary.

PARIĽtর̌s, the sides of the ovary or capsule.

Parinarí̃ m, Jussieu. From Parinari, the Guiana name of one of the species. Linn. 7, Or. 1, Nat. Or. Chrysobalanacea. A noble genus of plants. $P$. excelsum is a fine tree, attaining the height of sixty feet, with long leaves and large terminal bunches of flowers, succeeded by a fruit of plumlike appearance, which is eaten in Sierra Leone under the name of Rough Plum. The plants grow freely in three parts sandy loam and one part peat; ripened cuttings in pots of sand, under a glass, in heat, root readily. Synonyme: 1. Petrocarya campestris.

campéstré, 1 - . Yellow . S. Ev. S. Guiana . . 1824 macrophyllumm : White. : S. Ev. S. S. Leone : 1822

PǍRIs, Linn. From par, equal; in allusion to the regularity of the parts. Linn. 8, Or. 4, Nat. Or. Melanthacee. The species of this genus thrive in light sandy loam, in a shady situation; increased from divisions, or by seeds. The juice of the berries of $\boldsymbol{P}$. quadrifolia has been used in inflammation of the eyes.

polyphylla. . . Green . . 5, H. Her. P. Nepal . . 1826 quadrifollä. - Green : 5, H. Her. P. Britain verticillătă: : Green : : 4, H. Her. P. Caucasus : 1825

Parıvõa, Aublet. The Guiana name of the tree. Linn. 10, Or. 1, Nat. Or. Leguminosie. A very handsome pinnate-leaved stove tree, delighting in rich loamy suil, and propagated from cuttings. Synonyme: 1. Dimorpha grandiflora.

grandiflóră, 1 . Purple . S. Ev. T. Guiana . . 1821

PARKẼRİ̈, Hwoker. In honour of C. S. Parker, who first found the plant in Essequibo. Linn. 24, Or 1, Nat. Or. Polypodiacee. This species of fern grows best in turfy loam and peat mixed; it is increased by dividing the roots, or by seeds.

pteroides . . Brown . 8. S. Aq. P. Essequibo - 1825

PÂRKYÃ. Named by Brown in memory of the celebrated African traveller Mungo Park. Linn. 16, Or. 6, Nat. Or. Leguminosa. A beautiful genus of plants; for culture and propagation, see lnga. Synonymes: 1. Inga biglobosa, P. biglobosa.

afrieănă, 1. . Vermil. . 3, S. Ev. T. Africa . . 1822 uniglobôsă : : Vermil. : 3, S. Ev. T. S. Leone : 1822

PARKInsōñ̌̆, Linn. In honour of John Parkinson, a London apothecary, and author of Theatrum Botanicum, \&c. Linn. 10, Or. 1, Nat. Or. Leguminosa. This is a very handsome species, but seldom suffered to grow large enough to flower: a mixture of peat and loam suits it, and cuttings root in sand, under a glass. The imported seeds of it also vegetate freely.

aculeâtă . . Yellow • S. Ev. S. W. Ind. - 1739

PARMEIX̌ , Acharius. From parma, a kind of small shield, and heilo, to inclose ; the thallus. Linn. 24, Or. 8, Nat. Or. Lichenes. The species of this genus are found on rocks, trunks of trees, \&c.; several of them are used in dyeing-adglutinätă, ambigŭă,

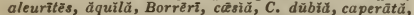
Clementiānă, columnäris, conspęrsă, corrugätă, cycloselìs, diacāpsìs, diatripă, eläină, encaũstă, fahlu-

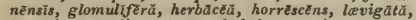
lanuginosã, olivăcěu, omphalodẽs, parietină, perforiță, perlată, physodēs, pitỹrēă, plümběă, pulverulēntă, recūrvă, reticulätă, rubiginosă, rugסsă,

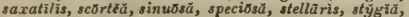
sulcată, tiliāeĕă.

PARñ̄ssĭ L, Linn. From Mount Parnassus, the abode of grace and beauty; these plants, on account of their elegance, are feigned to have first sprung up there. Linn. 5, Or. 3, Nat. Or. Saxifragacece. The plants do best in a moist peat soil and a shady situation. $\boldsymbol{P}$. palustris is one of our most elegant marsh plants; increased by divisions, or by seeds, which ripen plentifully.

asarifolra . . White . 7, H. Her. P. N. Amer. . 1812 caroliniană : : White : 5, H. Her. P. N. Amer. : 1812 palüstrīs : White $: 7$, H. Her. P. Britain. speciósi : Wream

PAROCBÊTŬs, Hamilton. From para, nigh, and ochetos, a brook; in allusion to the habitation of the plants. Linn. 17, Or. 4, Nat. Or. Leguminosce. A light rich soil will answer this pretty creeper, which is readily increased by dividing.

commũnìs . . Purple - 7, F. Ev. Cr. Nepal . . 1820

Paroñ̄chĭă, Tournefort. From para, near, and onyx, a claw; supposed to cure a tumour which rises near the nail. Linn. 3, Or. 1, Nat. Or. Illecebraces. From the dwarf stature of the species, they are all well adapted for ornamenting rock-work; they, however, thrire best in pots, in a mixture of sand and loam, and are easily increased by dividing at the roots, or by cuttings under a glass, or by seeds. Synonymes: 1. Illecebrum capitatum. 2. I. echinatum. 3. I. Paronychia.

alsinifoliă . . White - 7, F. Her. P. Spain

bengalénsĩs : White :7, H. Her. P. Bengal: : 1817 brasiliână : White : 6, F. Her. P. Brazil : 1890 canariénsts : Whito : 9, G. Her. P. Teneriffe : 1829 capitata, 1. . White = 7, H. Her. P. Spain : 1683 hechinâta, 2 : Greenish 7, H. A. S. Eur. : 1821 itslied marYuma : White $7, \mathrm{H}$. De Tr. Pyrenees nIvea : : White : 7, H. Her. P. Pyain : 1819 polsgonifalir : : White : 6, H. Ev. Tr. Span : 1812 puhéseéns : : White : 6, H. De, Tr. Pyrenees: 1820

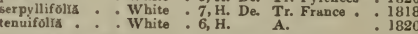

PĀRrY̌x, R. Bronn. In honour of Captain William Edward Parry, R.N., commander of the expedition sent to discover a north-west passage. Linn. 15, Nat. Or. Crucifere. A pretty little annual, grow. ing well in the border of the flower-garden.

aretica . . . Purple - H. Her. P. Melville Is 1820

Parsleg, see A piom.

PARgLeT-P1FRT, see Alchemillĭ arvënsis.

PARSLEX-P1ERT, see Erícă uphănẽs.

Parsipip, see Pastināca.

PARsónsĩ , $R$. Brơnn. In memory of James Parsons, M.D., a Scotch botanist. Linn. 5, Or. 1, Nat. Or Apocynacea. Ornamental plants; for culture and propagation, see Echites. Synonymes: 1. Echites corymbosa. 2. E. floribunda.

corymbork, 1 . . Red . . 7, S. Ev. Tw. S. Amer. - 1820 floribunda, 2 : : White : 7, S. Ev. Tw. Jamaica : 1820 PARTRD, divided, but not to the base.

Parthenīe M, Linn From parthenos, a virgin; sup. posed medicinal qualities. Linn. 19, Or. 4, Nat. Or. Compositce. Plants of no beauty, growing in any common soil-Hysterophörüs, incänum, integrifoliă.

$\mathbf{P}_{\text {AscãLǏ̆ }}$, Ortega. In honour of Dedan Pascal, M.D., a professor at Parma. Linn. 19, Or. 2, Nat. Or. Composita. This species should be grown in pots, as it requires the protection of the frame in severe frosts; loam and peat suits it well, and cuttings planted under a glass, soon root.

glaúcă . . . Yellow . 7, H. Her. P. Chile • 1799

PAspălîM, Flugge. From paspalos, one of the Greek names for millet. Linn. 3, Or. 2, Nat. Or. Graminec. Curious species of grass, without much beauty, and of easy culture. Synonymes: 1. P. pubescens. 2. P. Swartziana. 3. P. littorale. 4. $P$. orbiculatum. 5. Digitaria pilosa.

distichũm . . Apetal : . 7, Grase. Jamaica * 1776

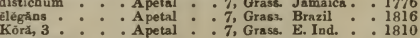
panieulătūm : A Apetal : 6, Grass. Jamaica : 1782 quadrifâriúm : Apetal : 7, Grass. Triuidad : 1820 scrobiculătūm : A petsl : 8, Grass. E. Ind. 1778 stoloniferúm : Apetal : 8, Grass Peru : 1794 ciliatiforam 1 , conjugātam, døŭlé, dịforrmĕ, dissêctam, [ 232 ] 


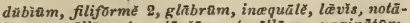
tūm, pusîllūm 4, setācēūm, tenellũm, vaginătam, villōsūm, virgātûm.

PAsqua-ri OWrR, see Aněmōnĕ pulsatillă.

Passarīiă, Linn. From passer, a sparrow; in allusion to the beaked seeds. Linn. 8, Or. 1, Nat. Or. Thymelacea. The plants of this genus flourish well in a mixture of sandy peat and loam; and cuttings of the young wood root freely in sand, under a glass. The seeds of $P$. annua may be sown in spring in the open ground. Synonymes: 1. Stellera Passerina. 2. S. Chamajasme.

\begin{tabular}{|c|c|c|}
\hline $\begin{array}{l}1 \\
\text { lordès } \\
\text { rafolia } \\
\text { és } \\
\text { nis: }\end{array}$ & 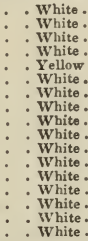 & $\begin{array}{l}7, \mathrm{H} . \\
: 5, \mathrm{G} \\
: 7, \mathrm{G} \\
: 5, \mathrm{G} \\
: 7, \mathrm{G}\end{array}$ \\
\hline
\end{tabular}

1759 1823

1789

1818

1834

1810

1752

1759

1804

1820

1817

1817

1817

Passtrióră, Linn. From passio, passion, and flos, a flower; in allusion to the filamentous appendages or rays bearing a resemblance to the emblems of the passion of Christ. Linn. 16, Or. 2, Nat. Or. Passifloracee. The species of this interesting and elegant genus are admirably adapted for stove and greenhouse climbers, being of easy culture, free growers, and if allowed plenty of room, producing abundance of beautiful Howers; many of the kinds produce fruit freely, from which, through impregnation, several fine hybrids have been raised. The fruit of some, as $\boldsymbol{P}$. edulis, laurifolia, and $\boldsymbol{P}$. quadrangularis, or Granadilla, are eaten; the succulent pulp which surrounds the seeds is found to be fragrant, cooling, and pleasant, agreeably acid, and admirably adapted for allaying thirst in hot climates. $P$. edulis and $P$. laurifolia will fruit freely in the plant stove. The quadrangularis bears fruits resembling a large lime, and to cause it to produce them in abundance, should be treated as follows:-Plant it in a large box, or in a partitioned-off corner of a stove, or tanpit; if in the latter, holes may be bored in the sides to admit the egress of the roots into the tan. The shoots should be trained parallel to the glass as vines, and treated similar to melons, that is, the most vigorous shoots removed, as they will be found not to bear so freely as those of a moderate growth; it will generally be found necessary to set the fruit by artificial impregnation, taking care to give the plant abundance of water. All the species will thrive well in a mixture of loam and peat, and are easily increased by cuttings planted in sand. The hardy kinds should be planted in sheltered situations. Synonymes: 1. P. heteropliylla. 2. P. lunata. 3. P. lyrafolia. 4. P. palmata. 5. P. hircina. 6. P. hibiscifolia. 7. P.glabrata. 8.P.peltata. 9. P. discolor. 10. P. glauca. 11. P. punctata.

Adiăntûm . . Yellow . S. Ev. Cl. Norfolk Is, 1792 alătă : : Gr. blu. red 6, S. Ev. Cl. W. Ind. . 1772 alătó-cœinùlẻa : White. 8, S. Ev. Cl. Hybrid : 1823

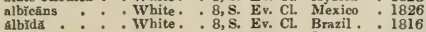
Andersōnn : : Striped : 8, S. Ev. Cl. St. Lucia - 1823 S. Ev. CL. Mexico

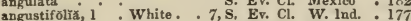

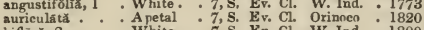
biflöră, 2 . White. - 7, S. Ev. Cl. W. Ind bryonieefoliă . Whitish - S. Ev. Cl. Mexico cærŭlęa . Wht. blue 8, H. De. Cl. Brazil angustifolya : Whit. blue 8, F. Ev. Cl. Hyhrid
Colvillir. Varieg. 8, H. De. Cl. Hybrid glaueophylla . Blue * 8, H. De. Cl. Brazil. carcie 8, Ev. Cl. Hybrid capsulariśs * * Yel. grn. * 6, S. Ev. Cl. W. Ind. geutióba * Yel. grn. * 6, S. Ev. Cl. Brazil. geminifóliă . Yel, grn. . 6, S. Ev. Cl. Jamaica Cavanillësil : : Copper : 8, S, Ev. Cl. W. Ind. cephaheimă : S. Ev. Cl. Brazil. chinensǐs - . Wht, blue 8, G. Ev. Cl, China . ciliata * - Pink * 8, S. Ev. Cl Jamaiea - Searlet 9, S. Ev. Cl. Guiana [ 233 ] cùprèă

digitat

filamentề

gossy pi iffǒlǐă, $\epsilon$

gracilis

hederảeéa

hemicỹelă, 7

heterophȳllă

hirsûtã

holoserìcę .

incarnātă

kermesinà

laurifolix

ligulárìs

houdón

lutea $\dot{0}$

maliformis

Maximiliänă,

Mayãnĩ

mexicănă

minimă.

mueronătă

multiflóră

multiförmis

normalis

oblongătà

obseñá.

onyehină

pällida

palmăt

pătŭla

peltáta

perfolistå

phœnicéa

picturata

pubéscẽns

punctătă

quadrangulärǐs

racemósa

prīneēps

Raddiāna

rũbrà

rūbrá

serrătā

serratifolia

sexiflóră

stipula tă, 10

suberosa

tinifolra

tuberōsă, 11

tucnmanēnsìs

ulmiforliă

vespertǐliōo
vitifolià

Passion rlower, see Passiflörŏ.

Pasrin Ācă, Tournefort. From pastinum, a dibble; in allusion to the form of the root. Linn. 5, Or, 2 , Nat. Or. Umbelliferce. P. sativa, or Parsnep, is a well known culinary root: the other species are unworthy of cultivation. They are only increased from seed, which should be sown in spring in the open ground. Synonymes: 1. Ferula faniculacea. 2. Malabaila graveolens. 3. Smyrnium ntudicaule. 4. Malabaila pimpinelloides. 5. P. opaca, P. sylvestris. 6. P. dissecta-P. fæniculäcẽă 1 , divarícãtă, gravěolēns 2, latifolǐă, lŭcĭdă, nudicaũlĭs 3, panacifroliă, pimpineltifolǐă 4, satīvă 5 , Sekăkūl 6, stenocärpă, taraxacifoliă, umbrôsă.

Patagonũua, Linn. From the name of its native country, Patagonia. Linn. 5, Or. 1, Nat. Or. Boraginacede. This is an ornamental tree, growing well in an equal mixture of loam and peat; cuttings planted in the same kind of soil, under a glass, root readily. Synonyme: 1. Cordia Patagonula.

amerieānă, 1 . . White . . 7, S. Ev. S. S. Amer. . 1732

PATEILĀRİ́, Fries. Derived from patella, a sancer; form of the cup. Linn. 24, Or. 9, Nat. Or. Fungi. A.n extremely minute species, found on woodP. atrātă.

PAtent, spreading, diffuse.

Patersônî́, R. Bronn. In honour of Colonel William Paterson, an excellent botanist. Linn. 16, Or. 1, Nat. Or. Iridacea. A handsome genus of plants, in habit and growth resembling the Iris; they succeed well in sandy peat, and may be increased by divisions, or seeds. Synonyme: 1.P. glauca. 


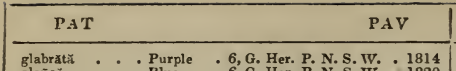

glaūeă : : Blue : 6, G. Her. P. N. S. W. : 1820 lanātă * : Blue : . 6, G. Her. P. N. S. W. 1824 longifolră : Blue * 6, G. Her. P. N. S. W. : 1818 longiscã pă, 1 : Blue : . 6, G. Her. P. N. S. W. mediă ${ }^{-}$Purple 6, G. Her. P. N. S. W. 1816 occidentalis : Blue : 6, G. Her. P. N. S. W. : 182 sericea . : : Blue : 6, G. Her. P. N. S. W. : 1803

\section{Patırnce, see $R$ ũmēx patiēntiă.}

Patríñă, Jussieu. Named in compliment to M. Patrin, a Siberian traveller. Linn. 4, Or. 1, Nat. Or. Valerianacea. Pretty plants, succeeding well in a light rich soil; multiplied from seeds. Syno. nonymes: 1. P. nudiuscula. 2. Valeriana sibirica, Fedia rupestris. 3. P. serratulifolia. 4. P. coronata, Valeriana ruthenica, $V$. sibirica.

intermédră, 1 . Yellow . 6, H rupéstris. $2:$ : Yellow : 5, H. scabiosæfoliă, 3 : Yellow :6. H.

B. Siberia . 1820 B. Siberia : 180 B. Dahuria : 1817

\section{Paturous, slightly spreading.}

Pauciftōră, few-flowered.

Pauli.inĩă, Schumacher. In honour of S. Paulli, professor of botany at Copenhagen. Linn. 8, Or. 3, Nat. Or. Sapirdacea. These species succeed well in light loamy soil, and ripened euttings root in sand, under a glass, in heat. Some of them are said to be poisonous.

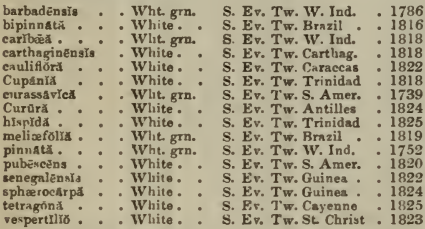

Paurtĩĭ̌̀, see Serjäiă.

PAUPBRitrous, poor, having a starved appearance.

PAvêtrō, Linn. The name of one of the species in Malabar. Linn. 4, Or. 1, Nat. Or. Cinchonaced. Handsome shrubs, growing best in an equal mixture of sandy loam and peat; increased from cuttings in sand, under a glass, in heat. Synonymes: 1. P. indica. 2. P. alba, Ixora paniculata.

arenŏsă, 1 . . White. . 6, G. Ev. S. China . . 1799

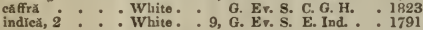

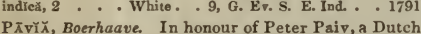
botanist, once professor at Leyden. Linn. 7, Or. 1, Nat. Or. Asculacea. Handsome flowering shrubs or trees; increased by layers, or by prafting on the common horse chesnut. When seeds can be obtained, they should be sown in March in common soil, about an inch deep. Synonymes: 1. Asculus discolor, Pavia hybrida. 2. E flava. 3. Esculus Pavia macrocarpa. 4. P. parviflora, E. macrosta. chyu. 5. A. neglecta. 6. AE.Pavia. 7.P. humilis. chrnea - . Red . H. De. T. 1820 discolor, 1 : Red yel. : 6, H. De S. N. Amer. : 1812 flava, 2.: Yellow :5, H. De. T. N. A mer. : 1764 macrocäpă, 3. Red yel. 5, H. De. T. 1826 maerostachyin, 4. White - 6, H. De T. N. Amer. : 1820 neglécta, 5. : Pa. yel : 5, H. De. T. 1823 rübră. 6. : Scarlet 5, H. De. S. N. Amer. arkatá : : Red : : 5 H. H. De. S. Europe N. Amer.

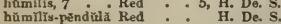

sublaciniătă. . Red : 5 , H. De. S. N. Amer.

PAvōnĩ Á, Cavanilles. In honour of Don Josef Pavon, M.D. of Madrid, a traveller in Peru, and, in conjunction with Ruiz, the author of "Flora Peruviana." Linn. 16, Or. 8, Nat. Or. Malvacea. Mostly species of no merit, growing in any light rich soil cuttings root readily in sand, under a glass; they may likewise be increased by seeds. Synonymes. 1. Hibiscus cancellatus. 2.P. spicuta. 3. Lebretonia Schrankii. 4. H. spinifex. 5. Urena Typhalea.

encrĭnea

SchrănkiI, 3

Tyohà lé, 5 typhaloidè
Scarlet

S. Ev. S. St. Domin.

1816 Scarlet * 7, S. Ev. S. Brazil Pa, red. S. Ev. S. Trinidad
PAV

PEG

cancellätă 1, Columèllă, corymbósă, leptocärpa, odorütă, paniculätă, parvifloră, pramorsă, racemósă 2, sidoìdēs, spinnîfex 4, ûrēns, zeyläniccă.

PAvonrous, spotted so as to resemble a peacock.

Paxtóñ̌, Lindley. In compliment to Joseph Paxton, F.L.S., H.S., gardener to His Grace the Duke of Devonshire, Chatsworth, and conductor of the Magazine of Botany. Linn. 20, Or. 1, Nat. Or. Orchidncea. This pretty species may be success. fully grown in a mixture of very turfy loam, leafmould, and sand, with the treatment given to Bletias.

rơsèă . . Pink . . 7, S. Ter. Philippines . 1837

PEA, see Pisñm.

PвAcr, see $A$ my̆gdălŭs.

PEAR, see Py̆rǔs.

Prarlwort, see Sagīnd.

Prctinarĭ Liun. 5, Or. 2, Nat. Or. Asclepiadace.e. This species requires the same treatment as the genus Stapelia. Synonyme: 1. Stapelia articulata.

articulätă, 1 . . Purple - 7, S. Ev. S. C. G. H. $\quad 1800$ Prctinate, or pectinated, like the teeth of a comb, or rake.

Pücris, Less. From pecten, a comb; appearance of the teeth of the pappus. Linn. 19, Or. 2, Nat. Or. Composita. Stove annuals, of neither interest nor beauty, and the simplest culture-P. canesseens, cili. àris, humifüsă, linifolīă, prostrütă.

Pectoral, relating to the breast.

Prdálí $\mathrm{M}$, Linn. From pedalion, a rudder; in reference to the dilated angles of the fruit. Linn. 14, Or. 2, Nat. Or. Pedaliacea. A curious annual, remarkable for its hard, nut-like fruit, with sharp points or horns; it prefers a mixture of loam and peat.

mürex - . . Whlt. pur. 8, S. A. E. Ind. . 1778

PEDAtB; when leaves are cut in divisions, and the outer divisions again lobed, they are pedate

Pedatifid, cut into lobes, the lateral ones not radiating from the petiole like the rest.

Prorezr, commonly applied to the partial footstalks of flowers.

PedicuziñÝs, Linn. From pediculus, a louse; supposed effect on sheep eating it. Linn. 14, Or. 2, Nat. Or. Scrophulariacea. Beautiful little plants, with very regular, finely-cut leaves; they thrive best if planted in a mixture of peat soil, and kept moderately moist. The best way of obtaining an increase is by seeds. Synonyme: 1.P. asplenifolia.

adscêndēns . . . Red . . 7, H. Her. P. SwitzerL. . 1819 atrorúbens, 1 : : Dk. red : 7, H. Her. P. Switzerl. : 1819 canadensis's: : Yellow: 7, H. Her. P. N. Amer. : 1780 canadensis : : Yellow : 7, H. Her. P. Italy

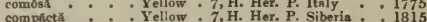
euphrasioldès : Purplo: F. Her. P. Siberia : 1816 flammea . - Yel. sear. 7, F. Her. P. SwitzerL: 1775 foliósa : : Cream 7, F. Her. P. Austria : 1786 gyroféxa: : - Purple: 7, F. Her. P. Switzerl: 1819

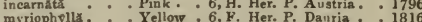
mylústris : : Purple: 6, H. Her. P. Britain: 1816 recutita: : Purple : 6, F. Hex. P. Austria : 1787 resupinåăa : Purple: 7,F. Her. P. Siberia : 1810 rostráta : Purple:6, F. Her. P. Switzerl. 1819 Scēptrüm carolinúm Yellow : 7, F. Her. P. Sweden . 1793 sylvatiex. - Pink : 8, H. Her. P. Britain : 1799 uncináta : : : Yellow : 6, F. Her. P. SwitzerL: Her. P. Siberia : 189 versicolor : Y Yellow: 5, F. Her. P. Switzerl. 1819 verticillata : : Rose : 7, F. Her. P. Austria : 1790

Pedrr.̄̄Nthŭs, Necker. From pedilon, a slipper, and anthos, a flower. Linn. 11, Or. 3, Nat. Or. Euphorbiacee. Curious plants, resembling Euphorbia in habit and general appearance, to which genus they may be referred for enltivation, \&z. Synonymes: 1. Euphorbia canaliculata. 2. Crepidaria carinata. 3. C. cordellata. 4. P. myrtifolius, Crepidaria myrtifolia.

canaliculătŭs, 1. A petal . 7, S. Ev. S. S. Amer. . 1820 carinătŭs, 2 : A petal : 7, S. Ev. S. S. Amer. : 1820 cordellåtŭs, 3 : : A petal : 7, S. Ev. S. S. Amer. : 1699 padifólíus : : A petal :7, S. Ev. S. S. Amer. : 1699 subcarinatŭs : Apetal :7, S. Ev. S. S. Amer. : 1795 tithymaloidës, 4 : A petal : 7, S. Ev. S. S. Amer. : 1820

Peduncti, flower-stalk.

PEgÃNür, Linn. From peganon, rue; on account of the resemblance. Linn. 11, Or. 1, Nat. Or. Zygo- 


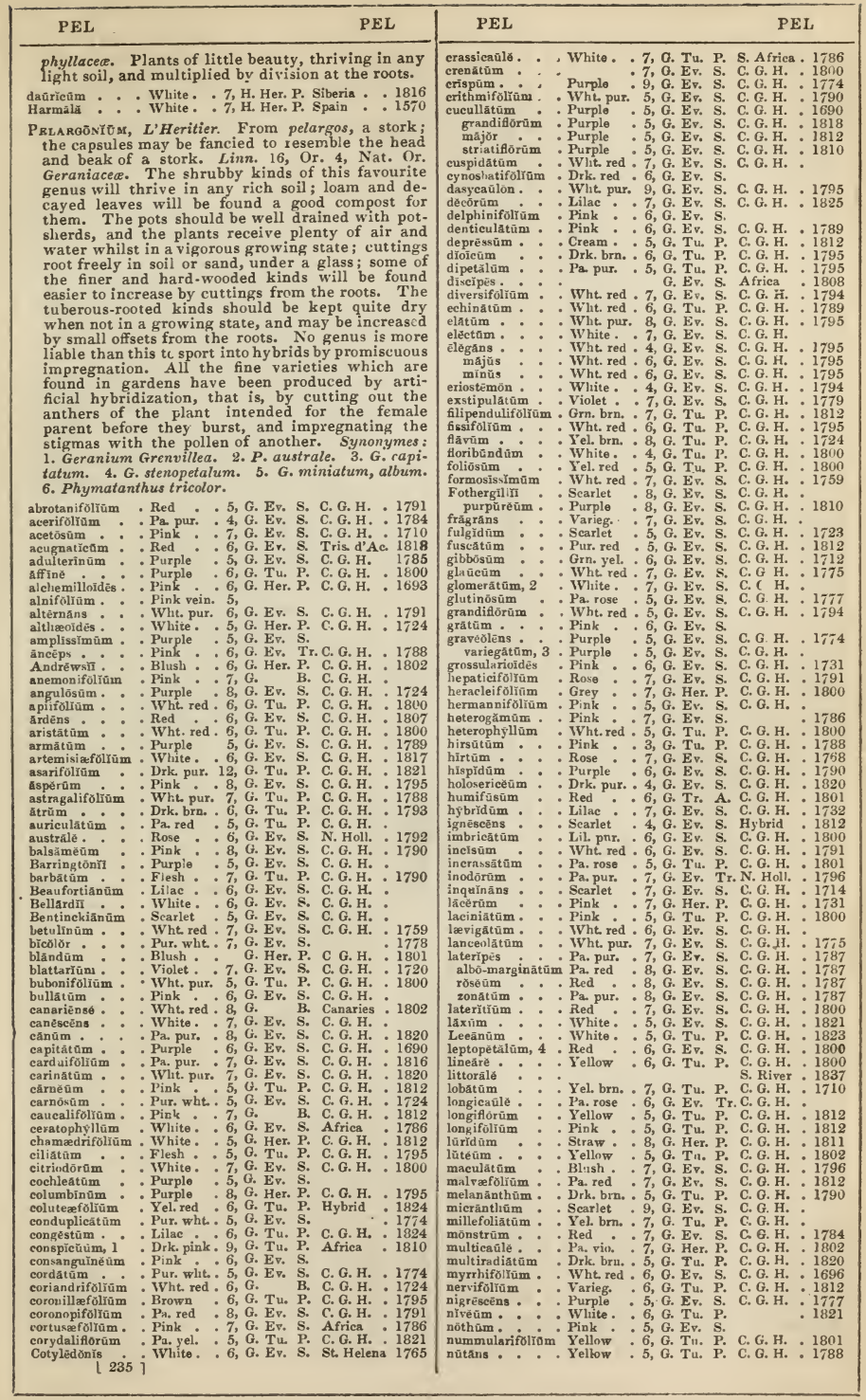




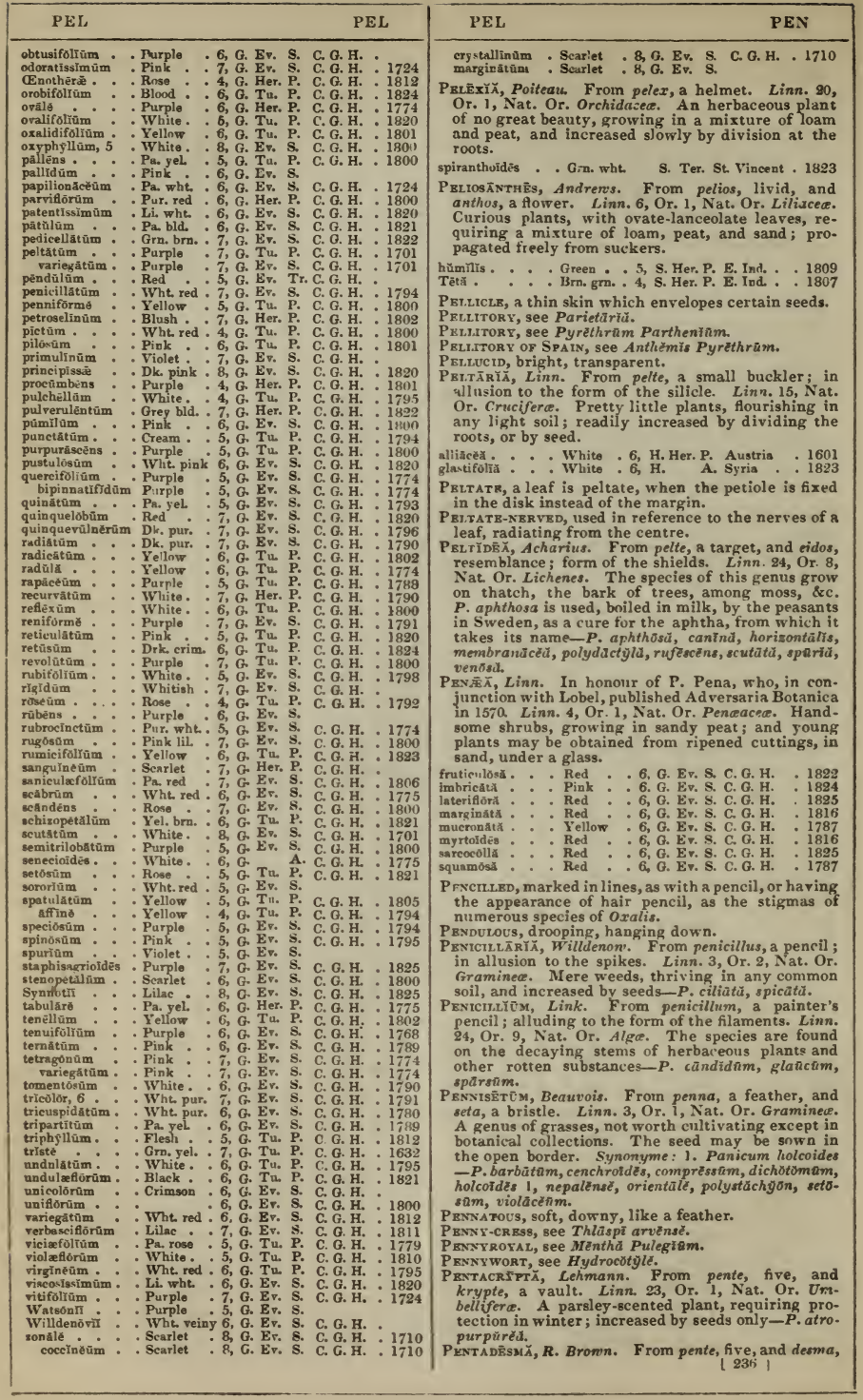


a bundle; the stamens are disposed in five bundles. Linn. 18, Or. 2, Nat. Or. Guttiferce. A handsome, lofty-growing tree, very difficult to transplant, on account of the long tap-root, which, if injured, will kill it; the tree produces its flowers when about twenty feet high. It requires a strong moist heat. A mixture of loam and peat suits it; and ripened cuttings, with their leaves not shortened, will root in sand, under a glass, in a moist heat.

butyråcěă . . . . 11, S. Ev. T. S. Leone . 1822

Pristagonal, having five angles.

Prentagnous, having five styles.

Pentandrous, having five stamens.

Pentapetalous, having five petals.

Pextäpētes, Linn. One of the Greek names for Cinquefoil. From pente, five; alluding to the fivecelled fruit. Linn. 16, Or. 7, Nat. Or. Sterculiacea. Beastiful flowering plants, growing in any light rich soil; cuttings soon root in mould or sand, under a glass, in heat. Synonyme: 1. Brotera ovata.

ovătă, 1 . - Searlet . 7, S. B. N. Spain . 1805 phœenicéă: : : Scarlet :7, S. Her. P. India : 1690

Pentarāphǐă, Lindley. From pente, five, and raphis, a spike. Linn. 14, Or. 2, Nat. Or. Gesneracee. A handsome West Indian plant; for culture and propagation, it may be referred to Gisneria. Synonyme: 1. Gesnera ventricosa.

longitiôră, 1

$$
\text { 7, S. Ev. S. Jamaica - } 1823
$$

Prathŏrūm, Linn. From pente, five, and horos, a boundary; the capsule is terminated by five beaks. Linn. 10, Or. 5, Nat. Or. Crassulacece. A succulent plant of little beauty, growing in light sandy soil, and increased by division at the roots; cuttings also root freely under a glass.

sedoïēés . . . Grn. yel. . 7, H. Her. P. Virginis • 1768

Prntstēmōn, L'Heritier. From pente, five, and stemon, a stamen; there are four perfect, and one imperfect. Linn. 14, Or. 2, Nat. Or. Scrophulariacee. Charming herbaceous plants, worthy of a place in every collection; they all delight in a mixture of loam and peat, and are readily increased by divisions, or by seeds. Synonymes. 1. Chelone carulea, hirsuta. 2. C. atropurpurea. 3. C. cristata. 4. C. erianthera. 5. P. Bradburii. 6. C. angustifolia. 7. C. elegans, P. elegans. 8. C. rosea, angustifolia.

acuminátŭm - Purple * 7, H. Her. P. N. Amer. 1827 acuminátúm : Purple * \% H Her. P. Amer. albiaum " White * 7, H. Her. P. Missouri - 1823 sngustifolrŭm, 1 . Li. pur. - 8, H. Her. P. Louisiana * 1811

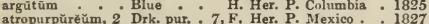
atropurpŭrĕŭm, 2 Drk. pur. . 7, F. Her. P. Mexico *. 1827
attentı̄tūm

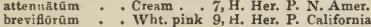
brevifiōrūm - Wht. pink 9, H. Her. P. California campanulatūm : Li. pur. . 6, H. Her. P. Mexico Cobãa - Pa, pur. - H. Her. P. Texas. confertüm : Pa. yel. 7, H. Her. P. N. Amer. crassifơlĭủm : Blue . .6, H. Her. P. N. Amer. deūstūm * Cream . H. Her. P. N. Amer. diffúsūm : Purple 9, H. Her. P. N. Amer digitalirs : White. 8, H. Her. P. Arkansas erianthērūm, 3 : Purple : 8, H. Her. P. Louisiana glảbrûm, 4. - Drk. pur. 8, H. Her. P. Louisiana glaberrinuŭm : Blue - H. Her. P. Columbia glandulósŭm : Pa.blue $6, \mathrm{H}$. Her. P. N. Amer. glaũcūm : Pă lilac grăcillis

7, H. Her. P. N. Amer. 8, H. Her. P. N. Amer. 7, H. Her. P. N. Amer. heterophyllum : Red : 7, H. Her. P. California
hirsütūm
Kúnthǐ, $6:$ Pa. pur. : 8, H. Her. P. N. Amer. heterophyllum : Red : 7, H. Her. P. California
hirsütūm
Kúnthǐ, $6:$ Pa. pur. : 8, H. Her. P. N. Amer.

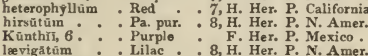
lævigãtûm : Lilac : : 8, H. Her. P. N. A
Mackayãnūm : : Pur. yel. : 8, H. Her. P. Ohio Murrayãnūm - Scarlet : 8, H. Her. P. S. Felipe ỡa ûm. . Blue . 7, H. Her. P. N. Amer. procürüm - Purple : 7, H. Her. P. N. Amer. pruinōsũm - . Blue 6, H. Her. P. N. A mer. pubẽscēns : Pa. pur. : 8, H. Her. P. N. Amer. pulchellūm, 7 . Lilac : 7, 5 . Her, P. Mexico. RichardsōnII . Drk. pur. - 7, H. Her. P. Columbia . 1825

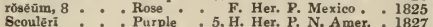

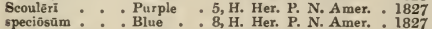
staticaforlum : Lilac: : 6, H. Her. P. California : 1833 triphyllūm : . Pa, red : 7, H. Her. P. California : 1827 venūstūm : : Purple : 6, H. Her. P. N. Amer. : 1827

Pentž̆. Named by Thunberg, in honour of his pupil Charles John Pentz. Linn. 19, Or. 1, Nat. Or. Composita. A bushy, hoary-branching shrub, with cory mbs of little yellow flowers; it grows in a $[237$ ] mixture of loam and peat, and ripened cuttings root freely in sand, under a glass. Synonyme: 1 . P. crenata, Tanacetum flabelliforme.

flabelliformis, 1 . Yellow . 6, G. Ev. S. C. G. H. . 1774 PEPRRōmĭă, Ruiz and Pavon. Analogo:as to Piper. Linn. 2, Or. 3, Nat. Or. Piperacee. This is the herbaceous tribe of Pepper. The species grow freely in an equal mixture of sandy loam and peat, and may be increased by cuttings, or divisions of the roots.

acuminsta.

alstir

Apetal

6 , S. Her. P. W. Ind.

812

alati:- Apetal

amplexiföliă

A petal

3, S. Hex. P. S. Amer

S. Her P. W. Ind. : 1793

, S. Her. P. S. Amer. 1823

brachyphyllă: A petal

capensis

clusiæfoli :

coriácèa

Green

7, S. Her. P. S. Amer.

5, S. Ev. Cr. C. G. H. 1820

5, S. Ev. Cr.S. Amer.

A petal 5, S. Ev. S. E. Ind.

discőlör. : A petal

distăchy̆ă : : A petal

hispidüla : A Aeta

hūminlis : : A petal

inaequalifolia : Apetal

macrostắchy̆ă: : Green

magnoliæfóliă . Apetal

maculōsă A petal

nummulariæfóliŭ A peta

obtusifóliă . . A petal

ovalifolia : : Green

pellucĭda : A peta

pereskiæefolř : A peta

polystáchýa - A petal

pulchêllă: : : A petal

quadrifölĩa : A peta

renifôrmis . Green

rëpêns : : Apetal

rotundifóliă : A petal

rubellă ${ }_{\text {rubricaúlis: : : A petal }}$

serpeñs

stellată : : A petal

subrotûnda $\quad$ A petal

talinifoliă . . Green

tenêllă . . : Green

tıicarinătă . : Green

S. Her. P. S. Amer. 182

6, S. Her. P. S. Amer. : 1793

8, G. B. Jamaica : 1818

6, S. Her. P. W. Ind. : 1768

S. Hex. P. Peru

5, S. Ev. Cr. Trinidad 182

2, S. Her. P. W. Ind. 1793

S. Her. P. St. Domin. 1790

6, S. Her. P. Jamaica 1818

5 S. Her. P. W. Ind. 1739

5, S. $E_{\text {V}_{0}}$ Cr. St. Vincent 1824

6, S. A.S. Amer. . 1748

5, S. Her. P. S. A mer. . 1820

S. Hex. P. Jamaica : 1775

8, S. Her. P. Jamaica 1778

6, S. Her. P. S. A mer.

5, S. Ev. Cr. St. Vincent 1824

, S. Ev. Cr.S. Amer. 1823

6, S. Her. P. S. Amer : 1822

3, S. Her. P. W. Ind. : 1820

5, S. Ev. Cr. Jamaica : 1820

6, S. Her. P. Jamaica 1809

2, S. Her. P.

S. Ev. Cr. W. Ind. 1820

5, S. Ev. Cr. Jamaica : 1820

5, S. Ev. Cr. W. Ind. 1818

5, S. Ev. Cr. W. Ind. : 1826

tristăchy̆a : . 5 , S. Ev. Cr. W.Indane. Linn.

6, Or. 1, Nat. Or. Lythracece. The species of Water Pursiane grow in any very moist soil, in which also the seeds may be sown.

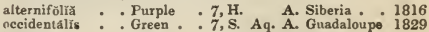
necidentálís : : Green : 7, S. Aq. A. Guadaloup
Portũlă . : : Purple : 8, H. Aq. A. Britain .

Peppisr, see Pïpěr.

PBPPERMint, see Mënthă piperită.

PEPPER MINT-TRER, see Eucalȳptüs piperītă.

PePprR-vine, see Ampelópsis bipinnütă.

Peppkrwort, see Lepídiũm.

Perdičùu, Linn. From perdix, a partridge; partridges were fond of the original plant. Linn. 19, Or. 2, Nat. Or. Composite. An uninteresting hardy herbaceous plant, succeeding in any common soil. Synonyme. 1. Tussilago Anandria-P. Anandriŭ 1.

Perkgrinous, wandering, diffuse.

Perensial, lasting many years without perishing.

Pereskř F. Pieresk, of Aix, in Provence, a lover of botany. Linn. 12, Or 1, Nat. Or. Cactaceae. Grotesque and ornamental plants, very different from the rest of the genera in Cactacea, from the branches being woody, as well as furnished with proper leaves. The species grow freely in any light soil; and cuttings root readily in mould, under a glass, in heat. Synonymes : 1. Cactus Pereskia. 2. C. portulacafolia. a culeâtx, 1. . . White . 10, S. De. S. W. Ind. • 1696 Bléó. : : Par red : 11, S. De. S. Mexico : 1827 grandifoira: : : Par red S. De, s. Brazil : 1818 longispină : S. De. S. S. Amer. : 1808 portulacæefolina, 2 . White - S. De. S. W. Ind. : 1820

Perforated, full of holes.

Perguläkră, Linn. From pergula, trellis-work; twining plants, fit for arbours, \&c. Lirnn. 5, Or. 2, Nat. Or. Asclepiadacea. A genus much prized for the fragrance of the flowers. All the species prefer a rich mould, and are readily multiplied by cuttings. 

caly $x$ cannot be distinguished from the corolla, as in Lilium, \&c. \&c.

PrRIBĀLĨ̆, Trinius. From periballc, to encompass. Linn. 3, Or. 2, Nat. Or. Gramineu, A worthless species of grass, growing in any common soil, and increased by seeds. Synonyme: 1. Aira involucrata -P. hispānācă 1 .

Pertcāliris, D. Don. From perikalles, very pretty; radial ligulæ beautiful. Linn. 19, Or. 2, Nat. Or. Compositie. A very desirable plant; increased by cuttings or seeds, and treated as the Cinerarias. Synonyme: 1. Cineraria tussilaginis, Senecio tussilaginis.

tussilaginnǐs, 1. . Purple . 4, G. Her. P. Teneriffe . 1829

Pericarp, the seed-vessel.

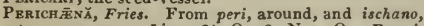
to encompass. Linn. 24, Or. 9, Nat. Or. Fungi. Very minute Fungi, found on the cones of Pinus Abies, and dead trunks of trees-P. populină, strobiînă.

PrRichastal, leaves which in mosses surround the base of the stalk of the theca.

Prerigong, the calyx and corolla.

Prrigynons, inserted in the calyx, or in the disk which adheres to it.

PERT̃L, L, Linn. The meaning not explained. Linn. 14, Or. 1, Nat. Or. Labiate. Plants of little merit, flourishing in any light loamy soil.

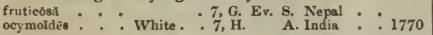
PrRILUMİ, Humboldt and Bonpland. From peri, around, and loma, a fringe; in allusion to the menbranaceously-winged achenia. Linn. 14, Or. 1, Nat. Or. Labiate. For the culture and propagation of this pretty species, see Prostanthera.

ocymoidés . . Purple . 8, G. Ev. S. Peru

PrRiŏlă, Fries. From peri, about, and ioulos, down; appearance of the species when growing. Linn. 24, Or. 9, Nat. Or. Fungi. A minute fungus, growing on potato roots, \&c., $\boldsymbol{P}$. tomentosad.

PERIPIő́ca, Linn. From periploke, an intertwining ; alluding to the habit of the plants. Linn. 5, Or. 2, Nat. Or. Asclepiadacea. Handsome species, growing freely in any common soil. $\boldsymbol{P}$. greca is a valuable hardy plant for covering naked walls, \&c. They are readily propasated by layers, or cuttings, under a glass.

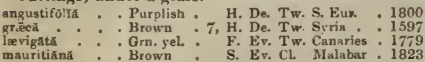

mauritiañă: : Brown : S. Ev. CL. Malabar: 1823 cock; resemblance in the form of the flower. Linn. 16, Or. 8, Nat. Or. Malvacee. A pretty little shrub, growing about three feet high, in a mixture of loam and peat. The species ripens its seed freely, from which it may be increased, as also from cuttings in sand, under a glass. Synonymes : 1. Sida Periptera, Anoda punicea.

punIceà, 1 . . . Crimson . 5, S. Ev. S. N. Spain . 1814 Preipheric, circular, curved.

PERTstérí, Hooker. From peristera, a dove; in allusion to the dove-like appearance of the column. Linn. 2n, Or. 1, Nat. Or. Orchidacere. This is a genus of splendid plants, the most remarkable and interesting of which is the P. elata; it produces a long spike of yellowish-white waxy flowers, yielding a very pecut's fragrance. In the neighbourhood of Panama, it is known to the natives by the appellation of "el Spirito Santo," and the reason for this name is quite obvious on looking at the flower; the centre of it exhibits a column which, with its summit and the projecting gland of the pollen-masses, together with the erect wings, bears a very striking resemblance to the figure of a Dore: whence the English name of the genus Dove-flower. The species should be grown in pots well drained, in a mixture of fibrous loam, lenfmould, and sandy peat, and must not be overwatered at any season, more especially when torpid; they are increased by separating the pseudo-bulbs.

Barkéri . * Yellow . 6, S. Epi. Mexico • . 1837

$\begin{aligned} & \text { Barkéri } \\ & \text { cerina }\end{aligned}: \vdots:$ Yellow : 6, s. Epi. Mexico * : ${ }^{1837}$

cerínă : : : : Yellow : 6, s. Epi. S. Main : 1835

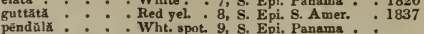

Pertstome, the rim which surrounds the orifice of the theca of a moss.

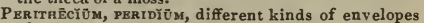
of the reproductive organs of Fungi.

Peritómă, Decandolle. From peritume, a cutting round about; base of the calyx. Linn. 15, Nat. Or. Capparidacec. The seeds of this plant require to be sown on a gentle hotbed, and the plants, when large enough, to be turned out into a sheltered situation in the flower-garden. Synonyme: 1. Cleome serrulata.

serrulată, 1 . Purple - 7, H. A. Missouri - 1823

Periwixkle, see Vincă.

PERMANENT, or PERsistent, remaining, not falling off. PERörǐs, Aiton. From peros, deficient; alluding to the flower. Linn. 3, Or. 2, Nat. Or. Graminea. An annual species of grass, succeeding in any common garden soil.

latifolră . . A petal . . 8, Grass. E. Ind. . 1777 PrRpusĩllǔs, very small.

Persǔñ, Gartner. A name applied by Theophrastus to an Egyptian tree. Linn. 9, Or. 1, Nat. Or. Lauracea. This ornamental species succeeds well in a mixture of turfy loam and peat. The best way of propagating it is by layers, which root freely. ripened shoots, taken off at a joint, and planted in sand, under a glass, in heat, will sometimes root. Synonyme: 1. Laurus Persea.

gratisvima, 1 . . Grn. yel. . S. Ev. S. W. Ind. . 1739 Persian sux's-eye, see Tálipă ocũlŭs solis.

PERsICÃ, Tournefort. So named from the Peach-tree - coming originally from Persia. Linn. 12, Or. 1, Nat. Or. Rosacee. To this genus belong the well' known and much-esteemed fruits the Peach and Nectarine. The different kinds are propagated by budding on Damask plum-stocks, and new varieties are raised from the stone, after a mixture of the sorts by impregnation. In this country, they are usually trained on south walls in the fan manner, which is allowed to be the most natural. The soil best suited for them is three-parts mellow loam, enriched with one-part vegetable mould. Synonymes: 1. Amygdalus Persica Nectarina. 2. A. Persica.

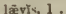

vulgärís, 2

albi.

Red

4, H. De. T. Persia . 1562

Red : 4, H. De. T. Persia

1562

comprëssă

White:

4, H. De. S. Persia

4, H. De. T.

fol. variegátis

4. H. De. T. Persia
4, H. De. T. Yersia

PersoōnǏs, Smith. In honour of C. H. Persoon, a distinguished botanist, the author of Synopsis Plantarum, and other valuable botanical works. Linn. 4, Or. 1, Nat. Or. Proteacec. An ornamental genus of plants, growing from five to seven feet high, and thriving well in a mixture, of equal parts of loam, peat, and sand; and cuttings of the ripened wood root in sand, under a glass.

chamxpitys . . Yellow . 6, G. Ev. S. N. Holl. - 1824 ferrugineă . : Yel. red. : 6, G. Ev. S. N. s. W. : 1823 hirsütá. : Yellow . 6, G. Ev. S. N. S. W. 1800 flexifolia: : Yellow : 6, G. Ev. S. N. Holl. : 1824 6, G. Ev. S. N.S. W. * 1826 latiföluă. : : Yellow : 6, G. Ev. S. N. S. W. : 1795

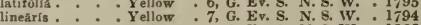
lineăris : : : Yellow : 7, G. Ev. S. N. S. W. $: 1794$
mollis : : myrtilloidẽs : $\quad$ G. Ev. S. N. S. W. : 1837 nütāns . : Yellow G. Ev. S. N. Holl. : 1824 pâllìdă : : Orange : 7, G. Ev. S. N. Holl. 1824 pinifolia : : Yellow : 6, G. Ev. S. N. S. W. 1822 pruinösă * - Yellow • 6, G. Ev. S. N. S. W. • 1824 stlicină. . . Pink * 7, G. Ev. S. N. S. W. - 1795 scábră : : Yellow : 6, G. Ev. S. N. S. W. : 1824 spatulata
tenuifoliă

l'urrus $\rightarrow$ RIA, Acharius. Derived from pertusus, full of holes. Linn. 24, Or. 8, Nat. Or. Lichenes. A new genus of cryptogamic plants, nearly allied to Verrucaria- $P$, isidioldês.

P'ERvius, having a passage through which anything can be transmitted.

l'rouatérín, Thouars. From pipto, peso, to fall, and [238 ] 
meros, a part; the sepals are spentaneously thrown off from the flower shortly after they have expanded, just as leaves are thrown off the stems of many of these plants when they receive a sudden check, and then the petals and labellum only remain to constitute the flower. Linn. 20, Or. 1, Nat. Or. Orchidacea. The plant is nearly related to Bletia and Phaius, but will probably be found to grow best under the treatment given to Burlingtonia.

tetragðnă . . Brown . 12, S. Epi. Maurit. . . 1837 Petat-likg scales in Alsinacea and Silenaced, the stales which are fixed to the throat of the petals.

Petalostēmẽ M, Michaux. From petalon, a petal, and stemon, a stamen; the stamens are joined to the petals at the base. Linn. 16, Or. 2, Nat. Or. Lcguminosa. Pretty herbaceous plants, growing in any border soil; young plants are readily obtained by divisions. Synonyme: 1. Dalea Kuhnistera.

căndĩdūm . . White . . 7, F. Her. P. N. Amer. cárnétum : Flesh : 7, F. Her. P. N. Amer. corymbōsūm, l White 8, H. Her, P. N. Amer. Violet 1811

Petals, divisions of a corolla.

Petiolate, or PETIOLED, having footstalks.

Petiol,viate, having little petioles.

Petivérís. Named by Linnzus in honour of $J$. Petiver, F.R.S., a London apothecary. Linn. 7, Or. 1, Nat. Or. Petiveracee. Ornamental plants, growing in a mixture of loam and peat; they propagate readily by cuttings under a glass.

alliāceă . . . White. . 6, S. Ev. S. Jamaica

White $6, \mathrm{~S}, \mathrm{E}$. W. Ind 1759

PETRĒă. Linnæus dedicated this genus to Robert James, Lord Petre, a famous patron of botany, who died in 1742. Linn. 14, Or. 2, Nat. Or. Verbenacece. Beautiful stove plants. $\boldsymbol{P}$. volubilis is one of the most handsome stove twiners we possess. To grow them well, they must be planted in good rich mould, and kept in a strong heat. They may be propagated readily by cuttings under a glass.

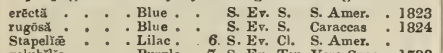
volubilis : : Purple 7, S. Ev. Tw. Vera Cruz : 1733

Petrōbĭum, R. Brown. From petros, a rock, and bio, to live; habitation of the species. Linn. 19, Or. 1 Nat. Or. Composita. An ornamental shrub, growing well in sandy loam; and cuttings root without difficulty in the same kind of soil. Synonymes: 1 . Bidens arborea, Spilanthes arborea.

arborěûm, 1 . Pa. yel. . S. Ev. S. St. Helena . 1816

Petroctirliss, R. Bronv. From petros, a rock, and kalos, beautiful; the plant adorns the rocks on which it grows. Linn. 15, Nat. Or. Crucifera. This little plant is weIl fitted for ornamenting rock-work, or it may be grown in pots, in a mix. ture of sandy loam and peat, and is multiplied by seeds, or divisions at the root. Synonyme: 1. Draba pyrenaica.

pyrenăǐcă, 1 . . Pink - . 5, G. Hex. P. Pyrenees . 1759 Perromarỗŭ, A. Decandolle. From petros, a rock, and maron, a bitter herb. Linn. 5, Or. 1, Nat. Or. Campannlacee. This plant requires to be grown in a sheltered situation, and protected by a frame in winter; it may be increased by divisions. $S y$ nonyme: 1. Phyteuma pinnata.

pinnātă, 1 . . Pa, blue - 8, F. Her. P. Candia 1640

Petrophý, $\boldsymbol{R}$. Bronn. From petros, a stone, and phileo, to love; in allusion to the places in which the plants are found. Linn. 4, Or. 1, Nat. Or. Proteacee. A genus of ornamental shrubs, nearly related to $\boldsymbol{P}$ rotea, to which genus they may be referred for culture and propagation. Synonyme 1. Protea fucifolia.

acicularǐs . . Wlits red . 5, G. Ev. S. N. Holl

canēscêns.

canēscèns

filiföliz

pedıneulátă: White

6, G. Ev. S. N. Holl

teretifolia . . White. 7, G. Ev. S. N. Holl

. 1830

. 1830

.1803

182

182

1824

1790

1824

1824

Petroseiñūm, Hoffmann. From petros, a rock, and selinon, parsley; habitation of the species. Linn.
5, Or. 2, Nat. Or. Umbellifera. P. sativum, the common Parsley, is a well-known culinary herb. The seeds of all the speciee may be sown in spring, in the open ground. Synonymes: 1 . A pium Petroselinum. 2. Sison segetum. 3. Ligusticnm peregrinum.

satīiūm, 1. . Lgt. yel . 6, H. B. Sardinia . 1548

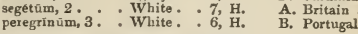

1633

Pвтty-Whin, see Genistă anglică.

Patūñ̌̆, Jussieu. The Brazilian name for tobacco is Petzn; applied to this genus because of its affinity with Nicotiana, Linu. 5, Or. 1, Nat. Or. Solanacea. A highly ornamental genus of freeflowering plants, well adapted for turning out in beds or borders during summer. They will grow in any light soil, but prefer a mixture of sandy loam and vegetable mould; cuttings will strike at any season in heat, care being taken to keep them from damp. Synonymes: 1. Salpiglossis linearis, Nie rembergia intermedna. 2. Nicotiana nyctaginiflora. 3. P. pharicea, Nierembergia phonicea, Salpiglossis integrifolia.

acuminăta - White . 7, F, Her. P. Chile 1827 Atkinsiāna : Crim. pur. 7, H. A. Hybrid: 1834 intermédia, 1 : Yel. pur. 8, F. Her. P. B. Ayres: 1832 nyctaginifloră, 2 White. $\quad 8$, F. Her. P. S. Amer. : 1823 violäcé, 3 . Rose pur. 8, F. Her. P. B. Ayres : 1831

Peucedănẽy, Koch. From penke, a pine, and dunos, parched; so named because of its strong resinous smell. Linn. 5, Or. 2, Nat. Or. Umbelliferc. The species are of no interest, and will grow in any common garden soil. Synonymes: 1. Cnidium alsaticum. 2. Selinum venetum. 3. S. austriacum. 4. S. baicalense. 5.S. peucedanoides. 6. S. polymorphnm. 7. S. Oreoselinum. 8. S. gallicum. 9. S. elegans, P. lineare, 10. S. Bellardi. 11. P. tauricum. 12. P. palustre, Thysselinum palustre. 13. Heracleum pumilum-P. äluūm, alpēstrĕ, alsatǐcūm 1, A. albiflörüm 2, arenärî̃m, aūrēūm, austriăcūm 3, baicalēnsĕ 4, daürīcüm, involucrätūm 5 , isetēnsê, longifolīnm, montānûm 6, officinälë, O. itälícūm, Oreoselīnūm 7, paniculätūm, parisiēnsě 8 , rablēnsĕ $9, \boldsymbol{R}$. Bellärdĩ 10 , rnpēstrë, ruthenīcūm, $R$. tuurĩcūm 11 , seseloz̄dēs, sibĩricūm, S. sylväticum 12, tenuifolīüm, Vocontiörūm 13.

Peūmŭs, Persoon. From Penmo, its Chilian name. Linn. 22, Or. 2, Nat. Or. Monimiacea. An odoriferous tree, attaining the height of thirty feet; it delights in peaty loam, and ripened cuttings root readily in sand.

frăgrāns

S. Ev. T. Chile

1824

PeYroēsĭ French navigator. Linn. 3, Or. 1, Nat. Or. Iri. dacea. A genus of tine bulbous plants, requiring the same treatment as Ixia. Synonyme: 1. Galaxia plicata.

aculeãta

äncêps corymbö̀să

Fabrieli

Blu. yel. . 6, G. Bl. P. C. G. H Blu. yel. 6 , G. Bl. P. C. G. H. Blue Blue
Blue faleătă : Blue fasciculătă, 1 : Blue fissifoliă 5, G. Bl. P. C. G. H. : 1825 6, F. BL. P. C. G. H. : 1791 5, G. Bl. P. C. G. H. $\quad 1825$ silenoidẻs : : Violet: : 6, G. Bl. P. C. G. H. : 1829

PrzizX, Dillnyn. Name derived from Pezica, a tribe of fungi in Pliny. Linn. 24, Or. 9, Nat. Or. Fungi. This is a very extensive genus, containing some of the most beautiful of our fungi, which appear in the end of autumn on decayed wood, or in places where trees have formerly stood; they are in the form of small undulated scarlet cops. Synonymes : J. P. cyathoides. 2. P. epidendra. 3. P. albella-P. Abbotiānă, acetabülä, aciculārìs, aruginōsă, agaric̄̄nă, ällర̄-spadīcěă, albo-violäscẻns, amörphă, anomălă, arcnósă, A. salicīnă, argillācěă, Aspegrēnīin, atrātŭ, atror ūfă, atro-vǐrēns, aurāntăă,

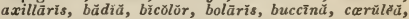
cäsīă, calycülüs, campanülă, cērĕă, cerīnă, chrysocơmă, cinērěă, citrīnă 1 , clandestīnă, claróflāvă, cochleätä, coccĭnēă 2, comprēssă, concinnă, conigěră, cribrossŭ, cupuläris, domestică, episphäerĭă, erēctă, erratīcă, erūmpēns, faginēă, fasciculärǐs, fibuliformĭs, fïrmă, fisssŭ, flēxěllă, fructigĕră, furfuräcěă, füscă, fuscarioĩdēs, granulätă, Grevilliī, hemisphärǐcă, herbărăm, hïrtă, hispĩdŭlă, humósă, hyalīnă, 
inflëxd̆, leporīnă, leucolömă, leucostigmă, macröpŭs, Marchäntīe, melalómă, melastomă, melaxänthă, nidũlüs, ochrācẻd, onotícă, pallēscểns, papillãrǐs,

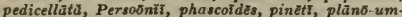

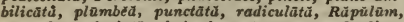
repändă, reticulatĭ, rhabarbarină, $R \delta s \bar{\omega}$, rufo.oliväcêŭ, rutîlāns, saniósă, sclerotioĩdēs, scutellätă, serotĩnă, stercorĕă, subtilís, sulphüréa, trìcolor, tübŭ, tuberōsă, variecollor, vesiculosŭ, villosŭ, vinઠsă, vir-

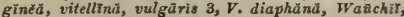
ranthostigmă.

Prăcă, Linn. From phago, to eat; a name adopted from Dioscorides. Linn. 17, Or. 4, Nat. Or. Leguminosue. Ornamental herbaceous plants, growing well in the open borders, in common garden soil; they are all increased by dividing the plants at the root, or by seeds, which is by far the best method of propagating them. Synonymes: 1. P. membra. nacea. 2. Astragalus leontinus, oroboides.

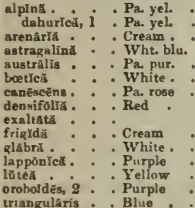

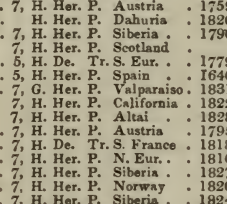

Praç̇tř Jussieu. From Phakelos, a bundle; in reference to the disposition of the flowers. Linn. 5, Or. 1, Nat. Or. Hydrophyllacee. Hardy plants of some beauty, flourishing in any common garden soil; young plants may be obtained by divisions or seeds. Synonyme: 1. Hydrophyllum magellanicum.

Pink 0 , Peru bipinnatîfiă: : Blue : 6 , H. Her. P. N. Amer. 1824 eircinata, 1 : Pink: : 6, H. Her. P. Magellan. 1817 congéstü : : Pur. blue : 6, H. A. Texas. 1835 tanncetifolla : Blue : 6, H. A. California 1832

Phac̄̃oỸu, Fries. From phakos, a lentil, and eidos, similar. Linn. 24, Or. 9, Nat. Or. Fungi. Curious species, found on oak-leaves, both in a living and dead state, raspberry-leaves, \&c.-P. carbonäcënm, coronătam, dentatim, Laurocerăst, PInt, repändam, Rubt.

Pнacospērmă, Hanorth. From phakos, a lentil, and sperma, seed. Linn. 11, Or. 1, Nat. Or. Portulacacer. An ornamental plant, succeeding in peat and loam. The best way to obtain young plants is from seed, which it ripens freely.

peruviână . . Purple . 5, S. Her. P. Peru . 1820

Phanooamous, such plants as possess visible sexual organs.

Prẫús, Loureiro. From phaios, shining; in allusion to the beauty of the original species. Iinn. 20 , Or. 1, Nat. Or. Orchidacee. This is an interesting and valuable genus of plants, especially $\boldsymbol{P}$. albus, which ought to be in every collection of orchidiceous plants; the following is the best way of cultivating it:-When the plant becomes dormant, it should be placed in a cool house, the temperature of which, in winter, should not be more than 45 or 50 degrees. After reposing the proper time, it will begin to push from the base of the stems; and when the young shoots are about half an inch in length, the plants should be repotted into heath soil, well drained at the bottom, and mingled with an abun. dance of finely-broken potsherds, according to the usual method of cultivating orchidaceous plants. For a moderate-sized plant, the pot should be about six inches in diameter at the top, which will allow of its completing the annual grow th without being again potted. It will bear a free supply of water when growing vigorously, and may then be syringed once or twice a day, till it shows signs of flowering, when the syringing must be discontinued. When it has ceased flowering, it should be kept in a cool house, and sparingly watered until the leaves begin to turn yellow, when it must be removed to its winter quarters, and kept dry, merely supplying as much water as will keep the plant alive, and taking care never to wet the stems; for the culture of the other species, see Bletia. Synonymes: 1. Bletia Tankervillia. 2. B. Woodfordit.

âlbŭs. . . . White . . 7, s. Epi. Sylhet . . 1836 bícölor : Brn. yel: "S. Epi. Ceylon 1778 maculátǔs, 8 : Wht. brm. 4, S. Ter. China : * 1778 Wallichir : Oran yel. 4, S. Ter. Khoosea : 1837

PhalzanōpsIs, Blume. From phalaina, a moth, and opsis, resemblance; in allusion to the appearance of the flower, which bears a striking resemblance to that insect: whence the name Indian Butterflyplant. Linn. 20, Or. 1, Nat. Or. Orchidacee. This is a very rare and extremely beautiful plant. The flowers are produced on a nearly erect spike, and are very elegant, on account of their large size and the brilliant whiteness of the broad leathery petals. It requires a very hot, damp part of the house, and is otherwise treated as the genus Vanda. It can only be increased from side shoots, which it does not appear to throw out freely.

amabrits . . . . Wht yel. 6, S. Epi. Manilla . 1836

Phalangiū $M$, Decandolle. From phalanx, a venomous 8 pider; said to cure the bite. Linn. 6, Or. 1, Nat. Or. Liliacea. The greenhouse and frame species of this ornamental genus grow well in an equal mixture of sandy luam and peat: the hardy species do well in any light rich soil; they may all be increased by division at the root, or by seeds. Synonymes: 1. Anthericum Liliago. 2. Anthericum ramosum.

glnùcūm . White. 7, F, Her. P. Peru

White. 5, H. Her. P. S. Eur. . 1596

nepalēnsé : : White. : 5, F. Her. P. Nepal : : 1824

ramosúm, 2 : White: 5, H. Her. P. S. Eur. : : 1570

Phazăals, Linn. From phaluros, brilliant; having shining seeds. Linn. 3, Or. 2, Nat. Or. Graminea. Mostly uninteresting species. $P$. commutata and appendiculata are rather pretty; $\boldsymbol{P}$. canariensis is cultivated on account of its seeds (canary-seed), which are given to birds; they merely require to be sown in any common soil.

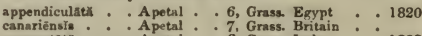
commutata : : A petal : 6, Grass. Itraly : 1823

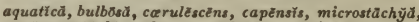
minŏr, nitidă, nodosă, paradoxă, quadrivälvis.

Phazkrocārpũs, G. Don. From phaleros, white, and karpus, fruit; because of the colonr of the fruit. Linn. 8, Or. 1, Nat. Or. Ericaces. This pretty little plant may be referred to Oxycoccus for cul. ture and propagation. Synonymes: 1. Gaultherio serpyllifolia, Oxycoccus hispidulus.

serpyllifoliz, 1 . White. . 4, H. Ev. Cr. N. Amer. - 1815

Рнӓп.Ǔs, Michaux. From phallos, signifying a wooden club. Linn. 24, Or. 9, Nat. Or. Fungi. Fotidsmelling fungi, found in woods and hedges, on hazel trunks, \&c.-P. canīnŭs, faetîns, iōsmós.

Pralscálírs, Herbert. Not explained by its author. Linn. 3, Or. 1, Nat. Or. Iridacee. This remarkable plant produces a delicate and beautiful flower on a strong and tall stem. It will, perhaps, be found to succeed well under a warm south wall in the open ground; seeds. Symonyme: 1. Capella plumbea.

plûmbeă, 1 . Lead sol. . 7, F. Bl. P. Mfexico . . 1837

Pharbĩty, Choisy. Meaning not explained. Linn. 5, Or. 1, Nat. Or. Convolvulaced. This is a genus of very showy, tender annuals. The seed should be sown on a hotbed, and when the plants are large enough, they should be planted into pots, in a mixture of sandy loam and decayed leaves; and afterwards treated as other tender annuals. Synonymes: 1. Ipomae barbata. 2. I. barbigera. 3, I. carulescens. 4. I. cuspidata. 5. I. Dillenii. 6. I. hederacea. 7. I. hispida. 8. I. Nil, I. carulea. 9. I. punctata. 10. I. scabra. 11. I. varia.

barbsttă,

barbigera, 2: Blue - 9, H. Tw. A. Virginja

. Pa. blue * 7, H. Ev. Tw. E. Ind. 1820

Dillenir, 5 * Purple 7, G. Tw. A. Peru

diversifolra : Blue : : 6, G. Tw. A. Athiopia .

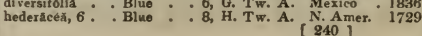




\begin{tabular}{|c|c|}
\hline PHA & PHA \\
\hline 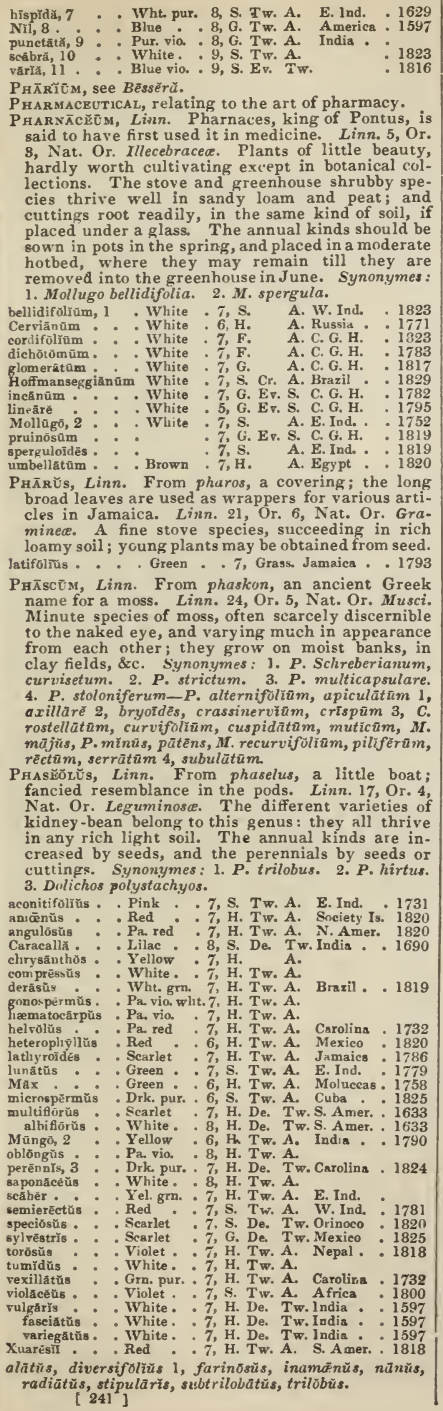 & 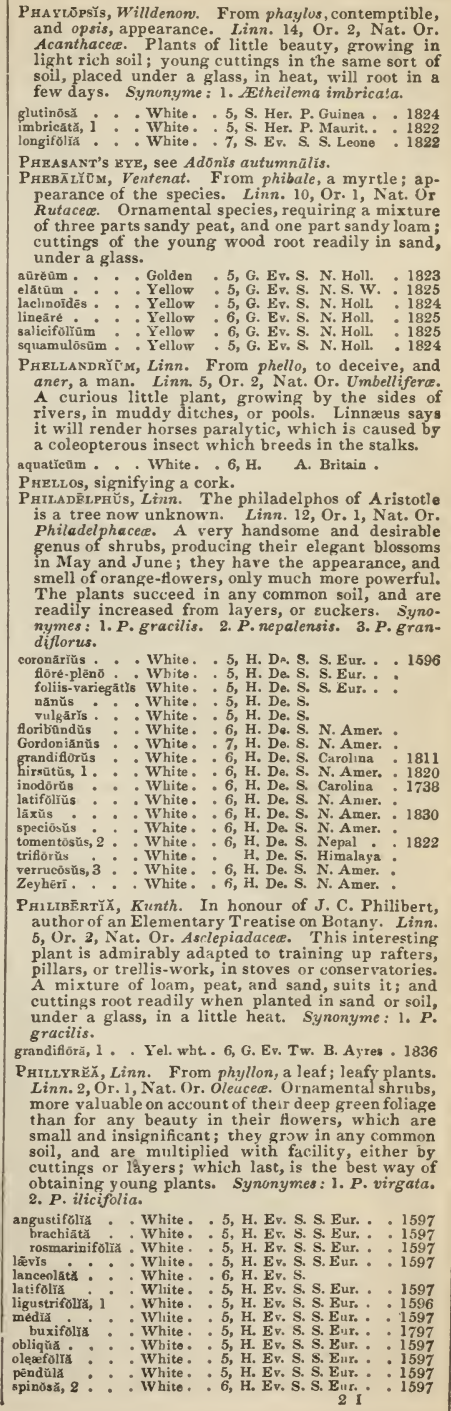 \\
\hline
\end{tabular}


Phimodēndrōn, Lindley. From phileo, to love, and dendron, a tree; in allusion to the habits of the plants of this genus to overrun trees in the South American forests. Linn. 21, Or. 3, Nat. Or. Aracece. This is a curious species, thriving in loam and peat, and increased by divisions of the roots.

erassinērv̛̀üm . . Gru wht. 12 , S. Ev. Cl. Brazil . . 1835

Рнготнёсӑ, Rudge. From philos, smooth, and theke, a sheath; smooth tube of stamens. Linn. 16, Or. 6, Nat. Or. Rutacea. An ornamental plant, requiring the same treatment as Phebalium. Synonyme: 1. Eriostemon salsoloides.

austrălǐs, 1. . . Pa. red . 4, G. Ev. S. N. S. W. . 1822

Priloxêrŭs, R. Branin. From philos, a lover, and xeros, arid; the plants like an arid situation. Linn. 5, Or. 1, Nat. Or. Amarantaceo. Plants of little beauty; and of easy culture and propagation. Syncnyme: 1. Illecebrum vermiculare.

aggregattǔs . . . White . . 8, S. Ev. Tr. Trinidad . 1820 brasiliensis : White: 8, S. Ev. S. Brazil : 1.790 8, S. Ev. Tr. S. Amer.

Phiñ̄DRūm, Banks. From philos, a lover, and hydor, water. Linn. 1, Or. 1, Nat. Or. Philydracea. A pretty little speries, with hairy leaves, and spikes of bright yellow flowers. It delights in a mixture of three parts loam and one part peat, in which it merely requires to be sown.

lanuginósūm - Yellow . 6, G. B. China . . 1801

Priskī , Fries. From phleps, a vein; veiny branches. Linn. 24, Or. 9, Nat. Or. Fongi. Three rather interesting species, common in the latter part of the year on Alder trees-P. merismotdes, radiútä, vägă.

Phl.̌̃u, Linn. Supposed to be the Greek name for Typha. Linn. 3, Or. 2, Nat. Or. Graminea. $P$. pratense and its varieties are extensively cultivated as spring grass for fodder, and are considered very valuable herbage: they prefer a strong stiff soil the other speries have little to recommend them, being mostly uninteresting. Synonyme: 1. P. sto loniferum.

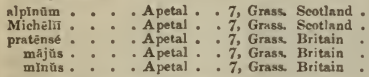

Bertolinโ̌ 1, commutätam, cchinütam, felīnam, Gerürdi, nodosam.

Pнцйміs, Linn. From phlogmos, a flame; in reference to the down being used for wicks. Linn. 14, Or. 1, Nat. Or. Labiate. Very handsome plants, the greenhouse and hardy kinds all succeeding well in a rich light soil ; cuttings, planted under a glass, root freely. The perennial species may be increased by seed, or divisions. Synonymes: 1. P. samia. 2. P. cretica 3. P, rotundifolia. 4. P. microphylla. 5. P. salviafolia. 6. P. lunarifolia Russelliana. 7. P. virens.

agrări. alpinà : : Purpla : 7, H. Her. P. Siberia : 1802 angustifoblia : Cream : 7, F. Ev. S. Levant : 1596 nrmeniaca . : Yellow : 7, H. Her. P. Armeniz : 1834 breolor, 1 : Yel. pur. . 6, H. Er. S. Lybia : 1714 - Pa brn. . 6, F. Her. P. Spain . 1820 erraginéa - Yel, brn. . 6, H. Ev. S. Naples - 1823 eretícŭ, 2 - Yellow 6, H. Ev. S. Creto - 1820 floceð̋ă . : Yellow 8, F. Ev. S. Egypt : 1828

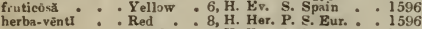
italícă, 3 : : Purple : 7, H. Ev. S. Italy : : 1661 laciniáta : : Purple : 7, H. Her. P. Levant: : 1731 lanAtat, 4 : : Yellow :6, H. Ev. S. Candia : 1696 lunarifolia . - Yellow . 6, H. Her. P. Levant - 1818 Lychnites' . . Yel, brn. . 7, H. Ev. S. S. Eur. - 1658

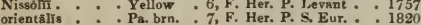
púngens : : Brown : 7, H. Her. P. Armenia : 1820 purpŭréa, 5 : Purple : 7, H. Ev. S. S. Eur, : 1661 6. H. Her. P. N. Africa: 1821 tuherósă : : : Purple : 8, H. Tu. P. Siheria. : 1759 viscôsăă 7: : Yellow : 6, H. Ev. S. Levant:

PнLōx, Linn. From phlnx, a flame; appearance of the flowers. Linn. 5, Or. 1, Nat. Or. Polemoniaces. This is an elegant genus of plants. The species are all rendered more valuable, from their lively red, purple, or white flowers, being produced at a season of the year when the majority of the plants that flower at the same period are syngenesious, and for the most part vellow; the trailing kinds are admirably adapted for growing on rock-work, or in small pots; they grow best in a rich loamy soil. All the species root freely by cuttings, under glass, or by divisions. Synonymes: .1. $\boldsymbol{P}$. amana. 2. P. stolonifera. 3. P. crassifolia. 4. P. scabra. 5 P. longiflora.

acuminátă • . P^. pur. . 7, H. Her. P. N. Amer. . 1812 acutifoliă. : Purple :8, H. Her. P. N. Amer. : 1825 ariståta : : Wlite. : 4, F. Her. P. Carolinn : 1828 9, H. Her. P. Eng. hyl. 1834 carnéă. : : Pink : :, H. Her. P. N. Amer. : 1816 major

Carolină : Pa pur. : 8, H. Her. P. Carolina : 1728 cordātă : : Pa pur. : H. Her. P. Carolina : 1827 grandifiöra - Pa, pur. H. Her. P. Gardens rờseả : Rose : 7, H. Her. P.

distrchă : Red : 8, H. Her. P. N. Amer. 1826 divarieata : Lgt. blu. .3 H. Her. P. N. Amer. : 1746 Drummōndi̊ . . Purple 7, H. A. Texas : 1835 elătă . : Lilac . 9, H. Her. P. N. Amer. . 1898 excelsă : : Purple : 8, H. Her. P. N. Amer. : 1824 floridană. : Rnse . 4, S. Ev. P. N. Amer. 1834 glaberrima
Ingramianx $:$ Red : Lilac : 7, H. Her. P. N. Amer. : 1725
, H. Her. P. Hybrid $: 1834$ intermedira : Prirple $: 7$, H. Her. P. N. Amer. involueráta : Lilac * 6, H. Her. P. N. Amer. : 1830 læ̂tă . . . White. . 8, H. Her. P. N. Amer.

latifolra : : Purple : 7, H. Her. P. Carolina : 1812

maculată : : Purple : 7, H. Her. P. N. Amer. : 1740

nìtídă : : Purple : 7, H. Her. P. N. Amer. : 1800

nivaliss. : Whito. 4, H. Her. P. N.Amer. : 1820

odorắă - Lilac : 8, H. Her. P. N. Amer.

omniflora . . White. 8, H. Her. P. Hybrid.

ovata *. Purple 6, H. Her. P. N. Amer. : 1759

Lietoniánă Purple 7, H. Her. P. N. Amer, 1816

paniculátá . Pink , 8, H. Her. P. N. Amer. 1738

ălbă . : White. : 8, H. Her. P. N. Amer. 1813

penduliflơră : : Ro. pur. 10 , H. Her. P. N. Amer. : 1823

pilósà. : : Purple 5, H. Her. P. N. Amer. : 1759

amöñ , 1. Pink - 6, H. Her, P. N. Amer. 1809

procūmbèns . Flesh . . 5, H. Her. P. N. Amer. . 1827

pulchella : . Wht pink 8, H. Her. P. Hybrid - 1835

White . 6, H. Her, P.

corymbösñ . Purple . 7, H. Her. P. N. Amer.

pendulifioră Purple : 7, H. Her. P. N. Amer.

reflexă * . Drk. pur. . 8, H. Her. P. Hybrid.

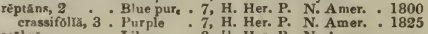

scabra. Lilac

setấcéă Flesh $4, \mathrm{H}$ Her. P. N. Amer.

7. Her P. Hubrid. 1786

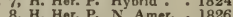

speciosa : Flesh :

suaveolens: : White: $7, \mathrm{H}$. Her. P. N. Amer. : 1766

variegátă : White: 7, H. Her. P. N. Amer. : 1766

subulátá : Drk pur. : 5, H. Her. P. N. Amer. : 1786

suffruticósă . - Drk. pur. . 8, H. Her. P. N. Amer. : 1790

tardifloră, 5. White. . 9, H. Her. P. N. Amer. . 1825

purpüréa . Purple . 8, H. Her. P. Hybrid . 1836

triftlônă - . Pn lilac \& 8 H. Her. P. Carolina 1816

undulătă : : Purple : 7, H. Her. P. N. Amer. : 1759

Vernoniánă: Purple : 8, H. Her. P. Hybrid: 1834

virginieà : : Purple : 7, H. Her. P. Virginia : 1812
alha

Wheeleriäna " Pink : 8, H. Her. P. Hybrid : 1824

Phāxīx, Linn. The Greek name of the Date. Linn. 22, Or. 3, Nat. Or. Palmacea. The Date of the ancients is included in this noble genus of palms. $\boldsymbol{P}$. alctylifera is a fine lofty-growing tree, with a rugged trunk, and leaves from six to eight feet long. The inhabitants of Arabia, Upper Egypt, \&c., chiefly live upon the fruit of it; the hard stones are even ground up as food for their camels, and of the leaves they make bags and baskets. In Barbary, the boughs are used as fences for their gardens, and they sometimes make use of the trunks in small buildings. The threads of the integuments between the boughs are made into ropes, and the rigring of smaller vessels; a juice is sometimes extracted from the tree by incisions, or scooping holes at the top, which is afterwards made into an agreeable wine. $\boldsymbol{P}$. farinifera contains a farinaceous substance in the heart of the stem, which is said to be as nutritive as saga The species all delight in a strong rich soil, and the only way of obtaining young plants is by seeds.

acaûlis : * - Wht. gro. * Palm. E. Ind. * 1816 dactyliférà . - Whit. grn. - Palm. Levant * 1597 [ 242] 
PHOE

lèonẽnsĭs

paludósă

pygmäă

reclinătă

sylvēstrìs

Рнавосо̆мӑ, Don.

Wht. grm.

Palm. S. Leone . . 1823

Palm. E. Ind. : : 182

Palm. Maurit: : 1823

Palm. C. G. H. : 1792

rom phoinos, bloody, and kome,

involuerum. Linn. 19, Or. 2, Nat. Or. Com

posita. An ornamental species, requiring the same treatment as Elichrysum. Synonyme: 1. Elichrysum proliferum.

proliferă, 1 . . Crimson . 9, S. Ev. S. C. G. H. $\quad 1789$

Proridōtă, Lindley. From pholis, a scale, and ous, (otos, ) an ear; in allusion to the scaly ear-like bracteæ of the spike. Linn. 20, Or. 1, Nat. Or. Orchidacece. These are very pretty plants, and of easy cultivation; by keeping them constantly moist, they will grow well with the same treatment as the Burlingtonias. Synonyme: 1.P. imbricata.

articulata

imbricátă

pällìdă, 1

Wht. yel.

4, S. Epi. Khoosea

1837

undulătă

Yellowish

2, S. Epi. E. Ind.

S. Epi. E. Ind.
S. Epi. E. Ind.

1828

Phoutūrŭs, Trinius. From pholis, a scale, and oura, a tail. Linn. 3, Or. 2, Nat. Or. Graminec. A curious species of grass, growing in any common soil, and increased by seeds, which only require sowing in the open ground. Synonyme: 1. Ophiurus pannonicus.

pannonǐcŭs, 1. . A petal . . 7, Grass, Hungary . . 1804

Рно̄мй, Fries. From phos, a pustule; appearance of the plants, Linn. 24, Or.9, Nat. Or. Fungi. Minute and curious species of brown-coloured fungi, commonly found on dead willow and poplar leaves-

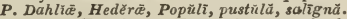

Рнокмйм, Thunberg. From phormos, a basket; use made of the plant in its native country. Linn. 6, Or. 1, Nat. Or. Liliacee. In its native country this is a very useful plant, serving the inhabitants of New Zealand, Norfolk Island, \&c., with cordage, coarse thread, and linen. Attempts have been made to grow it for manufacturing purposes in New Holland, but without success. It requires to be grown in a rich strong loam, and is multiplied by divisions of the root.

tẻnāx . . . Grn. wht., 8, H. Her. P. N. Zeal. . 1798

Pноті̄кй, Lindley. From photeinos, shining; in reference to the leaves. Linn. 12, Or. 2, Nat. Or. Rosacece. A very handsome genus of trees, with fine, bright, glossy leaves, and corymbs of white flowers. The species require very little protection except in severe weather. They thrive best if planted in a mixture of loam and peat against a wall, in a warm situation ; ripened cuttings put in sand, under a glass, will root readily; they may also be grafted or inarched on the different species of Pyrus, or Mespilus. In Nepal, they use the bark of $\boldsymbol{P}$. dubia for dyeing scarlet. Synonymes: 1. Mespilus bengalensis. 2. Crategus glabra.

arbutifolǐa . . White. . 7, F. Ev. T. California - 1796 dübiă, 1 : White. F. Ev. T. Nepal : 1821

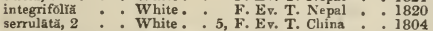

Phragmidĩum, Link. From phragma, a division, and eidos, similar. Linn. 24, Or. 9, Nat. Or. Fungi. Extremeì minute species of black fungi. $\boldsymbol{P}$. gracile is found in autumn on raspberry leaves; the others on the leaves from which they have taken

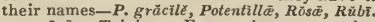

Phragmitīs, Trinius. From phragmos, a hedge; forming hedges, Linn.3, Or. 2, Nat. Or. Graminece. This plant is very common in ditches, and is readily increased by divisions. Synonyme: 1. Arundo Phragmites.

commūnis, 1 . A petal . 8, H. Aq. P. Britain .

Рнкт̃мă, Linn. Meaning unknown. Linn. 14, Or. 1, Nat. Or. Labiata. A dwarf-growing plant, of $n$ great merit. It succeeds best in a mixture of peat and loam, and cuttings planted under a glass root readily.

leptoståchy̆ă . . Wht. pur. 8, H. Her. P. N. Amer. . 1802

Phrynīum, Willdenow. From phrynos, a frog; plants inhabiting marshes. Linn. 1, Or. 1, Nat. Or. IIarantacee. Plants resembling Caluthea in general appearance. "In China, they use the leaves fo [243]
PHY

PHY

wrapping up cakes in the oven; they are infused before expansion in spirit of rice or sugar, with three times its quantity of water, to make vinegar."

-Loudon's Ency. of Plants. For culture and propagation, see Canna. Synonymes : 1. Maranta Casupo. 2. M. comosa. 3. M. spicuta. 4. Myrosma cannafolia.

angustifolīn - Yellow 6, S. Her. P. E. Ind - 1894 captifolim - Yellow * 6, S. Her. P. E. Ind. captátưm * - Whit. pur. 7, S. Her. P. E. Ind. . 1807 casūpo, 1 - Yellow - 7, S. Her. P. S. Amer. - 1820 comósūm, 2 : Yrange : 5, S. Her. P. Brazil : dichotómūm: White. 7, S. Her. P. E. Ind. elliptīeñm, 3 Pa, yel. • Pa, yel. * 7, S. Her. P. Guiana • 1822 grandiflórūm * Yellow * 7, S. Her. P. Brazil * . 1823 imbrieātūm . Pa. red . 6, S. Her. P. E. lnd, . . 1818

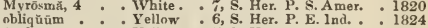
Parkêri : : Yellow : 7, S. Her. P. Grenada: 1823 parviflórūm - Yellow * 7. S. Her. P. E. lnd. * 1820 setósūm *ā́n : : Purple : 6, S. Her. P. Rio Jan. - 182 virgatūm: White : 6, S. Her. P. E. Ind. : 1818

Pнyе̄̄Lră, Lindley. A diminutive of phykos, red

alkanet; colour of the flowers. Linn. 6, Or. 1

Nat. Or. Amaryllidacea. Very pretty plants, succeeding in a mixture of one part loam, one of sand, and the rest peat. They are sufficiently hardy to grow well if planted in a pit, frame, or warm border, with a slight protection in severe frost; increased by offsets from the bulbs, or by seeds. Synonymes: 1. Amaryllis cyrtanthoides. 2. P. ignea glauca. 3. A. ignea. biflöră corūscă - Scarlet thöidès, 1. Crimson.

Herbertiān

igněă, 3 Red Red yel. Searlet

4, G. B1. P. Chile 7, G. Bl. 9, G. Bl. P. Coquimbo : 1836 6, G. Her. P. Chile 182 6, G. B. Valparaiso 1824 6, G. Bl. P. Andes 1825 4, G. Bl. P. Chile : 1824 10, G. Bl. P. Valparaiso

Phylícă, Linn. From phyllikos, leafy ; in allusion to the abundant evergreen foliage. Linn. 5, Or. 1 Nat. Or. Rhamnacea. Ornamental shrubs. P.ericoides covers tracts of land about Lisbon in the same manner as heath does in England. They grow best in sandy peat, and young cuttings root readily in sand, under a glass, in heat. Synonymes: 1. $P$. reflexa. 2. P. pubescens. 3. P. eriophora.

White . W, G. Ev, S. C. G. H. 1820 acuminătă: : White: 5, G. Ev. S. C. G. H austrälìs : : White : 5, G. Ev. S. N. Holl bǐcőlŏr : : White : G, G. Ev. S. C. G. H. eallōsă, 1 * - Yel, grn. 3, G. Ev. S. C. G. H. capitātä, 2 . - White - 6, G. Er. S. C. G. H. Commelinī . "White - 5, G. Ev. S. C. G. H. cylindrïca : . Yel. grn. 6, G. Ev, S. C. G. H ericoídēs: : White 6, G. Ev, S. C. G. H excels Yel. grn 5, G. Ev T. G. glabrătă: : White globǒsă. : : White : 6, G. Ev. S. C. G. H. liirsūtă . . White , 6, G. Ev. S. C. G. H horizontalis * . White - 5, G. Ev. S. C. G. H. imbērbǐs - . White - 6, G. Ev. S. C. G. H imbricătă : White 10, G. Ev. S. C. G. H. lanceolãtă : : White 5, G. Ev. S. C. G. H. lanceoláta : : White : 5, G. Ev. S. C. G. H. ledifol nĭtǐdă eriophōră, 3 papillós parvifiōră pineă pinifölĩ plumôsă pŭmı̌l rosmarinifolia.

White .11, G. Ev. S. C. G. H. Pa. yel. : 6, G. Ev. S. C. G. H. White 6, G. Ev, S. C, G. H. White. 11, G. Ev. S. C. G. H White - 7, G. Ev. S. C. G. H. White - 4, G. Ev. S. C. G. H. White: 6, G. Ev, S. C. G. H G. Siv. S. H 5, G. Ev, S. C. G. H. squarrosă: : : White : 9, G. Ev. S. C. G. H.
trichótómă: : White: 6, G. Ev. S. C. G. H.
villosă squarrosă: : White : 9, G. Ev. S. C. G. H.
trichótömă: : White : 6, G. Ev. S. C. G. H.
villösă

1820 1819
1818 1817 1774 1800

Pнyцícã, see Soulängĩa.

PHYLİcă, see Trichocephălŭs.

Phy I.t.̄ंNthŬs, Linn. From phyllon, a leaf, and anthos, a flower; flowers produced from the edges of the leaves. Linn. 21, Or. 10, Nat. Or. Euphorbiacece. A very interesting genus of plants. The shrubby kinds thrive well in a mixture of loam and peat, and cuttings of the ripened wood root freely in sand, under a glass, in heat. The annuals and biennials may be sown in a hotbed frame; they require the same treatment as other tender annuals. In India the root, leaves, and young shoots of $\boldsymbol{P}$. Niruri, aré 


\begin{tabular}{|cc|}
\hline PHY & PHY \\
\hline considered deobstruent and diuretic. & P. Urinaria
\end{tabular}

is also powerfully diuretic.

ealycinǔs : - : 5. S. enntoniênssis : Grn. yel. 8, S. A. Canton . 1820

Conami Green . 7, S. Ev, S. W. Ind. 1791

cuneatŭs : Grn. yel. . 8, S. A Chins . 1818

fraxinifollŭs : Green . 8, S. Ev. S. E.1nd. . 1819

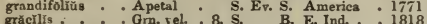

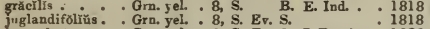

lanceolātŭs : :Grn. yel. : 8, S. Ev. S. I. Bourbon 1822

longifolrüs. . Grn. yel. . 8, S. Ev. S. L. Bourbon 1822

- Grn. yel, 8, G. Ev. S. China * 1820

maderaspatensis . Apetal * 7, S. Ev. S. E. Ind. . 1783

microphyllä : Grn. yel. : 8, S. Ev, S. Caraceas : 1817

mirürídés : : Green : : 8, S. Ev. S. Caribbees : 1817

nưtáns : : Grn yei. : 8, S. Ev. S. Jamaies : 1820

obeordátŭs: : Grn yel : 8, S. B. E. Ind. : 1817

oborátŭs : : Apetal : 7, H. A. N. Amer. 1803

polyphylüs: : Green : 8, S. Ev, S. E. Ind. : 1805

polyphings

Red 8, S. Ev. S. E. Ind.

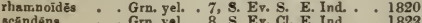

simplēx. : : Grn. yel. : 8, S. Ev. Cl. E. Ind. : : 1828

strietüs: : : Grn yel. : \& S. A. E. Ind. : 1824

thymidies : : G. Ev. S. N. Holl, : 1835

turbinătăıs . . Green * 7, S. Ev. S. China

virüsǔs : : : Grne yel. : 8, S. Ev. A. E. Ind. : 1819

Phyluls, Linn. From phyllon, a leaf; its chief recommendation. Linn. 5, Or. 2, Nat. Or. Cinchonacea. An ornamental shrub, growing from two to three feet high, and producing axillary corymbs of green flowers in abundance. It succeeds best in a rich strong mould, and cuttings root freely under a glass, in sand.

Nóbläs, in sand. paucifif $6 \mathrm{~d}$ : : 6, G. Ev. S. Canaries : 1699

Phyiloczădǔs, Richard. From phyllun, a leaf, and klados, a branch. Linn, 21, Or. 10, Nat. Or. Tax. eced. An ornamental tree; for culture and propagation, see Podocarpus. Synonyme : 1. Podocarpus asplenifolius.

rhomboidalis, 1 . A petal . G. Ev. T. V. D. I. 1825

Phylrodič, a dilated petiole, with the consistence of a leaf.

Phyllolóbīè, Fischer. From phyllon, a leaf, and lobos, a pod; in allusion to the flat membranous pods. Linn, 16, Or. 6, Nat. Or. Leguminose. This species will grow well in a mixture of peat and sand, and cuttings will root in the same kind of soil, with a glass over them, in heat.

zanziharënse

S. Her. P. Zanguebar . 1826

Pницiomă, Link. From phyllon, a leaf, and loma, a fringe; in reference to the coloured edges of the leaves of P. aloiflorum. Linn. 6, Or. 1, Nat. Or. Liliacea. A genus of plants nearly related to the Aloes. They grow well in sandy loam, and are readily increased by suckers; they require to be very cautiously watered. Synonymes: 1. Dracana marginata, Lomatophyllum borbonicum. 2 Aloe hexapetala, Lomatophyllum Jacquinii. 3. A. macra. 4. $A$. rufocincta.

aloiflưrüm, 1 . . Orange - 4, S. Er. T. Bourbon . 1766 JacquinI, 2 : Orango : 6, G. Ev. S.

măcrúm. 3. : Orange : 6, G. Ev. S. Maurit. . 1817 rufocinctum, 4 : Orange $6, G$, Ev, S. E. Ind: 1818

Phymatãnthuัs, see Pelargónĩum.

Physălís, Linn. From physa, a bladder; alluding to the calyx. Linn. 5, Or. 1, Nat. Or. Solanacere. A genus principally composed of weeds. The stove and greenhouse species will grow well in any rich light soil ; young plants may be obtained from cuttings, which root readily under a glass. The hardy kinds thrive in common garden suil, and are increased from seeds. The annual speeies merely require sowing in the open ground. Synonymes: 1. Atropa aristata. 2. P. tuberosa. 3. P. faetidissima. $P$. nodosa. 4. Atropa frutescens. 5. $P$. parviflora. 6. P. dubia. 7. P. Lagasca, P. Rothiana. 8. P. edulis. 9. P. atriplicifolia. 10. P. pruinosa, P. barbadensis. 11. P. flexuosa. 12. P. pennsylvanica. 13. P. Jacquini.

Alkekêng1. . White

arborêsceêns : Yellow

aristată, 1.: Yellow

frutéscếns, 4 : : Yellow peruviasnă
edūlis, 8 : : Yhlite

8, H. Her. P. S. Eur.
7, G. Ev. S. C. G. H.

7, G. Ev. 8. Canaries

6, G. Ev. S. Spain

7, G. Her. P. S. Amer.

1548

1700

1779

1787
PHY

PHV

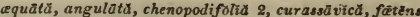
3 , indícă 5, Linkiänă 6, micränthă, minìmă 7 , parviflorä, philadelphäcă 9 , prostrātă, pubëscēns, $P$. pruinosă 10, somnüferă, S. flexuösă 11 , viscơsă $12, V$. Jacgeūn̄̄ 13.

Physấcú , Persoon. From physa, a bladder; appearance of peridium. Linn. 24, Or. 9, Nat. Or. Fungi. Curious species, found on dead beech-wood, decaying trunks of trees, \&c.-P. aũrễm, hyalīñm, leucơpüs, metallicūm, nigrịpès, nưtāns, rubiginôsūm, sulcâtū $m$, vǐridé.

Physematĩũ M, Kaulfuss. Derivation not certain Linn. 24, Or. 1, Nat. Or. Polypodiaced. Ornamental plants, growing well in a mix ture of peat and loam, and they may be increased by divisions. Synonyme: 1. Woodsia pubescens.

mollě * : Brown * 7, S. Her. P.

pubēscēns, I . Brown : 8, S. Her. P. Brazil . 1820

Prysiñnthứs, Martius. From physa, a bladder, and anthos, a flower; the corolla is inflated at its base. Linn. 5, Or. 2, Nat. Or. Asclepiadaced. This is a very interesting climber, well adapted for training to the rafters or pillars of a stove. It grows in sandy loam and peat, and is increased by seeds or cuttings.

Glbëns . . . White. . 7, S. Ev. Cl. B. Ayres . 1830

Physic-NuT, see Jatrŏphă.

Physingü, Lindley. Name not explained. Linn. 20, Or. 1, Nat. Or. Orchidacese. This is said to be 8 plant of no beauty, but very clurious; it has the habit of an Epidendrum, and will require similar treatment to most other Mexican epiphy tes.

prostritü . . . Purple . S. Epi. Demerara . 183-

Prysochlaĩnă, Don. Derived from physa, a bladder, and chlaina, an outer garment; alluding to the inflated calyx. Linn. 5, Or. 1, Nat. Or. Solanacea. The species of this genus produce their very elezant flowers early in the season, and are therefore desirable plants. They grow well in any soil, and are easily increased by divisions of the root, or by seed. Synonyme: 1. Hyoscyamus orientalis. 2. H. physaloides.

orientalis, 1 . Pur. blue - 4, H. Her. P. Iberia . 1821 physaloidés, 2. . Pur, via. . 3, H. Her, P. Sileria : . 1777

Prysolöво̄ м, Bentham. From physa, a bladder, and lobos, a pod; alluding to the shape of the seedvessel. Linn. 10, Or. 1, Nat. Or. Leguminosa. This genus is quite unknown to us.

elătūm

Swan R. . 1837

Physosīphôn, Lindley. From physa, an inflated containing object, and siphon, a tube; the calyx is tubular, and inflated at the base. Linn. 20, Or. 1 , Nat. Or. Orchidacea. Curious little plants, with the habit of Pleurothallis, and requiring precisely similar treatment to that genus. Synonyme: Stelis tubata.

carinktũs

8, S. Epi. Mexico . . 1838 eparginătŭs. - . S. Epi. Peru LoddigësIt, 1 - Orange * 4, 8. Epi. N. Spain . 1828

Physospīrmồ, Vela. From physa, a bladder, and sperma, a seed; the teguments do not adhere to the seed in a young state. Linn. 5, Or. 2, Nat. Or. Umbelliferc. A rather ornamental genus of plants for culture and propagation, see Pleurospermum. Synonymes: 1. Ligusticum cornubiense. 2. Smyr. nium nudicaule.

commutătûm, 1 . White. : 7, H. Her. P. England : 1817

Physostügřă, Bentham. From physa, a bladder, and stege, a covering; alluding to the calyx. Linn. 14, Or. 1, Nat. Or. Labiate. Ornamental plants; for culture and propagation, see Dracocephalum. Synonymes: 1. Dracocephulum cordatum. 2. D. denticulatum. 3. D. speciosum. 4. D. variegatum. 5. D. virginianum.

cordătă, 1 . . . Purple ． 7, H. Her. P. N. Amer. - 1824 denticulatx, 2 . Striped : 8, H. Her. P. Carolina 1787 imbricătă : Pa. pur. : 9, H. Her. P. Texas . 1833

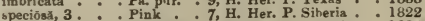
specióat, 3.: Pink : 7, H. Her. P. R. Felipe : 1834 variegată, $4:$ Purple : 8, H. Her, P. Carolina : 1812 rirginiánă, 5 : : Red : 8 H. Her. P. N. A mer. : 1683 albă . : White: : 8 , H. Her. P.

Phтtrlĕph As, Ruiz et Pavon. From phyton, a plant, 
and elephas, ivory; buttons are made from the hard albumen of the plant. Linn. 22, Or. 12, Nat. Or. Cyclanthacee. This ornamental shrub succeeds well in sandy loam and peat.

macrocārpă

S. Ev, S. Peru

1822

Paxteû̀n. Linnæus adopted this name from Dioscorides; meaning unknown, Linn, 5, Or. 1, Nat. Or. Campanulacea. Handsome herbaceouss plants, well adapted for rock-work, or growing in small pots; they will grow in any common soil, and increase readily by divisions or seeds. P. spicatum is occasionally eaten as an article of food. Synonymes: 1 . P. strictum, P. virgatum. 2. P. cordatum. 3. P. brevifolium. 4. P. ellipticum. 5. P.ovatum.

betonicifolion $\mathrm{Pa}$. $\mathrm{H}$. Her. P. S. Eur.

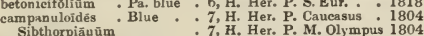
ñẻscéns Charmêliı : : Blue 6, H. Her. P. Pyrenees : 1823 comōsūm Blue 6, H. B. Austria. globularifơlîm : Blue : 6 , H. Her. P. S. France : 1820 Hallêrí . Violet. . 5, H Her. P. S. France - 1822 hemisphærǐcūm : Blue : - 7, H. Her. P. Switzerl. 1752 hispidum : : Blue : : 6, H. Her. P. Switzerl. : 1825 inæquătūm : : Blue : 6 , H. Her. P. Austria : : 1820 lanceolntũm : White : 6, H. Her. P. Armenia : 1826 limoniffolrúm, 1 . Red H. Ev. S. SwitzerL : 1832 Michêri * Red $\cdots$ 6, H. Her. P. Bohemia

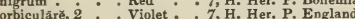
decipe, $2 \cdot 3$. Vhlet: digantor. gigantēm, 4 . Blue : 7, H. Her. P. France : 1817 pauciflōrūm - . Blue * . 5, H. Her. P. Switzerl. : 1823 Scheuchzêrí, $5^{\circ}$ : Blue * . 5, H. Her. P. Switzerl. : 1813 scorzonerifóliūm: Blue : : 7, H. Her. P. Alps: 1819 sibirineũm : . Blue : 7, H. Her. P. Siberia : 1817 spicātūm : : Blue : 5 , H. Her. P. Europe : 1597

Pнүтод $\overrightarrow{\mathrm{A}} \mathrm{Cc}$, Linn. From phyton, a plant, and lacca, lac; in allusion to the crimson colour of the fruit. Linn. 10, Or. 5, Nat. Or. Phytolaccacee. The stove species of this ornamental genus grow well in any rich light soil, and may be increased either from cuttings or seeds. $\boldsymbol{P}$. decandra is a fine herbaceous plant, requiring a good deal of room, on account of its wide-spreading branches. Its greatest beauty is in the numerous bunches of black berries, which make a pretty appearance; it grows freely in rich soil, and is increased by seed, or cuttings under a glass. Synonymes: 1. P. icosandra. 2. P. heptandra.

abyssiñ̌că . . Wht. grn. 5, S. Ev. S. Africa - 1775 bogotensir: : White. S. Her. P. Bogota 1824 decāndră : Li. pur. : 8, H. Her. P. Virginia . 1815 dioică . Wht grn. S. Ev. T. S. Amer. : 1768 dodecāndră

icosāndră White. 9, S. Her. P. Africa

White. 9, S. Her. P. K. Ind. 1758

mexicaña, 1 . White. 7, s. Her. P. Mexico - 1824

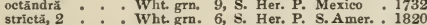

PIARÃTthŭs, $R$. Bromn. From piar, fatness, and anthos, a flower. Linn. 5, Or. 2, Nat. Or. Asclepiadacea. A genus of plants scarcely distinguishable from Stapelia, to which genus it may be referred for cultivation. Synonymes: 1. Stupelia arida. 2. S. Gussonerna. 3. S. incarnata. 4. S. mammillaris. 5. S. parviflora. 6. S. pulla.

arìdǔs, 1 - Pa. yel. 8, S. Ev, S. C. G. H. Gussoneanis. 2 incarnátŭs 3 mammillaris 4 : Brown. 6, S. Evo S. C. G. H. parvifiorŭs, 5 . : Yel. grn. : 8, S. Ev. S. C. G. H púllǔs, 6 .: Drk. pur. : 8, S. Ev. S. C. G. H punctătǔs : : Drk, pur. . 8, S. Ev. S. C. G. H.

Picramnĭ, Swartz. From picros, bitter, and thamnos, a shrub; whole plant very nauseous. Linn 22, Or. 5, Nat. Or. Anacardiacec. Shrubs of little beauty, succeeding in peat and loam; large cuttings will root in sand, under a glass, in heat.

Antidēsmă • Green • • S. Ev. S. Jamaica • 1793 pentāndră . Green . S. Kv. S. W. Ind. : 1829 PICridĩũ Desfontaines. From picros, bitter. Linn. 19, Or. 1, Nat. Or. Composite. The perennial species of this genus thrive well in common garden soil and are increased by seed or divisions. The annual kinds merely require sowing in the open ground Synonymes: 1. Crepis albida. 2. Sonchus picroides. 245 albüdúm, 1. Wht. yel, 8, H. Her. P. France . 1781

ilicifolrum : Yhlow yel. 8, H. Her. P. France : 1781 tingitanum ${ }^{*}:$ Yellow $: 7$, F. Her. P. Teneriffe : 1829 vulgăé, 2 . : Yellow : $7, \mathrm{H}$. A. France. : 1773

Pīcris, Linn. Derivation same as the genus Picridium. Linn. 19, Or. 1, Nat. Or. Composite. A genus nearly allied to, and requiring the same treatment, as Picridium. Synonyme: J. Crepis lap. pacea-P. altissimă 1, asperrimŭ, asplenioz̃dẽs, barbarơrūm, dahurīcă, hieraciōides, hispĩdă, Kamtschä. tĩcă, lyrātă, nepalēnsĩs, pauciflơră, Rhagadiólüs, rĭgĩdă, Sprengeriānă, strigð̋ă.

Picta, painted.

Pictêtî́, Decandolle. In honour of A. Pictet, a celebrated physician. Linn. 17, Or. 4, Nat. Or. Leguminosce. Ornamental plants, growing freely in a mixture of loam and peat; young cuttings will root readily in sand, under a glass, in heat. Synonymes 1. Eschynomene aristata. 2. Robinia squamata.

aristātă, 1 . . Yellow . 6, S Ev. S. St. Domin. . 1816 squamătă, $\dot{2}$ : : Yellow : S. Ev. S. W. Ind. : 1824

Pikrārdĭă, Roxburgh. In honour of Mr. Pierard, of Kew. Linn. 8, Or. 1, Nat. Or. Sapindacee. An edible-fruited tree. It grows in a mixture of loam, peat, and sand, and ripened cuttings root in sand, under a glass, in heat. Synonyme: 1. Pierardia sapida.

dülčss, 1 . . Yellow . S. Ev. T. Sumatro

1820

Pigron-PEA, see Cajānŭs.

PrL $\breve{k}$, Lindley. From pilos, a cap; one of the divi sions of the perianth. Linn. 21, Or. 4, Nat. Or. Urticacece. A neat little creeper, making a good cover to hide the earth of large pots, \&c.; it will grow in any common soil, and propagates freely from cuttings.

muscōsă . . Green . . 5, S. Ev. Tr. W. Ind. . 1793 Pilkate, having a cap or lid like the cap of a mushroom.

PrLI, long stiffish hairs.

Pilirgrous, bearing hairs.

PrцовǒLŭs, Tode. Derived from pilos, a cap, and boleo, to eject. Linn. 24, Or. 9, Nat. Or. Fungi. A curious little species, of a very fugacious nature, found on dung during the summer and antumn months-P. crystallinŭs, $\boldsymbol{C}$. rorĩdŭs.

PrLose, covered with long soft hairs.

Pilulấr̆̌̆, Linn. From pilula, a pill; shape of the heads containing the reproductive organs. Linn. 24, Or. 5, Nat. Or. Marsileaced. An obscure little plant, found in damp meadows among grass, especially where they have been overflowed with water during winter.

globulifféră - Brown - 7, H. Ev. Tr. Britain .

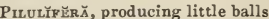

PrMEL $\overline{\mathrm{E}}$, Banks. From pimele, fat. Linn, 2, Or, 1 , Nat. Or. Thymelacea. A genus of beautiful shrubs, growing three or four feet high, and producing numerous heads of flowers. To flourish well, they must be planted in a mixture of three parts sandy peat and one part loam, the pots being carefully drained; young cuttings will strike in sand, under a glass; they likewise produce seeds, by which they are readily increased.

\begin{tabular}{|c|c|c|}
\hline 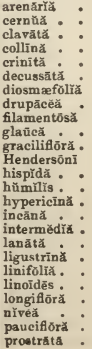 & 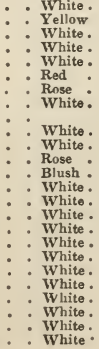 & $\begin{array}{l}\text { 7, G. Ev. S. Australia } \\
\text { 4, G. Ev. S. N. Holl. } \\
\text { 4, G. Ev. S. N. Holl. } \\
\text { 8, G. Ev. S. Swan R. } \\
\text { 5, G. Ev. S. N. Holl. } \\
\text { 7, G. Ev. S. N. Holl. } \\
\text { : 5, G. Ev. S. N. Holl. } \\
\text { G. Ev. S. N. Holl. } \\
\text { G. Ev. S. N. Holl. } \\
\text { 6, G. Ev. S. K. G.'s Sd. } \\
\text { : 7, G. Ev. S. K. G.'s Sd. } \\
\text { 5, G. Ev. S. N. Holl. } \\
\text { 9, G. Ev. S. N. Holl. } \\
\text { 9, G. Ev. S. K. G.'s Sd. }\end{array}$ \\
\hline
\end{tabular}




\begin{tabular}{c} 
PIM \\
\hline rŏsĕ $\cdot * \cdot$ Red $\cdot$. 6, G. Ev. S. N. Holl. $\cdot 130 n$
\end{tabular}

spicătă : : : White: : 6, G. Ev. S. N. Holl. : 1824 sylvéstrìs : : Blush : 6, G. Ev. S. N. Holl. : 183v

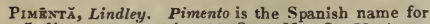
Indian-pepper. Linn. 12, Or. 1, Nat. Or. Myrtacea. This species forms in Jamaica a handsome tree, growing thirty feet high, and producing a fruit well known in this country under the name of Allspice. It delights in a strong loamy soil, and ripened cuttings will root in sand, under a glass, in heat. Synonyme: 1. Myrtus pimenta.

vulgắriss, 1. . . White. . 6, S. Ev. T. W. Ind. . 1723

\section{PiMprRner, see Anagällis.}

P1Mpix to the leaves being twice pinnate. Linn. 5, Or. 2, Nat. Or. Unbelliferce. Worthless species, growing best in a dry sandy soil, and increased only by seed, which ripen in abundance. Synonymes: 1. Tragium Anisum. 2. T. aromaticum. 3. T. Broteri. 4. $\boldsymbol{P}$. tenuis. 5. $\boldsymbol{T}$. depressum. 6. $\boldsymbol{P}$. dissecta. 7 . Columna, 11. T. villosum-P. Antsă 1, a romătică 2 ,

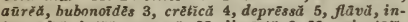
termédiă, lütěă, măgnă, $\boldsymbol{M}$. dissếctă $6, \boldsymbol{M}$. orientălìs 7, peregrină 8 , rotundifólĭă, Saxifrägă, S. nïgră 9, Tragiñm 10, villosă 11 .

PIм PLED, covered with minute pustules, resembling pimples.

PinckNés̆́. Named by Michaux in honour of Mr. Pinckney, an American, now forgotten. Linn. 5, Or. J, Nat. Or. Cinchonacee. A handsome halfhardy tree, furnished with long downy leaves, and dividaing but little into branches. It grows best planted against a south wall, with a little protection in severe weather; sand and peat is the best soil for it, and cuttings will root, if planted in sand, under a glass.

pübèng . . . . Red . . 6, F. Ev. T. Georgia . . 1786

Pink, see Pinūs.

PINE-APPLB, see Ananizssă.

Pravuícúr $r \grave{A}$, Linn. From pinguis, fat ; in allusion to the greasiness of the leaves. Linn. 2, Or. 1, Nat. Or. Lentibulacea Beautifill little plants, but diffi. cult to keep artificially. $\boldsymbol{P}$. grandiflora will succeed in common bog soil. The other species require a shaded morass to come to any perfection. $\boldsymbol{P}$. vulgaris acts on cow's-milk the same as common rennet. In Sweden and Norway the milk of the Reindeer is poured on the leaves, and set aside for a day or so, when it acquires consistence and tenacity, and then neither the whey nor the cream will separate, forming a very grateful food.

alpină . . . White . 4, H. Her. P. Germany . 1794

edentủla : : Yellow : 4, F. Her. P. N. Amer. : 1893

grandiflöră: : Blue : 4, H. Her. P. Britain .

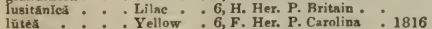

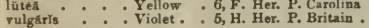

Pinguis, fat, greasy.

Pink, see Diänthüs.

PiNNA, the leaflets of a pinnate leaf.

Piscate; when a leaf is divided into numerous small leatlets, as the leaves of the ash.

PiNNATELY-TRRNATB, having three leaflets disposed in a pinnate manner.

Pinnatipid, when a leaf is divided into lobes from the margin neaily to the mid-rib.

PinNatifidix-sinuated, scolloped in a pinnatifid manner.

Pix-pilitar, see Opantiă curassãvĩcă.

Pivês, Linn. From pinos, a Greek word used by Theophrastus to designate a pine-tree; and some authors derive it from the Celtic pin, or pyn, a mountain or rock; alluding to the habitat of the tree. Linn. 21, Or. 10, Nat. Or. Conifera. This much-esteemed and well-known genus contains some of the trees of most universal use in civilised socicty, and forming a very important article of commerce both in Europe and America. Most, if not all, of the species are highly deserving of culture, being very ornamental and beautif $u$ in every stage of their growth. They will succeed on almost any kind of soil, but to bring the timber to its greatest state of perfection, a somewhat loamy and a cool subsoil are requisite. Young plants may be obtained by a variety of methods. All the
PIN

species may be propagated by layers, by inarching on nearly allied kinds, by herbaceous grafting; many may also be increased by cuttings; but the speediest way is by seed, and which process we shall briefly notice. In some of the species the cones attain their full size the first year, but, in most, not till the end of the second autumn. The cones of $\boldsymbol{P}$. sylvestris and the like, open of themselves shortly after being gathered from the tree, and spread out in the sun; but the cones of $P$. Pinaster, P. Pinea, and similar kinds, do not, though treated in the same manner, open their scales for several months. The seed should be sown on finely-prepared rather sandy soil, in March or April. The seeds of the most common kinds are always sown on beds, and after being gently beaten down, are slightly covered with light soil. The seeds of the rare kinds are sown in pots filled with finely-prepared soil, and when up, treated like other hardy seedlings. For a great mass of other useful information relative to these fine trees, indeed, for every thing that it is necessary to know respecting them, we refer the reader to Loudon's Arboretum el Fruticetum Britannicum, a work which ought to be in the hands of every lover of hardy trees and shrubs.

Under Pinus, we have included the genera Abies and Picea, of Don and other authors, believing them to be so nearly akin as to render it unnecessary to keep them generically distinct. We have, however, in this genus departed a little from the original plan of the work, by dividing it into Sections, so that those who differ from us in opinion, will have no difficulty in recognising the species of Abies and Picea of authors, every species of those genera being retained alphabetically under the respective Sections.

SвCT. 1. Y'̃xũs, Linn. Derivation same as genus. Synonymes: 1 . $P$. palustris. 2. $P$. genuensis. 3. $P$. oocarpa. 4. P. Pinaster Ascarina. 5. P. Lemoniana. 6. $\boldsymbol{P}$. nova-zelandica. $7 . P$. echinata, $\boldsymbol{P}$. uncinata. Q. P. rubra.

\section{apulcênsǐs. . A petal} australise, 1 austriacă

Banksian

brūtră

californica

canariênsIs

Cémbră

helveticer

pvgméă .

Coultêri

Devoniănă

excelsă.

Gerardiẳnă

halepēnsís.

genuênsìs, 2

maritima

minōr

Hartwegin

inôps

insignIs :

Lambertiānă

Larǐč̄ō

caramănícă

corsicānă

subviridin

leiophylla

Llaveán

longifơliă

macrophylla

mitis

Montezúma

montreơlá

oecidentaly

Ocôte, 3

Pallasiannă

pãtūlā.

A petal

A petal

A petal

A netal

Apetal

A petal

A petal

A petal

A petal

A peta

A petal

A petal

A petal

A petal

A petal

A petil

A petal

A petal

A petal

A petal

A petal

A petal

A peta

Apeta

Apetal

A petal

A retal

A peta

A peta.

- A peta

A peta

Aberdónié, 4 : A petal chinēnss's : A petal fol, variegattis - A petal Lemoniănă, 5 . A peta maritimă Massoniānă - A petal minơr : A petal nepalênsis: : A petal novi hollandi- - A petal St. heleniex '. A petal Pinén . . : A petal
H. Ev, T. Mexico .

H. Ev. T. N. Amer. : 1839

6, H. Ev. T. Austria 1835

5, H. Ev. T. Huds. B. : 1785

H. Ev. T. Calabria

H. Ev. T. Californis : 1829

F. Ev. T. Canaries : 1815

5, H. Ev. T. Siberis . 1746

, H. Er. T. Siberia .

H. Ev. T. Siberia : 1746

. Californis 1832

H. Ev. T. Mexico : : 1839
H. Ev. T. Nepal : 1823

H. Tepal

6, H. Ev. T. Levant : : 1683

5 , H. Ev. T.

5, H. Ev. T

5, H. Ev, T. Mexico . • 1839

H. k. T. T. N. Amer. . 1739

H. Ev. T. Californ. 1833

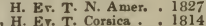

5, H. Er. T. S. Eur. : : 1820

5, H. Ev. T. Corsica . 1814

5, H. Ev. T.

F. Ev, T. Mexien

1801

5, H. Ev. T. N. Amer. : 1739

H. Ev. T. Mexico .

H. Ev. T. Californ. : 1831

F. Ev. T. St. Domin, .

F. Ev. T. Mexico : 1838

5, H. Ev. T. Siheria : 1820

H. Ev. T. Mexico . 1826

6, H. Ev. T. S. Eur. . . 1596

5, H. Ev. T. Nice - 1825

5, H. Ev. T. China

5, H. Ev. T.

5, H. Ev. T.

5, H. Ev. T. China : 1824

5, H. Ev. T. France : 182

5, H. Ev. T. N. Holl. . 1816

5, H. Ev. T. St. Helena . 1816

6, H. Ev. T. S. Evr. : 1548
5, H. Ev. T. Switzerl. : 1819

5, H. Ev. T. Genera : : 1830 


\begin{tabular}{|c|c|}
\hline PIN & \\
\hline americăna & - Apetal \\
\hline cretica & - A petal \\
\hline fragilis . & - Apetal \\
\hline ponderōsă & - Apetal \\
\hline $\begin{array}{l}\text { pseudostró } \\
\text { pumilióo. }\end{array}$ & - A petal \\
\hline Fischêrrì & - Apetal \\
\hline Mūghüs, 7 . & - Apetal \\
\hline nānă : & - Apetal \\
\hline rubriflōră & - A petal \\
\hline pũngēns. & - A petal \\
\hline pyrenăed. & - Apetal \\
\hline resinōsă, 8 . & - Apetal \\
\hline rĭgìda $: \cdot$ & - Apetal \\
\hline Russelliāna & - A petal \\
\hline Sabiniānă . & - Apetal \\
\hline serotină & - A petal \\
\hline sinënsǐs. : & - Apetal \\
\hline Strōbǔs . . & - A petal \\
\hline slbà. & - Apetal \\
\hline brevifoliă & - Apetal \\
\hline compréssa & - A petal \\
\hline sylvēstris . & - Apetal \\
\hline altăiea : & - Apetal \\
\hline genevēnsĭs & - A petal \\
\hline haguenēnsis & - A petal \\
\hline horizontalis & - Apetal \\
\hline intermédiă & - A petal \\
\hline monophylla & - A petal \\
\hline rigēnsis . & - A petal \\
\hline seariósă. & - Apetal \\
\hline tortuōsa . & - A petal \\
\hline uncinátă & - Apetal \\
\hline vulgäriss . & - Apetal \\
\hline Tädă & $\therefore$ A petal \\
\hline ocóté. & A petal \\
\hline timoriēnsis: & - Apetal \\
\hline variabiliš . & A petal \\
\hline
\end{tabular}

5, H. Ev. T. America

5 , H. Ev. T. Crete

H. Ev. T. N. Amer. : 1828

H. Ev. T. Mexico : 1839

5, H. Ev. T. Europe.

5 , H. Ev. T.

5, H. Ev. T. Austria

5, H. Ev. T.

5, H. Ev, T. N. Amer. . 1804

5, H. Ev. T. Pyrenee : 1834

5, H. Ev. T. N. Amer. : 1756

5, H. Ev. T. N. Amer. : 1759

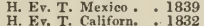

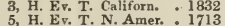

F. Ev. S. China : 1825

4, H. Ev. T. E. Amer. : 1705

5 , H. Ev. T.

4, H. Ev. T. Floetbeck

5, H. Ev. T. Scotland

H. Ev. T.

5, H. Ev. T. Geneva .

1836

5, H. Ev. T. Haguen

5, H. Ev. T. Scotland

5, H. Ev. T.

5, H. Ev. T. Livonia .

5, H. Ev, T. France

5, H. Ev. T.

5, H. Ev. T. Scotland

, H. Ev. T. Scotland

5, H. Ev. T. N. Amer. : 1713

5, H. Ev. T.

H. Ev. T. Mexico.

H. Ev. T. Timor

1820
1828

Sвст, II. ÄвйĒs, Tourn. From abeo, to rise; allusion to the aspiring habit of growth of the tree, or from a pios, a pear-tree; the cones being like its fruit; Abies species of most authors. Synonymes: 1 .

Abies excelsa. 2. A. alba. 3. A. canadensis. 4. A. cephalonica. 5. A. Douglasii. 6. A. Menziesii. 7. A. nigra. 8. A. orientalis. 9. A. rubra. 10. A. Smithiana, A. Morinda.

A biès, 1

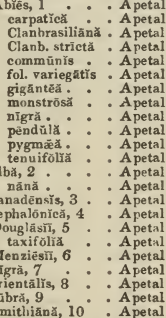

4, H. Ev. T. N. Eur.

4, H. Ev. T. Carp. M.

5, H. Ev. S. Moira

5 , H. Ev. S. Florence $\mathrm{Cl}$

4, H. Ev. T. N. Eur.

1548

H. Ev. T.

H. Ev. S.

4, H. Ev, T.

H. Ev. T.

H. Ev. T.

H. Ev. S.

5, H. Ev. T. N. Amer. - 1700

5, H. Ev. S. N. Amer. : 1736

5, H. Ev. T. Cephalonia : 1824

5, H. Ev. T. N. Amer. : 1826

, H. Amer.

H. Ev, T. N. Amer.

5, H. Ev. T. N. Amer. : 1700

5, H. Ev. T. Levant : 1825

5, H. Ev. T. N. Amer. 1755

H. Ev. T. Kamaon : 1818

Sect. III. Pīcǩn̆, D. Don. From pix, pitch; the tree producing abundance of resin-Picea and Abies species of most authors. Synonymes: 1. Picea amabilis. 2. P. balsamea, Abies balsamifera. 3. P. Fraseri, A. Fraseri. 4. P. grandis, A. grandis. 5. P. nobilis, $A$. nobilis. 6. $P$. pectinata, $A$. pectinata. 7. P. Pichta, A. Pichta. 8. P. Pindron. 9. P. Pinsapo. 10. P. Webbiana, Pinus spectabilis, A. Webbiana.

amabilǐs, 1. . A petal

balsāméa, 2 A petal longifólíă: A petal

Frasēri, 3 : A peta]

grāndis, 4 : : A petal

nobilirs, 5 : A petal

Picēă, $6:$ : A petal

Pichtă, $7:$ : A petal

Pindrôw, 8 : A peta

Pinsăpó, 9 : A peta]

H. Ev. T. N. Calif,

5, H, Ev, T, N. Amer.

5, H. Ev. T.

5, H. Ev. T. Pennsylv. 1811

5, H. Bv, T, N, Calif, 1831

H. Ev. T. N. Amer. 1831

5 H. Ev. T. Germany : 1603

5, H. Ev. T. Siberia - 1820

, H. Ev. T. Kamaon : 1837

H. Ev. T. Nepal : 1822

Pīpěr, Linn. From pippul, a Bengalese name, or pepto, to digest. Linn. 2, Or. 3, Nat. Or. Piperacea. All the species of this interesting genus flourish in a mixture of loam and peat, requiring but little water; they are multiplied with facility by cut-
PIP

PIS

tings and suckers. The well-known pepper of the shops is principally produced by $P$. nigrum. $P$. Betle furnishes the Betle-leaf of the Southern Asiatics, in which they inclose a few alices of the Areca-nut, and a little shell lime; this they chew to sweeten the breath, and to keep off the pangs of hunger, and such is the immense consump. tion of this luxury in the East, that it nearly forms

as extensive an article of commerce as that of tobacco in the West.

•. A petal

üncūm * A A petal

Amālăgō * : A petal

colubrinūm

decumânūm : : A pet

discǒlŏr.:A A petal

geniculātūm : A pet

glábrumm * A pet:

glaucēscëns : A petal

hírsútūm * A petal

hispĩdúm . * A peta

lauriföliủm ..

lôngūm .

macrophy̆llüm : A peta]

medium : : A petal

nìgrúm .

nĭtỉdūm

peltâtūm

racemōsūm

reticulātūm

Siriböă.

tomentōsūnı

triตับิอ̄̄m

tuberculätuิm

A peta

A petal

A petal

A petal

Apetal

Apeta

A petal

Apeta

A petal

S. Ev. S. Peru

- 1823

E. Ev. S. Jamaica $: 1748$

Ev. S. Jamaica $\cdot 1759$

S. Ev. S. E. Ind. 1804

S. Ev S. Cazil . 1820

7, S. Ev. S. W. lnd. : 1768

S. Ev. S. Jamaion: 1823

S. Ev. S. Campeachy 1768

S. Ev. S. W. Ind.

7, s. Ev. S. S. Amer. 1793

Ev. S. W. Ind 1768

S. Ev, S. E. Ind.

S. K. S. W. W. Ind. 1800

S. Ev, S. W. Ind. 1820

S. Ev. Cl. E. Ind. - 1790

S. Ev. S. Jamaica

S. Ev. S. Campeachy 1768

S. Ev. S. W. lnd. 1748

8, S. Ev. S. E. Ind. 1768

- 1768

S. Ev. S. Ind. 1818

6, S. Ev. S. W. Ind. : 1748

Piperitus, hot, pungent.

Pipkwort, see Eriocaũlón.

Piptānthữs, Sn'eet. From pipto, to fall, and anthos, a flower; the flowers are very fugacious. Linn. 10, Or. 1, Nat. Or. Leguminosie. A very handsome and ornamental shrub when in flower, and sufficiently hardy to thrive in the open ground without any protection; it grows well in a rich loamy soil, and is increased by layers, or cuttings of the nearly ripened wood, planted in sand, under a glass. $S y$. nonyme: 1. Anagyris indica.

nepalênsis, 1 . Yellow . 5, H. De. S. Nepal . . 1821

PiptathērūM, Beauvois. From pipto, to fall, and ather, an awn. Linn. 3, Or. 2, Nat. Or. Graminea. Curious species of grass, requiring the same treatment as Milium. Synonymes: 1. Milium corulescens. 2. M. multiflorum, arundinacetm. 3. M. paradoxum, Arachne virescens.

cærulëscēns, 1 . A petal

1319

multiflórūm, 2 . A petal 6, Grass. S. Eur. . 1778

paradöxūm, 3 : A petal : 6, Grass. France : : 1771

Piptocrāină, Don. From pijto, to fall, and klaina, a cloak; the calyx is deciduous. Linn. 5, Or. 1, Nat. Or. Ehretiacee. The seeds of this annual should be sown on a hotbed, and in May or June the plants should be planted out in the open border. Synonyme: 1. Heliotropium supinum.

supină, 1 . . . Yel, wht. . 6, H. A. S. Eur. . . 1640

Prquêríă, Cavanilles. After Andreas Piqueria, a Spanish botanist. Linn. 19, Or. 1, Nat. Or. Compositce. $\boldsymbol{P}$. trinervia is a pretty herbaceous plant all the species are of easy culture, and are mul. tiplied by divisions.

trinërviå . . White . 7, H. Her. P. Mexico . 1798 artemisioz̃dēs, ovātă, pilosă.

PiscĭDİa, Linn. The leaves, bark, and twigs are used for the purpose of stupifying fish; whence the name from piscis, a fish, and cido, to kiil. Linn. 16, Or. 6, Nat. Or. Leguminose. This genus, the Jamaica Dogwood, consists of two ornamental timber-trees, with spreading branches and pinnate leaves. Sandy loam suits them best, and cuttings may be rooted in sand, under a glass, in heat. Synonyme: 1. P. Erythrina.

carthaginēnsǐs, 1 . Dirty $w$. S. Ev. T. Carthage 1690 Erythrind. : Dirty w : S. Ev. T. W. Ind. : 1690

Pisiforms, formed like a pea.

Pisonyă, Linn. In honour of M. Piso, an eminent physician of Amsterdam. Linn. 7, Or. 2, Nat. Or. Nyctaginacea. Stove shrubs, of not much merit. 
$P$. aculeata is remarkable for its spiny branches, and for its glutinous and burry seeds, which fasten to whatever tonches them. A mixture of peat and loam suits them best, and they are easily propagated by cuttings in the same sort of soil.

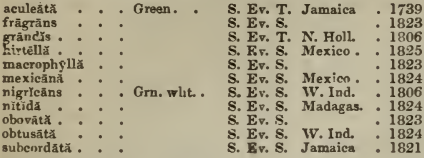

Pistachia-tree, see Pistizciă.

PIs r Ācǐx̆, Linn. Altered from Forstag, its Arabic name. Linn. 22, Or. 5, Nat. Or. Terebinthacere. Ornamental plants. The greenhouse kinds thrive in loam and peat, and cuttings of the ripened wood root in sand, under a glass. The hardy species do best planted against a wall, as they are rather tender; common garden soil suits them, and they may be increased by layers, or cuttings in sandy soil under a glass. Synonymes: 1. P. Lentiscus massitiensis. 2. $\boldsymbol{P}$. efficinarum. 3. P. reticulata.

atlantícă . . Apetal

Lentiscūs: : A petal angustifolia, 1 Apetal chia. A petal

Terebinthùs: : A petal sphrerocarpa véră, 2 ... A petal narbnnēnsls, 3 . A petal trifỗă A petal

1790

5, G

5, H. Ev. T. S. Eur.

5, H. Ev. T. Scio .

5, H. Ev. T.

5, H. De. T. Syria

4. H. De. T. Narbonne 1759

5, H. De. T. Syris

Pistillem, or pistil, the columnar body in the centre of a flower, consisting commonly of three parts; viz., the ovary, styles, and stigmas.

Pistritusiñ, Fries. From pistillum, a pestle; form of the plants. Linn. 24, Or. 9, Nat. Or. Fungi. The species constituting this genus are chiefty found on the decayed leaves of ferns-P. mícäns, muscicollă, puberĭlă, pusillă, quisquiliāris.

Pistorinîn, Decandolle. The meaning is unknown to us. Linn. 10, Or. 5, Nat. Or. Crassulacer. The seeds merely require sowing in light soil in any dry situation in the open border, or on rock-work, where it has a pretty appearance. Synonyme: 1 . Cotyledon hispanica.

hispănİĕ, 1 . . Red . . 6, H. B. Spain . 1796 Pjoũ x, Linn. From pis, the Celtic word for pea; whence the Latin pisum. Linn. 17, Or. 4, Nat. Or. Leguminose. This genus affords one of the most valuable and well-known legumes, the $\mathrm{Pea}$, and like most cultivated vegetables, it has produced nur. Jus improved varietics, growing from a foot to twelre feet high. They prefer a rich dry soil, in which they may be sown at any season, according to the time when they are wanted.

americắnūm . Purple . 7, H. Her. P. S. Amer. . 1800 Purple 7, Her. P. Amer.

elătûm : : Drk, blue. 7, H. Cl. A. Iheria

maritimñm : Purple : 7, H. Her. P. England

white $7, \mathrm{H}$. Cl. A. S. Eur.

hŭmilę: : White: : 7, H. Cl. A

macrocripuim: White. 7, H. Cl. A

quadrătinm : White: $7, \mathrm{H} . \mathrm{Cl}$. A

saccharătum : White. : 7, H. cl. A

umbellatúm : Purple: 7 H. Cl. A.

Pirction physician of London. Linn. 6, Or. 1, Nat. Or. Bromeliacea. A handsome genus of plants, remarkable for their long narrow prickly leaves, and regular panicles of flowers; for culture, \&c., see Tillandsia.

\section{Ihyons.}

bromeliefolià

bracteăta - . Scarlet

chilēnsls - : Scarlet

furfurāeéa: : Red

hümHIYs: : . Sesrlet

integrifolia : Red

intermedra : Scarlet

ridifloră : Scarlet

Intifolia: : : Scarlet medră . . Searlet

staminax

i, S. Her. P. S. Amer. 182 sulphŭré: : : Yellow : 8, S. Her. P. W. Ind. : 1797

Prtcher-lear, see Nepēnthẽs Phyllâmphöră.

Pirchri-plant, see Nepenthés.

Pitchers, hollow leaves, having the appearance of pitchers.

Prra, medulla, occupying the centre of a stem or shoot.

Prtrospŏrūm, Banks. From pitte, to pitch, and sporos, a seed; the seeds are covered with a resi. notis pulp. Linn. 5, Or. 1, Nat. Or. Pittis poracea. All the species are very handsome shrubs, on account of their glossy foliage and pretty flowers, which render them well adapted for conservatories. $\boldsymbol{P}$. Tobira will succeed against a south wall, with the protection of a mat in severe weather. All the species thrive well in a mixture of peat and loam, and ripened cuttings root in sand, under a thlass. Synonyme: 1. P. hirsutum.

Andersōnĭ , Yellow . 5, G. Ev. S. N. Holl. . 1820 angustifolrüm: Yellow: 6, G. Ev S N, S. WV : 1830 bracteolatüm : G. Fv. S. Norfolk Is. 1837 eapense. cornifơlîn ferrugineưm fülvũm .

hirtūm, 1

ligustrifolrùm

mauritiănn

oleifollūm

revolútuีm

tenuifolrüm

Toblră

tomenthsūm

undulatūm .

variegatūm

G. Fv. S. Norfolk Is. 1837

Blue * 5, G. Ev. S. Ev. S. Madeira : 1783

Brown : 5, G. Ev. S. N. Zeal. : 1827

Yellow . 3, G. Ev. S. Guinea . 1787

Yellow 4, G. Ev. S. N. Holl. 1820

5, G. Ev. 8. Canaries 1822

9, G. Ev. S. N. Holl. - 1823

Yellow 5, G. Ev. S. Mauritius : i825

G. Ev. S. N. Holl. 1823

Yellow 3, G. Ev. S. N. Holl. : 1795

White. 5, G. Ev. S. N. Holl. 1820

Yellow 7 , G. Ev. S. Japan. - 1804

Whe grn. 4, G. Ev. S. N. S. W. 1789

Wht. jel. 4, G. Ev. S. Gardens :

riridiforūm : Green . 5, G. Ev. S. C. G. H. : 1806

Placknta, that part of the capsule to which the seeds are attached.

Plañeră, Roxburgh. From pladarns, abounding in juice. Linn. 4, Or. 1, Nat. Or. Gentianacea. The seed of these plants should be sown on a hot.bed, and treated similarly to balsams.

decussata . . White. . 8, G. B. W. Ind. 1816

Plagiānthưs, Forster. From plagios, oblique, and anthos, a flower; direction of the flowers. Linn. 16, Or. 7, Nat. Or. Euphorbiacec. These plants grow well in any rich light soil, and cuttings of the young wood root freely in sand, under a glass, in heat.

divarieătŭs, 1. Red 6, G. Ev, S. N. Zeal. - 1828 sidoldés, 2.: Yelsh.: : 9, G. Ev. S. V. D. L.

Pr.agrobōtr řs, Fischer and Meyer. From plagios, transverse, and bothrys, a pit; the pits at the base of the carpels are transversc, and not longitudinal. Linn. 5, Or. 1, Nat. Or. Boraginacea. A hardy annual, net worth cultivating except in botanic gardens-P. ruféscêns.

Plagiolóвí s, sneet. From plagios, transverse, and lobos, a pod; alluding to the shape of the pod Linn. 17, Or. 4, Nat. Or. Lcruminosie. A genus of very beantiful greenhouse plants. For culture and propagation, see Hovea.

chorozemaföluum Purple . 3. G. Ev. S. N. Holl. . 1824 ilicifoliũm. . Purple : 3, G. Ev. S. K. G.'s Sd. . 1824

Planêă, Michaux. In honour of J. Planer, a Ger. man botanist. Linn. 4, Or. 3, Nat. Or. Ulmacea. A genus very nearly related to Ulmus, growing freely in a loamy soil, in moist situations; they may be multiplied by layers or grafts. Synonymes : 1. Planera aquatica. 2. Ulmus nemoralis.

Gmelini, 1 . . Brown * 4, H. De. T. N. Amer. - 1816 Richârdı, $2^{\circ}::_{\text {Brown }} \quad$ : 4, H. De. T. N. Amer. : 1760 Plake tres, see Platănñts.

PI.ANK PLANT, see Bossiāeă scolopëndrĭă.

PlantĀGô, Linn. Derived from planta, the sole of the foot; resemblance in the leaves. Linn. 4, Or. 1, Nat. Or. Plantaginacea. A genus, the greater number of the species of which are mere weeds, of the easiest culture and propagation. Synonymes: 1. P. sphaerocephala. 2. P. crispa. 3. $\boldsymbol{P}$. rigida. 4. P. Cornuti. 5. P. Cornuti. 6. P.alpina. Ispaghūla . . . White . 6, H. A. E. Ind. . 1824 Kentuekensis : White : 6, H. Her. P. N. Amer. 1829
, S. Her. P. Jamaica 4, S. Her. P. W. Ind

11, S. Her. P. Rio Jan.

7, S. Her. P. S. Amer

7, S. Hex P. S. Amer

8, S. Her. P. W. Ind

7, S. Her. P. S. Amer. 7, S. Her. P. S. A me 8, S. Her. P. W. Ind. [248] 
afrā, ălb̌̌cāins, alpiñă, altīssĭmă, amplexicaūlǐs, arenärŭă, asiatĭcă, Bellārd̄̄ 1, brasiliēnsìs, brūtīŭ, capēnsìs, ceratophÿllă, cordätă, coronöpüs, crässă 2 , crassi-

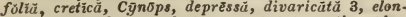
gâtă, eviostächy̆ă, exaltată, garyănĭcă, gentianoĩdēs,

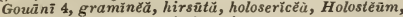
humifüsă, hungarĭcă, indīcă, interrū ptă, Jacquīnĩ 5 , Kamtchätícă, Lagopüs, lanceolätă, L. variegätă, Leflīngīi, lusitünīcă, macrorhīză, mäjör, $M$. rösĕă, $M$. scopärĭă, marîtímă, $M$. variegätŭ, $M$. vivipără, măxĭmă, medīă, mexicänă, microcēphălă, mìnīmă, montānă, notütŭ, parvifóră, patagonĩcă, pilösă,

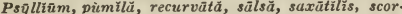

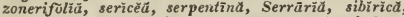
sinuätă, spharocéphălă 6, squarrósŭ, strīctă, subulată, tenulflōră, teretifóliă, tumìlă, vaginātă, vārĭă, villøsŭ, virginīcă, Wulfēnī.

Plantain, see Alismä Plantāgo.

Plantain, see Plantägo.

Plantain tree, see Müsă.

Puatānthērã, Richard. From platys, broad, and anthera, an anther. Linn. 20, Or. 1, Nat. Or. Orchidacea. Pretty plants. For culture and propagation, see Orchis. Synonymes: 1. Orchis bifolia. 2. Fabenaria ciliaris. 3. $\mathrm{H}$. cristata. 4. $\mathrm{H}$. dilatata. 5. H. fimbriata. 6. H. flava. 7. H. herbiolu. 8. H. blephariglottis. 9. H. orbiculata. 10. H. hyperborea. 11. H. incisa. 12. H. psychndes, $\boldsymbol{H}$. lacera 13. $\boldsymbol{H}$. gigantea.

bifolră, 1. . White. . 6, H. Ter. Britain

eiliăris, 2. : Yellow * 6, H. Ter. N. Amer. : 1796

eristătă, 3 . . Yellow . 9, H. Ter. N. Amer. . 1806

dilatătă, 4 : White : 9, H. Ter. Canada : 1823

flävă, 6 : Y Yellow:7, G. Ter. N. Holl. : 1823

herbiölä, $\dot{7}:$ Green $: 6$, H. Ter, N. Amer. 1789

holopetălă, 8 : : White: : 5, H. Ter. Canada : 1820

Hookêrī, 9 : : Green : : 6, H. Ter. N. Amer. : 1822

hyperbürěă, io : Green . 6, H. Ter. N. Amer. : 1805

incist, 11 psychổes, $12:$ Pa yel. : Y, F. Ter. N. Aner. : 1826

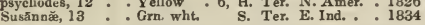

Platăxŭs, Linn. From platys, ample; in allusion to the spreading branches and shady foliage. Linn. 21, Or. 9, Nat. Or. Platanacea. Noble trees, of peculiar grace and elegance, well fitted for large plantations, or to stand singly on a lawn. They are easily increased by layers, or cuttings planted out in autumn, in a sheltered situation. Syno. nymes: 1. P. acerifolia. 2. P. cuneata.

occidentälis . Apetal . 4, H. De. T. N. Amer. . 1636 orientålis . A petal : 4, H. De. T. Levant. : 1548 acerifolliă, 1 . A petal :4, H. De. T. Levant :

cuneảtă, 2 - A petal * 4, H. De. T. Levant

Platycārpiūm, Humboldt. From platys, broad, and karpos, fruit; in reference to the compressed seedpod. Linn. 5, Or. 1, Nat. Or. Bignoniacea. This tree thrives in peat and loam; and half-ripened cuttings planted in sand, and placed under a handglass, root readily. If the plants are kept rather dry in winter, it will tend to throw them in to flower.

orinocěnsĕ . . . $\mathrm{Pa}$ rose - S. Ev. T. Orinoco . 1813

Platychīıūm, Delaunay. From platys, broad, and cheilos, a lip; breadth of corolla. Linn. 16, Or. 6, Nat. Or. Leguminose. A beautiful plant, requiring the same treatment as the Hoveas. Synonyme: i. Gompholobium celsianum.

Celsiānūm, 1 - Yellow . G. Ev. S. N. Holl. . 1820

Pr.atycōnōn, Decandolle. From platys, broad, and kodon, a bell; the flowers are broad and bell-shaped. Linn. 5, Or. 1, Nat. Or. Campanulacea. A neat, elegant plant when in flower; it grows best in sandy loam, and may be increased by seeds or young cuttings. Synonyme: 1. Campanula grandiflora.

grandiflōrûm . . Blıe * . 6, H. Her. P. Dahuria . 1782

Platxuŏbīù, Smith. From platys, broad, and lobos, a pod; in reference to the broad legumes. Linn. 16, Or. 6, Nat. Or. Leguminosa. Free-flowering shrubs, of rather difficult culture; they require a mixture of three-parts sandy peat and one part loam; the pots must be carefully drained, to allow the water to pass off freely, and care must be taken not to over-water them. They may be propagated by cuttings in sand, under a glass; or by seeds, which are sometimes produced in abundance. [249]

\section{formősūm}

Murrayãnăm

Orange

Yel, red

Orange

vâtūmgúñm. Orange

parciflôrūm

Orange

riangulärè

D. Don.

7, G. Ev. S. N. Holl

5, G. Ev. S. V. D. L.

7, G. Ev. S. N. Holl.

7, G. Ev. S. N. Holl.

From platys, broad, and lophos, a crest; the capsule, from being much com pressed at the apex, appears as if winged. Linn. 10, Or. 2, Nat. Or. Cunoniacea. The White Ash of the English colonists is an elegant tree. It sueceeds well in a mixture of loam and peat; and cuttings of the ripened wood root freely in sand, under a glass. Synonyme: 1. Weinmunnia trifoliata.

trifolıâtŭs, 1

G. Ev. T. C. G. H.

1820

Praţ̦́p̌̌rĭs, Humboldt and Bonpland. From platys, broad, and pteron, a wing; appendage to the seed. Linn. 19, Or. 1, Nat. Or. Composite. A small plant of little beauty, growing in any peaty soil, and increased by cuttings, in the same kind of soil, under a glass. Synonyme: 1. Spilanthus crocatus.

erocătă, 1 . . . Orange . 3, S. Her. P. S. Amer. . 1812

Pratyspéraûm, Hooker. From platys, broad, and sperma, a seed. Linn. 6, Or. 2, Nat. Or. Cruciferce. Mere annual weeds, growing in any garden soil. Synonymes: 1. Caucalis littoralis. 2. C. orientalis. 3. Daucus muricatus-P. littorälís 1, orientälìs 2,0 . pulcherrīmũm, muricātũm 3.

Píatystīsōn, Bentham. From platys, broad, and stemon, a stamen. Linn. 13, Or. 1, Nat. Or. Ranunculacece. A genus of rather pretty annuals, growing freely in sandy loam.

ealifornicušs - Yellow - 8, H. A. California . 1833

Pratrstīgma, Bentham. From platys, broad, and stigma; the stigma is ovate. Linn. 13, Or. 1, Nat. Or. Ranunculacec. This plant somewhat resembles Platystemon californicus, and requires the same treatment as that plant.

lineăré . . Yellow . F. Her. P. California . 1933

Pliatystřlis, Sneet. From platys, broad, and stylos, a style; in allusion to the dilated style. Linn. 17, Or. 4, Nat. Or. Leguminosa. A very handsome genus of flower-border plants. For culture and propagation see Orobus. Synonymes: 1. Orobus cyaneus. 2. O. sessilifolius. 3. O. stipulaceus.

eỹañĕă, 1 . . Furple - 5, H. Her. P. Caucasus . 1823 sessilifölǐus, 2 . Purple :5, H. Her. P. Tauria * 1823

Plectrānthǔs, L'Heritier. From plektron, a cock's spur, and anthos, a flower; referring to the shape of the flowers. Linn. 14, Or, 2, Nat. Or. Labiatie. Any light rich soil will suit the stove and rmeenhouse shrubby and herbaceous kinds; and $\mathrm{cL}$ engs root readily. The seeds of the annual and biennial species require to be sown on a hotbed, and treated the same as other tender annuals and biennials. Synonymes: 1. P. secundus. 2. Ocymum molle. $\mathbf{3}$. O. scutellarioides.

\section{ineånŭs . - . Blue * . 7, G. Her. P.}

. 1822 punctätŭs - Blue 1805

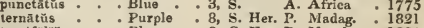

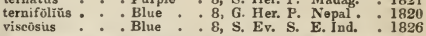

äspĕr, austrūilis, Coētsŭ, colorülūs, comōsŭs, cordifoliŭs 1 , galeūtūs, graveōlëns, mölìs 2 , rotundifoliñs, scu-

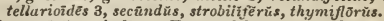

Prectrītis, Lindley. From vlektron, a cock's-spur in reference to the flower being gibbous in front Linn. 3, Or. 1, Nat. Or. Valerianacea. The seed of this plant only requires to be sown in the open border. Synonyme: 1. Valerianella congesta.

congëstà, 1.:
minōr

Prectrōnĭă, Linn. From plektron, a cock's-spur tree with large spines. Linn. 4, Or. 1, Nat. Or. Cinchonacea. An ornamental tree; for culture and propagation, see Chiococca.

corymbồå . . . Wht. grn. G. Ev. T. C. G. H. . 1816

Plë̈̆̆, Michaux. From pleias, the seven stars; dis. position of the flowers. Linn. 9, Or. 2, Nat. Or. Melanthacea. A species succeeding well in peat 
soil, in a moist situation : it also grows well in pots, placed in pans of water; increased by seeds.

tenuifolra . . Brown . . 7, Grass. Carolina . 1824

PleopezLtYs, Humboldt and Bonpland. From pleos, full, and pelte, a shield; the form of the indusium. Linn. 24, Or. 1, Nat. Or. Polypodiacee. A genus of Ferns, succeeding well in loam and peat, in a shady situation; readily increased by dividing the roots, or by seeds.

ensifolra . . Brown . 5, S. Her. P. S. Anuer. . 1823 latifolra : : Brown :5, S. Her. P. S. Amer. : 1823 nūdă : : Brown 5 , S. Her. P. Nepal :

PlsRómX̃, Don. From pleroma, fulness; cells of the capsule. Linn. 10, Or. 1, Nat. Or. Melustomacea. Ornamental shrubs, from three to six feet high. For culture and propagation, see Melastoma. Synonymes: 1. Melastoma heteromalla. \&. M. villosum. 3 Rhexia viminea.

heteromalls, 1. Purple 7, S. Ev. S. Brazil . 1819 villosa, 2 : : Wlite. 7 , S. Ev. S. S. Amer. : 1820 viminé, 3 : : : Purple : 7, s. Ev. S. Brazil : 1821

Plagerandra, Lnbillardiere. From pleuron, a side, and aner, a male; in allusion to the stamens being on one side of the calyx. Linn. 13, Or. 2, Nat. Or. Dilleniaced. A very pretty genus of plants, growing about two feet high, in a mixture of sandy loam and peat; and cuttings of the ripened wood root readily in the same sort of soil, under a glass.

seleularis . . Yellow . 5, G. Ev. S. N. Holl. 1822 bracteath : : Yellow: 5, G. Kr. S. N. Holl. : 1823 calyetnA : : Yellow : 5, G. Ev. S. N. Holl : 1826 Cneorum : : Yellow : 6, G. Ev. S. N. Holl ericafolrs: : Yellow : 5, G. BV S N. Holl nitrids : Yellow : S, G. EV. S N. Hoil nitrid : : : Yellow : 5, G. Ev. S. N. Holl

Pusurospèrycr, Hoffman. From pleuron, a rib, and sperma, a seed; in allusion to the membranes of the pericarps both having ribs. Linn. 5, Or. 2, Nat. Or. Umbellifere. A plant of no interest, growing in any common soil, and readily increased by seeds. Synonyme: 1. Ligusticum austriacum-P. austriacam.

Pleurnthilly, R. Bronn. From pleuron, a side of rib, and thallo, to flower; in allusion to the onesided disposition of the flowers of some of the species. Linn. 2n, Or. 1, Nat. Or. Orchidacee. This is a genus of curious little plants, well fitted for cultivating on wood, in the same way as the Burlingtonias.

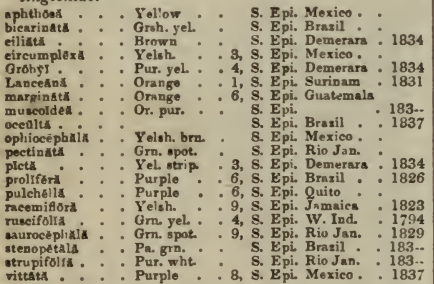

Pricatr, plaited; 3,4 , or 5 , plicate, means 3, 4, or $b$ plaited.

Proctxx Aiton. From plokamos, bent hairs; allud. ing to the pendulous branches. Linn. 5, Or. 1, Nat. Or. Cinchonacer. The plant grows best in a mix. ture of loam and peat; and it may be readily propagated by cuttings, in sand, under a glass.

pendâlă. . . White. G. Ev. S. Canaries

$17 \div 2$

PLoughuan's gpIKBNard, see Bacchŏris.

Pluk RNÉtî́. Named by Plumier in honour of Leonard Plukenet, an English botanist. Linn. 21, Or. 10, Nat. Or. Euphorbiacea. Uninteresting stove climbers, growing in a light loamy soil; increased by cuttings, under a glass, in sand- $P$. verruchsa, volubilis.

Plom, see Prante.

PLUMв̄̄Go, Linn. From plumbum, a disorder in the eyes, which some species were formerly said to cure. Linn. 5, Or. 1, Nat. Or. Plumbaginacee.

Pretty free flowering plants, growing in any $\mathrm{com}$ mon soil, and increased readily by cuttings. The root of $P$. europoea, it is said, when chewed will cure the toothach. Synonymes: 1. P. zeylanica, scandens.

capensis * * Blue * . 11, G. Ev. S. C. G. H. - 1818 europêa : Blue : 9, H. Her. P. S. Eur. . 1596 lapatliffolra : Whito $6 . \mathrm{H}$. Her $P$. Iberia : 1829 mexiç̋nă. : White: 7, S Ev, S. Mexico: : 1829

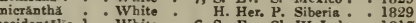
occidentalis, 1 . White 6, S. Ev. Cl. W. Ind. 1817 rhombifolra : Blue. . 9, S. A. S. Amer. : 1826 roser : : Red : 5 , S. Ev. S. E. Ind. : 1777 tristls : : Brown : 5, G. S. C. G. H. 1799 zeylanYed: : Whito : 6, S. Ev. S. E. Ind. : 1731

Plumiêr IX, Iinn. In honout of C. Plumier, a celebrated French botanist. Linn. 5, Or. 1, Nat. Or. Apocynacee. A genus of very fine flowering plants, growing best in a light loamy soil, or a mixture of peat and loam; large cuttings, with their leaves on, after being dried for a few days, will grow freely in pots of mould, without being watered. The plants, when in a dormant state, must be kept dry, otherwise they do not flower freely. Synonymes: 1. P. tricolor. 2. P. Gouani.

acuminata. . Red yeL. . 7, S. Ev. T. E. Ind. . 1790 albă . : White. 7, S. Ev. T. Jamaica : 1733 bicolor : Wht yel. 8, S. Ev. T. S. Amer. : 1815 Blundfordiant : 7, S. Ev. S. S. Amer. : 1825 conspleüal : : 7, S. Ev. S: S. Amer. : 1820 incarnats: :Flesh : 7, S. Ev. S. Peru : 1820 KerI, 1. : Yellow : 8, S. Ev. T. Mexico: 1815 Lambertifnz, 2 : White. 7, S. Ev. S. Mexico : 1819 leuednthi . . White. 7, s. Ev. S. S. Amer. : 1823 longifolia : : White. 7, s. Ev. s. Madag. : 1819 lütex ${ }^{\circ}$ : Yellow 7, 8. Ev. \&. Peru 1815 macrophylla . White. T, S. Ev. S. S, Amer. . 1825 Millerr : Flesh

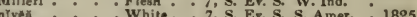

7. Eves

obtüs .: : White. : 7, S. Ev. T. W. Ind. : 1733

pudica : Yellow 7 , s. Ev. \$. S. Amor.

purpürea : : Purple : 7, s. Ev. S. Peru : : 1820

tenuiforia : : Red * 7, S. Ev. T. Jnmaiea : 1690

tuberculats : White. 8, S. Ev, S. Si. Domin. 1818

Puvmoss, resembling feathers.

Plumōst's, feathery, downy.

Premura, the young leaf in the embryo.

PLiRilocular, having many cells

PruvituYs, expanding in wet weather.

Pöă, Linn. From poa, siguifyink grass or herbage. Linn. 3, Or. 2, Nat. Or. Gramined. This Renus contains some valuable hay and pasture grasses, succeeding well in rich loamy soll; some of the species are aquatic, growing only in water or very moist situations; increased by seeds, or divisions of the roots. Synonymes: 1. Arundo pocformis. 2. P. thermalis. 3. P. flexwosa.

al pina

- Apetal . . 6, Grass Seotland

nemoralls : Apetal. 7, Grass Britain

praténsis : A petal: : 5, Grass. Britnin

snquatifrila - A petal * 7, Gras Germany :

abyssiñicd, amboynenars, ancéps, angustata, anntia, aspert, atrovirens, australls 1, badensis, brachyphglld, bromotdes, bulbosd, caesid, caespitosă, capillaris, caroliniand, cenisid, chinënsls, cilianensis, coarctútă, collinä 2, eompressa, conctnnă, convolntă, debilis, decip:ēns, depauperätă, diändră, digitată,

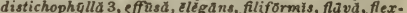
urisd, Gaudint, glancĕ, Gmeltnt, gräcills, Halleri, hirsntă, hũmflis, hybridă, imbecillă, läxă, meliâceă, Molineri, mucrunata, nemoralls, $N$, angustifolid, ncrvätă, pallıd̆, papillờă, peruviānd̆, plebeid, Poirettr, retroflexă, scariösã, serotină, S. palûstris, spicātă,

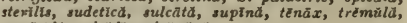
versicolör, viridis, vivĩpărä.

Pöñckĩ̌, $\boldsymbol{N}$. C. Seringe. In honour of Richard Pococke, a botanical traveller in the Levant. Linn. 17, Or. 4, Nat. Or. Leguminosc. The seeds merely require sowing in the open border about the beginning of April. Synonymes: 1. Trifolium cretica, Melilotus cretica.

eretıč̆, 1... Yellow . 7, H. A. Candin . . 1713

POD, a kind of seed-vessel, such as that of the pea tribe. 
Podalsaỹ, Lambert. Podaly rius, in heathen my tho logy, was the son of Esculapius. Linn. 10, Or. 1,

Nat. Or. Leguminose. A genus of elegant shrubs, with silky leaves. They grow well in an equa quantity of loam and peat; cuttings will root in sand, under a glass, but they are generally raised from seeds. Synonymes: 1. P. biflora. 2.P. calyptrata.

Wht red 4, G. Ev, S. C. G. H. Burchellin.: : Purple : 6, G. Er. S. C. G. H Burchellir . : Purple 6, G. Ev. S. C. G. H cordata

glaũeã

hirsutiă

liparioidès

myrtillifolia

olexfolră

sericę

subbiflōră 6, G. Ev, C. H. Blue : 6, G. Ev, s. C. G. H White. 6, G. Ev, S. C. G. H. Purple 6, G. Ev. S. C. G. H. Red 7, G. Ev. S. C. G. H Flesh: 4, G. Ev. S. C. G. H. Purple 6, G. Ev. S. C. G. H. Purple G. Ev. S. C. G. H Purple : 6, G. Ev. S. C. G. H. flower; in allusion to the flowers being on long pedicels. Linn. 5, Or. 1, Nat. Or. Asclepiadec. For the culture and propayation of the species which form this genus, refer to Stapelia. Synonyme: 1. Stapelia verrucosa.

ITr. S. C. G. H. 1795

inorāta : : Yrn. str. 11. 8, S. Ev. S. C. G. H.

pulchella : Yel, str. . 5, S. Ev. S. C. G. H.

pülchră . Yel str. 8, S. Ev. S. C. G. H.

rerrucósă, i : Pa, yel. 8, S. Kiv. S. C. G. H.

1795

1795
1800

1800
1800

1802

roriflüa * * Yel, str. : 8, S. Ev. S. C. F. H. : 1802

PорА̄хтнйs, Lagasca. From pous, a foot, and anthos, a flower; stalked. Linn. 19, Or. 5, Nat. Or. Composite. An ornamental hardy shrub, succeeding well in a mixture of loam and peat, and readily increased by cuttings.

Mitinut. Yellow 9, H. Ev. S. Chile . 1824

POD PERN, see Ellobocārpŭs.

Podisōmă, Link. Pous, a foot, and soma, a body. Linn. 24, Or. 9, Nat. Or. Fungi. Found on juniper leaves- $P$. folíicülūm.

PoDocĀpís, L'Heritier. From pous, a foot, and karpos, a fruit; length of the footstalks. Linn. 21, Or. 10, Nat. Or. Taxacer. A genus of small trees loam and peat suits them best, and cuttings of the ripened wood root readily in sand, under a glass. The Chinese species bear our winters when planted in a sheltered situation in the open border. Syno. nymes: 1. Thalamia asplenifolia. 2. Taxas chinensis. 3. T. elongatus. 4. T. nucifer.

clininênsis, 1,

G. Ev. S. N. Holl.

1825

longãtús, 2 A patal

latifólins : - A petal

macrophrltùs : A petal

neriifolrüs : A petal

nucifer, $3:$ : A petal

spinulosŭs: : A petal

taxifolirus: : A petal

verticillatŭs : A peta

G. Ev. T. China

1800

- 1774

7, G $T$. Pundus

S. Ev. T. E. Ind. : 1820

G. Ev. T. Japan : 1828

G. Ev. T. N. Holl. 1820

Ev. T. S. Amer

G. Ev. T. Japan

1820

PoDotêris, I,abillardiere. From pous, a foot, and lepis, a seale; flower-stalk covered with scales. Linn. 19, Or. 2, Nat. Or. Composite. A mixture of loam and peat suits the species of this genus, which are easily increased by dividing the roots, or by seeds. Synonymes: 1. Scaliajaceoides. 2. Stylolepis gracilis. scuminată, 1 . . White. . 6, G. Her. P. N. S. W. - 1803 aristăta.

- 'Yellow 7, H. Her, P. V Ran R. 1837

contorta * Yellow : 7, H. Her. P. V. D. L. 1837

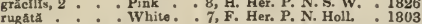

Podol.бвiัūm, R. Brown. From pous, a foot, and lobos, a pod; the legume stands on a stalk within the calyx. Linn, 10, Or, 1, Nat. Or. Leguminosce. A very elegant and desirable genus of dwarf shrubs, well adapted for planting out in a conservatory they require to be yrown in an equal mixture of loam, peat, and sand. Cuttings of the young wood, with a glass over them, will root in sand. Synonymes: 1. Chorozema scandens. 2. Podulobium ayvifolium.

\section{coriáçēūm}

Yellow Y Yellow 1 . Yellow lumifüstam . Yellow taurophȳllūm, 2, Yellow trilobatam $; \dot{0} ;$ Yellow
4, G. Ev. S. N. Holl. 6, G. Ev. S. N. Holl. 4, G. Ev. Cl. N. Holl. 4, G. Ev, Tr. N. Holl 4, G. Ev. S. N. Holl. 4, G. Ev. S. Holl.

PodophF̄uŨ $\mathrm{M}$, Linn. Abridged from Anapodophylium, a word signifying a duck's-fuot: the leaves bear some resemblance to that; whence the English name Duck's-foot. Linn. 13, Or. 1, Nat. Or. Podo. phyllaced. This phant requires a moist shady situa. tion, and to be grown in peat soil; increased by division at the root.

peltātūm . . Whito . . 5, H. Her. P. N. Amer. . 1664 Podoptărěs, Humboldt and Bonpland. From pous, a foot, and pteris, a wing. Linn. 6, Or. 3, Nat. Or. Polygonacee. A handsome plant, requiring to be planted in an equal mixture of loam and peat; young cuttings planted in any light mould, under a glass, will root readily.

mexiç̆nŭs - 7, G. Ev. 8. Mexico - 1825

Podospéruú, Decandolle. From pous, a foot, and sperma, a seed. Linn. 19, Or. 1, Nat. Or. Compositc. Pretty plants, producing flowers resembling those of Scorzonera; they thrive in any com. mon soil, and plants may be raised from seed. The annual and biennial kinds only require sowing in the open border. Synonyme: 1. Scorzonera taraxacifolia. angustifólıūm . Yellow * 6, H. B. S. Eur. * . 1828 calcitrapifolium : Yellow : 6, H. Her. P. Levant : 1820 cănùun. Russia * . 1838 coronopifơlrüm. Yellow .6, H. Her. P. N. Afriea . 1818 laciniatūm - Yellow * 6, H. B. S. Eur. * . 1640

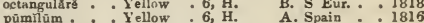

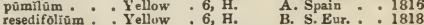
taraxacifolium, i Yellow : 6, H. Her. P. Bohemia : 1820

Podosprrm, the stalk on which some seeds are borne.

Porricưs, celebrated by the poets.

Port's cassia, see Osy̆ris.

PogōNǏ, Jussieu. From pogon, a beard: in allusion to the fringed lip of the flowers. Linn. 20, Or. 1 , Nat. Or. Orchidacece. Tuberous-rooted plants, growing best in peat soil, and increased by offsets. divaricătå . . Pink * 6, H. Ter. N. Amer. - 1787 ophioklossoidès: : Ro, pink: H. Ter. N. Amer. 1816 pendũla. : Pink: 8, H. Ter. N. Amer. 1824

Pogostikmon, Desfontaines. From pogon, a beard, and stemon, a stamen. Linn. 14, Or. 1, Nat. Or. Labiatu. These plants grow well in any rich light soil ; young cuttings of $\boldsymbol{P}$. plectranthoides, planted in the same kind of soil, root freely. Synonymes: 1. Ori. ganum indicum. 2. 0 . bengalense.

Heyneanuim, 1 . White. - S. A. E. Ind. pleetranthoĩdés, 2 White: 7 , S. Ev. S. E. Ind.

Pornciñxă, Decandolle. In honour of $M$. de Poincl once governor of the Antilles, and a patron of botany. Linn. 10, Or. 1, Nat. Or. Leguminosa. This genus, the Barbadoes Flower-fence, is truly elegant and ornamental. $\boldsymbol{P}$. pulcherrima is a spiny plant, growing about twelve feet high, the bruised leaves of which emit an odour resembling Savin. They require a good rich soil, and a strong heat to make them flower well in our stoves; cuttings will strike readily in sand. They sometimes produce seed, from which they may also te increased.

elatt

Gilliesil: * Yellow

Gilliesin. - Yellow

- Copper S. Ev. S. S. Amer. 1823

Red yel 7, s. Ev, S. E. Ind. : 1691

ręgra : Crimson: S. Ev. T. Madag.: 1828

Poinsêtrŭ Graham. In honour of Mr. Poinsette, who discovered the plant in Mexico in 1828 . Linn. 21, Or. 1, Nat. Or. Euphorbiaced. This is a truly splendid and very desirable genus, growing well in good open, rather sandy loam, mixed with a little vegetable mould; and in order to keep the plants in a clean, free-growing state, they shuuld have plenty of water at the roots, and be frequently syringed over the leaves and branches. In spring, before the plants are potted, or the buds begin to push, the branches of the previous year should be cut down to within three or four eyes of the old wood. These parts should be laid to dry for a few days, anc then made into cuttings, and planted in sand, or sand and loam mixed; if placed in a gentle bottom heat, with a glass over them, they will root very readily, but before the cuttings are planted in the soil, they should be dried for a day or two in an airy part of the house.

pulchērrima : - Brt. scar. 3, S. Ev. S. Mexico . 1834 Porkēry, Ventenat. In honour of J. L. M. Poiret, A 
French botanist and traveller in Barhary. Linn. 16, Or. 6, Nat. Or. Leguminosce. A pretty species; for culture and propagation, see Pictetia. Syno. nymes: 1. Glycine punctata, Turpinia punctata.

scåndẻns, 1 . . $\quad$ 3, S. Ev. CL. Caraccas . 1823

PoIson-RULB, see Brunsvigiăă toxicärĭă.

Porson-Burb, see Criñüm asiatīcūm.

PoIson-Nur, see Strūychnīs Nux-vomīcă.

PoIson OAK, see Rhüs Toxicodéndrön.

Poīvrěx, Commerson. Named in compliment to $\mathbf{N}$. Poivre, intendant of the Mauritius, in 1766. Linn. 10, Or. 1, Nat. Or. Combretaced. This is a very elegant genus of plants, all well worthy of being cultivated for ornamenting the pillars or back of the stove. 'They grow best in a mixture of sandy loam and peat, and most of them strike with ease from young cuttings, planted in sand, under a glass, in heat. Synonymes: 1. Combretum Afzelii. 2. C. barbatum. 3. C. purpureum. 4. C. comosum. 5. C. decandrum. 6. C. intermedium.

Afzélin, 1 . . . Scarlet . 4, S. Ev. Cl. S. Leone . 1826 barbati, 2. White. S. Ev C Mannh 1890 coccinea, $3^{\circ}$ : : Scarlet :9, S. Ev, Cl. Madagas, : 1818 comósă, 4 : : Purple : decếndră, 5 : : White. : 4, S. Ev. Cl. E. Ind. : 1826 intermédiá, 6 : Scarlet : 4, S. Ev. Cl. S. Leone : 1823

Polaxīsĭn, Rafinesque. From poly, many, and anisos, unequal; stamens numerous and unequal. Linn. 11, Or. 1, Nat. Or. Capparidacee. A genus of pretty plants, growing about a foct and a half high. They require to be sown in a hotbed frame, and turned out into a sheltered situation in the open border, about the middle of May. Synonymes : 1 . Cleome cheladonii, 2. C. dodecandra. 3. C. dodecandra canadensis. 4. C. uniglandulosa, 5. C. viscosa. 6. C. icosandra.

CheladōnI, 1. Rnse 6, H. A. E. Ind. 1799 dodecåndră, $\mathbf{2}^{\circ}$ : White: : 6, H. H. A. E. Ind. : : 1799 graveúléns, 3 . : Pinksh. : 6, H. A. A. Ind. : 1795

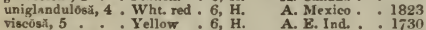

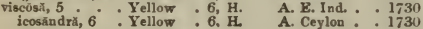

Polemoxiơx, Linn. From polemos, war; Pliny says this plant gained its name from having caused a war between two kings, each of whom claimed the honour of having first discovered its virtues. Linn. 5, Or. 1, Nat. Or. Polemoniacea. Ornamental border plants. P. caruleum is one of long standing. They are all of the easiest culture and propagation. Synonyme: 1.P. bursifolium.

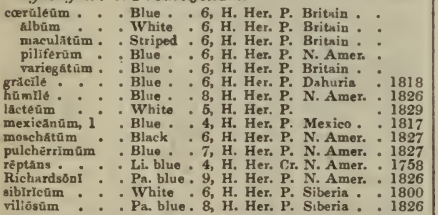

Poliāntase, Linn. Prom poly.many, and anthos, a flower; abundance of flowers. Linn. 6, Or. 1, Nat. Or. Liliacee. Highly odoriferous plants. P. tuberosa is the well-known Tuberose. The bulbs are imported annually, principally from Italy; they flower well if planted in a mixture of sandy loam and rotten dung, or leaf-mould, with a moderate supply of water; they require to be brought forward in a hotbed frame or pit; when in flower, they may be placed in a greenhouse or warm room, where they will remain a considerable time in blossom.

grăchlis. . . Pa. yel. . 8, S. Tw. P. Brazil . 1829 tuberösă : White. 8. G. Tw. P. E. Ind. 1629 flöré-plènó : White: : $8, G$, Tw. P.

Polurn, powder contained in the anthers, composed of globules, and containing the fecundating fluid; also the bloom of leaves.

Poulĩch Ĩ , Linn. In honour of John Adam Pollich, M.D., author of a History of the Plants of the Palatinate of the Rhine. Linn. 1, Or. 1, Nat. Or. Illectbracer. An obscure plant, of the simplest culture.

campestris

Apetal
PoLLīnǐn, Linn. After Cyrus Pollini, a professor of botany at Verona. Linn. 23, Or. 1, Nut. Or. Gramineve. A genus of worthless grasses, growing in any common soil, and increased by dividing the root. Synonymes: 1. Andropogon distachyos. 2. A. striatus. 3 A. undatus-P. distäch y̆d 1 , striātă 2 , undată 3.

POLTANDROUs, having more than twenty stamens inserted in the receptacle.

PolXÃNGÍ̄M, Link. From poly, many, and angium, a capsule; many piridiums. Linn. 24, Or. 9, Nat. Or. Fungi. A species of Fungus, about the size of a grain of sand, found on damp trunks of trees$P$. vitellinūm.

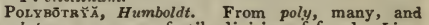
botrys, a raceme; fertile division of frond. Linn. 24, Or. 1, Nat. Or. Polypodiacer. Handsome spe. cies of Fern, delighting in a hot humid atmosphere, and turfy peat soil; increased by division at the root, or by seeds.

acuminātă . . . S. Her. P. 1831 cervină- : : Brown
vivipară

Polxcārpōn, Laffling. From poly, many, and karpos, a fruit; numerous seeds. Linn. 3, Or. 3, Nat. Or. Illecebraced. Worthless annuals, merely requiring to be sown in the open border,

diphyllüm . . White. . 6, H. A. Spain . 1821 tetraphyllúm . White. . 7, $\mathrm{H}_{0}$ A. Eugland

Polyckēaūu, Linn. From poly, many, and kneme, a knee. Linn. 3, Or. 1, Nat. Or. Chenopodiacea. The seeds of the different species only require sowing in the open ground.

arvěnse . A petal $: 7, \mathrm{H}$

mslacoplipliam: A petal : $7, \mathrm{H}$

oppositifólrüm : A petul : $7, \mathrm{H}$

recúrvüm : A petal : 7, ï

sclernspeirmám : A petal : 7, $\mathrm{H}$.

A. S. Eur. . 1640

A. Caucasus: : 1823

A. Siberia : : 1826

A. France : 1820

A. Tauria : : 1818

Porテ̃ŏ̆L̆, Linn. From poly, much, and gala, milk; reputed effects of the plant on cattle that feed upon it. Linn. 17, Or. 3, Nat. Or. Polygalacea. All the species of this genus are very showy. The greenhouse kinds thrive well in one part turfy loam, and three yarts peat, with a quantity of sand mixed in it. To obtain cuttings fit for planting, the shoots should be topped, which will cause thein to push out numerous young ones; these should be taken off close when in a growing state, about three inches long, planted in pots of sand under glass, and placed in the propagating house; the glasses must be occasionally taken off and wiped. The hardy perennial kinds thrive in a peat soil, and increase freely by seeds or divisions of the roots. The annual kinds require sowing in the open ground, preferring a peat soil. The root of $\boldsymbol{P}$. Senega is diuretic, expectorant, purgative, emetic, and sudorific; it has been used with success in croup, and as a cure against the bite of venomous reptiles. According to Barton, $\boldsymbol{P}$. sanguinea possesses similar qualities. Synonymes : 1. P.oppositifolia. 2. P. cordifolia. 3. P. grandiflora. 4. P. viridescens. 5. P. sanguinea.

amără . . . Blue . . 6, H. Her. P. Europe . 1775 ambigưă : : Purpsh. : 6, H. A. N. Amer. : 1824 attenuáta. : : Purple : 7, G. Ev. S. C. G. H.
sustriăcă borboniæfóliă, i Purple : 6, G. Ev. S. C. G. H. : 1790 bracteolata : Purple : 7, G. Ev. S. C. G. H. : 1713 brevifollä : : Red : 6, H. A. N. Amer. : 182

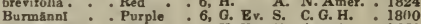

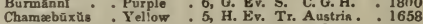

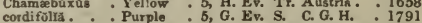
cordifulis. : Purple : 5, G. Ev. S. C. G. H. : 1791

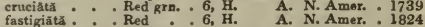
GarcinII : : Purple : 7, G. Ev. A. N. Amer. genistoidés: : Purple: 7, G. Kv. S. C.G. H. : 1823 graminifölra . Li. yel. , 6, H. Her. P. Carolina : 189 incarnáta : : Pink : 6, H. A. N. Amer, 1818 intermédir : : Purple: : 6, G. Ev. S. C. G. H intermedir : : Purple : 6, G. Ev. S. C. G. H. : 1820 lanceolata . Purple latifolia, 2 . Purple : S, G. Ev. S. C. G. H. 1820 liguläris . . Purple . 6, G. Ev. S. C. G. H. . 1820 lifiifolrs : : Purple : 7, G. Ev. S. C. G. H. 1823

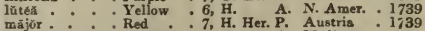
monspelirea : : Blue : $6, \mathrm{H}$ A. Mediter. myrtifoulta : Purple : 7, G. Ev. S. C. G. H. : 1707 grandiflöră, 3 Purple : 7, G. Ev. S. C. G. H : [ 252 ] 


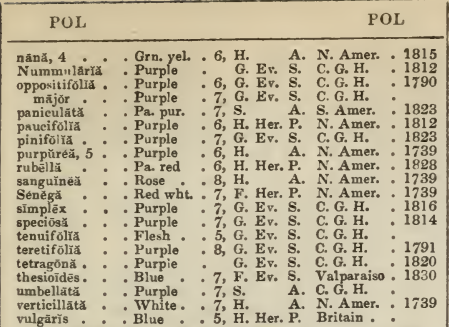

Polygaxous, when some flowers are male, some female, and others hermaphrodite, on the same plant.

Polygonātūr, Desfontaines. From poly, many, and gonu, a knee; referring to the numerous joints of the stem. Linn. 6, Or. 1, Nat. Or. Liliacea. Pretty border plants, growing about two feet high in any rich soil, and readily increased by seed or divisions of the root. Synonymes: 1. P. latifolium. 2. Convallaria verticillata. 3. C. Polygonatum.

angustifolyüm White 5, H. Her., P. N. Amer. 182

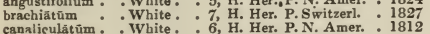

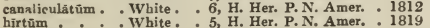
latifóliūm : : White: : 5, H. Her. P. Germany : 1802 leptophyllüm : White. 6, G. Her. P. Nepal : 1816 macrophyllũm, 1 . White. : 5, H. Her. P. N. Amer. : 1800 maltiforum : White: 6, H. Her. P. Britain : 182 oppositifolǐnm : White. : 4, G. Her. P. Nepal : 1822 polyanthémūn : White. : 5, H. Her. P. Caucasus : 1826

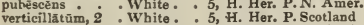
vulgăré, 3 . : White : 5, H. Her. P. England floré-plēnō: : Wht. grn. 6, H. Her. P. England : Gard. minōr : Wht. grn. 6, H. Her. P. England Gard.

PoLY̆GŏxüM, Linn. Derivation same as that of Polygonatum. Linn. 8, Or. 3, Nat. Or. Pslygonacea. The species of this genus grow freely in any light rich soil. The perennial kinds are readily increased from seeds, or by divisions of the root. The hardy annual species merely require sowing in the open ground. The tender kinds must be raised on a gentle hotbed, and transplanted into the flowerborder. Some species, such as $\boldsymbol{P}$. Hydropiper, are extremely acrid, and said to blister the skin. The seeds of $\boldsymbol{P}$. Fagopyrum and tataricum are used as food, and according to Humboldt, the leaves of $\boldsymbol{P}$. hispidum are used in South America as a substitute for tobacco, Synonymes: 1. P. petiolatum. 2. $\boldsymbol{P}$. elegans. 3. P. flagellare.

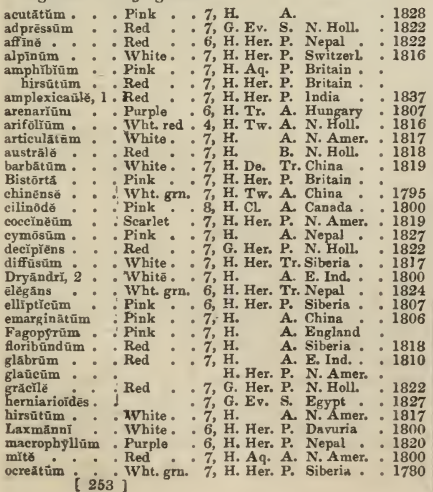

\section{POL} POL

orientàlë : . Red . . 8, H. A. E. Ind. . 1707
albūn : : White: 8, H. A. E. Ind.: 178 oxyspērmúm. - H. Her. P. Russia . 1831 pãtens. - . 7, H. Her. Tr. Nepal . 1893 patǔlūm : White. : 8, H. A. Tauria: : 1820 pennsylvănìcŭm Red : 7, H. A. N. Amer. : 1800 persicarioidès. Pink: 7, H. A. Mexico : 1816 pleberiñm - : Red : 7, G. Her. P. N. Holl. : 1829 sagittātūm : Wht. grn. 7, H. Tw. A. N. Amer. : 1759 salsugineũm - Pink : 6, H. Aq. A. Caucasus : 1817

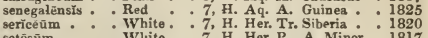
setōsūm * : White. - 7, H. Her, P. A. Minor . 1817 virginiānum : White: 8, H. Her. P. N. Amer. vivịpărūm : Wlıt. grn. 7, H. Her. P. Britain .

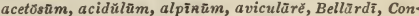
vơlvūlüs, divaricātüm, dumetoram, equisetüformé,

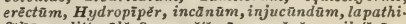
fơtīum, littorälě 3 , marîtĭmûm, mĩnŭs, nilotĩcûm, Persicărĭă, ramosīssimūm, salīgnūm, scāndēns, tata. rîcū̃m, undulātūm.

PoLȲ̄pīs, Agardh. From polyeides, multifarious; diversity of appearance. Linn. 24, Or. 7, Nat. Or. Alga. A very singular worm-like species of Alga, found in the sea during the month of NovemberP. lumbricālis.

PoLf̆mî̃, Linn. Polymnia was the name of one of the Muses. Linn. 19, Or. 4, Nat. Or. Composita. Species of no great beauty, succeeding well in com mon garden soil. P.abyssinica requires to be raised on a hotbed, and when potted off, set with the stove plants.

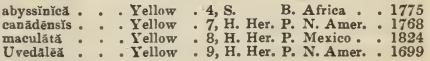

PoLyMorphous, assuming various forms.

PoL,YPETalous, having many petals.

PoLyphors, an elongated receptacle, which bears many ovaries, but not the petals or stamens.

Pourpódî̃u, Snartz. From poly, many, and pous, a foot; numerous root-like feet. Linn. 24, Or. 1 Nat. Or. Polypodiacea. A genus of very ornamental ferns. The stove and greenhouse species require, to grow them well, a mixture of loam and peat. The hardy kinds are well adapted for ornamenting rock-work, or they may be grown in pots, in light loamy soil. All the species may be readily increased by dividing the roots, or by seeds. $\boldsymbol{P}$. crassifolium is said to be sudorific and anti-rheumatic. In the Sandwich Islands, they use the bruised fronds of $P$. phymatodes to perfume the cocoa-nut oil. Synononymes: 1.P. scandens. 2. P. latifolium.

alpēstre̊ an gustiforinum areolãtūm asplenifơlīūm attenuătūm sūrē̉m auriculātūm Billardiērż, 1 ealcărěum Catharinæ̌ connēctr̂́iê connectio crassifóliūm eưvātūm. decumānúm deflexūm disšrmillĕ drepãnūm Dryoptĕriss effusūm fraxiniforiūm hastātūm . heterophȳllū hexagonổ ptérū incänūm incìsûm iridifơlīum jamaicēns juglandifólirim lanceolāturm .

latipès.

longifolinum lycopodioídēs olivacexm Otitẽes owariēnsé pertinātūm Phegoptêriss

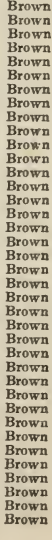

7, H. Her. P.

$5, \mathrm{~S}$. Her. Cr. W. Ind. S. Her, P. Brazil 7 S Her. P. VI artinico 5, S. Her. Cr. N. Holl. : 1823 3 , S. Her. P. W. Ind. : 1742 7, S. Her. Cr. Brazil * 1824 5, S. Her. Cr. V. D. L. , H. Her. P. Britain 6, H. Her. Y. Canada 8 S. Hex. P. Jamaica 8 , S. Her. P. W. Ind 8 , S. Her. P. Jamaica 8. S. Her. P. Brazil 7, S. Her. P

7, S. Her. P. Brazil

all S. Her. P. Madeira 7, H. Her. P. Britain 8. S. Her. P. Caraceas 7 , S. Her. P. Jamaica 7. S. Her. Cr. W. Ind. 7, H. Her. P. N. Amer. 8, S. Her. Cr. S. Amer. 7, S. Her. P. W. Ind. 9 , S. Her. P.

$6, \mathrm{~S}$. Her. P. Jamaica 7, S. Her. P. S. Amer. 8, S. Her. P. WV. Ind. 10 , S. Her. P. Brazil

7, S. Her. P. Brazil

, S. Her. Cr. W. Ind. 10, S. Her. P. Brazil S. Her. Cr. S. Leone 7, S. Her. P. W. Ind. 6, H. Her, P. Britain

1820
1824
1790
1823
1742
1824
1823
1824
1823
1823
1823
1823
1818
1830
1820

1769
1817
1820
1820
1811
1811
1810
1820
1822
1812
1819
1793
1834
1793




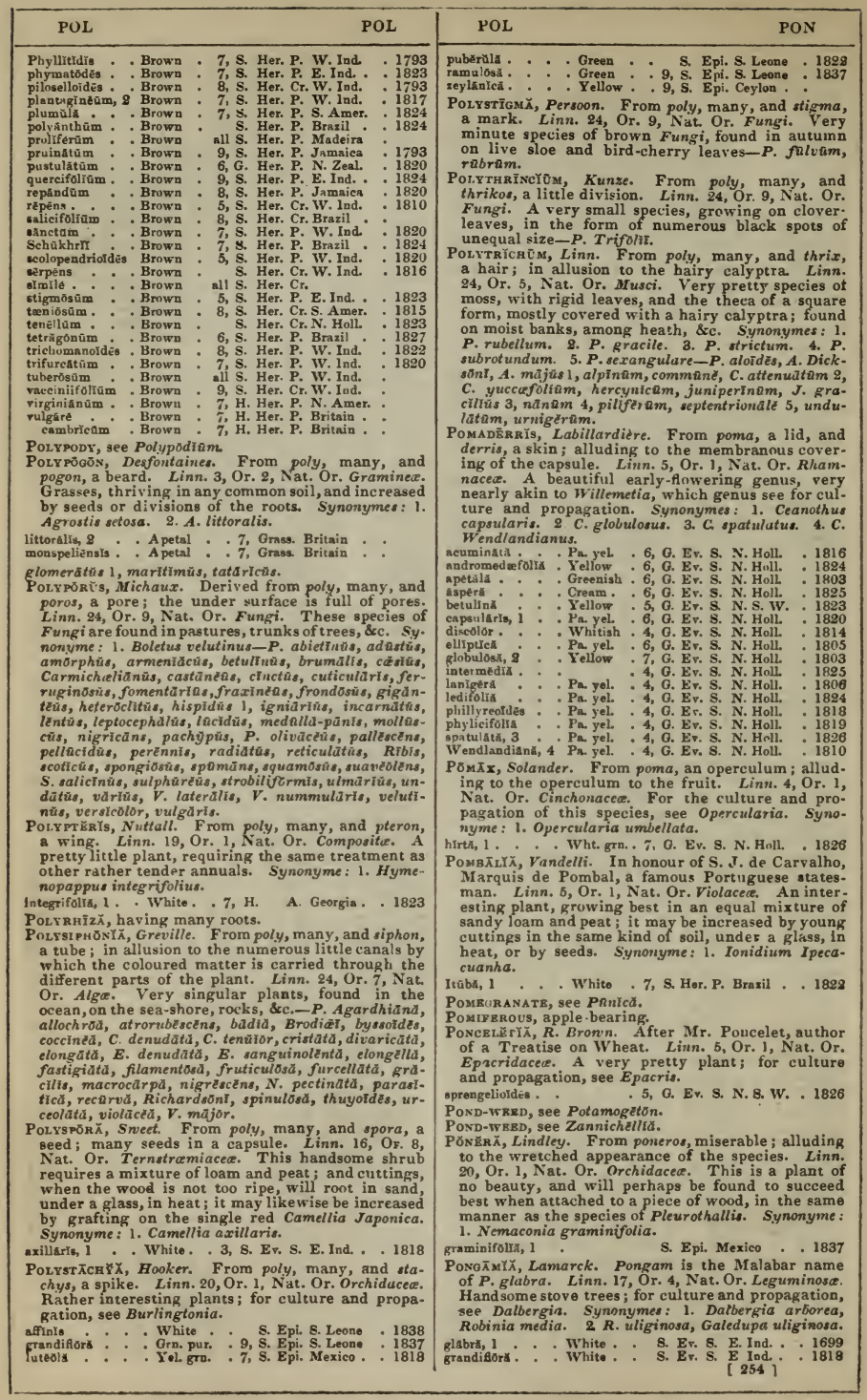




PON

Piscldra * White * S. Ev. T. E. Ind. * 1818

Pontrdểă, Linn. In honour of Julius Pontedera,

professor of botany at Padua. Linn. 6, Or. 1, Nat.

Or. Pontederacea. The species of this genus require

to be grown in rich loamy soil, in a tub or cistern of water; increased by division at the roots.

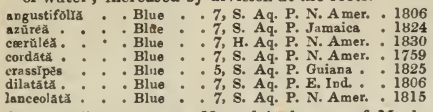

Ponthiह̂̀̆, $\boldsymbol{R}$. Broñn. Named in honour of $\boldsymbol{M}$. de Ponthieu, a French West Indian merchant, whe sent a number of plants to Sir Joseph Banks. Linn. 20, Or. 1, Nat. Or. Orchidacee. These curious plants grow well in a mixture of sandy loam and peat, with the pots well drained. They require to be kept dry when not in a growing state.

glandulos . . Green . . 2, S. Ter. W. Ind. . 1800 petiolatå : : Brown : : 8, s. Ter. St. Vincent 1822

\section{Poplar, see Popũlūs.}

Poppy, see Pupãvěr.

Popứứs, Tournefort. Some derive the word Populus from paipallo, to vibrate or shake; others suppose it obtained its name from being used in ancient times to decorate the public places in Rome, where it was called arbor populi, or the tree of the people. Linn. 22, Or. 7, Nat. Or. Salicacea. Most of the species of poplar are very ornamental, more especially in early spring, when the catkins of the males are produced. Their favourite place of growth is in moist soil near a running stream; but they do not thrive in very marshy situations. All the species are readily increased by cuttings or layers, and some by suckers. Synonymes: 1. P. nivea. 2. $\boldsymbol{P}$. suaveolens. 3. $\boldsymbol{P}$. viminalis, $\boldsymbol{P}$. longifolia. 4. $\boldsymbol{P}$. macrophylla. 5. P. acerifolia. 6. P. dilatata. 7. P. acladesca. 8. P. lavigata. 9. P. supina.

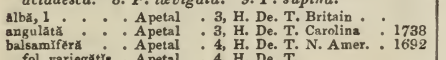
fol. variegătis - Apetal * 4, H. De. T.

intermedidid. A petal : 4, H. De. T

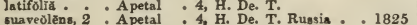

viminalls, 3 : Apetal : 4, H. De, T. Altai : : 1826

betulifolra. : Apetal : 3, H. De. T. N. Amer.

candícăns, 4 : : Apetal : 3, H. De. T. N. Amer. : 1772

canëscêns : A petal

acerifolră, $5^{\circ}:$ A petal

ægyptiăcă . A petal

nrembergiea : Apetal

belgicã . A petal

căndicăns : : A petal

bybrida . A petal

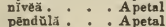

fastigiată, $6:$ : A petal

fcemină . A petal

grǣeà : : Anetal

Peta

péndúla : : A petal

meterophŷla : : A petal

Lindleyănă: : A petal

variegată: A Apetal

$\underset{\text { sulicifolrá : : Apetal }}{\text { nigra }}$ viridYs: A petal

trểmúlă . : A petal

laevipată, 8 : A petal
pendúlä. : A petal

pẻndúla 9 : : A petal

3, H. De. T. England

H. De. T

H. De. T. Egypt

H. De. T

H. De. T. S. Eur. .

H. De, T.

4, H. De. T. Caucesus . 1816 H. De. T.

H. De. T.

3, H. De. T. Italy

3, H. De. T. Italy

3 , H. De. T N. Amer.

3. H. De, T. N. Amer.

. 1820

5, H. De. T. Canada. : 1765

5, H. De. T. Canada : : 1772

5, H. De. T

3, H. De. T. Britain

4, H. De. T. Floetbeck : 183

4, H. De. T. Britain Gard.

3, H. De. T. Britain

3, H. De. T. N. Amer. 1760

4, H. De. T.

3, H. De. T. N. Amer. , 1824

H. De. T. N. Amer. : 1812

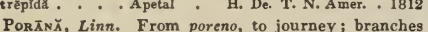
extending to a great distance. Linn. 5 , Or. 1 , Nat. Or. Convolvulacer. An ornamental plant, requiring a mixture of loam and peat, and increased by seeds. volǔbinlıs . . . White - 7, S. Ev. Tw. E. Ind. . . 1820

PorĀnthēră, Rudge. From poros, a pore, and anthera, an anther. Linn. 5, Or. 3, Nat. Or. Euphorbiacea. This ornamental species grows freely in a mixture of sandy loam and peat, and young cuttings will root readily if planted in sand, under a glass.

tricifolla . . White. . 7, G. Ev. S. N. Holl. . 1824

Porcuping, see Chatärĩd hystrix.

$[255]$
POR

POT

Porcupine, see Horděr $m$ hystrix.

Pores, apertures in the cuticle, through which trans. piration takes place, or apertures in the anthers through which the pollen is ejected.

Porină, Acharius. From porinos, anything that crumbles away. Linn. 24 , Or. 9 , Nat. Or. Fungi. A curious species, found on the bark of trees, \&c. $-P$. pertūsã.

Porliêră, Ruiz and Pavon. In honour of Andrew de Porlier, a Spanish patron of botany. Linn. 8 Or. 1, Nat. Or. Zygophyllacece. A curious and ornamental shrub, with leaves the linear leaflets of which remain open in serene weather, and contract before rain. It grows in a mixture of loam and peat, and ripened cuttings will root in sand, under a glass, in heat.

hygrometriç - . S. Ev. S. Peru

1820

PoRoph $\bar{Y}$ ILǓs, having porous leaves.

PORPHY̌RĂ, Agardh. From porphyra, purple; the colour of the species. Linn. 24, Or. 7, Nat. Or. Alga. Curious purple species, found during summer on the sea-shore. P. laciniata is stewed, and considered a great luxury-P. laciniātă, purpürĕ̃.

Porrectus, stretched out, diffuse.

Portlásilă, P. Bronne. Named in honour of the Duchess of Portland, a great patroness of botany. Linn. 5, Or. 1, Nat. Or. Rubiacece. Superb plants, worthy of a place in every collection, on account of their large showy flowers. They require a mixture of sandy loam and peat; and cuttings, with their leaves whole, will root in sand, under a glass, in heat. A strong heat is necessary for them; without that, they will never grow well.

coccinex . - Scarlet . S. Ev. S. Jamaica 1812 grandiflöră. . White. S. Ev. S. Jamaica . 1775

\section{Portugal laurel, see Cerăsŭs lusitanťcŭs.}

Portulācă, Linn. From porto, to carry, and lac, milli juicy nature of the plants. Linn. 11, Or. 1, Nat. Or. Portulacacer. The seeds of the hardy annual species of this genus may be sown in a sheltered part of the flower-garden in spring. The stove and greenhouse kinds require the same treatment as other stove and greenhouse annuals.

foliosă . Yellow . 6, H. A. Guines . 1822 Gilliêsrí : : : Red pok. : G. Ev. S. Mendosa : 1827 grandifiora : Yel. pur, . 6, F. Tu. P. Chile : 1827 lúteá : Y Yellow : 6, G. Tu. P. Chile : 1827

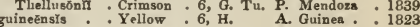
halimoIdés: : Yellow: 6, F. A. Jamaica : 1823 involucrátă Pink $6, \mathrm{H}$ A meridiană : : Yellow: 5, G. A. E. Ind. : 1791 meridiană $:$ Yellow $: 5$, G.
mueronătă

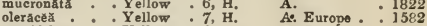

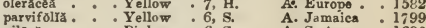
pilosá. : : Pink . 6, s. A. S. Amer. : 1690 pusilla : : Yellow : 6, s. A. Trinidad : 1894 quadrifida : : Yellow : 8 s. A. E. Ind. : 1773 aũré : : Yellow : 8, H. A. S. Amer. 1652

Portulacīrĩ̌, Jacquin. Altered from Portulaca. Linn. 5, Or. 1, Nat. Or. Portulacacece. This plant, the African Purslane-tree, will grow well in any dry light soil; and young cuttings, taken off and dried for a few days, when potted, will root freely. The plant has never flowered in British gardens. afră

$$
\text { G. Ev. S. Africa }
$$

PosoevẼ̄ĩn, Aublet. Aymara posoqueri is the name of P. longiflora among the natives of Guiana. Linn. 5, Or. 1, Nat. Or. Cinchonacte. The species are remarkably pretty when in flower; for culture and propagation, see Garderia. Synonymes: 1. Solena gracilis. 2. S. longiflora.

grăclils, 1 * . White. . S. Ev. S. Guiana * 1825 ongifora, 2 Whito . S. Ev. S. Guiana : 1822

PotAMOgĒTós, Linn. From potamos, a river, and geiton, near; growing in rivers and ponds, Linn. 4, Or. 3, Nat. Or. Fluviales. The species of this genus mostly grow wholly immersed in water they are increased by seeds, or by dividing the roots. The roots of $\boldsymbol{P}$, natans are said to be eaten in Siberia.

acutifoliūm comprẽssūm crispúm cuspidåtūm dēnsūm .

Grn. yel. 6, H. Aq. P. Britain Green Green: 6, H. Aq. P. Britain 6, H. Aq. P. Britain 6, H. Aq. P. Britain 


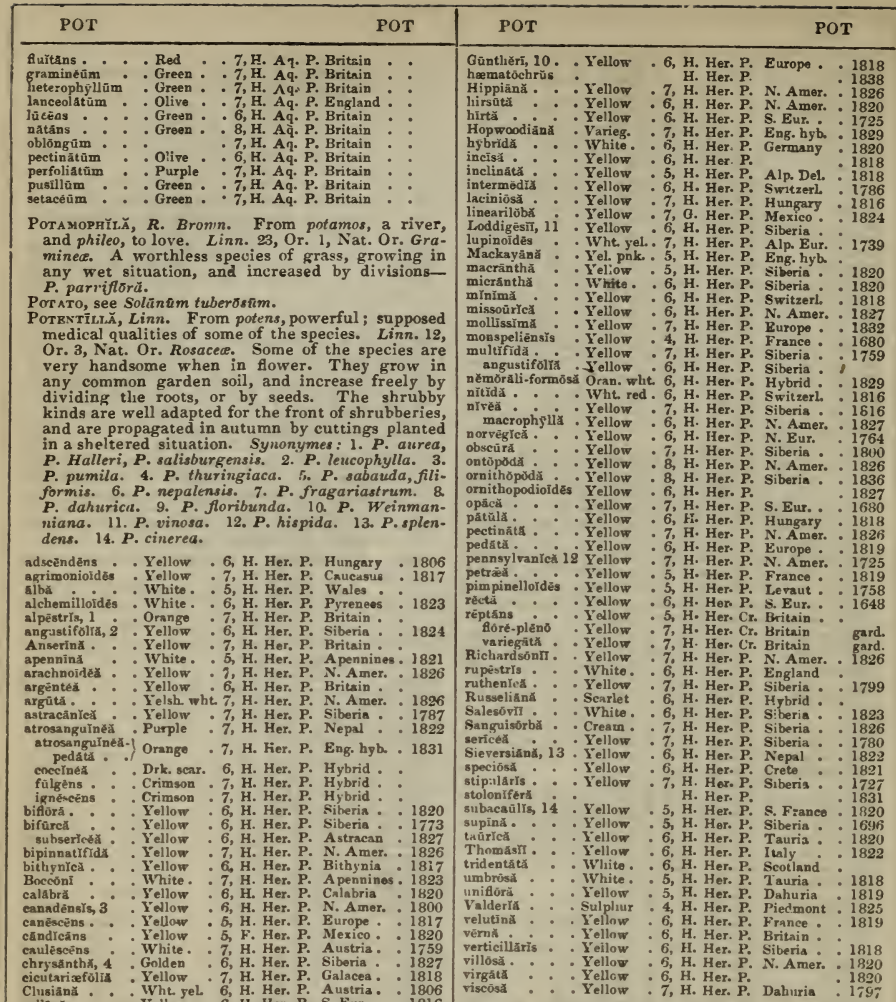

collina

conférta Yellow

croceé, 5 : : Copper

dealhat : Y Yeilow

débrlıs. : : Yellow

declinála: : Y Yellow

diffüsà : : Yellow

effura : : Yellow

elatior: : Yellow

ferrugtnex : Or, blue

Filipêndũlă : Yellow

flagellaris. : Yellow

formösa, 6 : Purple
Gamieriāna

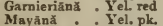

Pragăriă, 7 : White.

fragarioidès - White

frigidar : : Yellow

frigidă : : Yellow

dahurǐch, 8 : Yellow

tenuilôbă, 9 . Yellow

geoidés : Yellow

geranioides : Yellow

glaciălis : : Yellow

glandulosa : Yellow

incisas : Yellow gräcilis
grandifirra : : Yellow : 7, H. Her. P. N. Amer. : 1826
Yellow

6, H. Her. P. S. Eur.: 1816

H. Her. P.

1831

8, H. Her. P. Switzerl.

7, H. Her. P. Altai . SwitzerL.

5, H. Her. P.

7. Her. P. : 1817

5, H. Her. P. Denmark: 1820

6, H. Her. P. Siberia. : 1824

7, H. Her. P. Hybrid . 1835

6, H. Her. P. Dahuria - 1823

6, H. Her. Cr. Siberia : : 1820

7, H. Her. P. Hybrid

7, H. Her. P. Hybrid

5, H. Her. P. Britain .

6, H. Her. P. S. Kur

5, H. Her. P. Alp. Delp: 1819

7, H. De. S. England

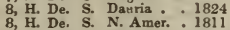

6, H. Her. P. Tauria : : 1820

6, H. Her. P. Armenia : 1820

7, H. De. S. Dahuria : 1818

8, H. Hes. P. California 1830

7 , H. Her. P. California : 1835

Poterič L, Linn. From poterion, a ckp. P Sangui surba is used in cooling drinks. Linn. 21, Or. 9 Nat. Or. Rosacec. Plants of little beauty. The shrubby species grow well in any light rich soil and young cuttings root readily under a glass. The herbaceous kinds grow in any common soil, and are increased by seeds. Synonyme: $1 . P$. hyiridum.

agrimonifolrüm . Green . . 7, H. Her. P. Spain . . 1829 hybridü, 1 :Green: 6, H. Her. P. France: 1822 eaudatúm . - Green : 3, G. Ev. S. Canaries : 1779 polygămum * Brown * 7, H. Her. P. Hungary : 1803 Thuisörba . Green . 7, H. Her. P. England spinösüm * Green : 7, H. Ev. S. Archip. : 1595

Pötrōs, Linn. Pothos, the name of a species in Ceylon. Linn. 4, Or. 1, Nat. Or. Aracece. Very singular epiphytal plants: in the West Indies and South America, they grow on trees, as the Ivy does in England. The leaves of $P$. palmata are three feet, and the footstalks foir feet long. They all succeed well in peat and loam, and may be increased by dividing the roots. Synonyme: 1 . P. grandifolia.

acaūlìs : . A Aptal * 5. Epiphy. W. Ind. - 1790 angustatia : : Apetal : : 5, Epiphy. Trinidad : 1890 256 ; 


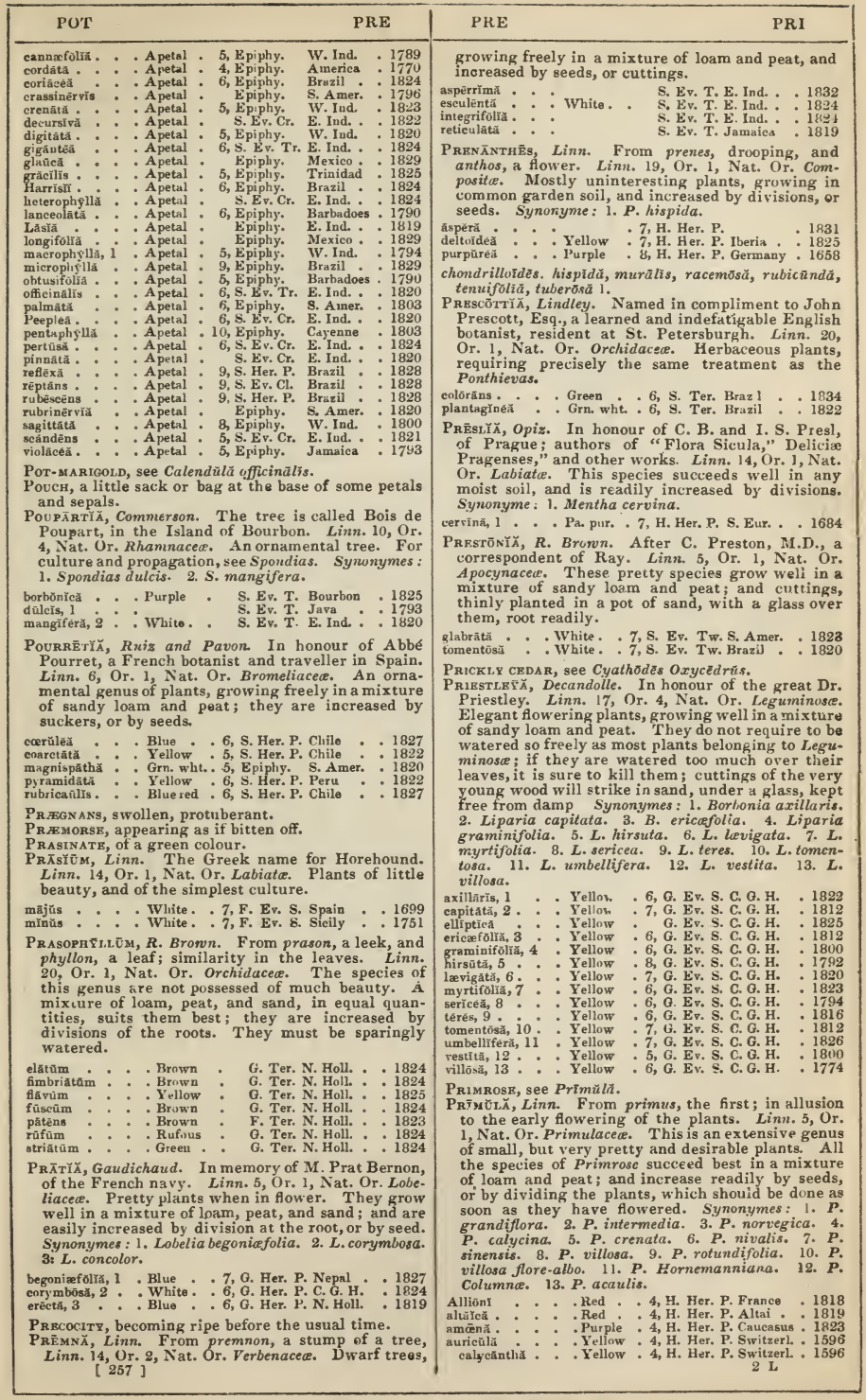


hortěnšs . . . Varieg. . 4, H. Her. P. Europe . 1596

integẽrrima : Varieg. 4, H. Her. P. Switzerl: 1596

Yellow - 5, H. Her. P. Switzerl. 1590

luter-plẽna: : Yellow: 4, H. Her. P. Gardens

Balbisir Yellow 4, Her P H. Hur.

versicólör : : Yel. red: 6, H. Her. P. France : 1818

carniolica, $1:$ : : Purple: 3, H. Her. P. Carniola : 1826

ciliătă . : : Red : 4, H. Her. P. Switzerl. : 170

purpuráti . . Drk. pur. 5, H. Her. P. Hylirid . 1833

cortusoidés . . Red . 6, H. Her. P. Siheria - 1794

davūrică, 2: : Red: : 5, H. Her. P.Siberia: 1806

decōră . . 4, H. Her. P. S. Eur.

denticulata : Purple 5, H. Her. P

dentiflôră. : : Red . 6, H. Her. P. Siberia

elátiōr : : Yellow : 5, H. Her. P. Britain

flöré-plēnó *. Brn. crim.

polyánthă . Varieg.

farinōsă : $\dot{3}$ : Red : Violet

finmärchǐcd, 3 : Violet

giglantéă : : : Ped : Pink :

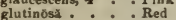

helvêtícă: : : Red

albs

integrifoliá . Pink

latifolta.

longiflor : * Rea

longifolia: : : : Red

majour

minima

4, H. Her. P. Britain

4, H. Her. P. Britain

6, H. Her. P. Britain

5, H. Her. P. Norway

6, H. Her. P. Siherin

6, H. Her. P. SwitzerL

6, H. Her. P.S. Eur.

5, H. Her. P.

5, H. Her. P. Hungary - 1825

6 , H. Her. P. Prrenees . 1799

4 , H. Her. P. Pyrenees . 1820

4, H. Her. P. Switzerl. . 1777

4, H. Her. P

Red: 4, H. Her. P. S. Eur.

6. H. Her. P. Eur. - 1819

4, H. Her. P. Dahuris 1790

4, H. Her, P. Siberis

4, H. Her. P. Naples

6 , H. Her. P. Altai

6. H. Her. P.Spain

: 1823

Puliñ̄̃

Pallasit

Perriniana

fimbriātă-ălbă

5, H. Her. P. China

6, G. Her. P. Gardens

6, G. Her. P. Gurden

5 , H. Her. P. China

4, H. Her. P.S. Eur.

6 , H. Her. P. N. Amer.

6 , H. Her. P. Scotland

5, H. Her, P. Siberia

4, H. Her, P. Switzerl. - 1768

4, H. Her. P. Denmark 189

4, H. Her. P. Italy

4, H. Her. P.S. Eur.

4, H. Her. P. Hungary

5, H. Her. P. Britain

5 , H. Her. P. Britain

3, G. Her. P. Egvpt

H. Her, P. Switzerl - 1896

4. Her. P. Piedmont 1768

6, H. Her. P. Britain

H Her. Pritai

4, H. Her. P. Britain

4) H. Her. P. Britain

4, H. Her. P. Britai

4, H. Her. P. Britain

4, H Her, P. Britain

4. H. Her, P. Britain

4, H. Her. P. Britain

gard.

gard.

gard.

gard.

plena-violácéa . Violet

gard. brevistylä: : Yellow. 6, H Her. P. E. Eur. 1893

calycán thă . . Varieg. . 4, H. Her. P. Britain

inflată . Yellow

marginâtă, 5 : : Pink

6, H. Her. P. Europe 1825

, H. Her. P. Levant : 1790

priènItẽes. 7

4, H. Her. P. Altai

These plants grow well in sand, loam, and peat; and cuttings of the young wood, planted in the same kind of soil, under a glass, will root freely: they are also easily increased by seeds. The species are showy when in flower. Synonymes: 1. Trachelinm diffusum. 2. Camparula fruticosa. 3. C. interrupta. 4. C. Prismatocarpus.

diffũzūs, 1 • - Blue • . 8, G. Ev. S. C. G. H. 1787 fruticōsŭs, 2 . Blue : - 8, H. Ev. S. C. G. H. - 1787 interrū ptüs, 3 . Blue : 6, G. Her. P. C. G. H. 1818 nitrdùs, 4 : White: 6, G. Her. P. C. G. H. : 1787 Prismatocãrits, see Speculitrì.

Prĩvă, Adanson. Derivation unknown. Linn. 14, Or. 2, Nat. Or. Perbenacea. A genus composed of small verbena-looking plants, with insignificant flowers; loam and peat suits them well, and cuttings root readily under a glass. Synonymes: 1 .

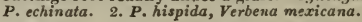

lappulācę, 1 . Blue * . 7, S. Her. P. W. Ind. 1817 mexicână, 2 . Violet . . 8, S. Her. P. Mexico . . 1726

Privir, see Lignstrûm.

Procksses, protrusions either natnral or monstrous.

PRö́кй 13, Or. 1, Nat. Or. Bixacce. Ornamental shrubs, thriving in a mixture of loam, sand, and peat; cuttings root freely if planted in sand, under a glass, in heat. Synonyme: 1. Ludia heterophylla.

crūcirs : : Y Yellow : 7, S. Kv. S. W. Ind. . 1822 theaformis, 1: Yellow : 7, S. Ev. S. Bourbou : 1820

Prö́cRls, Commerson. Procris was the wife of Cephalus. Linn. 21, Or. 4, Nat. Or. Urticaces. Herbaceous plants, of no interest, growing in any common soil, and increased by divisions- $P$. integrifotid, punctätă.

Prowyrrous, when a plant produces young plants about its ront in abundance, or when the inflores. cence bears shoots instead of flowers, contrary to the usual course of things.

Prosĩ̄a, Hugel. In honour of M. Pronay, a French naturalist. Linn. 5, Or. 1, Nat. Or. Pillusporacede. This species will be found to succeed in a mixture of loam, peat, and sand.

elegans... Binzjur... 3. Ev. S Swan R. 1837

PRōuls, having the face downwards.

Propennevr, hanging forwards and downwards.

Proszrpisäcä, Linn. From proserpo, to creep; nature of the species. Linn. 3, Or. 3, Nat. Or. Onagracede. These plants should be grown in large pans of water, with a litcle mould for the roots to run in; or they may be grown in ponds. They require shelter in winter.

White. 7, H. Aq. A. Canaria . gard. pectinat . . White. 7, H. Aq. A. N. Amer. : 1821

gard. Prosōpls, linn. From prosopis, a mask; but why

PRĩcerps, chief, principal.

Princes' reATRER, see Amaränthŭs hypochondriăcŭs.

$\mathbf{P}_{\mathbf{R}} \overline{\mathrm{I}}$ ōs, Linn. Prinos is the Greek name of the Holly, which the present genus much resembles. Linn. 6, Or. 1, Nat. Or. Aguifoliacee. Ornamental plants. The stove species will grow in loam and peat; and ripened cuttings root in sand, under a glass, in heat. The hardy kinds are well adapted for shrubberies; they will grow in any soil, but thrive best in peat, and are easily increased by layers, or by seeds, which do not vegetate till the second year. Synonymes: 1. Ilex prinoides. 2. I. canadensis.

ambǐgŭn̆s . - White - H. De. S. Carolina - 1812 atomáriňs : - White. 7, H. De. S. N. Amer. : 1822 coriàceŭs : White. 6, H. De. S. N. Amer. 1890 deeĩdũŭs, 1 . White. 6, H. De. S. Virginia 1736 White. - 7, H. De. S. N. Amer. - 1736 flaber : : Whigatrs: White.: 6, H. De. S. N.Amer. : 1812 lavigatús : : White. : 6, H. De. S. N. Amer. : 1812 lueidris, 3 : : White: : 6, H. Ev. S. N. Amer. : 1778

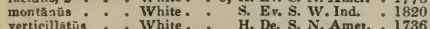

Prismatic, formed like a prism.

PrismatocÁrũs, L'Heritier. From prisma, a prism, and karpos, a fruit; long prismatic form of the fruit. Linn. 5, Or. 1, Nat. Or. Campanulacea. Leguminosa. Fine stove trees. For culture and proparation, see Inga. Synonymes: 1. Acacia cumanensis. 2. A. edulis. 3. A. falcata, Mimosa

cumanensis, 1. - Wht.grn. S. Ev. T. Cumana - 1822 domingênsìs : Y Yel. grn. . S. Ev, T. 8ı. Dumin. 1818 dũlers, 2 : Whe gm. S. Ev. T. Spain. 1818 juliflöră, 3: : Yellow . S. Ev. T. Jamaica: 1800 spieIgerri : Yel grn. : S. Ev. T. Coromandel 1812 adenantlëră, 4 Yel. grn. : S. Ev. T. Coromandel 1820

Prostānthêră, Labillardière. From prostheke, appendage, and anthera, an anther. Linn. 14, Or. J, Nat. Or. Labiala. Pretty greenhouse plants, re. quiring a sandy peat soil, and the pots carefully drained, as the plants are apt to damp off; they may be increased by cuttings of the young shoots, in sand, under a glass.

denticulat

incisă

7, G. Ev. S. N. S. W. Wv. S. N. S. W.

linegris. - . . 7, G. Ev. S. N. S. W

7, G. Ev. S. N. S. W. 1823

* 7, G. Ev. S. V. D. I. . 182

Prosthiтём, Kunze. Derived from prosthema, an addition. Linn. 24, Or. 9, Nat. Or. Fungi. A very minnte black fungus, found in autumn on the trunks of trees-P. betulinñm. sea-god; in allusion to the diversity of appearance of the species. Linn. 4, Or. 1, Nat. Or. Proteacea. [ 258 ] piliflora. 4. Adenanthera acnleata.

lasiānthờs: : Pur. li. 6, G. Ev. S. N. S. W

PRōtř̆, Linn. From Proteus, a self-transforming 
This is an extensive genus of magnificent evergreen shrubs, generally considered difficult of culture; but this supposed difficulty may be removed by attending strictly to the watering of the plants. The soil best suited for them is light turfy loam, mixed with about a third part fine sand; the pots must be well drained, and it is advisable to mix some smal pieces of broken free-stone with the soil, in poting, to prevent them from retaining too much moisture ; the roots are also fond of running among the freestone or broken potsherds. Care must also be taken not to let them droop for want of water, as the young roots are of a fleshy substance, and are as liable to suffer from too much drought as they are from too much water, whence the necessity of the waterings being regular and noderate. Ripened cuttings will root when taken off at a joint, planted thinly in sand, and placed under a glass, but not in heat; the glass should occasionally be removed to allow them to dry, as they are liable to damp off. Water them, but not over the leaves, whenever they want it, and let them get a little dry before the glass is placed over them again. Synonymes: 1. P. longifolia. 2. P. speciosa.

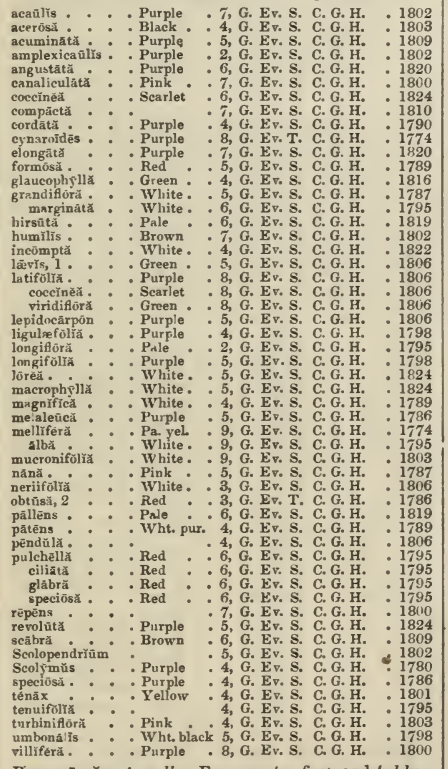

P'rotocōccǔs, Agardh. From protos, first, and kokkos, a berry. Linn. 24, Or. 7, Nat. Or. Alga. This species is found on rocks during summer-P. nivalis.

ProtonèMĂ, Agardh. From protos, first, and nema, a filament; in allusion to the simplicity of structure. Linn. 24, Or. 7, Nat. Or. Alge. Singular species of Alg $\&$, found in caverns, on the earth, hotbeds, \&c. P. cryplärũm, frūgrāns, muscīcūlă, Orthotrĭchĩ, rēpēns, umbrōsūm, velutīnũm.

Pruivose, covered with glittering particles, as if fine dew had been consealed upon it.

PrUNÉLtã, Linn. Altered from Brunella, derived from the German die Braune, a disorder in the jaws and throat, which this plant was supposed to cure. Linn. 14, Or. 1, Nat. Or. Labiata. The species of [259] this genus grow freely in a light rich soil, and are well adapted for ornamenting rock-work, or the front of flower-borders; they are readily increased by divisions. Synonymes: 1. P. australis. 2. P. pennsylvanica. 3, P hirta. 4. P. alba, P. laciniata. 5. $\boldsymbol{P}$. incisa, $\boldsymbol{P}$. longifolia.

Browniăna, 1. Blue . . 8, H. A. N. S. W. 1826 grand floră. : : Blue : 8, H. Her. P. Austria : 1596

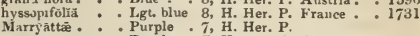
ovâta : : Purple:7, H. A. America elongătă, $2:$ Violet : 7, H. Her. P. N. Amer. flöré-plênó : Pink. 7, H. Her. P. Britain hispĩdn, 3 - Pa. pur. . 7, H. Her. P. Europe laciniátă, 4. White pinnatifíd, 5 . Purple - 7, H. Her. P. S. Eur. Wübră. : : Red : 7, H. Her. P.

Pronǔs, Linn. From prune, its Greek name. Linn. 12, Or. 1, Nat. Or. Rosacer. All the kinds of Plum grow well in any common soil, and are increased by seeds or suckers, or by grafting or budding to perpetuate the particular kinds.

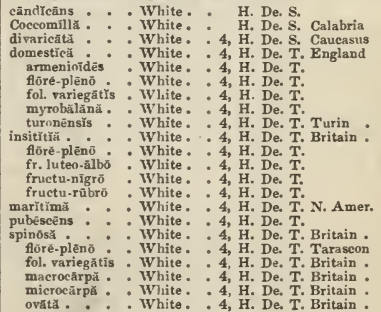

1820 1824
1820

PURteNT, causing an itching sensation.

Psत̄MMĂ, Romer and Schultes. From psammos, sand; its place of growth. Linn, 3, Or. 2, Nat. Or. Graminea. A grass with a strong perennial creeping root; on some parts of the coast it is planted to keep the sand from being removed by the wind and tides; it is also used for mats and thatch. Synonyme : 1. Arundo arenaria.

arenāiñă, 1 . . A petal . . 6, Grass. Britain

Psı̄̄ñ̌, Jacquin. From psias, a dew-drop; in allusion to the glutinous exudation on the leaves. Linn. 19, Or. 5, Nat. Or. Compusita. A species of little beauty, growing in any light rich soil cuttings will root freely under a glass. Synonyme 1. Conyza glutincsa.

glutinōš̆, 1 . . Yellow . 6, S. Ev S. Maurit. . 1796

PsidîtM, Linn. Derived from psidion, the Greek name of Pomegranate. Linn, 12, Or. 1, Nat. Or. Myrtacce. The species of Guava grow well in a mixture of loam and peat, and cuttings will root in sand, under a glass; they will al so root from layers. Some of the species fruit well in our stoves, but they are not considered to be of much value. P. Cattley anum has a fruit of a fine claret colour, and bears some resemblance in consistence and flavour to the strawberry. Synonymes: 1. P. grandiflorum. 2. P. clinense. 3. P. guianense. 4. P. sapidissimum.

aromătrcīm

White.

S. Ev. S. Guiana 1779

grandifforrum, i White.

Cattleyānûm, 2 . White

cordatum ${ }^{*}:$ White
fluviátíle, 3 : White

frägrăns

White

7, S. Ev. S. Guiana : : 1800

5, S. Ev. T. S. Amer. : 1818

6, S. Ev. S. Guiana . : 1823

. Amer.

oligospermúm: : White

polycárpon .: : White. : 5, S. Ev. S. Trinidad : 1810

ponifierũm : White. : 6, S. Ev. S. W. Ind. : 1692

sapidissimũm, 4 White. 6, S. Ev, S. W. Ind. 1824

Psilōñă, Fries. From psilos, a spot. Linn. 24, Or. 9, Nat. Or. Fungi. A reddish-coloured species, 
to sixty feet, and growing best in a loamy soil. Cuttings of the young wood not deprived of any of their leaves, will root in sand, under a glass, in heat. The wood of $P$. santalinus yields the officinal

Red Sanders-wood; the wood of the tree is dark red with black veins, capable of a good pulish, and

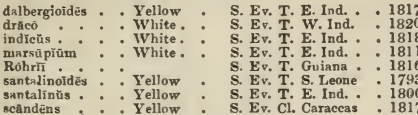

scândēns Yellow

1817

1811

800

1817 so heavy as to sink in water.

PTE

longifolia

nūtān

ophioglós

ophioglos

Prrrocrphălǔs, Vaillant. From pteron, a wing, and kephate, a head; in allusion to the receptacle of the flowers being villous. Linn. 4, Or. 1, Nat. Or. Dipsacea. P. dumetorum will grow well in sandy loam, and increase freely from cuttings, or seeds. The annual kinds merely require sowing in the open border where they are intended to flower Synonymes: 1. Scabiosa dumetorum. 2. P. brachiata. 3. C. papposus, P. Vaillantii. 4. P. diandrus. 5 C. plumosus.

dumetôrüm, 1. . White . 6, G. Ev, S. Teneriffe 1820 dumetórùm, 1. White. 6 , G.

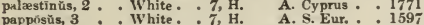
pappósũs, 3 * White * 7, H. A. S. Eur. : 1597 diāndrŭs, 4.
plumōsŭs, 5 : Purple

Pterogóñōm, Snartz. From pteron, a wing, and gonos, a shoot; referring to the pinnated stems. Linn. 24, Or. 5, Nat. Or. Musci. These plants are found on trees and sub-alpine rocks. Synonyme: 1 . $\boldsymbol{P}$. caesyitosum-P. filiformè 1, grăcĭlè, Smithī.

Prrkoneúrôn, Decandolle. From pteron, a wing, and neuron, a nerve; because of the winged placentre. Linn. 15, Nat. Or. Crucifera. Rock plants, requiring a light soil, and increased by seeds, which may be sown where the plants are intended to remain. Syuonymes: 1. Cardamine carnosa. 2. C. gracum.

camōsūm, 1. Pale - . 6, H. Her. P. Hungary . 1824 grâeūm, 2 : White: 6, H. A. S. Eur. : 1710

Pteróniă, Linn. From pteron, a wing; the feathery scales of the receptacle. Linn. 19, Or. 1, Nat. Or. Composita. A genus of interesting plants, growing well in loam and peat, and readily increased by cuttings.

camplorãtă

eamphō

echinātă

glomerăta : : Yellow

pâlěns : : Yellow

scariôsă: : Y : Yllow

6, G. Ev. S. C. G. H.

7, G. Ev. S. C. G. H

1774

6, G. Ev. S. C. G. H.

7. G. Ev, S. C. G. H

6, G. Ev. S. C. G. H.

7, G. Ev. S. C. G. H.

7, G. Ev. S. C. G. H.

Ptrrospêruūm, Schreber. From pteron, a wing, and sperma, a seed; the seeds are winged. Iinn. 16, Or. 7, Nat. Or. Sterculiacea. Large-leaved trees. They thrive in a mixture of peat, loam, and sand; and cuttings not deprived of their leaves will root in sand, under a glass, in a moderate heat.

acerifölǐumm . . White. . 8. S. Ev. T. E. Ind. . . 1790 canẽscēns : White. S. Ev. T. E. Ind. : 1823 lanceafoliñm : White. - S. Ev. T. E. Ind. : 1820 platanifoliñm . - White. - S. Ev. T. E. Ind. - 1820

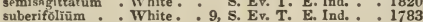

Ptenostüğ̌̃, Fischer and Meyer. From pteron, a wing, and stegos, covering; involucrum winged. Linn. -, Or. -, Nat. Or. Polygalaced. This species may be grown in any common soil.

drymariōiēs . Green . . H. A. California . 1836

Ptreostr̆Lis, R. Bronn. From pteron, a wing, and stylos, a style; in allusion to the column being winged at the top. Linn. 20, Or. 1, Nat. Or. Orchidacec. Interesting plants. For culture and propagation, see Prasophyllum.

acuminătă - . Pa, yel. . . 5, G. Ter. N. Holl.

cucullátă. : Pa yel. G, G, Ter. V. D

cürtă $:$ Pa. yel.: 5, G. Ter. N. Holl.

gibbósă: : : Pa, yel.: : ${ }^{-}$G. Ter. N. Holl.

grandifioră : Pa.yel. : G. Ter. N. Holl.

[ 261 ] hairs. 1822 1824

PTER Y GôDĪ Ũ S, Swartz. The name is probably derived from pterygodes, wing-like; because of the appearance of the sepals. Linn. 20, Or. 1, Nat. Or. Orchidacee. A genus of tuberous-rooted plants, requiring the same treatment as Corycium.

alătūm • . • • 7, G. Ter. C. G. H.

7. G. Ter. C. G. H. 1897

PrılostīphĨ̄m, Kunth. From ptilon, a feather, and stephos, a crown; from the feathery-like pappus. Linn. 19, Or. 2, Nat. Or. Compositie. The seed of these plants should be sown on a gentle hotbed, and the young plants transplanted into the open border.

coronopifoliũm . Yellow . 6, H. A. Mexico • 1823 trifidum : Yellow 6, H. A. Mexico: 1823

Pтіӣтӑ, Agardh. From ptilotos, pinnated; the form of the frond. Linn. 24, Or. 7, Nat. Or. Algu. This species and its variety, are found in the oceanP. plumōsă, P. tenuissimă.

Pтусно̄тіs, Koch. From ptyche, a plait, and ous, an ear; the petals have a plait emitting a segment resembling a little ear. Linn. 5, Or. 2, Nat. Or. Umbeiliferce. Annuals not worth cultivating. Synonymes: 1. Seseli ammoides, 2. Trachyspermum copticum. 3. S. corsicum. 4. S. saxifragum, Carum Bunius, Meum heterophyllum. 5. S. verticillatum, pusillum-P. ammoĩdēs 1, cōptĭcă 2, corsīcă 3 , heterophȳllă 4, verticillätä 5.

Puberǔtă, rather downy.

Pubescrit, downy, hoary, covered with short soft

Pucč̃ĭ̌̆, Persoon. In honour of $T$. Puccinius, a professor of anatomy at Florence. $\operatorname{Lin} n .24$, Or. 9, Nat. Or. Fungi. The species of this genus have all the appearance of blackish or brown smut; and are found, as most of the specific names imply, upon the leaves of various plants-P. Adrixē, Agopũdī, Anèmōnēs, Asparŭgĩ, Aviculārī̄ē, Betonìcăe, Būxĩ, Câlthā, Campanŭlă, caricină, Centaūrī̄e, Chrysos. plēniz, Circă̄̄, clandestīnă, Epilobī̄, Galiס̄ñm, Glechomătìs, globōsă, glomerätă, Gramīnīs, Herāclē̌, Lychnideārūm, Mēntȟ̄e, Polȳgōnī, Prīmūlāe, Prünörūm, pulverulēntă, Sanicülāe, Scorodōnīā, Syngenesiūrūm, tumìă, Ulmārī̄e, Umbelliferūrūm,

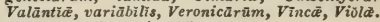

Puccoon, see Sanguināriă.

Pudică, modest, humble.

Pubrārià, Decandolle. In honour of M. M. N. Puerari, a professor at Copenhagen. Linn. 16, $\mathrm{Or}$. 6, Nat. Or. Leguminose. Ornamental plants. For culture and propagation, see Clitoria. Synonyme: 1. Hedysarum tuberosum.

tuberōs Wallichīi : : Yellow : G. Ev. Cl. Nepal : 1826

Purf-BALL, see Lycupërdón.

Pulmonălă, Linn. So named from its supposed medical properties in diseases of the lungs. Linn. 5, Or. 1, Nat. Or. Boraginacea. Very pretty flowering plants, well adapted for ornamenting the front of shrubberies. They thrive in any comnion soil, and are readily increased by divisions. Synonyme: 1. P. oblongata.

angustifolla . Violet. 4, H. Her. P. Britain oblongãtă, 1 : Pink : 5, H. Her. P. Germany azürễã Blue 4, H. Her. P. Poland

arandiflöră: Pink ${ }^{5}$ H. Her. P. France: 1823

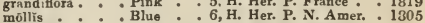
möllis : : Pink: : 4, H. Her. P. England White 6, H Her P. England puhếscēns: : Purple : 5, H. Her. P. Russia : 1821

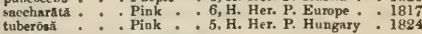

PuLmonārĭă, see Mertēnsĭă.

PulteñeA, Smith. In honour of W. Pulteney, M.D., a botanical author. Linn. 10, Or. 1, Nat. Or. Leguminose. The beautiful little shrubs of this genus succeed best in a compost of loam, peat, and sand, and placed in an airy part of the greenhouse or conservatory. Cuttings of the half-ripened wood root readily in sand, under a glass.

argêntěă - . Yellow . 4, G. Ev. S. N. Holl. . 1824 aristãă . : Yellow . 5. G. Ev. S. N. Holl. : 1824 asperá : : Yellow : 6, G. IV.S. N. Holl. : 1824 


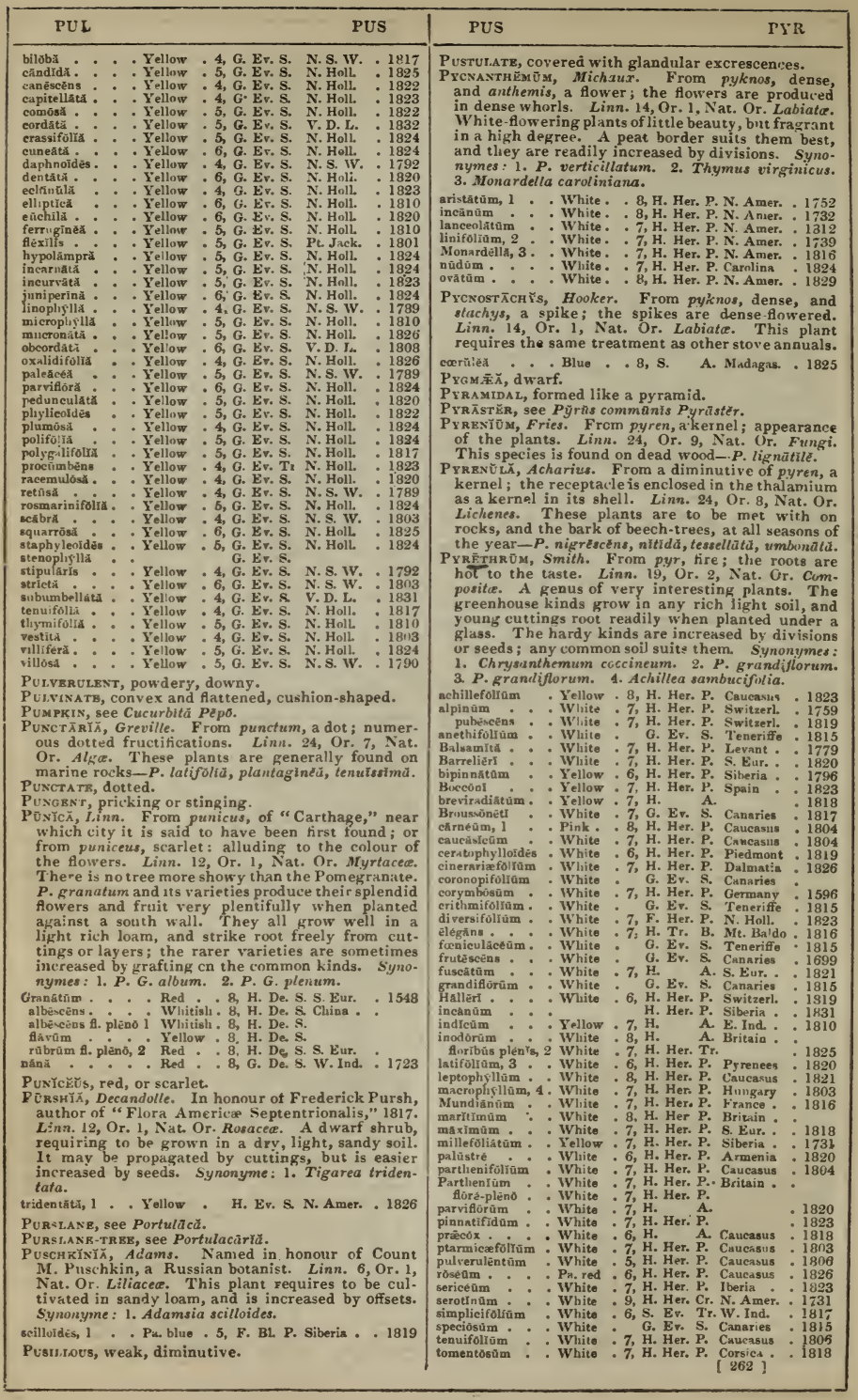


trifureatũn - Yellow - 7, H. A. Barbary .1820 uliginôsūm - White - 8, H. Her. P. Hungary : in the leaves. Linn. 10, Or. 1, Nat. Or. Pyrolacee. A genus of very pretty plants, rather difficult to cultivate. A shaded peat border appears to suit them best, and they are readily increased by divisions or seeds. Synonymes: 1. P. chlorantha. 2. P. rosea.

esarifŏlĭ . . . Grn. yel. . 6, H. Her. P. N. Amer. . 1810 cenvolũă, 1 . Grn. wht. . 6, H. Her. P. N. Amer. - 1818 elliptică : : White. 6, H. Her. P. N. Amer. : 1818 media : : Wht red . 6. H. Her. P. England

minor, 2 * Red - 6, H. Her. P. Britain -

rotundifolia - White. 6, H. Her. P. Britain

secūndă : : White. 6, H. Her. P. Britain .

Pyrolírior, Herbert. Literally Fire-lily; from the coloür of the flowers. Linn. 6, Or. 1, Nat. Or. Amaryllidacee. Rather a pretty plant, growing in saindy loam, and increased by offsets. Synonyme: 1. Amaryllis peruviana.

aūreũm, 1 . . . Gold clrd. . 5, G. Bl. P. Perı . . 1833

PyRUiArĭ̌, Michaux. The meaning is not known to us. Linn. 23, Or. 2, Nat. Or. Suntalaced. An ornamental shrub, growing in sandy loam, and increased by cuttings. Synonyme: 1. Hamiltonia oleifera.

pũberă . . . Grn. yel. . F. De. S. N. Amer. . 1800

PY̌rǔs, Linn. From peren, the Celtic word for pear. Linn. 12, Or. 2, Nat. Or. Rosacece. To this genus belong the Pear and A pple, as well as the Servicetree, and many others, either prized for their fruit or their ornamental appearance. In our shrub. beries, they grow in any common soil; but for the more highly cultivated ones a deep loam is necessary. They are increased by seeds, and the established kinds are multiplied by grafting the choicer on the common kinds. Synonymes: 1.P. malus sylvestris. 2. P. sulicifolia. 3. P. alpina. 4. P. sylvestris, $5 . P$ orientulis. $6 . P$. pubens. 7 . $P$. edulis. 8. Sorbus latifolius. 9. Sorbus microcarpa. 10.S. hybrida. 11.P. Bollnylleriana. 12. Surbus domestica. 13. $P$. hybrida, $P$ spuria sambucifolia. 14. Cratagus torminalis. 15. P. Pashia. 16. P. nepalensis.

acērhă, 1 . . White . 4, H. De. T. Europe .

americăna : White: 5, H. De. T. Canada : 1782

amygdaliförmìs, 2 White. . 5, H. De. T. S. Eur. . 1810

angustiföliă : Pink: 5, H. De. T. N. Amer. : 1750

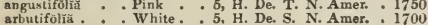
intermèdiă: White. : 5, H. De. S.

pumila . White. 5, H. De. S.

serotină : White. 6, H. De. S.

Arīă. White. 5, H. De. T. Britain

acutifülix, 3 . White. 5, H. De, T. Europe

buliătă . White. 5, H. De. T. S, Eur.

cretică : White : 5, H. De. T. Crete

obtusifolra: White: 5, H. De. T. Europe

rugósá White: 5 , H De. T. S. Eur.

undulấă : White: : 5, H. De. T. S. Eur.

estracănică : White: 6, H. De. T. Astracan

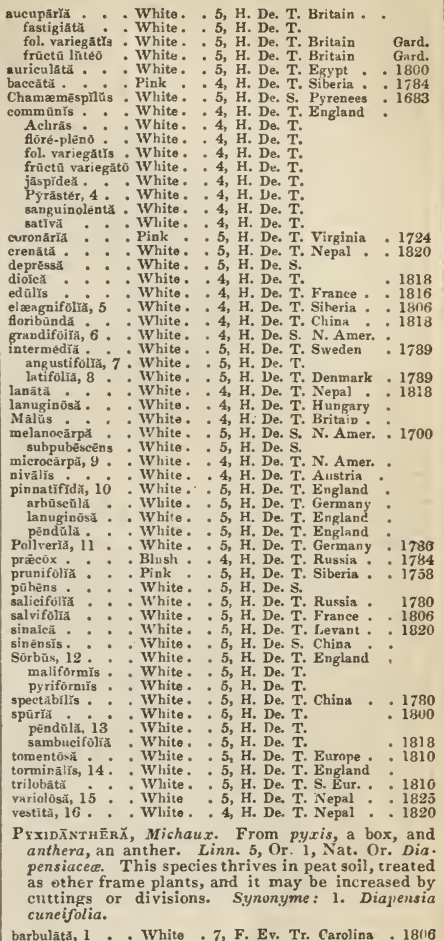

1810 PYXIDĀTĂ, box-shuped.

Q.

UADRANGULAR, four-angled.

Q. QUADRATK, square.

QUĀTRİ, Ruiz and Pavon. In honour of Antonio de la Quadra, a Spanish cultivator. Linn. 4, Or. 1, Nat. O:. Proteaced. . This tree requires to be grown in peat and loam, and propagated by cuttings, in sanả, under a glass.

leterophỵllă

G. Ev. T. Chile * . 1826

QUADRIYARIOUS, arranged in four rows.

QUARRIFID, divided into four parts.

QUAKNG-GRAss, see Brīzĭ.

QU $\bar{A} \mathrm{I} \breve{.}$. , Aublet. The name of the tree among the Guianese Indians. Linn. 1, Or. 1, Nat. Or. Vochy. acece. This tree will grow best in peat and loam, and is said to be increased by seeds.

violäcĕă. . . Violet . . S. Ev. T. Brizil . 1824

QUamash, see Scilllă esculēntü.

QิИамо̄сıĨ', Tournefort. From kyamos, a kidneybean, and klitos, dwarf; the species of this genus resemble the kidney-bean in their climbing stem's, but are less tall. Linn. 5, Or. 1, Nat. Or. Convolonlacece. This genus, for the most part, consists of very beautiful half-hardy annuals. They require to be reared on a hotbed, and about the end of May they may be planted out in a warm sheltered situation in the open border; some of them may be kept in the greenhouse, where they will flower and ripen their seeds freely. The perennial kinds are well adapted for covering pillars in the stove or greenhouse. Any light rich soil suits them, and cuttings of the young wood root readily in sand, under a glass, in heat. Synonymes: 1. Ipomaca coccinea. 2. I. digitata. 3. I. hastigera. 4. I. hederifolia. 5. I. longiflnra. 6. I. luteola. 7. I. phrenicea. 8. I. sanguinea. 9. I. triloba. 10. Y. Quamoclit.

\section{coccīnẻ,}

digitata, $2:$ Purple

Scarlet

8, S. Tw. A. Purple

9, S. Tw. A. S. Ame
S, Tw. A. W. Ind

- . P, S. Her. Tw. Mexico : 1824 hederifoliă, 4 : Viojet : 7, E. Tw. A. W. Ind. 1773 [263] 


\begin{tabular}{l} 
QUA \\
\hline longiflöră, 5 . White $\cdot 6$, S. Her. Tw. Cuba \\
\hline Whe
\end{tabular}

luteola. 6.: : Or yel. : 8, S. Tw. A. Guatemala : 1759 phœniceă, 7. . Crimson . 6, S. Tw. A. E. Ind. . 1806

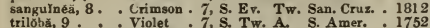
vulgaris, 10: : Scarlet:9, S. Tw. A. E. Ind. : 1629 albiflora : White: 9, S. Tw. A. E. Ind. : 1629

QUARTz, a kind of stone.

QUĀssĩ A, Linn. Quassi, the name of a negrn slave, who first used the bark as a febrifuge. Linn. 10 , Or. 1, Nat. Or. Simarubacea. This valuable tree thrives in loam and peat; and cuttings of the ripened wood, with their leaves left whole, will root in sand, under a glass, in heat. The wood of this tree is well known as one of the most intense bitters, and is considered an effectual remedy in any disorder where pure bitters are required.

amäră . . . Red . . 6, S. Ev* T. Guiana . . 1790 Quatranary, arranged in fours.

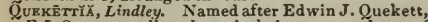
F.L.S., an excellent botanical observer, and one of our best vegetable anatomists. Linn. 20, Or. 1, Nat. Or. Orchidacea. Dr. Lindley says, "although this little plant is only a few inches high, and has no attractions for the vulgar eye, it is in some respects one of the most interesting I know, if examined microscopically." It will be found to succeed best on wood, treated precisely as the species of Pleurothallis.

microscőpică . Yellow . S. Epi.

QURrcitron, see Quércūs tinctortă.

Qū̃rcuัs, Linn. Fron the Celtic quer, fine, and cuez, a tree, fine tree; others derive it from the Greek word choiros, a pig; because those animals feed on the acorns. Linn. 21, Or. 9, Nat. Or. Cupulifere. All the species of this very important genus have a highly ornamental appearance, either on the lawn or in the forest; the wood is also much superior to that of any other tree, teak alone excepted, for the purpose of naval architecture; indeed, there is no purpose in the arts to which the wood of the oak is not applicable. Q. Suber is very valuable on account of its being the only tree which produces in any quantity that very important article, cork. The bark, leaves, and fruit, of all the species abound in astringent matter, and in tannin. The oak succeeds best in a deep loamy soil, and in a somewhat low situation. The species are generally increased from seed; and it is only when particular varieties are to be perpetuated, that grafting is resorted to. The seeds may either be sown when they drop from the tree, or they may be thoroughly dried, and preserved till the following March; previous to sowing, the soil should be well prepared, and after the drills are opened, or the earth drawn off the beds, the acorns may be scattered along the drills or over the beds, keeping them about two inches apart; before covering, the acorns must, if sown in beds, be patted down with the back of a spade, or the back of a wooden headed rake if sown in drills. They should be covered from half an inch, to an inch and a half deep, according to the size of the acorn, with finely broken soil. The after culture of the oak does not require any notice here. Synonymes: 1. Q. Phullata. 2. Q. conglomerata. 3. Q. hemisphaerica. 4. Q. nana. 5. Q. austriaca. 6. Q. Lucombeana crispa. 7. Q. L. dentata. 8. Q. cerris dentata. 9. Q. L. heterophylla. 10. Q. L. incisa. 11. Q. exouiensis. 12. Q. Ragnal. 13. Q. L. suberosa. 14. Q. frondosa. 15. Q. discolor, Q. elongata, Q. triloba. 16. Q. humilis, Q. nana. 17. Q. lanuginosa. 18. Q. aquntic . 19. Q. stellata 20. Q. Banisteri, Q. montana. 21. Q. fastigiata. 2:. Q laciniata. 23. Q. pendula. 24. Q. purpurea. 2.5. Q. cinerea. 26. Q. sericea. 27. Q. Castanea. 28. Q. montana. 29. Q. prinoides. 30. Q. Michanxii. 31. Q. Tauzin. 32. Q. Robur. 33. Q. pubescens.

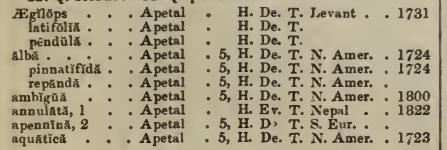

QUE

QUI

maritima, 3 . A petal - 5, H. De. T. N. Amer.

maritima, 3 . Apetal . 5, H. De. T. N. Amer.

- A peta

austrălisa . A petal

Catesbei : : A petal

Cërris - Apetal

sustriàcă, $5:$ A peta

cana-mājor . A petal

cánā-minơr . A petal

crispa , 6. A petal

dentătã, 7 . A petal

fullıanénsiss, 8. A petal

heterophyllă, 9 A peta

incisă, 10

A petal

hucombeână, 11 A petal

Rágnảl, is: : A petal

suberōsă, 13 . A petul

variegatå. A petal

vulgărĭs, 14 . A petal

cocelféră *. Apetal

coccineá : : A petal

Cookiñ * : : A petal
Escŭlŭs: A petal

falcatir, i5: : A petal

Falkenbergểnsìs : A petal

Fontunēsil . - A petal

gramúntis: : A petal

heterophyllā ; 0 A petal

lugbrida-nand, 16. A petal

erispa: : : A A petal

fagifolix : : A petal

integrifolix : A petal

latifolra . A petal

longifoliz: : A petal

serratifolia : A petal

variegátá : A petal

Ilicifoliă * - A petal

imbricarla . - A petal

lanăth, 17 . A petal

aurifoliă : : A pelal

lusitanica: : A petal

luter : : A petal

lyrata : - A petal

macrocárpá : A petal

myrtifolra : : : A petal

myrtifolra : : A petal
nIgră, $18:$ A petal

ohtusilöbă, 19: A petal

oliveformis : A petal

palústris, 20 : A petal

pedunculată - A petnl

foligiatá, 21. A petal

lieteropliyllä, 22 A petal

Hodginsit?. A petw!

pẻpdūlă, $23^{\circ}$ : A petal

pubéscéns : A petal

purpunres, 24 . A petal

Phêllos

cinéré, 85 : A A petal

hūmiliss . . A petal

latifolya . A petal

serīcéă, 26 : A petal

sylvătica : A petal

Prinŭs: : A petal

acuminata, 27 : A petal

mont ieoli, 28 . A petal

púmñă, 29: : A petal

tomentósă, 30 : A petal

preüdo-cnceíferă . A petal

pseũdð-súhēr . A petal

pyrenaica, 31 : A petal

rübrà

pubèscêns, 33 : A petal

. 1738

5. H. Ev. T. Portugal

, H. Ev. T. Barbary

5, H. De. T. N. Amer. 1823

5, H. De. T. S. Eur. . 1735

5, H. De. T. A ustria . 1824

, H. De. T. S. Eur.

5. De. T. S Eur.

H. Ev. T. Exeter

H. Ev. T. Exeter

H. De. T. Fulham

H. Ev. T. Exeter

5, H. Bv. T. Exeter

5, H. De. T. Exeter

5, H. De. T. S. Eur.

5, H. De. T. Ragual

De. T. Exeter

, H. De. T. S. Eur.

, H. De. T. S. Eur.
H. Ev. T. S. Eur.

H. De. T. N. Amer

H. Ev. T. Gibraltar

5, H. De. T. S. Eur.

H. De. T. N. Amer.

H. De T. Hanover

H. De. T. Calabria

6, H. Kv. T. France.
5, H. De. T. N. Amer.

5, H. De. T. Hybrid.

5, H. Ev. T. S. France

5, H. Ev. T. S. France

5, H. Ev. T. S. France

5, H. Ev. T. S. France

H. Ev. T. S. Frauce : 1781

H. Ev. T

H. Ev. T. S. France . 1781

H. Ev. T.

5, H. Ev. S. N. Amer. . 1800

H. De. T. N. Amer. . 1786

H. Ev. T. Nepal * 1818

5, H. De. T. N. Amer. : 178

5, H. De. T. N. Amer. : 1786

6, H. Ev. T. Portugal . 1824

5, H. De. T. Mexico . : 1825

, H. De. T. N. Amer. . 1786

H. De. T. N. Amer.

H. De. T. N. Amer. . 1800

H. Ev. T.

5, H. De. T. N. Amer . 1739

5, H. De. T. N. Amer. 1819

5, H. De. T. N. Amer. : 1811

5, H. De. T. N. Amer. 1800

. De. T. Britain .

, H. De. T. S. Eur.

5, H. De. T. Britain

1820

, H. Ev. T. Britain

5, H. De. T. Britain

5, H. De. T. Britain

5 , H. De. T. Brituin

5, H. De. T. N. Amer.

5, H. De. T. N. Amer.

5, H. De. T. N. Amer.

5, H. De. T. N. Amer.

5 , H. De. S. N. Amer. 1724

5, H. De. T. N. Amer. : 1723

6, H. De. T. N. Amer. : 1730

5, H. De. T. N. Amer. . 1822

5, H. De. T. N. Amer. 17:0

H. De. T. N. Amer. 172

5, H. De. T. N. Amer. . 1823

H. De. T. N. Amer. : 1800

H. Ev, T.

5, H. De. T. S. Eur. . . 1824

5 , H. De. T. Pyrenees : 1822

5, H. De. T. N. Eur. . : 1739

, H. De. T. Britain

5, H. Ev. T. Spain

5, H. De. T. N. Amer.

5, H. De. T. N. Amer.
5, H. De. T. N. Amer.

sinuósă: A petal

Qǖrlă, Laffing. In honour of Don J. Query Mar

3, Or. 3, Nat. Or. Alsinaced. The seed of this plant only requires sowing in the open border.

hispănică . A petal . 6, H. A. Spain . 1800

Qutllwort, see Isoêtés.

QurNcr, see Cyd̋̄nža.

QUisquALis, Linn. From quis, who, and qualis, what

kind; when the genus was named, it was uncertain to what class or order it belonged. Linn. 10, Or. 1, Nat. Or. Combretaced. The species of this genus are all very great favourites with cultivators, on account of the brilliancy of their flowers. For culture and propagation, see Poivrea. 


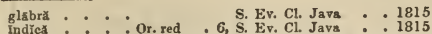

pubeseens: : Or, red : S. Ev, Cl. Guinea :

Quivĭs̆̆, Commerson. From Bois de quivi, the name of one of the unintroduced species in the Isle of
France. Linn. 10, Or. 1, Nat. Or. Meliacer. This shrub sueceeds well in a mixture of peat and loam; and sipened cuttings root freely in sand, under a glass, in heat.

heterophylla . . White. - S. Ev. S. I. France

R.

PACEME, a term commonly applied to flowers, R when they are arranged round a filiform simple axis, each particular flower being stalked.

$\mathbf{R}_{\text {ACEMOSB, flowering in racemes. }}$

R ACEMOSELY-CORYM BOSE, flowers disposed in a manner between a corymb and a raceme, or numerous racemes forming a corymb.

RAcris, that part of a culm which runs up through the ear of corn, and consequently that part which bears the flowers in other plants; also the common petiole of a pinnate leaf.

RACODĪu , Link. From rakos, a torn garment; in allusion to the appearance of the plants. Linu. 24, Or. 9, Nat. Or. Fungi. This species is found in undisturbed wine-cellars. Synonyme: 1. Fibrillaria vinaria $-R$. celläré.

( a flower is said to be so when, in a cluster RADIATE, $\left\{\begin{array}{l}\text { orhead of florets, those of the circum- } \\ \text { ference or ray are long and spreading, }\end{array}\right.$ RADIANT, $\{$ and unlike those of the disk. A stigma RAYED, is said to be rayed or radiant when its divisions resemble the rays of a star.

RAnical, belonging to, or proceeding from, the root RADICANT, rooting, producing roots from the stem.

RADICL, the root of an embryo.

RADiŏLĂ, Gmelin. From radiolus, a little ray; in allusion to the capsule being rayed. Linn. 4, Or. 3, Nat. Or. Linacere. A little white-flowering, insignificant plant, found in sandy places.

millegränă. . Wlite 7 H. A. Britain

RADIsH, see Raphănuัs.

RADIUS, the ray of a compoind flower.

RAFNĭ, Thunoerg. In honour of C. G. Rafn, of Copenhagen, a botanical author. Linn. 16, Or. 6, Nat, Or. Leruminose This is a genus of remarkably pretty plants; they succeed well in peat and loam, and young cuttings root without difficulty in sand, under a glass. Synonymes : 1. Crotaiaria opposita. 2. Borbonia corduta.

cuneifơlı̆ă . . . Yel. pur. . 6, G. Ev. S. C. G. H. ellipticeś : Y Yellow 6 , G. Ev. S. C. G. H. lānceӗ : : Yellow $\quad 6$, G. Ev. S. C. G. H.

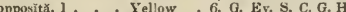
trifloră, 2 : : : Yellow : 6, G. $\quad$ B. c. G. H. $\quad 1786$

R AGGED RORIN, see LĢchnis Floscūcŭlt.

RAGWORT, see Othönnă.

R.AGwort, see Senēe č̃o Jacobrēü.

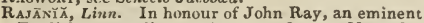
English naturalist. Linn. 22, Or. 6, Nat. Or. Dioscoreacec. Stcve climbers, of no beauty, growing in peat and loam. They may be readily increased by division of the root- $R$. cordútü, hastütă, quinquefíliü.

RAMALі̄̌̆, Acharius. From ramale, a withered branch; habitat of the plants. Linn. 24, Or. 8, Nat. Or. Lichenes. Greyish-coloured Lichens, found on rocks and dead branches of trees- $R$. furinäcěă,

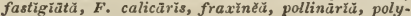
mörphă, scopulörūm.

RAMENTA, little brown withered scales, with which the stems of some plants, especially ferns, are covered.

RaMifications, subdivisions of roots or branches.

RAMÖNDİ̃, Richard. In honour of M. L. Ramond, a French botanist and traveller. Linn. 5, Or. 1, Nat. Or. Gereter A genus consisting of one very pretty little alpine plant, well adapted for the front of flower-borders, or for growing in pots. Any light soil suits it, and it is readily increased by division of the root. Synonymes: 1. Verbascum Myconi, Chaixia Myconi.

pyrenăıă, 1 . Purple . 5, H. Her. P. Pyrenees . 1731

RAMON-TREE, see Trophis.

RAMOSE, branchy.

[265]
Rampion, see Plıyteūmă.

RAMP1ON, see Campänüld̆ Rapancŭlŭs.

RAmpion, see Cȳphĩă Phyteũmă.

RAmult, twigs, or small branches.

RÃNDĬĂ, Houston. In honour of $J$. Rand, a London botanist. Linn. 5, Or. 1, Nat Or. Cinchonacea. This genus is nearly allied to Gardenia, and requires precisely the same treatment. Synomymes: 1 . $\boldsymbol{K}$. aculeata, obovata, Gardenia Randia. 2. G. multiflora. $3 \boldsymbol{R}$. longiflora. 4. $\boldsymbol{R}$. obovata. 5. Petunga Roxburghii.

Bowieñnă - . Pa. yel. - S. Ev. S. Brazil 1815

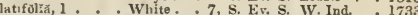
longiflöră, 2 White

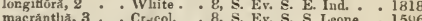
macránthă, 3 - . Crycol. - 8, S. Ev. S. S. Leone - 1596 parviflóră * White. . 8, S. Ev. S. W. Ind. 1818 pubéscēus, 4 . White. 7, S. Ev s. Peru . 1820

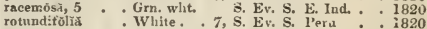
sinēnsis. - White: 7, G. Er. S. China: : 818

RANēxcuัLuัs, Linn. From rana, a frog; many of the species are found in moist places frequented by that reptile. Linn. 13, Or. 1, Nat. Or. Ranunculacer. Many of the plants belonging to this extensive genus are well worth the cultivator's care, and they have long been favourites with the florist. The aquatic kinds require to be grown in water. The grumose-rocted species will thrive in any common soil, and in any situation; they are increased by offsets from the roots, or by seeds. $\boldsymbol{R}$. asiaticus and its varieties should be grown in good fresh loam and well-rotted cow-dung; the tubers should be planted in October or March; if in the former month, they will require to be slightly protected in bad weather. Seeds selected fron the best semi-double varieties, sown early in October, and kept growing during the winter, will flower the next season; these latter may also be increased by dividing the roots. These plarits are mustly poisonous. Synouymes: 1. R. polyanthemos. 2. aureus, villosus. 3. pyrenaus. 4. Thomasi. 5. sericeus. 6. apiifolius. 7. monspeliacus. 8. polyanthemos. 9. aureus, villosus. 10. rigidus, eircinatus. 11. peuredanifolius. 12. pyrenaus, plantayinens. I3. aconitifolius. 14. muricatus, brasilianus, i5. Breynianus.

aconitifoliňs crassicaũliss hümillis

ãcrīs.

albùs:

multiffiduัs,

piēnŭs

sylvătǐcŭ

al pêstris

amplēxícaúlis

angulātùs

angustifolrŭs

apiffơliǔs

aquartilis

peltatǔs.

aretīicus .

asiăticǔs

sanguině̆ĭs

tenuifölüs

auricōmŭs

monariẻnsis.

bracteātŭs

fiơrè-plēnò

ochroleũcŭs

brevicaúliss.

Breyniănĭs, 2

Brêtis

bulbōsūs

bullătũs

fiórè-pieñ

grandiflörǔs

White .

White.

5, H. Her. P. Alp. Eur.. 1596

Yellow

White.

Yeslow

Yellow

Yellow

White.

White

Wlite

Wlit, red

White.

Wlite

Yellow

Varieg.

White.

Yellow

Yellow

Yellow

Yellow

Pa yel.

Yellow

Yellow

Yellow

Yellow

Yellow

Yellow

Yellow

Yellow

5, H. Her. P. Europe

5 , H. Her. P. Europe

6, H. Her. P. Britain

6 , H. Her. P.

6 , H. Her. P. Europe

6 , H. Her. P. Britain

6, H. Her. P. France

7, H. Her. P. Sentland

H. Her. P. Pyrenees

H. Tu. P. Naples

5. 1832

6 , H. Her. P. Bonaria : 1816

6, H. Aq P. Brituin

6, H. Aq. P. Britain

7, H. Her. P. N. Amer. 1827

5, H. Tu. P. Levant . 1596

5, H. Tu. P. Syria

5, H. Tu. P. Greece

5, H. Her. P. Britain

5, H. -Tu. $\mathbf{P}$

8, H. Tu. P. England

5, H. Her. P. N. Amer. 1827

6, H. Tu. P. Nap.es 1894

6, H. Her. P. Su ilzerl. : 1318

5 , H. Her. P. Italy * 1823

5, H. Tu. P. Britain

5, H. Tu. P. S. Eur.

5, H. Tu. P. S. Eur.

3640

1640

5, H. Tu. P. S. Eur. $\quad 2640$

$2 \mathrm{M}$ 


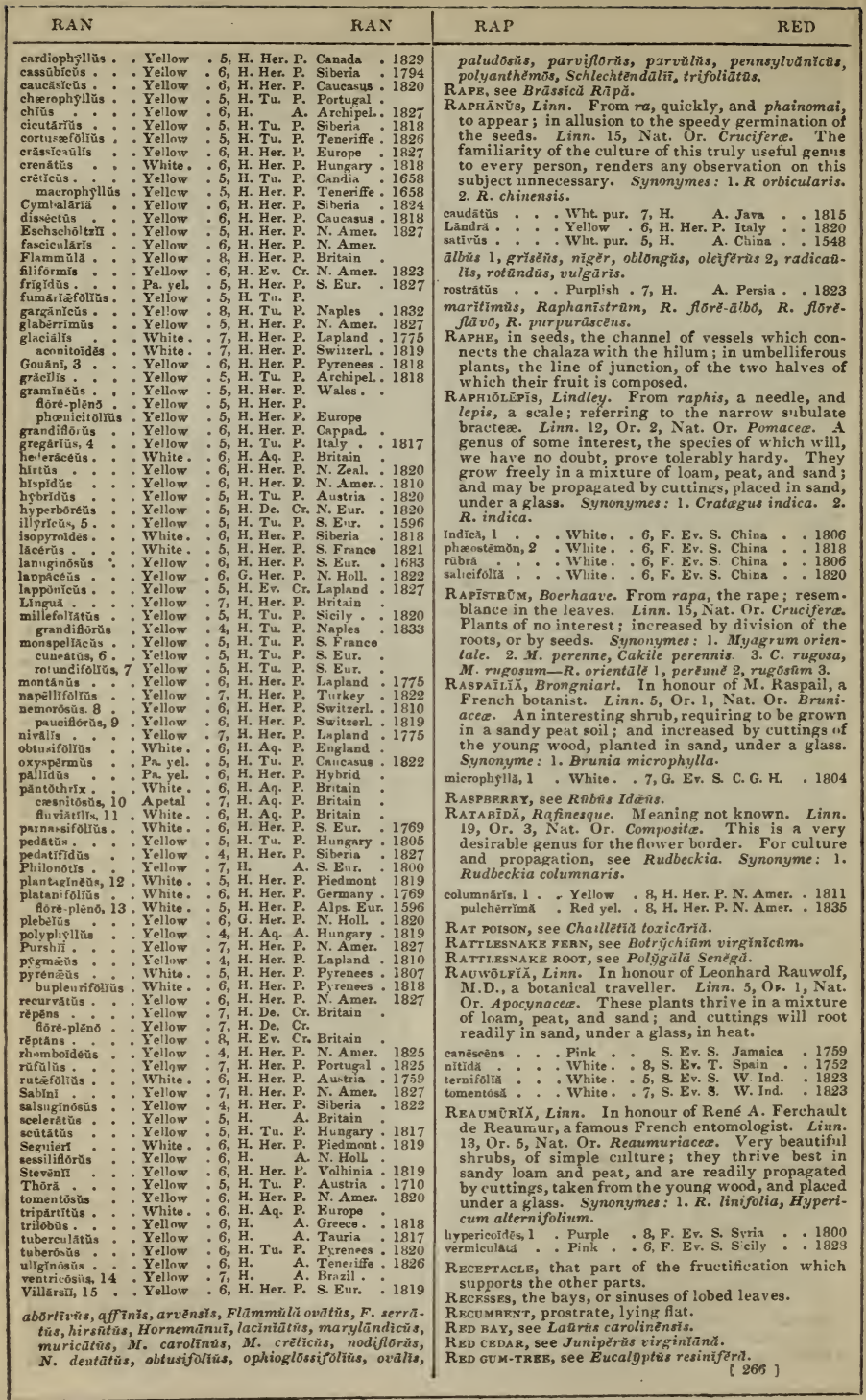


RED LAc, see Rhas succedanęă.

R KD N1GHTshADE, see Erīcă Halicăcăba.

RHD OSIRR, see Sălīx rübră.

REDOCTTA. Named by Ventenat, in honour of P. J. Redouté, a celebrated French botanical artist. Linn. 16, Or. 8, Nat. Or. Malvacee. This shrub grows in peat and loam, and may be increased by cuttings planted in sand or loam, under a glass, in heat; it may also be raised from seed sown in the usual way.

heterophyllă . . Yellow . 6, S. Ev. S. W. Ind. . 1822

RxD SAUNDERs-WOOD, see Pterocïrpŭs santalīnŭs.

RED WATER-TREB, see Erythrōphlêum.

RED woon, see Ceanothris.

$\mathbf{R}_{\text {bD }}$ wood, see Rhämnñs Erythroxy̆lon.

RED wood, see Melhänīă Erythroxy̆lōn.

REED, see Phrägmītěs.

REED-UPON-REEN, see Calamagrōstĭs effüsă.

ReEvesià. Named by Lindley, in compliment to John Reeves, Esq., F.L.S., of Canton, from whom the botany of China has received material assistance, and to whom our gardens are indebted for many of their fairest ornaments. Linn. 16, Or. 8, Nat. Or. Sterculiacea. This very handsome shrub may be referred to the greenhouse species of Sterculia, for culture and propagation.

thyrsoĩdéă . . . White. . 1, G. Ev. S. Clina . . 1826

REFRIGERANT, producing coolness.

Rднма̄NNĩ̆, Libosch. Not explained. Linn. 14, Or. 2, Nat. Or. Scrophulariacea. The flowers of this plant are large, but their colour so much destroy's the effect of their magnitude, that the plant is, on that account, more curious than ornamental. Though hardy, it will succeed best in a cool greenhouse or frame, planted in any common soil, and is propagated by cuttings.

obinēnuřs . . . Dingy * * H. Her. P. China • . 1835

REICRĀRDĬA, Roth. In honour of John James Reichard, a celebrated botanist and author. Linn. 10, Or. 1, Nat. Or. Leguminosa. For the culture and propagation of this ornamental tree, see Poinciana. Synonyme: 1. Casalpinia ligulata.

hexapétălă, I. Yellow . S. Ev. S. E. Ind. . . 1824

ReLĀ̄x̌̆, L'Heritier. In honour of the Rev. Richard Relhan, author of "Flora Cantabrigiensis." Linn. 19, Or. 2, Nat. Or. Composita. For the culture of these ornamental plants, see Athanasia. Synonymes: 1. Athanasia genistifolia. 2. Leysera ericoides.

genistifoliă, 1. Yellow - 5, G. Ev. S. C. G. H

fateriflōră : Yellow : 9, G. Ev. S. C. G. H.

paterifura. Yellow

paleacea, $2 \div:$ Yellow

squărnósă : : Yellow : 5, G. Ev. S. C. G. H.

1823

1823

- 1818

1820

Rrmīrē Ă, Aublet. Its name in Guiana. Linn. 3, Or: 1, Nat. Or. Cyperacea. A plant of no value; it is increased by seeds or divisions-R. maritimă.

RENANTHËR̆, Loureiro. From ren, a kidney, and anthera, an anther; in allusion to the kidney or reniform shape of the anthers or pollen-masses. Linn. 20, Or. 1, Nat. Or. Orchidacea. R. coccined is a truly splendid plant. The flowers are produced on a lateral loose panicle; the sepals are of a pale scarlet, obscurely and irregularly blotched; the petals are marked with yellow bands on a beautifu. scarlet ground; the labellum is yellow and scarlet. The plant will succeed in peat mixed with broken potsherds, carefully placed about the roots, so as to ensure a safe drainage; but the best way of growing it, is to plant it in ephagnum or hypnum moss, cut short and packed close about the roots, with a quantity of broken potsherds to act as a drainage. Any of the young branches taken off and potted in moss will soon make plants, which succeed well in any place where a strong heat and an abundance of moisture is kept up; when the plant has attained a good size, about the height of six feet, it should be placed in a house where the heat is from 65 to 70 degrees, and kept perfectly free from moisture, except what arises from watering and occasional syringing. The whole of the plant should be as near the glass and as much exposed to the sun as possible; and to prevent the leaves from shrivelling too much, it may be occasionally syringed in the afternoon. After being in this house two or three months, the flower spikes will make their appearance; when the flowers are expanded, the plant should be removed to a cool house, and placed in a light situation: it will there continue in perfection for a great length of time. Synonyme: 1. Aerides arachnites.

arachnités, 1 - Brn. pur. - S. Epi. Japan . 1793 coccinéă : Sear. or. : 8, S. Epi. Co. China : 1816

RENeÃLĬ, $R$. Brown. In honour of P. and M. L.

Renealme, the first a famous French physician, and the other a botanist. Linn. 3, Or. 1, Nat. Or. Iridacea. These plants may be referred to Alpinia, for culture and propagation.

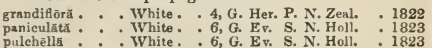
pulchells white. 6, G. Ev S. N. Holl. 1823 RENIFoRs, kidney-shaped.

REPAND, a leaf is said to be repand when its margin is undulated, and unequally dilated.

REPLICATB, folded back

REPTANT, creeping and rooting.

Requienta, Decandolle. In honour of M. Requien, a botanist of A vignon. Linn. 16, Or. 6, Nat. Or. Leguminosa. This plant should be grown in a mixture of peat, loam, and sand; and young cuttings will strike if planted in sand, under a glass, in heat. The glass must be occasionally taken off and wiped, to prevent dimp. Synonyme: 1. Pcdalyria obcordata.

obcordâtă, 1 . . Yellow * 7, S. Ev. S. Senegal • 1825

Rnsēdă, Linn. From resedo, to calm or appease; the Latins considered its application useful in external bruises. Linn. 11, Or. 3, Nat. Or. Resedacea. The Mignonette is an old and universal favourite, on account of the very pleasant odour emitted by the flowers. In summer it merely requires the treat. ment of other hardy annuals; but to obtain flowering plants through the winter and spring months, two other sowings must be made; to obtain flower. ing plants from December to March, the seeds should be sown about the middle of July upon a light, rich, open border, and the plants potted before the frost sets in, plunged in old tan or ashes, and covered by a frame, which should front the west. Those to flower from March to June, should be sown in pots not later than the third week in August, and treated in a manner similar to the November sowing. The third, or spring crop to succeed the last, may be sown about the middle of February; these should be placed in a frame in a gentle heat, and the plants thus obtained $w i l ?$ be in perfection by the end of May. The suffruticose species may be increased by cuttings or seeds.

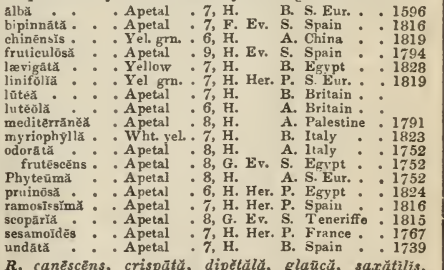

R. canēscēns, crispātă, dipětălă, glaūcă, saxătilis, virēscëns.

ResolvBN, having the power to dissolve.

Ristharrow, see Ononis.

RẼstiō, Linn. From restis, cord; used as cord at the Cape of Gond Hope. Linn. 22, Or. 3, Nat. Or. $\boldsymbol{R}$ estiacea. These plants grow in any common soil, and are increased by divisions. Synonyme: 1. Calcrophus elongatus.

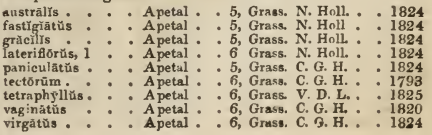




RES RHA

REsUPINATg, lying on the back.

Retanĩllă, Decandolle. Its Peruvian name. Linn. 5, Or. 1, Nat. Or. Rhamnaced. Small evergreens, thriving in loam and peat, and propagated by cuttings planted in sand, under a glass. Synonymes: 1. Colletia Ephedra. 2. Colletia obcordata.

Ephēdră, 1 . * Green . - F. Ev. S. Chile * 1823

Reticulärĭă, Bulliard. From reticulum, a net; appearance. Linn. 24, Or. 9, Nat. Or. Fungi. These species are found upon rotten sticks, leaves, \&c. R. argẽntẽă, minũtă, olivãceẽă.

RxTrCui.ATRd, netted, resembling a net.

RRTRACTED, bent backwards.

RBTROGRADE, usually applied to hairs when they are bent back or down, instead of forward, or up.

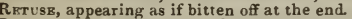

RĒrž̃̆, Linn. In honour of Anders Johan Retzius, professor of natural history in the University of Lund; author of "Observations on Botany." Linn. 5, Or. 1, Nat. Or. Retziacec. This plant thrives in any light soil; and cuttings will root readily in sand, under a glass.

spieātă . . . Brown . 5, G. Ev. S. C. G. H.

Rxvouvtr, rolled back: usually applied to the edges of leaves.

RHARDOCHLÖ̆, Beauvois. From rhabdos, a twig, and chloa, grass. Linn. 3, Or. 2, Nat. Or. Graminea. Pretty annuals, growing in any light soil; and increased by seeds. Synonymes: 1. Chloris cruciata. 2. Chloris poaformis, Cynosurus virgatus.

cruciata, 1 . . A petal . . 7, Grass. W. Ind. . . 1818 mucrỏnátã : : A petal : : 7, Grass. N. Amer. : 1820 virgăta, 2 : : A Apetal : : 7, Grass W. Ind. : : 1820

RhaganY̌ŏťs, Tournefort. From rhagas, a slit; in allusion to the divisions of the calyx. Linn. 19, Or. 1, Nat. Or. Compositc. Annuais of no interest; increased by seed in any common soil. Synonymes: 1. $\boldsymbol{R}$. lapsanoides, Lapsana Rhagadiolus. $2 . \mathrm{Kal}$ pinia linearis- $R$. édulis $1, K u l$ pinäa 2 , stellatŭs.

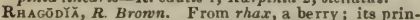
cipal distinction. Linn. 23, Or. 1, Nat. Or. Cheno. podiacte. Interesting plants, growing well in a mixture of loam and peat; and increasing readily by cuttings, placed under a glass.

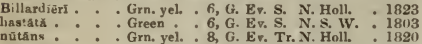
pútans : : : Grn. yel. : 8, G. Ev. Tr. N. Holl. : 1820

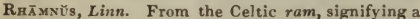
tuft of branches. Linn. 5, Or. 1, Nat. Or Rham. nacea. The plants belonging to this genus are mostly valued on account of their foliage. The stove and greenhouse kinds are easily grown in any light soil; and increase readily by euttings under a glass. The hardy kinds grow in any common soil, and are usually propagated by layers and seeds. The plants and berries possess very strong purgative qualities. The juice of the berries of $\boldsymbol{R}$. catharticus is sold under the name of syrup of buckthorn; the French berries of the shops is the juice of the unripe fruit of the same species, and is used for dyeing Turkey or Morocco leather yellow. The wood of $\boldsymbol{R}$. dahuricus is red, and is known to the Russians by the name of sandal-wood. Syno. nymes: 1. R. Clusit. 2. R. Willdenovianus. 3. $R$. rupestris. 4. $R$. pumilus. 5. R. pumilus.

angustifoliü, 1 . Green : 5 , H. Ev, S. S. Eur.

baleârică : Green : 5 , H. Ev. S. S. Eur.

fol, argêntêis : Green : . 5, H. Ev. S. S. Eur. :

fol. aürêis : Green : 5, H. Ev. S. S. Eur.

fol. maculätis : Green : 5 , H. Ev. S. S. Eur.

hispanicä : Green : . 5, H. Ev. S. S. Eur.

alnifolrǔs . : Green : 5 , H. De. S. N. Amer.

alpinŭs . . . Green . . 5, H. De, s, Stritzerl.

buxifolrŭs

5, H. Ev Sumidis

H. Ev. S.

earolinianūs

cathartieũs.

hydriensis

celtiffoliňs

erenulătŭs

Green . 5, H. De, S. N. Amer. 1832

Grn. yel. : 5, H. De. S. England

Grn. yel. . 6, H. De. T. C. G. H.

Grn. yel. : 4, G. Ev. S. Teneriffo

dahüricŭs . Grn. yel. . 5, H. De. S. Davuria 1778

Erythroxylön : : Yel. grn. : 7, H. De. S. Siberia : 1823

Rngustissimŭm

Frăngŭlă

H. De. $\mathbf{S}$. Caucasus

RHA

RHI

glandulösǔs . . Green * . 6, G. Ev. S. Canaries . 1785

hỵbrỉdüs : : Green: : H. De. \&

nfectoriǔs.: : Grn yel. : 6, H. De. S. S. Eur. . 1683

integrifoliǔs : Green : ${ }^{-}$G. Ev. S. Teneriffe : 1829

lancenlātús : Green : : 5, H. De. S. N. Amer. : 1812

latifolliŭs - Green : 7, H. De. S. Azores : : 1778

lycioĩdés : Grn. yel. 11, H. De. S. Spain : 1752

arragnnënsǐs . Grn. yel. 10, H. De. S. Arragon : 1759

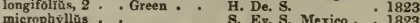

olénidés. : : Grn yeL. 6, H. De. S. Spain : : 1759

Pallásiñ : : : H. De. S. Russia : 1838

prinoĩdés : : Yellow $\quad 6$, G. Ev. S. C. G. H. : 1778

pubêscéns . - Pa yel. 5, H. Ev. S. France. : 1817

püminlús, 3. : Grn. yel. : 7, H. De S. Carniola : 1752

rupístris : : Green $\quad 5$, H. De. S. Naples : 1823

saxătilis : Gra yel. : 5, H, De. T. Europe : 1758

spatulaefolrŭs : : H. De. S. Russia : 1838

surinamēnsis: :Gm. yel. . S. Ev. S. Surinam : 1890

tetragonnŭs . : Green . : G. Ev. S. C. G. H. : 1816

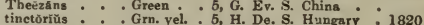

valentinŭs, 4 : : Green . : 5, H. De. T. S. Eur. : 1816

virgatũs : Green : 6, H. De. S. Nepal : 1820

RHĀPIs, Linn. From rhapis, a needle; alluding to the acute awns of the corolla Linn. 23, Or. 1, Nat. Or. Palmaceo. Dwarfish palins, thriving well in sandy loam; and increasing by suckers from the roots.

arundinăcéă. . Green . . 9, Palm. Carolina . . 1765

Rнато̄nť̀̆, Decandolle. From rha, rhubarb, and Ponticus, of Pontus. Linn. 19, Or. 3, Nat. Or. Composita. These plants will grow in any common soil, and may be readily increased by divisions. Synonymes: 1. Centaurea Rhapontica. 2. C. Rhapontica.

Pallesin, 1 . . Purplo * 7, H. Her. P. Switzerl. . 1818 pülchră. : : Purplo ${ }_{\text {H. }}$ B. Caucasus: 1837 scriosa, 2 : : Purple * 7, H. Her. P. Switzerl. : 1640 lyráta : : Purple : 7, H. Her. P. Switzerl. : 1819 unitêră. : : Purple : 7, H. Her. P. Siberia : 1796

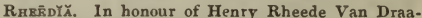
kenstein, author of Hortus Malabaricus, in ten vols. folio. Linn. 12, Or. 3, Nat. Or. Guttiferce. This very handsome, broad-leaved tree, will grow in a mixture of peat, loam, and sand; and ripened cuttings will root in sand, under a glass, in a moist heat.

javănǐeă . . . $\quad$ S. Ev. T. Java . . 1826

Rнйе̃ M, Linn. From $r h n$, the Wolga: the first plants were brought from its banks. Linn. 9, Or. 2, Nat. Or. Polygonacee. The culture and uses of the Rhubarb are well known. The plants all thrive well in a rich loamy soil; and are increased by divisions of the roots, or by seed. Synonyme: 1. $R$. Emodi.

australe, 1. . Purple . H. Fu. P. Nepal . 1823 austriąeũm. : White. : 5, H. Fu. P. Austria: : 1800 elspicüm : Whito: 5, H. Fu. P. Kussia : 1817 compăetúm : Whe gra. 5, H. Fu. P. Tartary : 1758 crispum : White. 5, H. Fu. P. Tartary : 1800 fenestrátūm : : White.: 5 , H. Fu. P. hybrìdūm .: : Wht. grn. 5, H. Fu. P. Asia : : 1778 leucorhizüm : Striped . 5, H. Her, P. Siheris : 1827 nūtâns . : White. . 5, H. Fu. P. Siberis : 1800 palmatum : : Wht grn. 6, H. Fu. P. Bucharia : 1763 Rhapōntieúm : Wlith grn. 5, H. Fu. P. Asis : 1573 Ribes : . Whe grn. 5, H. Fu P. Levant : 1724 sibiricuim : : White grn. 5, H. Fu. P. Siberia : 1800 sibiricūm : : White. $\cdot$ 6, H. Fu. P. Sebria : 1800 undulâtūm: : Whe grn. 5, H. Fu. P. Chins . 1734

RHÊxऍ̆, Linn. From rhexis, a rupture; from its astringent qualities, it is supposed to cure ruptures. Linu. 8, Or. 1, Nat. Or. Melastomacese. This is a genus of very elegant plants when in Hower. The plants grow best in a bed of peat sril, but are sometimes grown in pots in the same kind of soil. They are readily increased by division at the root. snpustifoliă . . White. . 7, H. Her. P. N. Amer. - 1812 ciliōsA . Purple 7, H. Her. P. Carolina : 1812 mariañ mañlla : Pink virginicé : : Purple : 7, H. Her. P. N. Amer. : 1759

Rhis̄̃stu'̌s, Linn. From rhin, a snout, and anthos, a flower; alluding to the appearance of the corolla. Linn. 14, Or. 2, Nat. Or. Scrophulariaced. The seeds of the Yellow Rattle have only to be sown in a moist situation. Synonymes: 1. R. Alectorolsphus, Bartsia Trixago, Trixago rhinanthina.

[268 ] 
Alectorolophăs. Yellow . 7, H. A. Europe . 1820 Cristardophàs - Yellow : 7, major : Yellow : $: 7, \mathrm{H}$ Trixăgo, 1: : Yellow :7, $\mathrm{H}$. A. Britain . A. Europe: 1800

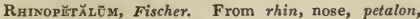
petal; base of upper sepal. Linn. 6, Or. 1, Nat. Or. Liliacea. For culture and propagation, refer to the hardy species of Lilium.

Karelinï . . . Pa. pk. spt. 1, H. Tu. P. Ural . . . 1834

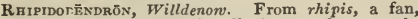
and dendron, a tree; in allusion to the growth. Linn. 6, Or. 1, Nat. Or. Liliacee. This genus may be referred to the Aloes for culture and propagation. Synonymes: 1.R. distichum, Aloe plicatilis.

plicătīlé, 1 - . Rea * 6, G. Ev. S. Africa * 1723 RHIPSĀLIs, Haworth. From rhips, a willow branch; in allusion to the flexible branches. Linn. 12, Or. 1, Nat. Or. Cactacece. The plants of this genus are more singular than beautiful. A light vegetable soil, mixed with a little brick rubbish, suits them best; and they are readily increased by cuttings. Synonymes: 1. Cactus pendula. 2. C. funalis.

Cassỹthă, 1 . . Yellow . 9, S. Ev. S. W. Ind. - 1758 cereúscūla

fasciculätă

Grsh. wht.

S. Ev. T. Brazil

White 8, S. Fv, S. W. Ind

mesemhryânthoỉdès White. : S. Er. S. S A mer. : 1817

parasítică :. Yellow 1800

galicornoidês: Yellow $6, \mathrm{~S}$. Ev, S. F. Ind. : 1817

RнIzоcто̄кӑ, Decandolle. From rhiza, a root, and kteino, to destroy; the name is applied in consequence of its destroying the roots upon which it grows. Linn. 24, Or. 9, Nat. Or. Fungi. This species is found on Colchicum and the roots of the Crocus-R. Crocơrūm.

Rнizóm, applied to roots which spread under ground, similar to those of the Iris.

R нizoмōrphă, Roth. From $r h i z a$, a root, and morphe, form; the appearance of the plants. Linn. 24, Or. 9, Nat. Or. Fungi. The species of this genus are found beneath bark and in cellars- $R$. divërgēns, meduliàris, subcorticālis, subterränëă.

Rнizŏрно̆RĂ, Linn. From rhiza, a root, and phoreo, to bear; the branches of this tree throw vut roots very freely, which descend into the mud; consequently, every branch being supported by its own roots, one tree may, in this manner, extend over a considerable space. Linn. 11, Or. 1, Nat. Or. Rhizophoracec. The Mangrove may be tried in loam and sand, well mixed, and kept moist by the frequent application of salted water. It is difficult, if not altogether impossible, to cultivate it in this country.

Mănglë . . . . Pa. yel. . S. Ev. T. E. Ind. . . 1820

RHzopōGōs, Trinius. From $r h i z a$, a root, and pogon, a beard. Linn. 24, Or. 9, Nat. Or. Fungi. This species is found by the waysides. Synonyme: 1 . Lycoperdon gibbosum-R. älbüs 1 .

RHODĀTHĒ, Liudley. From rhodon, a rose, and anthos, a flower; in allusion to the colour of the flower-heads. Linn. 19, Or. 1, Nat. Or. Composita. This is one of the most delightful annuals ever introduced to our collections. To obtain flowering plants in March, the seed should be sown in August, in a compost of decayed leaf-soil and light maiden earth, in equal parts, having the pots well drained. The seed-pots should not be placed in a lower temperature than 60 nor ever higher than 80 degrees. The earth should never be allowed to become too dry, taking care to apply water of a temperature nearly equal to that of the house. They will require several shifts previous to flower. ing; at the two last, viz. those in January and I arch, decayed manure should be substituted for leaf mould, and a small portion of white sand added to the compost; a second sowing should be made in October and treated as the first, and they will flower beautifully the following May; and if a final sowing is effected in March, the plants wil be ready to plant out in the flower-garden in Mas or June, where they will flower during the au tumnal months. After the plants raised from any of the sowings have been potted, they should be removed to much cooler house, and when pro[ 269 ] perly established, placed on some elevatec situation near the glass. Seed should be obtained from the plants grown in the greenhouse.

Manglēsir . . Ro. yel. . 6, G. A. S. River . 1832

RHoDtoLA, see Sẽdūm.

RHODODENDRŌ, Linn. From rhodon, a rose, and dendron, a tree; because of the appearance of the terminal bunches of flowers. Linn. 10, Or. 1, Nat. Or. Ericacee. The Rhododendron is decidedly one of the finest of all known genera, containing some of the most handsome, elegant, and showy shrubs; all of which are admirably adapted either for ornamenting the greenhouse or shrubbery, or for planting singly on lawns. Peat soil is most suitable to these plants, but they may also be grown in very sandy loam, or vegetable mould. Propagation may be effected by layers or seeds; if the latter mode be preferred, the seeds must be sown early in spring, in tlat pans filled with peat soil, and the seed covered very slightly over; the pans should then be set in a close frame till the plants make their appearance, taking care to water very slightly, when the soil appears dry. The seedlings having attained to a sufficient height, so as to admit of their heing drawn without fear of injury, should be removed into other pots or pans, using the same kind of mould. After this removal they should be kept in a close frame till fresh roots are produced, and they may then, by degrees, be hardened to the air. The small-wooded kinds may be also increased very freely by young cuttings, planted in sand under a glass. The tender kinds may be easily propagated by young cuttings torn off close to the stem, planted in sand and plunged in heat under a glass. Synonymes: 1 . $R$. aromaticum. 2. $R$. cinnamomeum. 3. $R$. album. 4. $R$. Russellianum. 5. R. Nobleanum. 6. R. officinale. 7. $\boldsymbol{R}$. azalcoides. 8. $\boldsymbol{R}$. myrtifolium. 9. $\boldsymbol{R}$. obtusum. 10 $\boldsymbol{R}$. indicum Smithii, Azalca indica Smithii. 1]. $\boldsymbol{R}$. Smithii. 12, Rhodora canadensis.

albiflörüm . . . White. . 6, H. Eৃ. S. N. Amer. ãltă-clërēnsĕ : Crimson : 5, H. Eণ̃. S. Fing, hyb. arborénon, 1. "Purple - 5, F. Evi Nepal cinnamōmèūm, 2 Purplete $: 5$, F. Ev. S. Nepal : nĩveum, 3 . White : 3 , H. Ev. S. Nepal T. Nepal niveúm, 3 * White. 3, H. Ev. T. Nepal sanguĩnénin: : Scarlet : 4, H. Ev. T. Nepal : undulāũm : Rieh p. : 4, H. Ev. S. Eng. hyb. venuีstủm : Pk, spot. 3, H. Ev. S. Evg. hyb.

venuี stuีm

H. Ev. S. Nepal campanulátủm : Pa. pink $: 5$, F. Ev. S. Nepal
H. Ev. S. Kamt. catawbrēnsé : Purple : 7, H. Ev. S. N. Amer. Russelliánūm, 4 Bt. ro. . : 3, H. Ev. S.

tigrinúm - Ro, spot. : 3, H. Ev. S. Hybrid

Catesbēi : Purple 5, H. Ev. S. N. Amer.

caucăsĩeûm $\cdot$ Purple $\quad 8$, H. Ev. S. Caucasus

Nobleãnūm, 5 . Dp. red . 3, H. Ev. S. Hybrid

pulchẻrrinnūm . Pa. rose - 3, H. Ev. S. Hybrid .

straminéúm. Straw . 4, H. Ev. S.

Chamacistǔs : Pa. pur. : 5, H. Ev. S. Austria

daûrieûm : : Purple: 3, H. Ev. S. Siberia : 1780

atrovirēns: Purple

Farrêrż : : Lilac

ferruginēūm : Searlet

albüm

bȳbridúm

by̆bridum

variegätūim

White

3, H. Ev. S. Siberia

3, H. Ev. S. China

6, H. Ev. S. Switzerl. 175

6, H. Ev S. Pyrenees - 1830

7, H. Ev. S.

6, H. Ev. S. Switzerl. 1656

6 , H. Ev. S. 1800

6. F. Ev. S. Lapland: 1825

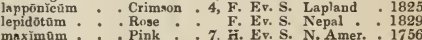

mnximúm : Pink : 7. F. Ev. S. N. Amer.

ălbūm : White: 7, H. Ev. S.

hybridunm : Wht. pur.. H. Ev. S. Hybrid . 1830

pōntícûm - Purple :5, H. Ev. S. Gibraltar : 1763

azaleoĩdés, 7 . Pink . 7, H. Ev. S. Hybrid . 1820

Lōwī - * White . - H. Ev. S. Eng. hyb.

mrrtifolium, 8 Purple :5, H. Ev. S. Gibraltar

obtūsūm, 9 . Purple :5, H. Ev. S. Armenia

odorātüm - Pinkle

. 9, H. Ev. S. Eng. hyb. . 182

punctatûm . Pink .

majus *. Pink .

purpŭrêum - Purplo - 7, H. Ev. T. N. Amer.

Púrshî . White. 7, H, Ev, S. N. Jersey . 181

Rhodōră, 12 . Ph. pur. . 5, H. De. S. N. Amer. - 1767

setōsîm : Purple F. Evy S. Nepal . 1825

Rноромйц melos, a limb, colour of the fronds. Linn. 24, Or. 
\begin{tabular}{|c|} 
RHO \\
\hline 8, Nat. Or. Alga. These plants are found in the
\end{tabular} 8, Nat. Or. Alga. These plants are found in the
ocean, on the sea-shore, \&c. $-R$. dentätá, lycopodiożdés, pinastrożdes, scorpiożdès, subfüscă.

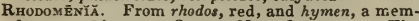
brane. Linn. 24, Or. 8, Nat. Or. Alge. The species of this genus, like those of the one immediately preceding, are found in the ocean, \&c. Synonymes: 1. Spharococcus bifidus. 2. S. ciliatus. 3. S. c. angustus. 4. S. c. jubatus. 5. S. c. palmatus. 6. S. c. spinosus. 7. S. cristatus. 8. S. laciniatus. 9. S. Palmetta. 10. S. reniformis $-\boldsymbol{R}$. bưfĩdǔs 1 , ciliâtǔs 2, C. angûstǔs 3, C. jubātũs 4 , C. palmätŭs 5, C. spinбsūs 6 , cristätüs 7 , laciniātũs 8, Palméttă 9, polycärpă, reniformnis 10 , sobolifĕrŭs.

R HODð̃RA, see Rhododēndrơn.

Rномв or RHOMBOID, like a Rhombus.

Rномв-оVATE, ? between rhomboid and egg-

Rном BоID-OVATE, $\{$ shaped.

RHUBARB, see Rhẽum

$\mathrm{R}_{\mathrm{H}} \overline{\mathrm{t}} \mathrm{s}, \mathrm{Linn}$. Derived from rous, in Greek, which is from rhudd, a Celtic word signifying red; alluding to the colour of the fruit and leaves of some species in autumn. Linn. 5, Or. 3, Nat. Or. Anacardiacee. The stove and greenhouse species will grow well in any common soil ; and may be readily increased by ripened cuttings planted in sand, under a glass; the stove species must be placed in heat. The hardy kinds are rather ornamental and well fitted for shrubberies; some are propagated by cuttings of the roots, and others by cuttings and layers. The juice of $R$. radicans and Toxicodendron is milky, stains black, and is extremely poisonous. $\boldsymbol{R}$. Coriaria is powerfully astringent, and is used in tanning Turkey or Morocco leather. Synonymes: $1 . R$. Bucǩu Amela. 2. R. lucida. 3. Laurus canstica. 4. $R$. lucida. 5. spicato. 6. oxyacrnthoides. 7. carnliniana, elegans. 8. elongata. 9, theezans. 10. venenata. il. juglandifolia.

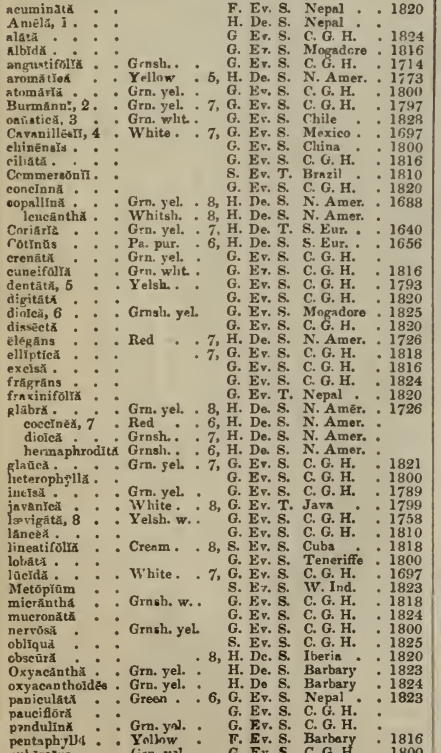

820 97 88 40 16 793

(1)

825 726 818 (1) (1) 820
726

821 89 799 (1) 818 800 697 823 824
800

85 825 823 324 816 1800 pümrlă . . . Grn. yel. . 7, H. De. S. N. Amer. . 1806 pyroīdés : : : G. Ev. S. C. G. H. : 1816

radreăns :Grm. yel. 6, H. De. Cr. N. Amer.

volübrlis : Grn. yel. : 6, H. De. Cl. N. Amer. :

valgäriss : Girn. yel. : 6, H. De. Cr. N. Amer,

riğdă. G. Ev. S. C. G. H. : 1700

rosmarinifolix: Green . G. Ev. S. C. G. H. : 1800

schinoidés : Greon * Ev. S. Brazil : 1824

semiălătă. : $\quad$ G. Ev. T. Macao : 1780

serzæfoliă : . $\quad$ G. Ev. S. C. G. H. : 1816

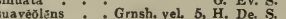

succedānēr . Grn. yel. . 6, G. Ev. S. China 1768

Thunbergīană Grnsh. vel. G. Ev, S, C. G. H.

G. Ev. S. C. G. H. : 1768

tomentosa : Grn. yel. * G. Ev. S. C. G. H. • 1691

Toxicodēndrōn . Grn. yel. . 6, H. De. Cr. N. Amer. . 1640

$\begin{array}{lll}\text { tridāctylliss : : Grnsh. yel. } & \text { G. Ev. S. C. G. H. : } 1816 \\ \text { tridentătă }: \text { Grnsh. yel. } & \text { G. Ev. Cl. C. G. H. : } 1816\end{array}$

typhină : Grn. yel. . 7, H. De. T. N. Amer. . 1629

arboréscēn. Grn. yel. . 7, H. Da. T.

- Grn. yel. 7 , G. H 1816

vérnix, 10 : Gru. yel. 7 , H. De. T. N. Amer. : 1713

verniciferă, 1 : Grn. yel. : H. De. T. Nepnl. : 1823

villox. . : Grn. yel. : 7, G. Ev. S. C. G. H. : 1714

viminalis: : Grn. yel. : G. Ev. S. C. G. H. : 1774

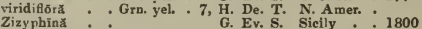

RAYNchōš̌̆, Loureiro. From rhynchos, a beak; the keel of the flower is beaked. Linn. 17, Or. 4, Nat. Or. Leguminose. These plants are not possessed of much beauty; any rich light soil suits them; and they are easily increased by cuttings or seeds. Synonymes: 1. Glycine angustifolia. 2. Dolichos scarabceoides. 3. Glycine earibiza. 4. G. tomentusa, volubilis. 5. G. erecta. 6. Dolichos minimus. 7. G. mollis. 8. G. phasenloides. 9. G. precatoria. 10. G. reniformis. 11. G. reticulata. 12. G. rhombifolia. 13. Dolichos scarabaroides. 14. G. suaveolens. 15. G. picta, Cytisus violaceus. 16. G. viscosa, glutinosa. caribea. 3 • Yellow 9, S. Er. Tw. W. Ind. - 1742 eréctă, 5 . Sulphur : 7, H. Her. P. N. Amer. 1820 reniformis, 10 : Yellow: 7, F. De. Tw. Carolina . 1806 retieulátă, 11 : White. : 8, s. Ev. Tw. Jumaica : 1779 suavéolēns, 14 : Yel. red : 8, S. Ev. S. E. Ind. : 1816 R. angustifol̆ă 1, bifloră 2, difformĭs 4, Frederĭč̆ană, minimă 6, móltis 7 , phaseolotděs 8 , precatóriă 9, rhombifolìă 12, scarabaożdès 13 , violäcéă 15 , viscōsü 16.

RHYNChospōră, Vahl. From rhynchos, a beak, and spora, a seed. Linn. 3, Or. 1, Nat. Or. Cyperucea. Worthless plants, growing in bogs, \&c.-R. a lbä, comãtă, füscú.

R 11 rĩsmä, Fries. From rhytis, a wrinkle; appearance of the plants. Linn. 24, Or. 9, Nat Or. Fungi. Found upon sycamore leaves and other live plants, as some of the specific appellations imply $-\boldsymbol{R}$. ace-

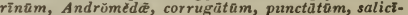
nūm, Urticuēe

$R_{1 B}$, the projecting vein of anything.

Rİ⿴囗̌s, Linn. From Ribas, the name of an acid plant mentioned by the A rabian physicians, which is known to be Rhenm Ribes. Linn 5, Or. 1, Nat. Or. Grossulacer. This is a valuable genus, and contains the gooseberry and currant, the uses of which every cottager is familiar with; and in addition to these much esteerned fruits, some of the species are well suited for ornamenting shrubberies. The most ornamental species are $\boldsymbol{R}$. atropurpureum, aureum, sanguineum, and speciosum. All the species of Ribes will grow in any soil, and increase from cuttings, planted in autumn, or early in spring. Synonymes: 1. R. aureum sanguineum. 2. R. hybridum. 3. $R$. reclinatum. 4. Uvacrispa. 5. $R$, oxy. acanthoides. 6. R. glandulosum. 7. R. laxiflorum. 8. $R$. malvaceum. 9. $R$. stamineum. 10. $R$. missouriense. 11. $R$. stamineum.

aciculâré . . White. H. De. S. Siberia .

albiuêrvlûm : Green . 4, H. De. S. N. Amer.

alpinûtn : Green . 4, H. De. S. Britain.

foilis-variegătis Green - 5, H. De. S. Britain .

pümllüm : Green . 4, H. De, S.

aureùm. . Yellow 5, H. De. S. Mistouri . 1812

präcōx : Yellow 4, H. De. S. N. Amer. 1812

serotinũm: : Yellow : 6, H. De. S. N. Amer. : 1812

villósūm : : Yellow : 4, H. De. S. N. Amer. : 1812

carpathY̌m : : Green : 4, H. De. S. Carpnthin : 1818

cēréūm . . White. : 4, H. De. S. N. Amer. : 1827

Cynosbät * . Green : 4, H. De. S. Cnnada . 1759

Diaeânthă . Grn. yel. 5, H. De. S. Siberin: $17 B]$ divaricatün : Wht. red : 4, H. De. 8. N. Ame 


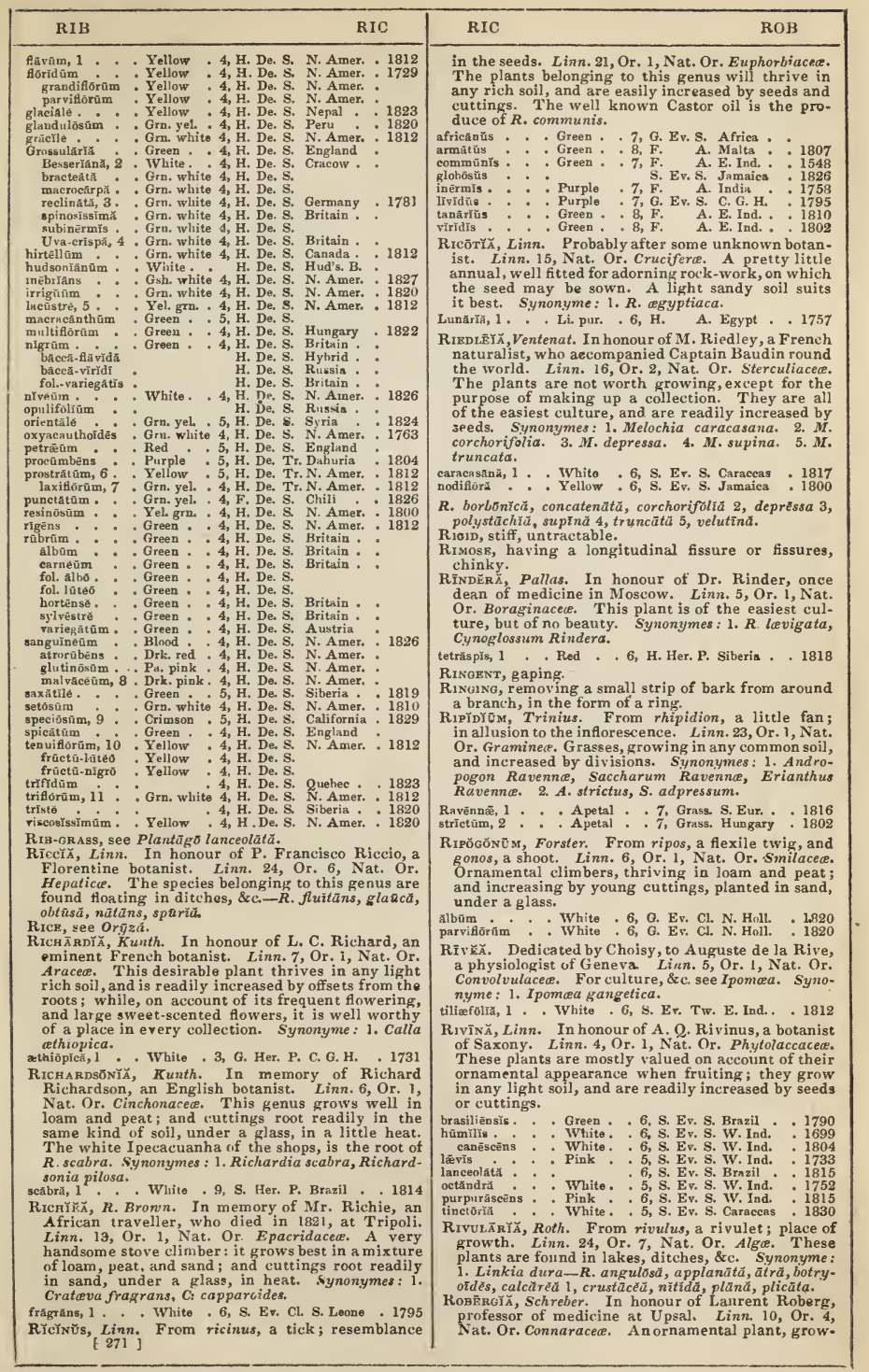



ROB
ROE
sand, under a glass, in heat.

frutesscuñ. . . White . . S. Ev. S. Guiana . . 1823

RonĩRTï̈, Decandolle. In honour of M. Robert, a Corsican botanist. Linn. 19, Or. 1, Nat. Or. Composita. Mere weeds, of the most common culture; seeds. Synonyme: 1. Hypocharis pinnatifida-R. pinnatüfidă 1 , taraxacoīdēs.

RกBīnĭ, Decandolle. In honour of Jean Robin, a French botanist, once herbalist to Henry 1V. of France. Linn. 17, Or. 4, Nat. Or. Leguminose. The hardy kinds of Robinia are remarkably handsome when in flower, and well adapted for ornamenting the shrubbery. They will grow in any common soil; and are increased either by layers or by grafting the rare species upon the common kinds, chiefiy on $R$. Pseud-acacia. The store and greenhouse species should be grown in a mixture of loam, sand, and peat; and young cuttings will root, if planted in sand, under a glass. $R$. Pserd-acacia, if properly seasoned, is equally as strong and as durable as oak. Synonymes : 1. R. hybrida, ambigua, echinata. 2. grandiflora, macrophylla. 3. amorphafolia. 4. monstrosa. 5. penduhu. 6. procera. 7. sophorafolia. 8. stricta. 9. inermis.

dnvüric:

dũbiã

dũbian, 1 Wht. red : 5, H. De. T. Davurin

guineżusis: : White. S. Ev, S. Guines

hispids

macrophylli, 2 Red : 5, H. De. T. N. Amer.

nână . . . Pink * 6, H. De. S. Carnlina

rüseã - : Red : 7 , H. De S N. Amer.

amörphæ̈foliz, 3 Wht. red : 5, H. De. T. N. Amer.

erisps . White. 6, H. De. T. N. Amer.

fiore lūtéơ : : Yellow: 5 , H. De. T.

inêrmis $:$ : White. : 5 , H. De. T. N. Amer.

latisiligua : W Wite: $5, \mathrm{H}, \mathrm{De}$. T

macrophylla : White: 5, H. De. T. N. Amer.

microphyllax. White . 5, H. De. T. N. Amer.

monstrós, 4 Wht. red. 5, H. De. T. N. Amer.

pêndúla, 5 . Pink : 5, H. De. T. N. Amer.

procera., 6 . Whit red. 5, H. De. T. N. Amer.

sophoráfolli, 7. Whe red. 5, H. De. T. N Amer.

spectäbllis : White. 5, H. De. T. France

atrict4, 8 . Whe red . 5, H. De. T. N. Amer.

tortuôs. : White. $5, \mathrm{H}$. De T

umbraculiferả, 9 White : 5 , H. De. T. N. Amer.

purpǔrę̆. . Purple

viscósă. : : Pa. pur.

7, S. ET. T.

7 , H. De. T. N. Amer.

1820

1822

1743

1640

Rocashols, see Altiom Scorodoprasom.

Roccḱllä, Decandolle. Altered from the Portuguese Roccha, signifying a rock; in allusion to its place of growth. Linn. 24, Or. 8, Nat. Or. Lichenes. $R$. tinctoria is the Orchall of the dyers, so famed for the fine purple colour which it yields $-R$. fucifor mis, tinctorid.

Rö́н $\overrightarrow{\mathrm{A}}$, Decandolle. In honour of M. de la Roche, a botanical writer. Linn. 5, Or. 5, Nat. Or. Crassulacea. This is a very elegant genus of succulent plants when in flower. They require to be treated in a manner similar to that recommended for the genus Globulea.

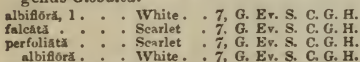

Rосквт, see Eracă.

ROCKвT, see Hësperis.

ROCK-ROSE, see Cfotús.

ROcK-Ross, see Convolvŭlŭs Dorğcniam.

Rodĭgî̀, see Serida.

Roprtouīzî̉, Ruiz and Pavon. In honour of Em. Rodriguez, a Spanish physician and botanist. Linn. 20, Or. 1, Nat. Or. Orchidaced. These interesting plants may either be grown in peat, in a manner similar to that recommended for the species of Stanhopea, or be fastened on a piece of wood, and treated like the genus Burlingtonia. Synonymes: 1. Gomeza recurva. 2. Pleurothallis coccinea.

Barkêrī . . . Green . . 1, S. Epi. Brazil

eríspă. : . : Green . . S. Epi. Brazil

laxiffiră : : : Pa.grn. : S. Epi. Brazil

laxificra : : Pa. gra. - S. Epi. Brazi

planifollă : : Yellow . 6 , S. Epi. Brazil

recūrvă, 1 * : Yellow * 6 , S. Epi. Brazil : 1824

secũndx, 2 . : Red . 7, S. Epi. Trinidad : 1820

RoĒur, Linn. In honour of William Roell, professor of anatomy at Amsterdam. Linn. 5, Or. 1, Nat. Or. Campanulacea. Elegant plants when in flower. The soil best adapted for them is a mix ture
REE

ROS

of sandy loam and peat. They are readily increased by seed; or young cuttings will root freely planted in the same kind of soil, with a glass over them. Synonymes: 1. R. filiformis 2. Zygophyllum fruticulosum.

ciliatz. - * Wht. pur. 7, G. Ev. S. C. G. H. . 1774 decürrens. : Blue . 8, F. A. C. G. H. : 1787 elégañs : : Purple : 2, S. Ev. S. C. G. H. : 1836 fruticulōa : Yellow : 7, G. Fv. S. N. Holl : 1820 squarrós: : : White: : , G. Her. S. C. G. H. 1787 Bergin, i : : Blue : : 8, G. Ev. S. C. G. H. : 1816

RePẼ̄ă, A. Jussieu. In honour of J. Rœeper, a writer on the Euphorbias of Germany. Linn. 8, Or. 1, Nat. Or. Zygophyllacea. Ornamental little plants, growing freely in loam, peat, and sand; and readily increasing by young cuttings or seeds. $\boldsymbol{R}$. aurantiaca flowers beautifully when planted out in the open border. Synunyme: 1. Zygophyllum fruticulosum.

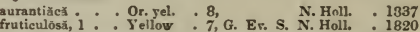
ROLĀNDRÃ, Rottboell. In honour of Daniel Rolander, a pupil of Linnæeus, who visited Surinam. Linn. 19, Or. 5, Nat. Or. Composite. This plant thrives in loam and peat, and is readily increased by cuttings. argêntéă . . . White. . 7, G. Ev. S. W Ind. , 1714 RōHDĔĂ, see Tuptstră.

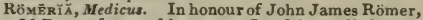
M.D., professor of botany at Landshut; died 1820 . Linn. 13, Or. 1, Nat. Or. Papaveracea. Very pretty annuals. The seed has only to be sown in the open border early in spring. Synonyme: 1. Chelidonium hybridum.

hybridh, 1. . Purple . 5, H. A. Britain .

refracta. : Violet. $6, \mathrm{H}$. A. Tauria : 1823 RONDEL.ẼTY̌, Blume. In honour of William Rondelet, M.D., a famous natural historian of Montpellier. Linn. 5, Or. 1, Nat. Or. Cinchonacea. Shrubs, well worth cultivating. They should be grown in a mixture of loam, peat, and sand; and cuttings will root freely if planted in sand, under a glass, in heat.

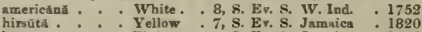
hirtata : : : Pink. : 7, s. Ev. S. Jamaica : 1776 lavigaté . White. : 7, s. Ev. s. W. Ind. 1790 laurifólia . . White. 7, S. Ev, S. Jamsica : 1824 psniculata: : White: 7, S. Ev. S. E Ind.. 1820 racemósá : Whito. : 7, S. Ev. S. Jamaica : 1820

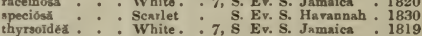
tomentosa: : White. : 7, s. Ev. S. Jamaica : 1819

Rop̄̄L Ă, Aublet. From Roupala, its aboriginal name. Linn. 4, Or. 1, Nat. Or. Protenced. Ornamental trees, growing well in a mixture of loam and peat; and increasing by cuttings, in sand, under a glass, in heat.

\begin{tabular}{l} 
dentătă . : : Green * 6, G. Ev. T. S. Amer. 1802 \\
médiă \\
\hline
\end{tabular} mediå : : 5, G. Ev. T. Guiana : 1823 Ropr-Grass, see $R$ éstió.

Rŏsă, Linn. From the Celtic rhod, red; in reference to the prevailing colour of the flowers. Linn. 12, Or. 3, Nat. Or. Rosacer. The name of this genus carries with it a charm as well for the beauty as the unrivalled fragrance of its flowers, and it has justiy been the theme of writers, from the reinotest antiquity, as a favourite and universal object of culture among all civilised nations. The plants vary in size, and the colours are red, white, purple, yellow, striped, or of almost numberless shades and mixtures, from single to semi-double and double. $A s$ it would be impossible to give a standard list ot the most improved cultivated kinds, owing to the number of superior sorts raised annually from seed, and many of the varieties being annually lost, going out of repute, or entirely changing their appearance from time and local circumstances; we would on that account recommend those who wish to form a selection of these popular plants, to resort to the latest and best catalogue of Roses now actually in cultivation; such as that of Messrs. Rivers and Son, of Sawbridgeworth, Hertfordshire, which is not only the best as a catalogue, but as containing other particulars worthy of the cultivator's con. sideration. The rose is propagated by every method capable of being applied to ligneous plants; by 
seeds for new varieties, for obtaining sweet-briar, and for stocks. The Indian, Chinese, and climbing kinds, by cuttings of the young wood placed in a gentle heat. The Moss, and Provence or Cabbage rose, by layers or suckers; also by cuttings of the large fleshy roots, which being planted, and covered with a little light rich earth, will each throw up one or more shoots. This will be found a good and an expeditious mode of obtaining young plants. Budding is chiefly used to produce standard roses, or to increase the number of kinds upon one plant; it is also resorted to to preserve some of the more tender kinds which languish upon their own roots. Rusa canina, or common dog-rose, is the best for budding upon; it is asserted by some cultivators, that all roses flower finer and last. longer, by being budded on this stock. The Moss and Provence kinds are well adapted for forcing in winter and spring; the Chinese, and other tender kinds, for decorating the greenhouse nearly throughout the year. To keep a succession of Howers of the first named kinds from Christmas, until their natural season of flowering, a quantity should be introduced into the furcing-house every month from the first of October to the first of March; the dung heat at first should not be more than 55 degrees, but it may be gradually raised to 65 or 70 degrees of Fahren. heit. The fruit of $R$. canina is astringent, and employed in medicine in cases of chronic diarrhœa and other maladies. The various preparations from the flowers are rose water, vinegar of roses, attar, or essence of roses, \&c. Synonymes : 1, $\boldsymbol{R}$. hybrida.

2. $R$. rubiginosa inodora. 3. $R$. canina casia. $4 R$. leucantha. 5. R. canina dumetorum. 6. R. parvifolia. 7. $R$. Fraseriana. 8. $R$. odorata. 9. $R$. floribunda. 10, $R$. laxa. 11. $R$. Eglanteria, 12, $R$. platyphylla, R. Roxburghii. 13. R. scabriuscula.

ncieulărî̀ : - Blush 6, H. De. S. Siberia - 1805 albã. : : Wlite 6, H. De. S. S. Eur. : 1597

globōsă

helleborin 1

hispidelly

lẩ vìs.

lagenărĭ

pilôsũlă

pimpinellifolia

pyriförmis .

setōsă

sorbinella:

speciôsă.

turbináta

arvensis

Andersonit

Ayrshinirea

bybrida, 1

Banlrsice

lūtea

bracteäta

scahriūscūlä

bractéxcēns

Brunōnไ̄

cāsiă. 3

canină aciphȳi

er จp ptiăcă

ambîngüi. .

borbunīand

fastigiâta

flaucéscens

hispida

Meratieână

nIténs

H. De. S.

H. De. S.

H. De. S.

H. De. S.

H. De. S.

H. De, S

H. De. S

H. De. S

H. De. S.

H. De. S

Scarlet - 6, H. De.

White 7, H. De. Tr. Britain

Pa. flemh 6, H. De. Tr. Britnin

White 8, H. De. T. Scotland

Flesh : 6, H. De. Tr. Switzerh

White 6, H. De. Cl. China

Pa buff . 6, H. De. Cl. China

Pa red . 6, H. De. S. Brisain .

White - 7, H. Ev. S. China

Pink. . 6, H. Ev. S. England

White 6, H. De. Cl. Nepal

Pink wht. 7 , H. De. S. Scotland

Pa. red . 6, H. De. S. Britain

Pink . 6, H. De. S. Britain

H. De. S. Egy pt

H. De. 8 .

Purple . 6, H. De. S. Bourbon

H. De. S. France

6, H. De. S. France

H. De. S.

H. De. S, France

H. De, S. France.

6, H. De E.

obtusifolra: : Fink * 6, H. De. S

pilosiūscūlঝ̌ : H. De. S.

H. De. S.

ubifíră

squarrosă

H. De. S.

H. De. S.

surculōsă

enrolină

caucăsể, 4

H. De. $\mathrm{s}$.

Germany

Crimson . 6, H. De. S. N. Amer. : 1726

Red - 6, H. De. S. Iberia : 1798

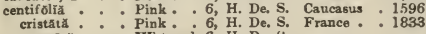

muscosă . Wht. red 6. H. De. 8 .

muscōsă cristătă Wht red $6, \mathrm{H}$. De. S.

pompons

- Europe

H. De. S. Dahuria

damascênă: : Pink * 6, H. De. S. Syria

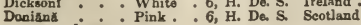
[ 273 i hŏrrìă . Pink , 6, 4. De, S.

dumetōrūm, 5: : Pink: 6, H. De. S. England férōx : : Red : 7, H. De. S. Cancasus nitēns : : Pa. crim. 7, H. De. S.

Forstērì : Pink. 6, H. Do. S. Britain .

fraxinifóliă . Red . 6, H. De. S. Newfound,

frutetorūm. - Pink * 6, H. De. S. Volhynia , 1818

gällǐeă . Pink. 6, H. De. S. S. Eur. . 1596

A găthă

arvinã : - H. De. S. Silesia .

inapêrtă: : Wht red H. De. S.

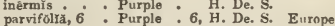

pūmìla . : Red : 6, H, De.s. Aurtria

glutinósă : Pr. blush 6, H. De. S. Candia

grăcilirs . . - Pa, pink . 6, H. De, S. Britain

grandifloræ⿸ . White 5, H. De. S. Siheria

hibērnǐcă * Blush * 8, H. De. S. Ireland

ibërică . . Pink . 6, H. De. S. Iteria

ndicx all H. Ev S. Clin

Blairrs 6, H. Ev S, Hybrid . 1789

caryophyllexa: H. Ev. S.

cruéntă : -

Fraseriână, 7 : Pink - 6, H. Ev. S. Hybrid

longifóliă : Pink . 6, H. Ev. S. Clina

nivea . - Wht, red 7, H. Ev. S. Gardens

Noisettlånă . Pa. red . 6, H. Ev. S. Hybrid

ochroleñcă * Cream . 6, H. Ev. S. China

odoratissina, 8 Pa pink 6, H. Ev. S. Chiua

pannóšx.

H.

pưmila

rügà.

Smithi

involuerat:

involuta

Kant:chătică

Klükih, 9

Lawrencīàn

Lindleyi 10

lûcida 11

flóré pleño

Hōggî

punicea

subrūbră

lutêscêns

macrophÿlla

majălis

micrănthă

microcărpă.

mierophylla

alba

Montezuี่ma்

moschată

nivez

multifloră .

Boursantiti

cârnéa

Grevillę̄̌, 1

Russelliana

myriacătha

nitıdda

Pur. ros

Bh, white 7, H V. Sina

Yellow . 6, H. Ev. S. Eng. hyb.

White .7, H. Ev. S. E. Ind.

Pa. red . 6, H. De. S. Scotland

Red. 7, H. De. S. hamtschat. 179

Blush H. De. S. Tauria . 1819

Red 4 , De s. N. Amer.

Red : 7, H. De S. N. Amer.

Yelluw 6. H De S. German.

Yellow

Yellow : 6, H. De. S. Amer. hyb. 1832

Yel. scal. 6, H. De. S. Austria . . 1596

Red yel. . 6, H. De. S.

Pa. yel. . 6, H. De. S. N. Amer. - 1780

Red . H. De. S. Gosaingsthan

Pa. red . 5, H. De. S. Britain.

Pa. red . 6, H. De. S. Britain

White 7, H, De. Cl, China . 182

White: 9, H. Ev. S.

White

Red . 6, H. De. S. Cancasus . 1818

Pa. red . 6, H. De. S. Mexico . 1825

White 8, H, De. 'Tr. Barbary - 1596

Red.6, H, De. Cl. China 189

Pink 6, H De Cl Hubrid

Pink 6, H. De. Cl. Chins : 180

Purple: 6, H. De. Cl. China: 189

H. De. CL.

White . 5, H. De. S. France . . 1820

Red : 7, H. De. S. N. Amer. : 1807

Red . 6, H. De. S. Siberia . 1820

flore plëno: Blush - 7, H. De. S. N. Amer.

7 , H. De. S. N. Amer. 1724

parritiora

Red. 6, H. De S.

7, He. S.

Red . N. Amer.

rapà. Re

revērsă

rubifolin

fenestrălis

aculeatissim

flexuōsă

grandiflöră

Lỵōnì

majoòr

nemoralis

parvifoliz

paberă

rntundifolla

opinulifoliã

umbellăta

$\checkmark$ aillantrăna

rubrifolia

hispidunla

inêrmis

pinnatifida:

$P_{\text {a. red }}$

Flesl

Hingary

Pink.

7, H. De. Tr. N. A mer.

Dritain.

H. De. 8 .

H. De. S.

H. De. S.

Sem. d. H. De. S.

H. De. S. France

Pa H. De. S.

Pink : 6, H. De. S.

H. De. S. Germany

H. De. S.

Pink. . 6, H. De. S.

Red . 6, H. De. S. S. Eur.

Red 6, H. De. S.

Purple 6, H. De. S. Switzerl

Purple 6, H. De. S. Switzerl.

Par red : 6, H. De. S.

White red He, S. Britain.

sanguisorbifolǐ̆

sarmentaceēa

semperflörens

White 6, H. De. S.

Pink . 6, H. De. S. Britain

Whit A. E. China : 1789

6, H. Ev. Cl. S. Enr. : 1629

Clarè - Dp. red . 6, H De. Cl. Eng. hyb.

Leschenaultiañ Violet $.6, \mathrm{H}, \mathrm{Ev}$. Cl. Neelglierry

Ruaselliand. Blush : 6, H. De. CL Eng. hyb.

sépĩum. : : Pink : 6, H. De, \& Britain.

1814

1822 


\begin{tabular}{|c|c|}
\hline ROX & КоY \\
\hline 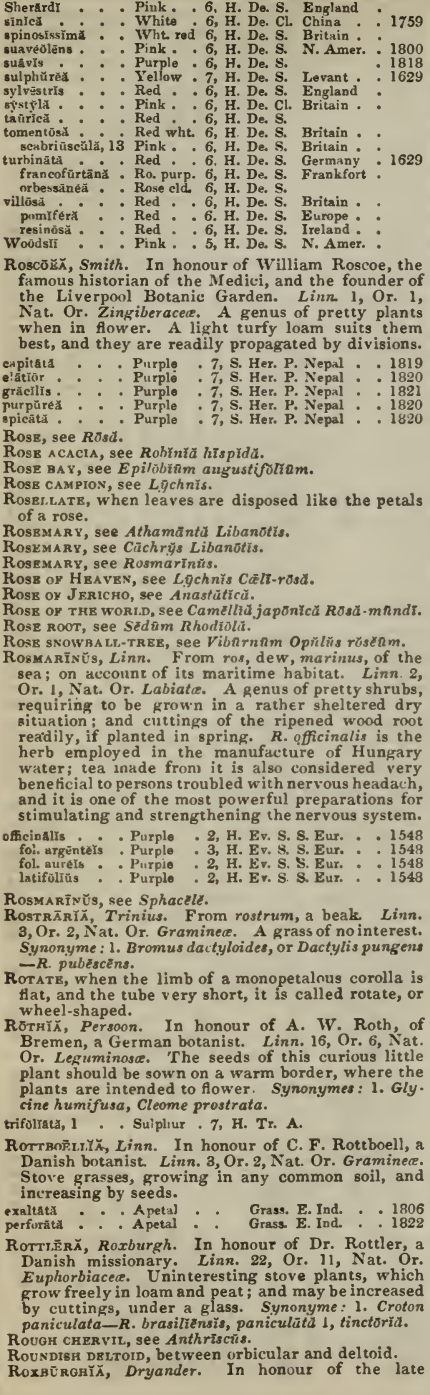 & 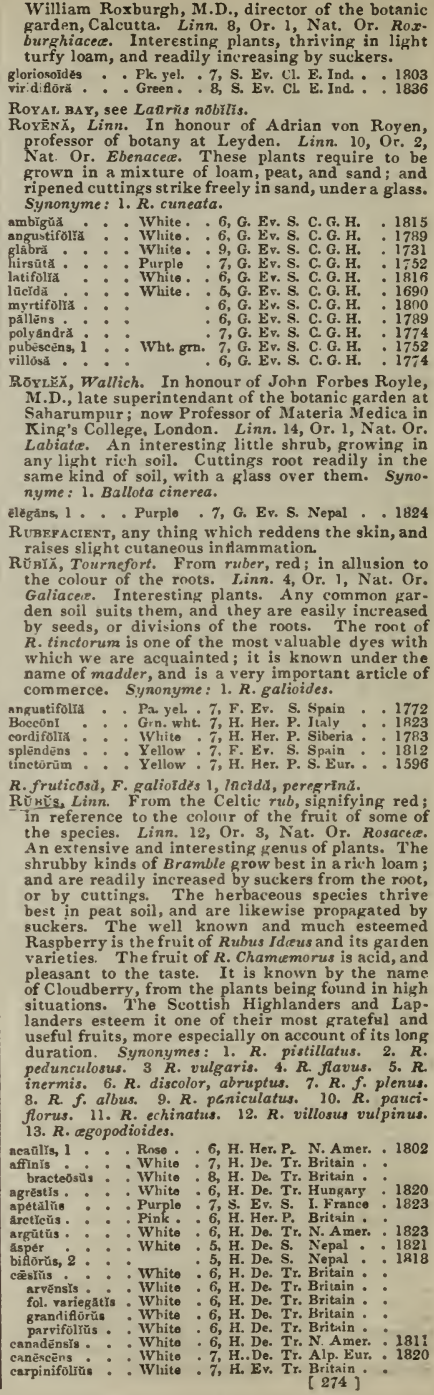 \\
\hline
\end{tabular}




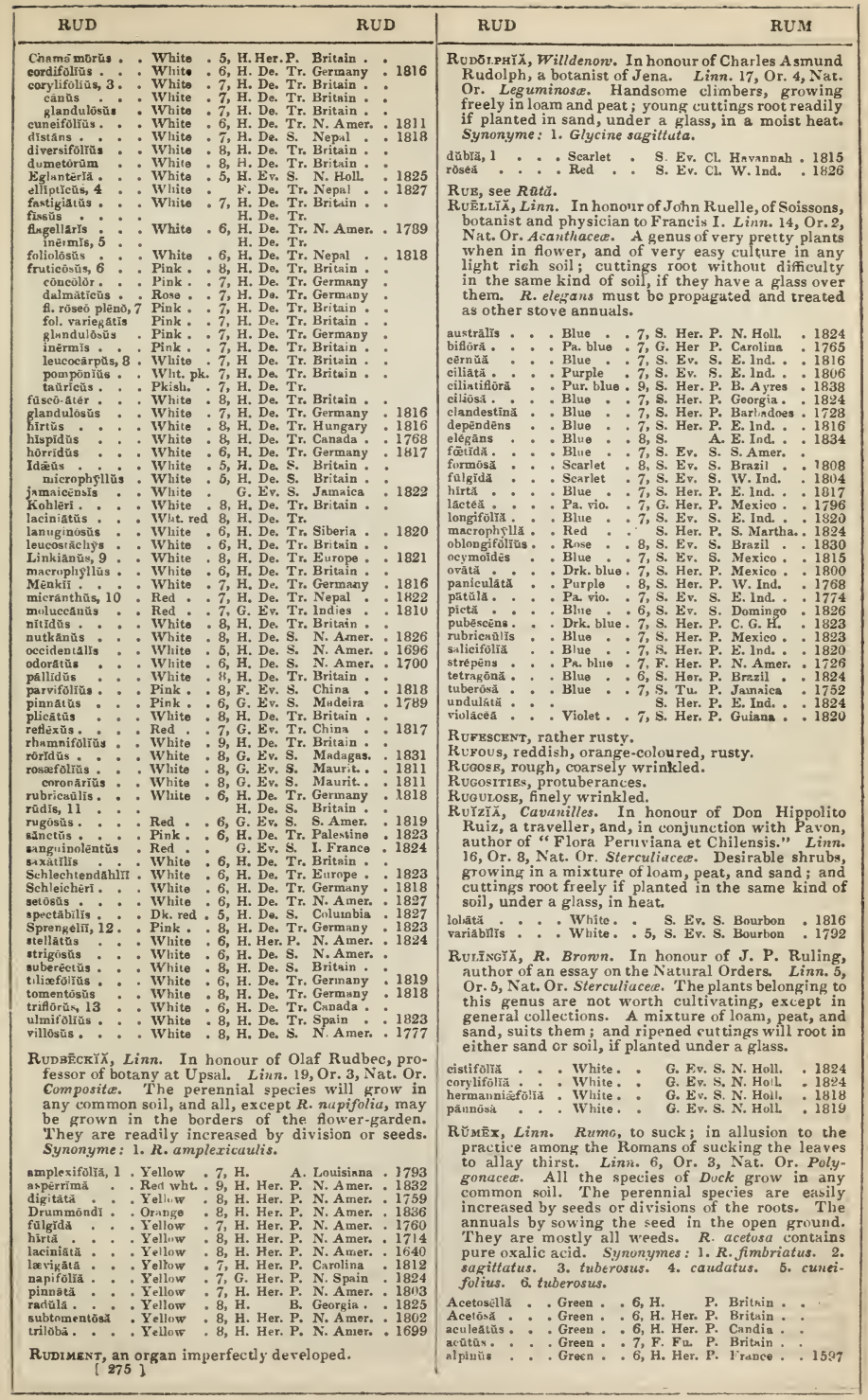


británnicŭs . Green . 6, H. Fu. P. N. Amer. Brôwnir, 1 : Green: 6, G. Tu, P. N. H.ll : 1823 bucephalophörăs Gresn: : 6, H. A. Itnly : 1683 frutéscêns . Green : 6, H. Ev. S. Tris. d'Ae. 1823 graminifolrŭs : Green : 7, H. Her. P. Russia ? 1820 hastulástús : Green : 6, F. Her. P. Chile : 1823 lăcerūs : : Green : : 6, H. A. Egypt: : 1810 Lunarla : : : Green : 6, G. Ev. S. Canaries : 1690 Patientiă : : Green : : 6, G. Ev. S. Canaries : 1690 purpüreŭs: Green: 7, F. Fu P. Switzerl. 1819 pyrenăicŭs : Green : 6, H. Her. P. Pyrenees : 1812 sanguineŭs : Green . . 6, H. Fu. P. England sarcurhizüs, 4 : Green: : 7, G. 'Tu. P. C. G. H. trianguläris, 6 Green 6 , H. Tn $P$. tuberósús vesicảriús: : Green: : 7, H. Tu. A. Africa: : 1656

abyssinnícŭs, Acetcselllă, đgyptrăcūs, amplexicañlis, aquâtǐcūs, arifoliǔs, brasiliensis, Burchelli 2, condylëlès, confértús, crispätülùs, crispüs, cristätüs, den-

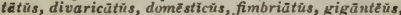
glomerütûs, hastafoliūs, heterophȳllüs, Hydroldpü'ham, intermédiús, lancifðiūs, hevigätüs, longifóliüs, luxûrīuns, marîtimŭs, mäximùs, montevidēnsìs, multifídйs, Nemolăpătham, nemorosŭs, nepalänsĭs 3 , obtusifoliūs, palastris, persicarioìdes, polygonifoliǔs,

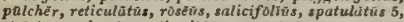
strīctũs, sylvesstris, tingitänǔs, wcrānicùs, uncūtǔs, venösŭs, verticillüris.

Rồî́, Hoffiman. Rumia, the name of the goddess who presided over suckling. Linn. 5, Or. 2, Nat. Or. Umbelliferc. An uninteresting plant, growing in any common soil, and readily increasing by divisions or by seeds.

taūricax. . . White . 7, H. Her. P. Crimea . , 1819

Runcivatz, a term applied to the lobes of leaves; a leaf is said to be runcinate when it is irregularly lobed, the lobes gradually diminishing to the base, and hooked back.

RuNNFrs, procumbent shoots, which root at their extremity

R UPESTRIs, growing on rocks.

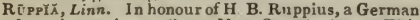
botanist. Linn. 4, Or. 3, Nat. Or. Fluviales. This species is found in ditches in various parts of Britain.

maritĭmă . - Green. . 7, H. Aq. P. Britain .

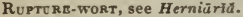

Rêscǔs, Linn.; formerly Bruscus. From beus, box, and kelen, holly; the Celtic for box-holly Linn. 22, Or. 13, Nat. Or. Liliacea. Ornamental plants. The greenhouse species will grow well in any rich soil, and are readily increased by dividing the roots. The hardy kinds are very suitable for the front of shrubberies; any common soil suits them, and they are easily increased by suckers.

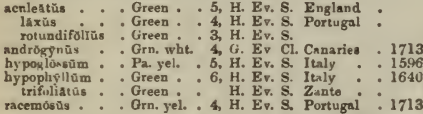

reticulătŭs . . Green . . 4, G. Ev. Cl. C. G. H. . 1816 volübrliss : : Green: : 4, G. Ev. CL. C. G. H. : 1816 Rush, see Jincǔs.

RusH, see Chondrillă juncěă.

Rush вR00M, see Viminäriă.

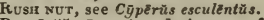

Rusșílı̆, Jacquin. In honour of Alexander Russel M.D., F.R.S., author of a Natural History of Aleppo, 1756. Linn. 14, Or. 2, Nat. Or. Scrophulariaced. These plants are very showy when in flower, and are on that account well deserving of a place in every collection. A light ricl soil is best adapted to them; and cuttings root freely under a glass, in heat.

florihuandă . . Red . . S. Ev. S. Mexico . . 1824 jûncé̃ : : : Serrlet : 7, S. Ev. S. Mexico: 1833 multitlöră : : Red : 7, S. Ev. S. S. Amer. : 1819 ternifolia : Red : S. Ev. S. Mexico : 1818

Rüră, Linn. From the Greek rute, from ruo, to flow; probably in reference to some reputed qualities of the plants; hence the English word Rue. Linn. 8, Or. 1, Nat. Or. Rutacec. The species of $\boldsymbol{R} u$ are all of the simplest culture. Any light rich soil suits them, and they are readily increased by cuttings placed under a hand-glass; or by seeds, which are produced in abundance by many of the species. Synonyme: 1. R. chalepensis.

albifôră : White . 7, F, Ev, S. Nepal . 1823 graveoléns: : : Yel. grm. 8, H. Kv. S. S. Eur. : 1562 angustiforiă 1 , bracteōsă, cörsìcă, divaricütă, macrophylla, montană, pinnata.

RUPs:HĪ, Jacquin. In honour of Fred. Raysch, M.D., who published the "Hortus Amstelodamensis," a pusthumous work of John Commelin: he died 1731. Linn. 5, Or. 1, Nat. Or. Marcgraaviacede. This very desirable shrub will succeed well in a mixture of loam and vegetable mould; and ripened cuttings will root freely in sand, under a glass, in heat. In Guiana and the Caribbee islands, it is a parasitical under-shrub, rooting on trees in moist woods, similarly to the ivy with us.

clusiæfolia. - Purple. . S. Ev. S. W. Ind. 1823

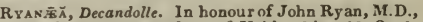
F.R.S., a correspondent of Vahl. Linn. 13, Or. 1, Nat. Or. Flacourtiacece. This is described as a very beautiful stove plant, thriving in peat and loam: and it is propagated by ripened cuttings, planted in sand, under a glass, in heat.

speciōsă . . Cream . 8, S. Ev. S. Trinidad . . 1823 R Y

R Y B GAAs, see Lolinm.

R гтidophílū̃x, Martius. From rytis, a wrinkle, and phyllon, a leaf; the surface of the upper side of the foliage is wrinkled. Linn. 14, Or. 2, Nat. Or. Gesneracea. An ornamental under-shrub, nearly related to Gesnera; which see, for culture, \&c.

anricnlătüm . Yel, red. 11, S. Ev. S. Brazil . 1836 RrтівндеA, Agardh. From rytis, a wrinkle, and phleo, to abound in. Linn. 24, Or. 7, Nat. Or. Algae. A genus of sea-weeds-R. complanată, tinctoriá.

$\mathrm{S}$

GABAL, Adanson. Not explained. Linn. 6, Or. 3, Nat. Or. Palmaceat. This noble genus of Palms grows best in a light loamy soil. Suckers are ocetasionally produced, by which the species may be multiplied. Synonymes: Chamerops acaulis, Corypha minor, Rhaphis acaulis.

Adansỏni, 1. . Green . . 7, Palm. Florida . . 1810 Blnckbürniană: Green: : Palm. Tropies: : 1825

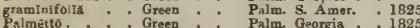
umbraculiferà : Green: Palnı. Jamaica: 1825

SABвĂтĨ, Adanson. In honour of L. Sabbati, a celebrated Italian botanist. Linn. 5, Or. 1, Nat. Or. Gentianaced. The species of this genus are very handsome when in flower, and are, on that account, deserving of a place in every collection. The seeds, as soon as ripe, sliould be sown thinly

in pots, or on a shady border, in peat soil ; if grown in pots, they should be placed in shallow pans of water, as the species are natives of marshes or bogs. Synonyme: 1. Chironia gracilis.

angulárís - . Purple . 7, H. B. N. Amer. . 1826 angularis : - Purple $: \ddot{H}$. calyeosa * - Dk. red - 7, H. chloroidēe - - Red * 7, H. B. N. Amer. grăclis, 1 : : Rose : 7, H. Her. P. N. Amer. : 1817 paniculata. . White.

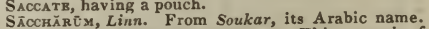
Linn. 3, Or. 2, Nat. Or. Graminece. This genus is of very great importance, on account of its containing the suyar cane, S. officinarum. The species are all of very simple culture, in a light rich moist soil, with a good heat; and are increased by suckers, or cuttings of the stem will throw out shoots at their joints. 


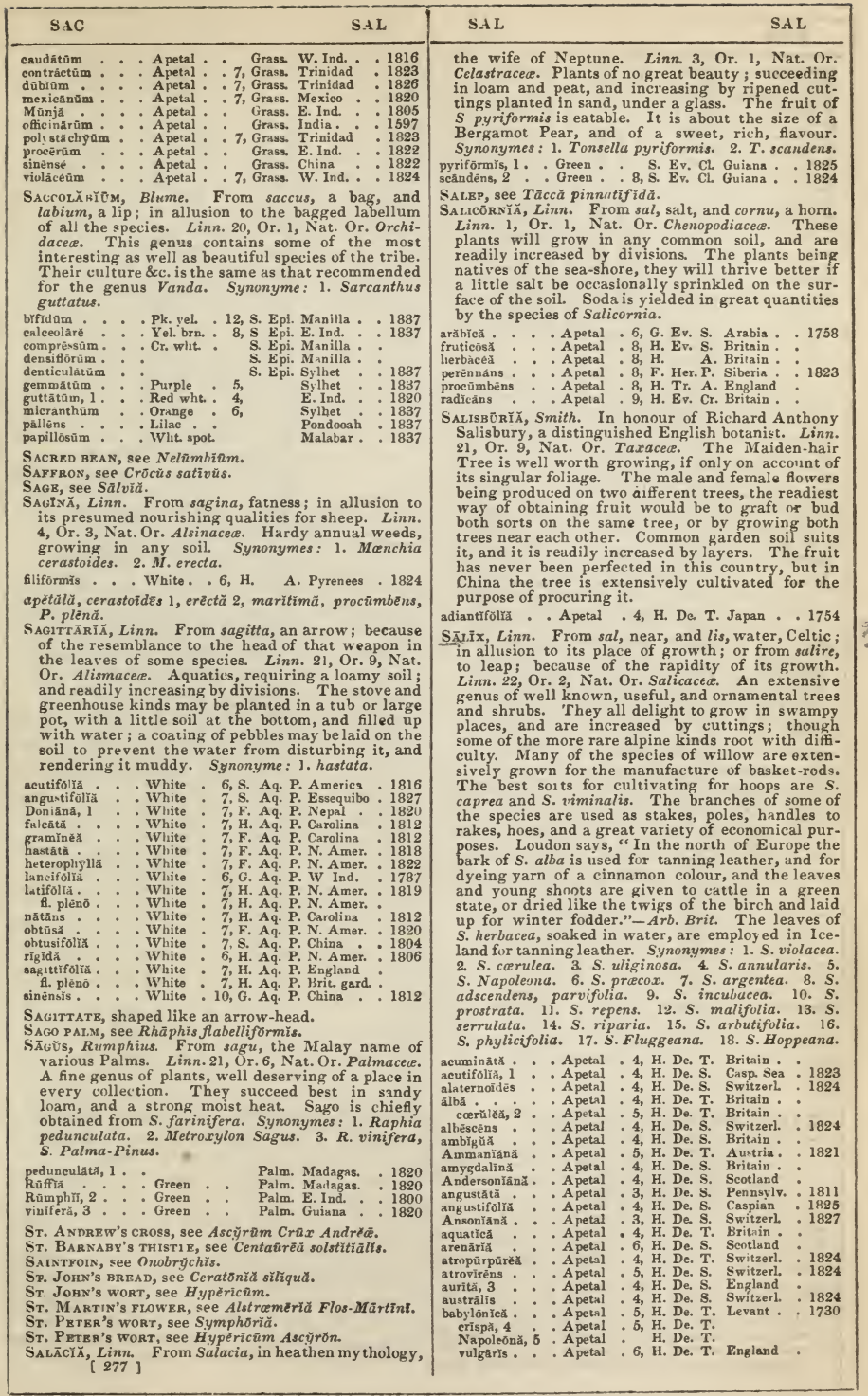




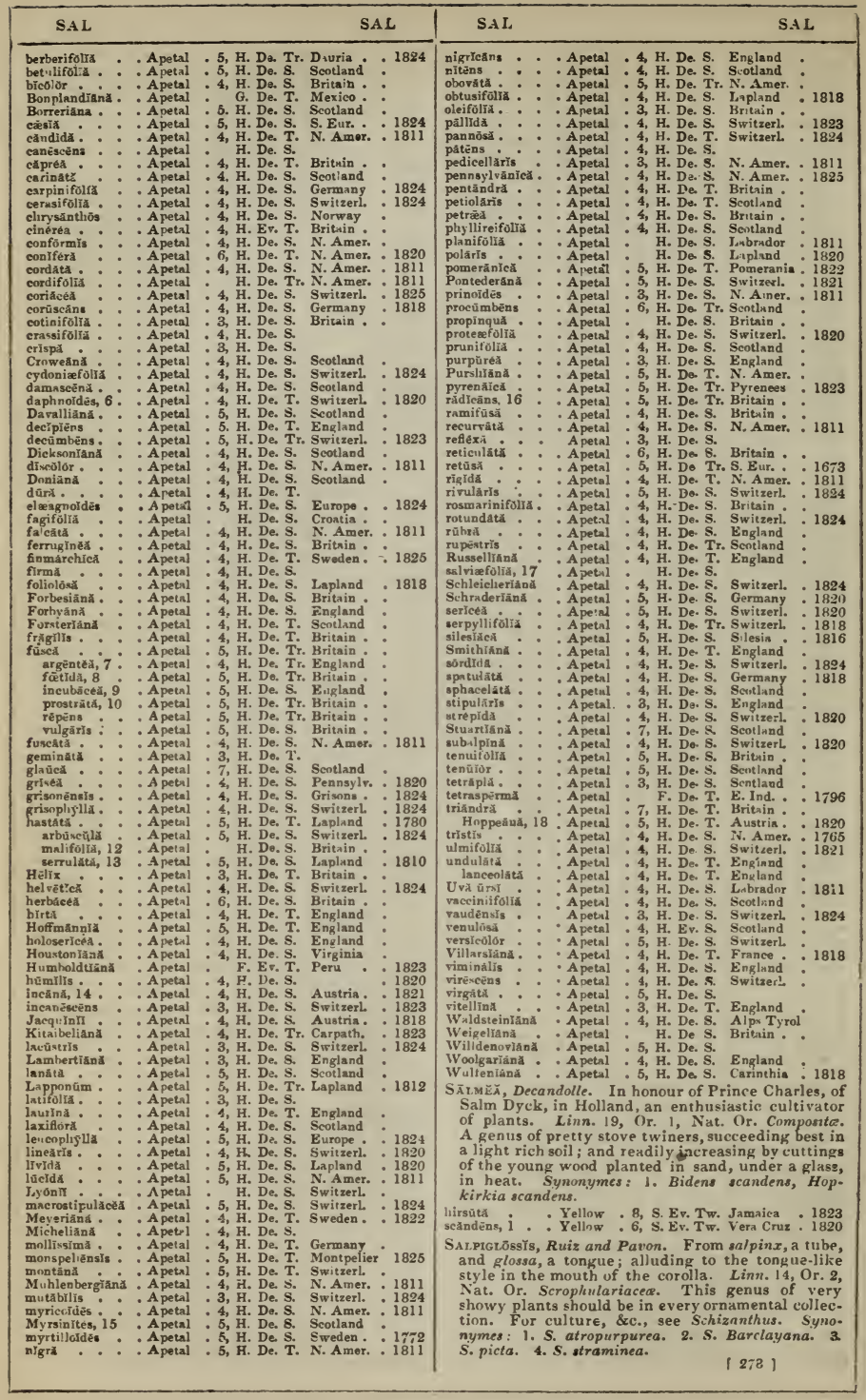


sinuštx, 1 . Purple . 8, H. B. Chile * 1824 Barelnyánă, 2 . Bro, yel. : 7, G. pieth, 3 . Varieg. : 5, H 4 .

Salsiry, see Tragopógon porrifoliñ

Salsôr, Á, Linn. From sa'sus, salt; in allusion to the saline properties of the species. Linn. 5, Or. 2 , Nat. Or. Chenopodiacee. A genus of not much beauty. For culture and propagation, see Salicornia. Synonymes: 1. Anabasis foliosa. 2. S. spicata.

brachiāta

foliósă, 1

glaûcã,

Kăl

laniflóră

micropliyllă

oppositifolic

riglda

ròācēă

ativă

Sodã

tnmariscīnă

Trágŭs

vermiculâtă

Brown $* 7, \mathrm{H}$.

A. Tauria

1818

Pink 7, H.

A. Caucasus - 182

Pink.

$7, \mathbf{F}$.

A. Siberia . 1820

Fleoh

7, $\mathrm{H}$.

A. Britain

Yellow

$7, \mathrm{H}$.

A. Siberia

A. Spain

7, F. Lv. S. Sicily

Green

7, F. Ev. S. Siberio

Pink

$7, \mathrm{H}$.

A. Asia

Pink

$7, \mathrm{H}$.

A. Spain

A. St Eur.

A. Tauris

A. Siberia

A. S. Eur. : : 1817
A. Siberia : 1817

1797

1759

1823

175.9

1783

Yellow $\quad 7, \mathrm{H}$

Green : 7,

Green

7. $\mathrm{H}$.

Saltatoria, having a leaping or dancing motion.

SALT-TRER, see Halimodēndrôn.

SAlt,TORT, see Sulsolü.

Sälvĩ̄, rinn. From salvo, to save; in allusion to the healing qualities of the sage. Linn. 2, Or. 1, Nat. Or. Labiate. This is a very extensive genus, consisting chiefly of extremely showy flowering plants, well worthy of cultivation. They are easily grown in a rich light soil. The shrubby kinds increase freely by cuttings of the young wood, under a glass; those of the stove species must be placed in heat; the herbaceous kinds must be multiplied by division of the roots. The seeds of the annual and biennial kinds simply require to be sown in the open ground where they are intended to bloom. The common sage, Salvia officinalis, is a well known culinary herb. Synonymes: 1. s: patula, pyramidalis. 2. S. colorata. 3. 5. polymorpha. 4. S. multifida, laciniata. 5. S. rosea. 6. S. prismatica. 7. S. Boosiana, 8. S. trichostemoides. 9. S. pilantha. 10. S. abyssinica, applanata. 11. S. betonicafolia, hastata. 12. S. lineatifolia. 13 S. hamatodes, Tenorii, variegata. 14. S. foliosa. 15. S. vulnerariefolia, Hablitziana. 16. S. Simsiana. 17. S. elongata, bullata. 18. S. dominica. 19. S. campestris, mollis. 20. S. agyptiaca. 21. S. nemo. rusa, valentina. 22. S. coarctata. 23. S. oblongata. 24. S. affinis, amplexicaulis, gigantea. 25. S. truncata, Spielmanni.

methiopis

friepis

Violet

$5, \mathrm{H}$.

B. Auntria

amarisslma : Blue

amethystina . Blue

angustifoliă: Blue

argênteă, 1 - Yellow

aũréă, $\mathbf{8}:$ : Blue

austriăc . . Crenm

azúréa : * Blue

Barreliêrı : : Red wht.

bracteátă : Purpl

byzantina: : Blue

cēslă : : Plue

canariēnsis : Purple

candidíssima . Wlite

ceratophylla: : Yurpilow

ceratopliflloidés: Yellow

chamadryoídé. Blue

clandestina, 3 : Blue

multǐfid 4 : Blue

coccineã, 5 . Scarlet

comprēssă

confertifloră : Red

crassifolľă * Blue

crêtieă .

dentată

dolichostăchì: Scarlet

erós

formosă : : Scarle

Forskôhin: Black

fülgẽn :i glutinōsă . . Yellow . 7, H. Her. P. Germany . 1769

Grahāmi : Pur. blue 9, .G. Her. P. Mexico i 189

grandifloră - Blue . 7, H. Her. P. S. Eur. : 1816

hirsūtă $;$ : Blue : 5 , H. A. $\quad$ Hlue: 1801

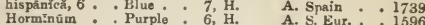

rübră : : Red : 7, H. A. S. Eur. : 1596

violăcéă : Purple:6. H. A. Sur. * 1596

Indică. : Blue : 6, H. Her. P. Indis : 173

interrúptă - White : 7, H. Ev. S. Barbary : 1790

involucràta : Red . * 8, S. Ev. S. Mexico . 1824

lamiifólia, 7 : Blue : 7, G. Ev. S. S. Amer. : 1821

leucānthă, : White: 7, G. Her. P. Mexico : 1813

H. Her. P. Russia : 1838

Linkiānă, 9 - Blue . 7, H. Her. P. Levant . 1823

lusitáleă - Blue - 6, H. Her. P. Spain * 1819

6, S. Her. P. Nexico. - 1728

mieräntlă : Blue $5, \mathrm{~s}$. A. Cuba : 1823

Muorcroftiănă Pa.blue 7, H. Her. P. India :

napifoliá * Dk, blue 16, H. Her. P. Italy : 1776

nepetifolia: Blue: $7, \mathrm{H}$ : A. Eurnpe: 1823

nilotica, 10 : Blue: 7, H. A. Egypt : 1780

núbra : - Blue: 6, G. Her. P. A hyssinia: 178

nubieola *. Yellow . 10, F. Her. P. Nepal * 1823

necidentalis: White - W. Ev. S. Jamaic. 1780

odorătă White

officinalis: : Blue : 7, G. Ev. S. Bagdad. Ev. S. S. Eur. 1804

tenũior: : Blue: : 6, H. Ev. S. Spain : : 1597

variegatå : Blue : 6, H. Ev. S. S. Eur. : 1597

paniculăta : Violet : 7, G. Ëv. S. C. G. H. : 1758

plilomoídés: : Blue : 5, H. B. Spain : 1805

pinnata : Purple : 7, H. B. Levant: 1731

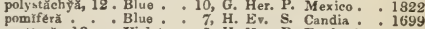

pratensis, 13: : Vinlet : 5, H. Her. P. England: 169

Pseúdó-coccłnéă Scarlet * 7, H. Her. P. S. Amer. : 1797

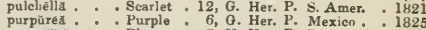

pyrenăica: : Blue.: 7, H. Her. P. Pyrenees: 1824

rhombifoliă, 14. Blue all S. A. Peru . 1827

runcinata: : Blue red 7, G. Ev, S. C. G. H. 1775

scabiosæfolia, 15 White : 8, H. De. S. Siberia : 1818

scã bră. - Blue . 6, G. Er. S. C. G. H. : 1774

Scläré, 16 : Wht pur. 8, H. B. S. Eur. : 1569

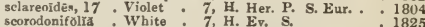

serntină, 18 : Blue : 8, G. Her. P. Ohio. : 1803

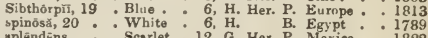

aplēndéns. : Scarlet *12, G. Her. P. Mexico * 1822

sylvëstris, 21 . Pur. vio. 8, H. Her. P. Germany : 1759

siriăcả . . White. 7, H. Her. P. Levant : 1759

tíliæfoliă . Blue . 5, S. Her. P. Caraceas: 1793

tingitảnă, 22 . White : 7, H. B. Barbary : 1796

tuhifloră: : : Searlet: 6, H. De. S. S. Eur. P. Mexico: 1596

urticifolya * Blue * 6, H. Her. P. N. Amer. . 1799

verbascifoliz: . White 5, H. Her. P. Ilerin : 1823

oblongiforira, 23 Blue : 9, H. Her. P. Britain : 1820

versicolór. Bl. wht. 7, H Her. P. Spain - 1820

verticillată : Blue - 8, H. Her. P. Germany: 1628

virgătă, 24 . White: 9, H. Her, P. Armenia: 1758

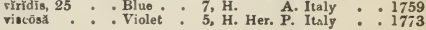

Salvinix, Guettard. In honour of Antonio Maria Salvini, a Greek professor at Florence, Linn. 24, Or. 4, Nat. Or. Salviniacea. A hardy aquatic, growing in light loamy soil; and increasing by divisions.

n⿳亠口冖̆ํำs

7, H. Aq. P. Italy

1818

SАмвёсて̌s, Linn. From sambuca, a musical instru. ment, which is supposed to have been made of elder-wood. Linn. 5, Or. 3, Nat. Or. Caprifoliacea. The species of Elder are all of the simplest culture, in any soil or situation. The shrubby species are increased by cuttings; the herbacenus species by divisions. The wood of the Elder is remarkable for its hardness; and various kinds of medicine are obtained from the different species, but more espe. cially from $S$. nigra. Synonymes: 1. S. nigra variegata. 2. S. aurea. 3. S.laciniata. 4. S. nigra albida. 5. S. viridis.

canadensĭs . - White , 7, H. De. S. N. Amer. - 1761 chinēnsĩ : : White :9, H. Her. P. China : 1823 Ebŭlǔs . : Wht red 6, H. Her. P. Britain : hũmrlis . . Wht. pk 6, H. Her. P. nigra
fol. argentere, i White : 6, H. De. S. Britain 


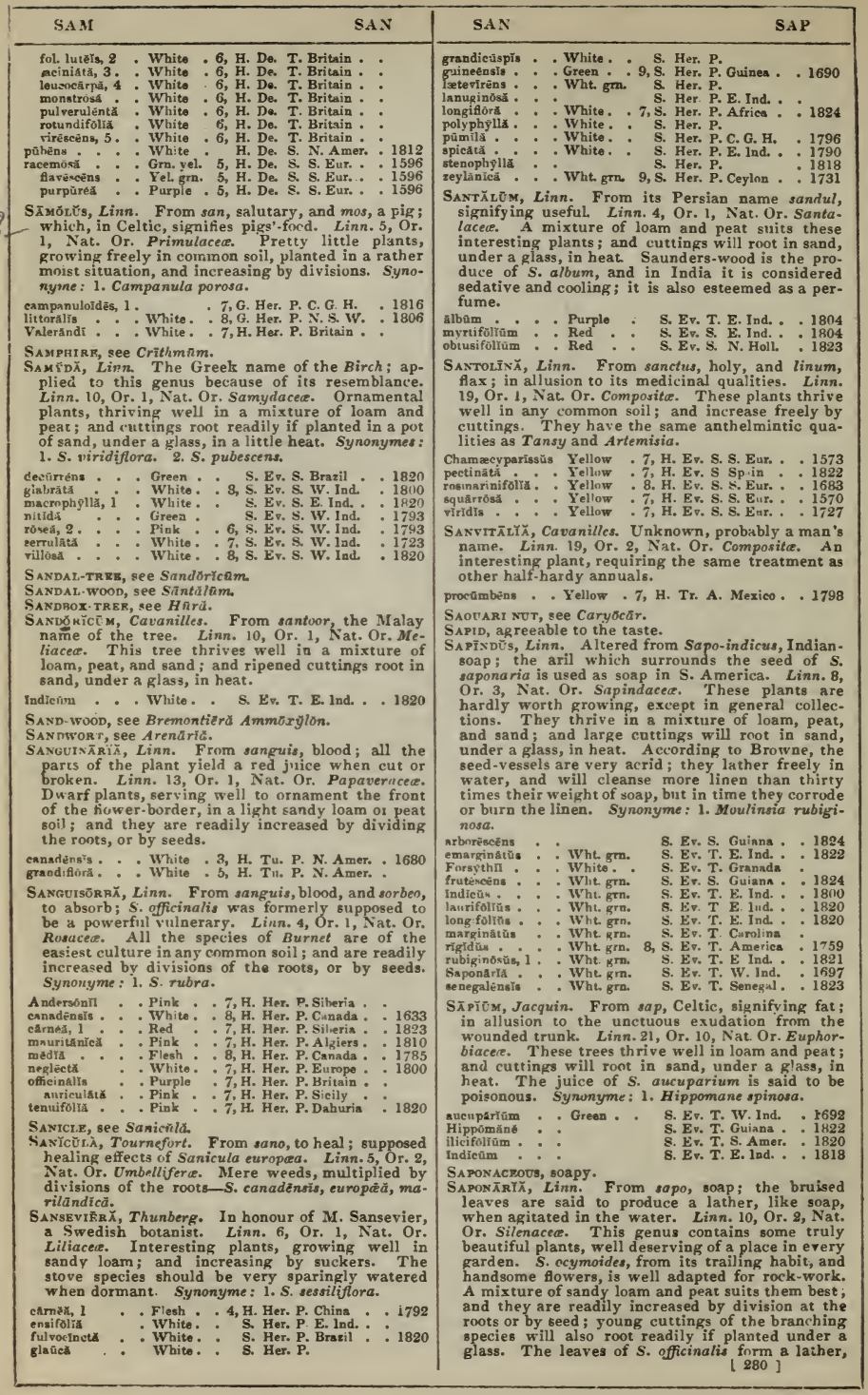


which rnuch resembles that of soap, and is similarly efficacious in removing grease spots.

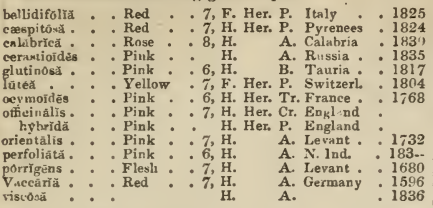

SĀrÄcră, Ruiz and Pavon. In honour of Isidore Saracha, a Benedictine monk, much attached to botany, and who enriched the royal gardens at Madrid with many rare plants. Linn. 5, Or. 1, Nat. Or. Solanacea. These plants will grow well in any common yarden soil. S. viscosa is easily increased by cuttings. The seeds of the annual species should be sown in the open border in spring.

procĩmbēus : Crenm. * 6, H. Tr. A. Peru : 1822

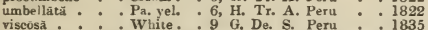

SARCAnthè's, Lindley. From sarx, flesh, and anthos, a flower; in allusion to the fleshiness of the flowers. Linn 20, Or. 1, Nat. Or. Orchidacea. The plants of this genus are highly deserving of cultivation. They require to be grown in a hot damp atmosphere, and treated the same as the Vandas.

oxyphyllŭs

S. Epi. China

præmórsùs * Green * S. Eii. E. lud.

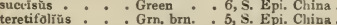

1837

1824

824

1824

ARCocĀPnŏs, Decandolle. From sarx, flesh, and capnos, the Greek name for fumitory; in allusion to the fleshy leaves. Linn. 17, Or. 2, Nat. Or. Pupaveracea. This plant thrives well in the open border or on rock-work, and is easily increased by seeds or cuttings. Synonyme: 1. Fumaria enneaphylla.

enneăplyyllă, 1 . Pa. yel. . 6, H. Her. P. Spain • . 1714

Sarcocarp, the most fleshy part of fruit, under the pericarp.

Sarcocaũtŏn, Decandolle. From sarx, flesh, and caulos, a stem; fleshy stems. Linn. 16, Or. 7, Nat. Or. Geraniacea. Ornamental under-shrubs, growing best in a mixture of loam, peat, and leaf mould or sand; they are readily increased by planting young cuttings in sand, under a glass, or by cuttings of the root. Synonymes: 1. Geranium spinosum. 2. Monsonia spinosa.

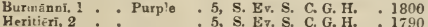

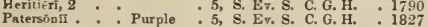
Patersōnī. . Purple. 5, S. Ev. S. C. G. H. * 1827 kephale, a head; in allusion to the fruit being combined into a fleshy head. Linn. 5, Or. 1, Nat. Or. Cinchonacea. This interesting plant is seldom seen in collections. It requires to be grown in a mixture of loam, peat, and sand, and kept in a hot part of the house. Cuttings will root in sand, under a glass, in heat. The heads of the fruit are eatable and are vnuch sought after by the negroes.

esculêntǔs . . Pink . . 7, S. Fiv. S. S. Leone . 1822

Sarcnchīlǔs, $\boldsymbol{R}$. Brown. From sarx, flesh, and cheilos, a lip; in allusion to the fieshy lip. Linn. 20, Or. 1, Nat. Or. Orchidacea. A genus of rather interesting plants. For culture, \&c., see Burlingtonia.

f^l-âtǔs . . . . White. . 4, S. Epi. N. Holl. . . 1821 olivâcéŭs. . Gr. grn. * S. Epi. N. Holl.

parvillörŭs : : Green : S. Epi. N. Holl.

SARcóōccă, Iindley. From sarx, flesh, and kokkos, a capsule; fleshy capsiles. Linn. 21, Or. 4 , Nat. Or. Euphorbiacea. This plant thrives well in a mixture of sandy loam and peat; and cuttings of the half-ripened wood will root readily in sand, under a glass, in a little heat.

pronifoliz . . Pa yel. . 6, G. Ev. S. Nepal . . 1820
Sarcŏlŏhŭs, R. Bronn. From sar $x$, flesh, and lobos, a pod; the seed-vessels are fleshy. Linn. 5, Or 2, Nat. Or. Asclepiadacer, Ornamental twiners. For culture and propagation, see Perguluria.

carinătŭs - . Grn. yel. S. Ev. Tw. K. Ind. . 1823 globusủs *. White S. Ev. Tw. E. Ind. 1823

Sarcoph F̃LēM, Thunberg. From sarx, fiesh, and phyllon, a leaf; alluding to the fleshy leaves. Linu, 16, Or. 6, Nat. Or. Leunminosa. 'This species should be grown in a mixture of loam, peat, and sand; and young cuttings root fieely in sand, under a glass. Much water will injure the plant.

carnōsūm . . Y'ellow . 7, G. Ev. S. C. G. H. . 1812

SARcostēmmă, R. Brown. From sarx, flesh, and stemma, a crown; the leaflets of the inner corona are fle-hy. Linn. 5, Or. 2, Nat. Or. Asclepiadaceu. Ornamental plants, requiring the same treatment as the Ceropegias. Synonymes: 1. Asclepias viminulis. 2. Cynanchum viminale.

Swartzuănūm, 1. White * S. Ev. Tw. Jamaica : 1820 viminale, 2. White 7 , S. Ev. Tw. E. lnd. : 1731 SARMEXTOSE, producing runners, or trailing offsets.

SARRACENİ̈, Linn. In honour of Dr. Sarrasin, French physician. Linn. 13, Or. 1, Nat. Or. Sarra. ceniacea. These curious and interesting plants grow well in pots partly filled with rough peat soil, and the rest sphaynum moss. They should be kept in a cool frame and a moist close atmosphere; the mode of propagation is by division. Synonymes : 1. S. psittacina. 2. S. adunca.

Alāvă . . Yellow . 6, F. Her. P. N. Amer. . 1752 minŏr : : Pur. grn. 4, F. Her. P. Carolina. 1752 pur| ŭréă: : Purple: $:$ F Her. P. N. Amer. : 1640 rubră, 1
variolaris, $2:$ : Purple : 6, F. Her. P. N. Amer. : 1786

Sassafras, see Laũrŭs Süssŭfrŭs.

Saturễă, Linn. From SSáțar, the Arabic name for all labiate plants. Linn. 14, Or. 1, Nat. Or. Labiata. This genus contains the we!l known herb Savory. For culture and propagation, see Thymus. Synonymes: 1. Thymus Tragoriganum. 2. S. obovata.

hortënsis - Pink 7, H. A. ltalg " Pink * 7, H. H. Atalg * 1562 mūticä : nervósã : : Purple : F. Ev. S. lon. 1s. . 1820 rupestris : : Purple : 6, H. Her. P. Carniola : 1798 virgătì, 2 Purple

Saturä̀̆ă, see Micromerĭă.

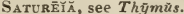

SATÝrîm, Swartz. Said to be from satyrus, a satyr, because of its supposed aphrodisiacal properties. Linn. 20, Or. 1, Nat. Or. Orchidaced. This is a genus of very pretty tuberous-rooted plants. For culture, \&c., see Corycium.

căndìdrim . . White . . 9, G. Ter. C. G. H. . 1836 cârnéùm . Pink , 6, G. Ter. C. G. H. 1797 chrysostächy̆üm . Orange . G. Ter. C. G. H. 1836 corifölium Yellow 10, G. Ter C. G. H 1890 corifoliam * Y Yllow . 10, G. Ter. C. G. H. 1820 papillôsūm : : : Ko. purp. : G. Ter. C. G. H. : 1836 -6, G. Ter. C. G. H. : 1789 pustulatüm . . Purple . . G. Ter. C. G. H. : 1800

Saurā̄jă, Willdenow. From Sauraujo, the name of a Portuguese botanist known to Willdenow. Linn. 12, Or. 5, Nat. Or. Ternstromiacea. These trees are well worth cultivating on account of their fine leaves and flowers. They grow well in loam and peat; and ripened cuttings root in sand, uncier a glass, in heat.

excellsă . . White S. Ev. S. Caraccas . 1820 nepalẽnsĭs : : : White : 8, S. Ev. S. Nepal : 1824

Saurogrōssūm, Lindley. From saura, a lizard, and glossa, a tongue; many of the parts of the plant bear a striking resemblance to the tongue of some reptile, Linn. 20, Or. 1, Nat. Or. Orchidacea. This very cnrious species reouires the same treatment as is recommended for Neottia.

elātúm . . White . 4, S. Ter. Brazil . . 1832

SaUrūrŭs, Linn. From saura, a lizard, and oura, a tail; in allusion to the appearance of the flowerspike. Linn. 7, Or. 3, Nat. Or. Piperacea. These plants should be grown in sandy loam, in a pond or cistern; they are readily increased by divisions or seeds. 


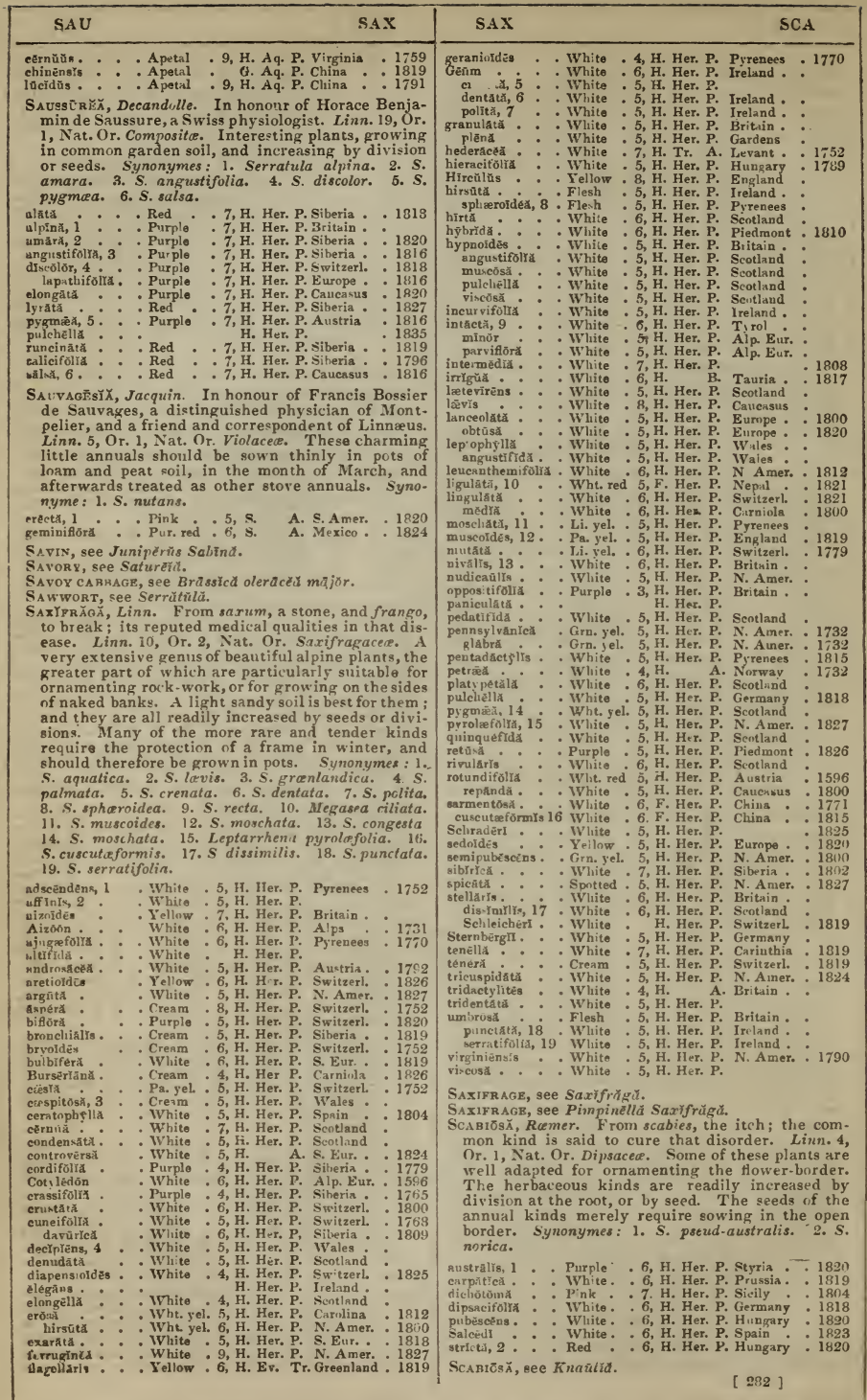




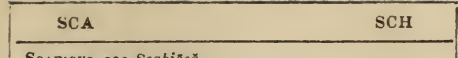

Scabious, see Scabiosă.

Scarrots, rough from little asperities.

SCAEVớL, Linn. Froin sçeva, the left hand; in allusion to the form of the corolla. Linn. 5, Or.1, Nat. Or. Scavolacea. Ornamental plants, thriving in a mix ture of turfy loam, peat, and sand; and cuttings will root readily if planted in the saine kind of soil, under a glass, the stove speries in heat. Synonymes: 1. Goodenia ramosissima. 2. G. albida. 3. Scavola Lobelia, Lubelia Plumieri. 4. G. calendulacea.

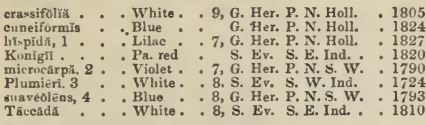

Táccåda * . White. 8 , S. E

Scalss, any small processes, resembling minute leaves.

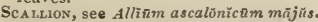

Scammony, see Convolvülüs Scammonid.

SCANDENT, climbing.

ScÃsix, Gartner. The Greek name of an eatable plant. Linn. 5, Or. 2, Nat. Or. Umbelliferce. Un interesting plants; the seeds may be sown in the open border in spring. Synonymes: 1. Wylia radicans. 2. W. grandiflora. 3. W. iberica. 4. S. Pecten-S. austrălís, brachycārpă, falcūtă l, grandi-

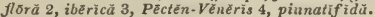

SCAPE, a stem rising from the roots and bearing nothing but the flowers.

ScApнygiotrís, Poppig. From skaphos, a boat, and glotta, a tongue; in allusion to the form of the labellum. Linn. 20, Or. 1, Nat. Or. Orchidacece. The species of this genus are altogether destitute of beauty. For culture and propagation, see Burlingtonia.

\section{reflex $\mathrm{x} \tilde{\mathrm{T}}$}

S. Epi. Demerara * 1838 violàceă . . . Pink . . 2, S. Epi. Demerara : 1837

Scartose, membranous, and dry.

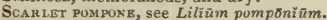

SCEPTRĀNTHĒs, Graham. From skeptron, a sceptre, anthos, a flower. Linn. 6, Or. 1, Nat. Or. Amaryllidacece. An ornamental plant, for the culture and propagation of which see Zephyranthes. Synouyme : 1. Zephyranthes Drummondi.

Drummondi, 1 . Wht. pink 7, F. Tu. P. Texas . . 1835

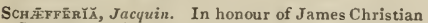
Schæeffer, a German naturalist. Linn, 22 , Or. 4, Nat. Or. Celastracece. This plant thrives well in a mixture of loam, peat, and sand; and half ripened cuttings root freely in sand, under a glass, in heat. Synonyme: 1. S. completa.

frutéscēns, 1 . . White. . 8, S. Ev. S. W. Ind. . 1793

Schrdoxŏrŭs, Rąmer. From schedon, near to, and oros, a mountain. Linn. 3, Or. 2, Nat. Or. Gra minece. A genus of perennial grasses, growing in common soil; and increasing by seeds. Synonymes : 1. Festuca calamaria. 2. F. decidua. 3. F. elutior. 4 Bromus inermis. 5. Festuca loliacea. 6. F. ni grescens. 7. F. nutans. 8. F. poaformis. 9. F. pratensis. 10, F. Scheuchzeri. 11. F. spadicea. 12. F. sylvatica. 13. F. tenella, Brachypodinm festucoides. 14. $F$. violacea.

decY̛dŭǔs, 2 . . A petal • . 6, Grass. Britain

elatiorr, 3. : A potal : 6, Grass. Britain

loliáceús, 5 : : A patal : 6, Grass. Britain

rigrescens, 6 - Apetil . 6, Grass. Switzerl.

poæfirmis, 8 . Apetal . 6, Grass Switzerl.

phonicnidés - A petal . 7, Grass. Switzerl.

pratēnsis, 9
spadiceŭs, $1 \mathrm{i}:$ : A petal : : 6, Grass. Britain

1819

1819 1819

sylrăticǔs, 12 : : A petal : : 7, Grass. Germany: : 1775

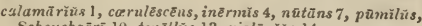
Scheuchzërī 10, tenëllüs 13, violäcëüs 14.

Sсhеднатмйră, $R$. Brown. In honour of C. C. Schelhammer, professor at Jena. Linı. 6, Or. 1, Nat. Or. Melanthaced. A mixture of peat and loam suits these pretty finwering plants best; and they are easily increased by divisions. They succeed well in a warm border, but require the protection of the greenhouse in winter. undulata : : Purple .6, G. Her. P. N. Hoil. : 1824

ScheUChzĒrï, Linn. In honour of John and Jameq

Scheuchzer, German botanists. Lann. 6, Or. 3

Nat. Or. Juncaginacec. A native species, found in marshes and spongy bogs.

palûstrǐs . . Brown . 6, H. Her. P. Euglnnd

Scrǔxuัs, Linn. From schinos, the Greek name of

the mastick; a resinous juice exudes from this tree similar to mastick. Linu. 22, Or. 9, Nat. Or. Anacardiacea. Ornamental plants. For culture and propagation, see the greenhouse and stove species of Rhus. Synonyme: 1. Schinus Molle.

Molle, 1 - . Green - 7, S. Evv. S. Peru

terebiuthifolia: : Grasli, wht. S. Ev. T. Brazil : 1829

Sснӣsmuัs, Beauvois. From schisme, a cleft; alluding to the outer palea. Liun. 3, Or. 2, Nat. Or. Graminer. An annual species of grass, of no interest. Synonyme; 1. Festuca culycina-S. marginütüs 1.

Schistóstĭgă. From schistos, split, and stege, a covering; the lid is split at the margin. Linn. 24, Or. 5, Nat. Or. Musci. This species is found on banks. Synonyme: 1. Gymizostomum pernatumS. pennätă 1 .

SсHiveríckl̆, Andrzejonski. In honour of Andr. Schivereck, a Russian botanist. Linn. 15, Nat. Or. Cruciferce. This species will thrive in common garden soil; and is readily increased by divisions. Synonyme: 1. Alyssum podolicum.

podölíeă, 1. . . Yellow :6, H. Her. P. Podolia . 1821 Sсніz无ă, Snartz. From schizo, to cleave; appearance of the fan-like spikes. Linn. 24, Or. 1, Nat.

Or. Osmundacee. A genus of ornamental ferno. For culture and propagation, see Davallia.

brfrdă . . . Brown . 6, G. Her. P. N. Holl. . 1822 elègāns . . Brown . 6, S. Her. P. Trinidad . 1819 penicillata: : Brown :6, Her. P. S. Amer. : 1816 pusilla : : Brown : 6, H. Her. P. N. Amer. pusillà : : Brown : 6, H. Her. P. N. Amer.
rupéstriss : Brown : 6, G. Her. P. N. Holl.

SchizÃNnRĂ, Michaux. From schizo, to cleave, and aner, a man; the stamens are split. Linn. 21, Or. 5, Nat. Or. Anonacee. An ornamental plant, thriving in a mixture of sandy loam and peat; ripened cuttings root readily in sand, under $n$ glass.

coccineă . . Scarlet . 6, G. Ev. Tr. N Amer. . 1806

SchizĀxtrư̌s, Ruiz and Pavon. From schizo, to cut, and anthos, a flower; in allusion to the irregularly divided corolla. Linn. 2, Or. 1, Nat. Or. Scrophulariacea. This is a genus of extremely beautiful and showy annuals. A light fiesh soil, not ton rich, appears to suit these plants best. They succeed well if the seed be sown in an open border early in spring; they may also be reared on a hotbed in spring, planting a portion in the open border, and growing the remainder in pots in the greenhouse, with a free admission of air and light. To procure flowering plants early in suminer, the seed should be sown in pots during the autumn, and the plants kept in a frame or greenlous? throughout the winter.

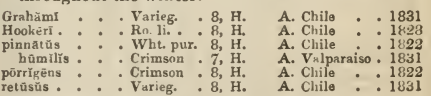

Schizom ̌̆RIĂ, D. Don. From schizo, to cut, and meris, a fart; alluding to the cut petals. Linn. 10, Or. 2, Nat. Or. Araliacere. An ornamental shrub, succeeding in loam and sandy peat, and increasing by cuttings.

ovatd . . White. . G. Ev. S. N. Holl. . 1825

Schizon̄̇ă, Agardh. From schizo, to divide, and nema, a filament. Liun. 24, Or. 7, Nat. Or. Alga. These plants are found upon the sea-coast, and in lakes-S. lacūstiè, Sniťthĩ̄.

Schizopĕtắró, Sims. From schizo, to cut, and petalon, a petal; the petals are cut. Linn. 15, Nut. Or. Cruciferc. 'This very singular plant should bn raised in pots in the greenhouse during spring, and $w$ hen of sufficient size, some of the seedlings may be planted out in the open border: others mжy 


SCH kept in pots in an airy part of the house, where

be kept in pots in an airy part of the house, where
they will sparingiy produce seeds. A mixture of loam, peat, and sand suits it best.

WalkërI . . White. .6, F. A. Chile . 1822

Schiznph fulüm, Fries. From schizo, to cut, and phyllon, a leaf; in allusion to the appearance of the plants. Linn. 24, Or. 9, Nat. Or. Fungi. Found upon the trunks of trees-S. commnñe.

SchkÜнRĨ, Roth. In honour of Christian S.hkuhr, a German botanist. Linn. 19, Or. 2, Nat. Or. Compositu. A Mexican annual of no interestS. ahrotanotiés.

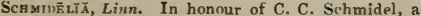
professor of hotany at Erlangen. Linn. 8, Or. 1, Nat. Or. Sapindacee. Ornementdl plants, thriving in a mixture of loam and peat; cuttings of the ripened wood will root readily in sand, under a glass, in heat. Synonymes: 1. Ornitrophe Cominia. 2. 0. serrata.

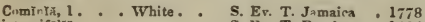
integrifolra: : : Shite. Ev. T. Bnarbon : 1878 S. Br. T. W. Ind. : 1828
occidentâlis : : White. . 5, S. Ev. T. E. Ind. neirati, 2 : : White. : S. Ev. T. E. Ind. : 1804

Schмїртй, Sternberg. In honour of M. Sthmidt, a German botanist. Linn. 2, Or. 2, Nat. Or. Graminece. A small annual grass. Synonyme: 1. Coleanthus subtilis.

sübeilis, 1 . . A petal . . 6, Grass. Bohemia . 1820

Scrēsťs, Beanvois. From schoinos, a cord, made inte cordare. Linn. 3, Or. 1, Nat. Or. Cyperacede. Rishes, growing in bogy.

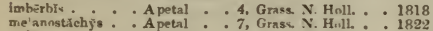

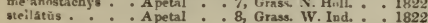

\section{murronītūs, nigrĭrāns.}

ScномвL̄RGRİ̈, Lindley. In hononr of $\mathrm{Mr}$, Robert H. S.homburyk, a zedlous naturalist, and a traveller in British Guiana on account of the Royal Gengra. phical Society. Linn. 20, Or. 1, Nat. Or. Orchidacer. This very elegant plant, and another, not yet introduced, were originally discovered by the gentleman to whom the genus is dedicated. $S$. marginata is at present supposed to be rather dificult of culture. It will not grow so as to flower if kept in a pot, but thrives perfectly well when attached to a piece of wood, with a little mosa on its rnots. It muzt be kept in a hot, moist part of the honse. "In its native state, its fower-stalk is frequently four feet high, branching, and covered with flowers. During the dry season, it will bear intense heat without injury."-Sertum Orchidaceum.

marginata . . Red yel. . 8, S. Epi, Surinam . . 1834

Sснб̆тð. Jacquin named this genns in honour of Richard Van der Schot, his companion in his travels. Linn. 10, Or. 1, Nat. Or. Legnminose. The plants of this genus are very beautiful when in flower. For cuiture and propagation, see Schmidelia. Synonyme: 1. Omphalobium Schotii.

alser . Crimson . 6. G. Ev. S. C. G. H.

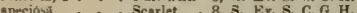

stipulata: : Crimson:7, S. Ev, S. C. H. 1794

tumarindifolia : Crimson : 8, S. Ev. S. C. G. H. : 1795

SChrapīră, Vahl. In honout of Henty A. D.

Schrader, a German bntanist. Linn. 6, Or. 1, Nat. Or. Cinchonacee. This plant grows well in a mixture of loam, peat, and sand; and cuttings root in sand, under a glass, in heat.

cephalótẽs. . . Red . . 7, S. Ev. CI Jamaica . 1820

SchrĀnkIX, Willdenow. In honour of Francis Paula von Sihrank, a famous German hotanist, and author of many botanical works. Linn. 23, Or. 1, Nat. Or. Leguminosa. These plants are very interesting on account of their leaves, which, like those of the sensitive plant, fall at the slightest tonch. A mixture of loam, peat, and sand, is best adapted to them; and they may be increased by young cuttings, planted in sand, under a glass, in heat, or by separating the tubers of the roots.

aculeâtă . . Red . . 7, S. Her. P. Vera Cruz . 17k3 uncináta : : Red : 7, F. Her. P. N. Amer. : 1789 Scruaterĭñ, Martius. In honour of H. B. Schubert, a professor at Erlangen. Linn. 5, Or. 1, Nat. Or. Asclepiadacea. To grow this pretty stove-climber well, it should be potred in a mixture of loam, peat, and sand; and cuttings root readily in sand, under a glass, in heat.

graveouléns . Cream . . S. Ev, Tw. Brazil . .

SchURĒrtĬ̃̆, see Tuxōdinm.

Schuitīsĭn, Martius. Named in honour of Joseph Angustus Sihultes, M.D., professor of botany of Landshut; author of Systema Vegetabilium. Linn. 4, Or. 1, Nat. Or. Gentianacere. For culture and propagation, see Stbora. Synonyme: 1. Sebaa guianensis.

Aublētin, 1 . . Pa. red . S. A. Guiana . . 1825

SснŨ̃tzĭă, Sprengel. In honour of M. Schultz, an eminent German botanist. Linn. 5, Or. 2, Nat. Or. Umbellifere. A plant of no interest; increased by seeds in the open ground. Synonyme: 1. Sison crinitum-S. crinzîta 1 .

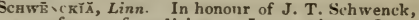
a professor of medicine at Jena. Linn. 2, Or. 1, Nat. Or. Primulacex. This plant grows in any light soil, and may either be increased by cuttings or seeds.

smericãnă . . Lilac . . 8, S. B. Guiana . . 1781

Scīlt., Linn. From skyllo, to injure; roots poisonons. Linn. 6, Or. 1, Nat. Or. Liliacer. An extensive genus of interesting bulbous plants. A light soil is most suitable for them; and they are readily increased by offsets from the bulbs. Synonymes: 1 . S. monophylla. 2 s. Lifolia rubra.

amōnă . . . Blue . . 3, H. Bl. P. Lerant . 1596 Blue 6 . B. Lerant . 1596

autumnalis : : Pink: 8, H. Bl. P. England: 182

alba

major : Pink : $8, \mathrm{H}$ Bl. P. Britain

bifolia : : : Blue : 3 , H. Bl. P. England

alha . . . White . 3, H. BL P. S. Eur.

rühril : Red : 3, H. B1. P. S. Eur.

brevifolia * Pink . 1, G. Bl. P. C. G. H. : 1811

campunulata : Drk. blue 5, H. Bi. P. Spain: : 1683

Alba . . White. 5, H. Bl. P. S Eur. : : 1683

chrnể : : Pink : 5, H. Bl. P. E Eur. : 1683

cirnua : : Pink : 3, H. BL P. Spain : 1815

corymhosa . . Pink . 10, H. Bl. P. C. G. H. 1793

Cupaniana : : Purple 6 , H. B1. P. Sicily : 1834

esculenti. : White. 6, H. B1. P. N. Amer. 1811

S BL $\mathrm{P}$ Ind.

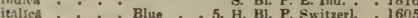

Lilló-Hviacinthŭs: Blue : : 6, H. B. P Eumpe : 1597

lusitanien : Blue : 5, H. BL P. Portugal : 1777

mauritaniea : Blue : 4, H. BI. P. Manrit. : 1819

non-acripta : Blue : 4, H. Bl. P. Britain

blba . White: 4, H. Bl. P. Britain

chrnea . Flesh . 4, H. Bi. P. Britain

obtusifolră . . Blue * 3. H. BI. P. S. Eur. . 1829

odorat : . Blue 5, H. Bl. P. Portugal : 1818

peruvilină . . Drk. blue 5, H. BL. P. Spain . 1607

plümbea : : Lead : : 5, H. B. P. C. G. H. : 1812

prebracteátă: . Blue . 6, H Bl. P. S. Eur. .

präcó x. . D Drk, blue 3, H. Bl. P.

5 , H, Bl. P. Hungarg

rû́milx, 1 . . Blue . . 5, H. Bl. P. Spain * 182

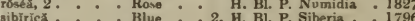

umbellata: : Blue: 4, H. B. P. Pyrenees: 1829

unifoliä. : : White. 5. H. Bl. P. Portugal

vêrna : Blue : 4, H. Bl. P. Britain

alba : : White: 5 , H. BL. P. Gardens

roved. - Rove * 5, H. Bl. P. Grriens

1831

ScionĂphrılêr, P. Broñe. From skioeides, shady, and phyllon, a leaf; the leaves are large, and consequently afford much shade. Linn 5, Or. 5, Nat. Or. Araliacea. The foliage of this genus being very handsome, the species are, on that account, well worth cultivating. Loam, peat, and sand mixed, appears to suit them best; and cuttings ront very freely in sand, under a glass, in heat. Synonymes: 1. Carolinea insignis. 2. Aralia sciodaphyllum. 3. Actinophyllum conicum. 4. A. digitatum.

acuminătûm - Yellow . G. Ev. CL Perı

anǒmălüm, 1 . Whe. grn. . S. Ev. T. Trinidad

BrownIh, 2 White. S. E. T. Jamaica

Brownli, 2 : White. S. Ev. T. Jamaica

cónicûm, 3 . Pa. red S. Ev. Cl. Peru

digitatilm, 4. Green . S. Ev. S. E. Ind. : 1820

pedicellatúm. Purple : G. Ev. Cl. Peru : :

pentảndrüm: : Par red : S. Ev. T. Perri 


\begin{tabular}{|c|}
\hline SCI \\
\hline Scros, a shoot intended for a graft.
\end{tabular}

Scİpüs, Beauvois. From the Celtic cirs, rushes. Linn. 3, Or. 1, Nat. Or. Cyperacea. Rushes, generally found in bogs. Synonymes: 1 . Schurius compressus. 2. Schœnus rufus-S. articulätüs, atrovĩrēus,

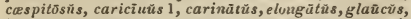
lacñstrīs, Luzülāe, marîtīmüs, mucronātūs, pauciflōrūs, quinquangulārìs, rüdícầs, rôfưs 2 , sylvătǐcūs, triqueterer.

Scleranthưs, Linn. From scleros, hard, and anthos, a flower; in allusion to the dry juiceless calyx. Linn. 10, Or. 2, Nat. Or. Scleranthacea. Mere weeds, not worth cultivating-S. ānuüūs, perēnň̌s, pūngēens.

Sclerociàrŭs, Jacquin. From scleros, hard, and karpos, a fruit; in reference to the hard covering of the grains. Linn. 19, Or. 3, Nat. Or. Compositie. A plant of very little beauty. It grows in any soil.

africănùs . . Yellow . 7, G. A. Guinea . . 1812

Scterochlö, Beauvois. From scleros, hard, and chloa, grass. Linn. 3, Or. 2, Nat. Or. Graminea. Worth. less annuals. Synouymes: 1. Triticum maritimum, Festuca muritima. 2. Poa procumbens. 3. P. rigida, Megrastachya rigida_S. articulată, dichötómă 1, divaricā̄tă, däră, procāmbēns 2 , rīgǘlă 3 .

Sclerodêrmă, Persoon. From scleros, hard, and derma, a skin; the hard coat. Linn. 24, Or. 9, Nat. Or. Fungi. Found in plantations, about oak roots, \&c. Synonyme: 1 Tuber solidum-S. Cëpă l, cĩtrinūm, spadicéü $m$, verrucōsũm.

Sčвrothämisư, $R$. Brown. From scleros, hard, and thamnos, a shrub; rigid plants, with stiff leaves. Linn. 10, Or. 1, Nat. Or. Leguminosec. A very ornamental shrub. For culture and propagation, see Dilln'ynia.

microphyllǔs . Yellow • 5, G. Ev. S. N. Holl. . 1803 Screrôtĩ sion to the texture of the plants. Linn. 24, Or. 9, Nat. Or. Fungi. These species are found on various kinds of decayed leaves. Synonyme: 1. S. quercinum-S. inullâtūm, dürūm, frūctüm, fungơrūm, herbūrūm, medullärē, muscorūm, neglēctūm, popı-

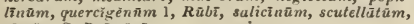

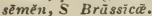

ScOLLAPED, having deep and wide indentations.

ScolopẼDRỸu, Smith. From scolopendra, a centipede; in allusion to the appearance of the under. side of the fronds. Linn. 24, Or. 1, Nat. Or. Polypodiacere. Interesting ferns, growing well on rock-work; they also succeed in shady situations, where hardly any other plants will live. They are readily increased by seeds, or divisions of the rnots. Important medical qualities are ascribed to several of the species. Synonymes: 1. S. palmatum, Asple. nium hemionitis. 2. A. scolopendrium.

Hemionity̌s, 1 . - Brown - 8, H. Her. P. Spain . . 1779 offieinarüm, 2: Brown : 7, H. Her. P. Britain angustifólíum . Brown : 7, H. Her. P. Britain crispūm. Brown : 7 , H. Her. P. Britain multifidúm. Brown 7, H. Her, P. Britain ranôsūm : Brown : $\bar{\tau}$, H. Her, P. Britain rantôsūm : Brown : 7 , H. Her. P. Britain

Scōtřmǔs, Linn. From skolos, a thorn; the plants are spiny. Linn. 19, Or. 1, Nat. Or. Composite. These plants succeed well in common garden soil ; the perennial kinds are readily increased by divi. sions or seeds. The seeds of $S$. maculatus need only he sown in the open ground. The roots of S. hispanicus are equally as good as Scorzonera; the leares and stalks are eaten as Cardoons by the people of Salamanca: the flowers are used for adulterating saffron.

grandiflñrǔs . Yellow . 5, H. Her. P. Barbary • 1820

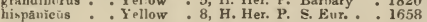

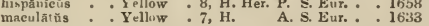
Scopग̃Yă, Linn. From scopa, a brooun; it may be used for similar purposes. Linn. 4, Or. 1, Nat. Or. scrophulariacea. This species requires the same treatment as other stove annuals. According to B:owne, it is an excellent vulnerary.

dũlc ǐs . . . White . 7, S. A. Jamaica . 1730

Scopōtř̆, Jacquin. In honour of John Anthony scopoli, a celebrated professor, and author of some totanical works. Liun. 5, Or. 1, Nat. Or. Sola[ 285]

nacea. This is a very desirable plant, on account of its producing its pretty flowers early in spring. It thrives best in a light dry soil, and a shady situa. tion. It may be increased by dividing the roots.

Synonymes: 1. S. atropoides, Hyoscyamus scopolia.

carniðlǐeă, 1 . . Drk. pur.. 4, H. Her. P. Carniola . 1780

Scorra, cinders, ashes.

Scorpton, see Gențstă scörpĩŭs.

Scorpton-GrAss, see Myosotis.

SCORpion-sRNNA, ste Coronillä ëmĕrŭs.

Scorpiūrŭs, Linn. From scorpios, a scorpion, and onra, a tail, alluding to the twisted form of the legumes. Linn. 17, Or. 4, Nat. Or. Leyuminosa. These plants are not possessed of much beauty. The seeds require to be sown in the open border in spring, and thinned as other hardy annuals, if they come up too thick.

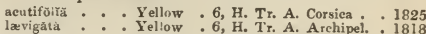
miricáta : : Yellow : 6, H. Tr. A. S. Eur. : 1640 subviliósă . - Yellow . 6, H. Tr. A. S. Eur. - 1731

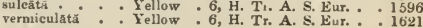

Scortonēră, Linn. From scurzon, the Catalonian name of the viper; in Spain the plants are considered a certain remedy for the bite of the viper. Linn. 19, Or. 1, Nat Or. Compositce. These plants require the same treatment as carrots. S. hispanica is diuretic, stimulant, and sudorific. The root resembles a carrot, and is about the thickness of a man's finger; when the outer rind has been scraped off, it is steeped in water to extract part of its bitter flavour; then boiled or stewed the same as carrots or parsneps. The roots are fit for use from August till the following spring. Synonymes: I. S. graninifolia. 2. S. austriaca. 3. S. undulata. 4. S. subulata. 5. S. villosa. 6. S. serrulata.

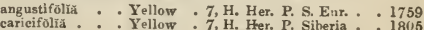
ensifolia : : Yellow : 7, H. Her. P. Siheria : Her. Paucasus: 1805
: 1825 ensiospérmă : : Yellow : 5, H. Her. P. Caucasus : 1825

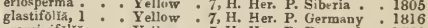
praminifolia : Yellow:7, H. Her. P. Portugal : 1759 hirsūtă. - Yellow : 5, H. Her. P. S. Eur. . 1818 hispānică : : Yellow : 7, H. Her. P. Spain: : 1576 lanátă: : Yellow: 7, H. Tu. P. Iberia : 1597 parvitlóră : : Y Yell w : 7, H. Tu. P. Austria: : 1819 purpureă : : Y Yellow : 5, H. Tu. P. Austria : 1719 rooéa * - Pink - T, H. Tu, P. Hungiry : 1807 taûricà - . Yellow * T, H. Tu. P. Tauria . 1820 tountosa : : Yellow : 6, H. Tu, F. Armenia: 1780

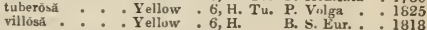
chondrilloīdĕs, crīspă, fistulōsă, jūlīă, macrorhĩză, mollis 3 , pinifoltă 4, radiūtă, rumicifơlua, strictă 5 , trachysjērmä 6 .

Scotch AspHODEL, see Tofiēldiă $a / p \bar{\imath} n a ̆$.

Sсотсн LABURNum, see Cy̆tisús alpĩnñs.

Ścōtrĭ̄, R. Broñ. In honour of R. Scott, M.D., professor of botany in Dublin. Linn. 16, Or. 6, Nat. Or. Leguminosa. A genus of elegant plants, thriving well in sandy loam and peat; cuttings of the young wood root freely in sand, under a ylass. angustifolra - Grn. yel. * 4, G. Ev. S. N. Holl. - 1825

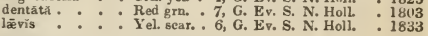

SCrRW-PINR, see Pandānŭs.

SCRRW-TREe, see Helīctērés.

Scrobrcuritr, excavated into little pits, or hollows.

Scrophuläriă. So named by Linnarus, from its sup. posed use in the cure of scrofula. Lina. i4, Or. 2, Nat. Or. Scrophulariacea. The species of Figwort are all of the easiest culture, growing freely in a light soil, preferring a moist situation. The shrubby species require protection in winter. They all increase freely by seeds. Synonymes: 1. S. Bulbisii. 2. S. chrysanthemifolia. 3. S. ylundulosa. 4. S. arguta. 5. S. frutescens. 6. S, mellifera. 7. S. rugosa. 8. S. appendiculata. 9. S. laciniata.

canină . . . Brn. pur. . 8, H Her. P. S. Eur. . 1683

chrysantliemi- Bri. pur. . 7, H. Her. P. Tauria . 1817 cordifilu, 2 grandiflotă orientális a ambueifoliră, 6 . Red grn. 8, H. Her. P. Spain : 1640 verhenafoliă, 9 . Brn. pur. . 7, H. Her. P. 1816 vernalis. - Yellow $: 4, \mathrm{H}$. B. Britain. 
adscêndèns, altăică, aquātĭcă 1, auriculătă, betonica-

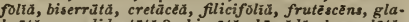
brätă, grandidentätă 3 , hirsūtă, hispĩdă, lanceolâtă, lacìdă, lyrātă, mariländică, melissaefoliă, multǘ ĩdä, nodosă, peregrind̆ 4, pinnatŭfídă, ramosissīmă 5, rupęstris, Scopolīi 7, scorodonàd, Smäthīi, tanacetifoliă, trifoliâtả 8 , variegātă.

Scrotíorm, shaped like a double bag.

SCRUBBY OAK, see Lophïă africānă.

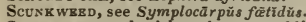

Scuryy, covered with scales, resembling scurf.

SicurVy GRAss, see Cochleāriä.

Scutat8, shaped like an ancient round buckler.

Scutrllärî̀, Linn. From scutelta, a little saucer; alluding to the form of the calyx. Linn. 14, Or. 2,

Nat. Or. Labiata. From the plants being for the most part very handsome when in flower, they are well suited for ornamenting the front of the flowerborder. They grow in any common garden soil, and increase readily by seeds and divisions; the shrubby species may be readily multiplied by young cuttings. The greenhouse and frame species require protection only in winter. Synonymes: 1 . S. nigrescens, pallida. 2. S. altaica. 3. S. lupulina. 4. S. decumbens. 5. S. Caroliniana, hyssopifolic. 6. S. ambigua. 7. S. rubicunda.

albrdx, 1

alpĩna, 2

lútẻ, 3

sangữnea

variegále

Colùmnä

commutātă

galericulatà

grundiftoră

hastifolia

havanēnsIs

linirtí, 4

humintegr foils, 5 :

lateritồrá

maciảnthă

mỉnōr

orientalis

parvüla, 6

peregrind, 7

pilosà

purpuráscéns

acordifolia

serrảáa

Tournetorti

Dirty wh

6, H. Her. P. Levant .

H. Her. P. Tartary

Yellow

Red

7, H. Her. P.

Pa yel. : 8, H. Her. P. Switzerl.

Drk. pur. : 7, H. Her. P. Crimea

Blie . 7, H. Her. P. S. Eur.

Purple

Blue

8, H. Her. P. Hungary

7, H. Her. P. Britain.

7. H. Her. P. Siberia

Purple : 6. H. Her. P. Germany
Blue . 5, S. Her. P. Havannah

Blue

$6, \mathrm{H}$. Her. P. Candia

Drk. pur.
Blue

6, F. Her. P. N. S. W.

7, H. Her. P. N. Amer

7, H. Her. P. N. Amer.

7, H. Her. P. Britain

7, H. Her. P. Virginia

8, H. Her, P. Levint .

7, H. Her. P. N. Amer.

8, H. Her. P. Tauria

$7, \mathrm{H}$. Her, P. N Amer. 1823

6, H. Her. P. W. Ind. : 1820

6, H. Her. P. Sileria . 1817

8, H. Her. P. N. Amer. 1800

6. H. Her. P. S. Eur. : 1821

Scyphānthŭs, Sneet. From scyphos, a cup, and anthos, a flower; in reference to the shape of the flower. Linn. 18, Or. 2, Nat. Or. Loasaced. This elegant little plant may be referred to Locsa for culture and propagation. Synonyme: 1. Loasa volubilis.

grandifórŭs, 1. Yellow . 8, H. Tw. A. Chile . . 1824

ScYтry hymen, a membrane; substance of plant. Linn. 24, Or. 7 , Nat. Or. Atgue. This species is found upon rocks-S. rupestris.

Scrtonēmă, Agardh From scytos, leather, and nema, a filament; the nature of the filamentous fronds. Linn. 24, Or. 7, Nat. Or. Alga. Some of these species are found on rocks, and others in the ocean -S. Büngir, byssoz̃deam, comoIdes, compäctam,

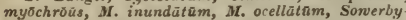
anum.

Scytusĩphō, Agardh. From scytos, leather, and siphon, a tube; the fonds are coriaceous and tubular. Linn. 24, Or. 7, Nat. Or. Alga. These plants are found only in the ocean-S. faniculäcěŭs, filum, F. thrix, F. tomentositm.

SBA Burrs, see Chenopódiàm marilimám.

Sga BUCKтноR, see Hippophüĕ.

Sra chickwerd, see Arenä riă peploädès.

SвAто̄Rthīa, $\boldsymbol{R}$. Brown. In honour of Francis Lord Seaforth, a botanical patron. Linn. 23, Or. 1, Nat. Or. Palmacece. An ornamental Palm, growing in turty loam and a little sand; and increasing only by seed. A cool part of the stove suits it. èiégán Palm. N. Holl. 1822

\section{SEA неАтн, see Frankẽnŭă.}

SBA Bor.Lу, see Ergyngitam.

SEa kalz, see Crämbè marífimà.

SRA LAVENDKR, see Stũtřce.

SBa matgrass, see Psāmmă arenärla.

SRA PARSNBP, see Echinơphoră.

SBA RAGWORT, see Cineräriă maritìma.

SBA ROCKRT, see Cakite maritimá.

Sgasidi balsam, see Crótón Eleuterid.

SEAsidi GRApB, see Coccollobă.

Srasidr LAURBL, see $X$ ylophglla latifoliz.

Seaside oat, see Uniolá.

SEA WRACKGRASs, see Zostẽră mariñă.

$\mathrm{S}_{\mathrm{B} B \overline{\mathrm{A}} \mathrm{A}}$, Solander. In honour of Al. Seba, an apothecary and botanical atthor, of Amsterdam. Linn. 4, Or. 1, Nat. Or. Gentianacee. These elegant plants require to be raised on a hotbed, and after. wards planted out into a warm sheltered border, towards the end of May.

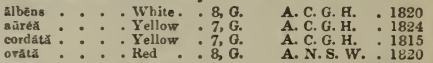

Sква丿⿱一𫝀口, sce Schultesiă.

SECĀL, Linn. An ancient name, said to be derived from seco, to cut. Linn. 3, Or. 2, Nat. Or. Gra. vined. The Rye is next to Wheat in value for making bread, and is used for this purpose gene. rally throughout the north of Europe. It is hardier and earlier than wheat. Synonymes: $1 . S$. cereule. 2. Triticum orientale.

cereálé

compð̌sitūm

hybêrnûm

vèrnuัm

frăglle,

A petal

A petal

A petal

Apetal

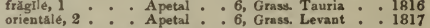

6, Grass. Crimea

6, Grass. Tauris

6, Grass. Tauria

6, Grass. Tauria

6, Grass. Tauria

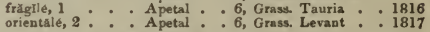

Sвсямо̄хй, $R$. Bronn. Altered from Squamona, the A rabic name of S. agyptiaca. Linn. 5, Or. 2, Nat. Or. Asclepiadaces. Ornamental plants. For cul. ture and propagation, see Pergularia.

regrptrăcă . . White. . 7, S. Ev. Tw. Egypt * 1752 elliptrea . - White S. Ev. S. N. Holl. 1824

SĒcrīus, Bronne. From sekiso, to fatten; the fruit serves to fatten hogs in the mountains and inland parts of Jamaica, where the plant is much cultivated. Linn. 21, Or. 10, Nat. Or. Cucurbitacece. This plant requires the same treatment as the Cucurbite. Synonyme: 1. Sicyos edulis.

edúle, 1 . . Yellow . 6, F. A. W. Ind. . 1816 Szcund, a rranged on one side only.

SeCuridācã, Linn. From securis, a hatchet; in allu. sion to the form of the wing at the end of the pod. Linn. 17, Or. 3, Nat. Or. Polygalacee. Pretty plants, growing well in loam, peat, and sand; cuttings will root without difficulty in sand, under a glass, in heat.

virgată . . White . S. Ev. Tw. Jamaica : 1739

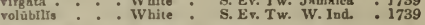

SévĭgĔRĂ, Decandulte. From securis, a hatchet, and gero, to bear; in reference to the shape of the pods. Linn. 17, Or. 4, Nat. Or. Leguminosa. The seeds have only to be sown in the open border in spring. Synonymes: 1 . Securidaca lutea, Coronilla securidaca. Coronillã, 1 . Y Yellow . 7, H. A. S. Eur. . 1562

Sfcurĩñgă, Jussieu. From securis, a hatchet, and nego, to refinse; because of the extreme hardness of the wood. Linn. 21, Or. 5, Nat. Or. Euphorbiacea. These plants succeed well in a mixture of peat and loam; and cuttings of the half-ripened wood root readily in sand, under a glass, in heat.

CommersōnI . . S. Eৃ. T.

1815

nrtidd . White . 6, S, Ev. T. Maurit. : 1793

SĒDEM, Linn. From sedere, to sit; the plants are Find growing upon stones, rocks, walls, and roofs of houses. Linn. 10, Or. 4, Nat. Or. Crassulacec. The hardy species of this interesting succulent genus are admirably suited for ornamenting rockwork. Some of the rarer kinds may be grown in small pots, in light sandy soil, or in loam mixed with brick rubbish. They are readily increased by divisions or cuttings. The greenhouse kinds require the same treatment as the Globulere. The annual kinds also succeed best on rock-work, where the seed has merely to be sown. Synonymes: 1. Rhodiola sibirica. 2. Sedum fruticulosum, Jacquini, Sempervivum sediforme. 3. Sedum glaucum. 4. S. [286] 
rupestre. 5. S. maximum. 6. S. album micranthum. 7. S. hexapetalum, quinquefidum. 8. S. collinum. 9. S. recurvatum. 10. S. Guettardi, Monregalense. 11. Rhodiola rosea. 12. S. minus. 13. S. annuum. 14. S. sempervivoides. 15. S spirale. 16. S. argu tum, paucidens, triphyllum. 17. S. portulacoides.

\section{Acr
a!b
alt
alb
alt
alt
an
an
A
an}

r. Yellow . 6, H. Her. P. Brituin

iminūtũm - Yellow . 6, H. Her. P. England

elongătúm - Yellow . 6, H. Her. P. Ensland

izồn - Yellow $, 8, \mathrm{H}$. Her. P. Siberia

bëscêns - Yellow 6, H. Her. P. England

bǐcans . . White. 8, H. Her. P. Europe

lbüm . White. 6, H. Her. P. Eugland

altăieủm, $1,{ }^{*}$. Yellow * 6, H. Her. P. Altai

anacāmpsérōs: Furple $: 7$, H. Her. P. France

andegavênsé . Yellow : 7, H. A. Andeg.

Andersounin, 3 . White. . 6, H. B. Hungary

Englicum . White : 7, H. Her. P. Britain

hibernieūm: White. 7 , H. Her. P. Ireland

microplyllum White, : 7, H. Her. P. Britain

parte.

- Pa. yel

airrantià cûm. Orange

atrătūm - . Purpie

coruliseens : Yellow

coeruleūm : Pa. blue

calabricum ${ }^{\circ}$. Whitish

dentầtứm. : Purple

Ewerni

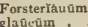

Yellow

- Yellow

Pa. yel.

Pink

7, H. Her. P. Britain .

6, H. Her. P. France

8 , H. A. Italy

7, H. Her. P

$7, \mathrm{H}$

A. France

$7, \mathrm{H}$.

A. Africa

6, H. Her. P. England

6, H. Her. P.

6 , H. Her. P. Siberia

7. H. Her. P. Wales

6 , H. Her. P. Spain

$6, \mathrm{H}$. Her. P. Siberia

hỵhrỉdũu

ibẻrieuñ

Yellow

7, H. Her. P.

involueratūm * Yeliow ${ }^{\circ}$, H. Her. P. Puitzerl

IFridūm WVlit grn, 7, H. Her. P.

micrāuthửm, 6 : White. 6, H. Her. P. England

micranthüm, 6 . White. 6, H. Her. P. Kand

mikerüm * - Green * 7, G. A. Mexico .

neglectûm : W White : 8, H, Her. P. Napies.

oblöngúm : White. . 7, H. Her. P. Britain

ochroleũcúm. Wlite. 7, H. Her. P. Greece

opponitifolium . White. $8, \mathrm{H}$. Her. P. Caucasus

păllĭdūm : : Par red

pectinātūm : White.

populifollùm "Wlite.

quadrifidum, 7 . Yellow

reflexunm: $\dot{8}$ : Yellow

recurvãtúm, 9 Yellow

rēnēns, 10 . Red

Rhodiólă, 11: : Yellow

rupéntre, 12 . Yellow

s\&xătilè, 13

sempervīuñ 14 Dp. pur.

septanguläré. Yellow

sexangulare, 15 . Yellow

sexfidūm.: White

spatulatum : White.

spürīum : : W White

Pink

stenopetỉlüm Gulden

semetis

$7, \mathrm{H}$

B. S. Eur.

7, H. Her. $\stackrel{\text { P }}{\text {. }}$

8, H. Her. P. Siberia

7, H. Her. P. N. Asin

H. Her. P. England H. Her. P.

6, H. Her. P. Europe .

6 , H. Her, P. Britain.

7, H. Her. P. England

6, H. Her. P. S. Eur.

7, H. Her. P. Iberia

7, H. Her. P.

7, H. Her. P. England

7, H. H. Ev. Cr. Jaupan

$7, \mathrm{H}$. B. Hungary

8, H. Her. P. Caucasus

7, H. Her. P. N. Eur.

7, H. Her. P. N. Amer. Amer

7, H. Her. P. N. Amer.

8 , H. Her. P. N. Aminer. H. Ev. Cr. England

7, H. Her. P. N. A mer.

8, H. Her. P. S. Eur.

teretitoliúm: : White

ternātūm, 17 . White

villōsūm

virëns

Pink

6, H. Her. P. Portugal

virúscēns : Grn, ye

6, H. Ev. S. Europe

1757

1794

183

1769
15.46

1816

1818

1820

1795
1640

1820

1822

1835

1810
1829

1732
1776

1794

1816

1837

1835
1777

1818

1816

1818

1780

1800

1815
1818

1826

1820

1825
1795

1816

1815

1816
1640

1826

1810

1789

1774

181.5
1824

SRGMFNT, a part of anything.

$\mathrm{S}_{\mathrm{RL}} \overline{\mathrm{A}} \in \overline{0}$, Linn. From the Celtic sel, sight, and jach, salutary; supposed medicinal qualities. Linn. 14, Or. 2, Nat. Or. Selaginacea. A genus of very pretty plants, of easy cillture; a mixture of loam, peat, and sand suits them; and cuttings root freely in saud or soil, under a glass. Synonymes: 1. S. lucida. 2. S. teretifulia. 3. S. fulvo-maculata. 4. S. diffisa.

\section{angustifölì}

bracteãtă, 1

canêstēens

canéscéns

dentâtà. 2 .

dentătă.

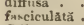

Gillir

8, G. Ev. S. C. G. H.

Purple

6, G. Ev. S. C. G. H.

- 1819 Pa. pur. - 9, G. Ev. S. C. G. H.

7, G. Ev. S. C. G. H.

7, G. Ev. S. C. G. H.

7, G. Ev. S. C. G H.

6, G. Ev. S. C. G. H.

3, G. Ev. S. S. Afric

7, G. Ev. S. C. G. H.

- 1812

- 1812

- 1699

- 1823

1774

1829

- 1823 [ 287

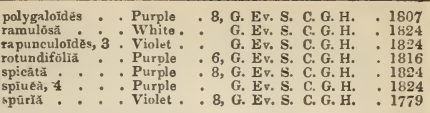

Seifheal, see Prunellă.

SeLIN ŪM, Hoffiman. From selinon, the Greek name for parsley; applied to this genus on account of the resemblance in the leaves. Linn. 5, Or. 2, Nat. Or. Umbellifere. Hardy plants, of no interest; increased by seeds. Synonymes: 1. Sescli pyrenaum, Angelica lancifolia. 2. Imperatoria cuacasica. 3. Thysselinum Plinii. 4. Angelica pyrenua. 5. Seseli pimpi=

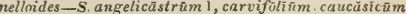

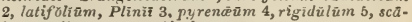
brüm, sibĩricūm, terebiuthücĕūm.

Sellö̃̆, Humboldt and Bumpland. In honour of Mr. Sello, a German botanist. Linn. 19, Nat. Or. Cornpositce. A worthless stove perennial; increased by cuttinge-S. glutinosč.

SBMBCĀRPǓs, Linn. From semeion, a mark; and karpos, a fruit; the black, acrid juice of the nut is used by the natives for marking cotton cloths. Linn. 23, Or. 2, Nat. Or. Anacardincece. For the culture and propagation of this lofty growing tree, see Anacardium. Synonyme : Anacardium longifolium, Cassuvinm.

Anacārdǐūm, 1 Grn, yel. S. Ev. T. E. Ind, 1890 eıneifơliūm : Grn. yel. : S, Ev, T. E. Ind.

1824

Sesi, half.

SEMrNal, belonging to the seed.

SEMPERvīvēM, Linn. From semper vivo, to live for ever; the tenacity of life of the Houseleek is well known Linn.11, Or. 7, Nat. Or. Crassulacea. These interesting plants are worthy of a place in every collection. The greenhouse species succeed best in a mixture of sandy loam and brick rubbish; and when not in flower, they must be very sparingly watered. Cuttings taken off, and laid to dry for two or three days, will root very freely. The readiest way of obtaining cuttings from $S$. tabulaeforme and some others, is to cut the top out, when lateral shoots will be immediately produced. The hardy kinds succeed best on walls or rock-work, and are easily increased by offsets. The juice of the common houseleek, S. tectorum, applied either by itself or mixed with cream, yives immediate relief in burns, and other external inflammations. Synonymes: 1. Sedum divaricatum. 2. Sempervivum calyciforme. 3. S. lineolare. 4. S. barbatum, ciliatum. 5. S. laxum. 6. S. grandiflorum. 7. S. soboliferum. 8. S. villosum.

africănūm

aizoỉdès, 1

arachnnî́téeum

mājŭıs

arbơrểm

variegātūm

auิreūm, 2

spunrium

bifürcūm

cæspitosủm, 4

canariense

lị̂brídūm

dichotơmūm,

dodrantale

flagellifoorme

frutesens

glnndulósūm

globiferam,

glutinōsūm

mierânthés

montānūm

primîlūm

retuisûm

tellátūm,

tubulæformé

tectōrūm .

tortuő-นิn

urbīeủm

uvif érûm

- Yellow

Purple

Red

God

Yellow

Yellow

Yellow

Yellow

White

Pa. yel.

Yellow

Flesh

Reddish

Yellow

Yellow

Yellow 
5, Or. 1, Nat. Or. Pittosporacee. Interesting plants, thriving well in a mixture of loam and peat, or any rich light soil; cuttings of the ripened wood will root without difficulty in sand, under a glass, in heat. Synonyme: 1. Celastrus verticillutus.

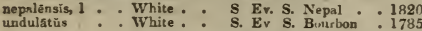

Szsertȟră, Poiret. In honour of John de Senebier of Geneva, a vegetable physiologist. Linn. 15, Nat. Or. Cruciferc. Plant 3 of no beauty. The seeds have only to be sown in the open ground. Synonymes: 1. Coronopus Ruellii. 2. Cochleariu nilotica. 3. Cononopus didymus, I.epidium didymum-S. Coronôpuns 1 , niloticä 2 , pinnatifídă 3 .

Skxecīilirs, Gertner. Probably a diminutive of Senecio. Linn. 19, Or. 2, Composite. Interesting plants, thriving in any light, rich soil, and increasing readily by divisions. Synonymes: 1. Cineraria glauca. 2. C. purpurata. glnúcă, 1.
purpurātă, $2:$

Skš̄cřo, Linn. From senex, an old man; the receptacle is nuked, and resembles a bald head. Linn. 19, Or. 2, Nat. Or. Compositue. An extensive genus of plants, many of the species of which are very ornamental. The shrubby kinds grow well in any lisht soil, and increase freely by cuttings. The hardy species will thrive in common garden soil, and may be increased by dividing the plants. The annuals and biennials are also of the easiest culture. Synonymes: 1. Cineraria alpina. 2. S. cinerarivides. 3. Cacalia sarracenica. 4. S. incanus. 5. Cineraria cordifolia. 6. Cineruria cruenta. 7. S. aquaticus. 8. S. glutinosus. 9. S. incanus. 10. S. cunescens. 11. Cineraria alpina, var. 12. S. puradoxus. 13. S. lancens. 14. Cacalia pinnata. 15. C. peucedanifolia. 16. S. chrysanthemifolius. 17. S. kraminifolius. 18. S. nemorensis, persicafolius. 19. S. leucanthemifolius.

adonidifolrŭs alplnăs, 1 :

ampulace

argut

eacaliaster, 3

exculioidés.

canadénsis

érnáás.

cinerarioidés

cordifolias 5

coriáceris

erassifollŭs

eroaticūs

eruéntús, 6

delphinifollūs

divaricătŭs.

Dôrīa

Dorơnìcũm .

"legans

flóre âlbó

plènũs ălhŭs

plënũs rủbér

erubéscêns

hæmatuphrilüs

halimifoliứs

hieracifóliús

ilicifoliǔs

japôñกleŭs

lasneéăs.

lanugi nósŭs

leueophylür, 9

lilacinüs

longifolins

1ร ratifoliús, 11

micropliylluăs.

nemorensis.

odurãatũs

opörionts 13

Othổnz̉, 14

ovătūs

paludōsūs

persicafolfüs

peucedanifolrŭs 1

Pseũdo.Chīnä.

puhigher uีs

purpủreǔs reclinătũs, 17 .

reclinătús, 17 :
rigèséns

rìnidũs

rusmarinifoirŭ

onrracēnǐcŭ:

scakér

soliangtneus:
Yellow

Yellow

Yellow

Yellow

Yellow

Yellow

Yellow

Violet

Yellow

Yellow

Yellow

Purple

Yellow

Yurple

Yellow

Purplo

Yellow

Purpla

Purpla

White

Red.

Purple

Yellow

Yellow

Yellow

Yellow

Yellow

Yellow

Yellow

I.ilac.

Yellow

Yellow

Yellow

Yellow

Yellow

Pink

Yellow

Yellow

Purple

Yurple

Red.

Purple

Purple

Yellow

Yellow

Yellow

Yellow

Yellow
7, H. Her. P. Europe

7. H. Her. P. S. Bur.

H. A. Texas.

G. Ev, s. Mexico 1834

7, G. Ev. S. C. G. H. : 1774

9 H. Her. P. France : 1772

8. S. A. Brazil . . 1820

7, H. Her. P. N. Amer. 1820

7, G. Ev. S. Mexico : 1826

7, H. Her. P. Austria : 1749

7, H. Her. I: Levant 1728

7, H. A. 8. Eur. : 1815

7, H. Her. P. Hungary

4, G. Her. P. Teneriffe

7, H. Her. P. Barbary : 1800

7, G. B. China . 1801

8. H. Her. P. Austria - 1570

7, H. Ev. S. C. G. H.

7. G. Ev, S. C. G. H. $: 1700$

7, G. Ev. S. C. G. H. $: 1700$

7, G. B. C.G.H. : 1774

4, S. Ev. S.

7, G. Ev. S. C. G. H. $: 1723$

8, H. A. N. Amer. 1699

6, G. Ev. S C. G. H. . 1731

8, H. Her. P. Japun. : 1774

8, G. Ev. S. C. G. H.

11, H. A.

7, H. Her. P. S Eur.

6, G. Ev. S. C. G. H.

9, G. Ev. S. C. G. H.

7, H. Her. P. Austrin

7 , H. Her. P. A uatria

H. Hex. P. N. Holl

$11, G$ Her. P. C. G. H.

T, H. Her P. Iberia.

9, H. Her. P. Germany

7, G. ET. S. C. G. H.

5, G. Ev S. C. G. H.

7, G. Her. P. E. Ind.

6, G. Ev. S. C. G. H.

8 , G. Her. P. C. G. H.

7. G. Ev. S. C. (i. H.

7, G. Ev. S. C. G. H.

7, G. Ev. S. C. G. H.

7, H. Her. P. Britain

7, G. Her. P. C. G H.

7, G. Ev. S. C. G. H. 1816

1826

1775

1818

1785

1817

1816

1820

1816

1732

1816

1774

1774
1815

1704
7, G. Ev. S. C. G. H. : 1700

speciơsūs . . Scarlet

telephifoliñ.s

Yellow

7, G. Her. P. China

Toarnefortis, is: Yellow

umbrosǔs . Y Yellow

unifloris : Yellow:

7, H. A. C. G. H. : 1789

7, H. Her. P. Pyrenees: 1810

7. H. Her. P. Hungary - 1815

valerianæføirü: : Yellow: 7, H. Her. A. Aurnpe : 1809

venüstǔs . . Purple : 8, G. Ev. S. C. G. H. : 1774

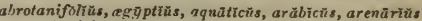
2, artemisicéliús, aürêus, auritüs, Buldénsis, Balsamïtä, Barreliēri, calcürēus, carniolicūs 4, chrysanthemifólīüs, cineriàscēns, coronopifoliùs, dentätùs, errüticüs 7 , erucifoltùs, gigānteñs, glaucẽscēns, glañcrüs,

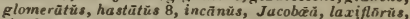
linifoliüs, lívĩdüs, lycopifoliñs 10 , lyrätùs, montĩnŭs 12 , nebrodensis, parviflorùs, preältŭs 16 , rotundifo-

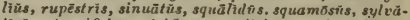
ticūs, tenuifotiñs, triflorn̆s, trilībüs, verbenaföliūs, vernälis, věrnñs 19, viscrisuns, vulgärïs.

SinNa, see Cãssiü lunceolätä.

SENsitiva PBRN, see Onöcleä sensỉbilis.

SENSiTIYr PIANT, see Mimôsă sensitivŏ.

Srpats, the divisions of the calyx.

SRPKDŨATCM, Link. From sepedon, putrescence. Linn 24, Or. 9, Nat. Or. Fungi. These species are found in autumn growing on decayed substances-S. $m y$ cophiläm, rósêm.

SEPTA, the partitions which divide the interior parts of a fruit.

Sēptàs, Linn. From septem, seven; the number seven prevailing in the fructification. Linn $7, \mathrm{Or} .4$, Nat. Or. Crassulucer. Neat little plants, thriving well in a mixture of loam, peat, and sand; and readily increasing by division of the tubers. They must be very sparingly watered when in a state of dormancy. Synonyme: 1. S. globiflora.

capensis . . White. . 8, G. Her. P. C. G. H. . 1774

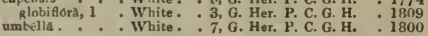

SEPTroth, see Tormentilla.

Septötă, Fries. From septum, a division. Linn. 24, Or. 9, Nat. Or. Fungi. These species appear as stains upon the leaves of the Elm, \&c.-S. AEgo pödit, Oxyacūnthä, Ulmí.

SRRĀPĪ́s, Linn. After an Egyptian divinity of that name. Linn. 20, Or.1, Nat. Or. Orchidacee Curious little plants, succeeding best when planted in light sandy soil, with the protection of a south wall.

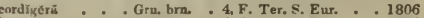
ling if : : Brown : 6, F. Ter. S. Eur : 1786 loogipetala : : Brown : 4, F. Ter. Rome: : 1826

Serterous, silky, downy.

Sertes, a row, or layer.

Serivgla, Gay. In honour of Nicholas Charles Seringe, a Swiss botanist. Linn. 5, Or. 1, Nat. Or. Sterculiacere. An interesting shrub, thriving in a mixture of sand, loam, and peat; young cuttings planted in the same kind of soil, under a glass, will root readily, or the species may be increased by seeds. Synonyme: 1. Lasiopetalum arborescens.

platyphylla, 1 . . White . 6, G. Ev. S. N. Holl. 1822 SERıŏL̆, Linn. From seris, succory; resemblance of the plants. Linn. 19, Or. 1, Nat. Or. Composito. There plants succeed in any common soil, and are readily increased by seeds. Synonymes: 1. Rodigia alliata. 2. $R$. commutata. 3. $R$. lavigata.

1826 albicañns . . Yellow . 4, H. Her. P. Sicily . . 1828

apargioidés: : Yellow

glañed - : Yellow : 4, H. Her. P. Sicily : : 1828 rubéscêns: : Redsh. : 7, H. A. Sicily:

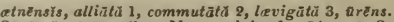

Serîssà, Commelin. Not explained. Linn. 5, Or. 1, Nat. Or. Cinchonacee. This plant succeeds best in a mixture of loam, peat, and sand; and cuttings root if planted in sand, nder a glass.

füttda . . . White . 7, G. Ev. S. Japnn . . 1787

SERJĀNǏ̃, Plumier. In honour of Paul Sergeant, a

French friar and botanist. Linn. 8, Or 3, Nat. Or. Sapindacer. Plants of little beauty, thriving in a mixture of loam and peat; large cuttinus will root in sand, under a glass, in heat. Synonyme: 1. Paullinia polyphylla.

caracasănă . . Whic grn. . S. Ev. Cl. Caraceas - 1816 
SzRmixus, late, or evening-flowered.

SERPICŬză, Linn. From serpo, to creep; in reference to the habit of the species. $\operatorname{Linn} .21$, Or. 5 , Nat. Or. Onagracea. This plant grows in any common soil, and is readily mult:plied by dividing the creeping shoots.

rêpēns . White 7, G. Her. Cr. C. G. H.

.1789

Serrate, cut like the teeth of a saw.

SERrätṹL Ă, Linn. From serra, a saw; the leaves are edged with cutting teeth. Linn. 19, Or. 1, Nat. Or. Compositce. All the species of Serratula succeed well in any common soil. The herbaceous kinds are increased by seeds or divisions of the roots; the annuals and biennials merely require sowing in the open ground. Synonymes: 1. Centaurea Behen. 2. S. alata, Carduus cyaroides. 3. Cnicus centaurioides. 4. Carduus nitidus. 5. S. linearifolia. 6. Centaurea nitens. 7. Carduus cerinthoides, cerintlifolius, glaucus. 8. Carduus pannonicus, serraluloides, Cnicus pannonicus. 9. S. ambigua, Carduus polyclonos. 10. S. centurrioides. 11. S. simplex.

alătă . . Purple . 7, H. Her. P.

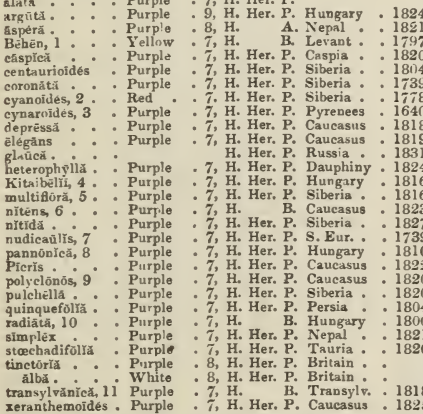

SrRratures, the teeth of a serrated leaf.

SERRULATED, having small serratures on the margin.

Śrrrúrí, Salisbury. In honour of Dr. James Serrurier, professor of botany at Utrecht. Linn. 4, Or. 1, Nat. Or. Proteacede. A genus of very de. sirable greenhouse shrubs. For culture and pro. pagation, see Protea. Synonymes: 1. S. arenaria. 2. Prutea decumbens. 3. P. alirctanifolia odorata.

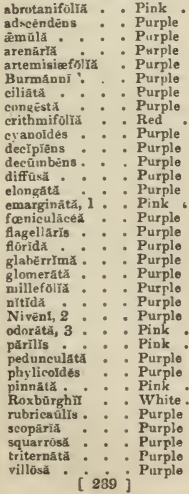
7, G. Bv. S. C. G. H 7, G. BV. S, C. G. H. 7, G. Ev, S. C. G. H. T. E. S. C G. H. G. Bv. S. C. G. H. 7. G. Ev. \&. C. G. H. 7, G. Ev. S. C. G. H. T, G. Bv. S. C. G. H. 7. G. Ev. S. C. G. H. 7, G. E*. S. C. G. H. 7, G. Ev. S. C. G. H. T, G. Ev, S. C. G. H. 7, G. Ev. S. C. G. H. 7, G. Ev. S. C. G. H. T, G. Ev. S. C. G. H. T, G. Ev. S. C. G. H. 7, G. Ev. S. C. G. H. 7, G. Ev. S. C. G. H. 7, G. Ev. S. C. G. H. 7, G. Ev. S. C. G. H. 7, G. Ev. S. C. G. H. 7, G. Ev. S. S. C. G. H. , G. Ev. S. C. G. H. 7, G. Ev. S. C. G. H. 7, G. Ev. S. C. G. H. 7, G. Ev. S. C. G. H. 7, G. Ev, S. C. G. H. 7, G. Ev, S. C. G. H. 7, G. Ev. S. C. G. H. T, G. Ev. S. C. G. H. 7, G. Ev. S. C. G. H. 7, G. Ev. S. C. G. H.

1803

1819

1803

$18 \cap 3$

1786

1803

1820

1803

1806

1818

1810
1810

1800

1820

1824

1825

1789

1803

1823

1800

1803

- 1803

1789
-1789

1803

1803

1806

1809

1810

1802
1829
SzRsalisĩ̌, R. Brown. In memory of John Baptiste Sersalis, a Neapolitan ecclesiastic, much praised by Fabius Columna. Linn. 5, Or. i, Nat. Or. Sapotacee. This shrub thrives best in a mixture of loam, peat, and sand; and cuttings root freely in sand, under a glass. Synonyme: 1. Sideroxylon sericeum.

seríceă, 1 . White. . S. Ev. S. N. Holl.

1772

ShRvick, see Pỹrĭs Sörbŭs.

SӖsămŪM, Linñeus. From sempsen, the Egyptian name of one of the species. Linn. 14, Or. 2 , Nat. Or. Pedaliacea. Only worth growing as botanical curiosities. They require the same treatment as other tender annuals. The seeds contain an abun. dance of oil, which might be substituted for olive oil; it is procured from them in Egypt in great quantities.

indieūm
orientalé

Sestāxĭă, Persoon. From Sesban, the Arabic name of S. agyptiaca. Linn. 17, Or. 4, Nat. Or. Leguminose. Interesting plants, requiring to be kept in a strong heat, or they will not thrive. A mix. ture of loam and peat suits them; and cuttings of the shrubby kinds will root in sand, under a glass, in heat. The annual species are increased by seeds, which they sometimes produce in this country. Synonymes: 1. Aschynomene Sesban. 2. AE. eannabina.

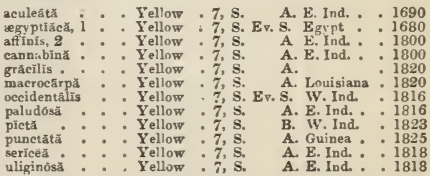

SĚš̈r, Linn. The Greek name of an umbelliferous plant. Linn. 5, Or. 2, Nat. Or. Umbelliferc. The species of Meadow-saxifraye are of very little interest. A sandy or chalky soil suits them, and they are readily increased by seeds. Synonymes: 1. Bubon siculum. 2. S. Athamanta, Bubon buchtornense. 3. S. annuum. 4. B. dichotomum. 5. Athamanta Libanotis. 6. S. glaucum. 7. S. crassifolium. 8. S. proliferum. 9. B. rigidum. 10. S. tauricum-S. Boccōnī 1, buchtornēnsē 2, campēstrě, cervariuefolīūm, charophyllō̄dés, colorütum 3 , dichotờmūm 4, divaricātam, elätūm, frăgìlë, grăcĭlë,

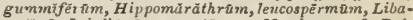

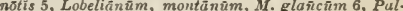

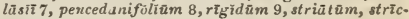
tū $m$, tortuঠsū $m$, triternütūm, vüriñm 10

SBst. ERİ, Arduini. In honour of M. Sesler, a phy. sician and botanist of the eighteenth century Linn. 3, Or. 2, Nat. Or. Graminea. Uninteresting grasses. Synonyme: 1. Cynosurus coruleus-S.

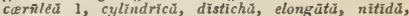
tenëllä, tenuifüliă, sphærocěphülü.

Skssile, without stalks.

Sesūviù, Linn. Not explained. Linn. 12, Or. 2 , Nat. Or. Tetragoniucee. These succulent plants require to be grown in sandy loam and peat. They increase freely by cuttings, (which should be dried a little,) in the same kind of soil, under a glass. They must be sparingly watered. Synonymes: 1. S. pedunculatum. 2. S. sessile, S. Portulacastrum.

longifólrùm * Red wht. 7, S. A. S. Amer. - 1816 Portulacăstrüm :Grn, red 6, G. Her. P. W. Iud. 1699 pedunculătūm, i Red wht. 6, s. Her. P. W. Ind. : 1699 sēssile, 2. . . Red wht. 6, S. Her. P. W. Ind. rĕpens : : Red wht. 7 , S. A. E. Ind. : 1816 Sвтасвотs, shaped like a bristle.

$\mathrm{S}_{\mathrm{BTAE}}$, bristles.

SztÁrĭ, Beauvois. From seta, a bristle; the involucrum is bristly. Linn. 3, Or. 2, Nat. Or. Graminece. These grasses are of no interest. Ther are nearly all annuals-S. äspërü, auricömü, cen. chroīdĕs, compossită, cylïndrică, erubëscēns, geniculätă, germänǐcă, glaũcă, helvola, intermédía,

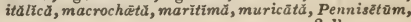




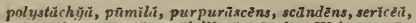

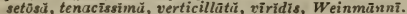

S̄̌тrĭĂ, Kunth. In honour of S. Sethi, anthor of a work on culinary vegetables. Linn. 10, Or. 3, Nat. Or. Mutpighiacee. This plant thrives well in turfy loam and peat, and cuttings will root in sand, under a slass, in a moist heat. Synonyme: 1. Erytluroxylon monogynum.

Indǐed . . . Yellow . S. Ev. T. E. Ind. . . 1824

Seriform, formed like bristles.

SkTinerous, bearing bristles.

SBTOSB, tovered with bristles.

Seisiskĩă, Pursh. In honour of Henry Seymer, an English nuturalist. Linn. 14, Or. 2, Nat. Or. Scrophulariaced. The seeds should be sown in a bed of peat soil. The plants are very pretty when in blossom, but rather difficult to cultivate. Synonymes: 1. Afzelia eassioides, Gerardia Afzelia.

pectinstă $;$ Y Yellow $: 7, \mathrm{H}$. A. N. Amer. 1820

Shatrot, see Allílum ascalónicionm.

Sh ARP crDar, see Acĭciü Oxycēdrĭs.

SHARP CBDAR, see Juniperris oxycédrüs.

SHEATH, the lower part of the leaf that surrounds the stem.

SH BBP I.AURRL, see Kälmlŭ angustifơlia.

SHEBP's scabious, see Jisiönë.

S hrBP's sorrit, see Rīméx Acetosella.

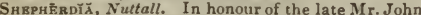
Shepherd, curator of the Botanic Garden of Liverpool. Linn. 22, Or. 4, Nat. Or. Elozagnacer. Ornamental trees. For culture, \&c., see Hippophac. Synonymes: 1. Hippophae argentea. 2. H. cana. densis.

argenteă, 1 . A petal - 4, H. De. T. Missouri - 1820 canadênsYs, 2 : : A petal : 4, H. De. T. N. Amer. : 1759

ShвphвRD's BgA RD, see Arnopōgon.

ShB PHRRn's crub, see Verbïscrin Th Thüpsüs.

SHgPHBRD's PURsR, see Capsellū.

SHISHERD'S PURSE, see Thlïspt.

SHBR $\bar{A} R D Y \bar{\lambda}$. Named by Dillenius in honour of his patron William Sherard, LL D., consul at Smyrna. Linn. 4, Or. 1, Nat. Or. Galiaced. Uninteresting plants: The seed has only to be sown in the open ground. Synonyme: 1. Gulium murale-S. arvensis, murälss 1 .

SHERDs, fragments of pots, employed to drain the soil supplied to potted plants.

Shizt.D, a broad table-like process in the flowers of Stapetia.

ShizLd yBRn, see Arpidinm.

SноввWвкD, see Littor ella.

SHORTIY-ACUMINATED, having a short tapering point.

SHORTLY-BIFIn,

SHORTLY.TWO-CLBFT, $\}$ two parts.

Shruhay tremoli, see Pteléd.

Shutrrĩ , Choisy. Named in honour of Dr. Shuter, formerly a physician at Madras. This beautifu twiner may be raised from seeds on a hotbed in spring, and the youny plants, when of a sufficien size, should be placed in separate pots, and trained to sticks. Unless a very warm sheltered situation can be found, they require to be placed in a stove or greenhouse to blossom and ripen their seeds. Synonyme: 1. Ipomea bicolor.

bícólör, 1 . . Yel. pur. . 8, S. Ev, Tw. E. Ind. . . 1812

Shutri.вcock, see Periptéră puňceă.

SIBBĀLDǏn, Linn. In honour of Robert Sibbald, professor of physic at Edinburgh. Liun. 5, Or. 5, Nat. Or. Rosacece. Small alpine plants, succeeding best when grown in pots in a mixture of loam, peat, and sand, and increased by dividing the roots. Synonymes: 1. Chamarhodos erectu. 2. Chamarhodos polygyna.

erêctu, 1 . . . Pink . . 7, H. Her. P. Siberia . 1806 parvifióră : : Yellow : 7, H. Her. P. Cappa .

polygyna, 2: : Yel.gm. 7, H. Her. P. Siberia : 1824

procümbens : Yellow 7, H. Ev Tr. Britain

americana . Yellow * 7, H. Ev. Tr. N. Amer. 1820

helvetica . . Yellow . 7, H. Ev. Tr. Switzerl. . 1819

Sibrrian Crab, see Pýrŭs prunifolía.

SiBgriaN PEA-TRRB, see Curagĩni.

SıвтнӧRpĩ, Linn. In honour of Humphrey Sibthorp, M.D., formerly professor of botany at Oxford. Linn. 14, Or. 2, Nat. Or. Scroptuluriacea. This singular species succeeds best in peat soil and a moist situation, and is readily increased by divisions.

europēex . . Yellow . 7, H. Her. Cr. England .

Sĭcřŏs, Linn. Sicyos is the Greek name for cucumber applied to this yenus because of the resemblance and affinity of the species. Linn. 21, Or. 10, Nat. Or. Cucurbitacece. Plants of no value exiept as curiosities. The seeds require to be sown in a hotbed in spring, and treated the same as Gourds.

angulătŭs . . . Yellow * 8, F. Tr. A. N. Amer. . 1710 laciniatús : : Yel low : 8, F. Tr. A. S. Amer. : 1824 microplǐ̧llŭs . Yellow : 8, F. Tr. A. Mexico.: 1823 parviflórüs: : Y Yellow : 8, F. Tr. A

SĩDĂ, Linn. Theophrastus gave this name to an aquatic plant, supposed to be identical with Atthiea. Linn. 16, Or. 8, Nat. Or. Malvacea. Mostly freeflowering plants, of no beauty, thriving in any rich soil; and increased by seeds, which they produce in abundance. The shrubby kinds may be increased by cuttinirs, placed in sand, under a glass. They are for the most part stove plants. S. cordifolia, mixed with rice, is used to alleviate the bloody flix. The bark of several of the species is so tena. cious as to be manufactured into cordage. Synonymes: 1. Abutilon avicenne. 2. A. acerifotinm. 3. A. albidum. 4. A. americanum. 5. A. arberenm. 6. A. asiaticum. 7. A. auritum. 8. A. crispum. 9. Napea divica, 10. A. ferrugineum. 11. S. viscose. 12. A. giganteum. 13. A. Flaucum. 14. A. globifinrum. 15. A. hernandioides. 16. S. pilosa, A. hirtmo. 17. A. incanum. 18. A. indicum, 19. A. Lechenaultianum. 20. A. Lucianum, 21. S, sub. erosa. 22. A. mauritianum. 23. S. granilifolia. A. molle. 24. A. mollicomum. 25. A. mollissimum. 26. Napau lievis. 27. A. nudiflorum. 28. A. orbiculatum. 29. A. periplocifilium. 30. A. permolle. 31. A. polyandrum. 32. A. populifolium. 33. A. pulclellum, Plagianthus Lampenii. 34 A. pulchrum. 35. A, reflexum. 36. S, philippica. 37. S. brasila. 38. A. Sonneratianum. 39. A. tiliafolium. 40. A umbellatum. 41. A. vesicarium. 42. A. virgatum.

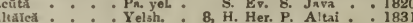
H. Her. P. Russia 1837 atressangurnea : Dk, pur. . 7, H. Her. P. S. Amer. 1795 añer : : Or. red : 7, S. Ev, S. India : 1830

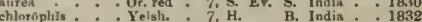
glnbiflóra, 14: : Wlite: 11, H. Ev. S. Maurit. : 1821 juvenalls : White: 8, H. H. A. Maurit : 1835 möllss 23 : : Yellow : 7, S. Ev. S. Peru : 1816 pyramidata : Yellow : 7, s. Ev. S. St. Dom. 1830 regra - Scarlet 6, H. Her. P. N. Amer. 1811 rơkeй : : Rове 10, S. Ev. S. Brazil . sericex: : : Roso : 1804 sessiliffớră : : Yellow S. Fv, S. S. Amer. 1827 atylós̊̊.: : Yelsh. : 7, H. Her. P. Amer. 1831 Abutîloón 1, acerifollŭ 2 , acränthă, acuminätă, albă, ălbìdă 3 , alnifólia, altheifolia, americünd̆ 4 , angusti-

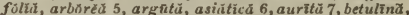
bracteolītú, brasiliensis, brevipěs, catyxkymenuid, canariênsĭs, carpinifoliŭ, carpinō̃dés, ciliñiris, compāctă, cumprèssü, confertü, contrüctü, cordifölua, crispà 8 ,

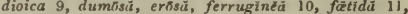
frutéscēns, gigäntēă 12, glancü 13, grandifloră, gra: véolens, Hernandioides 15, hirtä 16, huimilis, incequälìs, incänă 17 , Indícü 18, jamaicęnsis, jatrophoìdés, lusiustégä, Lechenaultzin nă 19, linifolză, lucianil 20,

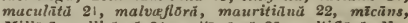
Milléri, mollicômä 24, moltrssimü 25, mulliftōrü, $\mathrm{Na}$ -

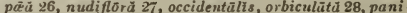

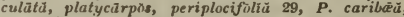
$\boldsymbol{P}$. zeylänicü, permölis 30 , pilosü, polyianthä 31 , populifoliä 32, pulchetlä 33, prilchrü 34 , purpuräscęns, recisă, reflēxà 35 , retũ ricinożdés, rơseă, rotundifoliau, Schränkīi 37, semicrenätü, Sonneratiană 38, spinosü, spirceifolia, stipulatü,

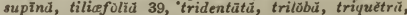

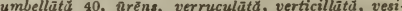

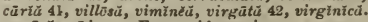

Singrítis, Linn. From sideros, iron; so named on account of its supposed property of healing fleshwounds made by iron Linn. 14, Or. 1, Nat. Or. Labiata. Many of these plants are admirably adapted for ornamenting rock-work. They prefer a dry sandy or chalky soil; and are readily in- 
creased by cuttings, seeds, or divisions. The annual kinds have only to be sown in the open ground in spring. Synonymes: 1. S. crefica. 2. S. elegans. 3. S. alpina, pyrenaica. 4. S. hyssopifolia. 5. S foetida.

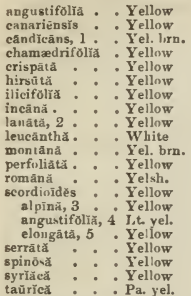

7, F. Ev. S. Spain
7, G. Ev. S. Cunaries
6, G. Ev. S. Madeira
7, F. Ev. S. Spain
7, F. Ev. S. Gibraltar
6, F. Ev. P. S. Eur.
7, F. Ev. S. Levant
7, F. Ev. S. Spain
7, F.
7, F. Ev. S. Egypt
7, H. S. A. Austria
9, F. Ev. S. Ievant
7, H.
9, H. Ev. S. Italy
7, H. Ev. S. Prance
7, H. Ev. S. Pyrenees
8, F. Ev. S. Spain
8, H. Her. P. Spain
8, H. Her. P. Spain
7, F. Ev. S. Levant
7, H. Ev. S. Tauria :
H.

182
169
171
181
181
1731
1759
1787
182
1759
173
174
159
182
1597
182
1818
159
189

Siderodêndrōn, Schreber. From sideros, iron, and dendron, a tree; in reference to the hardness of the wood. Linn. 4, Or. 1, Nat. Or. Cinchonacea. A lofty-growing tree, thriving in loam, peat, and sand; cuttings root in sand, under a glass, in heat.

triflōrūm . . Pink . - S. Ev. T. W. Ind. . 1793

SiderōxỹLō, Linn. From sideros, iron, and xylon, wood; because of the hardness of the wood. Linn. 5, Or. 1, Nat. Or. Sapotacea. These shrubs may be referred to Sersalisia, for culture and propagation.

inêrme White . 7, G. Ev. S. C. G. H

1692

SIDESADDT.E-FLOWER, see Sarracẽnĭd.

SIRGRS hĒCKT M.D., a German botanist. Linn. 19, Or. 2, Nat. Or. Composita. A genus of rather pretty annuals the seed should be sown on a hotbed in spring, and the seedlings, when sufficiently strong, planted into the open border, about the end of May.

droxeroidexs . : Yellnw: 8 , H

flosculōsa : Yellow:6, H.

ibérică

White

A. Mexico

1826

A. Iheria $: 1818$

triangulār̆š Yellow $\cdot 9, \mathrm{H}$. A. India • 1730

Sizvêrsiă, Willdenow. In honour of M. Sievers, a Russian botanical collector. Linn. 12, Or. 3, Nat. Or.

Rosacea. Interesting plants, thriving in any light soil; and readily increased by seeds, or by dividing the root. Synonymes: 1. Adamsia glacialis. 2. Geum Peckii. 3. G. triflora.

anemonoidés . Yellow * 7, H. Her. P. Kamtsch. . 1820 glaciālis, 1. . Yellow * 7, H. Her. P. Siberia . 1819 montảnd * . Yellow - 7, H. Her. P. Austria : 1597 rêptăns : : Yellow * 7, H. Her. P. N. Amer. 1826 rósé : Yellow: 5, H. Her. P. Rnckr M. 1827 triflôră, 3 : : Yellow : 7, H. Her. P. Louisiana: 1826

Sir.Āùs, Besser. A name given to an umbelliferous plant by Pliny. Linn. 5, Or. 2 , Nat. Or. Umbellifere. Hardy herbaceous plants, of no interest; increased by divisions or seeds. synonymes: 1 . Sium peucedanoides. 2. Ligusticum longifolium. 3. Peucedanum Silaus, Cnidiam Silaus. 4. Pastinaca rigida, Sium rigidum 5. S. Muthioli-S. carvnfoliús 1, longifoliūs

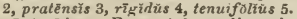

SrLENĔ, Lirr. Fron sialon, saliva; in allusion to the viscid moisture on the stalks of many of the species, by which the smaller kinds of flies are entrapped; hence, also, the English name of the genus, Catchfly. Linn. 10, Or. 3, Nat. Or. Silenaced. Elegant flowering plants, succeeding best in a light, rich soil. The shrubby kinds are readily increased by young cuttings, planted in sand or soil, under a glass.

The hardy herbaceous kinds may be planted in the open border; the dwarfer species thrive well on rock-work, but duplicates should be kept in small pots, as alpines, that they may be sheltered by a frame in winter. The seeds of the hardy annual and biennial kinds only have to be sown, about the beginning of April, where they are intended to remain. They may all be easily multiplied by seeds, and some of the herbaceous sorts by dividing the plants at the root in spring. Synonymes: $1 . S$. conoidea. 2. S.hirsuta. 3. Cucubalus chlorafolius.

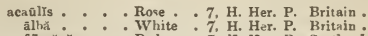

fø̄mină : : Red . 7, H. Her. P. Scotland

exscipa: : Red : 7, H. Her. P. Switzer1.

más Rove $7, \mathrm{H}$ Her. P. Seutland

egvptiăcă: : Pink: $7, \mathrm{H}$. Egypt

White 7, H. Her, P. Tartary

- 7, H. Her. P. Tartary - 1800

Europe 1817

Armeria : : : Pink : : 8, H. A. A. England:

albă

ascēndêns : - Red . $6, \mathrm{H}$.

Atōeǐôn * Pink * . 6, H.

- Pink $6 \mathrm{H}$

bupleuroidés

cæspitosã

campanūă

cãnă

canariênsìs .

cáspitua.

Cateshȳà

catholica

cheiranthifoli

chloræfolir

chlorãntha

ciliātá

cinèréa :

coaretátá

compacta

congéstå

congestă

corditoliă

corsicá

crassifólí:

crëtica

cylindrifloră

decûmbêns

deprêsaż

discôlor .

distâchỳă

disticha.

divaricăta

diversifolia

effús

êlegân

fahăriă:

fimbriātă

fla vëscēns

fruticōsă

galliea

geminiflồ

gigāntēa

Glancif
Bräcilis

graminifoly

Gyprophīa

lirsutinsimă, 2

hispănìc

hîspidă

imbricantă

inclûs

inflātĕ

hirstita

infract

jeniseênsis

läcèra

laciniata

laevigāta

latifóliă

laxiflôră

linifol

longicaũlĭs

longiftēră

longipétăla

lusitảnieă

maritimá

flóré plēnō

Mocinไănă.

mollissimă

multifloră

museípülă

nemorătis

niçeénsīs

noctiflora

noeturnă

nyetántlis

obtusifolia

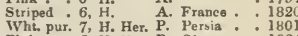

A.

A. Spain

A.

Pink . 6, H. Her. P. Ciucasus . 1824

Grn. wht. 7, H. Her. P. Piedmont . 1823

Fed : 6, H. Her. P. Madeira $: 1824$

Pink . 6, H. Her. P. Cancinsus . 1823

Pink . 6, H. Her. P. Carolina . 1810

Grn. wht. \&, H. Her. P. Italy - 1711

White : 7, H. A. S. Eur. $\quad$ A. San Rocco: 1821

Ji. yel. : 8, H. Her. P. Armenia : 1796

Grn. wht 7, H. Her. P. Germany . 1732

Purple : 6, H. Her. Tr. Crete : 1804

Pink : 6, H. A. Valencia : 1825

Purple 6, H. A. Morocco 1819

Pink . 8. H. B. Calreasus . 1823

Pink . 6, H. A. Greece * . 1818

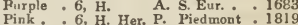

Purple: 6, H. Her. P. Cursica . 182

$\begin{array}{ll}\text { Brown : 7, G. } & \text { B. C. G. H. }: 1774 \\ \text { Grn. whit. } 7, \text { H. } & \text { B. Crete }\end{array}$

Red . 6, H. B. Levant: 1824

Red: 6, H. A. Spain . 1123

White $6, \mathrm{H}$. Her. P. Iberia - 1 16

Red . 4, H. A. Greece . 1817

Pa.pur. 6, H. A. Portugal * 1817

Red $: 6, \mathrm{H} . \quad$ A. Minorea : 1817

Purple: 6, H. A. Ailly

Whit. yel. 7, H. Her. P. Volga - . 1823

White 6, H. Her. P. Tauria * 1819

White 6, H. Her, P. Sicily

White . 6, H. Her. P. Caucasus - 1803

Yellow : 6, H. Her, P. Hungary, 1804

Pink 6, F, Ev, S. Sicily : 1629

Pink: 6, H. A. France: 1683

Purple 6, H. A. 1816

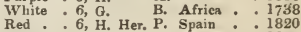

White $\tau, \mathrm{H}$. A.

White 6, H. Her. P. Altaia . 1819

White: 6, H. Her. P. 1822

White.6, H. A. Spain . 1821

Red . 6, H. Her. P. Spain - , 1819

White: 6, H. A. Barbary : 1817

White . 6, H. A. N. Africa 1818

Red . 6, H. A. Pritain 1817

White - 7, H, Her. P. Britain

White:7, H. Hex, P. Hungary : 1800

White $.5, \mathrm{H}$. B. Italy ? 1759

Pink.: 6, H. Her. P. Siberia : : 1817

White 7, H. Tr. B. Caueasus: 1818

Searlet : 7, H. Her. P. S. Amer. 1823

Red . 6, H. A. Greece . 1817

White: $6, \mathrm{H}$. Her. P. Barbary : 1817

Grn, yel. 7, H. A. Portugal : 1817

Wlit. grn. 6, H. Her, P. Carniola . 1816

Red . 6, H. A. Spain . 1818

Li. pur. 8, H. Her. P. Hungary - 1793

$\begin{array}{ll}\text { Grn. wht. 7, H } & \text { A. Aleppo : } 1822 \\ \text { Pink. 6, H. } & \text { A. Portuyal : } 1732\end{array}$

White 8, H. Her. P. Britain

White: 8, H. De. Tr. England

Purple : 6, F. Her. P. Mexico : 1827

Pink. 8, H. Her. P. Italy : 1739

White 6, H. B. Hungary : 1896

B. Hungary - 1816

White $6, \mathrm{H}$

Pink. . 7, H.

. $\%, \mathrm{H}$

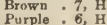

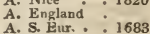

A.

A.

1815

1820
White $7, \mathrm{H}$. B. Hungary .1794 


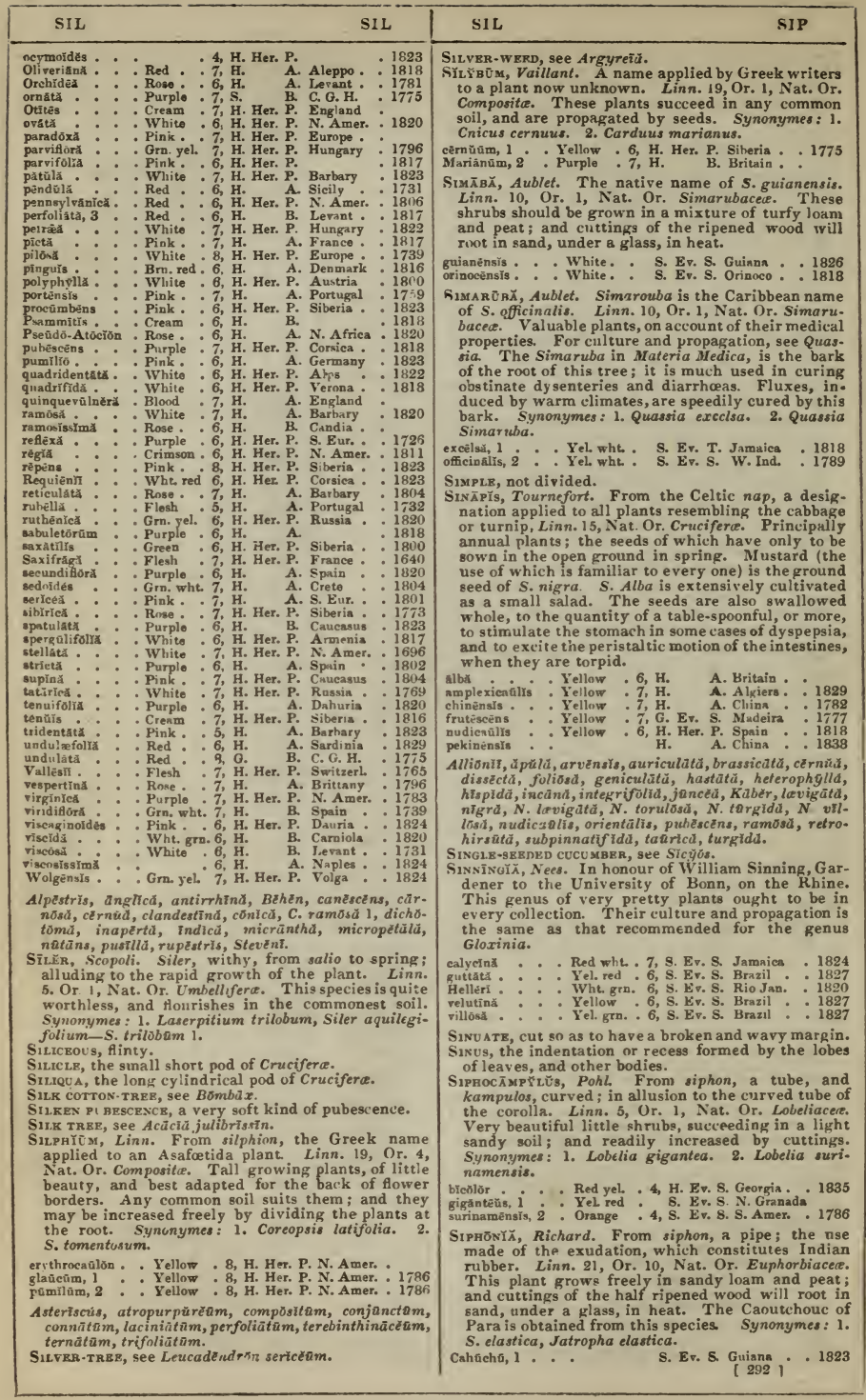


Sir JosRPR BANKs' pINe, see Aruucärlă imbricătă.

Sîsós, Linn. From the Celtic sisun, a running stream some plants formerly in this genus were found in running streams, Linn. E, Or. 2, Nat. Or. $\boldsymbol{C}^{\top}$ mbellifera. The seeds merely require sowing in common garden soil in spring-S. Amōmüm, arvēnsë, capilläcĕñm, flexuósüm.

Sistotrêmă, Fries. From sisto, to place, and trema, oririce; alluding to the pores being in rows. Linn. 24, Or. 9, Nat. Or. Fungi. This species is found by the waysides-S. conflüens.

Sisfrmbrî́, Allioni. An old Greek name of unknown origin. Linn. 15, Nat. Or. Cruciferce. $S$. Millefrlium is a pretty shrub, growing freely in any light soil; and readily increased by cuttings. The others are worthless annuals and biennials, flourishing in the open ground, in any soil. Synonymes: 1. S. sinapioides, Simapis pyrenaica. 2. S. altissimum. 3. S. orientale. 4. S. Loeselii. 5. S gallicum. 6. S. glabrum. 7. Erysimum officinale. 8. S. affine. 9. S. contortum.

Millefơlium - Yellow * 7, G. Ev. S. Canaries . 1779

Acutūngǔlūm 1, aspẻrūm, austrüăcūm, brachycārpâm, bursifôliñm, canēscêns, Colñmnā, C. altissimūm 2, C. orientīlé $3, C$. villosĩssìmūm 4 , contortuplicätūm, cornīcūlätũm, crassîfolīūm, Cummingiänüm, eckshartsbergënsé, erysimoz̃dès, fügāx, hirsutûm, hispä-

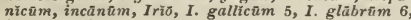

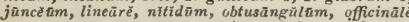
7, pannönīcūm, pêrsícum, pinnatîfidūm, polyceră-

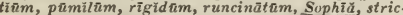
tĩssìmūm, subhastūtàm, supĩnùm, tunacetufotiùm, $\boldsymbol{T}$. affinè $8, T$. contörtüm 9, turaxacifoliūm, Tillièri, torulosūm, tripinnūtūm.

Sisyrīxchî̀u, Linn. From sys, a pig, and rygchos, snout; so called on account of swine grubbing the roots. Linn. 3, Or. 1, Nat. Or. Iridacee. A genus of very pretty plants when in flower. They succeed well in any light soil; and increase freely by seeds or offsets. Synonymes: 1. Marica iridioides. 2. M. iriäifolia. 3. S. bermudianum. 4. M. plicata.

ancêps . . Blue - 6, H. Her. P. N. Amer. - 6, G. Her. P. Bermudas : 173 calífórnícūm : Yellow, 7, F. Her. P. Californ. 1796 chilênsé : Blue 7, G. Her. P. Chile : 1826 convolūtüm : Yellow . 5, F. Her. P. S. Amer. : 1816 CummineII : : Cream . 7, H. Her. P. S. Amer. giaucophyllüm Blue : $8, \mathrm{H}$. Her. P. N. Amer. graminifoliūm: Yellow: 4,F. Her. P. Chile púmílúm : Yellow . 10, S. Her. P. Chìle grandiflórūm : White. 5, H. Her. P. N. Amer. hirtellūm : White. 7, F. Her. P. N. Amer. iridifolro : Yellow. A. Amer. jlincéum : Lilac.

lâxūm: : : Yellow

lūtéúm . Yellow

macrocéphalum . Yellsh.

maculătūm - Yel. spot

micrānthūna - Yellow

mucronātũm : : Blue
Nuttălli, 3. : Blue

odoratissimuñm : White .

palmifolium . White.

pedunculātũm . Y Yllow

plicătūm, 4

speciósúm

tenuifơlîum

Blue

Yellow

6, F. Her. P. S. Amer.

6, G. Her. P. Chile

6, F. Her. P. Chile

6, F. Her. P. S. Amer.

7, F. Her. P

6, F, Her. P. Chile

6, G. Her. P. S. Amer.

6, H. Her. P. N Amer.

6, H. Her. P. N. Amer.

6, F. Her. P. S. A mer

2, S. Her. P. Brazil

9, F. Her. P. Chile

2, S. Her. P. W. Ind.

6, G. Her. P. Clile

6 , H. Her. P. Mexico

1832

1830

1825

1826

1830

1832

1823

1830

1815

1812

1828

1823

1827

1779

$1-88$

Sî̀, Linn. From the Celtic siv, water; the habitat of most of the species. Linn. 5,. Or. 2, Nat. Or. Umbelliferce. These plants thrive best in a very moist soil; and are increased readily by dividing the roots, or by seeds. The succulent roots of $S$. Sisarum were formerly much esteemed in cookery under the name of Skirret. Synonymes: 1. Bunium ferulaceum, ferulafolium.

Falcåria

White - 7, H. Her. P. Europe

1726

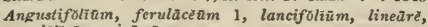
podolicum, virēscēns.

SktrRkT, see Sĭùm Sisărūm.

Skullcap, see Scutelläriü.

Slippra plan'r, see Pedilänthès.

Slipprawort, see Calceolürîă.

SiLĀNǨ̆, Linn. In honour of Sir Hans Sloane, once President of the Royal Society, founder of the British Museum, and Chelsea Botanical Garden, died in 1753. Linn. 13, Or. 1, Nat. Or. Tiliacece. A genus of fine lofty growing trees, with large leaves. They sucreed best in a mixture of loam and peat; and cuttings of the ripened wood will root in sand, under a glass, in heat.

dentátx . White S. Ev. T. S. Amer 1759 sinemariēnsis: : White. : S. Ev. T. Guiana. : 1823 SLoz-TRkE, see Prãnŭs spinosă.

Small hur, see Triumfettŭ Lappǔlă.

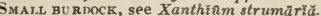

Small carnamon, see Amömūm Cardamómàm. SMALl LUPINE, see Lupz̃nŭs nānūs.

Small monarda, see Pycnänthèmúm monardelltŭ.

Smalr palm, see Sübül Palmēttó.

SMALl PEPPER MINT, see Thỹmüs Piperelllă.

SMRATH MĀNNǏ̃, Decandolle. In honour of Smeathman, a naturalist, who travelled in Africa, and collected many botanical specimens. Linn. 13, Or. 6, Nat. Or. Passifloracee. A very beautiful shrub, which ought to be in every stove. A compost of loam, peat, and sand, suits it; and half ripened cuttings root freely in sand, under a glass, in heat.

lævigată . . White . . 2, S. Ev. S. S. Leone . 1823

Sminač̄̌ă, Desfontaines. From smile, a scraper; alluding to the roughness of the stems. Linn. 6, Or. 1, Nat. Or.Smilacer. Interesting plants, succeeding well in any light soil; and increased readily by divisions.

bifolia

borealis

canadēnsǏs

ciliăta

racemōsă

ramósă

stellătă

umbellati

\section{White.
Yellow}

5, H. Her. P. N. Eur. 6, H. Her. P. N. Amer. : 1812 White. 5, H. Her. P. N. Amer. 1823 Pa. yel. 5, H. Her. P. N. Amer. 1640 Pa. yel. 5, H. Her. P. Siberia White $5, \mathrm{H}$. White. .5 , H. Her. P. STer. 1633 White : 6, H. Her. P. N. Amer. 1812

Smī̌ñx, Linn. From smile, a scraper; the stems are rough from prickles. Linn. 22, Or. 6, Nat. Or. Smilacex. Climbers, of little beauty. They grow well in loam and peat; and increase readily by suckers. S. Sarsaparilla is well known as a restorative of health, after the use of mercury. Synonymes: 1. S. mancitanica. 2. S. lanceolata, Watsoni. Chină * . Wht. grn. F. Ev. Cl. China - 1759 sagittæfolră * Grn, wht. 7, H. Ev. Cl. N. Amer. * 1812 Sarsaparilla : White. 9, G. Kv. S. China - 1820 Sarsaparillă : : Wht. grn. 7, H. Ev. Cl. N. Amer. : 1664
Watsōni Acuminātă, alpīnă, aspěră, A. auriculātă, A. mauri-

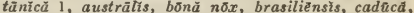
canariēnsis, catalénĭcă, cumanēnsìs, excẻlsü, gläbrü, glañcă, glycy phyllă, hastätă, H. lanceolätă 2 , hava-

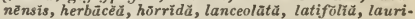
föliă, longifolüă, maculätă, ñ̄gră, ovalifölăă, pedun. culāris, prolíféră, Pseâdō-Chīnă, pabèră, quadrangulürìs, rotundifoliă, syphilitǐcū, tamnoĩdës, virginž̆ünă, Walterĭ, zeylänăcă.

Sмгтнй , H. Ken. In honour of the late Sir James Edward Smith, M.D., F.R.S., and P.L.S., founder of the Linnæan society, possessor of the Linnæan herbarium, and author of numerous well-known botanical works; died in 1829. Linn. 17, Or. 4, Nat. Or. Leguminose. The seeds of these plants should be sown in pots, in a mixture of peat, sand, and loam, and placed in heat. They must be potted off singly, and shifted into larger pots as they grow.

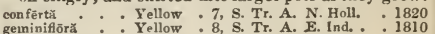
sensitivă $:$ : Yellow : 8, S. Tr. A. E. Ind. : 1785

Sмоотн, without hairs.

SMr̃rxî̀, Linneus. From smyrna, myrrh; the plants have the odour of Myrrh. Linn. 5, Or. 2, Nat. Or. Umbelliferce. These plants succeed in any common garden soil; and are readily increased by seeds.

apiifolıum . . Pur. yel. . 6, H. B. Candia . . 1731 cícutariüm: : Grn. wht. 6, H. Her. P. Caucasus : 1827 . Green . 5, H. B. Britain .

SNAIL-FTower, see Phaserlăs Caracällă.

SNAKE-(ЮURD, see Trichosanthēs.

SNAKE-ROOT, see Aristolochỉü serpentärĩă.

SNAKB-ROOT, see Ophiorhiză.

SNAKR's-BBARD, see Ophiopogסn.

SNAKE's-TONGUB, see Ophinglosstum.

SNAKZWRIE, see Polygơnūm bistörtă.

SNAKEWOOD, see Cecröpĩă.

SNAKEWOOD, see Colubrīnă.

SNAPDRAGON, see Antirrhinūm.

SNapDRAGon, see Silēné antirrhinud. 


\begin{tabular}{|c|c|c|c|c|}
\hline SNA & SOL & & & $O L$ \\
\hline 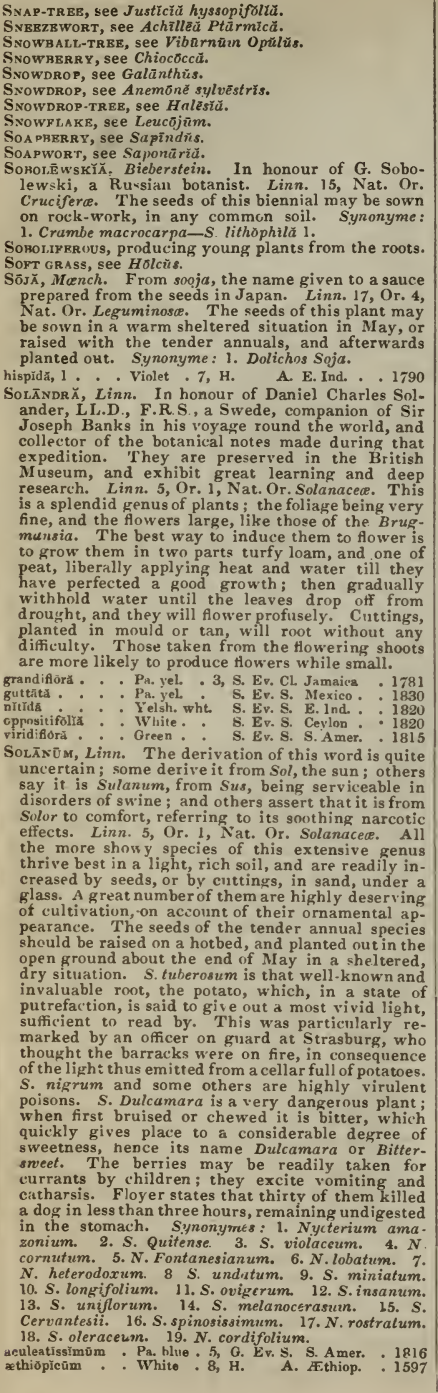 & 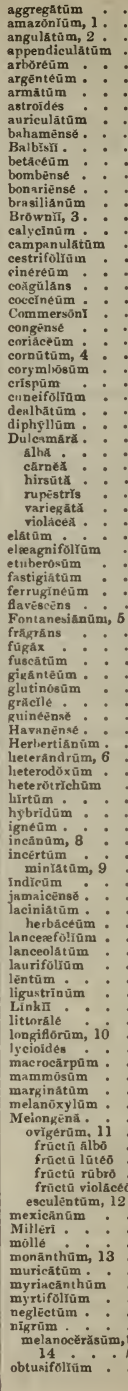 & 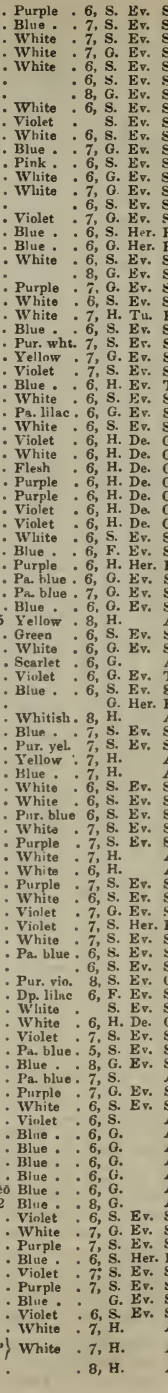 & 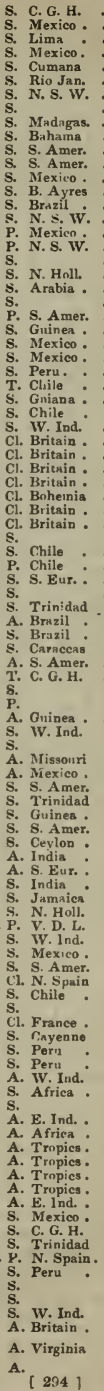 & 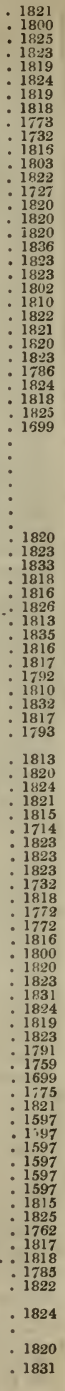 \\
\hline
\end{tabular}




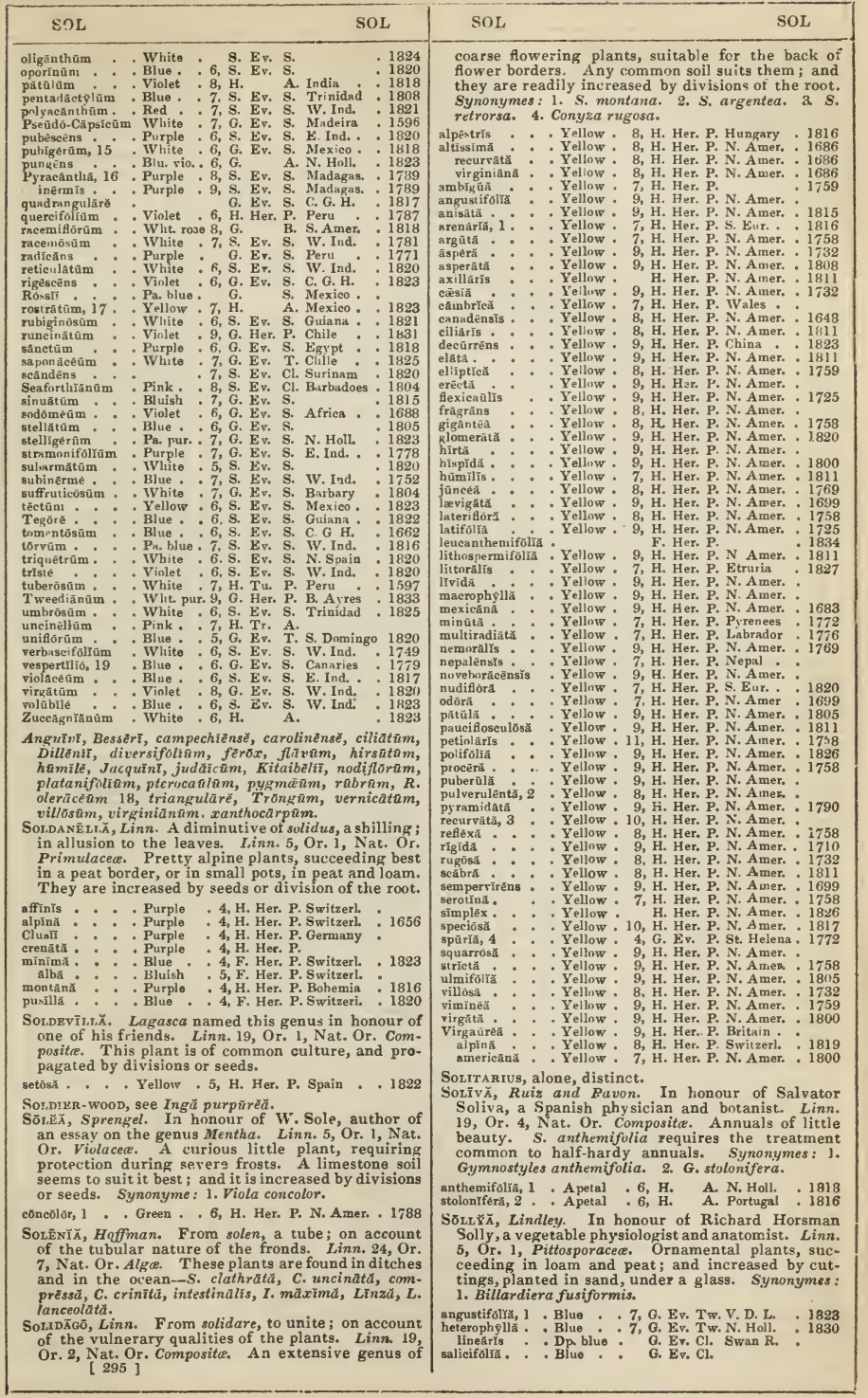




\section{Solomon's sEAL, see Convalläriă.}

Sotorĩnă, Acharius. From solos, solid, and rhinos, skin; in allusion to the firm texture of the fronds. Linn. 24, Or. 8, Nat. Or. Lichenes. Leafy fronds, found on the soil upon the tops of mountains-S. cröcēă, saccätă.

SOMNiFRR Us, causing sleep.

Sōscнŭs, Linn. From somphos, hollow; the stems are hollow. Linn. 19, Or. 1, Nat. Or. Composite. Plants of easy culture in any common soil. The shrubby kinds are increased by cuttings, placed in sand, under a glass; the herbaceous species by divisions. The seeds of the annual and biennial kinds only require to be sown in the open ground. Synonyme: 1. S. Jacquinii.

\begin{tabular}{|c|c|c|c|c|}
\hline 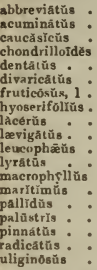 & $\begin{array}{l}\text { Yellow } \\
\text { Y Yellow } \\
\text { Yellow } \\
\text { Y Yellow } \\
\text { Y Yellow } \\
\text { Y Yellow } \\
\text { Y Yellow } \\
\text { Yellow } \\
\text { Yellow } \\
\text { Y Yellow } \\
\text { Purple } \\
\text { Yellow } \\
\text { Blue } \\
\text { Yellow } \\
\text { Y Yellow } \\
\text { Y Yellow } \\
\text { Yellow } \\
\text { Y Yellow } \\
\text { Yellow }\end{array}$ & $\begin{array}{l}\text { 6, G. Ev. S. } \\
\text { 8, H. } \mathrm{B} . \\
\text { 8, H. Her. P. } \\
\text { 6, H. } \\
: \text {, H. Her. P. } \\
: 7, \text { H. Her. P. } \\
: \text {, G. Ev. S. } \\
\text { 6, G. Ev. S. } \\
\text { 6, H. } \\
\text { A. Ev. S. } \\
: \text {, H. E. B. } \\
\text { G. Ev. S. }\end{array}$ & $\begin{array}{l}\text { Teneriffo } \\
\text { N. Amer. } \\
\text { Caucasus } \\
\text { Spain } \\
\text { Siberia : } \\
\text { Madeirs } \\
\text { Madeirs } \\
\text { Madeira } \\
\text { N. Amer. } \\
\text { Madeira } \\
\text { N. Amer. } \\
\text { S. Eur. } \\
\text { Canada : } \\
\text { England } \\
\text { Madeira } \\
\text { Canaries } \\
\text { Caucasus }\end{array}$ & $\begin{array}{r}1820 \\
: 1812 \\
: 1818 \\
: 1729 \\
: 1832 \\
: 1823 \\
: 1777 \\
: 1821 \\
: 1820 \\
: 1816 \\
: 1816 \\
: 1823 \\
: 1748 \\
: 1704 \\
: 1777 \\
: 1780 \\
: 1821\end{array}$ \\
\hline
\end{tabular}

Arvẽnsĭs, äspěr, oleräcēŭs, racemósŭs, rösěŭs, taraxaciföliăs, tenêrrimŭs.

SOPHठ̆Rn̆, R. Bron'n. Altered from sophera, the A rabic name of a papilionaceous tree. Linn. 10, Or. 1, Nat. Or. Leguminosa. S. chinensis and S. japonica are two of the most handsome species, and well adapted for growing singly on lawns. When young, they require a slight protection in winter. They are sometimes increased by layers, but generally by seeds. The stove and greenhouse kinds thrive well in a light, losmy soil; and cuttings will root, if planted in sand, under a glass. The hardy herbaceous kinds are increased by dividing the roots in spring. Synonyme: 1. Astragalus carnosus.

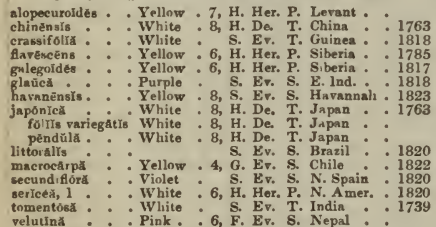

Sophronītis, Lindley. From sophrona, modest; in allusion to the pretty little flowers of the original species Linn. 20, Or, 1, Nat. Or. Orchidacea. S. grandiflora is a very lovely plant, the blossom being laxge, internally of a uniform red colour, approaching to orange, with darker red streaks; the other species are also well worthy of cultivation, for which, see Burlingtonia. Synonymes: 1. Sophronia cernua. 2. Cattleya coccinea.

cểrnǔă, 1 . - Red * * . 6, S. Epi. Rio Jan. . . 1827

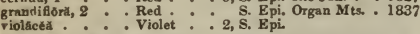

Sörortūa, Persoon. From Sorghi, its Indian name. Linn. 23, Or. 1, Nat. Or. Graminea. Annual plants, growing in any common soil; and increased by seeds. Synonymes: 1. Holcus avenaceus. 2. S. arduini.

avenđẹúm, 1 . Apetal . . 7, Grass. C. G. H. . . 1816 avenaceum, 1 : A petal: : 7, Grass. Persia : 1816 Caffrórum, 2 : : A petal : : 7, Grass. C. G.H. : : 1816

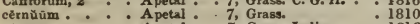
cêrnưữm: : : : A petal : : 7, Grass. Grass. India . : 1810

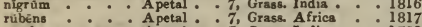

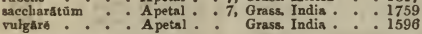
Elongätam, halepensè.
SorI, the patches of tructification on the back of the fronds ot ferns.

SoRINDEİA, Thouars. Not explained. Linn. 23, Or. 2, Nat. Or. Burseraced. This shrub may be referred to Boswellia for culture and propagation.

madagaseariênš̃s. Purple . S. Ev. S. Madagas. . 1828

SoRocĔpHĂLÜs, R. Brown. From soros, a heap, and kephale, a head; in allusion to the clustered heads of flowers. Linu. 4, Or. 1, Nat. Or. Proteaced. This genus of ornamental shrubs ought to be in every collection. For culture and propagation, see Protea.

diversifolu - Purple $6,0$. Ev S. C. G. H. imbërbis - Purple 6, G. Ev. S. C. G. H. imbricata : : : Purple : 7 G. Ev. S. C. G. H. : 1806 lanãtă . : Purplo : 8, G. Ev. S. C. G. H. 1790 setacéă . * Purple : 7. G. Ev. S. C. G. H. : 1823 spactal loídès : : Purple : 7, G. Ev s C. G. H. 1813

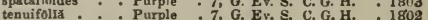

SORREL, see Ramẽx Acetosă.

SORREL TRBE, see $A$ nd ròméd d̆ arbðrĕĕ.

SoULĀNGĬĂ, Brongniart. In honour of Soulange Bodin, an eminent nurseryman near Paris Linn. 5, Or. 1, Nat. Or. Rhamnacec. Interesting plants, which may be referred to Phylica for culture and propagation. Synonymes: 1. Phylica arborea. 2. P. axillaris. 3. P. buxifolia. 4. P. cordnts. 5. P. dioica. 6. P. myrtifulia. 7. P. oleafolia. 8. P orientalis. 9. P. paniculata. 10. P. recliata. 11. $P$. thymifolia.

arborẽa, 1 . . White - G. Ev. S. Trist. d'Acun 1817 axillaris, 2.: White：5, G. Ev. S. C. G. H. . 1812 buxifoliă, 3 : Whĭ̌e : 7, G. Ev. S. C. G. H. : : 1759 cordata, 4. : Pur yel. 5, G. Ev, S. C. G. H. : : 1789 myrtifolia, 6 : Drk. yel. 7, G. Ev, S. C. G. H. : 1817 olezfolia, 7 : : White 6, G. Ev. S. C. G. H. : : 1800 orientallis, 8: : White : 6, G. Ev. S. C. G. H. : 1800

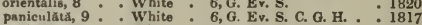
reclinkta, 10: : White : 6, G. Ev. S. C. G. H. : 1823 rubra : Red : 12, G. Ev. S. c. G. H. : : 1827 thymirgira, $111^{\circ}$ : White: 6, G. Ev, S. C. G. H. : : 1820

SOUR GOURD, see Adansoñŭ digitäta.

Sour guM, see Ngssă villosă.

Soursop, see Anond muricatd.

South ERNwOOd, see Artemisid arborezd.

SoUTH SRA TBA, see Ilex vomitoriă.

Sowrra夜, Smith In honour of James Sowerby, F.L.S., an eminent botanical artist. Linn. 6 , Or. 1, Nat. Or. Liliacea. This species succeeds well in sandy loam and peat; and young plants are readily obtained by divisions.

jance̊r . . Pink . . 5, G. Her. P. N. S. W. - 1792 SowTH1str.в, see Sonchŭ๕.

Soy, see Soja.

SPADIX, a spike enveloped in a spatha.

SPANĀNThê, Jacquin. From spanos, rare, and anthos, a flower; few flowers in the umbel. Linn. 5, Or. 2, Nat. Or. Uimbellifera. A stove biennial, not worth growing. Synonyme: 1. Hydrocotyle Spananthe-S. paniculätü 1.

SPANish HROOM, see Spãrtiam jancẽ im.

SPANiSH CRESS, cee Lepldîfim cardaminès.

SPANish ELM, see Côdiä Geraschīnthũs.

SPAxish nUT, see Moräă Sisyriachiam.

BPARÃXIs, Ker. From sparasso, to tear; alluding to the lacerated spathes. Linn. 3, Or. 1, Nat. Or. Iridacea. The species of this genus are very pretty when in flower. For culture and propagation, see Ixia. Synonyme: 1. Ixia auemoniflora.

anemoniflor $\mathrm{ă}_{1} 1$. White . 6, G. BL. P. C. G. H. 1825 bicolor bulblferă : : Vinlet 5, G. Bl. P. C. G. H. : 1758 fragrans : : Y Yellow : 6, G. Bl. P. c. G. H. $: 1825$ grandiflor . - P Purple * 4, G. Bl. Y. C. G. H. 1758

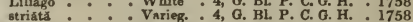
Itreatata $: \vdots:$ : Wht. plo 4, G. Bl. P. C. G. H. pendüla : : : : Drk pk. 6, F. BL P. C. G. H. 1825 stellaris. : : Purple . 7, F. Bl. P. C. G. H. : 1836 túcollör : : Orange : 5, G. B. P. C. G. H. : 1789 róséo-aiba : Pink : 4, G. Bl. P. C. G. H. 1811 sanguineo-purpŭrea Red . 4, G. Bl. P. C. G. H. . 1811 violácé-purpüré. Vi. pur. : 4, a. BL P. C. G. H. : 181 rersicolor pur. yel. 9, F. Bl. P. C. G. H. : 1825 SrargăNYơ, Linn. From sparganon, a fillet; because of the riband-like leaves. Linn. 21, Or. 3, Nat. Or. Typhacea. The common Bur Reed, found in ditches 
and stagnant waters: increased by seeds- $S$. alpinnam, nätäns, ramósūm, simplēx.

SPARGAXÓPHÖRŬs, Guertner. From sparganon, a fillet, and phoreo, to bear; shape of the seeds. Linn. 19, Or. 1, Nat. Or. Compositce. Tender annuals, not worth cultivating-S. Strüchìum, Vuilläntīin, verticillütüs.

SPARMANNİA, Thunberg. In honour of Andrew Sparmann, M.D., a Swedish botanist, who accompanied Captrin Cook in his second voyage round the world. Linn. 13, Or. 1, Nat. Or. Tiliacece. This beautiful early flowering shrub succeeds best in a mixture of loam and peat; and cuttings root freely in sand, under a glass.

africana. White . 5, G. Ev. T. C. G. H. . 1790

STARrow wort, see Passerină.

Starrow-Wort, see E ticŭ Passeriñŭ.

SFARSA, scattered.

SPARTINÁ, Schreber. From spartine, a rope made from broom. Linn. 3, Or. 1, Nat. Or. Gramineœ. Perennial grasses, of very easy culture; and increased by divisions and seeds.

alterniflórä . . . A petal . . 7, Grass, France . . 1819

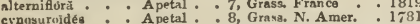

geniculatx 0 Apetal 7, Grass Java

jancéă : : Apetal : 7, Grass. N. Amer. : 1781

páténs : : A petal : 7, Grass. N. Amer. 1781

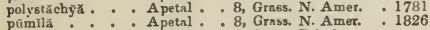

strietä : : : A petal : 8, Grass, Brituin

SpÄrtỸō L, Linn. From sparton, cordage; use made of the plant in early ayes. Linn. 16, Or. 6, Nat. Or. Leguminos.. These plants, from being very ornamental when in flower, are well adapted for planting in shrubberies. They are usually increased by seeds, but cuttings of the young wood will root, if planted under a glass.

acutifoliùm . Y Yellow . 8, H. De. S. Turkey. . 1836 jünceûm : : Yellow : 8, H. De. S. S. Eur. : 1548 före plénó : : Yellow : 8, H. De. S. S. Eur. : 1548 odoratissimum: Yellow : 7, H. De. S. Persia : 1834

Spatalānthǔs, Sweet. From spatalos, delicate, and anthos, a flower. Linn. 16, Or. 1, Nat. Or. Iridacee. A beautiful-flowering Cape bulb, succeeding in sandy loam and peat; and increased by offsets. Synonyme: 1, Trichonema monadelpha.

speciōsŭs, 1 .

H. Bl. P. C. G. H

. 1825

SPATĀLLĂ, Salisbury. From spatale, wantonness. Linn. 4, Or. 1, Nat. Or. Proteacea. This genus of ornamental plants requires the same treatment as that recommended for Serruria.

bracteata : Purplo : 6, G. Ev. S. C. G. H. 1806 brevifolia * - Purpie * 7, G. Ev. S. C. G. H. 1823 caudată : : Purpie : 6, G. Ev. S. C. G. H. : 1812 incūrră : : : Purpie : 5, G. Ev. S. C. G. H. : 1789
mollis nǐĕ : : : Purple : 6. G. Ev. S. C. G. H. : 1806 proirféră * : Purple : 7, G. Ev. S. C. G. H. : 1800 ramulosă : Purple : 8, G. Ev. S. C. G. H. : 1787 Spatra, a broad sheathing leaf, enclosing fiowers arranged on a spadix.

SpAThËLIĂ, Linn. From spathe, a palm-tree; similarity of habit. Linn. 5, Or. 3, Nat. Or. Amyridacees. This tree succeeds best in a mixture of loam and peat; and ripened cuttings will root in sand, under a glass, in heat.

eimplëx. . . Red . . S. Ev. T. Jamaica , 1778 SPAтHōDĔ, Beauvgis. From spathe, a spatha, in reference to the form of the calyx. Linn, 14, Or. 2 Nat. Or. Bignoniacece. This is a genus of truly splendid plants when in flower. For culture and propagation, see Bignonia. Synonymes : 1. Bignonia fraxinifolia. 2. B. chelonoides. 3. B. spathacea. 4. B. quadrilocularis. 5. B. uncata.

eorymbösă . - Yellow - S. Ev. T. Trinidad . 1824 S. Ev. Ci. Caraccas : 1829

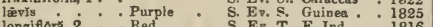
longiflóra, 2 . Red * S. Fv. T. E. Ind. : : 1816

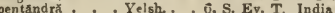

Rhêedn, 3. Cream : S. Ev. T. E. Ind. : 1794 Roxbürghil, 4: Pink : S. Ev. T. E.Ind. : 1820 uncâta, 5 : : : Yellow : S. Ev. Cl. Guiana : : 1804

Sратнёцйӑ, Fries. From spathula, a spreading knife so named from the form of the plant. Linn. 24, Or. 9 , Nat. Or. Fungi. This species is found in autumn upon dead leaves $s$. flăvĩdă.

Spatuia, a spatulate-shaped process.
Spaturate, like a spatula, a knife having the upper end broadest.

SPRARWORT, see Ranūncŭlŭs flämměă.

Sprcklin Ĭ , Lindley. Named after Rudolph Speckin, the artist who drew the woodcuts in Fuchs's Historia Plantarum. Linn. 20, Or. 1, Nat. Or. Orchidacea. Small plants, with dull green, purplespotted flowers. For culture and propagation, see Burlingtonia.

atropurpúréă . . Dk, pur. . S. Epi, Jamaica . . 1834 ciliariss obuvătă

orbiculârís: : Purple : S Epi. Demerara : 1836 rêpêns : : Grn. pur. : S. Epi. Mexico : 183.

SPRCULĀR Veneris. Linn. 5, Or. 1, Nat. Or. Campanulacece. For culture and propagation refer to Prismatocarpus. Synonymes: 1. Prismatocarpus filcatus. 2. $P$. hybridus. 3. $P$ pentagonius. $4 P$. perfoliatus. 5. $P$. sjeculum. 6. P. hirsutus.

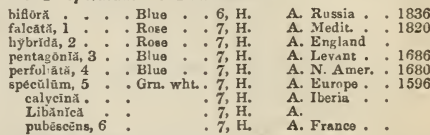

SPREDWrLi, see Veroñicŭ.

SPRLT, see Trïticū spêltă.

SpergǔLă, Linn. From spargo, to scatter; because it expels its seeds. Linn. 10, Or. 4, Nat. Or. llle. cebracece. None of these plants are worth cultivating, except in botanical gardens. They grow in any moist situation-S gläbră, la rĭcină, nodosŭ, pilifërü̆, saginō̄dès, subulātū.

SPERGULĀRİ̈, Persoon. Altered from Spergula, which see for explanation. Linn. 10, Or. 4, Nat. Or. Caryophyllacea. Worthless plants, undeserving of the culturist's care-S. arvēnsis, pāllìdă, pentāndră.

SpRrgutästrüm, Michaux. From spergula, spurry, and astrum, an affixed term, signifying like. Linn. 10, Or. 3, Nat. Or. Alsinacee. This species is of no interest, except in botanical collections. Sandy peat suits it, and young plants may be obtained by dividing the roots or by seeds. Synonyme: 1 . Micropelalon lanuginosum.

lanuginösûm, 1 . Wht. pnr. 6, H. Her. P. N. Amer. . 1821 Sipermacōce, Dillenius. From sperma, a seed, and akoke, a point; in allusion to the capsule being crowned by the calycine points. Linn. 4, Or. 1, Nat. Or. Cinchonacec. The species of Spermacoce are of the simplest culture. Any light soil suits them: and curtings of the shrubby and perennial kinds root freely in the same kind of soil, in a little heat. The annual species require the treatment common to hardy and tender annuals: Synonymes : 1. S. lavis. 2. S. strigosa.

glabră . . . White 7 , Roxburghir, 1: : White: 7, H. A. W. Ind. 1818 rübră, 2 : : Red : 10, s. A. Mexico: 1797 tenüror. : : Pink: : $7, \mathrm{H}$. A. W. Ind : 179

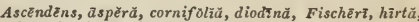
hĩspũdă, lävìs, latifoliă, linifoliă, mucronätă, rădicāns, scäbră, stylosă, suffruticơsă, villossă.

SPERMODERM, the outer covering of a seed.

SPERMĀX X̌RÛM, Labillardière. Froin sperma, a seed. and axyra, an anchor; the umbilical funicle is shaped like an anchor. Linn. 3, Or. 1, Nat. Or. Olacaces. This species succeeds best in loam and peat; and cuttings will root in sand, under a glass.

strictūm - . White. . G. Ev. S. N. Holl. . 1820

SPFRMó̄dĭ, Fries. From sperma, a seed, and a noideo, to 8 well; the diseased seeds. Linn. 24, Or. 9, Nat. Or. Fungi. This very minute species is found in autumn on the glumes of grasses-S. clēvtrs.

SPHACRLATE, withered, or dead.

SрнАс ̌̆ $\breve{E}$, Bentham. From sphakos, sage; similarity. Linn. 14, Or. 1, Nat. Or. Labiatce. Free-flowering plants, of easy culture in any light rich soil. Cuttings root readily in earth, under a glass. Syno. nyme: 1. Stachys Salvive.

eampanulătă . Pa. bluө . 7, G. Ev. S. Chile • . 1795 Lindlèyi, 1 : Violet : 7, G. Ev. S. Chile : : 1825 SPHACEı.LĀRĬh̆, Ly"gbye. From sphakelos, gangrene: 80 
appearance of the truncate extremities of the fronds. Linn. 24, Or. 7, Nat. Or. Alg @. These species are found in the ocean, on the sea-shore, \&c.S. cirrhסsă, C. palentissỉmă, distichă, Mertēnsīi, plumósă, racemōsă, rădicāns, scopārīă.

SPHÆRÃLẼ̆, St. Hilaire. From sphaira, a globe, and alcea, marsh-mallow. The carpels are disposed in a round head. Linn. 16, Or. 8, Nat. Or. Malvacea. Ornamental plants. For culture and propagation, see the greenhouse species of Malva. Synonymes: 1. Malva abutiloides. 2. M. angustifolia. 3. M. caroliniana, Modiola caroliniana. 4. M. decumbens, Modiola decumbens. 5. M. elegans. 6. M. obtusiloba. 7. M. prostrate, Modiola prostrata. 8. Mr. umbellata.

abutiloidès, 1 . Purple . 8, G. Ev. S. Bahamas - 1725

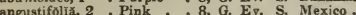
enroliniâná, 3 . Dk, red . 8, H. A. N. Amer. . 1723 decümbēns, 4 : Red : : 4, G. Her. P. S. Amer. : 1815 elégans, 5
obtusíoha, 6. prostrăti, 7 : Red : 7, H. A. Brazil : 1806 umbellată, 8. : Violet: : 4, S. Ev. S. N.Spain : 1814

SpमARĀNTHǓs, Linn. From sphaira, a globe, and anthos, a flower; alluding to the globular heads of towers. Linn. 19, Or. 1, Nat. Or. Composita. Stove plants, not worth growing-S. africänũs, hĩrtús, indicǔs.

SPH我藏, Linn. From sphaira, a globe; their shape. Linn. 24, Or. 9, Nat. Or. Fungi. Án extensive genus of very minute plants, foind at all seasons on a variety of decayed substances, as on the leaves and trunks of trees, honeysuckle leaves, fir cones, \&c. -S. acervätă, acuminütă, acâtă, AEgopödii, affinis. ulutäcēă, ambiēns, Angélicāe, anserīnă, aquifóliă.

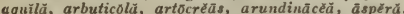

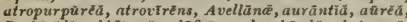

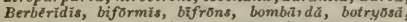
Brüssīcāe, brunnēolă, bullätă, byssisědă, cälvă, canẽs. cēns, capitätă, carpóplülă, ceratospērmă, ceuthocärpă, ceuthosporoìdĕs, cinnabarină, cirrhosă, citrina, clypeãtă, coccīnĕŭ, cohārēns, comätă, complanätă, concentrićă, convêrgēns, cornīcolü, corniculītä, coronätŏ, Cory̆lĭ, crinită, culmifrĕgă, cupulärĭs, curvirostră, Demūtîum, deñstă, Diānthĭ, digitütă, drotcă, disciformk, discatiěns, ditōpă, dollölâm, dothidēă, dâplexx, ellĩptică, elungată, Empetri, enteroleâcă, ẽntipủ, en tomorrhìză, excipuliformìs, favaiceü, ferrugìnéu, fibrosh̆, filicină, fimbriātü, fimeti, flavouIrēns, fragifor. $m i s$, frondícolü, fuliginठsă, furfuräcẻ, füscă, gelati nбsă, gnбmon, grăcillis, Grăminis, gyrosă, Heděrā, hedericolă, herbärâm, hirsñtă, hîspidă, Hookêri, hypodërmǐcă, hypoxy̆lon, hystrix, Ilīcis, immersä, inquinans, inquilinä, irregularis, jugländis, Janci,

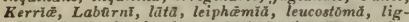

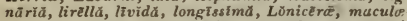
formis, malorîm, mammä formìs, melogrämmä, mi croscopică, militărìs, millepunctätă, milliärĭŭ, moriformìs, multiformìs, myriocämpä, nebulosă, nidüld̆, nigrêllă, nĩvéa, nucŭlă, nummulärĭa, obdacêns, obtu-

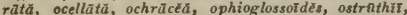
ovĩnă, pellită, petiolorâm, Peziză, pillfféră, pilosă, Pināstri, Pisi, Platäscā, polymorpha, pomiformis, populină, profüsă, pruinбsŭ, Prunästri, pulchellă, pul-

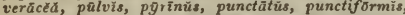
quaternätă, quercină, Racбdīum, ramosă, recutītrü, relicină, Rìbis, rosallă, rostellätă, rubëllă, rubiginosă,

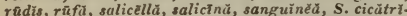
cûm, scirpicolă, scrophulärīā, semi-immērsă, sepin-

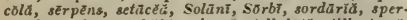
moīdĕs, sphcrocěphălă, spinøsă, stellulätă, stillostómă, striueformis, strigōsă, strobilīnă, stygmäă, succen-

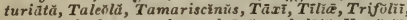

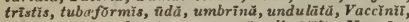
velätä, verruceformis, verrucōsä, vibrätîlis, Yâccēe.

Spr жRठ́вŏtũs, Tode. From sphaira, a globe, and ballo, to eject; the plant becomes elastic and emits a spherical sporangium. Linn. 24, Or. 9, Nat. Or. Fungi. Found in autumn, on dead wood, sharings, sawdust, \&c.-S. stellätũs.

SpH and karpos, a fruit; the seed-vessel is globular. Linn. 24, Or. 6, Nat. Or. Hepatica. This species is found during winter, in damp places-S. terrěstris.

SpHAERocóccūs, Agardh. From sphaira, a globe, and kokkos, fruit; the theca is round. Linn. 24, Or. 7, Nat. Or. Alga. The species of Spharococcus are found in the ocean, and on the sea-shore. Syno- nyme: 1. Chondria pusilla_S. aciculärĭs, Brodīäi, cartilagĭněŭs, confervō̃děs, C. älbidŭs, C. geniculätüs,

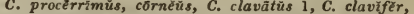

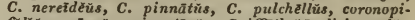

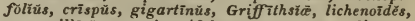
mammillossüs, membranifoliŭs, norvëgícūs, plicätŭs, purpurēscēns, rūbēns, Teēdit.

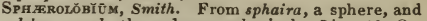
lobos, a pod; the pods are spherical. Linn 10, Or. 1, Nat. Or. Leguminosæ. These plants succeed best in a mixture of loam and peat; and young cuttings root freely in sand, under a glass. Syno. nyme: L. S. minus.

mědiũm • . Red • 7, G. Ev. S. N. Holl. • 1803 vimineùm, i : Yellow : 7, G. Bv. S. N. Hold : 1802

SPH \#RоNЕ̄mă, Fries. From sphaira, a sphere, and naima, gelatine; in allusion to the mucous recep. tacle in which the sporules are inclosed. Linn. 24, Or. 9, Nat. Or. Fungi. Found on dead wood-S. blepharistömă, subulätam.

Śph ȦRophórōn, Persoon. From sphaira, a globe, and phoreo, to bear; form of fructification. Linn. 24, Or. 8, Nat. Or. Lichenes. A very elegant genus of Lichens, easily known by its branched smooth habit. The species are found on rocks-S. compressûm, coralloìdes, frăgilè.

SPHAROPHỸsă, Decandolle. From sphaira, a sphere, and physa, a bladder; the pods are spherical and bladdery. Linn. 17, Or. 4, Nat. Or. Leguminosa. This species succeeds in common garden soil; but is difficult to preserve on rccount of the want of that saline principle in which it grows in its native country; the plants should, therefore, be occasionally watered with salted water: they are increased by seeds, which are sometimes ripened in this country. Synonymes: 1. Colutea caspica, Phaca salsula.

caspică, 1. . . Red . . 7, H. Her. P. Siberin . . 1818

SprAzRostẼmă, Blumc. From sphaira, a globe, and stema, a stamen; the filaments of the stamens are coadunated into a fleshy solid mass, the anthers only being at liberty, and nestling in a number of little excavations of the mass. Linn. 22, Or. 12, Nat. Or. Anonacea. This interesting plant succeeds well in a mixture of sandy peat and loam; and cuttings root in sand, under a glass, in heat.

propinquũm . Yellow . 7, S. Ev. CL Nepal . - 1828 Sphafostīgm, Fischer and Meyer. Frum sphaira, a globe, and stigma, a stigma. Linn. 8, Or. 1, Nat. Or. Onagracea. Same cultivation as for $\boldsymbol{O E n o -}$ thera.

Chamissonis - Yellow . 8, H. A. Russin - 1837 hirtúm : Yeliow :8, H. $\quad$ B. Russin: 1836

SprĀanūm, Linn. A name used by Pliny for some kind of moss, Linn, 24, Or. 5, Nat. Or. Musci. The species belonging to this genus are found in bogs at all seasons. The leaves are nerveless, and of a singularly whitish colour. Synonymes: 1.S.

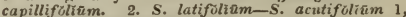

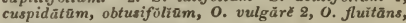
O. mīnŭ́s, squar rosūm.

SPHRNoDĒsMĚ, Jack. From sphen, a wedge, and desme, fascicle; in allusion to the fascicles of flowers. Linn. 5, Or. 1, Nat. Or. Verbenaced. This species succeeds in sandy loam; and is increased by cuttings, planted in sand, under a glass, in heat.

pentăndră

S. Ev. Cl. E. Ind. . . 1823

SPhenogřxŭ, R. Brown. From sphen, a wedge, and gyne, a female; in allusion to the wedge shaped stigmas. Linn. 19, Or. 3, Nat. Or. Composita. This is a genus of very elegant under-shrubs, and half-hardy annuals. They succeed best in a mixture of loam and peat; and cuttings of the shrubby kinds root readily in sand, under a glass. Synonymes : 1. Ursinia faniculacea, Arctotis faniculacea. 2. Arctutis leucanthemoides.

abrotanifolla - Yellow - 7, G. Kv. S. C. G. H. anthemnides: Y Yellow: 8, G. Ev. S. C. G. H. crithmifolia : Yellow: 8, H. Y. A. C. G. H. dentătă . Yellow: 6, G. Ev. 8. C. G. H. foniculẳč̆, 1 : Yellow: 8, G. A. C. G. H. leucanthemoides, 2 Yellow: 8, G. A. C. G. H. leucanthemoidès, 2 Yellow : 8 , Gellow: 5 , E. Ev. S. C. G. H. odorátă. - Yellow : 5, G. Ev. S. C. G. H. : 1774 pilifera : . Yellow: 12, G. Ev. 8. C. G. H. : 1821 
Yellow 6, G. Ev. S. C. G. H. - 177 speciōsă : : Yellow: 7, H. A. S. Amer. : 1836

Sрнвnŏtŏмă, $R$. Brown. From sphenoo, to cleave, and tome, a section; in allusion to the deeply divided limb of the corolla. Linn. 5, Or. 1, Nat. Or. Epacridaceu. Ornamental shrubs. For culture and propagation, see Epxcris. Synonymes: 1. Dracophyllum capitatum. 2. D. gracile.

capitãtūm, 1 . White. . 4, G. Ev. S. N. Holl. + 1830 grăcilos 2 : White. 5, G. Ev. S. N. Holl. 1823

SPHRR1CAL, round like a sphere.

Sphrrules, minute spheres, or globules.

Spicate, having a spike.

SPICKNEL, see Athamäntă.

SPIDER OPHRYs, see Ophry̆s aranǐferră.

SP1DERworT, see Tradescäntiă.

Spirlmàniă, Medicus. In honour of R. S. Spielmann, professor of medicine and botany at Strasburg. Linn. 14, Or. 2, Nat. Or. Verbenacea. This species will thrive in any light rich soil; and young plant are easily obtained from cuttings, planted in sand, under a glass.

africănă - . White. . 7, G. Ev. S. C. G. H. . 1710

SplgēLǏ̆, Linn. In honour of Adrian Spigelius, professor of anatomy and surgery at Padua; and a botanical author; died 1625. Linn. 5, Or. 1, Nat. Or. Spigeliaced. These plants are showy when in blossom, and therefore worth growing; a compost of loam and peat suits them best, and cuttings of the herbaceous species root freely in the same kind of soil, under a glass. The roots of $S$. marilandica are used in North America as a vermifuge, and if administered in large doses, it acts as a powerful cathartic.

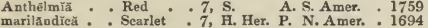

SP1kr, a long rachis of sessile flowers.

SP1KELETs, in grasses, are collections of fiorets.

SPike RUsh, see Eleochäris.

SpiLĀAthīs, Jacquin. From spilos, a spot, and anthos, a flower, in allusion to the original species havin yellow flowers and a brown disk. Linn. 19, Or. 1, Nat. Or. Composita. Worthless plants, requiring the treatment commonly given to stove annuals. Synonyme: 1. Acmella lanceolata-S. Acmēllă, älbă, brasiliēnsĭs, dēbīlǐs, exasperātă, olerūcĕă, PseūdōAcmēllă 1 , uliginösă.

Spiloc $\vec{Æ}$, Fries. From spilos, a spot; Linn. 24, Or. 9, Nat. Or. Fungi. This plant grows upon apples, whence its specitic name-S. pömí.

Sрго̄м Ă, Acharius. Spiloma, a spot; appearance of the fructification. Linn. 24, Or. 8, Nat. Or. Lichenes. The species of Spiloma are generally found on the bark of trees and decaying wood-S. aurätūm, decolōrāns, dispērsūm, melanŏpūm, micro. clōnūm, microscopícūm, murälè, punctätūm, tubercu-

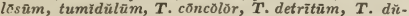

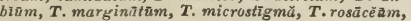
variolosūm, versícōlōr.

SpıNach, see Spinácĭă.

SPINĀcīa, Linn. From spina, a prickle, in allusion to the prickly processes of the fruit. Linn. 22, Or. 5, Nat. Or. Chenopodiacea. Valuable herbs, of the commonest culture, and well known by the English name Spinach.

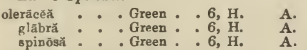

SPINDT.E-TREe, see Eüñ̆mŭs.

SPINEs, indurated and pointed branches or processes, which do not fall off from the part that bears them.

Sp1nous, furnished with spines.

SprrêA, Linn. From speirao, to become spiral; in allusion to the flexile branches being suitable for twisting into garlands. Linn. 12, Or. 2. Nat. Or. Rosicee. An extensive genus of very handsome plants, when in flower. The shrubby kinds are well adapted for planting in ornamental shrub. beries; and are increased by layers, or cuttings of the young wood. The herbaceous species look well in the flower border; and are easily increased by dividing the plants at the roots. Synonymes: 1. S. hypericifolia acuta. 2. S. media. 3.S. oblongifolia. 4. S. sororia. 5. S. Besseriana. 6. S. Ulmaria denudata. 7. S. altaiensis. 8. S. hypericifolia cre[ 299 ] nata. 9. S. carpinifolia. 10. S. salicifolia alba. 11

$S$. hypericifolia savranica ig, $S$. yrandiflora. 13.

S. triloba. 14. S. hypericifolia uralensis, S. crenata.

acutifoliă, 1 White 4, H. De. S. Siberia . 1817

alpina : White 7, H. De s. Siberia: 1806

White \%, He s. Siberia

H. De. S. Nepal

ariæfoliă : White 6, H. De. S. N. Amer. 182

Arūncŭs : White 6, H. Her. P. Siberia : 1633

americånĕ . White - 6, H. Her. P. N. Amer.

barbătă . * White . 6, H. Her. P. Nepal

betulifoliă . Pink. 6, H. De. S. N. Amer. 181

White 6, H, De S. Hungary

eapitată White 6, H. De. S. Columbia: 1827

ceanothifoliă White 6, H. De. S Columbia: 189

chamzedrifoliă" White:6, H. De S. Siberia : 1789

incisă . White : 6, H. De. S. Germany

mediă, 2 White $6, \mathrm{H}$. De. S. Canada

oblongifolrh, 3 . White . 6, H. De. S. Hungary . 1816

6, H. De. S.

corymbōsa : White

crenată, 5 White

cuneifơliă: White

denudată, $6:$ White

Filipèndŭlă

minor $\mathrm{r}$

multíplēx

pubēseêns

flexuôsă

hypericiforĭ

Pluken

lavigată, 7

lancenlat

laxiflör:

lobata

7, H. De, S. Virginia

nia 1819

, H. De. S. N. Amer. - 1829

4. H. De. S. Podnlia: 1739

H. De. S. India

7, H. Her. P. S. Eur.

7, H. Her. P. Siberia

9, H. Tu. P. Britain

8, H. Tu. P. Europe

8, H. Her. P. Brit. gar.

8, H. Tu. P. France

6, H. De. S, Europe

4, H. De. S. N. Amer.

4, H. De. S. Canada.

H. Her. P. Japan

5, H. De. S. Siberia.

H. De. S. Mauriti

White

White

Red.

obovată, 8

opulifoliă

tomen
palmātă

pickowiênsì

salicifollă

alpēstrís

cărnèă

grandiflöră

White

7. H. Her, P. N Amer.

6, H. De. S. Hungary

6, H. De. S. N. Amer.

6, H. De. S. N. Amer.

7, H. Her. P. China

6, H. De. S. Podolia :

7, H. De. S. Britain .

7, H. De. S. Russia

7, H. De. S. Britain :

7, H. Her. P. Kamtsch.

7, H. De. S. Europe .

7, H. Her. P. N. Amer.

4, H. De. S. Podolia

8, H. De. S. Siberia

8, H. De. S. Siberia

6, H. De. S. Dahuria

8, H. De. S. N. Amer.

5, H. De. S. Altai

8, H. Her. P. Britain

8, H. Her. P. Britain .

7, H. Her. P. Britain .

6, H. Her. P.

4, H. Her. P. Uralia

7, H. Her. P. India

SprRAz, twisted like a screw.

Spiralěpis, Don. From speira, a spire, and lepis, a scale; scales twisted. Linn. 19, Or. 2, Nat. Or. Compositce. Ornamental plants. For culture and propagation, see Gnaphalium. Synonymes: 1. Gnaphalium declinatum. 2. G. glomeratum. 3. G. mo. destum. 4. G. squarrosum.

declinâtă, 1 - Brown - 8, G. Her, P. C. G. H. - 1787

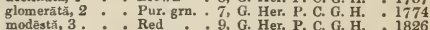
squarrosă, 4 Purple 9, G. Ev, S. C. G. H. 1816

SPIRĀNTHĒRĂ, St. Hilaire. From speira, a spire, and anthera, an anther; the anthers are spiral shaped. Linn. 5, Or. 1, Nat. Or. Rutacece. A very handsoin. flowering, sweet-scented shrub, thriving in a mix. ture of sandy loam and peat; and cuttings of the half ripened wood will root in sand, under a glass; but they must be planted thinly, and the glass occasionally removed to allow them to dry, as they are very liable to damp. Synonyme: 1. Terpnanthus jasminoides.

odoratissĩmă, 1 . Wht, red . S. Ev. S. Brazil . . 1823

SprrĀtrhēs, Richard. From speira, a spiral, and anthos, a flower; in allusion to the spiral manner in which the flowers are arranged. Linn. $20,0 r .1$, Nat. Or. Orchidaced. The species of Spiranthes (Lady's Traces) require the same treatmen: as the Neottia. 
bracteosă. . . . Wht. yel. . 5, S. Ter. St. Cather. . 1835 diurêtică: : : Grn. wht : 8, G. Ter. Valparaiso : 1838 grandiforă : . Green - 9, F. Tex. N. Amer.

SpLĀenNōur, Linn. From splagchnon, one of the Greek names for moss. Linn. 24, Or. 5, Nat. Or. Musci. These plants are chiefly found growing on mountains. Synonymes: 1. S. Turnerianum, 2. S. fastigiatum. 3. S. ovatum. 4. Grimmia splachnordes-

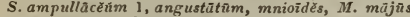

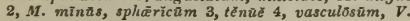
rugosinm.

SPLEENWORT, see Asplēnǐŭm.

S PóxuȲss, Linn. The Greek name for a kind of plum; the fruit resembles a plum. Linn. 10, Or. 4, Nat. Or. Spundiacer. The species of Spondias succeed best in a mixture of loam and peat; and cuttings of the ripened wood will root in sand, under a glass, in heat. The fruit of some of the species is eatable. Synonymes: 1. S. Myrobalanus. 2. S. Mombin.

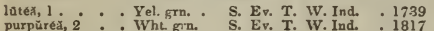
SPONGe-TRer, see Acāciã farnesiānă.

SPORENDONĒMă, Desmazières. From sporos, a seed, endon, within, and nema, a thread. Linn. 24, Or. 9 , Nat. Or. Fungi. Minute species; the first is found on cheese, the last on flies-S. cäset, müscä.

SporidĒsmîu, Link. From sporos, a sporille, and desme, a skin. Linn. 24, Or.9, Nat. Or. Fungi. A minute plant, found on some species of Thelephora -S. ñtrim.

SPORÖßót.Ũs, $R$. Bronin. From sporos, a seed, and ballo, to cast forth; its seeds are loose and easily scattered. Liun. 3, Or. 2, Nat. Or. Graminec. Annual grasses, of simple eulture in any common soil, and propagated by seeds. Synonymes : 1. Agrostis diandra. 2. A. purpurascens.

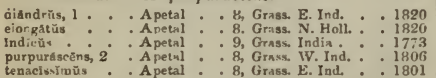

SPORŌCHXI's, Agardh. From sporos, seed, and chnous, wool; becalise of its reproductive organs being tufted.with hair. Linn. 24, Or. 7, Nat. Or. Alga. Marine plants $-\mathbf{S}$ aculeñtüs, Cubrërö̌, ligulatũs, pedunculätüs, rhizodès, $R$. mäjör, villosñs, viridis.

Sporoč̌́s̆, Fries. From sporos, a seed, and kube, a head. Linn 24, Or. 9, Nat. Or. Fungi. Found on the decaying stems of plants-S. byssotdes, Culiciotiles.

Sporotrichём, Lipk. From spora, a sporule, and thrix, a hair; alluding to the filamentous spornles. Linn. 24, Or. 9, Nat. Or. Fungi. Very minute species, found in various situations, chiefly on decayin' substances-S. aurě $Q m$, hadiam, fenestrülë,

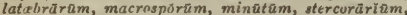
sulphürěrm, tenuissimam.

Sporules, in cryptogamic plants, those parts which are analorous to the seeds of other plants.

SPRFAgěLî, Smith. In honour of Christian Conrad Sprengel, of Brandenburgh, who published, in 1793, an ingenious work on the manner in which insects promote the impregnation of plants. Linn. 5, Or. 1, Nat. Or. Epacridaced. This very elegant little shrub requires the same treatment as is recommended for Epacris.

incarnăta . . . Flesh . . 5, G. Ev. S. N. S. W. . 1793

SpRIve GRAss, see Anthnxantham.

SpUMãrín, Persoon. From spuma, froth; appearance of the species. Linn 24, Or. 9, Nat. Or. Fungi. This plant is found in autumn on grass, rotten wood, \&c. -S. mucilägö.

Sptiosus, frothy.

SpURs, long processes, like horns, produced by rarious parts of a tlower.

SPURGr, see Euphorbiă.

SPURge LaURel, see Däphne Lauredla.

SpURIots, counterfeit.

SPURless violet, see Erpetión.

SPURRRY, see Spergúlă.

Squalidis, mean, unseemly.

Siliamarin, scaly, covered with scales.

SquamāRİA, Hooker. From squama, a scale; the thallıs is scaly. Linn. 24, Or. 8, Nat. Or. Lichenes. These plants are found on rocks, stones, and trees -S. miniātă, Muscöram, tribācěa.
Sevamiform, $\}$ formed like scales.

SQUARB PARSLRY, see Mẽum Būnũŭs.

SQUARROSE, spreading rigidly at right angles, or in a yet greater degree.

Sevash, see Cucũrbită Melopẽpo.

Seuilt, see Scillă.

Squinancy, an inflammation in the throat.

Squirting cưumber, see Momördícă Elaterĭam.

StAĀrǐ̆, Dahl. In honour of Martin Staaf, a correspondent of Linnæus. Linn 5, Or. 1, Nat. Or. Bruniacea. Elegant little shrubs, succeeding best in a sandy peat soil; cuttings of the young wood will root readily in sand, under a glass. Synonymes : 1. Brunia citiata. 2. B. gtutinosa. 3. B. radiata, Phylica radiata.

ciliătå, 1 . . White. . 6, G. Ev. S. C. G. H. . 1812 glutinôsă, 2 : White. : 4, G. Ev. S. C. G. H. : 1793 radiát, 3 . : White. : 5, G. Ev. S. C. G. H. : 1787

StacnYLĭ́ŭūm, Fries. From stachys, a spike, and eidos, similar; in allusion to the manner in which the sporisles are fixed on the filaments. Linn. 24, Or. 9, Nat. Or. Fungi. Found on dead wood-S. bicôtōr, terrêstrè.

Sтйснгs, Linn. From stachys, a spike; mode of flowering. Linn. 14, Or. 1, Nat. Or. Labiata. A genıs of rather weedy-looking plants, hardly worth cultivating for ornament. They all succeed in common garden soil. The greenhouse species require to be treated as other greenhouse plants. The perennial kinds are easily increased by dividing the rnot in spring or antumn. The seeds of the annual kinds should be sown in spring, in the open border. Synonymes: 1. S. cretica, intermedia, orientalis, sibirica. 2. S. tenuifolia. 3. S. diffusa, Iberica, scordifulia. 4. S. arvensis, hispida. 5. S. latifulia. 6. Hyssopus anisatus. 7.S. biennis, lusitanica, polyetachya. 8. S. phlomoides. 9. Ambleia inflata. io. S. salviafotia. 11. Sideritis decumbens. 12. Sideritis calycantha. 13. Strchys ambigut. 14. S. Balbisii. 15. Sideritis linearifolia.

thiôpieñ . Purple . 5, G. Her. P. C. G. H. 17:0 angustifolia, $2^{\text {: }}$ Purple $: 7, \mathrm{H}$. Her. P. Tauria 1823

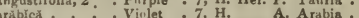
arabica. $3^{\circ} \cdot{ }^{\circ}$ arenariá, 3... Purple - 7, H. Her. P. Levant . 1864 betoniczefolia : Yellow * 6, H. A Rochelle : 1812
coccinea debrlis : : PH. vio. 7, H. Her. P. S. Amer. : 1825 Fœeñcūläm, 6 . Blue : 5, H. B. N. Amer. 1824 fruticulosa. . Purple - 7, H. Ev. S. Caucasiss . 11118 glaucéscens : Purplo: 7 H. Her. P. Caucasus: 1826 glaucéscens : Purple: 6, H. Her. P. Candia : 1729 Rlutinónă * Purple : 6, H. Her. P. Candia * 1729 Herăclé, 8 : Purple : 7, H. Her. P. Italy: 1822

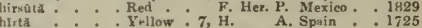
inflată, $9:$ : Pink : 7, H. Her. P. Africa: : 1832 Itảlieă, 10: : Purple: 6, H. Her. P. Burnpe. Lamäckit, i1 : Yellow: 7, G. Ev. S. C. G. H. : 1820 lanata Striped: 7, H. Her. P. Siberia : 789

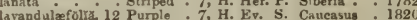
lavandulafolla, 12 Purple * 7, H. Ev. S. Calleasus - 1820

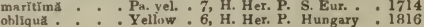
Palzestină: : Purple: 7, H. Kv. S. Syria : 1820 paucifora : : Yelsh. : G. Er. S. Egypt : 1834 pubéscèn8, 14 . Yelsh. . 7, H. Har. P. Europe . 1816 ré:A . . Yellow . 7, H. Her. P. S. Eur. . 1673 ruginsa: Pa yel. 7, G. Ev. S. C. G. H. : 1774 scordioldes . . Yellow : 7, H. Ev. S. Morneco . 1818 sericeă . . . Lilac. . 8, H. Her. P. Nepal . 1830

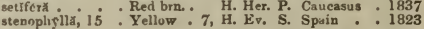

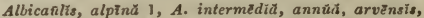
àsperă 4 , circinată 5 , cörsică, C. albă, decñmbēns, germănică 7, G, pubèscēns, grandidentütă, hyssopifoltă, mollissimă, nepetafoliă, palnstris, $\boldsymbol{P}$. älbă, $\boldsymbol{P}$. hybridä 13, P. variegată, spiñsă, sylvătică.

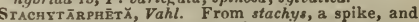
tarpheios, dense; manner of flowering. Linn 2 , Or. 1, Nat. Or. Verbenacea. The species of Stachytarpheta thrive in a light rich mould. The shrubby kinds are increased by cuttings, planted in sand, under a glass. The annuals and biennials require to be treated as other stove annuals and biennials. $S$. mutabilis is a handsome, ever-flowering shrub, the leaves of which have been imported from South America for the purpose of adulterating tea.

angustiforu . Blue . . 7, G. B. S. Amer.

cayennénsis : Blue : 5, S. Fv. S. Cavenne: 1822 hirsutissimi Blie: 4, 3. Her. P. Brazil : hirsutissima : - Blite - 4, 3. Her. P. Brazil : 1822
Indiea . . - White [300] 
jamnicēnals's . Blue . . 7, s.

mutäbrlis . Orange

orūbīeă

Orange

$6, \mathrm{~s}$.

B. W. Ind.

- 1714

S. S. Auner. 1801

prismática: : : Blue : 5, S. B. W. Ind. 1699

urticifolrà : Blue . . 6, s

B. S. Amer.

STACRноËš̌, Smith. In honour of Mr. Stackhouse,

a British botanist. Linn $5, \mathrm{Or}, 2$ Nat. Or. Stack-

housiacee. Ornamental plants, of commnn culture.

linariæfoliă • G. Ev, S. N. Holl. . 1823

monogỹă. : Pink. . 4, H. Her. P. V. D. L. : 1835

Stadranvia, Lamarck. In honour of M. Stadmann, a German botanical traveller. Linn. 8, Or. 1, Nat. Or. Sapindrcea. A lofty-growing tree, with very large showy leaves. It grows in loam and peat; and cuttings of the ripened wood, with the leaves

left entire, will root in sand, under a glass, in a moist heat.

australis Whitish. G. Ev. T. N. Holl. 1823

Sтғнвт.і̄A , Linn. In honour of Benedict Stæhelin, a Swiss botanist. Linn. 19, Or. 1, Nat. Or. Com positce. Any light rich soil suits these plants; and cuttings root readily in the same kind of soil. $S y$. nonyme: 1. Pteronia Chamapeuce.

arborêscêns ; Purple . 8, F. Ev. S. Candia - 1739 Clamæpeũcẽ, i : Purple : 7, F. Er. S. Candia : 1640

\section{STAFF-TREB, see Celästrŭs.}

Stalagmītìs, Murray. From stalagnos, a running out ; the trees exude a yellow resinous juice when cut. Linn. 18, Or. 2, Nat. Or. Guttiferce. A genus of very fine ornamental trees, thriving well in a mixture of turfy loam and peat, and requiring to be kept in a strong heat. Cuttings of the ripened wood will ront in sand, under a glass, in a moist heat. The fruit of some of the species is eatable. The trees yield a yellow viscid juice, hardly dis. tinguishable from gamboge, and used for the same purposes by painters. Synonymes: 1. Xanthochymus edulis. 2. $\boldsymbol{X}$. guineensis. 3. $\boldsymbol{X}$. lutcus. $4 \boldsymbol{X}$. macrophyllus. 5. $\boldsymbol{X}$. ovalifolius. 6. X. purpureus. 7. $\boldsymbol{X}$. tinctorius.
aûleìs, 1
uineünsiss, 2 : Y Yellow
liteǔs, 3. Yellow
macrophyllŭs, 4 . Yellow
ovalifölius, 5: Yellow
S. Ev. T. E. Ind.
1820
S. Ev, T.
S. Ev, T.
S. Ev, T. Ceylon
S. Ev. T.
S. Ev. $\mathrm{T}$. $\mathrm{T}$.

STAI.Ks, the foot-stalks of leaves or flowers.

STAMEN, the male organ of a flower.

STANDARD, the upper petals in a pea-flower.

SтAnнópũă, Hooker. In compliment to Earl Stanhope, president of the Medico-botanical Society. Linn. 20, Or. 1, Nat. Or. Orchidacea. The species of Stanhopea are splendid plants when in flower, particularly $S$. Devoniensis and $S$. tigrina, both of which are at present rare in collections. The flowers of all the species are more or less fragrant. The following is the method of cultivating these favourite plants at Chatsworth:-Over the drainage hole of the pot to be used for large plants, is inverted one of a smaller size, generally covering about half the bottom of the pot; above and around this is carefully thrown a quantity of broken pots, sufficient to fill the remaining cavity to within one-third of the top. A sufficient quantity of fibrous, moderately sandy peat is next selected, and placed on the top of the drainage, being first broken into various forms and sizes, but none of them less than a walnut. In placing these, care is taken to dispose of each, so as to leave a passage for the escape of water; this is more effectually secured by introducing, as the process of potting goes on, a few pieces of broken pots between every layer, more or less, according to the size of the plant; indeed, it is an excellent plan to continue a connexion of broken pots all the way up the centre, to the bottom of the pseudo-bulbs. After the peat becomes level with the summit of the pot, the successive external layers are made fast by means of small pegs, varying from four to six inches long: these pegs penetrate the layers of peat, and thus secure the whole firmly together. At eight inches above the edge of the pot the plant is placed on the top, the roots are carefully laid out, and covered up to the bulbs very carefully with smaller pieces of peat and potsherds. [301]

continuing to fasten the peat as before described, until the whole is finished; when it will be a foot or fifteen inches above the top of the pot;-small plants are not potted so high. When a single pseudo-bulb is first potted, it should be but very slightly raised above the level, and when a small plant of two or three bulbs is potted, it should not, at first, be raised more than two or three inches, but as it grows larger it is progressively elevated. In building up, as is here described, with peat, it does not terminate in the shape of a cone, but is carried up nearly square, being merely rounded a little at the top. Unless the plants are very healthy, water is given but sparingly at the ronts, and in winter very little or none is supplied; the great desideratum in the cultivation of Orchidacea being to preserve the roots, which, by over-watering, especially in winter, are almost sure to be destroyed. The general temperature of the house ranges from 60 to 85 degrees; in the afternoon, during the growing season, it is shut up early, and the paths well watered, and once or twice a week a little water is sprinkled over the plants. It is of great advantage to have a tan bed in the house, for the purpose of plunging the plants, as the heat from the tan circulates through the peat and potsherds, and causes the specimens to grow with great lux. uriance. Young plants are obtained by taking off one or more of the bulbs, potting them in proper sized pots, in the above soil, well drained, and placing them on a hot flue; being careful, in watering, not to allow the smallest quantity to rest upon the young buds. After they have formed roots, increase the size of the pots, and in other respects attend to them as before recommended.

Devoniēnsiss . . . Or. spot, red 7, S. Epi. Mexico

Devoniēnsís : : Or. spot red 7, S. Epi. Mexico
ebürnéa : White : 6, S. Epi. Brazil

ebūrnéă - * White - . G, S. Epi. Brazil

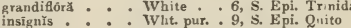

Lindleyĩ : : Brn.red : 8, S, Epi. Mexico

maculösă : Blue grn. : 8, S. Kpi. Mexico

oculáta : : Wht. pur. 6, S. Epi. Brazil

quadricórnirs : : Wht. spot. 6, S, Epi. S. Main

1824

Wardn : - Yel. brn. 8, Epi. Mexico

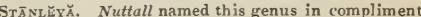
to Edward stanley, Earl of Derby, F.R.S., V.P.L S.

President of the Zoological Society, and a muniticent patron of the sciences, especially Botany and Ornithology. Linn. 15, Nat. Or. Cruciferce. A pretty little plant, succeeding well in the open border in vegetable mould; and increased by divisions of the root or by seeds. Synonyme: 1 . Cleome pinnata.

pinnatifida, 1. . Yellow . 6, H. Her. P. Louisiana . 1816 SrapĕLĭ. Named by Linnaus after Boderus Stapel, a physician of Amsterdam, and commentator on Theophrastus. Linn. 5, Or. 2, Nat. Or. Asrlepiadacer. An extensive genus of plants, well worth cultivating for their grotesoue appearance, and their singularly beautiful star-like flowers, which have usually a very fetid smell. The soil best suited for them is sandy loam, and old brick or lime rubbish. The pots should be well drained, and the plants at all times carefully watered, especially in winter, when they must be kept in a perpetually dry state. They are readily increased by cuttings, which should, if possible, be only taken off in spring, when the plants are dormant. They should be allowed to dry for a few days after they are taken from the mother plant; after which, they may be planted in separate pots, in the same compost as before recommended, when they will strike root in a very short time. Synonymes: 1. S. deflexa. 2. S. grandiflora.

acuminåta ambīgŭă apêrtá Asterriàs canēscēn comsta comatn.

concinna

faricomât

flavicomât

glandulif éră

glanduliflöră GordônI .

prandiflora

hamătă .
Pur. str. 8, S. Ev. S. C. G. H. Pur. str. 8, S. Ev. S. C. G. H. Yel, pur. 6. S. Ev. S. G. H. 5, G. Ev. S, C. G. H 7, G. Ev, S, C, G. H. Pa, yel. 9, G. Ev, S. C. G. H. 7, G. Ev. S. C. G. H. Yel, grn, G. Ev, S. C. G. H. G. Ev. S. C. G. H. G. Ev. S. C. G. H. Yellow Yellsh. Brown Dk, pur. - 10, G. Ev. S. C. G. H.

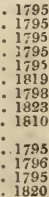




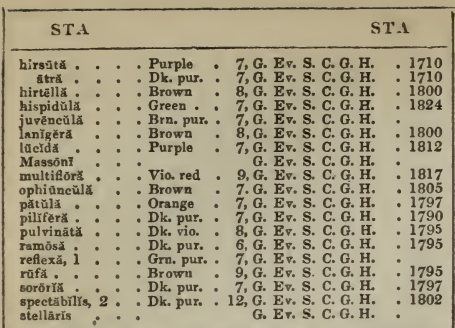

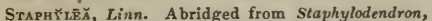
its ancient name, from staphyle, a bunch, and dendron, a tree; the fowers and fruit are disposed in clusters. Linn. 5, Or. 3, Nat. Or. Staphyleacea. Shrubs of very little beauty. They succeed well in any common soil, and are readily increased by suckers from the roots, by layers, or by cuttings, planted in autumn.

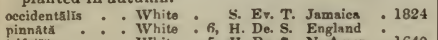
pinnată $:$ : White $: 6$, H. De. S. England
trifollă.

Star appi,k, see Chrysophgllim.

STAR yish, see Stapéltä Astériãs.

STÄRKǚ, Willdenom. In honour of the Rev. M. Starke, of Gros Tschirna, in Silesia, a cryptogamic botanist. Linn. 19, Or. 2, Nat. Or. Com. posito. A stove herbaceous perennial, growing in any light rich soil, and increased by divisions. Synonyme: 1. Amellus umbellatus-S. umbellätd.

STAR of BвтнLенRM, see Ornithogalam.

Star of thr kARTH, see Plantägo Coronoptes.

STARRY, in the manner of a star, radiating.

Star thistle, see Centaûréd calciträpỏ.

StARWORT, see Aster.

SrĂTíč, Linn. From statizo, to stop; in allusion to the powerful astringency of some of the species. Linn. 5, Or. 6, Nat. Or. Plumbaginacer. The species of Statice, or Sea Lavender, ought to be in every garden, on account of their lively little flowers. The greenhouse and frame kinds succeed best in sandy loam and peat, and may be increased by cuttings. The hardy herbaceous species are very suitable for ornamenting the front of flowerborders; they increase freely by division, or seeds, which latter some of them produce in abundance. The root of $S$. caroliniana is one of the most powerful astringents known. Synonymes: 1. Taxanthema australis. 2. Statice lyrata. 3. S. spatulata.

aceróct . . Pa. pink . 6, F. Her. P. Ararat.

acenot - Pa pink - 6 , F. Her. P. Ararat

agyptiaea : Pur, yel:

slată ${ }^{\circ}:$ : Pur. yeL : 7, F. Her. P. Siberia

arboreă : : Blue : : 7, G. Ev. S. Teneriffe

articulătă: : Blue : 7, H. Her. P. S. France

añrea : : Gnlden: H. Her. P. Siberia

arriculafoura : Blue : 7, F. Her. P. Galicia

australly, 1 , G. Hex. P. N. Holl.

bellidifolra : Pa. blue . 6, H. Her. P. Greece

binervosi . : Blue : 7, H. Her. P. England

earoliniana : : Blue : 6 , H. Her. P. Carolins

eflspice , : Pa blue $: 7$, H. Her. P. Casp. Sea

einereă : Blue $: 7$, G. Her. P. C. G. H.

conspicŭă: : Pink: : 7, F. Her. P. Russia

cordáta - . Bluo : 6, F. Her. P. S. Eur. .

Coriáriă . . Lilac . 7, H. Her. P. Cauessus

cıneâtă : Blue : 7, H. Her. P. Siberis

dichðtomă : Blue : 7, H. Her. P. S. Eur. .

Eeliñ̌s : Red : 7, H. Her. P. Cancasus

eehioides: : Ped blue: 7, G. Her. B. S Eur.

Pa blue 7, G. Her. Bar.

elati

ferulăcěă . Yellow : 7 , H. Her. P. Siheria

flexuōs : Purplo : 7, H. Her. P. Siberia

foliōsa : : Pur, wht. 7, F. Her. P. Graciosa

globularixefolia : Whito, : 8, H. Her. P. Mexico

Gmelini : Blue : 7, H. Her. P. Siberia

greên : : White: : 6, H. Her. P. Greece

graminifolix: : Rel : 6, H. Her. P. Siberia :

grandiforă

imbricâtă.

incsoü.

G. Ev. S

F. Her. P. Teneriffe

Iimbntum : Blue : 7, F. Her. P. England
STA

STE

macrophy̆lla . White. . 5, G. Her. P. Canaries . 182 minūtä : Red : 6, H. Her. P. Mediter. : 1658

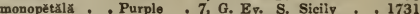
mucronată : Red : 7, F. Her. P. Barbary : 1784 nānă oleiforra : : Red : 7, H. Her. P. Italy : 1688 ovalifoliă. . Whito. 7, G. Her. P. Canaries : 1816 pectinătă . Blue : 9, F. Hex. P. Canaries : 1781 pruinōsă . White. 7, H. Her. P. S. Eur. . 1823 puberūlă . Violet pubësē̄ns purpurátă : : Purple : 6, G. Her. P. C. G. H. : 1800 purpurata : Purple : 6, G. Her. P. C. G. H. - 1800 seābră. : : Blue : 6 , G. Her. P. C. G. H. : 1788 Scopăriă . Blue : 7, H. Her. P. Siberia . 1796 sinuátă : . Pur. yel. . 8, F. Her, P. Levant . 1629 spatulată . Purple 7, H. Her. P. Barbary 1804 . White. . 7, F. Her, P. Russia . 1776 . White. 7, H. A. Caueasus . 1819

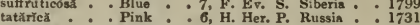
tetragónă: : : Red : : 7, G. Her, P. C. G. H. : 1820 ThouinII : : Blue : 8, H. Her. P. N. Africa : 1700 viminnea : Blue : 7, H. Her. P. Spin 1818 virgată Stauracānthŭs, Link. From stauros, a cross, and akantha, a spine; the spines have each two smaller spines at the side; which give them the appearance of a cross. Linn. 16, Or. 5, Nat. Or. Leguminosae. A very beautiful dwarf shrub, well suited for the front of shrubberies; it is easily increased by young cuttings, planted in sand, or by seeds. Synonyme: 1. Ulex genistoides.

aphy̆llüs, 1 . . Yellow . 5, H. Bv. S. Portugal - 1823

STǨL̆s, Swartz. Not explained. Linn. 20, Or. 1 , Nat. Or. Orchidaced. The species of Stelis are small, rather interesting plants. For culture and propagation, see Pleurothallis.

nierántlia *. Oreen * 4, S. Fpi. Jamaica * 1805 ophioglossoides: : Pur. brn. 9, S. Epi. Jamaica : 1791 tristylas.: : Green.: S. Epi. Brazil

Stret.̄̄RIX, Linn. From stella, a star; the flowers are star-like, Linn, 10, Or. 3, Nat. Or. Alsinacec. Weeds, of no known use. Synonymes: 1. S, uliginosa. 2. S. multicaulis. 3. S. dichotoma-S. aquáticà 1, arenāriä, bulbosad, cerastoždès, C. triflorä 2 , crassi-

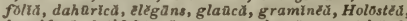
humifrsil, latifrlia, Laxmännt, longlpes, médiă 3 multicanlis, murülts, nemoram, scapigéră, velutină, visciddi.

Strm-claspixo, when applied to a leaf, signifies that its base surrounds the stem.

Strmōdř, Linn. From stemon, a stamen, and dis, double; in allugion to each stamen bearing two anthers. Linn. 14, Or. 2, Nat. Or. Scrophuluriacea. Plants of little beauty, growing well in any light rich soil, and increased by cuttings or seeds. The annual species are half-hardy. Synonymes: 1. Capraria durantifolia. 2. Columnea trifoliata.

ehilēnsiss * - Red * 9, F. Da Cr. Chile • . 1829 suffruticósă, $2^{*}$ : Blus : : 7, S. Ev S. N. Granada 1820 durantifolĭă 1 , marîtimă, parviflöră, verticillaris, vis $\cos$.

Stzмомітіs, Gleditsch. From stemon, a stamen; the plant may be compared to the male organ of a flower. Linn. 24, Or. 9, Nat. Or. Fungi. Found upon rotten wood. Synonyme: 1. Triclia nuda-S. firsciculätà 1, obtusată, papillätă.

Strañctís, Nees. Probably from stene, narrow, and aktin, a sunbeam; from the narrow and sunlike rays of the expanded flower. Linn. 19, Or. 2, Nat. Or. Composita. This is a very showy plant, well adapted for planting in beds; it grows in any common garden soil ; and is readily increased by dividing the root, or by seeds, which it produces in great abundance.

speciosa . . . Purple . 7, H. Her. P. Californ. . 1831

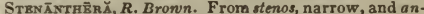
thera, an anther; the flaments are broader than the anthers, which causes the latter to appear narrow. Linn. 5, Or. 1, Nat. Or. Epacridacea. This beautiful greenhouse shrub requires a soil composed of one third sandy loam, and two thirds very sandy peat. The pot should be well drained, as the fine roots of the plants are easily injured by much wet; it should be kept in a shaded part of the house in summer. Cuttings taken from the young shoots, will strike with ease, if planted in sand, under a glass.

pinifourrä . . Scarlet . 6, G. Ev. S. N. S. W. . 1811 


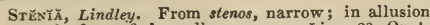
to the form of the pollen-masses. Linn. 20, Or. 1, Nat. Or. Orchidacea. This is rather a pretty species, requiring to be treated the same as the species of Maxillaria.

pallídă . . Yellow . 8, S. Epi. Demerara . 1837

StrnocĀrpǔs, R. Brnwn. From stenos, narrow, and karpos, fruit. Linn. 4, Or. 1, Nat. Or. Proteacee. An equal mixture of sandy loam and peat suits this plant, and cuttings of the ripened wood will root in sand, under a glass.

saliguŭs . . Green . . 6, G. Ev. S. N. Holl. . 1819

Sтекосні̄LŬs, R. Bronn. From stenos, narrow, and cheilos, a lip, in allusion to the narrow lip of the flower. Linn. 14, Or. 2, Nat. Or. Myoporacea. Pretty little greenhouse shrubs, thriving in sandy loam and peat; and readily increased by cuttings, planted in sand, under a glass.
glähèr
Red
G. Ev. S. N. Holl
.1803
incănŭs. : . Gm. pur.
longifollŭs : : Scarlet :4, G. Ev. S. N. Holl.
maculătŭs : : : Scarlet
viscósŭs
1825
viscösŭs * * Yellow . 10, G.
STBPHĀNǏ, Willdenow. In honour of S. Stephan, once a professor at Moscow, died 1817. Linn.6, Or. 1, Nat. Or. Capparidacea. Well worth cultivating, on account of the beauty of the flowers. It thrives in loam, peat, and sand, and cuttings of the young wood will root in sand, under a glass, in heat. Synonyme: 1. Capparis paradoxa.

cleomoĩdès. 1

S. Ev, S. Caraceas . 1823

Strencēlì, Linn. From Sterculius, a God, derived from stercus; the flowers and leaves of some of the species are fetid. Linn. 21, Or. 10, Nat. Or. Sterculiacea. These plants succeed best in light turfy loam; or a mixture of loam and peat; and cuttings of the ripened wood, with the leaves left entire, will root freely in sand, under a glass, in heat. The seeds of S. acuminata afford the Cola or Kola, of tropical Africa, so much spoken of by African travellers; and which, when chewed or sucked, enhances the flavour of anything that may be eaten afterwards; and is even said to render putrid water agreeable. The seeds are brown, and about the size of a pigeon's egg. Synonymes: 1. S. heterophylla. 2. Helicteres apetala. 3. S. crinita. 4. S. brilanghas. 5. S. pubescens.

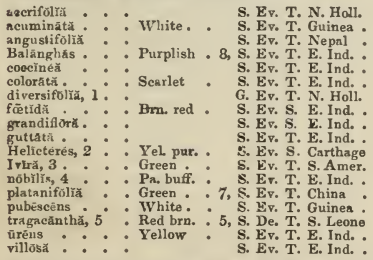

- 1824 1795 1893 1787 1818 1824 1690 1820 1825 1787

StrerzocaūLŏx, Schreber. From stereos, rigid, and kuulon, a stem, firm branching fronds. Linn. 24, Or. 8, Nat. Or. Lichenes. This is the first of its tribe found clothing the lava of volcanoes-S. botry-

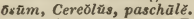

StвRїGMă, Decandolle. From sterigma, a fork; the larger stamens are joined at the base, and forked at the top. Linn. 15, Nat. Or. Crucifera. The species of this genus are well adapted for ornamenting rock-work. They require to be treated as other alpine plants. Synonymes: 1. Cheiranthus tomentosus. 2. C. torulosus.

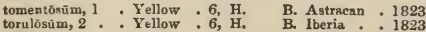

STRRILR, barren.

STERNBËRGĬĂ, Waldstein and Kitaibel. In honour of Count Caspar Sternberg, a celebrated botanist. Linn. 6, Or. 1, Nat. Or. Amaryllidacea. Handsome hardy bulbs, though seldom met with in ordinary collections. They succeed well with common treatment, in any rich garden soil; and are increased by offsets.

Clusiảna * Pa. yel.

colchicifiora Yellow 8, H. Bl. P. Constant.

- 8, H. Bl. P. Hungary : 1816

- 8, H. Bl. P. N. Africa . 1820

- 8, H. Bl. P. S. Eur. * 1596

Strenutatory, possessing qualities which provoke sneezing.

STrvĒnĭ, Adanson. In honour of Christian Stephen, Counsellor of the University of Mosenw, and author of a paper on some new plants from Caucasus, published in the Linnæan Transactions. Linn. 15, Nat. Or. Cruciferce. The seeds of these plants should be sown on rock-work, but not sooner than the beginning of A pril-S. alyssoĩděs, cheiranthoĩdẽs.

STĒvĭĂ, Cavanilles. In honour of Peter James Esteve, M.D., professor of botany at Valencia. Linn. 19, Or. 1, Nat. Or. Composite. Pretty autumnal flowering plants, succeeding well in the flower border during summer; they require the protection of a frame in severe weather, and are increased by cuttings, divisions, or seeds. Synonyme: 1. S. ca. nescens.

adenophor:

angustifőlia

breviażsta

Eupatōrĭ̉a

fascicularis

fastigiäta

hyssopifoliă

incanéscēns, 1 .

ivæfolia

iancenla

lūer̃dă

microphyllă

nepetæfolix

ovátă

paniculata

pilōsă

pubēscēns

pur pŭ rěă

rhombifoli

salviæfólìa

sarviæi

suavếlēns

subpubèscêns

ternifolá

trîfïdü

violăcě̆ă

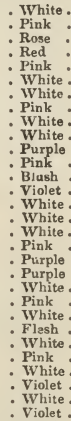

8, F. Her. P. Chile 8, F. Her. P. Mexico

: 1823

H

9 , G. Her P. Mexico - 1798

8, F. Her. P. N. Spain : 1826

8, H. Her. P. Mexico.

8, F. Her. P. N. Spain

8, H. Her. P. Mexico.

8, G. Her. P. N. Spain

y, G. Her. P. Mexico.

8, F. Her. F. Mlexico

8, F. Her. P. Mexicn

8, F. Her. P. Mexico

8, F. Her. P. N. Spain

8, F. Her. P. Mexico.

8, F. Her. P. Mexico.

8, H. Her. P. Mexico

8, F. Her. P. Mexico

8, F. Her. P. Mexico.

8, F. Her. P. Mexico

8, H. Her. P. Mexico

8 , F. Her. P. N. Spain

8, G. Her. P. N. Spain

8, F. Her. P. Mexico.

8, F. Her. P. N. Spain

8, H Her. P. Mexico

8, $\mathrm{F}^{*}$ Her. P. Mexico

1827

1816

1824

1828

1826
1894

1816

1824

1820

1812

18013

1827

1799

1820

1824

1827

1899

1821

StewĀrtĩă, Cavanilles. In honour of $J_{\text {ohn }}$ Stewart, Marquis of Bute, once a distinguished patron of botany. Linn. 16, Or. 8, Nat. Or. Ternströmiacea. This beautiful species deserves a place in every collection of ornamental shrubs. For culture and propagation, see Malachodendron. Synonyme: 1. S. Malachodendron.

virgỉnǐcă, 1 . . White. . 7, H. De. T. N. Amer. . 1743

STīcr , Schreber. From stiktos, dotted; in allusion to the little pits on the under surface of the fronds. Linn. 24, Or. 8, Nat. Or. Lichenes. A handsome genus of Lichens, found growing upon trees. $S$. pulmonacea possesses the same qualities as the Iceland moss of the shops-S. aurätă, ciliãtă, crocãtă, fuliginōsă, limbātă, macrophȳ!lă, pulmonäceă, scrobiculātă, sylvătĩcă.

Бтїстіs, Persoon. From stiktos, dotted; the dot-like appearance of many of the species. Linn. 24, Or. 9, Nat. Or. Fungi. Very minute species, found on dead branches-S. abietīnă, lōngă, pällìdă, radiütă, sicrōstŏmă, spharālǐs, versicólor.

SтйFrtĩ̄, Mikan. Named after some unknown botanist. Linn. 19, Or, 2, Nat. O1. Composita. A fine showy plant, requiring the same treatment as the shrubby species of Baccharis.

insignis.. White. G. De. S.

.1838

Stigma, the female organ of a flower.

StromaphPII.̃N, Jussieu. From stigma, a stigma, and phyllon, a leaf; stigma foliaceous. Linn. 10, Or. 3, Nat. Or. Malpighiacee. These handsome plants produce their fine yellow flowers, from three to five together, in an umbel. For culture and propagation, see Banisteria. Synonyme: 1. Banisteria auriculata.

aristătũm. * Yellow . 7, S. Ev. Tw. Brazil • . 1832 auriculātŭm, 1 : Yellow : S. Ev. Tw. Brazil : 1820 [ 303 ] 
StgMatoss, when the stigma is long, lateral, or on one side of the style.

Stroñ̄̄Mă, Agardh. From stigon, dotted, and nema, a filament, alluding to the regular annular dots of the fllaments. Linn. 24, Or. 7, Nat. Or. Algre. Smali tark green tufts, found on rocks-S. atrovïrëns, panniformé.

Stru.̄̄Gō, Liñ. From stylos, a style; probably alluding to its length. Linn. 22, Or. 3, Nat. Or. Stilaginaced. Ornamental trees, thriving in a mixture of sandy loam and peat; cuttings will root in sand, under a glass, in heat.

Būnǐus. . . Apeta. * \& S. Ev. T. E. Ind. . . 1757 diāndră: : : Apetal : Q E. Er. T. E. Ina. : 1800 Stribospŏră, Pcrsoon. From siílbo, to shine, and spora, a sporule; the naked sporutez are imbedded in a black substance, flowing from deaa trruks and branches of trees-S. betulinnü, biloculätü, projusău.

Sтїциё, Tode. From stilbrs, shining; the species are found upon old rotten wood, and are at first watery and gelatinous, but become opaque as they ripen. Linn. 24, Or. 9, Nat. Or. Fungi-S. and-

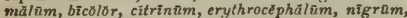
pellñcidñm, piliformé, tomentôsâm, vulgäré.

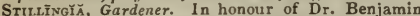
Stillingfleet, an eminent English botanist. Linn. 21, Or. 10, Nat. Or. Euphorbiaced. The species of Stillingia should be grown in a mixture of sandy loam and peat; and euttings will root in sand, under a glass, in heat. S. sebifera is the Tallowtree of China; its kernel contains an oil, which, when expressed, consolidates throngh the cold to the consistence of tallow, and by boiling, it becomes as hard as bees-wax.

$\begin{array}{ll}\text { popūineă : : : Yellow } & \text { S. Ev. T. Ceylon : } 1823 \\ \text { sebiferă. Ev. S. China }: 1703\end{array}$

lizustrind̆, sylvătică.

Strmut.ativg, exciting.

STINKIN HORzhOUND, see Ballotă.

STipă, Linz. From stipe, a silky or feathery substance. Linn. 3, Or. 2, Nat. Or. Graminea. A genus of beautiful grasses; they are increased by divisions. S. pennuta is grown in the flower-garden for the sake of its beautifully feathered beards, which; Gerarde says, the ladies used to wear as feathers.

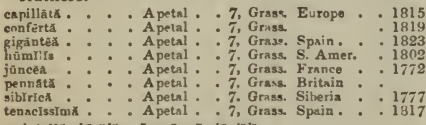

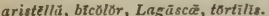

Sripe, the stalk of a fern leaf, or of the head of a fungus.

STIPITATE, furnished with a stipe.

STrpurre, small scales at the base of the petioles,

Stitchwort, see Plantägo holostétum.

Sтrтchwort, see Stellüriü.

Sтов $\bar{A} \bar{A}$, Thunberg. In honour of Dr. Stobæus, of Lund, one of Linnæus' first patrons. Linn. 19, Or. 1, Nat. Or. Compositı. Any light rich soil suits this interesting plant, and young cuttings root readily in sand, under a glass.

pinnata. . . Yellow . 6, G. Ev. S. C. G. H. . 1812

Srock, see Mathiolñ.

STāsiš, Leysser. From stibas, a bed of leaves; the original plant was so used. Linn. 19, Or. 5, Nat. Or. Compositc. Interesting plants, succeeding best in a mixture of sandy loam and peat, and increasee by young cuttings, planted in sand, under a glass. Synonyme: 1. Seriphium alopecuroides.

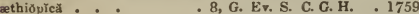
cinereaz. cinered : : : : 8, G. Ev. S. C. G. H. : 1816

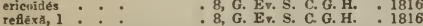
STokÉs̆́, L'Heritier. In honour of Jonathan Stokes, M.D., the coadjutor of Withering, in his arrange ment of British Plants. Linn.19, Or. 1, Nat. Or. Compositie. A very handsome herbaceous plant, succeeding well in the open border during the sunmer months. It is increased by seeds or by division of the roots.

eyaned. . . Blue. . 8, G. Her. P. Carolina . 1766 Srovoss, runnerd, which root nt the joints.

Stotontrarous, bearing runners which root at the joints.

Sтомленг, agreeable to the stomach.

STONBCrop, see Sédũm.

Stone pine, see Pĩnùs Pineéa.

STORAx, see Stỹūax.

STORK's BILL, see Pelargrnĩlm.

Strangury, a disease produced on plants by tight ligatures.

STRANVESİA. Lindley named this genus in honour of the Honourable William Fox Strangways, F.R.A., a learned and indefatigable investigator of the Flora of Europe. Iinn. 12, Or. 2, Nat. Or. Rosuceu. This species is better known under the name of Cratogus glauca; it is ornainental, and succeeds best when planted against a south wall, with a slight protection in severe weather. It is readily increased by grafting or budding upon the common thorn. Synonyme: 1. Cratugus glauca.

glaucēscēns, 1. . White. . 6, H. Eマ. T. Nepal . 1828

Strapwood, see Corrigiơlă.

Strata, layery, beds.

STrRATıōtǔs, Linn. From stratos, an army; in allu. sion to its long sword-like leaves. Linn. 22, Or. 10, Nat. Or. Hydrocharacece. An ornamental aquatic, increasing so fast in the ponds where it is planted as to become almost a troublesome weed.

aloìdĕs. . . White. . 6, H. Aq. P. England .

Stravīoũe м, Jussieu. From Tsjeria Samstravadi, tha Malabar name of one of the species. Linn. 16, Or. 8, Nat. Or. Myrtacea. Fine ornamental trees. For culture and propagation, see Barringtonia. Syno. nymes: 1. Barringtonia acutangula, Eugenia acutangula. 2. B. ractmosa, $E$, racemosa.

acutánqŭlūm, 1 . Purple : S. Ev. T. E. Ind. . 1822

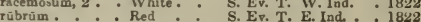

Strawberry, see Fragärĭa.

STRA WBgRRY BLTTR, see Blitrim.

STRAWHRRRY TRER, see Arbatũs.

STREAKs, little furrowed lines.

STRELİZİ̃. Named by Aiton in honour of the Queen of George III., from the house of Mecklenburgh-Strelitz. Linn. 5, Or. 1, Nat. Or. Musacece. A genus of splendid plants, generally found in our stoves, though they will thrive equally as well in the greenhouse. A very turfy loam suits them, and they may be increased slowly by suckers; but young specimens are more readily obtained by impregnating the stigma when the plants are in bloom.

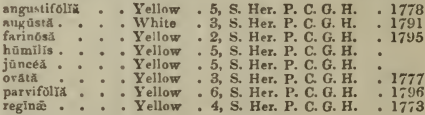

Streptanthēră, Sweet. From streptos, twisted, and anthera, an anther. Linn. 3, Or. 1, Nat. Or. Iridacex. Very pretty bulbs when in flower. A mix. ture of loam and peat suits them best; and young plants are obtained by offsets.

cūprę . . . Coppeı • 6, G. Bl. P. C. G. H. 1825 elégans : : : : Wht. blne 5, G. BL P. C. G. H. : 1827

Strkptন̄nthŭs, Nuttall. From streptos, twisted, and anthos, a flower; twisted claws of petals. Linn. 15, Nat. Or. Cruciferc. The seed of these plants may be sown in the open border late in spring; or they may be reared on a gentle hotbed; and afterwards planted out.

hyacinthrides . Purple 9, H. A. Texas . 1834 obtusifoliús : : Rose . : 8, H. A. Arkansa : 1833

Strर̄ptǐŭM, Roxburgh. From streptos, twisted; in allusion to the spiral tube of the corolla. Linn. 14, Or. 2, Nat. Or. Verbenaces. A pretty plant, of very easy culture, and propagated by cuttings. Synonymes: 1. Priva loptostachya, Tortula aspera.

đsspěrūm, 1 . Violet . . 7, S. Her. P. E. Ind. . 1799

Streptocārpǔs, Lindley. From streptos, twisted, ana carpos, a fruit; the capsule is spirally $t$ wisted. Linn. 2, Or. 1, Nat. Or. Cyrtandrucere. A very pretty plant, succeeding in any rich soil or vege. ( 304 ) 
table mould: and readily insreased by division. Syunyme: 1. Didymocarpus Rexii.

RèxII . . . Blue * . 6, S. Her. P. C. G. H. . 1824

STRẼprǒpǔs, Michaux. From streptos, twisted, and pous, a foot; in allusion to the twisted flower-stalks Linn. 6, Or. 1, Nat. Or. Liliacele. Interesting plants, of common culture in any light soil; and nuultiplied by seeds or divisions.

amplexifolin̆s . White. 5, H. Her. P. Hungary distôrtüs : Yellow 5, H. Her. P. N. Amer. lanuginósŭ` : Yel. grn. 6, 6. Her. P. N. Amer.

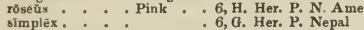

1822

STRIF, smail streaks.

Str1Ārl̆, Greville. From stria, a groove, the plant is marked with grooves. Linn. 24, Or. 7, Nat. Or. Alga. Found in the ocean-S. attenuätă.

STRIATED, having streaks.

STrict, upright, straight.

Strig.s, little upright unequal, stiff hairs, swelled at their bases.

Strigosg, covered with strigr.

Strobin înthès, Blume. From strobilos, the cone of a pine, and anthos, a flower; the inflorescence in the bud state resembles the cone of a pine. Linn. 14, Or. 2, Nat. Or. Acanthacere. This beautiful stove plant is well deserving of a place in every collection, on account of its very showy purple flowers, and the deep purple colour of the under side of the leaves. For culture and propagation, see Ruellia. Synonyme: 1. Ruellia Sabiniana.

Sabiniānă, 1 . . Blue pur.. 3, S. Ev. S. Nepal . . 1826

Stroninz, a fir cone, the fruit of the Magnolia, or a fructiferous organ of a similar form.

Strophānthŭs, Desvaux. From strophos, a twisted thong, and anthos, a flower; the segments of the corolla are long, narrow, and twisted. Linn. 5, Or. 1, Nat. Or. A pocynacea. Very beautiful shrubs, of easy culture in a mixture of sandy loam and peat; and cuttings root readily in sand, under a glass, in a little heat. Synonymes: 1. S, divergens. 2. Echites caudata.

Chinēnsǐs, 1 * Yellow . 6, S. Ev. S. China * 1816 dichơtōmŭs, 2: : Rosy : 6, S. Ev. S. E. Ind. : : I816 sarmentósŭs : Red : 6, S. Ev. S. S. Leone : 1824

Srropiriols, a round protuberance at the base of some seeds.

Struma, a wen, or protuberance.

Strumārĭ̄, Jacquin. From struma, a tubercle; in allusion to the base of the calyx.t Linn. 6, Or. 1, Nat. Or. Amaryllidacece. Interesting plants, suc. ceeding well in sandy loam; and increased by offsets.

angustifoliă ： - Pink . 4, C. Bl. P. C. G. H.

crispì : Pink: 6, Bl. P. C. G H

filifolia : : : White : 11, G. Bl. P. c. G. H

gemmátă : : Pa yel. : \&, G. Bl. P. C. G. H

finguafolia : White : 4, G. BI. P. C. G. H

rubella. : Pink . 5, G. BI. P. C. G. H.

spiráliss. . Pink . 7, G. Bl. P. C. G. H.

stellåris. - • Pink . 10, G. Hl. P. C. G. H

truncătă : White: 4 , G. Bl. P. C. G. H.

1795

1790

1774

1795

1774

1794

undulătă * W. W. P. C. G. H. 1820 resemblance of the seeds to a beak. Linn. 4, Or. 1, Nat. Or. Thymelacea. A very pretty Cape genus, thriving best in sandy peat; and young cuttings root with facility in sand, under a glass. Synonyme: 1. S. stricta.

\begin{tabular}{|c|c|c|}
\hline & \\
\hline & & \\
\hline réctă, 1 & & mite. \\
\hline abră. & : & Yellow \\
\hline nbricátă . & & Yellow \\
\hline 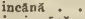 & & White. \\
\hline juniperina . & & - White. \\
\hline lateriflöra. & & - Yellow \\
\hline longiflōră & & - Yellow \\
\hline lücểns. & & . Yellow \\
\hline ăta & & White. \\
\hline pubēscēns & & - Red . \\
\hline riâtă & & - Yellow \\
\hline nentos & & - Yellow \\
\hline ath & & . \\
\hline
\end{tabular}

- 7, G. Ev. S. C. G. H. 6, G. Ev. S. C. G. H. 6, G. Ev, S. C. G. H. 6, G. Bv S C. G. H. 6, G. Ev. S. C. G. H. 8, G. Bv, S. C. G. H. 6, G. Ev. S. C. G. H. 7, G. Ev. S. C. G. H 7, G. Ev. S. C. G. H. 6, G. Ev. S. C. G. H. 4. G. Ev. S C. G. H. 6, G. Ev. S. C. G. H. 7, G. Ev, S. C. G. H. 8 , G. Ev. S. C. G. H. 6, G. Ev. S. C. G. H.

1816 1779 1820
1794 1894 1758 1819 - 1823 1817 1792 1790 1820 1799 1779

StruthiōptŭRís, Willdenow. From strouthios, an ustrich, and pteris, a fern; the fronds bear a resemblance to feathers. Linn. 24, Or. 1, Nat. Or. [ 305 ]
Polypodiacece. An ornamental genus of Ferns, of common culture. Synonyme: 1. Osmunda Struthiopteris.

germánică, 1. Brown , 7, H. Her. P. Europe . 1760 pennsylvănìcă : Brown : 8, H. Her. P. N. Amer. : 1812

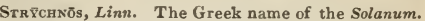
Linn. 5, Or. 1, Nat. Or. Apocynacece. Valuable plants, on account of the medicinal properties ascribed to them. They all succeed well in a mixture of loam and sandy peat, and half-ripened cuttings will root in sand, under a glass, in heat. $S$. colubrina is given as an anthelmintic in intermitting fevers. The seeds of $S$. Nux-vomica are well known by the latter name, as possessing a dangerous narcotic property, which depends upon the presence of a peculiar principle valled Strychnia. It has been administered in a great number of cases with different degrees of success; small quantities have been given for mania, gout, epilepsy, hysteria, and dysentery. It is a most violent poison, and its energy so great, that half a grain blown into the throat of a rabbit, occasions death in five minutes. Its operation is always accompanied with symptoms of locked jaw and other tetanic affections. The seeds of $S$. potatorum are sold in the Indian bazaars for the purpose of clearing muddy water: the vessel containing the water being rubbed for a minute or 5 wo round the inside, with one of the seeds; after which, by allowing the water to settle for a short time, however impure and muddy it may have been before, it becomes clear and wholesome.

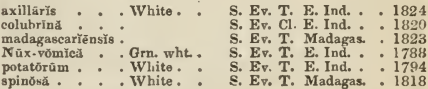

\section{STUPA, filamentose matter.}

STrLÃDRĂ, Nuttall. From stylos, a column, and aner, a male; the gynostegium is pedicellate. Linn. 5, Or. 2, Nat. Or. Asclepiadacea. For culture and propagation, see Asclepias. Synonymes: 1. Podostigma pubescens, Asclepias pedicellata.

pūmiña, 1 . . . Grn. yel. * 7, F. Her. P. N. Amer. . 1824 STrLE, the stalk which bears the stigma, and intervenes between that and the ovary.

Strutdīn, Swartz. From stylos, a column; the stamens and style are joined. Linn. 20, Or. 2, Nat. Or. Stylidiacea. Beautiful and rare little plants, succeeding best in sandy loam and peat. Cuttings of the shrubby kinds root very readily in sand, under a glass; a few of the herbaceous kinds are increased by divisions of the ruot, but chiefly by seeds. Synonymes: 1.S.glandulosum. 2. Ventenatia minor. 3. S. laricifolium.

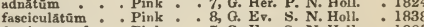
fruticōsūm, 1 : Pink : 7, G. Ev. S. N. Holl, : 1803 graminifolüm : Pink : 7, G. Her. P. N. S. W. : 1803 firsūtǔm *: Rose : 6, G. Her. P. K. G. S. : 1830 iûncéum : Rose G. Her. P. N. Holl. 1830 jûncéum : : : Rese : : 6, G. Her. P. N. Holl. : 1812

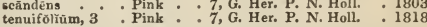
Strocos̄intrēs, Swartz. From stylos, a style, and anthos, a flower; in allusion to the flower having a long style. Linn. 16, Or.6, Nat. Or. Leguminosa. Plants of little interest, except in botanical col. lections. They require to be prown in a mixture of sandy loam and peat; and cuttings of the shrubby kinds root readily in sand, under a glass, in a moist heat. Synonymes: 1. S. hispida. 2. Trifolium guiunense.

elătiơr, 1 . Yellow , 7, F. Her. P. N. Amer. . 1816 eréctă. Yellow: $;$, s. A. Guinea: 182 ereta. ${ }^{*}$ : Yellow : 7, S. A. Guinea : : 182 mueronātă Yellow 7, S. Her. P. Ceylon: 1817 procûmbêns: :Yellow : Y. Ev. Tr. W. Ind.: 1821 viscosă : : Yellow : 7, S. Ev S. W. Ind. : 1821

STYPĀNDRĂ, R. Brown. From stype, tow, and aner, an anther. Linn. 6, Or. 1, Nat. Or. Liliacee. These plants should be grown in a mixture of sandy loam and peat, and increased by divisions. They succeed well in a pit or warm border, if protected in severe weather. Synonyme: 1. Arthropodium glaucum.

$2 \boldsymbol{R}$ 
earspitōsă . . White . 6, G. Her. P. N. Holl. : 1824 frutéscéns : : Violet : 6, G. Ev. S. N. Holl. : 1836 glaũeñ, 1 : White : 6, G. Her. P. N. Holl. : 1823 propinqua . : Azure :9, G. Her. P. N. S. W. : 1839 umbelláta : : : Whito : 6, G. Her. P. N. Holl. : 1826

STYPHĔLĬ Ă, Smith. From styphelos, hard; in allusion to the habit of the plants. Linn. 5, Or. 1, Nat. Or. Epacridacea. A genus of very beautiful shrubs, succeeding best in a mixture of two parts sandy peat, and one of sandy loam; and increased by young cuttings, planted in sand, under a glass.
adscểnděns
G. Ev. S. N. Holl

epacrioides : Crimson : 7, G. Ev, S. N. Holl

lâtá. : Green : G. Ev. S. N. Holl.

latifolix : Pink. 6, G. Ev. S. N. Holl.

longifolra . : Green . 6, G. Ev S. N. Holl

Pink 7, G. Ev S N S. W $: 1807$

tubiföră : Scarlet : 7, G. Ev. S. N. S. W : 1800

viridiffồră : : Green : 5, G. Ev. S. N. S. W. : 1791

Stypric, having the power to staunch blood.

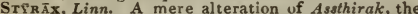
A rabic name of S. officinale. Linn. 10, Or. 1, Nat. Or. Ebenacec. The species of Styrax are very handsome when in flower, and are, therefore, well suited for ornamenting shrubberies. A light soil suits them best, and they are readily increased by layers, in spring or antumn. S. officinale is remark able for producing the very powerful and fragrant balsam known by the name of storax; it is bitter and pungent to the taste, and possesses a strong, agreeable odour. Synonyme: 1. S. glabrum.

grandifolyūm * . White - 7, H. De. S. N. Amer. - 1765 lae rigătum, 1 : White : 7, H. De. S. N. Amer. 1765 officinale . White . 7, H. De. S. Levant . 1597 pulverulēntúm : White : 6, H. De S. N. Amer. 1794

Suв, in composition, signifies somewhat; as sub umbellate, somewhat umbellate, sub-rotund, somewhat round or roundish, \&c.

SuRALATB, with a narrow wing, or margin.

SURFROSk, corky.

SuBur $\mathbb{R}_{\mathrm{R}} \mathrm{A}$, Linn. From subula, an awl; shape of the leaves Linn. 15, Nat. Or. Cruciferce. This little annual is very remarkable from expanding its flowers two or three feet under water, and impregnation taking place in that element. It only requires planting in a pond or rivulet, with a gravelly bottom; or it may be grown in pots filled with sand, and plunged in water.

aquătǐa . . White . 7, H. Aq. A. Britain .

SuBUratr, awl-shaped, tapering to a point.

Succedanious, taking the place of another.

Succīs $x$, Vaillant. From succisus, lopped ; appearance of the roots, Linn. 4, Or. 1, Nat. Or. Dipsacer. Plants of no great beauty, and of very common culture. Synonymes: 1. Cephalaria albescens. 8.

C. alpins. 3. C. attenuata. 4. C. coriacea, Lepicephalus leucantha. 5. C. corniculata. 6. C. cretucea. 7. Scabiosa glabrata. 8. Scabiosa decurrens, Cephalaria graca. 9. C. lavigata, Succisa centaurioides. 10. C. leucantha. 11. C. leucanthema, Lepicephalus leucantha. 12. Scabiosa suceisa. 13. Cephalaria rigida. 14. C. scabra. 15. C. syriaca. 16. C. tatarica. 17. C. transylvanica. 13. C. uralensis.

alhêseêns l . White . 6, H. Her. P. Siberia . 1804

alpInศ̆, 2 : White :6, H. Her. P. Switzerl. : 1570

attenuâtă, $\mathbf{3}$ : White : 6. G. Ev. S. C. G. H. : 1774

enriaceñ, 4 . : Striped : 6, H. Her. P. Tauris.

corniculata, 5 : Striped $: 7, \mathrm{H}$. Her. P. Hungary : 1801

cretăcēĕ, 6, Striped 7, H. Her, P. Gaucssus :

glubrătă, 7 . : : Purple : 6, H. Her. P. Austria : 1819

grē̌cŭ, , 8 : : Yellow: 6, H. Her. P. S. Eur. . 1819

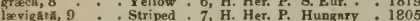

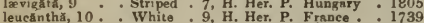

leueånthémã, i1: White :9, H. Her. P. France : 1820

pratēnsǐs, 12 . Violet : 8, H. Her. P. Britain

nigldă, 13 : White : 7, G. Ev. S. C. G. H.

scábri, 14 : White 6, G. Ev. S. C. G. H.

syriăcă, 15 . White

tatấrich, 16 ,

uralênsts, 18 . Yellow: $7, \mathrm{H}$. A. Siberia: : 1789

SucCory, see Cichorintm

Succōwř̈, Medirus. In honour of Professor Suckow, a botanist of Heidelberg. Linn. 15, Nat. Or. Cruciferc. A light soil suits this plant. The seed has only to be sown in the open border, or on rock-work. belefirica . . Yellow . 6, H. A. Minorea . 1781 Succulknt, fleshy, flled with juice.
Suborirle, having the power of producing perspiration.

Suryroticose, somewhat shrubby.

SUgAR cane, see Sacchărũm.

Sulcate, furrowed, channelled.

Sulphurwort, see Peucedăñm.

SUMACr, see $R$ hits.

SUMMRR CYPREss, see Köchĩă scopäriă.

SuNDEW, see Droséră.

Sun-rkan, see Poly podiam Phegepterris.

SUNFLOWRR, see Heliänthũs.

SuNFlower, see Actinotŭs Helianthi.

SUN RosR, see Heliänthëmam.

SUPRRIOR, this appellation is given to anything that is above the ovarium.

Supror, lying with the face upwards.

SUPPLB JAC:, see Serjäniă triternătă.

Surculi, young shoots.

SUTHERLANDǏ̃, $\boldsymbol{R}$. Brown. In honour of James Sutherland, one of the first superintendants of the Royal Botanical Garden at Edinburgh. Linn. 17, Or. 4, Nat. Or. Leguminose. This species is very showy when in flower; it succeeds best in loam and peat; and is readily increased by seeds, or young cuttings. Synonyme: 1. Colutea frutescens.

frutếscêns, 1 . . Scarlet . 6, F. Ev. S. C. G. H. 1683

SUTURE, the line formed by the eohesion of two parts. SUWARROW NUT, see Caryöcür.

SWAINSठ̋̃̄ă, Salisbury. In honour of Isaac Swainsnn, F.R.S., L.S., a celebrated cultivator of plants, about the end of the last century. His garden was at Twickenham in Middlesex. Linn. 17, Or. 4, Nat. Or. Leguminosa. Very elegant shrubs, well worthy of a place in every greenhouse. They succeed best in a mixture of sandy loam and peat; and young cuttings root freely in sand, under a glass; they may also be increased by seeds. Syno. nyme: 1. Colutea galegifolia.

coronillæfolrs . Purple . 7, G. Ev. S. N. S. W. . 1802 galegifalla, 1 : Red : 7, G. Ev. S. N. s. W. : 1800 nlbifloră.: : White.: 7, G. Er. S. N. S. W. : 1826 esaertiafolra : Purple 7, G. Ev, S. N. Holl. : 1824 Swallow-wort, see Asclépias.

SWALLOW-WORT, see Thípsiă Asclęprăs.

SWAмP LOCU8T-TREg, see Gleditschră monospërmă.

SWAM P-P0sT, see Quércüs lyrütă.

SWÃRTzİ̃, W'lldenow. In honour of Olof Swartz, M D., a long time resident in the West Indies, and author of "Flora Indiæ Occidentalis." Linn. 13, Or. 1, Nat. Or. Leguminosie. The species of this genus should be grown in a mixture of sandy loam and peat ; and cuttings, not deprived of their leaves, will root in sand, under a glass, in heat. grandiflóră : : Yellow : Y. Ev. S. Trinidad : 1821
pinnătă simplicifolra : Pa yel. : S. Ev. S. W. Ind. : 1818

SWFDtsh BвAM-TREB, see Pgrüs intermédYu.

SWRDIsh TURNIP, see Erässicü campestrĭs; var. rutabaga.

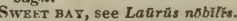

SWERT BRIAR, see Rosĭ rubiginósă.

SWERT CAlabash, see Passiflórü maliförmìs.

SWEBT YLAO, see Acörüs Călämüs.

Swget GaI r, see Mryrïcă Gäle.

SWEET GUM, see Liqnidambär styraciflüđ.

SWER̂Tî̀, Decandolle. In honour of Robert Sweet, F.L.S., anthor of numerous well-known botanical works. Linn. 17, Or. 4, Nat. Or. Leguminose. These plants should be kept in a strong heat, and grown in a mixture of loam and sand. They are increased by cuttings, planted in sand, under a glass, or by seeds. Synonymes: 1. Galega filifor mis. 2. Glyctne lignosa. 3. Galega longifolia.

filiformis, 1 . . Purple - 7, S. Ev. Tw. S. Amer. . 1820 lignōsă, 2 .. Purple . S. Ev. Tw. St. Domin. . 1824 longifoliză, 3 . . Purple . S. Es. Tw. S. Amer. . 1818

SWEBT MARJORAM, see OTiğ̄nțm Majoränă.

SWRET MAUDLIN, see Achinleă agerütüm.

SWBET PEA, see Lãthy̆rŭs odorätüs.

SwEBT Potato, see (Supplement) Batãtäs.

SWEETSOP, see Anठ̄ñ̆ squamठ̋s̆.

SwRET sultan, see Centafiréă moschatd.

SwEET WuLAM, see Diänthüs barlatüs.

SWERT Will.IAM, see Silëné Armérüă.

SwẼrtĭ , Linn. In honour of Iman. Swert, a famous cultivator of bulbs and flowers, in Holland. Linn. [306] 
5, Or. 2, Nat, Or. Gentianacea. These plants prefer a marshy or peat soil ; and are increased by seeds. S. perennis, though a perennial, may likewise be increased by seeds. Synonyme: 1. S. corniculata.

corniculāta - Pa. grn. - B, H. A. Siberia . 1817 Michauxiână, 1 Grn, vel. . 7, H. B. N. Amer, 1824 perênniss. Purple : 7, H. Aq. P. England :

SWIRTǏ̌x̌̆ Ă, Linn. In honour of Gerard Van Swieten, a Dutch botanist, and author. Linn. 10, Or. 1 Nat. Or. Cedrelacere. These interesting and valuable plants succeed well in a mixture of loam and sand; and ripened cuttings root in sand, under a handglass, in heat, but the leaves must not be shortened. The well-known mahogany is the produce of $S$. Mahagoni.

febrifúgă * . Wht, yel, . S. Ev. T. E. Ind. . 1796 Mahăgðnī : : : Red yel. : S. Ev. T. W. Ind." : 1734

SWINE's succory, see Hyð̆sĕrĭs.

SWORD FFRN, see Xiphoptérts.

Sword grass, see Alsiné segetülis.

Sword gRAss, see Melilotoùs segetālis.

SYĂGrŭs, MIartius. 'The first who wrote the history of the Trojan war in verse. Linn. 21, Or. 5, Nat. Or. Palmucee. This Palm succeeds in sandy loam and a moist heat ; it is multiplied by seeds.

cocoidęs Palm. Brazil

.1824

Sycamori, see Acĕr Pseñdo-Plătărŭs.

Symphíñdă, A. Decandolle. From symphio, to grow together, and aner, an anther; the anthers are connate. Linn. 5, Or. 1, Nat. Or. Campanulacea. For culture and propagation, see Campanula. Synonyme: 1. Campanula pendula.

pēndǔlă, 1 . . . Cream. . 7, H. B. Caucasus . 1823

SyMPhoricārpưs, Dillenius. From symphoreo, to accumulate, and karpos, fruit; in allusion to its clustered bunches of fruit. Linn. 5, Or, 1, Nat. Or. Caprifoliacee. The species of St. Peter's Wort are handsome dwarf shrubs, suitable for the fronts of ornamental shrubberies. They are readily increased by cuttings, planted in autumn or spring, or by suckers, which they throw up in abundance. Synonyיnes: 1. Symphoria montana. 2. S. racemosa. 3. Lonicera Symphoricarpos, Symphoria glomerata. 4. Symphoria glomerata fol. variegatis.

montănŭs, 1 . . Pink . . 8, H. De. S. Mexico . 1829 racemôsŭs, 2 : Pink : 8, H. De. S. N. Amer. 1817 vulgāris, 3 . : White : 8, H. De. S. N. Amer. 1730 fol, variegătīs, 4 Pink : 8, H. De. S.

S̆̈мpнйтūM, Linn. From symphyo, to make unite, and phyton, a plant; in reference to the healing qualities of the plant. Linn. 5, Or. 1, Nat. Or. Boraginacea. Showy plants, thriving in any soil or situation; some of the kinds are well adapted for the flower border, where they can be much shaded. They succeed well under the shade of trees, and flower throughout the principal part of the summer season; increase is obtained by division. Synonymes: 1. S. bohemicum. 2. S. bullatum.

aspẹrrĭmūm - . Red blue . 7, H. Her. P. Caucasus . 1799 hỹbrìdūm : : Red blue : 7 , H. Her. P. Hybrid. : 1825 caucăsĩeūm : Azure. : 6, H. Her. P. Caucasus: 1820 cordátúm Cream. 6, H. Her. P. Transyly - 1813 officinalé é White. bolıẻmǐcūm, 1 : Crimson : 5 , H. Tu. P. Bohemia pátēns pătēns * . Bluє * 6, H. Tu P. Britain orientălě . . White. . 5, H. Her. P. Turkey. peregrinūm
taūricūm bullátūm, 2 : Pa.yel. : 6, fi. Her. P. Caucasus : 1818 tuberōsüm . . Yellow , 7, H. Tu, P. Scotland

Sxмpıżz̆, Lichtenstein. From sympiezo, to press; in reference to the stamens, which adhere to the tube of the corolla. Linn. 4, Or. J, Nat. Or. Ericacea. A pretty little plant, thriving in turfy peat and sand; and readily increased by young cuttings, placed in sand, under a glass. Synonyme: 1. Biceria bracteatu.

capitellátă, 1 .

7, G. Ev. S. C. G. H. . 1812

Symplocārpŭs, Salisbury. From symploke, connexion, and karpos, fruit. Linn. 4, Or. 1, Nat. Or. Aracere. This is a curious species, bearing large, handsome leaves. It succeeds in a marshy situation, in peat soil ; and is increased by division. The roots and seeds are powerful antispasmodics; they are also expectorant, and useful in phthysical conghs. Synonymes: 1. Pothos fatidus, Dracontium fatidum.

fø̄tùdŭs, 1 . . A petal . 5, H. Aq. P. N. Amer. , 1735

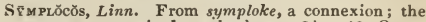
stamens are united at the base. Linn. 18, Or. 2, Nat. Or. Ebenacee. These plants thrive well in a mixture of loam, peat, and sand; and cuttings root without difficulty in sand, under a glass; the stove species requiring heat.

cocčñ̌a _. Rose . S. Ev. T. Mexico . 1895 siň̌eă : : White : 5, G. Ev. S. China : 1822 tinctôrĭ̌a : : : Yellow : G. Ev. S. Carolina : 1780

SyncẼsǏĂ, Taylor. Derivation unknown to us. Linn. 24, Or. 8, Nat. Or. Lichenes. This species is found on rocks, dry shores, \&c.-S. àlbïdă.

SYNRDRĒLI.Ă, Gartner. From synedrella, a little bench, in allusion to the naked receptacle. Linn. 19, Or. 2, Nat. Or. Composita. A stove annual, neither interesting nor beautiful. Synonyme: 1 . Verbesina nodiflora-S. nodifloră 1.

SyNGENEsiots, belonging to the 19th class in the sexual system.

SYNลẼTĬ, Sneet. In honour of W. Syrnet, who collected many plants at the Cape. Linn. 3, Or. 1 , Nat. Or. Iridacece. Pretty bulbous plants, requiring the same treatment as the species of Ixia. Symunymes: 1. Ixia bicolor, Sparaxis bicolor, Gladiolus bicolor. 2. Gladiolus galeatus.

bỉcolor, 1 . . Brn. yel. . 3, G. Bl. P. C. G. H. . 1796 galeată, 2 : : : Brn. yel. : 4, G. Bl. P. C. G. H. : 1825 Sycrherical, combining, a term used in an opposite sense to analy tical.

Sxprturtic, of or belonging to Syphilis.

Syrian Rur, see Pegänam Härmälü.

SYRĨNĂ, Linn. From syrinx, a pipe; the branches are long and straight, and are filled with medulla; hence the old name of the Lilac, pipe-tree. The English name of the genus is from lilac or lilag, the Persian word for the fiower. Linn. 2, Or. 1, Nat. Or. Oleacea. The species of Lilac are well known elegant shrubs; readily increased by layers, or by suckers from the roots. Synonyme: 1. S. chinensis.

Josikæ̃a pérsìcá : : Purple . 5, H. De. S. Persia . 1640

âlbă : White 5 , H. De. S. Persia: :

laciniąta . . Purple . 5, H. De. S. Persia .

salviforlǐă : 5 , H. De. S.

rothomagēnsìs, i : Purple : 6, H. De. S. Hybrid . . 1795 saugeănă . : Red : 6, H. De. S.

vulgăris .: Blue : 5, H. De. S. Persia . 1597

albă : White : 5, H. De. S. Persia

álbă măjơr : White . $5, \mathrm{H}$. De. S.

ălhă plênđ̆ : White 5 , H. De. S

coerüleă : : Blue : H. De. S.

rŭbră . Red : 5, H. De. S.

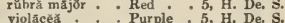

Syringa, see Philadēlphřs.

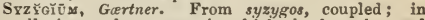
allusion to the manner in which the branches and leaves are united by pairs. Linn. 12, Or. 1, Nat. Or. Myrtacece. Interesting plants. For culture and propagation, see Myrica. Synonymes: 1. Culyptranthes caryophyllifolia. 2 C. Jambolana. 3. Eu. genia zeylanica.

caryophyllifolĩum, 1 White . S. Ev. T. E. Ind. . . 1822 Jambelănă, 2 *. White : 8, S. Kv. T. E. Ird. : 1796 zeylănĭeă, 3 . : : White : 6, s. $\Sigma_{\text {V. }}$ S. Ceylon : 1798 
TABERNAMONTÄNA, Linn. In honour of I James Theodore Tabernæmontanus, a celebrated physician and botanist. Linn. 5, Or. 1, Nat. Or. Apocynacea. A genus of interesting plants, mostly bearing white, sweet-scented flowers. A mixture of loam, peat, and sand, suits them best; and young plants may be obtained from cuttings, planted in sand, under a glass, in a moist heat. Synonymes: 1. $T$. citrifolia. 2. Nerium corcnarium. 3. T. multiflora. 4. Cameraria lutea, T. Tamaquarina.

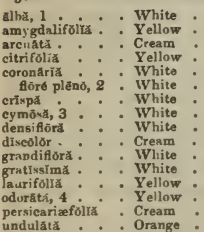

5, S. Ev. T. W. Ind. 1780 7, S. Ev. S. S. Amer. S. Ev. T. Peru * 1824 S. Bv. T. Jamaica : 1784 7, S. Ev. S. E. lnd. : 1770 7, S. Ev. S. E. lnd. : : 1770 7, s. Ev. S. E. lnd. : 1818 S. Ev. S. Carthag. : 1820 6, S. Ev. S. E. Ind. - 1824 4, S. Ev. T. Jamaica 1822 S. Ev. S. Trinidad : 1823 6, S. Ev, S. E Ind. 1824 5, S. Ev. T. W. Ind. 1768 10, S. Ev. S. Cayenne : 1793 S. Ev. T. Mauritius : 1819 S. Ev. T. Trinidad : 1824

'TÄcč̃, Forster. The Malay name of the species. Linn. 6, Or. 1, Nat. Or. Taccaced. Interesting plants, thriving well in a mixture of loam, peat, and sand; and readily increasing by division of the roots. They must be very sparingly watered whilst in a dormant state. The large fleshy roots, when scraped and frequently washed, yield a nutritive fæcula resembling arrow-root.

aspera Brown 7, S. B1. P. P. Ind 1816 anineénsis : : Brown 7. S. Bl. P. E lnd: 1823 integrifölye : Purple : 6, S. Her, P. E. Ind. : 1810 lérls . Brown : 7. S. BL. P. E. Ind. : 1820 phalliférä: : Browa : 7, s. BL. P. Maurit. : 1826

Тスсні̆ , Aublet. From Tachi, which, it is said, signifies an ant's nest; a name applied in its native country to $T$. Guianensis on account of its trunk and branches being usually full of ants; this species, we believe, is not yet introduced to this country. Linn. 5, Or. 1, Nat. Or. Gentianaceg. These plants will grow freely in a mixture of peat, sand, and loam; a small proportion of the last will suffice; cuttings planted in sand, under a hand-glass, in heat, will strike root readily. The species are rather difficul to keep through the winter, in this country, on acccount of their being liable to damp off; and in order to prevent this, they should be very sparingly watered in damp weather. Synonymes: 1. Hisianthus cordifolius. 2. L. longifolius. 3. $\boldsymbol{s}$. exsertus.

cordifolra, 1 . . Yellowy . S. Ev. S. Jamaica . 1816 longifolra, 2 : Yellow : S. Ev. S. Jamaica : 1793 Swártzli, 3 : Yellow : S. Ev. \&. Jamaica : 1793

TAcrig $\bar{L}, \bar{A}$, Aublet. Tachigali is the name of the species in Guiana. Linn. in, Or. 1, Nat. Or. Leguminose. This plant succeeds best in a light loamy soil ; and large cuttings ront readily if planted in sand, with a glass over them; they must be placed in heat.

bijügă . . . . Yellow . S. Ev. T. Brazil . . 1822

TArsōñ̌n, Jussieu. From Tacso, the name of one of the species in Peru. Linn 16, Or. 2, Nat. Or. Passiflora, and requiring the same culture as that genus. Synonyme: 1. Passiflora peduncularis.

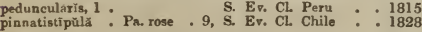

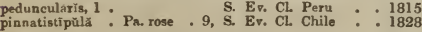

T д2NI0sUs, ribbon-like.

T xeniriss, Snartz. From taina, a tillet; alluding to the long, narrow frond. Linn. 24, Or. 1, Nat. Or. Polypodiacec. Interesting Ferns, succeeding in sandy loam and peat; and increased by division at the roots, or by seeds. Synonymes: 1. Pteris angustifolia. 2. P. lanceolata.

angustifơlıă, 1 . Brown * 7, 8. Ev. Cr. Jamaica * 1816

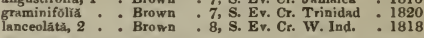
TAGẼTẼs, Linn. From the bealty of its flowers, this genus is named after Tages, a Tuscan divinity. Linn. 19, Or. 2, Nat. Or. Composite. A genus of elegant plants when in flower, and, therefore, well deserving a place in every garden. The annual species should be raised on a hotbed in spring, and planted o'it about the end of May. The herbaceous kinds thrive in any rich, light soil; and may be increased by cuttings or divisions.

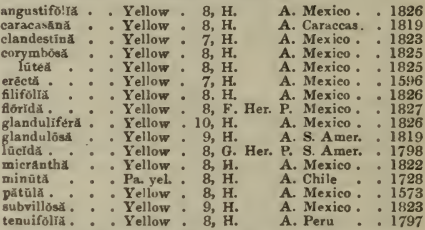

TAus, the certain fruits.

TALAŨmä, Jussieu. The vernacular name of the South American species. Linn. 13, Or. 6, Nat. Or. Insgnoliacea. The species of Talauma are well worth cultivating on account of their beautiful and fragrant flowers. A mixture of loam, peat, and sand, suits them well. They may be increased by layers, or by inarching on Magnolia obovata, and ripened cuttings will root with difficulty in a pot of sand, under a glass, in heat; but the leaves must not be shortened. Synonymes: 1. Magnolia odoratissima. 2. M. pumila.

Candollui, 1 . . Striped . 4, S. Ev. S. Java . 1827

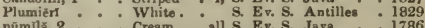
pumila, 2 . Its aboriginal name Linn, 6 , Or. 1, Nat. Or. Palmacee. An ornamental, loftygrowing tree, requiring to be grown in turfy loam and sand; increased by seeds. Synonyme: 1 . Corypha Taliera.

bengalénsisos 1 Palm. E. Ynd. . . 1893

TALĩNû, Adanson. Supposed to be from thalia, a green branch; durable verdure. Linn. 11, Or. 1 , Nat. Or. Portulacacea. Interesting succulent plants, growing best in a mixture of loam, peat, and sand; and readily increased hy cuttings. The biennial species must be raised on a hotbed, and afterwards planted out in a warm, sheltered part of the flower garden. Synonymes: 1. T . patens. 8. T. fruticosum. 3. Portulaca racemosa.

Andrếssī, 1 . . Pink . . 8, S. Ev. S. W. Ind. . 1800 crassifóliumm : Red * 8, S. Ev. S. 7. G. Ev. S. S. Amer. . 1810 cuneifotiúm . Purple * 7, S. Ev. S. Egypt . . 1820 pătêns . . . Red * . 9, S. Her. P. S. Amer. . 1776 refféxúm - . Yellow * 9, S. B. S. Amer. 1800

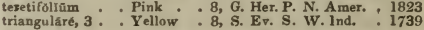

TALǏsİ, Aublet. Derived from Toulichi, its name in Guiana. Linn. 8, Or. 1, Nat. Or. Sapindacee. This shrub succeeds well in a mixture of turfy loam and peat; and large cuttings, not deprived of any of their leaves, will root in sand, under a glass, in a moist heat.

guianēnsis . . Rose . . S. ET. S. Guiana . . 1824 TALIoW-TREB, see Stilitingiă sebijferă. TAMARIND-TREE, see Tamarindŭs.

TAMARindưs, Linn. Tamar, in Arabic, is the name [ 308 ] 
of the date, and Indus, Indian; Indian-date. Linn. 16, Or. 6, Nat. Or. Leguminosie. The species of Tamarind thrive in a mixture of sandy loam and peat; and are readily increased by seeds, which are annually imported from the East and West Indies; they should be sown on a hotbed, and planted singly into pots, when about three inches high. Cuttings root readily in sand, under a glass, in heat. The preserved pulp of the tamarind is well known as a delicious confection.

indiex . Yellow . 6, S. Ev. T. India

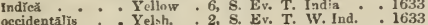

TAMARISK, see Tamärĩx.

TAMĂKĪX, Linn. So named on account of the plants growinu on the banks of the Tamaris, now Tambro, on the borders of the Pyrenees. Linn. 5, Or. 3, Nat. Or. Tamaricacee. This is a genus of very elegant shrubs. The hardy species is well suited for soil or sitnation; and increases freely by cuttings, planted in the open ground, in spring or autumn. $T$. orientalis succeeds well in a mixture of loam and peat; and cuttings root readily in sand, under a glass, in heat. The bark of all the species is slightly bitter, astringent, and probably tonic. The manna of I Iount Sinai is produced by' a variety of $T$. Eallica : it consists wholly of pure mucilaginous sugar. Synonyme: 1. T. articulata.

\section{diofex}

gallica :

orientälis i Flesh

S. Ev. S. E. Ind.

H. De. S. England

1823

TАMŌNĔX̆, Aublet. Tamone is its name in Guiana. Linn. 14, Or. 2, Nat. Or. Verbenacer. Ornamental biennials. They should be raised on a hotbed, and, when of sufficient size, planted singly into pots of sandy soil, and treated as other stove biennials. Synonymes: 1. T. verbenacea, Ghinia spinosa. 2. G. mutica.

eurss:ăvǐeă, 1 . . Blue . . 7, S. B. W. Ind. - 1823 mútică, 2 : : Blue : 7, s. B. Griana.: 1820

TĀMŬs, Linn. A name applied by Columella to a plant resembling a vine. Linn. 22, Or. 6, Nat. Or. Dioscoreacere. Hardy twining plants, of no interest, succeeding in common garden soil; division of the roots- $\boldsymbol{T}$. communis, crêtic ă.

TANACẼT T̃ M, Linn. Said to be altered from Athanasia. Linn. 19, Or. 2, Nat. Or. Cumposita. The species of Tanacetum or Tansy are not possessed of much beauty. The hardy kinds succeed in any common soil; and are readily increased by division The greenhouse species should be grown in a light, rich soil. They increase freely by cuttings. Withering asserts, that if meat be rubbed with the leaves of tansy, the flesh-fly will not touch it. Synonymes: 1. Achillea filipendula. 2. A bipinnata.

angulātūm, 1 Yellow 7. H. Her. P. Levant - 1890 crispiman, 1 Yellow 7 , Her. P.

globulíferúm : Yellow : 7, H. Her. ${ }^{\text {A. Russia . . } 1838}$ grandifôrūm Yellow 5, G. Her, P. C. G. H. 1820 H. Her, P. Altai

myriophȳllũm, 2 Yellow $\quad 6$, H. Her, P. Levant :

vulgare : Yellow : 6, H. Her. P. Britain

variegãtūm : Yellow : 7, H. Her. P. Britain

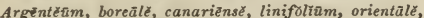
sibirīcūm, suffruticơsūm, vєstîtam.

TANAẼcīìm, Swartz. From tanaekes, long; stems elongated. Linn. 14, Or. 2, Nat. Or. Gesneracece This species is described as an ornamental, lofty. growing tree. For culture and propagation, see. Bignonia. Synonymes: 1. Crescentia pinnata, Tripinnaria africana.

pinnătūm, 1 . Red . . S. Ěv. T. Mozamb. . 1826

TANGhǏx̌̃, Du Petit Thuuars. From Tanghin, the Madagascar naine of $T$. veneriflua, the seed of which is the ordeal nut of that Island. Linn. 5, Or. 1, Nat. Or. Apocynacere. These remarkable plants may be referred to Tabernamontans for culture and propagation. $T$, veneniflua is the celebrated ordeal tree of Madagascar. The fruit is yellow; and incloses a flbrous stone or nut; the kernel inclosed in this stone, or nut, is said by some to be the part used for the ordeal, and to be infused in a liquid of which the accused person is made to drink; others say the infusion is made of the entire fruit. In Don's Dictionary of Gard. and [ 309 !
Bot., vol. 4, p. 98, is the following' passage relative to this subject:- "The custom of administering Tanghin as an ordeal, in Madagascar, has become far more universal during the present reign, than at any former period of the Huwa government. When her present Majesty, in the beginning of 1830 , came to the resolution of cleansing her lands from sorcerers, an ordeal was commanded in every town and village; and in Tannanarivoo scarcely any class of the inhabitant 3 escaped. On the 9 th of May, 1830, in compliance with the sovereign's mandate, a notable administration of Tanghin took place. The accused persons amounted to about thirty, including some of the highest rank in the kingdom. All the nobility recovered, while the unknown plebeians, who, according to the common jugglery, had been compelled to drink with them, died. The former made the usual triumphant entry into the town, on the 17 th, borne in open palanquins, amongst the shouting, dancing, and grimaces of the many thousands of people. In the following month, about an equal number of Mala. gassy ladies submitted to the same ordeal; but all survived, and, in due course, made a grand entry into town. The Tanghin is administered in private, as well as in public. A subject so deeply rooted in the minds of all the Malagassy people, from the sovereign down to the slave, is the belief in witch. craft; and so blindly are they led on by this belief, that a whole nation may be considered as labouring under a spell, as powerful as the fascination which they attribute to the unfortunate sorcerers themselves." Synonymes: 1. Cerbera laurifolia. 2. C. lactaria. 3. C. Odollam. 4. C. Tanghin.

laurifŏlă, 1 White . 6, S. Ev. T. E. Ind. 1818 Mānghãs, 2 : White : 8, S. Ev. T. Singapore: 1800 Odōllām, 3. : White. 8, S. Ev. T. India : 1756 veneniflŭă, 4 : : Pink : 5, S. Ev. T. Madagas. : 1826

TANGIrR PEA, see Lăthy̆rŭs tingitānŭs.

TANNA, see Euphorbiá tannénsis.

TANsy, see Tanacêtũ $m$.

TAPBRING, becoming gradually narrower.

TAP-ROOT, a root which penetrates deep and perpendicularly into the ground, without dividing.

TARchon Anthưs, Linn. From tarchon, the Arabic word for taragon, and anthos, a flower. Linn. 19, Or. 1, Nat. Or. Composite. Interesting plants, succeeding well in light rich soil; and readily increased by cuttings, in sand, under a glass.

camphoratús . Purple - G Ev. S. C. G. H. ellipticús : : G. Ev. E. C. G. H.

1690

\section{TARR, see Ervîm.}

TARGXōĩ̆, Michcli. In honour of John Anthony Targioni, a Florentine botanist. Linn. 24, Or. 6. Nat. Or. Hepatica. This species is found growing in broad patches, in wet places-T. hypophÿllă.

Tartareovs, consisting of tartar.

TAuschēRĪ, Fischer. In honour of Ignat. Frederick Tauscher, Professor of Botany at Prague, author of several botanical works. Linn 15 , Nat. Or. Creciferce. Annuals of no beauty. The seed merely reqnires to be sown in the open border, or on rockwork.

gymnocărpă • White. . 6, Н. A. Siberia . 1820 lasiocảrpă $:$ : White: : 6, H. A. Siberia : : 1824

TAverniêr nier, a traveller in the Levant. Linn. 17, Or. 4, Nat. Or. Leguminosa. For culture and propagation, see Dicerma. Synonymes: 1. Hedysarum lappaceum. 2. $\boldsymbol{H}$. nummularifolium.

lappáceă, 1 * Yellow * 7, G. Ev. Tr. Arabia - 1820 nummuläriă, 2 Rose 6, G. Ev. S. Levant . 1896

TAxódĩ $\mathrm{m}$, Richard. From taxus, the yew, and eidos, like; trees resembling the yew. Linn, 21, Or. 8 , Nat. Or. Coniferce. Ornamental, lofty-growing trees, well suited for planting singly on lawns. They grow best in a rich moist soil ; and are readily increased by seeds, layers, or by cuttings, with the leaves left whole, placed in a vessel of water, where they will root in a few weeks. The Deciduous Cypress is universally employed, throughout the United States, for making the best kind of shingles; and in Louisiana it is used for almost every other purpose to which timber is applied. Synonymes: 1. Schabertia capensis. 2, S, disticha. 3. S. d. pendula. 4. T. sinense pendulzcm. 5, T. sinense. 
capẽnsé, 1 * A petal - 4, G. Ev. 8. C. G. H.

istichũm, 2 . A petal

excëlsũm : A peta

nūtāns, 3 : A peta

pátēns : A petal

pendủumm, 4 . A peta

5, H. De. T. N. Amer. : 1640 5, H. De. T.

5, H. De. T.

5, H. De. T.

5, H. De. T.

TAxǔs, Linn. From toxon. a bow; being formerly used in making them; or from taxis, arrangement; the leaves are arranged on the branches like the teeth of a comb. Yew is supposed to be from the Celtic word $i w$, signifying verdure; alluding to the yew being an evergreen. Linn. 22, Or. 13, Nat. Or. Taxacea. Ornamental trees, well adapted for underwood, as they thrive under the shade and drip of other trees; they are also very ornamental when planted to form hedges. They will grow in any moist soil, but succeed best in loams and clays. They are chiefly propagated from seeds, which should be sown as soon as ripe; they may also be increased by cuttings, formed of either one or two years' wood, and planted in a shady border in the beginning of April or end of August. Synonymes

1. $\boldsymbol{T}$. fastigiata, $\boldsymbol{T}$. hibernica, $\boldsymbol{T}$. baccatu hibernica.

\begin{tabular}{|c|c|c|c|}
\hline 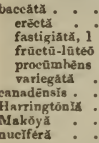 & $\begin{array}{l}\text { A petal } \\
\text { :A petal } \\
\text { A petal } \\
\text { A petal } \\
\text { A petal } \\
\text { A A petal } \\
\text { A petal } \\
\text { : A petal } \\
\text { A petal }\end{array}$ & $\begin{array}{l}\text { 2, H. Ev. T. Britain } \\
\text { H. Ev. T. Seedling } \\
: 4 \text {, H. Ev. T. Ireland } \\
: 4 \text { H. Ev. T. Ireland } \\
: 2 \text { H. Ev. S. Europe } \\
\text { 2, H. Ev. T. Europe } \\
\text { 2, H. Ev. T. Canada } \\
\text { 5, H. De. T. Penang } \\
\text { 5, H. De. T. Japan } \\
\text { G. Ev. T. Chins }\end{array}$ & $\begin{array}{l}: 1780 \\
: \\
: 1800 \\
: 1837 \\
: 1838 \\
1820\end{array}$ \\
\hline
\end{tabular}

Trak wooD, see Tectönd.

Trasal, see Dĩpsăcŭs.

TPATRD, having protuberances which resemble the teats of animals.

TBA-TRBB, see Thẻă.

Tвсо̆мĂ, Jussieu. From Tecomaxochitl, the Mexican name of the species. Linn. 14, Or. 2, Nat. Or. Bignoniacea. A genus of very elegant plants, welI worth cultivating. $T$. radicans is peculiarly adapted for ornamenting a wall, or front of a house. The other kinds require the same treatment as the species of Bignonia. Synonymes: 1. Bignonia Pandora. 2. B. capensis. 3. B. trandiflora, chinensis, Incarvillea grandiflora. 4. B. pentaphylla. 5. B. radicans. 6. B. stans. 7. T. incisa.

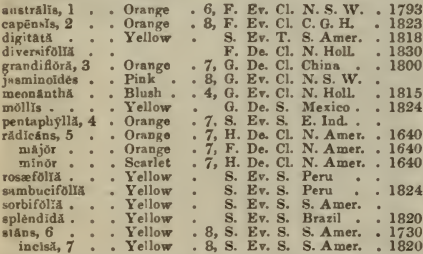

Tвсто̆NĂ, Linn. From its name in Malabar, Tekka. Linn. 5, Or. 1, Nat. Or. Verbenacea. This tree thrives well in a mixture of peat and loam, in a strong heat; and ripened cuttings will root in sand, under a glass, in heat. In its native country, it is much valued for the hardness and durability of its wood; of which some of the largest ships have been built, both at Calcutta and Madras.

grândis . . . White. . S. Ev. T. E. Ind. . . 1777

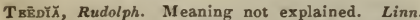
14, Or. 2, Nat. Or. Scrophulariacene. Pretty plants when in blossom. A rich light soil suits them best; and they are readily increased by cuttings or seeds.

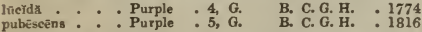

TEEsnĀLI author of a Catalogue of plants growing about Castle Howard. Linn. 15, Nat. Or. Cruciferce. Pretty little annuals, well adapted for rock-work, where the seeds have only to be sown, and may afterwards be allowed to scatter themselves. Synonymes: 1. T. nudicaulis. 2. T. regularis.

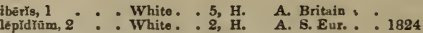
TrLїкцй, Beumgarten. Not explained. Linn. 19 , Or. 2, Nat. Or. Composite. This plant succeeds well in common garden soil ; and is readily increased by division of the roots. Synonyme: 1. Bupthalmum cordifolium.

speciósá, 1. - Yellow . 7, H. Her. P. Hungary . 1739

TrLĒPHĪ M. Linnæeus named this genus after Telephus, son of Hercules by Auge, and, according to some, king of Mysia. Linn. 5, Or. 1, Nat. Or. Illecebracea. A hardy herbaceous plant, not worth cultivatingT. Imperätī.

TÉLLiMä, R. Brovn. An anagram of Mitella; separated from it. Linn. 10, Or. 2, Nat. Or. Saxifragacee. A very handsome plant. For culture and propagation, see Mitella.

grandiförž . . Pink . . 4, H. Her. P. N. Amer. 1886

Telôpŭ厶̆, R. Brown. From Telopas, seen at a distance; alluding to the great distance from which its crimson-coloured blossoms are discernible in its native country. Linn. 4, Or. 1, Nat. Or. Proteacea. This magnificent plant is considered to be rather difficult of culture. A light soil, composed of equal parts of sandy loam and heath mould, with a good proportion of sand and gritstone, well incorporated, appears to suit it best. The pot in which it is grown must be well drained; and in watering, care must be taken never to allow the plant to flag, nor yet to over-water it. Though it requiresvery little water in the winter season, it must have a gond supply in the summer mouths, particularly while growing freely. It should always be kept in a light, airy part of the house. It may be propagated by cuttings, in sand, under a glass; but young plants may be obtained readier, and with greater certainty, by layers; as the plants naturally produce an abundance of suckers, which may be easily laid down into small pots, introduced round the one in which the plant is growing. In summer, the Warratah succeeds well in an diry part of the greenhouse, but in winter, it subsists better in a cool, airy part of the stove.

speciosissimi. . . Scarlet . 6, G. Ev. T. N. S. W. . 1789

TeMpletōnĭ , R. Brown. In honour of Mr.Juhn Templeton, of Orange Grove, near Belfast, an excellent botanist. Linn. 16, Or. 6, Nat. Or. Leguminosa. Interesting plants, thriving well in a mixture of sandy loam and peat; and increased by young cuttings, in sand, under a glass.

glaũed . . Red . . 4, G. Ev. S. N. Holl. • 1818 retas : : Red : 5, G. Ev. S. N. Holl. 1803 TrNax, tough, adhesive.

TENDRIs, the curiing, twining organs by which some plants lay hold of others.

TENōrĭ

Tephrósĩa, Persoon. From tephros, ash-coloured; in allusion to the colour of the foliage of some of the species. Linn. 17, Or. 4, Nat. Or. Leguminosc. The species of Tephrosia thrive well in a mixture of loam and peat, and are readily increased by seeds, or by young cuttings planted in sand, under a glass; those of the stove species, in heat. "The leaves and branches of $\boldsymbol{T}$. toxicaria, well pounded, and thrown into a river or pond, very soon affect the water, and cause it to intoxicate the fish, so as to make them float on the surface as if dead; most of the large ones recover after a short time, but the greater part of the small fry perish on those occasions. It has been introduced into Jamaica, and cultivated there on account of its intoxicating qualities."-Don's Gard. and Bot., vol. 2, p. 229. Synonymes: 1. Galega biflora. 2. Robinia candida. 3. G. caribea. 4. G. grandiflora. 5. G. heterophylla. 6. G. mucronata. 7. G. ochroleuca. 8. G. pallens. 9. G. piscatoria. 10. Indigofera stricta. 11. Robinia subernsa, 12. Galega virginica.

apollinéa . . Blue . . 7, S. Ev. S. Egypt . . 1816 biflór, 1: : Purple : 7, s. Ev. \$. Eypt - 1816 cândìn, $2:$ Pa red : S. Ev. S. Bengal : 1816 capensts : Purple : 7, G. Ev. \&. C. G. H. 1825 capitulată : Purple caribäz, 3 Red whh: 6, S. Bv. S. W. Ind. 1786 caribāa, 3 - . Red whh. 6, S. Ev. S. W. Ind. - 1786 chinonsis . - Purple * 7, G. Ev. S. China * 1822 colonlla . - Purple . 7, S. Ev. S. E. Ind. . 1818

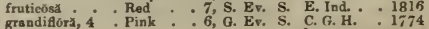
[3in] 


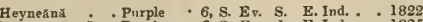

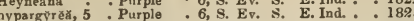
hypargyren̆, 5 . Purple * 6, S. Ev. s. E. Ind. • 1825 lineăris

littorāirs * Purple

longifoliã * * Red

mueronătă, 6 . Pale.

ochroleũcă, 7 . Cream

pallēns, 8 . : Pink

pentaphyllă : : Purple

piscatoría, 9 : Purple

purpúreă * : Purple

strictă, $10^{\circ}:$ : Pink

suherosă, 11 . . Rnse

toxiçriă . - Pa. red

villōsă . White

7, s. Ev. S

7. S. Ev. S. W. Ind.

1820
1823

7, S. Ev. Tr. W. Ind

6, S. Ev. S. S. Amer.

S. Ev. S. W. Ind.

G. Ev. S. C. G. H

6, S. Ev. S. E. Ind.

6, S. Ev. S. India

7 , S. Her. P. E. Ind

7, G. Ev S. C. G H.

6, G. Ev, S. C. G. H

S. Ev. S. W. Ind.

2, S. Ev. S. E. ind.

7, F. Her. P. N. Amer.

1824

1820

1823

1799

1818
1778

1768

1800

1774

1818

1791

1779

TERĀMNŬs, $\boldsymbol{P}$. Bronne. From teramnos, soft; in reference to the pods and leaves of the species being roft. Linn. 16, Or. 6, Nat. Or. Leguminosa. For culture and propagation, see Abrus.

uncinatǔs . . Red . . S. Ev. Tw. Jamaiea . 1822 volūbrilı : : Red : : S. Ev. Tw. Jamaica : 1824

TisRbinthinatr, consisting of turpentine.

TERETK, round and long, like a taper.

TERGEMINATB, three-paired.

TER MINAI, ending, bounding.

TERMIN $\bar{A} \mathbf{I} \bar{A}, \operatorname{Linn}$. T'he leaves are in bunches at the ends of the branches; hence the name, from terminus, end. Linn. 23, Or. 1, Nat. Or. Combretacea. Interesting plants. For culture and propagation, see Bucida. The fruit and bark of several of the species are astringent and tonic. The fruit and galls of $\boldsymbol{T}$ Chebula are highly valued by dyers, creating, when mixed with alum, a durable yellow. The batk and leaves of $\boldsymbol{T}$. Catappa yield a black pigment, with which Indian ink is made. A milky juice is said to flow from $\boldsymbol{T}$. angustifolia, which, when dried, is fragrant, and resembling

Benzoin is used as a kind of incense in the churches in the Mauritius. Synonymes: 1. T. Benzoin. 2.

T. subcordata. 3. $\boldsymbol{F}$. madagascariensis, Myrobalanus Fatraea.

S. Ev. T. E. Ind. . angustifolia, 1 . Wht. grn..

Bellérică

Wht. grn.

1692

S. Ev. S. S. Amer.

1822

Yel. grn.

S. Ev, T. E. Ind.

1823

subcordată, $\dot{8}$. Yel. grn.

Cisebü

S. Ev, T. $\mathrm{E}$. Ind.

S. Ev. T. S. Amer.

S. Ev, T, E. Ind.

Yel. grn.

distichă: : : Yel. grn

Fatrǣĕ, 3 . Yel. grn.

gangètǐeă *.Yel. grn.

latifolra

mauritiăna : : Yel. grn.

moluceānă

procēra

Yel. grn.

Yel. grm.

Yel. grm.

S. Ev T. E. ind

S. Ev. T. E. Ind.

S. Ev. T. Madagas.

S. Ev. T. E. Ind.

S. Ev. T. W. Ind

S. Ev. T. Maurit.

S. Ev. S. E. Ind.

S. Ev. T. E. Ind.

S. Ev. S. E. Ind.

1778

1816

1796

1824

1826

1820

1804

1816

TERN, in threes, or three in a whorl.

TrRnAR $y$, consisting of threes.

TrRNATB, applied to a leaf consisting of three leaflets.

Ternstrómïa, Mutis. In honour of Ternström, a Swedish naturalist and traveller, who died at

Palicandre, in 1745. Linn. 13, Or. 1, Nat. Or.

Ternstromiacec. Interesting plants, succeeding in

loam and peat; and cuttings of the ripened wood will root in sand, under a glass, in heat.

brěvĩpés . . Red . . 7, 8. Ev. 8. S. Amer. . 1818

pedunculařrs . White. 7, S. Ev. S. W. Ind. 1818

Yelsh. 7, Ev S, W. Ind.

punctátä: : : White. 7, S. Ev. S. Braxi? : 1824

Tesselatrd, variegated by squares, chequered.

TESTA, the skin or integument of a seed.

Trstaceovs, light brown.

Testudiñ̄rĭa, Salisbury. From testudo, a tortoise ; resemblance of the outside roots. Linn. 22, Or. 6, Nat. Or. Dioscoreacee. Curious and interesting plants, succeeding well in turfy loam and peat. They should be kept dry when not growing. Roots are frequently received from the Cape of Good Hope. The plants being diacious, there is no chance of obtaining speds in this country, unless specimens of both sexes should happen to fower at the same time. Synonyme: 1. Tamus elephantipes.

elephăntroēs, 1 - Yellow * 7, G. De. Cl. C. G. H. - 1774 montana : Yellow: 7, G. De. Cl. C. G. H. : 1816 Trranus, lockjaw. [ 311 \}
T втRAč̆Ră, Linn. From tetras, four-fold, and keras, a horn; the four capsules are recurved like as many horns, Linn. 22, Or. 12, Nat. Or. Dilleniacece. These handsome climbers are well suited for covering rafters or pillars in stoves. They succeed well in turfy loam and peat; and cuttings of the ripened wood root freely in sand, under a glass, in heat. Synonyme: 1. Dillenia scandens.

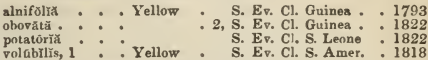

TETRACHotomovs, a stem that ramifies in fours.

TETRĀDĪ M, Loureiro. From tetradion, quaternary parts of flowers and fruit in fours. Linn. 22, Or. 4, Nat. Or. Connaracee. For culture and propagation, see Brucea. Synonyme: 1. Brucea trichotoma.

trichðtช̄mūm, 1

S. Ev. T. Cochin China 1820

TETragonaz, having four angles.

Trtragōnĭa, Linn. From tetra, four, and gonia, an angle; in allusion to the fruit being four-angled. Linn, 12, Or, 2, Nat. Or. Tetragoniaced. Plants not worth cultivating, except in general collections. T.expansa has been used as a substitute for spinach. T. crystallīnă, decūmbēns, echinätă, expünsă, fruti-

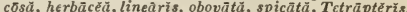

Trtragonólóbưs, Scopoli. The legumes are furnished with four wings or angles; whence the name, from tetra, four, gonia, an angle, and Lobos, a pod. Linn. 17, Or. 4, Nat. Or. Leguminosc. Ornamental plants, succeeding in common garden soil; and increased by seeds. The perennial kinds are well adapted for ornamenting rock-work, and the annual kinds for flower borders. Synonymes: 1. Lotus conjugatus, biflorus. 2. L. conjugatus. 3. L. Tetragonolabus. 4. $L$. siliquosus.

biflōrŭs, 1 Yellow $, 7, \mathrm{H}$. Tr. A. Barbary conjuzătŭs, $2^{*}$ : Purple : 7, H. Tr. A. Morbary : 1818 maŕtĩŭs : Yellow :8, H. De. Tr. Europe : 1683

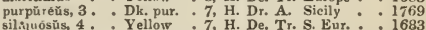

TETRAGoNothëcă, Dillnyn. From tetragonos, quadrangular, and theke, case; the four-angled grains. Linn. 19, Or. 2, Nat. Or. Compositu. An interesting plant, growing well in any rich, light soil; and increased by divisions or seeds.

heliantloiděs . - Yellow . 8, H. Het. P. Virgin. • 1726

Tstragynous, having four styles.

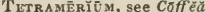

Tetramērĩũ M, see F́a

TeTrandrous, having four stamens.

TetranthēerĂ, Jacquin. From tetra, four, and aner, an anther. Linn. 9, Or. 1, Nat. Or. Lauracee. Ornamental plants, requiring to be grown in a mixture of turfy loam, peat, and sand, and ripened cuttings root readily in sand, under a glass, in heat. Synonymes: 1. Litsea citrifolia. 2. L. Cervantesii. 3. L. glaucescens. 4. L. chinensis. 5. T.involucrata. 6. L. zeylanica.

apèt̆la l 4, Grn yel. Ev, S. N. Hon dealbātä : Yel. grn. . 4, G. Ev. S. N. Holl. 1825 5, G. Ev. S. N. Holl. : 1824 glaucéscēns, 3. Y Yel. grn. - 5, S. Ev. T. Mexico . 1825 laurifolia, 4 * Green * 5, S, Ev S. China * 1822 trinervǐs, 6. : Yel. grn. 5, S. Ev. S. Ceylon: : 1821

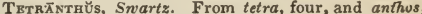
a flower. Linn. 19, Or. \&, Nat. Or. Composita. A pretty plant, thriving in sandy loam; and readily increased by division.

littoralis . . White - . 8, S. Ev. Cr. W. Ind. . 1820

TETRA PĒLrǐs, Wallich. Not explained. Linn. 20, Or. 1, Nat. Or. Orchidaced. This is an interestiug and bighly fragrant species. For culture and propagation, see Calogyne.

frăgråns . . White. . S. Epi. E. Ind. * . 1836

TETRAPBTALous, having four petals.

TETRĂPHǏs, Hedvig. From tetra, four; in allusion to the teeth of the peristome being in fours. Limn. 24, Or. 5, Nat. Or. Musci. Broad tufts, found on dry banks. Synonymes: 1. T. ovata, Grimmia Broniniana-T. Brovniānă 1, pellūcìdă.

TrTRAPōGōn, Desfontaines. From tetra, four, and 
pogon, a beard. Linn. 3, Or. 2. Nat. Or. Graminea, $A$ curious hardy annual species, of common culcure. villōsǔs . . . A petal. . 7, Grass. Barbary . . 1818

Teтra ро̆мă, Turcz. From tetra, four, and poma, a cover; capsule four-valved. Linn. 15, Nat. Or. Crucifera. We are not iccuainted with this plant, but we presume it is of little value- $\boldsymbol{T}$. barbareafolinm.

Tetrīptǐrts, Cavanilles. From tetra, four, and pteron, a wing; the carpols are each four-winged. Linn. 10, Or. 3, Nat. Or. Malpighiacea. Interesting plants, seldom seen in blossom. For culture and propagation, see Malpighia. Synonymes: 1. Triopteris buxifolia. 2. Tr citrifolia.

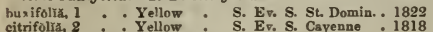

Terraquerrous, having four angles or sides.

TETRASB PALOUs, having four sepals.

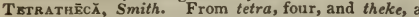
cell; alluding to the anthers being four-celled. Linn. 8, Or. 1, Nat. Or. Tremandracee. A genus of very pretty under-shrubs, rather difficult to cultivate. A mixture of loam, peat, and sand, in equal parts, seems to suit them best; and cuttings of the young wood root in sand, under a glass.

ericafoli. 7, G. Bv, S. N. Holl

glandulōsă : : Purple : 7, G. Bv. S. V. D. I.

füncea : : : Purple : 7, G. Ev. S. N. Holl.

pilôsă : : Purple : 7, G. Ev. S. V. D. L

rubioldes: : : Purple: 7, G Ev. S. N. Holl.

1820

1822

1803

1823

Trêcrīe mander, and father-in-law of Dardanus, king of Troy, Linn. 14, Or. 1, Nat. Or. Labiato. Interesting plants, of very easy culture. The perennial herhaceous kinds succeed well in common garden soil ; and are readily increased by division and by seeds. Most of the shrubby kinds require the protection of a frame or greenhouse in winter; they are easily increased by young cuttings. The seeds of the annual species only require to be sown in the open border in spring. Synonymes: J. Scutellaria cretica. 2. $\boldsymbol{T}$. orchideum. 3. $\boldsymbol{T}$. latifolium. 4. $\boldsymbol{T}$. supinum. 5. $\boldsymbol{T}$. capitatum, flavum. 6. $\boldsymbol{T}$. aureum. 7. T. pseudo-hyssopus.

sbutilnides . - Yellow

4, G. Ev, S. Madeira

6, H. Ev. S. Spain

A

betônYeûm

bicolor, 2

Botros

brevifoliūm

campanulătūm

canadẽnsé

cânuิm

Chambdrys . Purple

cubènsé

früțễns.

graphaloides

beterophyllũm

hyreãnicūm

infiătûm

lıvijatūm

LaxmânnI

lũeÎdù $m$

lusitănIcūm

Mărūm

mrssiliēnsé

montănúm, 4

multiflōrūm

nissoližñum

Yellow

Pink.

8, F. Ev. S. Candia

7, G. Bv. S. Madeira

Yel. red : 7, F. Her. P. Chile

Fed - 8, H. A. S. Eur.

7, H. Her. P. Lrete

P. Levant, 179

N. A mer. 1768

F. $Y$ v, S. A rmenia , 1836

7, H. Her. P. England

Purple. 7, F. Ev. S. Crete : 1824

Purple : 5, S. B. Cuba: : 1733

Yellow . 8, F. Ev. S. S. Eur. - 1640

Violet . 8, F. Ev. S. Spain . . 1648

. 6, F. Ev. S. Madeira 1759

6,1759

Purple 9, H. Her, P. Persin.

s. Her. P. Jamaica

G. Her. P.

Varieg. . 7, H. Her. P. Siberia : 1830

Purple . 8, H. Her. P. S. Eur. : 1730

Purple - 8, H. Her. P. Portugal . 1822

P. pur. . 8, F. Ev. S. Spain . 1640

Purple. H. Her. P. France 1731

F. Bv. S. S. Eur.: 1710

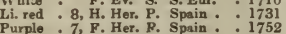

Purple * 7, F. Her. P. Spain * 1752

Blue - 7. H. Ev. S. Levant : 1752

Pólioum

angustifolrüm, 5. Purple

flavéscēns, 6. Yellow

vulgaré, 7 . White

Pseúdo-Chamēpĩty's Purple

Pseủdó-Scorodónĭă. Yellow

pūminlūm.: : Purple

pycnophy̧lũum . Purple

regiūm

regium : Purple

saxatile : $:$ Pa yel.

scordioìdès : . Purplo

Scôrdiūm.: : Purple

Serrodónĩa : Y Yellow

spinôsũm . . . White

7, F. Ev, \$. Spain

6, F. Ev. 8. S. Bur.

6, F.Ev. S. S. Eur.

F. Ev. S. \&. Bur. : 1820

7, H. Her. P. N. Africa 1818

7, F. Ev, S. Spain : 1816

7, H. Her. P. Spain : 1816
6. H. Her. P. Pyrenees . 1731

7, F. Ev, S. Bpain. 169

7, H. Ev. A. Barbary : 1801

7, H. Ev. Tr. Valentia : 1820

6 , H. Her. P. England

7, H. Aq. P. England

7, H. Her. P. Britain

H. A. Spain . 1648

1648
1816

thymifoliūm . . . Re'dish . 8, H. Ev. S. Spain . . 1816 rifidún . . Purple - 7, G. Ev. S. C. G. H. . 1791 rirginìcûm : : Blue . H. Her. P. N. Amer. 1768

Tranamus, that part of the flower which rises from below the ovarium, and sometimes supports the outer envelopes as well as the stamens in all the Thalamiflora.

ThĀLİ̃, Linn. In honour of $\mathbf{J}$. Thalius, a German physician, died in 1588 . Linn. 1, Or. 1, Nat. Or. Marantacece. Interesting plants, thriving well in a rich, light soil; and increased by division. $\boldsymbol{T}$ dealbata will withstand the severity of our winters. if planted about two feet beneath the surface of the water.

dealbata - Blue - 7, F. Aq. P. S. Camlina 179

Tha Lَ̄ctrề, Linn. From thallo, to grow green; in allusion to the bright colour of the young shoots. Linn. 13, Or.6, Nat. Or. Ranunculaced. The yreater part of the species are hardy herbaceous plants, adapted for the back of flower borders; any light soil suits them, and they are readily increased by division. Synonymes: 1. Anemone thalictroides. 2 T. rugosum. 3. $\boldsymbol{T}$. minus. 4. $\boldsymbol{T}$. corynellum. 5. $\boldsymbol{T}$. revolutum. 6. $\boldsymbol{T}$. ambiguum. 7. $\boldsymbol{T}$. vaginatum. 8. T. styloideum. 9. $\boldsymbol{T}$. speciosum. 10. $\boldsymbol{T}$. diffisum. 11. $\boldsymbol{T}$, acuminatum. 12. $\boldsymbol{T}$. discolor. 13. $\boldsymbol{T}$ minus.

acutilobūm . Pa yel. . 6, H. Her. P. Siheria . . 1820

slpinûm : Wht yel. 6, H. Her. P. Britain :

flōré plènó

ingustifollùm.

appendiculătūm

squilegifoliũm

atropurpūrề

formosūm

caläbrieûm

caroliniấnūm, $\mathbf{2}$

Chelidóñ̆

cinerétûm

collinum, 3

concinnûm

concinatim

Cornuat, $4:$
revolūtủm, $\dot{5}$

crenătúm

cynapifolrû̀m

dioñcūm

divaricâtūm

divêrgens

divêrgén

ambigù̃am,

exaltâtự

Gẫüm

vaginătüm, $\dot{7}$

dexuosüm

fcet:dóm, 8

galioides

glaucéneên

gla ũeũm. 9 .

ตserpitiffolfium

màjü:

medrūm, 11

mexieânūm

microcărpón

mInŭs

nigrieăns

nứtans, 12 .

petaloideũm

polygâmúm

purpuráscēns

ranunculæึúm

repens

rosmarinifoliom

rugosūm

saxătilé, 14

SchweiggèrI

sibiricum

simplex.

squarrós

stîpulăcēun

trigȳnūm

Pa. yel.

H. Tw. P. N. Amer. : 1768

H. Her. P. Russin . 1832

Li. pur. 6, H. Her. P. Austria . 1731

Dh. pur. . 6, H. Her. P. Auntria . . 1731

Purple . 6, H. Her. P. S. Eur. . . 1800

7, H. Her. P. Sicily : 1800

7, H. Her. P. Sicily : 1800

Purplish : 6, H. Her. P. Nepal * 1818

Yellow . 6, H. Her. P.

White, 6. H. Her. P. N. Amer. 1720

Pa. yel. . 6, H. Her. P. Europe . . 1800

Wht. grn. 6, H. Her. P.

White, 6, H. Her. P. Siberia . 1796

Wht yel 5, H. Her. P. N. Amer. 1806

I.gL yel. 6, H. Her. P. N. Amer. : 1806

Yellow . 7, H. Her. P. Europe . . 1800

Pur. yel. 6, H. Her. P. Siberia : 1893

Li. yel . 6, H. Her. P. N. Amer. : 1759

Yelsh . 6, H Her. P. Europe . . 1819

Yellow. 6, H. Her. P. Siberia . 1819

3, H. Her. P. Hunary: 1794

6, H. Her. P. Huagary : 1794

H. Her. P. Siberia.: 1839

Orange . 6, H. Her. P. Britain

6, H. Her. P. Siberia : 1810

6, H. Her. P. Germany 1820

Whit. yel. 6, H. Her. P. France . . 1640

Pur. yel. 6, H. Her. P. Nepal : 1819

Yollow 6, H. Her. P. Alsace: 1816

Grn. yel. : 6, H. Her. P. Russia : 1818

Yellow 6, H. Her. P. Spain : 1798

Yellow : 6, H. Her. P. Europe : 1810

Yellow .6, H. Her. P. Spain . 1739

Grn. yeL. 6, H. Her. P. England - 1789

Green 8 H Her.

H. Her, P. Russia : 1839

Pa yel 6, H Her. P. Britain.

Grn. yel. : 6, H. Her. P. Austria: 1798

Grn. yel. 6, H. Her. P. Switzerl. : 1819

Pur. yel. . 6, H. Her. P. Siberia . . 1820

Whe yel. 6. H. Her. P. Dauria . 1799

Whe pur. 6, H. Her. P. Pennaylv. . 1818

Pa. yel. . 6, H. Her. P. Switzerl. - 1819

Li pur. 6. H. Her. P. N. Amer. 169

Pa rel 6, H. Her, P. N. Amer. 1606

H. Her. P. Russia . 1839

Bir. yel. . 6, H. Her. P. 8. Eur. : 1816

Whe yel 7, H. Her. P. N. Amer. 1774

Yellow 6, H. Her. P. N. Amer, 1810

Yellow red. 6, H. Her. P.

Li. yel. 6, H. Her. P. Siberis . . 1775

Li. yel $5, \mathrm{H}$. $\mathrm{P}$. Sweden 1778

Yellow 6, Her. Siberia. 1806

Wht. yel. 6, H. Her. P. Eurnpe: : 1820

Grn. yel. 6, H. Her. P. Dahuria : 1818

ThaluUs, that part which bears the fructification in Liehens.

Tramnítūu, Link. From thamnos, a twig; the appearance of the plant when under the microscope. [ 312 ] 
Linn. 24, Or. 9, Nat. Or. Fungi. A minute plant, found on putrid substances- $T$. elęgäns.

TнAмNоснблтŬs, Bergius. From thamnos, a shrub, and chortos, grass; habit of the plant. Linn. 22, Or. 3, Nat. Or. Restiacec. This species succeeds well in sandy peat; and is readily increased by division. Synonyme: 1. Restio dichotomus.

diehơtomùs, 1 . . A petal . . 6, Grass, N. Holl. . . 1817

TнĀPsĬ being discovered in the Isle of Thapsus. Linn. 5, Or. 2, Nat. Or. Umbellifere. These plants will grow in any common soil. They can only be increased by seeds, which should be sown in autumn, as soon as ripe. Synonymes: 1. Laserpitium gummiferum, 2. L. thapsoides.

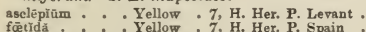

gargăniea : : Li, yel. :7, H. Her. P. Barbary

gummiferă, 1: Yellow: 6, H. Her. P. Spain

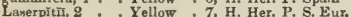

Silphiumm : \%. Her. P. Africa

villosa : : Yellow: 6, H. Her. P. S. Eur.

1596

1683

1683

1826

1824

ThÄPsỸ M, Nuttall. From the Isle of Thapsus, which gave the name to the Thapsia of the ancients; in allusion to its affinity with that genus. Linn. 5 , Or. 2, Nat. Or. Umbellifera. These plants will grow in any common soil, and are readily increased by divisions or seeds. Synonymes: 1. Ligusticum actaifolium. 2. Thapsia trifoliata.

actreifólinm, 1, White , 6, H. Her. P. Canada . . 1810 barbinōdē, 2. Yellow: 6, H. Her, P. Philadel. 1700

Tнйӑ, Linn. Derived from $T$ eha, the Chinese name for tea Linn 16, Or. 8, Nat. Or. Ternströmiacea. For the culture and propagation of these valuable plants, see Camellia. They only require to be protected from severe frost. All the different kinds of tea imported in to this country from China, are the produce of $\boldsymbol{T}$. viridis, the differences depending eritirely upon soil and climate, and the different ages at which their leaves are gathered, and the modes of drying. Tea is said to be the best of all medicines, moderately and properly taken; it is gently astringent; it strengthens the stomach and bowels; and is efficacious against indigestions. It refreshes the spirits in heaviness and sleepiness, and appears to counteract the effects of inebriating liquors. The immoderate nse of it is very prejudicial. From Dr. Smith's experiments, it appears that green tea has the power of destroying the sensibility of the nerves and the irritability of the muscles. For a very valuable account of this plant see Royle's Illustrations of the Himalayan Mountains, p. 107. Synonymes: 1. $\boldsymbol{T}$. chinensis Bohea. 2. $\boldsymbol{T}$. chinensis viridis.

\section{Bohēă, 1 . White}

latifolis. White

10, G. Bv. S. China

1768

virìdis,

White

all G. Ev. S. China

1825

Tнвс.ङ, the cases that contain the sporules of cryptogamic plants.

THBCAFHORK, an elongated receptacle, which bears one ovary only, but not the petals, nor stamens.

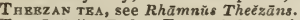

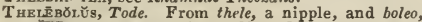
to ejet. Linn. 24, Or. 9, Nat. Or. Fungi. This species is found on cow-dung, after rain, in June and $J u l y-T$. stercőrěŭs.

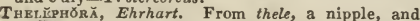
phoréo, to bear; in allusion to the papillose surface of all the species. Linn. 24, Or. 9, Nat. Or. Fungi. The species of Thelephora are common upon old roots and branches of trees. Synonymes: 1. Himantia candida. 2. Auricularia nicotiana-T, acerīnă,

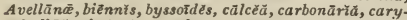

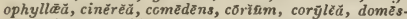
tăcă, èlëgāns, epidērměă, fraxiněa, füscă, gigāntēă, granulöă̆, hepătică, hirsūtă, incarnātă, incruistāns,

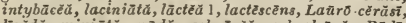

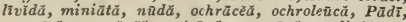
pannōsă, puฑvŭrĕă, puteānă, quercină, radiätă, $\boldsymbol{R}$. rimosă, rōsěă, rubiginōsă, Sambacī, sanguinolêntă,

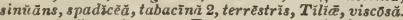

Thкцотвй, Acharius. From thele, a nipple, and trema, orifice; the protuberances of the thallus are perforated. I.inn. 24, Or. 8, Nat. Or. Lichenes. These plants are found on the bark of trees- $\boldsymbol{T}$. exanthemătīcrim, Hutchīnsī̄e, hymĕnīüm, lepadiñ̂m, melaleñcūm, variclarioz̄dès, $V$. agcläam. [313]
ThRL צ̆Gö̃ $\mathrm{M}$, from thelys, woman, and gonu, a knee; supposed resemblance in the joints. Linn. 21, Or. 9 Nat. Or. Chenopidiacea. Common garden soil suits this species; seeds-T. cynocrămber.

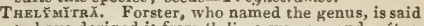
to have derived it from thelis, a woman, and mitra, a cap. Linn. 20, Or. 1, Nat. Or. Orchidacea. This is a tuberous-rooted genus requiring precisely the same treatment as Disa.

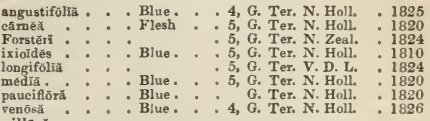
villosă.

THENĀRĬ. Kunth named this genus in honour of his friend, L. J. Thenard, a Frenchman, who has written on the chemical physiology of plants Linn. 5, Or. 1, Nat. Or. A pocynaced. An interesting plant. For culture and propagation, see Echites.

floribūndð. . Blue . . S. Ev. Tw. Mexico . 1823

ThвовRомA, Linn. From theos, god, and broma, food celestial food. Linn. 18, Or. 1, Nat. Or. Sterculiaced. The species of $T$ heobroma or Chocolate-nut grow well in a mixture of loam and peat; and cuttings root readily in sand, under a glass, in heat. Seeds do not retain their vegetative power for a great length of time. The seeds of $T$. Cacao furnish the chocolate of the shops. The seeds are very nourishing and agreeable to most people, and are, therefore, kept in the majority of the houses in America as a necessary part of the provisions of the family.

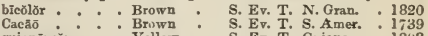

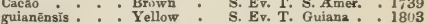
TheophnĀstă, Linn. Named after Theophrastus, the father of natural history. Linn. 5, Or. 1, Nat. Or. Myrsinacea. A small, handsome tree, with a tuft of long, evergreen branches at the top of its simple stem, something like a palm-tree. It is well worth cultivating, on account of its long, holly-like leaves. A mixture of peat, loam, and sand, suits it best ; and cuttings, with the leaves entire, root readily in sand, under a glass, in heat. Bread is said to be prepared from the pounded seeds of this tree in St. Domingo, where it is called Le Petit Coco.

JussieūI . . . White. . S. Ev. T. St. Domingo 1818

ThRR Mōpsis, R. Brown. From thermos, a lupine, and opsis, resemblance; because of the resemblance of the species to lupines. Linn. 10, Or. 1, Nat. Or. Leguminose. The species of Thermopsis are very elegant, but rather difficult to preserve. They succeed best in a light, rich soil; and the safest way of increasing them is by seed; for when the plants are separated at the roots they are very liable to suffer. Synonymes: 1. Podalyria alpina, Sophora alpina. 2. S. fabacea, T. rhombifolia. 3. T. Lupinoides, $\boldsymbol{P}$. lupinoides.

corgonēnsYs, 1. Yellow - 7, H. Her. P. Altais - 1820 fabăcēa, 2 : Yellow : 6, F. Her. P. N. Amer. : 181 lanceolătă, 3 . Yellow . 6, H. Her. P. Siberia - 1779 mean appearance of the plants. Linn. 5, Or. 1, Nat. Or. Santalacea. The herbaceous species grow best when planted in a chalky soil, and are increased by division or seeds. $\quad \boldsymbol{T}$. amplexicaule succeeds well in loam and peat, and is readily increased by cuttings, in sand, under a glass. Synonyme: 1. T. humifusum.

al pinuñm, 1 .

amplexicaūle

ebracteātûm

intermèdrūm

linophrllum montănūm.
White

White

White

White
White

White

6, H. Her. P. Germany

G. Ev. S. C. G. H.

6, H. Her. P. Germany

6, H. Her. P. German

6, H. Her. P. England
6, H. Her. P. Europe
1814

181

1818

1817
Thespäsĭa, Correa de Serra. Within the tropics $\boldsymbol{T}$. populnea is usually planted about churches whence the name from thespesios, divine. Linn. 16, Or. 8, Nat. Or. Malvaceo. Ornamertal trees, succeeding well in sandy loam; and cuttings of the half-ripened wood will root in sand, under a glass, in heat. Synonyme: 1. Hibiscus populneus. grandiflöră. . Scarlet - S. Ev. T. Pt. Rico popülneă, 1 : White : S. Ev. T. R. Ind.

guadalupensǐs - S. Ev. T. Guadal. 
Trubaũnťă, Pavon. In honour of Thiebaut de Berneaud, secretary of the Linnæean Society of Paris, and a botanical writer. Linn. 10, Or. 1, Nat. Or. Vaccinacere. This is a genus of extremely elegant plants, well deserving the gardener's care. They grow freely in a mixture of turfy loam, peat, and sand; and cuttings root readily in sand or soil, either with or without a glass over them. Synonymes: 1. Agapetes setigera. 2. A. variegata.

macrophyllax - White. S. Ev, S. F. Ind .

setigeri, 1.: : Scarlet : S. Ev. S. Khooseea : 1837

S. Ev, S. Khonseea 1837

variegătă, 2 : : Searlet S. Ev. S. Khooseea : 1837

ThIstLe, see Cärdü йs.

THLÄsp̃̄, Dillenius. From thlao, to compress; the seedvessels are compressed. Linn. 15, Nat. Or. Cruciferce. Not worth cultivating; increased by seed $-T$.

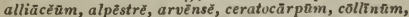
latifơliùm, montānūm, perfoliâtūm, umbellātã $m$.

Tномд̄sĩă, Gay. In memory of Peter and Abraham Thomas, collectors of Swiss plants in the time of Hailer. Linn. 5, Or. 1, Nat. Or. Sterculiacec. A genus of very elegant plants, well worth cultivating in every collection. They thrive well in a mixture of loam, peat, and sand ; and cuttings of the ripened wood root freely in sand, under a glass. Synonymes: 1. Lasiopetalum purpureum. 2. L. triFhyllum.

dunısia

White.

5, G. Ev. S. N. Holl.

purpüréă l : Purple : 6, G. Ev. S. N. Holl.

quercifolia. : : Purple : 5, G. Ev. S. N. Holl

solanácera : : White.
triplryllă, 2

THOR A APLE, see Datîrü.

THоRо:GH WAx, see Buplearam rotundifolínm.

Tнойкі̌ . Poiteau. In honour of André Thouin, a distinguished professor of $\mathbf{A}$ griculture in the Jardin des Plantes of Paris; died in 1820 . Linn. 8, Or. 1, Nat. Or. Sapindacee. This shrub grows well in a mixture of sandy loam and peat; and cuttings of the ripened wood will root in sand, under a glass, in heat.

pinnåtă . . . White . . S. Ev. S. N. Spain - 1823

ThrEADs, long hairs like threads.

THRIyr, see Statice.

Thrīñx, Linn. From thrinax, a fan; form of the leaves. Linn. 6, Or. 1, Nat. Or. Palmaced. This species succeeds in turfy loain, and is increased by seeds.

parvifüră . . Wht. grn. . Palm. Jamnica

1778

ThrīscYŭ, Roth. From thrigkos, battlement; the seed crown of the maryinal florets. Linn. 19, Or. 1, Nat. Or. Compositce. Uninteresting plants, succeeding in common garden soil; and increased by seeds. Synonymes: 1. Hyoseris hispida. 2. Apargia tuberusa, Leontodon tuberosus, Thrincia pruinosa $-T$. hIrtă, hispidă, maroceānd̆ 1 , tuberos̆̈ 2.

TnROAт, the orifice of a flower.

Throatwort, see Campănūlă Cervicā riă.

Throatwort, see Campänülä Trucheliam.

Throntwort, see Tracheliam.

THry $\overline{L L I s}$ Linn. A name given by the Greeks to Verbascum, which is derived from thrauo, to break however, the present plant has nothing to do with the plant of the Greeks, except in having yellow Howers. Linn, 10, Or. 3, Nat. Or. Malpighiacece. This plant succeeds in a mixture of loam and peat; and ripened cuttings root in sand, under a glass, in heat.

brachystăcluy̆s. . Yellow . 8, S. Ev. Cl. Rio Jan. - 1823

Trû́s̆, Linn. From thyon, a sacrifice; the resin of the Eastern variety is used instead of incense at sacrifices. Why it is called Arbor Vitce is not known, unless it be on account of the supposed medicinal qualities of its berries. In the East, the cypress is called the tree of life; and its berriesare considered a cure for all diseases. Linn. 21, Or. 10, Nat. Or. Conifere. In Britain the scecies of Arbor Vite can only be considered as ornamental, low shrubs or trees, well deserving of being cultivated, especially $T$. pendula; which, on account of its very rraceful, long, slender, pendulous shoots, ought to be in every collection. The American and European kinds succeed well in any soil or situation, but prefer low, sheltered, and swampy places. The

more tender species, natives of China, reouire, when young, the protection of the greenhouse. They are all readily increased by seeds, either imported from the places of their natural growth, or gathered from the trees in this country; some of the rarer kinds, as $\boldsymbol{T}$. pendula, are propagated by cuttings. Synonymes: 1. T. pyramidalis. 2. T. tatarica.

articulata - A petal : 8, F, Ev. T. Barbary 1815 australrs : : A petal : 5, H. Ev. T. S. Eur. . : 1820 : G. Ev. T. C. G. H. : 1799 nepa lênsǐs. . A petal oecidentalís : A petal . 5, H. Ev. T. N. Amer. . 1596 variegáă : Apetal : 5, H. Ev. T

orientälis . A petal . 5, H. Ev. T. China 1759 strictă, ] : Apetal : 5, H. Ev. T. Italy : 1824 tatăreă, 2 : A petal : 5, H. Ev. T. Tartary : 1820 pendũlä
plicătä. : : Apetal

T HUNBËRGYX, Linn. In honour of Charles P. Thunberg, F.R.S., a celebrated traveller and botanist. Linn. 14, Or. 2, Nat. Or. Acanthacee. A genus of extremely pretty plants when in blossom. They succeed best in a mixture of sandy loam and leaf mould, and are readily increased by cuttings or seeds.

Yellow 6, S. Ev. Cl. E. Ind. 1893

alba : : : White. : 5 , s. Ev. Cl. Madagas

angulatil : : White. 6 , s. Ev. Cl. Madagas..

aurantrĭcă . : Orange : 8, G. Her. P. C. G. H.

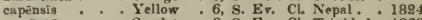

coccinea * . Scarlet . 6, s. Ev. Cl. Trinidad . 1823

cordata * * White. 7, S. Ev. Cl. E. Ind. - 1820

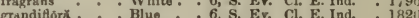

Hawtayneână : Searlet : 6, S. Ev, Cl. Nepal. : 1826

TнгмвR, Linn. Thymbra is the Greek name of a sweet-scented herb. Linn. 14, Or. 1, Nat. Or. Labiata. This plant is well adapted for rock-work, or growing in pots among alpine plants. A gravelly soil suits it best, and it is readily increased by young cuttings or seeds. Synonyme: 1. $\boldsymbol{T}$. verti. cillata.

spicătŭ, 1 . . . Pa. pur. . 6, F. Ev. J. Levant . . 1699

Tryмв, see Thgmŭs.

Trर̃mús, Linn. From thumos, courage, strength, the smell of thyme being reviving; or from thuo, to perfume, being formerly used for incense in the temples. Linn. 14, Or. 1, Nat. Or. Labicte. Well known under -shrubs or herbs, preferrine an exposed situation, and a dry, light, sandy soil. They are of very easy culture, and may be increased with facility either by divisions, slips, cuttings, or by seeds sown in March or A pril. Some of the razer species may be grown in pots among alpine plants, and protected in winter. The different purposes to which Thyme is applied are so well known, as not to require any notice here. Synonymes: $1 . T$. acicularis, odoratissimus, Zygis. 2. T.creticus, marinosci, Satureia capitata. 3. Thymbra ciliata. 4. Thymus Marschallianus, $5 T$. exserens, 6. $T$, citriodorus. 7. T. lanuginosus. 8. T. montanus, nummularius. 9. $T$. collinus.

angustifóluñs, 1. Purple

azoricŭs

Purnle:6, H. Tr. Azores.

7. H. Ev. S. Hungary

elungatũs.

ericgefollı̆s

fruticulōsŭs: Purple

glabrătŭs. : Purple

hirsútís: : Purple

lanceolátǔs : Purplo

pannónIeds, 4 . Purple

Piperêllă . Purplo

Serpyllūm, 5 . Pürple

albùs . White

citrin̆tŭs, 6 . Purple

lanuginôsŭs, 7 Purple

montanŭs, 8 . Striped

vasiegatüs Purple

vulgaris, 9 . Purple

spicătús . . Purple a

vulgarris : . Purple

variegatús ${ }^{\circ}$ : Purple

Tнумия, see Ziziphðră.

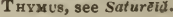

8, H. Ev. S.

7, H Ev S Spain

7, H. Ev. S. Sicily : 1822

7, H. Ev. S. S. Eur. : 1823

7, H. Ev. S. Spain : 182

7, H. Ev. S. N. Afric. 1823

7, H. Ev. Tr. Crimea . : 1817

F. Ev. S. Spain : 1810

H. Ev. Tr. Britain

H. Ev. Tr. Britain

7, H. Ev. Tr. Britain .

6, H. Ev. Tr. Hungary

7, H. Ev. Tr. Britain.

F. Ev. S. Pyren. . 1832

6, H. Ev. S. S. Eur. . . 1548

$6, \mathrm{H}, \mathrm{Ev}$. S.

7, H. Ev. Tr. Britain

[314] 
Try ass, a kind of dense panicle.

Thysuró fringed; whence the name, from thysanotos, fringed. Linn. 6, Or. 1, Nat. Or. Liliacea. A genus of very elegant plants when in flower. They succeed well in sandy loam, and are readily increased by offsets. elātiơr

intrieâtŭs

isanthĕrŭs

jüncéŭs

proliferŭs

tênŭǐs.

tuberosŭs

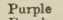

8, G. Tu. Per. N. Holl

1823 Purple. 7, G. Her. P. Swan R. . 1838 Purple: 8, G. Tu. P. N. S. W. . 1822 Purple G. Tu. P. G. Her. P.

N. S. W Purple

5 , F. Her. P.

Swan $R$.

1836

ThYsseñ̄NīM, see Selīnūm.

TiARÉLtă, Linn. From tiara, a Persian diadem; on account of the shape of the capsules. Linn. 10, Or. 2, Nat. Or. Saxifragacea. The species of Tiarella are well fitted for rock-work, or the front of flower borders; they are increased by division of the root. colôrăns eordifolia - . White White 6, H. Her. P. N. Amer. - 1827 Menziesin Whit polyphylla White 4, H. Her. P. N. Amer. . 1731 4, H. Her. P. N. Amer. 1812 4, H. Her. P. Nepal . 1820

TrARInIT̄, Lehmann. Fromtiara, a Persian diadem, and eidos, like; form of the capsule. Linn. 5, Or. 1, Nat. Or. Ehretiaceo. Half.hardy annuals, of cum.

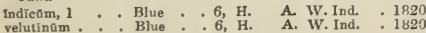

T'ıCK sERD, see Corispērmàm.

TigRr FIOWRR, see Tigridĭă

Tigrīnī, Jussieu. From Tigris, a tiger, and eilos, like; in reference to the spotted flowers. Linn. 16, Or. 1, Nat. Or. Iridncea. Splendid bulbs when in blossom. They thrive in a rich, light soil in the open border, but must be taken up when the flowers have withered or the frost will injure them. They should be kept in a dry place, free from frost, until the spring, when they may again be planted out increased by offsets or seeds. Synonyme: 1. Ferraria Tigridia, pavonia.

conchiföră . . Dk. yel. . 6, H. Bl. P. Mexico . 1823 ravōnǐa, $1 .:$ Or red : 6, H. Bl. P. Mexico : 1796
leōnă TIL ROOT, see Geissorhīză.

T $\tilde{L}_{\mathrm{L}} \mathbf{A}, L i n n$. The etymology of this word is entirely unknown; in Dutch it is called Linden, in AngloSaxon Lind, and in English Lime-tree. Linn. 13, Or. 1, Nat. Or. Tiliacea. Ornamental, lofty-growing trees, well suited for avenues and parks. They thrive well in any soil, and are increased by layers or seeds: if by layers, the tree must be cut down close to the ground, and from its roots a great number of shoots are produced, in the following year; these will be strong enough to lay down the following autumn. Trees raised from seed are far preferable to those raised from layers. The Russian bass-mats are made from the inner bark of the lime-tree; while the wood, from its being light and white, is much used by the carver, and musical instrument-maker. Synonymes: 1. T. argentea. 2. T. glabra, canadensis. 3. $T$. heterophylla. 4. $T$ laxiflora. $5 . T$. pubescens. 6. T. pub. leptophylla. T. intermedia. 8 . T. platyphylla laciniata. T. microphylla. 10. T. platyphylla. 11. T. rubra.

ătbă, 1 Yel. grn, 6, H. De. T. N. Amer. . 1752 Yel. grn. 7, H. De. T. N. Amer. White. 6, H. De. T. N. Amer. Yel. grn. 7, H. De. T. N. Amer. pub. leptophyllă, 6 Yellow 7, H. De. T. N. Anser.

europé, 7 . . Yel. grm. 7, H. De. T. Bntain ผūrēă

desystylä

Yel. grn. 8, H. De. T. Britain.

dasystylă 8

Yel. grn. 7, H. De. T. Tauria.

nuicrophypla, 9

Yel. $\mathrm{gm}$. 4 . De Tritain.

. Yel. grn 8, H. De. T. Britain

platyplyyz, 10: Yel. grn. 8, H. De T. Britain.

platyph. aureă - Yel. grn. H. De. T. Britain

rúbră, 11 . . Yel. grn. 8, H. De. T. Britain

TıLıAcōră, Colebrook. Tiliakora is its name in Bengal. Linn. 22, Or. 6, Nat. Or. Menispermacea. This species succeeds well in a mixture of sandy loam and peat; and cuttings root readily in sand, under a glass, in heat. Synonyme: 1. Menispermum polycurpon.

racemō๘ส,

[ $3 i 5$ ]
TuL $\tilde{\star} \check{A}$, Linn. In honour of M. A. Tilli, an Italian botanist. Linn. 4, Or. 3, Nat. Or. Crassulacere. The seeds of these plants have only to be sown in the open ground.

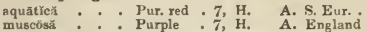

1816

TiILĀNDš̆ L Linn. In honour of Elias Tillands, professor of Physic at A bo. Linn. 6, Or. 1, Nat. Or. Bromeliacea. These interesting plants being epiphytal, will succeed well in baskets filled with moss, cut small, and mingled with broken pots; or they may be fastened to pieces of wood, with moss round their roots, and supplied regularly with water. The larger growing species may be treated like the Pitcairnia and Bromeliz. Increased by suckers, or by seeds. acaũlǐs * . White . 8, Epiphy. R. Jan. loifólǐa . Pink . 11, Epiphy. Trinidad ancẻps : . Blue . 4, Epiphy. W. Ind. angustifoliă : Blue : 8 , Epiphy. W. Ind. Bartrămī - . Blue - 4, Epipliy. Carnlina bracteăta bulbüsá eanẽscêns : Blue

coarctătă

8, Epiphy. W. Ind.

Blue 6, Epiphy. W. Ind.

comprēss

fasciculat

flexuōsă.

pällida

gràcilis

nìtida

nütáns

paniculātă

polystächyă

6. Liphy. W. Ind

6, Eviphy. Chile

Blue - 6, Epiphy. W. Ind.

Fellow: 6 , Epiphy. W. Ind.

6, Epiphy. Cliile

Blue : 10, Epiphy. Jamaica

7, Epiphy. S. Amer.

6, Epiphy. W. Ind.

6, Epiphy. S. Amer.

7. Epiphy. Rio Jan.

0, Epiphy. Trinidad

6, Epiphy. Cliile

7, Ep:pliy. Jamaica

6, Epiphy. Chile

Pink : 6, Epiphy. Brazil

Blue 6, Epiphy. WV. Ind.

9, Epiphy, Brazil

6, Epiphy. W. Ind.

7, Epiphy. W. Ind.

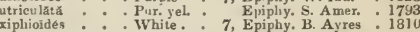

Blue

Purple

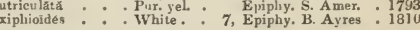

1326

1824

1822

1895

1824

1824

1823

1823

1790

1815
1823

1823

1793

1820

1825

1826

1823

1893

1823

1793

1824

1810

1823

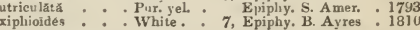

Tїмй, Hedvig. In honour of J.C. Timm, a Ger man botanist. Linn. 24, Or. 5, Nat. Or. MIsci. This plant is found in broad patches, in moist sandy plains $-\boldsymbol{T}$. megapolitünă.

Tissus is the elementary organization of a plant; it consists of a delicate transparent membrane formed into cells, tubes, vessels, \&c.

Tттно̆ of A urora; the flower is couleurd'aurure. Linn. 19 Or. 3, Nat. Or, Compositce. This plant succeed well in light rich soil, and is readily increased by cuttings, in sand, under a glass, in heat.

tagetifiora .8, T. Er. S. V. Crue

TiтtмāNNĩ̄, see Vandellž̆.

TOAD FLAX, see Linūrĭŭ.

Tовасco, see Nicotiānü.

Tocōcă, Aublet. Tococo is the name of $\boldsymbol{T}$. guianensis in Guiana. Linn. 10, Or. 1, Nat. Or. Melastomaces. The species of Tococa are remarkable for bearing bladders on their petioles. For culture and propa gation, see Melastoma. Synonymes: 1. T. Aubletii, Melastoma physiphora. 2. M. lanata.

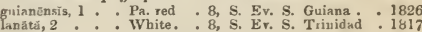

Tocoy Ẽxa, Aublet. Tocoyena is its name in Guiana Linn. 5, Or. 1, Nat. Or. Cinckonacea. This species succeeds well in sandy peat, mixed with a little loam; it is increased by cuttings of the young wood, in sand, under a glass, in heat. Synonyme: J. Merixna speciosa.

longifloră, 1 . Yellow . S. Ev. S. Guiana . . 1826

ToDDĀLĬ, Jussieu. From Kuka-Toddali, the name of $\boldsymbol{T}$. aculeata in Malabar. Linn.21, Or. 5, Nat. Or. Xanthoxylacea. Interesting shrubs, succeeding best in a mixture of loam, peat, and sand; and cuttings planted in sand will root readily, if placed under a glass, in heat. The bark of the root of $T$. aculeata is said to be employed as a cure for the remittent fevers caught in the jungles of the Indix hills. Synonymes: 1. Scopolia aculeata, Paullinia asiatica. 2. Rubentia angustifolia. 
aculeâtü, 1. . White. . S. Ev. S. E. Ind. . 1790 angustifoliă, $2^{*}$ : White.: $\quad$ S. Ev. S. Maurit. : 1824 TODDĀLI Ă, see Veprĭs.

Tō̄ĚĂ, Svartz. In honour of Henry Julius Tode, of Mecklenburg, an able and experienced mycologist. Linn. 24, Or. 1, Nat. Or. Osmundacec. Interesting Ferns, growing freely in loam and peat; and increased by division or seeds. Synonyme: 1. Osmunda barbara.

africană, 1. . . Brown - 6, G. Her. P. C. G. H. - 1805 austrăliss : : Brown : all, G. Her. P. N. Holl. : 1831

Torī̄LDY̌, Hudson named this genus in compliment to his friend Mr. Tofield. Linn. 6, Or. 3, Nat. Or. Melanthacee. Loam and peat, or any light soil, and a moist situation, suit the species of Tofieldic. They are increased by division of the roots. Synonyme: 1. T. palustris.

alpină, 1 . . . Green . . 7, H. Her. P. N. Eur.

glutinōsă : : Wreen : White: H. Her. P. N. Amer. : 1825 palūstrís : : Green : 7, H. Her. P. Britain -

palezseêns : : White: : 4, H. Her. P. N. Amer. 1790 stenopetălă : : Green : : 5, H. Her. P. N. Amer. : 1820

Tōtpĭs, Adanson. Meahing not known. Linn. 19, Or. 1, Nat. Or. Composite. A genus of very pretty annuals, well suited for ornamenting flower borders, where the seeds may be sown in spring. Synonymes:

1. Crepis barbata. 2. C. coronopifolia.

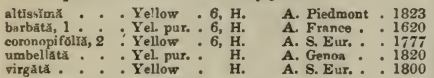

Tomentose, covered with dense white down.

Tomknrum, dense, close, white hairs, or down.

Tosic, bracing, corroborative.

Tonquin heas, see Diptérix.

TonsēL, see Salaciă.

TOOTHACHz-TREB, see Xanth $\delta x y ̆ l n m$.

Toothkn, divided, so as to resemble teeth.

TOOTRLBTTBD, furnished with little teeth.

TOoTHWort, see Lathräal.

Topical, local, confined to some particular place.

TordY̌Lİ̈M, Tournefort. An ancient Greek name, of unknown meaning. Linn. 5, Or. 2, Nat. Or. Umbelliferce. Uninteresting annuals. The seeds should be sown in the open border-T. lusitanicam, maxImam, peregrinam, sii ollam, syriăcam.

TORĒIA, Linn. In honour of Olof Toren, a Swedish clergyman, who discovered $\boldsymbol{T}$. asiatica, and other plants in China. Linn. 14, Or. 2, Nat. Or. Scrophulariaced. For culture, \&c., see Herpestis.

serbbră . . . Pa blue . 6, G. Ev. S. Moreton B. 1830

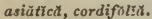

TORENIĂ, see Vandellia.

Törĭlı̆s, Sprengel. Not explained. Linn. 5, Or. 2, Nat. Or. Umbelliferce. The seed of these plants may be sown in the open ground. Synonymes: 1 . Caucalis Anthriscus. 2. C. arvensis, helvetica. 3. Scandix trichosperma-T. anthriscŭs 1, infestă 2, neglëctð̆, nodosă, trichospërmă 3 , tuberculätă.

TORM RNTílLL, Linn. From tormentum, pain; allnding to its supposed efficacy in tooth-ache, as well as to its being supposed to cure diseases of the bowels. Linn. 12, Or. 3, Nat. Or. Rosacea. British herbaceous plants, not worth growing, except in botanical gardens. The roots of $T$. erecta are so astringent as to be used in the western isles of Scotland for tanning leather; for which purpose they are superior even to oak bark. The root is likewise one of the most efficacious of our indigenous aromatic astringents, and may be used with great effect in cases where medicines of this class are proper. It is usually given in decoction. Synonymes: 1. T. afficinalis. 2. Potentilla humifusaT. erēctă 1 , humifüsă 2 , rẽptāns.

Torose, uneven, alternately elevated and depressed. 'TōRTǔLĂ, Hednig. From torqueo, to tirist; in allusion to the singular manner in which the teeth of the peristome are twisted together. Linn. 24, Or. 5, Nat. Or. Musci. Small plants, generally found in thick tufts. They are common to nearly all situations. The character from which the genus has received its designation will always faithfully indicate the species. Synonymes: 1. Zigotrichia cylindrica. 2. T. rigida. 3. T. imberbis, unguiculata. 4. T. nervosa. 5. T. apiculata, aristata, barbata, humilis, mucronulata - $\boldsymbol{T}$. breviröstrĭs, convolută, cuneifoliă, cylindrĭcă 1, enêrvǐs 2, fällüx $3, F$. brevi. cañlis, linot̄děs, grăcitis, G. viridìs, murălìs, M.

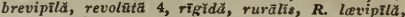
stellată, subulātă, $S$. obtũsă, tortuôsă, unguicuhätă 5 . Tŏrǔ Lu, Persoon. A diminutive of torus, a twisted cord ; appearance of the filaments. Linn. 24, Or. 9, Nat. Or. Fungi. Found upon dead stems of plants -T. cylindricü, Eriophori, herbüram, monilioldess, ovalisporă.

ToruLose, slightly torose.

Torus, the same as Thalamus

Touch-Mr-NoT, see Impătiēns.

TouRneförtĭ , Linn. In memory of Joseph Pitton de Tournefort, the distinguished author of an arrangement of plants under the title of "Institutiones Rei Herbaria," and other botanical works, from 1694 to 1717 ; his first work "Institutiones," laid the foundation of the arrangement now followed, called the Jussieuan, or Natural System. Linn. 19, Or. 1, Nat. Or. Ehretiacer. The species of Tournefortia are hardly worth cultivating for ornament. They are of the easiest manageinent; and are readily increased by cistings, in sand, those of the stove species in heat. Synonymes: 1 . Arguzia montana, Messerschmidia Arguzia. T. Ar. guzia.

angustifolix . Wht. grn. 8, G. Ev. S. Canaries 1020 argêntéă : : Whito. 8, S, Ev. S. E. Ind. . : 1822 bícollor : Green : 6, s. Ev. S. Jnmaica : 1812

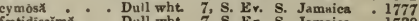
foctidissima . . Dull wht. 7, 8. Ev. S. Jamaica - 1739 fruticóxă : White. : 6, G. Ev. S. Cannries : 1800

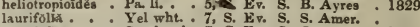
mutabrlls: : Gmsh. whi 7, G. Bv. S. Java : 1820 scábră . : : Wht red. 8, s. Ev. S. St. Domingo 1700

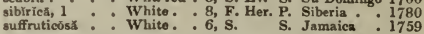

TourRètY̌̆, Dombey. In honour of Marc Antoine Louis Claret de la Tourrette, a friend of Rousseau, author of some botanical works. Linn. 14, Or. 2, Nat. Or. Bignoniacea. The seed should be sown on a hotbed, early in spring, and when the young plants are sufficiently strong, they may be planted in light soil, against a wall or pillar. Synonyme: 1. Dombeya lap pacea.

lappăceă, 1 . - Ro. grn. - 7, H. Cl. A. Peru • . 1788

TOWRR MUBTARD, see Turritis.

TOWBR MC'sTARD, see $A$ räbis Turrită.

TrAchéLIU M, Linn. From trachclos, the neck; from its supposed efficacy in diseases of the Trachea; hence the English name of the genus, Throatrvort. Linn. 5, Or. 1, Nat. Or. Campanulaced. This plant is very showy when in flower. It thrives best in light soil, against a south wall; and is easily in. creased by seeds, or by cuttings, planted under a glass, in spring.

ccerŭlêúm . . Blue . . 8, H. Her. P. Italy . 1640

TrAснумйхॅ̆, Rudge. From trachys, rough, and hymen, a membrane; channels of the fruit. Linn. 5, Or. 2, Nat. Or. Umbellifere. All the species will succeed well in a mixture of loam and sandy peat ; and they may be increased by young cuttings, in the same kind of soil, under a glass, or by seeds. $T$. carvilea is raised from seed, sown on a gentle hotbed; and afterwards treated like other greenhouse plants. Synonyme: 1. Didiscus caruleus.

albrta . . Brt. cream G. A. N. Holl. 1839 cærŭleă, 1: : : Blue $\cdot 7$, G. A. N. Holl. : 1827 gigănteä : :

incisă : : G, Ev, S. N. Holl. . 1819 lanceolata. : White. 7, G. Ev. S. N. Holl. : 1829 lineấř̀s.: : Yellow : 7, G. Ev. S. N. Holl. : 1824 TrACHYSPẼRM Ù, Link From trachys, rough, and sperma, a seed; in reference to the muricated fruit. Linn. 5, Or. 2, Nat. Or. Umbellifere. An uninteresting plant, of very simple culture, and increased by seeds. Synonymes: 1. Bunium rigens, Conium rigens- $\boldsymbol{T}$. rigens 1 .

TrAchYTÉLL Á, Decandolle. From trachytes, roughness: because the leaves, which have a very rough surface, are used for polishing wood, and also metal. Linn. 13, Or. 5, Nat. Or. Dilleniacere. This species succeeds well in a mixture of peat and loam, and ripened cuttings root freely in sand, under a glass. actä . . . Whito. . G. Er. Cl. China . . 1823 China ? 
Trankscāntĭ, Linn. In honour of John Tradescant, gardener to Charles I. Linn. 6, Or. 1, Nat. Or. Commelinacer. Interesting plants, suoceeding well in any rich, light soil; and readily increased by division. Synonyme: 1. T. multiflora.

caricifolra $\quad$ Blue 8 , H. Her. P. Texas congéstxt - 8, H. Her. P. N. Amer. - 6, S. Eva crassifolia : Whata: : 7 , S. Her. P. Brazil : 1825 discóor : : Blue: 6, S. Her. P. S. Amer. : 1783 diurêtě̌ă. Blue 6, S. Her. P. Brazil 1825 divaricătă : Blue : 6, S. Her. P. Trinidad . 1818 erẻctă . - Blue . . 7, H. A. Mexico . 1794 fuscr̆tí $\quad$ Blue , 9, S. Her. P. S. Amer. geniculátå , Blue * 7, S. Her. P. W. Ind, malabărĭcă Purpl Blue 6, G. Her. P. Mexice multiflōrn̆ paniculāt pilosà p. Purple procumbens, 1 . Blue

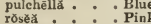

sơséă : : : Pinkă

spicáta : : Purple

subaspēră. . Purpl

tuberósă : Blue

undātă : Blue

alba : White cærūlĕă-albă . Blue wht. 7, H. Her. P. N. Amer. : 1629 pilósă . . White - 7, H. Her, P. N. Amer. 1629 plënă - . Blue * . 7, H. Her. P. N. Amer. . 1629

$T_{R} \bar{A}\left(: 1{ }^{A}\right.$, Plumier. In honour of Jerome Bock, generally called Tragus, a German botanist. Linn. 2], Or.3, Nat. Or. Euphorbiacee. Chiefly stove annuals, and uninteresting-T. cannabină, cor culätă, inféstă, involucrātă, Mercuriālis, pedunculätă, ürēns, urticaefoliă, volübilis.

TrĀGîu, see Pimpinëllă.

T'RAGopōGōn, Linn. From tragos, a goat, and pogon, a beard; in allusion to the long silky beard of the seeds. Linn. 19, Or. 1, Nat. Or. Compositce. Ornamental plants, succeeding in common garden soil. $\boldsymbol{T}$. porrifolius is the Salsafy of gardens; it is sown and treated in the same manner as carrots; the flavour of the root is mild and sweetish. Syno. nymes: 1. T. parviflorus. 2. T. livescens. 3. $T$. ruber. angustifoliŭs, 1 . Purple $\quad *$ 7, H. $\quad$ B. Italy : 1823 campéstrǐs - - Yellow * 6, H. B. Podolia * 1819 cảnŭs * - Yellow * 7, H. crocifóliŭs * : Purple : 6, H. $\quad$ B. Italy : 1739 dübǐs, 2 * : Pa. yel. - 5, H. $\quad$ B Podolia * 1818

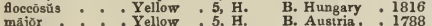
major orientăliss : : Yellow : 6, H. B. Levant : 1787 porrifoliŭs: : Purple : 5, H. B. England pratēnsís - Yellow $-5, \mathrm{H}$ pusillǔs. . Yellow . $6, \mathrm{H}$ rösés̆, 3 : * Red : $\cdot 5$, H undulătŭs : : : Pht. yel, 5, ${ }^{\mathrm{H}}$

B. Iberia : 1820 B. Siberia . 1826 B. Crimea. 1790 B. Spain . 179

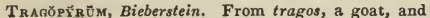
pyros, wheat. Linn. 8, Or. 3, Nat. Or. Polygonacea. Ornamental dwarf shrubs, thriving in a mixture of peat and sandy loam; and increased by layers in spring. Synonymes: 1. Polygonum crispulum, caucasicum. 2. P. frutescens. 3. P. polygamum, parvifolium.

buxifolrūm, 1 . White. . స, H. De. S. Siberia . 1800 lanceolätü, 2 . Pink : 7, H. De. S. Siberia : 1778 poly̆gămúm, 3 : Pink :7, H. De. S. Carolina: 1810 TRANSVRRSELY-SI.RXUOSE, waved in a cross direction. TRĀPĂ, Linn. Abridged from calcitrapa, the Latin name of an instrument called caltrops, furnished with four spines, formerly used in war to impede the progress of cavalry; the fruit of some of the species is furnished with four spines. Linn. 4, Or. 1, Nat. Or. Onagracea. Aquatic plants, requiring a rich, loamy soil, and to be grown in a cistern, or large pot or tub of water; increased by seeds. The large seeds of $T$. Dispinosa are sweet and eatable; they form an extensive article of cultivation. In Cashmere and other parts of the East, they are common food, and known under the name of Singhara nuts,

[317.]
bicornYs . . White. - 7, G. Aq. A. China . . 1790 bispinōsă * White. 7, S. Aq. A. E. Ind. - 1822

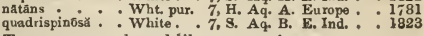

TRAPEZ1FORM, shaped like a trapezium.

Tra veller's joy, see Clèmătĭs Vitülbă.

Trav RLLeR's joy, see Clëmătis Viornă.

Treacla MUSTARD, see Clypéolö,

TRRB CBLANDiNE, see Boccōnǔă frutēscẽns.

TRRE MALLOW, see Lavatêră arborrĕă.

TREB OF SADNESS, see Nyctänthès arbor tristǐs.

TRER ONION, see Allīũm prolifférũm.

TREE SORREL, see Rũmẽx Lunārīă.

TREFOLL, see Trifoliñm.

Trembling american-Treb, see Pópŭlŭs trémŭla.

Treméthă, Dillenius. From tremo, to tremble; in allusion to the gelatinous texture of the plants. Linn. 24, Or. 9, Nat. Or. Fungi. Found growing on fallen branches of trees- $\boldsymbol{T}$. albidă, biparasitica $\tilde{a}_{\text {, }}$ cerebrină , clavariąformĭs, clavâtă, fimbriātă, foliācẻă, F. violäcĕă, intumëscẽns, mesentērîcă, sarcō̄děs.

T ReNtepōhtĭ , Agardh. In honour of M. Trentepohl, an obscure German botanist. Linn. 24, Or. 7, Nat. Or. Alga. Found on rocks, on the sea-coastT. a ūrĕă, A. ilicicolă, pulchëllă, P. chalybäĕ, pur. pürēă.

TrRVIRĀNĭă, Willdenon. In honour of Lud. Christ. Treviranus, M.D., professor of botany in the university of Bonn. Linn. 14, Or. 2, Nat. Or. Gesneracea. This species is extremely handsome when in flower. It requires to be grown in a light, rich 3oil, and when the blossoms have withered, the plants should not have any more water till the roots begin again to vegetate; when they must be taken out of the pots and divided. After they are potted, they require moisture and heat to make them grow and flower in perfection. Synonyme: 1. Cyrilla pulchella. $T$. coccinea.

pulchella, 1 . . Scarlet . 8, S. Her. P. Jamaica . 1778

TrEvōă, Hooker. Trevo, the name of a Spanish botanist. Linn. 5, Or. 1, Nat. Or. Rhamnacez. Interesting plants, thriving in sandy loam and peat; and increased by young cuttings, in sand, under a glass.

quinquenęrvia . White . . 6, G. Ev. S. Chile . . 1827 trinërviss . : Grn. yel. : G. Ev. S. Chile : : 1828

TRĒW̌̆, Linn. In honour of C. J. Trew, of Nurem. berg, a botanical author. Linn. 22, Or. 12, Nat. Or. Treniacea. This species succeeds well in sandy loam and peat; and is readily increased by cuttings, in sand, under a glass, in heat. Synonyme: 1. $T$. macrophylla.

nudiflōră, 1

S. Ev. S. F. Ind.

1796

TRIANDROUs, having three stamens.

TriĀNTHŭMĂ, Linn. From treis, three, and anthos, flower; flowers usually disposed in threes. Linn. 5, Or. 1, Nat. Or. Portulacacee. Plants of little interest. Any common garden soil suits them seeds.

decăndră . . Green . . 7, S. A. E. Ind. . 1824 monogy̆nă - Pur. grn. 7, S. A. Jamaica . 1820

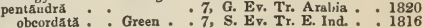

TRĪAs, Lindley. From trias, growing in threes; the floral envelopes are so arranged. Linn. 20, Or. 1, Nat. Or. Orchidacee. Small plants, growing best when treated as the Burlingtonice.

oblöngă. . . . Grn. ye]. . S. Epi. E. Ind. • 1837 racemósa : : : Grn. yel. : S. Epi. E. Ind. : : 1837

TR1BRĂCHY̌̆, see Bolbophȳllam.

TrīBŬLƯs, Linn. From treis, three, and ballo, to project; each carpel is armed with three, and sometimes four prickly points. Linn. 10, Or. 1, Nat. Or. Zygophyllacece. The annual species of this genus may be sown on a moderate hotbed, in spring; and the young plants, when of sufficient size, planted in a sheltered situation in the open border. $\boldsymbol{T}$. cistoides succeeds best in a mixture of loam and peat, and may either be increased by cuttings or seeds.

\begin{tabular}{|c|c|c|c|}
\hline 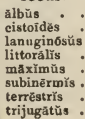 & : & $\begin{array}{l}\text { White } \\
: \text { Yellow } \\
: \text { Yellow } \\
: \text { Yellow } \\
: \text { Yellow } \\
: \text { Yellow }\end{array}$ & $\begin{array}{l}\text { 6, S. A. Guinea } \\
\text { 7. S. Ev. Tr. S. } 1 \text { mer. } \\
\text { 6. G. Tr. A. E. Ind. } \\
\text { 7, S. Ev. Tr. N. Holl. } \\
\text { 6, S. Tr. A. Jamaica } \\
\text { 6, G. Tr. A. Thibet. } \\
\text { 6, H. Tr. A. S. Eur. } \\
\text { 6, G Tr. A. Georgia }\end{array}$ \\
\hline
\end{tabular}


Trichītă, Link. From treis, three, and chate, a bristle. Linn. 3, Or. 2, Nat. Or. Graminea. A mere weed; increased by seeds. Synonymes: 1 . Bromus ovatus, Trisetum ovatum, Avena cvata-T. ovātă 1.

TRÍCHǏA, Hall. From thrix, a hair; in allusion to the internal mass of elastic fibres gradually expanding after the head bursts. Linn. 24, Or. 9, Nat. Or. Fungi. Small, pin-headed plants, fuund upon rotten wood. Synonyme: 1. Spharocarpus fragilis_T. fällāx 1 , nìtēns, ovütă, reticulätá.

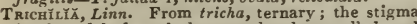
is three-lobed, and the capsule three-celled and three-valved. Linn. 10, Or. 1, Nat. Or. Meliacece. These trees succeed in a mixture of loam and peat; and cuttings of the ripened wood, with the leaves entire, will root in sand, under a glass, in heat. Synonyme: 1. T. glabra.

glandulōsă . : Whitish : 7, S. Ev. T. N. Holl * 1821 hirtansis, 1: White ${ }^{\circ}$ 6, s. Ev. T. Havannah : 1800 odorătă : : Grn, wht. 6, S. Ev. T. W. Ind. 1801 apondioidès : : Whitish. 6, S. Ev, T. Jamaica : 1800

Trichocenntrōn, Poppig. From thrix, a hair, and centron, a spur or centre; to what it refers we are not informed. Linn. 20, Or. 1, Nat. Or. Orchidaced. The species of this genus do not appear to be difficult of culture. They will probably be found to succeed best if attached to a piece of wood, with a little moss upon their roots; and treated after the manner recommended for the Burlingtonia. Synonyme: 1. Acoidium fuscum.

füscŭm, 1 . . Grn. wht. 7, S. Epi. Mexico . 1835 iridifoliúm : : : Yellow . 9, S. Epi, Denerara : 183-

TRтсносӗрHĂLе̌s, Brongniart. From thrix, hair, and kephale, a head; in allusion to the hairy heads of flowers. Linn. 5, Or. 1, Nat. Or. Rham. nacee. For culture, \&c., refer to Phylica. Synonymes: 1. Phylica ramosissima. 2.P.spicata. 3.P. otipularis.

ramosisšmŭs, 1 . White G. Ev. S. St. Helena , 1810 spiestǔs, 2. 1: White: 11, G. E. S. C. G. H. : 1774 stipularis, $\mathbf{3}$ : : Whito : 6, G. Er. S. C. G. H. : 1786

TrichochLö, Trinius. From thrix, a hair, and chlou, grass. Linn. 3, Or. 2, Nat. Or. Graminea. A genus of curious grasses, succeeding well in common soil ; and increased by seeds. Synonymes: 1. Agrostis filiformis, Cinna filiformis. 2. A. tenuiflora, C. tenuiflora. 3. A. mexicana, C. mexicana. 4. A, microsperma.

\section{capillaris. . A petal}

foliôsa, 1

mexichñ, 3

microspêrmǒ, 4 . A petal

sobolifera

7. Grass Carolina 7, Grass, N. Amer. 7, Grass N. Amer. 8, Grass. Mexico 7, Grass. Mexico

1818 181 1820 1780 1820 7, Gross. N. Amer. 1819

Trichociñdús, Persocn. From thrix, a hair, and klados, a branch t the branches are clothed with stellate hairs. Linn. 22, Or. 1, Nat. Or. Hamamelacea. For culture and propagation, see Trevor.

erinitǔs . . . Green . . 8, G. Ev. S. C. G. H. . 1823

TrichodËrmá, Persoon. From thrix, a hair, and derma, a skin; downy covering. Linn. 24, Or. 9 , Nat. Or. Fungi. Powdery masses, found upon dead branches-T, viride.

TRTCнODEsMA, $R$, Brown. From thrix, a hair, and desmos, a bond; the anthers are bound to each other by hairs. Linn. 5, Or. 1, Nat. Or. Boragi. nacee. Worthless half-hardy annuals, of the easiest culture-T, africannam, indican, zeylanicam.

TRTCHōDǏ̃ M, Schrader. From thrix, a hair, and eidos, like; hair-like appearance of inflorescence. Linn. 3, Or. 2, Nat. Or. Gramineo. Worthless plants, readily increased by seeds in common soil-

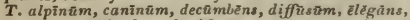
flavėscêns, hy̆bridūm, laxifloràm, neglēct $a m$, rübrüm, rupêstrě, setäcēũm.

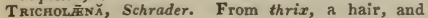
chluina, a cassock. Linn. 3, Or. 2, Nat. Or. Graminec. A pretty grass, succeeding in loam and peat; and increased by seeds. Synonymes: 1. Saccharum Teneriffie, Panicum Teneriffe.

micrănthă, 1 . Apetal . . 6, Grass. Teneriffe . 1825

Trichosăxĕs, Linn. From thrix, a hair, and manos, soft; the shining stems appear like tine hair.
Linn. 24, Or. 1, Nat. Or. Gleicheniacee. A genus of elegant ferns. A mixture of loam and peat suits them best; and they are increased by division or seeds. Synonyme: 1. Hymenophyllum alatum.

brevisętūm, 1 . Brown - 5, H. Her. P. Britain . membranācéūm . Brown . 5, S. Her. P. W. Ind. • 1820

Trichоке̄мй, Ker. From $t h r i x$, a hair, and nemı, a filament; the filaments are hairy. Linn. 3, Or. 1, Nat. Or. Iridacea. A genus of very pretty bulbs when in flower. They should be planted out, in a pit or frame, in a mixture of sandy loam and peat, and increased by offsets. Synonymes: 1. Ixia calestina. 2. T. cruciatum. 3. Ixia purpurascens. 4. I. quadrangula. 5. I. ramiflora.

Bulbocōdiūm . . Red • . 3, H. Bl. P. S. Eur. . . 1739 caulēscēns. Yellow: 6, G. Bl. P. C. G. H. 1810 chloroleũeūin: Grn. wht. : 6, G. Bl. P. C. G. H. : 1825 colestīnúm, 1: : Blue : 3, G. Bl. P. Carolina : 1818 Colúmnä : : Blue : 3, G. Bl. P. Italy : 1825 cruciātūm - Rose - 5, F. Bl. P. C. G. H. 1758 flifollūm : Yellow : 5, H. Bl. P. C. G. H. 1822 púdicum

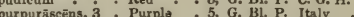

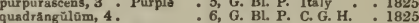

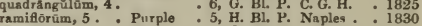
ramifiôrūm, 5.: Purple : 5, H. Bl. P. Naples. : 1830
recûrvũm

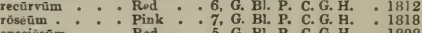
epeciôsũm . - Red ค 5, G. Bl. P. C. G. H. 1808 tortuósúm : Yellow . 5, F. Bl. P. C. G. H. : 1822

Trтснорйтйлём, Lindley. From thrix, a hair; and petalon, a petal; the inner series of the perianth is fringed. Linn. 6, Or. 1, Nat, Or. Liliaced. This curious species succeeds best if planted out in a pit, or frame effectively drained, with a southern aspect, and from which the frost is entirely excluded; it will also succeed in pots, well drained, in a light, rich soil; increased by divisions.

grăcn̊ . . Gmsh. . 7, F. Her. P. Chile . . 1828

TrichopHörēx, Richard. From thrix, a hair, and phoreo, to bear; the inflorescence resembles a bunch of hair. Linn. 3, Or. 1, Nat. Or. Cyperacea. The species are found in peat bogs. Their seeds are covered with a silky down, of which cluth, paper, and wicks of candles have been made; and with which pillows and cushions are sometimes stuffed. Synonyme: 1. Eriophorum montevidense.

alpinũm . . A petal . . Gruss. Scotland . cyperinüm: : A petal : : 7, Grass N. Amer. : 1802 Lockhärtï, montevidēnsé 1.

Trichopílí, Lindley. From thrix, a hair, and pilion, a cap; in allusion to the anther being concealed below a cap surmounted by three tufts of hair. Linn. 20, Or. 1, Nat. Or. Orchidacea. This is a beautiful and very curious species. It appears to succeed best when treated as the Max. illarice.

törtiliss . . Whh red . 1, S. Epi. Mexico . 1835

Trichosānthēs, Linn. From thrix, a hair, and anthos, a flower; the corollas are ciliated. ILinn. 21, Or. 10, Nat. Or. Cucurbitacea. The seeds of the Snake-Gourd should be sown on a hotbed in spring, and afterwards treated like cucumbers. Syno. nyme: 1. Cucumis anguineus.

anguina, 1. . White . 5, F. Tr. A. Chiras . . 1735 colubrină, cordîtă, cucumerīnă, lobätă.

Tвгсноутімй, Linn. From thrix, a hair, and stema, a stamen; in allusion to the slender, hair-like stamens. Linn. 14, Or. 1, Nat. Or. Labiata. 'The seeds of Trichostema should be sown in the open border.

dichơtŏmūm * Blue . . 6, H. A. N. Amer. . 1759 lineăre:- Blue: $: 7, \mathrm{H}$. A. N. Amer. 1759

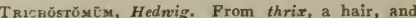
stoma, the mouth; the divisions of the mouth of the theca are very fine. Linn. 24, Or. 5, Nat. Or. Musci. Dark green tufts, found on mountains. Synonymes: 1. Dicranum aciculare. 2, $\boldsymbol{T}$. ericoides. 3. D. ellipticum. 4. D. patens, obtusum. 5. D. polyphyllum, cirrhatum - T. aciculäré 1 , canëscêns 2 , ellīpticâm 3 , fasciculärê, heterostichûm, lanuginठsâm, microcurpon, pătēns 4, polyphîllñm 5.

TRIchorнÊcīê, Link. From thrix, a hair, and theke, a seed-case ; the theca are intermixed among a mass of hair-like filaments. Linn. 24, Or. 9 , Nat. [318] 
Or. Fungi. Found upon decayed wood- $T$, heterosporrūm, rosĕñm.

Tricнотомоus, divided into threes.

Tricoccus, a fruit of three one-seeded cells, as that of Euphorbia.

TricốR̆̃ a club; in allusion to the form of the capsiles. Linn. 6, Or. 1, Nat. Or. Liliacece. The species of this penus thrive well in a light rich soil; and are readily increased by division; $\boldsymbol{T}$. simplex by seeds. elatror * : White $\quad$ 6, G. Her. P. N. Holl. 1824 simplēx: : White: : 7 , G. H. N. Holl. 1823 TricuspidATB, having three points.

Trictsspis, Beauvois. From treis, three, and cuspis, a point; in allusion to the structure of the flowers. Linn. 3, Or. 2, Nat. Or. Graminea. According to Pursh, this is a very valuable grass for mountain meadows. In Pennsylvania it produces two excellent crops every year; and lasts many year without manure, even upon indifferent soils; increased by seeds. Synonyme: 1. Poa carulescens.

quinquéfĩda, 1 . A petal . . 6, Grass. N. Amer. . 1820

TrīDix, Linn. From tridaknos, thrice-bitten; the rays of the flower are divided into three. Linn, 19, Or. 2, Nat. Or. Compositue. A hardy annual, of no interest. Synonyme: 1. Balbisia elongata-T. procũ mbẽns 1.

TRIDRNTATB, having three teeth.

TRID̄EntĔĂ, Haworth. From tridens, a trident; the segments of the outer corona are tridentate. Linn. 5, Or. 2, Nat. Or. Asclepiadacec. Nearly allied to the genus Stapelia; which see, for culture and propagation. Synonymes: 1. Stapelia gemmiflora. 2. S. hircosa. 3, S, vetula.

deprēsså - Brn, pur. . 7, S. Ev. S. C. G. H

genımifüră, 1 . Dk. pur. . 10, S. Ev. S. C. G. H.

paniculatà . : Grn. br. pur. 7, S. Ev, S. C. G. H.

moschātă, $2:$ Brn. pur. 7 , S. Ev. S. C. G. H.

Simsil, 3 . . Dk. pur. : S. Ev. S. C. G. H

styglă : : : Dk. pur. : 8, S. Ev. S. C. G. H

1805

1800

1810

TrIeNTÁls, Linn. From $t r .18$, one third, probably in allusion to the humble growth of the species. Linn. 7, Or. 1, Nat. Or. Primulaced. Interesting little plants, thriving in a light rich soil; and readily increased by division or seeds.

americană . . White . 7, H. Her. P. N. Amer. . 1816 europāă White 5, H. Her, P. Britain.

Trifarious, arranged in three rows.

TrIbID, divided into three.

Trifoliolate, having three leaflets.

TRIFón İeM, Linn. From tres, three, and folium, a leaf; all the species of the genus have trifoliolate leaves. The French call it trèfle; and the English trefoil or clover. Linn. 17, Or. 4, Nat. Or. Leguminosce. The white, red, and yellow clover are among tne most valuable herbage plants adopted in European agriculture. Lucern has been recommended as superior to clover, and saintfoin and various other leguminous plants have been highly extolled; yet the red clover for mowing, and the white for pasturage, far excel all other plants in these respects. All the species thrive in common garden soil, and many of them, being very showy, are well suited for ornamenting the flower borders. The perennial kinds are readily increased by dividing the plants at the root in spring, or by seeds. The seeds of the annual and biennial kinds only require sowing in the open border. Those species marked frame and greenhouse, require protection only in winter. Synonymes: 1. T. Cupani. 2. T. gracile. 3. $T$. hispidum. \&. T. pictum. 5. T. Molinerii. 6. T. conicum. 7. $T$. conicum. 8. $T$. obscurum. 9. $\boldsymbol{T}$. aristatum. 10. Lupinaster pentaphyllum. 11. T. albens. 12. T. irregulare. 13. Lupinaster macrocephalum. 14. T. strictum. 15. T. campestre. 16. Lupinaster oblongifolium. 17. T. squarrosum. 18. $T$. pratense flavicans. 19. T, recurvum.

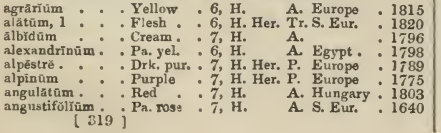

anð̌mălúm . . White. . 7, H. De. Tr.

anomàlüm: : White. armēnīūm

Cream

armēniǔüm

- Yream

Boceŏnt :

bracteátūm

Pa. pur.

8, H. Her P. Armenis

7 . H. Her. P. Armenia

7, H. Her. P. Pyrenees

cxerulescẽn

cæespitosūm

canéscëns
cērnǔŭm

Clierlèri

cinctīm

clandestinūm

clypeātûm

comōyûm.

congēstūm

cơnicūm

Purple

Bru. red
Purple

Cream

Pa. pur.

White

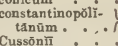

decīpīēns

diffūsūm

divaricâtūm

echinātūm

ëlègâns

erinácéùm

exìmīũ

albifơnūm

expånsūm

fucatum

gemēilüm

globßsúm

Gussóni.

hīrtūm, 3

pietūm, 4

hỵbrìum

incarnãtūm

interinediūm

Pa. yel.

Pa. red

Wht. red

Wht. red

$6, \mathrm{H}$

A. Spain .

B. Moroceo: 1804

7, H. H. Her. P. Siberia : 1827

5, H. Her. P. Cappadoc. 1815

$6, \mathrm{H}$. A. Spain . 1820

5, H. A. S. Eur. : 1750

6, H. A. A. Spain $\quad 1820$

6, H. A. Spain - 1826

6, H. Her. P. America : 1798

6, H. Tr. A. S. Eur. : 1820

Yellow 7 H. A. 1816

Blue * . 7, H. Her. P. Sicily . . 1826

Yellow $.6, \mathrm{H}$. A. Hungary 182

Whit red:6, H. A. S. Eur.

White. 6, H. A. Caucasus : 1821

Pa, red:7, H. Her. P. Europe: 1823

Pa red : 6, H. A. Iberia : 1818

Purple .6, H. De. Tr. Dihuria .1820

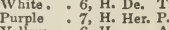

Yellow

Yellow

Purple

Purple

Purple

Purple

Flesh .

Whit. red

Pa. pur.

Kitaibeliānūm, 6. $\mathrm{Pa}$, pur.

Lagascānūm, 7 . Pa. yel.
Lagōpùs : Red

lappĩcéûm: : $\mathrm{Pa}$ red

lasiocéphälím: : Purple

latingim.

Purpla

leucãntlıūm, 8

Whit. re

ligûstǐcūm, 9

Wht. red

upinástér, 10 . Purple

malacānthūm : Purple

marítimūm, 12 : $\mathrm{Pa}$. pur

mädium üm, : Purple

négacéphălūm, 13 Yel. wht.

Micheliânũm : Y Yht. gr

micrănthūm * Y Yellow

mierophyllüm : Purple

montanum : * White

obscūrūm

ochroleũcūm

olỵmpicûm

pallëscēns

pallèscèn

pannoünìcūm

parisiênsé

parviflórūm, 14

pennsylvăaĭcūm

Pa. red

Sulphur

Creani.

Pa, yel.

Wht. sel.

Yellow

Rácún. Red

phleoidés

physodes

Wed

pratense - Purple

procümbēns 15 Yelle purpurtiseins, 16 . Purplo reflêxūm : : Purple

rêpēns : : White

pentaphyllum : White

rŭbẻns

rupēstré

saxătîlē .

scăbrüm

Sebastiānū

spadicéu

splıærocéphàlón

squarrōsūm

flā vĩeãns, $17 \dot{7}$

stellātüm

strictūm

aubterrānęùm

supinūm

supinûm

sylvăticüm

tenuiflōrủm

tenuifơlîum

tomentósúm * Purple

trichocéphălūm : Cream

uniflôrum : • Blue

$6, \mathrm{H}$.

6, H.

, $\mathrm{H}$.

7 , H.

H.

$7, \mathrm{H}$.

7, $\mathrm{H}$.

$6, \mathrm{H}$.

7, $\mathrm{H}$.

$\begin{array}{ll}7, \mathrm{H} & \text { A. Spain : } 1818 \\ 7, \mathrm{H} & \text { A. Spain : } 1827 \\ 7, \mathrm{H} . & \text { A. Mont pel. : } 1787\end{array}$

7. H. Her. P. C. G. H. 1823

6. H. Her. P. Italy

$6, \mathrm{H}$ A. Tauria

7. H. Her, P. Spain

7 , H. Her, P. Siberia

7, H. A.

A. Californ

A. Spain

A.

A.

Tr. Europ

A. S. Eu

A. Italy

A. Mexico

183

1818

1713

1817

1800

1777
1596

H. Britain

H. Her. P. England

$7, \mathrm{H}$ A. Italy.

6, H. Her. P. Scandin. : 1819

7, H. A. Europe : 1786

6, H. Her. P. Carinthia. 1821

5, H. Her. P. England

6, H. Her. P. S. Eur. : 1817

7, H. De. Tr. Carinthia . 1804

6, H. H. Her. P. Hungary : 1803

6, H. Her. P. Hungar

6, H. A. France : 1820

7, H. Her. P. N. Amer. 1811

5, H. De. Tr. Hungary : 1818

7, H. Her. P. Britain

6, H. Tr. A. Britain

6, H. Her. P. Siberia : 1816

6, H. A. France : 1816

7, H. A. Virginia : 1794

$6, \mathrm{H}$. Britain

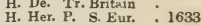

6, H. Her. P. Naples : 1820

5, H. Tr. A. Britain

$7, \mathrm{H}$. A

7, H. Her. P. Europe

1800 
vaginătūm, $18 \quad$. Pa yel. . H. Her. P. Switzerl. . 1819 vesiculōsūm, 19 : Red : $6, \mathbf{H}$. A. Hungary 1805 Wormskioldil . Purple" 8, H. A. 1830

arvënsĕ, A. grăç̌lë 2, cyathifolium, filiformĕ, fimbriätam, fragiferâm, glomerātam, resupinatum, spumosulm, striātūm, suffocütũ $m$, tridentātūm.

TrigLöchĭ, Linn. From treis, three, and glochin, a point ; in allusion to the three angles of the capsule. Linn. 6, Or. 3, Nat. Or. Juncaginacer. These plants are found in marshy situations. $\boldsymbol{T}$. bulbosum is increased by offsets, all the other species by division.

\begin{tabular}{|c|c|c|c|}
\hline 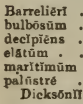 & $\begin{array}{l}: \\
\dot{0}: \\
\dot{\mathrm{r}}:\end{array}$ & $\begin{array}{l}\text { : Green } \\
: \text { : Purple } \\
\text { : Green } \\
\text { : Green } \\
\text { : Green } \\
\text { : Green } \\
\text { : Green }\end{array}$ & $\begin{array}{l}\text { 7, H. Her. P. Italy } \\
\text { 10, G. Bl. P. C. G. H. } \\
\text { 7, G. Her. P. N. Holl. } \\
\text { 6, H. Her. P. N. Amer. } \\
\text { 6, H. Her. P. Britain . } \\
\text { 7, H. Her. P. Britain } \\
\text { 7, H. Her. P. England }\end{array}$ \\
\hline
\end{tabular}

Trigonal, having three angles.

TrigonêLLA, Linn. From treis, three, and gonu, an angle; the vexillum of the flower is flat, while the wings spread and give it a triangular appearance. Linn. 17, Or. 4, Nat. Or. Leguminosa. These plants are not very ornamental. They all succeed best in a light sandy soil ; the perennial kinds are readily increased by dividing the plants at the root, or by seeds; while the annual kinds only require sowing in the open border in spring. The seeds of $\boldsymbol{T}$. Fenumgrecum are used in fomentations, for softening, maturing, and dispersing tumours. $S y$ nonymes: 1. Melilotus procumbens. 2. M. caruleus. 3. Trigonella flexuosa. 4. Trifolium ornithopodioides. 6. Trigonella media. 6. N. hamosa, uncinata.

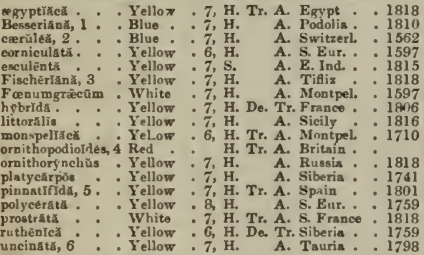
callicĕräs, cancellala, flexuosa, gladiátă, hamösă, spinōsu, striată, tēnŭis.

Triő́rĭ, Aublet. From treis, three, and gonu, an angle, the fruit is three-angled, three-valved, and three-celled. Linn. 16, Or. 2, Nat. Or. Celastracea. For culture and propagation, see Trenia.

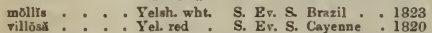

Trigonīñ̂̀, Lindley. From trigona, a triangle, and eidos, Tike; in allusion to the triangular form of Beveral parts of the plant. Linn. 20, Or. 1, Nat. Or. Orchidacer. This is rather an interesting genus of easily cultivated, though slow growing plants. They require to be grown in good fibruus peat, raised a little above the pot, which must be thoroughly drained.

acuminatŭm •. Straw col. - S. Epi. Demerara . 1834 acūtūm

S.

merara

Egertoniănūm : Pu brn. - S. Epi. Demerara

obtũsūm - Orange . 6, S. Épi. Demerara : 1834

Trious̄ră. Cavanilles named this genus after $D$. Trigueros, a Spanish botanist who first discovered the plant. Linn. 5, Or. 1, Nat. Or. Malvacea. For culture and propagation, see Verbascum. Synonyme 1. Verbascum Osbeckia.

ambrosiluch, 1 . Pursh, vio. 7, H. A. Spain . . 1752

Trioveous, having three styles.

Trîr.tō, Linn. From trilix, triple; the calyx has three sepals, the corolla three petals, the pistil three styles, and the stem three leaves. Linn. 6, Or. 3, Nat. Or. Melanthacea. Curious little tuberous rooted plants, succeeding best in a bed of peat soil, and rather slowly increased by dividing the rcots, or by seeds. The roots of all the species are violently emetic, and their mawkish, rather nauseous berries, are at least suspicious. Synonymes $1, T$. rhomboideum. 2. $\boldsymbol{T}$. pendulum. 3. $\boldsymbol{T}$. pictum. $\boldsymbol{T}$. erythrocarpum. 5. T. erectum var. 6. $\boldsymbol{T}$. pusillum. Catesbōi . . Red •. 5, H. Tu, P. Carolina . 1820 cếrnŭūm : White: 4, H. Tu, P. N Amer. 1758 discolor. : : Green: : 5, H. Tu. P. Georgia : 1831 erēctūm, 1. . Brown : 4, H. Tu. P. N. Amer. . 1759 albúm . . Wbite. . 4, H. Tu. P. N. Amer. 1700

viridiforoūm, 2, Pa. grn. 4, H. Tu. P. Canada erythrneărpūm, 3. Red wht. $5, \mathbf{H}$, Tu, P. N A

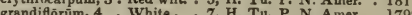
grandiforum, 4. Thite.

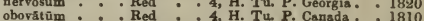
ovátüm. : Pa. pur. : 5, H. Tu. P. N. Amer. : 1812 pẽndũlũm, 5 . White. . 5, H. Tu. P. N. Amer. : 1805 petiolătūm . Brown . 4, H. Tu. P. N. Amer. . 1811 pümǔlūm, 6 . Red . . 5, H. Tu P. Carolina , 1819 sëssile . . . Brown : 4, H. Tu. P. N. Amer. : 1759 stỵlósūm : . Red . . 4, H. Tu. P. Carolina 189 undulătŭm : Red : 4, H. Tu. P. N. Amer. : 1818

TrinocuLAR, having three cells.

TrĩĭĂ, Heffmann. In honour of Dr. Trinius, famous Russian botanist. Linn. 5, Or. 2, Nat. Or. Umbellifera. Worthless hardy biennials. Syno. nymes: 1. Pimpinella dioica, 2. P. dichotoma, ramo sissima, glauca. 3. T. Henningii-T. Hoffmānnì 1 , Kituibele 2 , vulgärìs 3 .

TriŏdT̃̆, R. Bromn. From treis, three, and odous, teeth; the palea. Linn. 3, Or. 2, Nat. Or. Graminea. $A$ perennial hardy grass, increased by seeds. $S y$. nonyme: 1. Poa decumbens-T. dectlmberns.

Triōprěrls, Linn. From treis, three, and pteron, a wing; the carpels are each furnished with three wings. Linn. 16, Or. 6, Nat. Or. Malpighiacea. A Renus of very elegant $t$ winers, extremely dificult to bring into flower in this country. They grow well in a mixture of loam and peat; and curtings of the ripened wood will root in sand, under a glass, in heat.

jomaicênsY̌ - Yellow \&. Ev, Tw. Jamaica , 1892 sericed : Yellow: S. Ev. Tw. S.Amer. : 1823

Triōstน̆̄̄M, Linn. From treis, three, and osteon, a bone, in allusion to the three hard seeds. Linn. 5 , Or. 1, Nat. Or. Caprifoliacea. The spevies thrive well in a light rich soil; and are iacreased by cuttings, or by parting at the roots. $T$. perfoliatum is a mild cathartic. Its dried and roasted berries have been used as coffee.

angustifolrüm . Yellow , 6, H. Her. P. Virginia , 1699 perfoliatūm : Dk. red :6, H. Her. P. N. Amer. : 1730 TrIPBTArous, having three petals.

TaIPHĂsỸ, Loureiro. From triphasios, triple; the caly $x$ is three-toothed, and there are three petals. Linn. 6, Or. 1, Nat. Or. Aurantiaced. This plant succeeds well in turfy loam and peat; but it must be rarefully watered during winter. Cuttings, ripened at the base, will root in sand, under a glass, in heat. Synonymes: 1. T. aurantiola. 2. Limonic trifoliata.

trifoliata, 1 . White. . 6, G. Ev. S. China . . 1798

TrIPINNATB, thrice pinnate.

TRIPLĂRIs, Linn. From triplex, triple; the parts of fructification are disposed in threes. Linn. 22, Or. 8, Nat. Or. Polygonacea. For culture and propagation, see Trenia.

americână. . . Pa yel. . S. Ev. T. S. Amer. . 1824

ThIPIB-NERVRD, throwing out three side nerves a little above the base.

TrĪps̆́C̄M, Linn. From tribo, to thresh; in allusion to the purpose to which its grain may be applied. Linn. 21, Or. 3, Nat. Or. Graminea. These plants grow in any rich mould, and are increased by division. They are forage grasses of the West Indies- $T$. dactyloĩdĕs, monostăchy̆on.

Truprílos, Ruiz and Pavon. From treis, three, and ptilon, a feather; on account of the three divisions of the pappus. Linn. 19, Or. 1, Nat. Or. Composite. A genus of very pretty annuals. The seeds must be raised on a hotbed in spring, and planted out in the open border about the end of $\mathrm{May}$.

cordifolium : Whits. * $7, \mathrm{H}$. A. Chile : 1824

Triquerrous, having three sides or angles.

TrISRCTRD, cut into three parts.

Trisêtes, Persoon. From treis, three, and seta, a bristle, on account of the three awns of the flower. Linn. 3, Or. 2, Nat. Or. Graminea. According to [ 320 ] 
the Woburn experiments, $T$. pubescens is well suited for a permanent pasture on light rich soils; it is hardy, early, and more productive than many other kinds in similar soils. Synonymes; 1 . Avena planiculmis, alpina. 2. A. flavescens. 3. A. pubescens. 4. A. striata-T. airoìdés, Alopecū rüs, alpēstrě, al-

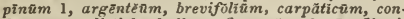
densātūm, distichophy̆llüm, flavēscěns 2, Loeflingiànūm, micrānthūm, neglēctũm, parviflórūm, penn-

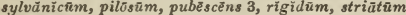
4, tënüĕ.

TRISTÃNİX, R. Bronn. In honour of M. Tristan, a French botanist. Linn. 18, Or. 2, Nat. Or. Myrtacee. Very pretty shrubs, thriving well in loam peat, and sand, and increased readily by halfripened cuttings, planted in sand, under a glass. Synonyme: 1. T. laurina.

\begin{tabular}{|c|c|c|}
\hline 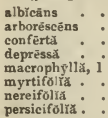 & $\begin{array}{l}\text { White. } \\
\text { Yellow } \\
\text { Yellow } \\
\text { : White. } \\
\text { : Yellow }\end{array}$ & $\begin{array}{l}\text { 6, G. Ev. T. N. Holl. } \\
\text { G. Ev. S. N. Holl. } \\
\text { 8, G. Ev. S. N.S. W. } \\
\text { 8, G. Ev. S. N. Holl. } \\
\text { 8, G. Ev. T. Moreton B. } \\
\text { G. Ev. S. N. Holl. } \\
\text { 7, G. Ev. S. N. S. W. : } \\
\text { G. Ev. S. N. Holl. }\end{array}$ \\
\hline
\end{tabular}

TRistĚGIs, Nees. From treis, three, and stege, covering; in reference to the three glumes or valves of the calyx. Linn. 3, Or. 2, Nat. Or. Graminea. Growing in common soil; seeds.

glutinōsă . . Apetal . . 6, Grass,

Tritenkī Ă, Lindley. From treis, three, and teleios, complete; in allusion to the perfect ternary arrangement of its parts. Linn. 3, Or. 1, Nat. Or. Liliacee. Very handsome plants, of easy culture in a mixture of peat, loam, and sand, and readily increased by offsets from the roots; or by seeds.

grandifiora . - White . 7, F. Bl. P. N. Amer. - 1826 laxa : : Dk, blue : 7, F. Bl. P. Californ. : 1832

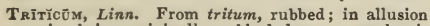
to its being originally rubbed down to make it eatable. Linn. 3, Or. 2, Nat. Or. Graminece. This is undoubtedly the most important genus of the order Graminea, as it includes the wheats, the properties of which are too well known to require any detailed notice in this work. Synonymes: 1. Secale creticum. 2. T. villosum. 3. T. Zea. 4. Secale villosum.

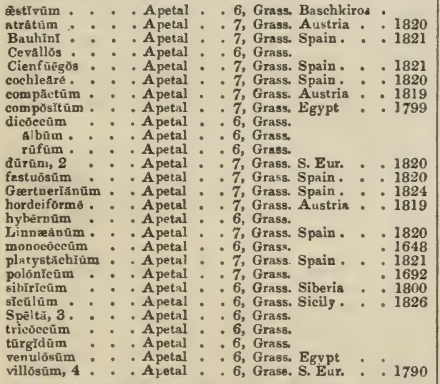

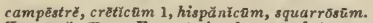

TRITOMÃ, Ker. From treis, three, and temno to cut; in allusion to the three sharp edges of the ends of the leaves. Linn. 6, Or. 1, Nat. Or. Liliacece, Handsome flowering plants, succeeding in a light rich soil, and readily increased by suckers from the root. The species often flower very late in autumn, and even through very mild winters; but they ought to have the protection of a frame.

Burehellir . . Yel. red . H. Her. P. C. G. H. . 1816 mêdra : . Orange 4, F. Her. P. C. G. H. 1789 pümrlă : : : Orange : 9, F. Her. P. C. G. H. : 1774 púmila : : : Orange $\quad: 9$, F. Her. P. C. G. H. $\quad: 1774$ TRITônī̌n, Ker, From triton, a weathercock; in allusion to the variable direction of the stamens in the various species. $\operatorname{Lin} n .3$, Or. 1, Nat. Or. Iridacee. Very handsome plants when in flower. They require the same treatment as the genus Ixia and other similar genera.

\begin{tabular}{|c|c|c|c|c|}
\hline & & & & \\
\hline & & & hite. & \\
\hline foncolór & . & & Yellow & Bl. $\mathrm{P}$ \\
\hline ocáta. & & & Orange & G. Bl, P. \\
\hline ispă & . & & Flesh. & G. B. P. \\
\hline deüsta ${ }_{\text {fenestrgtă }}$ & - & & Fulvid & B1. P. C. \\
\hline & & & Yellow & \\
\hline fucātă & . & & Red yel. & \\
\hline lineātă & . & & Varieg. & 31. P. \\
\hline longiffōră & & & White. & G. B1. P. \\
\hline & . & & & P. \\
\hline odorata. & & & Yellow & \\
\hline pâllïdã . & & & White. & G. Bl. \\
\hline $\begin{array}{l}\text { tināta } \\
\text { ractä. }\end{array}$ & & & $\begin{array}{l}\text { Yellow } \\
\text { Yellow }\end{array}$ & \\
\hline $\begin{array}{l}\text { retrac } \\
\text { rochē }\end{array}$ & & & Yellow & P. \\
\hline rớsěă & & & Pink & \\
\hline securiggèră & & & - Brown & \\
\hline $\begin{array}{l}\text { squalinda } \\
\text { striāta }\end{array}$ & : & & $\begin{array}{l}\text { Rufous } \\
\text { Blue }\end{array}$ & $5, \mathrm{G}, \mathrm{Bl}$ \\
\hline tenuiflóră & . & & Yellow & $\mathrm{H}$. \\
\hline Irínis & & & - Green & B] \\
\hline
\end{tabular}

1825

1811

181

1758

1787

1801

1780

1813

1774
1774

1795

1829

1806
1825
1815

1811

1793
1774
1774

1774

1825

1811

1825

Triturated, reduced to powder by pounding.

TriUMFẼTtă, Linn. In honour of John Baptist Triumfetti, an Italian botanist and author. Linn. 11, Or. 1, Nat. Or. Tiliaceve. Uninteresting plants, chiefly under shrubs, growing in common garden soil; cuttings and seeds. Synonyme: 1. T. macro-

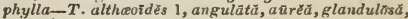
grandifloră, havanẻnsǐs, heterophôllă, Lüppülă, mi cropétălă, oblongată, pilosă, rhumboidẻă, rotundifoliă semitrillobă, suborbiculätă, trichoclädä, triloculäris.

Trīx Ǐs, P. Bronne. From trixos, triple; on account of its triangular capsule, with three cells. Linz. 19, Or. 4, Nat. Or. Compositce. Interestiug plants, of common culture. Synonymes: 1. Perdicium bra. siliense. 2. Leuceria senecioides.

auriculātă, 1 . White . R, S. Ev. S. Brazil

1827

TrizeẼxis, Lindley. From treis, three, and zeuxis, a union; in allusion to the cohesion of the three sepals. Linn. 20, Or. 1, Nat. Or. Orchidacee. A small plant, of no beauty. It succeeds best if fastened to a piece of wood.

falcătă . . Green . . 3, S. Epi. W. Ind. . 1820

TrochiscānthӖs, Koch. From trochiskos, a small wheel, and anthos, a flower. Linn. 5, Or. 2, Nat. Or. Umbelliferce. A hardy herbaceous plant, of no beauty. Synonyme: 1. Ligusticum nodiflorum-T. nodifloră.

TrochlaAtr, twisted like a pully.

T ROCHOCĀRPÄ, R. Bron'n. From trochos, a wheel, and karpos, fruit; the cells of the fruit diverge from a common centre like the spokes of a wheel. Linn. 5, Or. 1, Nat. Or. Epacridacea. An extremely handsome shrub. For culture and propagation, see Epacris.

laurină . . . Yellow . 6, G. Bl. P. N. Holl. . 1829

TRöllYưs, Linn. From trol, or trolin, an old German word signifying something round; in allusion to the shape of the flower; whence, also, the English name Globe-flower, Linn, 13, Or. 6, Nat, Or. Ranunculacea. Pretty border plants, thriving best in a light moist soil, and increasing by division or seeds. Synonymes: 1, T. laxus. 2. T. ranunculinus.

americănŭs, 1. . Yellow * 5, H. Her. P. N. Amer. - 1805 as aticŭs : : Drk, or. :5, H. Her, P. Siheria : 1759 caucăš̌cŭs : : Yellow : 5, H. Her. P. Caucasus : 1817 europæŭs : : Yellow : 5, H. Her. P. Britain . albǔs. : Whitish : 6, H. Her. P. Britain . hũmîlĭs: : Yellow : 5, H. Her. P. Austris : 1800 napellifolrŭs : Yellow 5 , H. Her. P. Europe patūlŭs, 2.: Orange : 5, H. Her. P. Siberia : 1800

Tromôtrích Ĕ, Havorth. From tromos, fear, and thrix, a hair; in reference to the cilia of the corolla being tremulous. Linn. 5, Or. 2, Nat. Or. Ascle. piadacea. Interesting plants. For culture and propagation, see Stapelia. Synonymes: 1. Stapelia fuscata. 2. S. obliqua. 3. S. revoluta.

fuscătă, 1 . . . Brn. pur. . 7, S. Ev. S. C. G. H. . 1814 glaúcă : : : Red pur. : 7, S. Bv. B. C. G. H. : 1799 
obliquă, 2 . . Dull yel. . 7, S. Ev. S. C. G. H. 1805 pruinōsă : : Drk. brn. 6, S. Ev. S. C. G. H. : 1795 revolută, 3 : : Purple : 7, s. Ev. S. C. G. H. : 1790

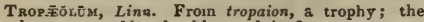
leaves resemble a buckler, and the flowers an empty helmet. Linn. 8, Or. 1, Nat. Or. Tropeolacee. All the species are very showy when in Hower, and are therefore desirable acquisitions to every collection. The greenhouse and frame species thrive in any light rich soil; and are readily increased by cuttings in the same kind of soil, under a glass. The annual species should be sown in the open ground in spring. The tuberous-rooted kinds succeed well in the open air, in a sheltered situation, during summer; in winter tiıey may be taken up and kept in sand until spring, when they may be again planted nut into the open ground. The seeds of $T$. majus are pickled, and used as capers, to which they are preferred by some. The roots of $T$. tuberosum are eaten in Peru. Synonyme: 1. T. peregrinum.

adūneūm, 1 . Yellow . 8, G. Ev. Cl. N. Granada 1810 brachvcerás: : Yellow: F. Tu P. Chile: 1830 hybrłdúm . Orange 7 , G. Ev. Tr. Peru

JurrăttII - . Scar. yel. G. Ev. Cl. Snntiago: 1836 majüs : : Or. yel. 7, H. Tw. A. Peru : 1686 atrnsanguinèüm Dk. red : $8, \mathrm{H} . \mathrm{Tw} . \mathbf{A}$. Peru : fióré plênó : Or. yel. : 8, G. Ev. Tw. Peru : 1686 mInūs : Or. yel. : \&, H. Tr. A. Peru : 1596 flürê plènó : : Or. yel. : G. Ev. Tr. Peru : 1596 pentaphyllūm: Or. yel. : 8, F. Ev. Tw. M. Video: 1824 pinnătum - : Y Yellow : 5, G. Ev. CL Peru : 1897 polyphylium - . Or. yel. 6, G. Ev. CL. Chile : 182 tuberósūm: : Yel red 9, F. Tu. P. Peru . 1836

Trŏprĭs, Linn. From trophe, fodder; the leaves and twigs are used as fodder for cattle when grass is scarce. Linn. 22, Or. 2, Nat.Or. Urticacece. These plants grow freely in loam and peat; cuttings.

americsn aspera . : : Green. : S. Ev. T. E. Ind. . 1809

TRöx广мōs, Don. From truximon, eatable. Linn. 19, Or. 1, Nat. Or. Composite. Any common soil suits these plants, and they are readily increased by division. Synonyme: 1. T. marginatum.

euspidātūm, 1 - Yellow - 7, H. Her. P. Louisiana - 1824 glnúeám. : Yellow: 5 , H. Her. P. Missouri : 1811

TRUB DNDDRR, see Cuscǔtă Epithy̆mrm.

Tri'B PARsLEY, see Aptam Petroselinam.

Trub service, see Pgrés Sorbús.

Trurple, see Tabér.

TrUMPBT-YLOWRR, see Bignonid.

Truncarus, blunt, as if cut off.

TRYмй, Yüa, Fensl. Not explained. Linn. 5, Or. 1

Nat. Or. Rhamnaced. This species is well deserving of a place in every collection of greenhouse plants, on account of its snow-white flowers; which, being produced in numerous loose, drooping panicles, render it a very beautiful object when in blossom its flowers are also deliciously fragrant. The wood is said to be soft and pithy, and the plant apt to die off in winter, if overpotted, and not kept in a warm and light situation: in other respects, it may be treated as the greenhouse species of Ceanothus.

odoratissimuim . White. . 2, G. Ev. S. N. Holl. • 1837

TUBв-rnower, see Clerodëndrŏn Siphonänthŭs.

TUBr of calyx, the tube formed by the cohesion of the sepals.

TUBR of stAMrNs, the tube formed by the cohesion of the filaments in monadelphous flowers.

TüBŭR, Michaux. An ancient Roman name for a fungus. Linn. 24, Or. 9, Nat. Or: Fungi. $T$. cibarium is the famous truffe, 80 celebrated in the annals of cookery. It grows under ground, and is found in light dry soils, in some of the southern counties; bit it is much more common in Italy, Germany, and the south of France, whence immense quantities are imported. Dogs are taught to find this fungus by the smell, and to scratch it up out of the earth. An instance is recorded of a man having possessed this power. It is brought to the table boiled or stewed. It is reported to have a stimulating aphrodisiacal quality, which perhaps renders it more popular than its fiavour, which is trifling. Loudon's Encyclop, of Plants-T. albüdam, cibarifm.

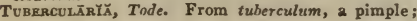

warted appearance of the plants. Linn. 24, Or. 9, Nat. Or. Fungi. Found upon dead branches. Synonyme: 1. Clavaria coccinea-T. älbìdz̆, cônflüĕns, discoideă, granuläta, nïgricans, vulgaris 1 .

Tubraculiatus, covered with knots or tubercles.

TUBrRosr, see Polyänthés tuberosd.

Tubrrous, bearing fleshy, solid, roundish, or longish root-like underground stems, as the potato.

TULBĀGHĪ $\bar{\Lambda}$, Linn. In honour of Tulbagh, a Ditch governor at the Cape of Good Hope. Linn. 6, Or. 1 Nat. Or. Liliaced. Interesting plants when in flower. They succeed well in sandy loam and peat, and are increased by offsets or seeds.

affinis * * . Brown * 6, G. B1. P. C. G. H. 1820 alliácéd: : : Brown : 6, G. Bl. P. C. G. H. : 1774 ceplcéa . * : Brown : 4, G. Bl. P. C. G. H. : 1795

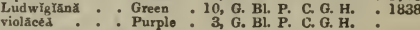

Tulip, see Tulipă.

TûLIPĂ, Tournefort. Said to be from Thoulyban, its Persian name. Linn. 6, Or. 1, Nat. Or. Liliacee. A genus of very celebrated and much prized florist's flowers. They succeed well in rich loam and sand, and are increased by offsets; new varieties are obtained from seed. The choicer kinds require to be taken up and dried after they have ceased flowering, and planted again in the autumn. They should be slightly protected in very rainy or frosty weather, or they are very liable to rot. Synonyme:

1. $T$. acuminata.

altằล

- Yellow 4, H. BL. P. Altai

: Yel. pur.

Yellow

H. B1. P. Russia

4, H. Bl. P. Italy 1827

Clusisna : Wht, pur. 7, H. Bl. P. Sicily : 1636

cornuta, 1 : : Striped

Striped 4 , H. Bl. P. Levant : 1577

laciniata : Varieg. 4, H. B.. P. Levant : 1603

lũteă. : - Yellow * 4, H. Bl. P. Levant - 1603

rersicolór: : Varieg. 4 H. Bl. P. Ievant 1603

5 , Bl P. Italy

variegate : Varieg 5 , H. BI. P. Italy : 1827

medra

montani" : Searlet 7, H. B1. P. Persis : 1896

óčlı̃a-solta": : Red blue : 4, H. Bl. P. Italy : : 1816

péroled : : Scar, blk.. 4, H. Bl, P. Persia : 1826

patúns

präesx. : Scarlet : 4, H. Bl. P. Italy : 1825

pubeзsсёns: : Red . 4, H. Bl. P. 182

répins : Yellow 4, H. Bl. P. Russis : 1819

sarátrlis : Yellow 4. H. BI. P. Crete: : 1827

scahriseapd : : Red yel : 4, H. Bl. P. Italy : : 18

stellata . : White. 4, H. Bl. P. Cumana : 1827

atrangulatia :

4, H. HI. P. S. Eur. . 1603

svlvêstrìs : . Yellow 4, H. Bl. P. England

: Scarlet .4, H. Bl. P. Russia . 1817

TULIP-TRRE, gee Liriodendrön.

TuLostő u厶, Persoon. From tulos, a wart, and stoma, the mouth; in allusion to the nature of the orifice by which the seeds are dispersed. Linn. 24, Or. 9 , Nat. Or. Fungi. Found upon the mossy tops of walls in winter and spring- $T$. brumale.

Tumid, swelling.

Tunic, a coat, or seed cover.

TŨen, D. Don. Tupa is the name of $T$. Feuillei in Chile. Linn 5, Or. 1, Nat. Or. Lobeliacea. These plants are well worth a place in every collection, on account of the beauty and singularity of their flowers. For culture and propagation, see Lobelia. Synonymes: 1. Lobelia arguta. 2. L. Tupa. 3. L. polyphylla. 4. L. purpurea. 5. L. gigantea, L. salicifolia.

argâtă, 1. Yellow 9, F. Her, P. Chilo

blândă : : Pink : F. Her. P. Chilo

Peutllel, 2 : Scarlet

Purple : 1824 Purple : 8, F. Her. P. Valparaiso. 1832 Balieifoliá, 5 : Purple: 8, F. Her. P. Valparajso. 1825

TUPĩstră, Kèr. A diminutive of typis, a mallet; in allusion to the peculiar form of the flower. Linn. 6, Or. 1, Nat. Or. Acoracere. These plants succeed well in sandy loam and peat, and are readily increased by dividing the root. Synonyme: 1. Rohdea japonica.

japoñč̆, 1. . A petal . 2, H. Her. P. Japan : 1783

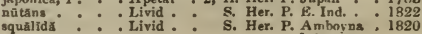
[ 322 ] 
'I'vRninate, having the figure of a top.

TuRgăNĭA, Hoffmann. From turgeo, to swell: the fruit. Linn. 5, Or. 2, Nat. Or. Umbelliferc. An uninteresting plant; seeds. Synonyme: 1. Cuucalis latifolia-T. Latifuliù 1 .

Tiraid, swollen, putfed.

Turgósĩ̆, see Crǘssúlă.

TURMRRIC, see Curcümä.

TLRN ĔRĂ. Linnzus dedicated this genus to the memory of William Turner, Prebendary of York, Canon of $W$ indsor, \&e., author of a "New Herbal," 1551, fol.; he died in 1568 . Linn. 5, Or. 3, Nat. Or. Tumeracea. A genus of very elejant plants when in flower. They thrive in any rich soil, and are all readily increased by seeds. The shrubby kinds may also be increased by cuttings. Synonymes. 1. Piriyueta racemosa. 2. $\boldsymbol{T}$. elegans.

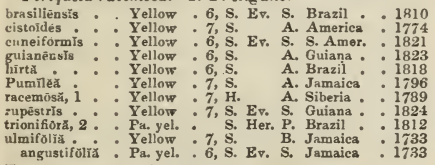

TURNSolk, see Heliotróplùm.

TURPENTiNe, see Srlphiñm terebinthücĕum.

TURPEntin B-TrBB, see Pistäcĭ Terebinthüs.

Turríĭ, Ventenat. In honour of M. Turpin, a dis. tinguished French botanical artist and naturalist. Linn. 23, Or. 2, Nat. Or. Staphyleacec. Trees of little beauty. They thrive well in a mixture of loam and peat, and are increased by cuttings in sand, under a glass, in heat. Synonymes: 1. Stuphylea occidentalis. 2. Dalrymplea pomifera.

occident面lis, 1 . White. . S. Ev. T. Jamaica . 1824 pomiteră, 2 :Yelsh, wht. 5, S. Ev. T. Sylhet : 1820

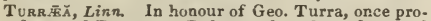
fessor of Botany at Padua, and author of several botanical works; died in 1607 . Linn. 16, Or. 6, Nat. Or. Meliacec. These plants succeed well in loam, peat, and sand, and are easily increased by cuttings, planted in sand, under a glass, in heat.

pinnătă. . . Pink . . 4, S. Ev. T. Sylhet . . 1828 rigidar : Yellow: S. Ev. T. Maurit.: 1816 rigĭdă : : : Yellow:
virēns : Shite. Ev. T. Maurit.:

'TurRītrs, Dillenius. Fromturris, a tower; the foliage is so disposed on the stems as to give them a pyra. midal form: and for the same reason the plants are called Toner-mustard. Linn. 15, Nat. Or. Crucifera. Hardy annuals, not worth growing-T. gläbrä, $G$. ramösč, Grühümĭ, mollìs, patülă, salsuginosĭ, strīctŭ.

TussināGö, Tournefort. From tussis, a cough; for curing which the flowers have been employer. Linn. 19, Or. 2, Nat. Or. Compasita. Some of the species are very pretty. They succeed well in common soil, and are readily increased by division. $\boldsymbol{T}$. Farfara is a demulcent bitter, and has been used to soothe irritations in the air passages; hence its reputation as a pectoral medicine. Synonymes: 1. T. bohemica. 2. $\boldsymbol{T}$. paradoxa. 3. $\boldsymbol{T}$. lobata. 4. $\boldsymbol{T}$. tomentosa.

albă . - . White . 3, H. Her. P. Europe , 1683

alpină : : Li. pur. 4, H. Her. P. Austria: 1710

díseőlör. : Li. pur. :4, H. Her. P. Austria : 1633

arfára : Yellow : 3, H. Her. P. Britain.

foliis variegătís Yellow : 3, H. Her. P. Britain .

frägráns *. White. 2, H. Her. P. Italy : 1806

frigidă : Pale - 5, H. Her, P. Lapland: 1710

lævigätă, 1: Yellow 5, H. Her. P. Bohemia : 1816

nivea, 2 : Whito. * 4, H. Her. P. Switzerl. *1713

purpüré : : Purple: 7, F. Her. P. C. G. H. : 1878

sagittăta : : Purple : 7, F. Her. P. C. G. H.

spuriă, 4 : : White : 4, H. Her. P. Germany : 1790

Petasǐtĕs, $\boldsymbol{P}$. hy̆brĭdŭ, sylvēstrís.

Tursas, see Androsāmūm.

TWAYBLAdE, see Listěră.

TWrËDİA, Hooker. In compliment to Mr. James

Tweedie, an intelligent and indefatimable collector of plants in Buenos Ayres, Tucuman, S. Brazil, \&c. Linn. 5, Or.2, Nat. Or. Asclepiadacea. These very interesting plants succeed well in sandy loam, with a little peat mixed; and they may be readily increased by cuttings or seeds. They will prove to be nearly, if not quite hardy.

cærŭleă - . Blue . - H. De. Tw. B. Ayres . 1836 versicolör: : Blue: 7, H. De. Tw. Tucuman : 1836

Tхгорнб̆RĂ, R. Brown. From tylos, a swelling, and phoreo, to bear; alluding to the ventricose pollen masses. Linn. 5, Or. 2, Nat. Or. Asclepiadaceo. Interesting plants. For culture and propagation, see Hoya.

barbāt

, 7, S. Ev. Tw. N. S. WV. . 1822 exilis : : Pa. pur. : 7, S. Ev. Tw. Sylhet: 1823 grandifīră : : $:$, S. Ev. Tw. N. S. W. : 1822

TуMPĂŇs, Tode. From tympanon, a drum; the re. semblance of the young velum. Linn. 24, Or. 9, Nat. Or. Fungi. Fonnd upon dead alder branches

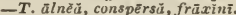

TริPHĂ, Linn. From typhos, a marsh; habitat of the species. Linn. 21, Or. 3, Nat. Or. Typhacer. The pollen of Typha is inflammable like that of $L y c o=$ podium, and is used as a substitute for it.

angustifoliă . . Brown . . 6, Grass. Britain . atifólia . * Brown - . 7, Grass. Britain 1822

TYPHŨL̆, Fries. A diminutive of Typha, to which the heads bear a miniature resemblance. Linn. 24, Or. 9, Nat. Or. Fungz. Found on rotten wood and dead leaves-T. erythrōpüs, filiförmìs, grăcĭlis, Phacorhiză, tënü̆̌s.

TrтōxĬ, G. Don. In honour of Arthur Tyton, F.L.S., by whom many of the oldest inhabitants of our gardens are preserved, but particularly those which were formerly cultivated by Miller, and which are now only to be found in his collection. Linn. 5 , Or. 1, Nat. Or. Balsaminacea. A beautiful aquatic plant, worthy of a place in every collection. It must be grown in large pots of water, in a rich loamy soil, and placed in the stove or on a hotbed. Tha seeds require to be sown in spring. Synonyme: 1. Impatiens natans.

nătฉ̄ns, 1 . Various . 8, S. Aq. A. E. Ind. .

1810
TLEX, Linn. Said to be taken from the Celtic ac, a point; in allusion to the prickly branches. Linn. 16, Or. 6, Nat. Or. Leguminosa. The double variety of $U$. Europaca is a very elegant plant, and is increased by young cuttings, under a handglass; the other kinds are increased by seeds. Synonyme: 1. U. hibernica.

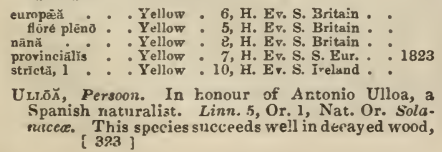

or vegetable mould; and is increased by euttings. Synonyme: 1. Juanulloa parasitica.

parasīĩcĭ, 1 . Red . . Parasite. Peru . . 1824 Ormưs, Linn. Supposed to be from the Saxon word elm, or ulm, a name which is applied, with very slight alterations, to the trees of this genus in all the dialects of the Celtic tongue. Linn. 5, Or. 2, Nat. Or. Ulmacea. Fine forest trees, sizcceeding best when grown on strong lands. They are increased by layers, from stools, or by grafting on the $U$. montana. Synonymes: 1. U. chinensis. 2. U. stricta. 3. U. humilis, microphylla, parvifolia, pu* mila. 4. U. planifolia. 5, U. sarniensis. 6. U. viscosa. 7. U. ciliata. 8. U. pendula. 9. U. americana, montana vegeta. 10. U. scabra. i1. U. crispa. 


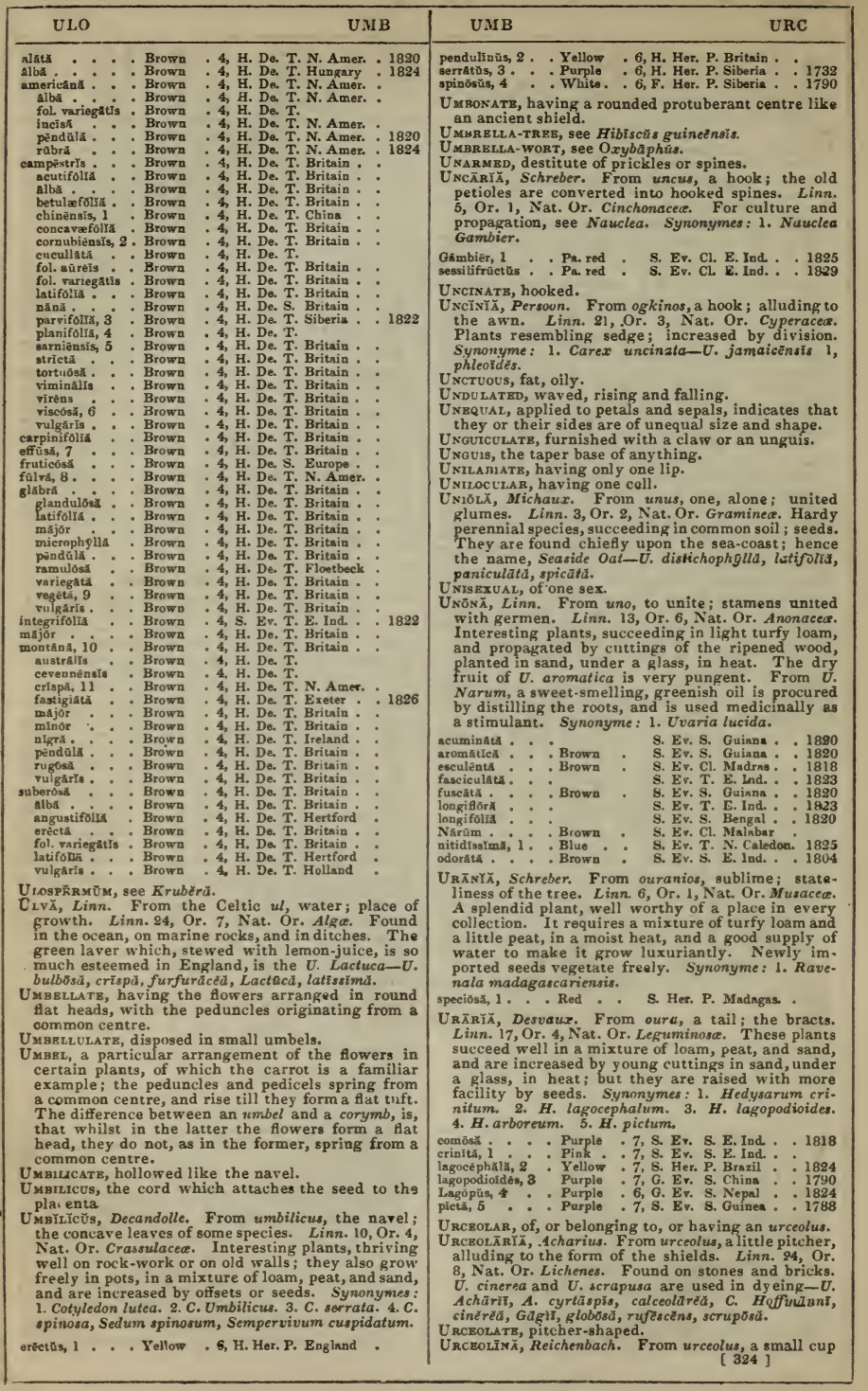


or pitcher; in allusion to the membranuus cup. Linn. 6, Or. 1, Nat. Or. Amaryllidacene. A curious little plant, said to thrive best in a strong rich loam, and may be increased by offsets. It must not be watered in winter.

péndũa . . Yel grn. . 6, G. BL. P. Peru

URcerous, the filaments joined into a pitcher-shaped bods constitute the urceolus of the stamens, or the name may be applied to any part of a similar form.

UTrềō, Persoon. From uro, to scorch; applied to those plants called mildew or blight. Linn. 24, Or. 9, Nat. Or. Fungi. The species of this obscure genus are found on the leaves of different plants. Synonyme: 1. Acidium Cardui-U. aecidiiformis,

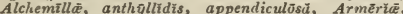
Bētāe, bĩfrôns, Campānülä, cāndïdä, Caryophyllace-

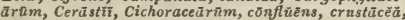

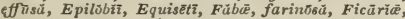

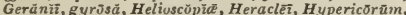
intrūsă, Irîdis, Labiatārüm, lineāris, Līnī, oblongātū,

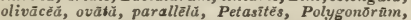
Populīnŭ, Potentīllāe, Potérīi, Prīmiñlē, pustulātă, Pyrōlā, Quērcŭs, Rhinantheūrūm, Rosāe, rubōrîm, rūmrācūm, Sălīišs, Saxifragärūm, Scillürūm, Seneciōnis, Sönchi, suavěoulēns 1, Tussilägĭnis, Umbella-

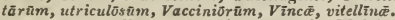

URĒNĂ, Linn. From uren, its name in Malabar. Linn. 16, Or. 8, Nat. Or. Malvacea. Uninteresting stove under-shrubs and annuals, growing in peat and loam; cuttings and seeds. Synonymes: $1 . U$. lobata. 2. $U$. americana-U. heterophīllă, lobātă, multĭfỉdă, muricätă, repāndă, reticulätă, scabriascülü 1 , Siebĕrī, sinuätă, speciōsă, subtrilobä, Srvārtzī 2 , tricūspis.

URopこ̌rĂLón, Ker. From oura, a tail, and petalon, a petal; the divisions of the flower are lengthened out. Linn, 6, Or. 1, Nat. Or. Liliacea. Interesting plants, succeeding best in a mixture of loam and leaf mould; they are increased by offsets or seeds. They should not be watered in winter. Synonyme: 1. Scilla serotina.

erispūm * . Green * G. Bl. P. C. G. H. . 1816 fülvūm, 1 . Grn. red : 7, F. Bl. P. Mogadore 1808 Green glaúcúm : : Pur, blue : 8, G. Bl. P. Mozamb. : 1825 Jongifolium : Pur. blue . 8, G. Bl. P. Mozamb. 1825 viride $:$ : Green : 8, F. Bl. P. C. G. H. : 1774

Criride ${ }_{\text {RTİ̆ Linn. From uro, to burn; in reference to }}$ the stinging properties of most of the species. Linn. 21 , Or. 4, Nat. Or. Urticacea. Plants of little beauty, and of the easiest culture. They all succeed in any common garden soil; and are increased by cuttings, divisions, and seeds. The effects of the venomous sting of the common Nettle are well known, but are, however, not to be compared with those of some of the Indian species, grown in the gardens of this country; yet all the known species are far surpassed for virulence by one, which in Timor is called daoun setan, or devil's leaf, the effects of which are said by the natives in many oases to cause death.

cannabină . A petal . 8, H. Hex. P. Siberia . 1749 divarieată : Yellow : 10, H. Her. P. Canada: 1816 gìgà : : Green: G. Bv. T. N. Holl: 1823 heterophyllă . Gree nierophyllã : Gree moroidès photeinophylla scriptã Green

7, S. Ev. S. E. Ind. . 1819 8, S. Her. P. W. Ind. 1793 G. Ev. T. N. Holl. 1823 G. Ev. T. Moret. B. : 1830

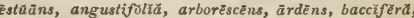
baleärică, canadēnsìs, capitellätă, caracasānă, cara. vellänă, chamadryoīdĕs, ciliūită, convẽxă, crassifolīă, deprêssă, diffūsă, dioīcă, diversifolǐă, Dodārtīī,

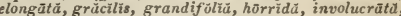
macrostüchy̆ă, membranäcēă, nìvēă, nudicanliss, num-

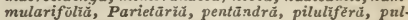
chēllä, pīmīlă, reticulätă, râfü, rugōsă, scabrëllä. ñëns.

URvīLĽ̃̆, Kunth. In honour of Captain Dumont D'Urville, of the French navy, who was sent out to ascertain the fate of La Peyrouse; an acute botanist. Linn, 8, Or. 1, Nat. Or. Sapindacer. plants of little beauty. They may be grown in a mixture of loam and peat, and moderate-sized cuttings will root readily in sand, under a glass, in heat.

ferrugĭnе̃ . . White . 6 , S. Er. Cl. Brazil . . 1823 ulmäeё : : White : S. Ev. Cl. S. Amer. 1824 UsNǐ̃, Dillenius. From achneh, a name applied to lichens in general by the Arabian physicians. Linn. 24, Or. 8, Nat. Or, Lichenes. Found in winter, on old trees-U. barbätă, articulätă, flöridă, plicätă, hïrtü.

UstıLĀGō, Link. From ustus, scorched; appearance. Linn. 24, Or. 9, Nat. Or. Fungi. Found upon grasses, \&c._U. antherārım, cāriēs, flosculosă, sŭgètūm, Urceoläram.

UsTULATE, blackened.

UTRRUS, the womb.

UTR1CLB, a little bladder.

UTRICULAR, composed of little bladders.

UrroulärĬ, Linn. From utriculus, a little bladder; applied to the small inflated appendages of the roots. Linn. 2, Or. 1, Nat. Or. Lentibulacea. Elegant little plants, found in ponds and rivulets.

intermèdia. - Yellow .5, H. Aq. P. Britain . minör: : Yellow 7, H. Aq. P. Britain vulgarrs . Yellow 6, H. Aq. P. Britain.

UVĀRĬ L Linn. From uva, a cluster of grapes; resemblance in the fruit. Linn. 13, Or. 6, Nat. Or. Anonacea. Interesting plants, succeeding in a mixture of sandy loam and peat, and increased by cuttings of the ripened wood, in sand, under a glass, in heat.

Gærtnérī • - Brown * S. Er. S. E. Ind. • 1820 lūtéz : Grnsh. yel. S. Ev. S. tomentosa : Brown S. Ev S. F. Ind . 1829 velutină: Brown: S. Ev. S. E. Ind. : 1823 villósă. : : Brown: S. Ev \&. E. Ind. : 1831 zeylănǐcă: : Scarlet: S. Ev. Tw. Ceyion : : 1794

UvULĀRY. Linn. The plants were formerly used in diseases of the uvula. Linn. 6, Or. 1, Nat. Or. Liliacece. A light sandy soil suits these plants best, and they are readily increased by division at the root.

flâvă

grandifiōră

lanceolātă

perfoliătă

puberủlă

sessilifolia
5, H. Her. P. N. Amer. . 1810 5, H. Her. P. N. Amer. - 1802 7, H. Her. P. N. Amer. * 1710 5, H. Her. P. N. Amer. 1710 6, H. Her. P. N. Amer. 1790
VACGǏNǏCM, Linn. An ancient Latin name, whether of a berry or a flower, is not satisfactorily known. Linn. 8, Or. 1, Nat. Or. Vaccinacece. All the species of this genus are well worth cultivating, some of them for the sake of their fruit, some for curiosity, and others for ornament. The different kinds of Whortle-berry and Bilberry succeed best in peat soil, or very sandy loam. Some of them grow best in moist situations, and others in dry. Those requiring the heat of the stove must receive the same treatment as the generality of stove plants ; and are readily increased by cuttings, planted in sand, under a glass, in heat; they may also, like the hardy species, be raised from root-suckers, [ 325 ) creeping roots, trailing rooting sterns, or from seeds treated as follows:-In autumn, as soon as the seeds are ripe, they should be sown in shallow pans, filled with very sandy peat soil, and covered slightly over; when about an inch high, they must be pricked out thinly into other pans, filled with the same kind of soil. After being well rooted in these pans, they must be planted out in spring in proper places, taking care to keep a ball of earth about the roots. If finally planted out in autumn, the worms are apt to throw them out of the ground during winter. Synonymes: 1. V. myrtilloides. 2 $\boldsymbol{V}$. diffusum. 3. $\boldsymbol{V}$. brachycerum. 4. $\boldsymbol{V}$. album, amcenum, disomorphum. 5. V. virgatum angusti- 
folium. 6. V. fuscatum, formosum. 7. V. virgatum. 8. $V$. hirtellum, frondosum. g. $V$. glaucum. $10 . V$. venustum. 11. V. maderense. 12. V. tenellum. 13. $V$. parviflorum. 14. $V$. album, elevatum.

albifiôrüm . White. . 5, H. De. S. N. Amer. 1833 angustifoliñm, 1 : Pa. yel. 5 , H. De. S. N. Amer. 1776 arböreúm, 2. : Wht red: 6, H. De. S. N. Amer. 1765 buxifolium, 3 : White. 5, H. Ev, s. N. Amer. canadēnsé. : Wht red $5, \mathrm{H}$. De. S. Canada 1825 caraensãnüm : White. : 7, s. Ev. S. Caraceas : 1825 cæespitōsūm . White. 5, H. De. S. Huds. Bay 1823 corymbësium, 4: White. 5, H. De. S. N. Amer. 1765 angustifollum, 5 White. H. De. S. N. Amer. 1767 fuscátūm, 6. Whit pink 6, H. De. S. N. Amer. 1770

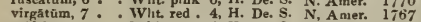
crassifollúm. : : White. : 6, H. De. S. Caroina. 1787 dumostim, 8 : White. 5, H. De. S. N. Amer. 1774 luâmile . . White. 5, H. De S. N. Amer. 1774 elongatūm : White. 7, H. De. S. N. Amer, 1912 froudósūm, 8 . Wlit. grn. 5, H. De S. N. A mer. 1761 venuistüm, 10 . Pink . 6, H. De. S. N. Amer. 1770 galêzăns. . White.: 5, H. De. S. N. Amer. 1806 glăbrüm : : Pink : 7, H. De. S. N. Amer. 1812 grandiflörün : White. 7, H. De. S. N. Amer. 1812

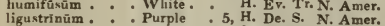
meridionales: Red wlit: 4, S. Ev, S. N. Amer. minutiförūm : : White. : H. De. S. N. Amer. 1812

Myrsinités : : Purple :5, H. De S. Carolina lanceolatũm : Purple : 5, H. De. S. Florida obtüsüm obtüsủm : : Purple
myrtifolrúm: : White.

myrtilinidess: Pink băceis ălbîs nit idưm decūmbèñ

Pink Pink , H. De. S. Carnlina 6, F. Ev. Tr. Carolina 6, H. Ev. Tr. Carolina : 1812 6, H. De. S. N. Amer. 1776 Pink . 5, H. Do. S. Carolina Pink - 5, H. De Tr. Carolina 7. A. Amer. 1826 padifoltüm, il: : Pn grn. : 7, H. De. S. Madeira . 1777
pallifumm. pällídūm.

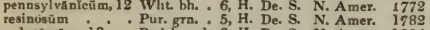
lutêscêns, 13 : Redsh. yel. 6, H. De. S. N. Amer. 1804 ruhēscēns : : Yal grn. 5, H. De. S. N. Amer. 1773 t White White.

Vitîs Idả̉ Pink

H. De S. Mexice

4. He Mexico

5, H. De. S. Britain

VAILI,ĀNTY̌, Decandolle. In honour of Sebastian Vail. lant, an eminent French botanist and author in the early part of the last century. Linn. 23, Or. 1, Nat. Or. Stellate, or Galiaced, Plants of little interest, growing in common soil, on rock-work, old walls, or in any dry situation; division and seeds. Synonymes: 1. Galinm articulutum. 2. G. cruciatum. 3. G. Bauhini. 4. G. pedemontanum. 5. V. glubra, Galium vernum. periemontsna, 4 . Yellow 6, H. De. Tr. A. Minor . 1816

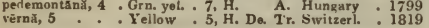

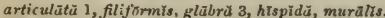
VALERIAN, see Valeriūni.

VALERIÃNA, Necker. Said by some to be named after Valerius, who first used it in medicine; others assert tinat it is derived from valere, to be in health, on account of the medicinal qualities of $\boldsymbol{V}$. officinalis. Linn. 3, Or. 1, Nat. Or. Valerianaced. Most of the species are very ornamental in flower borders. The perfectly hardy kinds succeed well in common karden soil; those from warnier climates should be grown in pots in a mixture of loam, sand, and peat, and placed in a frame or greenhouse in winter. They are all readily increased by division at the root. The root of $V$. officinalis is eminently antispasmodic. It is very frequently prescribed with success in hysterical cases. In habitual costiveness, it is an excellent medicine. The unpleasant favour of Valerian is best counteracted by a small addition of mace. Synonymes: 1. S. heterophyllia. 2. V. Cardamines.

allirriafotys asarifolia : : Red cnpênsis : : Red celuea : : White.

dioică. - Flesin .

globulariafólyă, 1 : Rer

globularizfolfá, 1. Rer
intermédia. . . White:

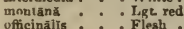

officinalts : : Flesh :
6, H. Her. P. Caucasur - 1826 6, H. Her. P. Crete 6, G. Her. P. C. G. H. 6, H. Her. P. Switzerl. 6, H. Her. P. Britain . 6, H. Her. P. Austria. 6, H. Her. P. Psrenees 6, H. Her. P. Pyrenees 6, H. Her. P. Pyrenee 7, H. Her. P. Switzerl.
6, H. Her. P. Britain 8, H. Her. $\boldsymbol{Y}$. Germany pyrenăǐca . . Pink . . 8, H. Her. P. Scotland Saliüncă : : Red : : 6, H. Her. P. Scotland : Her. France : 1824 sambueifoliă . White. . 7. H. Her. P. Germany : 1819 saxärlís : White. 7, H. Her. P. Austria : 1740 sis'mbrifrơlin, 2 : Red : 6, H. H. S. Euz. : 1824 supină . : Wht, red . 7, H. Her. P. Switzerl. : 1822 tripteris : : White. 5, H. Her. P. Switzerl. : 1752 tuberósa : . Ligt red : 6, H. Hur. P. S. Bur. : 1629

VAlertanǩLĬ, Manch. From a diminutive of Valeriana, which see. Linn. 3, Or. 1, Nat. Or. Valerianacea. The species only require to be sown in early spring, in the oper border. They answer well for a spring salad, and are generally known by the name of Lamb's-lettuce. Synonymes: 1. V. dasycarpa, dentata. 2. $V$. tridentata.

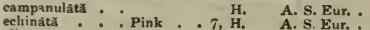

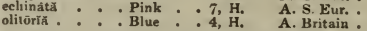

aurĭcŭlă, curinātă, coronittŭ, discō̄dĕü, eriocürpă,

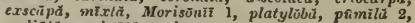
radiütü, uncinätă, vesicārlĭ.

VAlLĀRIs, Brovnn. From vallo, to inclose; used for fences in Java. Linn. 5, Or. 1, Nat. Or. A pocynacee. This species yrows well in sandy loam and peat, and is increased by cuttings, in sand, under a glass, in heat. Synonyme: 1. Pergularia glabra.

pergulănă, 1 . White . S. Ev. Tw. E. Ind. . . 1818

VAlI.ĒsǏ̃, Ruiz and Pavon. In honour of F. Vallesio, physician to Philip 1I. of Spain. Linn. 5, Or. 1, Nat. Or. Apocynaced. For culture and propagation, see Vallaris.

cymbifơlĩa . . Whito . 6, S. Ev. 8. N. Spain . 182i dielıótöna: : White:5, S. Ev. S. Peru : 182.

VALI.ISNËRỸ̈, Micheli. In honour of Antonio Vallisneri, an Italian botanist. Linn. 22, Or. 8, Nat. Or. Hydrocharacee. This aquatic plant requires to be grown in a large pot or tub of water, in the conservatory or greenhouse; it should be planted deeply in the water, since it grows at the bottom of ditches in its native country.

spirallis . . . Brown . 7, G. Aq. P. S. Eur. . . 1818 VAiLöră, Herbert. In honour of Pierre Vallot, a French botanist. Linn. 6, Or. 1, Na:. Or. Amaryllidacee. For culture ard propagation, see Amaryllis. Synonyme: 1. Amaryllis purpurea.

purpŭreă, 1
ulıð̆r VALvATB, opening like a valve.

VAIVAFORM, shaped as a valve.

VAIves, the divisions of the capsule.

VALVULAR, consisting of valves.

VAIVULAR-DIssepIMBNTs, partitions in the centre of the valves.

$V \bar{A} N D \bar{A}, \boldsymbol{R}$. Brown, Vandd is the Sanscrit name of the original species of this genus. Linn. 20, Or. 1, Nat. Or. Orchidacer. Tha species of this genus, as well as those elezant and interesting plants referred to it for culture, \&c., are all well deserving of the cultivator's best care and attention. The beauty of their deliciously fragrant flowers is quite suffi. cient to recommend them to all lovers of orchida ceous plants, besides their being in general such admirably free flowerers. Some of the species of Saccolabium and Sareanthus produce from thirty to one hundred spikes of flowers each; indeed, we know from the best authority, that there are single plants of Saccolabium guttatum, growing upon trees in the Botanic Garden, Calcutta, which produce every year from fifty to one hundred spikes or flowers. In their native districts, all, or the greater part of the plants referred to this genus, grow upon trees in dense forests, and consequently derive their chief support from the atmosphere; therefore their cultivation in this country is rendered very simple and easy, as the greater part of them require nothing more than a piece of wood to attach themselves to, or an ornamental wire basket filled with moss and broken pots, and suspended from the pillars or roof of the house. There are, however, exceptions to this rule; as, for instance, some of the stronger and more robust growing kinds, such as $V$ anda Roxburghii, and $V$. multiflora. These should be grown in wide shallow pots, carefully filled with cut sphagnum moss, and potsherds broken small. We would recommend oak branches for those intended to be grown upon wood. They [ 326 ] 
all require a good strong moist heat, and a plentiful supply of water during the growing season, which ought to commence about the beginning or middle of June, and continue to the end of September, from which time they should be kept cool and dry until the beginning of March, when they should be placed in a strong dry heat to induce them to flower. They will, if thus treated, flower most abundantly; whereas, if kept in a continued moist atmosphere, they will do nothing but grow from year to year, and of course never produce flowers, because they are not allowed a proper season to elaborate and perfect their flower-buds, neither have they a proper season for the development of those buds. Propagation is effected by carefully detaching the lateral shoots after they have grown to the length of about six inches, and fastening them to another block of wood in a similar manner to the old ones; but great caution is necessary to preserve them from excision by moisture till they have recovered from the effects of being severed from the parent plant, and commenced growing.

cruēntä

lamellātå

multiflóră

Roxbürglin tessellătă

Pr. yel.

8, S. Epi. China
8, S. Epi. Manilla

8, S. Epi. Manilla
6 , s. Epi. China.

Wlit pur. 7, S. Epi. Clina.

unìcōlör

Wht. pur.

7, S. Epi. China.

Red yel.

3, S. Epi. Silhet

1819

1837

1800

1810
1816

1828

VANDĒLLY̌ L Linn. In hononr of Dominico Vandelli, professor of botany at Lisbon. I Iinn. 14, Or. 2, Nat. Or. Scrophulariacea. These plants require the same treatment as other tender annuals. Synonymes: 1. Hornemannia ovaia, Tittmannia ovata. 2. H. vis$\operatorname{cosa}, T$, viscosa. 3. Torenia diffusa.

crustâcèă, 1 . Blue . . $6, \mathrm{~s}$.

6, s. A. India . 1816 diffüsă * . White. .7 , s. A. Santa Cruz 1824 hirsũtă, 2 . * Blue * 6, H. A. India * 1823 RoxbūrghII, 3. . Purple * 7, s. A. Coroman. - 1818

VANOUERǏ̃, Commelin. Altered from Voa-Vanguer, the name of $V$. edulis in Madagascar. Linn. 5, Or 1, Nat. Or. Cinchonacer. These plants succeed best in a mixtıre of loam and peat, and they are readily increased by cuttings, in the same kind of soil, under a glass, in heat. The fruit of $\boldsymbol{V}$. edulis, as the name implies, is succulent and eatable.

edūlis

spinōsă : Green * 6, S. Ev S. Madras.: 1809

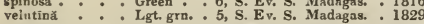

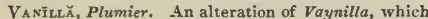
is a diminutive of Vaina, a Spanish word signifying a sheath; in reference to the cylindrical pod being like the sheath of a knife. Linn. 20, Or. 1, Nat. Or. Vanillacere. These plants thrive best in a mixture of moss and turfy peat, in a moist warm atmosphere. They should have the rough bark of a piece of wood, or a wall for their long roots, which issue from erery joint, to cling to; and they are readily increased by cuttings. The fruit is one of the most delightful aromatics known, and is extensively used in the manufacture of liqueurs, chocolate, and various articles of confectionary, and also for perfuming snuffs.

aromătieã . . White . 7, S. Ev. C1. S. Eur. . . 1739 bícōlör : : Dull red : S. Epi. Guiana plarifóliă : White, 5, S. Ev. Cl. W. Ind.

$: 1800$

VARicosE, swollen here and there.

VAriolárĭ́, Persoon. From variolo, measles; the shields of these plants resemble the eruptive spots of the measles. Linn. 24, Or. 8, Nat. Or. Lichenes. Crustaceous plants, found on rocks, walls, and the bark of trees-V. amäră, $A$. discoĩdeŭ, chlorotheč̃ă, ciněrěă, commiñn̆s, C. aspergîllă, constellätă, deal-

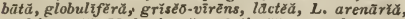
multipūnctă, M. lavigātă, polythēciă, terrǐcơlă, tôrtă, veläto.

VARRŌNǏ̆, see Cördiă.

VAscōă, Decandolle. In honour of Vasco de Gama, the celebrated Portuguese circumnavigator. Linn. 16, Or. 6, Nat. Or. Leguminosa. Showy plants when in blossom. They grow well in a mixture of loam and peat; and young cuttings root readily in sand, under a glass. Synonymes: 1. Rafnia amplexicaulis, Crotalaria amplexicaulis. 2. Borbonia perfoliata, C. amplexicaulis.

amplexicaūlis, 1 . Yellow * 7, G. Ev. S. C. G. H. . 1816 perfoliata, 2, Yeliow : 7, G. Ev. S. C. G. H. : 1812 [ 327 ;
VAscuIAR, composed of tubes or vessels.

VAUĀNTHÊs, see Grammänthēs.

VAUCHйR $\breve{A}$, Decandolle. In honour of the Rev. M. Vaucher of Geneva, a botanical author. Linn. 24, Or. 7, Nat. Or. Alge. Found in ditches, \&c.-V. dichŏtŏmă, D submarĩnă, Dillwy̆nī, geminată, multicapsula rìs, racemōsă, radicâtā, terrēstrìs.

VAULTRD, formed like a vault.

VRINLESS, without veins.

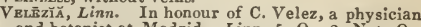
and botanist at Madrid. Linn. 5, Or. 2, Nat. Or. Silenacec. The seeds may be sown in any light soil.

rīgìdă . . . Wht. pur. 7, H. A. Spain . . 1683

VẼLLŭ, Decandolle. From velar, the Celtic name of the Cress. Iinn. 15, Nat. Or. Cruciferce. This shrub is commonly grown as a greenhouse plant, but it is sufficiently hardy to endure the winte when planted in a dry, warm, south border: it is increased by young cuttings, in sand, under a glass.

Pseūdō.cy̆třsŭs * Yellow * 4, G. Ev, S. Spain * . 1759

VELLËJĂ, Smith. In honour of Major Velley, a gentleman who paid much attention to marine Alga. Linn. 5, Or. 1, Nat. Or. Goodeniaced. Interesting plants, succeeding best in a mixture of loam, peat, and sand, and increased by division, or by seeds, which are sometimes produced in this country. The plants must be sparingly watered in winter.

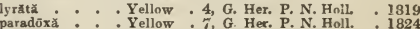

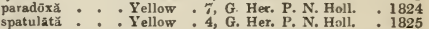

VRLThEIMǐă, Gleditsch. In honour of F.A. Veltheim, a German botanist. Linn. 6, Or. 1, Nat. Or. Liliaceo. The species of Veltheimia thrive best in a light loamy soil; and are readily increased by offsets from the bulbs; the leaves pulled off close to the bulb, and planted in pots of soil, will produce bulbs at their base.

glaūcă . . Flesh . . 3, G. Bl. P. C. G. H. . 1781

rubescēntĩ pur- $\rangle$ Red pur. . 7, G. Bl. P. C. O. H. 1834

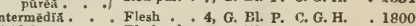

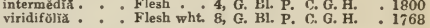

VBLVETY, covered with down resembling velvet.

VENTRICOSE, inflated

VRNus's comi, see Scāndix Pẽctên-Věněrĭs.

VENUS's FLYTRA P, see Dionäă muscĭpülă.

VkNUs's HAIr, see Adiāntüm Capilluis-Vĕnĕržs.

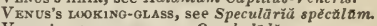

VENUS's NAVBLWORT, see Omphalodés.

V'̄̄Pris, Commelin. From vepres, a briar or bramble. Linn. 21, Or. 8, Nat. Or. Rutacece For culture and propagation, see Toddalia. Synonyme: 1. Toddalia paniculata.

obovāex . . . White. . S. Ev. S. Maurit. . 1824

VERATrOM, Linn. From vere, truly, and ater, black; in allusion to the colour of the root. Linn. 23, Or. 1, Nat. Or. Melanthacea. A genus of elegant plants when in flower. They thrive best in a rich soil, and are increased by division or seeds, "The dangerous medicinal properties of the root of Veratrum are owing to a peculiar alkaline principle, called Veratrin, which acts with singular energy on the membrane of the nose, exciting yiolent sneezings, though taken in very minute quantity. When taken internally in very small doses, it produces excessive irritation of the mucous coat of the stomach and intestines, and a few grains are found fatal to the lower animals. $V$. viride is an acrid, emetic, and powerful stimulant, followed by sedative effects." Lindley's Nat. Syst. of Bot., $2 d$ Ed. p. 348.

\section{ălbūm}

angustiføirūm

Lobeliānūm

nīgrūm

parviflörüm

viride

-White .

7, H. Her. P. Europe

1548

Drk, pur. . 6, H. Her. P. Siberia * 1596

VRRBĀsCŌ Y, Linn. Said to be from barbascum, bearded in allusion to the bearded filaments. Linn. 5, Or. 1, Nat. Or. Scrophulariacea. The species of Verbascum are strong, robust growing plants, producing an abundance of showy, yellow flowers, and on that account they are well adapted for planting at the back of flower borders, or in shrubberies. They 


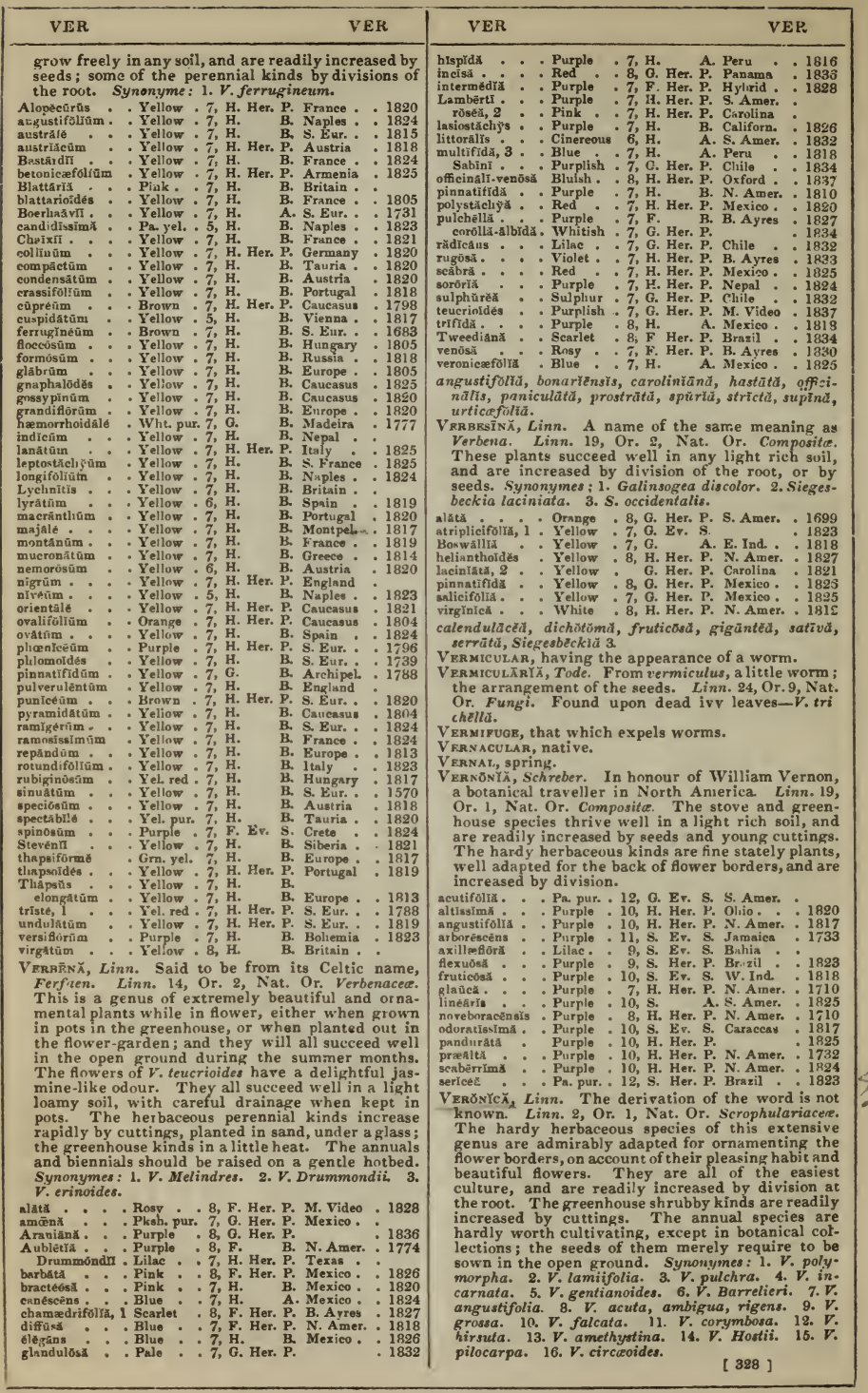




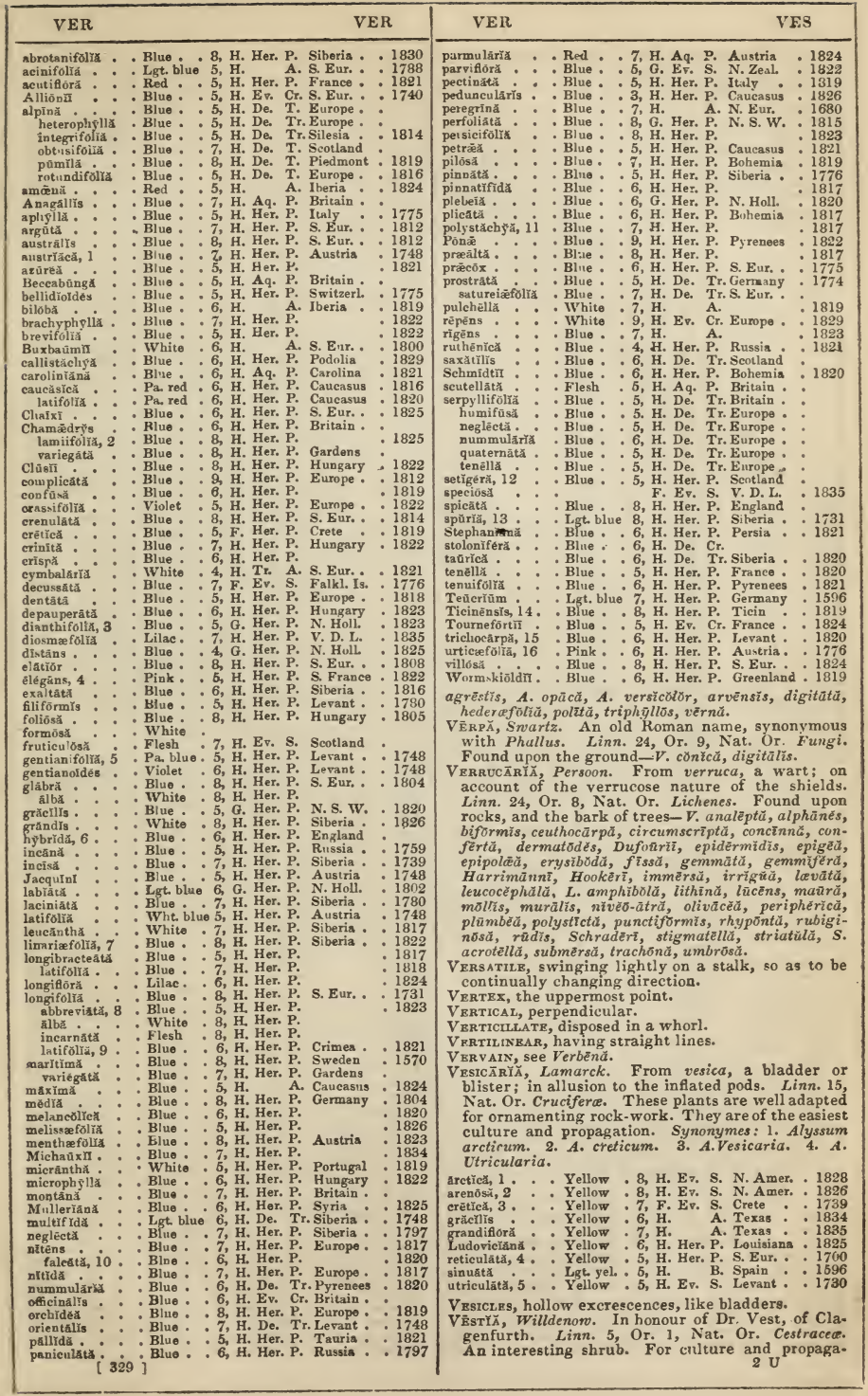




\begin{tabular}{|c|c|}
\hline VET & VIC \\
\hline
\end{tabular}

lycioIdés, 1. . Yellow . 6, G. De. S. Chile . . 1815

Vвтсн, see Viciă.

VETCH, see Astrăgălŭs Cĭcěr.

Visching, see Läthy̆rŭs Aphăcă.

VExirluU, standard, the upper petal of a pea flower.

VıвōrGĬA, Ortega. In honour of Eric Viborg, a Danish botanist. Linn. 16, Or. 6, Nat. Or. Leguminosce. Pretty plants. For culture, \&c., see Loddigesia. Synonyme: 1. Crotalaria floribunda, obcordata.

cbcordătã, 1 : Y Yellow : 7, G. Ev. S. C. G. H. : 1810

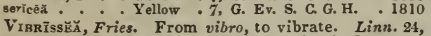
Or. 9, Nat. Or. Fungi. This species is found on the branches and trunks of trees lying in waterV. truncoram

Viẫ rũ $M$, Linn. Said to be from vieo, to tie; because of the pliability of some of the branches. Linn. 5, burnum are all very elegant, rather early-flowering shrubs. The hardy kinds are well fitted for planting in ornamental shrubberies. They are increased by layers, or by cuttings, planted under a glass, in a shady situation. The fruit becomes eatable after fermentation, and is made into a sort of cake by the North American Indians. Synonymes: $1 . V$. squamatum. 2. V. Opulus roseum. 3. V. lucidum. 4. V. strictum virgatum. 5. V. strictum.

acerifoliũ - White. . 6, H. De. S. N. Amer. . 1736 cassinoides. : : White. : 6, H. Ev. S. N. Amer : 1761 cotinifolram : Whito. 6, H. De. S. Himal, Mits. 1830 dahurícủm: : : White. 6, H. De. S. N. Amer. : 1763

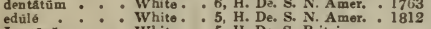
edülé Lantănă

White: 5 , H. De. S. N. Amer.
White.: 5, H. De. S. Britsin

follis variegatis White. 5, H. De. S. Britain

grandifollum : White: 6, H. De. s. Britain
lantanoĩdés

lærigatūm

Lentấo : : White: 7 , H. De. S. Spain

Lentago

monogỹun

White: : 5, G. Ev. s. N. Amer.

1812

F. Bv. S. Java

nưdũm.. White. 6, 1758

nưdũm - Pa yel. *6, H. De. S. N. Amer. . 17.52

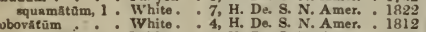

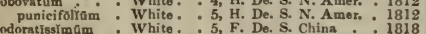

7, H. De. S. Britain

Opúlús variegatis: White: $6, \mathrm{H}$. De. S. Britain

fol, variegät's : White. 6 , $\mathrm{H}$. De. $\mathrm{S}$.

ntéríle, $8^{\circ}$ : : Wlite. 7, H. De. S. Britain

orientsle : : White. 5, H. Den s. Caucnsus

oxyebcevs : White. 6, H. Da. S. N. Amer.

subintegriforrom White. 7, H. De. S. Columbia

prunifólúm - White. . 5, H. De. S. N. Amer.

pubescéns : : White.: 6, H. De. S. N. Amer.

pyrifolrûm - * White. 6, H. De. S. N. Amer.

righsam

Tinùs

hIrtúm, $\dot{3}$

lâciันuีm.

White.

S. Ev. S. S. Amer.

7, H. Ev. S. S. Eur.

White. : 7, H. Ev. S. S. Eur.
White. 7, H. Ev. S. S. Eur.

variegătūm

White

8, H. Br. S. Algiers

virgătûm, 4

White.

8 , H. Ev. S.

White $8, \mathrm{H}$. E. S. Italy

variegátûn : White. 8, H. Ev. S. S. Eur.

tomentôsữ

G. Ev. S. Japan
F. Ev. S. Jamaica

VIC

VIE

americănă - White. . 6, H. De. Cl. N. Amer. . 1800 amānă : Purple : 6, H. De. Cl. Silierin : 1818

amphicârpós : Purple : 5, H. Cl. A. France : 1815

angustifólră, 1 . Red : 5, H. Cl. A. Britain .

argéateñ ${ }^{\circ} \cdot{ }^{\circ}$, Her. P. Pyrenees : 1827

ntropurpürez Purple $6, \mathrm{H} . \mathrm{Cl}$. A. Algiers : 1815

biéticã. * Purplo * 7, H. Cl. A. Europe . 1820

benghalēnsłs . . Dk. pur. * 6, H. Cl. A. E. Ind. : 1793

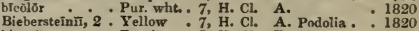

biênnis : : Purple : 8, H. CL B. Siberia : 1753

biflōră * Blue * 7, H. Cl. A. Algiers 1801

Bithy̆nìcă, 3: Pur. via :7, H. Her. P. Britain

calcarătă, 4 : Red blue : 7, H. Cl. A. Rarbary : 1790

canēscêns . : Blıe : 7, H. Cl. A. Lihanus : 1800

expénsis : : Purple : 7, H. Her. P. C. G. H. : 1802

caroliniănă, $\mathbf{5}^{\circ}$ : White. : 6, H. De. Ci. Carolina : 1820

cassúbiex . . Lgt. blue . 7, H. De. Cl. Germany : 1711

consentină : Blue : 6, H. Cl. A. Italy : 1318

Crēceá. : Violet. : 7 H. De. Cl Britain.

flörïbŭs albis : White: : 7, H. De. Cl Britain :

flöribüs rübrls Red : 7, H. De. Cl. Britain:

dentâtă rubris Violaceous 7, H. De. Cl Siberia : 1819

dispērmă, 6 : : White. . 7, H. Cl. A. S. France : 1820

dūbră . : : Purple : 7, H. Cl. A. S. France : 1820

dumetơrūm : : Purple : 7, H. De. CL. France : 1752

Gerărdī * Viulet. * 7, H. De. Cl. S. Eur. 1810

zlabra. . Purple * 7, H. Cl. A. Switzerl. : 1819

globósi : : Blue : 7, H. CL A.

grandieoră: Yellow : 7, H. Cl. A. s. Eur. : 1818

hirsútă : Yellow : 7, H. Cl. A. Siberia : 1818

hirtă : - Pa, cream 6, H. Cl. A. Europe: 1816

incisa : : Purple : 6, H. Cl. A. Caucasus : 1820

intermèdiă : Purple 7, H. CL. A. Enrope : 1818

revigấă $;$ - Pa. yel, * 5, H. De. Cl. England

leucospermy, 8. Purple 6, H. Cl. A. Europ - 1810

loucosperma, 8: Purple : 6, H. Cl. A. Suria : 1810

lútea : : Yellow : 7, H. Cl, A. Britain:

megalospérmá : Purple : $, \mathrm{H}, \mathrm{Cl}$ A. Tauria : 1798

MichaũxI : White : 7, H. Cl. A. Tauria * 1798

monadel pha : : Purple : 7, H. B. N. Amer. 1820

H. Her. P. Russia . 1839

narbonensls : Purple : 7, H. Cl. A. Europe: - 1818

Nissoliănâ, 9 Dk. pur. : 7, H. CL A. Levant: : 1773

ochroleûeâ . Pa yel. : 7, H. De. Cl. Italy : 1835

onobrychroldès: Purple: 6, H. Cl. P. S, Eur. : 1759

pannơnlea * White. 6, H. CL A. Hungary : 1638

pelläcìda . : Purple * 7, G. De. Cl. C. G.H. : 1773

7, H. Cl. A. S. Eur. . 1779

pilōsa . Purple : 7, H. Cl. A. Tauria: 1818

pimpinelloidde: Purple: 7, H. A. Rome: 1832

pisiformls : Cream. 7, H. De. Cl. Austria : 1739

platycárpa : : Purplo : 7, H. Cl. A. Germany : 1793

polyphyllă : : Pa pur. : 7, H. De. Cl. Algiers. : 1816

polyspérma 10 Purplo :6, H. CL. A.

punctáta . . Purple 7, H. Cl. A. Switzerl. : 1819

pyrenăleă. : Purple : 5, H. Her. P. Pyrenees : 1818

sativă . Purple : 5, H. C1. A. Britain

nemorâlY̧s : Purplo 5, H. Cl. A. Britain :

segetalis : Violet. 5, H. Cl. A. Britain .

séplüm : Violet. . 5 , H, Cl. A. Britann .

serratifolix - Purple - 6, H. CL. A. Hungary : 1723

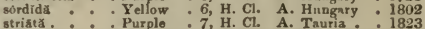

sylvatiea : - Wht. blue 7, H. De. Cl. Britain :

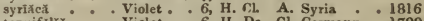

tenuiforlre Violet. . 6, H. De. Cl Germany - 1799

ThouInI : Purple : 6, H. Cl. A. Europe : 1800

tricólor : : Pur. yel, : 7, H. Cl. A Italy : : 1818

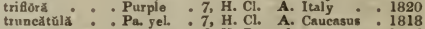

variegătă. : $\mathrm{Pa}_{\text {a pur. }}:$ 7, H. De. Cl. Caucasus : 1818

villöвà. : : Dk pur. : 6, H. C. A. Germany : 1815

because the species have tendrils by which they bind other plants. Linn. 17, Or. 4, Nat. Or. Leguminose. Some of the species of this genus are well worth cultivating in the flower border for the beauty of their flowers. They are of the easiest culture in any common garden soil. The perennial kinds may be readily increased by dividing the ront or by seeds. The seeds of the annual kinds only require to be sown in the open border in spring. $V$. sativa and its varieties are extensively cultivated, and well known by the cominon name of vetch or tares; they are used as food for all kinds of cattle, and are allowed to be more nutritive and profitable than hay or any other herbage. Syronymes: $1 . V$. luganensis. 2. V. sordida. 3. Lathyrus Bithynicus. 4. V. monantha. 5. V. Cracca. 6. V. parviflora. 7. Ervum soloniense. 8. $\boldsymbol{V}$. alba. 9. $\boldsymbol{V}$. atropurpurea. 10. V. tenuifolia

abbreviată . . Pa. blue - 6, H. De. Cl. Caucasus . 1818 altíssima : : Pa. blue : 8, H. De. Cl. Barbary : 1820

VIBUSsEẽ xY̌, Laroche. In honour of M. Vieusseux, a physician of Geneva. Linn. 3, Or. 1, Nat. Or. Iridacere. Ornamental plants when in flower, and requiring precisely the same treatment as the genus Homeria. Synonymes: 1. Moraa tricuspis lutea. 2. Iris pavnia. 3. M. lurida. 4. M. pavonia, Iris pavonia. 5. M. tenuis. 6. Iris tricuspis, Morea tricuspis, Ferraria tricuspis. 7. M. tripetala, I. tripetala. 8. M. unguiculata. 9. Iris villosa, $M$. villosa.

Bellendêni, 1 - Yellow * 6, G. Bl. P. C. G. H. - 1803 fügãx glaucôprs, 2 : Red brn. :6, F. BL. P. c. G. H. : 1776 pavonină, 4 : : Red blue : 5, G. BI. P. C. G. H. : 1790 paronina, 4 : Ked bite. 5, G. Bl. P. C. G. H. : 1890

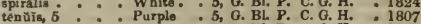

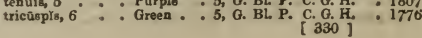


tripetaloīděs, 7 . Violet * . 6, G. Bl. P. C. G. H. 1802 unguieulărìs, 8 . Varieg. 6, G. BL. P. C. G. H. . 180 villósă, 9 - Purple * 7, G. Bl. P. C. G. H. . 1789

VĪGNĂ, Savi. In memory of Dominic Vigni, a commentator on Theophrastus, Linn. 17, Or. 4, Nat. Or. Leguminose. The seeds of this species may be sown in a warm sheltered situation in the open ground. Synonyme: 1. Dolichos luteolus.

gläbră, 1 . . Yellow . 7, H. Tr. A. N. Amer. . 1685

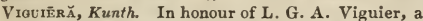
botanist of Montpelier. Linn. 19, Or. 3, Nat. Or. Composita. Interesting plants, succeeding well in a mixture of sandy peat and loam, and increased by cuttings in sand, under a glass. Synonyme: 1 . Helianthus dentatus.

dentãtă, 1 * Y Yellow * 7, S. Her. P. Mexico . 1826 helianthoidès: : Yellow: 7, S. Her. P. Cuba : 1825 VIL.ĀRsĭ Ventenat. Named in honour of D. Villars, a famous French botanist. Linn. 5, Or. 1, Nat. Or. Gentianacea. A genus of very elegant plants when in blossom. The stove and greenhouse aquatic species should be grown in tubs or cisterns of water. The hardy kinds succeed well in a pond. The marshy kinds, as $V$. geminata, require to be grown in pots, in a mixture of peat and sand, and the pots to be placed in water. They are all readily increased by divisions, or by seed. Synonymes: 1. Menyanthes indica. $2 \mathrm{~V}$. cordata. 3. MI. nympkoides.

chilensis - . Yellow . 6, F. Aq. P. Chile * . 1832 geminată : Y : Yellow :6, G. Her. P. N. Holl. : 1828 indica, $1:$ - White : 7, S. Aq. P. C. G. H. 1792 lacunösă, 2 - White * 6, G. Aq. P. N. Amer. . 1812 nymphoídés, 3 . Yellow . 6, H. Aq. P. England ovàtä: : Orange : 6, G. Aq. P. C. G. H. : 1786 parnassifolia: : Yellow: 8, G. Aq. P. N. S. W. : 1825 parnasaifolia: Y Yellow : 8, G. Aq. P. N. Hol: 1825 reniformiss : Yellow: 7, G. Aq. P. N. Holl. : 1820
sarmentösa

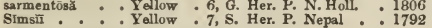

Vill, long, close, rather soft hairs.

Vulueus, covered with soft, close, long, loose hairs.

Virmorinĩu, Decandolle. In compliment to M. Vil morin, a famous French cultivator, and Member of the Agricultural Society of Paris. Linn. 17, Or. 4, Nat. Or. Leguminosa. For culture and propagation, see Clitoria. Synonyme: 1. Clitoria multiflora.

multiflōră, 1 - Purple - S. Ev. S. W. Ind. - 1826

VIMiñ̄rŭ, smith. From vimen, a twig; the appearance of the species is that of a bundle of twigs, being destitute of leaves. Linn. 10, Or. 1, Nat. Or. Leguminose. For culture and propagation, see Jacksonia.

denudata - . Yellow 8, G. Ev. S. N. Holl. . 1780 laterifloră : : Yellow . 7, G. Ev. S. N. Holl. : 1824

V̄̄ncă, Linn. Probably from vinculum, a band; in allusion to the suitableness of the shoots for making bands. Linn. 5, Or. 1, Nat. Or. Apocynacea. These plants are well adapted for covering naked ground in shaded situations. Any common soil suits them and they are readily increased by separating the rooted trailing shoots. Synonymes: 1. V. media flore pleno. 2. V. media.

herbācēa - . Pur. blue - 6, H. Ev. Tr. Hungary • 1816 maajjơr . Pur. blue . 8, H. Ev. Tr. Englan flôré plènō, i : Blue - 8, H. Ev. Tr. Gardens intermédr̆ă, 2 . Blue : 8, H. Ev. Tr. Gardens variegăta - Blue - 7, H. Ev. Tr. England ninor florĕ ålbö - . White. - 7, H. Ev. Tr. Gardens flòré plēnō - Violet . 5, H. Ev. Tr. Gardens flore punǐcéo : Red : H. Ev. Tr. Gardens fol. argēntěrs : Violet: : 7, H. Ev. Tr. Gardens fol aưreis : Violet : : 5, H. Ev. Tr. Gardens

\section{Vīvc Ă, see Catharīnthŭs.}

VINR Bowrer, see Clemütžs Viticéllă.

VINB LBEK, see Allīîm ampelöprŭsūm.

VıōtĂ, Linn. Latin name of the flowers. Linn. 5 , Or. 1, Nat. Ur. Violucea. All the species of this genus deserve to be cultivated, either for the beauty or the scent of their flowers. The hardy perennial kinds are well fitted for ornamenting the front of flower-borders or rock-work, but the smaller species succeed best when grown in pots, in a mixture of loam, peat, and sand. The species, natives of America, tlirive best in vegetable mould or peat, and are readily increased by parting the roots, or by seeds. The greenhouse and stove species should be grown in a mixture of loam and peat; the her [ 331 ] baceous kinds of them are increased by seed, or dividing the roots, and the shrubby kinds by cuttings, which root readily when planted under a glass. The annual species may be sown in the open borders or on rock-work. The Neapolitan violet, $\boldsymbol{V}$. odorata pallido-plena, may be made to flower throughout the winter and early spring, by placing it in a stove or warm pit. $V$. canina is said to be famous agent in removing cutaneous diseases Synonymes: 1. V. sororia. 2. V.Pallasii, chrysantha. 3. V. Allioni. 4. V. lanceolata. 5. V. Patrinii nepalensis, primulafolia. 6. V. multifida. 7. V. dentata.

8. V. sibirica. 9. V. odorata. 10. V. stagnina. 11.

$\boldsymbol{V}$. Hornemanniana. 12. $\boldsymbol{V}$. primulofolia. 13. $V$.

prunellafolia. 14. $\boldsymbol{V}$. digitata. 15. V. ranunculifolia.

16. V. ericetorum. 17. V.lancifolia. 18. V. littoralis.

19. $\boldsymbol{V}$. Broussonetiana. 20. $\boldsymbol{V}$. saxatilis. 21. $\boldsymbol{V}$. $a r=$ vensis. 22. $\boldsymbol{V}$. Kitaibeliana. 23. $\boldsymbol{V}$. calcarata.

aff inIs, 1 . . Blue . . 4, H. Her. P. N. Amer. . 1802 alleghanēnsis: : Blue : 5 , H. Her. P. N. Amer. : 1824 alpina : : Purple : 6, H. Ev. Cr. Austria : 1823 altălcă, 2 . Dk pur. 5, H. Her. P. Siberis . 1808

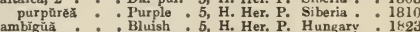
amø̄enă : : Purple: 6, H. Her. P. Scotland : Pa. blue. 5, G. Ev. S. Spain : 1779 Blue. 6, H. Her. P. France. 182 Bue . 5, H. Her. P. N. Amer. . 1820 Pa. yell. . 5, H. Her. P. Nepal •. 1824 attenuătă, 4. White - 7, H. Her. P. N. Amer. . 1759 bannătică. - Yel. pur. 8, H. A. Germany - 1820 bicōór - Blue - 8, G. Her. P. N. Holl. - 1820 bifióră: Yellow: 6, H. Her. P. Alp. Eur. - Yllow : 6, H. Her. P. Alp. Eur. 1752 bláná. White : 5, H. Her. P. N. Amer. 1802 calcarătă : Lgt. blue 5, H. Her. P. Switzerl. 1752 campéstrís: : Purple.4, H. Her. P. Tauria. : 1824 canadénsis - : White : 5, H, Her. P. N. Amer. : 1783 díscólor : : Blue wht. 6, H. Her. P. N. Amer. : 1783 canină . . Blue . 5, H. De. Tr. Britain

albă . . White . 5, H. De. Cr. Gardens

rūbră * Red . 5, H. De. Cr. Gardens

cenİšă . - Blue . 6, H. Her. P. Mt. Cenis : 1759

clandestīna : Brown: 4, H. Her. P. Pennsylv. 1800

collină: : Blue : 5, H. Her. P. Poland : 1822

cornúta: : : Blue: :5, H. Her. P. Pyrenees: 1776

cucullată : Blue : 5, H. Her. P. N. Amer. 1762

dactyloìdës - Blue . 5, H. Her. P. Siberia . 1820

dêbilils : . Pa. blue. 4, H. Her. P. N. Amer. 1820

Pa. blue . 6, H. Her. P. Pannonia 1818

dicurans. Pr.

dissēeta, $6: \therefore$ Violet 5 , H. Her, P. Altaian Mis.

emarginătă 7 Blue 5, H. Her, P. N. Amer.

epipsela : : Yellow: 6, H. Her. P. Livonia : 182

eriocārpă : : Yellow : 6, H. Her. P. N. Amer. : 1823

flabellifólia : Blue :6, H. Her. P. N. Amer. 1823

flavicournis . Yell. blue 6, H. Her. P. Britain .

glaūeă $\mathrm{Pa}$ blue . 5, H. Her. P. Poland.

Gmeliniānă, 8 . Blue . 5, H. Her. P. Siberia .

grăcilis a 8 Purple 6, H Her. P. 1820

grandiflór

hastata.: Yellow : 5, H. Her. P. Carolina

hirsuta: : : Blue :5, H. Her. P. Bohemia

hümกlı

japōnică, 9

Greyish : 5, H. Her. P. England

Krờcērí

lacteă, 10

lanceolata

Langsdōrit

Langscou

mirabilis

montänă

strict $₫, 1$

neglēctă

nummularifolia

White 5, F. Her. P. Mexico.

Blue . 5, H. Ev. Cr. Jupan

Pa. red . 5, H. Her. P. Siberia

White $6, \mathrm{H}, \mathrm{Her} P \mathrm{~N}$. Amer.

Pluter. 1759

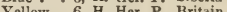

Y ellow. 6, H. Her. P. Britain

Lgt. blue 7, H. Her. P. Germany : 1732

Lgt. blue 5, H. Her. P. Alp. Eur. . 1683

Pur. blue 5, H. Her. P. Crimea : 1817

Her. P. Missouri . 1820

Yel. blue 5, H. Her, P. N. Amer. 1769

ochroleūcă : : Cream 5, H. Her. P. N. Amer. 1800

occūltă: Veiny :6, H. A. N. Aner. 1839

allba

Veing : 6, H. Ev. A. Britain .

: White 4, H. Ev. Tr. Britain

albo-plena - White . 4, H. Ev. Tr. Britain

corclea - Blue H. Ev. Tr. Britain

coruleó-plēnă . Blue 4 H. Ev. Tr. Britain

pällidó-plenă * Pa. blue . 4, H. Ev. Tr. Britain 。

purpŭrę - Purple 5, H. Ev. Tr. Britain

purpǔrēō-plènă Purple : 4, H. Ev. Tr. Britain

orěades

oreades - Purple 6, H. Her. P. Tauria . 1818

pata, 12 . . Pur. blue 5, H. Her. P. N. Amer. . 178

palmensis * Purple - 5. F. Ev. S. S, Eur. - 183

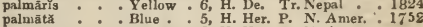

variegată : Pur. wht. 6. H. Her. P. N. Amer.

palūstrís . Blue . 5, H. Her. P. Britiin 


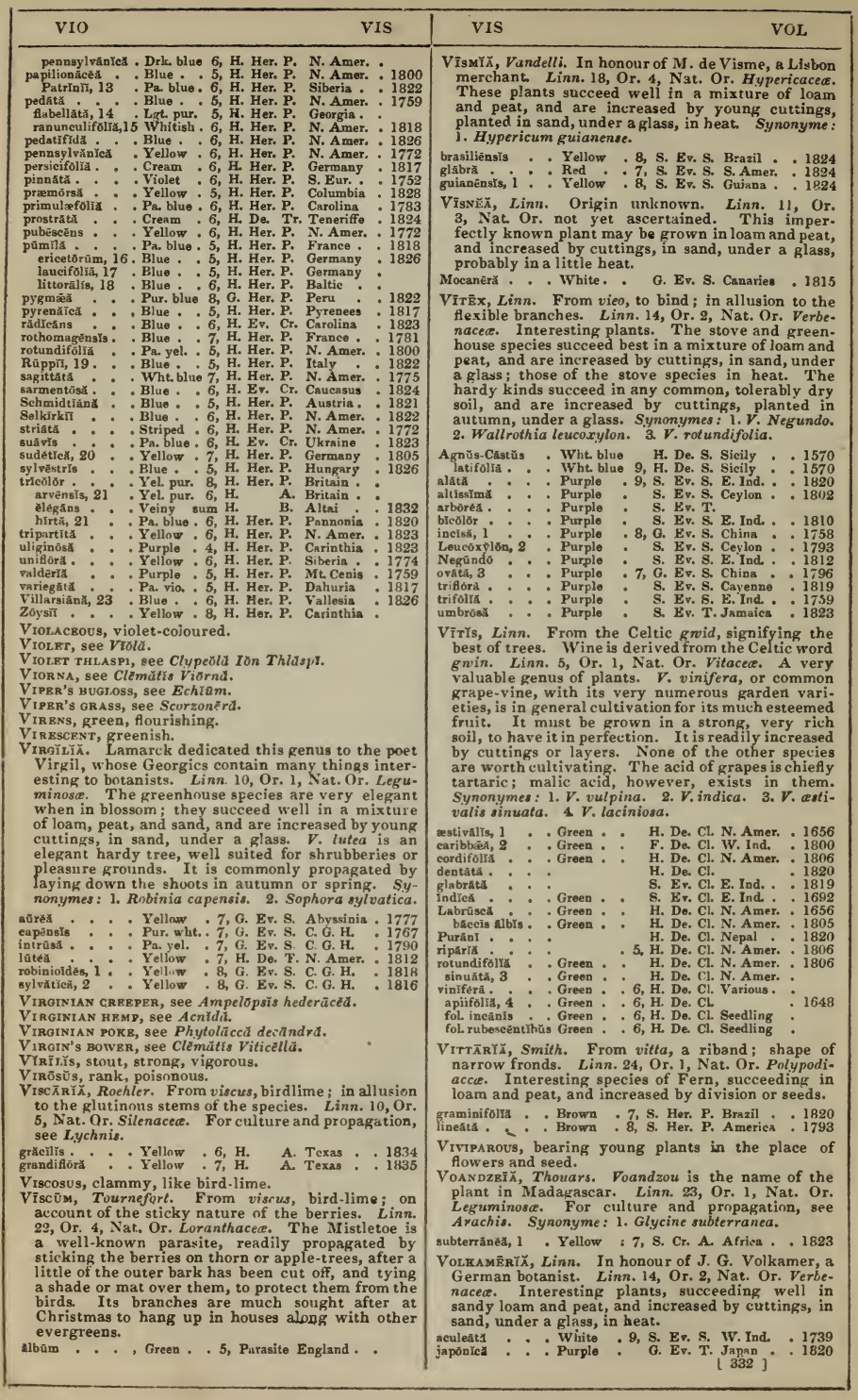




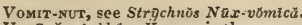

VoUĀPL̆, Aublet. Vouapa is the name of the species in Guiana. Linn. 3, Or. 1, Nat. Or. Leguminosa. This plant succeeds in sandy loam and a little peat, and is increased by ripened cuttings, in sand, under a glass, in heat.

bifolră . . Violet. . S. Ev. S. Guiana . . 1823
Vơră, Aublet. From Voyra, the name of a species in Guiana. Linn. 5, Or. 1, Nat. Or. Gentianucea. This species may be grown in a mixture of sandy loam and peat; seeds.

rǒsē . . . Red . . 7, S. Her. P. Guiana . . 1822 VULNRRARY, useful in the cure of wounds. VuLviform, like a cleft, with projecting edges.

W.

TVACHENDÖRFIX, Linn. In honour of $J$. E. Wachendorf, a Dutch botanist. Linn. 3, Or. 1, Nat. Or. Hamodoracee. The species of Wachendorfia succeed well in a mixture of very sandy loam and a little peat, taking care to supply them with little or no water when dormant. If planted out in a pit or frame, where they can be protected from frost, they will tlower much stronger than if kept in pots. 'They are increased by offsets, or by seeds. Syno. nyme; 1. W. paniculata.

breviforră . Purple 4, G. Bl, P. C. G. H. 4, G. Bl. P. C. G. H graminé̃ : : Yellow : 4, G. Bl. P. C. G. H. Hibbertiñ, 1 : Yellow : 4, G. Bl. P. C. G. H. hirsütă. : Violet. 4 , G. Bl. P. C. G. H hirsütă : : Yiolet. : 4, G. Bl. P. C. G. H. panieulata.: : Y Yellow : 4, G. Bl. P. c. G. H. $\quad: 1700$ thyrsiförä: : Yellow : 5, G. Bl. P. C. G. H. $\quad 1759$ WARLRNBÊRgĭ, Schrader. In honour of George Wahlenberg, M.D., author of "Flora Lapponica," \&c. Linn. 5, Or. 1, Nat. Or. Campanulacee. Interesting plants. The herbaceous species sicceed best when grown in pots, in a mixture of loam and peat, and kept rather moist; they are increased by division or seeds. The annuals should be raised on a slight hotbed, and afterwards planted in a warm sheltered border. Synonymes: 1. Campanula elongata, W. elongata. 2. C. grandiflora. 3. Wahlenbergia pendula.

capénsiss, 1 . Blue . 7, H. A. 1819 grandiflóră, 2 : Blue : : 7, H. Het. P. Siberia . 1782 lobelioidés, 3 . Pa.red : 7, H. A. Madeira 1777 rēpēns. . . Whtsh, : 7, H. Evr. Cr. Mr. 1830

WALDSTEİNĭ Von Waldstein, a German botanist and author. Linn. 12, Or. 2, Nat. Or. Rosacere. This plant thrives in any common garden soil, and is readily increased by division or seeds.

geoĩdès. . . Y Yellow . 6, H. Her. P. Hungary . 1804 WALKĒRĂ, Schreber. In honour of Richard Walker, D.D., founder of the Cambridge Botanic Garden. Linn. 5, Or. 1, Nat. Or. Ochnacece. Ornamental plants, succeeding in a mixture of sandy loam and peat, and cuttings of the ripened wood will root in sand, under a glass, in heat. The root and leaves of $W$. serrata are bitter, and employed in Malabar in a decoction of milk or water as a tonic, stomachic, and anti-emetic.

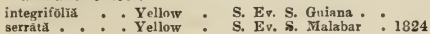

WaI.L crRss, see $A$ tăbis.

WALL YLOWER, see Cheirūnthŭs.

WALL-FLOWRR, see Brüssīcŏ Cheirānthr̆s.

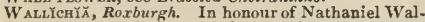
lich; M.D., F.R.S. and L.S., superintendant of the Botanic Garden, Calcutta. Linn. 21, Or. 6, Nat. Or. Palmacere. This genus of Palms should be grown in a strong, rich soil, and a warm temperature; they can only be increased by seeds.

caryotoìdés . . . Palm. E. Ind. . . 1825 spectährilıs Palm. E. Ind. : : 1831

WALIRŌTHĬ Sprengel. In honour of F. Wallroth, M.D., a German botanist. Linn. 5, Or. 2, Nat. Or. Umbellifere. Worthless, hardy, herbaceous plants; seeds. Synonymes: 1. Ligusticum splendens, $W$. splenders. 2. Bunium alpinum, L. alpinum-W. tenuifólīä 1 , tuberósă 2.

WALL RUB, see Asplēnīûm Rãtr̆ murarĭă.

Wallsûr $\not$, Roxburgh. Altered from Wallursi, its Telinga name. Linn. 10, Or. 1, Nat. Or. Meliacea. For culture and propagation, see Walkera.

robũstă ' [ $33 \dot{3}$ ]
WALNUT, see Jüglans.

WALTHËRİ, Linn. In honour of A. F. Walther, professor of medicine at Leipsic. Linn. 16, Or. 2, Nat. Or. Sterculiacec. Uninteresting stove shrubs, of simple culture. $W$. americant, being biennial, is increased by seeds; the other species by cuttings. Synonyme: 1. W. lievis-W. americänă, ellīptică, gläbrä 1, indǐcă, microphyllă.

W AM PBE-TRBE, see $C o \delta k i \breve{a}$.

W ANGRNHBİMĬ, MÆnch. In honour of F. A.J.Wang enheim, a German botanist. Linn. 3, Or. 2, Nat. Or. Graminea. A worthless, hardy, annual grass.

Synonyme: 1. Dinebra lima-W. Lìnả l.

WARratah, see Caméllia japonlcă var.

Warratah, see Telopéă.

WVART cRrss, see Senebiërŭ.

WARTED, covered with wart-like protuberances.

WARTWort, see Euphórb̌̃ă helioścöpĩa.

Water caltrops, see Träpă.

WATER CHICKWRED, see Móntżă fontānă.

WATER-CRESS, see Nastīrtĩ̄im officinale.

WATER DOCK, see Ramex. Hydrolapătham.

WATER DROPWORT, see Enänthe.

W ATER GRRMANDBR, see Téncrĭñm Scordrūm,

WATBR HEMTOCK, see Phelländriūm.

WATBR hOREhoUND, see Lycópús.

WATBR LEAF, see Hydrophȳllüm.

WATER I.EMON, see Passiflóra laurifolia.

WATER LILY, see Nymphäă.

WATER MRLON, see Cucũmis Citrullüs var.

W'WATR MILfoIl, see Myriophyllam.

WATRR PARSNIP, see $\boldsymbol{S} \tilde{i}$ mm.

WATER PEPper, see Poly̆gðnūm mītĕ.

W ATRR PEPPEk, see Elätine Hydropĩpèr.

WATER PI.ANTAIN, see Alismä Plantūgo.

IVATrR PURSLANk, see Pëplis.

W ATER RBED, see $A \imath$ ũndo

WATER SOLDIRR, see Stratiotěs.

WATBR STARWORT, see Callitrichĕ.

WVATBR vine, see Tetracëră potatórĭd.

WATBR VIOLRT, see Hottōnĭă.

Warsônĭ, Ker. In honour of W. Watson, a cele. brated London apothecary. Linn. 3, Or. 1, Nat. Or. Iridacece. All the species of this genus are very handsome when in flower. For culture and propagation, see Wachendorfia.

aletroidès . . Scarlet - 6, G. Bl. P. C. G. H. 1774 variegata : Varieg. : 6, G. Bl. P. C. G. H. : 1774 angūsta. - Scarlet . 6, G. Bl. P. C. G. H. 1825 brevifolia : : Pink . 5, G. Bi. P. C. G. H. 179 compăctă - . Purple . 6, G. Bl. P. C. G. H. 1821 fülgida . - Red . 5, G. Bl. P. C. G. H. 1795 huminls. : : Lake: : 6, G. Bl. P. C. G. H. : 1754 iridifolia minór Pink, 8, G. Bl. P. C. G. H. 1812 minor plantağnĕ

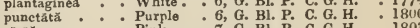
Pink * 7, G. Bl. P. C. G. H. rősế-ălıă . - Pink wht. 7, G. Bl. P. C. G. H. variegáta : Varieg. 7, G. Bl. P. C. G. H. spicātă. Pink . 5, G. Bl. P. C. G. H. : 179 strictiflóră : Red : 6, G. Bl. P. C. G. H. : 1810 WATTLED, having processes, like the wattles of a cock. WAVY, undulated.

WAYPARTNG-TREB, see Vibūrnüm Lantünă.

WVEBढ̆RĂ, see Cüpüă.

WedēLiă, Jacquin. In honour of George Wolfgang Wedel, a German botanist. Linn. 19, Or. 4, Nat. Or. Composita. Uninteresting plants, of very easy culture and propagation.

acapulcēnsis . Yellow - 7, S. Her. P. Acapulca . 1826 aûrea : : Yellow : 9, F. Tu. P. Mexico . 1829 bengalềns: : Yellow 6 , H. Cr. A. E. Ind. 
carnos: Yellow 6, S. De, Cr. W Ind 1820 helianthoiders : Yellow: j1, H. A. A. Guieto. : 1827 hispídá. : Yellow : 6, F. Her. P. N. Spain : 1819 radiósă : : Yellow: 6, S. Ev. S. Brazil . 1820

WвINMĀNNǏ, Linn. In honour of John William Weinmann, apothecary at Ratisbon, author of "Phytanthoza Iconographica." Linn. 8, Or. 2, Nat. Or. Cunoniacee. These plants thrive in any light rich soil, and are readily increased by cuttings, under a glass, in heat. The bark of some of the species has been used in Peru for tanning leather, and it has also been employed in the adulteration of Peruvian Bark. Synonymes : 1. W. pinnata. 2. Acrophyllum venosum.

australls : * G. Ev. S. N. Holl. * 1836

elliptică : : : White. . 5, S. Ev..S. S. Amer. : 1824

gläbră, 1 : : White: 5, S, Ev, S. Jamaier : 1815

hirta : : White: 5 , s, Ev. S. Jamaica : 1820

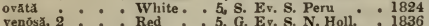

W'īssǐn, Hedwig. In honour of F. W. Weis, a German botanist. Linn. 24, Or. 5, Nat. Or. Mrusci. Greenish mosses, found in wet places, on rocks, and alpine banks. Synonymes: 1. Grimmia acuta. 2. Brium calcareum. 3. Grimmia cirrhata. 4. G. controversa. 5. G. crispula. 6. G. recurvirostra. 7. G. lanceolata. 8. G. nigrita. 9. G. nuda. 10. G. pusilla. 11. G. recurvata. 12. G. Starkeana. 13. Funaria Templetoni. 14. G. trichodes. 15. G. verticillata-W. acûtă 1, affĩn's, calcărēă 2, cirrhätă 3, controversă 4 , crispülä 5 , curvirōsträ 6 , elongätă, lan ceolätă 7 , latifoliă, nigrită 8 , nàdă 9 , pusillă 10 , recurvätă 11 , Starkēeană 12 , striata, $S$. mäjör, $S$. minör, Templetöni 13, tenuiróstris, trichödés 14, verticillata 15.

W' вI.sH ONION, see Allrüm fistulósũm.

WRNDIĀNDİA, Bartling. In honour of Henry Ludovicus Wendland, Curator of the botanic garden at Hanover. Linn. 6, Or. 4, Nat. Or. Cinchonacea. An ornamental plant, succeeding well in a mixture of loam, peat, and sand, and increased by cuttings, in sand, under a glass, in heat. Synonymes: 1 . Rondeletia paniculata. 2. Cocculus carolinus.

paniculâtx, 1 . White * . S. Ev. T. Malay Is. . 1820 populiforra, 2 : White : 6, G. Ev. Tw. Florida : 1759

W RRNĒRY, Kunth. In honour of A. G. Werner, the celebrated mineralogist. Linn. 19, Or. 2, Nat. Or. Compositc. This species thrives well in a light soil, and is increased by division of the roots. Synonyme: 1. Doronicum peruvianum.

rigìida

2, G. Her. P. Quito 1828

WrstrinaYx, Smith. In honour of J. P. Westring, phy sician to the king of Sweden. Linn. 14, Or. 1, Nat. Or. Labiute. A light rich soil suits all the species well, and young cuttings, planted under a glase, soon strike root.

angustifolra - White.

White. 7, G. Ev. S. N. Holl.

6, G. Ev. S. N. S. WW.

glabră * * White. . 6, G. Ev. S. N. Holl.

White. 6, G. Bv. S. N. Holl

rigida . . White. . 6, G. Ev. S. N. Holl

rusmariniformYs : $\mathrm{Pa}$, blue : 7, G. Ev. S. N. S, W

rubirfoliă . : Pn blue : 6, G. Ev. S. N. Holl.

WIrRAT, see Trïticnm.

WHIRLING PIANT, see Desmodylam g.̣̂rüns.

W urrk BEAN-TREB, see Pýrüs Arid̆.

WhITB CEDAR, see Cupresssüs thyoíders.

Whrte clover, see Trifolĩam rēpéns.

WhITB YIORIN, see Agrostis albă.

Whitr spruck, see Pĩnũs älbă.

WHIT TRRk, see Melalencă Leucadendrön.

WhItв viNe, see Clemätis vitülbü.

W нтте wood, see Petróbĩa m.

WHITLOW GRAss, see Lepĩdiem Drülut.

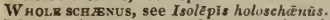

Whoris, leaves arranged in a regular circumference round a stem.

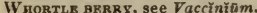

WIDOW-WAII, see Cneôrũm.

WIGÃNY̌A. Named by Kunth in honour of $J_{0 h n}$ Wigand, a bishop of Pomerania. Linn. 5, Or. 2, Nat. Or. Hydroleacea. "If well grown, and formed into $\mathrm{a}$ bush, feathered to the surface of the ground, this plant must have a very beautiful appearance with its large clusters of delicate lilac flowers, which continue to open in succession for a long time. But if formed into a sort of stake, with a few leaves and flowers at the top, as is too frequently the case with stove plants, it will be found to possess little claims to attractiveness." Lindley in Bot.

Reg. For the culture and propagation, we can give no certain directions.

caracasañnă. • Lilac • . S. De. S. Caraceas . 1836

WILD BAsıL, see Clinoprdî̃um.

WILD BвEт, see Stätīcĕ Limoññ̄m.

WILD BLITB, see Amaränthüs Blītam.

WIID BUGLoss, see Lycopsis.

WILD снамомиL, see Matricärü chamomällă.

WILD CLOVB-TREE, see Mürcĩă acrìs.

WILD cumin, see Lagäciă cuminoĩdès.

WILD LIQUORICB, see Abrüs.

WILD OAT, see Avẽnă fütŭd̆.

Wud ourv, see Rhos Cotinrs.

WiLd oLIVB, see Däphnē Thymelēă.

Wild PURsLane, see Euphorbid Peplis.

WILD RADIsH, see RaphänQs Raphanistrimm.

WiL.D Rosemary, see Andrōmédă polifoliza, var.

WiLn servick, see Pỹrús torminülis.

WILD TAMARIND, see Codĩrím.

WiLd tansy, see Potentīllă anserindx.

WiLd тнхмE, see Thymüs Serpyllam.

WILD vINE, see Vitis Labröscă.

WILLDRNơvī, Thunberg. In honour of Charles Louis Willdenow, a celebrated professor of botany at Berlin. Linn. 22, Or. 3, Nat. Or. Restiacea. In. teresting plants, succeeding well in loam and peat, and increased by dividing at the root.

striati . . . A petal * 6, Grass. C. G. H. . 1818

WицLвмйті̆ Necker. In honour of P. R. Willemet, author of Herbarium Mauritianum. Linn. 5, Or. 1, Nat. Or. Rhamnacea. A pretty shrub, succeeding in a mixture of sandy loam and peat, and increased by young cuttings, planted in sand, under a glass. Synonyme: 1. Ceanothus africanus.

africăna, 1. . . Blue . . 5, G. Ev, S. C. G. H. . 1712 Wrrow, see Sŭlix .

Wruow, see Lgthrôm salicărĭd.

WILLOW HERB, see EPilObiRm.

WILLUGHARĪA, Roxburgh. In honour of Francis Willughby, F.R.S., a friend and pupil of Ray. Linn. 5, Or. 1, Nat. Or. Apocynaced. This shrub succeeds well in a mixture of loam, peat, and sand, and is increased by cuttings, planted in sand, under a glass, in heat. The fruit, as the name implies, is eatable.

edualis . . . Pa pink . 7, S. Ev. S. E. Ind. . . 1818

Wind FLowrR, see Gentiañ l'neumonünthẽ.

Wine palm, see Manicăriă sacciferă.

WiNe, in Botany, signifies a meinbrannus border, wherewith many seeds are supported in the air, when floating from place to place.

WING, the side petals of a pea-flower.

WINGED PBA, see Tetragonólobǔs purpürêtis.

WINTRR ACONITR, see Eranthis.

WINTER BERRY, see Prinós.

Wintra cherry, see Physilis.

WINTrR chrrry, see Cardiospermám Halicilcábàm.

WINTBR CREss, see Barbürë.

WINTRR GRAPB, see Vitis cordifolid.

WintrR gREgn, see Pyróla.

WINTRR GRREN, see Trientülis.

WINTBR sWBBT, see Origŭñm heracleoticîm.

W'isB MRN's BANANA-TREE, see Masă supiēntñm.

WIsrĀrĭn, Nuttall. In honour of Caspar Wistar, once professor of anatomy in the university of Pennsylvania. Linn. 17, Or. 4, Nat. Or. Legumi. nose. Hardy elimbers, bearing flowers of great bearty, and on that account they ought to be in every collection of plants. They thrive best in a light rich soil, trained against a south wall, where they will flower in great profusion. They are commonly increased by layers, but cuttings root very freely if planted in either sand or soil, under a glass. Synonymes : 1. Glycine sinensis, $\boldsymbol{W}$. Conseguana. 2. G. frutescens, W. speciosa, Apios frutescens.

sinēnsīs, 1 . Bluish pur. 5, H. De. Cl. Chinn . . 1818 fruteseens, 8: : Bluish pur. 7, H. De. Ci. N. Amer. : 1724 [334] 
Wiтсн HAZEL, see Hamamël:s.

W'ATPRRTAGÁ, L'Heritier. In honour of William

Withering, M.D., author of a "Botanical Arrangement of the Vegetables of Great Britain," Birmingham, 1776. Liun. 5, Or. 1, Nat. Or. Solanacea. Interesting plants, thriving well in a light rich soil, and readily increasing by cuttings, under a glass, or by seeds. W. phyllantha should be raised on a gentle hotbed in spring, and, when of sufficient size, planted in the open border.

erassiföliæ •. Yellow . 6, G. Ev. S. C. G. H. 1706 montană : : White. 6, G. Hero P. Perı : 1822 pliyllanthă : Yellow : 7, G. A. Peru : 1822

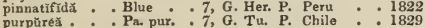
solanâcéă: : : Yellow : 7 , s. Her. P. S. Amer. : 1742 stramoniforiă : Yellow : 6, S. Ev, S. Mexico : 1823

Wiтнy, see Laserpǐtiñm Sïlěr.

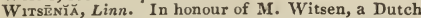
patron of Botany. Linn. 3, Or. 1, Nat. Or. Iridacece. Ornamental plants, succeeding best in a sandy peat soil, and increased by offsets from the roots, or by seeds.

corymbósă • Pur. blue 6, G. Her. P. C. G. H. 1803 maúră : : Yel. blue 12, G. Her. P. C. G. H. : 1790 ramōsa : : : Pur. blue 4, G. Her. P. C. G. H. : 1819

WoAD, see Isătĭs.

WoLF's-BANE, see Aconĩtūm lupulīnūm.

Woodmine, see Caprifoliùm Periclymēnūm.

Woodrink, see Polỹgönūm Convõlvūlūts.

WOOD BVRRLAST1NG PRA, see Lăthy̆rŭs sylvēstrǐs.

WoODroor, see Asperülá.

WoOd sAGB, see Teâcrî̀m Scorodonĩúm.

Woōdsť̆, R. Brown. In honour of Joseph Woods, a British botanist, Linn. 24, Or. 1, Nat. Or. Polypodiacece. Ferns, growing best in peat and loam mixed, and increased by division, or by seeds.

hyperboré̌ . Brown . 7, H. Her. P. Scotland

ilvensis. : Brown 6 , H. Her. P Britain.

Perriniaña: : Brown : 6, H. Her. P. N. Amer.

WOOD SORRRT, sEe Oxălls.

WOODW̄̄RDİ, Smith. In honour of Thomas Jenkinson Woodward, an English botanist. Linn. 24, Or. 1, Nat. Or. Polypodiacea. For culture and propagation, see Wuodsia. Synmymes: 1. W. onocleoides, Osmunda caroliniana. 2. Blechnum virsinicum.

angustifolră, 1 Brown - 8, H. Her. Cr. N. Amer. 1812 rădicáns : . Brown : 7, G. Her. P. Madeira : 1779 virginñ̌că, $2{ }^{*}:$ Brown : 8 , H. Her. P. N. Amer. : 1724 Worm orass, see Spigĕliă.

WôRMǏĂ, Rottboll. In honour of Olaus Wormius, M.D., a famous Danish philosopher and naturalist. Linn. 13, Or. 5, Nat. Or. Dilleniacede. This is a very elegant stove plant. For culture and propagation, see Dillenia. Synonyme:,1. Dillenia dentata.

dentătă, 1 . Yellow . S. Ev, T. Ceylon .

1818

Wormwoon, see Artemžsiă.

WOUNDWORT, see Anthỹllis vulneräria.

WRACK GRAss, see Zosterŭ.

WRīgнtĭĂ, R. Brown. After the late William Wright, M.D., F.R.S., L. and E., F.L.S., a Scotch physician and botanist, resident in Jamaica. Linn. 5, Or. 1, Nat. Or. Apocynacece. Ornamental plants. For culture and propagation, see Strophanthus. Synonymes: 1. Nerium antidysentericum. 2. N. coccineum. antidysentèrǐcă, 1 White . - S. Ev, S. Cevlon : 1778 coccīué, 2. . Scarlet 7 , S. Ev. T. E. Ind. . 1822 pubésceens : : Grn. jel. : 3, S. Ev. S. N. Holl. : 1829
t1petoriă

WuLFǏNǏx, Jacquin. In honour of the Rev. Francis Xavier Wulfen, a botanical author. Linn. 2, Or. 1, Nat. Or. Sctophulariacece. This is a very showy plant when in blossom; and is well adapted for ornamenting flower-borders. A light rich soil suits it, and it is readily increased by division or seeds. It requires the protection of a frame in winter, as it is very apt to rot at that season, if allowed to remain in the open air.

carinthraca . Blue . . 7, H. Her. P. Carinthia . 1817

WÜRмRĚx, Thunberg. In honour of F. Van Wurmb, Secretary to the Academy of Sciences at Batavia. Linn. 6, Or. 3, Nat. Or. Melanthacee. Pretty plants when in flower. They grow well in sandy peat, mixed with a little loam, and are readily increased by offsets. Synonymes; 1. Melunthium monopetalum. 2. M. spicatum.

eampanulată, 1 White . 6, G. Bl. P. C. G. H. 1819 longittóră : White. 5, G. Bl. P. C. G. H. : 1788

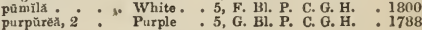
WrCH ILM, seè Ulmŭs montānă.

$\mathrm{X}$.

Y ĀNTHǏCM, Tournefort. From xanthos, yellow ; the plants being formerly used by the Greeks to dye their hair. Linn. 21, Or. 5, Nat. Or. Composite. Plants of no great beauty. The seed may be sown in the open border.

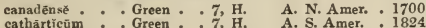

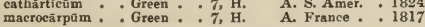

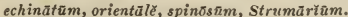

ХАNтноним мйs, see Stalagmitĭs.

Xanthorhīză, Marsh. From xanthos, yellow, and rhiza, a root; the roots being of a deep yellow colour. Linn. 5, Or. 6, Nat. Or. Ranunculacez. An interesting dwarf shrub, succeeding well in common garden soil, and increased by suckers. The wood contains both a gum and a resin, each of which is intensely bitter.

apiifolra . - Pur. grn. . 2, H. Ev. S. N. Amer. . 1766

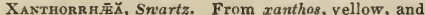
rheo, to flow; yellow resinous exudation. Linn. 6 , Or. 1, Nat. Or. Liliacece. These plants thrive well in a mixture of peat and loam, and are increased by offsets from the roots. Synonyme: 1 . X. pumilio. austrālǐs . . White. 4, G. Ev. S. N. Holl. 1824 bracteåta . . White. 4, G. Her. P. N. S. W. . 1810 hastills . * White. * 4, G. Ev. S. N. S. W. . 1803 húmills, 1 . White. . G. Her. P. N. Holl. 1825

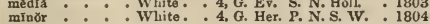

XANThōsǐn, Decandolle. From ranthos, yellow; in allusion to the yellow down with which some species belonging to this genus are clothed. Linn. 5, Or. 2, Nat. Or. Umbellifere. A very curious [ 335 ] under-shrub, succeeding well in a mixture of loam, peat, and sand, and readily increased by cuttings, or seeds.

rotundifoliă . - Wht. red . 6, G. Ev. S. Pt. Jachson 1836

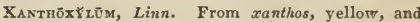
xylon, wood; the roots are yellow. Linn. 22 , Or. 5, Nat. Or. Xanthoxylacece. Ornamental trees and shrubs. The hardy species, from their beauty, are well adapted for planting in shrubberies. They grow freely in any common garden soil, and are readily increased by cuttings of the ripened wood, planted under a glass. The stove and greenhouse kinds are of easy culture, and are increased by cuttings, in sand, under a glass. The bark and capsules of $\boldsymbol{X}$. fraxineum have a hot, acrid taste, and are used for easing the toothache; hence the name Toothache tree. $\boldsymbol{X}$. Avicennoe and Piperitum are used in China and Japan as an antidote against all poisons, and in Japan the capsules of the latter species are used as a substitute for pepper. Syno. nymes: 1. Fagara Budrunga. 2. F. Piperita. 3. F. Pterota. 4. F. tragodes.

acuminātûm armātūm aromĕtícūm A vicénn⿳亠丷厂 . Budrũng Budrüngà, 1 clăvă HêreǔlY̌s fraxinệum. mitè . nītน̃น ûm Piperitâm, $\dot{q}$ Pterotă, 3 .
S. Ev S. Jpmaic 1818 S. Ev. S. Jemnica, : 1818 S. Ev. S. W. Ind. 1824 G. Ev. B. China : 1823 White. . 3, S. Ev. T. E. Ind. • - 1825 Grn. wht. G. Ev. S. W. Ind. 1739 Grn. wht. S. E7. S. Jnmaics • 1739 Grn, wht. 3, H. De. S. N. Ainer. - 1759 Yellowish 3, H. De. S. N. Amer. . 1818 Grm. whit. S. Ev. S. China - 1823 White. 9, G. Ev. S. Japan . . 1773 White. 8, S. Ev. T. Jamaica : 1768 
XвRĀNTHĔMŨx, Tournefort. From xeros, dry, and anthemon, a flower; alluding to the dry nature of the flower, which retains its form and colour for years. Litn': 19, Or. 2, Nat. Or. Compositce. Plants of the easiest culture in any rich light soil.

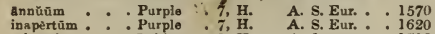
inapèrtūm : : Purple : 7, H. A. S. Eur. : 1620
oriéntal6

X'RROPHY̌LLŨ M, Michaux. From xeros, $\mathrm{d}$ ry, and phyllon, a leaf; in reference to the dry grassy leaves. Linn. 6, Or. 3, Nat. Or. Mrelanthacee. Handsome plants when in flower, and, therefore, well worth cultivating. They succeed best in a peat border, and will, if treated with care, ripen their seeds, from which they may be increased, as also by dividing the roots. Synonymes: 1 . $\boldsymbol{X}$. setifolium, Helonius asphodeloides. 2. H. graminea. 3. Veratrum Sabadilla, Vellozia squamata. 4. Helonias tenax.

asphodeloides, 1. White. . 5, H. Her. P. N. Amer. - 1765 gramineūm, 2. : White. : 5, H. Her. P. N. Amer. 1812 Sabadilla, 3 : White: : H. Her. P. Vera Cruz : 1830 tẻnâx, 4 : : White. :5, H. Her. P. N. Amér. : 1811

X̌rrōtēs, R. Brown. From xerotes, dryness; because of the aridity of the herbage. Linn. 22 , Or. 6, Nat. Or. Juncacea. A genus of herbaceous plants. They succeed well in light rich soil, and are readily propagated by dividing the plants at the root. Synonyme: 1. Lomaria longifolia.

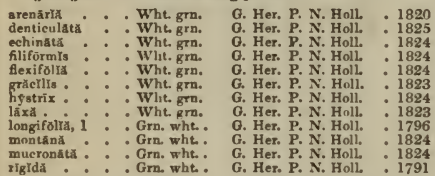

G. Her P. N Holl 1791

X a Spanish apothecary. Linn. 19, Or. 2, Nat. Or. Composita. Interesting plants, of common culture. Synonymes: 1. Coreopsis heterophylla. 2. Simsia ficifulia.

Cavanillesin, 1 . Yellow * 8, H. B. Mexico. 1820 cordata . . Yellow : 9, G. Her. P. Mexico: : 1826

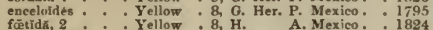
heterophylli: : Yellow : $7, \mathrm{H}$. A. Mexico: : 1827

XIMĒNY̌̆, Linn. In honour of Francis Ximenes, a Spanish monk, who wrote a work upon medicinal plants. Linn. 8, Or. 1, Nai. Or. Olacacea. A mixture of loam and peat suits these plants, and cuttings root readily in sand, under a glass, in heat. The drupes of $\boldsymbol{X}$. americana have a sweet, aromatic taste, but are a little rough to the palate. They are eaten in Senegal; the flowers are very sweet. smericẩñ . . . Gmsh. yel. S. Ev, T. W. lnd. : 1759 inermls.: : White. : S. Ev. T. Jamaica : 1810

XIPhİpYùx, Loefling. From xiphos, a sword; the leaves are sword-shaped. Linn. 3 , Or. 1, Nat. Or. Homodoracee. An equal mixture of loam, peat, and sand, suits these species, and they are readily increased by division of the root.

albūm . . White. . S. Her. P. W. Ind. 1787

çrŭlêūm : Blue : S. Her. P. Guiana • 1793

XıPHōptĕRǏs, Kaulfuss. From xiphos, a sword, and pteris, fern; form of the fronds; hence Sword Fern. Linn. 24, Or. 1, Nat. Or. Polypodiaced. Ornamental plants. For culture and propagation, see Pclypodium. Synonymes: 1. Grammitis heterophylla, Polypodium grammitoides. 2. Grammitis serrulata. heterophylla, 1 . Brown . 6, G. Her. P. N. Holl. - 1824 serruláta, 2 . Brown : 6, S. Her. P. W. Ind. 1823

XYiomēūm, Smith. From xylon, wood, and melon, an apple; appearance of the fruit of the plant. Linn. 4, Or. 1, Nat. Or. Proteacea. For culture and propagation, see Hukea. Synonyme: 1. Hakea pyrifurmis.

pyrifórmĕ, 1 . . $\quad$ G. Ev. T. N. S. W. . 1789

X̊LOPH Y̌LL , Linn. From xyton, wood, and phyllon, a leaf; rigidity of the leaves. Linn. 21, Or. 10, Nat. Or. Euphorbiacex. Ornamental shrubs, growing about three feet high. For culture and propagation, see Phyllanthus. Synonymes: 1. Phyllanthus angustifolius, epiphyllanthus. 2. P. falcatus. 3. P. latifolius. 4. P. linearis. 5. $\boldsymbol{P}$. ceramicus. 6. $\boldsymbol{P}$. arbuscula.

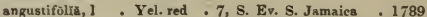
elongats : : Yel red : 8, S. Ev. S. Jamaica : 1890 faleñtă, 2: : : Yel. red : 7. S. Ev. S. Balıam. Is. : 1699 latifolră, 3 : : Yel, red : 8, S. Ev. S. Janaica : 1783 linearris 4 : : Yel. red : 8, S. Ev. S. Jamaica : 1819 longifollă, 5 : : Yel. red : 8, S. Ev. S. E. Ind. : 1816 medra - : Yel, red . 8, S. Ev. S. Jamaica 1825 montanx : : Yel. red : 8, S. Ev. S. Jamaica : 1819 obovata . : Yel, red : 8, S. Ev. S. Siheria . 1806 ramiford: : : Yel, red : 8, N. Ev. S. Siberia : 1785 speciósa, 6 : : : Yel. rod : 9, S. Ev. S. Jamaica : 1818

XYLöYx, Linn. Abridged from xylopicron, which is from xylon, wood, and picros, bitter; the wood of some of the species is extremely bitter. Linn. 13, Or. 6, Nat. Or. Anunacte. Ornamental plants for culture and propagation, see Phyllanthus. The wond of $\boldsymbol{X}$. glabra is so intensely bitter, that a quantity of sugar made from it, and sent from Jamaica in hogsheads, was so bitter that purchasers could not be found for it. A decoction of the wood is said to be of service in colics, and to be used for the purpose of creating an appetite.

frutéscéns . . . $\quad$ S. Evv. S. Guiana . . 1823 glabră : : S. Ev. S. Jumaica : 1820 inuricăta : . S. Ev. S. W. Ind. : 1779

XrRIs, Linn. From xyros, acute; the leaves terminate in points. Linn. 3, Or. 1, Nat. Or. Xyridacee. Curious rush-like plants. For culture and propa. gation, see Xerotes.

ahtisalma . . . Yellow . 9, G. Her. P. N. Holl. . 1826 ameriezn - Blue - 1826 bractents 7. a. Her. Nollo 1325 brevifolia : : Yellow : 7, H. Her. P. Carolina
grăeIlts : jüncé : : : Yellow : 7, G. Her. P. N. Holl. : 1822 läris $:$ : Yellow 7, s Her. P. N. Holl. : 1819 operculátå . . Yellow . 6, S. Her. P. N. S. W. . 1804 XYsмalóві̄o M, Bromı. From xysma, a thread, and lobos, a pod; in reference to the follicles being clothed with ramenta. Linn 5, Or. 2, Nat، Or. Asclepiadacea. For culture and propagation, see Asclepias. Synonyme: 1. Asclepias undulata.

undulatum, 1 . Green . . 7, G. Ev. S. C. G. H. . 1783

Y.

YAM, see Dioscore̋̌a.

Y YRrow, see Achtllĕ millefoltam.

YBLLW BIR 1 's NEST, see Monotröpă.

YBLLOW CHRSTNUT, see Quércũs Castäněă.

YBLLOW DBAD NETTIB, see Galeobdólon lutzam.

YrLLOW RATTLE, see Rhindnthüs.

YelLow Roor, see Xanthorhizd.

YrLLOW sultax, see Centârëa suavezléns.

YвiLow verchling, see Läthy̆rŭs Aphücă.

YBLLow-wort, see Chlord.

Y RW-TREB, see Tãxŭs.

Y Ūç̆, Linn. The name of the plant in Peru. Linn. [ $\mathbf{3 3 6}$ ]
6, Or. 1, Nat. Or. Liliacer. The epecies are mostly evergreen shrubs, with the habit of palm-trees. They are all of great beauty, and are, on that account, highly deserving of culture in every collection of plants. A light rich soil suits the whole of them, and they are all increased by suckers from the root. Synonyme: $1, \boldsymbol{Y}$. gloriosa.

acuminatz . . White. . 8, H. Ev. S. 18 no aletriform!s : : White. 2, Ev. S. C. G. H. : 1823 aloifolia : : White. . 8, G. Ev. S. S. Amer. : 1696 pendula: : Whic grm. 8 , H. De. T.

variegsta : : Wht. grn. 8, G. Ev. $\mathrm{s}$. 
angustifolra . . Wht. grn. 7, H. Ev. S. Missouri . 1811 arcuātă. concăvă: conspĩcŭă conspicũa dracōnis

fracōnis

filamentōsă

variegãt

fiāccìdă.

glaucēscē̉ng Wht. grn. 7, H. Ev. S. Wht. grn. 8, H. Her, P.

Wht. grn. G. Ev. S. S. 1818 Wht, Brn, H, Ev, S. Wht 1818 Wht. gra. 9, H. Her. P. Virginia : 1675 Whit. grn. 9, H. Ev. S. Wht. grn. H. Her. P. gloriósă. fol. variegätis . Wht. grn. 7, H. Ev. S.

grăcîlis . . Wht. grn. 7, S. Her. P. Mexico.

obliquă : : Wht. grn. H. Her. P.

mãjör : : Wht. grn. H. Her. P.

puberülă : Wht. grn. 8, H. Her. P.

rifó-

serrulātă

strīctă

supểrbă, 1

tenuifolia
Wht. grn. 8, H. Her. P.

Wlit. grn. 8, H. Ev. S. Georgia . 1794

Wht. grn. 7, H. Her. P. 1816

G. Ev. S. Carolina , 1808

Wht. grn. 7, H. Ev. S. Carolina : 1817

Wht. gra. 8, G. Ev, S.

.1817

Z.

7 ACINTHA, Gertner. The species was first found in the Island of Zante, formerly Zacinthus. Linn. 19, Or. 1, Nat. Or. Compositce. An uninteresting hardy annual, of easy culture. Syno. nyme: 1. Lapsana Zacintha-Z. verrucösă.

ZaLì̄ccă, see Călämǘs Zalâccă.

ZaLUż̄Nĭ́, Persoon. In honour of Zaluzianski, a Polish botanist. Linn. 19, Or. 2, Nat. Or. Compositce. A frame herbaceous plant, not worth growing. Synonyme: 1. Acmella trilobat $1-Z$. trilübŭ 1 .

ZĀMĬ, Linn. From zamia, loss; alluding to the sterile appearance of the male fructification. $L$ inn. 22, Or. 12, Nat. Or. Cycadacee. A genus of very remarkable plants, nearly related to both Ferns and Palms. The species thrive well in a light sandy soil, and are increased by suckers.

\begin{tabular}{|c|c|c|}
\hline angustiforir & & A petal \\
\hline căff́ră & & Apetal \\
\hline cycadifoliă & & - Apetal \\
\hline Cyeàdìs. & . & - A petal \\
\hline dêbillis & • & - A petal \\
\hline furfurãcèa & - & - A petal \\
\hline hörrìdă . & & A petal \\
\hline integrifolia & & - A petal \\
\hline lanuginōsă & & - Apetal \\
\hline latifólià & 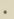 & - Apetal \\
\hline longifoliza & . & - Apetal \\
\hline mèdia. & . & A petal \\
\hline prunīféră & , & - A petal \\
\hline pūmrilă . & ${ }^{\circ}$ & A petal \\
\hline pūngēns & ${ }^{\circ}$ & A petal \\
\hline pygmвä & . & A petal \\
\hline repăndă & 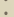 & A petal \\
\hline spinösă. & . & A petal \\
\hline spirális. & . & A petal \\
\hline tênuัìs. & - & A petal \\
\hline trident & & A petal \\
\hline
\end{tabular}

7, S. Her. P. C. G. H. S. Her. P. C. G. H G. Her. P. C. G. H. G. Her. P. C G. H. 7. S. Her. P. W. Ind. , S, Her. P. W. Ind. S. Her. P. C. G. H. 7, S. Her. P. W. Ind. G. Her, P. C. G, H. S. Her. P.

G. Her. P. C. G. H. S. Her. P.

S. Her. P. C. G. H,

S. Her. P. C. G. H.

5, S. Her. P. W. Ind.

S. Her. P.

, G. Her. P. N. S. wV S. Her. P. Bahama I
, S. Her. P. w. Ind. G. Her. P. C. G. H.

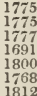

1868

1812

1775

1796

. 1814

Z ANN1CHĒLLĬ Zannichelli, a Venetian botanist. Linn. 21, Or. 1, Nat. Or. Fluviales. A hardy aquatic annual, found in ditches-Z. palüstrǐs.

ZAPPĀNY̌, Scopoli. In honour of P. A. Zappa, an Italian botanist. Linn. 14, Or. 2, Nat. Or. Verbenaceo. These plants succeed well in any light soil, and are readily increased by cuttings, under a glass. Synonymes: 1. Verbena nodiflora, Lippia nodiflora. 2. Lippia stoechadifolia-Z. nodifloră 1 , N. rơsěă, stæechadifolǐă 2.

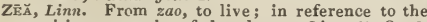
nutritive properties of the plants. Linn. 21, Or. 3, Nat. Or. Graminece. Z. MIays is the common, wellknown Indian Corn, some of the numerous varieties of which are hardy enough to endure the open air in this country.

Curăgŭ̌̆ . . . . A petal . . 6, Grass. Chile. . . 1824 Mays .: : : A petal : :6, Grass. America: : 1562

ZRBRA PLANT, see Caläthēă zebrīnă.

ZePhýĀNThĒs, Herbert. From zephyros, west wind, and anthos, a flower. Linn. 6, Or. 1, Nat. Or. Amaryllidacere. Very pretty plants when in flower. Their culture, \&c., is the same as that recommended for Amaryllis. Synonymes: 1. Amaryllis Atamasco. 2. A. candida. 3. A. tubispatha.

A tamåscō, 1 . White . . 5, H. Her. P. N. Amer. - 1629 cảndĩdă, 2 . White. 9, H. Her, P. Peru : 1829 carinătä : : : Pink : :5, F. Her. P. Mexico： 1824

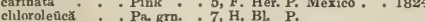

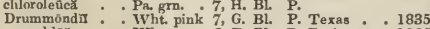
mesochlōă . : Wht. grn. 6, F. Bl. P. B. Ayres : 1825 rösèa - 337 i Red ? . F. BL. P. Havannah: 1823
Spofforthiănz striăta tubispâthă, 3 verecūnd̆̈.

4, G. Bl. P. Hybrid

White. 4, F. Bl. P. Mexico

1833

White. 5, S. Bl. P. S. Amer.

ZEXMTY Linn. 19, Or. 4, Nat. Or. Compositce. An interesting plant, succeeding in any common soil, and increased by seeds.

tagetiflōră . . Yellow . 9, F. Her. P. Mexico . . 1829

Zichr̆, Baron C. De Hugel. In honour of Countess Molly Zichy, a noble Austrian lady, fond of botany. Linn. 17, Or. 4, Nat. Or. Leguminosa. Pretty climb. ing plants, resembling Kennedya, and requiring precisely the same treatment as that genus.

Mólly

G. Ev, Tw. Swan R. , 1837 tricólor ? Red yel pur. G. Ev. Tw. Swan R. ，1837

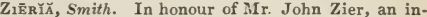
dustrious Polish botanist, who assisted Mr. Dickson in his Cryptogamia. Linn. 4, Or. 1, Nat. Or. Rutacee. This is a genus of remarkably pretty plants, thriving best in an equal mixture of sandy loam and peat, and young cuttings root readily, if planted in sand, under a glass. Synonyme: $1 . \mathbf{Z}$. Smithii.

hîrsūtă

lævigátă

macrophȳllă

microphyllá

obcordãtă

octāndră

pauciföră

pilōsă

White . 6, G. Ev, S, N. Holl

White. 6, G. Ev, S. N. Holl

White, : 6, G. Ev, S. N. Holl

White. : 6, G. Ev. S. N. Holl

White . 6, G, Ev, S, N. Holl

White , 6, G, Ev, S. N. Holl

Green . 4, G. Ev, T. N. Holl.

White. 6, G. Ev, S. N. Holl

White $6, G$, S. N. Holl

White. 6, G. Ev. S. N. Holl

1822

180

1820

1824

1825

1822

$Z_{\text {IETĒNY̌̆ }}$ see Stăchy̆s.

ZIGADĒNǓs, Michaux. Fiom zygnuo, I join, and aden, a gland; in allusion to the double glands on the perianth. Linn. 6, Or. J, Nat. Or. Melanthacee. A genus of pretty plants when in flower. They succeed best in a moist peat soil, and are readily increased by dividing the plants at the root, or by seeds. Synonymes: 1. Helonias bracteata. 2. H. glaberrima.

bracteātŭs, 1 . Cream. . 5, H. Her. P. N. Amer. . 181 commutãtŭs, 2 . Creaın . 6, H. Her. P. N. Amer. 181 ēlègans . Thite. 5, H. Her, P. N. Amer. 1828 elabrrimŭs : Cream 6 , H. glaūcǔs. : : Green : 7, H. Her. P. N. Amer.

\section{Zigotrīchĭă, see Tórtülă.}

Z1GZAG, a stem is zigzag when it bends from side to side.

Zirnă, Forskahl. The name of an Egyptian plant. Linn. 15, Nat. Or. Cruciferce. Interesting plants, growing best in a light rich soil, and readily increased by cuttings.

\section{macrocārpa}

F. Ev. S. Egypt . . 1820

ZĩNGĬ MĔR, Gartner. The Indian name. Linn. 1, Or. 1, Nat. Or. Zingiberacea. The species of Zingiber or ginger succeed best when grown in a mixture of loam, peat, and sand, and they are readily increased by division of the roots. Ginger is the root of $Z$. officinale, and is much valued for the sake of its aromatic, stimulating properties.

capitátūm . . Yellow - 2, S. Her. P. E. Ind, . 1825 Casumuñär : : Wht. yel. 2 , S. Her. P. E. Ind. : : 1807 chryøantliūm . Y Yellow . 7, S. Hex. P. E. Ind. . . 1821 elátūm. : : Yellow : 7, s. Her. P. E. Ind.: : 1820 
ligulātûm . . Pink * . 6, S. Her, P. E. Ind. . - 1823 Miögă : : Pink : 5, G. Her. P. Japan : 1796 officinale: : Red : 7, S. Her, P. E. Ind. 1605

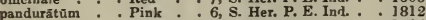
purpŭréüm : : Purple : 9, S. Her. P. E. Ind. : 1796 rơsêun . . Ro. yel. 8, S. Her. P. E. Ind. . 1822 rübēns . . . Red . . 10, S. Her. P. E. Ind. . 1822 squarrösüm . Pink . . 8 8. Her. P. E. Ind. . 1822 Zerümbêt . . Yel. grn. + 8, S. Her. P. E. Ind. . . 1690

Zìnĩ , Linn. In honour of John Godfrey Zinn, professor of botany at Gottingen. Iinn. 19, Or. 2, Nat. Or. Composita. A genus of very pretty annuals, well deserving extensive cultivation. The seeds require to be raised upon a gentle hotbed in spring, and afterwards planted in warm sheltered situations of the flower-garden. Synonyme: 1. Z. violacea.

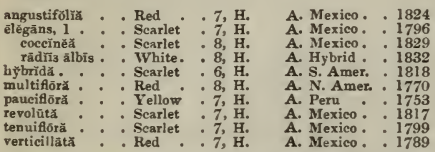

ZizĀNĬ, Linn. The Greek name of darnel. The modern plants have no relation to the ancient, being natives of America. Linn. 21, Or. 6, Nat. Or. Graminee. $\quad Z$. aquatica has been acclimated in Middlesex and Ross-shire; it grows on the margin of ponds, and is exceedingly prolific of bland, farinaceous seeds, which afford a very good meal. It abounds in all the shallow streams of North-West America, where its seeds contribute essentially to the support of the wandering tribes of Indians, and feed immense flocks of wild swans, geese, and other water-fowl. Pinkerton says, "this plant seems intended by nature to become the bread-corn of the north." - Loudcn's Encycloparia of Plants.

aquăticá . . Green - . 8, H. Aq. A. N. Amer. . 1790 Gữtáns. - Green - 7, H. Aq. A. N. Amer. . 1824

miliácés - 7, H. Aq. A. Carolina * 1816

botanist. Linn. 5, Or. 2, Nat. Or. Umbellifere.
Thing a German The species of this genus succeed best in a moist soil, and they are easily increased by dividing the roots, or by seeds. Synonymes: 1. Smyrnium aureum. 2. S. cordatum, S. trifoliatum. 3. S. integerrimum.

aйเว้า 1

cordătă, 2 : Yellow

5, H. Her. P. N. Amer. - 1699

6, H. Her. P. N. Amer. - 1597

Zızїpróră, Linn. Said to be from zizi of the Indians, and phoreo, to bear. Linn. 2, Or. 1, Nat. Or. Labiato. The species of this genus are very pretty, and the perennial kinds well suited for growing on rock-work, or in pots well drained, in light sandy soil; they are increased by seeds and cuttings. The seeds of the annual species should be $80 \mathrm{wn}$ in the open border in A pril. Synonymes: 1. Z. ser. pyllacea, Thymus lucidus. 2. Z. media, Z. serpyllacea. 3. Z. Pouschkini.

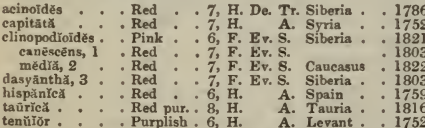

Ziž̆pHŬs, Tournefort. Zircuf, in A rabic, is the name of the Lotus. Linn. 5, Or. 1, Nat. Or. Rhamnacea. The species of Zizyphus are all very pretty, and deserve to be grown in every collection of plants. The stove and greenhouse species thrive well in loam, peat, and sand, and ripened cuttings root readily in sand, under a glass. The hardy kinds are well fitted for shrubberies, and are easily increased by ripened cuttings, planted in soil, with a glass over them, or by slips of the roots. The fruit of $Z$. Jujuba and Lotus is very excellent, and is partaken of by all classes of people, in the enuntries to which these species are indigenous. It is sweet and mealy. Synonymes: 1. Rhamnus
Jujuba. 2. R. Lotus. 3. Z. bubalina. 4. Z.sororia. 5. Rhamnus Ziryphus.

ălbêns - Grn. yel. - G. Ev. S. China $\quad$ - Go Caracūttä: Grn. yel. : 5, S. Ev. S. Mysore: 1823 flexuousă : : Yelsh.: H. De. S. Nepal : 1820 incürvă . . Grn. yel. - H. De. T. Nepal : 1823 Jujūbă, 1 . . Pur. grn. . 4, G. Ev. S. E. Ind. . . 1759 Lơtŭs, 2 . . Grn. yel. F. Ev. S. Africa : 1731 mucronătă, 3 : Yel, gm.: G. Ev. S. C. G. H.: 1810

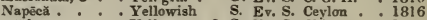
nitrda : : Yellow . 6, S. Ev, S. China : 1822 Enōplǐa : : Grn. yel. : S. Ev. S. Ceylon sinēnsis. . White. 5, F. Ev. S. China spīnă-Chrîsti . . Gro. yel. . 8, H. Ev. S. Egypt inêrmis . . Grey : 8, H. Ev. S.

trinērvĭa, 4 . Grn, yel. S. Ev, S. E. Ind. 1891

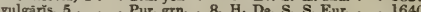

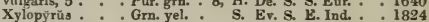

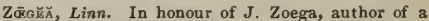
"Flora Islandica." Linn. 19, Or. 3, Nat. Or. Composite. A worthless hardy annual-Z. Leptaurěă.

Zon̄̄ñ̆, Agardh. From zona, a girdle; transverse lines. Linn. 24, Or. 7, Nat. Or. Alga. Marine plants-Z. atomärăă, dichotömŭ, D. intricätă, mul-

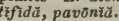

ZoNATE, having a dark belt in the shape of a horseshoe.

ZoNBs, stripes or belts.

ZörNî̀, Gmeliu. In honour of John Zorn, once an apothecary at Kempten, in Bavaria, a botanical author. Linn. 16, Or. 6, Nat. Or. Leguminasa. Interesting plants. For culture and propagation, see Myriadenus. Synonymes: 1. Z. diphylla. 2. Hedysarum tetraphyllum. 3. Z. diphylla ciliata. 4. Anonymos bracteata, Hedysarum tetraphyllum.

angustifolia, 1 . Purple . 7, s. A. India . 1733 capensis, $\mathbf{2}$ : Yellow: 7, G. Her, P. C. G. H.: 1824 dietvocarpa : Yellow: 7, S. Her. A. N. Holl. : 1820 glochidiata. : Yellow : 7, s. A. Guiana : 1823 reticulata, 3, : Yellow : 7, s. A. W. Ind. 1810 tetraphyllä, 4. Yellow : 7. G. Her. P. Carolina : 1824 geyloningis, Yellow , 7, S. A. Ceylon. 1825

Zostīßă, Linn. From zoster, a riband; the leaves. Linn. 1, Or. 1, Nat. Or. Fluviales. This pretty aquatic is found in ditches.

marină . . A petal . 8, H. Aq. P. Rritain .

ZozimǏ, Hoffman. In honour of A. N. and Z. Zozima, distinguished editors of the Greek classics. Linn. 5, Or. 2, Nat. Or. Umbelliferc. A mere weed. Synonyme: 1. Heracleum absinthifolium-Z. absinthiföliă.

Z YGNËмĂ, Agardh. From rygos, a yoke, and nema, a filament ; flaments jointed together in pairs. Linn. 24, Or. 7, Nat. Or. Alga. The species of this genus are found in rivulets, ditches, \&c.-Z. bĭcólor, cruč̃atฉm, C. brěvi-urticulätâm, C. löngi-articulätūm,

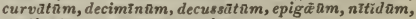
pectinüt $\pi m$, punctatnm, quinżñm.

Z roŏnō, Hooker. From zygos, a yoke, and odous, a tooth, the teeth are yoked together in pairs. Linn. 24, Or. 5, Nat. Or. Musci. A pale-green species of moss, found on the trunks of trees. Synonyme: 1 . Mnium conoideum-Z conoz̃dẽăm.

Z YGoPǩтǍLŪM, Hooker. From zygos, a yoke, and petalon, a petal; in allusion to the adhesion of the segments of the perianth by their bases in the original species. Linn. 20, Or. 1, Nat. Or. Orchidacece. This is a genus of extremely beautiful and fragrant plants when in flower. They are easily cultivated in a damp heat, and must in all respects be treated similarly to the genus Stanhopea. Synonyme: 1. Z. crinitum, Eulophia crinita.

cochleără.

Mâckãy̆ .

Wht pur. - 8, S. Epi. Demerara

crinitūm, i : Wlt. grn. : 9, S. Epi. Brazil : : 1829

maxilläré : Brn. grn. 9, S. Epi. S. Amer. : 1829

Murrayānúm . . Gm. wht. . 7, S. Epi. Brazil . : 1837

rosträtüm * . Wht. brm. 9, S. Epi. Demerara * 1827

ZyGophȳuLū, Linn. Frum zygos, a yoke, and phyllon, a leaf: the leaves are in pairs. Linn. 10, Or. 1 , Nat. Or. Zygophyllacea. The species of this genus are all very handsome when in flower. The stove and greenhouse species should be grown in a mix. ture of loam, peat, and sand, and are readily in creased by cuttings, in sand, under a plass, or by 
seeds, when these can be obtained. Z. Fabago grows well in any light soil, in a dry situation; it can only be increased by seeds, which should be sown in a pot, and placed in a frame, and when the plants are large enough, they may be planted out in the open border, in a warm, dry, sheltered situation.

albūm . . . White . 10, S. Ev. S. Canaries , 1779

Scarlet 1823

cordifóliũm : : Orange : 10, G. Ev, S. C. G. H. : 1774

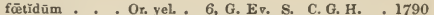
insuăvé: :Yellow: 7, G. Ev. S. C. G. H. : 1790 maculătūm : Yellow: 10, G. Ev. S. C. G. H. : 1782 microphÿllüm : Yellow: 7, G, Ev, S. C. G. H. : 1816 Morgsānă - Yellow : 8, G. Ev. S. C. G. H. : 1732 prostrátủm * Yellow * 7, G. Evv. Tr. C. G. H. : 1810 sessiliföliúm : Yellow 7, S. Ev, S. C. G. H. 1713 simplēx 18.05

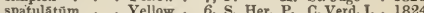
spatulatum 


\begin{tabular}{|c|c|c|c|}
\hline $\mathrm{ABU}$ & ECH & ECI & $A G A$ \\
\hline
\end{tabular}

\section{SUPPLEMENT.}

[THE lapse of time consequent on the passage through the press of a work of this description and extent, has necessarily caused the omission of many plants that have been discovered or described since its commencement. All of these that have hitherto (June 1840) been made known, are now inserted in due alphabetical order. Those new genera upon which no remarks are supplied, have not yet fallen beneath our observation, and we are unwilling to furnish any unauthenticated accounts.]

Asû́ TY̌̆ŏ, Maench. A Arabic name of a plant analogons to the marsh-mallow. Linn. 16, Or. 8, Nat. Or. Malvacece. "It is a greenhouse shrub of the easiest culture, and of great beauty."-Bot. $R e g$.

striàtūm . . Orange all, G. Ev. S. Brazil . .

\section{Асйстัй.}

astrīngēns . .

cultráta

cuneătă. : : Yellow

cyanophyllă : : Yellow

depēndēns

lioloserices:

humifũsă

Kermesin * *

Kermesina . . Purple

leptocārpa

liguläta. .

neurocár pa .

persnoninides

pulchellix

māgna

Riceinà

nericăt

Simsin :

spectabilis..

umbeliată

viminklis

vomeriformis.

xylocârpă

Aç̄⿰冫广.

oplēndēns

G. Ev, S. N. S, IV. G. Ev. S. N. Holl. G. Ev S, Swan R G. Ev. S. Swan R G. Ev. S. N. Holl. G. Ev. S. V. D. L. G. Ev. S. N. Holl. G. Ev. Tr. N. Holl. S. De. S.

G. Ev. S. N. S. W

G. Ev. S. N. S. W

G. Ev. S. N. Holl.

G. Ev. S. N. Holl.

G. Ev. S. N. Holl.

Yellow

G. Ev. S.

Yellow

3. G. De. S.

G. Ev. S. N. Holl.

G. Ev. S. N. Holl

G. Ev. S. N. S. W

G. Ev. S. N. S. WV

G. Ev. S. N. Holl.

G. Ev, S. N. Holl.

G. Ev, S. N. Holl

G. Ev. S. N. Holl.

G. Ev. \$.

Ā Č̆R.

campẽstrơ

austrĭ̌cữ . . Grn. yel. . 6, H. De, T. Austria hebecărpūm . Grn. yel. . 6, H. De. T. Britain lævigatūm . Grn, yel. $6, \mathrm{H} . \mathrm{De} . \mathrm{T}$

nănüm . Grn. yel. . 6, H. De. S.

AchIr.t.̄.̆. Synonyme: 1. A. amana.

Millefơliūm

variegata - White - 8, H. Her. P. Gardens vermicularis, 1 : Yellow: 8, H. Her. P. Russia.

Aconītē .

ochrânthüm - Yellow . 8, H. De. P. Russia .

ACRRMôxบ̄êM-alternūtũm.

Acrōstĭchüm.

asplenifơlīum . citrifoliúm . jugl+ndifoliùm latifolrūm . nicotianifoliūm Scolopëndrîum Brown

S. Her. P. Brazil Blue. , S. Her. P. W. Ind. S. Her. P. Surinam S. Her. P. Jamaica

\section{A cTINōTŭs.}

leucocẹphảlūs . .

Brown . 10, S. Her. P. W. Ind

Brown : 8, S. Her. P. W. Ind.

A diĀntūM.

æethiōpičum . Brown

concīnnūm : : Brown

fabellifoliunm : Brown

foliōsūm : Brown

Foviănūm: : Brown

lūeid ũmm : "Brown

Moritzĭañūm: Brown

obliquūm : : Brown

Swan R.

1837

9, S. Her. P.

6, S. Her. P. N. Holl.

9, S. Her. P. Jamaica

8, G. Her. P.

5, S. Her. P. W. Ind.

8, S. Her. P. S. Amer. : 1824

S. Her. $\mathbf{P}$.

S. Her, P. W. Ind.

1838

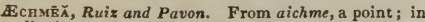
allusion to the rigid points on the calyces. Linn.
6, Or. 1, Nat. Or. Bromeliacece. These plants require to be grown in a compost of loam, peat, and sand.

Mertēnsī. . Gm. red . 3, S. Epi. Demerara . 1830 suaré̆lēns : Pink : 4, S. Her. P. Brazil : 1838

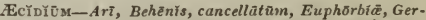
änīi, Orobĩ, quadrŭfidùm, Soldanëllë, Valerianace. ārâm.

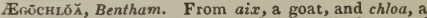
green herb; alluding to the fetid smell of some of the species. Linn. 5, Or. 1, Nat. Or. Polemoniaced. For culture and propagation refer to the genus Gilia.

atractyloĩdès - Blue . . H. A. California . 1833 eryngioides $*$ Blue pubèseéns : : : Blue : : H. H. A. California : 1833

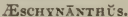

ramosissimŭs . . Scarlet . 6, S. Epi. Khoseea . . 1837 ÄscŭLǔs.

Hippocåstăn uีm

fiôréplēnô . White . 3, H. De. T.

fol. argentels : White : 3, H. De. T. Gardens

Eтhêrĭ. Linn. 20, Or. 1, Nat. Or. Orchidaced. Synonymes: 1. Goodyera occulta, Platylepis Goodyer. oides.

oceūltă, 1 . . . Wht. grn. 10, S. Ter. Manritius .

AganIsť̆, Lindley. From aganos, quiet, or desirable; in allusion to the pretty, neat appearance of the plant. Linn. 20, Or. 1, Nat. Or. Orchidacea. In sneaking of the cultivation of this superlatively pretty plant, Dr. Lindley remarks : "In order to cultivate this plant successfully it should be sus. pended upon a block of wood from the rafters of the stove, and its thick fleshy roots allowed to hang in the air and imbibe its moisture. A damp atmosphere, syringing its roots and leaves freely when in a growing state, and shade during bright sunshine, are the principal requisites in its cultivation. In other respects it may receive the same treatment as the rest of this tribe." - Bot. $R$ eg.

pulchellă . . Cream . . 6, S. Epi. Demerara .

AgĂRǏcŭs-adipōsŭs, areolātūs, atomātūs, balanīnŭs, bîfrōns, bländūs, bolärìs, bullīicě̃us, calypträförmis, camptophyllūs, Candolleânūs, Centũneũlüs, cerảsĩnũs,

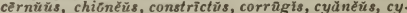
phelliformis, decolörūns, deflüēns, $D$, rñbidìs, elätüs, erubēscēns, erythröpüs, excëlsüs, fönisēcï, fibrillosŭs, flocculosūs, fuliginosüs, fumósũs, homatophy̆llüs, Hookērī, hypnophìlüs, iliopðdiūs, imbricūtius, inamǟnüs, Irǐs, lascīvǔs, lëntüs, limônnŭus, livido-ochra.

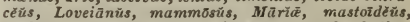

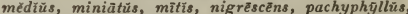
paupërcülüs, pelianthřnŭs, phyllöphīlüs, polystïctüs.

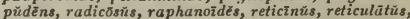

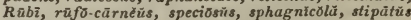
solităriǔs, S. graminéūs, striätülŭs, striätŭs, tenēr rìmйs, trechisporŭs, undätüs, unguinōsüs, vălìdüs, vitellīnŭs.

$A \in \bar{A} \vee \bar{B}$.

êlĕgāns . • . S. Her. $\boldsymbol{P}$.

glaucéscēns : $\quad$ G. Her. P. Mexico . . 1835

polycanthoidè: : $\quad$ G. Her. P. Mexico : 1835

$[340]$ 
pulchërrimă $\quad$ G. Her. P. Mexico, 1835 saponáría.: Gru. yel. . G. Her. P. Mexico:

A Grostล̄Mmă.

suêcǐcă . . . Pink . . 8, H. Her. P. Šweden . 1824

A GRōsrǐs.

èlégăns . . Apetal . . 6, Grass. Russia . . 1834

A rrôpsìs.

pulchëlla . . Apetal . 3, Grass.

.1831

A JŪGă.

rēptāns

variegata . Blue . 4, H. De. Cr. Britain. .

A LeURítËs.

cordātā . . Apetal . S. Ev. T. Japan . . 1818

A Li.ANTōDĩă.

strigōsă . . . Brown all, S. Her. P. Madeira

ĀLLǏ̃̃ M.

pũlelı̃ūm . . Yellow . 6, H. Bl. P. S. Eur. .

Ā LNČs.

barbātă .

jorullënsis .

subcordàtă .

H. De. S. Russia . 1838

H. De. T. Mexico.

H. De. S. Russia : 1838

A I.š̃ñ.

laricifolìă .

H. Her. P. Siberia . 1834

A lstromărĭ́ă

acutifólià

tūreà - Yellow . 9, F, De. Tw.

Barclayănă . Orange . 7, F. Tu. P.

Berteroānă , Pa, pk. 7, F, Tu, P.

bieólor. : 9, S. Tu. P. Chile: 1826

chilensis : Pink F, Fu P. Chile:

Errembaultin : Wht. spot 8, F. Tu. P. Hybrid 1835

A LTernanthễă

filifōrmīs . .

nodiflōră

A LFssî̀.

mierānthüm - Yellow - 8, H. Ev. Tr. Russia * . 1836 orientālé

variegātūm . Yellow . 4, H. Ev. S. Gardens

procūmbẻns . H. Ev. S.

AMART̄LLIS.

psittacīnă

hybrídă . . Red. grn. . 4, S. Bl. P. Hybrid .

A MELĀNCHĬ ĔR.

flöridă * . White - 5, H. De. T. N. Amer. . 1826 parvifoliă : White : 5, H. De. S.

ovālǐs

semi-integrifolia White . 5, H. De. T. N. Amer.

subcordata . White . 5, H. De. T. N. Amer.

A MŌRPH

fruticósă

angustifóliă . Purple . 6, H. De, S

cerüleă . Blue 6, H, De.

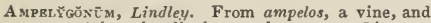
gonu, a joint; in allusion to the stems. Linn. Or. -, Nat. Or. Polygonaceœ. This plant has lately flowered in the garden of the Horticultural Society, where it has been raised from seed received from Dr. Falconer of Saharunpur. It forms a spreading herbaceous plant, from one and a half to two feet high, with ovate-lanceolate, acuminate, stalked leaves, and with small heads of yellowish-white, fleshy flowers, which are succeeded by a black, succulent fruit. This latter circumstance has led to the establishment of a new genus, to which a name indicating its grape-like fruit has been as. signed.

chinènsé . . Ysh. wht. 8, G. Her. P. Saharunpur

A мрнісомм $\breve{\mathrm{k}}$, Royle. From amphi, around, and kome, hair; in allusion to the seeds. Linn. 14, Or. 2, Nat. Or. Bignoniacea. An elegant perennial, probably hardy enough to stand out, if planted in any dry situation, or on rock-work, and protected during winter from the wet and most severe frost by a hand-glass. It is very impatient of wet even in summer, and requires to be kept particularly dry during winter; it thrives best in a loamy soil, with a small portion of sandy peat added, and may be increased by seeds or cuttings. The seeds should be sown in February, in a loamy soil, and placed in the greenhouse. Cuttings of the young shoots strike at any time from March to September, but rather slowly.

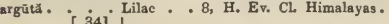

A Msīnckĭ Lĕ, Lehmann. Meaning unknown. Linn. 5 , Or. 1, Nat. Or. Boraginaces. The seeds of these plants only require to be sown in the open ground, about the beginning of May, in a dry, warm, sheltered situation. They are not worthy of cultivation, except in botanical gardens-A. angustifoliă, lycopsĩotiěs.

AM พॅ̈GD̆LLัs.

pedunculāts . . H. De. S

.1833

Anacrerũs.

pỵrêthrūm . . . H. Her. P.

A NAGÃLLIS.

Monēllī

lilacină . . Lilac . 5, G. Her. P.

1836

A NiRIL ĒMă.

crispătă

G. Her. P. N. Holl.

1822

ANRIMIÁ.

longifoulĭa . . Brown . 8, S. Her. P. Brazil .

rădieăns : : S. Her. P. Brazil

ANĔMōn Ě.

hortēnsis

miniātă . . Brt. red . 5, H. Tu. P. Gardens

nemorōsă

cærūleă . . . Lgt, blue . 5, H. Tu, P. Gardens

Pulsatillă

albǐd:

rübră

virginiână

grandiflöră

ANGELONลัĂ.

Gardnērī .

A NGR F̄EẼ M.

armenlăcūin .

gladiifolǐum.

Whitisl - 4, H. Her. P. Germany

Redsh. 5 , 1834

White . 6, H. Her. P. Gardens

Wht. pur. 5, S. rier. P. Pernambuco 1838

White. S. Epi. Mauritius:

AxICrĀNgī

ANIgozÃNThŏs.

coceiněŭs . . Crimson . 7, G. Her. P. Swan R. . 1837

flăvĩdùs

bǐcōlör . . Scar. grn. . F. Her. P. Swan R. . 1837

hümìlis, 1 : Brown - F. Her. P. Swan R.

Manglēsī

angustifoliŭs : Grn, red . 6, G. Her. P. N. Holl. . 1836

Anôtřs, Decandolle. From $a$, privative, and ous, an ear; teeth to calyx. Linn. 4, Or. 1, Nat. Or. Rubiacea. "A pretty little plant, which will flower from June to September, in the open border, or on rock-work, for which it is remarkably well adapted."-Gard. Mag. It requires the protection of a frame or greenhouse during winter, and may be increased by dividing the root. Synonymes: 1 . Hedyotis ciliolosa, Houstonia ciliolosa.

ciliolōsă, 1 . . Pa, lilac . 7, F. Her. P. N. Amer. . 1832 Anтнӗмйs. Synonyme: $1, A$ porrigens.

mucronulātă, 1. . H. A. Italy . . 1836

Aхтнйllis. Synonyme: 1. A. italica.

Vulneráriă

hirsutīssīmă, 1 Red . . 7, H. Her. P. Furope . . 1816

Antirrhīnề.

mājüs

earyophylloĩăs Sear. striped 8, H. Her. P. Hybrid . ochroleũcüm . . Pa, yel. . 7, H. Her. P.

AōTuัs.

grăcilìs . . . G. Ev. S. N. Holl. - 1820

A pLotĀxiss. "A handsome herbaceous plant which has lately been introduced by the East India Company. It forms a bush about three feet high, with long, lanceolate, deep green leaves, hoary with down on the under side. The flower-heads are arranged in a panicled manner, and are narrow, with pale, bright, purple blossoms."-Bot. Reg.

albēscēns . . Purple . 7, H, Her. P. India . . 1837 AQUilĔoǏ̃.

āretĩeă . . . Red yel. . 6, H. Her. P. Siberia . canadēnš̌s

lateă. * Pa. yel. . 5, H. Her. P. N. Amer. . 1835 glandulōsă

discōlör .

leptocerās :

6, H. Her. P. Siberia . . 1789

vulgărìs

H. Her, P. Russia: : 1838

èlègăns

ĂR̆BǏs.

allbrida

variegată . White. . H. Kv. Tr. Gardens 


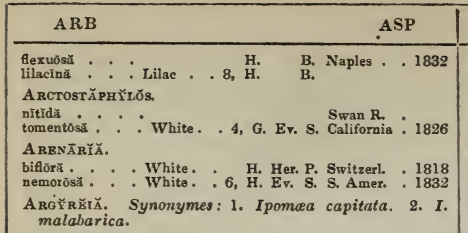

capitãtă, 1 . Purple . 7, S. Ev, Tw. E. Ind. . 1823 Malabarică, 2 : Cream. : 7, S. Ev. Tw. E. Ind. : 1823

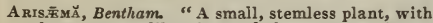
tuberous roots like those of the common Arum, purple stalked pedate leaves, and a pink or purple spathe from tive to six inches long. It will probably form a greenhouse herbaceous plant. Mr. Hartweg found it in shady woods near Morelia flowering in July, and sent it to the Horticultural Society, with whom it has been raised."-Bot. Reg.

macrospãthă . . $\quad$ 7, G. Tu. P. Morelia 1839

Ar1stoLōchĬ

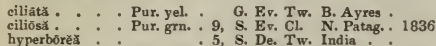

ARMgNǏ̆c̆ Synonyme: 1. A. pedunculata.

vulgăr̆s

flôrể plènō, 1 . White. . 4, H. De. T

fol. variegátis: White. 4 , H. De. T

A RMĒrita.

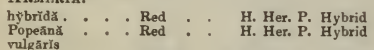

ålbă . . . Whito. . 9, H. Her. P. Gardens

cocciněă : : Red : 9, H. Her. P. Gardens

Arpophỹllōm, ra Llave. Linn, 20, Or. 1, Nat. Or. Orchidacea. "One of the most graceful and beautiful of the Mexican Orchidacex; recently introduced. The stem is slender and a foot or a foot and half high, with the sheaths as rough as shagreen leather; it is terminated by one long, curved leaf, from the axil of which there curves, in an opposite direction, a dense spike of pink, or pale purple flowers. It is a species of great rarity even in Mexico, where it has hitherto been only seen at Sultepec and near Arimbaro, growing upon trees," -Bot. Reg. The genus belongs to Epidendrea, and may therefore, probably, be referred to the other genera of this sub-order for cultivation, \&c.

spicătūm . . Pink . . S. Epi. Mexico . . 1838

A RTRMǏš̃̆.

A brơ̆tănūm

hūmilè . . Yel. grn. . 9, H. De. S. S. Eur. . .

tobolskrănử Yel. gro. 9 , H. De. S.

aprieă :

H. Ev. Tr.

vulgăriss

variegata . Purple . 8, H. Her. P. Gardens

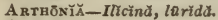

ART̃.

sarmentōsũm .

S. Hex. P. Brazil . 1835

Arondīnă, Blume. From arundo, a reed; resem. blance. Linn. 20, Or. 1, Nat. Or. Orchidacea.

bambusifolra - Purple . S. Epi. Nepal

Asagr $\bar{\mp} \check{A}$, Lindley. In compliment to Dr. Asa Gray, the author of a treatise upon North American Melanthaced. Linn, 6, Or. 3, Nat. Or. Melanthaced. A plant of not much beauty, the culture and propagation of which is, we believe, similar to that of Tigridia. Synonymes: 1. Helonias officinalis, Veratrum officinale.

offieinaliss, 1 . . White - 9, F. Bl. P. Vera Cruz .

A scơво̆цŬs-ciliātūs, glāběr, Trifolī, vinossüs.

A sperocōccǔs, Lamour. From asper, rough, kokkos, seed; rough surfaced. Linn. 24, Or. 7 , Nat. Or.

Alga. This species is found on rocks-A. compressurs.

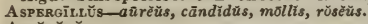

A SPĔRŬLă. scutelları̌s
tyrăică A sphŏDǨ̆ Ŭs.

cspillăriss. . . Pa. yel. . 6, H. Her. P. S. Enr.

microcărpŭs : :

ASP

AZA

Aspidīstră.

elătrờ . . . Brown . 10, S. Her. P. Japan . . 1835

variegátå : Brown : 10, S. Her. P. Japan : 1835

A șT̃̃̆̃̄a.

crinitum . . Brown . 8, S. Her. P. Maurit. . 1831

CunninghâmI Brown

drepanum : : Brown

Goldiānūm: : : Brown

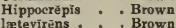

7, G. Her. P. N. Zesl. P. Madeira

1831

retevirèns

8, H. Her. P. N. Amer.

4, S. Her. P. Jamaica

aspērrimă : Brown

lücēns ârrimà : Brown

púcēns

proliferūm . : Brown

pũngëns : . Brown

G. Her. P. Madeira

7, H. Her. P. N. Amer.

S. Her. P. Maurit.

G. Her. P. W. Ind.

S. Her. P. Brazil

G. Her. P. WV. Ind.
G. Her. P. W. Ind.

A spl.̄̄ñ̌̃ M.

alātūm

. Brown

smbǐgŭuีm: : Brown

auritum : : Brown

biauritūm : : Brown

cuneãtûm . . Brown

deprèssũm . . Brown

obtusifoliūm . Brown

púlehrüm : Brown

s. Her. P. W. Ind.

G. Her. $P$, W. Ind.

9, S. Her. P. S. Amer.

7, s. Her. P. W. Ind.

9, S. Her. P. W. Ind.

, S. Her. P.

7, S. Her. P. Jamaica

salicifölium : Brown 7, s. Her. P. W. Ind.

AstīLǏ̆, R. Brown. From $a$, without, stelechos, a stem.

Linn. -, Or. - Nat. Or. Asphodelede. A curious

plant, with the flowers of which we are unacquainted. It thrives in the greenhouse, in a light loamy soil, and produces an abundance of offsets. These, if detached, and planted either in sawdust or very porous earth, with a slight bottom heat, will speedily form roots.

Bănksĭ .

N. Zeal. . 1837

AstĒR.

bessarăbìcūs . . Purple . 9, H. Her. P. Russia . . 1834

AstrRAcĀNThx̆. From aster, a star, and akantha, a spine. "This is a handsome, greenhouse, herbaceous perennial, seeds of which were sent to the Horticultural Society by Mr. M'Culloch, one of the gardeners to His Highness the Pacha of Egypt. If care is taken to reduce the vigour of leaves, by not giving the plant too much shade and moisture, it becomes very handsome, but if it is permitted to run 'to leaf' too much, its beauty is considerably impaired."-Bot. Reg.

longifơlia . . .

G. Her. P. Egypt . .

AstrRoč̆pan̆lǔs.

bannăteuัs

albǔs . . . White - 7, H. Her. P. Gardens

A STERŌMñ-reticulatã $m$.

A străgăLớs.

calycinuัs

dasyănthüs

hymenocårpŭ

hypoglōteìs

albe :

macrocèphălŭs

Schangiñัăñ̆.

strobiliferŭs

sylvìcolŭs

8, H. Her. P. Caucasus . 1819 6, H. Her. P. Hungary : 1819 Yellow . 7, H. Her. P. Russia . 1835 - Whita

6, H. De. Tr. Gardens

H. Her. P. Siberia . 1832

H. Do. Tr. Caucasus . 183

H. Her. P. Siberis . 1832

A TBLÃNDR.̆. Derivation unknown. Linn. 14, Or. -

Nat. Or. Labiatoe. A pretty shrubby plant, not yet thoroughly known in this country, but doubtless requiring a compost of loam and peat, and propagating by cuttings.

incanx. . Slate

G. Ev. S. Swan R.

A тн А

ATRĂGĔN

macropètăla

H. Da. Cl. Russia . . 1831

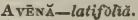

Azẵ.̌̆̃̆.

Indică

latertitax - Brick . G. Ev. S. China • 1833

Rawsōni : Crimson : 5, H. Ev. S. Hybrid : 1833

speciōsä. : Purple : 5, G. Ev. S. Hybrid : : 1830

splêndêns: : Red : 2, G. Ev. S. Hybrid : : 1835 nudiflöră

eximĭ . . Crimson . 4, H. Ev. S. Hybrid . . 1839

pōntǐcă .

årdēns: : Brt red . 5, H. Ev. S. Hybrid .

ärens : : Brt red : 5, H, Ev. S. Hybrid: 1834

căndida.: - White. 5 , H. Ev. H. Hybid "

coronăria : Yellow . 6, H. Ev. S. Holland • 1832 [ 342 ] 


\begin{tabular}{|c|c|}
\hline $\mathrm{BAB}$ & BER \\
\hline
\end{tabular}

mũltíplěx . Purple . 6, G. B1. P. C. G. H. . 1834

Bactrīdīè, Kunze. From baktron, a staff, and eidos, resemblance. Linn. 24, Or. 9, Nat. Or. Fungi. Found on the horizontal surface of stumps-B. atrovirëns.

BАЕ̄RĬ, Fischer and Meyer. In honour of Professor Baer, of the university of Dorpat. Linn. 19, Or. Nat. Or. Composite.

chrysostŏmă . Y Yellow . 5, H. A. California . 1835

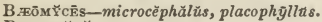

BAISAMĨN.

Mastersiānă . Purple . 7, S. A. Khoseea Hills 1837

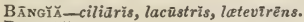

BĀNKSĬ.

Hugèlī . . G. Ev. S. N. S. W. , 1837 ilicifoliă : : G. Ev, S. K. G. S. : 1837 Menziēsin : : : $\quad$ G. Ev. S. Swan R. : 1837

BA pTĭš̃̆.

versīcőlör . . Li. puz. - 7, H. Her. P. N. Amer. . 1824

BARBĀR̄̄ Ă-arcuātă, orthocērŭs.

BARKB̈RĬ, Knonles and Westcott. In honour of G. Barker, Esq., of Birmingham. Linn. 20, Or. Nat. Or. Orchidacea. "An elegant little Mexican Orchidaceous plant, with tapering fleshy stems like those of a meagre Cycnoches, narrow-lanceolate, acuminate, membranous leaves, and a terminal inflorescence, in the form of a racemenf a few large bright pink flowers. It is well figured in the Floral Cabinet, and is one of the few plants which rival the Cattleyas in gaiety of appearance. It is, however, said to be difficult of cultivation, and is at present of great rarity. The genus is well distinguished from Cattleya, to which it approaches most nearly, by its lip being flat and undivided, instead of cucullate, and more or less completely three-lobed, as well as by its peculiar habit.-Bot. Reg.

Elęgans . . . Lgt. pink. S. Epi. Mexico . . 1836

BatĀtĀs, Choisy. According to Rumphius, a Malay, and to Neiremberg, a Mexican word. Linn. 5, Or. 1, Nat. Or. Convolvulacea. The species of this genus are strong, free-growing plants, requiring room to spread; and, being tuberous rooted, they shouldb kept dry when in a dormant state. Light rich soil suits them, and young cuttings strike readily under a hand-glass, in heat. Synonymes: 1. Ipomaa bignonioides. 2. I. Cavanillesit. 3. I. Batatas. 4. I. glaucifolia. 5. I. heterophylla. 6. I. eriosperma, I. gossypifolia, I. insignis. 7. I. pentaphylla. 8. I. senegalensis. 9. I. ternata. 10. I. venosa. 11. I. Willdenovii.

betảcĕă - . Pa vio. - G. De. Tw. Demerara

bignonioidès, 1 . Drk. pur. . 7, S. De. Tw. Cayenne . 1824

Cavanillessir, 2: Wht red . 8, S. De. Tw. 1815

edũlis, 3. : Wht. \& pur. S. De. Tw. E. Ind. : 1797

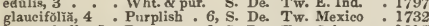

heterophyllă, 5 . Pa. pur. : 9, S. De. Tw. Cuba *:1817

panieulata, 6 : Purple : 7, S. Tw. P. E. Ind. : 1799

pentaphyllă, 7 . White. 8, S. De. Tw. E. Ind. - 7339

senegalënsis, 8 . White : 7, S. De. Tw. Guinea: 1823

ternătă, 9 . White. - 7, S. De. Tw. Brazil : 1824

venōsă, 10 : Purple:7, S. De. Tw. Mauritius 1820

Willdenōrir, i1: Purple :7, S. De. Tw. 1818

BEGŌNIัĂ.

S. Fv. S. Brazil - 1899

Barkēí. : : White , 1, G. Her. P. Mexico: : 1837

eastaneifoliă : S. Ev. S.

Drēgri : : S. Ev. S. $\quad$ : 1838

fagiforia : : - S. Ev. S. $\quad$ S. 1838

Meyërī * * :White . 5, S. Ev. S. $\quad$ S. 1830

parviroliă : : White: :9, S. Wv. S.
sinuătă : : White. : 6, S. Ev. S.

vitifoliă.

White: $\mathrm{s}$.

integrifơlĭă . Wht, pksh. 7, H. A. Texas . . 1834

BĒLLับิ M.

intermědrüm . White . 8, H. Her. P.

BвLôñ̌, Carmichael. From belone, a needle; in allusion to the acicular filaments. Linn. 24, Or.7, Nat. Or. Alga. Found on decaying marine Algæ tomulossu.

B̄̄RRĔRǏs.

floribūnda

$$
\text { [ } 343 \text { ) }
$$

BES

BOS

mitis

virgătă.

- Yellow

H. Ev, S. N. Amer. . 1834

vulgārĭ̊

dūlciss . . Yellow

5, H. Bv. S. Austria

BĒsš̆rĂ, Schultz. Named after Dr. Besser, Professor of Botany at Brody, and author of an enumeration of the plants of Volhynia, Podolia, \&c. Linn. 17, Or. 3, Nat. Or. Liliacee. These plants require to be grown in a mixture of peat and sand, to be liberally supplied with water, and kept perfectly dry and cool when the leaves wither and fall off, until next season. They are propagated by offsets. Synonyme: 1. Pharium fistutosum.

èlęgāns * : Searlet :9, G. Bl. P. Mexico .

1831

Вётск к̆ӑ, Decandolle. In honour of M. Betcke, who has described many species of Valerianella. Linn. 3, Or. 1, Nat. Or. Valerianacece. The seeds only require to be sown in the open ground in May, in a sheltered situation. mājŏr

samollfơlir.

- 8, H. A.

A. Chile

1836

Bвто̆NĬсӑ.

serǒtǐnă . . Red . . 8, H. Her. P. Austria . 1832

B̄̄TŬ1.Ă. Synonymes - 1. Betula urticifolia. 2. B. laciniata. 3. B. pendula.

alb

fóliis variegătis Apetal urticifolĩa, 1. A petal grändis .

palléscēns : A petal

papyräcēă

platyphȳllă . A petal

trichoclẳä . A Apetal

populifólĩa

laciniată, 2 . A petal

pēndülă, 3 . A petal

Scopolii : : Apetal

BīDĒxs.

coronată

BITRENĀRĬ.

longicōrnǐs .

BIGNōกัม.

adenophyllă

serrulattá

5, H. De. T.

H. De. T. N. Amer. , 1834

H. De. S.

6, H. De. T.

6, H. De. T.

7, H. De. T.

H. De. S.

8, H. B.

1829

BILI.A RDTĒRĂ

daphnoìdès . Yel. mur, , G. S

Biscutâñ

Br.̄̄chNêm.

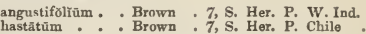

BนĒTř̆.

Parkinsōni . . Rose . . 1, S. Ter. Mexico

1838

BOERHĀ̄vĩă.

mutäbrrs . .

$10, \mathrm{~S}$.

P. N. Holl.

1821

BоLBopHF̆LL̃ M.

apifërūm - . Drk, red. - 5, S. Epi. Gambia R.

1835

. Chocol. S. Epi. S. Leone.

BoLËTưs-călōpūs, larǐcīnūs.

BōRน̆

scirpoīdę .

Bossı $\widetilde{\AA}$, Ventenat. In honour of M. Bossieu Lamar. tiniere, a French botanist, who accompanied the unfortunate La Peyrouse round the world. Linn. 16, Or. 6, Nat, Or. Leguminosue. The species are neat, elegant plants when in flower, and will thrive best in a mixture of turfy loam, peat, and sand; but care must be taken that the pots are well drained, as nothing injures them more than too much water. Cuttings of the half-ripened wood will strike, if planted in a pot of sand, under a glass.

Yellow 5, G. Ev, Tr. N. Holl, einerrěă : : Yellow : 6, G. Ev. S. V. D. L. 1802 cordifoliă : Yellow : 5, G. Ev. S. N. Holl, : 1820 ensătă . - Yellow : 5, G. Ev. S. N. Holl. : 1824 K. G.S.: 1837 foliōsă : Yellow . 5, G. Ev. S. N. Holl. 1824 heterophylla: Yellow:9, G. Ev, S. N.S. N. 1792 , G. Ev. S. N. Holl, * 182 Orange - 8, G. Ev. S. N. Holl. - 1803 mierophyllä . Yellow . 7, G. Ev. S. N.S. W. . 1803 prostrátă : : Yellow : 8, G. Ev. Tr. N. S. W. : 1803 


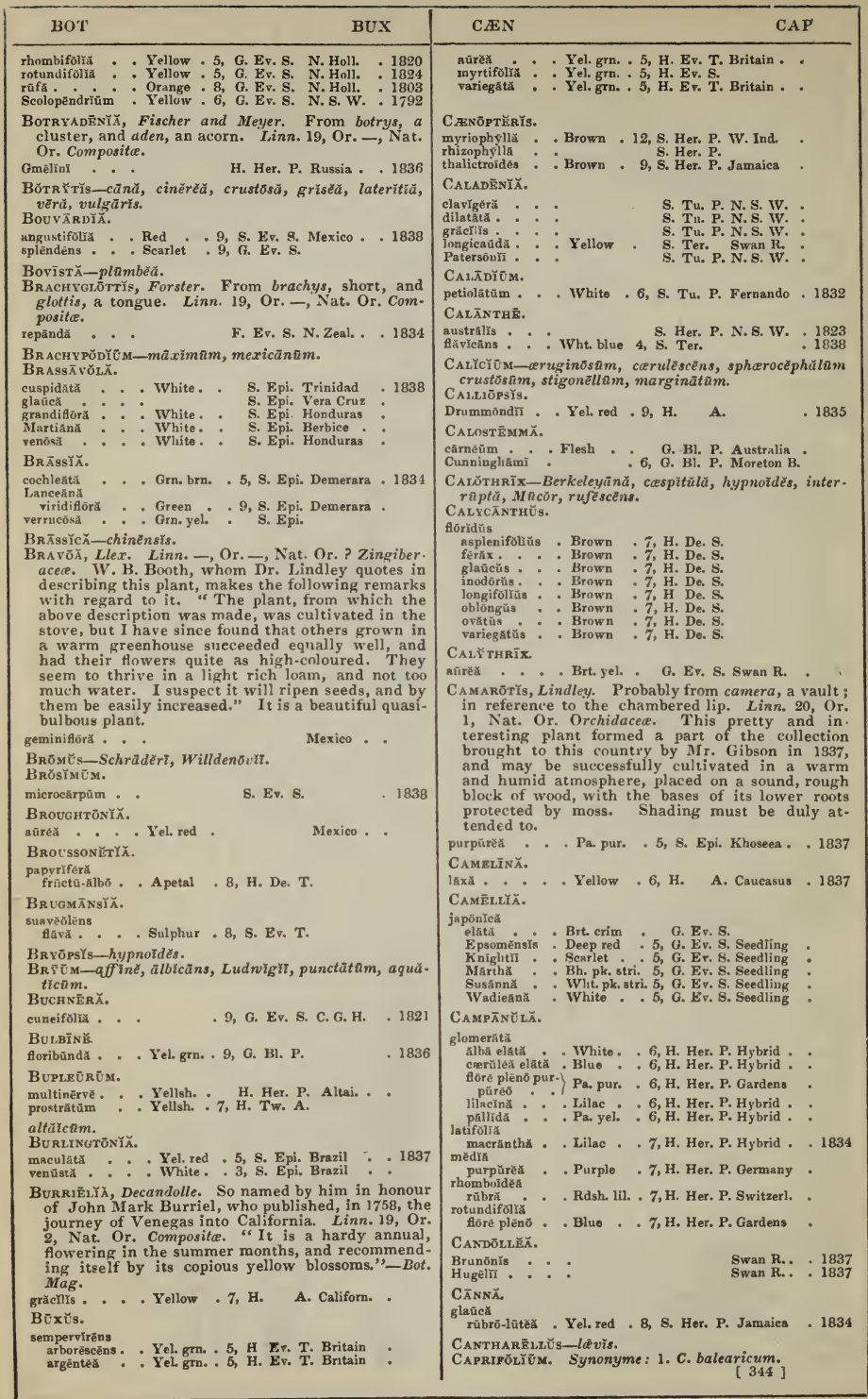




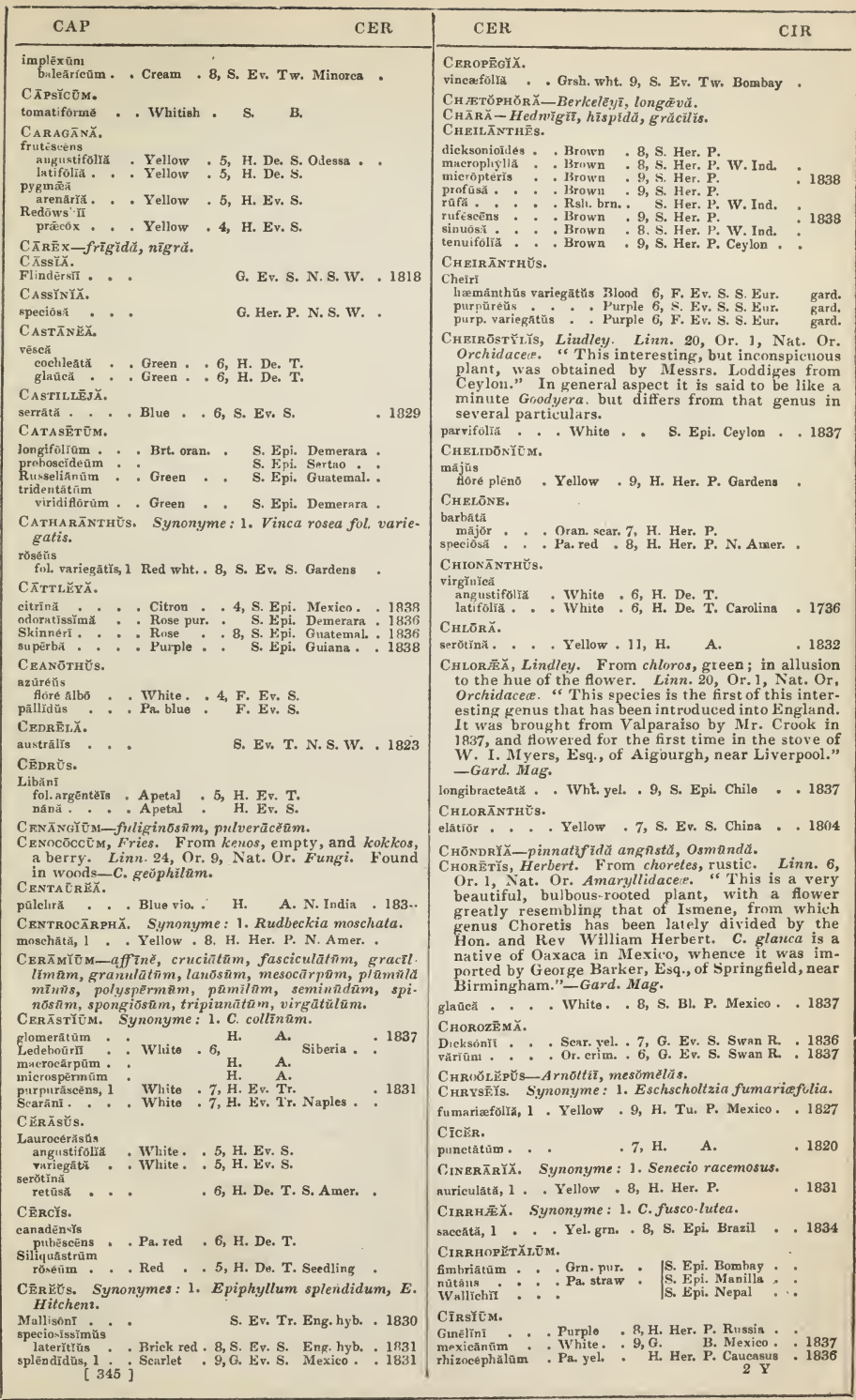




\begin{tabular}{|c|c|}
\hline $\mathrm{COO}$ & CRA \\
\hline 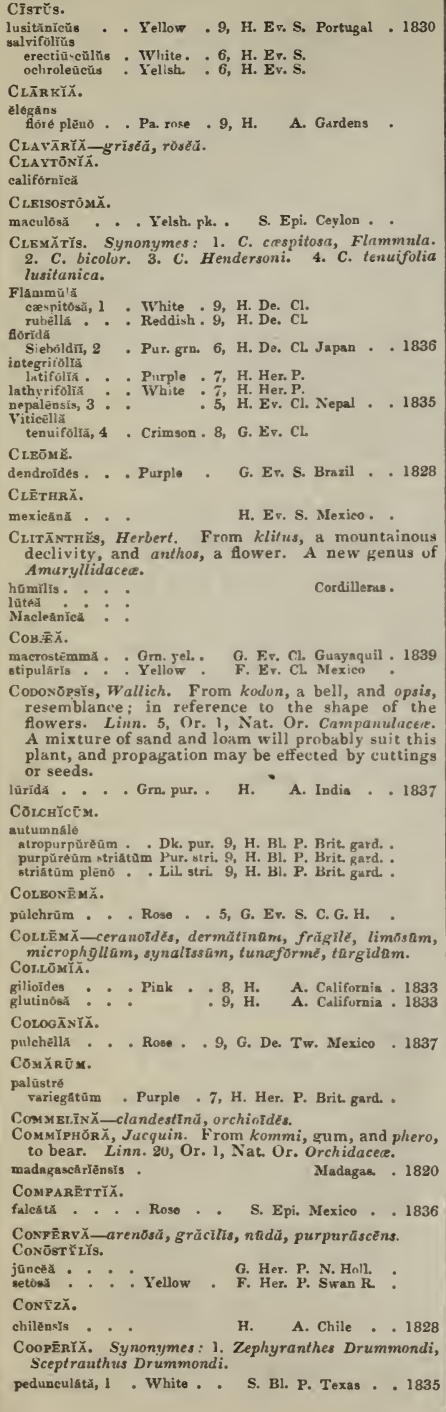 & 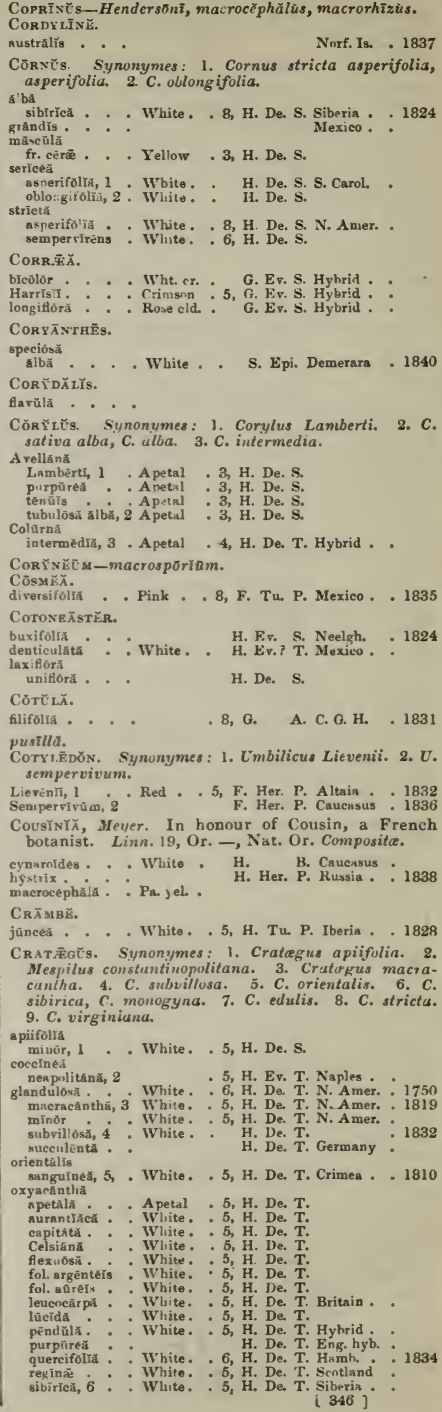 \\
\hline
\end{tabular}


transylvănǐca White. - 5, H. De. T. Transylv. punetắtå̉

brevispina . White. . 5, H. Ev. T. N. Amer. rübră, 7 . White. 5, H. De. T. N. Amer. ruhră strīetī, 8 White. - 5, H. De. T. N. Amer.

virgīnieă, 9. . White . 6, H. Da. S. Virginia . 1812

Cratêrî́ M-mutŭbilě, pyriforme.

CRĒPǏs-multicaülis, pסntícŭ.

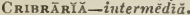

Crotal. $\bar{A}$ R̆̃̆.

undulātă - Yellow - G. Ev, S. Mexico .

Cructanēltă.

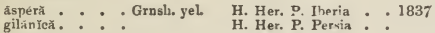
$\begin{array}{ll}\text { gilănică: } & \text { H. Her. P. Pervia : : } \\ \text { suaveoléns : } & \text { H. Her. P. Russia : } 1838\end{array}$

CRYPTĀNDRĂ.

arbutifiōră. .

S. River . 1837

CẼ PHĚ̆.

milenoĩdés . . Bluish . 9, F. A. ${ }_{1836}$

Cuprêssǔs.

Coultërn . . Apetal . 5, H. De. S. Mexíco . . 1838 thyoides

fol. variegătǐs Apetal . 6, H. Ev. T. Ireland . . 1831

Curcēmă.

Roscoeañă . . Red yel. . S. Her. P. E. Ind. . . 1837

C T̄CLĂMĔx.

pērsicũm

lilācéúm . Yilac . 3, G. Tu. P.

punctảtūm: :Vhı lì. : 3, G. Tu. P

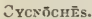

chlorochilon . Green . . 6, S. Epi. Demerara . 1838 maculătă - : Yel. brn. . S. Epi.

Cгсто̆ ז̌x̌̆, Bentham. Linn. -, Or. -, Nat. Or. Leguminose. A profuse flowering Swan River plant, whose blooms are highly beautiful. It is worthy of a place in every collection.

canêscēns . . Purple . 5, Swan R. .

CพDŌNน̌Ă.

japơnìcă

f. sémi-plēnō . Red , . 8, H. De. S.

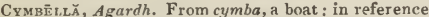
to the shape of the pustules. Linn. 24, Or. 7, Nat. Or. Alger. Small yellowish plants, inhabiting marshv places-cymbiformis, hyalīnă, mīuor.

CумBİ̃̈м.

hícollor . . . Brn. crim. - S. Epi, Ceylon . .

iridifoliüm: : Fuscous: S. Epi.

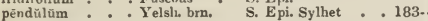

Cynoglōssūm.

cælestinūm , Whit, blue $8, \mathrm{H}$. B. India . 1837

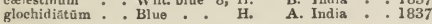
Crpล̄rüs.

pygmāŭs . . Apetal . 9, S. Grass, E.Ind. . . 1829 Cyphērlă, Fries. From kyphellon, a cup. Linn. 24, Or. 9, Nat. Or. Fungi. This species is found on decayed grass-C. cuticulōsă.

CурHoñmă. Linn.-, Or. - , Nat. Or. Amaryllidacece. "A remarkable new genus, of which a live specimen in flower has been sent to Spofforth by Mr. Loddiges, imported, as he states, from Valparaiso, being the first Cyrtanthiform plant found elsewhere than in South Africa." - Bot. Mag. A sharle of doubt has been cast upon the fact of its being a native of the above-mentioned country, Messrs. Loddiges having had many Cape bulbs in the same house with those inported from Chili.

Loddigesiānūm . Grn. strip. . S. Bl. P.

CYrochīLŪM.

stellătūm . . Gm, wht. 10, S. Epi. Rrazil .

Cyrtopōdĩ M.

Willmốrěi . . . Grn. yel. . 6, S. Epi. Venez. . . 1834

CУTispōRĀ-carphospērmă, fūgāx, orbiculärìs, rubēs. cēns.

Cگัтกัsuัs. Synonyme; 1.C.L. incisum.

æölìcuัs

flōré plēnō . White. . 5, H. De. S. England fol. variegatis . Yellow . 5, H. De. S. Gardens alpīnŭs

odorátŭs . . Yellow . 6, H. Je. T. Hyhrid . pēndǔlüs :Yellow 6, H. De. T. Gardens [ 347 j

\section{Lahürnūm \\ quercifoliūm, i Yellow}

fol. variegăţs. Yellow $, 5, \mathrm{H}, \mathrm{De}, \mathrm{T}$

frăgrăns : Yellow : 5, H. De. T. Gardens

péndŭlı́m * Yellow . 5, H. De. T.

Weldënir: $:$ Yellow

5, H. De. T.

H. De. T.

DACR ั м YัcĒs-violucĕŭs.

DAcrY̌lem, Nees. From daktylos, a finger. Linn. 24, Or. 9, Nat. Or. Fungi. Found on the mouldering stems of herbaceous plants-D. pyrĭfērūm.

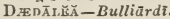

DĀHL İ̃.

Barkērǔ̃e . . Blush . 8, H. Tu. P

excēl

anemonæfloră . Light . . 9, G. De. S. Mexico

glabrătă . Lilac . . 7, H. Her, P. Mexicn.

1830

seap̌̌eră White

1837

DĀPHNĔ.

Cneôrūm

fol. variegātǐs . Grn. yel. . 5, H. Ev. S.

indieả

rühră * - Pur. pink - G. Ev. S.

pōntieă

†ol. variegãtís . Pink . . 8, H. Ev. S.

viridifloră *. Green . H. Ev. S. Nepal . 1829

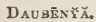

fūlvă - . Yellow • S. Bl. P. Africa .

DAẼcť̀s-sǐcülüs.

DAVIĒs̆̌̃.

genistoīdès . - G. Ev. S. N. Holl.

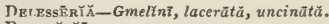

DELPHINITEM.

decōrūm H. Her. P. Russia 1838 discðiơr.: : Bl. wht. . 8, H. Her. P. Siberia : 1834 grandiffồrüm

Hũlmñ . . Blue . . 8, H. Her. P. England

rūbrūm : . Red pur. . 8, H. Her. P.

moschàtūm : Drk, blue 8, H. Her. P. Switzerl. . 1834

DENDRōBǏ M.

aūréūm

pallíaúm . White . 3, S. Epi. Cerlon .

bicamerătūm : Yel. pur. : 8, S. Epi. Khinseea : 1837

Cambridgeanum : Yellow . S. Epi, Khoseea : 1837

casıythoídés : Goiden : . 9, G. Epi. P. Jacks.

Devoniānúm $\therefore$ 5, S. Epi. E Ind. : 1837

Heyneānūm. . Wht. grn. : 3, s. Epi. Bombay . 1838

macropliyllũm: Rose.: S. Epi. Manilla : 1838

Partōní : Or. Sin. Khoseea : 1837

plicãtle : : : Yel, red : S. Epi. Manilla

DRNTĀR̆̌̃.

dasylōbă .

H. Her. P. Russia . 1838

Drsvat̄xĭ $R$. Brown. In honour of N. Desvaux, a French botanist. Linn. -, Or. -, Nat. Or. Desvauxiacea.

Billardiëri .

S. A. N. Holl. 1823

\section{Deūtzĭă.}

corymiıosă . . White. - H. Ev. S. Himalaya .

DiĀNTHŭs.

barbătŭs

flüré-plēnō . Wht. rose - 7. H. Her. P. Gardens .

DiАто̄мĂ—aurītūm, brachygōıūm.

DICH F⿱艹

ochrãcēă - . . Yellow . S. Epi. Demerara

\section{Dı́кร̄̄NǏ̃.}

davallioidés - Brown . 9, S. Her, P. New Holl.

rubigin

rubiginōsă
scăndèns

S. Her. P. Brazil .

DĨ́crăNūM-flagellärē.

DICR FPTĂ.

bicólor . Yel, hlk. 8, S. Epi, Demerark . 1834 díscólŏr: : : Orange: 8, s. Epi. Demerara

iridifólia: : : : Yel. sp.: : 8, S. Epi. Trinidad : 1835

Did̄̄ mă, Personn. From dis, double, and derma. skin; in allusion to the dotible peridium. Linn. 24, Or. 9, Nat. Or. Fungi. Found on bark, moss, dead oak-leaves, \&̌c.-D. Carmichaelinnūm, cyanés cēns, deplanātñm, nītēns, spumariō̄děs, umbilicūtum,

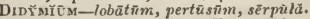

Dinyмоснцихӑ, Desvaux. From didymos, double, and chlaina, cloak; indusinm. Linn. 24, Or. 1, Nat. Or. 


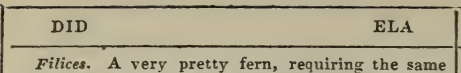
treatment as other stove plants of its class.

pulehêrrìma . . Brown . 7, S. Her. P. Brazil . .

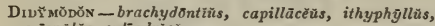
crispütüs, cylīndricrus.

Digitälīs. Synonyme: 1. Digitalis hybrida.

Campbelliānă, 1 . Blue yel. . 7, H. Her. P. England .

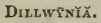

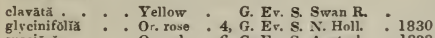
glreinifolĩă : : Or. rose : 4, G. Ev. S. N. Holl.
speciósă. . : : Or. yel.

DIPLĀZT̃

acumiıătúm . - G. Her. P. Brazil . .

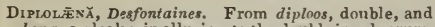
lena, a cloak; in allusion to the double involucrum. Linn. -, Or. _, Nat. Or. Rutacev.

Dampiêrī . . . G. Ev. S. Swan R. . 1837

Dıpı.opërtřs, Endlicher. From diploos, double, and pelte, a buckler; the application is unknown to us. Linn. 23, Or. 1, Nat. Or. Sapindaces. This plant will prohably require a similar treatment to Cape plants, such as Hebenstreitius, striking freely from cuttings of the young wood, and will bear to be planted in the open border during the summer season.

HugëlI . . . . White. . G. Her. P. Swan R. . 1837

Diûrĭs.

filifolra . . Yellow . S. Ter. Swan R. .

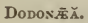

cerntncărpă . . $\quad$ G. Ev. S. K. G. S. .1837

DoōDǏA.

mâxĩmă . . Brown . 8, S, Her. P. N. Holl.

DoRõNĬcūm.

eñdifŏliúm . . H. Her. P. Ruskia . . 1839 macrophyllam : Yellow $, 7, \mathrm{H}$. Her. P.

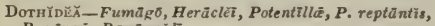
P. vêrnūe, Ranâncŭli.

\section{DRĀBĂ.}

grandiflóră - White. . H. Her. P. Altai - 1832

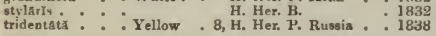

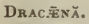

salicifolra

S. Ev. T.

DRACOCĚPHĂLẼ M.

mexichnüm . . Blue . . 7, H. Her. P. Mexico . . 1832 pinnătūm. : Blue : ' H. Her. P. Siberia : 1832

\section{Drễs.}

octopétăla

minór . White . 7, H. Ev. Tr.

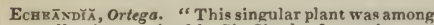
a collection received by Sir Charles Lemon in 1837 from Mr. John Rule, superintendant of the Real del Monte Mines, Mexico, in the neighbourhond of which it is probably a native. It flowered in the greenhonse at Carclew in June 1839 , and continued during July and August to send out a succession of five or six flowers ditily. It promises to produce seeds, by which there is every chance of its being increased."-Bot. Reg.

ternifloră . . Golden . 7, G. Her. P. Mexieo . 1837

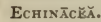

dũbră . . L Lilac . . 9, F. Tu. P. Mexico . 1837

EcHINĒLLĀ_oblongă, rotātă.

Eсні̄NōPs.

bannăticŭs

albǔs . White. . 5. H. Her. B. Hungary . 1839 dahūricŭs: : Blue : 8, H. Her. P. Dahuria : 1828

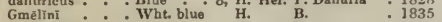

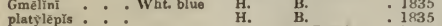

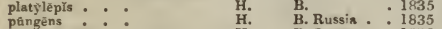

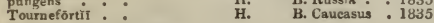

EcTOcĀRPŤs-distôrtǔs.

EDWARDĭ́.

Macnabiāñ̆ - Yellow . G. Ev. S.

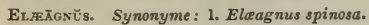
angustifollă daetylifōrmìs .- H. De. T. spinōsă, 1 . H. De. T.

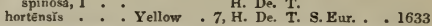

Eцарно̆мг̆сẼs, Nees. From elaphos, a stag, and mukes, a fungus. Linn. 24, Or. 9, Nat. Or. Fungi. Found on dry heathy ground, \&c.-E. granulätūs, muricãtŭs.

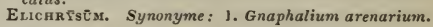

affinè, 1 - Pa. yel. - 8, S. Ev. S. C. G. H. .

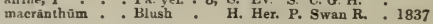

EMPẼTrū M.

nīgrùm

scơticūm . Apetal . 5, H. Ev. S. Scotland .

ENARTHROCARPĽs.

lỹătǔs . . . . Yel, pur. . 7, H. A. Alexand. . 1836

ENDOCĀRPŏn-eupløcūm, lietevīrēns, macrocīrpŏn, psoromoìdës, pulchēllūm, rufo-virēscêns, rugסsūm, sorediâtūm, sulphưrêum.

Eхтеromórphă, Link. From enteron, entrail, and morphe, form; in reference to the appearance. Linn. 24, Or. 9, Nat. Or. Fungi. Found in pools and oceans-E. cornucöpǚé, Linkiänă.

EPĀCris.-

coecinéa - . Scarlet . 4, G. Ev. S. Seedling .

imprếsă

parvithöră . . Red . . 9, G. Ev. S. N. Holl.. .

Epidēndričm.

Candóllēi

cepiformé : : : Brn, yel, $\quad$ S. Epi.

cinnaharinam : Vermil. :6, S. Epi. Pernambuco

coriáceúm : Grn pur. S. Epi. Demerara

S. Epi. Mexico.

densifórürn: : S. Epi. Mexico: 1839

glumáceūm : : : Wht. pink. S. Epi. Brazil : : 1838

incümbëns: : S. Epi.

inversurm : Strw, cold S. Epi. Brazil .

Parkinsoniannum : Grn, yel. : S. Epi, Mexico:

Stamfordianum : S. Epi. S. Amer.

viridi-purpũreûm Pur.grn. . 9, S. Epi, Jamuica :

vitellinüm . - Orange. : 9, s. Epi. Mexico. : 1839

Epilōatũa.

minũtũm . . Whito . 8, H. Her. P. Russia . . 1838

E

Musschið̃nūm . White . 3, H. Her. P. Japan . . 1836

ËIPHỸLLŪM.

Russelianũm . . Dp. pink . 5, S. Ev. S. Organ Mts. 1838 speciosúm

Jenkinson1 . . Crimson . 5, S. Ev. S. Eng. hyh. .

hateriua . : : Red . 6, S. Ev. S. Eng. hyb. .

Eрıтнйçă, Knon'les and Westcott. From epitheke, an appendage; in allusion to the shape of the flower. Linn. 20, Or. 1, Nat. Or. Orchidacee.

glaụcă . . . Grn. pur. . 6, S. Epi. Mexico . . 1837

Eriă.

bicolor . . White . . S. Epi. Ceylon .

ferrnginea : : : Pink gra. : 3, S. Epi, E. Ind. : 1837

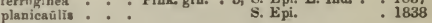

Erīcă.

arbōrea

nilnImă . . White. . 4, F. Ev, S.

cinēreă

pallirda
icliromata

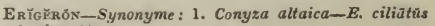
1 , elongotũs.

Eriocaćlón.

sexangulare . - White . 9, G. Aq. P. E. Ind. . . 1819

ERIOSTĔMŎN.

g̣laucếscêns : . $\quad$ G. Ev. S.

ERōnับิM.

géfoliūm . Lilac . H. B. 1835 pulverulentúm : Lilac : : H. B. Spain :

Erucatríă.

pérsìcă . . . H. A. Persia . 1834

ERT̃NGTM.

macrophyllûm . H. Her. P. 1831

ER

Perofskiănūm . Brt, oran. 7, H. B. 1838

ER Y̌sŤPHĒ-maculärīs, tơrtĭlis. 


\section{ERYThRöNIับัM.}

gigántéum . .

EUCAL צ̃ PTŬs.

alpiñă . . .

H. Bl. P. N. Amer.

EUักัN

europæè̆s

latifoliǔs *. White. . 6, H. De. S.

garcini folrŭs . Pa. yel. * H. De. T. Nepal • 1820

japōmìcŭ

maculātǔs. Pink . 7, F. Ev. S. Japan . 1836

variegatǔs : Pink: 7, F. Ev. S. Japan: : 1836

Euphōraĩ.

amygdalides

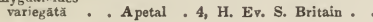

dictyocärpơn.

Eurร̌Bt̆.

glutinósă . . Pa. vio. , G. Ev. S. V. D. L. .

EuTōcă.

viscidă . . Brn, rose . 7, H. A. California . 1834

Exč̆PŬLĂ—strigøsă.

EyseNhĀRDTĬA, Kunth. In honour of Charles William Eysenhardt, M.D., a professor in the University of Konigsbery, in Prussia. Linn 17, Or. 4, Nat. Or. Legnminos P. This shrub will thrive in a mixture of loam and peat, and young cuttings will strike root in sand, under a bell glass, in heat.

amorphoìdés . Pa. yel. . G. Ev. S. Mexico . . 1837

FAвтд̄xă, Ruiz and Pavon. In honour of Francisco Fabiano, of Valencia in Spain, a promoter of botany. Linn. 5, Or. 1, Nat. Or. Solanacea. The soil adapted to this pretty little shrub is peat and sand, and it may be multiplied by cuttings or seed, in the same manner as Cape heaths.

imbricătă . . White. . G. Ev. S. Chili . .

F ĀGŬs.

ferruginę

caroliniănă . Apetal - H. De. T. Carolina

sy]vătīcă

cristátă . Apetal . 5, H. De. T.

cūprea : A petal : 5, H. De. T.

fol. argēntèis A petal : 5, H. De. T

fol. aūreís - A petal :6, H. De. T

pěndülă . A petal . 5, H. De. T.

FẼ İ̃̆.

gibbōsă . . . $5, \mathrm{H}$. A.

.1834

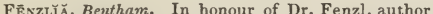
of a monograph of Alsinaceze Linn. 5, Or. 1, Nat. Or. Polemoniacea. For culture and propagation, refer to Leptosiphon.

dianthiflōră . Pur. yel. . H. A. Californ. 1833

\section{FERNANDĒzĩ.}

luniferă . . .

8. Epi. Brazil .

FĚrŭLÃ.

ammonĩăcă . White . 6, H. Her. P. Persia . . 1831

seseloz̄dĕs.

Frs r ర̄cĂ-geniculätă.

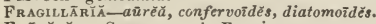

FrĀxĨnũs. Synonyme: 1. Fraxinus nana.

americână

latifơlĩă. . Green . . 5, H. De. T.

excêlsiór

aūreă pēndŭlă Green • . 4, H. De. T. Britain .

Kineairnǐē, Green: 4, H. De. T. Kincairney

heteropliyllă

varipgată . Green . . 4, H. De. T. Ireland . . 1836

juglandifóliz

subintegērrimă Green . 5. H. De. T

polemoniffoliă, 1 Green: : 4, H. De. S. N. Amer. . 1812

pubéscēns

loneifoliă . Green . . 5, H. De. T.

quadrangulătă

nervōsă . Green . 5, H, De, T

Fritillär Ĭ

imperiāirs

au rāntiă * Or. red . 4, H. Bl. P. Gardens

flävă-plēnō: Y Yellow : 4, H. Bl. P. Gardens

rūbră-plēnô. Red * 4, H. Bl. P. Gardens

variegăta . Red . . 5, H. Bl. P. Gardens

Frolōvĭa. In honour of Frolow, a Russian botanist. [ 349 ]
Linn. 19, Or. -, Nat. Or. Composite. Synonyme : 1. Saussurea Frolovii.

lyrătă, 1 . . Sulphur. 9, H, Her. P. Altaia . . 1834

FrustũLĬ A Agardh. From frustula, fragments; of which this genus is composed. Linn. 24, Ur. 7, Nat. Or. Alya. These species are found in fresh water-F. fasciütă, Ulvă.

Füchsĭ.

cylindräcèă - Scarlet . 8, F. De. S. Mexico . . 1837 globōsả

Devōnǐa . . . Red . . 1, G. Ev. S. Hybrid .

FūNKİ̃.

lancerfoliz

fol. variegătǐs . Lilac , 7, H. Her. P. Gardens

undulâtă : Lilac: 8, F. Her. P. Japan : 1834 variegátă : Lilac : 8, F. Her. P. Japan: : 1834

Furcr舟分.

longàvă . . . $\quad$, Dalm.

.1833

FusĀR Ī̃̄M-rŏsě̃um.

Fusispōrî̀u, Link. From fusus, a spindle, and sporos, a seed; referring to the fusiform sporidia. Linn. 24, Or. 9, Nàt. Or. Fungi. Found on onions, decayed cucumbers, \&c.- $F$. atrovīrēns, aurantīă$c \bar{u} m, B \bar{u} x \bar{\imath}$.

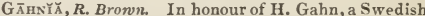
botanist. Linn. 3, Or.-, Nat. Or. Graminea-G. procēră.

GALEōBdŏLŏN.

lūteûm

variegãtūm - Yellow . 5, H. Her. P. Britain * .

GĀLY̌ùM-arenārīūm, Barteliērĩ, capillīpēs, pallēscēns, rugōsūm.

Gardōeur̃ă.

multiflōrà . . Drk. pur. . 8, G. Ev. S. Chile .

GĀRR

laurifólı̆ . . Mexico .

Gastrolōbĩū M.

cordátūm . . Yellow - G. Ev. S. Swan R. .

GEĀstrē M-Bryāntī̄, striātām, S. mīnŭs.

GraLĒră, Fischer and Meyer. In honour of Gebler, a German botanist. Linn. -, Or. -, Nat. Or. Euphorbiaceue.

H. De. S. Russia 1835

GRLAsĩ $\breve{E}$, Herbert. From gelasinos, a smiling dimple, Linn, 6, Or. 1, Nat. Or. Iridacea. A bulbous rooted plant, with rather small dark-blue flowers. It was found by Mr. Tweedie in stony places near Rio (irande. "Seedlings grow rapidly, and will probably flower at a year and a halt old. The speci. men figured flowered in the greenhouse at Spofforth, but Mr. Herbert thinks the species will prove very nearly hardy, and will retain its leaves, in part at least, through the winter."-Gard. Mag.

azûréă . . . Blue . . G. Bl. P. S. Amer. . 1838

GENīstă. Synonyme: 1. Spartium interruptum.

germaniccă

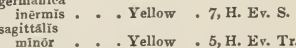

flöré plēnō. Yellow . 7, H. Ev, S. Gardens

hirsută : Yellow: 7, H. Ev. S. Britain

latifoliă : Yellow $: 8$, H. Kv. S. Auvergne

praténsiss : Yellow : 7, H. Ev. S. Italy ?

triacăntlioss

interrūptă, 1 . Yellow . 6, H. Ev. S. Tangier .

GrNTiñnă.

asclepiādèa

mâjor . . Blne . . 7, H. Her. P

ocliroleūcă : Cream: $7, \mathrm{7}, \mathrm{H}$. Her. P.

Geblēri . H. Her. P. Russia 1839

plebēră: : Drk. blue 7, H. Her. P. Germany . 1834

Pneumoñañ
flōré ālbō . Wht. grn. 8, H. Her. P. Gernany . 1834

flōré ālbō - Wht. grn. 8, H. Her. P. Germany *
vêrnă
flōrē ãlbō . . White. . 5, H. Ev. Tr. Gardens .

GeogLōssū M-diffōrmě, glutinōsūm.

GBRĀNİ̃M.

aff In' . .

H. Her. P.

asphodeloides: 


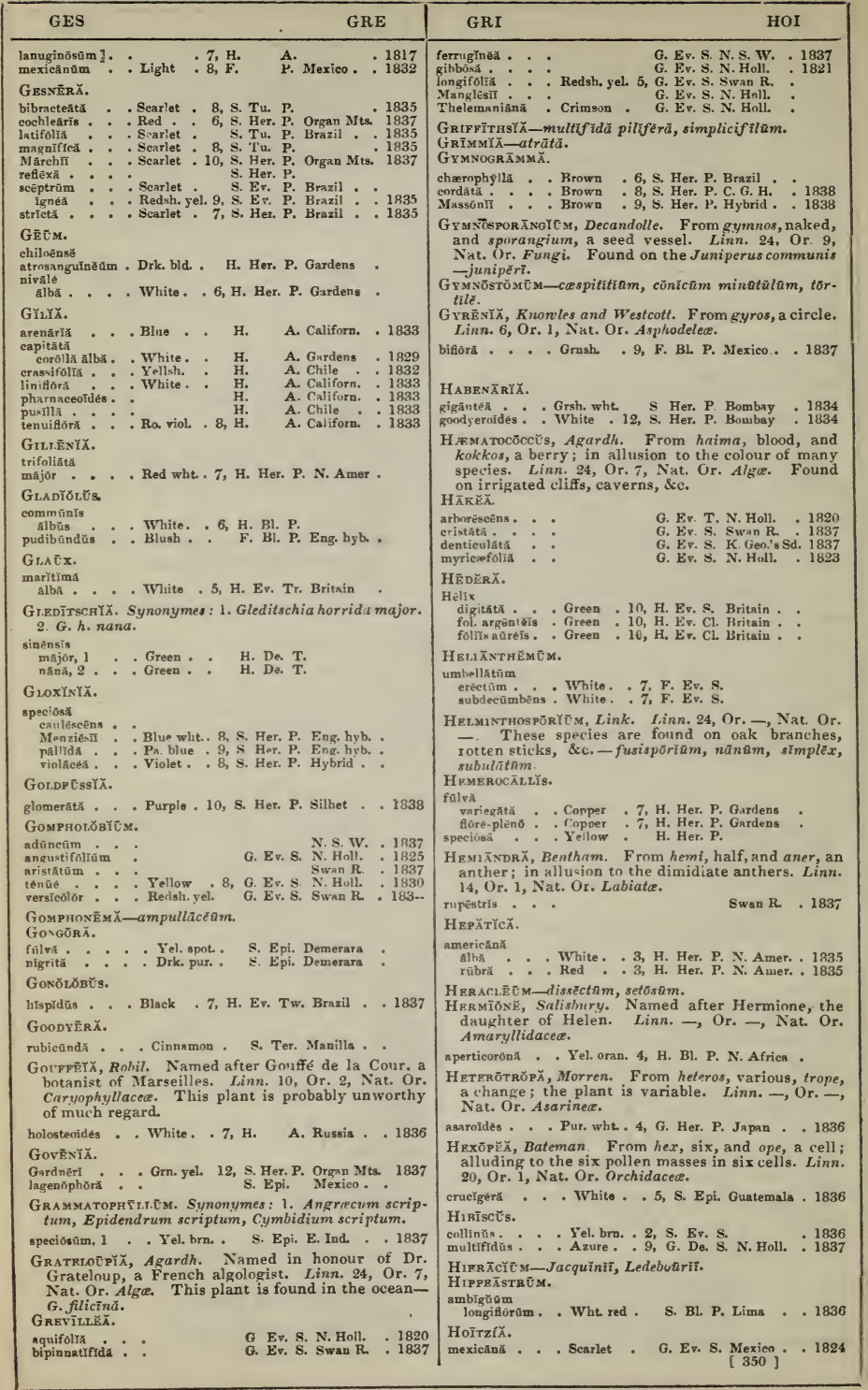


Hot,ARRHĒNĂ, R. Brom'n. From holos, entire, and arrken, a inale; alluding to the anthers. Linn. 5, Or. 1, Nat. Or. A pocynacea. This plant may be referred to Echites for culture and propagation.

villŏsă . . .

S. Ev. S. E. Ind. . . 1820

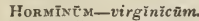

HOSĂCKĬA.

stolnnĩféră . . Red . . 6, H. Her. P. N. Amer. . 1830

HousTōNบั.

ciliătă. . . Whitish . 7, F. Her. P. N. Amer.

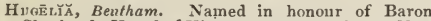
Charles de Hügel of Vienna. Linn. 5, Or. 1, Nat. Or. Polemoniacea... For culture and propagation, see Gilia.

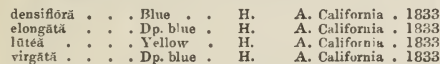

HūMưLťs.

Lũpŭlŭs

variegātŭs . Yellow . 7, H. De. Tw. Britain gard.

H̄̃NTLĔYă, Bateman. In compliment to the Rev. Mr. Huntley, a zealons collector of rare plants. Linn. 20 , Or 1, Nat. Or. Orchidacea. These rare and charming species require to be grown in a humid atmosphere either in pots placed on the stage or plunged in the bark-bed, or to be hung up, as those kinds with thick tleshy roots frequently succeed well in the latter way. They may be propagated by taking off the young shoots.

meleăgrǐs . . Yel. brn. . 7, S. Epi. S. Amer. . 1838 violāceă : : Violet : : S. Epi. Gıirna : 1837

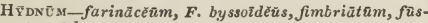
cū $n$, ûdũ $m$.

HYIRANGË̌̃.

arborēseēns

díscólōr. . Wht, grn. 8, H, De. S.

niัveă

glabéllă . . Wht. grn. 7, H. De. S. Gardens

HгрRб̆рно̆RĂ, Tode. Derived from hydor, water, and phoreo, to bear; in allusion to the watery peridiolum. Linu. 24, (Or. 9, Nat. Or. Fungi. Found on rats dung-H. murīnä.

HrmbNocĀt.l.1s, Herbert. "This speries, very unlike any yet known, was imported from Mexico by $T$. Harris, Esq., of the Grove, Kingsbury ; and three bulbs of it, sent through his liberality to Spofforth. flowered there with their first shoot in the stove a the beginning of April. The seerls of this genus are apt to burst the capsule, and become fully exposed to view in their progress to maturity; but in this species the singular phenomenon has appeared of one of the ovules, which are erect and fill the cell of the germen, splitting it, and forcing itself ont, twelve hours atter the impregnation of the stigma, while the flower was still fresh."Bot. Reg.

\section{Harrisiānă.}

НумкNOPХ̆RĂMIs, Wallich. From hymen, a membrane, and pỹramis, a pyramid; alluding to its substance and growth. Linn. -, Or. -, Nat. Or. Verbenacea. A mixture of loam, leaf-mould, and sand, will suit this plant, and it may probably be increased by cuttings.

brachiātri . .

S. De. S. E. Ind. . . 1832

HYPǨRĬcūm. Synonyme: 1. H.fasciculatum.

axilláré, 1 . . Yellow - 7, H. Ev. S. Georgia .

galinidës : Yellow:8, H. Ev. S. N. Amer.

macrocearpüm: : 8, H. Fer. P. N. Aner. : 1828

HГ̃PNC̄M-alopecūrâm aquãtīcūm, confērtūm subsecun-

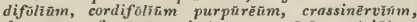

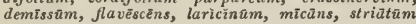
minuัs.

Hy Pöxis.

grăcīlls. . . . Yellow . 6, S. Bl. P. Mexico . . 1829

HYssōpǔs.

ofticinålys

flore rübro . . Red . 7, H. Ev. S. Gardens variegătũs: Blue : 7, H. Ev. S. Gardens

Hystêrî̃̂-Vaccinti. [351]
ILEิX.

Aquifolinum

altaclerēnse. . White. . 5, H, Ev, T, Britain * angustifólĩum: White. 5, H. Ev, $T$, Britain : aūréó pīetùm : Whì : . 5, H. Evv. T. Britain . cilıătūm - White. 5, H. Ev. T. Rritain cil. minŭs : White. . 5, H. Ev. T. Britain . crispūm . White. . 5, H. Ev. T. Britain . fêrôx argë̀ntéum White. : 5, H. Ev. T. Britain : férox aureũm. White. :5, H. Ev. T. Britain : féróx aureüm. White. : 5, H. Ev. T. Britain
frūctū ábō. White.

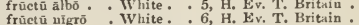
latifólīum : White. : 5, H. Ev, T. Brittin laurifölîum: White. : 5, H. Ev. T. Britain marginätüm : White. 5, H. Ev. T. Britain senêscếns : White. 5, H. Ev. T. Britain serratifölrum . White. 5, H. Ev. T. Britain

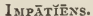

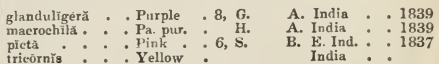

tricōrnǐs Yellow

INGĂ.

Harrinl1. . Crimson . 2, S. Ev. Cl. Mexico.

Iิ พันLĂ.

gläbră . . . H. Her. P.

.1831

I Ромळ̄̆. Synonyme; 1. Batatas bonariensis.

bonariēnsǐs, 1 . Purple . 8, S. Tu. P. B. A yres . 1826

Leârî̀ . . Blue * 6, S. Ev. Tw. Ceylon

longifơliă: : White: 8, S. Tu. P. Mexico: 1838

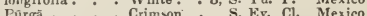

rûhró-cæerúleă : Rdsh. blue $\quad$ S. Tw. P. Mexico schiediānà. : Blue. 10, S. Tw. P.

IRIs. Synonyme: 1. Iris missouriensis pleno.

Biondôwi . H. Her. P. Altai ensátá : : Blue pur. . 6, H. Her. P. Austria

floreutină

minōr . . I.gt. grey . 5, H. Her. P. Gardens

frãgråns : : Bl. pur. .6, H. Her. P. Iudia?

germŭnĭcă

fôre âlbò . . White . 5, H. Her. P. Gardens

lævigată

H. Her. P.

1836

Psend-Acỏrŭs . Yellow , 6, H. Her, P.

pũmilà

albã . . White. 5, H. Her. P.

albă cæerùleă : Wht pa.bl. $5, \mathrm{H}$. Her. P.

cærūlez. . Pa. blue . 5, H. Her. P.

sibiričă

flóre plēno, 1 . Purple . 5, H. Her. P.

variegat

De Berg: : Yel. brn. : 5, H. Her. P. Belgian hyb.

Van de Will : Yel. brn. 6, H. Her. P. Belgian hyb.

Inpêx, Fries. From irpex, a rake, or harrow; alluding to the hymenium, which somewhat resem. bles that instrument. Linn. 24, Or. 9, Nat. Or.

Fungi. These species are found on pine and beech wood-I. läctēüs, pēndülüs.

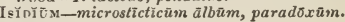

IsMĒNE.

deflèxă . . . G. B1. P.

IsoTRōpIs. "This is a very pretty little greenhouse shrub The stem is soft, and slightly downy, the leaves oval, the flowers papilionaceous, clear orange yellow, with rich, deep crimson, forked veins, even more distinctly marked than those of Abutilon striatum. It was communicated by Robert Mangles, Esq., of Sunning Hill."-Bot. Reg.

striātă . . . Or. yel, cıim. G. Ev. S. Swan R. . 183-

J ACKsōN ǏĂ.

grandiflòră. - Pa. yel. - G. Ev. S. Swan R. Sternliergiänă. : G. Ev. S. Swan R. thesioides. G. Ev, S. N. Holl.

1837

JASMĪNŪM.

multiforûm - White. . S. Ev. S.

JUNGERMĀNN ǏA. Synonymes: 1. Jungermannia epi phylla furcigera. 2 J. endiviofolia. 3. J. affuis-J. barbãtă minnŏr, bidentã̂tă obtusātă, calycīnă 1 , epiphy̆llă longifülĭă 2, hamatifulīă echinätă, $\boldsymbol{H}$. exstipulätă, microscōpřcă, plutaphȳllă mījör, $\boldsymbol{P}$. Thñgă, rēptāns bipinnätü, setiformis britännìcă, Tamarīsc̆ a piculätă, turbiuētă 3 ,

JUNǏPL̆RŨs. Synonymes: 1. Juniperus vulgaris fruti$\cos a, J$. communis erecta. 2. $J$. lusitunica. 


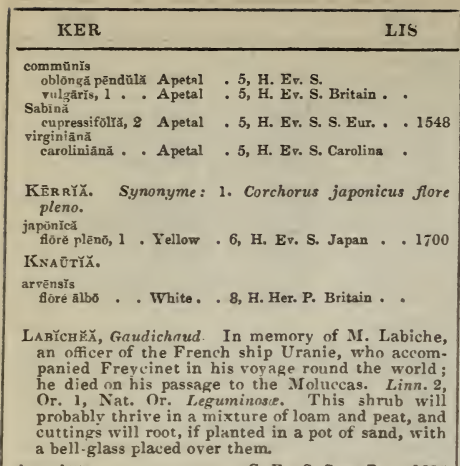

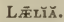

cinnaburInă . . Vermil. . . 5, s. Epi. Brazil •. 1836 Perrinn : : : Lilac : 9, S. Epi. Brazil : 1835 superbrēns : : : $\quad$ S. Epi. S. Amer. : 1840

LAGRNó PhŏRă, Endlicher. From lagenos, a flask, and phoros, bearing. Linn. 19, Or. -, Nat. Or. Composita.

Forstërİ . . Yel. pur. . G. Her. P. N. Zeal. . 1837

LАMнЕ̄RTIั.
ovalifolia
G. Ev. $\mathrm{S}$,

LĀMỸ̄M. Syncnyme: 1. Lamium maculatum album.

lonsifônūm

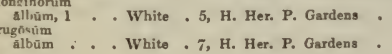

âlbūm

LANTล̄NĂ.

multifiōră

Selloviannă

S. Er. S.

S. Ev. S. Monterid.

LA S1ĀNDR̆̃.

petiolata . . Blue . . 6, S. De. 8

1836

LAXMĀNNǏ̃.

grandiflóră . . Wht. brn. G. Her, P. Swan R.

LEPTocÄLLIs , Don. From leptos, slender, and kallos, beanty; the plant being slender and verv pretty. Linn, $5, \mathrm{Or}, 1$, Nat. Or. Convolvulacee. This plant may be referred to Ipomaz for culture, \&c. Synonymes: 1. Ipomaa muricata, $I$. armata.

guinstă, 1 . Violet . 7, G. Her. P. Mexico. .

LвPTODERris, Wallich. From leptos, slender, and derma, the skin; the branches are covered with separating tibrons bark. Linn. 5, Or. 1, Nat Or. Rubiacec. For cultivation, \&c., refer to Hamiltonia. Synonyme: 1. Hamiltonia fruticosa.

lnnceolătă, 1 - Yellow - G. S. Nepal . .

LRPTōsǏPHōN,

grandiflōrūs . Rlue gol. . 9, H. A. C.alifnrn. . 1833 lüteŭs : : Dp. yel. : 9, H. A. Californ. : 1833 pallidùs: : : Pa yel. :9, H. A. Californ. : 1833 parvifiórūs . : Yellow 9, H. A. Californ. : 1833

LıваNōtřs, Scopoli. From libanos, incense. Linn. 5, Or. 2, Nat. Or. Umbellifere. This plant is of easy culture, requiring a sandy, or chalky soil, and it is readily increased by seeds. Synonyme: 1. Ligusti. cum athamantoides.

athamantoides, 1 . White $7, \mathrm{H}$. Hex. P.

LIIYYT.

speciô*ūm

albiflōrūm

stellatr

verticillatia

White.

F. BL P. Japan . .

N. Holl.

Lissochīlťs, R. Brown. From lissos, smooth, and cheilos; in allusion to the lip of the flower. Linn.

\section{LOB}

MAS

20, Or. 1, Nat. Or. Orchidacere. For culture, \&c. see Bletia.

lūteŭs * - Yellow * 5, S. Ter. C. G. H. . 1822 parvifiōrŭs : Pa, red. 12, S Epi Algna B. speciōsǔs : . Yellow : 6, S. T'er. C. G. H. : 1818 LонЕ̄LIA.

ignéa . - Flame - 6, F. Her. P.

.1838

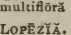

lineātă

G. S. Mexico .

L UPT̄xǐs.

Barkẽrí. . . Blue pls. 7, H. A. Mexico.

Lxcopōdî̀, Synonyme: 1. Selayinilla cordata,

brasiliēnsê . - Brown . 11, S. Ev. Cr. Brazil . cordatüm, l.

S. Her. P.

1838

LYstмА̄снй̈.

nèmŏrūm

variegátūm . Yellow .6, H. Ev. Tr.

MacnonÁdĭ. Linn. 20, Or. 1, Nat. Or. Orchidacee. antennifferă

M acrospórī a, Fries. From makros, long, and sporos, a seed. Linn. 24, Or. 9, Nat Or. Fungi. The first of the under.mentioned is fond on decaving leaves of cabbage, and the latter on those of Cheiranthus -M. Brässìcēe, Cheiräntht.

M Ац, chidacec. "This very singular plant was given to Mr. Bateman by Mr. William Hooper of Lambeth, who received it from $\mathrm{R}$ io in 1836 . It is a remarkable renus, resembling Mrgaclinium in some respects, but belonging in reality to Vandea, among which it is marked by the nearly total absence of petals, the cirrhate column, and the soft fleshy cinnamon coloured gland. to which a pair of reniform pollen masses are slightly attached. In this division of Orchidacece it is uncertain where it must stand; probably other genera still undiscovered will connect it with the system better than can at present be done."-Bot. Reg.

clavata . . . Grn, pur. - S. Epi. Ria Jan. . 1836

M ĀLV̆.

campanulata - Pa pink lil. G. Ev, P.

concinna : Light . 5, 8. Ev. S. S. Amer. . 1835 laclda : : Light *

Mandevīr.r. Lindley. Named after Henry John Mandeville, Esq., H. B.M. Minister at Buenos Ayres, to whom we are indebted for the introduction of this and many interesting plants. Linn. 5 , Or. 1, Nat. Or. A pocynacee. 'This new climber, according to Lindley, is remarkable for its deliciously sweet, snowy white, and very beautiful flowers "It will," says he, "probably form an abundant flowerer; but, like all seedling shrubs, its first stage of growth is more productive of foliage than blossoms."-Bnt. Reg. It appears that, in order to grow this plant to perfection, it should be planted out in the border of the conservatory. If cultivated during summer in the open air, or in pots in the greenhouse, it grows freely, but does not flower. After the flowering season is over, the plants should be pruned similarly to vines, or other plants which bear their flowers and fruit upon the wood of the same year. It may be propagated by cuttings or seeds, sown in a pit, with a litsle heat.

suaveơlèns - . White. . G. Ev. Cl. B. Ayres -

MANGLĒsĭ, Lindley. "This plant has found its way into yardens, having been raised from Swan River seed by Robert Mangles, Esq., of Sunning Hill. It is a Proteaceons plant, allied to Grevillea, with neat toothed, long-stalked leaves, and very small, white flowers, of no beauty. It is for its foliage alone that it will be cultivated."-Bot. Reg. glabrătæ . . White. . G. Ev. S. Swan R. MARĀTTIX. [ 352 ] 
Masdevall, a Spanish botanist. Linn. 20, Or. 1, Nat. Or. Orchidacea.

infräetă . . Whtsh. yel. S. Epi, Brazil . MAXILLĀRYX,

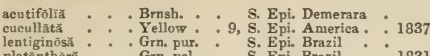
lentiginōsă . . Grn, pur. . S. Epi. Brazil . platänthĕră . . Grn yel. : S. Epi. Brazil : 1831 M RDICĀGō.

clypeātă . .

H. Her. P. India

MENīsč̄ēM.

palüstre - . Brown , 5, S. Her. P. W. Ind.

triphŗllūm - Brown S. Her. P. Ceylon

Micropēră, Lindley. From micros, small, and pera, a pouch. Linn. 20, Or. 1, Nat. Or. Orchidacea. Synonymes: 1. Micropera pyrifolia. 2. Microtis pallida.

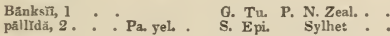

MII.TōNıัА.

eăndìdă

flavēscêns . Yellow. . 9, S. Epi. Brazil .

MONACHĀNTHǓs.

disscőlör

viridiflör̆̆ . Green . 8, S. Epi. Demerara . 1835

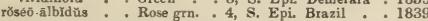

MoNochīLŬs, Fischer and Meyer. Derived from monos, one, and cheilos, a lip; alluding to the flower. Linn. -, Or. -, Nat. Or. Verbenacea.
gloxinifoliă .
S. Tu. $\mathbf{P}$.

1838

MonorĀxı̌s, Brongniart. From monos, one, and taxis, a series; in allusion to the male and female flowers. Linn. -, Or. -, Nat. Or. Euphorbiacea.

simplex - . $\quad$ G. Ev. S. N. Holl.

MORT̄NĂ.

longifólia . . Purple - F. Her. R. E. Ind. .

MoRMōnĒs.

buecinătōr. . Pa grn. . S. Epi.

Mōrīs.

alba

nervōsă . . Apetal . 6, H. De. T.

M ÃNThǔs

barbătĭs

labēllō ālbō . . Drk. grn. . 5, S. Epi. Demerara

1835

spinōsŭs . . : Grn spot. . S. Epi. Brazil

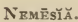

floribūndă . . Wht. yel. . 7, H. A. C. G. H.

N̈вPĒTĂ.

salviæföliă . . White. . H. Her. P. Himalay.

NuträLĭ̌.

malvaflora. . Lgt rose . 8, F. Her. P. Texas.

1838

OrFRōxĭ, Lindley, Linn. 20, Or. 1, Nat. Or. Orchidacea. Two species of this remarkable genus have been figured in Lindley's splendid work entitled "Sertum Orchidaceum," where he makes, among other, the following remarks. - "The genus Obe. ronia consists principally of small, fleshy-leaved epiphytes, inhabiting the branches of trees in the woods of India, and having the most tiny of flowers.

Fourteen species have been described, of which one only, and that the least interesting, O. Iridifolia, has been seen alive in Europe. The resemblance to insects and other animal forms, which have been perceived in the orchidaceous plants of Europe, and which have given rise to such names as Fly Orchis, \&c., may be traced so plainly in the genus Oberonia, in every species, that it alone would furnish a magazine of new ideas for the grotesque pencil of a German admirer of the wild and preternatural. If the Brahmins had been botanists, one might have fancied they took their doctrine of metempsychosis from these productions; in the genera Oberonia and Drymoda, Pythagoras would have found a living evidence of animals transmuted into plants."

cylindriea
OCTOMĽŘ̃.

diăphănă - . White - S. Epi. Brazil . .

ODONTOGLŌssêM.

Clowësìi . . Yel. brn. - S. Epi. Brazil .

grănde : : : Epi. Guatemala.

maculătüm: : Yel. brn. . S. Epi. Mexico .

Rōssi̊ : : : Wht grn. : S. Epi. Mexico: 183.

Oxč̆̀น̌̄̇.

Batemaniănūm . Yellow . S. Epi. Mexico . . 1838

earinătüm - . S. Epi. Xalapa

côncőlŏr. : : Lemon $\quad$ S. Epi. Organ Mís. : 1837

excavātūm: : Yellow : S. Epi.

Forbèsir . . . Yel. brn. . S. Epi.

hĩans . : Brn yel. : S. Epi.

Huntiānūm : . Yel. red . 9, S. Epi. Brazil

Insleãyi . . . Drk. brn. . S. Epi. Mexico

rơsēûm * * * Rose * S, Evi

trulliférüm : Brn. yel. 9, S. Epi. Brazil

Passitrōă.

hispĩduัlă . . Yel wht.

Mooreānă: : Whtsh. 7, H, De, Cl, B. Ayres . 1837

Patresōnín.

sapphirină. - Sapphire . G. Her. P. Swan R. .

Panthāndĭă, Herbert. In honour of I. B. Pentland, Esq., consul-general in Peru. Linn. 6, Or. 1, Nat. Or. Amaryllidacee. "There are two forms of this species, differing very slightly from each other. The first was found in Cusco in Peru, and was sent to Spofforth under. the name of the red Narcissus, by I. B. Pentland, Esq., in compliment to whom the genus is narned; and the other was found by Commodore Sulivan, during his command on the west coast of South America, in 1837. Both varieties flowered for the first time in England, in August, 1839,"-Bot. Reg.

miniătă. - Red 9, Tw. P. Pern 1839 lacunōsă : :

Sulivănǐcă .

PвntstēMŏN,

gentianoỉděs - Drk, pur. . 8, H. Ev. P. N. Amer. .

PhILADẼLPHŬS.

mexicānŭs . . White . . Mexico .

PнLоgocāstrǔs, Nees. From phlox, a flame, and akanthus, the type of this family; in allusion to the long spike of yellow or flame-coloured flowers. Linn. 2, Or. 1, Nat. Or. Acanthacea. For this magniticent shrub, British collections are mainly indebted to Dr. Wallich. Its common height is from four to six feet, and it may most likely be grown in rather a rich soil.

curviflōrŭs . . . Red yel. . 6, S. Ev. S. Sylhet . . 1839 PleurothäLLís.

scābrǐpēs
villōsă

PolystăchY̌̃̆.

bracteōsă . . Orange . S, Leone

PorTurācă.

Thellusōnī . Drk. red . F. A.

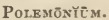

eærŭlëūm

grandiflórtum. Blıe . - H. B. Indis , .

Prímét.

prǣnītēns

plēnă

Cream.

Qū̄raťs.

Brāntīi .

mannĭferă

régiă

RIGIDĒLL to the rigidity of the flower-stalk, when supporting the seed-vessel. Linn. 16, Or. 1, Nat. Or. Iridacece. This very pretty plant was found lately by $\mathbf{M r}$. Hartweg, and it is remarkable for its dissimilarity to any other genus yet known. For culture and propagation it may be referred to Tigridia.

flămmĕă . . Flame, . 5, S. Tu, P. Mexico . 1839 


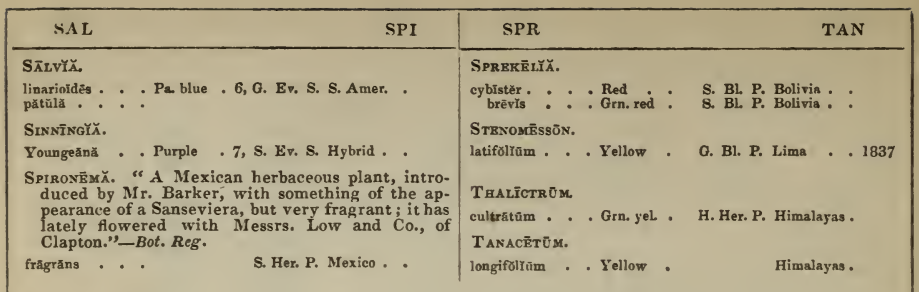

THE END, 






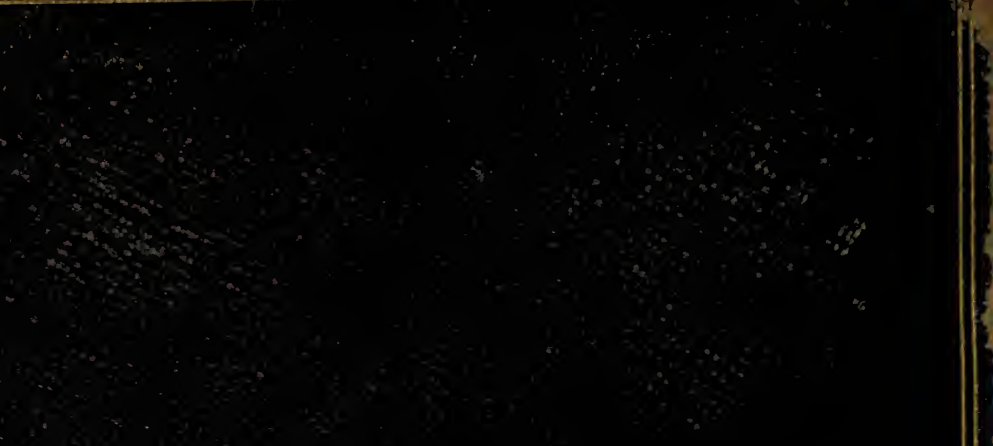

